\title{
(8) exine:
}

Pfiranownhysiologisches Qrolerisurn.

Sitheite Buftorge.

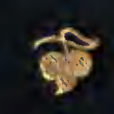

denc.

Perlag von Gustav Fischer. 


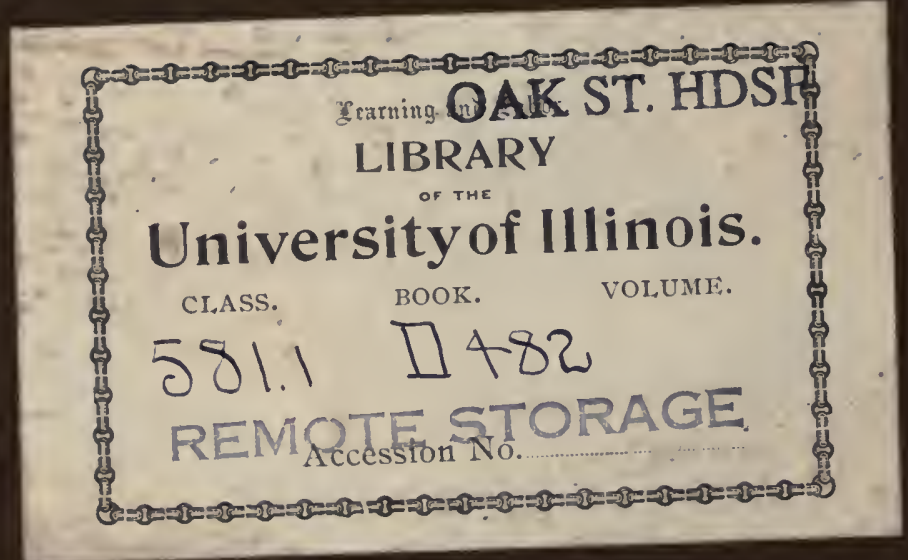






\section{DAS \\ PFLANZENPHISIOLOGISCHE \\ PRAKTIKUM.}

\section{ANLEITUNG \\ ZU PFLANZENPHYSIOLOGISCHEN UNTERSUCHUNGEN}

Fü R

STUDIRENDE UND LEHRER DER NATURWISSENSCHAFTEN SOWIE DER MEDICIN, LAND- UND FORSTWIRTHSCHAFT

VON

Dr. W. DETMER,

PROFESSOR AX DER UXTVERSITÄT JENA.

MIT 184 ABBILDUNGEN.

ZWEITE, VÖLLIG NEU BEARBEITETE AUFLAGE.

J $\mathbf{E} \mathbf{N}$,

VERLAG VON GUSTAV FISCHER. 1895. 


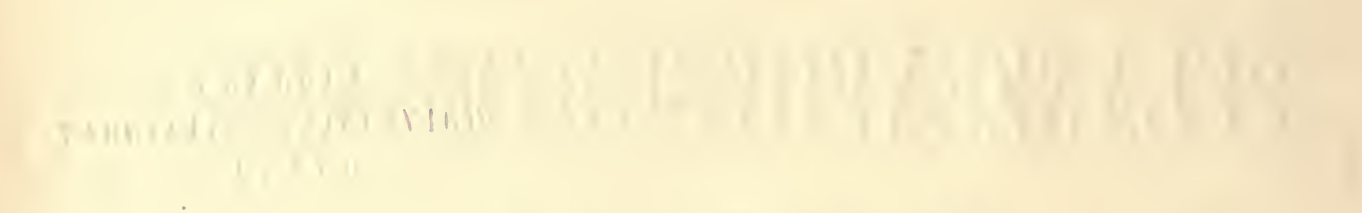

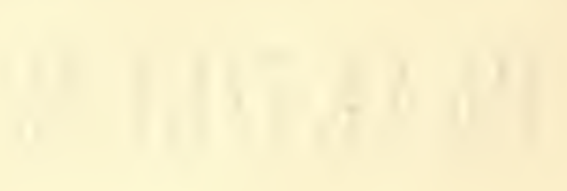




\section{REMOTE STORAGE}

\section{Seinen Eltern}

\section{Dankbarkeit und Verehrung}

zugeeignet

rom Verfasser. 



\section{Vorwort zur ersten Auflage.}

Für denjenigen, welcher sich eingehender mit pflanzenphysiologischen Studien beschäftigen will, genügt es keineswegs, Vorlesungen über Pflanzenphysiologie zu hören oder Lehrbücher dieser Disciplin durchzuarbeiten, sondern er muss vor allem bestrebt sein, die Untersuchungsmethoden aus eigener Erfahrung kennen zu lernen.

Die Pflanzenphysiologie ist heute für die Ausbildung der Studirenden der Naturwissenschaften, der Land- sowie Forstwirthschaftswissenschaft und der Medicin von einer so hervorragenden Bedeutung geworden, dass man bestrebt sein sollte, dem genannten Unterrichtsgegenstande auf den Universitäten und anderen höheren Lehranstalten eine grössere Aufmerksamkeit zuzuwenden, als bisher geschieht. Vor allem erscheint es zweckmässig, pflanzenphysiologische Uebungen für die Studirenden einzurichten, und da ich an der Universität Jena selbst ein solches Praktikum mit sehr günstigem Erfolg eingeführt habe, weiss ich aus Erfahrung, dass die auf den ersten Blick bedeutend erscheinenden Schwierigkeiten des Unternehmens recht gut zu überwinden sind.

In dem vorliegenden Buche habe ich mir die Aufgabe gestellt. nach Kräften zur Förderung des pflanzenphysiologischen Studiums beizutragen. Das „pflanzenphysiologische Praktikum" ist aber keineswegs ausschliesslich zum Gebrauch für Studirende bestimmt, sondern ich denke, dass dasselbe auch manchem Lehrer an höheren Schulen willkommen sein dürfte. Die Botanik bildet aus zahlreichen Gründen einen ganz besonders geeigneten Lehrgegenstand für die Schule, und dem botanischen Unterricht kann durch die Vorführung einer Reihe physiologischer Experimente ein ganz eigenartiger Reiz sowie eine erhöhte Bedeutung für die Geistesbildung der Jugend verliehen werden.

Was die Anordnung des Stoffes im vorliegenden Buche anbelangt, so ist dieselbe freilich nicht genau, aber doch im Wesentlichen in derselben Weise wie in meinem 1883 im Verlage von E. Trewendt in 
Breslau erschienenen Lehrbuche der Pflanzenphysiologie durchgeführt worden. Theoretische Erörterungen, denen in der zuletzt genannten Schrift naturgemäss ein ziemlich breiter Raum gegeben werden musste, fehlen in der vorliegenden fast völlig.

Die Arbeit, welche ich in den letzten vier Jahren zur Herstellung des "pflanzenphysiologischen Praktikums" aufwandte, ist eine sehr erhebliche gewesen. Vor allem kam es für mich darauf an, eine grosse Zahl der verschiedenartigsten pflanzenphysiologischen Experimente und mikroskopischen Beobachtungen selbst auszuführen, um zu einem möglichst selbständigen Urtheil über den Werth und die Brauchbarkeit der Untersuchungsmethoden zu gelangen. Ueberall ist besonderes Gewicht auf die Feststellung der Beziehungen zwischen dem anatomischen Bau sowie der physiologischen Function der Pflanzenorgane gelegt worden, und ebenso sind die biologischen Verhältnisse nicht unberücksichtigt geblieben.

Ich habe mich bemüht, denjenigen Apparaten, welche in diesem Buche zur Ausführung der physiologischen Untersuchungen in Vorschlag gebracht werden, eine möglichst einfache Form zu geben, damit dieselben von jedem ohne grosse Mühe zusammengestellt werden können; gewisse complicirtere und daher auch werthvollere Instrumente, z. B. gute Mikroskope, eine chemische Waage, ein Spectroskop, einen Inductionsapparat, einen Klinostaten etc., kann man bei pflanzenphysiologischen Untersuchungen freilich nicht entbehren.

Jena, Ende September 1887.

\section{W. Detmer.}

\section{Vorwort zur zweiten Auflage.}

Indem ich hiermit die zweite Auflage des, ,pflanzenphysiologischen Praktikums" der Oeffentlichkeit übergebe, bin ich mir, mehr als jemals, der Schwierigkeiten bewusst, welche mit der Bearbeitung einer Anleitung $\mathrm{zu}$ physiologischen Experimenten verbunden sind. Diese Schwierigkeiten haben ihren Grund theils in der Sache selbst, theils aber auch darin, dass von verschiedenen Seiten durchaus nicht die gleichen Ansprüche an ein „Praktikum“ gestellt werden.

Die Gliederung des Stoffes hat im Vergleich zur ersten Auflage keine wesentlichen Aenderungen erlitten. Im Uebrigen liegt aber 
eigentlich ein neues Buch vor, denn fast jeder Abschnitt hat Erweiterung oder Umarbeitung erfahren. Ich habe zahlreiche neue Experimente, die sich für Demonstrationen in der Vorlesung oder zur allgemeinen Orientirung beim Selbststudium eignen, aufgenommen, und ebenso bin ich bemüht gewesen, das Buch für denjenigen in erhöhtem Maasse brauchbar zu gestalten, der die Absicht hat, sich eingehend mit pflanzenphysiologischen Studien zu beschäftigen, und vor allen Dingen den Wunsch hegen muss, die Untersuchungsmethoden genauer kennen zu lernen. Daher sind die Forschungsmethoden denn auch in vielen Fällen in der vorliegenden Auflage sehr detaillirt in Verbindung mit kritisehen Bemerkungen und unter Hinweis auf concrete Beispiele zur Prüfung ihrer Leistungsfähigkeit behandelt worden. Uebrigens sei ausdrücklich betont, dass hauptsächlich nur solehe Methoden Berücksichtigung erfahren konnten, welche eine allgemeinere Bedeutung beanspruchen, während auf die für specielle Zwecke ausgearbeiteten Methoden der Untersuchung höchstens kurz hingewiesen ist, zumal dann, wenn dieselben in leicht zugänglichen Originalarbeiten eingehend behandelt worden sind.

Zahlreiche neue Abbildungen, ein Sachregister und eine Uebersicht der Bezugsquellen für Apparate werden dem Buch ebenfalls sicher zum Vortheil gereichen.

Viele Sorgfalt habe ich auch der Auswahl der für die Experimente empfohlenen Untersuchungsobjecte gewidmet. Bei dem Gebrauch meines Buches wird man finden, dass hierbei nicht allein das im Sommer zur Verfügung stehende Material, sondern ebenso dasjenige Berïcksichtigung erfahren hat, welches im Winter zweckmässig verwandt werden kann. Gerade in der minder günstigen Jahreszeit ist die richtige Auswahl des Beobachtungsmaterials doppelt wichtig.

Die Anzahl der von mir zur Prüfung der Untersuchungsmethoden in den letzten 4 Jahren angestellten Experimente ist eine sehr grosse gewesen. Ich habe auch verschiedene neue Apparate construirt, die in dieser Auflage beschrieben und abgebildet sind.

Bemerkt muss auch werden, dass die nach Mitte des Jahres 1894 erschienene Litteratur keine Berücksichtigung mehr erfahren konnte.

$\mathrm{Zu}$ besonderer Freude gereicht es mir, dass Herr Dr. Mrcheels in Ypern im Jahre 1890 eine französische Uebersetzung meines Buches herausgab, die in Paris erschienen ist. Eine englische Uebersetzung ist in Vorbereitung.

Dem Herrn Verleger sage ich verbindlichsten Dank dafür, dass er für vollendete Ausstattung des Buches die grösste Sorge trug.

Jena, im April 1895.

\section{W. Detmer.}




\title{
Inhalts-Uebersicht.
}

\author{
Erster Theil.
}

\section{Physiologie der Ernährung.}

Erster Abschnitt.

\section{Die Nährstoffe der Pflanzen.}

\section{Der Assimilationsprocess.}

1. Constatirung der Thatsache, dass grüne Pfanzen organische Substanz aus anorganischem Material zu erzengen vermögen . . . . . . . . . . . . .

2. Die Production organischer Substanz in der grünen Pflanzenzelle unter dem Einfluss des Lichtes . . . . . . . . . . . . . . . . . . . . . . . 7

3. Die Assimilationsorgane . . . . . . . . . . . . . . . . . . 8

4. Die Durchleuchtung der Pflanzengewebe . . . . . . . . . . . . . . 11

5. Die Chlorophyllkörper . . . . . . . . . . . . . . . . . . 13

6. Der Chlorophyllfarbstoff ..................... . . 17

7. Das Absorptionsspectrum und die Fluorescenz des Chlorophyllfarbstoffes . . . . 18

8. Die Zersetzang des Chlorophyllfarbstoffes ............... 22

9. Die herbstliche Färbung der Blätter und die winterliche Färbung ausdauernder Pflanzentheile ...................... 25

10. Die Entstehung des Chlorophyllfarbstoffes . . . . . . . . . . . . . . . 26

11. Die Sanerstoffproduction bei der Assimilation . . . . . . . . . . . . . . . 29

12. Die Kohlensäure and der Assimilationsprocess . . . . . . . . . . . . . . . . 33

13. Volumetrische Verhältnisse des Gaswechsels bei der Assimilation . . . . . . 35

14. Der makro- und mikrochemische Nachweis von Stärke in den Assimilationsorganen . . . . . . . . . . . . . . . . . 38

15. Die Assimilationsproducte . . . . . . . . . . . . . 39

16. Die Abhängigkeit der Stärkebildung bei der Assimilation von äusseren Verhältnissen ........................ 42

17. Die Spaltôffnungen and der Assimilationsprocess . . . . . . . . . . . 47

III. Die Entstehnng der Eiweissstoffe in den Pflanzen.

18. Die Versorgung niederer Organismen mit Stickstoff . . . . . . . . . . 49

19. Vermag die Pflunze den freien Stickstoff der Atmosphäre zur Bildung von Eiweissstoffen zu verwerthen? ...................... 50

20. Bacterium Radicicola und die Papilionaceen als Stickstoffsanmler . . . . . . 52

21. Der Nacbweis des Ammoniaks und der Salpetersäure im Wasser und in der Pfanze und die Lebensthätigkeit von Nitromonas . . . . . . . . . . . . . . 57

22. Die Salpetersãure als Pflanzennahrnngsmittel . . . . . . . . . . . 60

23. Das Ammuniak als Pfanzennahrungsmittel . . . . . . . . . . . . . . . 61

24. Der Ort der Eiweissbildung in den böheren Plavzeı . . . . . . . . . . . 61

25. Die Zersetzung der Nitrate in den Pflanzen . . . . . . . . . . . . . 61 
III. Die Aschenbestandtheile der Pflanzen.

Selto

26. Die mechanische Bodeuanalyse . . . . . . . . . . . . . . . 65

27. Der Nachweis einiger Pflanzennährstoffe im Boden . . . . . . . . . . . . 66

28. Ver Gehalt des Wassers un Pflunzennährstoffen . . . . . . . . . . . . . . 67

29. Die Aschenanalyse .. . . . . . . . . . . . . . . . . . . 68

30. Das Mineralstoffbedürfniss der höheren Pflanzen und die Entbehrlichkeit des Natriums sowie des Siliciums für dieselben . . . . . . . . . . . . . 70

31. Die Unentbehrlichkeit des Phosphors, Schwefels, Kaliuıns, Calciums, Magnesiums und Eisens für die höheren Pflanzen . . . . . . . . . . . . . . . . 71

32. Das Mineralstoffbedürfaiss der Pilze . . . . . . . . . 73

33. Die Formen, in denen einige Mineralstoffe in den Pfanzen vorkommen . . . . . 74

IV. Die organischen Verbindungen als Pflanzennahrungsmittel.

34. Die Humuskörper des Bodens und die Mycorhiza . . . . . . . . . . . . . 76

35. Experimente mit Penicillium crustaceum . . . . . . . . . . . . . . . 78

36. Einige weitere Saprophyten . . . . . . . . . . . . . . . . 80

37. Experimente mit saccharomyces cerevisiae . . . . . . . . . . . . . . 80

38. Die Bacterien . . . . . . . . . . . . . . 81

39. Einige parasitisch lebende Hilze . . . . . . . . . . . . . . 84

40. Die Flechten . . . . . . . . . . . . . . . . . . . 86

41. Experimente mit fleischverdaueuden Pflaızen . . . . . . . . . . . 86

\section{Zweiter Abschnitt. \\ Die Molekularkrätte der Pflanzen.}

I. Die wichtigsten organisirten Gebilde der Pflanzenzellen.

42. Die Meinbranen der Pflauzenzelleı . . . . . . . . . . . . . 90

43. Die Stärkekörner . . . . . . . . . . . . . . . . . . . 9 93

44. Das Verhalten der Stärke zum Jod . . . . . . . . . . . . . . . . . . 96

45. Das Verhalten der Stärkekörner im polarisirten Licht . . . . . . . . . . . 97

46. Die protoplasmatischen Gebilde der Pflanzenzellen. . . . . . . . . . . . . . 97

II. Die Zerstörung der Molekularstructur organisirter pflanzlicher Gebilde.

47. Die Einwirkung niederer Temperaturen auf Pflanzen ............. 103

48. Die Veränderungen, welche Pflanzen in Folge des Erfrierens eifahren . . . . . 104

49. Die Eisbildung in gefrierenden Yflanzen . . . . . . . . . . . . . . . 105

50. Die Tődiung der Pflauzen durch zu hohe Temperaturen . . . . . . . . . 108

51. Die Veränderungen, welche Pflauzen in Folge der Tödınng durch zu hohe Temperaturen erfahren ...................... 110

52. Die Vernichtung der Mlolekularstructur durch mechanische Eingriffe . . . . . 111

53. Die Wirkung des Austrockneus auf Pfanzentheile . . . . . . . . . . . 112

54. Die Einwirkung der Elektricităt auf Pflanzen. . . . . . . . . . . . . . 113

55. Die Einwirkung von Giften auf die Pfauzen . . . . . . . . . . . . . 115

\section{Elementare Molekularvorgänge in den Pflanzen.}

56. Der Imbibitionsprocess . . . . . . . . . . . . . . . . . 117

57. Die Diffusion und die Endosmose . . . . . . . . . . . . . . . 120

58. Die diosmotischen Eigenschaften der Zellhsut und des Protoplasmas . . . . . 122

59. Der Turgor und die Plasmolyse . . . . . . . . . . . . . . . 125

60. Die isotonischen Coëfficienten . . . . . . . . . . . . . . . . 127

61. Die Grösse der Turgorkraft . . . . . . . . . . . . . . . . . . . . 129

62. Der Temperaturzustand der Gewächse . . . . . . . . . . . . . . . 130

63. Die elektromotorischen Wirkungen an Yflanzen .................... 132

IV. Die Bewegung der Gase in den Pflanzen.

64. Einiges über das Verhalten der Gase im Allgemeinen . . . . . . . . . 135

65. Das Intercellularsystem der Pflanzen . . . . . . . . . . . . . 138 
Selte

66. Die Lenticellen . . . . . . . . . . . . . . . . . . . 140

67. Die Spaltöffnungen und ihre Bedeutang beim Gaswechsel der Pflanzen . . . 142

68. Positiver und negativer Gusdruck in den Pfanzen . . . . . . . . . . 147

\title{
V. Die Wasseraufnahme seitens der Pflanzen.
}

69 Die Wasscraufnabme seitens der Wurzeln aus dem Boden . . . . . . . . 156

70. Die Wasseraufuahme seitens der Blätter . . . . . . . . . . . . . 157

71. Einige Bewegungserscheinungen an Pflanzentheilen, die mit der Wasseraufnahme derselben im Zusammenhang stehen ................ 157

72. Die Wusseraufnahme der Früchte und Sumen . . . . . . . . . . . . . 160

73. Weitere Experimente über den Quellungsprocess der Samen . . . . . . . 163

74. Die Wasseraufnahme der Moose . . . . . . . . . . . . . . . 164

\section{Die Wasserbewegung in den Pflanzen.}

75. Constatirung der Frscheinung des Wurzeldracks . . . . . . . . . . 166

76. Der Saftausfluss aus im Freien wachsenden verletzten Bäumen . . . . . . 168

77. Der Einfluss äusserer Verhältnisse anf den Saftausfluss aus decapitirten Pflanzen 169

78. Die Periodicitåt des Wurzeldrucks . . . . . . . . . . . . . . . . 172

79. Die Ursachen des Wurzeldrucks und verwandter Erscheinungen . . . . . . 172

80. Weitere Experimente über den Austritt tropfbar flüssigen Wassers ans Pflanzen 173

81. Die Organisation der Pflanzentheile und die Transpiration : . . . . . . . . 176

82. Weitere Transpirationsversuche . . . . . . . . . . . . . . . 178

83. Der Einfluss äusserer Verlältnisse auf die Transpiration der Pfinzen... . . 181

84. Das Holz als wasserleitendes Gewebe und der Eiufluss der Transpiration anf die Wasserbewegung in der Pflanze . . . . . . . . . . . . . 189

85. Die Beweglichkeit des Wassers im $\mathrm{Holz}$. . . . . . . . . . . . . . . 193

86. Die Geschwindigkeit der Wasserbewegung in der Pflanze . . . . . . . . . . 195

87. Die Erscheinung des Welkens der Pflanzen . . . . . . . . . . . . 197

\section{Die Mineralstoffaufnahme seitens der Pflanzen.}

88. Die Wurzeln der Pflanzen als Organe der Mineralstoffanfnahme . . . . . 199

89. Die Mineralstoffuufnahme der Wurzeln aus Nährstofflösungen . . . . . . . 201

90. Die Corrosionserscheinungen . . . . . . . . . . . . . . 202

91. Die Ursachen der Corrosionserscheinungen . . . . . . . . . . . 203

92. Das Absorptionsvermögen des Bodens . . . . . . . . . . . . . . . 205

\section{Dritter Abschnitt.}

\section{Die Stoffwechselprocesse im regetabilischen Organismus.}

\author{
I. Das Verhalten der stickstoffhaltigen Verbindungen.
}

93. Die Eiweissstoffe, welche man aus Pflanzentheilen abscheiden kann . . . . . 208

94. Die makro- und mikrochemischen Eiweissreactionen . . . . . . . . . . 209

95. Allgemeines über das Verhalten der Eiweissstoffe in der Pflanze . . . . . 210

96. Das Pepsin und die Peptone .................... 211

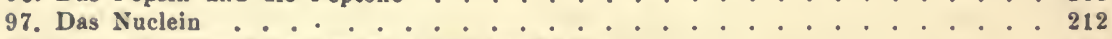

98. Der mikrochemische Nachweis des Asparagins . . . . . . . . . . . . 213

99. Die quantitative Bestimmung des Gesammtstickstoffs und des Stickstofis der Proteinstoffe und der Säureamide in Keimpflanzen . . . . . . . . . . . 214

100. Das Verhalten des Asparagins in den Pflanzen . . . . . . . . . . . . . 215

\section{Der Athmungsprocess der Pflanzen.}

101. Experimente zur allgemeinen Orientirung ijber die Pflanzenathmung . . . . .

102. Methode zur Bestimmung der bei intramolekularer und normaler Athmung der Pflanzen producirten Kohlensäure ................. 221

103. Die Kohlensãureproduction bei normaler Athmung der Pflanzen . . . . . . 226

104. Die Kohlenşureproduction bei intramolekularer Athmung der Pflanzen . . . . 229

105. Elementaranalytische Untersuchungen über den Athmungsprocess . . . . . 232

106. Sauerstoffaufnabme bei der Atlımung und Ermittelung des Respirationsquotienten $\frac{\mathrm{CO}_{8}}{\mathrm{O}}$ 
107. Das Verlaalten der Pflauzen is Contact mit Stickstoffoxydulgas .

III. Verhalten der stickstofffreien plastischen Stoffe der Pflanzen.

110. Das Amylum als Reservestoff . . . . . . . . . . . . . . . . . . . 245

11. Die quantitative Amyjumbestimmung . . . . . . . . . . . . . . . . 246

112. Das Vorkommen der Diastase in den Pflanzen und die Wirkungsweise des Fermentes . . . . . . . . . . . . . . . . . . . . . .

113. Der Einfluss verschiedener Substanzen sowie der Temperaturverhältnisse aut den Verlanf des Processes der Stärkeumbildung durch Diastase . . . . . . . . 250

114. Die Entstehung der Diastase in den Zellen höherer Pflanzen . . . . . . . . 250

115. Die Bestimmung und der mikrochemische Nachweis der Glycose . . . . . . . 251

116. Das Dextrin . . . . . . . . . . . . . . . . . . . . 252

117. Die Bestimmung und der mikrochemische Naclıweis des Rohrzackers . . . . . 253

118. Die Reservecellulose und das Anyloid . . . . . . . . . . . . . . . . . 254

119. Das Inulin .. . . . . . . . . . . . . . . . . . . . . 255

120. Die Pfanzenfette und die quantitative Bestimmung derselben . . . . . . . . 256

121. Die Reactionen der fetten Oele . . . . . . . . . . . . . . . . . . 257

122. Das Verbalten des Fettes bei der Keimung der Samen : . . . . . . . . . . 258

123. Die Keimung der Samen von Phaseolus multiflorus . . . . . . . . . . . . 260

124. Die Keimung von Triticum vulgare : . . . . . . . . . . . . . . . . . 262

125. Die Keimung der Kartoffelknollen . . . . . . . . . . . . . . . . . . . . 264

126. Der Einfluss der Temperaturverhältnisse aut den Zuckergehalt der Kartoffelknollen . . . . . . . . . . . . . . . . . . . 265

127. Das Reifen der Frïchte und Sumen . . . . . . . . . . . . . . . . 266

128. Die Gewinnung des für quantitative chemische Untersuchungen über Stoffwechselprocesse erforderlichen Materials . . . . . . . . . . . . . . . . .

129. Quantitativ-chemische Untersuchungen über das Verhalten der Fette und Kohlehydrate beim pflanzlichen Stoffwechsel ................

IV. Die Nebenproducte des pflanzlichen Stoffwechsels.

130. Die organischen Săuren der Pflanzeu . . . . . . . . . . . . . . .

131. Das Verhalten der freien organischen Săuren im Organismus der Crassulaceen und einiger anderer Pflanzen . . . . . . . . . . . . . . 273

132. Die Gummiarten und die Pflanzenschleime . . . . . . . . . . . . . . . . . 278

133 Die Gerbsäuren . . . . . . . . . . . . . . . . . . . . 278

134. Die ätherischen Oele und Harze . . . . . . . . . . . . . . . . 282

135. Die Farbstoffe . . . . . . . . . . . . . . . . . . . . . . 284

136. Der mikrochemische Nachweis von Alkaloiden und einiger anderer Stoffe in den Planzen . . . . . . . . . . . . . . . . . 285

137. Die Nebenproducte des pfanzlichen Stoffwechsels als Schutzmittel der Pfanzen . 287

V. Die Translocation plastischer Stoffe in den Pflanzen.

138. Experimente mit keimenden Pollenkörnern . . . . . . . . . . . . . 289

139. Experimente mit Blättern . . . . . . . . . . . . . . . . . . . . 289

140. Experimente mit Zweigen . . . . . . . . . . . . . . . . . . . . . . 291

141. Die Ringelungsversuche . . . . . . . . . . . . . . . . . . . 293

142. Die Stärke- and Zuckerscheide und ihre Functionen bei der Stoffwanderung . 296

143. Die Siebröhren und ihre Function bei der Stoffwanderung . . . . . . . . . . 297

144. Der Milchsaft . . . . . . . . . . . . . . . . . . . . . 299

145. Die Stoffaccumulation . . . . . . . . . . . . . . . . 301 


\title{
Zweiter Theil.
}

\section{Physiologie des Wachsthums und der Reizbewegungen.}

\author{
Vierter Abschnitt.
}

\section{Die Zuwachsbewegungen der Pflanzen.}

I. Die Eigenschaften wachsender Pflanzentheile und die auf inneren Ursachen beruhenden Wachsthumsbewegungen.

146. Die Dehnbarkeit nond Élasticität wachsender Pflanzentheile "

147. Relationen $\mathbf{z}$ wischen der Grösse der Turgorausdehnung, dem Wachsthum und der Dehnbarkeit der Pflanzentheile . . . . . . . . . . . . . . 303

148. Die Contraction der Wurzeln ................... 305

149. Die Långsspannnng . . . . . . . . . . . . . . . . . . . 307

150. Die Querspannung . . . . . . . . . . . . . . . . . . . 309

151. Die Vegetationspunkte und das Längenwachstbum der Pflanzentheile . . . . 310

152. Das Dickenwachsthum . . . . . . . . . . . . . . . . . . 313

153. Apparate zur Messung der Zuwachsbewegungen . . . . . . . . . . . 314

154. Die grosse Wachsthumsperiode . . . . . . . . . . . . . . . . . 319

155. Die Wachsthumsgeschwindigkeit und Wachsthumsenergie . . . . . . . . . 323

156. Die Torsionen . . . . . . . . . . . . . . . . . . . . . 324

157. Einige spontane Nutationserscheinungen . . . . . . . . . . . . . . 325

II. Die nothwendigen Wachsthumsbedingungen und die Beeinflussung der Zuwachsbewegung durch äussere Verhältnisse.

158. Das Stoffbedïrfniss wachsender Pflanzeutheile . . . . . . . . . . . 327

159. Der Wassergehalt der Pflanzen und das Wachsthum . . . . . . . . . . . . 328

160. Die Athmung nnd das Wachsthum . . . . . . . . . . . . . . . 329

161. Die Beeinflussung des Wachsthums durch Druck und Dehnung . . . . . . . . 330

162. Die Beeinflussung des Wachsthums durch die Temperatarverhältuisse . . . . . 332

163. Die Jahresperiode der Yflanzen . . . . . . . . . . . . . . . . 334

164. Das Wachsthum der Pflanzentheile in constuuter Finsterniss . . . . . . . . 337

165. Die Ursachen der Etiolirungserscheinungen . . . . . . . . . . . . . 340

166. Der Einfluss des Lichts auf das Wachsthum . . . . . . . . . . . . . . . 343

167. Der Einfluss der Beleuchtungsverhältnisse auf die Keimnng der Kartoffelknollen 345

Fünfter Abschnitt.

\section{Die Reizbewegungen der Pflanzen.}

I. Die Reizbewegungen protoplasmatischer Gebilde.

168. Die Bewegungserscheinungen des Protoplasmas............... 347

169. Die freien Ortshewegungen niederer Organismen (Schwärmerbewegungen etc.) 352

170. Die Bewegunken der Chlorophyllkörper . . . . . . . . . . . . . . . . 359

171. Die Bewegung der Plasmodien von Aethalium septicum . . . . . . . . . 360

II. Die geotropischen, heliotropischen und hydrotropischen Nutationen und einige andere Reizerscheinungen.

172. Das geotropische Verhalten der Wurzeln . . . . . . . . . . . . . . 363

173. Das geotropische Verhalten der Sprosse . . . . . . . . . . . . . . . . 367

174. Die Ursachen der geotropischen Krümmungen . . . . . . . . . . . . . 371

175. Die Fnnction der Wurzelspitze bei dem Zustandekommen geotropischer Krüm. mungen ...................... . . . 376

176. Experimente mit dem Klinostaten . . . . . . . . . . . . . . . 377

177. Experimente mit dem Centrifugalapparat . . . . . . . . . . . . . . . 384

178. Die heliotropischen Nutationen . . . . . . . . . . . . . . 388 
179. Weitere Orientirnng uber den Heliotropismus . . . . . . . . . . . . . . . 391

180. Der Hydrotropismns der Warzeln . . . . . . . . . . . . . . . 395

181. Der Hydrotropismus von Mncor Mucedo . . . . . . . . . . . . . . . . . 396

182. Der Thermotropismus der Pfanzen . . . . . . . . . . . . . . . . 397

183. Aërotropismus und Chemotropismns der Pollen- und Pilzschlàuche . . . . . . 398

184. Die durch den Wechsel der Beleuchtungsverhältnisse und durch Temperaturschwankungen inducirten Bewegungen der Laubblätter und Blüthentheile. (Nyctitropische Bewegungen) .................. . . 399

185. Die Darwix'sche Krümmung etc. . . . . . . . . . . . . . . . . . 403

\section{Das Winden der Ranken und Schlingpflanzen.}

186. Allgemeines über das Winden der Schlingpflanzen . . . . . . . . . . . 404

187. Die rotirende Nutation . . . . . . . . . . . . . . . . . 405

188. Die freien Windungen .................... . . . . 408

189. Die Mechanik des Windens der Schlingpflanzen . . . . . . . . . . . . . 409

190. Experimente über dss Ranken der Cucurbitnceen. . . . . . . . . . . . . 412

191. Experimente mit Ampelideenranken . . . . . . . . . . . . . . . 416

IV. Die Dorsiventralität, Polarität und Anisotropie der Pflanzenorgane und die Correlationserscheinungen im Pflanzenreich.

192. Die Dorsiventralität der Pflanzentheile . . . . . . . . . . . . . 418

193. Die Polarität der Pflanzentheile . . . . . . . . . . . . . . . . . . 419

194. Die Anisotropie der Pfianzenorgane . . . . . . . . . . . . . . . . . . 422

195. Allgemeines über die Festigung der Pflanzenorgane. . . . . . . . . . . . 430

196. Die Anordnung des mechanischen Gewebes in biegungs-, zug- und druckfesten

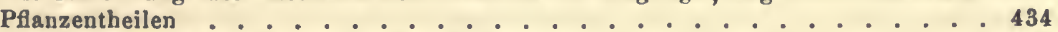

197. Die Correlationserscheinungen im Pflanzenreich . . . . . . . . . . . 436

\section{Die Variationsbewegungen der Pflanzen.}

198. Experimente mit Acacia lophanta . . . . . . . . . . . . . . . 438

199. Experimente mit Phaseolus multiflorus . . . . . . . . . . . . . . . . . . 439

200. Experimente mit dem Hebeldynamometer . . . . . . . . . . . . . . . . 442

201. Experimente mit Mimosa pudica und anderen Pflanzen . . . . . . . . . . . 444

202. Die durch Erschütterung oder Berihhrung hervorgerufenen Variationsbewegungen von Mimosa pudica .. . . . . . . . . . . . . . . . . . 445

203. Beobschtung weiterer durch Erschütterung und Berübrung hervorgerufener Variationsbewegungen . . . . . . . . . . . . . . . . . 447

204. Die spontanen Variationsbewegungen . . . . . . . . . . . . . . . . . . 448

205. Der Einfluss äusserer Verbältnisse auf einige Variationsbewegungeu . . . . . 449 Nachtrag . . . . . . . . . . . . . . . . . . 450 


\section{Bezugsquellen für Apparate, Utensilien, Pflanzenmaterial ete.}

(Nur die wichtigsten Apparate und Utensilien finden hier Erwäbnung.)

Samen- and Pflanzenmaterial liefern HaAge und Schmid in Erfurt. Durch einen hohen Grad der Keimfähigkeit ausgezeichnet sind auch die Samen, welche Hofgärtner Madrer in Jena liefert.

Rassenreine, stärkefreie, abgepresste Bier-und Brennereibefen, denen höchstens etwas Eiweissgerinnsel beigemischt ist, bezieht man im Preise von 5 Mk. p. kg. aus der Versuchs- und Lehrbrauerei zu Berlin, See- und Torfstr.-Ecke. Nach meiner Erfahrung versetzt zumal die von dort bezogene Brennereihefe PAsteUR'sche Năhrlösung bei ca. $20^{\circ} \mathrm{C}$. in sehr lebhafte Gährung. Hefereinculturen in Reagensglas werden von der genannten Versuchsbrauerei für $10 \mathrm{Mk}$. abgegeheu. In vielen Fällen genügt es, die Hefe, welche man benutzen will, selbst zu reinigen. Unterhefe aus einer Brauerei wird in destillirtem und durch Kochen sterilisirtem Wasser vertheilt. Haben sich die in der Flüssigkeit schwimmenden gröberen Theile abgesetzt, so giesst mau die Flüssigkeit, in der die Hefezellen suspendirt sind, ab und stellt sie an einen kühlen Ort. Hat sich die Hauptmasse der Hefe abgesetzt, so giesst man die trübe Flüssigkeit ab, vertheilt den Bodensatz abermals in Wasser und decantirt in angegebener Weise noch etwa $4 \mathrm{mal}$. Die gereinigte Hefe wird nun nochmals in Wasser vertheilt, man lässt etwas absetzen und entnimmt der Hefe enthaltenden Flüssigkeit mit Hülfe einer Pipette ein bestimmtes Volumen. An Stelle des zuletzt benutzten Wassers kann man anch unter Umständen eine gewisse Menge der Nährlösung verwenden (PAstedR'sche Nährlösung, Bierwürze etc.), die zu den Hefeculturen dienen soll. Kommt es darauf an, verschiedenen Nährlösungsportionen sehr genau die nämliche Hefemenge hinzuzufügen, so that man gut, die dem Wasser oder der Nährlösnng. welche mit der gereinigten Hefe versetzt worden ist, entnommene Flüssigkeitsmenge nochmals in Wasser oder Nährlösnng einzutragen, und erst von dieser Flüssigkeit unter fortwährendem Umschütteln mittelst einer Pipette ein bestimmtes Volumen zum Gehrauch abzuheben. In vielen Fällen ist erforderlich, Wasser und Nährstofflösung, in denen man die Hefe bei der Reinigung vertheilt, vor dem Gebrauch in einem mit Wutteverschluss versehenen Kölbchen durch Kochen zu sterilisiren.

Chemikalien aller Art sind zu beziehen aus der chemischen Fabrik von MErck (Darmstadt). Strasse.

Farbstoffe für Mikroskopie liefert Dr. G. Grübler in Leipzig, Bayrische

Glycerin-Gelatine von KAISEr zur Herstellang von Dauerpriiparaten ist ebenfalls von Dr. Grübler zu beziehell.

Desgleichen chin es is che Tusche (verflüssigt) nebst feinem Pinsel zum Auftragen von Marken auf Pflanzentheile.

Filtrirpapier, gewöhnliches und schwedisches, liefert Dr. H. Gerssler Nachfolger F. MÜLLER in Bonn.

Gewöhnliche Körke, Kautschukstopfen, Kautschukschläuche etc. sind $z u$ beziehen aus der Gummifabrik von WALlach in Cassel. Die Kautschukwaaren bewahrt man in einem grossen, verschlossenen Glascylinder auf, in welchem noch ein kleines, bis zur Hälfte mit Terpentinöl angefülltes Glas Platz findet. So conservirte Kautschukwaaren werden nicht spröde und brüchig. Hart gewordene Kautschukwaaren kann man wieder gebrauchsfähig machen, wenn man sie eivige Zeit lang der Einwirkung von Chloroformdampf aussetzt. $Z_{u}$ dem $Z$ weck gelangen sie nebst einem bis zur Hälfte mit Chloroform angefüllten $\mathrm{Gläschen} \mathrm{in} \mathrm{einen} \mathrm{verschliessbaren} \mathrm{Glascylinder.}$

Ka utschukkörke und Schläuche aus Paragummi voll besonders guter Qualität, die auch bei langem Liegen an der Luft kaum hart werden, liefern BENDER \& Hовег, München, Gabelsberger-Str. 76 a.

Platintieg el etc. liefert Heräus in Hanau.

Horn- nnd Porzellangeräthschafien aller Art liefert Ephraim Greixer in Stützerbach (Thüringen).

Glas w a ren aller Art (Röhren, Becherg]äser, Trichter etc.) liefern ALt EвERHaвdT und Jüger in Ilmenau (Thüringen) und Ephraim Gremer in Stützerbach (Thüringen).

Büretten, Pipetten, Waschflaschen, Gasentwickelungsapparate etc. sind zu beziehen von Dr. R. Muexcke, Berlin NW, Luisenstrasse 58. 
Excelsiormühlen zum Zermahlen von Samen, Rinden etc. sind zu beziehen von Grosox in Magdeburg-Buckau oder von Wenderotu in Cassel.

Saftpressen und Presat ü cher liefern G. Wenderota in Cassel und Geisszer Nachf. F. Müller in Bonn.

H eberbarometer von besonders guter Qualität liefert Geisgler Nachf. F. MülLER in Bonn. Das Instrument ist zweckmässig an einem Stativ zu befestigen, welches es ermöglicht, das Barometer, wenn es nicht gebraucht wird, in geneigte Stellung zu bringen. Das Glas bleibt dann da, wo die Ablesungen erfolgen, immer sauber.

$\mathrm{G}$ ef a s $\mathrm{s}$ b a rometer in besonders guter Qualität mit Stativ und Thermometer liefert fï den Preis von $32 \mathrm{Mk}$. W. HAAK, Glasbläser in Jena.

Stative aller Art sind zu beziehen von DesaGa in Heidelberg. Stative mit Porzellanplatte, besonders geeignet zum Einsenken in Wasser, liefert BüruLER in Tübingen.

A p parate zur Stickstoffbestimmung nach KJeldanl liefert alt EberIARDT und JÄGRR in Ilmenau (Thüringen).

Ein Fernrohr (Kathetometer) für Ablesung bei gasanalytischen Arbeiten ist im Preis von 80-100 M. von MurNcke in Berlin $z u$ beziehen.

Schliteninductionsapparate und unpolarisirbare Elektroden etc. sind zu beziehen von $\mathbf{R}$. RothE, Universitätsmechaniker in Prag.

Chromsäureelemente und Tauchbatterien liefert Dr. Muencke in Berlin (s. Preisverzeichniss von 1894)

Spiegelgalvanometer sind zu beziehen aus den mechanischen Werkstätten von Dr. Th. Edelmann in München und H. MEYer in Zürich. Die letztere Firma liefert etwas billigere, aber doch sehr empfindliche Apparate. Besonders empfehlenswerth sind auch die Spiegelgalvanometer nach Hermann aus der mechanischen Werkstätte von Platu in Potsdam. Das Instrument, mit 2 Rollen von zussmmen 30000 Drabtwindungen, 2 Thermorollen von je 100 Windungen, vorzüglicher Dämpfung, Fernrobr und Scala ausgestattet, kostet 485 Mk.

Spectralapparate verschiedener Art sind zu beziehen von Geissler Nachf. F. MÜller in Bonn. Ein grosses Spectroskop nach Hofann mit Vergleichsprisma und Messvorrichtung kostet $240 \mathrm{Mk}$. Auch A. Krüss in Hamburg liefert sehr gute Iustrumente. Sehr empfehlenswerthe Taschenspectroskope mit Scala sind im Preis von 60 Mk. zu bezlehen von Schmidt \& HaEssca in Berlin, Stallschreiberstrasse 4

Luft pumpen, Wasserstrablpumpen, Wasserstrahlgebläse sind zu beziehen von Dr. Monxcke in Berlin. Besonders empfehlenswerth ist die ARzBERGER'sche Wasserstrahlpampe, mit Hülfe welcher eine sehr vollständige Evacuirung zu erzielen ist. Der Apparat wird im Preis von etwa 30 Mk. von C. Gerhand in Bonn geliefert. Auch ist derselbe von Dr. Mokscke in Berlin und in vorzilglichster Qualiät von PAUL BöuME in Brünn zu beziehen. Ferner empfehle ich selir nachdrücklich die Wasserstrablpumpe vom Glasbläser Hilonbrand in Erlangen. Der kleine Apparat (Preis 2 Mk.) wird mit Hülfe eines sehr dickwandigen Kautschukschlauches oder eines Hanfschlsuches an den Ausflusshahn der Wasserleitung befestigt. Die zu erreichende Evacuation ist eine sehr vollkommene, natürlich bis auf die Tension des Wasserdampfes.

Wa a gen für an alytische Arbeiten mit einer Tragkraft von $100-200 \mathrm{~g}$ und einer Empfindlichkeit von $1 / 10 \mathrm{mg}$ sind zu beziehen von G. KEHN in Ebingen (Württemberg) und P. Bunae in Hamburg (Eilbeck). Preis: 200-300 Mk.

O berschalige $W_{a}$ a gen, verhältnissmässig empfindlich, mit Tragkraft von $1-10 \mathrm{~kg}$ liefert Dr. MUEACKE in Berlin. Preis: 18-28 Mk. Fir viele Transpirationsversuche eignen sich besonders die sogen, oberschaligen Pflanzenwargen (Belastung bis zu $2 \mathbf{k g}$, Empfindlichkeit $0,1 \mathrm{~g}$ ), welche G. KERN \& Sohn in Ebingen (Württemberg) im Preise von $140 \mathrm{Mk}$. liefern. Die nämliche Firma liefert auch für den Preis von 28 Mk. eine WestrhaL'sche Waage zur Bestimmung des specifischen Gewichts von Flissigkeiten.

$\mathrm{K}$ le ine Wassermotoren, direct an den Ausflusshahn der Wasserleitung mittelst eines Hanfschlsuches anzubringen und besonders geeignet, um z. B. Centrifugalapparate in Bewegung zu setzen, sind zu beziehen von F. A. Herrertz in Köln.

T hermometer werden geliefert von Greiner \& Friedricus in Stützerbach, EPHraim GREJNER in Stützerbach, KIRCHLER in Ilmenau, HAAK, Glasbläser in Jena, GeIssLer Nachf. F. MÜLleR in Bonn. Für genaue Untersuchungen ist es erforderlich, die Thermometer prüfen zu lassen. Diese Prüfungen werden in der physikalisch-technischen Reichsanstalt zu Charlottenburg bei Berlin ausgeführt. Die Prïfung eines Normalthermometers van HAAK in Jens, welche suf meinen Wunsch im physikalischen Institut zu Jena susgeführt wurde, ergab z. B. folgende Werthe. Bei $0^{\circ} \mathrm{C},-0,10^{\circ}$, bei $10^{\circ} \pm 0,00^{\circ}$, bei $20^{\circ}+0,05^{\prime \prime}$, bei $30^{\circ}+0,05^{\circ}$, bei $40^{\circ}+0,00^{\circ}$, bei $50^{\circ}+0.05^{\circ}$. Die negativen Vorzeichen einer Correctur bedeuten, dass die betreffende Grösse von der unmittelbar beobachteten abzuzieben ist. Die angegebenen Correcturen gelten unter der Voraussetzung, dass der Quecksilberfaden sich seiner ganzen Länge uach in der zu messenden Temperatur befindet. Wenn ein Theil des Fadens aus dem Raume, dessen Temperatur gemessen werden soll, herausragt, só tritt zu der abgelesenen und nach den vorstehenden Fehlerangaben berichtigten Temperatur eine Correction hinzu, die aus der folgenden Formel berechnet wird: 


$$
\frac{n\left(t-t^{\prime}\right)}{6500}
$$

worin $n$ die in Graden ausgedrückte Länцe des herausraqenden Theiles des Quecksilberfadens, $t$ die zu messende Temperatur und $t^{\prime}$ die mittlere Temperatur des herausragenden Fadens bedeuten. Es genigt in den meisten Fällen, für $t^{\prime}$ die Temperatur des Arbeitsraumes einzusetzen. Ist diese Temperatur niediger als die zu messende Temperatur, so ist der gefundene Werth der Temperatur, welche das Thermometer anzeigt, hinzuzuaddiren.

Apparate zum Abdampfen, Destilliren von Wasser und Heizen der Troekenschränke liefert in jeder gewünschten Grösse Dr. Murncks in Berlin.

Dampfsterjlisirungs a parate zum Sterilisiren im strömenden Wasserdampf nach Kocr, ganz aus Kupfer gefertigt von $1 \mathrm{~m}$ Höhe, sind für $60-80 \mathrm{Mk}$. zu beziehen von H. Rohrbeck, Berlin NW, Karlstrasse 24. Vergl. Preisverzeichniss von 1891-92, S. 21. Näheres über Construction und Benutzung des Apparates vergl, man im erwähnten Catalog.

M ikroskope vorzïglicher Qualität sind zu bezieben von C. ZEIss in Jens und von W. \& II. SeIberT in Wetzlar. Ein für die gewöhnlichen Zwecke vollkommen ansreichendes ist $\mathrm{z}$. B. das von ZEISs, Stativ Nr. VII a mit den Ocularen 2, 4 u. 5 und den Objectiven B. u. D. Preis $153 \mathrm{Mk}$. Vergrösserung 95-580-fach. Zeichenprismen 20-30 Mk., den neuen Zeichenapparat von $A B B E$, bei dessen Benutzung man auf horizontaler Fläche zeichnet, für $60 \mathrm{Mk}$., Objectivmikrometer $10 \mathrm{Mk}$; Objectträger und Deckgläser kann man ebenfalls von ZeIss in Jena beziehen.

Ein für pflanzenphysiologische Untersuchungen sehr empfehlenswerther Centrifugalapparat ist nach meinen Angaben vom Mechaniker des physikalischen Instituts zu Jena G. Tegturyer construirt worden. Der Apparat ist für den Preis von 60 Mk. von dem genannten Mechaniker zu beziehen (vergl. Fig. 155). G. TrgtMexer liefert auch meinen Apparat zur Bestimmung der Dehnbarkeit, Elasticität und Festigkeit von Pfianzentheilen, Preis 35 Mk. (vergl. Fig. 179), ebenso die von mir construirten und in Fig. 49 sowie 146 abgebildeten Apparate.

Von E. ALbrecht, Universitätsmechaniker in Tübingen können die folgenden Apparate bezogen werden.

Grosser Kljnostat nach Pfeffer, Preis 320 Mk.

Kleiner Klinostat, Preis 220 Mk.

A u a n o meter nach Preffer, Preis $320 \mathrm{Mk}$.

Zeiger a m Bogen nach Sachs, Preis $60 \mathrm{Mk}$.

A p parat zum Registriren des $S$ afta usflusses nach Baranetzky, Preis $100 \mathrm{Mk}$.

Horizontales Messmikroskop, Preis $125 \mathrm{Mk}$.

Hebeldynamometer, Preis 15 Mk.

Gaska mmer, nach dem Princip der Engelmann'schen, Prejs 15 Mk.

Zwejspiegeliger Heljostat nach Retisch, Preis $335 \mathrm{Mk}$.

Wortmans's $\mathrm{K}$ linostat ist mit allem Zubehör im Preis von 200 Mk. zu beziehen ans der technischen Anstalt der Gebrüder Ungerer in Strassburg.

Das Azotometer ist im Preis von ca. 30 Mk. von Enrhardt \& Metzger in Darmstadt zu beziehen.

Thermostaten, Thermoregulatoren, Gasdruckregulatoren, Gas brenner liefert Dr H. RoHrbeck in Berlin, Karlstrasse 24. Besonders empfeblenswerth sind die in Preisverzeichniss von 1891-92 unter 114 und 129 aufgelührten Thermostaten. Preis je nach Grösse 50-200 Mk. resp. 20-30 Mk. Als Thermoregulator empfehle jeh z. B. den unter 149 aufgeführten. Preis gefüllt und geprüft 19 Mk. Recht empfehlenswerth sind auch die Thermoregulatoren (mit Quecksilber und Amylalkohol gefülit) vom Glasbläser HAAK in Jena. Preis 8-10 Mk.

Ich mache hier auch aufmerksam auf das neue Preisverzeichniss (1895) der Firma ZErss in Jena, besonders auf folgende in demselben angegebenen Apparate: Mikroskope verschiedener Constructionen, Mikrospectralobjectiv nach ENGELMANN, S. 67, Ocnlarmikrometer, S. 72, Zeichenapparat nach $\mathrm{ABBE}$, S. 82, Polarisationseinrichtungen für Mikroskope, S. 85, Mikrospectroskop, S. 88, Heizvorrichtung zur Erwärmung mikroskopisclıer Objecte während der Beobachtung nach PFEIFFER, S. 93.

Millimeterpapier (durchscheinendes Pause-Skizzirpapier) ist za bezieben von Schlemcher und SchülL in Düren, Rheinpreussen; Preis von 25 Bogen 12 Mk.

Polarplanimeter liefert im Preise von 45 Mk. nebst Gebrauchsanweisung J. Kery in Aarau, Schweiz.

Eine Art $\mathrm{Kleb}$ a chs, Plastilin genannt, welches in manchen Fälen gute Dienste leistet, wenn es sich z. B. darum handelt, Pfanzentheile in Glasröhren luftdicht einzukitten, ist zn beziehen von PIEning \& Soden in Hamburg, Breitestrasse.

Sämmtliche Apparate, welche in diesem Buch Erwăhnung finden, können bezogen werden aus der mechanischen Werkstätte von DEsAGA in Hejdelberg. Diese Firma hat es sich zur besonderen Aufgabe gestellt, die Apparate selbst herzustellen oder doch zu beschaffen. 


\title{
Erster Theil. \\ Physiologie der Ernährung.
}

\author{
Erster Abschnitt.
}

\section{Die Nährstoffe der Pflanzen.}

\section{Der Assimilationsprocess.}

\section{Constatirung der Thatsache, dass griue Pflanzen organische Substanz aus anorganischem Material zu erzeugen vermögen.}

Die Thatsache, dass grüne Pflanzen organische, d. h. kohlenstoffhaltige, verbrennliche Substanz aus anorganischem Material zu erzeugen vermögen, ist von so fundamentaler Bedeutung, und die zur Feststellung dieser Thatsache anzustellenden Experimente sind so lehrreich, dass denselben eine ganz besondere Aufmerksamkeit zu widmen ist. Die Versuche können fast zı jeder Jahreszeit angestellt werden; sie liefern freilich im Sommer der dann herrschenden günstigen Vegetationsbedingungen wegen die weitaus besten Resultate, und wenn es sich um Experimente handelt, bei denen die Pflanzen zu völliger Entwickelung und Samenreife gebracht werden sollen, so ist dies natürlich im Winter nicht möglich. Als Untersuchungsobjecte verwendet man zweckmässig den Mais, den Weizen, den Hafer, den Buchweizen oder die Bohne.

Es kommt zunächst darauf an, das Trockengewicht der zum Versuch dienenden ruhenden Früchte resp. Samen zu ermitteln, um den Gehalt derselben an organischer Substanz beurtheilen zu können. Einige Früchte, resp. Samen werden auf einer kleinen Handmühle zu einem feinen Pulver zermahlen, und es dient dann eine kleine Quantität dieses Pulvers, deren Gewicht aber genau festgestellt werden muss, zur Bestinmung des Trockensubstanzgehaltes des ursprünglich lufttrockenen Materials. Etwa $3 \mathrm{~g}$ des Pulvers werden in ein geeignetes Gläschen (Wägegläschen) gebracht und im Trockenschrank bei $100^{\circ}$ C. vom Wasser befreit. Als Resultat dieser Untersuchungen ergiebt sich, dass die lufttrockenen Früchte oder Samen etwa $85 \%$ Trockensubstanz enthalten. Freilich besteht nun diese letztere nicht ihrer Gesammtmasse nach aus organischen Stoffen, sondern es sind neben diesen noch Mineralbestandtheile vorhanden, aber die Quantität 
derselben ist verhältnissmässig so gering, dass wir sie hier unberücksichtigt lassen dürfen.

Für die Culturversuche, welche angestellt werden sollen, wählen wir einige möglichst vollkommen ausgebildete Früchte oder Samen aus. Jedes Untersuchungsobject wird einzeln gewogen und das Gewicht notirt. Es lässt sich nun unter Berücksichtigung des Resultates der ausgeführten Trockensubstanzbestimmung, das Trockengewicht jeder einzelnen Frucht oder jedes einzelnen Samen berechnen. Die Untersuchungsobjecte werden jetzt einzeln in kleine Glas- oder Porzellanschälchen gelegt, mit Wasser übergossen und 12-24 Stunden lang mit diesem zum Aufquellen in Berührung belassen. Darauf bringt man die Früchte oder Samen in feuchten Sägespänen, die sich in einem geeigneten Kasten oder Blumentopf befinden, zum Keimen. Es sei hier ein für alle Mal bemerkt, dass die gut durchfeuchteten Sägespäne $z$ wischen -den Händen gerieben und zu einem möglichst lockeren Keimlager in den Gefässen 'angehäuft werden müssen. Die Phaseolussamen legt man horizontal in das Keimbett, so dass die ausgetretene Wurzel einen rechten Winkel mit der Längsachse der Samen bildet. Maiskörner werden 'so gelegt, dass die austretende Wurzel, ohne Krümmungen auszuführen, gerade nach abwärts wachsen kann. Ebenso legt man z. B. auch Samen von Vicia Faba mit nach abwärts gewandter Mikropyle in die Sägespäne. Wenn die Keimwurzeln die Länge von.mehreren Centimetern erreicht haben, so werden die Keimpflanzen, vorsichtig aus den Sägespänen herausgenommen, sorgfältig abgewaschen und mit Hülfe der Methode der Wassercultur zu weiterer Entwickelung gebracht.

Wir bedürfen dazu zunächst geeigneter Glascylinder, die, wenn wir z. B. mit Maispflanzen experimentiren, so gross sein müssen, dass sie etwa 2 Liter Flüssigkeit fassen. Für kleinere Pflanzen genügen auch kleinere Gefässe. Die Glascylinder werden, um dem Mineralstoffbedürfniss der Pflanzen, auf das wir an anderer Stelle eingehend zurückkommen werden, zu genügen, nicht mit reinem Wasser, sondern mit einer Nährstofflösung angefüllt. Dieselbe bereitet man sich zweckmässig gleich in grösserer Quantität und bewahrt sie in wohl verschlossenen Gefässen im Dunkeln auf. Eine geeignete Nährstofflösung erhält man, wenn man auf 1 Liter destillirten Wassers die folgenden Mengen der nachfolgend aufgeführten Körper benutzt ${ }^{1}$ ):

1 g salpetersauren Kalk $\left(\mathrm{Ca}_{2} \mathrm{NO}_{3}\right)$;

0,25 , Chlorkalium $(\mathrm{K} \mathrm{Cl})$;

0,25 , schwefelsaure Magnesia $\left(\mathrm{Mg} \mathrm{SO}_{4}\right)$;

0,25 " phosphorsaures Kali $\left(\mathrm{K} \mathrm{H}_{2} \mathrm{PO}_{4}\right)$.

Der Auflösung dieser Stoffe in dem Wasser werden dann noch einige Tropfen verdünnter Eisenchloridlösung hinzugesetzt.

Diese Nährstofflösung habe ich oft mit gutem Erfolg benutzt. Eine recht geeignete Nährstofflösung erhält man auch durch Eintragen der folgenden Salzmengen in 1 Liter Wasser:

$1 \mathrm{~g}$ salpetersaures Kali;

0,5 ,, Chlornatrium ;

0,5, schwefelsaurer Kalk;

0,5 " schwefelsaure Magnesia;

0,5 " dreibasisch phosphorsaurer Kalk.

1) Es genügt durchaus, die angegebenen Salzmengen unter Benutzung einer kleinen Handwage mit Hornschalen abzuwägen. 
Das Kalkphosphat wird in sehr fein pulverisirtem Zustande angewendet. Es ist in Wasser sehr schwer löslich und bildet daher in den Culturgefässen einen Bodensatz. Dieser Nährstofflösung sind endlich noch einige Tropfen verdünnter Eisenchloridlösung hinzuzusetzen.

Sind die Glaseylinder mit der Nährstoffllösung gefüllt, und hat man passende, mit einer grossen Bohrung verseheneKorke zum Verschluss der Culturgefässe ausgewählt, so werden die Keimpflanzen mit Hülfe von Watte in den Bohrungen der Korke befestigt. (Vgl. Fig. 1.) Jede Pflanze erhält einen besonderen Cylinder. Die Wurzeln der Untersuchungsobjecte müssen in die Nährstofflösung hineinragen; die noch vorhandenen Reservestoffbehälter (Endosperm oder Cotyledonen) dürfen freilich nicht in dieselbe eintauchen, inüssen aber vor dem Austrocknen geschützt sein. Die Culturgefässe werden, nachdem sie mit den Pflanzen beschickt worden sind, an ein Fenster gestellt, wo die letzteren directes Sonnenlicht empfangen. Die Glascylinder beklebt man übrigens mit schwarzem Glanzpapier, damit die Entwickelung von Algen in der Nährstofflösung und auf den Wurzeln der Gewächse ausgeschlossen bleibe. Die weisse Fläche des Glanzpapiers muss nach aussen gekehrt sein, damit die Flüssigkeit in den Cul-

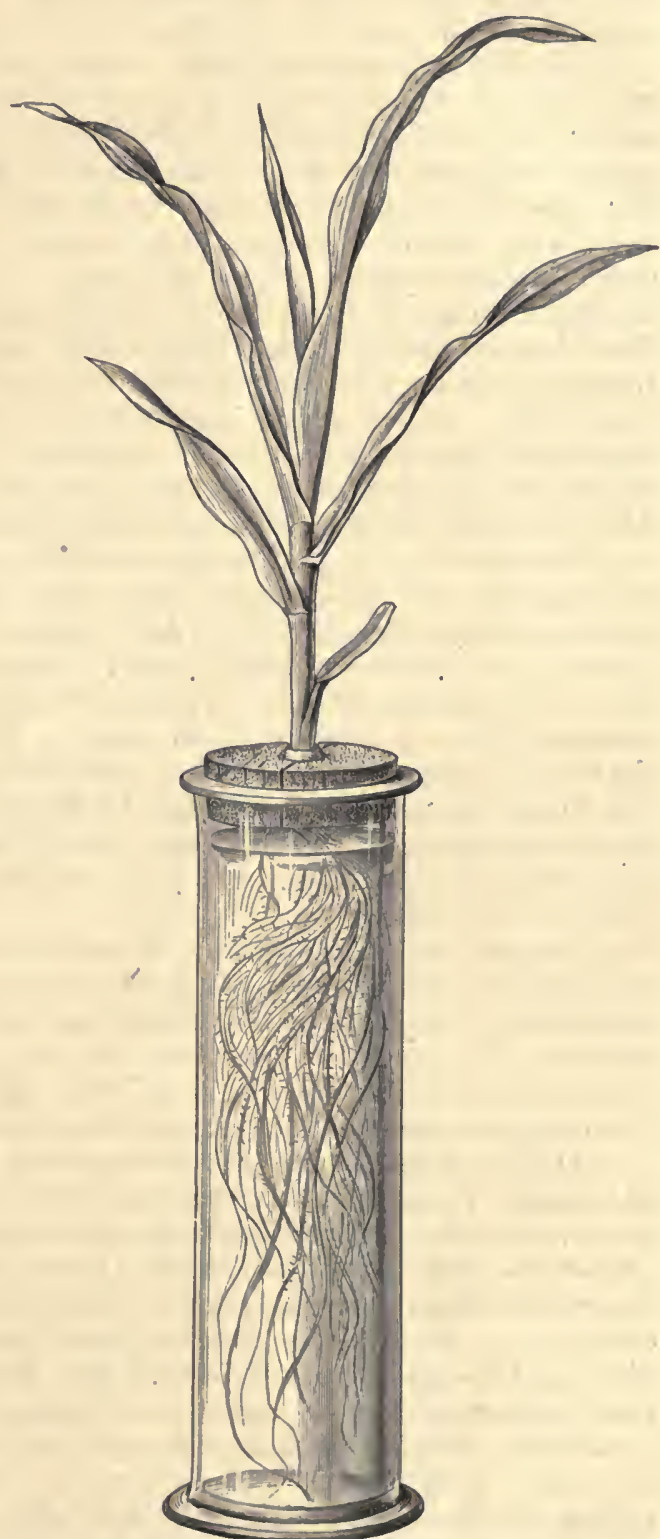

Fig. 1. Maispflanze, die mit IIille der Methode der Wassercultur zur Entwickelung gebracht worlen ist.

turgefüssen keine $\mathrm{zu}$ hohe

Temperatur annimmt. Einfacher ist es noch, um das Licht von den Wurzeln fern zu halten, jedes Culturgefäss in einen Hohlcylinder von 
Pappdeckel zu stellen. Während der Vegetation der Untersuchungsobjecte ist selbstverständlich oft für einen genügenden Ersatz des aus den Nährstofflösungen aufgenommenen Wassers durch Zugabe von destillirtem Wasser zu sorgen.

Die Vorsichtsmaassregeln, welche berücksichtigt werden mũssen, wenn es sich darum handelt, Pflanzen mit Hülfe der Methode der Wassercultur zu weit fortgeschrittener Entwickelung zu bringen, sollen weiter unten in diesem Abschnitt Erwähnung finden. Zunächst kommt es nur darauf an, den Nachweis zu führen, dass grüne Pflanzen überlaupt organische Substanz zu erzeugen vermögen, und es genügt daher vollkommen, wenn sie einige Wochen lang vegetiren und kräftige Stengel, Blätter, sowie Wurzeln producirt haben. Wir nehmen die Pflanzen dann aus den Nährstofflösungen heraus, führen sie durch Liegenlassen an der Luft möglichst schnell in den lufttrockenen $\mathrm{Zu}$ stand über, zerschneiden jerle Pflanze für sich mit der Scheere in möglichst kleine Stücke und benutzen entweder die ganze Masse eines Individuums oder einen abgewogenen Theil der luftrockenen Substanz zur Trockensubstanzbestimmung.

Vergleicht man das Trockengewicht einer Pflanze mit demjenigen des Samens, so findet man, dass das erstere das Vielfache des letzteren beträgt. $\mathrm{Da}$ der Aschengehalt der geernteten Pflanzen, ebenso wie derjenige der Samen, relativ sehr gering ist, so folgt, dass eine grosse Menge organischer Substanz von unseren Untersuchungsobjecten erzeugt sein muss. Wir haben unseren Pflanzen aber keine organischen Stoffe, sondern nur Wasser, einige Salze und die Bestandtheile der Luft zur Verfügung gestellt, und es beweisen unsere Culturen demnach, dass die benutzten Untersuchungsobjecte im Stande sein müssen, aus rein anorganischem Material organische Körper zu produciren.

Handelt es sich darum, Wasserculturversuche in grösserer Ausdehnung anzustellen und die Untersuchungsobjecte (Hafer, Mais, Buchweizen etc.) $\mathrm{zu}$ völliger Entwickelung und Fruchtreife $\mathrm{zu}$ bringen, so erfordern die Culturen natürlich eine weit grössere Aufmerksamkeit als dann, wenn nur der Nachweis geliefert werden soll, dass grüne Pflanzen überhaupt organische Substanz zu erzeugen vermögen.

1) Die Samen oder Früchte werden 12, resp. 24 Stunden lang in destillirtem Wasser angequollen und dann in gut gewaschenen und locker in Blumentöpfe eingefüllten Sägespänen zur Keimung gebracht. (Näheres ist bereits oben gesagt worden.) Unter Umständen, zumal bei genauen Untersuchungen über das Mineralstoffbedürfniss der Gewächse, empfiehlt es sich, die Samen oder Früchte nach dem Anquellen zwischen schwedischem Fliesspapier anzukeimen. Man bringt die Samen in horizontaler oder verticaler Lage, nachdem sie gequollen sind, $z$ wischen vielfach zusammengefaltetes Fliesspapier und stellt dasselbe dann senkrecht derartig auf, dass es mit seinem unteren Ende in destillirtes Wasser eintaucht, welches den Boden eines weithalsigen Glasgefässes bedeckt. Die Vorrichtung wird endlich unter eine Glasglocke gebracht, deren Tubuius lose mit Watte verstopft ist.

2) Haben die Wurzeln der Keimlinge die Länge von einigen Centimetern erreicht, so gelangen sie in die mit den Nährstofflösungen angefüllten Culturgefässe, die je nach Umstânden 1-4 Liter Flüssigkeit fassen. Die Culturcylinder können mittelst eines mit drei Oeffnungen versehenen Deckels aus lackirtem Zinkblech oder besser aus Porzellan 
verschlossen werden. Die mittlere Oeffnung dient zur Aufnahme eines halbirten und durchbohrten Korkes. In dieser Bohrung werden die Keimlinge in bereits oben angegebener Weise mit Hülfe von Watte befestigt. Man kann die Keimlinge aber auch direct ohne Kork in die ca. $3 \mathrm{~cm}$ weite Oeffnung des Deckels einführen. Die zweite Oeffnung des Deckels ist mit einem durchbohrten Kork verschlossen, und in die Bohrung das untere Endo eines dünnen Holzstabes fest eingeschoben, der den sich entwickelnden Pflanzen als Stütze dienen kann. Die dritte Oeffnung des Deckels wird mit einem nicht durchbohrten Kork verschlossen.

3) Die Verdunkelung der Wurzeln in den Culturgefässen erzielt man leicht durch Einsetzen derselben in geeignete, aus Pappe gefertigte Cylinder oder durch Umwickeln der Cylinder mit.mehreren Lagen Flanell. $\mathrm{Ku}$ achten ist darauf, dass die Nährlösung an heissen, sonnigen Sommertagen keine zu hohe Temperatur annimmt.

4) Die Culturgefässe sind am Fenster eines nach Süden gelegenen Zimmers aufzustellen. Sehr förderlich für die Entwickelung der Pflanzen ist es, wenn man die Culturgefässe so oft wie möglich ins Freie vor das Fenster stellt. Führt man jährlich ausgedehnte Untersuchungen mit Hülfe der Methode der Wassercultur durch, so ist es sehr zu empfehlen, ein besonderes aus Glas und Eisen construirtes Gewächshaus erbauen zu lassen, welches derartig construirt ist, dass die in Rollwagen stehenden Culturgefässe so oft wie möglich leicht ins Freie gebracht werden können $\left.{ }^{1}\right)^{2}$ ).

5) Selbstverständlich ist oft für genügenden Ersatz des aus der Nährlösung verdunsteten Wassers zu sorgen. Haben die Pflanzen ein kräftiges Wurzelsystem gebildet, so empfiehlt es sich, die Untersuchungsobjecte etwa jede Woche für $1-2$ Tage aus den Nährstofflösungen herauszunehmen und in destillirtes Wasser einzusetzen.

6) Sorgfältig ist darauf $\mathrm{zu}$ achten, dass die Nährlösung stets schwach sauer reagire. Alkalische Reaction der Nährlösung ist höchst gefährlich und kann, wenn sie eingetreten ist, durch Zusatz von wenig Phosphorsäure beseitigt werden.

7) Um den Wurzeln in der Nährlösung stets genügenden Sauerstoff darzubieten und um der bei Sauerstoffmangel eventuell eintretenden Bildung von Schwefeleisen vorzubeugen, empfiehlt es sich, täglich einoder gar zweimal einen Luftstrom durch die Nährlösung zu leiten. Es geschieht dies in einfachster Weise unter Benutzung eines Gasometers. Das bis auf den Boden des Culturgefässes reichende, die Luft zuführende Glasrohr wird durch die dritte Oeffnung des bereits unter 2) erwähnten Deckels der Culturgefässe eingeführt ${ }^{3}$ ).

8) Eine sehr häufige Erneuerung der Nährstofflösung ist gar nicht erforderlich, ja nicht einmal vortheilhaft, wie die Erfahrung vielfach gezeigt hat. In der Regel genügt es, wenn man mit Culturgefässsen von

1) Ueber Vegetationshäuser geeigneter Art vergl. WoLFF, Versuchsstationen, 13d. 8, S. 485 , und NoBBE, ebendaselbst Bd. 12, S. 477.

2) Es empfiehlt sich sehr, den für die Pflanzen bestimmteu Raum ausserhalb des Gewāchshauses mit Drahtnetz zu umgeben, damit die Untersuchungsobjecte keine Beschädigung durch Vögel erfahren.

3) Gasometer sind zu bezichen von R. Mukxcke, Berlin, Luisenstr. 58. Sehr bequem zur Durchlüftung zu benutzen sind auch die von MUkxcke zu beziehenden Wasserstrahlgebläse, ein $A$ pparat, der in einfachster Weise an einem Wasserleitungsabflussrohr angebracht werden kann. Vergl. Mutxcke's Preisverzeichniss, 1886; Thl. 1, S. 76. 
etwa 3 Liter Inhalt arbeitet, die Lösung 2- oder 3 mal im Sommer zu erneuern. Es ist bequem, von vornherein concentrirte Lösungen der Nährsalze herzustellen und diese dann für den Gebrauch entsprechend zu verdünnen. So kann man z. B. in je $50 \mathrm{ccm}$ Wasser $1 \mathrm{~g}$ salpetersauren Kalk, 0,25 g Chlorkalium und 0,25 g saures phosphorsaures Kali lösen; in einer zweiten Lösung auf je $50 \mathrm{ccm}$ Wasser $0,25 \mathrm{~g}$ schwefelsaure Magnesia vorräthig halten. Der fertig hergestellten Nährlösung sind nur noch einige Tropfen verdünnter Eisenchloridlösung hinzuzufügen. $\mathrm{Zu}$ empfehlen ist es, die Pflanzen, wenn das Stadium der Fruchtreife naht, aus der Nährstofflösung zu entfernen und ihnen nur destillirtes Wasser darzubieten, welches man, wenn die Untersuchungen es zulassen, ganz schwach mit Salpeter- oder Phosphorsäure ansäuert.

- 9) Zur Blüthezeit der Pflanzen muss dafür gesorgt werden, dass die Befruchtung normal stattfindet. Gewöhnlich genügt es, die Untersuchungsobjecte im Freien, z. B. vor dem Fenster oder hinter dem geöffneten Fenster, stehen zu lassen. Die Uebertraguug des Pollens auf die Narbe kann dann durch Insekten vermittelt werden.

Für das Gedeihen der mit Hülfe der Methode der Wassercultur zu cultivirenden Pflanzen können, wie gesagt, zumal eine zu starke Er-

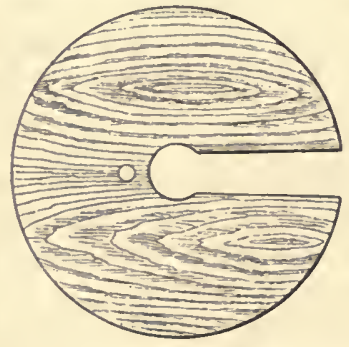

Fig. 2. Holzdeckel eines Tasserculturgeftisses. wärmung der Nährlösung und ferner Sauerstoffmangel in derselben sehr nachtheilig werden. Wortmans ${ }^{1}$ ) hat nun ein einfaches Verfahren angegeben, um die bezeichneten Gefahren für die Pflanzen, wenn nicht völlig $\mathrm{zu}$ beseitigen, so doch wesentlich zu beschränken, ein Verfahren, das namentlich sehr empfehlenswerth ist, wenn es sich darum handelt, schöne Pflanzen mit Hülfe der Methode der Wassercultur für Demonstrationszwecke zu ziehen. 'Man cultivirt die Versuchsobjecte nämlich in sehr grossen Gefässen. Geeignete Gläser sind im Preis von $5 \mathrm{M}$. von Ehrhardt und Metzger in Darmstadt zu beziehen. Sie sind $60 \mathrm{~cm}$ hoch, haben $25 \mathrm{~cm}$ Durchmesser und fassen $26^{1} / 2$ Liter Wasser. Man füllt die Glascylinder, wenn es sich nur um Demonstrationsversuche handelt, mit Brunnenwasser an, setzt die angekeimten Pflanzen (z. B. Phaseolus) ein und lässt sie zunächst etwa 6 Tage ruhig vegetiren. Dann mischt man dem Wasser so viel Nährsalz zu (dasselbe ist z. B. nach der auf S. 2 in zweiter Linie angegebenen Art bereitet), dass die Lösung eine Concentration von $1 \%$ besitzt. Nach 3-4 Tagen wird die Concentration auf $2 \%$ und nach abermals 3-4 Tagen auf $3 \%$ erhöht. Alle 3-4 Tage rührt man die Nährstofflösung gut durch. Eine Erneuerung derselben ist nicht erforderlich, nur auf Ersatz des verdunsteten Wassers achte man. Zur Verdunkelung der Wurzeln genügt es, 1-2 Lagen weissen Leinen- oder Wollstoffs um die Cylinder herumzuschlingen.

Als Deckel des Culturcylinders dient eine runde Holzplatte, deren Rand etwas über denjenigen des Gefässes hinausragt. Das Verschieben des Deckels auf dem Gefässe kann leicht vermieden werden, indem man aut der Aussenseite des Deckels (von unten her) einige Nägel eintreibt. In der Mitte hat der Deckel ein Loch von $3 \mathrm{~cm}$ Durchmesser, in welches

1) Vergl. Wortmaxw, Botan. Zeitung, 1892. 
die Pflanze in bekannter Weise eingesetzt wird. Dicht neben dieser Oeffnung befindet sich eine zweite zur Aufnahme eines nicht zu dicken Stabes, der z. B. einer cultivirten Phaseoluspflanze als Stütze dient. Von der $3 \mathrm{~cm}$ weiten Oeffnung läuft eine ca. $2,5 \mathrm{~cm}$ breite offene Rinne zur Peripherie des Deckels. Durch diese Rinne kann die Versuchspflanze leicht ein- und ausgeführt werden. Die Rinne ist mittelst des Holzstückes zu verschliessen, welches zu ihrer Herstellung aus dem Deckel herausgesägt werden musste. In Fig. 2 ist der Holzdeckel, von oben gesehen, abgebildet. Ich brachte in einem in angegebener Weise her. gerichteten Gefässe, welches sogar nur etwa 5 Liter Wasser fasste, eine Phaseoluspflanze zur prächtigen Entwickelung. Eine völlige Erneuerung der Nährstofflösung fand von Beginn des Versuchs an bis zur Blüthe der Pflanze, wo sie über mannshoch war, gar nicht statt. Bei Culturen der Bohnen machte 'ich oft die Erfahrung, dass diese Pflanze in meinem Arbeitszimmer, wo Mais sich kräftig entwickelte, nicht zur normalen. Ausbildung kam. Relativ trockene Luft und die Verbrennungsproducte des Gases scheinen auf die Vegetation der Bohne weit nachtheiliger einzuwirken, als z. B. auf diejenige des Mais; die erstere Pflanze ist daher, wenn kein Vegetationshaus zur Verfügung steht, stets vor dem Fenster im Freien zu cultiviren.

Ein ausgezeichnetes Object für Wasserculturen, die zur Demonstration dienen sollen, ist auch die Weide. Ich setzte z. B. Anfang Februar. 1894 ein ca. $25 \mathrm{~cm}$ langes und $2 \mathrm{~cm}$ Durchmesser besitzendes Aststück von Salix fragilis in den Holzdeckel des zur Cultur dienenden, 5 Liter fassenden Gefässes ein. Das Gefäss enthielt zunächst nur Brunnenwasser, in das das Aststück bis zur Hälfte seiner Länge eintauchte. Ueber den aus dem Gefässe hervorragenden Theil des Untersuchungsobjectes wurde ein Glascylinder gedeckt. Nach Verlauf von 4 Wochen begannen die Knospen zu treiben, und die Wurzeln waren schon ziemlich lang geworden. Nun wurde der Glascylinder entfernt und das Brunnenwasser im Culturgefäss durch Nährlösung (halb concentrirte) ersetzt. Nach abermals 4 Wochen gelangte Nährlösung von gewöhnlicher Concentration in das Culturgefäss. Jeden Tag fand Ersatz des verdunsteten Wassers und etwa nach je 2 Monaten Erneuerung der Lösung statt. Im Laufe des Sommers entwickelten sich ein mächtiges Wurzelsystem und sechs lange, verzweigte, stark verholzte, ganz normale Seitenäste mit zahlreichen Blättern. Die Pflanze stand im Sommer oft im Freien vor dem Fenster. Anfang September wurde die Nährlösung durch Brunnenwasser ersetzt; das Untersuchungsobject blieb im warmen Zimmer hinter einem nach Süden gelegenen Fenster stehen. Es warf seine Blätter ganz allmählich in der Zeit von Mitte October bis Ende December ab und befindet sich jetzt (10. Januar 1895) noch im Zustande der Winterruhe.

\section{Die Production organiseher Substanz in der griinen Pflanzen. zelle unter dem Einfluss des Lichtes.}

Die Production organischer Substanz in der grünen Pflanzenzelle ist an die Mitwirkung des Lichtes gebunden, ein wichtiger' Lehrsatz der Pflanzenphysiologie, von dessen Richtigkeit man sich durch das Experiment überzeugen muss. Einige Maiskörner werden einzeln gewogen und ilır Trockensubstanzgehalt ermittelt. (Vergl. unter 1.) Nach dem Anquellen und Ankeimen der Körner in Sägespånen wird 
jede Keimpflanze für sich in einem mit Nährstofflösung angefüllten Cylinder in der Weise, wie es unter 1 angegeben worden ist, befestigt. Einige Culturgefässe bringt man nun unter einem grossen Pappkasten ins Dunkle; die anderen werden unter übrigens gleichen Verhältnissen an einem sehr gut beleuchteten Ort dem Wechsel von Tag und Nacht ausgesetzt. Die Blätter der Dunkelpflanzen ergrünen nicht, wie diejenigen der Lichtpflanzen, sondern sie nehmen eine gelbe Farbe an, da sich das normale grüne Chlorophyllpigment nur bei Lichtzutritt in den Zellen ausbilden kann. Nach 4-5 Wochen nimmt man die Untersuchungsobjecte aus den Näln'stofflösungen heraus, trocknet sie an der Luft und ermittelt das Trockensubstanzgewicht jeder Pflanze, das nun mit dem Trockengewicht des betreffenden Samenkornes zu vergleichen ist. Das Trockensubstanzgewicht der Lichtpflanzen findet man erheblich grösser als dasjenige der benutzten Maiskörner, während das Trockengewicht der Dunkelpflanzen unter Umständen, wovon ich mich überzeugte, um 50\% geringer als dasjenige der Samen ausfällt. Bei Lichtabschluss kann keine organische Substanz neu gebildet werden, sondern es wird im Gegentheil ein grosser Theil der vorhandenen organischen Körper durch Stoffwechselprocesse (Athmung) zerstört. Bei Lichtzutritt erfolgt freilich ebenfalls Verathmung organischen Materials, aber die dadurch herbeigeführten Verluste werden durch den Assimilationsprocess mehr als gedeckt, so dass die im Licht vegetirenden Pflanzen fortschreitend reicher an Trockensubstanz werden können ${ }^{1}$ ).

\section{Die Assimilationsorgane.}

Wenn wir zunächst nur diejenigen Verhältnisse berücksichtigen, die uns bei den höheren Pflanzen entgegentreten, so ist zu bemerken, dass die meisten derselben entwickelte Laubblätter tragen. Diese sind in allererster Linie als Assimilationsorgane anzusehen. Ihre Spreite bietet der kohlensäurehaltigen Luft eine grosse Fläche dar, und ihr grünes Gewebe wird durch die eigenthümliche Anordnung der Nerven in einem ausgespannten Zustande erhalten. Die Nerven führen dem Mesophyll auch die für das Leben und die Functionen der Zellen des chlorophyllreichen Parenchyms nothwendigen Wasser- sowie Mineralstoffquantitäten zu. Die Anordnung der Nerven im Blatt ist bei verschiedenen Gewächsen freilich eine ungemein mannigfaltige, und man kann sich z. B. in folgender Weise specieller über die hier in Betracht kommenden Verhältnisse orientiren. Ein Blatt von Impatiens parviflora wird in Alcohol gelegt, bis der Chlorophyllfarbstoff extrahirt ist. Dann bringt man das Blatt einige Zeit in eine Aufösung von 5 Thl. Chloralhydrat in 2 Thl. Wasser. Darin wird das Untersuchungsobject in hohem Grade durehsichtig, und es können Stücke desselben ohne weiteres der mikroskopischen Untersuchung- unterzogen werden. Im Mesophyll fällt das Vorhandensein von gestreckten Zellen auf, die Raphidenbündel (Krystalle von Kalkoxalat) enthalten. Das Blatt wird von einem ziemlich starken Mittelnerven durchzogen, von dem aus Seitennerven erster Ordnung nach dem Blattrande zu abgehen, wo sie, im Bogen verlaufend, an die nächst höheren Seitennerven erster Ordnung ansetzen. Die Nerven erster Ordnung geben die Nerven zweiter

1) Ueber ähnliche Versuche, wie solche hier besprochen worden sind, vergl: Detwer, Versuchsstationen, Bd. 14. 
Ordnung ab, diese diejenigen dritter Orlnung etc., so dass ein vielfach gegliedertes Netzwerk gebillet wird, dessen letzte, sehr feine Zweige zum Theil blind im Mesophyll endigen ${ }^{1}$ ).

Zur allgemeinen Orientirung über den anatomischen Bau des Mesophylls stellen wir uns nunmehr möglichst dünne Querschnitte aus Blättern her und wälılen als Untersuclıungsobject z. B. die Laubblätter von Dahlia variabilis, Vitis vinifera, Berberis vulgaris, Syringa vulgaris, Trifolium pratense, Ilex oder Fagus silvatica. Bei mikroskopischer Untersuchung der Querschnitte fällt sofort auf, dass das grüne Mesophyll auf der Ober- und Unterseite der Blätter, der angeführten Pflanzen nicht gleichmässig gebaut ist. (Vergl. Fig. 3.) Unter der Epidermis der Blattoberseite constatiren wir das Vorhandensein schlauchförmiger, rechtwinkelig zur Blattoberfläche gestreckter Zellen, die man

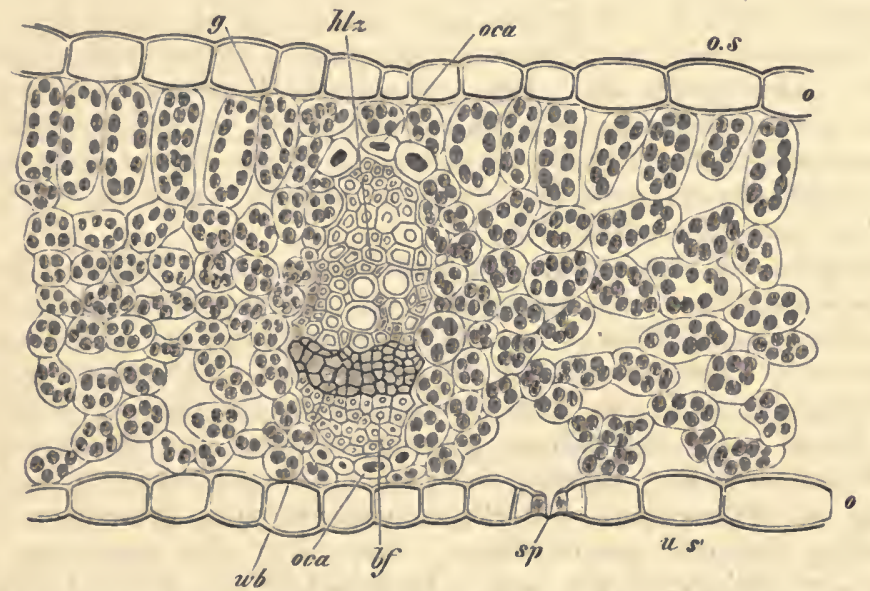

Fig. 3. Quersehnitt eines Theiles eines ansgewachsenen Blattes ron Trifolium pratense. $0 . s$ Oberseite, u.s Unterseite des Blattes, o Epidermis, sp Spaltöffnung, oca Krystall von Kalkoxalat in der Krystallscheide des Gefässbündels, $h t_{\approx}$ Holztheil des Gefässbündels, g Gefässe, $u b$ Weichbast, of Bastfasern. Vergr. 300. (Nach H. DE VRIES.)

als Palissadenzellen bezeichnet, während auf der Blattunterseite das an Intercellularen reiche Schwammparenchym entwickelt ist. Freilich führen sowohl die Zellen des Palissaden-, sowie diejenigen des Schwammparenchyms Chlorophyllkörner, aber aus Gründen, die erst an anderer Stelle specieller auseinandergesetzt werden können, ist das erstere für das Zustandekommen einer recht energischen Assimilation von besonderer Bedleutung, und daher verdient das Vorhandensein desselben an der Oberseite vieler Blätter specielle Beachtung.

Zur Begründung der Anschauung, nach welcher das Palissadenparenchym als specifisches Assimilationsgewebe angesehen werden muss; lassen sich auch Thatsachen der vergleichenden Anatomie geltend machen.

Sarothamnus vulgaris ist ein Strauch, der nur sehr kleine Blätter trägt, die für die assimilatorische Arbeit nicht ausreichend erscheinen. Die vielfach verzweigten Stammgebilde müssen hier neben den Blättern

1) Vergl. SACHs, Vorlesungen über Pflanzenphysiologie, 18s2, S. 60. 
thätig sein, um genůgende Quantitäten organischer Substanz für die Pflanze zu erzeugen. Ein Stengelquerschnitt stellt sich uns als fünfstrahliger Stern dar, und wenn wir einen dünnen Querschnitt mikroskopisch untersuchen, so ergiebt sich, dass unter der Epidermis der Strahlenenden sklerenchymatisches Gewebe vorhanden ist, während das peripherische Gewebe der Buchten zwischen den Strahlenenden grün erscheint. Wir stellen fest, dass dies Gewebe in seinen äusseren Schichten aus Palissadenzellen besteht, die rechtwinkelig zur Stengeloberfläche gestreckt erscheinen, während weiter nach innen $\mathrm{zu}$ mehr isodiametrische chlorophyllhaltige Zellen folgen. Wir untersuchen auch noch einen dünnen Querschnitt aus dem Stengel von Spartium junceum. Das assimilatorisch thätige Gewebe unter der Epidermis besteht hier seiner Gesammtmasse nach aus Palissadenzellen. Es folgen etwa 6 Schichten rechtwinkelig zur Stengeloberfläche gestellter, stark gestreckter, grüner Zellen auf einander. Das grüne Gewebe bildet aber keinen geschlossenen Ring unter der Oberhaut, sondern es wechselt im Umkreise des ganzen Stengels Assimilationsgewebe mit Sklerenchym ab. Bei armlaubigen Pflanzen oder solchen Gewächsen, die gar keine grünen Blätter produciren, muss das grüne Gewebe der Stammgebilde die Arbeit der Assimilation der Hauptsache nach oder gänzlich übernehmen, und dies Gewebe besteht daher im Wesentlichen oder völlig aus Palissadenzellen.

Uebrigens ist keineswegs den Laubblättern aller Pflanzen der Besitz des Palissadenparenchyms eigenthümlich. Untersucht man z. B. Querschnitte der jungen Blätter von Triticum vulgare, so findet man, dass das Mesophyll, welches an der Blattober- und Unterséite von der Epidermis begrenzt und von den Gefässbündeln durchzogen wird, seiner ganzen Masse nach aus nahezu gleichgestalteten, im Querschnitt rundlichen Zellen besteht. Blätter, hei denen es noch nicht zu einer Differenzirung von Palissaden- und Schwammparenchym gekommen ist, sind auch häufig dadurch ausgezeichnet, dass nicht das gesammte Gewebe zwischen der Epidermis der beiden Blattflächen aus chlorophyllführenden Zellen besteht. Untersuchen wir z. B. einen Blattquerschnitt von "Iris germanica, so finden wir unter der Epidermis der Blattoberseite sowie der Blattunterseite grünes Gewebe. Ausserdem treten die Gefässbündel deutlich hervor, deren Basttheil nach aussen hin mit einem Bastfaserbeleg versehen ist, und ferner sieht man sofort, dass die Mittelschicht des Blattes aus saftreichen, nicht grünen Zellen besteht. Solche chlorophyllfreie Zellen sind auch in den Blättern von Hyacinthus orientalis und den succulenten Blättern der Aloë-Species reichlich vorhanden.

Es muss hier ferner auf die interessante Thatsache hingewiesen werden, dass die Blätter mit deutlich entwickeltem Schwamm- und $\mathrm{Pa}$ lissadenparenchym eben hierdurch streng dorsiventral gebaut erscheinen und zu den exquisit plagiotropen Organen gehören. Aber keineswegs sind sämmtliche Laubblätter streng dorsiventral gebaut; es giebt auch viele Dicotylen mit centrisch organisirtem Mesophyll der Blätter, die dann meist eine mehr orthotrope Entwickelung zeigen. So besitzen z. B. die Blätter von Anchusa italica, Centaurea Jacea, Tragopogon orientalis, Aster Amellus, Genista tinctoria etc. centrischen Bau. Bei der zuletzt genannten Pflanze besteht das Mesophyll fast nur aus senkrecht zur Blattfläche gestreckten Zellen. Centaurea Jacea variirt, wovon ich mich oft überzeugte, je nach ihrem Standort ungemein. Die der Sonne stark ausgesetzten Individuen erzeugen z. B. lange schmale Blätter, welche relativ dick sind. Die Blätter der Schattenpflanzen erscheinen dünner, 
aber mehr in die Fläche entwickelt. Das Mesophyll der Blätter von Centaurea Jacea, zumal der Sonnenpflanzen, ist nicht dorsiventral, sondern centrisch gebaut. Man sieht leicht boi mikroskopischer Untersuchung zarter Querschnitte, dass auf der Ober- sowie Unterseite der Blätter Palissadenparenchym vorhanden ist ${ }^{1}$ ).

Die Blattstiele sind gewöhnlich arm an chlorophyllführenden Zellen, weil sie meistens nicht als Assimilationsorgane der Gewächse functioniren, sondern für ganz andere Leistungen in Anspruch genommen werden. Die mikroskopische Untersuchung eines Querschnitts durch den Blattstiel von Vitis vinifera lehrt, dass nahe unter der Epidermis Gruppen von Collenchymbüudeln vorhanden sind, und dass sich zwischen diesen Bündeln schwach entwickeltes grünes Parenchym sowie Zellen befinden, von denen bald viele, bald nur wenige einen rothen im Zellsaft gelösten Farbstoff führen. Die aus den erwähnten verschiedenartigen Geweben bestehende Rinde des Blattstiels umschliesst den Gefässbündelkreis und das Mark. Auch bei der Untersuchung der Blattstiele anderer Pflanzen, z. B. derjenigen von Chenopodium bonus Henricus, lässt sich leicht feststellen, dass sie sehr arm an grünem Gewebe sind.

Wir stellen auch noch einen Querschnitt des Blattstieles einer Begonie (ich untersuchte speciell Begonia manicata) her. Auf die Epidermis folgt ein Collenchymring, dann grosszelliges Grundgewebe, in welchem die Gefässbündel nicht in einem Kreise angeordnet sind. Die peripherischen Schichten des grosszelligen Grundgewebes sind freilich chlorophyllhaltig, aber die Zellen führen nur wenige, allerdings relativ grosse Chlorophyllkörner.

Die grünen Stengel der Pflanzen betheiligen sich gewöhnlich ebenso wie die Blattstiele nur in sehr beschränktem Umfange an der assimilatorischen Arbeit, und daher enthält die Hauptmasse ihres Gewebes keine Chlorophyllkörner. Stellen wir z. B. einen Querschnitt aus dem Stengel einer Mohnspecies her, so gewahren wir im Centrum das Mark. Nach aussen folgen die Gefässbündel, von denen jedes, abgesehen vom Holztheil, aus einer breiten Weichbastzone und dieser nach aussen angelagerten Bastfaserregion besteht. Die Markverbindungen zwischen den einzelnen Gefässbündeln bestehen aus grossen Zellen. Für die Rinde ist das Vorhandensein eines geschlossenen Sklerenchymcylinders beson. ders charakteristisch; nach aussen wird dieser von einer im Verhältniss zur Gesammtmasse des Papaverstengels schwach entwickelten Schicht grünen Gewebes umschlossen, und an dieses Chlorophyllparenchym grenzt unmittelbar die Epidermis. Wir untersuchen auch noch einen Querschnitt des Stengels von Chenopodium bonus Henricus und finden, dass unter der Epidermis Collenchym und grünes Parenchym mit einander abwechseln ${ }^{2}$ ).

\section{Die Durchleuchtung der Pflanzengewebe.}

Das Licht ist für den Verlauf sehr verschiedener physiologischer Processe in der Pflanze von grosser Bedeutung, und die Lichtstrahlen von ungleicher Brechbarkeit sind bezüglich des Einflusses, den sie auf

1) Vergl. Hervricuer, in Pringsheim's Jahrb. f. wissensch. Botanik, Bd. 15.

2) Literatur über das Assimilationsgewebe: PrCK, Beiträge zur Kenntniss des assimilirenden Gewebes armlaubiger Pflanzen, Bonn 1881; G. HABERLANDT, Pringsheim's Jahrbücher f. wissenseh. Botanik, Bd. 13; StAHL, Botan. Zeitung, 1880: 
das Pflanzenleben ausüben, keineswegs als gleichwerthig zu betrachten. Es ist daher nicht ohne Interesse, einige Experimente über die Durchleuchtungsverhältnisse pHanzlicher Gewebe anzustellen. 'Die Tiefe, bis zu welcher Lichtstrahlen in pHanzliche Gewebe cindringen, hängt einerseits $a b$ von der Intensität, sowie der Brechbarkeit der ersteren, andererseits von der chemischen Beschaffenheit der Zellenbestandtheile selbst und dem anatomischen Bau der Gewebe. Mit Rücksicht auf diesen letzteren Punkt spiclt unter anderem das Vorhandensein eines mehr oder minder entwickelten Intercellularsystems eine wichtige Rolle. Sind z. B. viele Intercellularen vorhanden, so müssen die einfallenden Strahlen sehr oft aus der Zellflüssigkeit und den mit Wasser imbibirten Zellhäuten in Luft übergehen, was den Grad der Durchsichtigkeit eines Gewebes natürlich erheblich herabmindert. Die Bedeutung der Intercellularen für die hier in Rede stehenden Verhältnisse wird sofort klar, wenn man das folgende Experiment anstellt. Ein Blattstück von Begonia manicata wird in Wasser gelegt, das sich in einem kleinen Glase befindet. Man verschliesst die Mündung des Glases mit einem Kautschukkork, durch dessen Bohrung der eine Schenkel eines im rechten Winkel gebogenen Glasrohres gesteckt worden ist, während der andere Schenkel mit der Luftpumpe in Verbindung gesetzt wird. Evacuirt man, so entweicht die Luft aus den Intercellularen des Blattstückes; dieselben füllen sich aber mit Wasser, und das Untersuchungsobject erscheint nun weit durchscheinender als bei Beginn des Versuchs. Taucht man die Spreite eines Blattes von Primula sinensis in Wasser und nimmt man das Ende des Blattstieles in den Mund, um die Luft aus dem Intercellularsystem durch Saugen zu entfernen, so dringt durch die Spaltöffnungen des Blattes Wasser in die Intercellularen ein, wodurch das Gewebe ziemlich durchscheinend wird.

Einen geringen Grad von Durchsichtigkeit besitzt in Folge der specifischen Natur seiner Zellmembranen das Korkgewebe. Ebenso absorbiren chlorophyllreiche Gewebe in Folge der Gegenwart des grünen Pigments viel Licht und lassen nur relativ wenig passiren. Hier ist auch der Ort, zu erwähnen, obgleich wir unter 7 noch specieller auf das Absorptionsvermögen des Blattgrüns für Lichtstrahlen zurückkommen, dass das Chlorophyllpigment ein sehr energisches Absorptionsvermögen für die sogen. chemischen Strahlen besitzt. Man kann sich hiervon leiclıt überzeugen, wenn man ein beliebiges grünes Blatt auf ein Stück photographischen Papiers legt und dasselbe nunmehr zwischen zwei Glasplatten dem Einflusse des Lichtes exponirt. Der nicht von dem Blatte bedeckte Theil des Papiers bräunt sich schnell; der bedeckte verändert seine weisse Farbe nicht oder nicht wesentlich, weil der Chlorophyllfarbstoff im Blattgewebe die sogen. chemischen Strahlen sehr energisch absorbirt.

Um die Tiefe $\mathrm{zu}$ bestimmen, bis $\mathrm{zu}$ welcher Licht von einer Intensität, die für das Auge noch wahrnehmbar ist, in Gewebeschichten eindringt, benutzt man nach $\mathrm{SACHS}^{2}$ ) das einfache Diaphanoskop (Fig. 4). Dieser Apparat besteht aus einem aus dicker Pappe gefertigten Rohr $a$ von $60 \mathrm{~mm}$ Länge und $35 \mathrm{~mm}$ Durchmesser, das an einem Ende offen, am anderen Ende bis auf eine kleine Oeffnung von

1) Vergl. SACHS, Sitzungsber. d. Akadem. d. Wiss. zu Wien, 1860, Bd. 43. Vergl. auch ExGelsians, Bot. Zeitung, 1857, S. 393. 
etwa $10 \mathrm{~mm}$ Durchmesser geschlossen ist. Ueber dieses Ende des Rohres a kann eine $z$ weite Pappröhre $l$ gesehoben werden, die ganz ähnliche Beschaffenheit wie das Rolır a besitzt. Legt man die Untersuchungsobjecte zwischen die Röhren, hält das offene Ende des Rohres $a$ dicht an das Auge und richtet den Apparat gegen die Sonne oder eine helle Wolke, so kann man die Durchleuchtungsverlıältnisse pflanzlicher Gewebe studiren. Als ich ein Blattstück von Lonicera tatarica in das Diaphanoskop einschaltete, erschien das durchgegangene Licht hellgrün. 4 Blattstüicke eingeselıaltet, liessen alsbald deutlich erkennen dass grünes Licht hindurchging. Wurden 6 Blattstücke eingeschaltet, so nahm clas Auge nach längerem Hineinsehen in den Apparat einen gelblichen Schein wahr.

Zur Herstellung eines analysirenden Diaphanoskops braucht man das einfache Diaphanoskop nur über den vorderen 'Theil der Rölıre eines geeigneten Spectroskops zu schieben, und dieses, indem man beobachtet, gegen helle Wolken oder den blauen Himmel zu richten. Als ich ein Blattstïick von Syringa vulgaris in das Diaphanoskop eingeschaltet hatte, zeigte sich, dass dasselbe Roth, Orange, Gelb, Grün und etwas Blau, freilich geschwächt, passiren liess. Die brcchbareren Strahlen wurden völlig absorbirt. 2 Blattstücke von Syringa liessen nur noch Roth, Orange, Gelb und Grïn sehr geschwächt

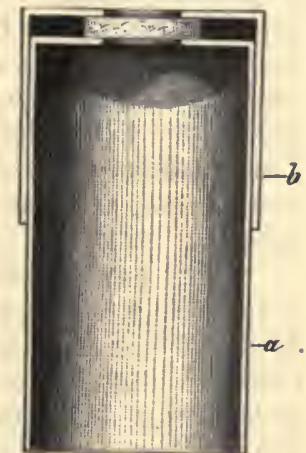

Fig. 4. Diaphanoskop, im Iaingsschnitt dargestellt. passiren, andere Strahlen nicht. Eine $17 \mathrm{~mm}$. dicke Gewebeplatte aus dem Parenchym einer Kartoffelknolle, die ich in das Diaphanoskop eingeschaltet hatte, absorbirte die brechbareren Liclitstralılen völlig, liess aber Roth, Orange, Gelb, Grün und eine Spur Blau sehr gesehwächt passiren. Nach den Resultaten dieser Beobachtungen dringen die weniger brechbaren Lichtstrahlen also tiefer als diejenigen von hoher Brechbarkeit in das Pflanzengewebe ein.

\section{Die Chlorophyllkörper.}

Als Organe der assimilatorischen Thätigkeit der Zellen sind die Chlorophyllkörper anzusehen. Die Gestalt derselben ist gewölnlich eine scheibenförmige; in den Zellen mancher Algen kommen auclı andersartige Chloropliyllkörper vor. Wir bringen z. B. einige Fäden einer Algenart, die in stehenden Gewässern laăufig vorkommt, nämlich einer Zygnemaspecies, mit einem Wassertropfen auf den Objectträger, bedecken mit dem Deckglase und untersuchen das Object bei etwa 500 facher Vergrösserung. Es zeigt sich, dass jeder Faden aus einer ganzen Reihe von Zellen besteht, und dass in jeder Zelle zwei grün gefärbte, sternförmige Gebilde, eben die Chlorophyllkörper, vorhanden sind. Wir sehen auch den Zellkern in der Mitte jeder Zelle.

Die Spirogyra-Arten sind Algen, welche zumeist in stehenden Gewässern vorkommen und aus unverzweigten Zellfäden bestehen. In jeder Zelle erblickt man bei mikroskopischer Untersuchung grüne Spiralbänder, je nach den Arten in verschiedener Anzahl, welche dic Chlorophyllkörper repräsentiren. Das wandständige Plasma und der 
im Zellsafte mittelst dünner Plasmafäden ausgespannte Zellkern sind häufig leicht zu beobachten. Bemerkt sei noch, dass den Bändern der Spirogyra in gewissen Abständen kugelige, farblose Gebilde eingelagert sind, die Amylumherde, welche je ein aus Eiweissstoffen bestehendes Pyrenoid von eckigen Contouren umschliessen. Die Pyrenoide sind von vielen kleinen Stärkekörnern umgeben.

Wenn man einmal in den Besitz guten Spirogyramaterials gelangt ist, so sollte man dasselbe, da wir es bei der Ausführung verschiedener physiologischer Experimente gebrauchen, zu cultiviren suchen. Dies geschieht nach STRASBURGer am besten, indem man die Algen in nicht zu tiefe, mit Brunnenwasser gefüllte Gefässe bringt, deren Wände nicht durchsichtig sind oder durch Ueberkleben mit schwarzem Papier undurchsichtig gemacht werden. Man setzt dic. Algen hellem, diffusem Licht (nicht directem Sonnenlicht) aus und wirft von Zeit zu Zeit kleine Torfstückchen, welche nach dem Auskochen mit gewöhnlicher Nährstofllösung, wie man sie bei der Ausführung von Wasserculturversuchen braucht, getränkt sind, in das Wasser.

Sehr häufig sind in stehenden, sowie fliessenden Gewässern Arten der Gattung Cladophora, Algen, die rauh anzufühlende, verzweigte Fäden darstellen. Die Seitenzweige entspringen aus dem oberen Ende der Gliederzellen. Zur weiteren Untersuchung ist ziemlich starke Vergrösserung anzuwenden, und es ergiebt sich dabei, dass der grüne Wandbeleg der Zellen aus kleinen, polygonalen Gebilden besteht, die durch zarte, farblose Linien von einander getrennt sind. Die Chlorophyllkörper von Cladophora sind denjenigen höherer Pflanzen schon ziemlich ähnlich.

Es mag hier auch gestattet sein, einen merkwürdigen Organismus, der oft in Wassertümpeln an untergetauchten Pflanzentheilen haftend angetroffen wird, zu erwähnen. Ich habe hier die Hydra viridis im Auge, ein kleines Wasserthierchen von 5-12 mm Länge und grüner Farbe. Wenn wir die Hydra in einen Wassertropfen bringen und sie, um sie nicht zu beschädigen, ohne Benutzung eines Deckglases mikroskopisch untersuchen, so erkennen wir leicht, dass der Organismus ein sackartiges Gebilde darstellt, das aus zwei Hüllen, dem Ektoderm und dem Endoderm, besteht, am vorderen Ende eine Mundöffnung besitzt (eine Afteröffnung fehlt), die von vielen Tentakeln umgeben ist, und sich contrahiren, aber auch wieder ausstrecken kann. In Endoderm des cylindrischen Körpers der Hydra, sowie im Endoderm der Tentakeln gewahrt man zahlreiche grüne, kugelige Gebilde. Es sind dies einzellige Algen, die im symbiotischen Verhältniss mit der Hydra viridis leben. Diese gewährt ihnen Schutz, während die Algen der Hydra dadureh nützen, dass sie ihr in Folge ihrer assimilatorischen Thätigkeit organische Substanz, sowie freien Sauerstoff zur Verfügung stellen.

In Gewächshäusern, in welchen Farne cultivirt werden, findet man gewöhnlich mit Leichtigkeit an feuchten Wänden oder an den Stämmen von Baumfarnen Farnprothallien auf, kleine, grüne, meist herzförmige, dem Substrat anliegende Gebilde, die wir, nachdem wir sie mit der Pincette von ihrer Unterlage abgehoben und mit Wasser abgespült haben, im Wassertropfen mikroskopisch untersuchen. Die Prothallien sind bis auf einen medianen Theil einschichtig; sie sind gewöhnlich dureh den Besitz einer an ihrem vorderen Ende befindlichen Einbuchtung ausgezeichnet und produciren auf ihrer Unter- 
oder Bauchseite ziemlich lange Wurzellıare. Für unsere Zwecke ist es besonders wichtig, dass in den grün ersclieinenden Prothalliumzellen zahlreiche Chlorophyllkörper leicht zu sehen sind.

, Lehrreich ist es ferner, ein Blatt des verbreiteten Mooses Funaria hygrometrica mikroskopisch zu untersuchen. Wir wählen, aus hier nicht zu erörternden Gründen, Pflanzen aus, die einige Zeit lang diffusem Tageslicht ausgesetzt gewesen sind, und finden, dass die Zellen des bis auf die Mittelrippe einschichtigen Blattes viele grosse Chloropliyllkörner enthalten, die zum Theil in Theilung begriffen sind.

Wir stellen ferner einen Quersehnitt durch den Thallus von Marchantia polymorpha (es ist dies ein auf feuchtem Boden recht häufig vorkommendes, gabelig verzweigtes Lebermoos) her. Ohne Rücksicht auf Details genügt es uns hier, das Vorhandensein eines chlorophyllreichen Gewebes an der Thallusoberseite $\mathrm{zu}$ constatiren. Es folgt eine chlorophyllarme Mittelschicht, und an der Bauchseite befinden sich wieder zwei chlorophyllreichere Zellschichten.

Wird ein Blatt aus der Knospe von Elodea canadensis in einem Wassertropfen auf den Objectträger gebracht, so werden wir bei mikroskopischer Betrachtung nach kurzem Suchen Zellen finden, welche die in Fig. 5 dargestellten Verhältnisse zur Anschauung bringen. Das wandständige Plasma, die kernhaltige Protoplasmamasse und die von dieser letzteren ausgehenden Protoplasmastränge sind leicht $\mathrm{zu}$ sehen. Das Protoplasma zeigt häufig auch ziemlich lebliafte Bewegungserscheinungen, und im Plasma treten die Chlorophyllkörper deutlich hervor.

Werden von der Unterseite eines Escheveriablattes die äusseren Zellschichten entfernt, und untersucht man Schnitte des folgenden lockeren Blattgewebes, so erblickt man in den niclit verletzten Zellen grosse Chlorophyllkörner, dic deshalb besonders interessant sind, weil sie, bei ziemlich starker Vergrösserung untersucht, eine schaumige Struc-

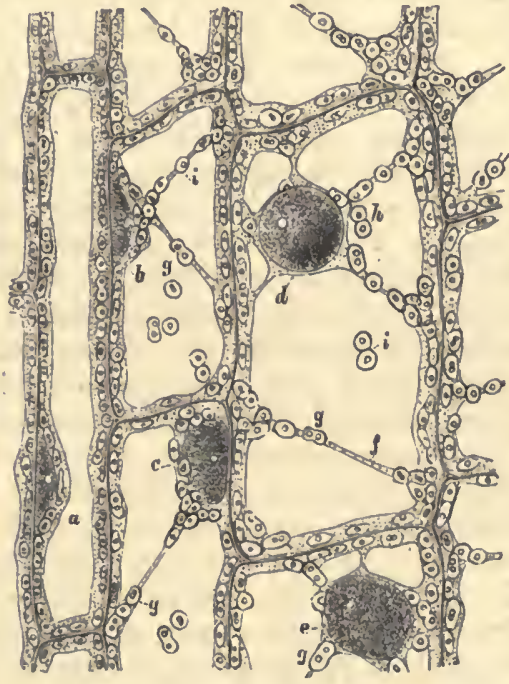

Fig. 5. Einige Zellen aus dem Blatt ron Elodea eanadensis, $a$ bis $e$ Zellkerne, $f$ Protoplasmabänder, $g$ Chlorophyllkörner, zum Theil in Theilung und mit Einschluss von Stärkekörnchen. (Nach K×Y.) tur relativ deutlich hervortreten lassen. Man darf, annehmen, dass alle Chlorophyllkörper ein solche Struetur besitzen; dieselbe ist aber keineswegs stets leicht $\mathrm{zu}$ constatiren.

Wenn wir Lupinensamen bei Lichtzutritt zum Keimen bringen, so nehmen die über die Bodenoberfläche hervortretenden Cotyledonen eine grüne Farbe an. Die mikroskopische Untersuchung des Querschnittes eines Keimblattes lässt die Epidermis, das Grundgewebe, sowie die Gefässbündel leicht wahrnehmen, und in den Zellen des 
Grundgewebes, zumal den peripherisch gelegenen, sind viele relativ grosse Chlorophyllkörner zu erkennen ${ }^{1}$ ).

Es ist von Wichtigkeit, hier zu betonen, dass es manche Pflanzentheile giebt, die nicht chlorophyllgrün aussehen, aber dennoch reichliche oder geringe Chlorophyllmengen enthalten und demnach zu assimilatorisclier Thätigkoit befähigt sind. Wir stellen Querschnitte durch Blätter rothblättriger Varietäten von Corylus oder Fagus her. In den Zellen des Palissaden- sowie des Schwammparenchyms sind, wie in denjenigen grüner Blätter, zahlreiche Chlorophyllkörner vorhanden, aber die Epidermiszellen enthalten roth oder violett gefärbten Zellsaft; die in der Epidermis vorhandenen Pigmente verdecken in den unversehrten Blättern also nur die Farbe des Blattgrüns. Die jungen Blätter mancher Pflanzen (z. B. der Eichen) erscheinen nicht grün, sondern roth, später werden die Blätter aber grün. Das Mesophyll der jungen Blätter enthält zahlreiche Chlorophyllkörper, wovon man sich beim Studium von Querschnitten überzeugen kann, indessen im Zellsaft der Zellen des Assimilationsgewebes, zumal des Palissadenparenchyms, sind rothe Farbstoffe aufgelöst. In diesem Falle dient das rothe Pigment den jugendlichen, tiefer liegenden grünen Zellen als ein Schutzmittel gegen $\mathrm{zu}$ intensives Licht.

Die Neottia Nidus avis ist eine zu der Familie der Orchideen gehörende Pflanze, welche im humusreichen Boden feuchter Wälder häufig angetroffen wird. Die ganze Pflanze besitzt eine braune Farbe; sie scheint keinen Chlorophyllfarbstoff zu enthalten. Ein Querschnitt, den wir aus einer etwa $6 \mathrm{~cm}$ unter dem.Blüthenstande liegenden Region des Stengels führen, lässt bei mikroskopischer Untersuchung die Epidermis, das Parenchym der Rinde sowie des Markes und einen dazwisehen befindlichen Sklerenchymcylinder sammt den Gefässbündeln dentlich erkennen; grüne Chlorphyllkörper finden wir aber nirgends. Wird eine Neottiapflanze nach dem Zerquetschen mit Alkohol übergossen, so ist es leicht, einen chlorophyllgrünen Extract zu erhalten, der auch die gewöhnlichen Fluorescenzerscheinungen einer Blattgrünlösung zeigt. In der That enthält die Neottia, wie Wiesser ${ }^{2}$ ) zuerst fand, Chlorophyllfarbstoff; die Pflanze kann also assimiliren und einen Theil der organischen Substanz, deren sie bedarf, aus anorganischem: Material selbst produciren, während sie freilich einen anderen Theil von aussen aufnimmt. Zur weiteren Orientirung stellen wir die folgende Beobachtung an. Wir ziehen ein Stückchen Epidermis von dem Fruchtknoten einer Neottiabluthe ab und untersuchen dasselbe- bei starker Vergrösserung. In der Umgebung des Zellkernes der Zellen sehen wir rundliche oder spindelförmige, braun gefärbte Farbstoffkörperchen, die, wenn wir das Präparat mit Alkohol behandeln, ergrünen. Solche Pigmentträger finden sich ebenfalls, freilich nicht in so grosser Menge, in den Geweben des Stengels, und in allen Fällen hahen wir es mit Farbstoffträgern zu thun, die neben dem Chlorophyllpigment einen unter gewöhnlichen Umständen die grüne Farbe desselben völlig verdeckenden braunen Farbstoff führen.

In den braunen Fucusarten ist die Farbe des Chlorophyllpigments ebenfalls durch das Vorhandensein eines braunen Farbstoffes verdeckt, wovon ich mich in folgender Weise überzeugte. Ich sammelte in der Nähe von Cuxhaven Fucus vesiculosus, verpackte die Algen gut, so dass

1) Ueber verschiedene hier berührte Verhältnisse vergl. STRAsBurgeR's Botan. Practicum.

2) Vgl. WifsNer, Pringsheim's Jahrbücher f. wissensch. Botanik, Bd. 8, S. 575. 
das Untersuchungsmaterial frisch blieb, und stellte den eigentlichen Versuch am nächsten Tage an. Die jüngeren Theile der Pflanzen wurden abgeschnitten und kurze Zeit mit Wasser ausgekocht. Nach dem Abgiessen der braunen Brühe erschien das Gewebe der Algen grün ${ }^{\mathbf{1}}$ ). Icl spülte sie nun mit kaltem Wasser ab und übergoss sio mit Alkohol. Dieser nahm alsbald eine gelbgrünliche Farbe an; er wurde entfernt und durch eine neue Alkoholmenge ersetzt. Man erhält auf diese Weise eine prächtig grün gefärbte Chlorophylllösung, welche stark fluorescirt ${ }^{2}$ ).

Wir behandeln Blätter aus der Ḱnospe von Elodea, Blätter von Funaria hygrometrica oder Farnprothallien (die beiden zuletzt genannten Objecte sind hier besonders zu empfelılen) längere Zeit mit Alkohol. Die Pflanzentheile werden farblos, und bei mikroskopischer Untersuchung erblickt man die von ihrem Pigment befreite protoplasmatische Grundınasse der Chlorophyllkörper in den Zellen. Bringen wir die Präparate mit einem Tropfen einer verdünnten wässerigen Lösung von Methylviolett in Berührung, so werden die entfärbten Chlorophyllkörper stark tingirt.

\section{Der Chlorophyllfarbstoff.}

In neuerer Zeit sind zahlreiche Versuche, zumal von SAchsse, Hansen und Tschirch, gemacht worden, den Chlorophyllfarbstoff in reinem Zustande aus grünen Pflanzentheilen $\mathrm{zu}$ isoliren. Diese Untersuchungen haben ebenso wie auch schon die älteren von G. Kraus ${ }^{3}$ ) zu dem Resultate gefïhrt, dass das Chlorophyllpigment ein Gemisch zweier Farbstoffe, nämlich eines blaugrünen, des Cyanoplıylls, und eines gelben, des Xanthophylls, repräsentirt. Wir wollen hier aber auf die neueren Arbeiten nicht genauer eingehen, denn einmal besitzen ihre Resultate heute noch ein melır phytochemisches als speciell pflanzenphysiologisches Interesse, und ferner sind die bei der Isolirung mehr oder minder reiner Chloropliyllpräparate zur Anwendung kommenden Methoden recht complicirter Natur, und ihre Handhabung eine selır zeitraubende. Dagegen müssen wir die Untersuchungen von G. KRaus specieller berücksichtigen.

Sogenaunte Rohchlorophylllösungen können wir schliesslich aus beliebigen grünen Pflanzentheilen darstellen, aber es ist zweckmässig, um einen relativ reinen Chlorophyllextract zu gewinnen, junge Weizenpflanzen oder Elodea-Exemplare als Untersuchungsmaterial zu verwenden. Wir schneiden die oberirdischen Theile junger Weizenpflanzen, die sich etwa bis zur Ausbildung des sechsten Blattes entwickelt haben, ab, oder wir sammeln eine nicht zu kleine Menge frischer Elodeapflanzen, bringen das Material (etwa 100-150 g frischer Substanz) in eine Porzellanseliale und kochen es auf dem Wasserbade einige Zeit $(1 / 4-1 / 2$ Stunde lang) mit destillirtem Wasser aus. Die Brühe wird abgegossen, das Pflanzenmaterial mit Wasser mehrfach ausgewaschen und nun nach dem Abpressen in einem geräumigen

1) Den erwähnten braunen Farbstoff nennt man Phycophaein. Der rothe, in Wasser lösliche Farbstoff, den dic Florideen neben Chlorophyll enthalten, heisst Phycoerythrin. Die blaugrünen Spaltalgen enthalten neben Chlorophyllfarbstoff Phyeocyan.

2) Vgl. Haxsex, Arbeiten d. bot. Instituts in Würzburg, Bd. 2, S. 289.

3) G. KraUs, Zur Kenntniss der Chlorophyllfarbstoffe. Stuttgart 1872. 
Kolben mit 1/2-1 Liter 95-proc. Alkohol übergossen. Die Extraction geht, zumal wenn man schwach erwärmt, ziemlich schnell ror sich. Es ist nothwendig, den Auszug im Dunkeln zu bereiten, da der Chlorophyllfarbstoff, wie wir später sehen werden, sehr leicht durch den Einfluss des Lichtes zersetzt wird. Die erhaltene Chlorophyllpigmentlösung besitzt eine prachtvoll grüne Farbe.

Das Blattgrün, wie dasselbe an eine protoplasmatische Grundmasse gebunden in den Pflanzenzellen vorkomint, ist nun auf keinen Fall als ein chemisches Individuum aufzufassen, sondern es stellt dasselbe ein Gemenge zweier Farbstoffe, des gelben Xanthophylls und des blaugrünen Cyanophylls, dar, wovon man sich leicht durch den folgenden Versuch überzeugen kann.

Wir bringen recht concentrirte alkoholische Chlorophylllösung in einen Glascylinder, fügen ihr tropfenweise etwas Wasser hinzu, aber nur so viel, dass keine Trübung bemerklich wird, versetzen sie mit Benzol, schütteln tüchtig und überlassen die Flüssigkeit darauf der Rule. Die Mischung sondert sich schnell in eine unten stehende alkoholische, goldgelbe Xanthophylllösung und in eine darüber stehende blaugrüne Lösung des Cyanophylls in Benzol. Der gelbe Farbstoff ist leichter in Alkohol als in Benzol löslich, der blaugrüne umgekehrt leichter in Benzol als in Alkohol, und daher tritt die erwälnnte Scheidung der beiden Pigmente bei der Ausführung des Versuchs hervor.

In den Zellen im Dunkeln erwachsener, gelber Pflanzentheile sind beträchtliche Mengen von Etiolinkörnern vorhanden (vergl. unter 10). Diese bestehen aus einer protoplasmatischen Grundmasse und einem gelben Farbstoff, den man isoliren kann, wenn man z. B. bei Lichtabschluss erwachsene etiolirte Weizen- oder Gerstenkeimpflanzen mit Alkohol extrahirt. Der Auszug besitzt eine schön gelbe Farbe. Das Pflanzenmaterial gewinnt man, indem man gequollene Weizen- oder Gerstenkörner auf feuchten Sägespänen aussäet und die sich entwickelnden jungen Keimlinge etwa 8 Tage lang im Dunkeln cultivirt.

\section{\%. Das Absorptionsspectrum und die Fluoreseenz des Chlorophyllfarbstoffes.}

Zur Untersuchung des Absorptionsspectrums des Chlorophyllfarbstoffes bedürfen wir geeigneter Spectroskope. Je nach Umständen werden wir den Bunsen'schen Spectralapparat, ein geradsichtiges Spectroskop, ein Taschenspectroskop oder einen mit dem Mikroskop in Verbindung zu bringenden Mikrospectralapparat benutzen. Dieser letztere Apparat wird in vorzüglicher Qualität mit Scalenrohr und Vergleichsprisma von der Firma Zerss in Jena oder von SEIBERT und KRAFFT in Wetzlar geliefert. Die anderen Spectralapparate, welche genannt wurden, liefern z. B. R. Muencke in Berlin, Luisenstr. 58 und Geissler Nachf. in Bonn. Eine genaue Beschreibung aller Apparate würde hier zu weit führen. Näheres findet man z. B. in MÜLLER's Lehrbuch der Physik und Meteorologie, 1879, Bd. II, erste Abtheilg., S. 206.

Ich weiss aus eigener Erfahrung, dass es am bequemsten ist, mit geradsichtigen Spectroskopen zu arbeiten. Bei Untersuchungen, welche den Zweck haben, die Lage der Absorptionsbänder genau zu bestimmen, bedient man sich am besten solcher Apparate, welche mit 
Scalen versehen sind, die keine beliebige Theilung, sondern solche nach Wellenlängen besitzen. Die richtige Einstellung der Scala kann dann in einfacher Weise unter Zuhülfenahme der Frauenhofer'sclien Linien geschehen.

Gehen wir zunächst auf den Mikrospectralapparat ein, wie er in der von SEIBERT und KRAFFT in Wetzlar gelieferten Form in Fig. 6 dargestellt ist, so sei bemerkt, dass $t$ die den Spalt und das Vergleichsprisma bergende

Trommel darstellt. Die Schraube $d$ dient zur Verengerung, $h$ zur Verkürzung des Spaltes, $f$ ist die Ocularröhre, $o$ die Schraube zum Einstellen des Spaltes für das Auge des Beobachters; in der Röhre $r r$ befinden sich die Prismen, $s$ ist ein Spiegel, um dem Vergleichsprisma, wenn es eingeschaltet ist, Licht zuzuführen. $p \quad p$ ist eine durchbohrte Platte, die seitlich an der Trommel $t$ angebracht und mit federnden Klammern versehen ist. Zur Erzeugung eines Vergleichsspectrums wird der betreffende Körper inöglichst dicht vor die Durchbohrung von $p p$ gebracht. Auf die complicirte Einrichtung des Messapparates, welcher dem oberen Ende des Spectroskops seitlich eingesetzt werden kann, gelien wir hier nicht näher ein. Man vgl. vielmehr Behrens, Hilfsbuch bei mikroskopischen Untersuchungen, 1883, S. 121.

Will man Chlorophylllösungen untersuchen, so sind dieselben nach der unter 6 angegebenen Weise zu bereiten. Wir wollen auch hier wieder nur mit der gewöhnlichen alkoholischen Rohchlorophylllösung experimen-

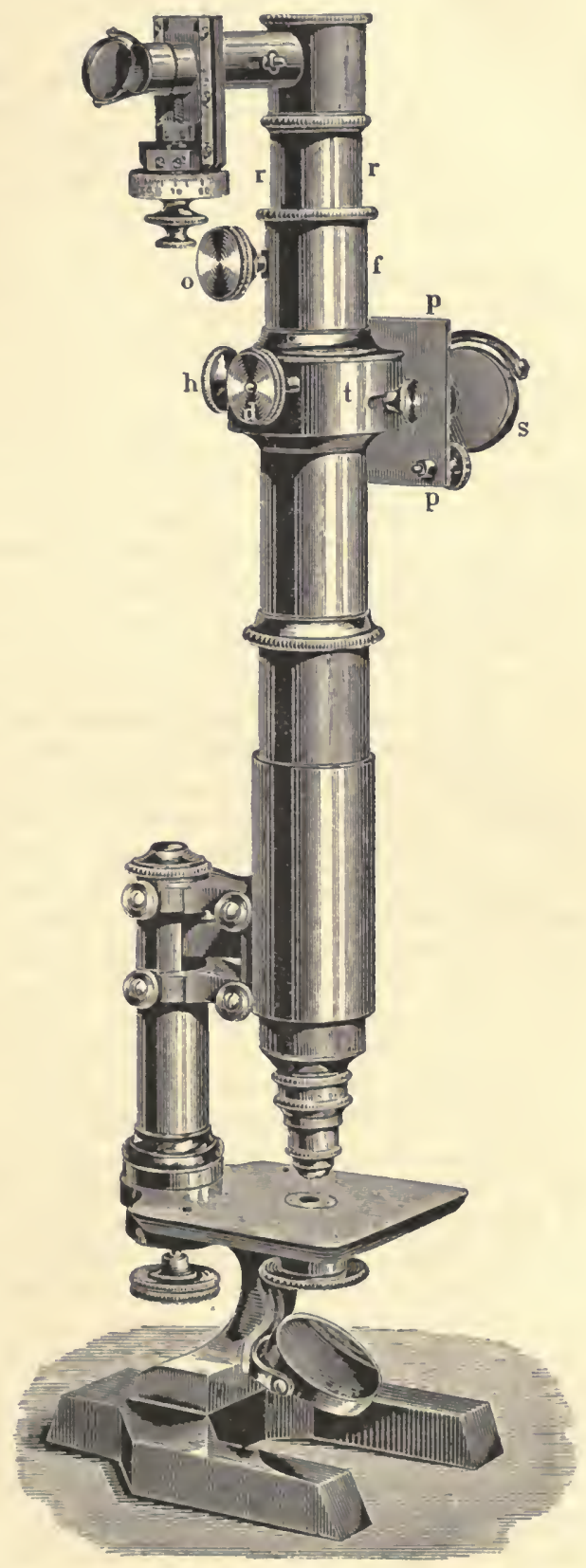

Fig. 6. Mikroskop mit rollstilndigem Irikrospectrosk op. 
tiren und anderweitige Chlorophyllpräparate, die umständlich herzustellen sind, nicht berücksichtigen. Die im Dunkeln bereitete, frische Lösung gelangt in kleine, mit planparallelen Wänden und dicht schliessenden Stopfen versehene Glasfläschchen, die von Murxcke in Berlin bezogen werden können. Diese Gläser legt man einfach auf den Objecttisch des Mikroskops und studirt nun das Spectrum. Das Chlorophyllspectrum zeigt 7 Absorptionsstreifen, wie sie auch in Figur 8 dargestellt sind. Besonders der Streifen im Roth ist sehr charakteristisch und selbst noch bei Benutzung sehr verdünnter Lösungen wahrzunehmen. Verwendet man concentrirtere Lösungen, so treten die Bänder $I-I V$ zwar noch deutlich hervor, aber die Streifen $V, V I$ und $V I I$ sind $z u$ einer Endabsorption zusammengeflossen. Um auch sie zu sehen, muss man mit verdünnteren Lösungen und unter Benutzung directen Sonnenlichtes arbeiten. Die Resultate der Beobachtungen sind in eine Scala einzuzeichnen, in welcher die Lage der Frauexhofer'schen Linien angegeben ist. Bei genauen Untersuchungen ist der Messapparat, der mittelst des an ihm befestigten Spiegels beleuchtet werden kann, zur Hülfe zu nehmen. Das Vergleichsprisma unseres Apparates leistet zumal dann sehr gute Dienste, wenn es sich darum handelt, das bekannte Spectrum eines Körpers mit den noch nicht studirten eines anderen $\mathrm{zu}$ vergleichen. Schalten wir nämlich das Vergleichsprisma ein und beleuchten dasselbe gut, so erblicken wir zwei, nur durch eine zarte schwarze Linie getrennte, über einander liegende Spectra. Wenn die Substanzen, welche man untersucht, dieselben sind und auch im gelösten Zustande in gleichen Concentrationen Verwendung finden, so fallen die Absorptionsstreifen des unteren Spectrums genau in die Verlängerung der Streifen des oberen.

Handelt es sich darum, dünne Gewebeschnitte oder auch z. B. einzelne Chlorophyllkörner mit Hülfe des Mikrospectralapparates zu untersuchen, so werden dieselben in gewöhnlicher Weise auf dem Objectträger, in einem Tropfen Wasser resp. Glycerin liegend, mit Deckglas bedeckt. Behufs Einstellung des Präparates entfernt man das die Prismen tragende Rohr und öffnet den Spalt nur so wenig wie möglich. Bei dem Studium vieler chlorophyllhaltiger Objecte (ich experimentirte z. B. mit Cladophorafäden) nimmt man nur Band $I$ im Roth und eine aus der Verschmelzung der Bänder $V, V I$ und VII hervorgegangene continuirliche Endabsorption wahr; die Bänder II, III und IV treten überhaupt nicht hervor.

Bei der Untersuchung ganzer Blätter legt man dieselben einfach auf den Objecttisch und benutzt ein schwaches Objectiv. Beleuchten wir unser Object, indem wir diffuses Tageslicht oder Gaslicht auf den Spiegel des Mikroskops fallen lassen, so sind nur die Bänder I, II u. III des Chlorophyllspectrums sichtbar. Verwenden wir directes Sonnenlicht, so treten auch die Bänder $I V$ und $V$ hervor, während die Bänder $V I$ u. VII der starken Endabsorption wegen oft nicht deutlich erkannt werden können. Dass wirklich die Bänder $I-V$, welche wir beobachteten, den Bändern $I-V$ der Chlorophylllösung entsprechen, lässt sich zeigen, wenn man das Vergleichsprisma, das durch einen besonderen Spiegel Licht empfängt, in Anwendung bringt, um mit Hilfe desselben gleichzeitig mit dem Spectrum eines Blattes dasjenige einer alkoholischen Chlorophyllösung zu beobachten. Es zeigt sich dann fast völlige Uebereinstimmung in der Lage der Absorptionsstreifen beider Objecte; nur sind die Bänder des Spectrums der Lösung im Vergleich zu denjenigen des Blattspectrums etwas gegen das Violett hin verschoben, eine Erscheinung, die durch das benutzte Lösungsmittel (Alkohol) herbeigeführt wird. 
Sollen Chloropliylllösungen unter Benutzung von Taschenspectroskopen, Bussex'scher Apparate oder geradsichtiger Spectroskope von Hofans oder StFinherl untersucht werden, so füllt man sie in Gläser mit parallelen Wänden, wie solche z. B. von MUExcke in Berlin zu beziehen sind, ein (rgl. Fig. 7); oder man bringt sic am besten in ein Haemoskop (von DESAGA in Heidelberg zu beziehen), um in sehneller und beliebiger Folge Flüssigkeitsschichten von verschiedener Dicke prüfen zu können. Wird als Lichtquelle eine Gas- oder Petroleumflamme in Anwendung gebracht, so sind deutlich oft nur die Bänder $I$ und $I I$, respect. diese und $I I I$ der Chlorophylllösung zu erkennen ${ }^{1}$ ). Die genauere spectroskopische Untersuchung des Chlorophyllfarbstoffs kann im directen Sonnenlicht erfolgen. Das Spectroskop ist in einem Dunkelzimmer aufgestellt. Das Licht fällt durch eine Oeffnung im Fensterladen ein, und vor demselben befindet sich, um die Riclitung der Strahlen unverïndert zu erhalten, ein Heliostat, dessen Spiegel mit der Hand bewegt oder besser mittelst eines Uhrwerkes gedreht werden kann. Heliostaten liefern in guter Ausführung EHrhardt und MEtzger in Darmstadt. Im Dunkelzimmer, welches überhaupt bei vielen plyysiologischen Arbeiten sehr gute Dienste leistet, sind Wände, Fussboden, Decke, Fensterladen, Tische etc. mattschwarz angestrichen. Die Absorptionsstreifen im stärker brechbaren Theil des Chlorophyllspectrums sind nur dann deutlich getrennt von einander zu sehen, wenn man mit relativ verdünnten Chloroplyylllösungen experimentirt. Die Resultate der Untersuchungen werden nach Maassgabe der Beobachtungen, die man unter Benutzung der Scala des Spectroskops ge-

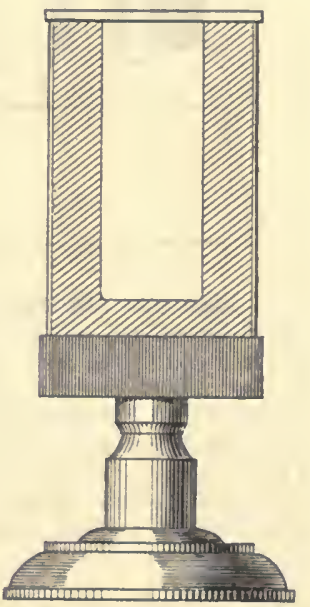

Fig. 7. Glasgeftiss mit purallelen Whinden? zur Aufnahme von Flïssigkeiten, die speetroskopiseh untersucht werden sollen. wonnen hat, aufgezeichnet ${ }^{\boldsymbol{y}}$ ).

Es ist unter 6 angegeben worden, dass der normale griine Chlorophyllfarbstoff ein Gemenge zweier Farbstoffe, des Xanthophylls und Cyanophylls, repräsentirt. Es ist auch schon die Methode besprochen, welche man anwenden muss, um diese beiden Farbstoffe von cinander zu trennen. Die Lösung des gelben Xanthophylls (wenigstens die verdünnte Lösung) zeigt bei spectroskopischer Untersuchung nur drei Absorptionsstreifen, sämmtlich im Blau und Violett gelegen. Die blaugrüne Cyanophylllösung besitzt 7 Absorptionsstreifen: I im Roth,

1) Sehr lichtstarke Spectra geben aueh die Taschenspeetroskope nach BrowNING, die, mit Scala versehen, von ScmmDT und Ḧ̈xscr in Berlin zu bezichen sind. Als Lichtquelle kann zweckmässig ein Argandbrenner mit Blechkamin dienen. Die erwähnten Spectroskope werden heute oft bei Studien über das Absorptionsspectrum der Chlorophyllösungen verwandt. Mit Hülfe derselben ist es möglich, namentlich die Lage der Bänder $I-I V$ recht genau zu bestimmen. Vgl. WEGscheider, Ber. d. Deutseh. botan. Gesellschaft, Bd. 2, u. VoGEL, Praktische Spectralanalyse, Nördlingen, 1877.

2) Vgl. Krats, Zur Kenntniss der Chlorophyllfarbstoffe, 1872; Prixgsherm, Monatsber. d. Berliner Akademie, 1874 und 1875, und Sitzungsber. der Berliner Akademic, 1856; HAssis, Arbeiten d. botan. Instituts in Würzburg, Bd. 3, H. 1; Tscrircir, Berichte d. Deutschen botan. Gesellschaft, Bd. 1. 


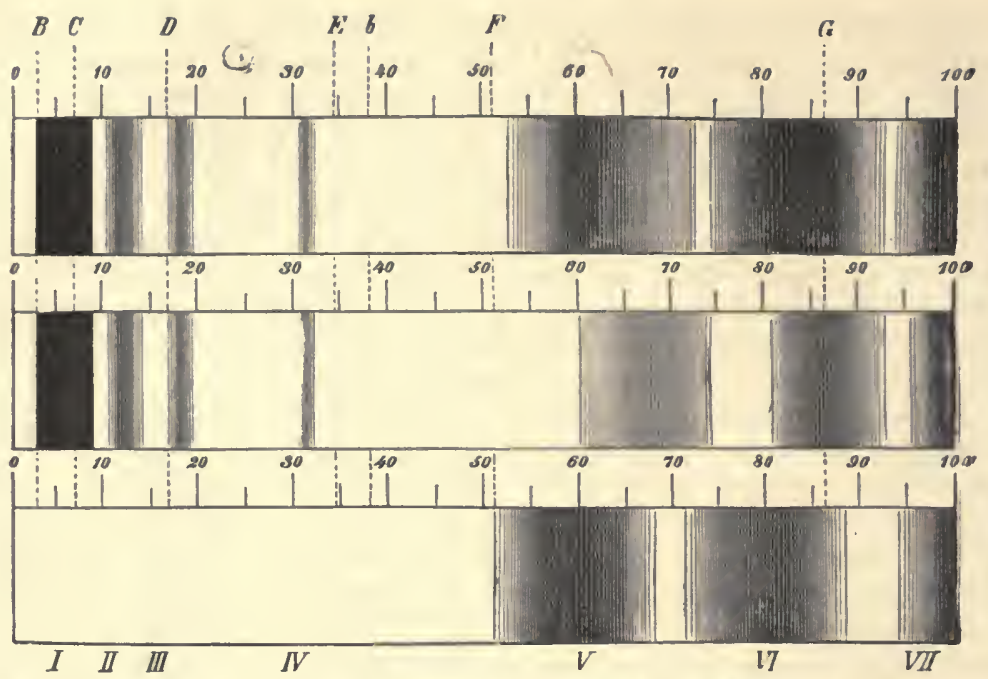

Fig. 8. Absorptionsspectren des Chloruphyllfarbstoffes naeh Kraus. Das obere Spectrum ist das des alkoholischen Extractes grüner Blätter, das mittlere das des in Benzol löslichen blaugrünen Bestandtheiles, das untere das des gelben Bestandtheiles. Die Absorptionsstreifen der beiden oberen Spectren sind im minder brechbaren Theile $B-E$ nach einer mehr concentrirten, im stärker brechbaren Theile nach einer verdünnten Lösung angedeutet. Die Buchstaben $A-G$ bedeuten die bekannten Frauexhofer'schen Linien des Sonnenspectrums, die Zahlen $I-V I I$ numeriren nach Krats die Absorptionsstreifen, vom rothen zum violetten Ende fortschreitend. Die Striche 0-100 theilen die Länge des Spectrums in 100 gleiche Theile.

$I I$ im Orange, $I I I$ im Gelb, $I V$ im Grün, $V, V I, V I I$ im Blau und Violett.

Wenn man concentrirte alkoholische Chlorophylllösungen im auffallenden Licht betrachtet, so zeigt sich, dass dieselben eine rothe Farbe besitzen. Noch deutlicher und schöner lässt sich die rothe Farbe der Chlorophylllösung im. auffallenden Licht zur Wahrnehmung bringen, wenn man mit Hülfe einer biconvexen Linse ein Sonnenbild an der Oberfläche der Lösung entwirft. Der Chlorophyllfarbstoff fluorescirt mit rothem Licht, wie auf die angegebene Art leicht festzustellen ist.

\section{Die Zersetzung des Chlorophyllfarbstoffes.}

Man stelle in Töpfen cultivirte, kräftige Exemplare von Tropaeolum majus ins Finstere, z. B. in einen Schrank. Ist die Temperatur nicht zu niedrig, so haben die Blätter bereits nach 8 Tagen auffallende Farbenveränderungen erfahren. Die älteren Blätter sehen, trotzdeın sie noch saftig sind, gelb aus, während die jüngeren fleckig und die iüngsten noch völlig grün erscheinen. Der Lichtmangel hat, wie die mikroskopische Untersuclıung dünner Schnitte aus dem Mesophyll der gelben Tropaeolumblätter lehrt, einen wesentlichen Einfluss auf die Chlorophyllkörner geltend gemacht. Dieselben haben an Grösse verloren, und statt des grünen Pigments ist nur noch ein gelbes vor- 
handen $\left.{ }^{1}\right)$. Werden Spirogyrafäden in einem etwas Wasser enthaltenden Glase längere Zeit (bei meinen Versuchen 5-8 Tage lang, Temperatur $15-20^{\circ} \mathrm{C}$ ) constanter Finsterniss ausgesetzt, so haben sich die Chlorophyllkörper wesentlich verändert. In manchen Zellen sind freilich noch grün gefärbte Spiralbänder vorhanden, in anderen ist aber bereits ein mit Verfärbung des Pigments verbundener Zerfall der Chlorophyllkörper zu unregelmässigen Ballen eingetreten.

Der Chlorophyllfarbstoff in Pflanzenzellen erfährt ferner tiefgreifende Zersetzungen, wenn er mit Säuren in Berührung gebracht wird. Wir legen Spirogyra- oder Zygnemafäden (letztere benutzte ich mit besonderem Erfolg) in eine Mischung von 1 Theil concentrirter Salzsäure und 4 Theilen Wasser. Das Chlorophyllpigment erfährt einen Farbenwechsel, und nach Verlauf längerer Zeit (zuweilen erst nach 20 Stunden) treten in den Cllorophyllkörpern, zumal an deren Rändern, bräunlich oder rostbraun gefärbte Massen, Zersetzungsproducte, die in Folge der Wirkung der Salzsäure entstanden sind, auf (Hypochlorinreaction) ${ }^{2}$ ).

Ebenso wird eine Rohchlorophylllösung (hergestellt durch Behandlung grüner Pflanzentheile mit Alkohol) wesentlich verändert, wenn man sie mit Säuren versetzt. Versetzt man eine solche Lösung z. B. mit sehr wenig Salpeter-oder Salzsäure, so geht ihre schön grüne Farbe sofort verloren, und sie nimmt einen bräunlichen Farbenton an.

Die alkoholische Rohchlorophylllösung entlıält freilich neben dem Chlorophyllpigment nocl eine ganze Reihe anderweitiger Substanzen, aber trotzdem kann man dieselbe bequem benutzen, um den Nachweis zu liefern, dass der Chlorophyllfarbstoff im hohen Grade lichtempfindlich ist. Im Dunkeln erhält eine alkoholische Chlorophylllösung sich lange Zeit unverändert; sie verfärbt sich nur ganz allmählich. Diffuses Licht wirkt nicht sehr schnell, directes Sonnenlicht dagegen sehr schnell verändernd auf die Rohchlorophylllösung ein; im directen Sonnenlicht ist eine solche Lösung bereits nach Verlauf einer halben Stunde sehr deutlich verfärbt. Lehrreich ist es auch, den Einfluss des Lichtes von verschiedener Brechbarkeit auf Rohchlorophylllösungen zu studiren. Es wird uns hier zum ersten Mal die Aufgabe gestellt, pflanzenphysiologische Experimente unter dem Einfluss des Lichts von verschiedener Brechbarkeit vorzunehmen, und es muss daher die Untersuchungsmethode, deren wir uns anch später bei manchen anderen Versuchen $\mathrm{zu}$ bedienen haben, specieller beschrieben werden.

Die fast concentrirte wässerige Lösung des doppelt-chromsauren Kalis lässt in nicht $\mathrm{zu}$ dicken Schichten das Roth, Orange, Gelb und einen Theil des Grün fast ungeschwächt passiren. Die Lösung des Kupferoxydammoniaks (dieselbe stellt man durch Auflösung von schwefelsaurem Kupferoxyd in Wasser und Zusatz überschüssigen Ammoniaks her) absorbirt im Gegenteil diejenigen Strahlen, welche das doppelt-chromsaure Kali durchlässt, verhindert aber den übrigen Strahlen, also einem Theil des Grün, dem Blau, Indigo und Violett, den Durchtritt nicht. Mit Hülfe der beiden angefülirten Lösungen ist man demnach im Stande, das weisse Licht nahezu genau in die

1) Vgl. SAcHs, Botanische /eitung, 1864, S. 38.

2) Vgl. Privgsheim, Jahrbücher für wissenschaftl. Botanik, Bd. 12. 
weniger und die stärker brechbare Hälfte zu zerlegen. Zur Aufnahme der farbigen Lösungen benutzt man sehr allgemein doppeltwandige Glocken (vergl. Fig. 9) ${ }^{1}$ ). Der Zwischenraum zwischen den beiden Glaswänden der Glocken, also auch die Dicke der farbigen Flüssigkeitsschicht, beträgt gewöhnlich etwa $1 \mathrm{~cm}$. Zur Abhaltung gemischten weissen Lichts stellt man die Glocken bequem in mit Sand gefüllte Teller. Die unter die Glocken gebrachten Untersuchungsobjecte empfangen dann nur gemischtes gelbes oder gemischtes blaues Licht. Ich benutzte auch häufig bei Experimenten über den Einfluss des Lichts von verschiedener Brechbarkeit auf physiologische Processe

Fig. 9.

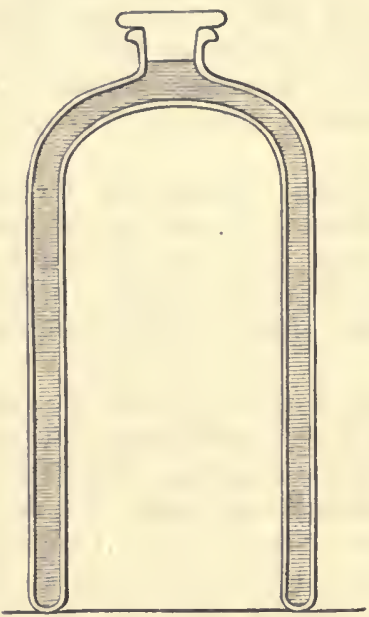

Fig. 10.

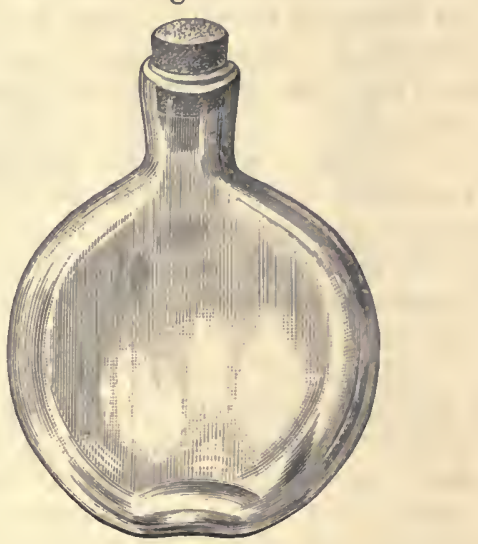

Fig. 9. Doppeltwandige Glasglocke zur Aufnahme farbiger Fliissigkeiten, im Längsschnitt dargestelit. keiten.

Flg. 10. Glasflasche mit parallelen Wänden zur Anfnahme farbiger Flissig-

innen und aussen mit mattschwarzem Papier beklebte Pappkästen, deren hintere Wand durch eine wohl verschliessbare Klappe gebildet wird, während die vordere Wand mit einer grossen Oeffnung versehen ist. Vor diese Oeffnung werden in geeigneter Weise Glasflaschen mit parallelen Wänden, welche mit den farbigen Flüssigkeiten angefüllt sind, angebraclit (vergl. Fig. 10). Die in die doppeltwandigen Glocken oder in die zuletzt erwähnten Glasflaschen eingefüllten Lösungen des doppelt-chromsauren Kalis und des Kupferoxydammoniaks werden einer spectroskopischen Untersuchung unterzogen, indem inan das Rohr des Spectroskops in die Glocken einführt oder die Glasflaschen mit parallelen Wänden dicht vor den Spalt bringt. Man muss die Flüssigkeiten nur in einen derartigen Concentrationsgrad versetzen, dass die eine, wie es oben angegeben wurde, nur die weniger, die andere nur die stärker brechbaren Lichtstrahlen durcligehen lässt.

Wenn man nun Rohehlorophylllösungen dem Einfluss des gemischten gelben und des gemiscliten blauen Lichts exponirt (directes Sonnenlicht),

1) Solche Glocken sind von DeSAGA in Heidelberg zu beziehen. 
so ergiebt sich, dass die weniger brechbaren Strahlen die Zersetzung (Verfärbung) des Chlorophyllfarbstoffs weit schneller als die stärker brechbaren Strahlen herbeiführen. Die sogen. chemischen Strahlen, d. h. diejenigen, welche das Chlorsilber zu zersetzen vermögen, betheiligen sich an der Chlorophyllfarbstoff-Zersetzung also nur in untergeordnetem Grade, denn das gemischte blaue Licht ist reielı, das gemischte gelbe Licht arm an diesen chemischen Strahlen, wovon man sich leicht überzeugen kann, wenn man photographisches Papier dem Licht von verschiedener Brechbarkeit aussetzt ${ }^{1}$ ).

\section{Die herbstliehe Färbung der Blätter und die winterliche Färbung ausdauernder Pflanzenthelle.}

Viele Blätter färben sich im Herbst vor dem Abfallen roth. Diese Erscheinung lässt sich besonders schön an den Blättern von Rhusarten, sowie an denjenigen von Cornus sanguinea und Ampelopsis liederacea studiren. Die genannten Blätter lassen den rothen Farbenton hauptsächlich an ihrer Oberseite erkennen, und die mikroskopische Untersuchung zarter Quersclinitte lehrt uns in der That, dass ins Besondere die Zellen des Palissadenparenchyms das rothe Pigment enthalten. Dieses ist im Zellsaft aufgelöst. Die Epidermiszellen führen keinen Farbstoff. Bei der herbstlichen Gelbfärbung der Blätter nehmen die sich desorganisirenden Chlorophyllkörner einen gelblichen Farbenton an, wie wir dies z. B. feststellen können, wenn wir im Herbst Ahornblätter untersuchen. Protoplasma und Chlorophyllkörper werden bei fortschreitendem Vergilben der Blätter mehr und mehr aufgelöst; ihre Substanz geht in die austauernden Pflanzentheile über, und sclliesslich bleibt nur Xanthophyll in Form kleiner glänzender Körnchen in den Blattzellen zurück. Einige Blätter, z. B. diejenigen der Eichen, färben sich im Herbst braun, eine Erscheinung, die auf eine Braunfärbung der Zellhäute, sowie des Zellinhalts zurückzuführen ist.

Interessant sind ferner die Veränderungen der Farbe solcher Pflanzentheile, die den Winter über ausdauern. Wenn im Herbst oder im Winter die ersten Fröste eingetreten sind, so beobachtet man, dass die dem Licht zugewendete Fläche der Zweige von Thuja orientalis eine braune Farbe angenommen hat"). Diese Erscheinung beruht darauf, dass der Chlorophyllfarbstoff theilweise zerstört wird und rothe Pigmente in den Chlorophyllkörnern auftreten. Werden braun gefärbte Thujazweige in ein warmes Zimmer gebracht, so verschwindet der rothe Farbstoff, und die Untersuchungsobjecte ergrünen wieder. Lichtzutritt ist dazu nicht erforderlich. Gebräunte Zweige von Thuja orientalis, die ich bei $15-20^{\circ} \mathrm{C}$. im Dunkeln hielt, waren nach acht Tagen aufs Neue grün geworden.

Die winterliche Rothfärbung ausdauernder Pflanzentheile ist auf die Bildung eines im Zellsaft löslichen rothen Pigments zurückzuführen, während die Chlorophyllkörper intact bleiben, höchstens Veränderungen ihrer Lage in den Zellen erfahren. Untersuchen wir im S. 18.

1) Weitere Literatur vgl. bei Dermer, Lehrbuch d. Pflanzenphysiologie, 1883,

2) Specielle Angaben über den anatomisehen Bau der Zweige von Thuja (freilich Th. occidentalis, nicht Th. orientalis) findet man bei FRANK, Pringsheim's Jahrbücher, Bd. 9, S. 159. 
Winter Querschnitte der Blätter von Mahonia aquifolium, so ergiebt sich, dass besonders die Zellen des schön entwickelten Palissadenparenchyms rothes Pig̀ment enthalten ").

\section{Die Entstehung des Chlorophyllfarbstoffes.}

Einige Samen von Lupinus werden in Gartenerde ${ }^{-2}$ ), die sich in Blumentöpfen befindet, im Dunkeln, z. B. in einem Schrank, zum Keimen gebracht. Es ist gar nicht so ganz leicht, einen Raum herzustellen, in welchem nahezu absolute Dunkelheit herrscht, und wenn man Pflanzen bei möglichst vollkommenem Lichtabschlusse cultiviren will, so darf man diese Thatsache nicht aus dem Auge verlieren. Für unseren Zweck genügt es übrigens, wenn man die mit den Samen beschickten Blumentöpfe in dem Schrank unter einem undurchsichtigen Papprecipienten aufstellt und das Schlüsselloch des Schrankes sorgfältig verstopft.

Das hypocotyle Glied und die Cotyledonen treten bald über die Erdoberfläche hervor, wenn die Keimungsbedingungen einigermaassen günstige sind; aber die Keimblätter erscheinen nicht grün, wie diejenigen am Licht erwachsener Lupinenkeimpflanzen, sondern sie besitzen eine gelbe Farbe. Untersuchen wir Querschnitte der Cotyledonen mikroskopisch, so erkennen wir die Epidermis, die Gefässbündel, sowie das Blattparenchym deutlich. Die Zellen des letzteren, zumal die mehr peripherisch gelegenen, enthalten, abgesehen von sonstigen Inhaltsbestandtheilen, kleine, gelb gefärbte Körnchen, die Etiolinkörner. Setzt man die im Dunkeln cultivirten Keimlinge dem Licht aus, so ergrünen sie bald, und wir finden nun in den Zellen des Blattparenchyms Chlorophyllkörner. Dieselben sind unter dem Einfluss des Lichtes aus den Etiolinkörnern hervorgegangen, unterscheiden sich von diesen aber nicht allein durch ihre grüne Farbe, sondern ebenso durch ihre beträchtlichere Grösse. Werden Keimpflanzen von Phaseolus oder Pisum im Dunkeln zur Entwickelung gebracht, so erzeugen dieselben lange, weiss gefärbte Stengeltheile und kleine, gelbe Blätter. Ich fand, dass die Blätter von Erbsenkeimpflanzen, die im Finstern mehrere Internodien gebildet hatten, und welche dann ans Licht gelangten, nicht sämmtlich, sondern nur theilweise ergrünten. Die jüngeren Blätter bildeten freilich am Licht Chlorophyll. Die älteren blieben aber gelb.

Die meisten Pflanzen bilden allein bei Lichtzutritt normales grünes Chlorophyll; einige Gewächse vermögen aber auch im Finstern zu ergrünen. Werden z. B. Samen von Pinus silvestris in Gartenerde ausgesäet und bei Lichtabschluss zur Keimung gebracht (die Keimung geht relativ langsam vor sich), so bricht zunächst die Wurzel hervor. Dann streckt sich das hypocotyle Glied, erscheint aber zunächst knie-

1) Ueber die winterliche Färbung ausdaucrnder Pflanzentheile vgl. H. v. MoHL, Vermischte Schriften, S. 375, und G. HABERLANDT, Sitzungsberichte d. Akademie d. Wiss. zu Wien, Bd. 72, Abtheil. I, Aprilheft.

2) Es sei hier ein für alle Mal bemerkt, dass man zu Culturversuchen gewöhnlich am besten die schwarze, sehr humusreiche Erde benutzt, wie sie für Gerächshauspflanzen gebraucht wird. Man feuchtet die Erde so weit an, dass sie sich eben noch zwischen den Händen zu eirer feinkrümeligen Masse zerdrücken lässt, wirft sie durch ein Sieb, dessen Oeffnungen 1,5 mm im Quadrat messen, und rütlelt sie in die Culturgefässe ein. 
förmig gebogen, weil die Cotyledonen noch im Samen stecken. Endlich treten die Kieimblätter aus dem Boden heror, das hypocotyle Glied streckt sich dann gerade, und die Keimung ist vollendet. Auffallend erscheint vor allem der Umstand, dass die Cotyledonen grün sind. Iclı habe miclı davon überzeugt, dass dies Ergrünen der Pinuskeimblätter in einem finsteren Raume erfolgt, in welchem Weizenkeimpflanzen nicht ergrünen, sondern nur eine gelb gefärbte Plumula entwickeln.

Dic im Finstern crwachsenen Keimlinge mono- sowie dicotyler Pflanzen (Plıseolus, Pisum, Raphanus, Triticum, Zea etc.) ergrünen nicht nur, wenn sie relativ hellem Licht ausgesetzt werden, sondern die Chlorophyllbildung erfolgt auch schon in einem sehr gedämpften Licht, wovon man sich leicht überzeugen kann, wenn man dic Untersuchungsobjecte an der hinteren Wand eines Zimmers aufstellt und sie hier nocl in geeigneter Weise beschattet. Man kann Pflanzen ferner auch in künstlichem Licht zum Ergrünen bringen. So stellte ich im Dunkeln erwachsene Weizenkeimlinge mit $2-3 \mathrm{~cm}$ langer Plumula $15 \mathrm{~cm}$ entfernt von der Flamme ciner Petroleumlampe auf. Die Keimlinge befanden sich mit etwas Wasser in einer Krystallisirschalc. Diese von dem Licht, welches von der Lampe ausging, beleuchteten Untersuchungsobjecte ergrünten deutlich in wenigen Stunden; Controlpflanzen, die im Dunkeln gehalten wurden, ergrünten nicht.

Lchrreich ist es ferner, den Einfluss des Lichtes von verschiedener Brechbarkeit auf die Chlorophyllbildung $\mathrm{zu}$ studiren. $\mathrm{Zu}$ dem Ende bringt man z. B. Weizenkeimlinge, deren Plumula etwa $2 \mathrm{~cm}$ lang ist, und die sich im Finstern entwickelt haben, mit etwas Wasser in kleine Glasschälchen. Diesc, oder auch kleinc mit Erde gefüllte Blumentöpfe, in denen die Keimlinge zur Entwickelung gelangten, werden nun unter doppeltwandige Glasglocken gestellt, von denen die eine mit einer Auflösung von doppelt-chromsaurem Kali angefüllt ist, wälırend die zweite eine Auflösung von Kupferoxydammoniak enthält (vgl. unter 8). Man kann sich leicht davon überzeugen, indem man zugleich Stücke photographischen Papiers unter die Glocken legt, dass das gemischte gelbe Licht fast völlig frei von sogen. chemischen Strahlen ist, während das Licht, welches die Kupferoxydammoniaklösung passirt hat, die Zersetzung des Chlorsilbers selır schnell bewirkt. Als ich die Apparate am Morgen eines trüben Novembertages in einem nach Süden gelegenen Zimmer bei einer Temperatur von ca. $20^{\circ} \mathrm{C}$. in einer Entfernung von $5 \mathrm{~m}$ vom Fenster aufgestellt hatte, fand ich die Plumula der Weizenkeimlinge nach 24 Stunden unter dem Einfluss des gemischten gelben Lichtes völlig ergrünt, während diejenigen Keimpflanzen, welche der Einwirkung des gemischten blauen Lichtes ausgesetzt gewesen waren, eine Plumula von hellgrüner Farbe besassen. Setzt man die Apparate hingegen dem directen Sonnenlicht aus, dann erfolgt das Ergrünen im gemischten blauen Licht schneller als in gemischten gelben Licht. Dem Resultat dieses letzteren vergleichenden Experiments gegenüber lassen sich aber, wenn man nicht ganz besondere Vorsichtsmaassregeln in Anwendung bringt, Bedenken geltend machen, denn ich habe inich davon überzeugt, dass sich die Luft unter einer mit Kupferoxydammoniak beschickten doppeltwandigen Glocke, wenn sie dem Einfluss directen Sonnenlichtes ausgesetzt wird, viel stärker erwärnt als die Luft unter 
der mit doppelt-chromsaurem Kali angefüllten Glocke. Trotzdem ist es sicher, dass es nicht als gleichgültig für das Resultat des Experiments betraclitet werden darf, ob man die im Dunkeln cultivirten Untersuchungsobjecte dem diffusen Licht oder dem directen Sonnen* licht preisgiebt. Werden Weizenkeimlinge mit gelber Plumula dem diffusen, andere gleichzeitig dem directen Sonnenlicht ausgesetzt, so crgrünen jene schnell, z. B. im Laufe von 3 Stunden, während diese weit langsamer normalen Chlorophyllfarbstoff erzeugen. Wir haben nun unter 8 gesehen, dass sich das Chlorophyllpigment in alkoholischen Extracten aus grünen Pflanzen im directen Sonnenlicht sehr schnell zersetzt (verfärbt), während diffuses Licht dieselbe Wirkung sehr langsam geltend macht, und diese Thatsache muss bei der Erklärung der im Vorstehenden zur Kenntniss gebrachten Erscheinungen Beachtung finden. Im directen Sonnenlicht, mag dasselbe direct als solches, oder nachdem es eine Lösung von doppelt-chromsaurem Kali passirt hat, auf Keimlinge einwirken, ergrünen diese langsam, weil das entstehende Chlorophyllpigment zum grossen Theil wieder zerstört wird. Im diffusen Licht, wie auch im directen Sonnenlicht, welches eine Auflösung des Kupferoxydammoniaks passirt hat, kann keine energische Chlorophyllzersetzung erfolgen, deshalb häuft sich das entstehende Blattgrün schnell in den Zellen der Keimptlanzen an. Schwaches diffuses Licht wirkt kaum mehr zersetzend auf den Chlorophyllfarbstoff ein, und wenn man Keimpflanzen weit entfernt vom Fenster unter doppeltwandigen Glocken aufstellt, so ergrünen sie im gemischten gelben Licht schneller als im gemischten blauen, weil ersteres fast lediglich seine grössere chlorophyllbildende Kraft geltend macht, während die chlorophyllzersetzende sehr in den Hintergrund tritt ${ }^{1}$ ).

Will man untersuchen, ob die dunkeln Wärmestrahlen ein Ergrünen im Finstern erwachsever Keimlinge hervorrufen können, so bringt man 7. B. Weizenkeimlinge mit gelber Plumula, die sich in kleinen Gläschen befinden, unter doppeltwandige, mit einer Auflösung von Jod in Schwefelkohlenstoff angefüllte Glasglocken. Bei hinreichender Concentration lässt diese Lösung gar keine Lichtstrahlen, wohl aber die Wärmestrahlen passiren. Die an ihrem unteren Rande mit Sand umgebenen Glocken werden dem directen Sonnenlicht oder diffusem Tageslicht ausgesetzt; ein Ergrünen der Untersuchungsobjecte tritt aber nicht ein.

Handelt es sich um das Studium der Abhängigkeit der Chlorophyllbildung von den Temperaturverhältnissen, so ist es z. B. bequem, Gerstenkeimlinge als Untersuchungsobjecte zu benutzen. Eine ganze Anzahl kleiner Blumentöpfe füllen wir mit Gartenerde an, sähen Gerstenkörner in jeden Topf und stellen dieselben ins Finstere. Wenn die Plumula der Pflänzchen etwa $2 \mathrm{~cm}$ Länge erreicht hat, so bringen wir einen Blumentopf vor das Fenster eines nach Norden gelegenen Zimmers, in welchem eine Temperatur von $6^{\circ} \mathrm{C}$. herrscht. Ein anderer Topf wird in einem benachbarten Zimmer, in welchem das Thermometer $20^{\circ} \mathrm{C}$. anzeigt, aufgestellt. Die Pflanzen sind also gleichen Beleuchtungsverhältnissen, aber verschiedener Temperatur ausgesetzt, und es ergiebt sich, dass das Ergrünen bei $6^{\circ} \mathrm{C}$. weit langsamer als bei $20^{\circ} \mathrm{C}$. erfolgt. Bei $30^{\circ} \mathrm{C}$. geht die Chlorophyllbildung noch etwas schneller als bei $20^{\circ} \mathrm{C}$. vor sich, bei $37^{\circ} \mathrm{C}$. wieder langsamer, und bei $45^{\circ} \mathrm{C}$. findet kein Ergrünen

1) Vgl. Wiesser, Sitzungsberichte d. Akademie d. Wiss. in Wien, Bd. 69, I. Abtheilung. 
mehr statt. Um die Pflanzen Temperaturen von 30,37 und $45^{\circ} \mathrm{C}$. auszusetzen, stellen wir sio in Thermostaten auf, die durch Heizung auf diese Temperaturen gebracht worden sind (Abbildung und Beschreibung eines geeigneten Thermostaten findet man im zweiten Abschnitt bei Gelegenheit der Untersuchungen über den Wurzeldruck). Es ist noch zu bemerken, dass die Untersuchungsobjecte, bevor sie beleuchtet werden, cinige Zeit in den Räumen von genau bekannter Temperatur verweilt haben müssen, damit sich ihnen sowie den Töpfen und dem Bodenmaterial diese mitgetheilt hat. Es existiren nach dem Gesagten Temperatur-Minima, -Optima und -Maxima für den Ergrünungsprocess der Pflanzen. Die Lage derselben ist für verschiedene Pflanzen aber keineswegs genau die nämliche ${ }^{1}$ ).

Endlich wollen wir noch den Nachweis liefern, dass der Ergrïnungsprocess am Licht nicht bei Sauerstoffausschluss erfolgen kann. Wir füllen zwei retortenartige Gefässe ( $a$ und $b)$ mit nusgekochtem und in verschlossenen Gefässen wieder

abgekühltem destillirtem Wasser an, bringen einige in Dunkeln erwachsene Weizenkeimlinge in das Wasser und stellen die Gefásse unter Benutzung eines geeigneten Stativs derartig auf, dass ihre Mündungen unter Quecksilber tauchen (vgl. Fig. 11). Nun verdrängen wir das Wasser in dem Apparat $a$ bis auf einen kleinen Rest durch reines Wasserstoffgas, das Wasser im Apparat 6

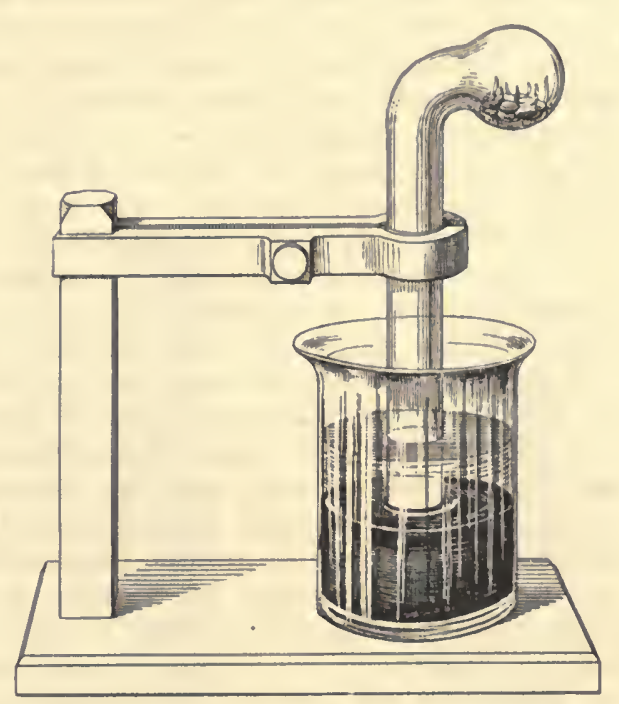

Fig. 11. Apparat zur Cultur ron Pflanzen in sauerstoffreiem Raum. aber durch atmosphärische

Luft. Werden die Gefässe jetzt dem Einflusse diffusen Lichtes ausgesetzt, so ergrünen die Keimlinge in. $b$ schnell, diejenigen in $a$ aber nicht ${ }^{2}$ ).

Es sei noch bemerkt. dass man das Wasserstoffgas aus Zink durch Uebergiessen desselben mit verdünnter Salzsäure herstellt, und zur Reinigung Lösungen von Kalihydrat, salpetersaurem Silberoxyd und übermangansaurem Kali passiren lässt. Zur Gasentwickelung dient zweckmässig ein Krpp'scher Apparat (vgl. den dritten Abschnitt).

\section{Die Sauerstoffproduction bei der Assimilation.}

Unter dem Einfluss des Lichtes findet in den Chlorphyllkörpern die Zersetzung von Kollensäure statt. Der Sauerstoff wird abge-

1) Vgl. W'nessier, Die Entstehung des Chlorophylls in den Pflanzen, Wien 1877.

2) Vgl. DetMer, Landwirthschaftliche Jahrbücher, Bd. 11. 
schieden und kann, wenn man geeignete Untersuchungsobjecte benutzt, leicht als solcher nachgewiesen werlen.

Wir bringen in ein Glas etwa $200 \mathrm{ccm}$ Brunnenwasser, in das wir nicht $z u$ viel reine Kohlensäure einleiten. Die Kohlensäure wird aus Marmor durch Uebergiessen desselben mit verdünnter Salzsäure entwickelt, und sie muss zur Befreiung von etwa mitgerissener Salzsäure, bevor sic in das Brunnenwasser eintritt, eine Auflösung von doppeltkohlensaurem Natron passiren. Als Untersuchungsobject wählen wir zunächst ein ziemlich langes Sprossende von Hippuris vulgaris, das, wie es Fig. 12 zeigt, unter dem Wasserspiegel mit seiner Basis in ein mit Vasser angefülltes Probirglas hineinragt. Die Vorrichtung wird nummehr einige Zeit dem directen Sonnenlicht ausgesetzt. Es zeigt sich, dass von der Schnittfläche des Untersuchungsobjectes Gasblasen in dem Wasser emporsteigen, und in dem Probirglas sammelt sich nach und nach eine erhebliche Gasmenge an. Wenn wir die Mündung des Reagensrohres schliesslich unter Wasser mit dem Finger verschliessen, dasselbe umkehren und einen glimmenden Span einführen, so brennt derselbe sofort mit lebhaft leuchtender Flamme. Unsere Pflanze hat also Sauerstoff producirt.

Dies ungemein lehrreiche Experiment zur Nachweisung der Sauerstoffabscheidung assimilirender Pflanzen kann auch in etwas modificirter Weise angestellt werden (vgl. Fig. 13). Eine ganze Anzahl Zweigstücke von Elodea oder Ceratophyllum wird unter einen Trichter in ein mit kohlensäurehaltigem Wasser angefülltes Glas gebracht. Ueber die sich noch unter dem Wasserspiegel befindende Mündung des Trichterrohres wird ein mit Wasser angefülltes Probirglas gestülpt und der Apparat dem directen Sonnenlicht ausgesetzt. Der Sauerstoff oder, besser gesagt, die sauerstoffreiche Luft sammelt sich, wie bei der Ausführung des vorigen Experimentes, in dem Reagensglase an. Das Pflanzenmaterial zu diesen Versuchen steht auch lange Zeit im Winter zur Verfügung, wenn man kräftige Elodea-Exemplare im Herbst in ein grosses; mit Brunnenwasser gefülltes Gefäss bringt, das Gefäss im warmen Zimmer am Fenster aufstellt und das Wasser hãufig erneuert.

Ein Glascylinder wird mit Brunnenwasser, in das wir, wenn dasselbe arm an freier Kohlensäure ist, eine kleine Menge dieses Gases eingeleitet haben, angefüllt. Wir bringen nun ein Zweigstück von Elodea oder Hippuris, das wir zweckmässig an einen Glasstab angebunden haben, in die Flüssigkeit (vgl. Fig. 14) und werden beobachten, dass aus der Schnittläche am oberen Ende der Pflanzentheile bei Lichtzutritt Gasblasen entweichen. Die Anzahl der aus sauerstoffreicher Luft bestehenden Gasblasen lässt ohne Weiteres auf die Energie schliessen, mit der die grünen Pflanzentheile assimiliren. Im directen Sonnenlicht z. B. scheiden Elodeazweige lıäufig einen so leblaften Strom feiner Blasen ab, dass man die Zahl der in bestimmter Zeit entweichenden Blasen nicht oder nur mühsam bestimmen kann. Andere Zweige der nämlichen Pflanze assimiliren unter denselben Uinständen weniger energisch. Die aus den Schnittflächen von Hippuriszweigen entweichenden Gasblasen sind ziemlich gross und treten nicht in so ïbermässiger Anzahl hervor.

Ohne näher auf die Beziehungen zwischen der Intensität des Lichtes ciner- und der Energie der Assimilation andererseits einzugehen, ist es doch leicht, sich davon zu überzeugen, dass dic Saucr- 
stoffabscheidung grüner Pflanzentheile im hellen diffusen Licht lebhafter als im mehr gedämpften Licht vor sich geht. Ein an einem Glasstab festgebundenes Elodeazweigstück wird unter Wasser dein Einfluss hellen diffusen Lichtes ausgesetzt. Wir ermitteln die Zahl der Blasen, welche in bestimniter Zeit, z. B. in einer oder in fünf Minuten, aus der Schnittfläche hervortreten. Nun stellen wir eine mattgeschliffene Glasplatte vor unserem Apparat auf, und es wird sich zeigen, dass jetzt in einer oder in fünf Minuten weniger. Blasen als vorher in dem Wasser emporsteigen. Beschatten wir den Elorleazweig stark, so hört die Assimilation, damit auch die Sauerstoffproluction, gänzlich auf.

Elodea- oder Hippuriszweige werden in Brunnenwasser, in welches

Fig. 13.
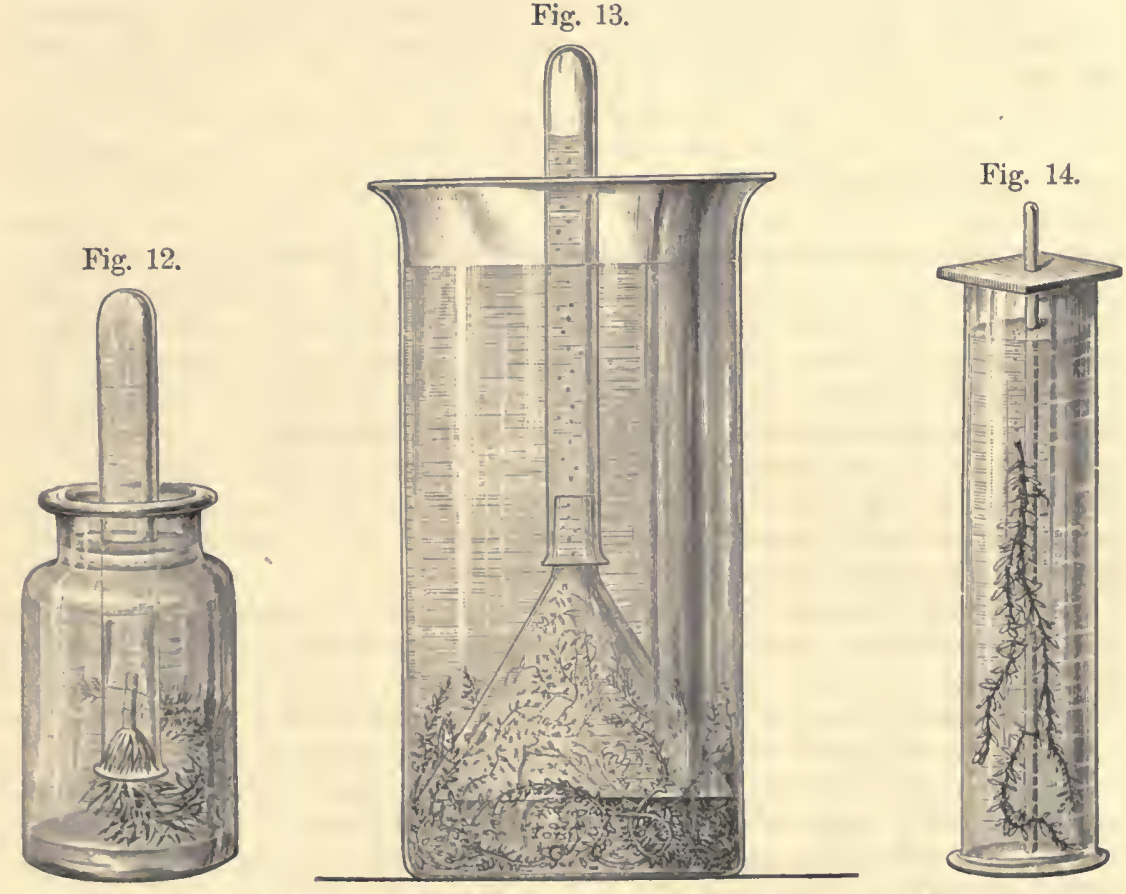

Fig. 12. Apparat zum Auffangen des ron assimilirenden Wasserpflanzen producirten Sauerstofs.

Fig. 13. Apparat zn demselben Zweck.

Fig. 14. Apparat zur Bcobachtung der Gasblasenabseheidung assimilirender Wasserpflanzen.

man eventuell etwas Kohlensäure eingeleitet hat, sehr hellem diffusen Licht ausgesetzt. Man ermittelt die in bestimmter Zeit entweichende Blasenzahl. Man deckt nun eine mit einer Lösung von doppelt-chromsaurem Kali gefüllte doppeltwandige Glasglocke über das die Pflanzentheile enthaltende Gefäss, um abermals die Zahl der entweichenden Blasen zu bestimmen. Dann entfernen wir die Glocke, um sie, nachdem wir abermals die Blasenzahl ermittelt haben, die im hellen diffusen Licht oder im directen Sonnenlicht ausgeschieden wird, durch 
eine mit liupferoxydammoniak angefüllte doppeltwandige Glasglocke zu ersetzen. Auch unter diesen Umständen stellen wir die Blasenzahl fest. Man tlıut wohl, zur Controle der Temperaturverhältnisse während der einzelnen Stadien des Versuchs ein Thermometer in das die Untersuchungsobjecte nmgebende Wasser zu bringen. Auf die im Vorstehenden angegebene Weise gelingt es, wovon ich mich überzeugte, sehr leicht, die interessante Thatsache festzustellen, dass die weniger brechbaren Strahlen, welche die Lösung des doppelt-chromsauren Kali passirt haben, eine fast ebenso energische Sauerstoffabscheidung aus grünen Pflanzentheilen hervorrufen, wie das gemischte weisse Licht, während dieser Process der Sauerstoffabscheidung unter dem Einfluss der brechbaren Strahlen, welche die Kupferoxydammoniaklösung passiren können, mit nur sehr geringer Energie erfolgt ${ }^{1}$ ).

Elodea- oder Hippuriszweige werden nebst einem Thermometer in kohlensäurehaltiges Wasser in ein Becherglas gebracht. Die Temperatur des Wassers möge etwa $12^{\circ} \mathrm{C}$. betragen. Wir ermitteln die Blasenzahl, welche die Untersuchungsobjecte in bestimmter Zeit, z. B. in 1, 3 oder 5 Minuten, bei Lichtzutritt abscheiden. Jetzt erwärmen wir das Wasser im Becherglas, ohne die Pflanzen aus demselben zu entfernen, bis auf etwa $24^{\circ} \mathrm{C}$. Es wird sich zeigen, dass die von den Elodea- oder Hippuriszweigen producirte Blasenzahl jetzt erlieblich grösser ausfällt, als bei niederer Temperatur. Zu achten ist natürlich darauf, dass die Pflanzen bei den vergleichenden Versuchen möglichst genau derselben Lichtintensität ausgesetzt sind; man stellt die Experimente daher am besten bei völlig wolkenlosem Himmel an. Das Temperaturoptimum für die Sauerstoffabscheidung von Elodea und Hippuris, welches übrigens noch nicht genauer ermittelt ist, dürfte etwa bei $32^{\circ} \mathrm{C}$. anzunehmen sein. Bei Temperaturen, die jenseits dieses Temperaturoptimums liegen, erfolgt die Sauerstoffabscheidung wieder langsamer ${ }^{2}$ ).

Einige Elodeazweige setzen wir in kohlensäurehaltigem Brunnenwasser, das zuvor mit Chloroform geschüttelt worden ist, dem Einfluss des Lichtes aus. Dic Sauerstoffabscheidung dauert merkwürdig lange (bei meinen Versuchen über $1 / 4$ Stunde) fort; endlich erlischt sie in Folge der giftigen Wirkung des Chloroforms gänzlich ${ }^{3}$ ).

Will man den Nachweis liefern, dass chlorophyllfreie Pflanzentheile nicht $\mathrm{zu}$ assimiliren vermögen, so braucht man z. B. nur Wurzelstücke in kolllensäurehaltigem Wasser dem Licht auszusetzen. Sauerstoffabscheidung erfolgt nicht.

Eine sehr interessante Methode zum Nachweis der assimilatorischen 'Thätigkeit grüner Zellen ist zuerst von Engelmaxx ${ }^{4}$ ) in Anwendung gebracht worden. Wir entnehmen den Reinculturen von Bacterium Termo, die wir in einer später anzugebenden Weise hergestellt haben, schwärmende Individuen, bringen dieselben in einem Wassertropfen auf den Objectträger, legen das Deckglas auf und verkitten dessen Ränder mit Vaselin.

1) Genauere Angaben über den Einfluss des Lichtes von verschiedener Brechbarkeit auf den Assimilationsprocess finden sich in meinem Lehrbuche der Pflanzenphysiologie. Ueber Assimilationsversuche im objectiven Spectrum vergl. PFEFFER, Botan. Zeitung, 1872, No. 23. Ueber Herstellung des objectiven Spectrums vergl. den Abschnitt über heliotropisehe Nutationen.

2) Vgl. Heixrich, Versuchsstationen, Bd. 13, S. 136.

3) Vgl. DetMer, Landwirthschaftliche Jahrbücher, Bd. 11.

4) Vgl. Figelmaxx, Botan. Zeitung, 1881 und 1882. 
Unter Benutzung starker Vergrösserung constatiren wir, dass die sehr sauerstoffbedürftigen Bacterien bald zur Ruhe kommen; nur in der Nähe von Luftblasen im Präparat dauert die Bewegung fort, um indessen auch schliesslich aufzuhören. Haben wir aber gemeinsam mit den Schwärmern einen Algenfaden in das Präparat gebracht, so danert die Bewegung der Bacterien, wenn die Alge beleuchtet ist, ununterbrochen fort. Der von den Chlorophyllkörpern erzeugte Sauerstoff wirkt als Reizursache und bedingt die Bewegung sowie auch die Bewegungsrichtung der Spaltpilze. Die Ansammlung derselben, welche in der Nähe der sauerstoffspendenden Alge eintritt, folgt, wenn wir z. B. mit Spirogyrafäden experimentiren, dem Verlauf der grünen Bänder. Unsere aërotropen Schwärmer sind also ein ausgezeichnetes Reagens auf Sauerstoff. Bei Verdunkelung der Algenfäden in Präparat hört die Bacterienbewegung auf; sie macht sich aber bei erneuter Beleuclitung sofort wieder geltend, weil dann abermals Sauerstoff durch Assimilation in hinreichender Quantität frei wird ${ }^{1}$ ).

\section{Die Kohlensäure und der Assimilatlonsprocess.}

Die Kohlensäure, welche im Assimilationsprocess verarbeitet wird, entstammt ihrer Gesammtmasse nach in letzter Instanz der atmosphürischen Luft. Diese repräsentirt ein Gasgemisch, das, abgesehen von einigen unwesentlichen Beimischungen, aus etwa 79 Volumprocent Stickstoff, 21 Volumprocent Sauerstoff und wenig Kohlensäure (in 10000 Volumthl. Luft sind nur 3 Volumth. $\mathrm{CO}_{2}$ vorhanden) besteht. Dass die Luft Sauerstoff enthält, lässt sich leicht demonstriren. Man befestigt an dem einen Ende eines zweimal in einem rechten Winkel gebogenen dicken Drahtes ein mit Alkohol getränktes Stück Watte. Der Alkohol wird entzündet und ein umgekehrt gehaltener Glascylinder über die Flamme gestülpt. Taucht man die Mündung des Cylinders jetzt schnell unter Wasser, so erhebt sich die Fliissiglieit sogleich in demselben, während die Flamme alsbald erliseht. Der Alkohol bedarf des Sauerstoffes zu seiner Verbrennung; er entnimmt ihn der Luft im Glascylinder, und in dem Maasse, in welchem der Sauerstoff verschwindet, steigt das Wasser in die Höhe.

Dass die atmosphärische Luft Kohlensäure enthält, ist ebenfalls leicht zu beweisen. Fin Luftstrom, den man mit Hülfe einer Wasserluftpumpe oder eines Tropfaspirators erzeugt, wird zu dem Zweck durch klares Barytwasser geleitet. Dieses trübt sich dahei allmählich, weil die Kohlensïure eine Abscheidung von kohlensaurem Baryt bedingt. Bei genauen quantitativen Untersuchungen über den Kohlensäuregehalt der atmosphärischen Luft muss die Menge der den Apparat durchstreichenden Luft mit Hülfe einer Gasuhr gemessen werden. (Ausführliche Angaben über die Bestimmung des Kohlensäuregehaltes von Gasgemischen vergl. im dritten Abschnitt bei Untersuchung der Athmungsvorgänge.)

Das Wasser ist im Stande, eine nicht unerhebliche Luftmenge zu absorbiren. Wird ein etwa bis zur Hälfte mit Brunnenwasser gefülltes Glas unter den Recipienten einer Luftpumpe gestellt, und evacuirt man nun, so entweicht die im Wasser aufgelöste Luft alsbald, weil der auf

1) Die Exgrumax'sche Methode ist anch benntyt worden, um dic Stäke der Kohlensäurezersetzung mo Sauerstoffprorluetion in den versehiedenen Theilen des Spectrums zu messen. \%u diesem Zwecke dient das von /13ss (Cafalog 1885, Nr. 93, Preis 1:24 M.) angefertigte Mikrospectralobjectiv. 
dem Wasser lastende Luftdruck schnell sinkt. Versetzt man etwas Blunnenwasser mit klarem Kalk- oder Barytwasser, so entsteht eine mehr oder minder erhebliche Trübung der Flüssigkeit, weil sich kohlensaurer Kalk resp. Baryt abscheidet. Freilich beweist das Auftreten dieser Trübung nicht streng, dass das Wasser freic Kohlensäure in Lösung enthält; sie kann auch dureh Kohlensäure verursacht werden, die in lockerer Bindung im Kalkbicarbonat des Wassers vorbanden ist.

Ohne die Gegenwart von Kohlensäure in den die Pflanzen umgebenden Medien (Luft oder Wasser) ist keine Assimilation, keine

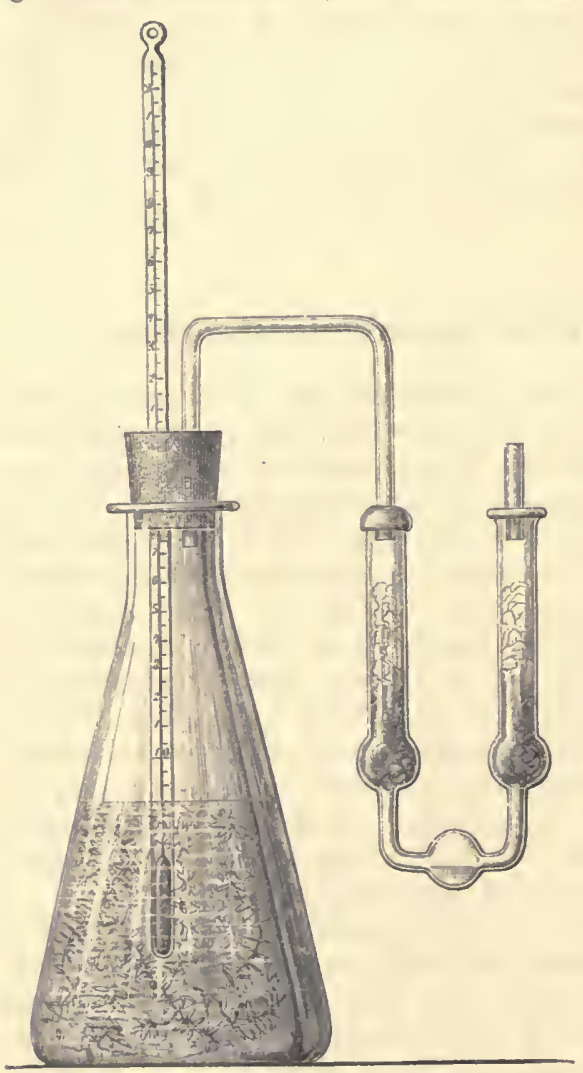

Fig. 15. Apparat zur Feststellung der Thatsache, dass grtine P'flanzen nur dann Sauerstoff produeiren können, wenu ihnen Kohlenshure zur Verfigums steht.
Bildung organischer Substanz und natürlich auch keine Sauerstoffproduction möglich. Der Nachweis, dass in der grünen Pflanzenzelle nur dann organische Körper neu erzeugt werden, wenn es nicht an Kohlensüure mangelt, soll später geliefert werden. Hier wollen wir ein Experiment ausführen, dessen Resultat deutlich zeigt, dass die chlorophyllhaltigen Pflanzenzellen nur dann Sauerstoff produciren, wenn ihnen Kohlensäure zur Disposition steht. Ein Glaskolben von etwa $400 \mathrm{ccm}$ Capacität wird mit 300 ccm Brunnenwasser angefüllt ${ }^{1}$ ). Wir bringen nun eine erhebliche Menge Elodeaptlanzen in das Wasser, verschliessen die Kolbenmündung mit einem durchbohrten Kautsclıukkork und führen in die Bohrung den einen Schenkel eines Glasrohres ein, das durch seinen anderen Schenkel mit einem U-förmigen Glasrohre in Verbindung steht, welches vorher mit Bimssteinstückchen, die mit Kalilauge getränkt sind, und mit Stückchen Aetzkali angefüllt worden ist (vgl. Fig. 15). Die PHanzen leiden keinen Luftmangel, denn die Luft kann durch das U-förmige Rohr zum Wasser gelangen. Der Zutritt von Kohlensäure aus der Atmosphäre zu den Pflanzen
ist dagegen ausgeschlossen. Setzen wir unseren Apparat dem Einfluss des directen Sonnenlichtes aus, so sehen wir, dass die Pflanzen eine lebhafte Sauerstoffabscheidung auf Kosten der im Wasser gelösten Kohlensäure unterhalten. Wir fassen bestimmte Elodeaexemplare genauer ins Auge und bestimmen von Zeit zu Zeit, etwa alle halbe

1) Zweckmässiger ist es noch, an Stelle des Kolbens einen Glaseylinder von geringem Durchmesser zu benutzen. 
Stunde, die Anzahl von Gasblasen, welche sie in einer Minute liefern. Es ergiebt sich dabei, dass die Sauerstoffabscheidung allmählich schwächer und schwächer wird; endlich (bei meinen Experimenten nach 6 Stunden) hört die Sauerstoffentwickelung völlig auf, weil die Kohlensäure des Wassers verbraucht wird. Oeffnen wir den Apparat jetzt und leiten etwas Kohlensäure in das Wasser ein, so beginnt die Saucrstoffabscheidung der Pflanzen am Licht aufs Neue ${ }^{1}$ ).

\section{Volumetrische Verhaltnisse des Gaswechsels bei der Assimilation.}

Wir stellen unsere Untersuchungen nach einer Methode an, die von PFEFFEl ${ }^{2}$ ) genau beschrieben worden ist, und die auch HoLI, ${ }^{3}$ ) benutzte. Der Apparat ist in Fig. $16 \mathrm{ab}$ gebildet. Den wesentlichsten Theil desselben macht ein an seinem oberen Ende bauchig erweitertes Glasrohr aus, dessen Gesanımthöhe etwa $360 \mathrm{~mm}$ beträgt, von welchen etwa $260 \mathrm{~mm}$ auf das calibrirte Rohr $c$ (im Folgenden Steigrohr genannt) fallen. Dieses ist am oberen Ende in einer Länge von 70 bis $75 \mathrm{~mm}$ zu einem Bauche $b$ aufgeblasen und endet mit dem kleinen oftenen Rohr ॥. Der Voluneugehalt des gesammten Apparates beträgt etwa 115 bis $120 \mathrm{ccm}$, von denen etwa 75 dem Bauche zukommen. Der Nullpunkt für die Graduirung wird von der durch die freic Aussenöffuung des Rölırchens $a$ gelegten Ebene gebildet; die Theilstriche sind aber erst auf das Steigrohr aufgetragen, dessen Durchmesser, wie noch bemerkt werlen mag, 14-15) mm beträgt. Dic Theilung kann, was in ler Abbildung nicht zum Ausdruck gelangt, bequem bis auf $2 / 10 \mathrm{ccm}$ durchgeführt werden.

Bei der Ausführung der Versuche ïber die Volumenverhältnisse bein Gaswechsel assimilirender Blätter wird der Blattstiel der Untersuchungsobjecte nöthigenfalls bis auf ein kur\%es Stiick weggeschnitten, und an dieses kurze Stück ein ganz dünner Eisendralıt $(d)$ vermittelst Durchstechens und mehrmaligen Umwickelns befestigt. Das an dem Draht befestigte Blatt wird in dem Steigrolır emporgeschoben, eine Operation, die gut gelingt, wenn man die

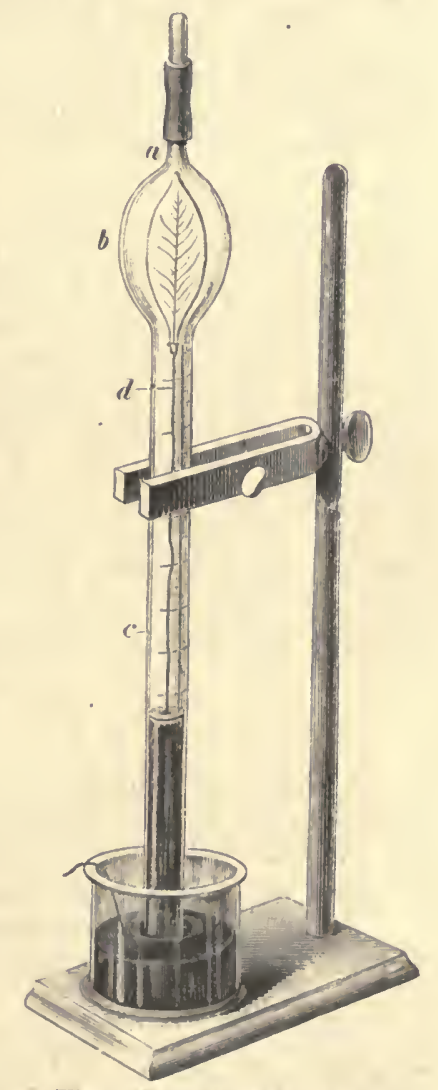

Fig. 16. Aplorat zur Bestimmung der Koblensïuremenge, welehe assimilirende Pflanzen zersetzen.

1) Vgl. Frıхк Scuwalz in Untersuchungen aus d. bot. Institut zu Tübingen, Bd. 1, S. 97.

2) Vgl. PFFFFre, Arbeiten des botan. Instituts in Würzburg, Bd. 1, H. 1.

3) $\mathrm{Vgl}$. Houle, Flora 1877. 
Blattränder sanft nach rückwärts umbiegt, das' Untersuchungsobject in das Steigrohr einführt und unter Beihülfe eines Holzstabes nach aufwärts befördert.

Der Apparat wird nun derartig aufgestellt, dass das untere Ende les Steigrohres in ein Quecksilber enthaltendes Glasgefäss eintaucht $\left.{ }^{1}\right)$, und man bringt sofort $(0,3 \mathrm{ccm}$ Wasser mit Hülfe einer an ihrem unteren Ende umgehogenen und zu einer feinen Spitze ausgezogenen Pijette 'über das Quecksilber in das Steigrohr. Ueber das bisher noch immer offene Rohr $a$ ist ein Kautschukschlauch gezogen. Derselbe wird in Verbinduug mit einer Wasser enthaltenden Saugflasche gesetzt, und indem man aus dieser durch Saugen etwas Luft entfernt, muss das Quccksilber im Steigrohr unseres Apparates emporșteigen. Der ülıer das Röhrchen $a$ gezogene Kautschukschlauch wird mittelst eines Quetschhahnes zur rechten Zeit abgeschlossen. Man führt dann in den Kautschukschlauch ein Stïck Glasstab ein, das man nach Entfernung des Quetschhahnes bis auf die Ränder des Röhrchens $a$ herunterdrückt, denen sich der Glasstab mit seiner abgeschliffenen und eingefetteten Fläche völlig anschliesst.

Wenn das Quecksilber im Steigrohr auf die angegebene Weise emporgehohen worden ist und sich nach einiger Zeit die Gastemperaturen ausgeglichen haben, so kann man zu ilen erforderlichen Ablesungen schreiten. Man liest das Gasvolumen am unteren Wassermeniscus ab, ferner die Höhe der Wasserschicht und den Stand des Quecksilbers über dem Niveau. Die in Millimetern angegebene Höhe der Quecksilbersäule sowie der der Wasserschicht entsprechende Quecksilberdruck repräsentiren die vom Barometerstand zu subtrahirenden Druckhöhen. Temperatur und Barometerstand sind natürlich genau zu notiren. Vom abgelesenen Gasvolumen ist noch das Volumen des Drahtes sowie des Blattes, welches man durch Eintauchen der Objecte in Wasser in bekannter Weise feststellt, abzuziehen, ebenso noch 0.3 ccm für den Wassermeniscus. Das Gasvolumen wird jetzt auf $0^{\circ} \mathrm{C}$, $1000 \mathrm{~mm}$ Quecksilberdruck und den Zustand der Trockenheit reducirt $\left.{ }^{2}\right)$.

$$
v^{\prime}=\frac{(v-m)\left(b-b^{1}-b^{2}\right)}{\left(1+0,00366 t^{0}\right)}
$$

$\mathrm{v}^{\mathrm{I}}$ ist das reducirte Gasvolumen; $\mathrm{v}$ bezeichnet das abgelesene Gasvolumen, $\mathrm{m}$ die Meniscuscorrection, b den Barometerstand, $\mathrm{b}^{1}$ die für die Quecksilbersäule im Steigrohr abzuziehende Druckhöhe, b ${ }^{2}$ die Tension des Wasserdampfes bei der Temperatur $t^{0}$.

Jetzt leitet man etwas (etwa $8 \mathrm{ccm}$ ) gereinigte Kohlensäure in las Eudiometer ein, stellt abermals das Gasvolumen im Apparat fest

1) Das zu verwendende Quecksilber muss recht rein sein. Die Reinigung mehrfach gebrauchten Quecksilbers wird in folgender Weise ausgeführt. Man übergiesst das Metall in einer dickwandigen Flasche mit dem gleiehen Volum Wasser, fügt wenig Salpetersäure hinzu und schüttelt die Mischung $1 / 4-1 / 2$ Stunde lang gut dureh. Nun wäscht man mit Wasser sorgfältig aus. Eventuell sind diese Operationen noch einmal zu wiederholen. Schliesslich trocknet man das Quecksilber init Fliesspapier ab, erwärmt es in einer Schale unter einem Abzug auf $120^{\circ} \mathrm{C}$., bedeckt die Schale mit einem Bogen Papier und lässt abkühlen. Fndlich wird das Metall noch durch Schreibpapier filtrirt, das man mit einigen Nadelstichen rersehen hat.

2) Vgl. Bussex, Giasonetrische Methoden, 1\$57, und Hfanpis, Gasanalytische Methorlen, 1890. 
und kann durch Subtraction des früher gefundenen von dem nummehr ermittelten und reducirten Gasvolumen leicht das Volumen der zugeführten Kohlensäure bestimmen. Beim Einleiten von Kohlensäure, iiberhaupt auch bei der Ausführung der vorhergehenden Operationen. ist darauf zu achten, dass man die Apparate möglichst wenig berührt, damit die Temperaturverhältnisse sich vor den Ablesungen möglichst schnell (in etwa 10-20 Minuten) ausgleichen können.

Alle analytischen Arbeiten müssen bei Ausschluss directen Sonnenlichtes vorgenommen werden. Ist die Kohlensäure in das Eudiometer eingeleitet, so kann man die Apparate aber, $11 \mathrm{~m}$ recht energische Assimilation hervorzurufen, einige Stunden lang den directen Sonnenstrahlen exponiren. Gleich nach der Exposition wird das Blatt aus dem Eudiometer entfernt, wobei man dasselbe etwas dreht, wenn es das sperrende Quecksilber passirt, um anhaftende Luftblasen zu entfermen. Nach etwa ¿ Stunden, wenn sich der Apparat völlig abgekühlt hat, liest man das Gasvolumen ab, führt mit Hülfe einer kleinen Pipette, dic man am oberen Ende verschliesst und mit der Hand erwarrmt, Kalilauge in das Steigrolır ein und erınittelt das Gasvolumen abermals, wenn die nicht durch den Assimilationsprocess zersetzte Kohlensäure absorbirt ist.

Die Experimente über den Gaswechsel bei der Assimilation stellt man zweckmässig mit Blättern von Prunus laurocerasus oder Nerium an. Vor der Einführung in das Eudiometer mïssen die Blätter dem Licht ausgesetzt gewesen sein, damit sie keine absorbirte Kohlensäure in ilırem Gewebe enthalten. Die Blätter bleiben in Eudiometer :3 bis 6 Stunden dem Licht exponirt, eine Zeit, in der zumal im directen Somuenlicht erhebliche Mengen der zugeführten Kohlensäure zersetzt werden können. Mit Bezug auf die Menge der in das Eudiometer einzuleitenden Kohlensäure sei bemerkt, dass 6 - $\mathbf{c c m}$ genügen. In vielen Fällen, wenn nämlich die Intensität des Somnenlichtes, dem die Blätter ausgesetzt werden. sehr bedeutend ist, empfiehlt es sich, über deın Eudiometer eine doppeltwandige, mit Wasser angefüllte Glocke (vgl. Fig. 9) aufzuhängen, damit die Erwärmung des Blattes und der Gasmenge im Apparat keine zu erhebliche werde. Man kann das Eudiometer übrigens ja auch bei zu intensivem Licht etwas beschatten, wobei Papierschirme gute Dienste leisten. Will man den Eintluss farbigen Lichtes auf die Energie der Kohlensäurezersetzung studiren, so hängt man doppeltwandige Glasglocken, die mit farbigen Lösungen angefüllt sind, über den Eudiometern auf und hält das von unten kommende Iicht in geeigneter Weise unter Benutzung von schwarzem Wachstuch ab (vgl. PFefrer's citirte Abhandlung).

Hier interessirt uns aber wesentlich nur das Verhalten der Blätter im gemischten weissen Licht. Inter dem Eintluss desselben werden in kurzer Zeit ansehnliche Kohlensäurerjuantitäten zersetzt, und man wird sich. wenn man die angegebene Methode bei der Ausführung der Untersuchungen sorgfältig handhabt, davon ïberzeugen, dass das zurückbleibende Gasvolumen im Euliometer nach der Exposition der Blätter im Sonnenlicht ebenso gross ist, wie vor der Exposition. Von ganz kleinen Differenzen, welche in das Bereich der Beobachtungsfehler fallen, ist natürlich abzusehen. Bei der Assimilation wird also eine Sauerstoffmenge erzeugt, die dem Volumen nach gleich ist der Quantität der zersetzten liohensäure. 


\section{Der makio- und mikioskopische Nachweis ron Stärke in den Assimilationsorganen.}

In sehr zahlreichen grïnen Pflanzentheilen wird als erstes leicht sichtbares Assimilationsproduct Anylum erzeugt. Es gehört daher zu den gewöhnlichsten Aufgaben des Pfianzenpliysiologen, diese Stärke in den Assimilationsorganen nachweisen $\mathrm{zu}$ inüssen, und dies kann sowohl auf makro- sowie auf mikrochemischem Wege geschehen. Wir fassen zunächst den ersteren Weg ins Ange.

Die einfachste, zuerst von SACHS ${ }^{1}$ ) zu ausgedehnten Experimenten angewandte Untersuchungsmethode besteht darin, dass man die auf Stärkegehalt zu prüfenden Objecte (sehr zweckmässig ist es, mit den Blättern von Tropaeolum, Helianthus, Solanum oder Phaseolus zu arbeiten) einige Minuten in kochendes Wasser legt, um sie dann in recht starken, auf $60^{\circ} \mathrm{C}$. erwärmten Alkohol zu bringen. Wenn man grössere Alkoholmengen benutzt, so nimint derselbe den Chlorophyllfarbstoff der Blätter meist sehr schnell vollständig auf, und die extrahirten Untersuchungsobjecte sind nach wenigen Minuten farblos. Jetzt gelangen die Blätter in eine Jodlösung. Man bereitet diese, indem man eine grössere Menge Jod in starkem Alkohol auflöst und die Lösung dann in destillirtes Wasser einträgt, bis die Flïssigkeit etwa die Farbe eines dunkeln Bieres besitzt. Sehr $\mathrm{zweckmässig}$ verwendet man auch eine Jodjodkaliumı̈ösung. Die Blätter bleiben eine halbe, eine oder mehrere Stunden in der Jodlösung liegen, bis sie keine weitere Farbenänderung erfahren; man hebt sie mit der Pincette aus der Lösung und legt sie in eine mit Wasser gefüllte weisse Porzellanschale. Bei völliger Abwesenheit der Stärke erscheinen die mit Jod gesättigten Blätter von hellgelber oder ledergelber Farbe. Kleine Stärkemengen verrathen sich durch schwärzliche Farbe der Blätter, grössere durch tiefer schwarze Farbe derselben. Wenn man die stärkereichen, mit Jod gesättigten Untersuchungsobjecte mehrere Stunden lang auf einem Teller in Wasser liegen lässt, so nehmen sie oft eine blaue Farbe an. Bei Experimenten, die ich mit Tropaeolumblättern anstellte, trat dieser Farbenton besonders schön hervor.

Wenn es sich darum handelt, auf mikrochemischem Wege die Frage zu entscheiden. ob in den Assimilationsorganen Stärke rorlianden ist oder fehlt, so werden die Untersuchungsobjecte (z. B. Algenfäden oder zarte Querschnitte aus Blättern etc.) zunächst zur Extraction des Chlorophyllpigmentes in starken, erwärmten Alkohol gelegt. Die gebleichten Präparate werden dann entweder kurze Zeit mit heisser, oder 20 Stunden lang mit kalter, mässig concentrirter Kalilauge in Berïhrung gebracht, sorgfältig mit Wasser ausgewaschen, zur völligen Neutralisation des Kalis mit verdünnter Essigsäure belıandelt, abermals mit Wasser ausgewaschen und in einen Tropfen Jodjodkaliumlösung (bereitet durch Auflösen ron 0,05 g Jod und 0,2 g Jodkalium in 15 gr Wasser) gebracht ${ }^{2}$ ). Sehr bequem zu handhaben ist die folgende Methode des Nachweises von Stärke in grünen Zellen ${ }^{3}$ ). Die Untersuchungsobjecte (mit besonderem Erfolg benutzte

1) Vgl. SAcus, Arbeiten d. botan. Instituts in Würzburg, Bd. 3, S. 1.

2) Vgl. Böнm, Sitzungsberichte d. Akad. d. Wiss. zu Wien, Bd. 2*, S. 479, und SAchs, Botan. Zeitung, 1861, S. 291.

3) Vgl. A. MrYfr, Das Chlorophyllkorn, 18s3, S. 28. 
jch die gar nicht weiter präparirten Blätter von Elorlea canadensis und Funaria hygrometrica) werden ohne weiteres, odler, was oft erforderlich ist, nach der Extraction mit Alkolıol auf dem Objectträger in einen Tropfen der Lösung des Chloralhydrats (־) Thl. Chloralhydrat auf 2 Thl. Wasser) gelegt, etwas Jodjorlkaliumlösung hinzugesetzt und sofor't beobachtet. Der Chlorophyllfarbstoff wird gelöst, die Stärkekörner quellen etwas auf, und sie nehmen in Berïhrung mit der Joljodkaliumlösung eine schön blaue Färbung an, ebenso wie dies geschieht, wenn die mit Kali und verdünnter Essigsäure behandelten stärkehaltigen Untersuchungsobjecte mit dem Jodreagens in Contact zcelangen.

Wollen wir uns davon über\%eugen, dass das durch Assimilation gebildete Amylum nicht etwa an beliebigen Orten einer Zelle, sondern in Ilen Chlorophyllkörpern vorhanden ist, so wählen wir zweckmäissig Spirogyra, Zygnema oder Blätter von Funaria hygrometrica als Beobachtungsobjecte. Wir bedienen uns bei der Ausführung der Untersuchung der zuletzt angefülnrten Methode unter Zuhülfenahine von Chlorallygirat.

\section{Die Assimilationsproducte.}

Es unterliegt gar keinem Zweifel, dass die Stärke in den Blättern zahlreicher Ptlanzen als erstes leicht sichtbares Assimilationsproduct auftritt. Dagegen existiren andere Gewächse, welche selbst unter sehr guinstigen Assimilationsbedingungen nur relativ geringe, resp. selır kleine Stärkemengen oder endlich gar keine Stärke erzeugen. Am Nachmittag eines heissen Sommertages schneiden wir z. B. in derselben Stunde Blätter von Tropaeolum majus, Phaseolus mnltiflorus, Helianthus annuus, einer Polygonumart, einer Gentianaspecies, von Tamus communis und von Allium Cepa ab. Es ist am besten, wenn sich die Pflanzen, denen wir die Blätter entnehmen, unter möglichst ähnlichen Bedingungen entwickelt haben, wie solche z. B. im System der botanischen Gärten gegeben sind. Z $\mathrm{u}$ bemerken ist noch, dass wir stets mit völlig ausgewachsenen Blättern operiren müssen. Die Untersuchungsobjecte werden in ler Art, wie es unter 14 angegeben worden ist, makroskopisch oder mikroskopisch auf ihren Stärkegehalt geprüft, und wir constatiren, dass die Blätter von Tropacolum. Phaseolus und Tamus reichliche Amylummengen in ihren grünen Zellen enthalten, während die Helianthusblätter schon weniger Stärke führen. Noch geringer ist der Stärkegehalt der Polygonumblätter, sehr gering derjenige der Gentianablätter, und die Alliumblätter erweisen sich als völlig stärkefrei.

Zur weiteren Orientirung über die hier in Rede stehenden Verhältnisse stellen wir das folgende lehrreiche Experiment an. Eine erhebliche Quantität der Blätter von Helianthus tuberosus, die wir am Nachmittag eines heissen Sommertages gesammelt und nach Entfernung der Blattstiele in kleine Stücke zersehnitten haben, wird \%wischen Leinwand mittelst einer Handpresse ausgepresst. Wir bestimmen das Volumen des gewonnenen, dunkel gefärbten Saftes, kochen ihn auf, ersetzen das verdunstete Wasser wieder, wenn die Flüssigkeit erkaltet ist, und filtriren sie. In genau der nämlichen Weise stellen wir uns Saft aus den Blättern von Allium Cepa dar, die zur 
selben Zeit wie die Helianthusblätter eingesammelt worden sind. Wir ermitteln ıuı durch Filtriren diejenigen Saftmengen, welche zur Reduction von 10 ecm FEIILING'scher Lösung erforderlich sind, und finclen, dass eine bedentende Quantität des Helianthussaftes, dagegen eine sehr geringe des Alliumsaftes \%ur Reduction der FEnLING'schen Lösung verbraucht wir'( $\left.{ }^{1}\right)$. Blätter, die reichlichere Stärkemengen erzeugen, entlalten also wenig Glykose; Blätter, welche keine Stärke bilden, sind sehr glykosereich. Die Glykose in den Blättern von Allium und anderen Gewächsen ist, wie SACHS ${ }^{2}$ ) es schon vor langer Zeit aussprach, und wie es ArTHur MEYER ${ }^{3}$ ) specieller feststellte, in del That als Assimilationsproduct zu betrachten.

Wir können die Untersuchungen über Stärke- und Zuckergehalt assimilirender Laubblätter auch, wie folgt, ausführen und ebenfalls einerseits Helianthus-, andererseits Alliumblätter verwenden. Das Untersuchungsmaterial wird in einem grossen Trockenschranke bei etwa $80^{\circ} \mathrm{C}$. möglichst schnell getrocknet, dann sehr fein zerrieben und bei $100^{\circ} \mathrm{C}$. wasserfrei gemacht. Circa 5 g Trockensubstanz. ïbergiessen wir in einem Becherglas mit $100 \mathrm{ccm}$ Wasser von $30^{\circ} \mathrm{C}$. digeriren einige Sturiden, filtriren die Lösung ab und waschen den Ruickstand auf dem Filter sorgfältig aus. Dic auf $200 \mathrm{cem}$ aufgefüllte Lösung theilt man in zwei Portionen. In $50 \mathrm{ccm}$ der einen bestimmt man mit FeHLING'scher Lösung direct die Menge des vorhandenen, reducirend wirkenden Zuckers. Die zweite Portion wird mit wenigen Tropfen Salzsäıre längere Zeit erwärmt und schliesslich ihr Gehalt an Zucker bestimmt. Vergl. Näheres im dritten Abschnitt. Man gewinnt anf solche Weise schliesslich ein Urtheil iiber den Gehalt der Blätter an direct und erst nach der Inversion reducirend wirkendem Zucker. Um auch den Stärkegehalt der Blätter zu ermitteln, wird der Rückstand auf dem Filter mit $200 \mathrm{ccm}$ Wasser in einen Kolben gespült und in der in dritten Abschnitt angegebenen Weise weiter behandelt. Mit Hülfe FEHLING'scher Lösung ist es schliesslich möglich, die vorhandene Zuckermenge, die ein Maass für den Stärkegehalt der Blätter abgiebt, zu constatiren ${ }^{4}$ ).

Diese Methode lässt sich auch bei Untersuchungen über specifische Assimilationsenergie der Blätter ouler bei dem Studium der Abhängigkeit der Assimilation in den Blättern von Beleuchtungsverhältnissen etc. verwenden. Wir experimentiren z. B. mit Helianthus- oder Cucurbitablättern. Wir schneiden von einigen Blättern frühmorgens 5 Uhr die eine Hälfte ohne Verletzung des Mittelnervs ab. legen die Blattstücke auf ein Zeichenbrett, bedecken sie unter Ausschluss ler stärkeren Rippen mit dünnen Holzbrettchen von 50 oder 100 qcm Fläche, drücken diese an und schneiden mit einem Skalpell die Blattflächen aus. Die zweiten Blatthälften werden erst

1) Handpressen und Presstïcher sind von der Firma G. Wrivneroth in Cassel zu beziehen. Vergl. Preisverzeichniss No. 2907 . Sind die Säfte nach dem Filtriren schr dunkel gefärbt, so thut man gut, sie mit etwas Bleiessig zu versetzen, zu filtriren, unit Schwefelwasserstoff zu entbleien und den Schwefelwasserstoff durch Einleiten eines Luftstromes zu entfernen. Ueber Bereitung des Bleiessigs rergl. C. WoLfF, Anleitung zur Untersuchung landwirthschaftl. wichtiger Stoffe, 1875, S. 188. Die Frinlsg'sche Jösung wird in der im dritten Abschnitt angegebenen Weise dargestellt.

2) Vgl. SAcus, Handbuch d. Experimentalphysiologie d. Pflanzen, 1865, S. 326.

3) ARTII. Mreyer, Botan. Zeitung, 1885, Nr. 27.

4) Vgl. anch SAPOscrixikofF, Berinte d. Deutschen botan. Gesellschaft, Bd. 9. Ferner vergl. Browx und MonRIs, Jol'”nal of the chem. socjety, May 1893. 
nach 8-12-stündiger Assimilationsthätigkeit von der Pflanze abgeschnitten und damn ebenso wie die ersten behandelt. Es ist darauf zu achten, die Schablonen nach Möglichkeit symmetrisch gleichen Blattheilen aufulegen. Gleich nach erfolgtem Ausschneiden der Blattlächen werden die Blattstücke schnell bei $80^{\circ} \mathrm{C}$. getrocknet. Bei Helianthus annuus wiegen 500 (qcm Blattfläche trocken etwa $4 \mathrm{~g}$. כ-10 g Trockensubstanz dienen dann zur Bestimmung der vorhandenen Kohlehydrate (Zucker, Stärke), und man wird finclen, dass die nachtrïglich abgeschnittenen Blatthälften erheblich reicher an diesen Stoffen sind als die zuerst geernteten. Wenn die Assimilationsbedingungen am Tage günstige waren. Während die Blätter assimiliren, häuft sich nicht die Gesammtmenge der entstehenden Producte im Blatt an. Ein Theil der Kohlehydrate wandert aus und wird verathmet. Die Quantität dieser Stoffe ist nicht zu vernachlässigen. Man ermittelt sie annähernd genau, indem man an Abend Blättern, die jenen sehy ähnlich sind, welche $\mathrm{zu}$ den schon erwähnten Experimenten dienen, Stücke entnimmt, um sie auf Zucker und Stärke zu prüfen. Die zurückbleibenden Blattflächen schneidet man erst nach Verlauf von 8 Nachtstunden ab, um sie der Untersuchung zu unterwerfen. Unter Berïcksichtigung der Auswanderungsgrösse der Kohlehydrate findet man z. B., dass 1 qm Blattfläche von Helianthus pr. Stunde etwa 2 g dieser Körper unter günstigen Assimilationsbedingungen producirt '). Die ausgewanderte Menge an Kiohlehydraten ist bei der Berechnung natürlich der am Tage producirten hinzı zu addiren. Merkwürdig ist, wie neuere Beobachtungen lehrten, dass selbst bei Helianthus nur ein Bruchtheil (etwa $1 / 6$ ) der durch Assimilation gebildeten Kohlehydrate Stärke repräsentirt.

Die Gesammtmenge der durch Assimilation gebildeten Stoffe findet man auch annühernd genau, wenn man z. B. Helianthusptlanzen in angegebener Weise früh morgens und gegen Abend je 500 qcm Blattläche entnimmt und dieselben, ebenso wie andere, welche theils abends, theils erst nach 8 Nachtstunden abgeschnitten worlen sind, zunächst schnell bei etwa $80^{\circ} \mathrm{C}$, dann nach dem Zerpulvern bei $100^{\circ} \mathrm{C}$. völlig austrocknct. Die Werthe für die Gewichtszunahme von je 500 yem Blattfäche am Tage und für die Gewichtsabnahme von 500 qem in der Nacht sind zu addiren. Man gewinnt auf solche Weise cin ungefähres Maass für die assimilatorische Thätigkeit der Untersuchungsobjecte. Diese, sowie auch die früher erwälnnten Experimente sind an recht hellen, sonnigen Tagen und in recht warmen Nächten auszuführen.

Wir diurfen nun heute von der Anschaumng ausgehen, dass auch in den grünen Zellen solcher 13lätter, die sich als sehr stärkereich erweisen, in Folge des Assimilationsprocesses aus der Kohlensäure und dem Wasser nicht direct Stärke, sondern zunächst Glyliose erzeugt wirl. (Vgl. mein Lehrbuch der Ptlanzenphysiologie, 1883, S. 38 und 198.) Diese Glykosemenge kann in den amylumreich erscheinenden Blättern in Folge specifischer Eigenschaften ihrer Chlorophyllkörper sehr leicht in Amylum übergeführt werden, wälırend die Stärkebildung aus ler durch Assimilation erzeugten Glykose in den Zellen der Blätter anderer Ptlanzen mit mehr oder minder grossen Schwierig-

1) Vgl. SAcus, Arbeiten d. botan. Instituts in Würyburg, J3l. 3, und SAlos('Hsikoff, Berichte d. Deutsehen hotan. Gesellschaft, Bd. s. 
keiten verbunden ist. In dem hier in Rede stehenden Zusammenhange ist natürlich die Thatsache von grossem Gewicht, dass es gelungen ist, Blätter zur Stärkebildung auf Kosten der Glykose, die man ihnen von aussen zugeführt hat, zu veranlassen ${ }^{1}$ ). Ich habe solche Versuche nicht speciell angestellt, mich aber dlavon überzeugt, dass Blätter aus ihnen von aussen dargehotenem Rohrzucker ebenfalls Amylum zu bilden vermögen. Frische Blattstücke von Iris germanica, die etwa $10 \mathrm{~cm}$ Länge besassen, wurden, ohne die Wachsschicht zu beseitigen, auf 20-procentige Rohrzuckerlösung gelegt, die sich in einem flachen Glasgefäss befand. Die Blattstücke schwammen auf (ler Flïssigkeit, und ihre eine Fläche kam gar nicht mit derselben in Contact. Das flache Gefäss wurde mit einer Glasplatte bedeckt, aber zwischen diese und den Rand des ersteren ein Korkstüick gelegt, um den Zutritt der Luft zu den Pflanzentheilen nicht zu behindern. Die Untersuchungsobjecte blieben länger als eine Woche bei mittlerer Temperatur und im Dunkeln mit der Rolırzuckerlösung in Berührung. Bei Beginn des Versuchs prüfte ich einige Blattstücke makroskopisch auf Stärke; diese war nicht vorhanden. Die Blattstïcke aber, welche \& Tage lang auf der Zuckerlösung verweilt hatten, gaben deutliche Stärkereaction. Zu bemerken ist, dass die Irisblattstücke, bevor man sie bei Ausführung der Stärkereaction in die Jodlösung legt, ziemlich lange mit warmem Alkohol behandelt werden müssen, wenn man sie völlig rom Chlorophyllfarbstoff befreien will. Die Versuche lassen sich auch bequem mit den Blättern von Nicotiana Tabacum durchführen. Am frühen Morgen wird die eine Hälfte eines Blattes dieser Pflanze makroskopisch auf Stärkeabwesenheit geprïft, die andere aber auf Rohrzuckerlösung gelegt. Hat das Blattstück auf der Flüssigkeit einige Tage bei Lichtabschluss verweilt, so enthält es reichlich Stärke.

\section{Die Abhïngigkeit der Stärkebildung bei der Assimilation ron äusseren Verhïltnissen.}

Man lege einige Samen von Plaseolus in lockere Gartenerde, die sich in Blumentöpfen befindet, aus, cultivire die Pflanzen so lange im Dunkeln, bis die Cotyledonen eines sehr beträchtlichen Theiles ihres Reservestoffyorrathes beraubt sind, und untersuche die Primordialblätter nummehr auf makrochemischem Wege nach SACHS oder auf mikrochemischem Wege, indem man dünne Querschnitte mit Chloralhydrat- und Jodjodkaliumlösung behandelt (vgl. unter 14), auf Stärke. Anylum wird man nicht in den Mesophyllzellen antreffen. Lässt man die Pflanzen jetzt einige Tage lang bei Lichtzutritt stehen, so ergrünen sie, ihr Wachsthum beginnt aufs Nene, und in den Zellen der Blätter ist auf makro- oder mikrochemischem Wege nach der angegebenen Zeit Amylum nachzuweisen.

Werden die ausgewachsenen Blätter kräftiger, in Blumentöpfen bei Lichtzutritt cultivirter Exemplare von Tropaeolum oder Phaseolus makrochemisch oder mikrochemisch auf Stärke untersucht, so ist diese Substanz leicht in ihren Zellen nachzuweisen. Werden die Unter-

1) Vgl. Böнм, Botan. "/eitung, 1S63; А. MrYkr, Botan. /eitung, 1S55, Nr. 27. und besonders Botan. Zeitung, 15s6, Nr. כ. 
suchungsobjecte num bei hoher Sommertemperatur kure Zeit lang (vielleicht 48 Stunden), bei niederer Temperatur längere Zeit ins Finstere gestellt, so ist die Stärke aus dem Mesophyll ihrer Blätter verschwunden. Werden die Pflanzen wieder einige 'Tage lang dem Einfluss des Lichts ausgesetzt, so kann man sich leicht davon überzeugen, dass ilıre Blätter abermals stärkereich sind. Es ist zweckmässig, bei vergleichenden Untersuchungen über den Einfluss der Beleuchtungsverhältnisse auf die Entstehung und das Verschwinden des Amylums in den Zellen des Blattgewebes nach Ablauf der einzelneu Versuchsperioden nicht ganze Blätter von den Pflanzen abzuschneiden, sondern stets nur Stïcke der Blätter zu entfernen. Man ist dadurch in den Stand gesetzt, während der ganzen Versuchsdauer mit ein und demselben Blatt experimentiren zu können.

Untersucht man die Blätter der Knospen kräftiger und unter normalen Verhältnissen vegetirender PHanzen von Elodea canadensis auf Stärke, so findet man reichliche Mengen dieses Stoffes in den Zellen. Werden die Untersuchungsobjecte ins Dunkle gebracht, so verschwindet die Stärke völlig. (Nach meinen Erfahrungen bei hoher Sommertemperatur oft schon in 24 Stunden, freilich bei nicht so hoher Temperatur viel langsamer.) Erneute Beleuchtung bedingt bald wieder die Ansammlung grosser Amylumquantitäten im Blattgewebe. Ich habe es zweckmässig gefunden, die Elodeablätter vor der Behandlung mit Chloralhydrat und Jodjodkaliumlösung zunächst zur Entfernung des Chlorophyllfarbstoffes mit kochendein Wasser und heissem Alkohol zu extrahiren.

Spirogyrafäden sind bei höherer Sommertemperatur nach 1- bis 3-tägigem Verweilen im Finstern stärkefrei, wie die Prüfung auf Amylum mit Chloralhydrat- und Jodjodkaliumlösung lehrt. Setzt man die entstärkten Spirogyrafädlen dem directen Sonnenlicht aus, so enthalten sie in Folge der hohen Temperatur sowie der bedeutenden Lichtintensität sehr bald, z. B. schon nach einer halben Stunde, reichliche Amylummengen. Im diffusen Licht geht die Stärkebildung weit langsamer vor sich.

Will man den Einfluss des Lichtes von verschiedener Brechbarkeit auf die Stärkebildung im Chlorophyll untersuchen, so benutzt man als Beobachtungsobject bequem Spirogyrafäden oder Elodeapflanzen, die zur Entstärkung einige Tage im Dunkeln verweilt haben. Die amylumfreien Pflanzen werden in kleinen Schälchen, welche Brunnenwasser enthalten, unter doppeltwandigen Glocken oder in geeigneten Kästen (vgl. unter 8) dem Licht ausgesetzt, das die Lösung des doppelt-chromsauren Kalis und des Kupferoxydammoniaks passirt hat. Man setzt die Apparate dem directen Sonnenlicht oder dem diffusen Licht aus. Von Zeit zu Zeit, etwa alle 10 Minuten, wenn man bei directem Sonnenlicht, etwa alle 30 Minuten, wenn man bei diffusem Tageslicht experimentirt, untersucht man Spirogyrafäden oder Blätter aus den Knospen der Elodea auf Stärkegehalt. Es wird sich ergeben, dass, ebenso wie die Sauerstoffabscheidung im gemischten gelben Licht weit lebhafter als in gemischten blauen Licht erfolgt, auch die Stärkebildung durch die Strahlen von geringerer Brechbarkeit in viel ausgiebigerem Maasse als durch die Strahlen von grösserer Brechbarkeit herbeigeführt wird. Im direeten Sonnenlicht geht die Stärkebildung im Chlorophyll übrigens selbst unter dem Finfluss des gemischten blauen Lichtes ziemlich schnell vor sich, und ich fand z. B., dass anfangs stärkefreie Spirogyrafiden, die 35 Minuten lang bei hoher Temperatur 
dem Sonnenlicht ausgesetzt gewesen waren, das die Lösung des Kupferoxydammoniaks passirt hatte, nach dieser Zeit reichliche Stärkeeinschlüsse enthielten.

Lehrreich ist es ferner, panachirte Blätter, die kräftig assimilirt haben, nach der makrochemischen Methode von SAcHs auf Amylum zu untersuchen. Man benutzt z. B. zu solchen Versuchen die Blätter von Acer negundo oder von Sancheziaarten (letztere müssen ziemlich lange in der Jodlösung liegen). Es ergiebt sich, dass nur die grünen Blattheile, nicht die chlorophyllfreien, Stä.rke enthalten.

Das folgende Experiment, welches ich mit in Töpfen cultivirten Exemplaren von Tropaeolum majus ausführte, ist deshalb besonders interessant, weil es lehrt, dass die Stärkebildung im Mesophyll der Blätter insofern eine streng localisirte ist, als allein diejenigen Blatttheile assimilatorische Thätigkeit geltend machen, welche direct von

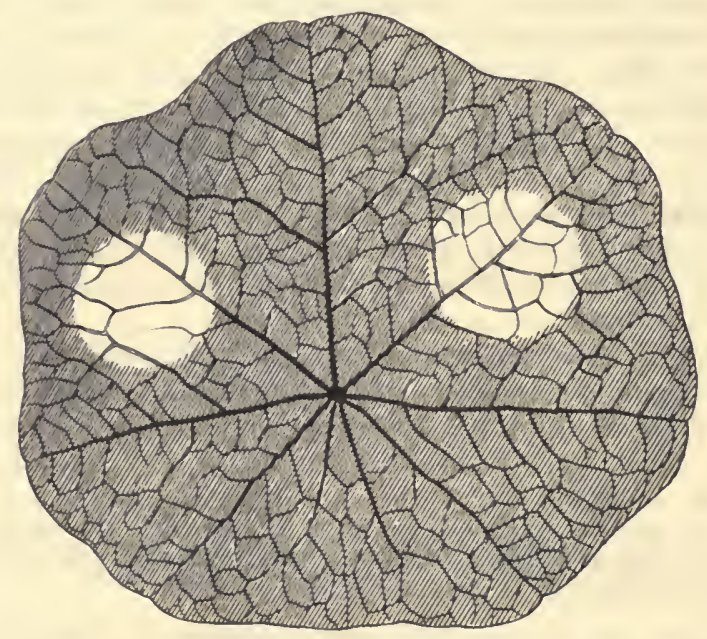

Fiı. 17. Ein der Jodprobe nuterworfenes Tropaeolumblatt. In den weiss erscheinenden Partien ist die Stärkebildung durch Verdunkelung unterdriickt worklen. langenden Untersuchungsobjecte von Lichtstrahlen getroffen werden kann. Nach einiger Zeit (bei meinen Experimenten nach $1 \frac{1}{2}$ Tagen). prüft man die stellenweis verdunkelt gewesenen Blätter makroskopisch auf Stärkegehalt. Das Mesophyll der kïnstlich verdunkelten Blattregionen ist amylumfrei; nur die Nerven führen Stärke. Die Blattstellen hingegen, welche von den Lichtstrahlen getroffen worden waren, erweisen sich als sehr amylumreich (vgl. Fig. 17).

Sehr wichtig ist es ferner, sich davon zu überzeugen, dass die Pflanzen nicht im Stande sind, Stärke bei Lichtzutritt in einer kohlensäurefreien Atmosphäre zu bilden, ja, dass die eventuell schon vorhandene Stärke unter diesen Umständen aus den Chlorophyllkörpern verschwindet. Wir legen einige Samen von Raphanus sativus oder von anderen Pflanzen (nit besonderem Erfolg experimentirte ich mit Lepidium sativum) in ausgeglïhten Sand, der mit gewöhnlicher, aber- 
mit Wasser verdünnter Nährstofflösung, wie man sie zu Wasserculturversuchen benutzt, gesëttigt ist und sich in kleinen Blumentöpfen befindet. Ist die Keimung bei Lichtzutritt so weit fortgeschritten, tlass die Cotyledonen ausgewachsen sind, dann gelangen die Untersuchungsobjecte, in deren Keimblättern man reichliche Stärkemengen leicht nachweisen kann, in den in Fig. 18 dargestellten Apparat. Die Glasschale $G^{\prime}$ enthält Quecksilber, iiber das wir eine diunne Wasserschicht bringen. An Stelle des Quecksilbers kann man auch Wasser verwenden. In der Glasschale $G^{\prime \prime}$ befindet sich starke Kalilauge und ein Glasklot\%, auf dem der Topf mit den PHanzen steht. Die Glasglocke $G g l$ wird über die Kieimlinge gedeckt; ihr unterer Rand taucht in das Quecksilber oder das Wasser ein, während durch die Bolırung des den Tubulus fler Glocke verschliessenden Kiorkes ein gebogenes Glasrohr geschoben wird, das mit dem $\mathrm{U}$-förmigen Rohre $U$, welches mit Kalilauge getränlite Bimssteinstücke sowie Kalihydratstückelen entlält, in Verbindung steht. Setzen wir den Apparat bis -2 Tage lang dem Einfluss des Lichtes aus (es ist vortheilhaft, wenn er während dieser Zeit, wenigstens periodisch, von directen Sonnenstrahlen getroffen wird), so sind die Cotyledonen stärkefrei geworden. Stellen wir slen Topf mit ilen PHanzen jetzt wieder frei ans Fenster, damn sammeln sich alsbald aufs Neue erhebliche Stärkequantitäten in den grünen Zellen der Keimblätter an ').

Will man Pflanzen längere Zeit in kohlensäurefreier Atmosphäre cultiviren, so thut man gut, um eine den Unter-

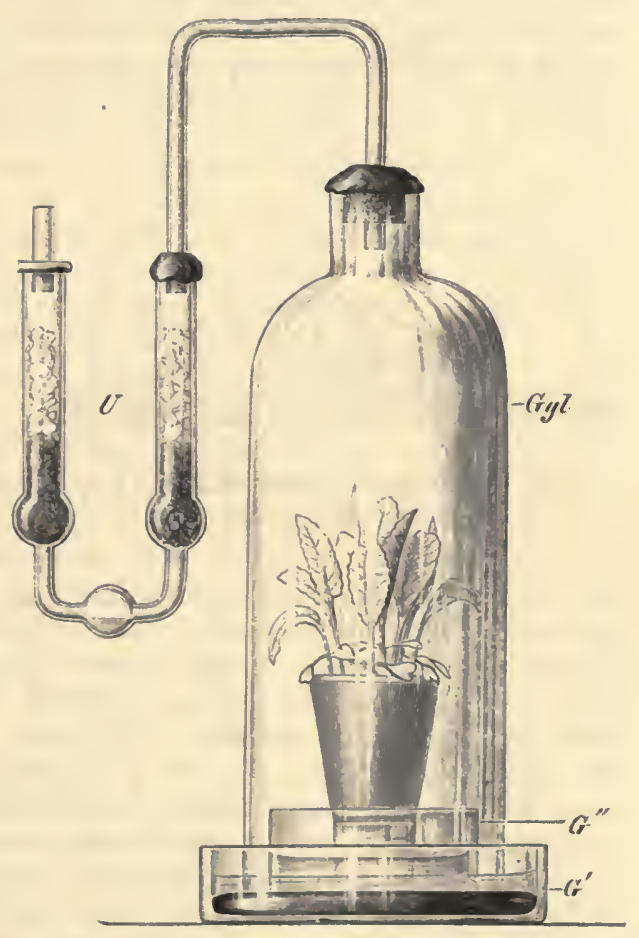

Fig. 18. Apparat zur Cultur rou Pflauzen bei Ausselıluss der Kohlensiure. suchungsobjecten nachtheilige, gar $\mathrm{zu}$ erhebliche Feuchtigkeitsansammlung in der Luft unter Ier Glocke des in Fig. 18 abgebildeten Apparates zu verhïten, in folgender Weise \%u experimentiren. Man benutzt eine recht grosse Glasglocke. Dieselbe taucht man in Quecksilber ein, iiber welches etwas Olivenöl geschichtet ist. Man kann auch eine Glocke mit wohl albgeschliffenem Rand verwenden und dieselbe auf eine matt geschliffene Glasplatte stellen. Den luftdichten Verschluss erzielt man unter Anwendung einer durch Zusammenschmelzen von :3-4 Thl. Schmalz und 1 Thl. Wachs hergestellten Mischung. Dieselbe ist in einem ver-

1) Vyl. Gond:wski, Flora, 1873, S. 382. 
schlossenen Gefäss, vor Staub geschïtzt, aufzubewalnen und kann oft zıun Dichten Verwendung finden, z. B. auch bei Experimenten mit der Luftpumpe. Im Uebrigen ist ler Apparat ebenso wie der in Fig. 18 abgebildete zusammengestellt. Eventuell sind Gefässe, die Chlorcalcium enthalten, in denselben einzuführen, un den Wassergehalt der Luft noch weiter herabzumindern.

Sehr interessant ist die von MoLI, ${ }^{1}$ ) festgestellte Thatsache, dass in manchen Fällen ein Blattstück in kohlensäurefreier Luft keine Stärlie bildet, wenn es mit einem anderen Theil desselben Blattes, der in kohlensüurereicher Luft stark assimilirt, noch in organischem Zusammenhang steht. Wir experimentiren in folgender Weise. Es werden zwei Krystallisirschalen ausgewällt (vgl. Fig. $19 a$ ॥. $a^{\prime}$ ), deren gut abgeschliffene Ränder genau an einander schliessen, wenn die Schälchen mit den Oeffuungen auf einander gestellt waren. Die Ränder der Schalen werden nun mit Talg bestrichen und Blätter von Cucurbita

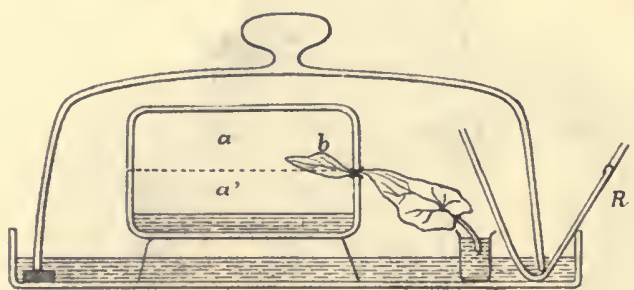

Fig. 19. Apparat nacl Moll zul Experimenten über Assimilationscrscheinungen.

Pepo oder Vitis vinifera, welche von Sprossen entnommen sind, die einige Zeit zur Entstärkung im Dunkeln verweilten, derartig zwischen die Ränder gelegt, dass die Blattspitze $b$ sich im abgeschlossenen Raum, Basis und Blattstiel sich aber draussen befinden. Die untere Schale enthält Kalilauge. Durch leisen Druck ist ein luftdichter Abschluss des zwischen den Schalen vorhandenen Raumes, der etwa $600 \mathrm{ccm}$ betragen mag, $\mathrm{zu}$ erzielen. Der Blattstiel taucht in ein kleines, Wasser enthaltendes Gefäss ein. Der ganze Apparat wird num unter eine grosse Glasglocke gestellt, welche calibrirt ist und etwa 4000 ccm Capacität besitzt. Sie rult auf flachen Marmorstückchen und taucht in Wasser ein. Mit Hülfe des gebogenen Rohres $R$ saugt man $200 \mathrm{ccm}$ Wasser empor, leitet dann zur Verdrängung dieser Flüssigkeitsmenge reine Kohlensäure in den Apparat ein und setzt ihn einige Stunden lang, eventuell unter Beschattung, dem directen Sonmenlicht aus. Es ergiebt sich endlich durch die Untersuchung, dass derjenige Blatttheil, welcher in der etwa 5 Proc. Kohlensäure entlualtenden Luft verweilte, sehr stärkereich ist, während in der Blattspitze keine Stärke producirt worden ist.

Versuche, welche lehren sollen, dass die Temperaturverhältnisse von Einfluss auf die Stärkebildung im Chlorophyll sind, stellt man zweckmässig im Herbst oder Winter an. In zwei Zimmern, die nach gleicher Himmelsrichtung gelegen sind, werden Gläser, die mit Brunnenwasser und im Dunkeln entstärkten Elodeapflanzen beschickt worden sind, aufgestellt. In dem einen Zimmer herrscht eine Temperatur von etwa $6^{\circ} \mathrm{C}$, in dem anderen eine solche von etwa $20^{\circ} \mathrm{C}$. Die Temperatur des Wassers des einen Gefässes wird constant auf $6^{\circ} \mathrm{C}$., diejenige des Wassers des anderen constant auf $20^{\circ} \mathrm{C}$. (nöthigenfalls durch Einbringen von Eisstückchen oder Zugiessen wärmeren Wassers) erhalten. Von Zeit zu Zeit (vielleicht alle

1) Vgl. MoLL, Landwirthsehaftl. Jahrb. BAl. 6, S. 345. 
30 Minutenj untersueht man Elodeablätter auf Stärkegehalt und findet, dass, trotzdem die Pflanzen den gleichen Beleuchtungsverhältnissen ausgesetzt sind, unter dem Einfluss der höheren Temperatur schneller grössere Amylummengen gebildet werden als bei niederer 'Temperatur ').

\section{1\%. Die Spaltiffinungen und der Assimilationsprocess.}

Die Resultate neuerer Untersuchungen von Stran lassen sicher erkennen, dass die Kohlensäure, welche im Assimilationsprocess verbraucht wird. unter normalen Verhältnissen (anders liegt die Sache, wenn der Kohlensäuregehalt der die Pflanzen ungebenden Luft erhöht wird) durch die Spaltöffnungen in das Blattimnere übertritt, und dass höchstens Spuren des erwähnten Gases ihren Weg durch die cuticularisirten Membranen in das Innere der Gewebe finden. Ich wiederlolte die Versuche STAHL's mit abgeschnittenen Zweigen von Lonicera tatarica und in Töpfen vegetirenden Exemplaren vou Phaseolus multiflorus. Die Untersuchungsobjecte verweilten zunächst 24 Stunden im Dunkeln; ihre Blätter waren dann entstärkt. Nun wurde die Hälfte der Unterscite einiger nicht abgeschnittener Blätter, um die Spaltöffnungen $\mathrm{zu}$ schliessen, mit einer erwärmten Mischung von 1 Thl. Wachs und :3 Thl. Cacaobutter mittelst eines Pinsels bestrichen, um dann sogleich dem directen Sonnenlicht ausgesetzt zul werden. Es ist zu empfehlen, den Zweigen oder eingewurzelten PHanzen bei den Experimenten nur einige Blätter zu belassen, damit sie schwach transpiriren und nicht welken. Nach +-6-stïndiger Insolation taucht man die Blätter in kaltes Brunnenwasser, löst die Fettliruste von ihrer Unterseite ab und unterwirft sie nach der Extraction mit Alkohol der Jodprobe (vgl. S. 38). Dic Blatthälfte, deren Stomata verschlossen waren, hat keine Stärke gebildet, wälurend die Assinilation in der anderen Blatthülfte normal stattfand (vgl. Fig. 20). Wird die Oberseite der Blätter bei der Ausfïlrung der Versuche mit Cacaowachs verkittet, so erleidet lie Assimilation keine wesentliche Einschränkung, weil eben dureh die Stomata der Unterseite reichliche Kohlensäuremengen in das Blattinnere eintreten. Dieses Experiment lehrt zugleich, dass das Vorhandensein des Wachsüberzuges an sich das Blatt nicht irgendwie schälligt.

Wir schneiden Zweige von Lonicera tatarica, Syringa vulgaris oder Sambucus nigra ab, um

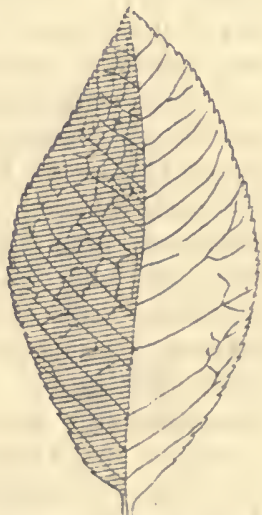

Fig. 20. Junges Blatt von Prunus pudus. Dic rechte Hälfte unterseits mit Cacaowachs iiberzogen gewesen. Dic Zeichnung ist nach dem der Jodprobe unterworfenen Material ausgeführt worden. (Nach. STAIL). sic zunächst zur Entstärkung 24 Stunden lang ins Dunkle zu stellen. Einigen Blättern werden kleine Fragnente entnommen und die Abwesenheit des Amylums constatirt. Ist dies ge-

1) Literatur über Stärkebilklung: SAcus, Botanische /eitung, 1862, $\mathrm{Nr}^{\circ} 4$; ebendaselbst 1864, Nr. 38; Arbeiten d. botanischen Instituts in Würzburg, Bd. 3, H. 1; G. KRAUs, Pringsheim's Jahrbücher, Bd. 7, S. 511; Naga.MATsz, Beiträge zur Kenntniss d. Chlorophyllfunetion, Dissertatiou, Würzburg, 1886 ; 
schehen, so schneiden wir einige Blätter von den Zweigen ab und zerlegen sie durch einen neben dem Mittelnerv verlaufenden Schnitt in zwei Hälften. Die den Mittelnerv führenden Hälften werden, um sie möglichst turgescent zu erhalten, sofort in feuchte Atmosphäre unter eine Glasglocke gebracht; der Blattstiel tancht mit der Sclnnittfläche in Wasser ein. Die andere Hälfte bleibt an einer schlecht beleuchteten Stelle des Zimmers liegen, bis sie ziemlich welk geworlen ist. Beide Blathälften werden nun in einem den Luftzutritt gestattenden Glaskasten dem directen Sonnenlicht ausgesetzt. Um eine iibermässige Erwärmung des mit seinem Stiel in Wasser eintauchenden und des welken Blattstückes $\mathrm{zu}$ verhindern, bringt man zwischen Sonne und Untersuchungsobjecten ein parallelwandiges, Wasser entlıaltendes Glasgefäss an. Nach ca. :3-stündiger Insolation werden die Blatthälften unter Benutzung der Jodprobe auf Stärke untersucht. Das welke Blattstiick hat kein Amylum, das frisch gebliebene reichliche Mengen desselben gebildet. Beim Welken haben sich in unserem Falle - und Aehnliches beobachtet man bei Versuchen mit sehr zahlreichen PHanzen - die Stomata des Versuchsobjectes geschlossen. und somit war die Kiollensäureaufnahme und Assimilationsthätigkeit des Blattes so gut wie ausgeschlossen. Experimentirt man mit Blatthälften von Hydrangea hortensis, so findet man, dass auch das noch nicht gar zu welke Blattstïck im Sonnenlicht Amylum erzeugt. Bei der zuletzt genannten PHanze schliessen sich die Stomata bein Welken des Gewebes nämlich nicht.

Wir cultiviren Keimlinge von Zea Mays einmal in normaler Nährstofflösung, zweitens in einer solchen, der wir 0,5) Proc. Kochsalz zugesetzt haben. Die ersteren PHanzen gedeilıen kräftig, die Kochsalzpflanzen bleiben aber völlig in ihrer Entwickelung zurück, ohne dass übrigens ihre Gewebe auffallende Veränderungen erfalıren. In den Blättern der Pflanzen, deren Wurzeln in normale Nährlösung eintauchen, sind reichliche Stärke- und Glycosemengen leicht nachzuweisen. Den Kochsalzpflanzen fehlen dagegen diese Stoffe völlig. (Die Prüfungen auf Stärke und Zucker sind vorzunehmen, wenn die Maispflanzen das Alter von einigen Wochen erreicht haben.)

Die im Vorstehenden erwähnten und zuerst von ScHImpr constatirten Thatsachen finden ihre Erklärung, wie STAнL fand, darin, dass die Maispflanzen, welche Chlornatrium aufnehmen, deshalb nicht assimiliren, weil sich ihre Stomata durch die Wirkung des Kochsalzes schliessen. Die Kohlensäureaufnahme seitens der Pflanzen ist dann keine ausreichende. Mit Hülfe der Kobaltprobe, die im Abschnitt über die Transpiration eingehender behandelt werden soll. kann das Geschlossensein der Stomata der KochsalzpHanzen in der That leicht festgestellt werden ${ }^{1}$ ).

1) V'gl. Stanl, Botan. Zcitung, 1894; Nagamats\%, in Arbeiten d. botan. Instituts in W ürzbury, Bd. 3; Schmpre, Sitzungsber. d. Akalem. d. Wiss. zn Berlin, 18 !, Sitzung v. 31 . Juli. 


\section{Die Entstehung der Eiweissstoffe in den Pflanzen.}

\section{Die Versorgung niederer Organismen mit Stickstoff.}

Es ist sehr wichtig, den Beweis dafür zu liefern, lass viele Pflanzenzellen die Fähigkeit besitzen, aus stickstofffreien organischen Stoffen (z. B. Zucker) und stickstoffhaltigem anorganischem Material stickstoffhaltige organische Körper, z. B. Eiweissstoffe, zu produciren. Als Untersuchungsobject benutzen wir die Hefe (Saccharomyces cerevisiae)' ${ }^{\prime}$ ).

Wir stellen :3 Kochflaschen $(a, b, c)$ von etwa 200 cem Capacität auf. In a bringen wir $100 \mathrm{ccm}$ destillirtes Wasser, in $b 100 \mathrm{ccm}$ Pastæun'sche Nährlösung (dieselbe besteht in 1000 Gewthl. aus 838 1'hl. Wasser, 150 Thl. Trauben- oder Candiszucker [bei meinen Versuchen benutzte ich meist den letzteren. da er leichter im reinen $\mathrm{Zu}$ stande als der Traubenzucker zu erlalten ist], 10 Thl. weinsaurem Ammoniak. 0,2 Thl. schwefelsaurer Magnesia, 0,2 Thl. phosplorsaurem Kalk und 2 Thl. saurem phosphorsaurem Kali) ${ }^{2}$ ); in $c 100$ cem einer Flüssigkeit, die ebenso zusammengesetzt ist, wie die Pasteur'sche Lösung, nur kein weinsaures Ammoniak enthält. Wir kochen die drei Flüssigkeiten einige Zeit lang in den Kochtlaschen, um sie möglichst zu sterilisiren. nachdem wir die Mündungen der Gefässe mit Wattejofropfen verschlossen haben. und bringen, indem wir die Pfropfen nach dem Erkalten der Nälırlösungen einen Augenblick entfernen, eine kleine Hefemenge in die Flüssigkeiten. Wir benutzen $1-2 \mathrm{cem}$ lıefehaltige Flüssigkeit (vgl. ,Bezugsquellen“"). Die mit Watte verstopften (iefässe werlen einer Temperatur von $25^{\circ} \mathrm{C}$. ausgesetzt und nun im Dunkeln oder bei Lichtzutritt unter häufigerem Umschütteln sich selbst überlassen. Die Flüssigkeit im Glase $\checkmark$ trübt sich alsbald bedeutend. und es entstehen sehr zallleiche neue Hefezellen, die sich massenhaft $\mathrm{zu}$ Boden setzen. Die Flïssigkeiten in $a$ und $c$ trüben sich nicht oder sehr wenig. Da die Hefe sehr schwer von allen fremden Bestandtheilen zu befreien ist, so kann wohl in $a$ und $c$ sehr schwache Hefevermehrung erfolgen, aber auf jeden Fall beweist die inassenhafte Hefevermehrung in $b$, dic auch durch Wägen der abfiltrirten und getrockneten Hefe genauer bestimmt werden kann, dass hier allein die normalen Lebensbedingungen des Pilzes erfüllt sind. Die Neubildung der Zellen muss nit einer Erzeugung stickstoffhaltiger organischer Körper verbunden gewesen sein, denn das Protoplasma der Zellen ist ja reich an diesen, und als Material können nur stickstofffreic organisehe Körper und Ammoniak Verwendung gefunden haben.

Während die höheren Gewächse die Salpetersäure vortrefflich für die Zwecke der Eiweissbildung zu verwerthen vermögen, ist die Hefezelle dazu nicht im Stande. Wenn wir Pasteur'sche Nährlösung herstellen, das weinsaure Ammoniak aber durch salpetersaures Kali

1) Vgl. A. MaY̌ir, Untersuchungen über die alkololische Gährung, 1868, und Lehrbuch der Gährungschemie, 1874, S. 108.

2) Nach den Untersuchungen von Molisch bedürfen auch die Pilze zur normalen Entwickelung des Eisens. Meist ist schon der Zucker etwas cisenhaltig. Will man aber ganz sicher gehen, so fügt man der PAsteun'sehen Lösung 0,01\% Eisenvitriol hinzu. 
ersetzen und Hefezellen in die Flüssigkeit bringen, so verhält sich der Pilz in dieser Nährlösung ähnlich wie in einer solchen. der wir überhaupt keinen stickstoffhaltigen Körper zugesetzt haben. Dagegen kann man sich durch Versuche, bei deren Ausführung man das weinsaure Ammoniak der Pasteur'schen Lösung durch Pepton ersetzt. davon überzeugen, dass dieser letztere Körper eine gecignetere Stickstoffquelle für den Hefepilz als das Ammoniak darstellt.

Dass nicht nur dic Hefe, sondern auch andere chlorophyllfreie Organismen die Fähigkeit haben, aus Zucker und Ammoniak Eiweiss zu erzeugen, lässt sich leicht feststellen. Es werden zwei kleine Gefässe $(a$ und $b$ ) aufgestellt. In $a$ bringt man 25 ccm PAsteur'sche Lösung, in $b 25 \mathrm{ccm}$ einer Flüssigkeit, die ebenso wie diese Lösung zusammengesetzt ist, der aber das weinsaure Ammoniak fehlt. Beide Gefässe stellt man nun unter eine Glasglocke und überlässt sie etwa 8 Tage lang sich selbst. Die Flüssigkeit in $a$ trübt sich alsbald in Folge inassenhafter Bacterienentwickelung bedeutend. Auch andere Organismen (bei meinen Versuchen z. B. der roth gefärbte Saccharomyces glutinis) können auftreten. Die Flüssigkeit in b trübt sich nur wenig, weil die Stickstoffquelle fehlt. Eine schwache Lebensäusserung der vorhandenen Keime kann erfolgen, weil die Flüssigkeit vielleicht. etwas Ammoniak aus der Luft anzieht.

\section{Vermag die Keimpflanze den freien Stiekstoff der Atmosphäre zur Bildung von Eiweissstoffen zu verwerthen?}

Die Pflanzenzellen vermögen aus stickstofffreiem organischem Material und stickstoffhaltigen anorganischen Verbindungen (Salpetersäure und Ammoniak) Eiweissstoffe zu erzeugen. Eine andere Frage ist es, ob auch der freie atmosphärische Stickstoff zur EiweissbildungVerwendung finden kann, und diese Frage besitzt nicht allein theoretisches, sondern zugleich ein hohes praktisches Interesse. Hier folgen zunächst Versuche, welche lehren, dass Keimpflanzen unter bestimmten Umständen bei ihrer Entwickelung weder treien Stickstoff aufnehmen, noch einen Stickstoffverlust erfahren.

Als Untersuchungsobjecte benutzen wir zur Beantwortung der aufgeworfenen Frage recht zweckmässig Erbsen- oder Weizenpflanzen. Wir verschaffen uns zunächst wohl ausgebildetes und durchaus keimfähiges Samenmaterial und bestimmen den Trockensubstanzgehalt, sowie den Stickstoffgehalt desselben ${ }^{1}$ ). Einige Weizenkörner (vielleicht 30 Stück) oder einige Erbsensamen (vielleicht 6 Stück), deren Gewicht man genau ermittelt hat, und deren Stickstoffgehalt man daher auf Grund der erwähnten. Stickstoffbestimmungen leicht berechnen kann, werden in einem Gläschen mit wenig frisch bereitetem destillirtem Wasser übergossen. Dieses Glas bleibt etwa 24 Stunden lang unter der Glasglocke des alsbald zu beschreibenden Apparates ruhig stehen. Nach dieser Zeit giesst man die kleine Menge des noch vorhandenen Quellwassers von den Samen $a b$, bringt die Flüssigkeit in eine Porzellanschale auf dem Wasserbade zur Trockne und stellt die den Rückstand enthaltende Schale in einen

1) Ueber die Methode der Stickstoffbestimmung nach Dumas oder KJELDAHI. sıwie Darstellung der erforderlichen Normalsäure etc. vergl. Kösıg, Anleitung zur Untersuchung land wirthschaftl. wichtiger Stoffe, 1891, S. 150 u. 682, und FrFsisius, Quantitative Analyse. 
Exsiccator. Die gequollenen Samen werden nun in dem in Fig. 21 dargestellten Apparat zu weiterer Eutwickelung gebracht. Auf einer matt geschliffenen Glasplatte steht ein Becherglas $B$, welches mit Tüll oder durchlöchertem Pergamentpapier überbunden ist und eine unter Benutzung frisch bereiteten destillirten Wassers hergestellte Nährstofflösung enthält, in der bis auf die Salpetersäure oder das Ammoniak alle Nährstoffe vorhanden sind (vgl. unter 22). Auf den Tüll oder das Pergamentpapier, an deren Stelle man auch ein durchlöchertes Silberblech benutzen kann, werden die gequollenen Samen gelegt, so dass die sich entwickelnden Wurzeln in die Nährstofflösung hineinwachsen. Die recht grosse Glasglocke $G$ wird mit ihrem abgeschliffenen Rande vollkommen luftdicht auf die erwähnte mattgeschliffene Glasplatte aufgekittet, was am besten mittelst eines Kittes gelingt, den man durch Zusammenschmelzen von 1 Thl. Wachs und 3-4 Thl. Schmalz hergestellt hat. Man kann die Glocke auch unten durch Quecksilber absperren, welches sich in einer grossen Schale befindet. Ueber das Metall muss aber etwas Wasser geschichtet werden, damit die Quecksilberdämpfe die Keimpflanze nicht schädigen. Oft empfiehlt es sich auch, die angequollenen Samen nicht direct, sondern erst nach dem unter der Glasglocke auf feucht gehaltener Glaswolle erfolgten Ankeimen auf die Bedeckung des erwähnten Becherglases zu legen. Der Tubulus der Glasglocke wird mit einem zweifach durchbohrten Kautschukkork verschlossen. Die eine Bohrung dient zur Aufnahme des rechtwinklig gebogenen Glasrohres $a$, dic andere zur Aufnahme des ebenfalls rechtwinklig gebogenen Glasrohres $b$. Durch $a$ wird dem Untersuchungsobjecte atmosphärische Luft zugeführt, die aber vor ihrem Eintritt in die Glasglocke $G$

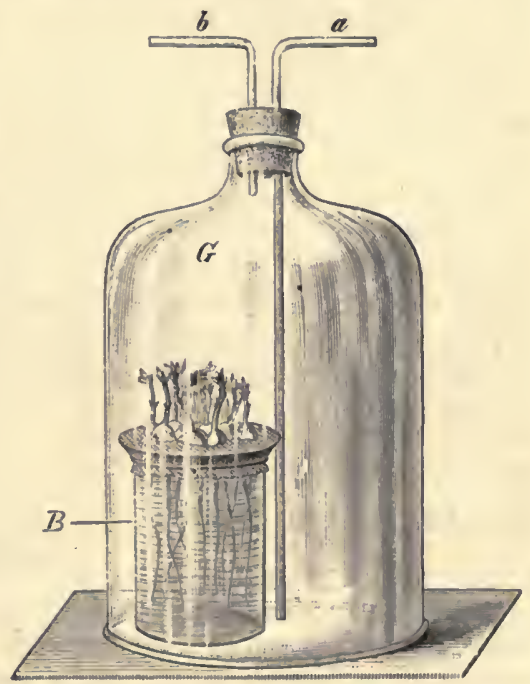

Fig. 21. Apparat zur Cultur vou Pflanzen bei Ausschluss aller Stickstoffverbindungen. von allen Stickstoffverbindungen befreit und wieder einigermaassen mit Wassergas gesättigt worden ist. Zu diesem Zweck muss die Luft vor ihrem Eintritt in $\boldsymbol{a}$ nach einauder Waschflaschen passiren, von denen die erste eine Lösung von doppeltkohlensaurem Natron, die zweite Bimsstein, der mit Schwefelsäure getränkt ist, und die dritte Wasser enthält. Das Glasrohr $b$ steht mit. einem Aspirator in Verbindung, aber man thut gut, zwischen diesem und $b$ noch ein kleines, Schwefelsäure enthaltendes Gefäss einzuschalten, damit die Luft unter der Glocke gar nicht mit der Atmosphäre direct communicire. (Ueber Benutzung des Aspirators vgl. im Abschnitt über Pflanzenathmung.) Leitet man von Beginn des Quellens der Samen an cinen continuirlichen, langsamen Luftstrom durch den Apparat und setzt die Pflanzen hellem, diffusem Licht aus, so entwickeln sie sich so gut, wie dies eben bei Abwesenheit von Salpetersäure und Ammoniak möglich ist. Die Versuche werden etwa 14 Tage oder auch länger fortgeführt und während dieser Zeit Tag und Nacht Luft durch den Apparat geleitet. 
Es handelt sich dann darum, den Stickstoffgehalt der Weizen- oder Erbsenpflanzen festzustellen. Die Untersuchungsobjecte werden in einer Porzellanschale zu einem Brei zerrieben. Das Gewicht der Schale und ebenso dasjenige eines Glasstabes, der zum Umrühren des Breies dient, muss bestimmt sein. Die Schale stellt man dann auf ein Wasserbad und fügt ihrem Inhalt noch den bis auf ein kleines Volumen eingedunsteten Rückstand der Nährstofflösung, in der sich die Wurzeln der Pflanzen entwickelten, sowie den Rückstand des Quellwassers und denjenigen des ev. zum Auswaschen der Glaswolle benutzten Wassers hinzu. Ist die Masse in der Schale ziemlich trocken geworden, so stellt man sie noch einige Zeit in einen Trockenschrank, in welchem eine Temperatur von etwa $50^{\circ}$ C. herrscht. Dann wird die Schale, lose bedeckt, 24 Stunden lang an die Luft gestellt, das Gewicht ihres lufttrockenen Inhaltes ermittelt und sofort der Trockensubstanzgehalt desselben festgestellt. Ferner sind Stickstoff bestimmungen auszuführen ${ }^{1}$ ). Vergleicht man nun schliesslich den Stickstoffgehalt der benutzten Samen mit demjenigen der geernteten Pflanzen, so wird man finden, dass zwischen beiden, wenn anders die Experimente sorgfältig durchgeführt wurden, höchstens Differenzen bestehen, die Folgen kleiner Versuchsfehler sind. Die Pflanzen sind nicht im Stande, unter den bezeichneten Umständen den freien atmosphärischen Stickstoff zur Bildung von Eiweissstoffen zu verwerthen ${ }^{2}$ ).

Will man sich davon überzeugen, dass Keimpflanzen bei ihrer Tegetation im Dunkeln weder freien Stickstoff aus der Luft aufnehmen, noch einen Verlust an Stickstoff erfahren, so sind die Versuche in ähnlicher Weise, wie wir dies beschrieben haben, anzustellen. Man hat nur dafür zu sorgen, dass die Untersuchungsobjecte nicht von Lichtstrahlen getroffen werden ${ }^{3}$ ).

\section{Bacterium Radicicola und die Papilionaceen als Stickstoff- sammler.}

Die Frage nach der Bedeutung des freien Stickstoffes als Pflanzennalıungsmittel ist vielfach experimentell behandelt worden. In wissenschaftlichen Kreisen war man bis vor kurzer Zeit unter Berïcksichtigung der Resultate der Untersuchungen BoussingaulT's sowie anderer Forscher allgemein der Ansicht, dass der Pflanze nicht die Fähigkeit zukäme, den elementaren Stickstoff im Ernährungsprocess zu verwerthen. Die Bedingungen, unter denen Boussingaui.T's Experimente angestellt wurden, schlossen auch in der That, wie wir heute wissen, die Verarbeitung des freien Stickstoffes in den Zellen aus; unter anderen Umständen kann dieselbe aber dennoch erfolgen, und es ist vor allem das grosse Verdienst Heluriegel's ${ }^{4}$ ), diese Thatsache sicher festgestellt zu haben.

1) Besonders empfehlenswerth ist es, die zerquetschten Keimlinge sowie die Rückstände des Quellwassers und der Nährstofflösung in HoFrMiIsTER'schen Schälchen (zu beziehen ron MÜxCKE in Berlin) einzutrocknen, um den Stickstoffgrehalt der Gesammtmasse des Untersuchungsmaterials zn ermitteln.

2) Diese Thatsache ist namentlich von Boussivgsum (rgl. Compt. rend., T. 39, p. 601) festgestellt worden.

3) Die Resultate meiner bezüglichen Versuche, sowie dic Trgebnisse der Arbeiten anderer Beobachter habe ich in meiner vergleichenden Physiologic des Keinungsprocesses der Samen, 1880, z.usammengestellt.

4) Vgl. Hethribget, Beilageheft zu der '/eitschrift d. Vereins f. Rübenzuckerindustrie d. Deutschen Reiches, November 1888. 
Zur allgemeinen Orientirung stellen wir zunächst die folgenden Versuche an, die aber nur in der wärmeren Jahreszeit durchgeführt werden können.

Der Boden verschiedener Glascylinder von $24 \mathrm{~cm}$ Höle und $14 \mathrm{~cm}$ Durchmesser, welche etwa 4-j $\mathrm{kg}$ Sand fassen können ${ }^{1}$ ), wird mit einer $3 \mathrm{~cm}$ hohen Schicht von gewaschenen und geglühten Quarzstïcken bedeckt. Auf diese legt man eine dünne Schicht ungeleimter. Watte und füllt die Cylinder mit Quarzsand, dessen Elemente der Hauptsache nach einen Durchmesser von $0,2-0,+11 \mathrm{~m}$ besitzen, an. Ein sehr geeigneter, doppelt gewaschener tertiärer Quarzsand aus der sächsischen Oberlausitz, dessen Stickstoffgehalt so gering ist, dass er hier nicht in Betraclit kommt, ist von der Firma: "Vereinigte Hohen-Bockaer Glassandgruben, Dresden H. WerchelT \& Co." zu bezichen. Der Sand wird vor dlem Einfüllen in die Cylinder in folgender Weise vorbereitet. Je $1 \mathrm{~kg}$ des zu benutzenden trockenen Sandes werden mit $4 \mathrm{~g}$ kohlensaurem Kalk, $0,150 \mathrm{~g}$ phosphorsaurem Kali, $0,070 \mathrm{~g}$ Chlorkalium, 0,070 g schwefelsaurer Magnesia (die letzteren drei Salze in $150 \mathrm{ccm}$ Wasser aufgelöst) und etwas phosphorsaurem Eisenoxyd vermischt. Der Sand wird num im feuchten Zustande in die Cylinder unter zeitweisem leichtem Andrücken eingebröckelt. Jeder Cylinder wird mit gleich grossen Mengen des Sandes angefüllt. Als Versuchsptlanzen wällen wir Hafer und Erbsen. Das Saatmaterial muss sehr normal ausgebildet sein und mittleres Gewicht besitzen. Wir bringen die Samen zwischen Fliesspapier zum Keimen, und setzen je 12 Haferund 6 Erbsenkeimlinge in den Sand verschiedener Cylinder ein. Nach einiger Zeit entfernen wir aus den Cylindern je 6 Hafer- und 3 Erbsenpflänzchen, wobei sorgsam darauf zu achten ist, dass die Samenreste und Wurzeln nicht im Sande zurüickbleiben. Die Cylinder sind dann mit 6 der am besten entwickelten Hafer-oder :3 Erbsenptlanzen beschickt. Den letzteren sind alsbald Stützen darzubieten. Die Cylinder werden an einem sonnigen Standorte im Garten aufgestellt, nur bei Regen und starkem Wind oder an zu heissen Tagen unter ein Schutzdach gebracht. Jeden Tag erfolgt Wägung (ler Cylinder, um das verdunstete Wasser zu ersetzen. Abgesehen von denjenigen Cylindern, deren Sand keine Stickstoffverbindungen beigemischt worden sind, stellen wir noch andere auf, die in der soeben angegebenen Weise beschickt werden, deren Sand aber noch einen Zusatz von $2,00,1,50,1,00,0,50$ oder 0,10 g salpetersauren Kalk erhält ${ }^{z}$ ). Im Laufe des Solnmers ergiebt sich, dass die Haferptlanzen ohne Zufuhr von salpetersaurem Kalk höchst kïmmerlich gedeihen, während das Productionsvermögen der Haferpflanzen mit zunehmendem Gehalt des Bodens an Nitrat bedeutend wächst und mit dieser Zunahme Schritt hält. Bei den Culturen mit Erbsen ist dagegen keine genaue Pelation zwischen der vorhandenen Nitratmenge und dem Productionsvermögen wahrzunehmen, ja es kommt vor, dass die Erbsen sich selbst bei Abwesenheit von Nitrat im Boden recht kräftig entwickeln. Trockensubstanzbestimmungen der geernteten Pflanzen und ein Vergleich der gewonnenen Werthe mit den über den Trockensubstanz-

1) Ich weiss aus Erfahrung, dass man bei den hier in Rede stehenden Experimenten auch schon zu ganz guten Resultaten gelangt, wenn man Glascylinder verwendet, die $21 / 8 \mathrm{~kg}$ Sand fassen.

2) Diese Nitratmengen sind nicht $1 \mathrm{~kg}$ Sand, sonderu der ganzen Sandmenge in jedem Cylinder beizumengen. 
gehalt der Samen ermittelten Zahlen geben noch näheren Aufschluss iiber das Productionsvermögen der Pflanzen unter den bezeichneten Bedingungen. Wenn man in der Trockensubstanz den Stickstoff bestimmt (am besten unter Benutzung der bekannten KJELDAHL'schen Methode), so findet man unter anderen, dass die in nitratfreiem Boden erwachsenen Erbsen oft reichliche Stickstoffmengen enthalten, während die im nitratfreien Boden entwickelten Haferpflanzen höchstens um einige Milligr. Stickstoff reicher sind als die ausgelegten Samen.

Die Erbsen (und ilhnen analog !verhalten : sich-auch die übrigen Papilionaccen, z. B. Lupinen, Bolnnen etc.) sind im Stande - so dürfen wir schon unter Berücksichtigung der Resultate unserer vorläufigen Untersuchungen schliessen - den elementaren Stickstoff bei Abwesenheit von Nitraten im Boden zur Eiweissbildung zu verwerthen. Die Haferpflanze und selır zahlreiche andere Gewächse vermögen dies nicht. Unsere Experimente lassen diese-letztere Thatsache freilich noch nicht mit absoluter Sicherheit feststellen; indessen wir verzichten lier auf Versuche, die durchaus entscheidend sind ${ }^{1}$ ), und ziehen es vor, das Verhalten der Papilionaceen dem elementaren Stickstoff gegenïber noch weiter zu verfolgen.

Eine Anzahl von Glascylindern, welche die angegebenen Dimensionen besitzen, wird mit Quarzsand und-Nährstofflösung etc., abel ohne Zugabe ron Calciumnitrat, beschickt. Die Glasgefässe reinigt man sorgfältig mit Sublimatlösung (1:1000), um sie dann mit Alkohol auszuspülen. Quarzkies und Watte werden vor dem Einbringen in dic Cylinder im Trockenschrank auf $150^{\circ} \mathrm{C}$. erwärmt. Den Sand, gemischt mit der schon oben angegebenen Quantität des kohlensauren Kalkes, füllt man noch warm ein, nachdem er zuvor 2-3 Stunden lang in einem geräumigen Sandbade auf etwa $180^{\circ} \mathrm{C}$. erhitzt worden war. Dem in die Gläser eingebrachten Sand mischt man die Nährstofflösung bei, nachdem dieselbe in Kolben mit Watteverschluss zunächst 1 Stunde und dann nach Verlauf von 2 Tagen nochinals vier Stunden im Dampfsterilisirungsapparat, zu beziehen von H. RoHRBECK in Berlin (vgl. Preisverzeichniss, 1887, S. 9), gekocht worden war ${ }^{2}$ ). Die Samen, Erbsen, gelangen zunächst 2 Minuten lang in eine Sublimatlösung $(1: 1000)$, werden dann mit gekochtem Wasser abgespült und in den Sand eingesäet. Die Oberfläche desselben bedeckt man mit sterilisirter Watte. Zum Begiessen wird stets nur gekochtes destillirtes Wasser verwandt. Man bestimmt täglich das Gewicht der $\mathrm{Cy}$ linder und ermittelt auf diese Weise, wie viel Wasser verdunstet, resp. wie viel Wasser dem Boden zuzuführen ist.

Ein Culturgefäss oder einige derselben empfangen keinen weiteren Zusatz. Andere erhalten einen Zusatz von 25 ccm Extract eines fruchtbaren Garten- oder Feldbodens, auf welchem erfahrungsgemäss Erbsen gut gedeihen. Den Auszug gewinnt man, indem man $8 \mathrm{~g}$ Boden mit $100 \mathrm{ccm}$ Wasser schüttelt und absetzen lässt, bis die Hauptmasse des Sandes und Thons zu Boden gefallen ist, was oft mehrere

1) Solche Versuche sind, wenn man sie anstellen will, nach BotssixgauLT's Methode (vgl. Agronomie, I, p. 69) durchøuführen. Vergl. übrigens unter 19.

2) Mehr zu empfehlen dürfte es sein, die Cylinder mit Kies sowie dem mit Nährstoffen und kohlensaurem Kalk gemischten feuchten Sand zu beschicken, um lie so vorgerichteten, mit Glasplatten bedeckten Culturgefässe dann im strömenden Wasserdampf des Dampfapparates zu sterilisiren. 
Stunden dauert. Bemerkt sei, dass der Gehalt solcher Bodenextracte an gebundenem Stickstoff so gering ist, dass derselbe für unsere Versuche nicht in Betracht kommt. Endlich drittens wird dem Sand in einigen Cylindern Bodenextract (wieder $25 \mathrm{ccm}$ ) hinzugefügt, der vorher durch längeres Kochen sterilisirt worden ist.

Die Culturgefässe stellt man in einem nach Sïden gelegenen Zimmer, dessen Fenster verschlossen gehalten werden, auf. Besser noch ist es, dic Culturen in einem besonderen kleinen Gewächsliause, las nicht zur Cultur noch anderer Pflanzen dient, vorzunehmen.

Die Versuche ergeben nun bei sorgfältiger Durchführung, dass sämmtliche Keimlinge zunächst normal wachsen. Nach :3-4 Wochen gerathen sie aber augenfällig in einen Hungerzustand. Dic Pflanzen in den Cylindern ohne Bodenextract und mit sterilisirtem Bodenextract erholen sich auch nicht wieder, sondern fristen fortan ein kümmerliches Dasein. Ihr Trockensubstanzgewicht ist bei Abschluss der Versuche, etwa nach :3-:31/2 Monaten, sehr gering, und Stickstoffbestimmungen ergeben, dass sie nicht oder kaum mehr Stickstoff als die ausgelegten Samen enthalten ${ }^{1}$ ). Von den unter Beihülfe nicht sterilisirten Bodenauszuges zur Ausbildung gelangenden Pflanzen wird die erwähnte Hungerperiode bald überwunden. Sie gedeihen üppig, bilden reife Früchte sowie Samen (dies geschieht auch bei der Erbse in geschlossenen Räumen bei Insectenausschluss) und erzeugen reichliche Trockensubstanz- wic Eiweissmengen.

Die Erbsen und die Papilionaceen überhaupt haben also die iberaus bemerkenswerthe Fähigkeit, bei Abwesenheit von Stickstoffverbindungen im Boden reichliche Eiweissmengen zu produciren. Den Gramineen sowie zahlreichen anderen Gewächsen geht dies Vermögen völlig ab; sie gedeihen nur normal, wenn ihnen Stickstoffverbindungen als Nahrungsmittel zur Disposition stehen. Die Papilionaceen müssen im Stande sein, den freien atmosphärischen Stickstoff zur Eiweissbildung zu verwerthen, und zwar kann dies, wie wir sehen werden, nur unter Vermittelung von Bacterien geschehen ${ }^{2}$ ).

Wenn man eine Erbsenpflanze (die Beobachtungen können auch unter Benutzung anderer Papilionaceen angestellt werden) kurz vor der Blïthezeit oder während dieser aus dem fruchtbaren Boden, in welchem sie gewachsen ist, heraushebt, so findet man, dass ihre Wurzeln eine oft sehr erhebliche Zahl, zuweilen recht grosser, Knöllchen tragen, die zur angegebenen Zeit meist rosenroth gefärbt erscheinen. Wenn wir unsere, im Sande cultivirten Erbsenpflanzen untersuchen, dann ergiebt sich, dass allein die Wurzeln derjenigen Pflanzen mit Knöllchen versehen sind, die sich unter Mitwirkung des nicht sterilisirten Bodenauszuges entwickelten. Bei Abwesenheit des Bodenauszuges überhaupt oder bei Gegenwart sterilisirten Bodenextractes kommen die Knöllchen dagegen nicht zur Ausbildung.

Wir stellen nun Querschnitte durch den mittleren Theil wohl aus-

1) Eine eventucll cintretende umbedentende Stickstoffzunahme hat ihren Grund darin, dass der Sand nicht völlig stickstofffrei ist, und dass die Blïter bekanntlich etwas Ammoniak aus der Iuft aufaunchmen vermögen.

2) Bezüglich der Frage nach der Versorgung der Papilionaceen, Granineen und anderer Pflanzen mit Stickstoff stimme ich durchans den Anschaumngen HrI,RIEGEL's und PrazMowski's (vergl. Versuchsstationel, Bd. 37 u. 38) hei. Fraxk's Auffassungen (vergl. Lauı wirthschaftl. Jahrbücher und Botan. Zeitung, 1893) kann ich dagegen nicht theilen; wenigstens sind die Tersuche FnAxk's nicht völlig beweisend. 
gebildeter, rosenroth gefärbter Knöllchen der Erbsenwurzeln her und untersuchen die Schnitte bei schwächerer und dann auch bei stärkererVergrösserung. Der mittlere Theil der Schnitte wird von einem recht grosszelligen, mit Intercellularräumen versehenen Gewebe gebildet, dessen Zellen plasmareich sind. Ausserdem nehmen wir eigenthümliche, verzweigte, stark glänzende Fäden wahr, die das erwähnte Gewebe, das als Bacteroidengewebe bezeichnet wird, durchziehen. Nach aussen schliesst sich an das Bacteroidengewebe ein Parenchym an, welches des Stärkegehaltes seiner Elemente wegen als Stärkeschicht zu charakterisiren ist. In diesem Parenchym verlaufen Fibrovasalstränge, die, wie die neueren Untersuchungen gelehrt haben, mit den Gefässbündeln der die Knöllchen tragenden Wurzeln in Zusammenhang stehen. Besonders zu beachten ist, dass der Bastkörper der Fibrovasalstränge in den Knöllchen nach innen gewandt, also dem Bacteroidengewebe zugekehrt ist, während der $\mathrm{Holz}$ theil nach aussen gerichtet erscheint. An der Oberfläche der Knöllchen ist eine Rindenschicht entwickelt, die aus mehreren Lagen verkorkter Zellen besteht.

Wer die Entwickelungsgeschichte der Papilionaceenknöllchen und die bei ihrer schliesslich erfolgenden Entleerung stattfindenden Processe studiren will, der ist bezüglich näherer Orientirung auf Prasmowski's Arbeit (Versuchsstationen, Bd. 37, S. 209) hinzuweisen, denn der uns hier zur Verfügung stelıende Raum gestattet ein Eingehen auf die bezüglichen, sehr complicirten Verhältnisse nicht. Es hat sich ergeben, dass die schon erwähnten, im Bacteroidengewebe auftretenden, stark glänzenden, fädigen Gebilde Schläuche sind, die zahlreiche Bacterien (Bacterium Radicicola) enthalten. Diese Spaltpilzform findet sich im Boden, dringt in die Wurzelhaare der Papilionaceen ein, bildet hier die Schläuche, welche nun ihrerseits in die Rinde der Wurzeln hineinwachsen und die Knöllchenbildung veranlassen. Unter Anschwellung der Schläuche gehen die in ihnen vorhandenen Bacterien, indem sie sich fortwährend stark vermehren, weiterhin in das Bacteroidengewebe der sich ausbildenden Knöllchen über, aber nach einiger Zeit verlieren dieselben ihr Theilungsvermögen, werden metamorphosirt und bilden die sogen. Bacteroiden, gabelig verzweigte Körperchen, die oft in ungeheurer Menge in den Zellen des Bacteroidengewebes angetroffen werden.

Bacterium Radicicola, der zu den Papilionaceen in einem symbiotischen Verhältnisse steht, ist derjenige Organismus, welcher auf Kosten des elementaren Stickstoff's offenbar unter Zuhülfenahme der von den Papilionaceen gelieferten Kohlehydrate Eiweiss erzeugt. Wenn bei der Entleerung der Knöllchen die Bacteroiden aus ihren Zellen verschwinden, so geht deren Eiweiss in die Organe der Papilionaceen über und wird hier für Ernährungszwecke verwerthet. Enthält der Boden, in dem sich z. B. Erbsen entwickeln, keine Stickstoffverbindungen, dann ist die Ausbildung der Pflanzen nach allem, was wir gesehen haben, nur dann möglich, wenn die Wurzeln durch Infection mit Bacterium Radicicola zur Knöllchenbildung etc. gebracht werden, und aus diesem Grunde konnten auch nur diejenigen unserer Untersuchungsobjecte ein erhebliches Productionsvermögen zeigen, welche im nicht sterilisirten Boden oder in einem mit frischem Bodenauszug begossenen sterilisirten Boden standen.

Wer sich damit beschäftigen will, Reinculturen von Bacterium Radicicola herzustellen, vergl. Prazmowski, Versuchsstationen, Bd. 37, S. 197 und 199, sowic Beyerinck, Botan. Zeitung, 1888. Prazmowski (vergl. S. 198) hat auch Versuche angestellt, welche lehren, dass aus 
Reinculturen entnommene Bacterien Knöllchenbildung an den Wurzeln der Erbse hervorrufen, wenn man den Boden, in welchem sich die Untersuchungsobjecte entwickeln, mit dem Spaltpilz inficirt, während bei nicht vorgenommener Infection keine Kinöllchenbildung eintritt. Endlich findet man bei Prazmowski (Versuchsstationen, Bd. 38, S. 20) noch Anleitung zu Experimenten, welche unter Benutzung einer sehr exacten, aber auch recht complicirten Methode den Nachweis gestatten, dass nur Bacteriun Radicicola, aber keine andere Spaltpilzform, die Ernährung der Papilionaceen unter Zuhülfenahme des elementaren Stickstoff's vermittelt ').

In dem von mir geleiteten pflanzenphysiologischen Praktikum lasse ich Versuche iiber Ernährung der Pflanzen mit freiem Stickstoff, wenn es sich nur 1 m eine allgemeine Orientirung handelt, wie folgt, ausführen. Der Boden geeigneter Glascylinder, welche etwa $2,5 \mathrm{~kg}$ Sand fassen, wird $1-2 \mathrm{~cm}$ hoch mit ausgeglühtem Kies bedeckt. Je $2,5 \mathrm{~kg}$ des schon auf S. 53 erwähnten Sandes werden in einer grossen Schale unit 375) com destillirtem Wasser, 0,375 g $\mathrm{H}_{2} \mathrm{KPO}_{4}, 0,200 \mathrm{~g}$ $\mathrm{K} \mathrm{Cl}, 0,200$ or $\mathrm{MgSO}_{4}, 10 \mathrm{~g} \mathrm{CaCO}_{3}$, sowie etwas phosphors. Eisenoxyd geinischt und in die Cylinder unter häufigen Aufstossen derselben auf eine weiche Unterlage eingekrümelt. Jedlè Cylinder empfängt noch $10 \mathrm{ccm}$ Bodenextract, bereitet durch Uebergiessen von $10 \mathrm{~g}$ Boden von einem Erbsenfelde mit $100 \mathrm{ccm}$ Wasser. Der Gehalt dieser Auszüge an Stickstoffverbindungen ist so gering, dass er vernachlässigt werden kann. Einige Cylinder werden mit je 4 in Sägespänen angekeimten Erbsen, andere mit je 4 Haferpflänzchen beschickt. Die Culturgefässe stehen im Zimmer am nach Süden gelegenen Fenster. Für Ersatz des verdunsteten Wassers ist täglich zu sorgen. Den Erbsenpflanzen sind Stützen darzubieten. Die Erbsen gedeihen, wenn sie die früher erwähnte Hungerperiode ïberstanden haben, sehr gut, während der Hafer kränkelt. Den Hafer kann man aber in solchen Culturgefässen $\mathrm{zu}$ freudiger Entwickelung bringen, deren Sand, abgesehen von all den genannten Stoffen, noch $0,250 \mathrm{~g} \mathrm{~K} \mathrm{NO}_{3}$ beigemischt worden ist. Die Gründe für das verschiedenartige Verhalten der Erbsen, sowie des Hafers bei den Culturversuchen ergeben sich aus den früheren Ausführungen.

\section{Der Nachweis des Ammonialis und der Salpetersäure im Wasser und in der Pflanze und die Lebensthäigkeit von Nitro- monas.}

Um sich davon zu überzeugen, dass in der Natur anorganische stickstoffhaltige Verbindungen (Ammoniak, Salpetersäure), die von den Gewächsen bei ihrer Ernährung verwerthet werden können, vorhanden sind, ist es zu empfehlen, das Wasser (Fluss-, Teich- oder Brunnenwasser) auf einen Gehalt an den beiden genannten Substanzen zu prüfen. Die Untersuchung auf Ammoniak geschieht mit Hülfe des NessLEl'schen Reagens. $2 \mathrm{~g}$ Jodkalium werden in $5 \mathrm{ccm}$ Wasser aufgelöst und der Flüssigkeit unter Erwärmen etwas mehr Quecksilberjodid hinzugefügt, als dieselbe zu lösen vermag. Die Lösung wird nach dem Erkalten mit

1) Bemerkf sei hier noch, dass man mit dem Namen Bact. Radie. vorläufig nicht nur eine, sondern eine grosse Gruppe von Spaltpilzformen bezeichnet, die für die Ernährung der Papilionaceen wichtig sind. 
$20 \mathrm{ccm}$ Wasser verdünnt, filtrirt und mit Kalilauge versetzt (auf $20 \mathrm{ccm}$ Filtrat $30 \mathrm{ccm}$ Kalilauge, die auf 1 Thl. Actzkali 2 Thl. Wasser entlaält). Man füllt nun zwei Röhren mit dem zu untersuchenden Wasser an, versetzt die Flüssigkeiten mit Natronlauge, filtrirt, wenn erforderlich, und bringt $z u$ dem Wasser in der einen Röhre etwa 30 Tropfen des Nessuer'schen Reagens. Ein Vergleich des Farbentons der Flüssigkeiten in den beiden Röhren lehrt, ob Ammoniak vorhanden oder ob dies nicht der Fall ist, denn boi Gegenwart desselben färbt sich die mit dem Reagens versetzte Flüssigkeit röthlich. Um die Anwesenheit von Salpetersäure im Wasser festzustellen, wird ein Tropfen desselben in ein weisses Porzellanschälchen gebracht und mit 2 Tropfen Brucinlösung (durch Schütteln von Brucin mit Wasser hergestellt) versetzt. Jetzt fügt man noch einige Tropfen concentrirter Schwefelsäure ${ }^{\text {) }}$ ) hinzu. Eintretende Röthung zeigt die Anwesenheit von Salpetersäure im Wasser an. Um die Gegenwart äusserst kleiner Salpetersäuremengen im Wasser noch festzustellen, verdunstet man einige ccm desselben und behandelt den Rückstand nun mit Brucinlösung und Schwefelsäure ${ }^{2}$ ).

Sehr bequem lässt sich die Gegenwart der Salpetersäure im Wasser auch feststellen, wenn man einige ccm Wasser in einer Porzellanschale verdampft und mit Hülfe eines Glasstabes zu dem Rückstande Diphenylamin, das in Schwefelsäure gelöst ist $(0,05 \mathrm{~g}$ Diphenylamin in $10 \mathrm{ccm}$ reiner concentrirter Schwefelsäure gelöst) bringt. Bei Salpetersäuregegenwart tritt in Folge der Bildung von Anilinblau Blaufärbung ein.

Ziemlich reich an Nitraten ist der Saft der Zuckerrübe. Wenn man Schnitte der Wurzel auf dem Objectträger mit der erwähnten Diphenylaminlösung behandelt, so erfolgt intensive Bläuung derselben ${ }^{3}$ ). Einen hübschen Vorlesungsversuch zum Nachweis von Nitraten in der Rübe kann man derartig anstellen, dass man eine Wurzel durchschneidet und die Schnittfläche einfach mit Diphenylaminlösung betupft. Die Bläuung tritt sofort hervor.

Eingehender ist das Vorkommen von Nitraten in den Pflanzen yon BERTHELOT und ANDRÉ ${ }^{4}$ ) sowie von SCHIMPER ${ }^{5}$ ) studirt worden. Sie fanden die Nitrate sehr verbreitet in den Gewächsen, und wenn man Schnitte aus dem Stengel von Helianthus oder z. B. den Blättern von Sambucus nigra auf dem Objectträger etwas eintrocknen lässt, um ihnen dann einen Tropfen der erwähnten Diphenylaminlösung linzuzufügen, so tritt die Blaufärbung momentan ein. Die meisten Blätter, z. B. diejenigen von Sambucus nigra, führen fast nur im Nervenparenchym Nitrate; in einigen Fällen (Blätter von Tradescantia Selloi) ist aber auch das Mesophyll sehr reich an Nitraten. Nitrite, welche ebenfalls mit Diphenylamin und Schwefelsäure Blaufärbung geben, kommen, so viel man bis jetzt weiss, nicht in der lebenden Pflanze vor. Zu betonen ist übrigens, dass dann, wenn die Reaction mit Diphenylamin ausbleibt, noch nicht mit absoluter Sicherleit auf

1) Die Schwefelsäure muss natürlich frei von Salpetersäure sein und nicht an und für sich mit Brucinlösung eine Röthung hervortreten lassen. Die Schwefelsäure kann man aber von eventuell vorhandener Salpetersäure befreien, indem man sie unter Zusatz von sehr wenig Schwefel zum Sieden erhitzt.

2) Vgl. Reichardi, Grundlagen zur Beurtheilung des Trinkwassers, 1880, S. 154 und 143 .

3) Vgl. MoLisch, Berichte d. Deutschen botan. Gesellschaft, 1. Jahrg., S. 150.

4) Vgl. Bertielot et Axpri, Annal. de ehem. et de physique, Ser. 6, T. 8.

5) Vgl. Schimper, Botan. Zeitung, 18ss, s. 120 . 
Nitratabwesenheit in den betreffenden Geweben geschlossen werden darf, denn es giebt manche Stoffe in den Pflanzenzellen, deren Gegenwart das Zustandekommen der Reaction verhindert.

Von hohem Interesse ist es, die Thatsache $\mathrm{zu}$ constatiren, dass es Organismen giebt, welche die Fähigkeit besitzen, das Ammoniak, welches sich z. B. im Boden vorfindet, in Salpetersäure überzuführen ${ }^{1}$ ). Diese Nitrification wird durch einen Spaltpilz, den man als Nitromonas bezeichnet und der wohl keinem Boden völlig fehlt, zum Abschluss gebracht.

Wir füllen einen Kolben mit $100 \mathrm{ccm}$ Culturflüssigkeit an. Dieselbe enthält, abgeselien von $100 \mathrm{ccm}$ Wasser, $0,05 \mathrm{~g}\left(\mathrm{NH}_{4}\right)_{2} \mathrm{SO}_{4}$, $0,1 \mathrm{~g} \mathrm{KH} \mathrm{KO}_{2} \mathrm{PO}_{4}$ und $1 \mathrm{~g} \mathrm{MgCO}_{3}$. $\mathrm{Zu}$ der Lösung fuigen wir wenig Ackererde, um die Infection mit Nitromonas herbeizufülıren. Nach Verlauf etwa eines Monats wird man mit Hülfe der Diphenylaminreaction constatiren können, dass viel Salpetersäure in der Lösung gebildet worden ist. Während dieser Zeit bleibt die Lösung klar. Nur an ihrer Oberfläche bildet sich ein dünnes Häutchen, und im Bodlensatz von kohlensaurer Magnesia entstehen Zoogloeaformen von Bacterien, durch deren schleimige Natur die Carbonattheilchen förmlich unter einander verklebt werden. Ich beobachtete diese Erscheinung besonders deutlich in einer Cultur, die drei Monate lang gestanden hatte.

Nun werden noch einige Kolben gewau in der soeben angegebenen Weise mit Culturflüssigkeit beschickt. Man versieht die Mündungen (ler Gläser mit Watteverschluss und erhitzt die Lösungen zur Sterilisirung zum Sieden. Nach längerem Kochen lässt man erkalten und inficirt jede Culturflüssigkeit mit einem Tropfen der umgeschiittelten Nitromonascultur, dic zuerst eingeleitet worden war. Ein Kolben bleibt frei stehen; einen anderen stellen wir in kohlensäurefreie Luft, indem wir den unter 16 beschriebenen und abgebildeten Apparat benutzen. Nur in der Culturflüssigkeit, zu welcher dic atmosphärische Kohlensäure Zutritt hat, wird sich im Verlauf einiger Zeit, z. B. eines Monats, lebhafte Nitrification durch den zur Entwickelung gelangenden Nitromonas geltend machen. Die Kohlensäure der kohlensauren Magnesia kann von diesem Spaltpilz nicht verarbeitet werden. Wird ein mit Culturflïssigkeit beschickter Kolben mit Watteversehluss versehen und sterilisirt, so bildet sich in der Lösung keine Salpetersäure, wenn man dieselbe nicht mit Nitromonaskeimen inficirt. In allen Fällen muss man sich natürlich davon überzeugen, dass die Culturflüssigkeit bei Beginn der Versuche nitratfrei ist. Man bringt zu dem Zweeke einen Tropfen der Lösung in eine weisse Schale und fügt in Schwefelsäure aufgelöstes Diphenylamin hinzu.

Nitromonas gehört $\mathrm{zu}$ denjenigen merkwürdigen Organisııen, welche im Dunkeln und ohne Chlorophyll die Fähigkeit haben, aus anorganischem Material organische Substanz 7, erzeugen. Es ist sehr schwierig und inühsam, dell strengen Beweis für die Richtigkeit dieser Behauptung beizubringen, weshalb wir auf den Gegenstand nicht näher cingehen. Vor allem handelt es sich bei beziiglichen

1) Literatur über Nitrification. Vgl. zumal Schiösisg und MÜsт\%, Compt. rend., T 84,85 u. 86 ; WLOGRADzkI, Landwirthschaftl. Jahrbuicher, 13d. 20, S. 175; GoDLEwsk, Anzeiger der Akad. d. Wiss. in Krakau, 1892. Nitromonas ist cine Bacterie von cllipsoidischer, etwas gestreckter Gestalt, die keine Fäden bildet. 
Experimenten darum, zunächst absolut reines destillirtes Wasser und ebenso Nährstoffe zu bereiten, die keine Spur organische Substanz enthalten.

\section{Die Salpetersäure als Pflanzennahrungsmittel.}

In Boden und im Wasser finden sieh salpetersaure Salze vor, die von den löheren Pflanzen als Nahrungsmittel verwerthet werden können. Dass die Nitrate thatsüehlich im Stande sind, den Stickstoff;

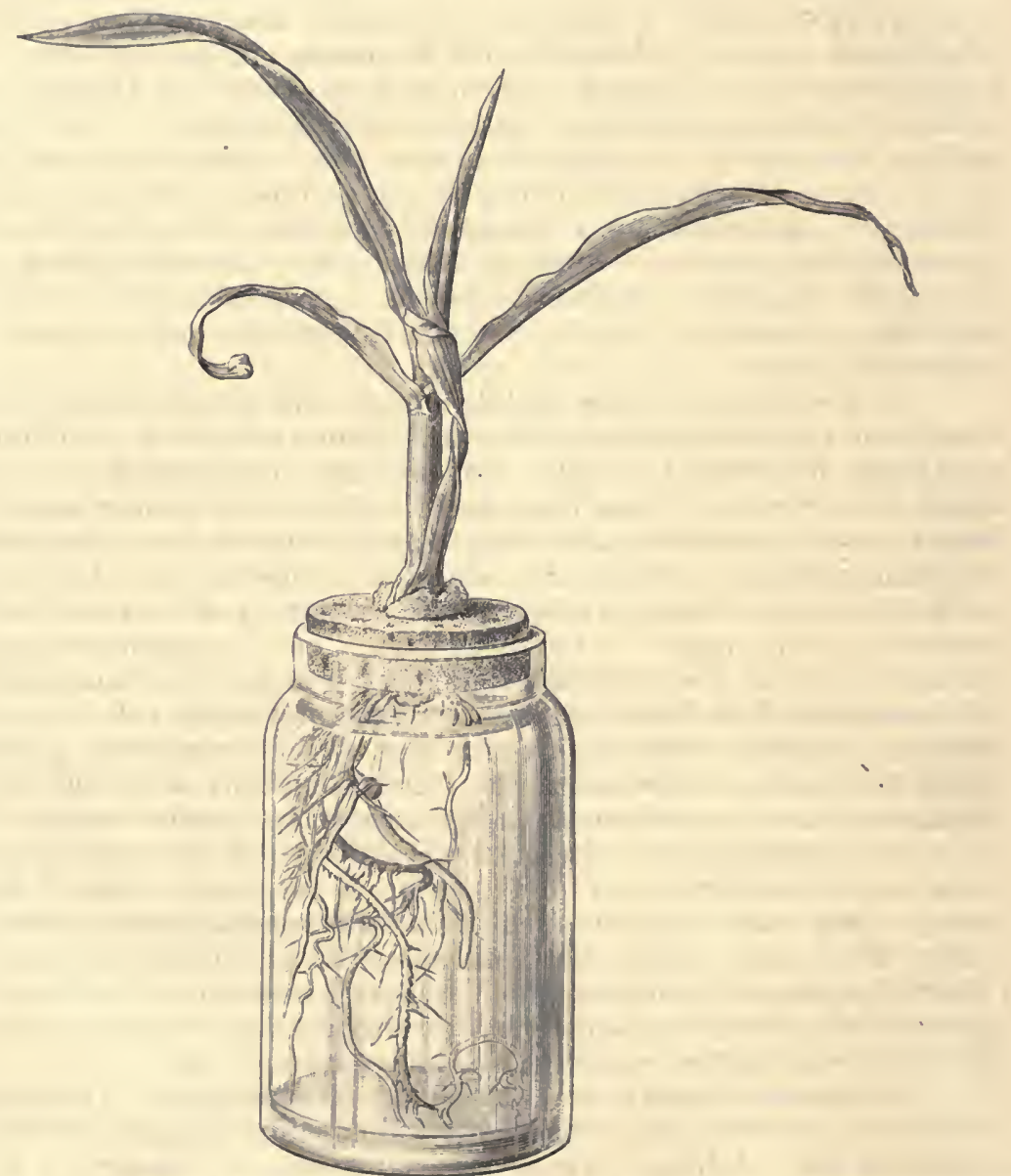

Fig. 23. Maispflanze, die mit Hiilfe der Methode der Wassercultur bei Ausschluss aller Stickstoffverbindungen in der Nährstofflösung zur Entwickelung gebracht worden ist.

welcher für die Eiweissbildung und die normale Entwickelung der Gewäehse erforderlieh ist, zu liefern, lïsst sich mit Hülfe der Methode der Wassereultur darthun. Als Untersuchungsobjecte dienen Mais, Hafer oder Buchweizen. (Ich benutzte Mais mit sehr gutem Erfolg.) Die Experimente werden in der Weise, wie es unter 1 angegeben ist, 
angestellt. Eine oder einige Pflanzen entwickeln sich in Berïhrung mit einer Nährstofflösung, welche die auf S. 2 aufgeführte Zusammensetzung besitzt (a). Andere Pflanzen gelangen mit einer Lösung in Contact, welche ebenso wie jene zusammengesetzt ist, nur statt des salpetersauren Kalkes $1 \mathrm{~g}$ schwefelsauren Kalk im Liter enthält (b). Die Pflanzen von a entwickelten sich bei meinen Versuchen sehr normal; diejenigen von b zeigten dagegen nach einigen Wochen ein sehr kümmerliches Aussehen (vgl. Fig. 22). Die unteren Blätter vertrockneten, und die Pflanze wuchs äusserst langsam. Den Versuchsobjecten standen nur die stickstoffhaltigen Reservestoffe des Samens als Stickstoffquelle zur Disposition; sie konnten lı̈̈chstens noch kleine Ammoniakmengen aus rler Luft aufnehmen, aber diese reichten nicht entfernt hin, um eine üppige Entwickelung des Organismus herbeizuführen.

\section{Das Aumoniak als Pfanzenuahrungsmittel.}

Will man sich davon überzeugen, dass die höheren Pflanzen im Stande sind, Ammoniaksalze, die sie mit Hülfe ihrer Wurzeln aufnehmen, für die Eiweissbildung $\mathrm{zu}$ verwerthen, so cultivire man Maispflanzen oder andere Gewächse in einer Nährstofflösung, die genau so wie die unter 1 erwähnte zusammengesetzt ist, nur statt des salpetersauren Kalkes $0,5 \mathrm{~g}$ phosphorsaures Ammoniak und $0,5 \mathrm{~g}$ schwefelsauren Kalk enthält. Es ist hier besonders darauf zu achten, dass die Reaction der Nährstofflösung während der Versuche keine wesentliche Veränderung erleidet, also stets eine schwach saure bleibt. Trägt man diesem Momente Rechnung, so gedeihen die Untersuchungsobjecte gut. Besonders empfehlenswerth ist auch folgende Nährstofflösung: $1000 \mathrm{ccm}$ destillirtes Wasser, $0,15 \mathrm{~g}$ schwefels. Magnesia, 0,12 g Chlorcalcium, 0,12 g schwefels. Kali, $0,50 \mathrm{~g}$ saures phosphors. Ammoniak und sehr wenig Eisenchlorid. Vor dem Gebrauch setzt man der Lösung so viel Ammoniak hinzu, dass sie nur noch schwach sauer reagirt. Die Lösung ist häufiger, etwa alle 5 Tage, zu ernenern. Fraglich ist übrigens, ob das Ammoniak nicht in der Pflanze vor seiner Verwerthung zur Eiweissbildung durch Oxydation in Salpetersüure übergeführt wird. Aber immerhin lehrt unser Experiment doch, dass das Ammoniak ïberhaupt ein Nahrungsmittel der höheren Pflanzen repäsentirt ${ }^{1}$ ).

\section{Der Ort der Eiweissbildung in den höheren Pflanzen.}

In den Blättern werden reichliche Mengen von Kohlehydraten flurch $\Lambda$ ssimilation erzeugt. Der Transpirationsstrom fülırt den Blättern salpetersaure Salze zu, und es ist daher anzunehmen, dass die Eiweissbildumg zumal in den erwähnten Organen vor sich geht.

Wir stellen Querschnitte durch. ein ausgewachsenes Blättehen ron Trifolium pratense her (vgl. Fig. 3). Abgesehen von der Epidermis sehen wir das einsehichtige Palissaden- und das melirschichtige Schwammparenchym. Der Bast- und Holztheil der Gefässbündel sind deutlich zu erkennen. Der Weichbast wird nach aussen von Bastfasern ungeben, und ebenso wird der Holzkörper nach aussen

1) Vgl. G. K̈̈нx und Hampr, Versuclisstationen, $186 \%$. 
von stark verdickten Sklerenchymfasern umsäumt. Auf der Aussenseite des Bastfaserbeleges und ebenso auf der Aussenseite der den Holzkörper umrahmenden dickwandigen Zellen ist eine einfache Lage chlorophyllfreier Zellen, die Krystalle von oxalsaurem Kalk enthalten, vorhanden. Die Krystallscheiden bedecken nur den Rücken der Faserstrånge; seitwärts erstrecken sie sich nicht weit ').

Da nun, wie wir unter 25 sehen werden, salpetersaure (und auch schwefelsaure) Salze unter den in den Pflanzen herrschenden Bedingungen von der Oxalsäure, die so sehr allgemein in Pflanzenzellen angetroffen wird, zersetzt werden können, so liegt die Annahme nahe, dass die erwähnten Krystalle von oxalsaurem Kalk als Producte derartiger Reactionen aufzufassen sind. Die Salpetersäure und Schwefelsäure können dann mit dem in den grünen Blattzellen gebildeten stickstofffreien organischen Material unter Vermittelung des Protoplasmas zur Eiweissbildung Verwendung finden. Mit Rücksicht auf die uns hier interessirenden Fragen beanspruchen nun namentlich die folgenden Beobachtungen und Experimente Beachtung ${ }^{2}$ ).

Will man die Gegenwart von Kalkoxalat in Blättern nachweisen, so werden die Untersuchungsobjecte (zur Orientirung über die Methode "verwendet man nach meinen Erfahrungen sehr zweckmässig nicht mehr ganz junge Blätter von Humulus) zunächst durch Eintauchen in heisses Wasser getödtet, dann extrahirt man sie mit Alkohol, legt sie in Chloralhydratlösung (auf $8 \mathrm{Thl}$. Chloralhydrat 5 Thl. Wasser) und beobachtet die Blattstücke mittelst des Polarisationsmikroskopes. Bei gekreuzten Nikols erscheinen die Kalkoxalatkrystalle leuchtend weiss oder farbig auf schwarzem Grunde, bei parallelen Nikols erscheinen sie fast schwarz auf weissem Grunde. Die Kalkoxalatkrystalle treten in den Zellen der Pflanzen in sehr verschiedenen Formen auf. Sie gehören theils dem tetragonalen, theils dem monoklinen System an ${ }^{3}$ ). Wenn man die Blattstücke in concentrirte Salzsäure legt und unter dem Polarisationsmikroskop weiter beobachtet, so kann man die allmähliche Auflösung des Oxalats gut verfolgen. Wasser und Essigsäure lösen die Krystalle nicht auf.

Bemerkungen über Art der Anwendung des Polarisationsmikroskops vgl. im 2. Abschnitt.

Untersuchen wir nach der angegebenen Methode einerseits junge, andererseits alte Blätter von Ampelopsis, so finden wir im Parenchym der Blätter zahlreiche Rhaphidenbündel und zwar in beiden Fällen ungefähr die gleichen Mengen. Ganz anders verhalten sich die meisten anderen dicotylen Gewächse, welche den oxalsauren Kalk in ihren Blättern nicht in Form von Rhaphiden führen. Wir prüfen z. B. junge, eben ausgewachsene und ältere Blätter von Alnus glutinosa, Ulmus campestris und Humulus. In allen Fällen entnehmen wir die Blätter solchen Sprossen, die sich im Schatten entwickeln, und finden, dass die Oxalatmenge im Parenchym der Blätter mit zunehmendem Alter derselben bedeutend wächst.

Wird eiu kräftiges, in einem Topf cultivirtes Exemplar von Pelargonium zonale an einen schlecht beleuchteten Ort gestellt, so dass keine Assimilation stattfinden kann, dann findet man im Parenchym der neu

1) Vgl. H. DE VRIEs, Landwirthseh. Jahrbuieher, Bd. 6, S. 900, und Taf. 44,

2) Vgl. Schimper, Botan. Zeitung, 1858.

3) Abbildungen der Caleiumoxalatkrystalle vergl. bei '/immermasx, Botan. Mikrotechnik, 1892, S. 56 . 
entstehenden Blätter wenig Kalkoxalat. Die Bildung dieser kleinen Oxalatmenge hängt gar nicht mit der Lichtwirkung zusammen, und man redet daher hier von dem Vorhandensein primären Kalkoxalats. Sind die Blätter im Dunkeln ausgewachsen, so hört unter den bezeichneten Umständen jede Kalkoxalatbildung auf. Dieselbe tritt aber wieder ein, wenn die Versuchspflanze ans Licht gelangt. Es entsteht dann das secundäre Kalkoxalat, dessen Production im Gegensatz zu derjenigen des primären Oxalats vom Licht abhängig ist (ScHimper).

Das Material zur Bildung des primären Calciumoxalats liefert einmal die in den Pflanzen durch Stoffwechselprocesse erzeugte Oxalsäure, andererseits der seitens der Wurzeln von aussen aufgenommene Kalk. Dieser letztere tritt namentlich in Verbindung mit Salpetersäure und Schwefelsäure aus dem Boden in die Pflanze ein. Wenn nun z. B. die Nitratc mit der im Stoffwechsel erzeugten Oxalsäure in chemische Wechselwirkung gerathen, dann bildet sich einmal freie Salpetersäure, welche für die Eiweissbildung Verwendung findet, andererseits entsteht Kalkoxalat. Vorübergehend können sich die Nitrate aber auch im Pflanzengewebe anbäufen, wie dies schon Beobachtungen lehrten, die unter 21 Erwähnung fanden.

Um den directen Nachweis zu liefern, dass aber auch eine Verarbeitung der Nitrate wirklich erfolgen kann, stellen wir den folgenden Versuch an. Zwei Topfexemplare von Pelargonium zonale werden ins Dunkle gestellt. Der Nitratgehalt der Blätter normal vegetirender Pflanzen ist meist gering, oder es ist gar kein Nitrat vorhanden. Untersuchen wir die Blätter der verdunkelten Pflanzen nach 4--6 Tagen, so zeigt sich, dass sie recht nitratreich geworden sind. Stellen wir die Pflanzen nunmehr ans Fenster, so dass sie hell beleuchtet sind, dann ist das Nitrat nach Verlauf von 8-14 Tagen wieder aus ihren Blättern verschwunden. Werden Stöcke von Pelargonium zonale oder Fuchsia globosa, deren Blätter stark panachirt sind, in derselben Weise, wie es soeben angegeben wurde, behandelt, so sieht man die Nitrate bei Lichtzutritt in den fast chlorophyllfreien Blättern nicht verschwinden.

Somit ergiebt sich, dass der Nitratverbrauch in Beziehung steht zum Chlorophyllgehalt der Blätter und zum Licht. Die Verarbeitung der Salpetersäure und die Eiweissbildung kann nach den neueren Untersuchungen im Organismus der höheren Pflanzen nur in den grünen Zellen und unter Mitwirkung des Lichtes vor sich gehen.

Schimper (vgl. auch Flora, 1890, S. 251 u. 260) ist der Ansicht, dass die Verarbeitung der Nitrate und des durch Assimilation entstandenen Zuckers zu Amiden und schliesslich zu Eiweiss, wobei als Nebenproducte vielleicht organische Säuren (Oxalsäure) ${ }^{1}$ ) entstehen, ganz direct vom Licht sowie der Chlorophyllthätigkeit abhängig gedacht werden muss. Einc Eiweissbildung in chlorophyllfreien Zellen, wie sie thatsächlich im Lebensprocess der Pilze stattfindet, ist nach ihm im Organismus der höheren Pflanzen ausgeschlossen. Streng bewiesen ist diese Ansicht meiner Meinung nach nicht. Freilich genügen auch die Versuche nicht, durch die manche das Stattfinden der Eiweissbildung in nicht grünen Zellen höherer Pflanzen wahrscheinlich zu machen suchen ${ }^{2}$ ). Die ganze Frage bedarf einer weiteren sehr eingehenden Behandlung, und möglich ist es, dass Licht sowie Chloro-

1) Diese Oxalsäure kann dann zur Entstehung des secundären Calciumoxalats Veranlassung geben.

2) FraNk (Lehrbuch d. Botanik, 1892, S. 568 und 570) ist der Ansicht, dass eventuell in jeder Zelle höherer Pflanzen Eiweissbildung möglich sei. 
phyllkörper nur indirecte Bedeutung für den Process der Eiweissbildung haben. Auch die Bildung des erwähnten secundären Oxalats könnte nur indirecte Beziehungen zum Liclit haben.

\section{Die Zersetzung der Nitrate in den Pflanzen.}

Es wurde bereits darauf hingewiesen (vgl. unter 24), dass die zur Eiweissbildung erforderliche Salpetersäure aus salpetersauren Salzen unter Vermittelung von Pflanzensäuren, zumal der Oxalsäure, in Freiheit gesetzt wird, während andererseits oxalsaure Salze entstehen. Diese und ähnliche Reactionen sind auch noch insofern von Wichtigkeit, als durch ihr Stattfinden die Pflanzensäfte von einem Uebermaass von Kalksalzen befreit werden können, denn der oxalsaure Kalk ist ja eine sehr schwer lösliche Verbindung und scheidet sich in der That in den Pflanzen sehr allgemein in Krystallform ab.

In der Pflanze findet die Einwirkung der Oxalsäure auf Kalk oder Kalisalze auf jeden Fall in sehr verdünnter Lösung statt, und daher hat es Interesse, Versuche zur Beantwortung der Frage anzustellen, ob die Reactionen, von denen hier die Rede ist, überhaupt noch bei Gegenwart sehr grosser Wasserquantitäten stattfinden ${ }^{1}$ ).

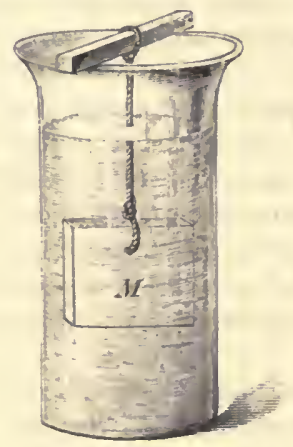

Fig. 23. Apparat zur Untersuchung der Finwirkung ron Oxalsi̊nre auf Nitrate.

Man stelle eine Anzahl von Gläsern auf, die Lösungen von $0,205 \mathrm{~g}$ (1 Aequivl.) salpetersauren Kalks in $400 \mathrm{ccm}$ Wasser enthalten. Ferner bereite man sich Auflösungen von je $0,090 \mathrm{~g}$ wasserfrei gedachter Oxalsäure in je $100 \mathrm{ccm}$ Wasser. Vermischt man nun je $400 \mathrm{ccm}$ der Kalksalpeterlösungen mit je $100 \mathrm{ccm}$ der Oxalsäurelösungen bei gewöhnlicher Temperatur, so entstehen Niederschlïge von oxalsaurem Kalk, während Salpetersäure frei wird. Die Zeit ist aber nicht ohne Einfluss auf den Verlauf der Reaction, wovon man sich überzeugen kann, wenn man die Menge des gefällten oxalsanren Kalkes in einem Falle sofort, im anderen erst nach Verlauf von 1, 2 oder 3 Tagen ermittelt. Je länger die Oxalsäure auf das Kalksalz eingewirkt hat, um so grösser ist die Menge des abgeschiedenen oxalsauren Kalkes. Bei der quantitativen Bestimmung des letzteren wird derselbe am zweckıässigsten in bekannter Weise in Sulphat übergeführt.

Dass in der That Salpetersäure frei wird, wenn Oxalsäure auf salpetersaures Kali einwirkt, davon kann man sich auf folgende Weise überzeugen. Es werden 5 Bechergläser $(a, b, c, d, e)$, von denen jedes $500 \mathrm{ccm}$ Wasser enthält, aufgestellt. $a$ erhält einen Zusatz von 0,210 g Salpetersäure $\left(\mathrm{H} \mathrm{NO}_{3}\right), \&$ einen Zusatz von 3,000 g Oxalsäure (dieselbe wasserfrei gedacht), $c$ einen Zusatz von $0,337 \mathrm{~g}$ salpetersaurem Kali, $d$ einen Zusatz von $0,210 \mathrm{~g}$ Salpetersäure und $3,000 \mathrm{~g}$ Oxalsäure und $e$ einen Zusatz von $0,337 \mathrm{~g}$ salpetersaurem Kali und 3,000 g Oxalsäure. In die Versuchsflüssigkeiten werden Marmorplatten (vgl. Fig. 23 M) von möglichst gleicher Grösse (40 mm Länge und Breite und $5 \mathrm{~mm}$ Dicke) hinein-

1) Specielleres ïber Nitratszersetzungen rgl. Exyerdixg, Versuchsstationen, Bd. 17 und 30. 
gehängt. Znm Aufhängen dienen Fäden, die an Stäben, welche auf dem Rande der Gläser ruhen, befestigt sind. Ueberlässt man die Flüssigkeiten sich selbst, so ergiebt sich, dass sich $a$ nicht trübt, ebensowenig $b$, denn die Marmorplatte bedeckt sich mit einer Kruste von oxalsaurem Kalk, die der weiteren Wirkung der Oxalsäure ein Ziel setzt. Die Flïssigkeit in $c$ bleibt auch klar, in den Glashäfon $d$ und $e$ bilden sich aber bedeutende Niederschläge von oxalsaurem Kalk. In $d$ wirkt die Salpetersäure auf den Marmor ein. Es entsteht salpetersaurer Kalk, der nun unter Bildung von oxalsaurem Kalk und Freiwerdung von Salpetersäure, die ihrerseits abermals auf den Marmor einwirkt, von der vorhandenen Oxalsäure zersetzt wird. Wenn in $e$ ein bedeutender Niederschlag entsteht, wie dies thatsächlich der Fall ist, so kann diese Erscheinung nur dadurch zu Stande kommen, dass die Oxalsäure aus dem salpetersauren Kali Salpetersäure frei gemacht hat, welche sich nach ihrer Bildung dann ebenso verhält, wie die Salpetersäure in $d$. Die Reactionen, von denen hier die Rede ist, gehen, wovon ich mich überzeugte, so energisch vor sich, dass in $d$ und $e$ bereits nach einer halben Stunde eine erhebliche Menge von oxalsaurem Kalk zur Abscheidung gelangt ist. Man kann also auf die angegebene Weise ganz bequem in Vorlesungen die Thatsache demonstriren, dass die Oxalsäure im Stande ist, das salpetersaure Irali zu zersetzen.

\section{Die Aschenbestandtheile der Pflanzen.}

\section{Die mechanische Bodenanalyse.}

Für die Beurtheilung der Natur eines Bodens ist es von grosser Wichtigkeit, den Gehalt desselben an gröberen und feineren Elementen genau zu ermitteln. Man unterscheidet daher bereits seit langer Zeit zwischen dem Skelett und der Feinerde des Bodeus. Die lotztere beansprucht unsere besondere Aufmerksamkeit, denn sie ist die Trägerin der wichtigsten Bodeneigenschaften und liefert den Pflanzen in erster Linie das Mineralstoffmaterial, dessen sie zu ihrer Ernährung bedürfen. Um die für den Zweck der chemischen Bodenanalyse erforderliche Feinerde zu gewinnen, wird der lufttrockene Boden auf ein Sieb von $0,5 \mathrm{~mm}$ Maschenweite gehracht und die Feinerde einfach ausgeschüttelt. Handelt es sich aber darum, den Feinerdegehalt eines Bodens zu bestimmen, so werden $50 \mathrm{~g}$ lufttrockner Erdo in einer Schale mit Wasser übergossen, etwa 1 Stunde auf dem Wasserbade erwärmt, darauf auf ein Sieb von $0,5 \mathrm{~mm}$ Maschenweite gebracht, und die Feinerde mit Hülfe eines Borstenpinsels, zuletzt unter einem feinen Wasserstrahl, ausgewaschen. Den Rückstand auf dem Siebe (Skelett) trocknet man und wiegt ihn. Das Skelett zerlegt man woiter in Streusand, Feinkies, Mittelkies und Grobkies. Es geschieht dies ebenfalls mit Hülfe verschiedener Siebe. Der Grobkies bleibt, wenn man mit dem Kxop'schen Siebsatze arbeitet, auf einem Siebe von 4,2 mm, der Mittelkies auf einem Siebe von $2,7 \mathrm{~mm}$, der Feinkies auf einem Siebe von $0,9 \mathrm{~mm}$ Maschenweite zurück.

Die Feinerde zerlegt man durch Schlämmen in Feinsand und thonige 
Theile. Dies geschieht mit Hülfe des Küıs'schen Schlämmcylinders (Fig. 24). Der Glascylinder hat eine Höhe von 28 und einen Durchmesser von $8,5 \mathrm{~cm}$ (beides im Innern desselben gemessen). $5 \mathrm{~cm}$ über

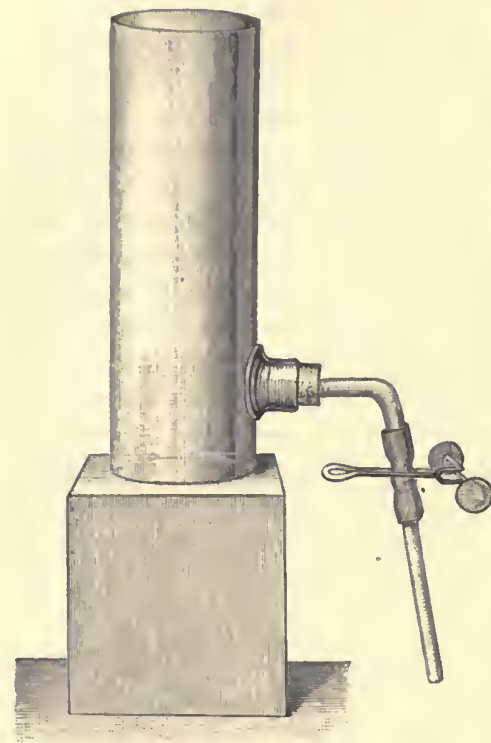

Fig. 24. Sehllimmeylinder. dem Boden des Cylinders befindet sich ein Tubulus, der in der Weise, wie es die Abbildung zeigt, verschlossen werden kann. Man bringt $30 \mathrm{~g}$ Feinerde, die zuvor längere Zeit in der Wärme mit Wasser behandelt worden ist, in den Schlämmcylinder, füllt diesen bis zu einer Marke am oberen Rande mit Wasser an, rührt die Erde unter Zuhülfenahme eines Stabes auf und lässt dann 10 Minuten lang ruhig stehen. Jetzt wird die trübe Flüssigkeit ahgelassen, ein neues Wasserquantum in den Cylinder gebracht, aufgerührt, und die Flüssigkeit nach 5 Minuten abermals entfernt. Man wiederholt diese Operationen so lange, bis alle thonigen Theile abgeschwämmt erscheinen, trocknet den Rückstand (Feinsand), der im Cylinder zurückgeblieben ist, und bestimmt sein Gewicht ${ }^{1}$ ). Die Feinerde besteht, wie die Schlämmanalyse unter anderem lehrt, aus Theilchen von sehr verschiedener Korngrösse, eine Thatsache, von welcher man sich schon überzeugen kanin, wenn man etwas Feinerde mit Wasser auf einen Objectträger bringt und der mikroskopischen Prüfung unterzieht. Die erwähnten Siebe und der Schlämmcylinder sind von Muencke in Berlin zu beziehen.

\section{2\%. Der Nachweis einiger Pflanzennährstoffe im Boden.}

Es liegt hier keineswegs in meiner Absicht, eine ausfübrliche Anleitung zur chemischen Untersuchung des Bodens zu geben. Wer solche Untersuchungen anstellen will und die Absicht hat, sich genau über den Werth der erhaltenen Resultate zu orientiren, muss die Schriften von E. v. WolfF ${ }^{2}$ ), Krop ${ }^{3}$ ), sowio meine Bodenkunde ${ }^{4}$ ) studiren. Hier handelt es sich allein darum, den Nachweis zu führen, dass der Boden bestimmte Pflanzennährstoffe enthält, und zwar verwenden wir als Untersuchungsmaterial stets die Feinerde des Bodens, welche in der Weise, wie es unter 26 angegeben, abgeschieden worden ist.

1) Ausführliche Erörterungen über die Function der Feinerde sowie des Skeleties im Boden und über die Aufgabe sowie die Methode der mechanischen Bodenanalyse findet man in meinem Lehrbuche der Bodenkunde, 1876, sowie in meiner Abhandlung über Bodenkunde, die in Bd. 2 des von v. D. GolTz herausgegebenen Handbuches der Landwirthschaft, 1888, ersehienen ist.

2) Vgl. E. V. WoLFF, Anleitung zur chem. Untersuehung land wirthsch. wichtiger Stoffe, 1875.

3) Kxop, Die Bonitirung der Ackercrde, 1871.

4) Vgl. Detmer, Lehrbuch der Bodenkunde, 1876. 
Will man die Gegenwart des Chlors im Boden constatiren, so werden $5 \mathrm{~g}$ Feinerde mit $200 \mathrm{ccm}$ Wasser einige Zeit in Berührung gelassen. Man filtrirt dann und bestimmt das Chlor im Filtrat in bekannter Weise mittelst salpetersauren Silberoxyds.

Zum Zweck des Nachweises der Schwefelsäure im Boden werden 2 oder $5 \mathrm{~g}$ Feinerde mit $20-50 \mathrm{~g}$ schwefelsäurefreicm kohlensaurem Natron vermischt. Die Mischung wird in eine Porzellanschale gebracht, mit Wasser übergossen and einige Zeit ausgekocht. In der erhaltenen Flüssigkeit kann die Schwefelsäure leicht qualitativ nachgewiesen oder quantitativ bestimmt werden.

Etwa $10 \mathrm{~g}$ Feinerde werden mit Wasser übergossen und unter fort. dauerndem Umrühren so lange mit Salzsäure versetzt, bis jede Kohlensäureentwickelung aufgehört hat. Nach einiger Zeit filtrirt man die schwach sauer reagirende Lösung $a b$, neutralisirt annähernd mit Ammoniak und versetżt unter gelindem Erwärmen mit essigsaurem Natron. Es bildet sich ein Niederschlag, der wesentlich. aus Eisenoxyd besteht, während man in der vom Niederschlag abfiltrirten Flüssigkeit unter Zuhülfenahme von oxalsaurem Ammoniak mit Leichtigkeit die Gegenwart des Kalkes nachweisen kann. Auf das ziemlich umständliche Verfahren, welches anzuwenden ist, um im Boden das Vorhandensein anderer Stoffe, zumal des Kalis sowio der Phosphorsäure, festzustellen, gehen wir hier nicht specieller ein; es sind in dieser Hinsicht die citirten Schriften zu vergleichen I).

\section{Der Gehalt des Wassers an Pflanzennahistoffen.}

Es dürfte von Interesse sein, die Gegenwart einiger Körper, welche als Pflanzennährstoffe Bedeutung besitzen, im Wasser festzustellen. Wir benutzen za derartigen Versuchen Flnss-, Teich- oder Brunnenwasser. Man säuert $20 \mathrm{ccm}$ Wasser mit einigen Tropfen Salzsäure an und fügt Chlorbariumlösung hinzu. Eine Trübung oder ein Niederschlag zeigt die Gegenwart von Schwefelsäure an. Entsteht ein woisser, käsiger, in Ammoniak löslicher Niederschlag oder eine Trübung, wenn man zu $20 \mathrm{ccm}$ Wasser, die mit reiner Salpetersäure angesäuert worden sind, eine Lösung von salpetersaurem Silber hinzufügt, so ist Chlor vorhanden. $50 \mathrm{ccm}$ Wasser werden mit Salzsäure angesäuert, darauf mit überschüssigem Ammoniak und endlich mit oxalsaurem Ammoniak versetzt. Ein entstehender weisser Niederschlag zeigt die Gegenwart von Kalk an. Der Kalk ist in den Wässern in Verbindung mit Schwefelsäure oder Kohlensäure (Calciumbicarbonat) vorhanden. Die Gegenwart des letzteren Körpers ist durch Erwärmen des frischen Wassers festzustellen, da sich derselbe bei höherer Temperatur leicht in einfach kohlensauren Kalk, welcher abgeschieden wird und eine Trübung der Flüssigkeit bedingt, sowie Kohlensäure zersetzt. Wird Brunnenwasser, das ziemlich reich an Calciumbicarbonat ist, in einem kleinen Glase bei gewöhnlicher Temperatur einige Zeit lang sich selbst überlassen, so scheidet sich einfach kohlensaurer Kalk in Krystallen ab, von deren Form man sich leicht durch mikroskopische Untersuchung überzeugen kann.

Da hier keine Anleitung zur Wasseruntersuchung gegeben, sondern nur die Ueberzeugung befestigt werden soll, dass das Wasser überhaupt

1) Vgl. auch Kösig, Untersuchung landwirthschl. wichtiger Stoffe, 1891. 
Pflanzennährstoffe enthält, so wollen wir von dem Nachweis anderer Stoffe im Wasser absehen. Uebrigens ist an anderer Stelle bereits gezeigt worden, wie man bei der Untersuchung des Wassers auf einen Gehalt an Ammoniak und Salpetersäure zu verfahren hat ${ }^{1}$ ).

\section{Die Aschenanalyse.}

Trotzdem die Ausführung qualitativer sowie quantitativer Aschenanalysen ziemlich umständlich und zeitraubend ist, kann ich demjenigen, welcher sich mit physiologischen Studien beschäftigen will, nur dringend rathen, derartige Untersuchungen auszuführen. Das Pflanzenmaterial wird zunächst sorgfältig gereinigt, z. B. auch vom anhaftenden Staub befreit. Frische Wurzeln müssen alsdann in Scheiben zerschnitten werden, die man, ebenso wie frische Stengel und Blätter, an Fäden im Trockenraum bei etwa $50^{\circ} \mathrm{C}$. zum Trocknen aufhängt. Die trocknen Wurzeln zerstösst man zu einem nicht sehr feinen Pulver, während man die getrockneten Stengel oder Blätter mit der Scheere zerschneidet. Lufttrockne Samen werden im Mörser zu einem groben Pulver zerstossen.

Es sei z. B. die Aufgabe gestellt, die oberirdischen Theile der Kleepflanze auf ihre Aschenbestandtheile zu untersuchen. Ein grösseres Quantum der Pflanzen wird im Trockenschranke getrocknet, zerschnitten, und das Ganze gut durcheinander gemischt. Zur Gewinnung der Asche dienen etwa $100 \mathrm{~g}$ Substanz. Die Verbrennung erfolgt am besten in einer grossen Platinschale; in Ermangelung einer. solchen kann auch eine Porzellanschale benutzt werden. Bei der Verbrennung selbst, die über dem freien Feuer der Lampe vorzunehmen ist, hat man sorgfältig darauf $\mathrm{zu}$ achten, dass die Hitze nicht zu sehr gesteigert werde; die Asche darf niemals ins Glühen kommen. Die Aschenanalyse wird nach der Vorschrift von E. v. WolFF ${ }^{2}$ ) angestellt. Ich habe mich oft von der Brauchbarkeit der Methode überzeugt. $1 \mathrm{~g}$ der gewonnenen Rohasche dient zur Kohlensäurebestimmung, die man z. B. zweckmässig mit Hülfe des Dietrich'schen Apparates ausführt ${ }^{3}$ ). $1 \mathrm{~g}$ Rohasche wird ferner mit verdünnter Salpetersåure behandelt, um in der erhaltenen Lösung das Chlor zu bestimmell. Weitere $3-4 \mathrm{~g}$ Asche werden in einer Kochflasche mit concentrirter Salpetersäure befeuchtet, dann mit starker Salzsäure iibergossen und hierauf einige Zeit lang bei beginnender Kiochhitze digerirt. Jetzt wird das Ganze in eine Porzellanschale gespült, zur Trockne verdunstet, und die trockne Masse längere Zeit im Trockenschranke belassen, dann mit concentrirter Salzsäure angefeuchtet und mit Wasser extrahirt. Der ungelöste Rückstand (Kieselsänre, Sand, Kohle) wird auf einem getrockneten und gewogenen Filter gesammelt, gut mit heissem Wasser ausgewaschen und nach dem Trocknen gewogen. $\mathrm{Der}$ in eine Platinschale gebrachte Inhalt des Filters wird

1) Genaue Angaben über die Methode der Wasseruntersuchung findet man bei Tremaxs, Anleitung zur Untersuchung von Wasser, 1874, und ReichardT, Grundlagen zur Beurtheilung des Trinkwassers, 1880.

2) Vgl. E. v. WOLFF, Anleitung zur chem. Untersuchung landwirthschl. wichtiger Stoffe, 1875 , S. 159.

3) Vgl. Dietrich, Zeitschrift f. analytische Chemie, Bd. 3 u. 4. Der Dietricilsche Apparat kann von der Firma J. H. Bücriler in Breslau bezogen werden. 
unter Zusatz von Natronlauge mit einer concentrirten Lösung von kohlensaurem Natron inehrmals ausgekocht, die Flüssigkeit durch das schon benutzte Filter filtrirt, um in dem gut ausgewaschenen, aus Sand sowie Kohle bestehenden Rïckstande den Gehalt an diesen Körpern durch Verbrennung festzustellen. Die alkalische Lösung dient zur Bestimmung der Kieselsäure; sie wird mit Salzsäure übersättigt, zur 'Trockne verdampft, der Rückstand mit angesåuertem Wasser ausgekocht, und die abgeschiedene Kieselsäure ihrem Gewicht nach bestimmt.

Die von dem erwälnten, aus Kieselsäure, Sand sowic Kohle bestehenden Rückstande abfiltrirte Flüssigkeit wird auf ein bestimmtes Volumen, z. B. 500 ccm, gebraclit und in zwei abgemessene Portionen getheilt. In der einen Portion bestimmt man die Schwefelsäure nit Chlorbarium, um die vom sehwefelsauren Baryt abfiltrirte Lösung bei gelinder Wärme mit Ammoniak, kohlensaurem, sowie oxalsaurem Ammoniak zu behandeln. Die vom entstandenen Niederschlag abfiltrirte Flüssigkeit wird zur Trockne verdampft, der Rückstand schwach geglülıt und mit Oxalsäure erhitzt. Der Glülırückstand muss mit Wasser behandelt, und die gewonnene Lösung nach dem Filtriren mit Salzsäure versetzt werden. Dann bringt man die Lösung wieder zur Trockne, glüht den Rückstand schwach und bestimmt das Gewicht der nunmehr reinen Chloralkalien. Das Kali trennt man in bekannter Weise mit Hülfe von Platinchlorid vom Natron. Dic zweite Portion der oben erwähnten Lösung muss annähernd mit Ammoniak gesättigt und mit essigsaurem Ammoniak versetzt werlen, um unter gelindem Erwärmen das vorhandene phosphorsaure Eisenoxyd zur Abscheidung zu bringen und die Phosphorsäure, sowie das Eisenoxyd nach der Formel $\mathrm{Fe}_{z}\left(\mathrm{PO}_{4}\right)_{z} \mathrm{zu}$ berechnen. Die vom phosphorsauren Eisenoxyd abfiltrirte Flüssigkeit erhitzt man unter Zusatz von oxalsaurem A ummoniak zur Abscheidung des Kalkes bis zum anfangenden Kochen (Kalkbestimmung) und übersättigt das Filtrat nach dem Eindampfen bis auf etwa 150 ccm stark mit Anmoniak. Nach 24-stündigem Stehen wird die abgeschiedene phospliorsaure Ammoniak-Magnesia auf einem Filter gesammelt, um aus der Menge derselben die Phosphorsäure sowie die Magnesia zu berechnen. Das Filtrat wird, wenn noch Phosphorsäure in demselben vorhanden ist, mit Magnesiamixtur (bereitet durch Vermischen von 1 Thl. krystallisirter schwefelsaurer Magnesia mit ? Thl. Chlorammonium, 8 Thl. Wasser und 4 Thl. Ammoniak) oder, wenn noch Magnesia zugegen ist, mit phosphorsaurem Natron gefällt.

Bei der Zusammenstellung der Resultate quantitativer Aschenanalysen ist der Gelialt ler vegetabilischen Trockensubstanz an Rohasche, sowie an Reinasche (= Rohasche - Kohlensäure, Sand und Kiohle) anzugeben. Ebenso inuss die procentische Zusaminensetzung der Reinasche berechnet werden.

Einige Pflanzenaschen, z. B. diejenige des Tabaks, enthalten auch Lithium. Man kann nun leicht einen hübschen Demonstrationsversuch anstellen, indem man Cigarrenasche mit verdünnter Salpetersäure anfeuchtet, das freie Ende eines in einer Glasröhre eingeschmolzenen Platindrahtes in die Mischung bringt und dann in die nicht leuchtende Flamme eines BunsEN-Brenners oder in eine Spiritusflamme hält. Die spectroskopische Prüfung der Flamme, z. B. unter Benutzung eines kleinen Taschenspectroskops, lässt fast immer sofort das Auftreten der so sehr charakteristischen rothen Lithiumlinie erkennell. 


\section{Das Mineralstoffbedlirfniss der höheren Pflanzen und die Entbehrlichkeit des Natriums sowie des Silieinms fïr dieselben.}

Die Fragen, um die es sich hier handelt, können am bequemsten und sichersten mit Hülfe der Methode der Wassercultur entschieden werden. Diese letztere ist unter 1. eingehender besprochen worden, und wir cultiviren z. B. Maispflanzen nach der dort gegebenen Vorschrift in einer completen Nährstofflösung, die also salpetersauren Kalk, Chlorkalium, schwefelsaure Magnesia, phosphorsaures Kali sowie etwas Eisenchlorid enthält. Gleichzeitig versuchen wir aber auch eine in Sägespänen angekeimte Maispflanze zur Entwicklung zu bringen, indem wir ihre Wurzeln nur mit destillirtem Wasser in Berührung lassen. Diese letztere Pflanze stellt ihr Wachsthum bald ein, während die Untersuchungsobjecte, deren Wurzeln sich mit einer completen Nährstofflösung in Contact befinden, kräftig weiter wachsen. Bei meinen Versuchen entfaltete die Maispflanze, welcher destillirtes Wasser zur Disposition stand, nur vier Blätter; dann hörte ihr Wachsthum auf. Mineralstoffe sind demnach erforderlich, wenn sich Gewächse normal entwickeln sollen. Werden die Pflanzenwurzeln nicht von einer Nährstofflösung, sondern voll destillirtem Wasser umgeben, so steht das Wachsthum der Pflanzen still, wenn die Reservestoffe der Samen verbraucht sind.

Unsere Nährstofflösung ist frei von Natron und Kieselsäure. Der Culturversuch lehrt also ferner, dass weder Natrium noch Silicium als unentbehrliche Pflanzennährstoffe $\mathrm{zu}$ betrachten sind. Uebrigens ist es möglich, dass das Silicium für manche Organismen einen unentbehrlichen Nährstoff repräsentirt. So z. B. für die Diatomeen, braun gefärbten, mikroskopisch kleinen Algen, denen man so oft auf im Wasser liegenden Steinen oder Pflanzentheilen begegnet, und deren Membranen mit grossen Kieselsäuremengen imprägnirt sind. Für die Gräser ist die Kieselsäure wohl entbehrlich, aber doch nützlich, und ähnlich mag es sich mit den Equiseten verhalten. Auf jeden Fall ist der Kieselsäuregehalt der Membranen der Epidermiszellen dieser letzteren ein sehr bedeutender, wovon man sich auf folgende Weise überzeugen kann.

Untersucht man Flächenschnitte des Stengels von Equisetum arvense, so findet man, dass spaltöffnungführende und spaltöffnungsfreie Streifen mit einander abwechseln. Jene erscheinen durch die Unterlage aus chlorophyllhaltigen Zellen grün, diese farblos. Die Epidermiszellen sind lang gestreckt; der Bau des Spaltöffnungsapparats ist ein complicirter. Wir legen einen Flächenschnitt auf cin Glimmerplättchen, betupfen den Schnitt mit concentrirter Schwefelsäure und glühen ihn in einer Gas- oder Spiritusflamme aus. Das Glimmerplättehen mit ler Asche legt man darauf'auf einen Objectträger und bedeckt das Präparat nach Zusatz eines Wassertropfens mit Deckglas. Bei mikroskopischer Untersuchung erblicken wir ein Kieselskelett, welches viele der wesentlichen Structurverhältnisse des ursprünglichen Flächenschnittes noch erkennen lässt. 


\section{Die Unentbchrliehkeit des Phosphors, Schwefels, Kaliums, Calciums, Magnesiums und Eisens fïir die höheren Pflanzen.}

Wir cultiviren Pflanzen, z. B. Maispflanzen, in der Weise mit Hülfe der Methode der Wassercultur, wie es unter 1 angegeben worden ist. Der completen Nährstofflösung geben wir aber eine etwas andere Zusammensetzung wie dort. Sie enthält im Liter, abgesehen von sehr wenig Eisenchlorid, $1 \mathrm{~g} \mathrm{Ca} 2 \mathrm{No}_{3}, 0,5 \mathrm{~g} \mathrm{~K} \mathrm{Cl,} \mathrm{0,5} \mathrm{g} \mathrm{MgSo}_{4}$ und $0,5 \mathrm{~g}$ fein pulverisirten $\mathrm{Ca}_{3} 2 \mathrm{Po}_{4}$. Der letztere Körper ist schwer löslich in Wasser und bildet daher einen Bodensatz in den Culturgefässen. Ferner stellen wir eine kalifreie Lösung her, indem wir das $\mathrm{K} \mathrm{Cl}$ der completen Nährstofflösung durch $0,5 \mathrm{~g} \mathrm{NaCl}$ ersetzen. Eine plosphorsäurefreie Lösung stellen wir dar, indem wir den $\mathrm{Ca}_{2}$ $2 \mathrm{Po}_{4}$ durch $0,5 \mathrm{~g} \mathrm{CaSo}$ ersetzen. Eine eisenfreie Lösung erhält man leicht, indem man das Eisenchlorid fortlässt. Die Culturgefässe werden sämmtlich, nachdem sie mit Maispflanzen beschickt worden sind, denselben äusseren Einflüssen ausgesetzt. Es ergiebt sich, dass der Mais in der completen Nälırstofflösung vortrefflich gedeiht, während die Pflanzen in der kali- sowie phosphorsäurefreien Lösung ihr Wachsthum alsbald einstellen, nämlich dann, wenn der in den Samen vorhandene kleine Kali- und Phosphorsäurevorrath erschöpft ist. Kalium sowie Phosphor sind demnach durchaus unentbehrliche Pflanzennährstoffe. Der Versuch mit der kalifreien Nährstofflösung lehrt überdies, dass das Kalium im Ernährungsprocess der höheren Pflanzen nicht durch das ihm chemisch so nahe verwandte Natrium vertreten werden kann. Auch schwefelfreie Lösungen sind leicht $\mathrm{zu}$ bereiten.

Die Pflanzen in eisenfreien Nährstofflösungen produciren zunächst normale grüne Blätter. Aber bald tritt eine Krankheitserscheinung hervor. Die Untersuchungsobjecte werden nämlich, wenn der Eisenvorrath der Samen erschöft ist, icterisch und chlorotisch. Die neu entstehenden Blätter erscheinen nicht melır grün, sondern weiss, und die mikroskopische Untersuchung derselben lehrt, dass nicht normal ausgebildete oder keine Chlorophyllkörper in ihren Zellen vorhanden sind. Wenn wir der Nährstofflösung einige Tropfen einer verdünnten Eisenchloridlösung hinzufügen, so ergrünen die vorher weissen Blätter in 2-3 Tagen, und die Pflanzen wachsen nun freudig weiter ${ }^{1}$ ).

Auch mit den folgenden Nährstofflösungen können wir bequem arbeiten. Wir werden finden, dass unsere Pflanzen in der Normallösung gut gedeihen, unter Benutzung derjenigen Lösungen aber, denen dieser oder jener Stoff fehlt, alsbald zu Grunde gehen.

Sämmtliche Lösungen, abgesehen von der zuletzt angegebenen, phosphorsäurefreien, sind bei Gebrauch im Verhältniss von 1:4,8 mit destillirtem Wasser $\mathrm{zu}$ verdünnen ${ }^{2}$ ).

$$
\begin{aligned}
& \text { Normall ös u n } \mathrm{g}^{3} \text { ): } \\
& 600 \text { ccm destill. Wasser, } \\
& 7 \mathrm{~g} \text { Kalinitrat, }
\end{aligned}
$$

1) Die Literatur über die hier bchandelten Verhältnisse habe ich in meinem Iehrbuche der Pflanzenphysiologic zusammengestellt.

2) Vgl. SCHIMPER, Flora, 1890, H. 3.

3) Sẩmmtlichen Lösungen ist wenig verdünnte Eisenchloridlösung hinzuzufügen. 
$1,5 \mathrm{~g}$ Schwefels. Magnesia,

1,5 , Chlornatrium,

1,5 , Neutrales phosphors. Kali, Gyps im Ueberschuss.

Kalkfreie Lösung:

Vorstehende Lösung ohne Gyps.

Kalifreie Lösung:

$600 \mathrm{ccm}$ destill. Wasser,

7 g Kalknitrat,

1,5 „Schwefels. Magnesia,

1,5 , Chlornatrium,

1,5 "Neutrales phosphors. Natron.

Magnesiafreie Lösung:

600 ccm destill. Wasser,

6 g Kalknitrat,

1,5 , Kalinitrat,

1,5 "Neutrales Kaliphosphat,

1,2 ., Kalisulfat.

Phosphorșäurefreie Lösung:

$1000 \mathrm{ccm}$ destill. Wasser,

$0,5 \mathrm{~g}$ Kalinitrat,

1 "Kalknitrat,

0,5 , Magnesianitrat,

0,5 , Neutrales Kalisulfat.

Dass Pflanzen, z. B. Mais und Bohnen, mit denen wir auch unter Benutzung der vorstehenden Lösungen experimentiren können, in phosphorsäurefreier Lösung alsbald $\mathrm{zu}$ Grunde gehen, ist schon deshalb natürlich, weil der Phosphor als ein wesentlicher Bestandtheil des Nucleins betrachtet werden muss, und dieses letztere wieder für die Erzeugung von Kernen unentbehrlich erscheint.

Werden Pflanzen in kalkfreien Nährstofflösungen cultivirt, so wachsen sie zunäclıst normal. Dann aber zeigen sie Krankheitserscheinungen, indem namentlich die jüngsten, später auch die älteren Blätter braunfleckig werden. Die bei Benutzung kalkfreier Lösung erwachsenen Blätter haben etwa die nämliche Grösse und auch den gleichen Chlorophyllgehalt wie unter normalen Verhältnissen entstandene. Sie können auch assimiliren, wie diese letzteren, aber sterben schliesslich doch ab. Den normalen Blättern gegenüber zeichnen sich die bei Kalkausschluss zur Ausbildung gelangten durch grossen Stärkereichthum aus. Die braunen Flecken, welche nach gewisser Zeit an ihnen auftreten, sind, wie die Untersuchungen ScHrmper's und LoEw's wohl sicher ergeben haben, die Folge der Einwirkung schädlicher organischer Säuren, zumal Oxalsäure, auf die Gewebe. Organische Säuren werden ja reichlich im pflanzlichen Stoffwechsel gebildet. Sie müssen neutralisirt werden, und die Function des Kalkes besteht in erster Linie darin, dies zu bewerkstelligen. Wenn die Bindung der Säuren nicht eintritt, so können manche Vorgänge in den Zellen, z. B. auch die normale Ableitung der Assimilate, nicht erfolgen, und schliesslich sterben die Zellen völlig ab. Der Kalk hat auch insofern Bedeutung 
für die Ernälıłung der Gewächse, als anorganische Säuren (Salpeterund Schwefelsäure) zumal in Verbindung mit Kalk in die Ptlanze eingeführt werden.

Das Kali scheint bei den Vorgängen der Anlage und Entwickelung der Pflanzenorgane eine wichtige Rolle zu spielen. Wenn man Pflanzen in kalifreien Lösungen cultivirt, so zeigen sie in der That auch ein wesentlich anderes Verhalten als bei Kalkabwesenheit. Zunächst reicht noch die aus den älteren Theilen der Versuchsobjecte auswandernde Kalimenge hin, um die neu entstehenden Organe bis zu einem gewissen Grade init Kali zu versorgen. Man wird aber beobachten, dass diese Organe, z. B. die Blätter, immer kleiner und kleiner werden, bis schliesslich der Tod der Pflanze eintritt. In den kalifrei gezogenen Gewächsen hört allmählich auch die assimilatorische Thätigkeit auf (NoBie, Schimper), indessen doch erst dann, wenn anderweitige Merkmale des kranklıaften Zustandes des Organismus, namentlich das beschränkte Wachsthum der neu entstehenden Organe, bereits vorher hervorgetreten sind.

\section{Das Mineralstoffbediirfniss der Pilze.}

Die Entwicklung der Pilze ist ebenso wie diejenige der höheren Pflanzen an die Gegenwart aufnehmbarer Mineralstoffe gebunden, und um diesen Satz zu beweisen, stellen wir geeignete Culturversuche mit dein Hefepilz, Saccharomyces cerevisiae, an. Wir bereiten uns eine grössere Menge einer Flüssigkeit, die in 100 Thl. 84 Thl. Wasser, 15 Thl. reinsten Candiszucker und 1 Thl. weinsaures Ammoniak enthält. Je 100 ccm dieser Flüssigkeit gelangen in Kiochflaschen. $a$ erlıält keinen Mineralstoffzusatz. $b$ erhält einen Zusatz von 0,2 Thl. $\mathbf{K ~ H}_{2}$ $\mathrm{Po}_{4}, 0,02$ Thl. $\mathrm{Ca}_{3} 2 \mathrm{Po}_{4}$ und $0,02 \mathrm{Thl} . \mathrm{Mg} \mathrm{So}_{4} \cdot c$ erhält einen Zusatz von $0,02 \mathrm{Thl}$. $\mathrm{Ca}_{3} 2 \mathrm{Po}_{4}$ und $0,02 \mathrm{Thl}$. Mg So $\mathrm{So}_{4} d$ erlıält endlich einen Zusatz von 0,2 Thl. $\mathrm{Na}_{2} \mathrm{HPo}_{4} \cdot 0,02$ Thl. $\mathrm{Ca}_{3} 2 \mathrm{Po}_{4}$ und

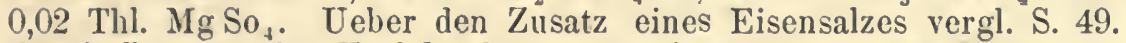
Die Oeffnungen der Kochflaschen verstopft man nun mit Watte, erhitzt die Flüssigkeiten zum Sieden und lässt sie wieder abkühlen. Man setzt jeder der 4 Nährstofflösungen, indem man die Wattepfropfen, mit denen die Kochflaschen verschlossen sind, für einen Monent lüftet, 1 ccm schwach milchigen Hefewassers zu. (Vergl. „Bezugsquellen".) Am besten ist es, die vier Fläschchen nummehr bei einer Temperatur von 25 bis $30^{\circ} \mathrm{C}$. im Thermostaten, unter häufigem Umschütteln, sich selbst zu ïberlassen.

Lebhafte Gährung und Hefevermehrung, die man quantitativ durch Sammeln der erzeugten Hefe auf einem getrockneten und gewogenen Filter bestimmen kann, tritt nur in der Flüssigkeit $b$ ein. Wenn in den Flüssigkeiten $a, c$ und $d$ eine schwache Trübung (bedingt durch geringe Hefe- oller Bakterienentwicklung) zu Stande kommen sollte, so ist das ein Zeichen für die Gegenwart kleiner Mineralstoff- resp. Kalimengen, die vielleicht im Zucker oder in dem zugesetzten Hefewasser vorhanden waren. Auf jeden Fall kann die Hefe sich nur normal entwickeln, wenn Mineralstoffe nicht in der Nälırlösung fehlen. Aber unsere Experimente lehren ferner, dass auch schon dann keine üppige Hefevegetation und keine Gährung eintritt, wenn nur das Kalium, das durch Natrium nicht vertreten werden kann, nicht zu- 
gegen ist ${ }^{1}$ ). Bei den Versuchen ist sorgfältigst auf Reinheit des Wassers, der Reagentien und des Hefematerials zu achten! Je günstiger die Verhältnisse nach dieser Richtung hin liegen, um so schlagender der Erfolg der Experimente.

\section{Die Formen, in denen einige Mineralstoffe in_den Pflanzen rorkommen.}

Die Mineralstoffe kommen bei weitem nicht immer nur in anorganischen Verbindungen in den Pflanzen, sondern sehr häufig auch in organischen Verbindungen vor, z. B. Schwefel in Eiweissstoffen, Phosphor im Nuclein ete. Diese Thatsache verdient hohe Beachtung, zumal wenn man die weitere Thatsache in Betracht zieht, dass ein bestimmter Stoff im Laufe der Entwicklung ciner Pflanze aus organischer Verbindung in anorganische übergehen kann und umgekehrt. Das Studium dieser Verhältnisse, welches für die Beurtheilung der Function der Mineralstoffe und in anderer Hinsicht wichtig erscheint, wurde neuerdings zumal von SchIMPER ${ }^{2}$ ) belebt, und wir wollen zunächst die Untersuchungsmethode kennen lernen, wobei wir uns auf den Nachweis der Phosphorsäure, des Kalis und des Kalkes beschränken. Weiteres ist bei ScHIMPER und ZIMMERMANN ${ }^{3}$ ) nachzusehen.

Zum Nachweis der Mineralstoffe auf mikrochemischem Wege werden die nicht gar zu dünnen Schnitte zunächst direct mit Reagentien behandelt, und ferner verascht man weitere Schnitte durch Glühen auf dem Deckglas, um die erhaltene Asche ebenfalls mit Reagentien zu prüfen. Die organischen Mineralstoffverbindungen lassen sich in den unveränderten Schnitten vielfältig nicht auffinden; erst in der Asche ist dann meist die Gegenwart dieser oder jener Basen oder Säuren leicht zu constatiren. Die zu verwendenden Reagentien sind mit besonderer Sorgfalt auf ihre Reinheit zu prüfen.

Um Calcium in den Asehen der Schnitte nachzuweisen, löst man dieselben auf dem Objectträger in 2-proc. Schwefelsäure auf und lässt langsam eintrocknen. Es entstehen dann namentlich am Tropfenrande, charakteristische Gypskrystalle. Vergl. Abbildungen bei HausHOFEr, Mikroskopische Reactionen, Braunschweig 1885, und ZimmerMANN's citirte Schrift, S. 64.

Der Nachweis des Kaliums gelingt mit Platinchlorid. Das Reagens ist besonders auf seine Reinheit zu prüfen. Die Krystalle des entstehenden Kaliumplatinchlorids stellen reguläre Octaëder oder Würfel dar. Die Schnitte werden mit einem Tropfen des Reagens versetzt, und man lässt eintrocknen. Die Asche löst man in etwas säurehaltigem Wasser auf, erwärmt den Objectträger über einer Spiritusflamme bis zum Eintrocknen der Lösung und fügt das Reagens hinzu. Die Krystalle entstehen stets zunächst am Tropfenrande, später auch in der Mitte des Tropfens.

Die Plısphorsäure fällt man bei mikrochemischem Nachweis als phosphorsaure Ammonmagnesia aus. Die Schnitte oder die Asche derselben (letztere nach dem Auflösen in säurehaltigem Wasser und

1) Weiteres über den Mineralstoffbedarf des Hefepilzes rgl. bei A. MaYer, Lehrbuch d. Gährungschemic, 1874, S. 121.

2) Vgl. Schimper, Flora, 1890, Heft 3.

3) Vgl. Zimmermaxs, Botan. Mikrotechnik, 1892, S. 46. 
Eindunsten der Lösung auf dem Objectträger) werden mit einer kleinen Menge der Mischung von $25 \mathrm{Vol}$. einer concentrirten wässerigen Magnesiumsulfatlösung, 2 Vol. concentrirter wässeriger Chlorammoniumlösung und 15 Vol. Wasser versetzt. Die entstehenden Krystalle von phosphorsaurer Ammonmagnesia (bei Untersuchung der Schnitte entstehen sie in denZellen) haben sehr charakteristische Formen.

Es bedarf noch sehr eingehender Studien, um die Vertheilung der organischen und anorganischen Mineralstoffverbindungen in den Pflanzen genauer $\mathrm{zu}$ erforschen. Einige Resultate haben die Untersuchungen aber locl bereits ergeben.

In den ruhenden Samen (man untersuche Schnitte aus angequollenen Samen von Phaseolus und Ricinus) sind Phosphorsäure, Kalk und Kali in organischen Verbindungen vorlıanden, daher nicht direct in den Schnitten, sondern erst in der Asche derselben nachzuweisen. Bei der Keimung werden diese organischen Mineralstoffverbindungen gespalten. Phosphorsäure, Kalk und Kali wandern als anorganische Salze im Parenchym der Rinde und des Markes sowohl des Stengels als auch der Wurzel und ebenso im Blattnervenparenchym. In allen diesen Geweben sind die genannten Stoffe daher direct (nicht nur nach den Einäschern derselben) aufzufinden. Reich an Kali und Plıosphorsäure ist z. B. das Parenchym der Maiskeimlinge.

In den Vegetationspunkten und im Mesopliyll der Keimpflanzen kommen reichliche Mengen organischer Phosphorverbindungen vor, während anorganische Phosphorverbindungen völlig felılen. Die Phosphorsåure ist also nur bei der Untersuchung der Asche nachzuweisen. Die Vegetationspunkte und das Mesophyll stellen demnach Endziele ler Wanderung dar, Bildungsstätten phosphorhaltiger organischer Körper. Das Parenchyı der Rinde, des Markes und der Nerven repräsentiren dagegen die Balnen, in denen die Mineralstoffe bei der Keimung wandern.

Bemerkt sei noch, dass die Vegetationspunkte, das Cambium sowie die Siebröhren (man kann z. B. den Saft der Siebröhren von Cucurbita und die Asche desselben prüfen) der Keimpflanzen und entwickelten Pflanzen fast oder völlig kalkfrei sind, während sie mehr oder minder reichliche Mengen von Kali und Plosphorsäure zumal in organischen Verbindungen führen.

Um die Methode des mikrochemischen Eisennachweises kennen zu lernen, quellen wir Samen von Sinapis alba in Wasser ein, entfernen nach erfolgter Quellung die Samenschale und legen den Embryo, der bekanntlich in einander gefaltete Cotyledonen trägt, in 2-procentige Lösung des gelben Blutlaugensalzes, die sich in einem Gläschen befindet. $\mathrm{Nach}^{1} / 2$ Stunde übertragen wir den Schnitt in 20-procentige Salzsäure,-waschen nach einiger Zeit mit destillirtem Wasser aus und breiten die Cotyledonen auf (lem Objectträger aus ${ }^{1}$ ). Nur die Anlagen der Gefässbündel der Cotyledonen (ebenso bei Untersuchung der Wurzel der Centralstrang derselben) haben sich blau gefärbt und treten als blaues Netz hervor.

Bei der Keimung der Senfsamen, mag dieselbe im Dunkeln oder bei Lichtzutritt erfolgen, verschwindet dlas Eisen in der Form, wie es im ruhenden Samen vorhanden war, nach längerer Zeit völlig aus den Untersuchungsobjecten. Es geht woll in organische Verbindungen

1) Benutzung von Stahlnadeln ist natürlich zu vermeiden. 
über, in denen es mittelst der erwähnten Reactionsmethode nicht melır nachgewiesen werden kann ').

\section{Die organischen Verbindungen als Pflanzen- nahrungsmittel.}

\section{Die Inumuskörper des Bodens und die Mycorhiza.}

Im Boden kommen eine ganze Reihe verschiedener, durch Verwesungs-, Vermoderungs- und Fäulnissprocesse aus Pflanzen- oder Thierresten entstandener organischer Verbindungen vor, die man als Humuskörper bezeichnet. Es ist nicht unmöglich, dass manche grüne Pflanzen (z. B. specifische Moorbewohner) ihr Bedürfniss an organischen Substanzen wenigstens zum Theil auf Kosten humoser Stoffe bestreiten kőnnen, und sicher spielen die Humuskörper im Ernährungsprocess vieler Pilze (Agaricus-, Boletusarten etc.) eine wichtige Rolle. Wir müssen uns daher mit den humosen Substanzen des Bodens bekannt machen. Fast in jedem Boden sind Humuskörper vorhanden; freilich in sehr verschiedener Menge. Ueberaus reich an Humus ist der Torfboden, den wir daher auch als Untersuchungsmaterial wählen.

Wir zerreiben Torf unter Zusatz von Wasser in einer Porzellanschale und fügen der Mischung Kalilauge zu. Die Flüssigkeit nimmt. eine braune bis schwarze Färbung an. Sie enthält huminsaures Kali in Lösung und kann vom unlöslichen Rückstande des Torfes abfiltrirt werden. Diesen Rückstand berücksichtigen wir nicht weiter; er stellt ein Gemenge von noch nicht völlig humificirten Pflanzenresten, noch nicht durch das Kali extrahirter Huminsäure und einem in Kali unlöslichen Humusstoff (dem Humin) dar. Wir versetzen die Lösung des huminsauren Kalis mit Salzsäure, bis eine deutlich saure Reaction der Flüssigkeit eingetreten ist. Die Huminsäure wird dadurch ausgefällt, während die saure Flüssigkeit noch kleine Mengen gewisser Humusstoffe (Quell- sowie Quellsalzsäure) in Lösung enthält. Wenn man die Huminsäure auf einem Filter sammelt, gut mit Wasser auswäscht und trocknet, so erhält man eine spröde, brüchige, schwarze Masse, die fast unlöslich in Wasser ist. Wird dagegen noch feuchte Huminsäure mit Wasser behandelt, so gehen etwas grössere Mengen der Substanz in das Lösungsmittel über. Diese Huminsäurelösung besitzt eine gelblich-braune Farbe. Trägt man Huminsäure in Ammoniakflüssigkeit ein, so löst sich dieselbe leicht unter Bildung von huminsaurem Ammoniak auf. Diese Lösung vermischen wir mit einer Auflösung von Chlorcalcium. Es entsteht ein Niederschlag, der ein Doppelsalz von huminsaurem Kalk und huminsaurem Ammoniak repräsentirt, eine Verbindung, die sich ohne Zweifel auch unter Umständen in der Natur bilden kann. Der Boden enthält sicher noch

1) Vgl. Moliscir, Die Pflanze und ihre Beziehungen zum Eisen, Jena 1892. Die von MoLIsch in dieser Schrift empfohlene Methode zum Nachiseis des in organisehen Verbindungen vorhandenen oder maskirten Eisens ist mit Mängeln behaftet, wie MoLISCH selbst und C. MÜLLER (beide in Berichten d. Deutschen botan. Gesellschaft, Bd. 11) nachgewiesen haben. 
eine ganze Reihe anderweitiger Humuskörper, iiber dieselben ist indessen nichts Genaueres bekannt.

Wir heben eine junge Buchenpflanze (Fagus silvatica) vorsichtig aus dem humusreichen Waldboden aus, welcher ihr zum Standort diente, und bringen sie, in feuchtem Moos verpackt, ins Laboratorium. Nach dem Abspülen der Wurzel mit Wasser gewahren wir noch immer feine Wurzelfasern, an denen kleine Humusstückchen haften. Diese Fasern schneiden wir ab, lassen sie, um den Humus aufzuweichen, einige Zeit in Wasser liegen und untersuclien die Fasern dann bei schwacher Vergrösserung. Wurzelhaare fehlen. Dafür ist die ganze Wurzeloberfläche von Pilzfäden umsponnen. Von den Wurzelfasern strahlen auch nach allen Richtungen lin feine Pilzfäden und recht dicke Pilzfädenstränge aus, an denen oft noch Humustheilchen haften (vgl. Fig. 25). Wir haben es hier mit der Mycorhiza ${ }^{1}$ ) zu thun, speciell mit der ectotropischen Form derselben, weil die Pilzfäden

Fig. 25.

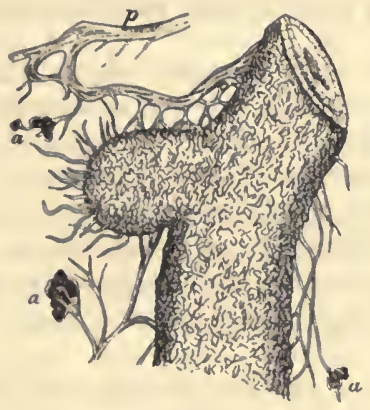

Fig. 26.

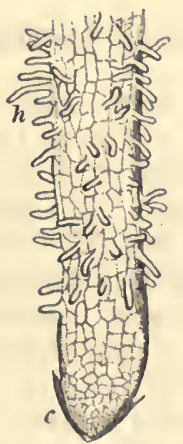

Fig. 25. Buchenwurzel, in nicht sterilisirtem Waldhumus gewachsen. $p$ Pilzfädenstränge, bei $a$ mit dem Humus verwachsen. Mehrmals vergrössert. (Nach Fraxk.)

Fig. 26. Buchenwurzel, in einem durch Sterilisirung pilzfrei gemachten Waldhumus gewachsen, unverpilzt, mit Wurzelhaaren $h$. Bei $c$ die Wurzelspitze mit der Wurzelhaube. Mehrmals vergrössert. (Nach Frask.)

nicht in die Wurzelzellen eindringen, sondern höchstens zwisehen die Epidermiszellen der Wurzel. Die Mycorhiza besteht aus den Wurzelfasern und den mit der Wurzel in Symbiose lebenden Pilzfäden. Diese letzteren saugen (die Wurzelhaare fehlen ja) Wasser und Mineralstoffe auf, deren die Buclıe (oder andere Gewächse, welche mit Mycorhiza versehen sind) bedarf. Wahrscheinlich werden auch stickstoffhaltige organische Stoffe von der Mycorhiza dem Boden entzogen.

Wir sammeln Humusboden in einem Buchenwalde. Das Material wird gut zerkleinert, gemischt und abgesiebt. Wir füllen einige Blumentöpfe von etwa $20 \mathrm{~cm}$ Höhe und Durchmesser mit diesem Boden und durchfeuchten denselben mässig. Einige Töpfe werden unmittelbar zu den folgenden Experimenten (nach Fraxk) verwandt, andere erst, nachdem sie sammt Inhalt zur Sterilisirung einige Stunden lang in einem Trockenschrank bei $100^{\circ} \mathrm{C}$. verweilt haben. Die Töpfe sind dabei mit Glasplatten

1) Vgl. Fraxk, Berichte d. Deutschen botan. Gesellschaft, Bd. 3 u. 6. 
$z u$ bedecken. Nun setzt man in den Boden jedes Topfes einige Buchenkeimlinge ein. Dieselben gewinnt man, indem man Buchelkerne am besten gleich nach der Ernte im Herbst zwischen feuchtem Fliesspapier ankeimt. Nach 12-18 Tagen erfolgt die Uebertragung der jungen Pflänzchen in den Boden der Töpfe, und nun stellt man diese ins Kalthaus. Zum Begiessen des Bodens verwendet man nur destillirtes Wasser.

Die sich in sterilisirtem Boden entwickelnden Pflanzen gedeihen auch im künftigen Sommer schlecht, bilden nur Wurzelhaare (vgl. Fig. 26) und gehen theilweise bald zu Grunde. Die übrigen Buchenpflanzen wachsen kräftig weiter; im Sommer sind ihre Wurzeln bereits sämmtlich verpilzt. Die Ausbildung der Mycorhiza ist also für die normale Entwickelung der Buche (und auch anderer Pflanzen) erforderlich.

Der ungünstige Erfolg unserer Culturen in sterilisirtem Boden ist nicht Folge des Sterilisirens selbst, denn solche Gewächse (z. B. Hafer), die nicht auf das Zusammenleben mit Pilzen angewiesen sind, sind leicht im sterilisirten Boden zu kräftigem Gedeihen zu bringen.

\section{Experimente mit Penicillium crustaceum.}

Wenn man eine Scheibe Brot mit Wasser durchtränkt, in eine Glasschale legt und nach Bedeckung mit einer Glasglocke sich selbst bei gewöhnlicher Zimmertemperatur überlässt, so entwickeln sich gewöhnlich zunächst kleinere Mucorarten auf dem Substrat. Bald nimmt die Oberfläche des Brotes aber eine grünliche Färbung an, in Folge des massenhaften Erscheinens von Penicillium crustaceum. Unter dem Mikroskop kann man das Mycel sowie die an ihrem Ende pinselförmig verzweigten, Sporenreihen tragenden Fruchthyphen dieses Pilzes leicht erkennen (vgl. Fig. 27).

Will man Culturversuche mit dem Penicillium anstellen, so bereitet man sich zunächst eine Mineralstofflösung, die in $100 \mathrm{ccm}$ Wasser 0,05 g phosphorsaures Ammoniak (dargestellt durch Sättigung von Phosphorsäure mit Ammoniak und Eindampfen der Lösung), 0,05 g saures-phosphorsaures Kali $\left(\mathrm{KH}_{2} \mathrm{PO}_{4}\right), 0,03 \mathrm{~g}$ schwefelsaure Magnesia und $0,01 \mathrm{~g}$ Chlorcalcium enthält. Ueber den Zusatz eines Eisensalzes vgl. S. 49. In diese Lösung bringt man die organischen Stoffe, deren Bedeutung als Nahrungsmittel des Penicilliums geprüft werden soll, sowie die Pilzsporen. Ich füllte z. B. 4 kleine Gläser mit je $20 \mathrm{ccm}$ der Mineralstofflösung an. 1 erhielt keinen Zusatz; 2 einen Zusatz von 0,2 g Traubenzucker; 3 einen Zusatz von 0,2 g Oxalsäure; 4 einen Zusatz von $0,2 \mathrm{~g}$ Citronensäure. 1 und 2 wurden noch durch Zusatz einiger Tropfen sehr verdünnter Schwefelsäure angesäuert. Die Aussaat minimaler Sporenmengen geschieht am besten derartig, dass man etwas Penicilliummaterial, welches sich z. B. auf Brot entwickelt hat, in viel Wasser vertheilt und den Nährstoftlösungen nun einige ccm dieses Wassers hinzufügt. Die Culturgefässe werden mit Fliesspapier bedeckt und sich bei gewöhnlicher Zimmertemperatur im Dunkeln selbst überlassen. Nach mehr als 8 Tagen war bei meinen Experimenten in 1 und 3 keine Penicilliumentwickelung wahrzunehmen, während sich die Flüssigkeiten in 2 und 4 alsbald mit einer dicken Schimmeldecke bedeckten. Traubenzucker und Citronensäure sind demnach gute Nahrungsmittel des Pilzes; Oxalsäure vermag derselbe nicht zu verwerthen. Bei Abwesenheit organischer Körper findet keine 
Pilzentwickelung statt. Man kann die verschiedensten organischen Stoffe in der angedeuteten Weise auf ihre Bedeutung für die Ernälırung des Penicilliums prüfen und, wenn es erforderlich scheint, die Menge der producirten Pilzmasse quantitativ bestimmen, indem man sie abfiltrirt, bei $100^{\circ} \mathrm{C}$. trocknet und wiegt ${ }^{1}$ ).

Um Reinculturen von Pilzen, z. B. von Mucor, Penicillium etc., zu gewinnen, kann man oft in folgender Weise verfahren ${ }^{2}$ ). Ungesäuertes Brod, von der Kruste befreit, wird 1-2 Tage lang im Trockenschrank zur Sterilisirung auf $120^{\circ} \mathrm{C}$. erhitzt. Man legt das Brod in eine durch Erhitzen sterilisirte Krystallisirschale und bedeckt diese mit einer sterilisirten Glasplatte mit übergreifendem Rand. Am besten ist es, das Brod mit einer Nährlösung zu durchtränken. Man zieht getrocknete Früchte (Rosinen, Pflaumen) mit kaltem Wasser aus, filtrirt die Lösung und dampft sie zur Syrupdicke ein. Von dieser sehr haltbaren Masse wird eine kleine Menge in Wasser aufgelöst, in einer Spritzflasche zum Sieden erhitzt, um schliesslich mit der kochendheissen Flüssigkeit das Brod in der Krystallisirschale zu durchtränken ${ }^{3}$ ). Das Sporenmaterial gewinnt man, indem man z. B. einige Sporangien von Mucor, der sich auf Brod oder Mist entwickelt hat, mit Hülfe der Pincette in ausgekochtes Wasser überträgt. Nach kurzer Zeit vertheilt man einige Tropfen dieser. Flüssigkeit, z. B. unter Benutzung einer sterilisirten flachen Nadel, auf dem Brod. Sollte die Cultur noch nicht völlig rein sein, so muss man ihr eine zweite folgen lassen, indem man das zu dieser erforderliche Sporenmaterial der ersten entnimmt. Bei der Ausführung von Reinculturen von Pilzen in Nährstofflösungen müssen diese natürlich auch

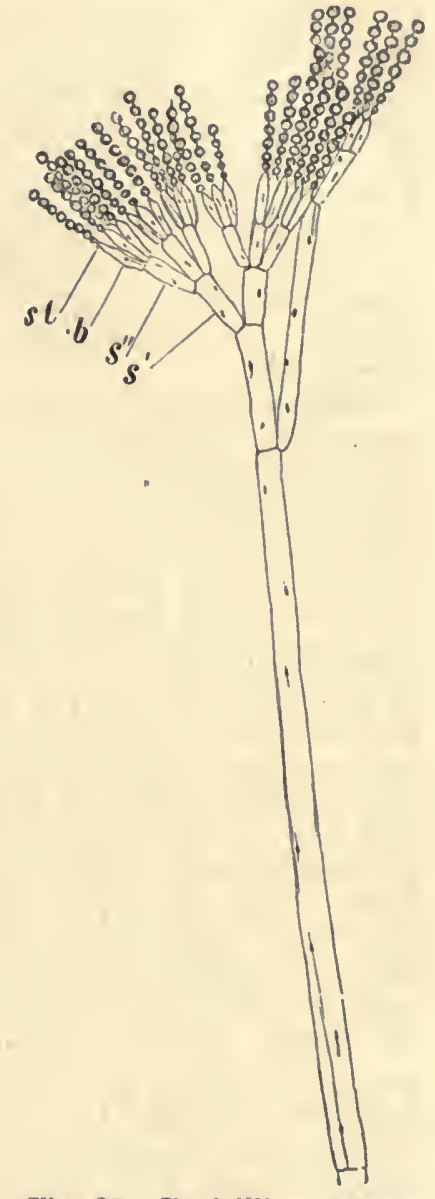

Fig. 27. Penicillium erustaceum. Gonidienträger mil Zweigquirlen $\left(s^{\prime}\right.$ und $\left.s^{\prime \prime}\right)$, Basidien $(b)$, Sterigma (st) und Gonidien. Vergr. 540. (Nach Strasburaer.) sterilisirt werden. Die in mit Watteverschluss versehenen Glaskölbchen befindlichen Lösungen werden eventuell durch einfaches Erhitzen oder durch Einstellen der Kölbchen in den Dampfapparat sterilisirt.

1) Vgl. NäGELI, Sitzungsberichte d. k. bayr. Akadem. d. Wiss., 1879, mathematisch-physikalische Klasse, und REINkE, Untersuchungen aus dem botanischen Institut der Universität Göttingen, 1883, Heft 3.

2) Vgl. besonders BREFELD, Botan. Untersuchungen über Schimmelpilze, Heft 4.

3) In manehen Fällen ist es erforderlich, die Săure im Fruchtauszug, da sie von verschiedenen Pilzen nicht ertragen wird, durch Ammoniakzusatz abzustumpfen. 


\section{Einige weitere Saprophyten.}

Werden Stengel von Vicia Faba, die im Herbst längere Zeit auf dem Felde verweilt haben, mehrere Stunden lang in Brunnenwasser eingeweicht, in eine Schale auf feuchtes Filtrirpapier gelegt, und das ( iefäss mit einer Glasplatte bedeckt, so entwickelt sich eine üppige Pilzvegetation auf den Bohnenstengeln. Besonders interessant ist das Auftreten der weisslichen, etwa $1 \mathrm{~mm}$ im Durchmesser besitzenden Fruchtkörper von Chondrioderma difforme, eines Myxomyceten, über dessen Cultur Strasburger ') genauere Angaben macht. Bei Versuchen, die ich anstellte, traten nach längerer Zeit auf den Bohnenstengelı unter anderem auch die roth gefärbten Fruchtkörper einer Peziza auf.

Wird frischer Kuhmist in eine Glasschale gebracht und mit einer Glasglocke bedeckt, so überzieht sich das Substrat in wenigen Tagen mit einer üppigen Pilzvegetation. Es tritt dies ein, wenn der Mist dem Einfluss des Lichtes ausgesetzt wird und ebenso bei völligem Abschluss des Lichtes. Zunächst wachsen die bis zu einigen Centimetern langen Fruchtträger von Mucor Mucedo aus dem Substrat hervor. Jeder Fruchtträger trägt an seiner Spitze ein rundliches Sporangium. und es ist lehrreich, diesen bekannten Pilz einer mikroskopischen Untersuchung zu unterziehen. Später kommt eine weitere Mucorinee zum Vorschein, die kurze Fruchtträger und relativ grosse, halbkugelige, schwarze Sporangien besitzt, nämlich Pilobolus cristallinus. Nach einigen Wochen stellt sich ein Hutpilz mit langem Stiel und kleinem Hut, der Coprinus, ein, und endlich erscheinen oft die gelblichen oder bräunlichen, becherförmigen Fruchtkörper von Ascobolus. Alle diese Pilze entwickeln ihr Mycelium in dem Mist, während ihre sporenerzeugenden Theile aus dem Substrat hervorragen. $\mathrm{Da}$ die erwähnten Organismen, wie sämmtliche Pilze, chlorophyllfrei sind, so gedeihen sie auf Kosten des organischen Materials des Mistes.

Wenn man eine Fliege in Wasser wirft, das aus einem Tümpel geschöpft wurde, so entwickeln sich auf dem alsbald faulenden Thierkörper gewöhnlich Repräsentanten aus der Gattung Saprolegnia oder Achlya. Bei mikroskopischer Untersuchung der weissen, den Fliegenkörper umgebenden Fäden zeigt sich, dass dieselben zunächst einzellig sind. Später gliedert sich am Ende eines jeden Fadens ein keulenförmiges Sporangium ab.

\section{3\%. Experimente mit Sacharomyees cerevisiac.}

Wenn man etwas Presshefe in einem Wassertropfen auf den Objectträger vertheilt und das Deckglas auflegt, so zeigt sich bei mikroskopischer Untersuchung, dass neben den kleinen, fast kugeligen Hefezellen reichliche Stärkemengen, durch welche die Presshefe verunreinigt ist, vorhanden sind. Auf Jodzusatz färbt sich das Protoplasma (ler Hefezellen bräunlich. Verdünnte Kalilauge löst den Inhalt der Hefezellen auf; die Zellhaut derselben bleibt zurück. Wenn man selır energisch gährenden Flüssigkeiten etwas Hefe entnimmt, so ergiebt

1) Vgl. Strasburgkr, Das botanische Praktikum, 1881, S. 403. 
sich bei mikroskopischer Untersuchung, dass die durch Sprossung entstehenden und sich später von ihren Mutterzellen loslösenden Tochterzellen zunächst noch mit diesen zusammenhängen.

Es werden zwei Glasgefässe, die etwa $150 \mathrm{ccm}$ Flüssigkeit fassen können, aufgestellt. In a bringen wir $100 \mathrm{ccm}$ einer Flüssiglieit, die aus 85 Thl. Wasser, 15 Thl. Traubenzucker, 0,2 Thl. $\mathrm{KH}_{2} \mathrm{PO}_{4}, 0,02$ Thl. $\mathrm{Ca}_{3} 2 \mathrm{Po}_{4}, 0,02$ Thl. $\mathrm{Mg} \mathrm{SO}_{4}$ und 1 Thl. salpetersaurem Ammoniak besteht. In $b$ bringen wir $100 \mathrm{~cm}$ einer Flüssigkeit, die ähnlich wie die erwähnte Flüssigkeit beschaffen ist, der aber der Zucker völlig fehlt. Man versetzt $a$ und $b$ nun mit 2 cem Hefewasser (vgl. „Bezugsquellen"). Dieselben werden alsdamn in einem Thermostaten bei $25-30^{\circ} \mathrm{C}$. unter häufigem Unschütteln sich selbst überlassen. In $a$ tritt bald ziemlich erhebliche Gährung ein, und die Flüssigkeit trübt sich in Folge von Hefeentwickelung. Die Lösung $b$ bleibt klar, weil ihr der Zucker, also die Kohlenstoffquelle für den Hefepilz, fehlt, und dieser sich nicht $\mathrm{zu}$ entwickeln vermag ${ }^{1}$ ). Wenn man die Flüssigkeit $a$ nach Verlauf längerer Zeit filtrirt und die Hefe auf einem vorher getrockneten und gewogenen Filter sammelt, so kann man auch die Menge der gebildeten Hefe genauer feststellen. Bestimmt man den Zuckergehalt in der Flüssigkeit $a$ vor dem Hefezusatz und nachdem die Gährung längere Zeit angedauert hat (vgl. die Methode im dritten Abschnitt), so zeigt sich, dass in Folge der Gährung, und zwar durch die Lebensthätigkeit des Hefepilzes, viel Zucker verschwunden ist. Der Zucker wird zumal zur Erzeugung von Kohlensäure und Alkohol und ferner für die Zwecke des Wachsthums des Hefepilzes verbraucht.

Es wird eine Lösung lergestellt, die aus 85 Thl. Wasser, 15 Thl. Traubenzucker, 0,2 Thl. $\mathrm{KH}_{2} \mathrm{PO}_{4}, 0,02$ Thl. $\mathrm{Ca}_{3} 2 \mathrm{Po}_{4}, 0,02$ Thl. $\mathrm{MgSO}_{4}$ und 1 ThI. Pepsin besteht $(a)$. Die Lösung $b$ ist ähnlich wie $a$ zusammengesetzt. Der Traubenzucker wird in ihr aber durch Rohrzucker (Candiszucker) vertreten. Beide Flüssigkeiten gerathen auf Zusatz reichlicher Hefemengen alsbald in lebhafte Gährung, zumal wenn man sie warm $\left(25-30^{\circ} \mathrm{C}\right.$.) stellt. Die Hefe invertirt den Rolırzucker, und das entstehende vergährbare Material erfährt schnell eine Zersetzung in Alkohol, Kohlensäure etc.

Wenn man Flüssigkeiten, die derartig, wie es soeben angegeben worden ist, mit wenig Hefe versetzt und die eine Lösung kühl (bei 10 oder $15^{\circ}$ C.), die andere warm (bei $25-30^{\circ}$ C.) hält, so ergiebt sich, dass in der ersteren schwaches Hefewachsthum und schwache Hefevermehrung erfolgt, wälırend die zweite alsbald lebhaft gährt und zugleich in ihr eine schnelle Hefevermehrung eintritt. Ebenso kann man sich durch entsprechend angeordnete Experimente leicht davon überzeugen, dass Gährung sowie Hefevermehrung in zuckerhaltigen Lösungen sowohl im Dunkeln als auch bei Lichtzutritt stattfinden. Vgl. weiteres im dritten Abschnitt.

\section{Dic Bacterien.}

Die Bacterien besitzen eine überaus weite Verbreitung in del Natur. Mit dem durch Luftströmungen fortgetragenen Staube gelangen

1) Vgl. A. MAYER, Iehrbuch d. Gährungschemie, 1874, S. 107, und Untersuchungen über die alkoholische Gährung, 1869. 
sie überall hin und entfalten unter günstigen Umständen ihre Lebensthätigkeit. Wir füllen einige ERLENMEYER'sehe Kolben mit einer filtrirten Flüssigkeit, die in 100 Thl. Wasser 1 Thl. Traubenzucker und 0.5 Thl. Fleischextract gelöst enthält. An den Kolbenwänden und zumal in Fleischextract haften zahllose Bacterienkeine, weshalb sich die Lösungen, wenn wir sie einige Tage stehen lassen, in Folge massenhafter Bacterienentwickelung bedeutend trüben. Durch zunächst vorgenommene Sterilisirung und dadurch, dass wir die Flüssigkeiten auch nachträglich sterilisirt erhalten, können wir aber diese Bacterienentwickelung ausschliessen.

Die ErLENMEYER'schen Kolben werden zunächst mit concentrirter Schwefelsäure, dann mit gekochtem destillirten Wasser ausgespült. Wir versehen die Mündung mit dichtem Watteverschluss, nachdem 100-200 cem der erwähnten Nährlösung eingefüllt worden sind. Besser ist es unter Umständen noch, die Kolben vor dem Einfüllen der Lösung 2 Stunden lang im Trockenschrank bei $150^{\circ} \mathrm{C}$. stehen zu lassen. Die Sterilisirung der Flüssigkeit wird dadurch herbeigeführt, dass man die mit derselben beschickten Gefässe mindestens 2 Stunden lang im Dampfsterilisirungscylinder nach KocH (zu beziehen von H. RoHкBECK in Berlin) strömendem Wasserdampf aussetz.t. ${ }^{1}$ )

Bei besonders sorgfältigem Sterilisiren verfährt man oft derartig, dass man das Sterilisiren im Dampfcylinder melırere Tage hinter einander wiederholt. Sollten zunächst noch Sporen an Leben geblieben sein, so keimen sie in der Zeit bis zum erneuten Erhitzen, und dieses tödtet dann die ausgekeimten Bacterien.

Wenn wir unsere mit Watteverschluss versehenen und mit sterilisirter Nährlösung angefüllten Kolben ruhig stehen lassen, so bleibt die Flüssigkeit klar; selbst nach Monaten zeigt sie noch dies Aussehen, weil keine Bacterienentwickelung zur Geltung kommen kann.

Reinculturen von Bacterium Termo, einem Organismus, der sehr allgemein beim Zustandekommen der Fäulniss betheiligt ist, kann man relativ leicht gewinnen. Wir bereiten uns CoHs'sche Normallösung. Diese enthält auf $200 \mathrm{Thl}$. Wasser $1 \mathrm{~g}$ saures phosphorsaures Kali, $1 \mathrm{~g}$ schwefelsaure Magnesia, 2 g neutrales weinsaures Ammoniak und $0,1 \mathrm{~g}$ Chlorcalcium. Hier genügt zur Sterilisirung einfaches Kochen der Lösung in den mit Watteverschluss versehenen ERLENMEYER'schen Kolben. Wir lassen nun mit Wasser übergossene Erbsen faulen, bringen mit Hülfe eines Glasstabes einen Tropfen der bacterienreichen Flüssigkeit in die Nährlösung, und übertragen aus dieser, wenn Bacterium Termo sich entwickelt hat, wieder einen Tropfen in eine neue Nährlösung. Dies wiederholen wir mehrfach, bis endlich eine Reincultur erzielt ist. Bei der Uebertragung der Bacterien aus einer in die andere Nährstofflösung bedienen wir uns durch Erhitzen in einer Spiritusflamme sterilisirter Glasstäbe. Zum Abkühlen legt man dieselben unter eine Glasglocke auf eine sterilisirte Glasplatte. Charakteristisch für Bacterium Termo ist es, dass die Flüssigkeiten, in denen er sich entwickelt, in den ersten Tagen milchig trübe werden und später ein grünliches Oberflächenhäutchen erlangen. Bacterium Termo stellt Stäbchen dar, die meistens zu zweien an einander gereilit sind. Die Bewegung dieser Zellen ist eine ruckweise, hin und her

1) Oft genügt es schon, die Flüssigkeit im Kolben nach erfolgtem Watteverschluss desselben einfach einige Zeit zu kochen. 
gerichtete. In der Zoogloea, welche in Form der erwälnten grünlichen Häute auftritt, sind unbewegliche Individuen vorhanden.

Wird etwas Malzextract (hergestellt durch Behandlung von Malzpulver mit Wasser und Abfiltriren der Lösung) sich selbst überlassen, so trübt sich die ursprünglich klare Lösung im Laufe einiger Tage. Durch mikroskopische Untersuchung lässt sich in der weiter unten anzugebenden Weise feststellen, dass zahllose Bacterien in der Flüssigkeit vorhanden sind. Bei niederer Temperatur (etwa $15^{\circ}$ C.) scheint sich zumal Bacterium aceti, bei höherer Temperatur (etwa $50^{\circ} \mathrm{C}$.), der man die Flüssigkeit leicht im Thermostaten aussetzen kann, aber Bacterium acidi lactici in Malzextract einzustellen. Nach DeLßBǘCK ${ }^{1}$ ) gewinnt man den Milchsäurepilz sicher, wenn man $200 \mathrm{~g}$ Trockenmalz mit $1000 \mathrm{~g}$ Wasser übergiesst und das Gemisch, ohne dasselbe zu filtriren, einige Zeit im Thermostaten bei $50^{\circ} \mathrm{C}$. stehen lässt.

Eino weite Verbreitung in der Natur besitzt der Heupilz, Bacillus subtilis, und um denselben sicher zu gewinnen, übergiessen wir Heu mit
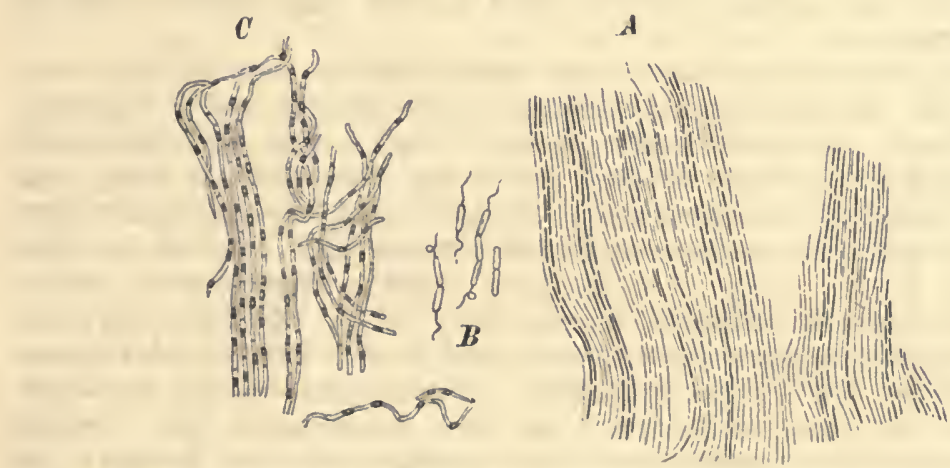

Fig. 28. Bacillus subtilis. A Die Kahmhaut, $B$ schwärmende Stäbchen, $C$ die Sporenbildung. $A$ 500, $C 800, B 1000$ Mal vergrössert. (Nach StrasburaEr.)

möglichst wenig Brunnenwasser, lassen 4 Stunden lang bei $36^{\circ} \mathrm{C}$. stehen, giessen die Flüssigkeit, ohne zu filtriren, ab und verdünnen sie, bis sie ein specifisches Gewicht von 1,004 zeigt. Ist der Aufguss zu sauer, so neutralisire man ihn jetzt mit kohlensaurem Natron, bringt ihn in einen Kolben von $800 \mathrm{ccm}$ Capacität, verschliesst dessen Mündung mit Watte und erhitzt die Flüssigkeit zum Sieden. Sie wird eine Stunde lang bei schwacher Dampfentwickelung gekocht und sich dann bei $36{ }^{0} \mathrm{C}$. im Thermostaten selbst überlassen. Im Verlauf von 1-2 Tagen bildet sich eine graue Haut, eine Kahmhaut, auf dem Heuextract, die aus der Zoogloea des Bacillus besteht. Die Sporen dieses Organismus haben die Siedehitze ertragen, andere Bacterien, die im Aufguss vorhanden waren, sind durch dieselbe vernichtet worden, und wir gelangen auf diese Weise zu einer Reineultur des Heupilzes. Die Kahmhaut besteht aus einer Gallerte, in der zahlreiche, aus Stäbchen zusammengesetzte, parallel zu einander orientirte Fäden vorhanden sind. Um die Stäbchen, aus denen die Fäden sich zusammensetzen, recht deutlich hervortreten zu lassen, färben wir sie, ein Verfahren, das häufig bei Bacterienuntersuchungen in Anwendung

1) Vgl. ZopF, in Schenk's Handbuch d. Botanik, Bd. 3, S. 65. 
gebracht wird. Eine kleine Menge der bacterienhaltigen Flüssigkeit wird auf ein Deckglas gebracht, ausgebreitet und einige Zeit der Luft zum Eintrocknen ausgesetzt. Jetzt zieht man das Deckglas mehrere Male schnell durch eine Spiritusflamme, wobei die mit Bacterien bedeckte Fläche nach oben gekehrt sein muss, breitet einen Tropfen wässeriger Methylviolett- oder Fuchsinlösung (am besten dadurch hergestellt, dass man eine kleine Menge vorräthig gehaltener alkoholischer Lösungen dieser Farbstoffe in destillirtes Wasser einträgt) auf dem Deckglas aus, lässt dasselbe mit nach unten gewandtem Präparat 20-30 Minuten lang auf destillirtem Wasser schwimmen, trocknet an der Luft, trägt einen Tropfen Terpentinöl auf und untersucht bei starker Vergrösserung ${ }^{1}$ ).

\section{Einige parasitiseh lebende Pilze.}

Es giebt zahlreiche Pilze, welche als Ursachen von Pflanzenkranklieiten bekannt sind. Sie ernähren sich auf Kosten der Substanz lebender Gewächse und gehören daher nicht zu den Saprophyten, sondern zu den Parasiten.

Im Mai und Juni gewahrt man häufig Blätter von Berberis vulgaris, die mit auf der Blattunterseite hervorgewölbten, polsterförmigen, orangefarbigen Anschwellungen besetzt sind. Die mikroskopische Untersuchung zarter Querschnitte durch ein Berberisblatt lehrt uns, dass das Mesophyll desselben aus Palissaden- und Schwammparenchym zusammengesetzt ist, und diese Gewebe lassen sich, freilich in etwas veränderter Form, auch an denjenigen Stellen wahrnehmen, welche die Anschwellungen erfahren haben. Hier ist der Zellinhalt (Plasma sowie Chlorophyllkörner) desorganisirt, und in den Intercellularräumen sind zahlreiche Pilzhyphen vorhanden. Diese gelıören' der Aecidiumgeneration von Puccinia graminis an, eben demjenigen Pilz, welcher uns an dieser Stelle interessirt. Bei Behandlung der Schnitte mit etwas Kalilauge treten die erwähnten Verhältnisse besonders deutlich hervor.

An der Unterseite der Polster gewahrt man eigenthümliche becherförmige Gebilde, welche bei ilırer Entwicklung das Gewebe des Polsters und schliesslich auch die Blattepidermis durchbrechen. Unter den Bechern sehen wir ein dichtes, aus Hyphen gebildetes Lager. Jeder Becher besteht seinerseits aus einer Hülle (Peridie) und den zalılreiche Sporen erzeugenden Basidien, die im unteren Bechertheile zum Hymenium vereinigt sind. An der Oberseite des Polsters des Berberisblattes sind keine Aecidienfrüchte vorhanden, wohl aber birnförmige Gebilde, die Spermogonien.

Die Sporen aus der Aecidiumfrucht von Puccinia gelangen nun von Mitte Juni an auf verschiedenen Gräsern (Weizen, Gerste, Hafer ete.) zur Keimung. Sie befallen zumal die Halme und Blattscheiden und rufen die bekannte Rostkrankheit des Getreides hervor. Bei der Untersuchung zarter Querschnitte aus einem Haferhalm, der in Folge der Vegetation der Uredolager von Puccinia mit rostbraun gefärbten Streifen bedeckt ist, findet man, dass zahlreiche Pilzhyphen das grüne Gewebe des Stengels durchzichen, den Inhalt der Zellen desselben desorgani-

1) Specielleres über Bacterienuntersuchung vergl. bei FuÜGGE, Die Mikro organismen, Iseipzig 1886, und HuFPPE, Methoden d. Bacterienforschung, 1886. 
sirend. Das Mycelium erzeugt ferner an bestimmten Stellen zahlreiche, nach aussen gerichtete Zweige, welche die Epidermis des Halmes durchbrechen und all ilıren Enden einzellige Sporen (Uredosporen) abschnüren. Die Uredosporen geben dann schliesslich zur Entstehung der Teleutosporenlager Veranlassung, auf welche wir hier nicht weiter eingehell.

Die gewöhnliche und in so hohem Grade epidemisch auftretende Kartoffelkrankheit wird durch einen Pilz hervorgerufen, der zu den Peronosporeen gehört. Es ist Phytophthora infestans, den man inı Sommer auf dem Laube, aber auch im Winter an den Knollen von Solanum tuberosum beobachten kann. Werden kranke Kartoffelknollen, die man leicht an dem Vorhandensein bräunlicher, etwas eingesunkener Flecken an der Schale als solche erkennt, zerschnitten, und lässt man die Stücke etwa zwei Tage lang im dampfgesättigten Raum unter einer Glasglocke liegen, so bedecken sich die Schnittflächen mit einem zarten, weissen "Schimmel". In der kranken Knolle ist das Mycel der Phytophthora von vornherein vorhanden; es findet sich hier in reichlicher Menge zwischen den Zellen und lebt auf Kosten der Bestandtheile dieser letzteren. Unter den bezeichneten Umständen treibt das Mycel aber Gonidienträger nach aussen hervor. Diese Gonidienträger sind, wie die mikroskopische Untersuchung lehrt, in ihrem oberen Theile verzweigt und bilden die Sporangien, welche aber in Berührung mit Wasser leicht abfallen. Lässt man Stücke kranker Kartoffeln längere Zeit unter einer Glasglocke liegen, so entwickelt sich eine reiche Pilzvegetation auf dem Substrat, die aber mit der Phytophthora direct nichts zu thun hat.

Sehr lehrreich ist es auch, den Entwickelungsgang einer Pezizaspecies, nämlich P. sclerotiorum, näher zu verfolgen. Es ist das ein Pilz, der zu den Discomyceten gehört und z. B. die Sclerotienkrankheit des Rapses bedingt. Icl will beschreiben, in welcher Weise ich den Pilz cultivirte. Einige Sclerotien werden auf die Oberfläche feuchter Gartenerde gelegt, die sich in einem Blumentopfe befindet. Man bedeckt den Topf mit einer Glasplatte, und indem man dafür. sorgt, dass die Erde nicht austrocknet, lässt man ihn im diffusen Licht unweit eines Fensters rulig stehen. Nach 6-10 Wochen entwickeln sich die kleinen, gestielten Fruchtkörper der Peziza aus den Sclerotieu. Nun wird eine Mohrrübe in Stücke zerschnitten, und nachdem man die Stücke durch Eintauchen in heisses Wasser oberflächlich abgebrüht hat, inficirt manl sie unter Benutzung einer ausgeglühten Nadel mit deı in den Fruchtkörpern der Peziza zur Reife gelangten Sporen. Die Keimung der Sporen erfolgt in einigen Tagen auf den in einer Krystallisirschale unter einer Glasglocke liegenden Wurzelstücken. Bald entwickelt sich ein üppig vegetirendes Mycel an der Oberfläche der Mohrrübenstücke, und dieses zerstört auch das durch das Abbrühen niclit getödtete innere Wurzelgewebe. An einzelnen Stellen des Mycels bemerkt man das Auftreten weicher, weisser Ballen, die sich nach und nach mehr verdichten und sich schliesslich mit dunkelgefärbter Rinde umgeben. Es haben sich Sclerotien gebildet, aus denen wieder, freilich erst nach längerer Ruhezeit, Fruchtkörper hervorgehen können. Wir bringen auch eine kleine Menge üppig auf einen Mohrrübenstück vegetirenden Pezizamycels in eine kleine Oeffnung, die wir an einer in einem zugedeckten Glase liegenden Kürbisfrucht angebracht haben. Das Mycel vermag in das lebende Gewebe 
cinzudringen; es entwickelt sich sehr üppig, bildet Sclerotien, während der Kürbis völlig zerstört wird ${ }^{1}$ ).

\section{Die Flechten.}

Die Flechten sind bekanntlich Organismen, welche ihr Dasein dem Zusammenleben (Symbiose) ron Pilzen und Algen verdanken. Die Symbiose vollzieht sich im Allgemeinen derartig, dass die Algen vermöge ihres Chlorophyllgehaltes das für ihr eigenes Dasein und dasjenige der Pilze erforderliche organische Material aus anorganischen Stoffen durch Assimilation erzengen, während die Pilze den Algen zumal Schutz gegen Austrocknung gewähren. Der Flechtenthallus erscheint entweder homöomer oder heteromer gebaut, und wir wollen einen Repräsentanten der letzteren Flechtengruppe, nämlich Usnea barbata, benutzen, um uns über den Bau der in Rede stehenden merkwiirdigen Organismen zu orientiren.

Wir verwenden frisches Material oder, wie ich es gethan habe, in Wasser aufgeweichtes Herbarmaterial und stellen einen zarten Querschnitt durch einen stärkeren Thallusast her. Bei mikroskopischer Untersuchung sieht man leicht, dass der Thallus aus einer Mark- und Rindenzone besteht. Die Elemente beider Schichten sind vielfach verzweigte Pilzhyphen. Die Rinde sowie ein axiler Strang des Markes sind von dichter Beschaffenheit, während die periphere Region des Markes aus locker neben einander liegenden Hyphen, die lufthaltige Lücken zwischen sich lassen, zusammengesetzt ist. Die grünen Algen sind an der Grenze von Mark und Rinde leicht zu sehen.' Sie bilden hier eine besondere Zone, die überall von Hyphen durchsetzt wird, welche vom Mark zur Rinde laufen. Will man sich über den Bau anderer Flechten unterrichten, so gewährt es zumal Interesse, die Fruchtträger von Cladoniaarten und den dorsiventralen Thallus von Stictaspecies $\mathrm{zu}$ untersuchen ${ }^{2}$ ).

\section{Experimente mit fleisehverdanenden Pflanzen.}

Droserapflanzen, welche man zu physiologischen Versuchen verwenden will, cultivirt man am besten in flachen, irdenen Gefässen auf feuchtem Sphagnum unter Glasglocken. Die Droseraarten trifft man häufig auf sumpfigem, moorigem Boden in grosser Menge an; für Culturen braucht man nur einen Rasen der Versuchspflanzen auf das Torfmoos zu legen. Es ist bekannt, dass die Blattspreite sich einkrümmt, und dass die Tentakeln sich zusammenlegen, wenn das Droserablatt gereizt wird. Wir bringen zunächst ein Stückchen rohen Rindfleisches von der Grösse eines Stecknadelkopfes auf die Mitte des Blattes eines gesunden Exemplares von Drosera rotundifolia. Nach lăngerer Zeit (bei Versuchen, die ich bei $20^{\circ} \mathrm{C}$. anstellte, in 24 Stunden) ist die Einbiegung sämmtlicher oder fast aller Tentakeln erfolgt. Sie

1) Zahlreiche Angaben über parasitische Pilze findet man bei FrAxk, Krankheiten der Pflanzen, Breslau, 1880.

2) Ueber Bau und Leben der Flechten vergl. die Zusammenstellungen von DE BARY in dessen vergleichender Morphologie und Biologic der Pilze etc., Leipzig, 1884, S. 425. 
umhüllen das Fleischstückchen nunmehr, das Secret ilurer Drüsenköpfehen wirkt auflösend auf das Eiweiss ein ${ }^{1}$ ), aber schliesslich (bei meinen Versuchen nach Verlauf von 48 Stunden) breiten sich die Tentakeln wieder aus. Bringt man stickstofffreic anorganische odler organische Körper (ich experimentirte mit Glasstückchen und Papierkügelchen) auf ein Droserablatt, so erfolgt freilich auch eine Einbiegung der Tentakeln, aber es lässt sich feststellen, dass diese Substanzen langsamer zu Stande kommende Bewegungserscheinungen als Fleischstückchen hervorrufen. Besonders zu beachten ist, dass, mag ein chemischer Reiz (durch Fleischstïckchen) oder ein Contactreiz (durch Glasstückchen) auf das Droserablatt einwirken, auch Tentakeln durch

Fig. 30.

Fig. 29.
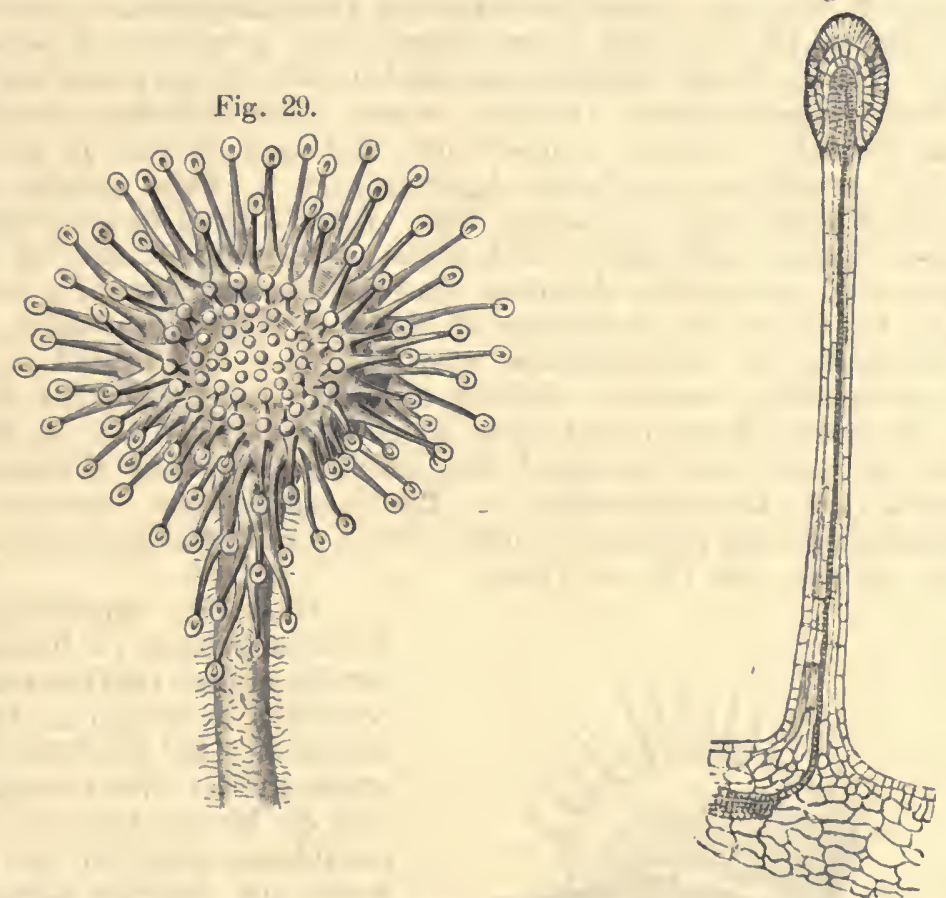

Fig. 29. Blatt rou Drosera rotundifolia, von oben gesehen. Viermal vergr, (Nach DARWty).

Flg. :30. Teutakel mit Drïsenkope von Drosera rotundifolia. Vergr. 60. (Nach Strasiurger.)

Reizfortpflanzung in Bewegung versetzt werden, deren Drüsenköpfchen nicht direct mit der als Reizursache wirkenden Substanz in Berührung gebracht worden sind.

Untersucht man Droseratentakeln mikroskopisch (es ist zweckmässig, dieselben zur Aufhellung des Gewebes auf dem Objectträger in einen Tropfen Chloralhydratlösung zu bringen), so findet inan, dass der Tentakelstiel aus lang gestreckten Zellen zusammengesetzt ist; die stärkeren Stiele werden in ihrer Mitte von Schraubengefässen

1) Ein peptonisirend wirkendes Ferment ist aus den Droserablättern von REess und WILL isolirt worden. Vgl. Botan. Zeitung, 1876, Nr. 44. 
durchzogen. Das Tentakelköpfchen besteht in seiner Mitte aus schraubig verdickten Elementen, die von radial gestreckten, fächerförmig angeordneten Elementen umgeben werden (vgl. Fig. 30).

Interessant ist es, die Erscheinungen der Aggregation oder Zusammenballung zu beobachten, welche gerade in den Zellen der Tentakeln von Drosera in sehr auffallender Weise unter bestimmten Umständen hervortreten ${ }^{1}$ ), Wir entnehmen einer Drosera, die, um die Entwickelung rother Farbstoffe in den Tentakelzellen recht zu begünstigen, stets intensiver Beleuchtung ausgesetzt gewesen war, einen Tentakel. Dieser wird in einem Wassertropfen mikroskopisch untersucht. Wir stellen eine Zelle der äusseren Schicht des Gewebes ein und sehen wandständiges Plasma sowie die Zellen gleichmässig erfüllenden rothen Saft. Nun bringen wir mit dem ein klebriges Secret absondernden Drüsenköpfchen einiger Tentakel unserer Pflanze ganz kleine Stücke von gekochtem Eiweiss in Contact. Nach 12-20 Stunden untersuchen wir die gereizten und von der Pflanze abgeschnittenen Tentakeln wieder. Wir erblicken das wandständige Plasma. Dasselbe umgiebt nun farblosen Zellsaft, in welchem aber die verschieden gestalteten Aggregationen in Form intensiv roth gefärbter Massen leicht zu sehen sind. Diese Aggregationen bestehen aus einer Wand, deren Natur noch nicht genau ermittelt ist; ich halte wenigstens die bezüglichen Angaben von DE VRIks tür nicht völlig beweiskräftig. Im Innern der Zusammenballungen ist Zellsaft vorhanden. Bei der Entstehung der Aggregationen muss sich der ursprïnglich in der Zelle gleichmässig vertheilte Zellsaft in zwei Theile gesondert haben, einen sehr farbstoffreichen und einen wasserklaren. Wie dies zu Stande kommt, ist noch nicht genügend festgestellt. Auch wenn kohlensaures Ammoniak mit Droseratentakeln in Berührung kommt, machen sich Aggregationsprocesse geltend, bei denen aber noch Eiweissausfällungen beobachtet worden sind (H. DE VRIES).

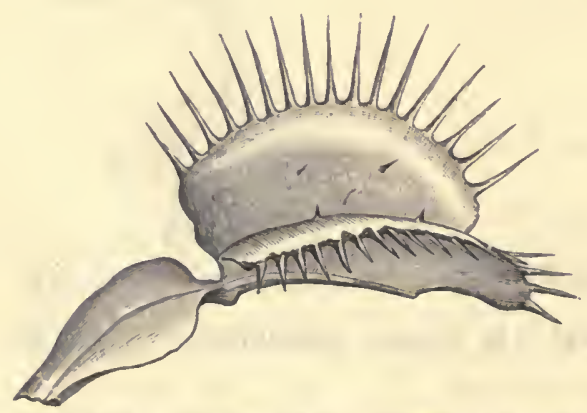

Fig. 31. Blatt von Dionaea muscipula im ausgebreiteten Zustande, ron der Seite gesehen. (Nach DarwIN.)

Die für physiologische Untersuchungen $\mathrm{zu}$ benutzenden Exemplare vonDionaea muscipula cultivirt man am $\mathrm{z}$ weckmässigsten auf feuchten Torfstücken unter einer Glasglocke. Auf die Morphologie des Dionaeablattes gehe ich hier niclit weiter ein, sondern mache nur auf einige leicht auszuführende Versuche aufmerksam. Werden die Filamente, die auf der Oberseite des Dionaeablattes vorhanden sind, berührt, z. B. mit einem kleinen Holzstückchen, so schliesst sich das Blatt sofort. Alsbald (bei meinen Versuchen nach Verlauf von $2 t$ Stunden) sind die Blattlappen aber wieder ausgebreitet. Werden Stückchen rohen Fleisches auf ein Dionaeablatt gebracht, so tritt, im Fall eine Berührung der Filamente stattfand, eine sofortige Schliessungs-

1) Literatur: DarwLx, Insektenfressende Pflanzen, 1876; Schmper, Botan. Zeitung, 1882; H. DE Vrues, Botan. Zeitung, 1886 ; KLEvi, Flora, 1892. 
bewegung ein. Das Blatt bleibt nun aber lange geschlossen (bei von mir angestellten Versuchen länger als 8 Tage), im Gegensatz zu solchen Blättern, welche durch auf der Blattfläche verbleibende stickstofffreie Körper (Glasstückchen, Papierkügelchen) oder durch einfache Berührung der Filamente zu Schliessungsbewegungen veranlasst worden sind. Oeffnet sich ein Dionaeablatt, welches Fleischstückchen erhalten hat, wieder, so ergiebt sich, dass das Fleisch mehr oder minder desorganisirt und aufgelöst ist, ein Vorgang, welcher durch ein Secret vermittelt wird, das dic an der Oberseite des Dionaeablattes vorhandenen Drüsen abscheiden. Dieses Secret ist von saurer Reaction und haftet oft noch in ziemliclier Menge an der Oberseite solcher Blätter, die mit Fleisch gefüttert worden sind, und sich nach Verlauf längerer Zeit wieder geöffnet haben. Stickstofffreie Körper, die auf ein Dionaeablatt gebracht werden, rufen die Abscheidung eines Drüsensecretes nicht hervor; die obere Fläche der Blattlappen bleibt bei Abwesenheit von Eiweissstoffen trocken ${ }^{1}$ ).

1) Specielles über das Verhalten der hier erwähnten Pflanzen rgl. bei DARWLN in dessen 1876 ersehienenem Werke über insektenfressende Pflanzen. Zur allgemeinen Orientirung vgl. DetMer, Lehrbuch der Pflanzenphysiologic, 1883, S. 65 und 282. 


\section{Zweiter Abschnitt.}

\section{Die Molekularkrïfte der Pflanzen.}

\section{Die wichtigsten organisirten Gebilde der Pflanzen- zellen.}

\section{Die Membranen der Pflanzenzellen.}

Die Membranen der Pflanzenzellen bestehen keineswegs immer der Hauptsache nach aus Cellulose, sondern sie sind häufig mehr oder minder reich an anderweitigen Substanzen, die im Allgemeinen als „Einlagerungskörper" bezeichnet werden können. Durch eine solche Einlagerung fremder Stoffe kommt z. B. die Cuticularisirung und Verholzung der Membranen zu Stande, von denen weiter unten die Rede sein soll. In vielen anderen Fällen bildet freilich die Cellulose den wesentlichsten Bestandtheil der Zellhäute, was sich unmittelbar aus dem Verhalten der letzteren verschiedenen Reagentien gegenüber ergiebt.

Wir bringen Samenhaare einer Gossypiumart oder einige Wattefasern in den Wassertropfen auf den Objectträger. Es lässt sich leicht feststellen, dass die Haare, welche im Grossen und Ganzen kegelförmige Gestalt haben, relativ dicke Membranen besitzen und sich auf Zusatz von Jodjodkaliumlösung (bereitet durch Auflösen von 0,05 g Jod und $0,2 \mathrm{~g}$ Jodkalium in $15 \mathrm{~g} \mathrm{H}_{2} \mathrm{O}$ ) nur bräunlich färben. Wir lassen nun Schwefelsäure (Gemisch von 2 Thl. concentrirter Schwefelsäure und 1 Thl. Wasser) vom Deckglasrande aus zum Object treten und beobachten alsbald, dass sich die Haare blau färben. Die Membranen anderer Zellen, welche ebenso wie diejenigen der Baumwollenhaare der Hauptsache nach aus Cellulose bestehen, geben dieselbe Reaction. Desgleichen färben sich alle im Wesentlichen aus Cellulose bestehenden Membranen der Pflanzenzellen bei Behandlung mit Chlorzinkjodlösung violett, wovon man sich leicht überzeugen kann, wenn man einige Wattefasern auf dem Objectträger mit dem Reagens behandelt. Die Chlorzinkjodlösung bereitet man in folgender Weise. Man löst reines Zink in Stangen in reiner Salzsäure bei gewöhnlicher Temperatur bis zur Sättigung auf, dampft unter stetigem Vorhandensein metallischen Zinks zur Schwefelsäureconsistenz ein, setzt so viel Jodkalium hinzu, als aufgenommen werden kann, und trägt endlich bis zur Sättigung Jod in die Flüssigkeit ein, das sich allmählich auflöst.

Von dem Vorhandensein der Cuticula kann man sich leicht bei dem 
Studium eines Querschnitts durch einen jährigen Stengel von Viscum album oder durch das Blatt einer Aloëspecies überzeugen. Ebenso ist die Cuticula sehr mächtig an der Oberfläche der Blätter von Ilex aquifolium entwickelt. Ein sehr zarter Querschnitt durch den Mittelnerv eines Tlexblattes lehrt, dass die Epidermiszellen an der Blattunterseite ein halbmondförmiges Lumen besitzen. Die cuticularisirten Schichten der Zellmembranen greifen in die Seitenwandungen der Zellen ein und werden nach aussen von der eigentlichen Cuticula überlagert ${ }^{1}$ ). Die Cuticula der meisten Blätter und anderer Pflanzentheile ist dünn und von sehr zarter Beschaffenheit.

Handelt es sich darum, das Korkgewebe kennen zu lernen, so untersucht man zweckmässig zarte Querschnitte, die man aus der Schale der Kartoffelknolle, dem gewöhnlichen Flaschenkork oder älteren (etwa $1 \mathrm{~cm}$ dicken) Stengelstücken von Aristolochia Sipho liergestellt hat. Die in radialen Reihen angeordneten Korkzellen sind von mehr oder minder tafelförmiger Gestalt. Bei dem Studiun des Periderms von Aristolochia zeigt sich, dass hier breitere Zonen weiterer und schmälere Zonen engerer Korkzellen mit einander abwechseln. Concentrirte Kalilauge färbt die cuticularisirten sowie verkorkten Membranen gelblich. Diese Färbung wird beim Erwärmen der Präparate intensiver ${ }^{2}$ ).

Wir stellen einen Querschnitt durch einen einige $\mathrm{mm}$ dicken Lindenzweig her. Das mikroskopische Bild ist leicht zu deuten und vor allem interessirt uns hier der insbesondere aus Gefässen von verschiedener Weite und Holzfasern bestehende Holztheil der Gefässbündel, sowie der Basttheil derselben. Die Bastmassen sind keilförmig zugespitzt, und zwar sind ihre Spitzen der Rinde zugewandt, während die keilförmigen Enden der primären Markstrahlen, welche mit den Bastmassen abwechseln, ihre Spitzen dem Holz zukehren. In den Bastmassen wechseln hell erscheinende Streifen, die aus sehr stark verdickten Bastfasern bestehen, mit dunkel erscheinenden Weichbaststreifen ab. Wir legen unsern Querschnitt jetzt auf dem Objectträger in einen 'Tropfen alkoholischer Phloroglucinlösung. Nach Verlauf einiger Zeit, wenn der Alkohol verdunstet ist, betupfen wir den Schnitt mit etwas concentrirter Salzsäure und beoachten ihn mikroskopisch. "Alle verholaten Elemente haben sich roth gefärbt, die unverholzten sind farblos geblieben, so dass das Phloroglucin also als ein vorzügliches Reagens auf Holzsubstanz anzusehen ist ${ }^{3}$ ). Es interessirt uns hier besonders, dass nicht allein die Elemente des eigentlichen Holzkörpers der Fibrovasalstränge, sondern anch die Elemente der Bastfaserstreifen zwischen den Weichbaststreifen roth gefärbt erscheinen, also verholzte Membranen besitzen.

Wenn man Querschnitte aus $2 \mathrm{~mm}$ dicken Zweigen von Fagus silratica in der angegebenen Weise mit Phloroglucin und Salzsäure behandelt, so ergiebt sich, dass in den folgenden Geweben Verholzung eingetreten ist: im gesammten Mark, in den Markstrahlen, im Holztheil der Gefässbündel und in den Bastfaserbelegen, welche sich nach aussen an

1) Specielles vgl. bei 1)E BAIrY, Vergleichende Anatomie d. Vegetationsorgane etc.,

2) Bezüglich weiterer Reactionen vgl. v. HöıneL, in Sitzungsberichten d. Akadem. d. Wiss. zu Wien, Bd. 76, erste Abthl., S. 507.

3) Wirsxer, Sitzungsber. d. Akadem. d. Wiss. zu Wien, Bd. 77, 1. Abthl., 1878, S. 60. Näheres über verholzte und verkorkte Membranen vergl. bei ZMIMERMANx, Die botanische Mikrotechnik, 1892, S. 140. Daselbst ist auch die Literatur genau angegeben. 
den Weichbast anschliessen. Die Elemente des Cambiums, des Weichbastes, des Rinden- und Peridermgewebes sind nicht roth gefärbt, also auch nicht verholzt. Ein recht brauchbares Reagens auf Holzsubstanz ist auch das schwefelsaure Anilin. Man stellt eine concentrirte Lösung desselben in Wasser her, der man noch etwas Schwefelsäure hinzugefügt hat, und bringt einen Tropfen des Reagens zu dem auf dem Objectträger liegenden Object, das untersucht werden soll. Die verholzten Elemente färben sich schnell mehr oder minder gelb. Leuchtend goldgelb fand ich z. B. die Bastfaserbelege der Zweige von Fagus silvatica durch schwefelsaures Anilin tingirt. In Contact mit einer wässrigen Lösung des Methylgrüns färben sich die verholzten Membranen schön grünblau, die unverholzten aber meist blau.

Um die wichtigsten Verdickungsformen der Elemente verholzter Gewebe kennen zu lernen, sind folgende Untersuchungen anzustellen.

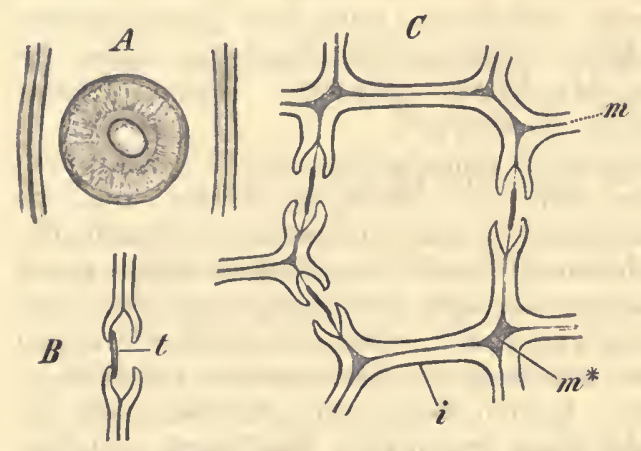

Fig. 3:. Pinus silvestris. A Ein Hoftüpfel einer Tracheide in Flächenansicht. $B$ Ein Hoftüpfel im tangentialen Längsschnitt, $t$ der Torus. $C$ Querschnitt einer ganzen Tracheide; $m$ Mittellamelle, $m^{*}$ ein Zwickel, $i$ das Grenzhäutchen. Vergr. 540. (Nach ŚTrasibURGER.)
Die behöften Tüpfel der Tracheiden des Coniferenholzes studirt man am besten an sehr zarten Querschnitten und radialen Längsschnitten aus den peripherischen Theilen des Holzes alter in Alkohol aufbewahrter Stammstücke von Pinus silvestris. (Vergl. Fig. 32.) Die Tracheiden sind langgestreckt, sie greifen mit ihren verjüngten Enden in einander und lassen auf ihren radialen, also denjenigen Wänden, welche den Markstrahlen zugekehrt sind, die behöften Tüpfel leicht erkennen. Stellt man zarte radiale Längsschnitte aus dem secundären Holz etwa $1 \mathrm{~cm}$ dicker Zweige von Aristolochia Sipho her, so beobachtet man zumal viele Tracheiden mit behöften Tüpfeln sowie enge und sehr weite Gefässe mit behöften Tüpfeln und ringförmigen Diaphragmen. Untersucht man radiale Längsschnitte aus den Zweigen von Berberis vulgaris, so ergiebt sich, dass das ganze Holz fast nur aus Gefässen, die behöft getüpfelt erscheinen, und Holzfasern besteht. Echte Spiralgefässe des primären Holzes der Gefässbündel sind sehr schön neben anderen Elementen (getüpfelten Gefässen, Holzfasern etc.) zu sehen, wenn man radiale Längsschnitte aus dem Stengel von Helianthus annuus oder dem fertig gestreckten hypocotylen Glied von Ricinus communis untersucht. Man verwende Alkoholmaterial oder bei Helianthus getrocknete Stammstücke ${ }^{1}$ ). (Vgl. Fig. 33.)

1) Ueber die chemische Natur der die Verholzung der Membranen bedingenden Substanzen vgl. Sirger, Sitzungsber. d. Akadem. d. WViss. zu Wien, 1882, Bd. 85, S. 345. Ein wichtiger Bestandtheil verholzter Membranen der Pflanzenzellen, dessen Vorhandensein de erwähnten Reactionen mit Phloroglucin und schwefelsaurem Anilin wohl bedingt, ist das Vanillin. Meiner Ansicht nach haben die neueren Arbeiten ron LAxge, Thomsex, Hegler u. A. die Frage nach der ehemischen Natur der Holzsubstanz aber noch nicht erledigt. 


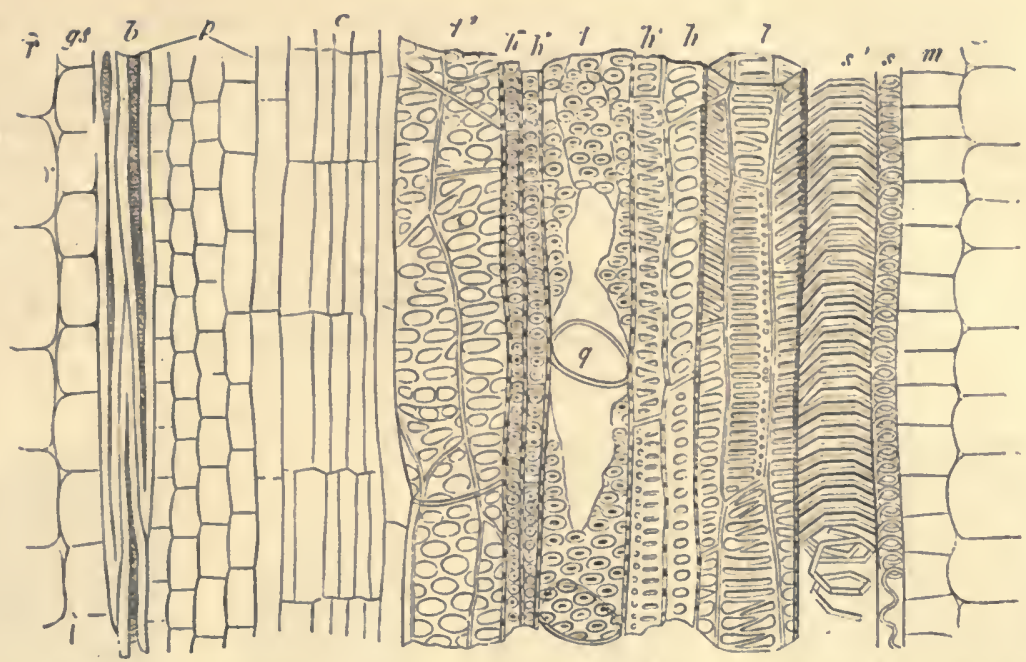

Fig. 33. I.aingssehnitt cines Gef:issbindels des fertig gestreekten lypocotylen Glicdes ron Rieimus communis. $r$ Rindenparenchym, $g s$ Gefäissbundelscheide, $m$ Markparcnchym, b Bastfasern, $p$ Bastparenchym, $c$ Cambium. Im Holztheil des Stranges bilden sich die Elemente, von $s$ anfangend, nach und nach bis $t^{\prime}$ aus; $s$ erstes enges, sehr langes Schraubengefäss, $s^{\prime}$ weites Schraubengefäss, beide mit abrollbarem Schraubenband, $\ell$ leiterförmig verdicktes Gefäss, zum Theil netzartig verdickt, $h$ und $h^{\prime}$ Holzzellen, $t$ getüpfeltes Gefäss, bei $q$ dic resorbirte Querwand; $h^{\prime \prime}$ und $h^{\prime \prime}$ Holzzellen, $t^{\prime}$ getüpfeltes Gefäss, nocl jung, die Tüpfel zeigen erst den ïusseren Hof, später tritt die Bildung des inneren Porus auf. Man bemerkt in der Gefässwand bei $l, t$ und $t^{\prime}$ die Grenzlinien der benachbarten, weggenommenen Zellen. (Nach SAcuis.)

Für denjenigen, der sich mit der Untersuchung der Natur der Holzelemente beschäftigt, ist es lehrreich, dieselben mit Hülfe der Macerationsmethode von einander zu trennen. Wir bringen einige Stückehen chlorsauren Kalis in ein weites Reagensrohr, übergiessen dieselben mit so viel Salpetersäure, dass sie völlig von dieser bedeckt sind, werfen nicht zu dünne Längsschnitte aus dem Holz eines $5 \mathrm{~mm}$ dicken Zweigs von Tilia in die Mischung und erhitzen über einer Spiritusflamme, bis lebhafte Gasentwickelung eintritt. Hat das Reagens noch einige Minuten auf die Holzstückchen eingewirkt, so giessen wir alles in eine grössere Wassermenge, fangen die umherschwimmenden Schnitte mit einem Glasstabe auf. spülen sie in reinem Wasser ab und legen sie in einen Wassertropfen auf den Objectträger. Durch das Macerationsverfahren ist die Mittellamelle zwischen den einzelnen Holzelementen zerstört worden, und die Präparate lassen sich daher jetzt leicht nit Nadeln zerzupfen, so dass die Elemente des Holzes isolirt beobachtet werden können. Wir constatiren vor allem die Gegenwart vieler Holzfasern und Gefässe (diese letzteren sind zum Theil in Stücke zerfallen), aber auch dünnwandige Holzparenchymzellen und Tracheiden fehlen nicht völlig. (Vgl. Fig. 34.)

\section{Die Stärkekörner.}

Eine kleine Menge lufttrockenen Kartoffelmehles wird im Wassertropfen auf den Objectträger gebracht und mit dem Deckglas bedeckt. 
Zweiter Abschnitt.
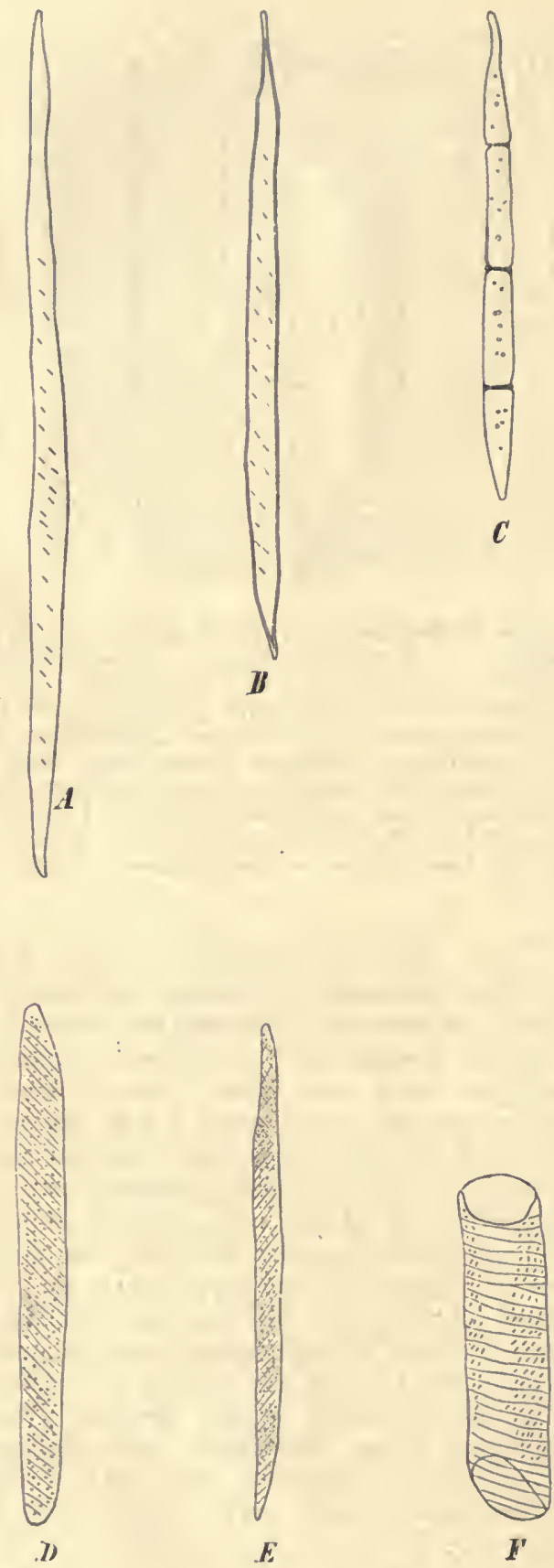

Fig. 34. Tilia parvifolia. Durch Maceration isolirte Elemente aus dem secundären Holz und Bast. $A$ und $B$ Holzfasern (Libriformfasern). $C$ Holzparenchym. $D$ und $E$ Tracheiden. $F$ Gefässglied. $G$ Bastfaser. Vergr. 180. Nach StrasBURGER.) 
Oder man zerschneidet eine Kartoffelknolle, schabt mit einem Messer etwas von der Schnittfläche ab und beobachtet die abgeschabte Masse unter dem Mikroskop. Die Kartoffelstärkekörner sind von recht verschiedener Grösse; einige erreichen eine relativ sehr bedeutende Grósse. Sie sind excentrisch gebaut, $d$. h. ihr organischer Mittelpunkt, um den sich die Schichten gruppiren, stimmt nicht mit dem genmetrischen Centrum überein (vergl. Fig. 35).

Wir durchschneiden ein Rhizom von Canna indica und schaben mit dem Messer eine kleine Menge Substanz von der Schnittfläche ab, um sie in einem Wassertropfen auf den Objectträger $\mathrm{zu}$ bringen und mit

Fig. 35.
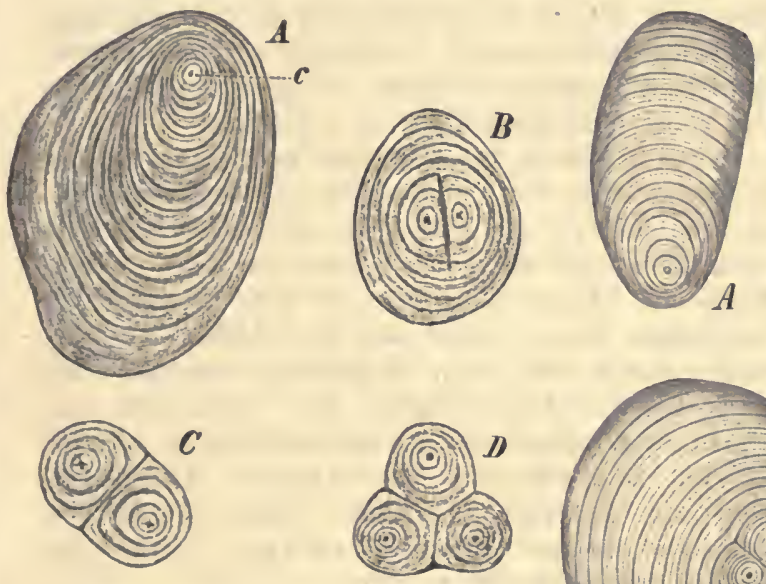

Fig. 37.
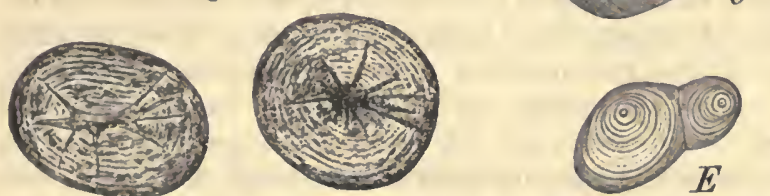

Fig. 36.
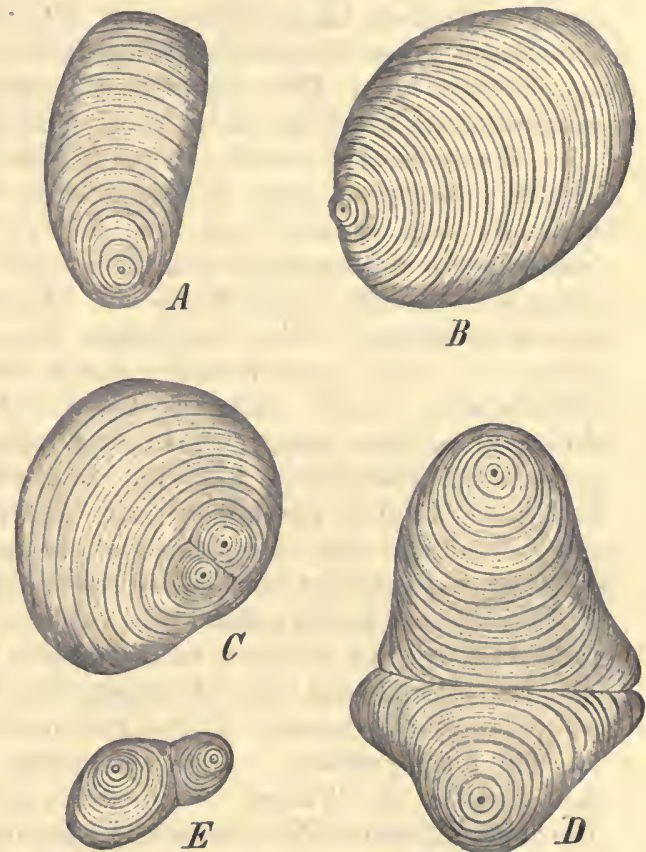

Fig. 35. Stärkckörner aus der Kartoffelknolle. A ein einfaches, $B$ cin halb zusammengesetztes, $C$ und $D$ ganz zusammengesetzte Stärkekörner, $c$ der organisebe Kern. Vergr. 540. (Nach Strasburger.)

Fig. 36. Stlirkckörner ans dem Rhizom ron Canna indiea. $A$ und $B$ einfache Körner, $C$ ein halb zusammengesetztes, $D$ und $E$ ganz zusammengesetzte Körner. Vergr. 540. (Nach STRAsbuRGER.)

Fig. 37. Stlirkeköruer aus den Cotyledonen von Plaseolus vulgaris. Vergr. 540. (Nach Strasburger.)

Deckglas zu bedecken. Bei mikroskopischer Untersuchung erblicken wir zahlreiche schön geschichtete, stark excentrisch gebaute Stärkekörner in unserem Präparat, welche eine beträchtliche Grösse besitzen. (Vergl. Fig. 36.)

Die Stärkekörner aus den Cotyledonen der Samen von'Phaseolus vulgaris sind centrisch gebaut. Untersucht man sie im Wassertropfen, so erblickt man in der Mitte eines jeden Kornes eine Höhlung, die aber erst unter dem Einflusse des Wassers entsteht, denn in Glycerin beob- 
achtete Stärkekörner der Bohne lassen diese Höhlung nicht erkennen. (Vergl. Fig. 37.)

Die Amylumkörner aus dem Endosperm von Tritioum präscntiren sich uns bei der Untersuchung als runde Gebilde von recht verschiedener Grösse. Sio sind centrisch gebaut. Schichtungserscheinungen sind schwer zu erkennen.

\section{Das Verhalten der Stärke zum Jod.}

Wenig Kartoffelstärke wird in einem Reagensglase mit destillirtem Wasser übergossen. Man lässt unter häufigem Umschütteln längere Zeit (einige Stunden lang) stehen und filtrirt die Flüssigkeit ab. Bringt man mit Hülfe eines Glasstabes etwas alkoholische Jodlösung zu dem Filtrat, so entsteht keine Bläumng der Flüssigkeit. Reines Wasser vermag den unversehrten Stärkekörnern keine Stärkesubstanz zu entziehen.

Wenig Kartoffelstärke wird in einem Reagensglase mit Wasser übergossen. Erwärmt man, so bildet sich ein trübes Gemisch von Amylumsubstanz und Wasser (Kleister). Fügt man dem erkalteten Kleister etwas alkoholische Jodlösung hinzu, so nimmt die Flüssigkeit eine sehr charakteristische, schön blaue Farbe an. Diese Reaction ist sehr empfindlich, wovon man sich leicht überzeugen kann, wenn man eine kleine Kleistermenge in sehr viel Wasser giesst und nun Jodlösung zusetzt. Die Flüssigkeit nimmt auch jetzt eine blaue Farbe an. Erwärmt man durch Jodzusatz blau gefärbten Kleister, so verschwindet der charakteristische Farbenton alsbald, weil Wasser von höherer Temperatur ziemlich viel Jod aufzulösen und dasselbe unter den bezeichneten Umständen daher der Amylumsubstanz zu entziehen vermag. Kühlt der Kleister ab, so tritt die blaue Farbe wieder hervor.

Sehr wenig Kartoffelstärke oder kleine Mengen einer anderen Amylumsorte werden auf dem Objectträger im Wassertropfen vertheilt. Nach der Bedeckung mit dem Deckgläschen bringt man einen Tropfen eines Jodreagens (Jodwasser, Jodjodkaliumlösung oder verdünnten Jodalkohol) an den Deckglasrand. Das Jodwasser stellt man dar, indem man Jod mit destillirtem Wasser übergiesst und mit diesem einige Tage lang in Berührung lässt. Zur Bereitung der Jodjodkaliumlösung übergiesst man 3 Thl. Jodkalium mit 60 Thl. Wasser und fügt einen Thl. Jod hinzu. Die Lösung kann durch Wasserzusatz verdünnt werden. Das an den Deckglasrand gebrachte Jodreagens dringt nun allmählich bis zu den Stärkekörnern vor, und es lässt sich bei mikroskopischer Betrachtung feststellen, dass dieselben sich zunächst schwach bläulich, nach und nach aber immer intensiver blau färben, indem sie das Jod mehr und mehr aufspeichern.

Trockene Kartoffelstärke wird auf dem Objectträger in einen Tropfen durch Auflösen von Jod in absolutem Alkohol frisch bereiteter Jodtinctur gebracht. Bei mikroskopischer Prüfung ergiebt sich, dass die Amylumkörner keine blaue, sondern eine bräunliche Farbe annehmen. Lässt man Wasser zutreten, so erfolgt die charakteristische Bläuung. Die Stärkekörner vermögen sich also nur dann auf Jodzusatz blau zu färben, wenn sie mit reichlicheren Wassermengen imbibirt sind. 


\section{Das Verhalten der Stärkekörner im polarisirten Licht.}

Es ist sehr lehrreich, sich über die von MoнL ${ }^{1}$ ) und NägeLI ${ }^{2}$ ) studirten Erscheinungen specieller zu unterrichten, welche Stärkekörner zeigen, wenn man sie im polarisirten Licht untersucht. Man bedarf dazu freilich eines Polarisationsapparates und eines Mikroskopstatives mit hinreichend holem Objecttisch. Der Polarisator wird in den Schlitten der Cylinderblendung eingeschoben. Als Analysator benutzt man am besten das Analysatorocular von ABBE, welches ebenso wie der Polarisator von Zerss in Jena zu beziehen ist.

Die Stärkekőrner werden in gewöhnlicher Weise in einem Wassertropfen auf dem Objectträger vertheilt und mit Deckglas bedeckt. Wenn die Polarisationsebenen des Analysators und Polarisators parallel zu einander stehen, so erscheint das Gesichtsfeld hell, und unter diesen Umständen muss die Einstellung der Objecte vorgenommen werden. Bei gekreuzter Stellung der Nicols (dieselbe ist leicht zu erreichen, indem wir das Analysatorocular drehen) erscheint das Gesichtsfeld dunkel. Die Amylumkörner heben sich sehr hell vom dunklen Grunde ab und tragen ein schwarzes Kreuz. Sehr schöne Farbenphänomene treten hervor, wenn man Stärkekörner mit Hülfe des Polarisationsmikroskops untersucht, nachdem zwischen das Object und den Polarisator Gypsplättchen von bestimmter Beschaffenheit eingeschaltet worden sind. ${ }^{3}$ )

Ich habe das Verhalten einer ganzen Reihe verschiedener Stärkesorten im polarisirten Lichte beobachtet; von allen ergab die Kartoffelstärke die schönsten Bilder. An der Ansicht, dass die Micellen der Stärkekörner und sonstiger organisirter pflanzlicher Gebilde die Natur optisch zweiaxiger Krystalle besitzen, kann man heute nicht mehr festhalten; vielmehr ist das eigenthümliche Verhalten der organisirten pflanzlichen Gebilde im polarisirten Licht auf andere Weise zu erklären ${ }^{4}$ ). Uebrigens lasse ich die Ansicht nicht fallen, wie ich schon an anderer Stelle betonte, dass die organisirten pflanzlichen Gebilde aus Micellen aufgebaut sind ${ }^{5}$ ).

\section{Die protoplasmatischen Gebilde der Pflanzenzellen.}

Als protoplasmatische Gebilde der pflanzlichen Zellen sind die sämmtlichen eiweissreichen und organisirten Inhaltsbestandtheile derselben (das eigentliche, lebensthätige Protoplasma, die Zellkerne, Leukoplasten, sowie die Proteinkörner etc.) anzusehen. Die Chlorophyllkörper wurden bereits unter 5 besprochen, und auf andere mit Farbstoffen imprägnirte protoplasmatische Gebilde kommen wir später zurück.

Das Bild, welches das Protoplasma (Cytoplasma) der Zellen unter dem Mikroskop gewährt, ist wesentlich abhängig von der Zahl und Grösse der in denselben vorhandenen mit Zellsaft erfüllten Vacuolen. Zahlreiche kleine Vacuolen im Plasma verleihen demselben ein schaumiges Aussehen, wäh-

1) Vgl. H. v. MoHL, Botan. Zeitung, 1858, S. 1.

2) Vgl. N NGeLI, Sitzungsberichte d. Akadem. d. Wiss. zu München, 1862, Bd. 1, S. 311 .

3) Vgl. Specielleres in Nïgeli s und Schwexdexra's Mikroskop."

4) Vgl. Strasburger, Bau und Wachsthum d. Zellhäute, 1882, S. 208, und Zimmermasx, Berichte d. Deutsehen botan. Gesellschaft, Bd. 2, S. XVII.

5) Vgl. Detwer, Lehrbuch der Pflanzenphysiologie, 1883, S. 71. 
rend sich uns das Protoplasma vieler Zellen, zumal der entwickelten mit einem einzigen zusammenhängenden Saftraum, in der in Fig. 5, S. 15 dargestellten oder ähnlicher Weise präsentirt. (Vergl. auch Fig. 38.) Wir bringen junge Blätter aus der Endknospe von Elodea ohne weitere Präparation in einen Wassertropfen auf den Objectträger, legen ein Deckglas auf und untersuchen. Der die Innenseite der Zellhaut jeder Zelle auskleidende protoplasmatische Wandbeleg ist leicht $\mathrm{zu}$ erkennen, ebenso die Protoplasmaansammlung um den Kern. Jener

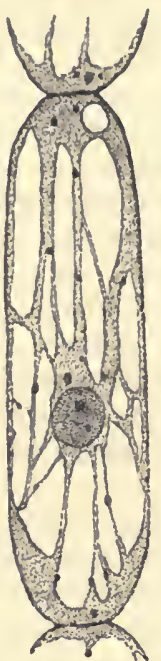

Fig. 38. Eine Zelle aus einem Staubfadenhaar von Tradeseantia virginica. Vergr. 240. (Nach Strasburger.)

\section{merk besonders auf das chlorophyllhaltige Bastparenchy dessen Wande} merk besonders auf das chlorophyllhaltige Bastparenchym, dessen Wände mit unbehöften Tüpfeln versehen sind. Diese Bastparenchymelemente haben rechteckige Gestalt. Zudem sehen wir noch die langgestreckten Bastfasern und die spindelförmig umschriebenen Durchschnitte der Markstrahlen. Nunmehr bringen wir neue Schnitte aus der secundären Rinde auf ein Deckglas, fügen einen Tropfen concentrirter Schwefelsäure hinzu und tauchen das Deckglas nach wenigen Secunden in ein mit Wasser gefülltes Gefäss, um die Schnitte rasch und möglichst vollkommen auszuwaschẹ. Nun färben wir die Schnitte mit wässerigem Anilinblau, waschen sie mit Wasser aus und legen sie in wässeriges Glycerin. An Stelle des Anilinblaues verwendet man auch mit Vortheil Pikrin-Anilinblau, hergestellt durch Auflösen von Pikrinsäure in 5-proc. Alkohol bis zur Sättigung und Hinzufügen von Anilinblau, bis die Flüssigkeit blaugrün gefärbt erscheint. Die Präparate sind gelungen, wenn die Wände der Bastparenchymzellen so stark gequollen erscheinen, dass sie etwa den nämlichen Durchmesser wie die contrahirten gefärbten Plasmakörper besitzen, und wenn auch die Mittellamellen stark gequollen sind. Nicht

1) Vgl. KrentTz-GerloFF, Botan. Zeitung, 1891, daselbst auch Literaturzusammenstellung. Vgl. auch Strasburger, Botæn. Praktikum. 
alle Präparate und nicht sämmtliche Zellen in einem Präparat eignen sich zur Untersuchung. Die Zellen müssen völlig unlädirt, und die Fixirung durch die Schwefelsäure muss schnell genug erfolgt sein.

Die Umrisse der einzelnen Plasmakörper der Parenchymzellen orscheinen an denjenigen Flächen glatt, mit denen sie an eine mit sehr feinen Poren versehene Zellwand grenzten; sie zeigen dickere oder dünnere Fortsätze dort, wo die anstossende Zellwand weitere Tüpfel besass. Die Fortsätze der Plasmakörper entsprechen sich in den benachbarten Ziellen. Wenn man die gequollene Schliesshaut betrachtet, die zwei besonders breite, gegen einander gerichtete Plasmafortsätze trennt, so findet man zwischen ihnen eine Anzahl äusserst feiner, körnig erscheinender Fäden ausgespannt. Es sind dies eben die Plasmafäden, welche auch die lebenden Plasmakörper mit einander verbinden. Wo die einander zugekehrten Flächen zweier Plasmakörper glatt erscheinen, sehen wir die Mittelschichten der Zellwand oft ihrer ganzen Ausdehnung nach von Fäden durchsetzt, die in ihrer Mitte etwas angeschwollen sind.

Der Protoplasmakörper wird stets, also auch dann, wenn er von einer Zellhaut umgeben ist, an seiner Oberfläche von einer hyalinen Schicht, der Hautschicht oder dem Hyaloplasma, begrenzt. Diese Haut. schicht fehlt aber auch dort nicht, wo Theile des Plasmakörpers an den Zellsaft angrenzen. Die Hauptmasse des Protoplasmas wird von der Körnerschicht desselben gebildet, welche sich durch ihren grossen Wasserreichthum und ihr Bewegungsvermögen, sowie dadurch auszeichnet, dass sie Mikrosomen und oft auch Chlorophyllkörper etc. führt. Das Hyaloplasma der meisten Zellen ist zu zart, um durch Beobachtung direct wahrgenommen werden zu können. In einigen Fällen lässt sich sein Vorhandensein aber leicht constatiren, und namentlich ist die Hautschicht in den Internodialzellen von Nitella, einer Algengattung, deren Repräsentanten in kalkarmen Gewässern häufig angetroffen werden, mächtig entwickelt. Die Massen der Körnerschicht des Protoplasmas sind hier in lebhafter Rotation begriffen, während sich das Hyaloplasma nicht an dieser Bewegung betheiligt.

Ich habe oft und mit Nachdruck darauf hingewiesen ${ }^{1}$ ), dass keineswegs Identität zwischen todten und lebendigen Eiweissmolekülen des Protoplasmas besteht. Damit in Einklang zu bringen sind die Resultate gewisser Beobachtungen von Loww und BoKonnx ${ }^{2}$ ), welche wir etwas ausführlicher erwähnen müssen. Wir stellen Kalilösung von 1,333 spec. Gew. her und vermischen $13 \mathrm{ccm}$ derselben mit $10 \mathrm{ccm}$ Ammoniakflüssigkeit von 0,960 spec. Gew. Das Gemisch wird auf $100 \mathrm{ccm}$ verdünnt. Ferner stellen wir eine 1-proc. Lösung von salpetersaurem Silberoxyd dar. Von der Kaliammoniakflüssigkeit und der Silberlösung werden vor dem Gebrauch je $1 \mathrm{ccm}$ mit einander vereinigt und auf 1 Liter verdünnt. Man legt nun in 1 Liter der alkalischen Silberlösung einige Spirogyrafäden (andere Zellen zeigen die Reaction, auf die es hier ankommt, zwar ebenfalls, aber nicht so deutlich), lässt dieselben einige Zeit in der Lösung verweilen (bei höherer Temperatur, z. B. $30^{\circ}$ C., etwa 3 Stunden, bei niederer Temperatur länger) und untersucht sie dann. Das Protoplasma in den Zellen hat sich in F'olge eingetretener Reduction des Silbersalzes der Lösung schwarz gefärbt, aber es ist besonders wichtig, dass diese

1) Vgl. z. B. Detarer, Lehrbuch d. Pflanzenphysiologie, 1883, S. 151.

2) Vgl. Loew und Bokorsy, Die chemische Ursache des Lebens, und Botan. Zeitung, 1882, S. 824 . 
Reaction nur eintritt, wenn die Zellen bei Beginn des Versuchs lebendig waren. Durch Hitze oder Alkohol oder auf andere Weise getödtete Spirogyrazellen nehmen beim Verweilen in der alkalischen Silberlösung nur eine gelbe bis braune Farbe an. Etwas langsamer, aber noch besser tritt die Schwarzfärbung des Protoplasmas ursprünglich lebender Spirogyrazellen ein, wenn man einige Algenfäden in eine Lösung legt, die auf 1 Liter Wasser $10 \mathrm{mg}$ salpetersaures Silberoxyd und $5 \mathrm{ccm}$ Kalkwasser enthält. Der Zutritt von kohlensäurehaltiger Luft ist hier während der Reaction sorgsam auszuschliessen.

Meiner Meinung nach kommt die Schwarzfärbung des Protoplasmas solcher Zellen, die in lebensthätigem Zustande mit den Silberlösungen in Contact gerathen, freilich nicht immer allein, aber doch häufig, wesentlich dadurch zu Stande, dass die stickstofffreien, aldehydartigen Körper, welche neben Amidosäuren und Säureamiden in Folge der Zersetzung der lebendigen Eiweissmoleküle entstehen, reducirend auf das Silbersalz einwirken. Todte Eiweissmoleküle sind ohne einen solchen Einfluss auf die Silberlösung, weil sie sich nicht in der Weise wie die lebendigen Eiweissmoleküle zersetzen.

Wir gehen zum Zellkern über. Dass derselbe eiweissartige Substanzen enthält, lehrt sein Verhalten zu Reagentien. In Contact mit Jodjodkalium (hergestellt durch Vermischen von $0,050 \mathrm{~g} \mathrm{Jod,} \mathrm{0,200} \mathrm{g} \mathrm{Jod-}$ kalium und $15 \mathrm{ccm}$ destillirten Wassers) nehmen die Zellkerne eine gelbliche Farbe an. Methylgrünessigsäure (hergestellt durch Eintragen von etwas Methylgrün in 1-proc. Essigsäure) tingirt die Kerne sehr schön. Bei der Behandlung der Zellen mit den erwähnten Reagentien treten die Kerne deutlicher hervor, was oft von besonderer Wichtigkeit ist. Sehr schön färben sich mit Methylgrünessigsäure, wie ich oft constatirte, die Kerne in den Epidermiszellen des Blattes von Aspidistra. Um die Kernreaction mit Jodjodkalium kennen zu lernen, verwenden wir Epidermiszellen des Blattes von Escheveria globosa oder zarte Querschnitte aus der ersten Blattscheide junger Maiskeimlinge. In den Zellen des Parenchyms der Scheide sind ziemlich grosse Zellkerne vorhanden. Schön entwickelte Zellkerne enthalten die den Spaltöffnungsapparaten der Unterseite des Blattes von Tradescantia virginica benachbarten Zellen, wovon man sich leicht überzeugen kann, wenn man Epidermisstreifen der Blätter mikroskopisch untersucht.

Ein besonderes Interesse besitzen die Stärkebildner für uns, Leukoplasten, denen, wie Sснімрек ${ }^{1}$ ) zuerst zeigte, die Function zukommt, aus wandernden oder schon in Reservestoffbehälter übergegangenen gelösten Kohlehydraten Amylumkörner zu regeneriren. Die schönsten und grössten Stärkebildner, welche man kennt, sind in den Scheinknollen von Phajus grandifolius anzutreffen. Diese zu den Orchideen gehörende Pflanze kann man z. B. zum Preise von 3 M. pro Exemplar von HAAGE und SoHumt in Erfurt beziehen. Zur Untersuchung wählen wir eine nicht zu alte Knolle, halbiren dieselbe und stellen aus ihrer Scheitelgegend dünne Längsschnitte her, die bis zur grün gefärbten Knollenoberfläche reichen. Ich habe mich davon überzeugt, dass es am besten ist, die Schnitte schnell in concentrirte Pikrinsïure $\mathrm{zu}$ ïbertragen, um sie in dieser $\mathrm{zu}$ beobachten. Die Stärkebildner der Zellen der inneren Schnitttheile sind farblos; nach aussen $\mathrm{zu}$ werden die Stärkebildner freilich grösser, aber ihre protoplasmatische Grundmasse ist mit Chlorophyllfarbstoff imprägnirt.

1) Vgl. Schimpikr, Botan. Zeitung, 1880, Nr. 52. 
Die im Profil gesehenen Stärkebildner (vgl. Fig. 39) erscheinen stäbchenförmig. Sie haben in Folge der Pikrinsäurebehandlung eine gelbliche Farbe angenommen, während die ihnen ansitzenden grösseren oder kleineren Stärkekörner nicht gefärbt sind.

Wir wenden uns nunmehr zur Untersuchung der protoplasmatischen Gebilde ruhender Pflanzentheile. Es interessiren uns hier vor allem die Formen, in denen die Reserveproteïnstoffe in den Samen vorhanden sind, und wir nehmen zunächst einen Lupinensamen in Untersuchung, indem wir den Samen halbiren, die Schnittfläche der Cotyledonen befeuchten und zarte Schnitte in Wasser untersuchen. Es treten uns in den Zellen zahlreiche, dicht gedrängt neben einander licgende, kleine Aleuron- oder Proteïkörner entgegen, deren Gestalt sich freilich in Folge des Einflusses des Wassers etwas verändert hat. Werden Präparate in Glycerin untersucht, so erscheinen die unveränderten Proteïnkörner als stark lichtbrechende Gebilde, die 'auf den ersten Blick wie kleine Stärkekörner aussehen. Eingebettet sind die Aleuronkörner in den Zellen in eine protoplasmatische Grundsubstanz. Sehr schön entwickelte, grosse Proteïnkörner sind, eingelagert in eine fettreiche Grundmasse, in den Endospermzellen der Ricinussamen vorhanden. Das erwähnte Gewebe lässt sich vortrefflich schneiden; die Schnitte können in Wasser untersucht werden, da sich dessen störende Wirkung erst langsam geltend macht. Fügen wir dem Präparat vom Deckglasrande aus Jodalkohol hinzu, so färben sich die Aleuronkörner gelb; sie zeigen überhaupt Eiweissreactionen. Lässt man zu den in Wasser liegendon Schnitten Alkohol vom Deckglasrande aus treten, so werden die Eiweisskrystalloide in den Aleuronkörnern ziemlich deutlich. Bei Untersuchung von Schnitten in einem Tropfen wasserfreier Essigsäure (Eisessig), quellen die Proteïnkörner stark auf, die Krystalloide verquellen sogar völlig, aber die Globoide treten scharf hervor.

Von besonderem Interesse ist es, Schnitte aus dem Endosperm der Samen von Bertholletia excelsa (Paranüsse) herzustellen. Wird zu einem in Wasser liegenden Schnitt absoluter Alkohol hinzugefügt, so treten in den Proteïnkörnern eigenthümliche Einschlussgebilde deutlich hervor. (Abbildungen vgl. bei PFeffrer in Pringsheim's Jahrbüchern f. wissenschl. Botanik, B. 8, Tafel 36, Fig. 16 und 17.) Es kommen hier einerseits die Eiweisskrystalloide, welche gerade bei Bertholletia relativ gross sind, und ferner die Globoide, Verbindungen einer gepaarten Phosphorsäure mit Kalk und Magnesia, in Betracht. Behandelt man Schnitte aus der Paranuss mit 1-proc. Ueberosmiumsäure (wässerige Lösung der Säure, die im Dunkeln aufzubewahren ist), so erblickt man die Krystalloide noch deutlicher, da sie sich nur langsam gelblich färben, während der übrige Inhalt der Zellen, zumal die fettreiche Grundsubstanz, in der die Proteinkörner liegen, schnell einen dunklen Farbenton annimmt. In den Proteïnkörnern von Ricinus kann man das Vorhandensein von Eiweisskrystalloiden 
ebenfalls feststellen, wenn man zarte Schnitte aus dem Endosperm in Ueberosmiumsäure untersucht (vgl. Fig. 40).

Wir stellen ferner zarte Querschnitte aus den Cotyledonen einer reifen, trocknen Erbse her. Auf die Schnittfläche bringen wir etwas Glycerin und untersuchen das Object auch in Glycerin, dem wir etwa $1 / 3$ destillirtes Wasser hinzugefügt haben. Das mikroskopische Bild, welches wir beobachten, ist in Fig. 41 dargestellt. Wir sehen rundliche Zellen, welche dreieckige Intercellularräume zwischen sich lassen. In

Fig. 41.
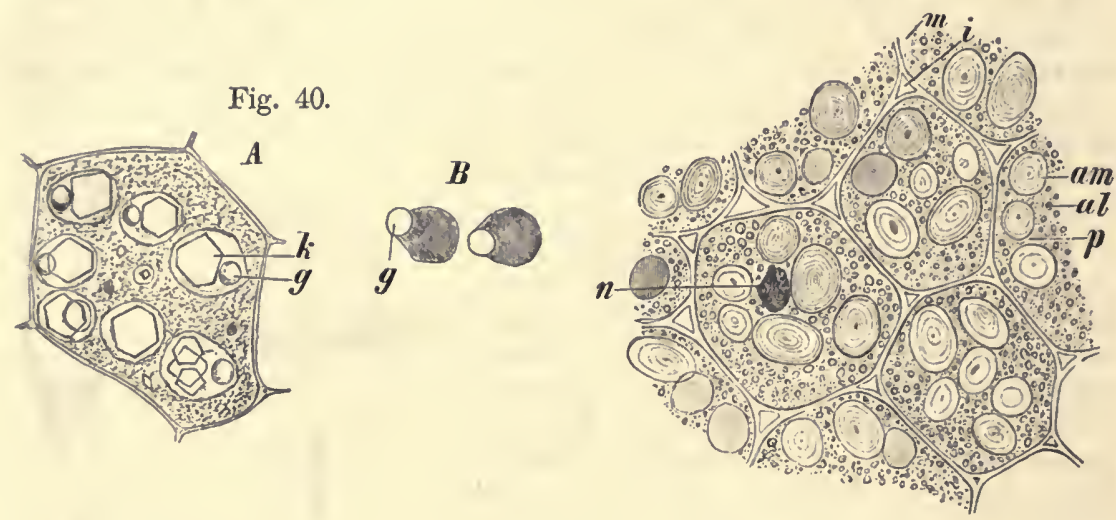

Fig. 42.

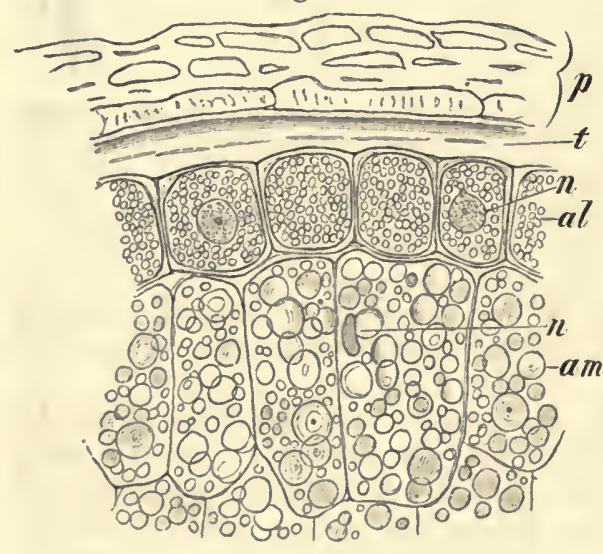

Fig. 40. Aus dem Endosperm von Ricinus communis. $A$ eine Endospermzelle mit Inhalt unter Wasser, $B$ einzelne Aleuronkörner in Olivenöl. $g$ das Globoid, $k$ Krystalloid. Vergr. 540. (Nach StrasBURGER.)

Fig. 41. Zellen aus den Cotyledonen der Erbse. $m$ Zellhaut, $i$ Intercellularraum, am Stärke-, al Aleuronkörner, $p$ Grundsubstanz, $n$ Zellkern, letzterer nach der Behandlung mit Methylgrünessigsäure ergänzend eingetragen. Vergr. 240. (Nach Strasburger.)

Fig. 42. Quersehnitt durch ein Weizenkoln (Triticum vulgare). $p$ Fruchthülle, $t$ Samenhaut. In den an letztere anstossenden Endospermzellen : al Aleuron-, am Stärkekörner, $n$ Zellkern. Vergr. 240. (Nach Strasburger.)

den Zellen befindet sich eine sehr feinkörnige Grundsubstanz. Dieser sind die ziemlich grossen Stärkekörner und die kleinen Aleuronkörnor eingelagert. Auf Jodzusatz färben sich die Amylumkörner blau, die Grundsubstanz sowie die Proteïnkörner, da sie wesentlich aus Eiweissstoffen bestehen, aber gelb. Zarte Schnitte aus den Erbsencotyledonen, in Methylgrünessigsäure gebracht, lassen erkennen, dass in jeder Zelle ein Zellkern, der sich grünblau gefärbt hat, vorhanden ist.

Wenn wir aus einem reifen Weizenkorn unter Betupfen der Schnitt- 
fläche mit Glycerin einen zarten Querschnitt herstellen und denselben in Glycerin legen, um ihn mikroskopisch zu untersuchen, so finden wir, dass dicht unter der Frucht- und Samenschale, die wir an anderer Stelle eingehender besprechen werden, eine Schicht rechteckiger Zellen liegt. Die Zellen enthalten keine Stärkekörner, wohl aber viele kleine Aleuronkörner. Die Zellen des tiefer liegenden Gewebes führen reichliche Amylummengen (vgl. Fig. 42).

\section{Die Zerstörung der Molekularstructur organisirter pflanzlicher Gebilde.}

\section{Die Einwirkung niederer Temperaturen auf Pflanzen.}

Dem Einfluss niederer Temperaturen gegenüber verhalten sich die Pflanzen sehr verschiedenartig. Manche Gewächse (viele Flechten, Moose und Bakterien, aber auch höhere Pflanzen, z. B. Bellis perennis und Stellaria media etc.) bleiben lebendig, wenn sie bei $-6=-8^{\circ} \mathrm{C}$. gefroren sind und dann schnell aufgethaut werden. Ich brachte auch Blätter von Primula elatior im Winter in Gläser, die nach dem Verschliessen mit einer Kältemischung, welche aus Schnee und Kochsalz in einem grossen Gefässe hergestellt worden war, umgeben wurden. Die Pflanzentheile blieben 6 Stunden lang einer Temperatur von $-5=-8^{\circ} \mathrm{C}$. ausgesetzt und wurden dann durch Eintauchen in Wasser von $6^{\circ} \mathrm{C}$. aufgethaut. Die Blätter waren bei Abschluss der Experimente nicht getödtet.

Wenn man Kartoffelknollen im Freien oder in Gläsern, die mit einer Kältemischung umgeben werden, einer Temperatur von $-8^{\circ} \mathrm{C}$. aussetzt, so gefrieren sie durch und durch und sind in diesem $\mathrm{Zu}$ stande klingend hart. Blätter, z. B. solche von Crassulaceen, Kohl-, Raps-, Bohnenpflanzen, einer Temperatur von $-8^{\circ}$ ausgesetzt, werden in Folge des Gefrierens spröde wie Glas. Thaut man die Kartoffelknollen oder die Blätter auf, indem man sie in gefrorenem Zustande in Wasser legt, so gehen sie zu Grunde. Sie sind erfroren und zeigen nunmelır die unter 48 aufgeführten Merkmale.

Die Kartoffelknollen sind, wovon ich mich durch zahlreiche Experimente sicher überzeugte, stets getödtet, wenn sie, nachdem ihr Gewebe wirklich gefroren war, nachträglich aufgethaut werden, mag dies langsam oder schnell geschehen. Man bringe einige Kartoffelknollen in ein grosses Gefäss mit Wasser und setze dieses einer Temperatur von $-8^{\circ} \mathrm{C}$. aus. so dass die Knollen langsam gefrieren. Das nachträgliche Aufthauen des Eises und der Knollen kann sehr langsam herbeigeführt werden, indem man das Gefäss in einen Raum stellt, in welchem cine Temperatur von $+1-2^{\circ} \mathrm{C}$. herrscht. Die aufgethauten Knollen - und dasselbe Resultat erhielt ich mit Escheveriablättern - sind todt. Ich habe auch Exemplare von Zannichellia palustris, die in Wasser liegend unter dem Einfluss des Lichtes reichliche Sauerstoffmengen abschieden, mit dem Wasser gefrieren lassen. Sie erwiesen sich nach dem Aufthauen als todt und zeigten keine assimilatorische Thätigkeit mehr. 
Sehr lehrreich ist es nach meinen Erfahrungen, Blätter von Begonia manicata, deren Blattstiel in Wasser eintaucht, deren Spreite aber unter einer Glasglocke von Luft umgeben ist, im Freien oder in einem Zimmer einer Temperatur von $-5^{\circ} \mathrm{C}$. oder $-10^{\circ} \mathrm{C}$. auszusetzen. Dic Blätter werden schon in Folge des Gefrierens missfarbig, und dieser Farbenton verschwindet auch nicht wieder, wenn man die Untersuchungsobjecte aufthaut. Die niederen Temperaturen bedingen eine Desorganisation des Protosplasmas, so dass der säurereiche Zellsaft auf die Chlorophyllkörper einwirken kann und das Chlorophyllpigment zersetzt. Wenn man Flächensclınitte erfrorener Blätter von Begonia manicata mikroskopisch untersucht, so ergiebt sich in der That, dass die Chlorophyllkörper nicht, wie im normalen Zustande, grün, sondern gelblich gefärbt sind. Experimente mit den erwähnten Untersuchungsobjecten sind deshalb so lehrreich. weil die bei niederer Temperatur eintretende Farbenänderung der Blätter direct erkennen lässt, dass schon das Gefrieren an sich den Tod der Zellen hervorruft ${ }^{1}$ ).

Wichtig ist ferner die von verschiedenen Physiologen festgestellte Thatsache, dass dieselben Pflanzentheile, welche im wasserreichen $\mathrm{Zu}$ stande Schaden leiden, wenn sie gefrieren, im wasserarmen Zustande nicht durch den Einfluss der Kälte leiden ${ }^{2}$ ). Man kann dies unter Benutzung lufttrockener sowie gequollener Samen von Phaseolus, Pisum, Triticum etc. leicht constatiren. Wenn man z. B., wie ich es gethan habe, einerseits lufttrockene Weizenkörner, andererseits solche, die 7 Stunden lang mit Wasser in Berïhrung gewesen waren, in kleinen Gläsern 15 Stunden lang einer Temperatur von $-10^{\circ} \mathrm{C}$. preisgiebt, so findet man, dass die ersteren, auf feuchtem Sande normalen Keimungsbedingungen ausgesetzt, noch keimfähig sind, während die letzteren nicht mehr keimen und zu Grunde gehen ${ }^{3}$ ).

Die gesammten Untersuchungen lassen namentlich diese Thatsache deutlich hervortreten, dass verschiedene Pflanzentheile und dieselben Beobachtungsobjecte in verschiellenen Zuständen keineswegs die gleiche Empfindlichkeit der Einwirkung niederen Temperaturen gegenüber besitzen.

\section{Die Veränderungen, welehe Pflanzen in Folge des Erfrierens erfahren.}

Beim Gefrieren von Pflanzentheilen tritt keineswegs, wie die Erfahrung lehrt, ein Zerreissen der Zellhaut ein. Wenn man z. B. Fäden von Spirogyra im Wassertropfen auf dem Objectträger gefrieren lässt, so sind nach dem Aufthauen keine Risse in den Zellhäuten wahrzunehmen. Wir wissen ja auch, dass beim Gefrieren von Geweben in der Regel nur in den Intercellularräumen etc., nicht aber in den Zellen selbst Eisbildung erfolgt.

Das Erfrieren ist sicher auf eine Zerstörung der Molekularstructur des Protoplasmas zuriickzuführen, was sich unmittelbar daraus ergiebt, dass dasselbe, wenn der Tod der Zellen durch Erfricren ein-

1) Vgl. Dermer, Botan. Zeitung, 18S6, Nr. 30.

2) Vgl. Drtmer, Vergleichende Physiologie d. Keimungsprocesses d. Samen, 1880 , S. 392 .

3) Weitere Literatur: SAcris, Versuchsstationen, 1860, Berichte d. sächs. Gesellschaft d. Wiss., 1860, Bd. 12, S. 27, und Flora, 1862; GöpPERT, Wärmeentwickelung in der Pflanze, 1830. 
getreten ist, seine normale Impermeabilität für Farbstoffe, Säuren etc. verloren hat.

Legt man gefrorene Stücke rother Rüben in Wasser von gewöhnlicher Temperatur, so nimmt dieses den rothen Farbstoff in grosser Menge auf, wälırend der Saft aus den Zellen nicht gefrorener Stücke rother Rüben, die man nach dem Abspülen in Wasser gelegt hat, nicht austritt. Erfrorene Kartoffelknollen lassen nach dem Aufthauen bei leisem Druck grosse Flüssigkeitsmengen ausfliessen. Die Zellen haben in Folge der Desorganisation des Protoplasmas ihren Turgor verloren, ebenso wie die Zellen erfrorener Blätter, welche schlaff herabhängen und bald vertrocknen. Sehr schön lassen sich diese Phänomene an erfrorenen Begonia- oder Escheveriablättern beobachten.

Wird Stärkekleister zum Gefrieren gebracht und dann aufgethaut, so hat man keine homogene Flüssigkeit mehr vor sich, sondern eine schwammige Masse, in deren Poren sich Flüssigkeit befindet. Es ist hier offenbar eine Umlagerung der Moleküle eingetreten, und das Ergebniss des erwähnten Versuclis ist im Stande, uns manche Vorgänge, welche beim Erfrieren von Pflanzenzellen im Protoplasma derselben stattfinden, einigermaassen $\mathrm{zu}$ versinnlichen.

\section{Die Eisbildung in gefrierenden Pflanzen.}

Ein einige $\mathrm{cm}$ dicker, gut abgewaschener und dann abgetrockneter Schnitt einer rothen Rübe wird in einer Schale, die man, um die Wasserverdunstung auszuschliessen, mit einer Glasplatte bedeclit hat, einer Tenperatur von etwa $-6^{\circ} \mathrm{C}$. ausgesetzt. Ist der Pflanzentheil vollkommen gefroren, so findet man seine Oberfläche mit einer Eiskruste berleckt, die, wie geeignete bei Temperaturen unter $0^{\circ} \mathrm{C}$. ausgeführte mikroskopische Untersuchungen lehren, aus parallel neben einander gestellten Eissäulen besteht. Besonders reichliche Eismengen findet man an der Unterseite des Rübenschnittes, da wo er den Boden der Schale berührt hat. Dieses Eis ist nicht rotl gefärbt, woraus erhellt, dass nicht der Zellsaft, sondern fast reines Wasser aus den Zellen des Untersuchungsobjectes herausgefroren ist.

Unter bestimmten Umständen kann freilich in den Zellen gefrierender Pflanzentheile Eis entstehen; gewöhnlich tritt aber das Wasser beim Gefrieren in die Intercellularräume oder in sonstige Höllungen der Gewebe iiber und erstarrt hier erst. Schneidet man an einer grossen Runkelrübe den oberen Theil weg, befestigt denselben aber wieder mit Hülfe eines Bindfadens an seinem ursprünglichen Platze, nachdem man im unteren Theile eine nicht $\mathrm{zu}$ grosse Höhlung angebracht hat, und setzt das Untersuchungsobjeet nunmehr längere Zeit einer Temperatur von etwa $-8^{\circ} \mathrm{C}$. aus, so sammeln sich beträchtliche Eismassen in der Höhlung an ').

Um den Nachweis zu liefern, dass beim Gefrieren der Pflanzen die erste Eisbildung in den Intercellularen stattfindet, werden Schnitte aus gefrorenen Kartoffelknollen oder Carotten, die mit stark abgekühlten Messern hergestellt worden sind, auf gut abgekühlte Objectträger gelegt und unter dem Mikroskop bei langsamem Aufthauen beobachtet. Man

1) Vgl. über das hier Gesagte und das Folgende MÜLLLER-Thurgau, Landwirthsehaftl. Jahrbüicher, Bd. 9, S. 133. 
sieht, dass sich die Eiskrystalle nicht in, sondern zwischen den Zellen gebildet haben, und dass sich die Zellreihen, welche durch die Eisdrusen auseinandergedrängt waren, beim Schmelzen des Eises einander nähern freilich nicht mehr bis zur vollständigen Berührung. Die Zellen geben also beim Gefrieren der Pflanzentheile Wasser ab. Dieses scheidet sich zunächst in den Intercellularen als Eis $a b$, und indem die Eismassen anwachsen, erfahren auch die Intercellularen eine Vergrösserung.

Sehr instructiv ist es, den Gang der Temperatur in gefrierenden Pflanzentheilen festzustellen, wie dies zuerst von MüLLER-Thurga u geschehen ist. Ich habe $\mathrm{zu}$ solchen Versuchen den in Fig. 43 abgebildeten Apparat benutzt. Unter der tubulirten Glasglocke $G g$ liegt der Glasring Gr. Auf diesen letzteren gelangt das Untersuchungsobject,

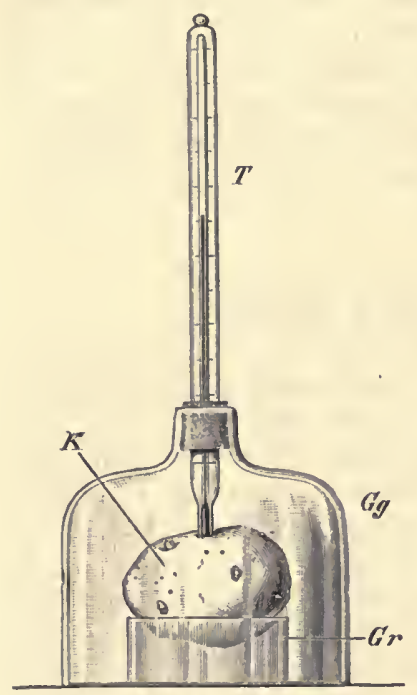

Fig. 43. Apparat zur Untersuchung des Temperaturganges in gefrierenden Kartoffelknollen.

z. B. die Kartoffelknolle $K$. Mittelst eines Korkbohrers ist in die Knolle ein bis zur Mitte derselben reichendes Loch gebohrt, und dieses dient, nachdem es mit Fliesspapier ausgetrocknet worden ist, zur Aufnahme des eylindrischen Quecksilberbehälters eines empfindlichen und in Zehntel-Grade eingetheilten Thermometers $T$. Sehr wünschenswerth ist es, dass die Glasglocke nicht einen, sondern noch einen zweiten, zur Aufnahme eines zweiten Thermometers dienenden Tubulus besitzt, um neben der' Temperatur der Knolle zugleich diejenige der sie umgebenden Luft unter der Glocke bestimmen zu können. Die ganze Vorrichtung wird in eine grosse Schale gestellt, und die Untersuchung in einem kalten Raum ausgeführt. Man umgiebt die Glocke in der Schale mit einer Kältemischung (Schnee und Kochsalz) und liest nun von $5 \mathrm{zu} 5$ Minuten den Stand des Quecksilbers in den Thermometern ab. Die Temperatur der Knolle sinkt allmählich auf $-3=-4^{\circ} \mathrm{C}$. Plötzlich aber steigt sie wieder auf $-1^{\circ} \mathrm{C}$., Jält sich längere Zeit ziemlich constant, um dann wieder zu sinken, bis die Temperatur der umgebenden Luft, z. B. $-8^{\circ}$ C., erreicht ist. Wenn Kartoffelknollen einer Temperatur unter $0^{\circ}$ ausgesetzt werden, so tritt zunächst, ohne dass Eisbildung in dem Gewebe erfolgt, eine Ueberkältung derselben ein. Ist das Ueberkältungsmaximum erreicht, so tritt die Eisbildung plötzlich ein, und durch die dabei frei werdende Wärme steigt die Temperatur in der Knolle auf den Gefrierpunkt derselben, welcher etwa bei $-1^{\circ} \mathrm{C}$. liegt. Allmählich sinkt dann die Temperatur der Knolle auf diejenige des umgebenden Mediums herab. Andere Pflanzentheile verhalten sich ähnlich. Ich umwickelte z. B. den Quecksilberbehälter eines Thermometers mit einem Blattstreifen einer Begonie (B. manicata), befestigte den Pflanzentheil mit Hülfe eines Bindfadens am Thermometer und kühlte das Untersuchungsobject ab. Das Ueberkältungsmaximum lag bei $-4,8^{\circ} \mathrm{C}$., der Gefrierpunkt bei - 0,8"C. Erst als dieser erreicht war, wurde der Blattstreifen missfarbig (vergl. unter 47). 
Bei ausführlichen Untersuchungen über den Temperaturgang gefrierender Pflanzentheile verwendet man zweckmässig einen Gefrierkasten, der, wie folgt, construirt ist (Müller-Thurgau). Er besteht aus einem kubischen Holzkasten von $1 \mathrm{~m}$ Kantenlänge, mit doppeltem Boden und doppelten Seitenwänden. Boden und Wände sind mit trockenen Holzsägespänen ausgefüllt. In diesen Holzkasten passt genau ein doppeltwandiger, oben ebenfalls offener Zinkblechkasten, dessen innere Wandung sich herausheben lässt. Bei der Verwendung des Apparates wird zunächst der äussere Zinkkasten mit etwa nussgrossen Eisstücken so weit angefüllt, wie die den inneren Zinkkasten tragenden Säulen reichen, hierauf der innere Zinkkasten an seine Stelle gebracht, und auch der Zwischenraum zwischen beiden Zinkkästen mit Eis angefüllt. Handelt es sich darum, im Gefrierkasten eine Temperatur unter $0^{\circ}$, z. B. von $-8^{\circ} \mathrm{C}$. hervorzubringen, so bringt man auf die Oberfläche des Eises zwischen den Wänden der Zinkkästen bestimmte Kochsalzmengen, die, indem sie einen Theil des Eises zum Schmelzen bringen, Kälte erzeugen. Als Deckel des Apparates dienen zwei viereckige Blechteller, welche, neben einander gelegt, den doppeltwandigen Zinkblechkasten zudecken und noch nicht völlig den oberen Rand des Holzkastens erreichen. Die Deckel, welche ebenfalls mit Eis unter Kochsalzzusatz zu füllen sind, lassen eine etwa $2 \mathrm{~cm}$ breite, nach oben sich erweiternde Spalte über dem ganzen Gefrierkasten offen, durch welche die Thermometer, mit Hülfe welcher die Temperaturverhältnisse der Untersuchungsobjecte sowie diejenigen der diese umgebenden Luft ermittclt werden sollen, ans Tageslicht treten. Die beiden Zinkblechdeckel sind schliesslich noch je mit einem Holzdeckel zugedeckt, die gerade mit dem oberen Rande des Holzkastens abschliessen. Zur Aufstellung des Gefrierkastens wählt man einen Raum von möglichst constanter Temperatur, z. B. ein nach Norden gelegenes Zimmer. Es gelingt dann bei einiger Aufmerksamkeit im Winter leicht, tagelang eine recht constante Temperatur unter $0^{0}$ im Apparat zu erhalten. Bei Ausführung der Beobachtungen müssen die Untersuchungsobjecte sich möglichst in der Mitte des Gefrierkastens befinden. Das obere Ende der Thermometer, deren Quecksilberbehälter von den Pflanzentheilen umgeben ist, wird durch geeignete Halter, die auf der einen Deckelhälfte stehen, festgehalten. Natürlich müssen die in Zehntel-Grade getheilten und häufiger mit einem Normalthernımeter $\mathrm{zu}$ vergleichenden Thermometer derartig construirt sein, dass diejenigen Theile der Scala, auf denen die Temperaturen von 0 bis etwa $-8^{\circ} \mathrm{C}$. verzeichnet sind, noch aus dem Gefrierkasten hervorragen. Die Ablesungen der Thermometer erfolgen bei den Untersuchungen in Zwischenräumen von einer Minute. Alle Resultate dieser Ablesungen werden in tabellarischer Form übersichtlich zusammengestellt.

Um die Thatsache $\mathrm{zu}$ begreifen, dass Temperaturen unter $0^{0}$ ausgesetzte Pflanzentheile eine Ueberkältung erfahren, und dass ihr Gefrierpunkt nicht bei $0^{\circ}$, sondern tiefer liegt, müssen wir uns an das Verhalten von Salzlösungen sowie an das Verhalten durch Adhäsionskräfte seitens fester Körper festgelialtenen Wassers beim Gefrieren erinnern. In den Zellen der Pflanzen ist ja auch kein reines Wasser, sondern eine wässerige Lösung verschiedener Stoffe vorhanden, und die organisirten pflanzlichen Gebilde halten das Wasser fest. Reines Wasser gefriert meist bei $0^{\circ}$, eine Lösung (z. B. Kochsalzlösung) aber stets erst bei tiefer liegenden Temperaturen. Je nach den Concentrationsverhältnissen lassen sich Kochsalzlösungen mehr 
oder weniger überkälten, bevor die Eisbildung beginnt. Die Temperatur der Lösungen steigt dann plötzlich, bis der eigentliche Gefrierpunkt, der stets unter 0 " liegt, erreicht ist. Man kann diese Verhältnisse leicht durch geeignete Experimente feststellen. Um das Verhalten durch Adhäsionskräfte gebundenen Wassers beim Gefrieren zu untersuchen, habe ich nach Müller-Thurgau's Vorgange den Quechsilberbehälter eines Thermometers mit Fliesspapier umwickelt, das zunächst mit Wasser durchtränkt und dann wieder äusserlich abgetrocknet worden war. Unter einer mit einer Kältemischıng umgebenen Glasglocke niederer Temperatur ausgesetzt, nahm das Fliesspapier allmählich eine Temperatur von - 3" C. an (Ueberkältungsmaximum), und dann stieg die Temperatur plötzlich bis auf etwas unter $0 \circ \mathrm{C}$.

Das in Lösungen vorhandene, sowie das durch Adhäsionskräfte seitens fester Körper gebundene Wasser - und das Wasser in der Pflanze befindet sich ja unter solchen Verhältnissen - gefriert also nicht bei $0^{\circ} \mathrm{C}$., wie reines Wasser, sondern erst bei tiefer liegenden Temperaturen. Der Gleichgewichtszustand zwischen den Wassertheilchen und den Salztheilchen oder den Theilchen der festen Körper wird erst bei Temperaturen unter $0^{\circ} \mathrm{C}$. aufgehoben, so dass die Eisbildung erfolgen kann. Freilich wird nun bei der Eisbildung eine erhebliche Wärmemenge frei; indessen die Temperatur der Salzlösungen oder der mit Wasser durchtränkten festen Körper erhebt sich doch nicht ganz auf $0^{\circ} \mathrm{C}$., da eine gewisse Wärmemenge verbraucht wird, um die Wassertheilchen beim Gefrieren von den Salztheilchen oder den Theilchen der festen Körper loszureissen.

\section{Die Töltung der Pflanzen dureh zu hohe Temperaturen.}

Als Untersuchungsobjecte dienen zunächst in kleinen Blumentöpfen zur Entwickelung gebrachte junge Pflanzen von Zea, Nicotiana, Cucurbita, Phaseolus oder Tropaeolum. Haben die Pflanzen einige Blätter entfaltet, so sind sie für die Experimente geeignet. Man bringt nun die Luft unter der Glocke eines Thermostaten auf diejenige Temperatur, deren Wirkung auf die Pflanzen studirt werden soll. Ist diese Temperatur constant geworden, so gelangt ein Untersuchungsobject in den Thermostaten. Man wartet, bis die Temperatur, deren Einfluss man untersuchen will, im Apparat wieder hergestellt ist, und überlässt die Pflanze dann dieser Temperatur gewisse Zeit lang. Oft empfiehlt es sich, die Erde in den Töpfen, um einen schnelleren Temperaturausgleich zu erzielen, mit warmem Wasser zu begiessen. Ein Thermometer ist in die Erde, in welcher die Pflanze wurzelt, eingesenkt, ein zweites hängt unter der Glocke und berührt die oberirdischen Theile der Untersuchungsobjecte. Man kann die Versuche nun vielfältig variiren. Wir belassen eine der genannten Pflanzen z. B. eine halbe Stunde lang bei einer Lufttemperatur von 40 oder $45^{\circ} \mathrm{C}$., oder wir setzen die Pflanzen im Apparat 10-30 Minuten lang einer Luftemperatur von $52^{\circ} \mathrm{C}$. aus. Darauf werden die Gewächse aus dem Thermostaten herausgenommen and normalen Lebensbedingungen ausgesetzt, um ihr weiteres Verhalten zu beobachten. Ein halbstündiges Verweilen in Luft von $40^{\circ} \mathrm{C}$. ertragen die Pflanzen gewöhnlich ohne Nachtheil; ein 10-30 Minuten dauernder Aufenthalt in Luft ron $52^{\circ} \mathrm{C}$. törltet sie aber in der Regel. Uebrigens 
1st $\mathrm{zu}$ beachten, dass die Pflanzen keineswegs sofort absterben, wenn sie zu hohen Temperaturen, z. B. $52^{\circ}$ C. während 10 Minuten, ausgesetzt gewesen sind. Vielmehr tritt der Tod oft erst nach Tagen ein. Die eben fertig ausgebildeten Blätter werden allmählich missfarbig, während die älteren Blätter und Internodien, sowie auch die Knospen erst später absterben. Bei der Ausführung genauer vergleichender Untersuchungen über den Einfluss höherer Temperaturen auf Pflanzen ist es notlıwendig, jedes Experiment bei bestimmter Temperatur mehrfach zu wiederholen, und ebenso ist jeder Versuch mit einer noch nicht benutzten, also vollkommen normalen Pflanze anzustellen. Man schützt sich auf diese Weise vor Irrthümern. Lehrreich würde es auch sein, Pflanzen längere Zeit (mehrere Stunden oder gar Tage) bei relativ niederen Temperaturen (z. B. 35 $-40^{\circ}$ C.) im Thermostaten zu belassen, um das nachträgliche Verhalten der Untersuchungsobjecte zu beobachten.

Während die Pflanzen ein 10 Minuten langes oder ein etwas längeres Verweilen in Luft von $52^{\circ} \mathrm{C}$. nicht ohne nachtheilige Folgen ertragen, rufen schon Temperaturen von etwa $45-48^{\circ} \mathrm{C}$., denen die Untersuclıungsobjecte $10 \mathrm{Mi}$ nuten lang ausgesetzt waren, den Tod derselben hervor, wenn das Medium nicht Luft, sondern Wasser ist. Um diese Thatsache zu demonstriren, taucht man die oberirdischen Theile in Töpfen cultivirter Pflanzen, nachdem man, um das Herausfallen der Erde aus den Töpfen zu verhindern, Sperrhölzer auf die Bodenoberfläche gelegt hat. in Wasser von der bezeichneten Temperatur. Diese wird während der Experimente constant erhalten, und nach Verlauf von 10 Minuten nimmt man die Pflanzen aus dem Wasser heraus, um ihr ferneres Verhalten zu beobachten.

Bei dem Studium über den Einfluss des Wassers von höherer Temperatur auf die Pflanzen kann man auch mit abgeschnittenen Pfianzentheilen, z. B. mit Blättern, experimentiren. Ich benutzte unter anderem $\mathrm{zu}$ solchen Versuchen Blätter von Begonia manicata und Vitis vinifera, die sehr geeigneteUntersuchungsobjecte darstellen, weil sie in Folge des Todes der Zellen eine wesentliche Farbenänderung erfahren. Taucht man die

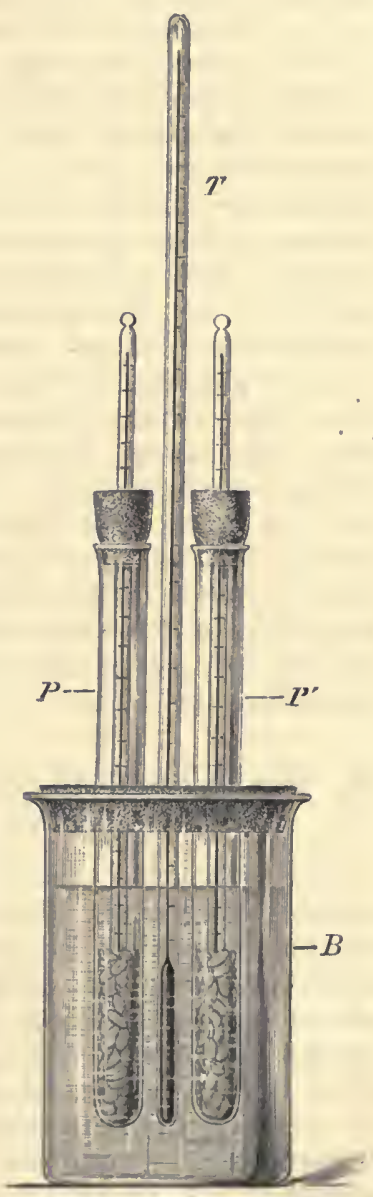

Fig. 44. Apparat zur Untersuchung der Einwirkung höhtrer Temperatur auf Samen. Blätter von Begonia 15 Minuten lang in Wasser von $40^{\circ} \mathrm{C}$., so sterben ilure Zellen nicht ab. In Wasser von $75^{\circ} \mathrm{C}$. eingetaucht, verfärben sich die Blätter fast momentan und sind dann getödtet. Wasser von $5^{\circ} \mathrm{C}$. tödtet die Blätter binnen zwei Minuten. 
Un die wichtige Thatsache $\mathrm{zu}$ constatiren, dass Pflanzentheile, zumal Samen, höhere Temperaturen weit besser im trocknen als im mit Wasser durchtränkten Zustande überdauern, benutzt man den Fig. 44 abgebildeten Apparat. Das Becherglas $B$ ist mit Wasser angefüllt. Der das Glas verschliessende grosse Kork hat mehrere Bohrungen, und durch die eine derselben ist das Thermometer $T$ gesteckt, während die beiden anderen zur Aufnahme von Probirgläsern ( $P$ und $P^{\prime}$ ) dienen. Die Mündungen dieser letzteren sind mit Korken verschlossen, in deren Bohrungen Thermometer eingeführt werden. Dic ganze Vorrichtung hängt in einem Metallringe und taucht in das Wasser eines Wasserbades ein. Man erwärmt nun mit einer Gas- oder Spiritusflamme, bis die Thermometer in den Probirgläsern diejenige Temperatur anzeigen, bei der man experimentiren will (z. B. 50, 60 oder $70^{\circ}$ C.). Jetzt werden in das eine Probirglas lufttrockne, in das andere gequollene Samen gebracht, und zwar benutit man z. B. je 50 bis 100 Samen von Pisum, Zea oder Triticum, um diese Untersuchungsobjecte einige Zeit lang (z. B. eine Stunde lang) der constant gehaltenen höheren Temperatur auszusetzen. Darauf werden die Samen in Sägespäne gelegt und normalen Keimungsbedingungen ausgesetzt. Die lufttrocken erwärmten Samen keimen noch zum Theil; die aber im gequollenen Zustande erwärmten gehen sämmtlich zu Grunde und keimen nicht.

Lufttrockne Körner von Pisum, Zea oder Triticum kann man eine Stunde lang Temperaturen von 65 oder $70^{\circ} \mathrm{C}$. exponiren, ohne dass sämmtliche Untersuchungsobjecte ihre Keimfähigkeit einbüssen; freilich wird dieselbe aber dadurch mehr oder minder geschwächt. Als ich lufttrockne Weizenkörner eine Stunde lang einer Temperatur von $62^{\circ} \mathrm{C}$. ausgesetzt hatte, erwies sich nachträglich noch ein nicht unerheblicher Procentsatz der Untersuchungsobjecte keimfähig. Die gequollenen Weizenkörner, welche eine Stunde lang einer Temperatur von $62^{\circ} \mathrm{C}$. ausgesetzt gewesen waren, gingen aber bei der Keimprobe sämmtlich zu Grunde ${ }^{1}$ ).

\section{Die Veränderungen, welehe Pflanzen in Folge der Tödtung durch zu liohe Temperaturen erfahren.}

Man tauche ein junges Blatt aus der Knospe von Elodea canadensis, in dessen Zellen das Stattfinden lebhafter Protoplasmabewegung constatirt ist, kurze Zeit (etwa 1 Minute lang) in Wasser von $60^{\circ} \mathrm{C}$. Infolge des Einflusses der hohen Temperatur wird die Protoplasmabewegung sofort sistirt; sie kehrt auch nach längerer Zeit nicht wieder; das Untersuchungsobject geht in einen desorganisirten Zustand über und ist abgestorben.

Sehr zahlreiche Blätter (ich experimentirte z. B. mit Kohlblättern) erfahren, wenn man sie einige Zeit lang in Wasser von höherer Temperatur (z. B. $60^{\circ}$ C.) bringt, keine wesentlichen Farbenveränderungen. Die Blätter sterben aber in dem warmen Wasser sehr schnell ab; die Zellen verlieren ihren Turgor, und die Pflanzentheile sind schlaff

1) Literatur: SACHS, Flora, 1864, S. 5, und Handbuch d. Experimentalphysiologie der Pflanzen, 1865, S. 64. Ferner vgl. DetMer, Vergleichende Physiologie d. Keimungsprocesses d. Samen, 1850, S. 401; HöHNeL in den von Fr. HaBerLANDT herausgegebenen wissenschl.-prakt. Untersuchungen auf dem Gebiete des Pflanzenbaues, Bd. 2, S. 77, und DetMer, Botan. Zeitung, 1886, Nr. 30. 
geworden. Sie können auch nicht wieder in den normalen turgescenten Zustand zurückgebracht werden. Wenn man Blätter, deren Zellen säurereich sind (ausgezeichnete Objecte sind nach meinen Erfahrungen die Blätter von Begonia manicata und Vitis vinifera) in heisses Wasser taucht, so werden dieselben schnell nissfarbig, weil die Chlorophyllkörper in Folge der Vernichtung des Protoplasmas jetzt in Contact mit dem säurereichen Zellsaft gelangen, und die Säure das Chloro-

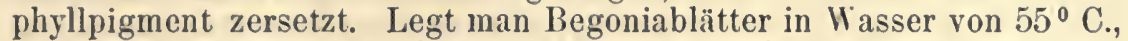
so sind sie nach Verlauf von '2 Minuten missfarbig; in Contact mit Wasser von $75^{\circ} \mathrm{C}$. verlieren sie fast momentan ilire grüne Farbe. Bei mikroskopischer Untersuchung von Flächenschnitten der getödteten Blätter von Begonia manicata ergiebt sich in der That, dass die Chlorophyllkörper nicht mehr. grün, sondern bräunlich gefärbt sind.

Dass das Protoplasma bei dem durch zu hohe Temperaturen hervorgerufenen Absterben seine normale Beschaffenheit einbüsst und in Folge dessen die Säuren des Zellsaftes leicht diosmosiren lässt, kann man nach meinen Erfahrungen leicht in folgender Weise feststellen. Ein Stück vom Blattsticle eines lebendigen Blattes von Begonia manicata wird nach dem Abspülen in destillirtes Wasser gelegt. Ein zweites Stück desselben Blattstieles tödtet man durch Einlegen in Wasser von $60^{\circ} \mathrm{C}$. Ist das Blattstielstück missfarbig geworden, so überträgt man es schnell in destillirtes Wasser. Zu diesem Wasser und ebenso zu demjenigen, in welchem das lebende Blattstuick verweilt, fügt man alsbald, nachdem man die Blattstücke entfernt hat, etwas Chlorcalciumlösung hinzu. Die eine Flüssigkeit bleibt klar, die andere, in der das getödtete Blattstück lag, trübt sich in Folge der Abscheidung von oxalsaurem Kalk. Das zerstörte Protoplasma ist permeabel für die Oxalsäure des Zellsaftes geworden und hat dieselbe nach aussen in das umgebende Wasser austreten lassen.

Werden Haare von den Staubfäden einer Tradescantia durch Eintauchen in Wasser vol 55 oder $60^{\circ} \mathrm{C}$. getödtet, dann in einem Wassertropfen auf den Objectträger gebracht und ihr Verhalten beobachtet, so zeigt sich, dass der rothe oder violette Farbstoff des Zellsaftes in den Zwischenraum zwischen Protoplasma und Zellhaut übergeht und schliesslich aus den Zellen in das umgebende Wasser gelangt. Das gesunde Protoplasma ist. impermeabel für den Farbstoff. IVenn man Stücke frischer rother Rüben zunächst sorgfältig abspült, um den aus den angeschnittenen Zellen hervortretenden Saft zu beseitigen, und dann in Wasser legt, so geben sie selbst bei stundenlangem Verweilen in der Flüssigkeit keinen Farbstoff an dieselbe ab. Sind die Zellen der rothen Rüben aber durch den Einfluss höherer Temperatur getödtet, so lassen sie ihren Farbstoff, in Wasser von gewölnnlicher Temperatur gelegt, schnell austreten. Legt man einerseits durch Eintauchen in Wasser von $60^{\circ} \mathrm{C}$. getödtete, andererseits aus lebenden Zellen bestehende Stücke weisser Rüben in den Saft rother Rüben, so dringt der Farbstoff binnen 24 Stunden nicht in die letzteren ein, während sich die ersteren durch und durch roth färben.

\section{Die Vernichtung der Molekularstruetur durch mechanische Eingriffe.}

Wenn es auch allbekannt ist, dass Pflanzentheile schwachen Druck oder schwache Zerrung ohne Nachtheil ertragen, wohl aber eine Zerstörung 
ihrer Molekularstructur unter dem Einflusse energischer mechanischer Eingriffe erfahren, so mögen dennoch einige nicht ganz unwichtige Experimente angeführt werden, deren Resultate die letztere Thatsache deutlich hervortreten lassen.

Etwas Kartoffelstärke wird mit Wasser von $15-20^{\circ} \mathrm{C}$. übergossen. Eine gleiche Menge der Stärke wird mit Wasser übergossen, nachdem man sie in einem Mörser mit reinem Quarzsand möglichst vollkommen verrieben hat. Nach einigen Stunden filtrirt man die Flüssigkeiten $a b$ und kann nuu in der einen mit Hülfe von Jod keine Granulose nachweisen, während das Wasser der mit Sand verriebenen Stärke Granulose entzogen hat. Der mechanische Eingriff führt zu einer Zerstörung der Molekularstructur der Amylumkörner, und diese geben daher Granulose an die Flüssigkeit ab, während die unversehrten Stärkekörner dies nicht vermögen.

Wenn man das Gewebe der Spreite des Blattes von Begonia manicata heftig zwischen den Fingern zusammenpresst, so nimmt dasselbe an der gedrückten Stelle alsbald eine bräunliche Färbung an. Die mikroskopische Untersuchung von Flächenschnitten von der gedrïckten Stelle lehrt, dass die Chlorophyllkörper in den Zellen missfarbig geworden sind, während sie im normalen Zustande schön grün erscheinen. Durch den Druck ist eine Zerstörung der protoplasmatischen Zellenbestandtheile herbeigeführt worden. Dieselben sind permeabel für den sauren Zellsaft geworden, und dieser hat zersetzend auf das Chlorophyllpigment eingewirkt ').

\section{Die Wirkung des Austrocknens auf Pflanzentheile.}

Werden krautige Sprosse abgeschnitten, und führt man ihnen nunmehr kein Wasser zu, so gehen sie alsbald in den welken-Zustand über. Wonn derselbe weit vorgeschritten ist, so kann man die Sprosse durch Wasserzufuhr nicht aufs Neue in den normalen Zustand überführen, dagegen erholen sich eben angewelkte Sprosse oft wieder, wenn man ihnen reichlichere Wassermengen zur Verfügung stellt.

Um den Einfluss kennen zu lernen, den das Austrocknen auf Samen sowie Keimpflanzen ausübt, verwende man Weizen- oder Erbsensamen. Das Material wird theils nach 24-stündigem Quellen, theils nachdem die Würzelchen soeben hervorgebrochen sind oder sich mehr oder minder weit entwickelt haben, in Glasschalen gebracht und dem austrocknenden Einflusse der Luft ausgesetzt. Sind die Samen oder Keimpflanzen lufttrocken geworden, so legt man sie in feuchtes Sägemehl und beobachtet ihr Verhalten. Die angequollenen Samen werden durch das Austrocknen wenig gelitten haben; ebenso diejenigen Untersuchungsobjecte, deren Wurzeln nur einen sehr geringen Grad der Entwickelung erfahren hatten. Der Einfluss der Austrocknung auf etwas weiter ausgebildete Keimpflanzen macht sich darin geltend, dass die jungen Keimtheile freilich absterben, aber bei erneuter Wasserzufuhr wieder durch Bildung von Adventivwurzeln und Entwickelung vorhandener Achselknospen ersetzt werden, während noch weiter ausgebildete Keimpflanzen durch das Austrocknen gewöhnlich völlig zu Grunde gehen? ).

1) Vgl. Detmer, Botan. Zeitung, 1856, Nr. 30.

2) Vgl. Nowoczck in Haberlandt's wissenschl.-prakt. Unters. auf den Gebiete d. Pflanzenbaues, B. 1, S. 122. 
Werden Rasen von Barbula muralis mehrere Wochen an der Iuft oder im Exsiccator über Schwefelsäure ausgetrocknet und dann befeuchtet und auf feuchte Erde gebracht, so wacbsen sie, obne die alten Blätter zu verlieren, ruhig weiter. Manche andere Moose verhalten sich ähnlich; es giebt aber auch Moose, die sich dem Austrocknen gegenüber recht empfindlich erweisen ').

Ueber die Frage, wie sich mehr oder minder weit ausgetrocknete, aber freilich noch immer ziemlich wasserreiche Keimpflanzen im Vergleich zu den normalen Untersuchungsobjecten bezüglich ihrer Athmungsenergio verhalten, stellte ich eine Reibe von Beobachtungen an ${ }^{2}$ ). Etwa 30 Erbsenkeimpflanzen werden nach der im dritten Abschnitt angegebenen Methodo auf ihre Athmung untersucht. Man bestimmt die Kohlensäuremenge, welche die Keimpflanzen in 2 oder 3 Stunden bei constanter Temperatur aushauchen. Dann wird den Versuchsobjecten einige Tage lang kein Wasser dargéboten und das mehr oder minder ausgetrocknete Material wieder bei derselben Temperatur wie früher auf seine Athmungsenergio geprüft. Dieselbe ist jetzt erheblich gesunken. Lufttrockene Samen geben nach meinen Beobachtungen keine nachweisbaren Kohlensäuremengen aus.

\section{Dic Einwirkung der Elektricitit auf Pflanzen.}

Ueber die Einwirkung der Elektricität auf Pflanzen ist, namentlich soweit es sich dabei um das feinere Detail handelt, noch relativ wenig bekannt ${ }^{3}$ ). Von physiologischem Interesse erscheint zumal die Thatsache, dass constante Ströme sowie Inductionsströme nicht ohne Einfluss auf die Protoplasmabewegungen sind, indem sie den Verlauf derselben meistens verlangsamen oder die Bewegungen völlig aufheben und schliesslich den Tod der Zellen horbeiführen.

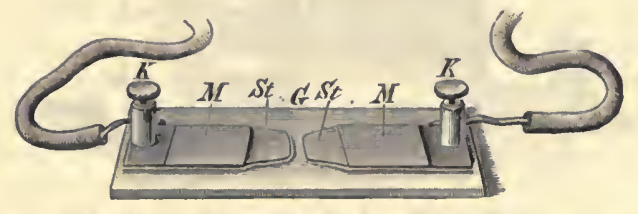

Fig. 45. Objecttrïger zur Untersuchung der Einwirkung elektrischer. Ströme auf Pflanzentheile.

Um die in Frage kommenden Phänomene zu studiren, verwendo man junge Blätter von Elodea oder Haare von den jüngeren Theilen einer Kürbispflanze. Die Untersuchungsobjecte werden im Wassertropfen unter Deckglas der mikroskopischen Beobachtung unterzogen, und die Objectträger haben die in Fig. 45 dargestellte Form. Auf der Glasplatte $G$ sind zwei Messingplatten $M, M$ mit Asphaltlack (Auflösung von Asphalt in Terpentinöl) festgekittet. An jeder Messingplatte ist eine Klemmschraube $K$ festgelöthet. Die beiden Staniolblättchen $S t$, $S t$ werden mit Hülfe von Asphaltlack auf den Messingplatten und der Glasplatte befestigt; sie lassen einen Zwischenraum zwischen sich, der dem Wasser-

1) Vgl. ScHröDER, Untersuchungen aus dem botan. Institut zu Tübingen, Bd. 2, S. 18.

2) Vgl. Detmer, Landwirthschaftl. Jahrbücher, Bd. 11, S. 230.

3) Literaturzusammenstellungen vergl. an verschiedenen Orten in PFEFrer's Handbuch der Pflanzenphysiologie. 
tropfen, in welchem sich das Untersuchungsobject befindet, Raum gewährt. Will man die Einwirkung von Inductionsströmen auf die Pflanzenzellen studiren, so schraubt man die Enden der vom Inductionsapparat kommenden Drähte am Objectträger fest und kann nun die mikroskopischen Beobachtungen anstellen, während die Ströme ihren Einfluss auf die Zelleu geltend machen. Es ist bei physiologischen Untersuchungen wichtig, die Stärke der Ströme reguliren zu können, und daher verwende man Inductionsapparate, wie sie für medicinische Zwecke von den Mechanikern geliefert werden. Diese Apparate sind gewöhnlich sammt dem stromerregenden Elemente in einem geeigneten Kasten angebracht. Die Regulirung der Stromstärke kann auch mittelst des Schlittenapparats von Du Bois Rermond vorgenommen werden (vgl. Fig. 46), bei dessen Benutzung man die Drahtenden der Hauptspirale $A$ mit dem Elektromotor und dem Rheotom verbindet, während von der Nebenspirale $B$ aus die Verbindung mit den Klemmschrauben des Objectträgers hergestellt wird. Gewöhnlich ist der Schlittenapparat mit dem Rheotom (meistens einem magnetischen Hammer), der in Fig. 46 nicht dargestellt ist, verbunden. Als stromerregendes Element verwendet man zweckmässig das in Fig. 47 abgebildete Chromsäuretauchelement. Die Flasche enthält eine Lösung, die man darstellt, indem man $92 \mathrm{~g}$ gepulvertes doppeltchromsaures Kali mit $93,5 \mathrm{ccm}$ concentrirter Schwefelsäure, das Pulver allmählich zu-

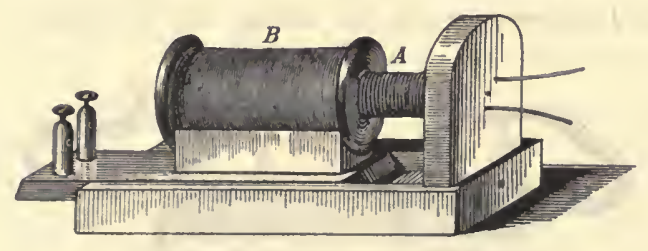

Fig. 46. Inductionsapparat.

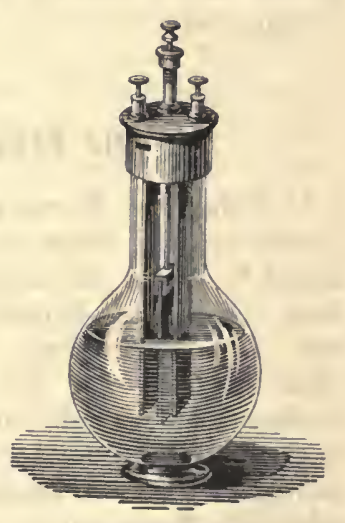

Fig. 47. Chromsaureelement.

setzend, mischt. Unter Umrühren löst man die Masse dann in $900 \mathrm{ccm}$ Wasser. Die Zinkplatte des Elementes kann zwischen den Kohlenplatten mittelst eines Stabes eingesenkt oder, wenn der Apparat ausser Thätigkeit gesetzt werden soll, über das Flüssigkeitsniveau emporgehoben werden.

Bei Versuchen mit den Blättern von Elodea canadensis fand ich, dass schwächere Inductionsströme die Protoplasmabewegung in den Zellen sistirten; nach Aufhebung des Stromes stellte sich dieselbe allmählich wieder ein. Stärkere Inductionsströme sistirten die Protoplasmabewegung in einer Zelle für immer. Da stärkere Ströme die Zellen tödten und der abgestorbene Zustand des Protoplasmas leicht daran kenntlich ist, dass dasselbe permeabel für manche Stoffe (z. B. Farbstoffe) wird, die es im lebenden Zustande nicht durchlässt, so würde es instructiv sein, auf Haare der Staubfäden von Tradescantia elektrische Ströme einwirken zu lassen. Das Absterben der Zellen müsste sich leicht an dem Farbstoffaustritt aus dem Zellsaft, resp. aus den Zellen feststellen lassen. Bei Untersuchungen über den Einfluss elektrischer Ströme auf Pflanzenzellen 
achte man auch auf die Formänderungen, welche das Protoplasma unter der Einwirkung der Ströme erleidet 1).

Lehrreich ist es ferner, das folgende Experiment auszuführen ${ }^{2}$ ). Man legt zwei Blattstïcke von Begonia manicata, die einige $\mathrm{cm}$ Länge besitzen, auf eine Glasplatte. Durch das eine Blattstück schickt man nun etwa 15 Minuten lang einen nicht zu schwachen Inductionsstrom, indem man dio Elektroden (kleine Metallstücke) den beiden Enden des Blattstreifens auflegt. Das zweite Blattstück dient nur als Vergleichsobject. Nach der angegebenen Zeit gelangen beide Blattstreifen in ein verschlossenes Glas. Der nicht elektrisirte Pflanzentheil bleibt grün und frisch; der elektrisirte bräunt sich alsbald, verliert seinen Turgor und wird schlaff, weil der Inductionsstrom das Protoplasma seiner Zellen getödtet hat.

\section{Die Einwirkung von Giften anf die Pflanzen.}

Bei Untersuchungen über die Frage, ob diese oder jene Stoffe sich den Pflanzenzellen gegenüber giftig verhalten, benutzt man zweckunässig Samen. Freilich ist immer zu beachten, dass ein Stoff, wenn er das Leben einer Pflanzenart schädigt oder vernichtet, darum noch nicht als Gift für alle Gewächse angesehen werden darf. Handelt es sich z. B. darum, die Wirkung des Sublimats, des Kupfervitriols, der Salicylsäure, der Carbolsäure, der Citronensäure, des Atropins, des salzsauren Chinins, des Kochsalzes etc. auf Pflanzen zu prüfen, so stellt man sich $0,1-, 0,2-, 0,5-, 1,0$-procentige oder verdünntere, resp. concentrirtere Lösungen dieser Stoffe her, bringt dieselben in kleine Gläser und legt eine nicht zu kleine Anzahl Erbsensamen oder Weizenkörner in die Flüssigkeiten. Nach 24 Stunden werden die gequollenen Untersuchungsobjecte auf flachen Schalen mit etwas Wasser in Contact gebracht oder in feuchtes Sägemehl gelegt. Man stellt nun fest, wie viele Samen in bestimmter Zeit keimen, und welche Länge die Keimtheile im Vergleich zu denjenigen solcher Keimptlanzen erreichen, die sich von Anfang an unter durchaus normalen Verhältnissen entwickelten. So fand ich z. B., dass 0,1-proc. Salicylsäurelösungen schon äusserst giftig auf Erbsen einwirkten ${ }^{3}$ ).

Man cultivire ferner Keimpflanzen von Pisum in flachen Schalen, indem man dafür sorgt, dass dic Cotyledonen stets bis etwa zur Hälfte vom Wasser bedeckt sind. Nach einigen Tagen bestimmt man die Länge der Wurzel- sowie Stengeltheile der Keimlinge, ersetzt das Wasser durch Lösungen verschiedener Stoffe von bekannter Concentration und lässt die Keimpflanzen 24 Stunden lang mit der Flüssigkeit in Contact. Dann misst man die Länge der Keimtheile wieder, bringt die Untersuchungsobjecte aufs Neue mit reinem Wasser in Berührung und ermittelt, ob Wachsthun derselben eintritt oder nicht. Nach meinen Erfalırungen heben manche Gifte das Wachsen der Keimptlanzen für

1) Bei den Untersuchungen über den Einfluss der Elektricität auf Pflanzen wird man fernerhin, um zu völlig einwurfsfreien Resultaten $z u$ gelangen, bemüht sein müssen, unpolarisirbare Elektroden zll verwenden. Vgl. über dieselben die Abschnitte über elektromotorische Wirkıngen an Pflanzen.

2) Vgl. Detakk, Botan. Zeitung, 1886, Nr. 30.

3) Vgl. Detwer, Landwirthschl.' Jahrbiicher, Bd. 10, S. 733. 
immer auf; andere sistiren dasselbe freilich auch, aber die Untersuchungsobjecte beginnen doch ilure Entwickelung wieder, wenn sie nachträglich mit destillirtem Wasser in Berührung gebracht werden.

Ich habe ferner gequollene Samen von Pisum sativum auf flachen Glasschalen mit etwas Wasser in Berührung gebracht und, nachdem noch ein Glas mit Chloroform neben der Schale aufgestellt. worden war, das Ganze mit einer Glasglocke bedeckt. Bei nicht zu niederer Temperatur $\left(18^{0}\right.$ C.) keimte kein Same $\left.{ }^{1}\right)$. Die giftige Wirkung des Chloroforms auf Pflanzenzellen kann man auch leicht in Vorlesungen demonstriren, wenn man in eine flache Schale Chloroform giesst und diese sowie ein Blatt von Begonia manicata, das mit seinem Stiel in Wasser eintaucht, unter eine Glasglocke stellt. (Vgl. Fig. 48.) Die Blattzellen sterben alsbald ab. Das Blatt wird missfarbig, indem die zu Grunde gehenden Protoplasmamassen für die Säure des Zellsaftes permeabel werden, so dass eine Zersetzung des Chlorophyllfarbstoffes erfolgen kann ${ }^{2}$ ).

Will man untersuchen, ob bestimmte Stoffe die Entwickelung von Penicillium oder von Bacterien beeinträchtigen oder völlig aufheben, so stellt man die Culturen in derselben Weise an, wie es unter 35 und 38 angegeben ist, nur mit dem Unterschiede, dass den Nährlösungen bestimmte Mengen derjenigen Körper (z. B. Salicylsäure, Sublimat etc.) zugesetzt werden, deren Wirkung auf die Pflanzen geprüft werden soll. Controlversuche ohne Zusatz der Gifte zu den Nährlösungen sind natürlich nicht zu unterlassen.

So habe ich z. B. Pasteur'sche Nährlösung, die Rohrzucker enthielt

Fig. 48. Apparat zur Untersuchung der Einwirkung des Chloroforms auf Pflanzentheile.

(vgl. über Darstellung der Lösung unter 18), einmal ohne weiteren Zusatz und in einem anderen Falle mit einem Zusatz von $0,2 \%$ Salicylsäure 8 Tage lang sich selbst überlassen. Die letztere Flüssigkeit war nach Verlauf dieser Zeit noch klar; in der ersteren hatte sich eine bedeutende Bacterienvegetation entwickelt, und sie erschien daher sehr trübe. Um die Wirkung von Giften auf Spirogyra oder auf andere Algen festzustellen, bringt man die Fäden derselben einfach in die betreffenden Lösungen, z. B. in solche von Kupfersalzen, Oxalsäure etc. ${ }^{3}$ ). Sind die Lösungen nicht gar zu concentrirt, so dass die Giftwirkung langsam eintritt, dann erfolgt meist zunächst ein Einschrumpfen des Kerns und Verquellung der Chlorophyllkörper.

1.) Vgl. Detaker, Wollny's Forschungen auf dem Gebiete der Agriculturphysik, Bd. 5, S. 253.

2) Vgl. DetMer, Botan. Zeitung, 1886, Nr. 30.

3) Vgl. Loww, Flora, 1892, Heft 3, S. 374 und 386. 


\section{Elementare Molekularvorgänge in den Pflanzen.}

\section{Der Imbibitionsprocess.}

Wir stellen einen zarten Querschnitt aus dem Stengel einer jungen Laminaria her. Bei mikroskopischer Untersuchung des in Alkohol liegenden Objects ist wenig von den Structurverhältnissen zu sehen. Dieselben treten aber auf Wasserzusatz deutlich hervor. Wir unterscheiden die Aussenrinde, deren Zellen braune Membranen besitzen, die sog. Innenrinde, welche die Hauptmasse des Gewebes bildet, und deren Zellmembranen farblos sind. In der Mitte des Querschnitts sehen wir das aus schlauchförmigen Zellen bestehende Markgewebe. Wenn man $\mathrm{zu}$ den in Alkohol liegenden Laminariastücken Wasser treten lässt, so kann man durch mikroskopische Beobachtung feststellen, dass das Beobachtungsmaterial im Moment der Wasseraufnahme eine bedeutende Volumenzunahme erfälırt. Ebenso kann man sich von dieser letzteren überzeugen, wenn man einerseits die Dimensionsverhältnisse trockner, andererseits diejenigen der nämlichen mit Wasser durchtränkten Stücke von Laminariastielen durch Messung mit dem Millimetermaassstab ermittelt. Die Laminariasubstanz ist also quellungsfähig, und der Vorgang, durch den die Quellung zu Stande kommt, wird als Imbibition bezeichnet. Die Volumenzunahme, resp. Quellung der sich mit Wasser in Contact befindenden Laminariastücke geht aber nicht bis ins Unendliche weiter, sondern sie ist eine begrenzte, und dieser Umstand ist von besonderer Wichtigkeit, denn derselbe lehrt, dass ein Laminariastück, dem sich die organisirten pflanzlichen Gebilde überhaupt ähnlich verhalten, in Contact mit Wasser von gewöhnlicher Temperatur ganz andere Erscheinungen zeigt, wie z. B. Gunmi.

Wird ein Stück Laminarialaub, dessen Gewicht im trockenen Zustande bekannt ist, in Wasser gelegt und nach Verlauf bestimmter Zeitintervalle (z. B. alle 8 Minuten) aus der Flüssigkeit herausgenommen, mit Fliesspapier abgetrocknet und gewogen, so ergiebt sich, dass die Wasseraufnahme seitens des Pflanzentheils in der Zeiteinheit zunächst eine rapide ist, allmählich eine Verlangsamung erfährt und schliesslich aufhört. Hängt man das mit Wasser imbibirte Stück Laminarialaub mittelst eines Platindrahts an der freien Luft auf und bestimmt $a b$ und zul (vielleicht alle halbe Stunde) das Gewicht des Untersuchungsobjects, so findet man, dass in der Zeiteinheit zunächst viel, später immer weniger Wasser verdunstet.

Einige geschälte Erbsensamen werden in Wasser von etwa $5^{\circ} \mathrm{C}$. gelegt. Ferner legt man geschälte Erbsensamen, die möglichst genau dasselbe Gewicht wie die ersteren besitzen, in Wasser von etwa $20^{\circ} \mathrm{C}$. Nach Verlauf von 4 Stunden werden die abgetrockneten Samen wieder gewogen. Es ergiebt sich, dass die Samen bei der höheren Temperatur mehr Wasser als bei niederer Temperatur aufgenommen haben; höhere Temperatur beschleunigt also den Verlauf der Quellung. Wenn man gleiche Mengen geschälter Erbsen einerseits in Wasser, andererseits in eine 10- oder 20-proc. Kochsalzlösung legt, so lässt sich leicht durch nach Verlauf von einigen Stunden vorgenommene Wägungen feststellen, 
dass die Quellung in Salzlösungen nicht so schnell wie in reinem Wasser vor sich gelit.

Will man Untersuchungen über die Volumenzunahme anstellen, welche Samen oder Holzwürfel von verschiedenen Pflanzen bei der Quellung erfahren, so bringt man die Untersuchungsobjecte zunächst im trockenen Zustande in einen schmalen Glascylinder, dessen Volumen bis zu einer am oberen Theile befindlichen Marke genau bekannu ist. Man lässt nun verdünnten Alkohol aus einer Bürette bis zur Marke in den Cylinder einfliessen und kann unter Berücksichtigung der Menge der erforderlichen Flüssigkeit dann leicht das Volumen der Pflanzentheile berechnen. Bei der Volumenbestimmung der gequollenen Samen oder Hölzer benutzt man nicht verdünnten Alkohol, sondern Wasser. Bei vergleichenden Untersuchungen über die Gewichts- und Volumenzunahme, welche Pflanzentheile bei der Quellung erfahren, wird man oft, zumal bei Experimenten mit Hölzern, constatiren können, dass die factische Volumenzunahme der Untersuchungsobjecte keineswegs dem Volumen der aufgenommenen Wassermenge entspricht. Diese Thatsache ist auch durchaus verständlich, wenn man bedenkt, dass die Volumenzunahme quellenden Holzes nur durch die Imbibition der festen Holzsubstanz mit Wasser zu Stande kommt, während die Füllung der Lumina der Holzelemente mit Flüssigkeit keine Volumenzunahme des Untersuchungsmaterials zur Folge haben kann. Die Experimente, bei denen man gleichzeitig die Gewichts- und Volumenzunahme ein und desselben Holzstücks bei der Quellung feststellt, sind insofern besonders lehrreich, als sie keinen Zweifel darüber bestehen lassen, dass die Imbibition keineswegs mit der Capillarität verglichen werden kann. Wenn Flüssigkeiten in Capillaren übergehen, so dringen sie immer in präformirte Hohlräume ein; die Capillarität ruft also keine Volumenzunahme der Flüssigkeit aufnehmenden Massen hervor. Beim Zustandekommen der Imbibition dringen die Flüssigkeitsmoleküle $z$ wischen die Micellen der quellenden Körper ein; sie schaffen sich dabei selbst erst Raum zwischen den Micellen, und dadurch wird eben die Volumenzunahme quellender Substanzen herbeigeführt.

Quellendes Holz dehnt sich in der Richtnng des Radius und des Umfanges weit stärker aus als in der Richtung der Axe. Wenn man die Dimensionsverhältnisse ziemlich grosser walzenförmiger Holzstücke einerseits im trockenen, andererseits im gequollenen Zustande mit Hülfe eines Millimetermaassstabes feststellt, so kann man diese Thatsache leicht constatiren. Man benutze $\mathrm{zu}$ diesen Versuchen etwa $100 \mathrm{~mm}$ lange und $80 \mathrm{~mm}$ Durchmesser besitzende Holzstücke.

Sehr energische Quellungserscheinungen, die schliesslich mit der Zerstörung der Molekularstructur endigen, kann man z. B. an Stärkekörnern durch höhere Temperatur, Säuren, sowie Alkalien hervorrufen. Wird Kartoffelstärke auf dem Objectträger unter Ersatz des verdunstenden Wassers vorsichtig über einer Spiritus- oder Gasflamme erhitzt, so tritt eine sehr bedeutende Volumenzunahme der Körner ein, und, bei etwa $70^{\circ}$ C. sind sie zu glashellen Massen, deren Begrenzung schwer zu erkennen ist, verquollen.

Lässt man zu Kartoffelstärke, die auf dem Objectträger in Wasser liegt, vom Deckglasrande aus Kalilauge oder Schwefelsäure treten, und sorgt man dafür, dass die Reagentien ihren Einfluss sehr allmählich auf das Untersuchungsobject geltend machen, so sieht man die Schichtung der Körner bei beginnender Einwirkung deutlicher hervortreten, dann aber schwinden die Schichtungserscheinungen, die Körner erfahren eine 
bedeutende Volumenzunahme und verquellen endlich zu glashellen Massen. Dringen Wassertheilchen in imbibitionsfähige Körper ein, so muss nothwendiger Weise in Folge der energischen Anziehungskraft, welche von Seiten der Micellen auf die Flüssigkeit ausgeübt wird, eine Verdichtung derselben eintreten. Wenn aber solche Verdichtungsprocesse zu Stande kommen, so wird dabei Wärme frei, und in der That lässt sich zeigen, dass der Vorgang der Imbibition mit Wärmebildung verbunden ist. Ich habe $100 \mathrm{~g}$ Kartoffelstärke oder $100 \mathrm{~g}$ Erbsenmehl von bekannter Temperatur in Glascylindern mit relativ wenig Wasser von genau der nämlichen Temperatur vermischt. Am besten ist es, das Wasser aus einer Bürette zu der Stärke treten zu lassen. Die Temperatur der Gemische stieg sofort um etwa 1,50 C. Die Temperatursteigerung betrug aber, wie ich fand, $5^{0}$ C., wenn die Kartoffelstärke, nachdem sie zuvor durch Erwärmen ausgetrocknet worden war und sich wieder abgekühlt hatte, mit wenig Wasser vermischt wurde.

Bei dem Vorgange der Imbibition wird aber auch Arbeit geleistet, und zwar innere (welche die Micellen von einander entfernt), sowie äussere (durch welche äussere Widerstände, die sich der Volumenzunahme des quellenden Körpers entgegenstellen, überwunden werden können). Um in der Vorlesung über Pflanzenphysiologie zu demonstriren, dass bei der Quellung äussere Arbeit geleistet wird, benutze ich den in Fig. 49 dargestellten Apparat ${ }^{1}$ ). Auf der einen Seite des Holzgestelles ist mittelst einer

Schraube ein mit

Holzfuss versehener Glascylinder $g$, der eine Höhe von $10 \mathrm{~cm}$ und einen

Durchmesser von $35 \mathrm{~mm}$ besitzt, befestigt, welcher zur Aufnalime der quellenden Samen und des zur Quellung nöthigen Wassers dient. Fiür wasserdich-

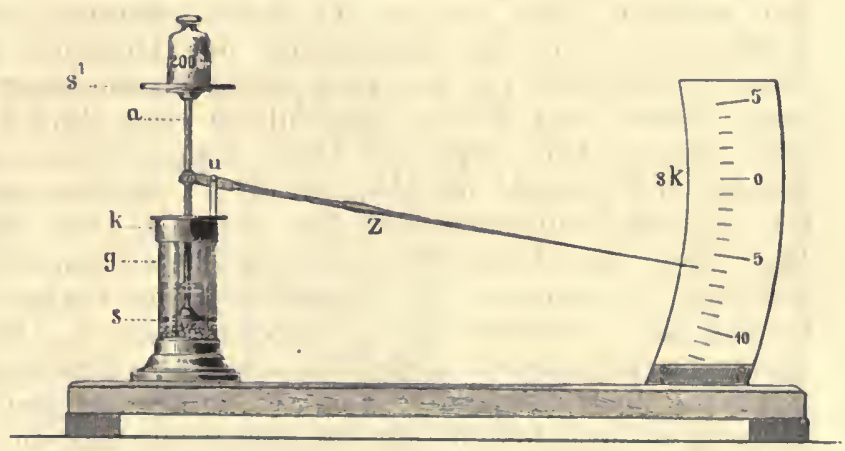

Fig. 49. Apparat zur Messung der äusseren Arbeit, welche quellende Samen leisten können.

\section{ten Verschluss}

am unteren Ende ist durch Verkittung des Bodens mit Siegellack gesorgt. In dem Glascylinder bewegt sich ein aus Metall gearbeiteter Stempel, dessen $16 \mathrm{~cm}$ lange Axe $a$ vertical gerichtet ist und an ihrem unteren Ende eine kreisrunde Scheibe $S$ trägt, welche sich in der Röhre bequem hin - und hersehieben lässt und der Samenschicht unmittelbar aufliegt. An ilırem oberen Ende trägt die Axe eine Messingscheibe $s^{\prime}$, die zum Tragen der zur Druckleistung dienenden Gewichte bestimmt ist. Zum Verschluss des Cylinders dient die Metallkapsel $k$, durch

1) Literatur: SAcirs, Handbuch d. Experimentalphysiologie d. Pflanzen, 1865, S. 431; Detmer, Vergl. Physiologie d. Keimungsprocesses d. Samen, 1880, S. 78 und 290; REINKE in den v. HANsTEIs herausgegebenen botanischen Abhandlungen, Bd. 4, Heft 1; Schufichert, Naturwissenschl. Woehenschrift, Bd. 7. 
deren Mitte die verticale Axe $a$ geführt ist, so dass sich die Kapsel frei um dieselbe drehen lässt. Zwischen der Kapsel $k$ und der Scheibe $s^{\prime}$ ist an dem verticalen Metallstab der horizontale Zeigerhebel $z$ befestigt, welcher mittelst einer Scliraube in verschiedener Höhe an der $\Lambda x e$ eingestellt werden kann und bei $u$ seinen Unterstützungspunkt hat. Der kurze Arm dieses Zeigerhebels hat eine Länge von $2 \mathrm{~cm}$, der lange Arm eine solche von ca. $33 \mathrm{~cm}$. Der Zeiger reicht bis zu dem rechts auf dem Gestell angebrachten Kreisabschnitt sk, welchem eine Centimeterscala aufgetragen ist. Jede Aufwärtsbewegung des Stempels in Folge des Druckes quellender Samen bewirkt eine Abwärtsbewegung des Hebels an der Scala und ermöglicht in entsprechend vergrössertem Maassstabe die Feststellung der Bewegung des Stempels in Folge der Quellung. Als der beschriebene Apparat z. B. mit $10 \mathrm{~g}$ kleiner Erbsen beschickt worden war, vermochten diese beim Quellen noch einen Widerstand von $1000 \mathrm{~g}$ zu überwinden.

\section{5\%. Die Diffusion und die Endosmose.}

Wenn gelöste Stoffe an irgend einer Stelle im Protoplasma oder im Zellsafte einer Zelle auftreten, so können sie sich von hier aus über das gesammte Protoplasma oder über den gesammten Zellsaft verbreiten. Bei diesem Vorgange spielen die bekannten Diffusionsprocesse eine wichtige Rolle, aber es ist sicher lehrreich, sich davon zu überzeugen, dass die Geschwindigkeit der Diffusion keineswegs immer eine so erhebliche ist, wie man häufig anzunehmen pflegt. Man stellt einen hohen, mit Wasser angefüllten Glascylinder auf einem zitterfreien Tisehe auf, wirft ein Stück doppelt-chromsauren Kalis in das Wasser und bedeckt die Mündung des Cylinders mit einer Glasplatte. Das doppelt-chromsaure Kali löst sich auf, aber selbst nach mehreren Tagen sind die oberen Flüssigkeitsschichten nur schwach gelb gefärbt, während die unteren die charakteristische Farbe einer concentrirten Lösung des benutzten Salzes erkennen lassen. Bei der Ausführung unseres Experimentes sind keineswegs alle Bedingungen, welche Veranlassung zur Entstehung von Strömungen in der Flüssigkeit geben können, ausgeschlossen; um so deutlicher tritt die Thatsache hervor, dass die Verbreitung gelöster Stoffe durch Diffusion nicht mit besonderer Geschwindigkeit vor sich geht.

Unter Berücksichtigung dieses Verhältnisses gewinnen solche Momente an Gewicht, durch welche die Ausbreitung gelöster Stoffe im Protoplasma und im Zellsaft eine Beschleunigung erfahren kann, und es müssen in manchen Fällen die Protoplasmaströmungen sowie die Bewegungen, denen die Pflanzentheile durch den Einfluss des Windes ausgesetzt sind, als solche Umstände angesehen werden.

Abgesehen von der Diffusion spielen bei der Stoffbewegung in der Pflanze in erster Linie osmotische Vorgänge eine sehr wichtige Rolle, und wir wollen ihnen daher unsere Aufmerksamkeit zuwenden.

Ein etwa $8 \mathrm{~cm}$ langes und $3 \mathrm{~cm}$ weites Glasrohr wird an seinem einen Ende mit einem Stück Schweinsblase versehlossen. Ein durchaus dichter Verschluss kann leicht erreicht werden, wenn man die Membran im feuchten Zustande über das Ende des Glasrohres bringt und sie mittelst eines Bindfadens oder besser noch mittelst einer Gummischnur festbindet. Das Glasrohr wird nun mit fast con- 
centrirter Rohrzuckerlösung völlig angefüllt und sein oberes Ende mit Hülfe eines durchbohrten Kautschukkorkes verschlossen, in dessen Bohrung ein langes Glasrohr (Steigrohr) eingeführt worden ist. Markirt man den Stand der Rohrzuckerlösung in dem Steigrohr und taucht man den unteren Theil des Apparates in destillirtes Wasser ein, so findet man, dass die Flüssigkeit im Steigrohre alsbald im Steigen begriffen ist. Das Wasser tritt auf osmotischem Wege dureh die Schweinsblase in die Zuckerlösung über, und wenngleich auch eine gewisse Menge dieser letzteren umgekehrt in das Wasser übergreht, so ist doch die in den Apparat einströmende Flüssigkeitsquantität grösser als die ausströmende; dadurch muss eine Volumenzunahme der Flüssigkeit im $\Lambda$ pparat erfolgen. Wird unsere Vorrichtung mit ihrem unteren Ende bestimmte Zeit lang (1-2 Stunden) abwechselnd in Wasser von gewöhnlicher Zimmertemperatur und in warmes Wasser (z. B. solches von $30^{\circ}$ C.) eingetaucht, so kann man durch Feststellung der Erhebung der Flüssigkeit im Steigrohr unter den verschiedenen Bedingungen leicht constatiren, dass die osmotischen Processe bei löherer Temperatur schneller als bei niederer vor sich gehen. Eine Verlangsamung der osmotischen Processe macht sich aber geltend, wie olne Sch wierigkeit zu ermitteln ist, wenn der untere Theil unseres Apparates sich nicht mit reinem Wasser, sondern z. B. mit einer 20proc. Kochsalzlösung in Berührung befindet ${ }^{1}$ ).

Für die richtige Beurtheilung zahlreicher physiologischer Erscheinungen, zumal soleher, welche durch den Turgor bedingt werden, ist es von grosser Bedeutung, sich davon

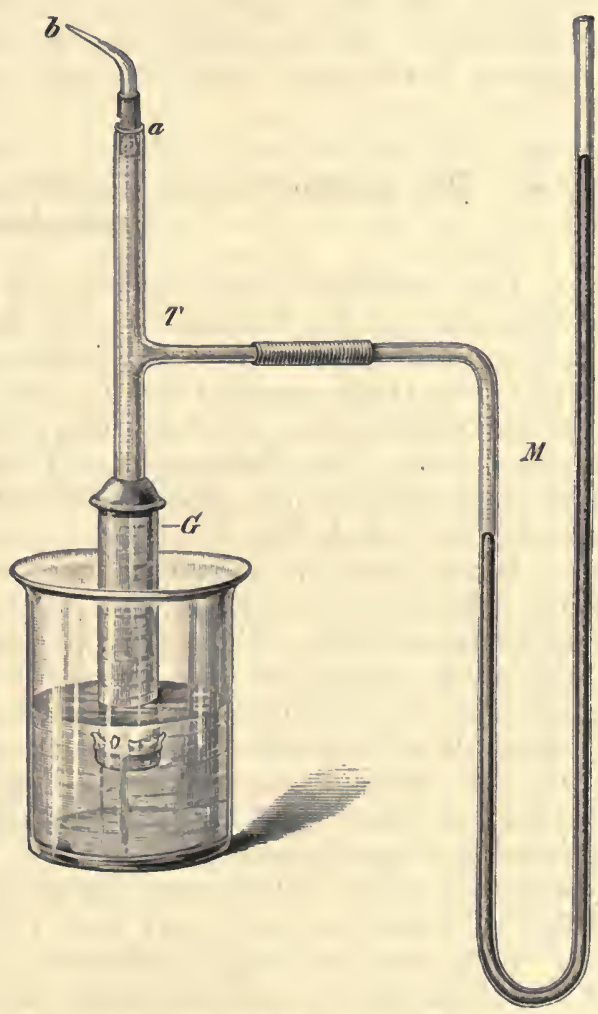

Fig. 50. Apparat zum Nachweis der dureh osmotische Processe erzeugten Druckwirkungen. zu überzeugen, dass durch osmotische Processe bedeutende Druckwirkungen erzielt werden können. Man construire sich z. B. den in Fig. 50 abgebildeten Apparat. Das $10 \mathrm{~cm}$ lange und $2 \mathrm{~cm}$ weite Glasrohr $G$ ist an seinem unteren Ende, mit welchem es in Wasser eintaucht, mit Schweinsblase verschlossen. Durch die Bohrung des das obere Ende des Glasrohres verschliessenden Kautschukkorkes wird das $t$-förmige Rohr $T$ eingeführt, dessen

1) Vgl. Detmer, Beiträge zur Theorie des Wurzeldrucks, in Preyer's Sammlung physiologischer Ábhandlungen, Bd. 1, H. 8, S. 29, Jena 1877. 
verticaler Arm bei $a$ mit einem kleinen, bei $b$ zu einer Spitze ausgezogenen Glasrohr in Verbindung steht. Der horizontale Arm des $t$ förmigen Rohres wird dagegen mittelst eines dickwandigen Kautschukschlauches, den man noch mit Draht umwickelt, mit dem Manometer $M$ verbunden. In diesem letzteren befindet sich Quecksilber; der übrige Theil des Apparates wird völlig nit fast concentrirter Rolırzuckerlösung angefüllt und die bei $b$ befindliche Spitze des kleinen Glasrohres schliesslich zugeschmolzen. Die Rohrzuckerlösung zieht bedeutende Wassermengen auf osmotischem Wege an. Dadurch entstelit ein Druck in Apparat, der das Quecksilber in Manometer zum Steigen bringt, und ich fand z. B., dass bei einem Experiment nach Verlauf von drei Tagen das Quecksilber in dem einen Schenkel des Manometers $47 \mathrm{~cm}$ höher als im anderen stand. Der Druck im Apparat betrug also erheblich mehr als eine halbe Atmosphäre ${ }^{1}$ ).

\section{Die diosmotisehen Eigensehaften der Zellhaut und des Protoplasmas.}

Ein ausgezeiclnetes Object zur Feststellung der diosmotischen Eigenschaften der Zellhaut sowie des Hyaloplasmas bietet sich uns in den Staubfadenhaaren von Tradescantia dar. Man kann die Haare leicht mit Hülfe einer Pincette vom Filament abtrennen und findet bei mikroskopischer Beobachtung, dass jedes Haar aus einer Zellreihe besteht. Die Zellhaut, das Protoplasma, der Zellkern und endlich der schön violett gefärbte Zellsaft sind an jeder Zelle leicht wahızunehmen. (Vgl. Fig. 38.)

Wir lassen nun vom Deckglasrande aus Glycerin oder auch mehr oder minder concentrirte Zucker-oder Kochsalzlösungen zu den Tradescantiahaaren treten. Diese Flüssigkeiten entziehen dem \%ellsaft Wasser, und daher contrahirt sich das Protoplasma, so dass Zwischenräume zwischen der Zellhaut und der Oberfläche des Plasmakörpers entstehen. Wir haben die Zellen aus dem turgescirenden in den plasmolytischen Zustand übergeführt. Durch unser Experiment ist aber ferner die wichtige Thatsache constatirt, dass das Hyaloplasma des lebenden Protoplasmas impermeabel für den im Zellsaft der Tradescantiahaarzellen aufgelösten Farbstoff sein muss, da dieser nach erfolgter Plasmolyse nicht aus dem Protoplasma austritt.

Eine ganz andere Erscheinung beobachten wir, wenn wir auf Staubfadenhaare von Tradescantia absoluten Alkoliol einwirken lassen und die Zellen dadurch tödten. Der violette Zellsaft geht nun, da das Hyaloplasma permeabel für den Farbstoff geworden ist, in das Plasma über. Dieses sowie zumal der Zellkern färben sich intensiv, und es kann sogar gefärbte Flïssigkeit aus den Zellen in deren Umgebung austreten. Sehr lehrreich ist es ferner, auf Zellen mit ungefärbtem Zellsaft, z. B. auf Epidermiszellen von Tradescantiablättern, Plasmolyse bedingende und Farbstoffe enthaltende Flüssigkeiten einwirken zu lassen.

Icl stellte solche Versuche z. B. in folgender Weise an. Epidermisstïckchen von Tradescantiablättern wurden durch Kochsalzlösung in angegebener Weise in den plasmolytischen Zustand versetzt und dann

1) Näheres bei PfwFfer, Osmotische Untersuchungen, 1877. 
in den durch Zerquetschen ziemlich dunkel gefärbter Kirschen gewommenen Saft gelegt. Der Farbstoff kann die Zellhaut passiren, er dringt in den Zwischenraum $\mathrm{z}$ wischen dieser und dem Plasma ein, aber das Plasma selbst nimmt ilhn nicht auf. Werden Epidermiszellen ron Tradescantia zunächst plasmolytisch gemacht, tödtet man die Zellen dann durch Eintauchen der Epidermisstücke in heisses Wasser und legt man sie nun in Kirschsaft, so färben sich das Plasma und der Zcllkern ziemlich intensiv, weil das getödtete Protoplasma leicht permeabel für viele Stoffe ist, die es im lebensthätigen Zustande nicht aufzunehmen vermag.

Will man den Nachweis liefern, dass das Protoplasma im normalen Zustande impermeabel, nach den Absterben aber permeabel für Zucker ist, so werden einerseits sorgfältig abgespülte Stücke rother Rüben direct, andererseits aber solche Stïcke nach dem Abtödten durch heisses Wasser in destillirtes Wasser von gewöhnlicher Zimmertemperatur übertragen. Entnimmt man den Flüssigkeiten nach einigen Stunden kleine Proben. versetzt man sie mit einigen Tropfen verdünnter Salzsäure und kocht sie kurze Zeit lang, so lässt sich in derjenigen Flüssigkeit, die sich mit den getödteten Rübenstücken in Contact befunden hatte, das Vorhandensein von Zucker leicht mit Hülfe von FEHLING'scher Lösung feststellen, während die andere Flüssigkeit keinen Zucker enthält.

Um den Nachweis zu liefern, dass das normale Hyaloplasma auch häufig impermeabel für Mineralstoffe ist, stellen wir uns 2-4-proc. Lösungen von Chlornatrium oder Kalisalpeter her. In diese Lösungen bringen wir Staubfadenhaare von Tradescantia oder Epidermisstreifen von dem Mittelnerv der Unterseite des Blattes von Tradescantia discolor. Die Zellen dieses letzteren im Gewächshause zu cultivirenden Objectes enthalten gefärbten Zcllsaft, und es ist dasselbe in jeder Jahreszeit zu haben. Die Lösungen dringen durch die Zellhäute in die Zellen ein, es erfolgt im Laufe von 1-2 Stunden Plasmolyse, und diese bleibt bestehen, wenn die Untersuchungsobjecte noch mehrere Stunden lang in den Salzlösungen verweilen. Diese letztere Erscheinung ist aber gerade von besonderer Wichtigkeit für uns, denn wäre das Plasma unter den bezeiclineten Umständen permeabel für Kochsalz oder Salpeter, so müsste sich mit wachsender osmotischer Leistungsfähigkeit des Zellsaftes der Protoplasmakörper in den Zellen allmählich wieder aus(lehnen ${ }^{1}$ ).

Die diosmotischen Eigenschaften des lebenden Hyaloplasmas einerund der Zellhant andererseits sind nach dem, was wir wissen, sehr verschiedene. Jenes ist gewöhnlich nicht permeabel für Farbstofte, Zucker etc., während sich die Zellhaut den genannten Stoffen gegenüber ganz ähnlich wie vegetabilisches Pergament verhält. Somit gewälirt, es Interesse, einige Versuche anzustellen, die uns Aufschluss über die Permeabilität dieses letzteren Materials bei der Osmose geben. Als Dialysator kann man ein weites, an seinem unteren Ende mit Pergamentpapier verschlossenes Glasrohr verwenden. Ich habe dem Apparat bei meinen Experimenten der bequemeren Handhabung wegen eine etwas andere Ein-

1) Literatur: Vgl. SAcus, Experimentalphysiologie d. Pflanzen, 1865, S. 447, wo namentlich die wiehtigen Arbeiten NïGrLI's besprochen sind. Ferner vergl DE VRIEs, Archives Néerlandaises, 1871, T. 6, und Prisgsilfin's Jahrbücher, Bd. 16, S. 588; DetMer, Journal f. Landwirthschaft, 27. Jahrgang, S. 380, sowic Botan. Zeitung, 1886, Nr. 30. 
richtung gegeben. Ein dickwandiges Glasrohr von $80 \mathrm{~mm}$ Länge und $40 \mathrm{~mm}$ Weite trägt an seinem unteren Ende einen Messingring, der aussen mit einer Schraubenwindung versehen ist. Der unteren Fläche dieses Ringes liegt die eine Seite der Membran aus vegetabilischem Pergament dicht an, während die andere Seite derselben sich in Berührung mit der nach oben gewandten Fläche eines zweiten, aber ziemlich dünnen Messingringes bofindet. Auf den gesammten unteren Theil des Dialysators kann endlich eine mit einer kreisrunden Oeffnung von $40 \mathrm{~mm}$ Durchmesser versehene Messingklappe aufgeschroben werden. Die frei liegenden Messingtheile des Dialysators sind mit einem geeigneten Lack überzogen. Man stellt den Apparat nun auf kleinen Glasklötzen in einer Krystallisirschale auf, giesst destillirtes Wasser in dieselbe und die Lösung des auf sein osmotisches Verhalten zu prüfenden Stoffes in den Dialysator. Bei Experimenten mit Extracten aus rothen Rüben, Zuckeroder Salzlösungen (z. B. Lösungen von Chlornatrium, salpetersaurem Kali etc.) lässt sich leicht feststellen, dass der Farbstoff, der Zucker sowie die Mineralstoffe im Stande sind, die benutzte Membran zu passiren und in das den Dialysator umgebende Wasser überzugehen.

Weiter ist es nun aber auch mit Rücksicht auf die Thatsache, dass viele Stoffe, welche die Zellhaut zu passiren vermögen, nicht in das Plasma eindringen, von besonderem Interesse, Membranen auf künstlichem Wege herzustellen, durch welche Stoffe, die durch Pergamentpapier diosmosiren, nicht hindurchgehen. Wir bereiten uns 1-proc. Lösungen von Calciumnitrat und Dinatriumphosphat. Diese letztere gelangt in unseren mit Pergamentpapier verschlossenen Dialysator, während jene erstere als Aussenflüssigkeit dient. Es entsteht im vegetabilischen Pergament eine Niederschlagsmembran von Calciumphosphat, und wenn wir der Dinatriumphosphatlösung im Dialysator nach Verlauf einiger Stunden wenige Tropfen einer wässerigen Methylenblaulösung hinzufügen, so ergiebt sich, dass der Farbstoff nicht in die Aussenflüssigkeit übergeht. Bei meinen Experimenten erschien dieselbe z. B. nach 24 Stunden noch durchaus ungefärbt. Entfernt man die im Dialysator vorhandene gefärbte Flüssigkeit, spannt neues Pergamentpapier in den Apparat ein, ersetzt die Aussenflüssigkeit durch reines Wasser und giesst die Methylenblau enthaltende Dinatrinmphosphatlösung wieder in den Dialysator ein, so findet man, dass der Farbstoff jetzt alsbald durch das vegetabilische Pergament in das Wasser übertritt. Bei meinen Versuchen war dasselbe bereits nach 2 Stunden merklich tingirt. Für Chlornatrium sind Niederschlagsmembranen von Calciumphosphat, wovon man sich ja leicht überzeugen kann, permeabel. Die angeführten Experimente haben, was besonders zu betonen ist, nur den Zweck, den Nachweis zu liefern, dass bestimmte Stoffe, die eine Membran passiren können, eine andere Membran häufig nicht zu diosmosiren vermögen. Solche Versuche sind offenbar für die Beurtheilung des Verhaltens bestimmter Stoffe der Zellhaut einer- und dem Protoplasma andererseits gegenüber von besonderem Interesse. $\mathrm{Ob}$ aber ein Körper, der eine künstliche Membran nicht passirt, zugleich nicht im Stande ist, in das Protoplasma einzudringen, muss immer erst durch besondere Beobachtungen ermittelt werden, und mit Bezug auf das Methylenblau ist zu bemerken, dass dasselbe in der That durch das Plasma in das Innere der Zellen übertreten kann.

Werden Exemplare von Elodea canadensis 24 Stunden lang mit einer 0,0008-proc. wässerigen Methylenblaulösung in Berührung belassen (man benutze 1 Liter Flüssigkeit), so ergiebt die mikroskopische Untersuchung 
der Blätter, dass ihr Zellsaft tief blau gefärbt ist. Die Zellen sind nicht abgestorben, denn es ist Protoplasmabewegung in ihnen vorhanden, und man sieht also, dass der Farbstoff die Zellhaut sowie das Plasma passirt haben muss ${ }^{1}$ ).

Nach den Resultaten unserer Untersuchungen zu urtheilen, vermögen manche Stoffe (Farbstoffe, Zuckerarten, Pflanzensäuren, Mineralstoffe) die Hautschichten des Plasmas häufig nicht als solche zu diosmosiren. Damit ist aber nicht gesagt, dass das Hyaloplasma unter allen Umständen impermeabel für die genannten Körper sei. Neuere Beobachtungen verschiedener Forscher, die aber noch keineswegs zum Abschluss gelangt sind, führen vielmehr zu einer anderen Ansicht. Es scheint, dass bestimmte Stoffe, die für gewöhnlich ảas Plasma nicht passiren, dasselbe zu durchwandern vermögen, wenn energische Stoffaccumulationen in den Zellen stattfinden. Das Hyaloplasma verändert auch wahrscheinlich in Folge der Lebensvorgänge selbst und den Bedürfnissen der Zellen entsprechend seine diosmotischen Eigenschaften, aber es wird erst fortgesetzte energische Forschung über diese Verhältnisse Licht verbreiten können.

\section{Der Turgor und die Plasmolyse.}

Die im Zellsaft gelösten Substanzen (Mineralstoffe, organische Säuren, Zuckerarten etc.) befördern auf osmotischem Wege Wasser in das Innere der Zellen. Indem das Volumen des Zellsaftes dadurch mehr und mehr wächst, übt derselbe einen Druck auf das Protoplasma und die Zellhaut aus, welche ihrerseits freilich dehnbar, aber zugleich auch elastisch sind. Die Grösse der 'Turgorausdehnung einer Zelle ist somit abhängig von der Grösse der in ihrem Innern zur Geltung kommenden 'Turgorkraft einer- und der Grösse des Widerstandes der gedehnten Zellschichten (Protoplasma sowie Zellhaut) andererseits ${ }^{2}$ ).

Man kann Apparate construiren, welche in der That gute Dienste leisten, wenn es sich darum handelt, eine unmittelbare Vorstellung vom Wesen des Turgors zu gewinnen. Ich benutze dazu Glasröhren von $80 \mathrm{~mm}$ Länge und $40 \mathrm{~mm}$ Weite. Man verschliesst zunächst die eine Oeffnung einer solchen Rölnre mit einem Stück Schweinsblase, füllt die Röhre mit einer fast concentrirten Rohrzuckerlösung völlig an und bindet auch über das obere Rölırenende ein Stück Schweinsblase. Diese sogen. künstliche Zelle taucht man nun in destillirtes Wasser unter. Die Zuckerlösung zieht auf osmotischem Wege Wasser an, so dass der Zellinhalt, dessen Volumen mehr und mehr wächst. einen immer stärker werdenden Druck auf die Membranstücke geltend macht. Diese wölben sich convex nach aussen vor, üben aber in Folge ihrer Elasticität ihrerseits auch einen Druck auf den Zellinhalt aus, so dass also in unserem Apparat eine beträchtliche Spannung (Turgorspannung) zwischen der Zuckerlösung und den Membranstücken zu Stande kommen muss. Wenn die künstliche Zelle energisch turgescirt, wird sie aus dem Wasser herausgenommen. Man lurchsticht die eine ihrer Membranen mit einer feinen Nadel und wird beobachten, dass sofort ein Flüssigkeitsstrahl aus der erzeugten

1) Vgl. PferFer, Untersuchungen aus d. botan. Institut in Tübingen, Bd. '2, S. 223 u. 302 und Abhandlungen der mathem.-phys. Cl. der K. Sächs. Gesellschaft d. Wiss., Bd. 16 .

2) Speciellere Auseinandersetzungen über das Wesen des Turgors vgl. in meinem Lehrbuch d. Pflanzenphysiologie, 1883, s. 213. 
Oeffnung hervorspritzt, während die Membranen erschlaffen. In der turgescirenden Zelle muss also ein erheblicher Druck bestanden haben.

Sehr lehrreich ist ferner das folgende Experiment, welches man auch bequem in der Vorlesung ausführen kann. Ein Gläschen wird mit verdünnter Ferrocyankaliumlösung angefüllt und ein kleines Stück Kupferchlorid in die Flüssigkeit geworfen. Das Kupferchlorid umgiebt sich sofort mit einer Niederschlagsmembran von Ferrocyankupfer, und indem es Wasser von aussen anzieht, wird diese letztere gedehnt. Es entsteht auf diese Weise eine turgescirende künstliche Zelle (TrauBE'sche Zelle), die aber schnell an Grösse zunimmt und allmählich mehrere cm Länge erreichen kann. Indem nämlich die braune Ferrocyankupfermembran gedehnt wird, treten von innen gelöste Kupferchloridmoleküle, von aussen Ferrocyankaliummoleküle in dieselbe ein. Diese Membranogene gerathen in der Membran mit einander in chemische Wechselwirkung; es resultiren Ferrocyankupfermoleküle, welche das durch Dehnung eingeleitete Wachsthum der Membran thatsächlich herbeiführen ${ }^{1}$ ).

Wenn man zu den Zellen der Staubfadenhaare von Tradescantia, zu den Epidermiszellen der Blätter dieser Pflanze oder zu Spirogyrafäden, die im Wassertropfen auf dem Objectträger liegen, vom Deckglasrande aus Glycerin oder Zuckerlösung treten lässt, so machen sich die unter 58 erwähnten Erscheinungen geltend. Die Zellen gehen aus dem turgescirenden in den plasmolytisclien Zustand über. Ihr Protoplasma löst sich von der Zellwand ab und zieht sich zusammen, indem der Zellsaft sein Wasser nach aussen an die wasseranziehenden Flüssigkeiten (Glycerin, Zuckerlösung) abgiebt. Durch die Plasmolyse gehen die Zellen keineswegs sofort zu Grunde, was sich schlagend aus der. Thatsache ergiebt, dass das Protoplasma plasmolytisch gemachter Zellen der Staubfadenhaare von Tradescantia noch längere Zeit impermeabel für den im Zellsaft gelösten violetten Farbstoff bleibt.

Wir müssen aber auch Versuche anstellen, um den Nachweis dafür beizubringen, dass es leicht möglich ist, aus vielen Geweben bestehende Pflanzentheile aus dem turgescirenden in den plasmolytischen Zustand überzuführen. Wir experimentiren mit jungen Blüthenschäften von Butomus umbellatus und Plantagoarten, mit Blattstielen von Tropaeolum, mit dem etiolirten Epicotyl von Phaseolus oder mit den Hauptwurzeln dieser Pflanze (Keimpflanzen in Sägespänen gezogen). Auf die $50-100 \mathrm{~mm}$ langen Stengel- respect. Wurzelstücke tragen wir in Entfernungen von $40-90 \mathrm{~mm}$ feine Tuschemarken auf. Die Wurzeln werden vor dem Auftragen der Marken sorgsam mit feiner Leinwand abgetrocknet. Wir benutzen beste chinesische Tusche, die wir mit Wasser anreiben. Zum Auftragen der Marken dient ein Marderpinsel, der stets sorgfältig rein zu lıalten ist. Haben wir die Untersuchungsobjecte nach dem Auftragen der Marken einige Minuten in feuchter Luft liegen lassen, um das Adhäriren der Tusche zu sichern, und die Entfernung der Marken mit Hülfe eines Millimetermaasstabes festgestellt, so gelangen die Pflanzentheile in eine 10-proc. wässerige Lösung von Kochsalz oder Kalisalpeter. Sie verlieren in diesen Lösungen ihren Turgor, gehen in den plasmolytischen Zustand über, werden schlaff, und man kann naclı Verlauf kürzerer oder

1) Vgl. Traube in Du Bors-Reymond's und Reichert's Archiv f. Anat. und Physiol., 1867, S. 87. 
längerer Zeit (4-24 Stunden) leicht feststellen, dass die Entfernung der Marken eine weit geringere als bei Beginn der Experimente ist. Die Salzlösungen entziehen den Zellen, ebenso wie dies Glycerin oder Zuckerlösungen thun, Wasser. Der dadurch bedingte Turgorverlust der Zellen führt die Contraction der Gewebe herbei ${ }^{1}$ ).

Verlieren PHanzentheile durch Welken Wasser, so verkürzen sie sich auch hierbei in dem Maasse, in welchem der 'Turgor ihrer Zellen abnimmt. Wir legen in Sägespänen erwachsene Pisumkeimpflanzen, deren Wurzeln eine Länge von etwa $50 \mathrm{~mm}$ erreicht haben, ${ }^{1} /$ \& Stunde lang in Wasser, damit die Wurzelzellen zunächst völlig turgescent werden. Wir trocknen die Wurzeln nun vorsichtig mit einem Leinentuch $\mathrm{ab}$ und tragen eine 'Tuschemarke dicht hinter der Wurzelspitze, eine zweite etwa 25 $\mathrm{mm}$ von dieser entfernt auf die Wurzeln auf. Lüsst man die Wurzeln nun 10 Minuten lang an der Luft welken, so haben sie sich, wie leicht $\mathrm{zu}$ constatiren ist, nicht unerheblich verkürzt. Legt man die Keimpflanzen jetzt in Wasser, so verlängerı sich ihre Wurzeln wieder, und die Entfernung der Marken wird dieselbe wie bei Beginn der Experimente ${ }^{2}$ ).

\section{Dic isotonischen Coëficienten.}

Die Grösse der osmotischen Leistungsfähigkeit einer Zelle ist abhängig von der Qualität und Quantität der im Zellsaft vorhandenen wasseranziehenden Substanzen. Handelt es sich darum, die Bestandtheile des Zellsaftes kennen zu lernen, so werden saftreiche Pflanzentheile (z. B. Blattstiele von Heracleum Spondylium, junge Rheumstengel, Blätter von Crassulaceen etc.) mit Hülfe einer Handpresse, am besten nachdem sie zuvor durch Erhitzen in geschlossenen Gefässen im Wasserbade getödtet worden sind, zunächst ausgepresst. Den gewonnenen Saft erlitzt man in verschlossenen Gefässen im Wasserbade bei $100^{\circ} \mathrm{C}$, um sicher alles Eiweiss zum Coaguliren zu bringen, und filtrirt ihn dann "). Werden $10 \mathrm{ccm}$ des klaren Saftes eingedunstet, um den Rückstand vorsichtig einzuäschern, so kann man in dem wässerigen Auszuge der Asche die Gegenwart von Chloriden leicht mit salpetersaurem Silberoxyd nachweisen. Die Gegenwart von Glycose ist mit Hülfe der FEHLING'schen Lösung zu constatiren. Rohrzucker lässt sich in der im dritten Abschnitt angegebenen Weise nachweisen. Als Reagens auf Oxalsäure benutzt man Chlorcalcium, und wenn man zu der chlorcalciumhaltigen Flüssigkeit, eventuell nach dem Abfiltriren des entstandenen Niederschlages, Alkolıol im Ueberschuss hinzusetzt, so scheiden sich äpfelsaure Salze ab, wenn dieselben vorhanden sind.

Die saure Reaction der meisten Pflanzensäfte beweist, dass die vorhandenen Basen nicht genügen, um die Gesammtmenge der organischen Säuren $z u$ neutralisiren. Wer quantitative Untersuchungen über die Zusammensetzung der Pflanzensäfte ausführen will, vgl. die Angaben auf S. 570 in der unten citirten wertlivollen Abhandlung von H. DE VRIES.

1) Vgl. H. DE: Vries, Untersuchungen über die mechanische 'Ursache der Zellstreekung, Halle 1877.

2) Vgl. SAciss, Arbeiten des botan. Instituts in Würzburg, Bd. 1, S. 396.

3) Das Erhitzen der Pflanzentheile und des Saftes erfolgt in Druckflasehen, die man von DrsagA in Heidelberg beziehen kann. 
Es existiren manche Pflanzensäfte (z. B. derjenige aus den Blattstielen von Heracleum Spondylium), die sehr reich an Glycose sind, und in solehen Fällen ist diese Substanz von besonderer Wichtigkeit für die osmotisehe Leistungsfähigkeit des Zellsaftes, also auch für die Turgorkraft der Zellen. In anderen Fällen, z. B. in den Blättern von Solanum tuberosum, tritt die Menge der Glycose sehr hinter der Menge anderer Körper zurück.

Es ist nun sehr wichtig, dass die osmotische Leistungsfähigkeit gleicher Mengen der versehiedenen in den Zellsäften der Pflanzen vorhandenen Substanzen keineswegs die nämliche ist. Vielmehr ist ein Körper im Stande, das Wasser mit grosser Energie anzuziehen, während ein anderer dies nur in beschränkterem Grade vermag. H. DE VRIES hat die Zahlen ermittelt, welehe uns die relative Grösse der Anziehung eines Moleküls eines Körpers in verdünnter wässeriger Lösung zum Wasser angeben. Diese Zahlen bezeichnet er als die isotonisehen Coëffieienten der betreffenden Substanzen. Zum Ausgangspunkt seiner gesammten Untersuchungen wählte H. DE VRIEs die wasseranziehende Kraft des Kalisalpeters. Der isotonische Coëfficient eines Moleküls dieser Verbindung ist, um mit ganzen Zahlen operiren zu können, $=3$ gesetzt worden.

Wir lassen hier theoretische Auseinandersetzungen bei Seite, sondern stellen sofort Experimente an, um uns an der Hand der Resultate derselben über das Wesen des Gedankenganges sowie der Methode von H. DE VRIES zu orientiren. Man bereitet sich vier Lösungen von Kalisalpeter in Wasser. Die erste enthält 0,1 , die zweite 0,12 , die dritte 0,13 , die vierte 0,15 Moleküle des Salzes, in Grm. ausgedrückt, im Liter. (Molekulargewicht des Kalisalpeters $\mathrm{K} \mathrm{NO}_{3}=101$ ). Ferner stellt man sich vier Rohrzuckerlösungen in Wasser her, von denen die erste 0,15 , die $z$ weite 0,2 , die dritte 0,22 und die vierte 0,25 Moleküle Rohrzucker, in Grm. ausgedrüekt, im Liter enthält. (Molekulargewicht des Rolirzuckers $\mathrm{C}_{12} \mathrm{H}_{2,} \mathrm{O}_{11}=342$.) Je $15 \mathrm{ccm}$ dieser 8 Lösungen werden in kleine Glasgefässe gebracht, und in jede Lösung gelangt noch ein kleiner, etwa $1-2 \mathrm{~mm}$ langer Streifen der Epidermis des Mittelnerven von der Unterseite des Blattes von Tradescantia discolor. Die Epidermiszellen dieses Untersuchungsobjectes, von dessen vorzüglicher Brauchbarkeit ich mich überzeugte, enthalten rothen Farbstoff in ihrem Zellsaft. Die Pflanze steht, was von besonderer Wichtigkeit ist, zu jeder Jahreszeit zur Disposition; sie ist im Warmlıause zu cultiviren. Man lässt die Epidermiszellen 2 Stunden lang mit den Flüssigkeiten in den verschlossenen Gefässen bei gewöhnlicher Zimmertemperatur in Berührung und untersucht das Gewebe dann mikroskopiseh. Es handelt sich darum, festzustellen, ob die Flüssigkeiten eine mehr oder minder weitgehende Plasmolyse in den Epidermiszellen hervorgebracht haben, oder ob eine Plasmolyse noch nicht eingetreten ist. Der Beginn der Plasmolyse, auf den es uns besonders ankommt, ist unter Benutzung der gefärbten Epidermis von Tradescantia discolor leicht zu erkennen. $\mathrm{Er}$ ist durch ein eben sichtbares Zurüekweichen des Protoplasmas von der Membran der Zellen charakterisirt, und wir reden im Folgenden vom „Beginn" der Plasmolyse; wenn sich das Plasma in etwa der Hälfte aller Zelleı eines Objectes etwas contrahirt hat.

Man wird finden, dass die Lösungen von 0,1 Kalisalpeter und 0,15 Rohrzucker keine Plasmolyse hervorrufen, diejenigen von 0,15 
Kalisalpeter und 0,25 Rohrzucker aber sehon reclit erhebliche plasmolytische Wirkungen veranlassen. Der Beginn der Plasmolyse tritt bei dazwischen liegenden Concentrationen ein, z. B. bei Lösungen von 0,13 Kalisalpeter und 0,22 Rohrzucker. Diese beiden Lösungen würden danach die nämliche wasseranziehende Kraft besitzen; sie rufen beide den Beginn der Plasmolyse hervor; ihre isotonische Concentration ist die gleiche. Die Werthe 0,22 und 0,13 stehen nun $\mathrm{zu}$ einander in dem Verhältniss von $1 \mathrm{zu} 0,591$, und wenn wir den isotonischen Coëfficienten eines Moleküls des Kalisalpeters $=3$ setzen, so berechnet sich derjenige eines Moleküls Rohrzucker zu 1,77. Man sielit also, dass einem Molekül des Kalisalpeters eine grössere wasseranziehende Kraft zukommt, als einem Molekül Rohrzucker.

H. DE VRIEs hat mit Hülfe seiner vergleichenden plasmolytischen Methode die isotonischen Coëfficienten einer ganzen Reihe verschiedener Körper, die im Zellsaft angetroffen werden, ermittelt. Ich gehe aber hier nicht weiter auf seine wichtigen Untersuchungsresultate ein : empfehle seine Arbeit aber ganz besonders zu genawem Studium ${ }^{1}$ ).

\section{Die Grösse der Turgorkraft.}

Handelt es sich darum, die Grösse der in Pflanzentheilen thätigen Turgorkraft festzustellen, so experimentirt man zweckmässig mit Sprossstücken von $1-2 \mathrm{~mm}$ mittlerer Dicke und $100 \mathrm{~mm}$ Länge, z. B. mit Blüthenschäften von Plantago oder mit Stengelstücken von Lonicera tatarica, welches Untersuchungsobject ich benutzte, etc. etc. Man bringt in einer Entfernung von $80 \mathrm{~mm}$ Tuschemarken auf den Pflanzentheilen an und versetzt sie durch 24 Stunden dauernden Aufenthalt in 10-proc. Kochisalzlösung in einen völlig plasmolytischen Zustand. Die eingetretene Verkürzung kann leicht mit Hülfe eines Millimetermaassstabes ermittelt werden. Jetzt werden die Untersuchungsobjecte unter Benutzung des in Fig. 51 abgebildeten Apparates einer Dehnung unterzogen. Sie ruhen dabei in horizontaler Lage auf einem Brett $B$ oder besser noch auf einer Korkplatte; ihr dünnes Ende wird mit einer kleinen Korkplatte $K$ bedeckt, welcher man mit Hülfe einer Schraube eine unverrückbare Lage ertheilt, während um ihr dickeres Ende cin Faden

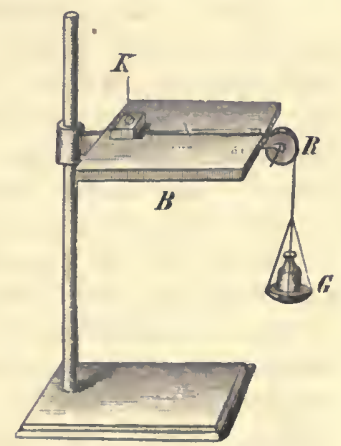

Fig. 51. Apparat zur Bestimmung der Grösse der Turgorkraft. geschlungen wird. Der Faden läuft über eine Rolle $R$ und trägt eine Schale $G$, die zur Aufnahme von Gewichten bestimmt ist. Man belastet die Schale so lange, bis die Entfernung zwischen den auf den Sprossstücken vorhandenen Marken wieder dieselbe wic vor der Plasmolyse, also $80 \mathrm{~mm}$, geworden ist. Was im Experiment die Dehnung durch das Gewicht leistet, das leistet in der Natur die Turgorkraft. Wir können somit durch unser Experinent die Grösse der Turgorkraft im unversehrten Pflanzentheile wenigstens Bd. 14

1) Vgl. H. DE VRIEs in Prixgshen's Jahrbüchern f. wissensehl. Botanik, 
annăhernd genau ermitteln. Wenn der mittlere Durchmesser eines cylindrischen Stengeltheiles $1 \mathrm{~mm}$ beträgt, so ist die entsprechende Querschnittfläche $=0,785$ qmm, denn der Inhalt eines Kreises $(J)$ lässt sich leicht nach der Formel $J=1 / 2 r . u$ berechnen, in der $r$ der Radius, $u$ der Umfang ( $2 r$. 3,141, Ludolph'sche Zahl) des Kreises ist. Braucht man ferner $50 \mathrm{~g}$, um den plasmolytisch gemachten Spross von $1 \mathrm{~mm}$ Durchmesser bis auf seine ursprüngliche Länge auszudehnen, so berechnet sich daraus die Grösse der Turgorkraft im frischen Pflanzentheile $=61 / 2$ Atmosphären. Derartige hohe Werthe erreicht die Turgorkraft thatsächlich laäufig; in einem bestimmten Falle fand ich sie für ein Stengelstück von Lonicera tartarica $=1,4$ Atmosphären ${ }^{1}$ ).

\section{Der Temperaturzustand der Gewäehse.}

Der Temperaturzustand eines Pflanzentheiles ist von sehr zahlreichen Momenten abhängig. Es kommen als solche in Betracht: die Organisation des Pflanzentheils, seine Lage im Organismus, sein Wassergehalt, seine Eigenwärme, seine Transpirationsgrösse, sein Wärmeabsorptions -, Wärmeleitungs - und Wärmestrahlungsvermögen etc. Somit leuchtet ein, dass es in zahlreichen Fällen schwierig sein wird, die Gründe des Näheren anzugeben, welche Momente eine bestimmte, durch Beobachtung festgestellte Temperatur eines Pflanzentheiles bedingt haben. Zudem sind viele Verhältnisse, welche hier in Betracht kommen, noch nicht oder nicht eingehend genug untersucht.

Stark transpirirende Glieder einer Pflanze sind häufig etwas kälter als die sie umgebende Luft, zumal deshalb, weil bei der Wasserdampfbildung viel Wärme gebunden wird. Andererseits nehmen Gewächse, die schwach transpiriren und eine fleischige, succulente Beschaffenheit besitzen, unter dem Einfluss der directen Sonnenstrahlen oft eine relativ sehr hohe Temperatur an. Wenn man die Blätter stark besonnter Crassulaceen (Sempervivum, Escheveria) mit der Hand berührt, so fühlen sie sich ganz warm an; ihre Temperatur ist eine weit höhere als diejenige der zarteren, dünneren Blätter anderer Pflanzen, die sich in ihrer unmittelbaren Nähe entwickeln. Es ist sehr lehrreich, den Temperaturzustand succulenter Pflanzen genauer durch thermometrische Messungen festzustellen ${ }^{2}$ ), und ich habe solche Beobachtungen unter Benutzung einer Cactusart (Echinopsis multiplex) ausgeführt. Mit Hülfe eines Korkbohrers wird ein bis zur Mitte des Cactus reichendes Loch in die Pflanze gebohrt, die Bohrung mit Fliesspapier gereinigt, um ein Thermometer mit cylindrischem Quecksilberbehälter in dieselbe einzuführen. Hat man für einen dichten Verschluss der Oeffnung Sorge getragen, der z. B. leicht unter Benutzung von etwas Fliesspapier zu erzielen ist, so wird das Untersuchungsobject an einem Ort im Freien aufgestellt, an welchem es während des Tages den directen Sonnenstrahlen ausgesetzt ist. Man stellt nun am Tage und auch in der Nacht Beobachtungen über den Temperaturzustand der Versuchspflanze an und vergleicht die gewonnenen Resultate mit denjenigen, zu welchen man bei Beobachtung 1) Vgl. H. DE VRIES, Die mechanischen Ursachen der Zellstreckung, Halle
1877, S. 118.

2) Vgl. Askexasy, Botan. Zeitung, 1875. 
eines im Schatten aufgehängten Thermometers gelangt. Sichere Bestimmungen der Lufttemperatur sind übrigens gar nicht so ganz leicht auszuführen. Am besten ist es, wenn das Thermometer in einem grossen Zinkkasten aufgestellt wird, der in gehöriger Entfernung rom Erdboden vor dem nach Norden gelegenen Fenster eines Grebäudes hängt. Der Kasten muss derartig eingerichtet sein, dass er Luftcirculation gestattet. Er darf auch nicht zu dicht vor dem Gebäude angebracht werden. Man wird bei der Ausführung der Untersuchungen über die Temperaturen erstaunen, welche der Cactus in der Sonne annimmt. An einem warmen Tage besass ein Beobachtungsobject um 101/2 Uhr Morgens eine Temperatur von 23,0 $0^{\circ} \mathrm{C}$; d dieselbe war bis um $21 / 2$ Uhr auf $40,5^{\circ} \mathrm{C}$. gestiegen. Lufttemperatur zu dieser Zeit im Schatten 24,5 ${ }^{\circ} \mathrm{C}$. Dieselbe Pflanze hatte am Nachmittag eines anderen Tages eine Temperatur von $45,5^{\circ} \mathrm{C}$. angenommen.

Will man Aufschluss ïber die Temperatur erhalten, welche im Innern von Baumstämmen herrscht, so bohrt man dieselben bis zur Mitte an und führt Thermometer in die Bohrungen ein. Ein luftdichter Verschluss kann ohne Mühe darch kurze Stückchen Kautschukschlauchs erzielt werden, welche man über die Thermometer gezogen hat. Die Temperaturverhältnisse im Innern der Bäume sind natürlich dicht über der Bodenoberfäche andere als in höher gelegenen Regionen, und es ist selbstverständlich ebenso nicht einerlei, ob das Untersuchungsobject im Laufe des Tages von directen Sonnenstrahlen getroffen wird, oder ob dies nicht der Fall ist. Wenn man mit nicht zu dünnen Baumstämmen, z. B. solchen von $40 \mathrm{~cm}$ Durchmesser, in welche die Thermometer also $20 \mathrm{~cm}$ weit hineinragen, operirt, so findet man im Allgemeinen, dass die Baumtemperatur am Tage niedriger, in der Nacht aber höher als die Lufttemperatur ist, und dass das tägliche Temperaturmaximum der Baumtemperatur erheblich später als das tågliche Maximum der Lufttemperatur eintritt.

Durch einen einfachen, auch in der Vorlesung über Pflanzenphysiologic leicht ausführbaren Versuch kann man die Thatsache demonstriren, dass trockenes Holz die Wärme schneller in der zur Stammaxe parallelen als in einer dazu rechtwinkeligen Richtung leitet. Eine glattgehobelte Platte Linden-, Birken - und Eichenholzes wird mit Hülfe eines in geschmolzenes Wachs eingetauchten Pinsels mit einer dünnen Wachsschicht überzogen. Man erwärmt nun einen Draht und stemmt sein warmes Ende rechtwinkelig gegen die Holzplatte. Es entsteht eine Schmelzungszone (S Fig. 52), die eine Ellipse darstellt, deren grössere Axe parallel zur Holzfaser gerichtet ist. Man kann die Länge der grösseren und kleineren Axe der Ellipse messen, um daraus das Verhältniss der Wärmeleitungsgeschwindigkeit in der Längs- und Querrichtung des Holzes zu berechnen. Wenn man an Stelle der Holzplatte eine mit dünner Wachsschicht überzogene Glasplatte zum Experiment benutzt, so erbält man kcine elliptische, sondern in Folge der gleichen Wärmeleitungsfähigkeit des Glases nach versehiedenen Richtungen hin eine kreisförmige Schmelzungszone.

$\mathrm{Da}$ die thermisehen Zustände des Bodens einen erheblichen Einfluss 
auf die Vegetation geltend machen, so ist es gewiss nicht ohne Interesse, das folgende Exporiment auszuführen. Wir stellen zwei würfelförmige Zinkkästchen von 6 oder $8 \mathrm{~cm}$ Durchmesser auf. In den einen Kasten bringen wir lufttrockenes Bodenmaterial, den anderen füllen wir mit der gleichen Bodenmenge an, nachdem dieselbe zuvor mehr oder minder oder gar vollständig mit Wasser durchtränkt worden ist. Beido Zinkkästen setzen wir nun einige Stunden lang den directen Sonnenstrahlen aus, es ist aber zweckmässig, die Kästen in eine Holzkiste zu stellen und mit einem schlechten Wärmeleiter (z. B. Watte) zu umgeben, damit die Sonnenstrahlen fast nur von oben her auf den Boden einwirken können. Führen wir Thermometer bis zur Tiefe von $1 \mathrm{~cm}$ in den trockenen, sowie den feuchten Boden ein, so werden wir leicht constatiren, dass der trockene Boden sich weit mehr als der feuchte erwärmt, und ich fand $\mathrm{z}$. B. bei Beobachtungen, die allerdings in etwas anderer Weise durchgeführt wurden, wie es hier angegeben worden ist, dass eine den directen Sonnenstrahlen exponirte trockene Torferde in $1 \frac{1}{2}$ Stunden eine Temperatur von $34,3^{\circ} \mathrm{C}$. an der Oberfläche angenommen hatte, während die Temperatur des nassen Bodenmaterials nur 29,50 C. betrug. Die geringere Temperatur des mit Wasser durchtränkten Bodens im Vergleich zum trockenen ist Folge der hohen specifischen Wärme des Wassers sowie des Umstandes, dass bei der Wasserverdunstung Wärme gebunden wird. Sehr wasserreiche Böden bezeichnet man auch wohl als kalte, eine Ansdrucksweise, die in der That nicht unzutreffend erscheint. Es ist hier nicht der Ort, die thermischen Zustände des Bodens weiter zu untersuchen ${ }^{1}$ ).

\section{Die elektromotorischen Wirkungen an Pflanzen.}

Um elektromotorische Wirkungen an Pflanzentheilen nachzuweisen, bedürfen wir verschiedener empfindlicher Apparate, vor allem eines Elektrometers (häufig wird das LIPPMANN'sche Capillarelektrometer verwandt) oder eines Galvanometers. Ich hatte Gelegenheit, die Brauchbarkeit des letzteren Apparates für unseren Zweck mehrfach kennen zu lernen. Spiegelgalvanometer mit Fernrohr liefern in vorzüglicher Qualität die in der Uebersicht der „Bezugsquellen" angegebenen Firmen. Der Apparat ist natürlich zitterfrei aufzustellen. Ferner bedürfen wir besonders noch eines elektrischen Schlüssels und zweier unpolarisirbarer Thonstiefelelektroden. (Diese Apparate sind zu beziehen von R. Rотне, Universitätsmechaniker in Prag.) Die Stative für diese Elektroden sind derartig gearbeitet, dass man diese letzteren in jeder beliebigen Lage leicht visiren kann (vgl. Fig. 53). Jerle Elektrode besteht aus einer einige Centimeter langen Glasröhre, in deren unteres Ende gut geschlämmter Thon eingeknetet wird. Aus dem Thon ragen die etwa $1 / 2 \mathrm{~cm}$ langen Enden gut ausgewaschener, weisser Baumwollenfäden hervor. Diese Fäden, die vor dem Gebrauch der Elektroden mittelst eines kräftigen Wasserstrahles ausgewaschen werden müssen und an deren Stelle man auch sehr zweckmässig lieine Pinsel benutzen kann, werden den Untersuchungsobjecten angelegt. Das Glasrohr der Elektroden füllt man mit einer Lösung von schwefelsaurem Zink an; in diese taucht ein Zinkstab ein ${ }^{2}$ ). Um dem Aus-

1) Specielleres vgl. bei Detmer, Lehrbuch d. Bodenkunde, 1876, S. 256.

2) Die Zinkstäbe sind, wenn erforderlich, durch Abwaschen mit Säure zu reinigen und durch Eintauchen in Quccksilber neu zu amalgamiren. 
trocknen der Pinsel vorzubeugen, taucht man sie, wenn sie nicht gebraucht werden, in Wasser ein. Eine Erneuerung des Thons ist dann nur $a b$ und an erforlerlich. Ein Ankneten des Thons mit 1/2-proc. Kochsalzlösung, wie es gebräuchlich ist, erscheint für unsere Versuche nicht nothwendig; erfahrungsgemåss genügt Brunnenwasser zum Ankneten.

Wir stellen nun die Verbindung zwischen den Elektroden und dem Galvanometer her, schalten aber in die eine Drahtleitung noch einen elektrischen Schlüssel ein, um die Leitung, indem wir durch das Fernrohr sehen, durch das der Ausschlag des Spiegelgalvanometers beobachtet wird, nach Bedürfniss schliessen oder öffnen zu können. Wir bringen nun die Fäden oder Pinsel der Elektroden mit einander in Contact. Erfolgt kein Ausschlag der Nadel des Galvanometers, wenn wir lie Strombahn mittelst des Schlüssels schliessen, so ist der Apparat brauchbar.

Nummehr gehen wir zu Experimenten mit Pflanzen über. Wir legen die Pinsel an zwei nicht weit von cinander entfernte Oberflächenstellen einer Sprossaxe an. In vielen Fällen, z. B. bei Versuchen mit Aristolochia, ist keine elektromotorische Wirkung $\mathrm{zu}$ constatiren, wenn man die Leitung schliesst.

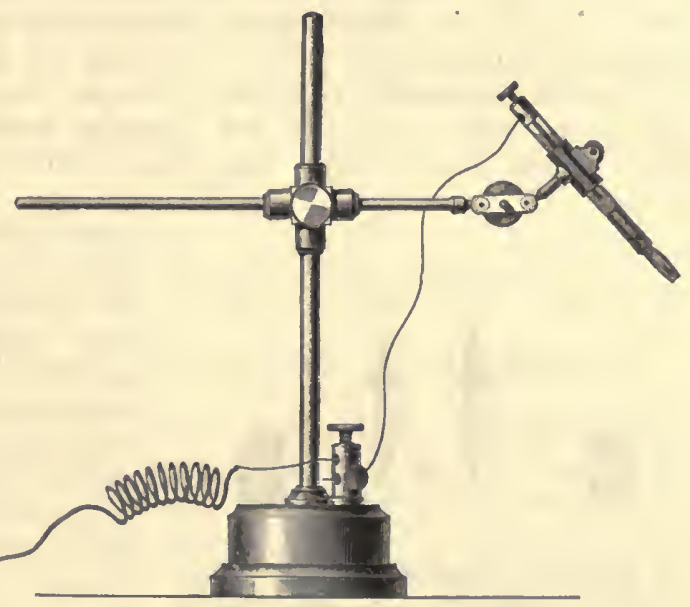

Fig. 53. Unpolarisirbare Elektrode. Eine starke Wirkung tritt

aber natürlich hervor, wie hier nur beiläufig bemerkt sei, wenn man die eine Elektrode an eine Stelle des Stengelumfanges, die andere aber an einen künstlich hergestellten Stengelquersehnitt legt.

Wir experimentiren weiter mit Sprossen von Vitis, Tropaeolum, Quercus etc. ete., die mit ihrer Basis in Wasser eintauchen, oder mit unversehrten Keimpflanzen von Pisum und Vicia. Bei diesen letzteren legen wir die Elektroden dem Stengel und einem der Keimblätter an. Es ist bei den Keimlingen eine besonders starke elektromotorische Wirkung vorhanden. Bei Versuchen mit Blättern (wir wählen junge, möglichst benetzbare Blätter, die aber an Spross stehen bleiben) wird die eine Elektrode dem Mittelnerv nahe seiner Basis, die andere dem Mesophyll etwa in der Mitte des Blattes angelegt. Es zeigt sich, dass sich in fast allen Fällen die Blattnerven positiv gegen das Mesophyll verhalten, d. h. die positive Elektricität strömt im ableitenden Bogen vom Nerv zum grünen Blattgewebe.

Nach KunkeL sollen in erster Linie Wasserbewegungen als Ursache der elektromotorischen Wirkungen an ruhenden, unversehrten Pflanzentheilen anzuseben sein. Wasserbewegungen rufen ja auch QurNcke's Diaphragmenströme hervor. Um festzustellen, dass Wasserbewegungen in der That elektromotorisch thätig sein können, stellen wir den folgenden 
Versuch an. Ein frischer Thoncylinder, wie man ihn zur Herstellung eines galvanischen Elementes benutzt, wird etwa bis zur Hälfte mit Wasser angefüllt. Die eine unserer Elektroden legen wir nahe dem Boden, die andere an einer Stelle über dem Wasserspiegel der Aussenwand unserer Thonzelle an. Es fliesst dann im Leitungsdraht, wie mit Hülfe des Galvanometers nachgewiesen werden kann, ein Strom von der oberen zur unteren Elektrode.

Mögen nun auch durch Wasserbewegungen und andere Vorgänge an Pflanzentheilen elektromotorische Wirkungen zu Stande kommen, so sind dieselben doch, wie HAAKE nachwies, in allererster Linie Folge ganz anderer Vorgänge, nämlich der mit der Lebensthätigkeit des Protoplasmas verbundenen Stoffwechsel- und Athmungsprocesse.

Zur Feststellung dieser interessanten Thatsache bedürfen wir noch des in Fig. 54 im Durchschnitt gezeichneten Apparates, wie er auch von HAAKE verwandt worden ist. Er besteht aus einem $20 \mathrm{~cm}$ langen, $31 / 2 \mathrm{~cm}$ im Lichten messenden Glasrohre, dem an einer Seite zwei je $2 \mathrm{~cm}$ weite und $1 \mathrm{~cm}$ hohe, $2 \frac{1}{2} \mathrm{~cm}$ von einander entfernte Tuben angeschmolzen sind. Ueber diese werden $5 \mathrm{~cm}$ lange, dünnwandige Kautschukschläuche

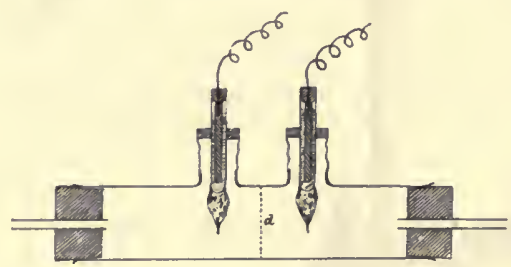

Fig. 54. Apparat zum Gebrauch bei Untersuchungen über die elektromotorischen Wirkungen an Pflanzentheilen. Im Durchschnitt dargestellt. (Nach HAAKE.) gezogen und, wie aus der Figur ersichtlich, an die hineingeschobenen Elektroden luftdicht angeschlossen. Die letzteren werden mit ihrem aus dem Apparat herausragenden Ende an den Stativen befestigt. Die Beweglichkeit der Elektroden ist eine hinreichende. Die beiden Enden des $20 \mathrm{~cm}$ langen Glasrohres sind noch mit durchbohrten Kautschukkorken zu verschliessen, in denen Glasröhren steckes. Wird nun in die feuchte Kammer ein $10-15 \mathrm{~cm}$ langer Erbsenkeimling gelegt, und leitet man langsam Luft, die zur Sättigung mit Wassergas ein kleines, mit nasser Glaswolle angefülltes U-Rohr passirt hat, durch den Apparat, so erhält man nach HAAKE einen recht starken Ausschlag am Galvanometer, wenn die eine Elektrode dem Wurzelhals, die andere dem Stengel des Keimlings angelegt wird. Der Ausschlag wird aber gering, wenn man nun etwa eine viertel Stunde lang einen langsamen Wasserstoffstrom durch den Apparat geben lïsst. Das Wasserstoffgas reinigt man, indem man es eine Lösung von Kaliumpermanganat passiren lässt; zur Sättigung mit Wassergas leitet man es über feuchte Glaswolle hin. Erneuter Luftzutritt ruft wieder einen starken Galvanometerausschlag hervor. Bei diesen Versuchen ist, um Assimilation auszuschliessen, stets für Verdunkelung des Untersuchungsobjectes zu sorgen.

Entzieht man also den Pflanzentheilen den Sauorstoff, so ruft dies eine Aenderung ihrer elektrischen Spannungsverhältnisse hervor und diese Erfahrung berechtigt eben $z u$ dem Schluss, dass Stoffwechsel und Athmung als Ursache der elektromotorischen Wirkungen, die man an Pflanzen beobachten kann, betrachtet werden müssen. Freilich, getödtete Pflanzen (z. B. durch heissen Wasserdampf getödtete Erbsenkeimlinge) machen ebenfalls clektromotorische Wirkungen geltend; indessen erfahren diese bei Sauerstoffentziehung keine wesentliche Aenderung, und dies beweist 
eben, dass sie ganz anderen Ursachen (chemischen Umsetzungen in den abgetödteten Pflanzentheilen) ihre Entstehung verdanken, wie jene, welche an der lebensthätigen Pflanze zu constatiren sind.

Sehr wichtig für die Beurtheilung unserer Beobachtungsresultate ist es, zu beachten, dass wir heute nur im Stande sind, das Vorhandensein von elektromotorischen Wirkungen an Pflanzen überhaupt zu constatiren. Ueber die wahre Grösse derselben erfahren wir aber nichts. Die Zollen können mit kleinen galvanischen Elementen verglichen werden, aber das Galvanometer zeigt immer nur die Differenz zwischen der Stärke der Ströme, die von den verschiedenen mit den Elektroden in Contact gebrachten Zellencomplexen ausgehen, an. Selbst wenn das Galvanometer gar keinen Strom mehr anzeigt, könnten doch noch von den Pflanzen elektromotorische Wirkungen zur Geltung gebracht werden; es könnten ja beide Stromcomponenten gleich $\operatorname{sein}^{1}$ ).

\section{Die Bewegung der Gase in den Pflanzen.}

\section{Einiges über das Verhalten der Gase im Allgemeinen.}

Es wird ein Reagensglas mit einem Ptlanzensaft angefüllt, z. B. mit Rübensaft, den man durch Zerreiben entrindeter Runkelrübenstücke auf einem Reibeisen und Auspressen des in ein Tuch gebrachten Breies gewonnen und eventuell dureh Filtriren geklärt hat. Ferner füllt man eine kleine Schale mit dem Rübensaft, bringt die Mündung des Reagensglases in diese Flüssigkeit und verdrängt endlich den Saft in dem Glase durch Kohlensäure. Lässt man den Apparat dann einige Zeit ruhig stelien, so zeigt sich, dass der Saft in dem Reagensglase emporsteigt. Die Kohlensäure wird von der Flüssigkeit absorbirt, und ebenso ist auch der in der unversehrten Zelle vorhandene Zellsaft im Stande, Kohlensäure, mit der er in Berührung gelangt, zu absorbiren. Das Absorptionsvermögen wässeriger Lösungen für Sauerstoff sowie Stickstoff ist ein weit geringeres als dasjenige für Kiohlensäure.

Es vermögen auch lufttrockene Pflanzentheile, z. B. Samen, nicht unerhebliche Kohlensäuremengen $\mathrm{zu}$ absorbiren. In eine am oberen Ende zugeschmolzene Glasröhre bringt man 15 oder 20 lufttrockene Samen von Phaseolus multiflorus und schiebt noch ein kleines Korkstückchen oder etwas Glaswolle nach, um die Samen im oberen Röhrentheil festzuhalten. Die Röhre wird nun derartig aufgestellt, dass ilı verschlossenes Ende nach unten gerichtet ist, ein kräftiger Strom Kohlensäure eingeleitet, die Mündung der Röhre mit dem Daumen verschlossen und diese schnell unter Quecksilber gebracht. Das Quecksilber steigt allmählich in der Röhre empor, da die Samen

1) Vgl. HAAke, Flora, 1892, und KUNKeL, Arbeiten d. botan. Instituts in Würzburg, Bd. 2. Bei KUNKFt vergl. auch Beobachtungen über die elektromotorischen Wirkungen ruhender und mechanisch gereizter Mimosablätter und über die sich bei der Reizung geltend machende Stromschwankung. 
im Laufe mehrerer Tage einige cen Kohlensäure absorbiren, und wenn man das Volumen des Gases in dem Apparat bei Beginn und bei Abschluss des Experimentes genau feststellt (vergl. Methode unter 13), so ist es möglich, die Quantität der von den Untersuchungsobjecten gebundenen Kohlensäure exact zu bestimmen'). Nach Borodis ab. sorbiren gequollene Bohnensamen nicht viel mehr Kohlensäure als lufttrockene, eine Angabe, die zu weiteren Experimenten auffordert.

Nach den Untersuchungen von Graham und Bunsex verhalten sich die Geschwindigkeiten, mit welchen die Gase poröse Scheide-

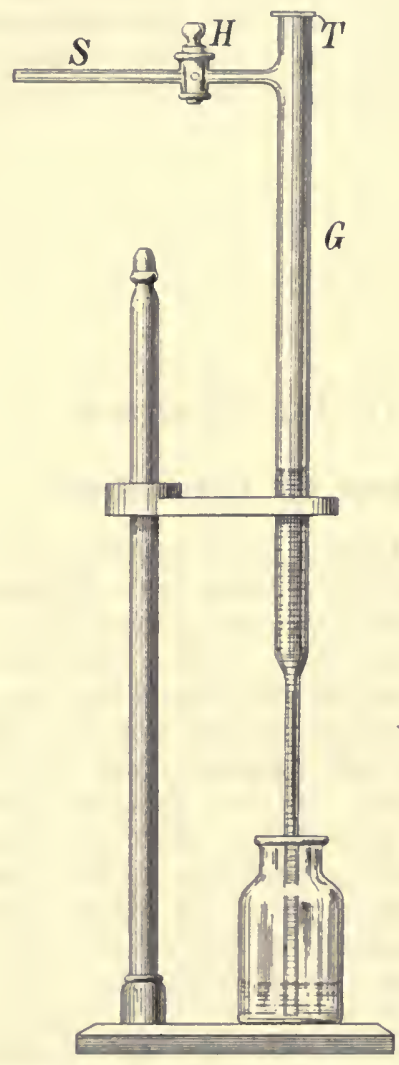

Fig. 55. Apparat für Untersuchungen über die Diffusion der Gase. empor. Dieser Apparat kann auch bei Ausführung mancher der folgenden Versuche Verwendung finden.

Die specifisch schwere Kohlensäure passirt nach demjenigen, was wir über die Bewegung der Gase wissen, derartige poröse Scheidewände wie Thonplatten auf jeden Fall viel langsanıer als atmosphärische Luft; indessen eine durchaus abweichende, geradezu entgegengesetzte Erscheinung macht sich geltend, wenn man Kohlensäure und atmo-

1) Vgl. Borodrs, Mémoires de l'acad. imp. de St. Pétersbourg, T. 28, Nr. 4. 
sphärische Luft durch eine Scheidewand von einander trennt, deren Substanz eine specifische Anzichung auf die Kohlensäure ausübt (Gasabsorption). Als ich ein Glasrohr an einem Ende mit einer d ün $\mathbf{n}$ e $\mathbf{n}$ Kautsehukmembran versehloss (die Kautsekukmembran bindet man am besten mit Gummischnur fest), die Röhre mit Kohlensäure anfüllte und ihre offene Mündung unter Queeksilber brachte, stieg dieses allmählich mehr und mehr in der Röhre empor. Freilich erhebt sich das Queeksilber nicht sehnell im Apparat, und es ist daher erforderlich, denselben längere Zeit (etwa 24 Stunden) ruhig stehen zu lassen. Handelt es sich nicht um die Ausführung genauer, messender Experimente, sondern nur um Demonstrationsversuehe, so ist es zweckmässig, neben der mıt einer Kautschukmembran versehlossenen Glasröhre noch eine $\mathrm{zweite}$ aufzustellen, welche die gleichen Dimensionen wic jene erste besitzt, aber am oberen Ende zugeschmolzen ist. Der Quecksilberstand in dieser zweiten Röhre lässt erkennen, welchen Einfluss die Temperatur- sowic die Luftdruckverhältnisse während der Versuche auf die eingeschlossenen Gase ausüben. Es stellt sich nun nach längerer Zeit heraus, dass das Quecksilber in der mit der Kautschukmembran verschlossenen Röhre erheblich höher steht als in der anderen, denn in Folge des Absorptionsvermögens des Kautschuks für Kohlensäure passirt dieses Gas trotz seines hohen specifischen Gewichts die benutzte Membran schneller, als die atmosphärische Luft dies vermag.

Als ich eine Glasröhre an einem Ende mit einem frischen Blattstück von Nerium Oleander verschloss, die Röhre mit Kohlensäure anfüllte und die offene Mündung in Quecksilber eintauchte, stieg dies ziemlich hoch in der Röhre empor. Den luftdichten Verschluss erreicht man bei diesem Experiment am besten dadureh, dass man ein durehbohrtes, als Widerlage dienendes Korkstück so weit über die Glasröhre schiebt, bis dic Mündung der letzteren genau in einer Ebene mit der oberen Sehnittfläche des Korkstückes liegt. Mit Hülfe von Siegellack, dlas man auf die untere Sehnittfläche des Korkstüekes bringt, befestigt man dieses an der Glasröhre. Die obere Korkfläche wird nun mit einer Mischung von 1 Thl. gelbem Wachs, 1 Thl. Olivenöl und 1 Thl. ausgelassenem Hammeltalg bestrichen, das Neriumblattstück über die Mündung des Glasrohres gelegt, so dass die spaltöffnungsfreie Oberseite des Blattes nach unten gewendet ist, und sehliesslich ein völlig dichter Verschluss durch Bestreichen der Ränder des Blattstüeks mit dem erwähnten Kitt hergestellt.

$\mathrm{Zu}$ genaueren Resultaten gelangt man unter Anwendung folgender Untersuchungsmethode. Ueber das obere gut abgeschliffene Ende einer Glasröhre von 5-6 $\mathrm{mm}$ Weite und 50-100 cm Länge wird ein als Widerlage dienendes, durchlochtes Stück Kork oder Hollundermark gezogen. Man erwärmt so vicl wie möglich und trägt feinstes geschmolzenes Siegellack auf. Man legt nun das Untersuchungsobject, z. B. ein trockenes unversehrtes Blattstück von Hedera Helix, dessen Qberseite bekanntlich spaltöffnungsfrei ist, odor eine zårte Korklamelle, die eventuell unter Benutzung des Mikrotoms hergestellt ist, auf eine Korkunterlage, kehrt die erwähnte Glasröhre um und bringt sie unter nicht zu starkem Druck, während das Siegellack noch geschmolzen ist, mit dem Gewebe in Berührung. In der Regel erzielt man auf solche Weise einen völlig luftdichten Verschluss. Nach völliger Abkühlung wird die Röhre nahezu horizontal gelegt und vorsichtig gänzlich oder nur zum Theil mit Queck- 
silber angefüllt, dann senkrecht aufgestellt, so dass ihr offenes Ende in Quecksilber eintaucht. Man verdrängt nun einen Theil des Quecksilbers im Glasrohr durch trockene Kohlensäure und lässt den Apparat in einem nach Norden gelegenen Raum ruhig stehen. Unter Berücksichtigung der erforderlichen Vorsichtsmaassregeln, und indem man Temperatur sowie Barometerstand notirt, wird dor Stand des Quecksilbers im Rohr abgelesen, und wenn man dies häufiger, z. B. jeden Tag einmal wiederholt, so gelangt man zu folgendem Resultat. Im Apparat, der mit einer trockenen Korklamelle verschlossen ist, steigt das Quecksilber sehr langsam, z. B. nur einen mm pro Tag. Gar kein Steigen erfolgt, wenn man nit trockenen Blattstücken von Hedera Helix experimentirt. Ein ziemlich lebhaftes Steigen des Quecksilbers macht sich geltend, wenn man auf die Gewebestücke, nachdem sie befestigt worden sind, das eine Ende eines mit dem anderen Ende in Wasser eintauchenden Fliesspapierstreifens legt, so dass sie sich mit Wasser imbibiren. Es ergiebt sich also, dass Gasdialyse, bei der ja Gasabsorption eine grosse Rolle spielt, nur in ausgiebigerem Maasse stattfiuden kann, wenn die Membranen der Pflanzengewebe mit Wasser imbibirt sind. Trockene Membranen lassen keine Gase dialysiren oder sie gestatten ihnen den Durchtritt nur sehr langsam (Periderme). Die Kohlensäure passirt die Pflanzenmembranen auf dialytischem Wege schneller als Stickstoff und Sauerstoff ${ }^{1}$ ).

\section{Das Intercellularsystem der Pflanzen.}

Die Intercellularräume der Pflanzen, welche für den Gaswechsel, die Durchlüftung und die an anderer Stelle $\mathrm{zu}$ behandelnde Wasserdampfbildung in den Gewächsen so wichtig sind, kommen namentlich zwischen den Zellen des Parenchyms, aber auch an anderen Orten vor. Sie sind entweder schizogenen oder lysigenen Ursprungs und im letzteren Falle oft von bedeutendem Durchmesser. Im Parenchym sind dic Intercellularräume gewöhnlich zwischen den abgerundeten Kanten der Zellen als dreikantige, mit einander communicirende Kanäle vorhanden. Wir unterwerfen zunächst zarte Querschnitte aus den Cotyledonen der ruhenden Samen von Lupinus luteus einer mikroskopischen Untersuchung. Man benutzt am besten etwas angequollene Samen zur Herstellung der Schnitte und constatirt alsbald das Vorhandensein der ziemlich engen Intercellularräume zwischen den Zellen. Dic luftführenden Räume sind natürlich für den normalen Verlauf der Keimung, der mit lebhaftem Gaswechsel verbunden ist, von besonderer Wichtigkeit. Auch zwischen den Zellen der über die Erdoberfläche emporgehobenen und ergrünten Cotyledonen von Lupinus lassen sich die Intercellularräume leicht auffinden.

Wir stellen ferner Querschnitte durch ein Internodium von Zea Mays her (vgl. Fig. 56). Es kann für unseren Zweck gerne an der Luft getrocknetes Material benutzt werden. Die Gefässbündel sind nicht im Kreise angeordnet, sondern durch das gesammte Grundgewebe vertheilt. Die Zellen des letzteren sind sehr gross, und es fallen uns sofort die

1) Literaturangaben vgl. bei DetMer, Lehrbuch d. Pflanzenphysiologie, 1883, S. 97, und bei Prefrer, Handbuch d. Pflanzenphysiologie, Bd. 1, S. 86. Experimentelle Untersuchungen, die hier von Interesse sind, hat N. J. C. MÜLLER (vgl. Prixgshety's Jahrbücher, Bd. 7) ausgeführt. Ferner Wirsser, Sitzungsber. d. Akad. d. Wiss. zu Wien, 1889, Bd. 98, Abth. I, S. 693. 
ziemlich weiten, als dreieckige Lücken zwischen den Zellen erscheinenden Intercellularräume anf. Jedes einzelne der collateralen Gefässbündel ist von einer Scheide, die aus lückenlos zusammenschliessenden, dickwandigen Sklerenchymzellen besteht, umgeben. Im Phloëmtheil der Gefässbündel sind die Siebröhren sichtbar, während im Xylem mehrere grosse Gefässe sofort in die Augen fallen. Auf der inneren Seite der Gefässbündel beobachten wir aber auch einen weiten Intercellularraum. Derselbe ist lysigenen Ursprungs, während die Intercellularräume des Grundgewebes auf schizogenem Wege entstanden sind.

Werden Querschnitte aus dem Stengel von Juncus glaucus mikroskopisch untersucht, so zeigt sich, dass unter der stark cuticularisirten Epidermis grünes Gewebe und Gruppen von

Sklerenchymfasern mit einander abwechseln. Unter den Sklerenchymfaserbündeln sind grosse, mit Luft erfüllte Hohlråume sichtbar, und ferner erblickt man zahlreiche, in das Grundgewebe ein-

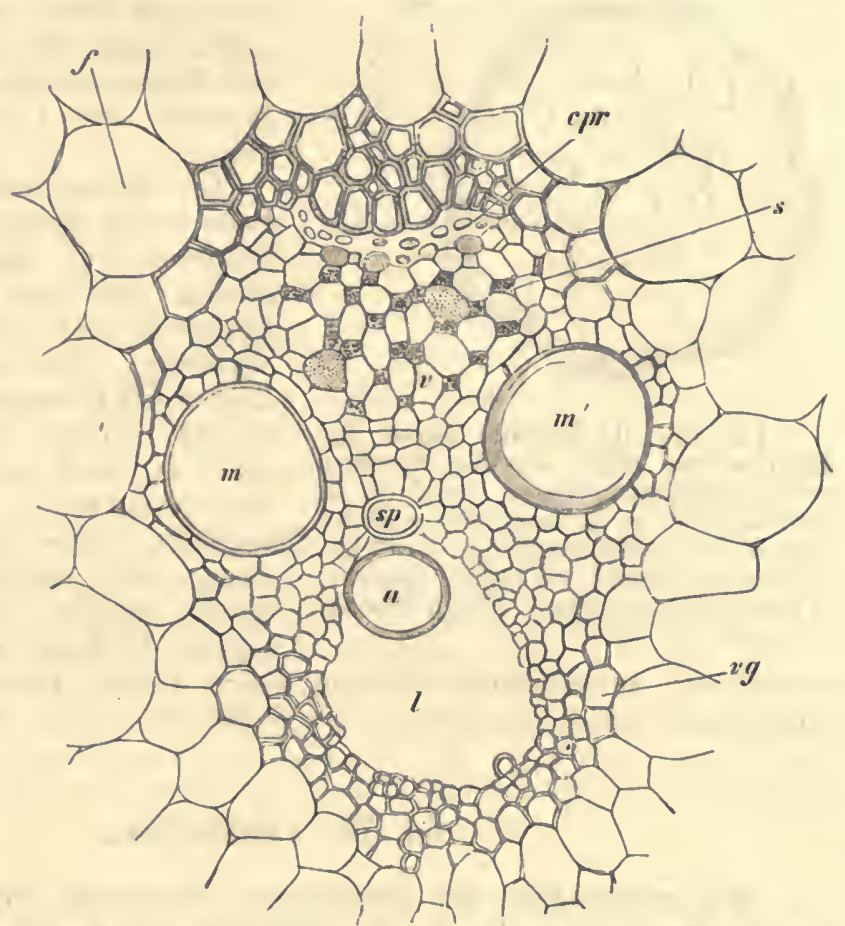

Fig. ä6. Quersehnitt dureh ein Gefissbündel aus dem inneren Theile eines Internodiums des Stengels ron Zea Mays. $a$ Glied eines Ringgefäisses, $s p$ Schraubengefäss, $m$ und $m^{\prime}$ unbehöft getüpfelte Gefässe, $v$ Siebröhre, $s$ Geleitzellen, cp zerquetsehte Cribralprimanen (Erstlinge des Basttheiles), $l$ Intercellulargang, $x g$ Scheide, $f$ Zelle des Grundgewebes. Vergr. 180. (Nach Strasibribr.) gebettete Gefässbündel, deren Holz- und Basttheile leicht kenntlich sind. Jedes Gefässbündel ist auf seiner Aussen- sowie Innenseite mit einem Sklerenchym. faserbelag versehen. Spaltet man einen Halm von Juncus glaucus der Länge nach, so zeigt sich, dass die wcite Höhlung in der Mitte des Untersuchungsobjectes keine continuirliche ist, sondern dass sie gekammert. erscheint. Dio Höhlung des Halms wird von zahlreichen Gewebeplatten, sogen. Diaphragmen, durchsetzt, welche, wie die mikroskopische Untersuchung lehrt, aus vielarmigen, sternförmigen Zellen bestehen.

Wird ein Querschnitt durch das Internodium eines vegetativen Sprosses von Equisetum arvense hergestellt, so ist schon bei schwacher Vergrösserung die eigenthümliche Anordnung des grüuen Parenchyms einer- und der hypodermalen Sklerenchymfaserstränge unter der Epidermis 
andererseits leicht festzustellen (vgl. Fig. 57). Nach innen folgt grosszelliges Rindengewebe, welches weite Luftlücken, die sog. Vallecularhöhlen, umschliesst. Den Gefässbündelkreis umgiebt eine Endodermis, und jeder Fibrovasalstrang lässt einen Holz- und einen Basttheil deutlich erkennen.

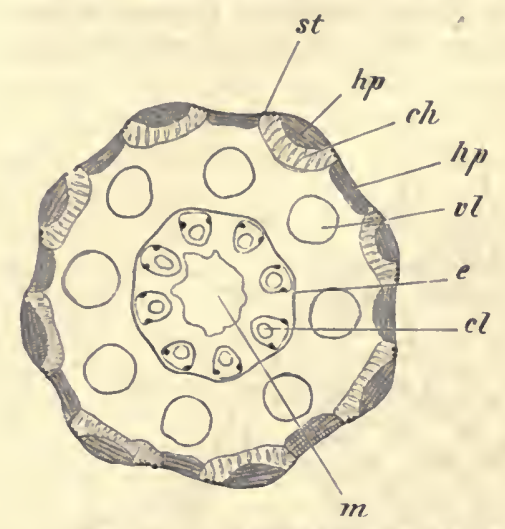

Fig. 57. Querschnitt durch das Internodium eines sterilen Sprosses von Equisetum arrense. $m$ Mark, $c l$ Carinalhöhle im Gefässbündel, $e$ Endodermis, $v l$ Vallecularhöhle, $h p$ Sklerenchymfaserstrang, ch grünes Gewebe, st Spaltöffnungsapparat. (Nach STrAsBURGER.)

sternförmic einzigen an den Kanal grenzenden Grundgewebezelle entspringt ${ }^{1}$ ).

\section{Die Lenticellen.}

Wir untersuchen die Zweige von Sambucus nigra, um uns über das Vorhandensein der Lenticellen, die eine so sehr allgemeine Verbreitung besitzen, zu unterrichten. An Querschnitten, die aus jungen Zweigen hergestellt worden sind, constatiren wir, dass unmittelbar unter der Epidermis hypodermales Collenchym vorhanden ist, das nur an einigen Stellen von dem grünen Rindenparenchym unterbrochen wird, welches an diesen Stellen eben selbst bis zur Epidermis reicht. Das innere Rindengewebe ist seiner Gesammtmasse nach aus grünen Zellen zusammengesetzt und umschliesst den Gefässbündelkreis. Bei der Untersuchung von Querschnitten älterer Sambucuszweige zeigt sich, dass der Pflanzentheil wesentliche Veränderungen erfaliren hat. Es ist nämlich dicht untel der Epidermis ein Korkgewebe entstanden, dessen gelblich gefärbte Zellen die lebendigen Gewebe der Rinde abschliessen. Aber dieser Abschluss ist kein vollkommener, denn die Sambucuszweige sind mit zahlreichen Lenticellen bedeckt. Dieselben lassen sich schon mit unbewaffnetem Auge als bräunliche Flecken erkennen, und bei mikroskopischer Untersuchung von Querschnitten stellen wir fest (vgl. Fig. 58), dass die Epidermis der Sambucus-

1) Literatur: DE BARY, Vergleichende Anatomic der Vegetationsorgane etc., 1877, S. 220, und Strasburger, Das botanische Praktikum, 2. Aufl., Jena 1857. 
zweige an denjenigen Stellen, an welchen sich Lenticellen befinden, aufgerissen ist und dass dic letzteren selbst mit einer pulverigen Masse stark gebräunter Zellen (Füllzellen) angefüllt sind. Diese Füllzellen werden bekanntlich ebenso wie dic Zellen des Phelloderma von dem Cambium der Lenticellen producirt. Die erwälınten Füllzellen, welche in demselben Maasse, wie sie von aussen der Desorganisation unterliegen, vom Cambium nachgebildet werden, schliessen aber nicht lückenlos zusammen, sondern es befinden sich zwischen ihnen mit Luft erfüllte Räume, die mit den Intercellularen der inneren Gewebe der Zweige communiciren. Um diese Thatsache durch ein

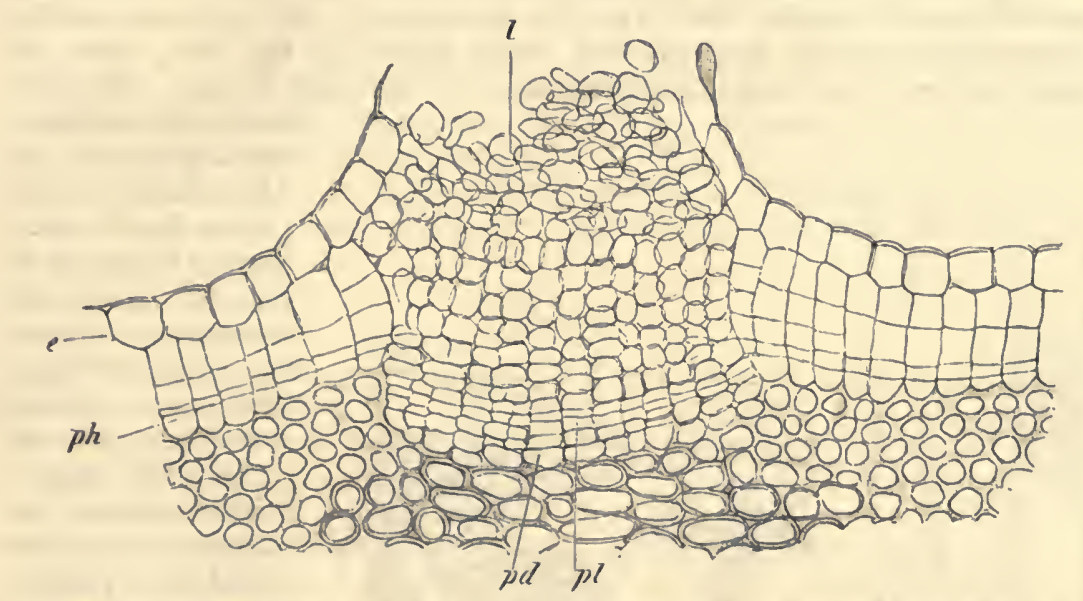

Fig. 5S. Querselınitt dureh eine Ientieelle von Sambueus niara. e Epidermis, $p h$ Phellogen oder Korkcambium, $l$ Füllzellen, yl Cambium der Ienticelle, pd Phelloderma. Vergr. 90. (Nach Strasnurger.)

physiologisches Experiment festzustellen, lefestigt man eine mit Periderm und Lenticellen bedeckte Sprossachse von Sambucus nigra Salix oder Pavia rubra mit Hülfe einer zum Schmelzen gebrachten Mischung von 2 Thl. Waclıs und 1 Thl. Colophonium in dem kürzeren Schenkel eines gebogenen Glasrohres. Die Sclinittfläche am oberen Ende des Zweiges wird ferner ebenfalls gut verkittet und die Vorrichtung in einen mit Wasser angefüllten Glascylinder gestellt. Giesst man nun Quecksilber in den längeren Schenkel des Glasrohres, so treten alsbald Gasblasen aus den Lenticellen des Untersuchungsobjectes hervor, die sich allmählich ablösen, um durch neue ersetzt $\mathrm{zu}$ werden. Ich habe derartige Beobachtungen im Winter an Sambucuszweigen gemacht, woraus erhellt, dass die Lenticellen auch zu dieser Jahreszeit nicht verschlossen sind. Bei manchen Pflanzen werden übrigens im Winter dichter zusammenschliessende Füllzellen in den Lenticellen als im Sommer gebildet. Wenn man daher im December und ferner Anfang Juni derartige Versuche, wie sie soeben beschricben worden sind, mit Zweigstücken von Ampelopsis anstellt, so ergiebt sich, dass im Juni weit leichter als im December grössere Luftmengen durch die Lenticellen gepresst werden können. Die Lenticellen spielen an den mit Periderm bedeckten Zweigen eine älınliche Rolle wie die Spaltöffnungen an jungen Pflanzentheilen. Sie sind 
ebenso wie diese für die Durchlüftung der Gewebe von Bedeutung'). Man kann diese Thatsache in einfachster Weise auch so feststellen, dass man Sprossachsen genannter Pflanzen an beiden Enden verkittet und sie dann in Wasser legt. Die erwärmte Luft tritt nun in Form kleiner Blasen aus den Lenticellen hervor.

\section{6\%. Die Spaltöffnungen und ihre Bedeutung beim Gaswechsel der 'Pfianzen.}

Ein ganz günstiges Untersuchungsobject für das Studium der Spaltöffnungen ist das Blatt von Iris florentina. Bei mikroskopischer Untersuchung zarter Querschnitte zeigt sich (vgl. Fig. 59), dass die Schliesszellen des Spaltöffnungsapparats Chlorophyllkörner enthalten.

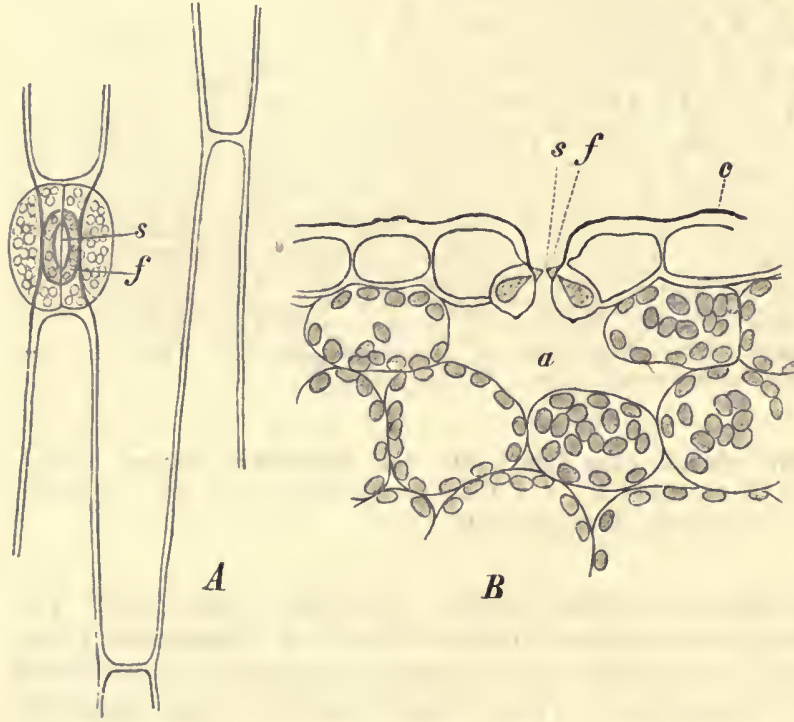

Fig. 59. Epidermis der Blattunterseite von Iris florentina. $A$ von oben, $B$ im Querschnitt. $f$ Grübehen, $s$ Spalt, $c$ Cuticula, a Athemhöhle. Vergr. 240. (Nach STRASBURGER.) eigenthümlich. Dagegen ist es für die Spaltöffnungen von Tradescantia virginica charakteristisch, dass sie fast immer von vier Epidermiszellen, die, wie leicht zu sehen ist, schöne Zellkerne enthalten, umgeben werden. Um dies Verhältniss festzustellen, untersuclit man ein Stückchen von der Unterseite des Tradescantiablattes abgezogener Epidermis. Die Blattoberseite ist weit spaltöffnungsärmer als die Blattunterseite (vgl. Fig. 60). Gute Objecte für das Studium des Spaltöffnungsapparats sind auch noch die Blätter von Hyacinthus orientalis und Lilium candidum.

1) Literatur: Stahl, Botan. Zeitung, 1873, und Kremairs, Jenaische Zeitschrift für IIedicin und Naturwissenschaft, Neue Folge Bd. 10. 
Wer sich mit der Untersuchung der Spaltöffinungen beschäftigt, wird alsbald die Wahrnehmung machen, dass die Anzahl der Stomata, welche auf gleichem Flächenraum bei den Blättern verschiedener Pflanzen oder auf gleichem Flächenraum der Ober- und Unterseite desselben Blattes vorhanden ist, sehr bedeutende Differenzen erkennen lässt. So z. B. beträgt nach WEIsS ${ }^{3}$ ) die Anzahl der Spaltöffnungen auf 1 qmin Blattfläche bei:

$\begin{array}{lcc} & \text { Oberseite } & \text { Unterseite } \\ \text { Acer platanoides } & 0 & 550 \\ \text { Brassica oleracea } & 219 & 301 \\ \text { Helianthus annuus } & 175 & 325 \\ \text { Ficus elastica } & 0 & 145 \\ \text { Orchis latifolia } & 20 & 67 \\ \text { Nymphaea alba } & 460 & 0\end{array}$

Die Spaltöffnungszählungen sind freilich mülısam. aber mit Hülfe einer einfachen Methode durchzuführen. Man zieht Epidermisstreifen von der Ober- und Unterseite ausgewachsener Blätter ab, bringt dieselben in einem Wassertropfen auf den Objectträger, legt ein Deckglas auf und bestimmt die Anzahl der im Gesichtsfelde des Mikroskops zu erblickenden Stomata. Aus einer Reihe solcher Beobachtungen leitet man dann die Mittelwerthe ab. Die wirkliche Grösse des Gesichtsfeldes ist leicht festzustellen, indem man den Gesichtsfelddurchmesser mit Hülfe eines Objectivmi-

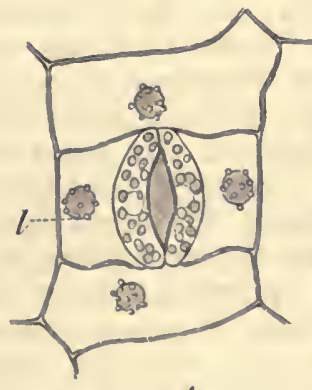

$A$

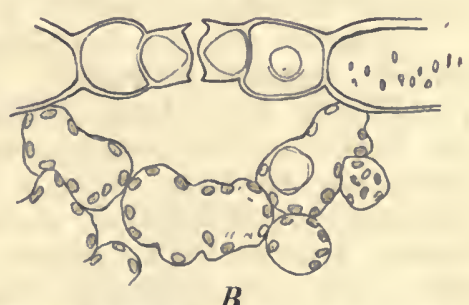

B

Fig. 60. Epidermis der Blattunterseite von Tradeseantia viroinica. $A$ von oben, $B$ Quersehnitt, $l$ Leukoplasten an den Zellkernen. Vergr. 240. (Nach StrasBURGER.)

krometers ermittelt, um unter Zugrundelegung des erhaltenen Werthes die Fläche des Gesichtsfeldes zu berechnen. Es ist schliesslich nur noch erforderlich, die für die Anzahl der Spaltöffnungen gefundenen Zahlen auf die Flächeneinheit, z. B. 1 qmm, umzurechnen.

Bei der Untersuchung des Spaltöffnungsapparates der Gewächse ist es wichtig, einer Eigenthümlichkeit derselben Erwähnung zu thun, die für die Vorgänge des Gaswechsels der Pflanzen und ebenso für den später zu besprechenden Transpirationsprocess grosse Berleutung besitzt. Der Spalte zwischen den Schliesszellen der Stomata kommt nämlich keineswegs immer die nämliche Weite zu. Man kann leicht constatiren, dass die. Spalte einer Spaltöffnung unter bestimmten Umstånden mehr oder minder weit geöffnet, unter anderen Verhältnissen aber geschlossen ist. Diese merkwürdigen Erscheinungen haben ihren Grund in Aenderungen des Turgorzustaniles der Schliesszellen, sowie der diesen benachbarten Epidermiszellen des Spaltöffnungsapparates,

1) Vgl. Weiss, in Prixgshem's Jahrbücher f. wissenschaftl. Botanik, Bd. 4. 
und wir wollen, olme indessen auf die complicirten Details näher einzugehen, einige Experimente zur Constatirung der Hauptthatsachen anstellen ${ }^{1}$ ).

Wir untersuchen zunächst einen Flächenschnitt eines am Tage abgeschnittenen Blattes von Amaryllis formosissima und finden die Spaltöffnungen geöffnet. Benutzen wir hingegen ein halb abgewelktes Blatt derselben Pflanze, so bemerken wir, dass die Spaltöffnungen geschlossen erscheinen. Man thut wohl, die Schnitte bei der Ausführung dieser Beobachtungen trocken zu untersuchen und ihnen erst dann Wasser hinzuzufügen, wenn man sich davon überzeugt hat, dass die Stomata der abgewelkten Blätter geschlossen sind. Der Wasserzutritt führt nun dahin, dass sich die Spaltöffnungen in wenigen Minuten weit öffnen, weil der Turgor der Schliesszellen erheblich zunimmt. Längeres Verweilen der Untersuchungsobjecte im Wasser bedingt aber einen Verschluss der Spalte, indem allmählich auch der Turgor der Epidermiszellen bedeutend wächst, und der Widerstand der Schliesszellen dadurch mehr und mehr überwunden wird.

Werden aber Amaryllisblättern, die gut besonnt waren, Schnitte entnommen, so gelingt es nicht, durch Wasserzufuhr einen Spaltöffnungsverschluss zu erzielen, da die Schliesszellen so reichliche Mengen osmotisch wirksamer Stoffe in Folge von Assimilation entlalten, dass sie stark genug turgesciren, um dem Turgor der benachbarten Epidermiszellen das Gleichgewicht halten zu können.

Aehnlich wie die Spaltöffnungen von Amaryllis verhalten sich diejenigen anderer Gewächse. Dagegen beobachten wir abweichende Verhältnisse bei solchen Pflanzen, für deren Spaltöffnungsapparat die den Schliesszellen benachbarten Epidermiszellen keine hervorragende Bedeutung besitzen. Werden Epidermisstreifen der Blätter von Orchis (ich experimentirte mit $\mathrm{O}$. mascula) abgezogen und zunächst im Wassertropfen untersucht, so ergiebt sich, dass die Spaltöffnungen sich niemals schliessen, sondern geöffnet bleiben. Durch Einlegen der Schnitte in einen auf dem Objectträger befindlichen Tropfen Rolirzuckerlösung lässt sich hingegen ein ziemlich schnell eintretender Verschluss der Spaltöffnungen herbeiführen. Ebenso verhalten sich z. B. auclı die Spaltöffnungen von Lilium candidum. Reichliche Wasserzufuhr zu der Pflanze, den abgeschnittenen Blättern oder den Schnitten öffnet die Stomata. Welken der Blätter oder Wasserentziehung an den Schnitten vermindert den Turgor der Schliesszellen und ruft einen Verschluss der Spalte hervor.

Der Spaltöffnungsapparat vieler Pflanzen reagirt auch auf den Wechsel der Beleuchtungsverhältnisse. In der Nacht sind z. B. die Stomata von Amaryllis formosissima geschlossen. Directes Sonnenlicht öffnet sie weit, und wenn man zunächst hell beleuchtet gewesene Amaryllisexemplare plötzlich verdunkelt, so findet man die Spaltöffnungen nach einigen Stunden geschlossen. Man kann auch, wie ich es oft that. mit abgeschnittenen und mit der Basis in Wasser gestellten Amaryllisblättern experimentiren. Untersucht man Schnitte solcher Blätter, die melırere Stunden hell beleuchtet waren, so findet man die

1) Literatur über die hier zu besprechenden Erscheinungen: MoHL, Botan. Zeitung, 1856, ScHWexdexer, Monatsberichte d. Berliner Akademie d. Wiss., 1881. LeitgeB (Mittheilungen d. botan. Instituts zu Graz, Bd. 1, Jena 1886, SchaEFER, Jahrbücher f. wissenschl. Botanik, Bd. 19. 
Stomata stets offen, bei den Dunkelblättern erscheinen dieselben dagegen geschlossen. SchaEfer (l. c. S. 194) zeigte direct, dass der Spaltöffinungsverschluss im Dunkeln durch herabgesetzten Turgor der Schliesszellen zu Stande kommt und nicht durch erhöhten Turgor der benachbarten Epidermiszellen. Bei Untersuchungen über den Einfluss der Beleuchtungsverhältnisse auf den Spaltöffnungsapparat vou Orchis maseula konnte ich keinen wesentlichen Untersehied in der Spaltweite dem Licht ausgesetzt gewesener sowie verdunkelt gehaltener Blätter feststellen, und auch LEITGEB hat kürzlich mit Bezug auf Orchis ein ähnliches Resultat erhalten (vgl. dessen citirte Abhandlung S. 160).

$\mathrm{Zu}$ sehr überraschenden Resultaten gelangt man ferner bei Experimenten über den Einfluss res Inductionsstroms auf den Spaltöffnungsapparat. Man zieht einen Epidermisstreifen von der Unterseite eines Blattes $a b$, dessen Spaltöffinungen sich weit öffnen können. Iclı experimentirte mit bestem Erfolg mit Blättern von Orchis mascula, die am Tage abgepflückt waren und einige Zeit in Wasser verweilt hatten. Der Epidermisstreifen gelangt auf den unter 54 beschriebenen und in Fig. 45 abgebildeten Objectträger, welcher für das Studium des Einflusses der Elektricität auf Pflanzenzellen bestimmt ist. Hat man einige Spaltöffnungen unter dem Mikroskop eingestellt und lässt man den Inductionsstrom auf das Untersuchungsobject einwirken, so schliessen sich die Stomata unter dem Auge des Beobachters im Laufe kurzer Zeit ').

Es ist sehr lehrreich, Experimente anzustellen, welche beweisen, dass die Spaltöffnungen offen und Ausführungs-

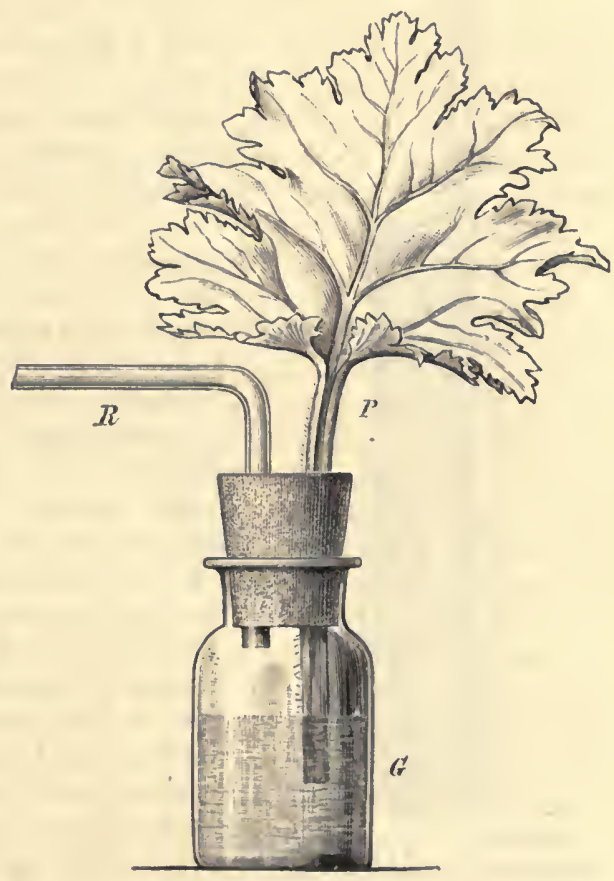

Fig. 61. Apparat zum Nachweis der Wegsamkeit der Spaltöffnungen für Luft. gänge der Intercellularen sind.

Zunächst möge der nachfolgende Versuch unter Benutzung eines unversehrten Blattes von Primula sinensis ausgeführt werden. I:s wird dazu der in Fig. 61 dargestellte Apparat benutzt. Das mit einem doppelt durchbohrten Kautschukkork verschlossene Glas $G$ füllt man halb mit Wasser an. Der eine Sehenkel des rechtwinkelig gebogenen Glasrohres $R$ mündet dicht unter dem Kork; der Stiel des Primula-

1) Dieser Versehluss der Spaltöffnungen kommt zu Stande, indem der elektrisehe Strom die Sehliesszellen tödtet. Die Stomata öfnen sich daher auch nachträglich nicht wieder, und der Inhalt der Schliesszellen zerfällt oft rasch. 
blattes $P$ taucht in das Wasser ein. Verdünnt man die Luft im Apparat durch Saugen mit dem Munde, so dringt neue Luft in die Spaltöffnungen des Blattes ein, und dieselbe tritt in Form eines Blasenstromes aus dem unter Wasser befindlichen Blattstielquerschnitt hervor. Experimentirt man mit anderen Blättern, so reicht häufig die durch Saugen mit dem Munde im Apparat erzielte Luftverdünnung nicht hin, um den Austritt von Luft aus dem Blattstielquerschnitt herbeizuführen. Man muss dann, um eine bedeutendere Evacuation zu erreichen, das Ende des Rohres $R$ mit der Luftpumpe in Verbindung setzen.

Man kann aber auch umgekehrt zeigen, dass Luft, die in den Blattstiel eingepresst wird, sich in den Intercellularen fortbewegt und aus den Spaltöffnungen entweicht. Ich benutze auch $\mathrm{zu}$

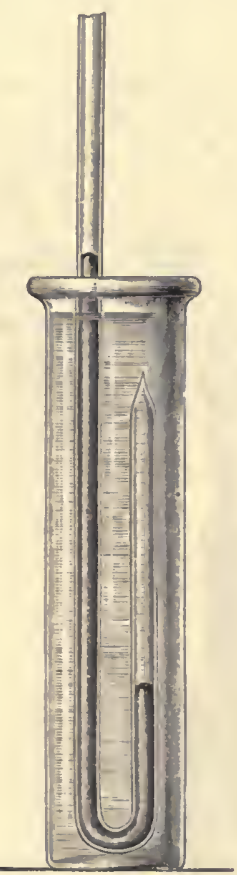

Fig. 62. Apparat zur Bestimmung der Wegsamkeit von Capillaren für Luft. gehaltenes Wasser im Stande ist, einem nicht unwesentlichen Druck das Gleichgewicht zu halten, stelle man den folgenden Versuch mit Hülfe des in Fig. 62 abgebildeten Apparates an. Der kürzere Schenkel eines gebogenen und einige Millimeter weiten Glasrohres wird an seinem Ende zu einer feinen Capillare ausgezogen. Man stellt das Glasrohr nun in einen mit Wasser gefülten Glascylinder, so dass sich die capillare Oeffnung einige Centimeter unter der Wasseroberfläche befindet, und giesst Quecksilber iu den langen Schenkel des Rohres, bis eine Druckhöhe von etwa $20 \mathrm{~cm}$ erreicht ist. Man sieht aus der Oeffnung des Glasrohres einen feinen Luftstrom hervortreten. Das Quecksilber sinkt im langen Schenkel des Glasrohres mehr und mehr herab, aber wenn nur noch eine 
Druckhöhe von einigen Centimetern vorhanden ist, so erfolgt kein weiteres Sinken des Quecksilbers, und zugleich hört der Luftstrom auf. Die feine Oeffnung ist capillar mit Wasser verstopft. Dem noch vorhandenen Quecksilberdruck wird durch die capillare Anziehung des Wassers in dem ausgezogenen Theile des Glasrohres das Gleichgewicht gehalten.

Taucht man die Spreite des Blattes von Caltha palustris oder Nymphaea oder einen Theil des Blattes von Allium Cepa unter Wasser und bläst in den Blattstiel resp. in das offene Ende des Alliumblattes hinein, so gelingt es auch hier, auf diese einfache Weise Luft durch die Untersuchungsobjecte zu pressen. Die Oberfläche des unter Wasser tauchenden Theiles des Alliumblattes zeigt einen schönen Silberglanz, weil dieselbe mit einer Luftschicht bedeckt ist, welche eine totale Reflexion des Lichtes herbeiführt. Entfernt man an beliebigen Stellen des Blattes die adhärirende Luftschicht durch Streichen mit dem Finger, so nehmen die jetzt benetzbar werdenden Stellen eine grüne Farbe an. Luft tritt jetzt nur da aus dem Blatte hervor, wenn man in das offene Ende desselben hineinbläst, wo die Epidermis noch mit dem silberglänzenden Ueberzuge versehen ist. Von den benetzten Stellen löst sich keine Luftblase los, da die Spaltöffnungen hier durch capillar festgehaltenes Wasser verstopft sind und der relativ geringe Druck nicht hinreicht, um das Wasser aus den Stomata herauszupressen.

Oft ist es auch bei Experimenten zur Feststellung der Wegsamkeit der Spaltöffnungen für Luft zweckmässig, das folgende Verfahren in Anwendung zu bringen. Man befestigt den unteren Theil eines Blattstieles, der cine unversehrte Spreite trägt, oder eines beblätterten Stengels (ich experimentirte z. B. mit dem Ende eines Camelliasprosses, der eine Knospe und ein Blatt trug) luftdicht in der Oeffnung des kürzeren Schenkels eines gebogenen Glasrohres. Den luftdichten Verschluss erzielt man je nach Umständen auf verschiedene Weise. Häufig genügt ein einfacher Verschluss mit einem durch Zusammenschmelzen gewonnenen Gemisch aus gleichen Theilen gelbem Wachs, Olivenöl und ausgelassenem Hammeltalg; in anderen Fällen nimmt man einen Kautschukschlauch zur Hülfe, oder man verschliesst die Oeffnung des Rohres zunächst mit einem durchbohrten Kork, durch dessen Bohrung der Blattstiel oder der Stengeltheil geführt worden ist, und stellt endlich den luftdichten Verschluss durch sorgfältiges Auftragen eines Kittes her. Giesst man Quecksilber in den längeren Schenkel des gebogenen Glasrohres und stellt man die Vorrichtung in einen mit Wasser angefüllten Glascylinder, so entweicht die comprimirte Luft aus den Spaltöffnungen, und es steigen kleinere nnd grössere Luftblasen von der Blattspreite aus im Wasser empor ${ }^{1}$ ).

\section{Positiver und negativer Gasdruck in den Pflanzen.}

Die Luft in den Intercellularen submerser Pflanzen, denen bekanntlich Spaltöffnungen gewöhnlich fehlen, steht häufig unter positivem Druck. Dieser Ueberdruck kann auf verschiedene Weise zu Stande kommen; insbesondere verdient aber mit Rücksicht auf seine Entstehung die assimilatorische Thätigkeit der grünen Pflanzentheile unter dem Einfluss des Sonnenlichts Berücksichtigung. Wenn man Zweige von Elodea in

1) Mit Bezug auf das hier Gesagte vgl. zumal SAcus, Handbuch der Experimentalphysiologie d. Pflanzen, 1865, S. 252. 
Brunnenwasser der Einwirkung des directen Sonnenlichts aussetzt, so quillt, wie wir unter 11 specieller nachgewiesen haben, ein Blasenstrom aus dem Stengelquerschnitt hervor. Diese Sauerstoffabschcidung hört fast sofort auf, wenn man dem Lichte keinen Zutritt mehr zu den Untersuchungsobjecten gestattet. Werden unversehrte Elodea - oder Ceratophyllumindividuen oder Zweigstücke dieser Pflanzen (ich experimentirte mit Elodeazweigen), deren Schnittfläche man mit Wachs verklebt hat, unter Wasser dem Einfluss des directen Sonnenlichts ausgesetzt, so entweichen keine Gasblasen aus den Untersuchungsobjecten. Der producirte Sauerstoff sammelt sich in den Intercellularen an; er geht nicht in dem Maasse, in welchem er gebildet wird, auf dialytischem Wege in das Wasser über, so dass das Gas in den Intercellularen alsbald unter positivem Druck steht. Wenn man den Stengel der Pflanzen mit Hülfe einer Nadel verletzt, so quillt in der That sofort ein sehr lebhafter, freilich sogleich wieder schwächer werdender Blasenstrom aus der verwundeten Stelle hervor. Wenn man diesen Versuch an Pflanzen wiederholt, die einige Zeit lang in Finstern unter Wasser verweilt haben, so ruft die Verwundung die Abscheidung reichlicherer Gasmengen nicht hervor, da die in Folge der Athmung gebildete Kohlensäure die Druckverhältnisse der Intercellulargase nicht wesentlich beeinflussen kann. Sio ist leicht löslich in Wasser und kann ohne Schwierigkeiten auf dialytischem Wege aus den Pflanzen in das dieselben umgebende Medium übergehen. Will man sich noch specieller über das Intercellularsystem von Elodea canadensis orientiren, so gelingt dies leicht bei mikroskopischer Untersuchung von Stengelquerschnitten. Unter der wenig scharf charakterisirten Epidermis liegt das relativ mächtig entwickelte Rindengewebe, das seinerseits das axile Gefässbündel umschliesst. Die Zellen des Rindengewebes lassen kleine Intercellularräume zwischen sich; zudem ist aber in der Rinde noch ein Kreis grösserer Luftkanäle vorhanden.

Die Luft in den Intercellularen kann aber auch unter Umständen geringen negativen Druck besitzen, also verdünnter sein als die atmosphärische Luft. Das Zustandekommen dieses negativen Druckes wird durch verschiedene Umstände herbeigeführt, aber ich will hier nur einen Fall specieller hervorheben. Wenn Baumäste von directen Sonnenstrahlen getroffen werden, so wird zumal ihr Rindengewebe häufig eine höhere Temperatur als die umgebende Luft erlangen. Die Gase in den Intercellularen dehnen sich aus, und wenn Lenticellen vorhanden sind, so entweichen sie durch diese. Die Luft in den Intercellularen ist nun verdünnter als diejenige der Atmosphäre.

Selır wichtig und für die Beurtheilung vieler Erscheinungen im Pflanzenleben von grosser Bedeutung ist die Thatsache, dass die Gase in den Elementen des Holzes, zumal zur Zeit starker Transpiration der Gewächse. unter erheblichem negativen Druck stehen. Wir kommen auf diese merkwürdige Erscheinung weiter unten eingehend zurück; zunächst wollen wir einige Verhältnisse ins Auge fassen, welche zu dem Phänomen des negativen Druckes der Holzluft in Beziehung stehen.

Zuerst ist zu bemerken, dass das Korkgewebe an sich, wenn wir von den Lenticellen absehen, selbst bei erheblichem Druck keine Gase passiren lässt ${ }^{1}$ ). Ich befestigte einen dünnen Korkquerschnitt, der aus

1) Vgl. Wiesser, Sitzungsberichte d. Akademie d. Wiss. zu Wien, 1879, 1. Abth., Bd. 79, Aprilheft, und ebendaselbst Bd. 98, S. 670. Vergl. ferner LiETzvars, Flora, 1887, Bd. 70, und Maxas, Extrait des Ann. de la science agronom. franç. etc., T. $1,1888$. 
einem kleinen Pfropf mit Hülfe des Rasirmessers hergestellt worden war, luftdicht mittelst Siegellacks auf der Oeffnung des kürzeren Schenkels eines gebogenen Rohres von einigen $\mathrm{mm}$ Weite. Als in den längeren Schenkel des Glasrohres Quecksilber gegossen wurde, entwich selbst bei erheblichem Ueberdruck keine Luft durch die Korkscheibe, und der Stand des Quecksilbers im Glasrohre war auch nach einiger Zeit noch derselbe, wie bei Beginn des Experimentes. Ebenso sind alle übrigen Gewebearten, die Wirsser prüfte, nicht im Stande, unter Druck stehende Gase durchfiltriren zu lassen, wenn diese Gewebe nach aussen völlig abgeschlossen sind. In vielen Fällen ist es bei der Ausführung der Untersuchungen zweckmässig, die Gewebeschichten bei den Druckversuchen, wie folgt, in dem gebogenen Glasrobr $\mathrm{zu}$ befestigen. Auf das $5-6 \mathrm{~mm}$ weite Glasrohr wird ein zerlegbarer Metallaufsatz eingekittet, in den das Untersuchungsobject luftdicht eingepasst werden kann. Um letzteres vor dem Zerquetschen zu bewahren, liegt es zwischen durchlochten Kautschukscheiben. Die Verschraubung der Theile des Apparates muss natürlich eine durchaus luftdichte sein. Geeignete Untersuchungsobjecte bilden die Fruchthaut des Apfels, Samenschalen der Erbse und Bohne sowie Stücke lebender oder trockener Epheublätter, deren Oberseite bekanntlich spaltöffnungsfrei ist.

Weiter wollen wir hier, bevor wir zur $\mathrm{Be}$ sprechung des negativen Druckes der Gase in den Elementen des Holzes übergehen, einige Angaben über die Wegsamkeit des Lumens der Holzgefässe sowie der Membranen der Holzelemente für Gase machen. Werden berindete Zweigstücke verschiedener Pflanzen von etwa $6 \mathrm{~cm}$ Länge und $8 \mathrm{~mm}$ Dicke mit Hülfe eines Kautschukschlauches in der Oeffnung des kürzeren Schenkels eines gebogenen Glasrohres befestigt (vergl. Fig. 63), giesst man dann Quecksilber in den längeren Schenkel des Rohres und

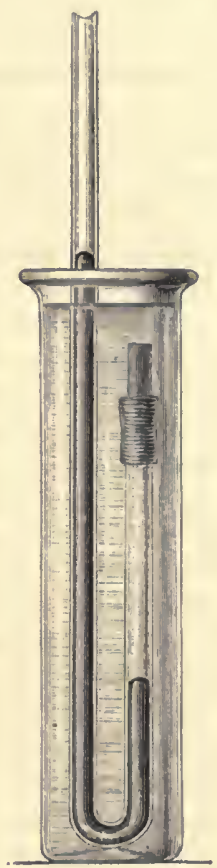

Fig. 63. Apparat zur Bestimmung der Wegsamkeit der Gefässe des Holzes für Luft. stellt den Apparat in einen Cylinder mit Wasser, so dass der obere Querschnitt des $\mathrm{Z}$ weigendes sich einige $\mathrm{cm}$ unter dem Wasserspiegel befindet, so sieht man zahlreiche Luftblasen aus der glatten Schnittfläche hervorquellen, wodurch eben die Wegsamkeit des Lumens der Gefässe für Luft bewiesen wird. Das Quecksilber sinkt mehr und mehr im längeren Schenkel herab, während es im kürzeren steigt, bis die Niveaudifferenz des Quecksilberstandes nur noch etwa einen oder einige cm beträgt. Ist das Quecksilber zur Ruhe gekommen, so hält das von aussen in die Gefässe (selbst in die weitesten Gefässe) eingedrungene und in diesen capillar gebundene Wasser dem noch vorhandenen Quecksilberüberdruck das Gleichgewicht. Es ist auch leicht verständlich, weshalb schliesslich ein geringerer Quecksilberüberdruck bestehen bleibt, wenn man das Experiment z. B. mit Vitiszweigstücken anstellt, als wenn man Sambueus-, Prunus- oder Crataeguszweigstücke benutzt. Die Gefässe der ersteren Pflanze sind, wovon man sich leicht durch mikroskopische Untersuchung 
überzeugen kann, viel weiter als diejenigen der letzteren Gewächse, und deshalb ist auch der Widerstand des von den Gefässen des Vitiszweiges capillar festgehaltenen Wassers geringer als derjenige, welchen das Wasser, das in die Gefässe der Sambucus-, Prunus- oder Crataeguszweigstücke eingedrungen ist, geltend machen kann ${ }^{1}$ ).

Von Interesse ist es auch, sich davon zu überzeugen, dass die Länge der Gefässe, respect. Gefässglieder der Pflanzen weitaus nicht so bedeutend ist, wie man seither gewöhnlich annahm. Aus einem etwa 5-jährigen Zweige von Alnus glutinosa isolirt man ein ca. $7 \mathrm{~cm}$ langes Mittelstück unter Wasser. An dem oberen Ende dieses Zweigstückes, d. h. demjenigen, welches dem Sprossgipfel ursprünglich zugekehrt war, bringt man mit Hülfe eines Kautschukschlauches eine $6 \mathrm{~cm}$ lange Glasröhre an, um dieselbe an ihrem entgegengesetzten Ende mit der Luftpumpe in Verbindung zu setzen. Das untere Ende des Zweigstückes taucht man in eine Flüssigkeit ein, die aus 3 Thl. Wasser und 1 Thl. des officinellen Liquor ferri oxychlorati ${ }^{2}$ ) besteht. Evacuirt man nun, so dringt die braune Flüssigkeit in die geöffneten Gefässe des Untersuchungsobjectes ein. In der Glasröhre erscheint aber eine völlig wasserklare Flüssigkeit. Man setzt die Evacuation etwa $1 / 4$ Stunde lang fort und schneidet dann mittelst einer Gartenscheere am unteren Ende des Zweiges ein Stück fort. Bleibt die Flüssigkeit bei Fortsetzung des Injectionsverfahrens auch jetzt noch wasserklar, wenn sie in die Glasröhre übertritt, so wiederholt man das Abschneiden abermals, eventuell noch vielfach, his endlich die braune Lösung in dem Rohr erscheint. Dies wird eintreten, wenn der Alnuszweig nur noch eine Länge von ungefähr $5,5-6 \mathrm{~cm}$ besitzt.

Das Eisenoxychlorid ist ein durchaus colloidaler Körper, der also nicht im Stande ist, Pflanzenmembranen zu passiren. Wenn demnach das Eisenoxychlorid bei erheblicherer Länge des Zweigstückes nicht in der Glasröhre erscheint, so muss sich seiner Fortbewegung in den Gefässen eine Membran (Querwand) in den Weg gestellt haben, und die Existenz solcher nicht perforirter Gefässquerwände kann in der bezeichneten Weise constatirt werden. Zugleich gewährt das Injectionsverfahren ein Mittel, um die Länge der mit schräg gestellten Zwischenwandungen versehenen Gefässe zu bestimmen. Diese Länge ist offenbar gleich derjenigen, welche das Zweigstück besitzt, wenn die Eisenlösung beim Evacuiren in der Glasröhre erscheint. Wir haben es immer mit Maassen zu thun, die sich aber auf die längsten der vorhandenen Gefässe beziehen. In 3-jährigen Sprossen von Corylus avellana beträgt die Gefässlänge. etwa $11 \mathrm{~cm}$; sehr lang sind die Gefässe in Aristolochiazweigen, oft $200 \mathrm{~cm}$ lang (6-jähriger Spross).

Wir behandeln nun ein $10 \mathrm{~cm}$ langes, mehrjähriges Zweigstück von Alnus genau in der angegebenen Weise. Wenn dasselbe nach länger dauernder Evacuation genugsam mit der Eisenlösung injicirt ist, tauchen wir das untere Ende des Untersuchungsobjectes in eine Mischung von 1 Thl. käuflichen Salmiakgeistes und 3 Thl. Wasser ein und evacuiren weiter. Durch mikroskopische Beobachtung von Längsschnitten sowie durch Vergleichung succesiver Querschnitte stellen wir fest, bis zu welcher Höhe in den Gefässen der unter dem Einfluss der Ammoniakflüssigkeit entstandene rothbraune Niederschlag reicht. An diesen Grenzen sind auch,

1) Vgl. SAcrs, Handbuch d. Experimentalphysiologie d. Pflanzen, 1865, S. 250.

2) Diese Flüssigkeit ist eine wässerige Lösung von Eisenoxychlorid. 
zumal auf Tangentialschnitten, die schräg gestellten, nicht perforirten Gcfässscheidewände zu sehen ${ }^{1}$ ).

Sehr wichtig ist nun die Thatsache, dass die Membranen der Holzelemente in hohem Grade impermermeabel für Luft sind, selbst für solche, die unter erheblichem Druck steht ${ }^{2}$ ). Diese Thatsache ist für die Theorie des negativen Druckes der Holzluft von grosser Bedeutung, ebenso für dic Theorie der Wasserbewegung in der Pflanze, und sie gewinnt auch ein ganz besonderes Interesse, wenn wir sie in Verbindung mit der später zu constatirenden Thatsache bringen, dass dieselbe Holzsubstanz, welche der Luft den Durchtritt so schwer gestattet, der Wasserbewegung fast gar kein Hinderniss entgegensetzt.

Will man sich davon überzeugen, dass die Holzsubstanz in der That sehr schwer permeabel für luft ist, so thut man am besten, aus frisch gefällten Stämmen von Taxus baccata oder Abies pectinata einige $\mathrm{cm}$ lange und etwa fingerdicke Holzstücke, die man den jüngsten Jahresringen entnimmt, herauszuschneiden. Diese Holzstücke werden mit Hülfe eines Kautschukschlauches in dem kürzeren Schenkel einer gebogenen Glasröhre luftdicht befestigt. Man giesst Quecksilber in den längeren Schenkel und stellt die Vorrichtung in einen mit Wasser gefüllten Glascylinder (vgl. Fig. 63). Experimentirt man mit frischen Holzstücken, oder noch besser mit solchen frischen Holzstücken, die noch einige Zeit in Wasser gelegen haben, so genügt oft der Druck von $76 \mathrm{~cm}$ Quecksilber nicht, um Luft durch die Untersuchungsobjecte zu pressen. Wir werden an anderer Stelle sehen, dass die Tracheiden des Holzes nicht direct - mit einander communiciren. Wir werden auch sehen, dass durch die Schliessmembranen der Hoftüpfel der Tracheiden Wasser überaus leicht filtrirt werden kann, während dieselben Luft selbst unter hohem Druck nicht passiren lassen. Wenn man findet, dass mit Hülfe des erwähnten Apparates bei erheblichem oder selbst bei relativ geringem Quecksilberdruck Luft durch Zweigstïcke von Coniferen gepresst werden kann - und dies Resultat erhält man wirklich zuweilen -.., so deutet dies immer darauf hin, dass im Untersuchungsobject sehr lange Tracheiden (z. B. in der Markkrone) oder Intercellularen vorhanden sind, die ja auch dem Coniferenlıolz nach Russow nicht völlig fehlen. Als ich z. B. mit einenı entrindeten Zweigstück von Taxus baccata von etwa $50 \mathrm{~mm}$ Länge und $6 \mathrm{~mm}$ Durchmesser experimentirte, trat bei $20 \mathrm{~cm}$ Quecksilberüberdruck Luft aus der oberen Schnittfläche des Zweigstückes hervor, bei $15 \mathrm{~cm}$ Quecksilberüberdruck entwich aber keine Luft mehr.

Auch mit Hülfe des Poroskops von Christiani kann man zeigen, dass die Tracheiden des Holzes impermeabel für Luft sind, die unter gewissem Druck steht. Der aus Glas gefertigte Apparat ist in Fig. 64 dargestellt und besteht, wie man sieht, im Wesentlichen aus zwei Manometern. Wird zwischen $a$ und $b$ ein entrindetes kurzes Stück eines Zweiges von Taxus oder Abies mit Hülfe von Siegellack luftdicht eingeschaltet, und bläst man nun in das Ende des Schlauches Sch hinein, so verändert sich natürlich der Stand des Quecksilbers inı Manometer $\boldsymbol{M}$ bedeutend, derjenige des Quecksilbers im Manometer $\boldsymbol{M}^{\prime}$

1) Vgl. zumal AduER, Inaugural-Disscrtation, Jena 1892, und auch StrasBURGer, Histologisehe Beiträge, Jena 1891, Heft 3, S. 510.

2) Vgl. SACHs, Arbeiten d. botan. Instituts in Würzburg, Bd. 2, S. 324, und M. Scheit, Botan. Zeitung, 1884, S. 180. 
aber nicht, da keine Luft das Holz passirt. Verwendet man gefässreiches Holz dicotyler Pflanzen zum Versuch, so ruft natürlich das Einblasen von Luft sofort eine Aenderung des Quecksilberstandes in beiden Manometern hervor, indem durch die Gefässe eine offene Communication $\mathrm{zwischen} a$ und $b$ hergestellt ist.

Ferner ist die durch das folgende Experiment anch in der Vorlesung zu erweisende Thatsache von Wichtigkeit, dass keine offene Communication zwischen den Gasen der cellularen Lufträume in der Pflanze und denjenigen der Intereellularräume vorhanden ist. Wir experimentiren mit $30 \mathrm{~cm}$ langen und $1 \mathrm{~cm}$ dicken, mit vielen Lenticellen besetzten Zweigstücken von Cornus mas, Philadelphus und Syringa. Ein Zweigstück wird in dem kürzeren Schenkel eines gebogenen Glasrohres derartig befestigt, dass es bis etwa $2 / 3$ seiner Länge in dieses hineinragt. Vorher hat man diejenige Schnittfläche, welche in das Rohr eingeführt werden soll, luftdicht mit Siegellack

Fig. 65.
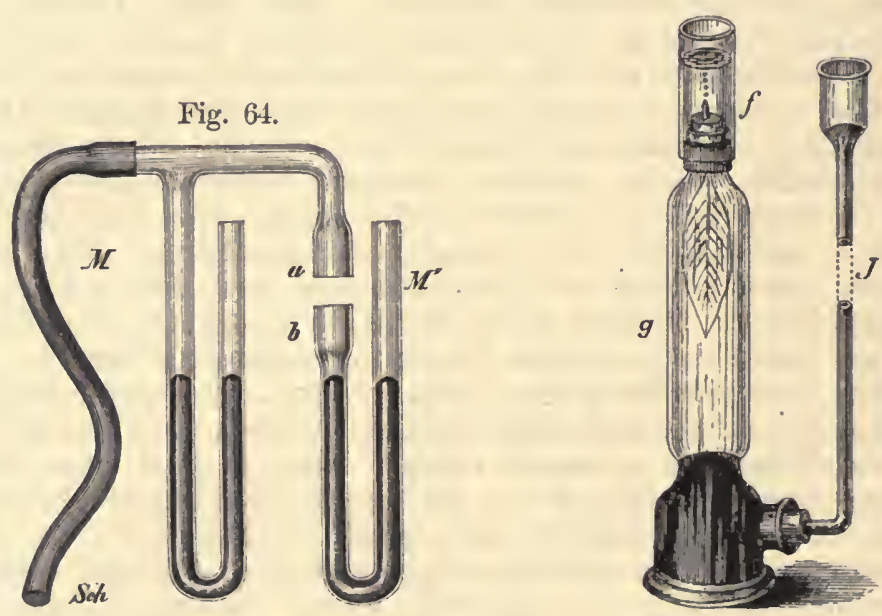

Fig. 64. Poroskop.

Fig. 65. Apparat für Untersuchungen über Gasbewegung in der Pflanze. (Nach PFefFer.)

verklebt. Man bringt die Vorrichtung nun in einen grossen, mit Wasser angefüllten Glascylinder und giesst Quecksilber in den längeren Schenkel des Rohres. Wendet man keinen zu hohen Quecksilberdruck, etwa $20-30 \mathrm{~cm}$, an, so tritt Luft auch am oberen Querschnitt der Untersuchungsobjecte nur aus der Rinde hervor, was eben beweist, dass keine offene Communication zwischen den Intercellularen einerund den Gefässen andererseits besteht. Steigert man den Quecksilberdruck, so entweicht, zumal nach Verlanf einiger Zeit, ebenfalls Luft aus dem Holzkörper der Untersuchungsobjecte, weil unter solchen Umständen ein Einpressen von Luft in die nach neueren Untersuchungen auch im Holz nicht völlig fehlenden, freilich sehr engen Intercellularen erfolgt $^{\mathrm{P}}$ ).

1) Vgl. Höhxis in Prixgsheis's Jahrb. f. wissensch. Botanik, Bd. 12, S. 72. 
Uebrigens ist ja auch möglich, dass wenigstens bei manchen Pflanzen, bei hohem Druck Luft aus den Intercellilaren durch die Membranen der Gefässe in kleiner Menge in diese übertritt (Gasfiltration).

Lehrreich ist es auch, die hier in Rede stehenden Erscheinungen mit dem in Fig. 65̆ abgebildeten Apparat zu untersuchen und Blätter von Heracleum, Aegopodium ete. oder Sprosse von versehiedenen Pflanzen (z. B. von Prunus Padus) als Untersuchungsobjecte zu wälılen. Der Glaseylinder $g$ ist mit einem Kork verschlossen, in dem der Blattstiel oder die Sprossachse des Beobachtungsobjectes luftdicht eingekittet wurde. Der Glascylinder $f$ ist ferner dem erwähnten Kork aufgepasst und enthält Wasser. Dicht unter der Wasseroberfläche liegt der Quersehnitt des Blattstieles oder der Sprossachse, so dass sie unter Benutzung eines an einem geeigneten Stativ angebrachten Mikroskops bei 20- bis 40-facher Vergrösserung beobachtet werden kann. Wird nun Quecksilber in das Rohr $J$ gegossen, um die in g vorhandene Luft, die am besten durch eine auf dem Quecksilber befindliche Wassersehicht feucht zu halten ist, zu comprimiren, so dringt die Luft in die Spaltöffnungen ein und entweicht, wie die mikroskopische Untersuchung lehrt, nur aus der Rinde und dem Mark am Querschnitt. Steigert man den Druck, so kömnen auch aus den Gefässen kleine Luftquantitäten liervortreten. Ganz instructiv ist es endlich noch, das Gefäss $g$ mit Kohlensäure und den Cylinder ' $f^{\prime}$ mit klarem Kalkwasser anzufüllen, um nun erst die Druckversuche anzustellen. Es ergiebt sich, dass die in die Spaltöffnungen eingepresste Kohlensäure, indem sie am Querschnitt hervortritt, eine Trübung.des Kalkwassers hervorbringt.

Wir gehen nunmehr dazu über, uns specieller mit den Thatsachen vertraut zu machen, die über den negativen Druck der Gefässluft bekannt sind. Es ist sicher, dass die Gefässe des Holzes zu bestimmten Zeiten, wenn die Transpiration der Gewächse gering ist, also im Frühjahr und auch im Sommer zur Nachtzeit, mehr oder minder reichliche Wassermengen enthalten. Bei stärkerer Transpiration der Gewächse wird das Wasser verbraucht, und da, wie wir gesehen haben, die Holzsubstanz in einem sehr hohen Grade impermeabel für Luft ist, so wird sich ein negativer Gasdruck in den Gefüssen entwickeln, dl. h. die Luft in den Gefässen wird unter geringerem Druck als die atmosphärische Luft stehen. Die Grösse dieses negativen Drucks kann eine sehr verschiedene sein; es ist sogar nicht ausgesehlossen, dass der Druck der Gase in den Gefässen ein sehr unbedeutender wird. Um uns von der Thatsächlichkeit des negativen Drucks der Gefässluft $\mathrm{zu}$ überzeugen, stellen wir folgende Experimente an.

Wir bohren in Sommer eine Birke an, befestigen in der bis zur Stammmitte geführten Bohrung den einen Schenkel eines in einem rechten Winkel gebogenen Glasrohres luftdicht und lassen den anderen Schenkel des Rohres in Wasser eintauchen. Wir werden alsbald sehen, dass das Wasser in diesem Selienkel des Rohres emporsteigt.

Wir stellen uns einen Apparat zusammen, wie er in Fig. 66 abgebildet ist. Ein abgeschnittener Spross (ich experimentirte mit solehen von Lonicera und zumal mit Weidenzweigen) wird mit seiner Basis in Wasser gestellt. Wir bringen nun das gebogene Glasrohr $G$ etwa bei $a$ mittelst eines Kautschukschlauches in luftdichte Verbindung mit dem Spross und sorgen dafür, dass das Glasrohr mit seinem offenen Ende in Wasser oder Quecksilber eintaucht. Infolge der durch die Transpiration des Sprosses hervorgerufenen Verdünnung der Gefässluft 
wird die Sperrflüssigkeit, ebenso wie bei der Ausführung des vorigen Experiments, alsbald in dem Glasrohre emporsteigen.

$\mathrm{Zu}$ den ferneren Versuchen verwenden wir Sprosse von Ampelopsis, Vitis, Clematis, Aristolochia, Phaseolus, Helianthus, Quercus, Robinia oder Juglans, die aber vor der Hand noch nicht von ihrer Mutterpflanze abgetrennt werden. Die Bohnenpflanzen können in Blumentöpfen zur Entwickelung gelangt sein. Bei Versuchen mit Ampelopsis, Quercus, Juglans etc. prüfen wir das Verhalten mehrjähriger Zweige. Wir biegen dieselben herab, tauchen sie an einer Stelle, die etwa 50 oder $100 \mathrm{~cm}$ weit von der Zweigspitze entfernt ist, in eine wässrige Lösung von Eosin und

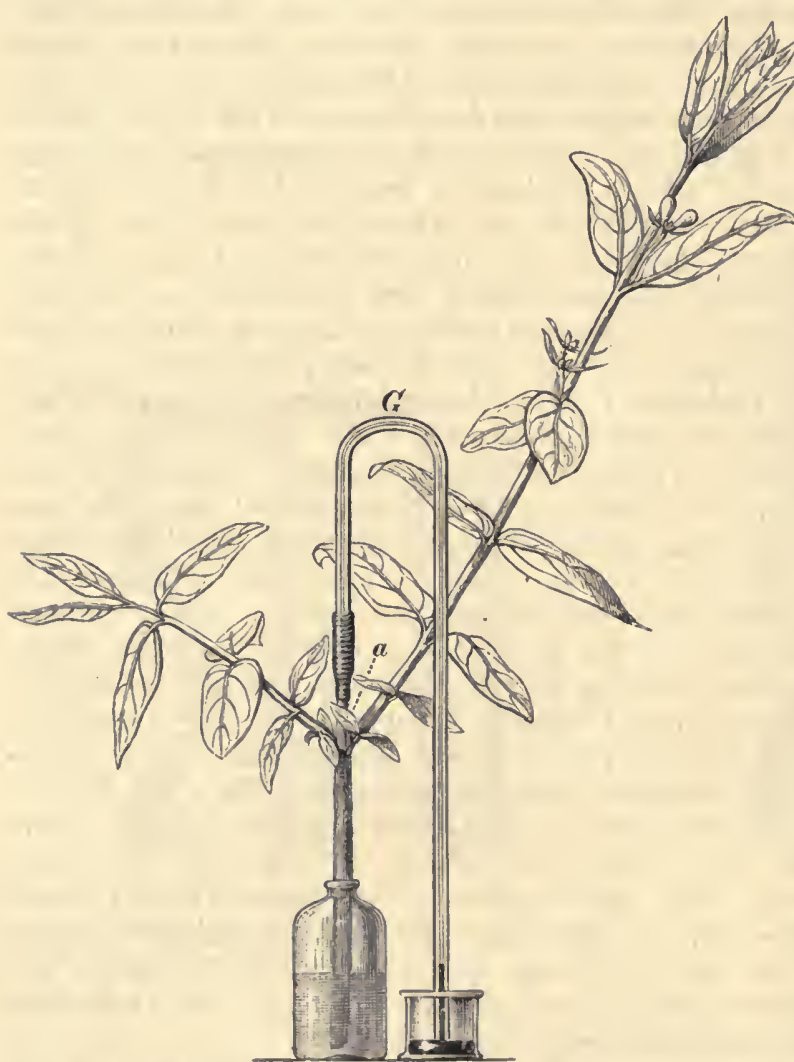

Fig. 66. Apparat zum Nachweis des negativen Druckes der Gefässluft. schneidenden Zweig an dieser Stelle unter der Lösung init einer Scheere ab. Die Schnittflächen verweilen noch 2 Minuten in der Lösung, wir spülen sie dann sorgfältig $a b$ und untersuchen den abgeschnittenen sowie den noch mit der Mutterpflanze in Verbindung stehenden Zweigtheil. Es ergiebt sich, dass die Farbstofflösung viele Centimeter weit in die Untersuchungsobjecte eingedrungen ist, wie leicht an der Färbung zu erkennen ist, welche das Holz der krautigen oder holzigen Untersuchungsobjecte angenommen hat. Die Experimente gelingen, wovon ich mich überzeugte, besonders gut mit Ampelopsis - und Plaseolussprossen und liefern zumal schöne Resultate, wenn man mit in Töpfen cultivirten Bohnenpflanzen, die ziemlich welk geworden sind, arbeitet, oder wenn man die Sprosse des wilden Weins an recht heissen, trockenen Sommertagen abschneidet.

Die beobachteten Erscheinungen beweisen das Vorhandensein negativen Drucks der Gefässluft, denn die bedeutende Erhebung der Farbstofflösung in den Pflanzentheilen kann nur dadurch zu Stande kommen, dass der Luftdruck die Flüssigkeit in die Gefässe hineinpresst. Dass die Erhebung der Eosinlösung nicht etwa nur Folge von Capillarwirkungen ist, lässt sich leicht beweisen. Schneidet man 
Sprosse der erwähnten Pflanzen in Luft ab und taucht sie dann alsbald mit ihrer Schnittfläche in Farbstofflösung, so erhebt sich diese nur wenig in den Gefässen, weil Luft in dieselben eingedrungen ist und kein negativer Luftdruek mehr in ilnen besteht. Es ist natürlich, dass "sich die Farbstofflösung bei diesen letzten Versuchın bis zu einer um so geringeren Höhe capillar in den Gefässen erheben wird, je weiter dieselben sind.

Wir stellen unsere Versuche nun in etwas modificirter Weise all, indem wir unsere Zweige an einer etwa $50 \mathrm{~cm}$ vom Gipfel entfernten Stelle in Quecksilber eintauchen und unter demselben durchschneiden. Nach 2 Minuten nehmen wir das Zweigende aus dem Quecksilber heraus, entrinden es und finden, dass das Quecksilber, wie sich an dem Vorhandensein vieler grauer, parallel laufender Linien schon äusserlich zu erkennen giebt, bis zu beträchtlicher Höhe dureh den äusseren Luftdruck in die Gefässe des Holzes hineingepresst worden ist. Bei Robinia kann z. B. das Quecksilber im proximalen Zweigstïck, d. h. dlem an der Pflanze verbleibenden, in einzelnen Gefässen $50 \mathrm{~cm}$ hoch emporgestiegen sein. Im distalen, $d . h$. dem abgeschnittenen Zweigende erhebt es sich nicht so hoch. Taucht man in Luft abgeschnittene Zweige mit ihren unteren Enden einige Centimeter tief in Quecksilber ein, so erhebt sich das Metall gewöhnlich nicht in den Gefässen, weil der Queeksilberdruck meistens einen geringeren Werth als die Capillardepression des Quecksilbers besitzt.

Während es leicht ist, das Vorhandensein des negativen Druckes der Gefässluft überhaupt zu constatiren, ist die Bestimmung der wahren Grösse dieses negativen Drucks mit Schwierigkeiten verbunden ${ }^{\mathrm{I}}$ ). Weitere Untersuchungen wären hier sehr erwünscht.

Recht lehrreich ist noch das folgende Experiment, welches auch bequem in der Vorlesung über Pflanzenphysiologie ausgeführt werden kann. Wir schneiden einen langen Zweig von Ampelopsis in der Luft ab, lassen die Schnittflächen einige Minuten mit der Luft in Berührung und stellen den Spross mit seiner Basis nun in Wasser. Nach 24 Stunden biegen wir eine Stelle des Sprosses, die etwa $10 \mathrm{~cm}$ höher als die erste Schnittfläche liegt, in Eosinlösung und schneiden sie unter der Flüssigkeit ab. Die Lösung steigt bis zu beträchtlicher Höhe in den Gefässen empor, woraus folgt, dass der negative Druck der Gefässluft sich in Sprossen, die in Luft abgeschnitten worden sind, nach Verlauf einiger Zeit unter den bezeichneten Umständen wiederherstellt, eine Erscheinung, die verschiedene Ursachen haben kann $^{2}$ ).

1) Vgl. Pfeffrer, Handbuch der Pflanzenpliysiologie, Bd. 1, S. 109, und ₹. HöHxt, Jahrbücher f. wissenschl. Botanik, Bd. 12, S. 99. Bei vergleichenden Untersuchungen über den negativen Gasdruck hat man weit mehr, als seither geschehen, Rücksicht zu nehinen auf die Länge und Weite der Gefässe, auf etwaige Veränderungen in der Weite eines Gefässes an verschiedenen Stellen desselben, auf die capillaren Widerstände der Gefässe und andere Verhältnisse. Es würde uns viel zu weit führen, alle diese Dinge hier näher zu erörtern. Vgl. auch besonders ADLER, Dissertation, Jena 1892, S. 42.

2) Die Verhältnisse, welche sich auf den negativen Luftdruck in den Gefässen beziehen, sind zumal von HörseL, Wissenschl.-praktische Untersuchungen auf dem Gebiete des Pflanzenbaues, herausgegeben von HabrerLandT, Bd. 2, S. 89 u. 120, sowic von SACHS, Arbeiten d. botan. Instituts in Würzburg, Bd. 2, S. 168, untersucht worden. 


\section{Die Wasseraufnahme seitens der Pflanzen.}

\section{Die Wasseraufnahme seitens der Wurzeln aus dem Boden.}

Die einzelnen Partikelchen des Bodens sind in mehr oder minder feuchtem Zustande desselben mit Wasserhüllen umgeben. Man kann sich vorstellen, dass diese letzteren die Bodenelemente in concentrischen Schichten umgeben, und es leuchtet ein, dass die Bodentheilchen die ihnen direct anliegenden Wassermoleküle energischer festhalten werden als die mehr peripherisch gruppirten. In der That ist dies der Fall, wie der folgende Versuch lehrt. Wir cultiviren eine Bohne in einem Blumentopfe. Die Pflanze wurzelt in guter Gartenerde, und der Topf wird, wenn die Primordialblätter der Bohne eine beträchtliche Grösse erreicht haben, in einen Raum gestellt, in welchem sio vor directem Sonnenlicht geschützt ist und nur schwach transpiriren kann. Wir führen dem Boden von jetzt ab kein Wasser mehr zu, so dass die Pflanze langsam welken muss. Wenn das Untersuchungsobject sehr welk geworden ist, entnehmen wir dem Boden an Stellen, die von vielen Wurzeln durchzogen sind, kleine Proben von einigen g Gewicht und bestimmen den Wassergehalt durch Trocknen bei $100^{\circ}$ C. genau. Ich fand bei Versuchen, die freilich nicht mit Phaseolus, sondern mit Cucurbita angestellt wurden, dass die benutzte humose Gartenerde nach eingetretenem Welken der Pflanze noch über 15 Proc. Wasser enthielt, und man sieht also, dass ein Theil des Bodenwassers von den Erdtheilchen sehr festgehalten wird. Die Pflanzen welken unter den bezeichneten Umständen eben deshalb, weil die Wurzeln dies fest gebundene Wasser nicht schnell genug und nicht in hinreichender Menge aufnehmen können, um die Transpirationsverluste zu decken ${ }^{\mathbf{1}}$ ).

Lehrreich ist es ferner, kleine Bodenmengen von einigen $\mathrm{g}$ Gewicht, die man dem Blumentopfe nach eingetretenem starken Welken der Versuchspflanzen entnommen hat, in einen wassergasreichen Raum, in dem aber Thaubildung ausgeschlossen ist, zu bringen und auf ihr Verhalten unter diesen Umständen zu prüfen. Man thut am besten, die gewogenen Erdproben in kleinen Schälchen nebst einem Wasser enthaltenden Gefäss und einem Psychrometer unter einen Kasten zu stellen. Die Luft im Kasten ist offenbar sehr wassergasreich, und das Quecksilber im trockenen Thermometer des Psychrometers wird daher auch nur einen wenig höheren Stand als dasjenige des feucht gehaltenen Thermometers besitzen. Trotz dieses hohen Wassergehaltes der die Bodenproben umgebenden Luft stellt sich heraus, dass dieselben kein Wasser durch Condensation binden; im Gegentheil, sie verlieren noch Wasser durch Verdunstung. Wir wissen, dass allerdings trockener Boden Wassergas zu condensiren im Stande ist, aber dieses Wassergasverdichtungsvermögen des Bodens besitzt für die Vegetation im Allgemeinen keine Bedeutung, da die meisten Gewächse, wie unsere Experimente lehren, schon zu Grunde gehen, wenn der Boden noch so viel Wasser enthält, dass sein Condensationsvermögen für Wasser-

1) Vgl. DetMer in WoLLixy's Forschungen auf dem Gebiete der Agriculturphysik, Bd. 1, und Journal f. Landwirthschaft, 27. Jahrgang. Daselbst ist auch die Literatur angegeben und sind weitere Verhältnisse der Wasseraufnahme seitens der Wurzeln besprochen. 
gas selbst unter selır günstigen Umständen noch gar nicht zur Geltung kommen kann.

\section{Die Wasseranfnahme seitens der Blätter.}

Die Frage nach der Wasseraufnahme seitens der Blätter beansprucht kein hohes physiologisches Interesse; trotzdem mag dieselbe hier kurz berührt werden. Beim Eintauchen der Lamina vieler Blätter (Brassica, Zea oder Aristolochia Sipho etc.) in reines Wasser erscheinen die Pflanzentheile von einer silberglänzenden Schicht überzogen, die nur dort, wo grössere Blattnerven verlaufen, unterbrochen ist. Nimmt man die Blätter aus dem Wasser heraus, so überzeugt man sich, dass lediglich die Cuticula über den Blattnerven sowie eventuell vorhandene Haare eine Benetzung erfahren haben. Die Cuticula über dem Mesophyll ist in Folge ihres mehr oder minder erheblichen Wachsreichthums nicht benetzbar und daher selbst nach der Berührung mit dem Wasser trocken. Der erwähnte Silberglanz rührt von einer Luftschicht zwischen dem Blattgewebe und dem Wasser her, wodurch das Licht eine totale Reflexion erfährt. Bei längerem Verweilen der Blätter unter Wasser wird die Oberfläche derselben benetzbar, und dann verschwindet auch der Silberglanz ${ }^{1}$ ). Bei solchem längeren Verweilen der Blätter unter Wasser kann die Flüssigkeit ohne Zweifel durch die Cuticula (aber auch auf anderem Wege) in das Innere der Pflanzentheile eindringen. Werden gewogene Blätter bei Abschluss des Lichts mit der Spreite in Wasser getaucht, während der Blattstielquerschnitt, den man zweckmässig mit etwas Wachs verkittet hat, unbenetzt bleibt, so ergiebt sich in der That, dass die nach einiger Zeit aus der Flüssigkeit entfernten und sehr vorsichtig mit Fliesspapier abgetrockneten Blätter jetzt ein höheres Gewicht als zu Beginn des Versuchs besitzen. Natürlich kann dies nur eintreten, wenn man mit Blättern experimentirt, deren Zellen nicht von vornherein das höchste Maass von Turgescenz erkennen lassen. Ich erhielt besonders günstige Resultate, wenn ich Blätter von Coffea arabica oder Syringa vulgaris kürzere Zeit (3 Stunden) oder längere Zeit (etwa 20 Stunden) mit der Spreite in Wasser tauchte, und wenn die abgeschnittenen Blätter vor Ausführung der Versuche 2 Stunden lang an einem schattigen Ort verweilt hatten und somit nicht $\mathrm{zu}$ wasserreich waren ${ }^{2}$ ).

\section{Einige Bewegungserscheinungen an Pflanzentheilen, die mit der Wasseraufnahme derselben in Znsammenhang stehen.}

Recht interessante Erscheinungen in Folge der Wasseraufnahme zeigen die inneren Blätter des Involucrums von Carlina acaulis, einer Pflanze, die auf trockenem, kalkreichem Boden wächst. Wird der gesammte Blüthenstand benetzt, so legen sich die sämmtlichen inneren Involucralblätter zusammen (vgl. Fig. 67); Austrocknung ruft wieder Ausbreitung der Blattgebilde hervor (vgl. Fig. 68). Die Involucralblätter besitzen silberweisse Farbe; nur der mittlere Theil ihrer Unterseite ist braun

1) Vgl. Sachs, Handbuch d. Experimentalphysiologie d. Pflanzen, S. 159.

2) Vgl. Detsier in Wollxy's Forschungen, Bd. 1, Heft 2, und Journal für Landwirthschaft, 27. Jahrgang, S. 105. 
gefärbt. Wird diese braun erscheinende Region eines einzelnen aus dem Blüthenstande der Carlina entfernten Involucralblattes mit Wasser benetzt,

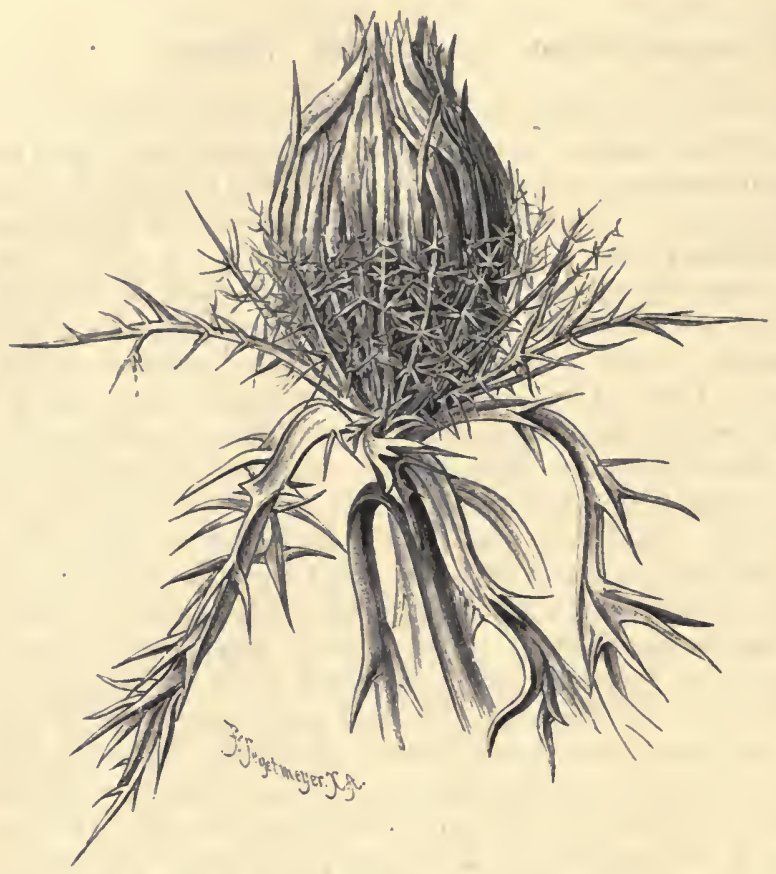

Fig. 67. Carlina aeaulis, Blüthenstand mit geschlossenem Involucrum.

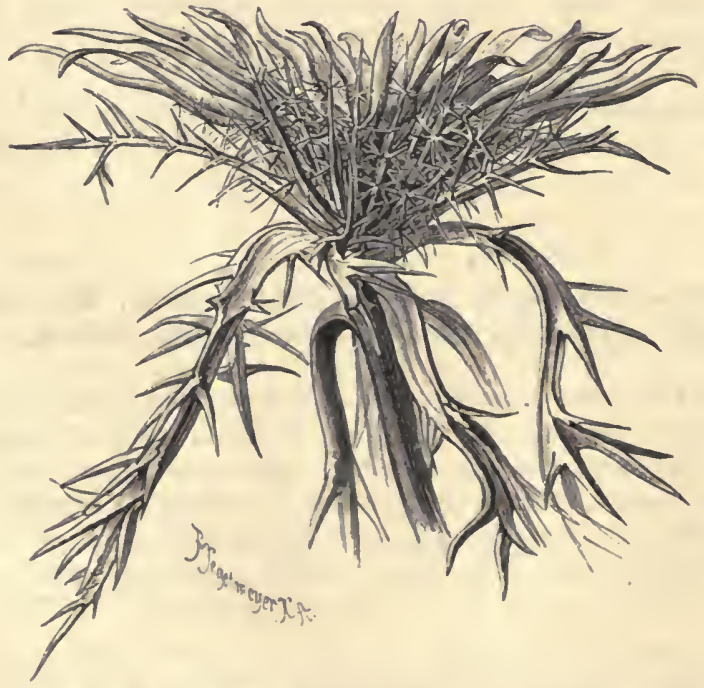

Fig. 6s. Carliua acaulis, Blüthenstand mit ausgebreitetem Involucrum. so tritt sogleich eine

Bewegungserscheinung an demselben hervor, und die Unterseite des Blattes ist alsbald convex gekrümmt. Wir stellen auch feine Querschnitte durch den mittleren Theil eines Involucralblattes her und constatiren das Folgende. Auf, der Ober- sowie Unterseite ist eine Epidermis vorhanden. Die Epidermiszellen der Unterseite sind braun gefärbt. Die Hauptmasse des Gewebes zwischen den Epidermislagen wird vom Parenchym gebildet, das von einigen Gefässbündeln durchzogen ist. Das Parenchym grenzt auf der Unterseite nicht direct an die Epidermis, sondern zwischen beiden ist eine Sklerenchymschicht vorhanden, die aus etwa 3 Lagen stark verdickter, lückenlos zusammenschliessender Zellen besteht. Dieses Sklerenchym vermittelt nun die erwähnten Bewegungen, indem die Zellen desselben sich bei Benetzung der Blätter beträchtlicher verlängern als diejenigen des Parenchyms, und indem sie sich beim Austrocknen der Blätter am bedeutendsten zusammenziehen. Die 
Bewegungserseheinungen der Involucralblätter von Carlina hängen nicht direct mit der Lebensthätigkeit der Zellen zusammen; denn auch die trockenen abgestorbenen Blätter sind bewegungsfähig ${ }^{1}$ ).

Wenn man Carlinapflanzen an ihrem natürlichen Standorte beobachtet, so stellt man leicht fest, dass die Carlinablüthenstände bei feuchter, regnerischer Witterung geschlossen erscheinen, indem sich die Involueralblätter in Folge eingetretener Benetzung zusammengelegt haben und die Blüthen dadurch vor nachtheiligen Witterungseinflüssen schützen.

Eigenthümliche Bewegungserscheinungen, die durch Wasseraufnahme bedingt werden, aber ebensowenig wie diejenigen der CarlinaInvolucralblätter mit dem Leben der Zellen direct zusammenhängen, lassen sich an den Schnäbeln der Erodiumfrüchte sowie an den Grannen von Stipa beobachten. In Fig. 69 ist eine trockene Theilfrucht von Erodium

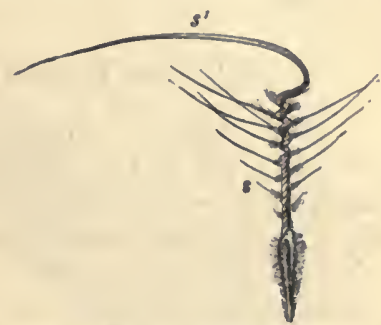

Fig. 69. Erodiumfrucht.

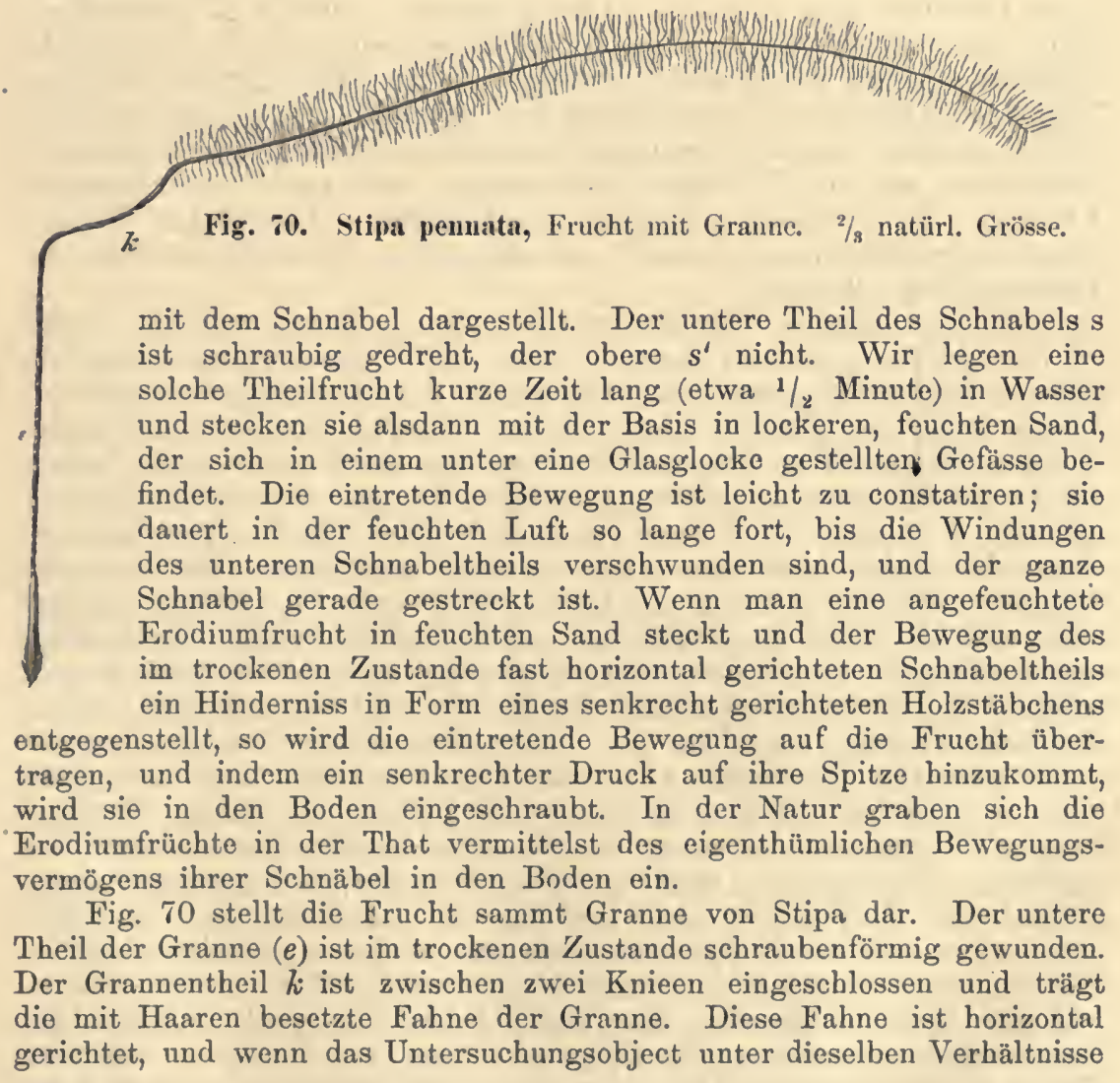

1) Vgl. DetMer, Journal für Landwirthschaft, 27. Jahrgang, S. 110, und RÄтнич, Sitzungsberichte der Akadem. d. Wiss. zu Wien, Bd. 83. 
wie eine Erodiumfrucht gebracht wird (vgl. oben), so bewirkt die Wasseraufnahme unter Zurückwinden des schraubigen Theils der Granne ein Einbohren der Frucht in den Boden. Die Ursachen der hier besprochenen Bewegungserscheinungen sind in gewissen Structurverhältnissen bestimmter Zellen der schraubenförmig gewundenen Theile der Erodium- und Stipafrüchte zu suchen.

\section{Dic Wasseraufnahme der Friichte und Samen.}

Es kommt häufig vor, dass saftreiche Früchte (Steinfrüchte, Beeren), die sich noch in Verbindung mit ihrer Mutterpflanze befinden, bei regnerischem Wetter aufreissen. Diese Erscheinung ist insbesondere Folge der unter den bezeichneten Verhältnissen fast völlig aufhörenden Transpiration der Pflanzen. Die Zellen des Parenchyms der Früchte turgesciren sehr stark, es kommen Spannungsverhältnisse im Fruchtgewebe zur Geltung (namentlich wird die Epidermis einer energischen Dehnung ausgesetzt), und schliesslich erfolgt das Aufreissen der Früchte. Bei dem Zustandekommen dieser Erscheinung kann nebensächlich auch ein anderes Moment mitwirken, nämlich die Aufnahme von Wasser seitens der Früchte, wodurch der Turgor der Parenchymzellen noch mehr gesteigert wird. Zur Constatirung der. Thatsächlichkeit dieser Wasseraufnahme werden unversehrte Kirschen oder Weinbeeren genau gewogen, derartig in Wasser gelegt, dass der Fruchtstiel aus der Flüssigkeit hervorragt, und nach 4-8-stündigem Verweilen in derselben sorgfältig abgetrocknet. Abermalige Wägung ergiebt gewöhnlich eine nicht unwesentliche Gewichtszunahme der Untersuchungsobjecte.

Wir legen einige Weizenkörner in Wasser. Nach etwa 12 Stunden ist der Quellungsprocess bereits sehr weit fortgeschritten, und die Körner sind weich geworden. Die dünne das Weizenkorn umgebende Schale lässt das Wasser leicht in das Innere desselben eindringen. Wollen wir suns über den anatomischen Bau der Frucht- sowie Samenschale des Weizens orientiren, so stellen wir die erforderlichen Querschnitte nicht aus einem Korn her, das bereits völlig aufgequollen ist, denn ein solches lässt sich sehr schlecht schneiden. Wir benutzen vielmehr Körner, die nicht zu lange mit Wasser in Contact gewesen sind, und behandeln die möglichst dïnnen Schnitte vor der Beobachtung mit Kalilauge. Diese ruft eine starke Quellung der Gewebe hervor, wodurch die Structurverhältnisse der Frucht- und Samenschale ziemlich deutlich werden (vgl. Fig. 71). Die Fruchtschale besteht aus der cuticularisirten Epidermis $e p$, einer Parenchymschicht $e$ und einer weiteren sich an diese anschliessenden Zellschicht, deren Elemente tangential gestreckt erscheinen, chl. Die Samenschale besteht aus mehreren Zellschichten, aber die zellige Structur der äusseren Lagen ii ist auf dem Querschnitt nicht gehörig zu erkennen, und dieselben präsentiren sich der Hauptsache nach nur als braun gefärbter Streifell. Die innerste Schicht $n$ der Samenschale, welche direet unter dem erwähnten braunen Streifen liegt, besteht aus wasserhellen Zellen. Die Samensehale unschliesst das Endosperm und den Embryo. Auf diese Theile des Weizenkornes kommen wir spāter zurïck. Es sei hier nur erwähnt, dass die unmittelbar unter der Samenschale liegende Endospermschicht (Kileberzellschicht) aus einer einfachen Lage fast 
Fig. 71. Triticum vulgare. $A$ Querschnitt durch die Frucht- und Samenschalc. An dieser $e p$ die Epidermis, $e$ an die Epidernis grenzende Schichten, chl dic Chlorophyllschicht; diese alle gehören zur Fruchtwandung. $i i$ die aus dem inneren Integument hervorgegangene Hülle, $n$ die ausserste verdickte Schicht des Nucellus; diese zusammen bilden die Samenschale. al die Aleuronschicht des Endosperms. Vergr. 240.

$B$ medianer Längsschnitt durch den unteren Theil einer reifen Frucht. In dieser links unten der Keim mit dem Scutellum $s c, l^{\prime}$ der Ligula am Scutellum, $v$ s seinem Gefässbündel, $c e$ seinem Cylinderepithel, $c$ dem Scheidentheil des Cotyledons, $p v$ dem Stammvegetationskegel, $h p$ dem hypocotylen Gliede, $l$ der Ligula an deinselben, $r$ der Radicula, $c p$ der Wurzelhaube der Radicula, el der Wurzelscheide; $m$ Austrittsstelle der Radicula, der Mikropyle der Samenknospe entsprechend, $p$ der Fruchtstiel, $v p$ Gefässbündel desselben, F Seitenwandung der Frucht. Vergr. 14. (Nach Strasburger.)

quadratischer Zellen besteht, die, was freilich bei der Untersuchung mit Kalilauge behandelter Schnitte nicht zu sehen ist, Proteinkörner (keine Stärke) enthalten. Es folgen darauf die mehr oder minder stärkereichen Gewebemassen des Endosperms.

Wir stellen Querschnitte des Samens von Lupinus luteus her. Am besten benutzen wir Samen, die in Folge von Wasseraufnahme bereits etwas aufgequollen sind, und untersuchen die Schnitte in Wasser und Aetzkalilösung. Die Cuticula ist ziemlich mächtig entwickelt und von einem körnigen Ueberzuge (Wachsmasse) bedeckt. Unser besonderes Interesse beansprucht die Epidermis, welche aus langen, radial zur Samenoberfläche gestellten Pallisadenzellen besteht. Die Wände dieser Zellen sind sehr stark verdickt. Die Pallisadenzellen führen einen braunen Farbstoff, der aber nur in bestimmten Gruppen der Epidermiszellen vorhanden ist, was das gefleckte Aussehen der Samen bedingt. Unter der Epidermis beobachten wir eine einfache Lage säulenförmiger Zellen, die sehr weite Intercellularräume zwischen sich lassen und radial gegen die Samenoberfläche gerichtet sind. Es folgt nun eine in Aetzkali stark aufquellende Zellschicht, die aus mehreren Lagen tangential gestreckter Zellen besteht. An diese schliessen sich die stark zusammengedrückten Reste des Endosperms an, und schliesslich sehen wir noch das Gewebe der Cotyledonen.

Werden viele Lupinensamen, vielleicht 100 Stück, in Wasser geworfen, so findet man, dass nach Verlauf längerer Zeit, z. B. 24 Stunden oder gar 8 oder 14 Tagen, noch keineswegs sämmtliche Individuen in den gequollenen Zustand übergegangen sind. Diese Schwerquellbarkeit, der eine erhebliche biologische Bedeutung zukommt, ist ausser den Lupinensamen vielen anderen Samenspecies eigenthümlich und

Detmer, Pfanzenphyslojogisches Praktikum. 2. Aufi. 
wird in unserem Falle dadurch bedingt, dass die Zellen der noch vollkommen intacten Pallisadenschicht der Samenschale in Folge besonderer Eigenthümlichkeiten ihrer Membranen sehr schwer permeabel für Wasser sind. Verletzt man die Pallisadenschicht eines Samens von Lupinus, so quillt er stets in Contact mit Wasser leicht auf ${ }^{1}$ ).

Die Samen von Pisum sativum gehören $\mathrm{zu}$ den leicht aufquellenden, wovon man sich überzeugen kann, wenn man das Untersuchungsmaterial mit Wasser in Berührung bringt. Die Testa von Pisum hat in ihrem Bau manche Aehnlichkeit mit derjenigen von Lupinus. Wir ziehen die Samenschale von den aufgequollenen Samen $a b$, falten sie zusammen und stellen zarte Querschnitte her, die wir in Aetzkali untersuchen. Auf die Pallisadenschicht folgt auch hier die Säulenschicht, dann ein aus vielen Zelllagen bestehendes Parenchym, dessen Elemente tangential gestreckt erscheinen, und endlich die Reste des zusammengedrückten Endosperms.

Die Quellung der meisten Samen wird durch den Imbibitionsprocess, sowie durch osmotische Vorgänge vermittelt. Bei einigen Samen, z. B. denjenigen von Linum usitatissimum, wird der Verlauf der Quellung noch dadurch beschleunigt, dass dieselben in Contact mit Wasser einen Schleim austreten lassen, der das Wasser sehr energisch anzieht und festhält. In der That umgiebt sich jeder Leinsame, den wir mit Hasser in Berührung bringen, sofort mit einer Schleimhülle. Wir stellen recht zarte Querschnitte aus trockenen Leinsamen her und bringen dieselben in Alkohol auf den Objectträger. Nun lassen wir; während wir beobachten, Wasser vom Deckglasrand aus zu dem Object treten. In dem Moment, in welchem das Wasser mit dem Schnitt in Berührung gelangt, quellen die Zellen der Epidermis der Samenschale sehr stark auf und lassen den als Verdickungsschichten der Aussenwände der Epidermiszellen vorhandenen Schleim, ohne dass die Zellwände zerreissen, austreten. Die Epidermiszellen sind, wie man jetzt leicht sieht, radial gegen die Samenoberfläche gerichtet. Auf die übrigen Zellschichten der complicirt gebauten Samenschale von Linum wollen wir hier nicht näher eingehen.

Betrachtet man einen trockenen Phaseolussamen und orientirt denselben derartig, dass der in Form eines weissen Streifens entwickelte Nabel dem Beobachter zugewandt ist, so findet man auf der einen Seite des Streifens eine kleine Vertiefung, die Mikropyle, welche dicht über der Wurzelspitze des Embryo liegt. Ain entgegengesetzten Ende des Nabels sieht man zwei kleine, durch eine seichte Naht getrennte Wülste, die Doppeltuberkeln. Diese, der Nabel und die Mikropyle bilden den hilaren Apparat des Samen. Die Mikropyle spielt bei der Quellung der in Wasser liegenden Bohnensamen, wie folgender Versuch lehrt, eine besonders wichtige Rolle. Ein Phaseolussamen $a$ wird völlig in Wasser eingetaucht. Einen zweiten Samen b, der möglichst genau das nămliche Gewicht wie $a$ besitzt, befestigt man in geeigneter Weise an einer Nadel und taucht ihn derartig in Wasser ein, dass seine Oberfäche mit Ausnahme des hilaren Apparates benetzt wird. Wägungen ergeben nach Verlauf einiger Stunden, daș a relativ viel, $b$ aber nur wenig Wasser aufgenommen hat ${ }^{2}$ ).

1) Vgl. Detmer, Journal f. Landwirthschaft, 27. Jahrg., S. 119.

2) Ueber den Bau von Samenschalen vgl. zumal SFMPOLOWski's Dissertation, Leipzig 1874. Daselbst ist auch die wichtigste Literatur zusammengestellt. Ferner vergl. Mattirola u. Buscaliost, Memorie della R. Accademia delle Scienze di Torino, Serie II, T. XLII. 


\section{Weitere Experimente iiber den Quellungsprocess der Samen.}

Die Wassermengen, welche verschiedene in:den völlig gequollenen Zustand übergegangene Samenarten aufgenommen haben, sind keineswegs die nämlichen. Die Quellungscapacität der Samen ist also eine verschiedene. Man bestimmt das Gewicht einiger lufttrockener Weizenkörner und Erbsensamen. Die Untersuchungsobjecte gelangen nunmehr in Wasser und verweilen in demselben 24 Stunden. Nach dieser Zeit trocknet man die Samen gut $a b$, um ihr Gewicht abermals zu ermitteln, legt sie wieder in Wasser und bestimmt nach Verlauf von 6 Stunden ihr Gewicht aufs Neue. Eventuell müssen noch mehrfache Wägungen ausgeführt werden, aber auf jeden Fall wird sich als Resultat des Versuchs herausstellen, dass, wenn das Gewicht der Untersuchungsobjecte keine wesentlichen Veränderungen mehr erfährt, die Erbsensamen viel mehr Wasser im völlig gequollenen Zustande als die Weizenkörner enthalten. Erbsensamen nehmen bei der Quellung etwa 100, Weizenkörner nur 40-60 Gewichtsprocent Wasser auf.

Bei Benutzung vieler Samen (z. B. Bohnen, Erbsen) zu Quellungsversuchen lässt sich die Thatsache sofort constatiren, dass das Volumen der gequollenen Untersuchungsobjecte weit grösser als dasjenige der lufttrockenen ist. Wir können uns aber auch die Frage vorlegen, ob das Volumen einer gegebenen Samenmenge und einer gegebenen als Quellflüssigkeit dienenden Wassermenge in seiner Gesammtheit in Folge der Quellnng Veränderungen erfährt. Das folgende Experiment kann zur Beantwortung dieser Frage ausgeführt werden. Wir benutzen den in Fig. 72 abgebildeten Apparat. In einen Kolben von ca. $600 \mathrm{ccm}$ Capacität bringen wir $300 \mathrm{~g}$ Erbsen (ich experimentirte mit weissen Riesenerbsen). Der Kolben wird dann völlig mit Wasser

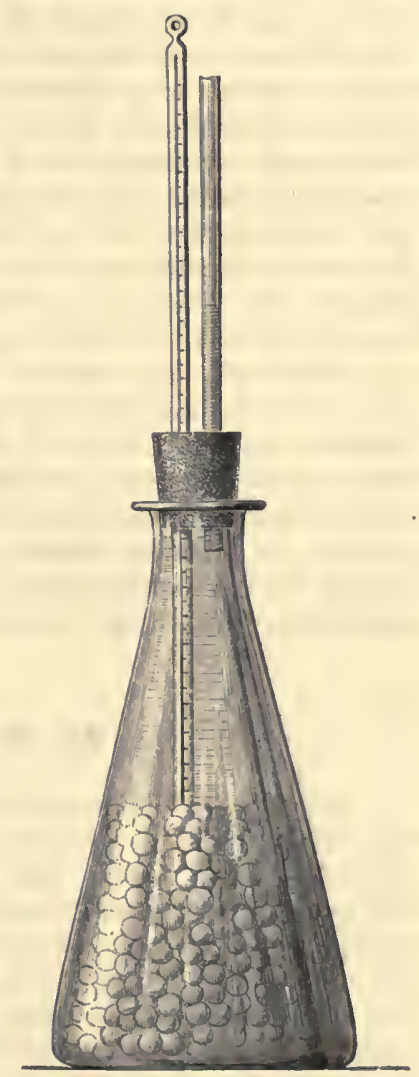

Fig. 72. Apparat zur Beobachtung von Quellungserscheinungen. angefüllt und sofort mit einem durchbohrten Kautschukkork verschlossen. Durch die eine Bohrung führen wir ein Thermometer, durch die zweite ein gerades Glasrohr (Steigrohr) von $0,5 \mathrm{~cm}$ Durchmesser ein. Der Stand des Wassers in letzterem kann bei Beginn des Versuchs und ebenso im Verlauf desselben von $5 \mathrm{zu} 5 \mathrm{Mi}$ nuten leicht mit Hülfe eines Millimetermaassstabes festgestellt werden, und man wird die Beobachtung machen, dass sich das Wasser im Steigrohr zunächst höher und höher erhebt. Dies Steigen dauert $3 / 4$, zuweilen auch $11 / 2$ Stunden, dann sinkt das Wasser im Steigrohr kurze Zeit oder unter Umständen auch einige Stunden, um schliesslich wieder zu steigen. 
Bei genauen Versuchen ist auch der Einfluss der Temperaturverhältnisse auf den Wasserstand im Steigrohre zu berücksichtigen.

Wenn Samen mit Wasser in Contact gelangen und in Folge dessen Imbibitionsvorgänge zur Geltung kommen, so muss eine Verdichtung des in die Samen eindringenden Wassers eintreten. Ein solcher Process würde aber zu einer Gesammtvolumenverminderung der Samen und des Wassers führen. Davon ist aber in unserem Experimente nichts zu sehen, vielmehr erhebt sich das Wasser bei Beginn des Versuchs rapide im Steigrohr; es tritt also eine Gesammtvolumenzunahme der Samen und der Quellflüssigkeit deutlich hervor. Die Ursachen, welche diese bedingen, beeinflussen den Wasserstand im Steigrohr also auf jeden Fall in überwiegendem Maasse, und sie sind in einer bei Beginn der Quellung der Erbsensamen eintretenden Faltung der Testa zu suchen. Diese hebt sich von den Cotyledonen der Samen ab; es entstehen mit verdünnter Luft erfüllte Hohlräume zwischen den Keimblättern und der Samenschale, so dàss das Gesammtvolumen der Samen und des Wassers zunehmen muss. Wenn man Erbsensamen, deren Testa man verletzt hat, in unserem Apparat mit Wasser in Berührung bringt, so kommt in der That, wie ich fand, das Steigen des Wassers im Steigrohre während der ganzen ersten Versuchsperiode nicht zu Stande.

Während der zweiten Versuchsperiode sinkt das Wasser im Steigrohre; es macht sich eine Gesammtvolumenabnahme der Samen und des Wassers geltend, die auf ein Eindringen von Wasser in Hohlräume der Samen zurückgeführt werden muss. Auf die Ursachen, welche dem erneuten Steigen des Wassers im Steigrohr während der dritten Versuchsperiode zu Grunde liegen, gehe ich hier nicht näher ein. Darüber und ebenso über das Verhalten anderer quellender Samen in der hier in Rede stehenden Beziehung ist meine citirte Schrift $\mathrm{zu}$ vergleichen ${ }^{\mathbf{1}}$ ).

\section{Die Wasseraufnahme der Moose.}

Die Moose besitzen keine eigentlichen Wurzeln, sondern Rhizoide. Um diese Organe genauer kennen zu lernen, wählen wir Bryum caespiticium, ein Moos, das häufig auf Mauern angetroffen wird. Mit Hülfe eines Wasserstrahles wird die den Pflanzen anlıftende Erde möglichst entfernt, der untere Theil eines Stämmchens abgeschnitten, auf den Objectträger gebracht und beobachtet. Es zeigt sich, dass aus dem Stämmchen lange, mehrzellige, recht breite, braun gefärbte Fäden hervorgehen, die vielfach feinere Zweige besitzen und nur an ihren Enden farblos sind. Die Scheidewände zwischen den einzelnen Zellen erscheinen schief gestellt. Den Rhizoiden, mit denen wir es hier zu thun haben, kommt vor allem die Aufgabe $\mathrm{zu}$, die Moospflanze im Boden zu befestigen. Als wasseraufnehmende Organe besitzen sie, wenigstens bei vielen Moosen, eine nur untergeordnete $\mathrm{Be}$ deutung.

Wird ein Rasen von Hylocomium triquetrum in feuchtem Zustande in eine flache, Wasser enthaltende Schale gestellt, so trocknen die oberen Theile der Pflanze alsbald aus. Dieser Versuch lehrt, dass im

1) Vgl. Detmer, Vergleichende Physiologie des Keimungsprocesses der Samen, Jena 1880, S. 71 , und die unter 72 eitirte Arbeit von Matrirola. Vgl. auch Botan. Centralblatt, 1892, Bd. 52, S. 155. 
Innern der Moospflanzen keine energische und ausreichende Wasserleitung wie im Organismus der höheren Gewächse stattfindet. Beobachtet man die in Wasser liegenden Hylocomiumrasen genauer, wenn die Enden der Pflanzen trocken sind, so findet man übrigens eine ziemlich lange, ïber dem Wasserspiegel liegende Partie der einzelnen Stämmchen feucht. Das Wasser wird also von den Moospflanzen bis zu einer gewissen Höhe emporgehoben, und zwar sind es Capillarkräfte, welche dies vermitteln. Das Wasser steigt in den engen Hohlräumen, welche zwischen dem Stämmehen und den diesen dicht angeschmiegten Blättern vorlanden sind, bis zu bestimmter Höhe empor, aber es müssen natürlich alle Theile der Moospflanzen austrocknen, welche durch diese äussere Wasserleitung nicht mehr mit Feuchtigkeit versorgt werden können. Wird ein kräftiger Zweig von Hylocomium triquetrum zwischen Fliesspapier gut abgetrocknet und dann mit seiner Basis oder Spitze in die Lösung eines Anilinfarbstoffes eingetaucht (ich benutzte eine wässerige Lösung von Methylanilinviolett), so beobachtet man leicht, dass die Flüssigkeit in der That bis zu einer gewissen Höle capillar emporsteigt. Werden von anhaftender Erde befreite Rasen von Hylocomium- oder Hypnumspecies im lufttrockenen Zustande gewogen, vielleicht 10 Minuten lang unter Wasser getaucht, auf eine schräg gestellte Glasplatte gelegt, damit das überschüssige Wasser abtropft, und nun abermals gewogen, so ergiebt sich, dass sie das Melırfache ihres ursprünglichen Gewichts an Wasser zurückzuhalten vermögen. Das Resultat dieses Experimentes ist im Stande, uns eine Vorstellung davon zu geben, wie gross die Wassernengen sind, welche der Moosrasen im Walde capillar festzuhalten vermag, und in der That spielen die Moose, wie hier niclıt speciell auseinandergesetzt werden kann, eine wichtige Rolle als Regulatoren der Feuchtigkeitsverhältnisse vieler Gegenden.

Untersucht man Querschnitte aus dem Stämmchen von Hylocomium triquetrum, so findet man das ganze Gewebe aus Zellen zusammengesetzt, deren Wände eine gelblichbraune Farbe besitzen und stark verdickt sind. Das Lumen der peripherischen und ebenso dasjenige weniger central gelegener Elemente (die letzteren bilden die Andeutung eines Centralstranges) ist viel enger als das Lumen der übrigen Zellen. Für solche Moose, welche keinen oder einen nur schwach entwickelten, bekanntlich aus sehr lang gestreckten Zellen zusammengesetzten Centralstrang besitzen, komint wesentlich nur die äussere Wasserleitung durch Capillarität in Betraclit. Dagegen scheint ein entwickelter Centralstrang die Möglichkeit zu einer ausgiebigeren inneren Wasserleitung zu bieten, und Versuche, welche man mit Polytrichum angestellt hat, bestätigen dies. In der That ist bei Polytrichum ein wohl ausgebildeter Centralstrang im Stämmchen vorhanden, wovon man sich bei mikroskopischer Untersuchung zarter Querschnitte überzeugt, und als ich einige Stämmchen von Polytrichum formosum dicht neben einander mit ihrem unteren Ende in Wasser stellte, blieben auch die oberen Blätter der Pflanzen frisch. In diesem Zustande stehen die Polytrichumblätter vom Stamme ab, während sie sich beim Austrocknen demselben nach oben anlegen.

Ein besonderes Interesse beansprucht auch noch die Art und Weise, in der die Sphagnumarten Wasser von aussen aufnehmen und die aufgenommene Flüssigkeit festhalten. Mit Rücksicht auf diese Verhältnisse mögen hier übrigens einige Andeutungen bezüglich des 
Baues der Blätter der erwälnten Pflanzen genügen. Wir unterziehen Blätter von Sphagnum acutifolium der mikroskopischen Untersuchung. Die grünen, röthlichen oder intensiv roth gefärbten Rasen dieses Mooses sind leicht aufzufinden, und jedes entwickelte Blatt besteht aus chlorophyllhaltigen Zellen, die zu einem Netzwerk mit einander verbunden sind, und aus nicht mehr lebensthätigen, Wasser oder Luft enthaltenden, farblosen Zellen, welche zwischen den grünen Zellen liegen und deren ringförmig oder spiralig verdickte Membranen mit wirklichen Löehern versehen sind. In diese Löcher dringt das Wasser leicht von aussen in die Zellen ein und wird von denselben festgehalten, so dass ein Sphagnumrasen schon aus diesem Grunde ähnlich wie ein Schwamm im Stande ist, bedeutende Wassermengen festzuhalten ${ }^{1}$ ).

\section{Die Wasserbewegung in den Pflanzen.}

\section{Constatirung der Erseheinung des Wurzeldrucks.}

Handelt es sich darum, den Nachweis zu liefern, dass in den Pflanzenzellen in Folge osmotischer Vorgänge und der Turgorverhältnisse Druckkräfte entstehen können, welche im Stande sind, den Zellsaft durch die Membranen der Zellen zu pressen, so dass er z. B. in die Gefässe des Holzes gelangt, so ist es bequem, die Phänomene, die durch den Wurzeldruck verursacht werden, zunächst näher ins Auge zu fassen. Kräftige, in Blumentöpfen erwachsene Individuen von Cucurbita, Helianthus, Ricinus, Begonia oder in Blumentöpfen gut angewurzelte Weidenstecklinge werden decapitirt, d. h. der Stengel der Pflanze wird in Höhe von einigen Centimetern über der Erde durchschnitten. Im Winter kann man z. B. mit Topfexemplaren von Sanchezia nobilis (zu den Acanthaceen gehörend $\left.{ }^{2}\right)$ ) experimentiren. Ueber den aus der Erde hervorragenden Stengelstumpf wird jetzt ein kurzer Kautschukschlauch (Fig. $73 k$ ) gezogen, der mit einem Glasrohr (Steigrohr $[s t]$ ) in Verbindung gebracht worden ist. Der Kautschukschlauch wird über dem Stengelstumpf sowie über der Glasröhre zur Herstellung eines luftdichten Verschlusses mit Bindfaden oder, was viel bequemer ist, mit Gummischnur festgebunden, und das Glasrohr dicht über dem Schlauche mit einer Marke $(m)$, die man mit Hülfe einer Glasfeile leicht herstellen kann, versehen. Füllt man das Glasrohr bis zur Marke mit Wasser an, so beobachtet man, wenn die Untersuchungsobjecte vor Einleitung der Experimente nicht stark transpirirt hatten, und wenn der Boden, in welchem sie wurzeln, reichliche Wassermengen enthält, dass das Flüssigkeitsniveau im Glasrohr alsbald steigt. Zur Constatirung des Saftausflusses aus den Stengelstümpfen kann man auch die in Fig. 74 abgebildete Einrichtung treffen. Auf dem Stammstumpf s wird mittelst Kautschuk $k$ ein t-Rohr (t) befestigt. Der Kautschuk

1) Ueber Wasseraufnahme d. Moose vgl. OLtmaxxs, Strassburger InauguralDissertation, 1884.

2) Dies ausgezeichnete Untersuchungsobject lïsst sich leicht durch Stecklinge vermehren. Ich fand, dass ein Exemplar bei Versuchen im Januar 14 Tage lang Saft gab. 
ist, um einen absolut luftdichten Verschluss herzustellen, wenn erforderlich, mit Draht zu umwickeln. In manchen Fällen wird man gezwungen sein, ein enges t-Rohr zu verwenden. Der verticale Schenkel des t-Rohres schliesst am oberen Ende mit einem Kork, durch den eine mit Glashahn versehene Glasröhre eingeführt ist, ab. Der horizontale Schenkel steht dagegen mit dem Ausflussrohr $r$ in Verbindung, das durch den nicht völlig luftdicht selıliessenden Kork n in den Messcylinder $b$ hineinragt. Das t-Rohr und das Ausflussrohr müssen bei Beginn des Experimentes mit Wasser angefüllt sein.

Um die Druckgrösse zu bestimmen, welche der aus Stammstümpfen ausfliessende Saft geltend zu machen im Stande ist, wird, wie es Fig. 75 zeigt, anstatt des Abflussrohres ein mit Quecksilber

Fig. 73.

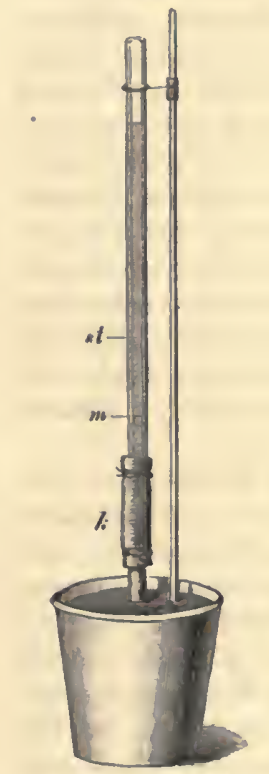

Fig. 75.

Fig. 74.

Fig. 73. Apparat zu Experimenten über den Wurzeldruck.

Fig. 74. Apparat zu Experimenten über den Wurzeldruck. (Nach PFEFFezr.)

Fig. 75. Apparat für Untersuchungen über den Wurzeldruck. (Nach PFEFFir.)

gefülltes Manometer an das t-förmige Rohr angebracht. In das t-förmige Rohr wird Wasser gegossen und ein Kork mit einem zu einer Capillare ausgezogenen Glasrohr $(g)$ eingesetzt. Die Spitze der Capillare muss so abgeschmolzen werden, dass im Apparat keine Luft zurückbleibt.

Wenn man Pflanzen in derjenigen Weise, wie es im Vorstehenden angegeben worden ist, behandelt, so zeigt sich, dass manche Untersuchungsobjecte nur einige Tage lang Saft ausfliessen lassen. Ich habe andererseits oft beobachtet, dass der Saftausfluss länger als eine Woche fortdauern kann. Werden Pflanzen decapitirt, und beobachtet man nun ihr Verhalten ohne Weiteres, so findet man, dass der Saft aus dem Holzkörper, zumal den Gefässen desselben, hervortritt. 


\section{Der Saftausfluss aus im Freien wachsenden verletzten Biumen.}

Im März oder Anfang April bringe man am Stamm einer noch nicht belaubten Birke ein Bohrloch an, welches ungefähr bis zur Mitte des Stammes reicht. Bei den von mir angestellten Versuchen wurden die $7 \mathrm{~mm}$ weiten Bohrlöcher in einer Höhe von etwa $40 \mathrm{~cm}$ über dem Erdboden, woselbst die Bäume einen Umfang von ungefähr $40 \mathrm{~cm}$ besassen, hergestellt. In das Bohrloch wird das Ende des einen Schenkels eines im rechten Winkel gebogenen Glasrohres luftdicht eingekittet, während der andere Schenkel in eine auf dem Erdboden stehende Glasflasche eingeführt ist. Unter Umständen fliesst sofort eine bedeutende Flüssigkeitsmenge aus dem Baume aus; auf jeden Fall ist es aber sehr lehrreich, das Verhalten der Pflanzen mehrere Wochen hindurch im Auge zu behalten. Wasserzufuhr zum Boden durch Regen begünstigt den Saftausfluss; er ist am Tage gewöhnlich geringer als in der Nacht, oder er ist bei Tage gar nicht und nur während der Nachtzeit vorhanden. Diese Erscheinung hat ihre Ursache darin, dass am Tage der durch die Wurzeln in den Stamm hineingepresste Saft zur Deckung des Transpirationsverlustes der Pflanze dient, wohingegen zur Nachtzeit mindestens ein Theil des Saftes ausfliessen kann, da jetzt die Wasserverdunstung durch die herrschenden äusseren Bedingungen in der Regel sehr herabgedrückt wird. Schreitet die Jahreszeit weiter vor und entfalten sich die Blätter der Birke, so hört der Saftausfluss völlig auf; die Transpirationsgrösse des Baums hat jetzt einen hohen Werth erreicht.

Die Beobachtungen über den Saftausfluss aus der Birke sind, um die Abhängigkeit der Erscheinung des Blutens von äusseren Verhältnissen näher verfolgen zu können, mit meteorologischen Beobachtungen zu verbinden. Man notire die Bewölkungsverhältnisse, den Barometerstand, und man stelle Beobachtungen über die Regenmenge, den Feuchtigkeitsgehalt der Luft sowie die Temperaturverhältnisse der Luft und des Bodens an. Die erforderlichen Apparate (Regenmesser, Thermometer, Minimumthermometer, Psychrometer, z. B. das bekannte von August mit einem trocken und einem feucht $\mathrm{zu}$ haltenden Thermometer) können sämmtlich von Muencke in Berlin, Luisenstrasse 58, bezogen werden. Um aus den Ablesungen an den Thermometern des AdGust'schen Psychrometers den Fenchtigkeitsgehalt der Luft abzuleiten, benutzt man die PsychrometerTafeln von JELINEK, Wien 1876.

Verdunstet man Birkensaft, so erhält man einen Rückstand, der aus organischen Stoffen und Mineralstoffen besteht. Von der Gegenwart der letzteren überzeugt man sich leicht, wenn man Birkensaft in einer Platinschale zur Trockne bringt und den Rückstand nun zur Zerstörung der organischen Stoffe glüht. Die Mineralstoffe bleiben zurück. Die Reaction des frischen Birkensaftes ist eine schwach saure. Beim Kochen des Saftes scheidet sich ein Coagulum von Eiweissstoffen ab. Wird eine kleine Menge des Saftes mit einigen Tropfen Schwefelsäure versetzt und unter Ersatz des verdunstenden Wassers gekocht, so erhält man eine Flüssigkeit, die, in heisse FenLING'sche Lösung eingetragen, eine Abscheidung von Kupferoxydul hervorruft. Der rohe Saft enthält nämlich Rohrzucker, der durch das Kochen mit Schwefelsäure in reducirend wirkenden Traubenzucker übergegangen ist. 


\section{7\%. Der Einfluss ausserer Verhailtnisse auf den Saftausfluss ans decapitirten Pflanzen.}

Kräftige, in Blumentöpfen zur Entwicklung gelangte Exemplare von Cucurbita, Helianthus, Ricinus oder Begonia werden deeapitirt und der Stammstumpf mit einem Steigrohre in Verbindung gebracht. Die Erde in den Blumentöpfen darf nicht übermässig feucht sein, und nachdem ein Thermometer in den Boden eingesenkt, dieser mit Stanniol belegt und der aus der Erde hervorragende Stengeltheil mit Stanniol umwiekelt worden ist, werden die Untersuehungsobjecte in ein Zimmer, in welchem eine recht constante Temperatur herrseht, oder in einen Thermostaten gebracht. Wenn der Boden in den Blumentöpfen die Temperatur der Umgebung angenommen hat, beginnt die Beobachtung. Es wird notirt, wie gross der Saftausfluss z. B. in der Stunde ist. Nach mehrstündigem Versuch wird die Erde, in der die Pflanzen wurzeln, stark begossen, und wenn die Temperaturverhältnisse sich ausgeglichen haben, aufs Neue der stündliche Saftausfluss ermittelt. Derselbe ist jetzt in Folge des grossen Wasserreichthums des Bodens viel erheblieher als früher. Bei diesen und den folgenden Untersuchungen ist nicht $\mathrm{zu}$ vergessen, dass der Saftausfluss bei vielen Pflanzen periodische Schwankungen zeigt, die sich unabhängig von äusseren Einflüssen geltend machen. (V gl. unter 78.)

Die nämlichen Untersuchungsobjecte können auch dazu benutzt werden, um festzustellen, dass die Temperaturverhältnisse von wesentlichem Einfluss auf den Saftausfluss sind. Die Erde, in der die Pflanzen wurzeln, wird bei Beginn der Versuche stark begossen, die Temperatur im Thermostaten aber von Zeit zu Zeit variirt, um nach jedesmaligem Temperaturausgleich (d. h. wenn der Boden die Temperatur der Umgebung angenommen hat) mit den Beobachtungen ïber die Grösse des Saftausflusses zu beginnen. Bei $16^{\circ} \mathrm{C}$. fliesst mehr Flüssigkeit in der Zeiteinheit (z. B. in einer Stunde) als bei $12^{\circ} \mathrm{C}$. aus. Bei $20^{\circ} \mathrm{C}$. ist der Saftausfluss erheblicher als bei $16^{\circ} \mathrm{C}$. Nach meinen Beobachtungen liegt das Temperaturoptimum für den Saftauftrieb von Cucurbita Melopepo bei etwa $26^{\circ} \mathrm{C}$. Noch höhere Temperatur deprimirt die Grösse der Flüssigkeitsausscheidung, und dieselbe hört bei einer Temperatur von $43^{\circ} \mathrm{C}$. gänzlich auf ${ }^{1}$ ).

Bei zahlreichen pflanzenphysiologischen Untersuchungen, z. B. auch bei denen, von welchen soeben die Rede war, kommt es darauf an, die Beobachtungsobjecte längere Zeit constanten Temperaturverhältnissen auszusetzen.

Wir wollen hier die Methoden und Apparate, welehe dies ermöglichen, besprechen.

Was zunächst die Thermometer anbelangt, so sind dieselben in den verschiedensten Formen, sowie Grössen und mit verschiedenen Theilungen versehen von den unter "Bezugsquellen" genannten Firmen zu beziehen. Gebraucht man mehrere Thermometer bei einem Experiment, so sind dieselben genau zu vergleichen, Prüfung der Thermometer nimmt das nnter „Bezugsquellen" genannte Institut vor. In besonderen Fällen, z. B. bei Experimenten mit dem Auxanometer, wird man vortheilhaft zur

1) Vgl. Detmer, Beiträge zur Theorie des Wurzeldrucks, Jena 1877, S. 30. Vgl. auch WrELER, in CoHs's Beiträgen zur Biologie der Pflanzen, Bd. 6, Heft 1. 
Registrirung des Temperaturganges ein WiLD'sches Registrirthermometer verwenden können, das in der von HASLER gelieferten Form sehr gut arbeitet.

Wenn man mit Registrirapparaten arbeitet oder mit grösseren Pflanzen experimentirt, die nicht in einen Thermostaten eingeführt werden kōnnen, so muss man bemüht sein, die Temperaturverhältnisse der Zimmer des Laboratoriums auf möglichst constanter Höhe zu erhalten. Sehr gut eignen sich in dieser Beziehung für kleinere Räume die mit Anthracitkohle zu heizenden sogen. amerikanischen Oefen, während für grössere Räume (solche über 150 Cubikmeter Rauminhalt) die grösseren Formen der Meidinger-Oefen (Kaiserslautern) sehr zu empfehlen sind. Pferfer ${ }^{1}$ ) gelang es, unter Benutzung solcher Oefen die Temperaturschwankungen in Tischhöhe und in einiger Entfernung vom Fenster während Tagen und Wochen auf $+0,18^{\circ} \mathrm{C}$. einzuengen.

Um Pflanzen längere Zeit einer Temperatur von $0^{0}$ auszusetzen, verwendet man den unter 49 beschriebenen Eiskasten. Räume von sehr constanten niederen Temperaturen über $0^{0}$ sind in tiefen Kellern, Eiskellern oder auch in nach Norden gelegenen Zimmern eines Gebäudes mit dicken Wänden gegeben.

Von ganz besonderer Wichtigkeit für viele physiologische Untersuchungen, z. B. auch für manche Experimente, die sich auf den Wurzeldruck beziehen, sind gute Thermostaten. Diese Apparate bezicht man z. B. von Dr. H. Roнrbeck (Berlin NW., Karlstrasse Nr. 24). Sehr empfehlenswerth ist ein Thermostat, den Rонввеск in seinem Preisverzeichniss von 1891-92 unter Nr. 114 aufführt. Preis je nach Grösse 50-200 Mk. Einen einfacheren Apparat, aber doch sehr brauchbar, findet man in dem nämlichen Preisverzeichniss unter 129. Preis je nach Grösse 20.-30 Mk. Dieser Thermostat, doppeltwandig, mit Wasserstandsrohr und Wasserabflusshahn, auf einem Dreifuss stehend, mit Glasdeckel, den man auch durch eine Glasglocke ersetzen kann, und vollständiger Filzbekleidung, ist am besten mit Ventilationsvorrichtung versehen anzuschaffen. In Figur 76 ist der Apparat dargestellt. Gasdruckregulatoren, Gasbrenner, z. B. die zweckmässigen Mikrobrenner behufs Herstellung sehr kleiner Flamme und Thermoregulatoren sind ebenfalls von Rонввеск zu beziehen. Unter 149 führt dieser einen Regulator auf, welcher gefüllt und geprüft 19 Mk. kostet. Der Kopf dieses leistungsfähigen Regulators ist aus Metall gefertigt. In diesem Metallkopf ist ein Rohr (Gaszuleitungsrohr) verschiebbar, das mit der Gasleitung in Verbindung gesetzt wird. Der Regulator findet im Wasserraum des Thermostaten seinen Platz. In manchen Fällen empfiehlt es sich aber auch, den Regulator in den Arbeitsraum des Thermostaten hineinragen zu lassen. Für Temperaturen bis $40^{\circ} \mathrm{C}$. ist er mit Quecksilber und Aether, für solche von $40-70^{\circ} \mathrm{C}$. mit Quecksilber und Alkohol zu füllen.

Beim Anheizen des Thernostaten zieht man das Gaszuleitungsrohr möglichst weit aus dem Regulator heraus. Die Aether- oder Alkoholdämpfe treiben das Quecksilber im Regulator bei steigender Temperatur empor, und wenn die gewünschte Temperatur erreicht ist, wird die Gaszuleitungsröhre so weit in den Regulator hineingeschoben, dass der an ihrem unteren Ende vorhandene dreieckige Ausschnitt eben vom Quecksilber bedeckt ist. Dem Verlöschen der Gasflamme wird durch das Vorhandensein einer feinen Oeffnung im Gaszuleitungsrohr vorgebeugt, durch

1) Vgl. Preffer, Zeitschrift f. wissenschl. Mikroskopie, Bd. 7, S. 449. 
welehe auch jetzt noch Leuchtgas zum Brenner gelangen kann. Der Apparat functionirt nun in bekannter Art weiter.

Nicht ohne Einfluss auf die Function des Regulators sind die Schwankungen des Luftdruckes, deren Grösse man leicht mit Hülfe eines Barometers ermitteln kann. Diesem Umstande muss bei Benutzung des Regulators Rechnung getragen werden, wenn man die Temperatur im Apparat lange Zeit bis auf Bruchtheile eines Grades C. coustant halten will. Es geschieht dies in der Weise, wie es RoнrвEcK in einem kleinen Aufsatze angiebt, den man auf Wunsch von demselben mit dem Regulator erhält.

Wenn es bei physiologischen Untersuchungen nur darauf ankommt, die Temperaturverhältnisse einige Zeit lang annähernd constant zu erhalten, so ist auch der folgende Apparat bequem $\mathrm{zu}$ verwenden, der ebenfalls bei Mangel eines Gewächshauses gute Dienste leistet, wenn es sich darum handelt, in Winter, zumal bei kalter Witterung, Keimptlanzen etc. schnell zur Entwicklung zu bringen. Der auf einem festen Gestell ruhende Thermostat stellt einen grossen, aus starkem Zinkblech gefertigten Kasten mit doppelten Wänden dar. Die Höhe des Kastens beträgt etwa $60 \mathrm{~cm}$; ebenso seine Breite und Tiefe. Der Zwischenraum zwischen den doppelten Wänden des Apparates kann 3-4 $\mathrm{cm}$ weit sein. Er wird ınit Wasser angefüllt, das man durch eine Oeffnung am oberen Theile des Kastens eintreten lässt, während sich am unteren Theile desselben ein Hahn zum eventuell erforderlichen Abfluss des Wassers befindet. Die doppeltwandige Decke des Kastens ist noch mit einer zur Aufnahme eines Thermometers dienenden Oefinung versehen. Die vordere Wand des Kastens wird, wie noch bemerkt werden muss, von

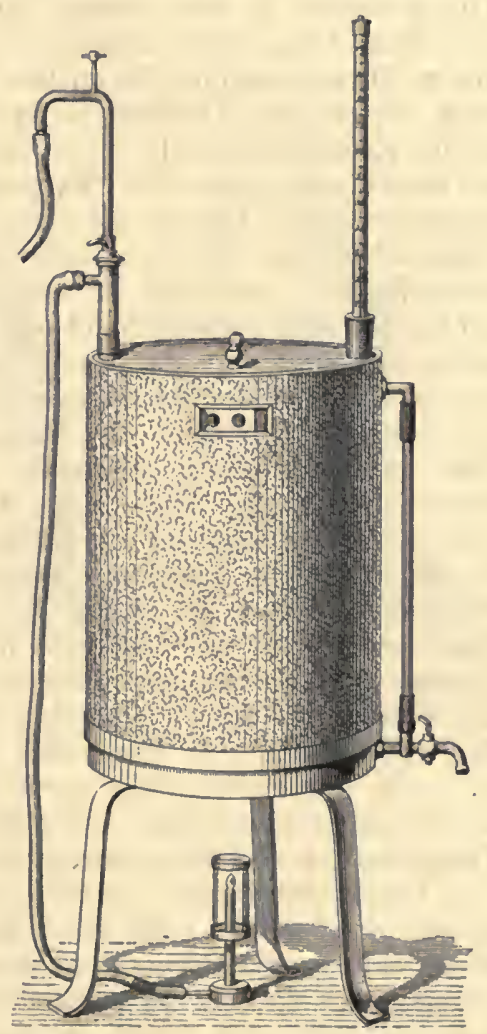

Fig. 76. Thermostat mit Thermoregulator. einer Doppelthür gebildet. Die Heizung des Apparats geschieht mittelst einer unter demselben angebrachten Gastlamme.

Die Thermostaten stellt man natürlich, wenn irgend möglich, in Räumen auf, deren Temperaturen schon an und für sich möglichst geringen Schwankungen unterliegen. Im Sommer benutzt man nach Norlen gelegene Råume; im Winter solche, die mittelst guter Füllöfen geheizt werden können. 


\section{Dic Periodicitit des Wurzeldrucks.}

Etwa 2 Monate alte, in Blumentöpfen cultivirte Individuen von Cucurbita Melopepo oder aus Knollen erwachsene 2 Monate alte Individuen von Helianthus tuberosus ${ }^{1}$ ) oder geeignete Exemplare von Prunus Laurocerasus werden decapitirt. Die Stammstümpfe bringt man nun mit einer der unter 75 beschriebenen Vorrichtungen in Verbindung, bedeckt den Erdboden in den Blumentöpfen mit Stanniol, um denselben vor erheblichem Wasserverlust zu schützen, führt ein Thermometer in den Boden ein und stellt die Untersuchungsobjecte in einen Raunı von möglichst constanter Temperatur, eventuell in einen Thermostaten. Ermittelt man nun, wie gross die Saftmengen sind, welche die Untersuchungsobjecte $\mathrm{zu}$ verschiedenen Tageszeiten in der Zeiteinheit (z. B. in je einer oder je zwei Stunden) ausscheiden, so findet 'man, dass die Pflanzen, trotz gleichbleibender äusserer Verhältnisse, nicht immer die nämlichen Flüssigkeitsmengen liefern. Der Saftausfluss ist bei Cucurbita und Helianthus kurz nach Mittag am lebhaftesten, während Prunus Laurocerasus nach meinen Beobachtungen erst gegen Abend das Maximum der Flüssigkeitsausscheidung erkennen lässt. In der Nacht sinkt die Grösse des Saftausflusses; sie erreicht in den frühen Morgenstunden ihr Minimum, um dann wieder zu steigen. Hat man die Stengelstümpfe mit einem einfachen Steigrohr in Verbindung gebracht, so muss man natürlich nach jeder Beobachtung die über der Marke stehende Flüssigkeit entfernen. Dies geschieht bequem mit Hülfe eines dünnen Glasrohres, welches man in das Steigrohr einführt. Die in Millimetern ausgedrückte Höhe der Wassersäule von der Marke bis zum Niveau der Flüssigkeit kann als Maassstab zur Beurtheilung der Grösse des Saftausflusses dienen. Relativ junge Pflanzen lassen, soweit die Untersuchungen reichen, das Phänomen der Periodicität des Saftausflusses noch nicht erkennen. Bei Individuen von Cucurbita Melopepo, die einen Monat alt sind, ist z. B. die Periodicität noch nicht entwickelt ${ }^{2}$ ). Selbstverständlich ist bei allen Versuchen besonderes Gewicht darauf $\mathrm{zu}$ legen, dass die Temperaturverhältnisse möglichst constant bleiben.

Bei ausführlichen Untersuchungen über die Periodicität des Wurzeldrucks empfiehlt es sich, einen Apparat zum Registriren des Saftausflusses nach dem von Baraxetzky (Abhandl. d. Naturf. Gesellschaft zu Halle 1873) angegebenen Princip zu verwenden. Dieser Apparat mit 36 Glasröhrchen zum Auffangen des Saftes ist im Preis von $100 \mathrm{Mk}$. vom UniversitätsMechaniker Albrecht in Tübingen zu beziehen.

\section{Die Ursachen des Wurzeldrucks und verwandter Erscheinungen.}

Ein Glasrohr von etwa $80 \mathrm{~mm}$ Länge und $40 \mathrm{~mm}$ Weite (vergl. Fig. 77) wird an einem Ende mit einer gut ausgewaschenen Schweins-

1) Die Versuche mit Cucurbita, Helianthus oder manchen anderen Gewächsen stellt man zweckmässig im Sommer an. Die Pflanzen müssen an einem sonnigen Orte im Freien oder im Kalthause eultivirt worden sein.

2) Literatur vergl. bei DetMer, Lehrbuch der Pflanzenphysiologie, 1883, S. 122, und in der unter 77 citirten Abhandlung WIELER's. 
blase verbunden, darauf mit concentrirter Rohrzuckerlösung völlig angefüllt und das obere linde der Röhre mit vegetabilischem Pergament verschlossen. Das Glasrohr ist durch die weite Bohrung eines grossen Korkes $(K) \mathrm{zu}$ schieben, so dass dasselbe, wenn der Kork auf ein Glas $(G l)$ gesetzt wird, welches destillirtes Wasser enthält, mit dem unteren Ende in diese Flüssigkeit eintaucht. Ueber den oberen, mit Pergamentpapier verschlossenen Theil des Glasrohres wird eine in ein Kautschukiohr auslaufende Kautschukkappe $(K k)$ gebunden und ein gebogenes Glasrohr $(G r)$ in das Kautschukrohr eingeführt. Ist der Apparat zusammengestellt, so beginnt derselbe' seine Thätigkeit alsbald. Es dringt auf osmotischem Wege Wasser in das am oberen sowic unteren Ende mit einer

Membran versehlosssene Glasrohr (künstliche Zelle) ein, in demselben kommen, da mehr Wasser ein. als

Zuckerlösung austritt, Druckverhältnisse zur Geltung, die nach einiger Zeit im Stande sind, den Filtrationswiderstand des Pergamentpapiers zu überwinden. Ist dies der Fall, so wird Flüssigkeit in das Glasrohr $G r$ gepresst, und sie kann in dem Gefäss $F$ gesammelt werden. Freilich sind die Vorgänge, welche sich bei dem Zustandekommen des

Wurzeldrucks und ver-

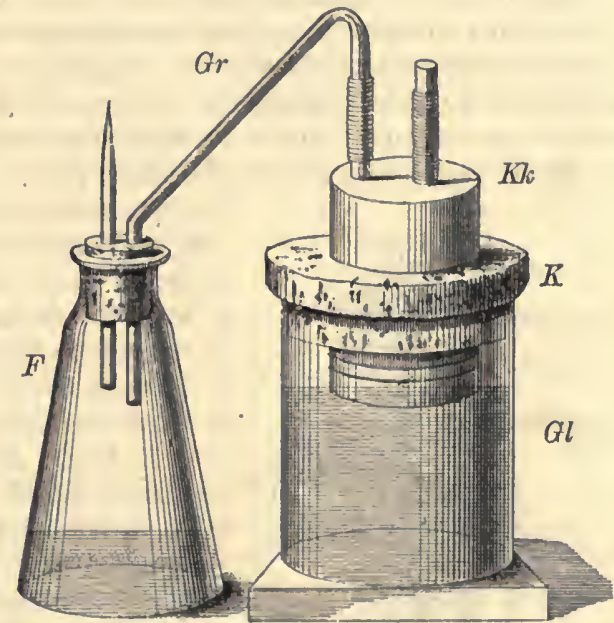

Fig. 77. Apparat zur Veranschaulichung derjenigen Vorgänge, welche sich beim Zustandekommen des Wurzeldrucks geltend machen. wandter Erscheinungen in der Pflanze geltend machen, $=$ weit complicirter als diejenigen, von denen im Vorstehenden die Rede war, und es ist namentlich zu betonen, dass in der Pflanzenzelle das Protoplasma (zumal die Hautschicht desselben) eine wichtige Rolle spielt, wenn in den Gewächsen durch osmotische Vorgänge Druckwirkungen zu Stande kommen; aber immerlin ist das erwälnte Experiment doch von erheblichem pflanzenphysiologischen Interesse. In den Zellen des Parenchyms der Wurzeln kommen in Folge der osmotischen Leistungsfähigkeit des Zellinhalts Druckkräfte zur Geltung. Die stark turgescirenden Zellen pressen schliesslich einen Theil ihres Inhaltes aus, dieser tritt in die Hol\%elemente ein und wird in denselben emporgetrieben.

\section{Weitere Experimente iiber den Austritt tropfbar fliissigen Wassers aus Pflanzen.}

Wenn in den Pflanzenzellen energische Druckkräfte in Folge osmotischer Processe zu Stande kommen, und diese Druckkräfte schliesslich den Filtrationswiderstand des Hyaloplasmas sowie der Zellhaut der Zellen überwinden, so werden Flüssigkeitsmengen aus 
den Zellen hervorgepresst. Die Untersuchungen über den Flüssigkeitsaustritt aus decapitirten Pflanzen unter Vermittelung des Wurzeldrucks haben uns bereits mit Phänomenen bekannt gemacht, deren Ursachen in osmotischen Druckkräften $\mathrm{zu}$ suchen sind. Aber es giebt noch eine Reihe anderweitiger Erscheinungen, die hier Berücksichtigung finden müssen.

In Blumentöpten cultivirte junge Mais- oder Tropaeolumexemplare werden in einen Thermostaten (vgl. Fig. 7 $\dot{6}$ ) gestellt und mit einer Glasglocke bedeckt. Den Boden, in welchem die Pflanzen wurzeln, hat man reichlich mit Wasser durchfeuchtet, und die Temperatur in Apparat muss constant auf einer Höhe von $20-25^{\circ} \mathrm{C}$. erhalten werden. Die Transpiration der Untersuchungsobjecte ist unter den bezeichneten Umständen fast gleich Null. In Folge der Thätigkeit des Wurzeldrucks füllen sich alle Hohlräume im Innern der Pflanze mit Wasser an, und dieses kann sogar nach aussen hervortreten. In der That beobachtet man denn auch, dass nach Verlauf von $1 / 2-2$ Stunden an den Blatt-

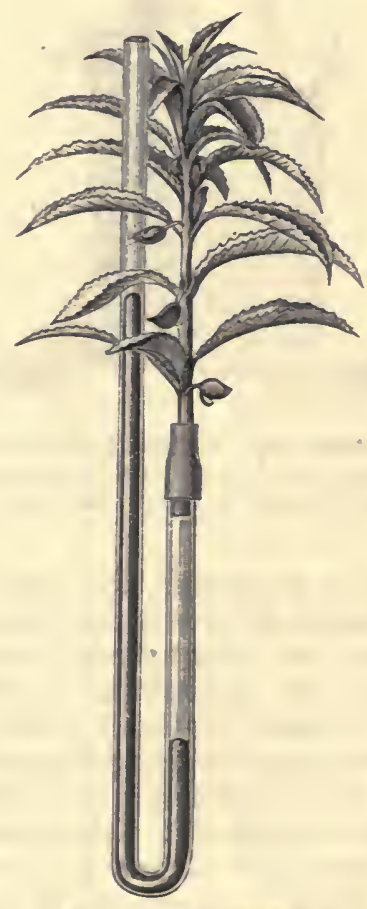

Fig. 7S. Apparat zum Nachweis des Einflusses von Druckkräften auf den Wasseraustritt aus Pflanzentheilen. spitzen von Zea sowie am Blattrande von Tropaeolum Wassertropfen erscheinen, die, wenn sie eine gewisse Grösse erreicht haben, abfallen und durch neue ersetzt werden. Bei Zea tritt das Wasser aus Rissen in der Epidermis hervor, bei Tropaeolum aus Wasserspalten.

Dass in der That Druckkräfte, wie sie durch den Wurzeldruck z. B. gegeben sind, eine wichtige Rolle beim Hervortreten von Wassertropfen aus Blättern spielen, lässt sich leicht beweisen. Man befestigt auf dem kürzeren Schenkel eines mit Wasser angefüllten Glasrohrs abgeschnittene Sprosse von Vitis, Tropaeolum oder Impatiens (vgl. Fig. 78). Der Stengelquerschnitt taucht in das Wasser ein. Wenn man die Vorrichtung nun in einen grossen Glascylinder stellt, den man mit einer Glasplatte zudeckt, um die Transpirationsgrösse der Untersuchungsobjecte möglichst herabzusetzen, und endlich Quecksilber in den langen Schenkel des Glasrohres giesst, so treten nach kürzerer oder längerer Zeit Wassertropfen aus dem Gewebe der Blätter hervor. Sehr schön sah ich die Tropfenabscheidung, als ich in der angegebenen Weise mit Sprossen von Impatiens Balsamina experimentirte. Bei einem Ueberdruck von $35 \mathrm{~cm}$ Quecksilber traten in wenigen Minuten Wassertropfen aus den Zälnnen des Randes der Blätter hervor ').

Nach den Angaben Prtra's soll es leicht sein, die Beobachtung zu machen, dass aus dem Stammquerschnitt abgeschnittener beblätterter Sprosse, die man fast völlig in Wasser eintaucht, Flüssigkeit in beträchtlicher Menge hervortritt. Ich habe viele Versuche Prtra's wiederholt, aber mit 
negativem Erfolg. Freilich reichen meine Erfahrungen für eine kritische Behandlung der Experimente des genannten Autors nicht aus, und ich gehe daher auch nicht specieller auf dieselben ein. Dagegen gelingt es ohne Mühe, den Nachweis zu liefern, dass nicht nur in den Wurzeln, sondern auch in den Zellen von Stammtheilen Druckkräfte auf osmotisehem Wege erzeugt werden können, die eine Flüssigkeitsauspressung zur Folge haben, wenn man.Stengelstücke von Zea oder Sorghum vulgare als Untersuchungsobjecte benutzt. Die Stengelstücke werden aus kräftigen Maisund im Beginn der Blüthezeit stehenden Sorghumexemplaren in einer Länge von ca. $10 \mathrm{~cm}$ derartig herausgeschnitten, dass ihre obcre Schnittfäche wenige Millimeter über einem Knoten liegt. Stellt man die Stengelstücke in Wasser, so dass ihre obere Schnittfläche aus der Flüssigkeit hervorragt, und bedeckt man mit einer Glasglocke, dann tritt alsbald aus dem Stengelquerschnitt Saft hervor. 'Trocknet man die Schnittfläche mit Fliesspapier ab, so erscheint sie bald wieder feucht.

Aber nicht nur osmotische Druckkräfte, auch andere Ursachen sind im Stande, einen Flüssigkeitsaustritt aus Pflanzentlıeilen herbeizuführen. So verhält sich die Sache z. B. bei vielen Nectarien '), und wir wählen diejenigen von Fritillaria imperialis zur Untersuchung. Am Grunde der Perigonblätter dieser Pflanze sind die relativ grossen, napfförmigen Nectarien leicht zu sehen. In ihnen ist ein zuckerreicher Saft vorhanden, der Glycose enthält, wovon man sich leicht überzeugt, wenn man die Basis einiger Perigonblätter mit wenig Wasser abspült und die erhaltene Flüssigkeit in siedende FEHLING'sche Lösung einträgt. Wir spülen ferner die Nectarien mehrerer Perigonblätter von Fritillaria recht sorgfältig und wiederholt mit reinem Wasser aus, trocknen sie mit Fliesspapier $a b$ und legen die Blumenblätter unter eine Glasglocke. In die Nectarien einiger Perigonblätter bringen wir nun ein Körnchen angefeuchteten Zuckers, in diejenigen anderer aber keinen Zucker. Jene ersteren enthalten nacl einigen Stunden wieder zuckerreichen Saft, diese letzteren bleiben trocken. Der Zucker zicht auf osmotischem Wege Wasser aus den Zellen der Nectarien an sich, olne dass dabei Druckkräfte ins Spiel kommen, und was der im Experiment zugeführte Zucker leistet, das leisten unter normalen Verhåltnissen vermuthlich osmotisch wirksame Stoffe, die durch Metamorphose aus der Substanz der äusseren Epidermiszellmembranen der Nectarien hervorgehen.

Wenn wasserreiche, abgehauene Baumstämme dem Einfluss der Sonnenstrahlen ausgesetzt sind, so quillt häufig Flüssigkeit aus den Querschnitten derselben hervor, eine Erscheinung, die ihren Grund darin hat, dass die Luft im Innern der Holzelemente durch die Sonnenwärme ausgedehnt wird und dadurch das gleichzeitig vorhandene Wasser aus den Pflanzentheilen hervortreibt. Genaueres lehren die folgenden Experimente. 20-50 cm lange und 3-5 cm dicke Aststücke der Weide, Ulme, Esche, des Nussbaumes oder von Pavia rubra, mit welchen letzteren ich zumal experimentirte, werden im Winter bei kaltem, aber feuchtem Wetter abgeschnitten und zur Erhöhung ihres Wassergehaltes, nachdem man recht glatte Schnittflächen an ihren Enden hergestellt hat, 24 Stunden lang in Wasser von etwa $2^{\circ} \mathrm{C}$. gelegt. Dann taucht man die Aststücke in Wasser von 25$30^{\circ} \mathrm{C}$. ein, welches sich in einem Glascylinder befindet, so dass nur ihr

1) Vgl. Witson in Untersuchungen aus d. botan. Institut zu Tïbingen, Bd. 1 Heft 1. 
oberes Ende etwas aus der Flüssigkeit herausragt. Es sammelt sich alsbald ziemlich viel Wasser auf der glatten Schnittfäche an. Ich beobachtete einen solchen, durch die Ausdehnung der in den Holzelementen vorhandenen Luft bedingten Wasseraustritt auch, als ich im Winter abgeschnittene, $15 \mathrm{~cm}$ lange und $2 \mathrm{~cm}$ dicke Aststücke von Abies pectinata in Wasser von $24^{\circ} \mathrm{C}$. eintauchte. Gelangten die Aststücke dann in Wasser von $5^{\circ} \mathrm{C}$, so wurde das vorher an der oberen Sehnittläche ausgetretene Wasser wieder vom Untersuchungsobject eingesogen, weil die Abkühlung eine Contraction der in demselben vorhandenen Luft herbeiführte ${ }^{1}$ ).

\section{Die Organisation der Pflanzentheile und die Transpiration.}

Es sind keineswegs die sämmtlichen Gewebe des Pflanzenkörpers leicht permeabel für tropfbar flüssiges Wasser oder für Wassergas. Vielmehr giebt es Gewebearten, die das Wasser nur äusserst schwierig passiren lassen, und dahin gehört in erster Linie das Korkgewebe. Diese Thatsache beansprucht ein erhebliches biologisches Interesse. Viele wasserreiche Pflanzentheile, z. B. Kartoffelknollen, die eine längere Ruheperiode zu überdauern haben, finden wir in der That mit einer mehr oder minder mächtigen Korkschicht umkleidet, und um die Bedeutung derselben für die Erhaltung des wasserreichen Zustandes des Parenchyms der Knollen festzustellen, genügt es, das folgende Experiment auszuführen ${ }^{2}$ ). Man verschafft sich zwei Kartoffelknollen von möglichst gleicher Grösse. Die eine Knolle wird geschält, um das Korkgewebe $\mathrm{zu}$ entfernen, die andere Knolle bleibt ungeschält. Man bestimmt nun das Gewicht beider Knollen und lässt sie dann neben einander liegen. Erneute Wägungen, die man nach Verlauf von 3, 6 und 24 Stunden vornimmt, lehren, dass die geschälte Knolle weit mehr Wasser als die ungeschälte verliert. Die kleinen Feuchtigkeitsmengen, welche die ungeschälte Knolle verliert, entweichen zumal aus den Lenticellen und aus feinen Rissen in der Schale.

Wenn man zwei Aepfel von möglichst gleicher Grösse aussucht, den einen abschält, den anderen ungeschält lässt, und das Gewicht der Untersuchungsobjecte von Zeit zu Zeit, z. B. alle 24 Stunden, feststellt, so ergiebt sich, dass der seiner Scliale beraubte Apfel weit mehr Wasser an die Luft abgiebt. als der ungeschälte. Die cuticularisirte Epidermis ist demnach ebenso wie das Korkgewebe auf jeden Fall sehr schwer permeabel für Wasser ${ }^{3}$ ).

Die geringe Wasserabgabe ungeschälter Kartoffeln und Aepfel wird insbesondere durch das Vorhandensein von Lenticellen vermittelt, und um noch direct darzuthun, dass diese Organe in der That nicht ohne Bedeutung für die Transpirationsgrösse sind, stelle man folgende Experimente an. Zwei möglichst gleichartige, unbeblätterte und mit Periderm überzogene Zweigstücke von Aesculus oder Ampelopsis von etwa $3 \mathrm{~g}$ Gewicht werden an ihren beiden Enden luftdicht mit Wachs verschlossen und sich nach erfolgter genauer Gewichtsbestimmung 24 Stunden lang selbst überlassen. Man ermittelt dann abermals das Gewicht der Untersuchungsobjecte und stellt dadurch ihren Tran-

1) Vgl. SACHs, Botan. Zeitung, 1860.

2) Vgl. Detmer, Journal f. Landwirthschaft, 1879, S. 119.

3) Vgl. Just in CoHs's Beiträgen zur Biologie der Pflanzen, 1875, Heft 3. 
spirationsverlust fest. In einem Zweige verkittet man nun die Lenticellen, an dem anderen entsprechend grosse Peridermstellen mit geschmolzenem Wachs, bestimmt das Gewicht der Pflanzentheile sofort und ebenso wieder nach 24-stündiger Transpiration. Der Zweig, dessen Lenticellen verlittet worlen waren, wird absolut oder wenigstens procentisch weniger Wasser als das Vergleiclisobject verloren haben.

Die Epidermis der Blätter ist, wie schon unter 70 hervorgehoben wurde, sehr allgemein mit Wachsüberzügen versehen, die bekanntlich in verschiedenen Formen auftreten. Diese Wachsïberzüge setzen die Transpirationsgrösse der Blätter nicht unwesentlich herab, wie z. B. das folgende Experiment lehrt. Man benutzt zweckmässig die beiden Blätter desselben Blattpaares von Eucalyptus globulus zum Versuch. Das eine Blatt wird ohne Weiteres, das andere, nachdem man den Wachsüberzug mit einem weichen Tuche abgewischt hat, genau gewogen. Die nach Verlauf ron 6,12 oder 24 Stunden wiederholten Wägungen der gewelkten Blätter lehren, dass das erstere Blatt einen geringeren Transpirationsverlust als das letztere erfahren hat ').

Die im Vorhergehenden angeführten Experimente lassen freilich keinen Zweifel darüber bestehen, dass bei der Transpiration der Gewächse höchstens ein geringer Theil des verdampfenden Wassers die cuticularisirte Epidermis passirt, zumal wenu die Cuticula mit wachsartigen Substanzen reichlicher imprägnirt ist. Indessen die Cuticula ist doch nicht völlig inpermeabel für Wasser, wie die folgenden Versuche lehren.

Wir legen ein abgeschnittenes, unversehrtes Blatt einer Begonic, dessen Obertläche spaltöffnungsfrei ist, neben einen Objectträger in eine Krystallisirschale. Nun versetzen wir eine grössere Kochsalzmenge mit wenig Wasser, so dass das Kochsalz etwas angefeuchtet ist, vertbeilen sowoh] auf die Blattoberseite, als auch auf den Objectträger kleine Kochsalzmengen und bedecken die Krystallisirschale mit einer Glasplatte. Das Kochsalz auf dem Blatt zerfliesst alsbald, weil es Wasser aus dem Blattgewebe, welches nur durch die Cuticula nach aussen gelangt scin kann, anzieht. Das Kochsalz auf dem Objectträger zieht höchstens wenig Wassergas aus der atmosphärischen Luft an nnd bleibt relativ trocken.

Wir stellen uns durch Zusammenschmelzen von Wachs mit Olivenöl oder Cacaobutter (sehr empfehlenswert ist eine Mischung von 1 Thl. Wachs mit 3 Thl. Cacaobutter) ein sehr leicht zu verflüssigendes Gemisch her. Es werden dann zwei möglichst gleichartige Blättchen von Mahonia al,geschnitten, und während wir boi dem einen Blättchen nur die Oberseite mit dem Gemisch von Wachs und Fett überziehen (es gelingt das leicht mit Hülfe eines Pinsels), so wird bei dem zweiten Blatt nur die Unterseite verklebt. Bei beiden Untersuchungsobjecten verklebt man den Blattstielquerschnitt. Nach völligem Erkalten und Erstarren der Wachsüberzüge bestimmen wir das Gewicht der Blätter, lassen sie mit ihrer nach oben gewandten freien Fläche am Licht liegen und ermitteln nach einiger Zeit abermals ihr Gewicht. Das Blättchen mit freier Unterseite wird mehr Wasser durch Verdunstung abgegeben haben als das andere, weil der Unterseite des Mahoniablattes Spaltöffnungen nicht fehlen. Die spaltöffnungsfreie Oberseite des Mahoniablattes giebt natürlich nur relativ wenig Wasser an die Luft ab, und dieses Wasser muss die Cuticula pas-

1) Vgl. G. Hanerdandt, Phrsiologisehe Pflanzenanatomie, 1884, S. 69. 
siren. Es giebt noch andere Pflanzen (Ilex, Nerium, Begouia, Ficus etc.), deren Blätter, da sie nur an ihrer Unterseite Spaltöffnungen besitzen, zu ähnlichen Experimenten wie die Mahoniablätter verwendet werden können.

Bei der Untersuchung der Beziehungen zwischen der Organisation der Pflanzentheile einerseits und ihrer Transpiration andererseits darf nicht unerwähnt bleiben, dass viele Blätter, übrigens auch andere Organe, Gewebe ausgebildet haben, die zur Aufspeicherung von Wasser dienen. Es kommen hier zumal Gewächse in Betracht, die an relativ trockenen Standorten vegetiren und die oft darauf angewiesen sind, eine längere Periode grosser Trockenheit zu überdauern. Zu nennen wären namentlich viele Cacteen, die cactusartigen Euphorbien, zahlreiche Crassulaceen, Aloë- sowie Peperomiaspecies. Wir stellen z. B. einen Querschnitt durch das Blatt von Aloë soccotrina her. Unter der sehr stark cuticularisirten Epidermis liegt das grüne Assimilationsgewebe, dessen Zellen relativ grosse Chlorophyllkörner führen. Die Mitte des Blattes wird von einem Gewebe, dem sog. Wassergewebe, eingenommen, dessen grosse Zellen sehr wasserreich sind und schleimige Substanzen in bedeutender Menge enthalten. An der Grenze zwischen dem Wassergewebe und dem Assimilationsgewebe, welches das erstere rings umschliesst, liegen die Gefässbündel. Wenn die Aloëarten in trockenen Zeiten nicht in der Lage sind, grössere Wasserquantitäten mit Hülfe ihrer Wurzeln aus dem Boden aufnehmen zu können, so wird das in dem Wassergewebe aufgespeicherte Wasser verbraucht, und die Pflanzen leiden nicht wesentlich in Folge der Dürre, die andere Gewächse vernichten würde. Das Blatt von Peperomia trichocarpa besitzt ebenso ein entwickeltes Wassergewebe, wie man sofort bei der Untersuchung von Blattquerschnitten erkennt. Unter der Epidermis der Blattoberseite liegt ein saftreiches, chlorophyllfreies Gewebe, dessen Zellen nach der Blattmitte zu an Grösse zunehmen. Das Assimilationsparenchym präsentirt sich auf dem Querschnitt als ein Gewebe von nur geringer Dicke. Es ist zwischen dem erwähnten Wassergewebe der Blattoberseite und einèr mächtigen Parenchymschicht der Blattunterseite ausgebreitet, deren Zellen zwar etwas Chlorophyll führen, aber wegen ihres bedeutenden Saftgehaltes doch wohl als solche anzusehen sind, die der Hauptsache nach ebenfalls für die Wasserspeicherung Bedeutung besitzen.

\section{Weitere Transpirationsversuche.}

Es ist beachtenswerth, dass von einer bestimmten Blattfläche erheblich weniger Wasser in der Zeiteinheit verdunstet, als von einer gleich grossen freien Wasserfläche. Zur Constatirung dieser Thatsache stellte ich unter Benutzung des in Fig. 79 abgebildeten Apparats die folgenden Versuche an. Ein $11 \mathrm{~cm}$ hohes, $8 \mathrm{~cm}$ weites Glasgefäss wird mit guter Gartenerde angefüllt und in dieselbe ein Bohnensame zur Keimung ausgelegt. Hat die junge Pflanze ihre Primordialblätter völlig entfaltet, so legt man eine halbirte Glasplatte auf den abgeschliffenen und mit Fett bestrichenen Rand des Gefässes. Die Glasplatte ist mit drei Löchern versehen. Das mittlere dient zur Aufnahme des Stengels der Bohnenpflanze und wird nöthigenfalls noch mit Watte verstopft. Das eine der beiden seitlichen Löcher nimmt das Thermometer $T$ auf, während man das andere mit einem Kork verschliesst. Man bestimmt nun das Gewicht des gesammten Apparats, ebenso dasjenige einer mit Wasser gefüllten Krystallisirschale. Die letztere hatte 
bei meinem Versuche einen Durchmesser von $5 \mathrm{~cm}$. Nach Verlauf von 24 Stunden ermittelt man das Gewicht der Apparate abermals. Die Bohnenpflanze hatte $4,6 \mathrm{~g}$, die freie Wasserfläche $2,23 \mathrm{~g}$ Wasser an die Luft abgegeben. Die Grösse der Wasserfläche berechnet sich zu $19,6 \mathrm{qcm}$. Die Obertläche der Bohnenblätter ermittelt man auf folgende Weise. Recht homogenes Papier wird mit einer Lösung von doppeltchromsaurem Kali getränkt. Nach dem Trocknen des Papiers bestimmt man das Gewicht eines Stückes desselben von bekannter Oberfläche. Man schneidet ferner die beiden Primordialblätter der Bohnenpflanze ab, legt sie auf genügend grosse Stücke des mit Kaliumbichromat getränkten Papiers und setzt dieses nunmelir einige Zeit lang dem direeten Sonnenlicht aus. Der Umriss der Blätter ist alsbald deutlich auf dem Papiere zu erkennen, denn die unbedeckten Theile desselben bräunen sich erheblich. Man schneidet die Blattabdrücke sor'gfältig aus, ermittelt das Gewicht der betreffenden Papierstücke und kann nun unter Berücksichtigung des Gewichts eines Papierstückes von bekannter Fläche auch die Oberfläche der Blätter leicht feststellen. Icl fand die Gesamm toberfläche der beiden Primordialblätter meiner Bohnenpflanze zu 230,9 qcil. Diese Blattfläche verdunstete sicher nicht mehr als 4,6 g Wasser, denn ich liabe die Oberfläche der Blattstiele, des Bohnenstengels und ler Endknospe ganz ausser $\Lambda$ cht gelassen, obgleich diese Organe ja auch kileine Wassermengen an die Luft abgeben. $19,6 \mathrm{qcm}$ freier Wasserfläche gaben in 24 Stunden $2,23 \mathrm{~g}$ Wasser $\mathrm{ab}$, also $100 \mathrm{qcm} 11,3$ g. $230,8 \mathrm{qcm}$ Blattfläche verloren in 24 Stunden

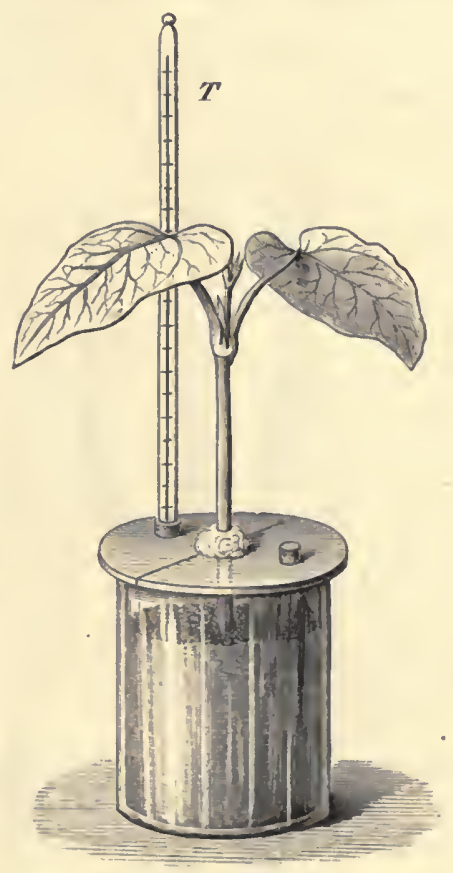

Fig. 79. Apparat zu Transpirationsversuchen. $4,6 \mathrm{~g}$ Wasser, also $100 \mathrm{qcm} 1,99 \mathrm{~g}$.

Unter 81 ist bereits festgestellt worden, dass die cuticularisirten Regionen der Epilermis der Blätter eine gewisse Bedeutung für den Process der Transpiration besitzen, denn sie sind, wie wir gesehen haben, nicht durchaus impermeabel für Wassergas. Aber trotzdem ist es sicher, dass die wesentlichste Bedeutung bei ${ }^{3}$ der Transpiration den Spaltöffinungen zukommt. Man hat nämlich eine entschiedene Abhảngigkeit der Transpirationsgrösse eines Pflanzentheils von der Anzahl der vorhandenen Spaltöffnungen constatiren können. Eine directe Proportionalität zwisehen der Anzahl der Spaltöffnungen auf bestimmter Blattfläche und der Transpirationsgrösse ist freilich nicht vorhanden, aber dies darf uns nieht wundern, denn das lurch die Spaltöffnungen entweicliende Wassergas wird ja in den Intercellularen gebildet, und es kommt somit nicht nur auf die Stomata allein, sondern ebenso auf die Form, Weite und Anzahl der Intercellularen an. 
GARREAU ') hat die 'Transpirationsgrösse der Ober- und Unterseite zahlreicher Blätter bestimut und zugleich die Anzahl der auf gleichen Blattflächen vorhandenen Spaltöffnungen festgestellt. Er gelangte z. B. zu folgenden Resultaten:

\begin{tabular}{|c|c|c|}
\hline & $\begin{array}{l}\text { Verhältnisszalıl der } \\
\text { Spaltöffnungen }\end{array}$ & $\begin{array}{c}\text { In } 24 \text { Std. transpirirtes } \\
\text { Wasser in } g\end{array}$ \\
\hline \multirow{2}{*}{ Atropa belladonna } & oben 10 & 0,48 \\
\hline & unten & 0,60 \\
\hline \multirow{2}{*}{ Nicotiana rustica } & oben & 0,57 \\
\hline & unten & 0,80 \\
\hline \multirow{2}{*}{ Tilia europaea } & oben & 0,20 \\
\hline & unten & 0,49 \\
\hline
\end{tabular}

Will man die Versuche

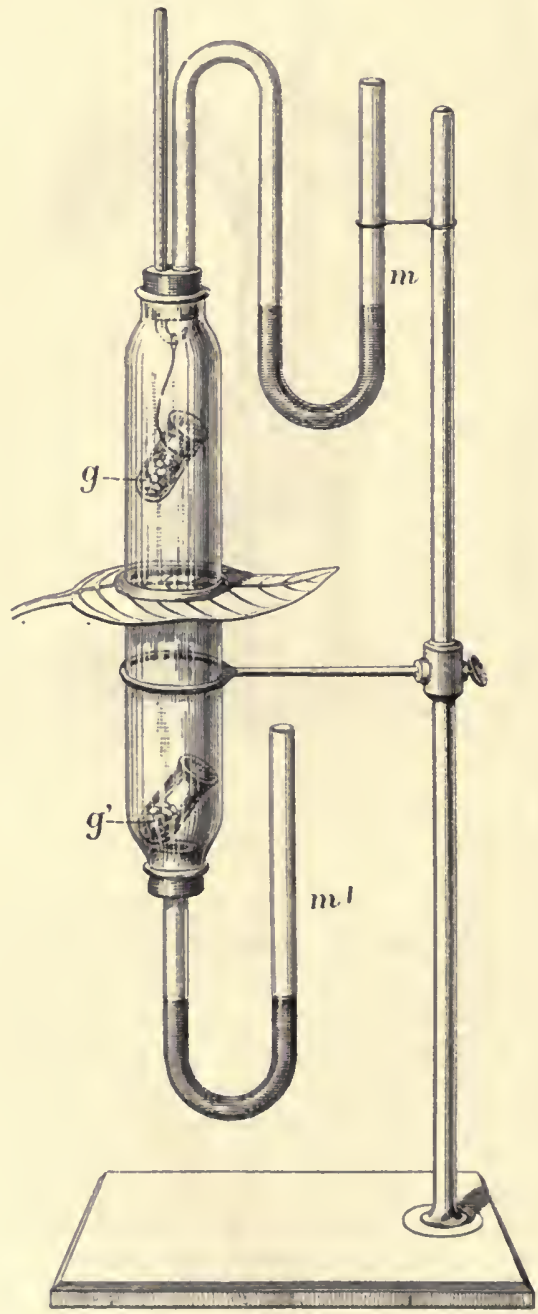

Garreau's wiederholen, so stelle man sich den in Fig. 80 abgebildeten Apparat zusammen. Zwei gleiche Glasglocken von je nach Bedürfniss verschiedener Grösse (etwai40, resp. $80 \mathrm{~mm}$ Durchmesser und $100 \mathrm{~mm}$ Höhe) werden auf die Ober- und Unterseite desselben Blattes aufgesetzt und mit Hülfe eines Kittes luftdicht befestigt. Als Kitt leistet, wovon ich mich überzeugte, ein durch Zusammenschmelzen von 2 Thl. Baumöl, 1 Thl. ausgelassenem Hammeltalg und 1 Thl. Wachs hergestelltes Gemisch gute

Dienste. Ist die Temperatur in demjenigen Raum, in welchem der Apparat steht, relativ hoch (z. B. über $20^{\circ}$ C.), so verwende man nicht 2 Thl. Baumöl, sondern eine geringere Menge. Die Glasglocken müssen tubulirt sein, damit man in den Stand gesetzt wird, die beiden mit Oel gesperrten Manometer $m$ und $m^{\prime}$ anbringen zu können. Unter jeder Glasglocke befindet sich endlich noch ein mit Chlorcalcium angefülltes Glas ( $g$ und $\left.g^{\prime}\right)$. Aus der Gewichtszunahme dieser Gläsel ergiebt sich die Transpirationsgrösse der Blattfächen. Es ist selbstverständlich, dass man niclit. mit abgesclmittenen, sondern mit den an der intacten Pflanze belassenen Blättern ex-

Fig. so. Apparat für 'Transpirationsversuche. $\begin{aligned} & \text { perimentirt. Bei einem unter } \\ & \text { meiner Leitung ausgeführten }\end{aligned}$

Fig. So. Apparat für 'Transpirationsversuche. $\begin{aligned} & \text { perimentirt. Bei einem unter } \\ & \text { meiner Leitung ausgeführten }\end{aligned}$

1) Vgl. Garreau, Ann. d. sc. nat. 1850. 
Versuch mit Begonia und Benutzung vou $42 \mathrm{~mm}$ weiten Glasglocken wurden folgende Resultate erhalten. In 4 Stunden verdunstet bei $20^{\circ} \mathrm{C}$. von der Blattoberseite $0,0075 \mathrm{~g}$, von der Blattunterseite aber $0,0520 \mathrm{~g}$ Wasser.

Neuerdings hat uns StaHL ${ }^{1}$ ) mit einer Untersuchungsmethode (Kobaltprobe) bekannt genacht, die bei Ausführung zahlreicher Versuche ïber die Transpiration vortreffliche Dienste leistet und anch zweckmässig benutzt werden liann, um zu zeigen, dass die cuticuläre Transpiration der stomatïren gegenüber ungemein in den Hintergrund tritt. Schwedisches Filtrirpapier wird mit einer $t-5$-proc, wïsserigen Lösung von Kobaltchlorür imprägnirt und am Ofen oder an der Sonne getrocknet. Wir legen ein Stück des über einer Spiritus- oder Gasflamme noch weiter getrockneten und dam intensiv blau erscheinenden Kobaltpapiers auf eine trockene Glasplatte. Auf das Papier bringen wir ein Blatt von Phaseolus multiflorus und bedecken dies mit einem zweiten Stïck ausgetrockneten Kobaltpapier's und einer zweiten Glasplatte. War das Bohnenblatt völlig frisch und vor der Benutzung dem Sonnenlicht ausgesetzt gewesen, so sehen wir schon nach sehr kurzer Zeit (einigen Secunden oder einer Minute), dass das mit der Blattunterseite in Berührung befindliche Kobaltpapier einen rothen Farbenton annimmt, wälırend das andere Stück des Papiers seine blaue Farbe behält. Dies Resultat wird stets erzielt, wenn man mit Blättern experimentirt (Blätter von Phaseolus, Salix Caprea, Popolus nigra, Liriodendron, Syringa vulgaris, Cyclamen, Blätter der letzteren Pflanze stehen ja auch in Winter zur Verfügung), deren Oberseite spaltöffnungsarm oder spaltöffnungsfrei ist. Die Röthung des Papiers kommt zu Stande, indem der Wasserdampf aus den Spaltöffnungen hervortritt und auf das Kobaltehlorür einwirkt; durch die Cutieula treten höchstens Spuren von Wasser aus, weshalb das die Blattoberseite berührende Papier keine oder nur eine höchst unbedeutende Farbenänderung erfährt.

Zum Nachweis der Verlunstung eines Blattes an der unversehrten Pflanze empfiehlt es sich gewöhnlich, statt der schweren Glasplatten grosse, dünne Glimmerblätter $\mathrm{zu}$ verwenden. Die Befestigung der Glimmerblätter geschieht vermittelst kleiner Haftklammern.

\section{Der Elnfluss äusserer Verhälnisse auf die Transpiration der Pflanzen.}

Die Apparate, welche man bei den zahlreichen vorliegenden Untersucluungen über den Einfluss äusserer Verhältnisse auf die Transpiration der Pflanzen in Anwendung gebracht hat, sind sehr versehiedenartig construirt worden. Wir wollen hier nur wenige Apparate benutzen, die ich aus eigener Erfahrung empfehlen kann. Der eine ist bereits unter 82 beschrieben worden und in Fig. 79 abgebildet. Dort ist angegeben, dass die Untersuchungsobjecte in dem mit Glasileckel verschliessbaren Glasgefäss selbst cultivirt werden können. Man kann die Pflanzen aber auch in Blumentöpfen zur Entwickelung bringen und diese in die genügend grossen und mit abgesehliffenem Rand sowie Glasdeckel verselienen Glasgefässe hineinstellen. Experimentirt man mit relativ grossen Pflanzen (z. B. Helianthus, Nicotiana), und ist

1) Vgl. StauL, Botan. Zeitung, 1894. 
man daher genöthigt, um eine recht kräftige Entwickelung der Gewächse $\mathrm{zu}$ erziclen, grosse Blumentöpfe $\mathrm{zu}$ benutzen, so stellt man diese in Zinkblechbehälter, dic mit einem halbirten Deckel verschlossen werden können. In diesen Deckel müssen Löcher zur Aufnahme eines Thermometers sowic des Stammes des Untersuchungsobjectes vorlıanden sein. Die Deckelfugen kann man mit cinem Kitt (1 Thl. Wachs und $1 / 2$ Thl. Olivenöl, zusammengeschmolzen) luftricht verstreichen. Transpirationsversuche mit relativ grossen Pflanzen (Helianthus, Nicotiana) sind schon deshalb lehrreich, weil sie uns zeigen, dass dieselben

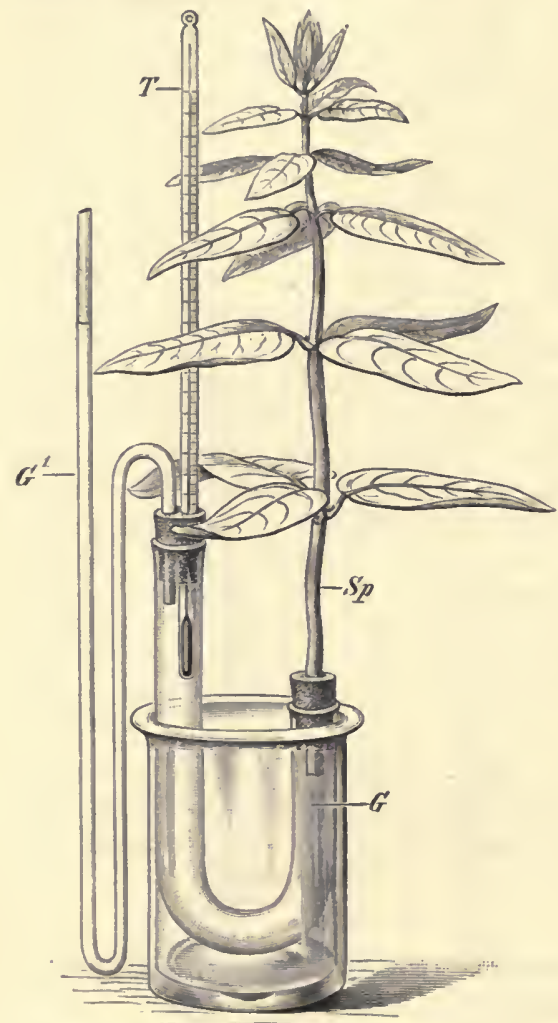

Fig. 81. Ipparat zu Transpirationsrersuchen. in kurzer Zeit (z. B. 24 Stunden) recht bedeutende Wassermengen an die Luft abgeben.

Der zweite bei Experimenten über dic Wasserverdunstung der Gewächse bequem, zumal bei Demonstrationen in der Vorlesung, zu verwendende Apparat ist in Fig. 81 dargestellt. Das U-förmig gebogene, ziemlich weite Glasrohr $G$ ist mit Wasser angefüllt. Dic Mündung des einen Schenkels wird mittelst eines Korlies verschlossen, in dessen Bohrung das untere Ende des Sprosses $S_{1}$, dessen Transpirationsgrösse ermittclt werden soll, steckt. Die Mündung des anderen Schenkels wird mittelst eines zweifach durchbolirten Korkes verschlossen. Die eine Bohrung dient zur Aufnahme des Thermometers $T$, die andere zur Aufnahme des einen Schenkels des gebogenen, dünnen und mit Wasser angefüllten Glasrohres $G^{1}$. Wir stellen unsere Vorriclltung in ein weites Glasgefäss und sind im Stande, indem wir den gesammten Apparat auf eine Waage bringen, den durch Transpiration des Sprosses herbeigeführten Gewichtsverlust festzustellen. Zugleich aber können

wir auch die durch die Transpiration bedingte Volumenverminderung des Wassers im Apparat direct beobachten, denn die Verdunstung bcdingt ein Sinken des Wassers im Glasrohre $G^{1}$.

Besonders empfehlenswerth für Transpirationsversuche ist der in Fig. 82 abgebildete Apparat. In die obere Oeffnung des mit Wasser angefüllten Gefässes $C$, das z. B. eine Höhe von $2 \overline{c m}$ und einen Durchmesser von etwa $6 \mathrm{~cm}$ haben kann, ist das Untersuchungsobject wasserdicht eingesetzt. Man kann mit Sprossen oder mit bewurzelten Pflanzen experimentiren. Den dichten Verschluss erzielt man durch Benutzung eines mit einer Bohrung zur Aufnahme des Pflanzentheils versehenen Kantschukkorkes, oder dadurch, dass man die bewurzelten Pflanzen init 
Hülfe eines halbirten Korkes einsetzt und die Fugen mit einer bei relativ niedriger Temperatur schmelzbaren Mischung von Wachs, Hammelfett und Olivenöl verstreicht. In den zweiten Tubulus des Gefässes $C$ ist das etwa $15 \mathrm{~mm}$ weite, mit Wasser angefüllte und graduirte Glasrohr $R$ eingesetzt. Das Wasser in $R$ bedeckt man mit dünner Oelschicht. Zweckmässig ist es, die Temperatur des Wassers im Apparat durch ein Thermometer bestimmen zu können. In vielen Fällen empfiehlt es sich, das Wasser im Gefäss $C$ mit einer Oelschicht zu bedecken, um auf diese einfache Weise die transpirirenden und Wasser aufnehmenden Theile des Untersuchungsobjectes von einander zu trenuen.

Durch Wägung des ganzen Apparates auf einer genügend empfindlichen Waage kann der Transpirationsverlust der Pflanze ermittelt werden. Die Wasseraufnahme ergiebt sich, natürlich unter Berücksichtigung ler Wärmeauslehnung des Wassers, aus den Ablesungen am Rohr $R^{\prime}$ ). Wenn längere Zeit constante äussere Einflüsse auf eine im Apparat befindliche bewurzelte Ptlanze einwirken, so stellt sich ein Gleichgewichtsverhältniss zwischen Transpiration und Wasseraufnahme her. Wird aber durch liohe Luftemperatur die Transpiration sehr gesteigert, so ist der Wasserverlust der Ptlanze grösser als die Wasseraufnalıme; stellt man die Pflanze nun aber unter eine Glasglocke, dann überwiegt die Wasseraufnahme ${ }^{\text {}}$ ). Als Untersuchungsobjecte eignen sich sehr gut mit Hülfe der Methode der Wassercultur zur Entwickelung gebrachte Bohnenoder Maisphtanzen und abgeschnittene Sprosse von Holzptlanzen, z. B. Salix. In vielen Fällen, z. B. bei Demonstrationsversuchen, genügt $e s$, die bei Experimenten über Transpiration zu benutzenden abgeschnittenen Sprosse in ein Wasser enthaltendes Gefäss zu stellen und die Wasseroberfläche mit einer Schicht Olivenöl zu bedecken. sich der Transpirationsverlust

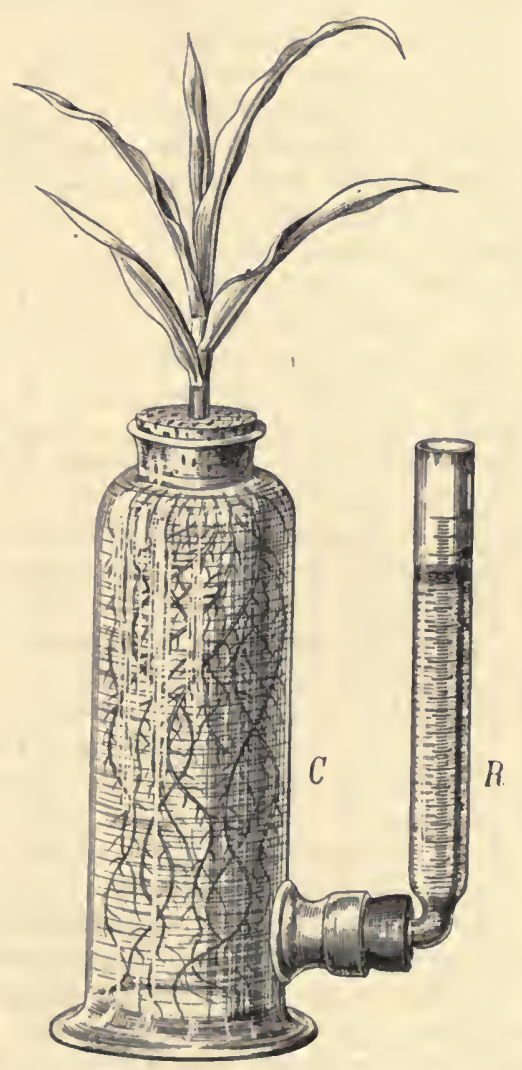

Fig. 82. Apparat zur Bestimmung der Wasseraufnahme und Wasserabgabe transpirirender Pflanzen. (Nach PFuFFER.)

Durch Wägung des Apparates lässt ermitteln. (Vgl. Fig. 83.) Kounmt

1) Vgl. PfefFer, Handbuch der Pflanzenphysiologic, Bd. 1, S. 135 u. 141.

2) Ueber das Verhältniss zwischen Wasseraufnahme und Abgabe der Pflanzen vergl. zumal Vfssoqu, Ann. d. sc. nat., 1876 u. 1878. 
es lierbei nicht auf sehr grosse Genauigkeit an, so benutzt man einc oberschalige Waage, die im Preis von ea. $20 \mathrm{Mk}$. von Muencke in Berlin zu beziehen ist. (Vergl. Fig. 83). Als Beobachtungsobjecte dienen Zweige von Salix fragilis, Helianthus, Euealyptus globulus (ein junger, 20 Blätter tragender Spross dieser Pflanze verdunstete unter gar nicht sehr günstigen Umständen z. B. 7 g Wasser in der Stunde) etc. Im Winter verwendet man zu diesen und anderen Transpirationsversuchen Sprosse von Fuchsia, die zumal in directem Sonnenlieht recht stark transpiriren.

Wollen wir uns davon überzeugen, dass Pflanzen in einer wassergasreichen Luft weit schwächer transpiriren als in wassergasarmer, so stellen wir einen unserer Apparate zunächst eine halbe Stunde lang unter eine Glasglocke, deren innere Wandfläche mit Wasser benetzt ivorden ist. Dann setzen wir unser Untersuchungsobject eine halbe Stunde lang der freien Luft aus. Man stelle die Versuche iibrigens nicht im Freien, sondern in einem Zimmer an und sorge dafür, dass das Beobachtungsobject während der Experimente stets den nämlichen Temperatursowie Beleuchtungsverhältnissen ausgesetzt bleibe.

Bei höherer Temperatur giebt eine Pflanze viel mehr Wasserdampf als bei niederer Temperatur ab. Die Temperaturverhältnisse an sich und die Feuchtigkeitsverhältnisse wirken hierbei gewölnlich zusammen.

Um die Abhängigkeit der Transpirationsgrösse von dem Wassergasgehalt der Luft und der Temperatur recht klar hervortreten zu lassen, stellte ich Versuche mit dem in Fig. 84 abgebildeten Apparat an. Auf einem Dreifuss steht der $40 \mathrm{~cm}$ hohe und $24 \mathrm{~cm}$ Durchmesser lialtende Zinkblecheylinder $Z$. Im Cylinder ruht auf einem kleinen Dreifuss die Porcellanschale $P$, während die Krystallisirschale $K$ auf einem Dralitgestell Platz findet, das an der Unterseite des den Cylinder verschliessenden Holzdeckels oder besser Metalldecliels befestigt ist. Das Thermometer $T$ dient zur Bestimmung der Temperatur der Luft im Cylinder. Man cxperimentirt zweckmässig mit Zweigen von Salix fragilis, die auch im Dunkeln noch recht lebhaft transpiriren, da ihre Stomata sich bei Lichtmangel nicht schliessen. Ein mit vielen Blättern besetzter Zweig wird abgeschnitten, in ein Wasser entlıaltendes Gläschen gestellt und die Wasseroberfläche, um Verdunstung von derselben zu vermeiden, mit einer Schicht ron Olivenöl bedeckt. Das Gläschen findet nun in der grossen Porzellanschale scinen Platz, nachdem in diese und auch in dic Krystallisirschale $K$ Chlorcalcium gebracht worden ist. Hat man bei Beginn des Versuchs das Gewicht des Gläschens und des Weidenzweiges ermittelt, und wiederholt man die Wägung nach etwa 4 Stunden, so gewinnt man Aufschluss über die Transpirationsgrösse des Zweiges 
in sehr wassergasarmer Luft. Jetzt ersetzt man das Chlorcalcium in $P$ und $K$ durch Wasser und lässt den Zweig + Stunden lang in der wassergasreichen Luft verdunsten. Hat man den relativ geringen Tran-

spirationsverlust unter diesen Umständen constatirt, so wird das Untersuchungsobject nochmals der wassergasarmen Lutt ausgesetzt. Der Apparat findet am besten in einem nach Norden gelegenen Zimmer Platz, denn in einem solchen Raum sind die Temperaturschwankungen wảhrend eines Tages nur unbedentend.

Bei Versuchen über den Einfluss der Temperatur werden die Zweige zunächst bei niederer Temperatur und nachdem $P$ und $K$ mit Chlorcalcium beschickt worden sind, im Apparat gehalten. Dann erwärmt man clie Luft in Apparat und setzt das Untersuchungsobject der löheren Temperatur aus. Ein Weidenzweig verdunstete z. B. (immer in wassergasarmer Luft) in je 4 Stunden bei $21^{\circ}$ C. 5,2 g, und bei $32^{\circ}$ C. $8,5 \mathrm{~g}$ Wasser.

Es ist klar, dass in letzten Experiment dic Transpirationsgrösse nicht nur durch die höhere Lufttemperatur, sondern zugleich auch dadurch gesteigert werden musste, dass das Untersuchungsobject aus dem warmen Wasser eine relativ grosse Flüssigkeitsmenge aufnahm. Un dies letztere Moment auszuschliessen, kann der folgende Apparat (vgl. Fig. 85) Verwendung finden, den ich auch benutzte, um die Abhängigkeit der Transpirationsgrösse vom Wassergehalt zu demonstriren. Auf dem Ring des Stativs $S t$ ruht eine in ihrer Mitte mit einer Oeffnung versehenen flache Porzellanschale $P$. Die mit dem 'Thermometer $T$ beschickte Glasglocke $G$ wird zweckınässig zieınlich gross ( $30 \mathrm{~cm}$ hoch und 15 cm Durchmesser) gewählt. In den Kork $K$ des mit Wasser gefiillten U-Rohres $U$ steckt das Thermometer $T^{\prime}$ und die Basis

Fig. 8t. Apparat für Transpirationsversuche. Der Zinkeylinder $Z$ ist durchsichtig gedacht.

eines Sprosses (z. B. Syringa), während die Blätter des Sprosses von der Glasglocke $G$ bedeckt sind. In der Oeffnung der Porzellanschale wird der Spross mittelst Watte befestigt. In die Bohrung des Korkes $K^{\prime}$ des U-Rohres wird der eine Schenkel des Glasrolıres $G l$ von ca. $2 \mathrm{~mm}$ Weite im Lichten eingeführt. Der andere Schenkel des Rohres ruht neben einem Millimetermaassstab auf einer vom Stativ 
getragenen Holzplatte. Sind $U$ und $G l$ bei Beginn des Versuchs völlig mit Wasser angefüllt und lıat man den Boden von $P$ mit Chlorcalcium bedeckt, so wird die Glocke $G$ aufgesetzt. Nach Verlauf einiger Zeit bestimmt man die Lage des Meniscus in $G l$ und kann die Grösse des Wasserverbrauchs der Pflanze nun ermitteln, indem man z. B. ron 5 zu 5 Minuten constatirt, um wiè viel Millimeter der Meniscus in $G l$ zurückgewichen ist. Um die Temperatur der Luft unter $G$

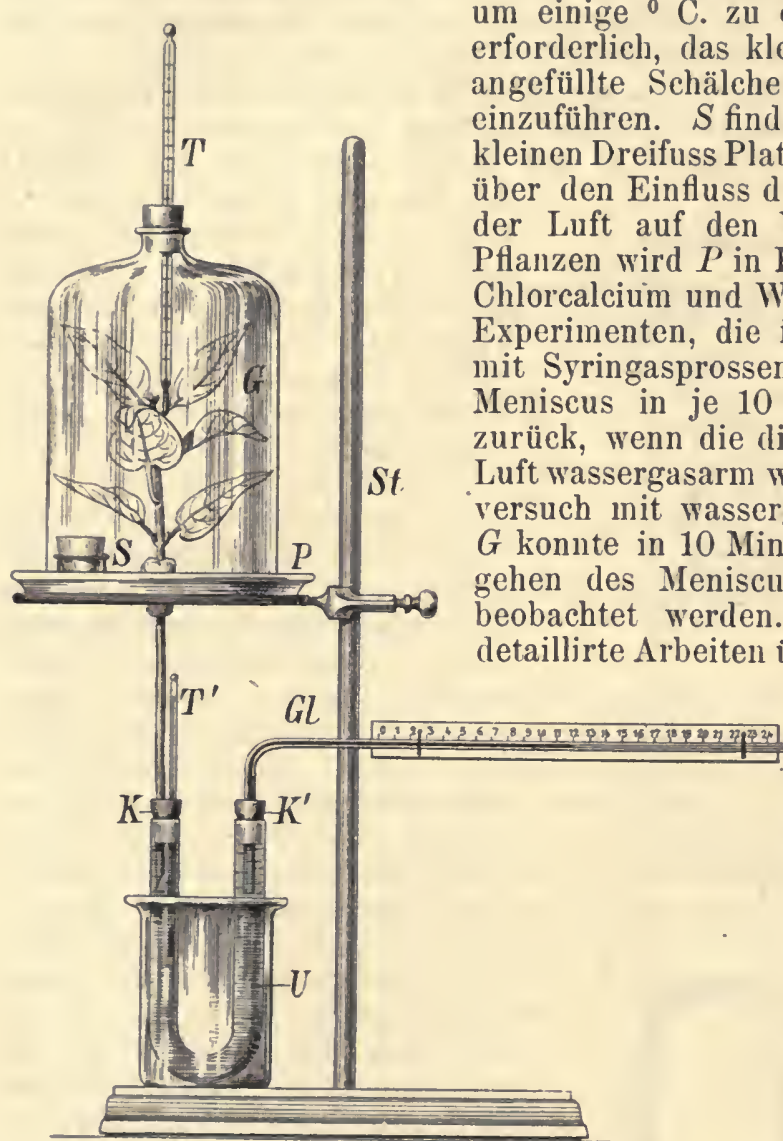

Fig. S5. Apparat zur Messung der Wasseraufnahme transpirirender Pflanzen. um einige ${ }^{0} \mathrm{C}$. $\mathrm{zu}$ erhöhen, ist es nur kleine mit heissem Sand angefüllte Schälchen $S$ in den Apparat let unter $G$ auf einem asser beschickt. Bei anstellte, wich der Minuten um $10 \mathrm{~mm}$ (lie Blättel umgebende war. In einem Parallel(n) unter beobachtet werden. Für manche sehr ber die Transpiration eignet sich auch der Apparat von Конц. Bei dem Gebrauch desselben und ebenso bei der Benutzung der in Fig. S5̃ abgebildeten Zusammenstellung ist übrigens wohl zu beachten. dass, wenn die Wasseraufnahme seitens der Pflanzen im Allgemeinen auch mit der Transpiration sinkt und steigt, die erstere doch

keineswegs unter allen Umständen in ihrer Ausgiebigkeit durch die Transpiration bestimmt wird. Die Apparate sind aber doch für vergleichende Versuche von kurzer Dauer recht zu empfehlen.

Einen dem Apparat von Kowl sehr ähnlichen erhalten wir, wenn wir die Schale $P$ in Fig. 85 durch eine in ihrer Mitte mit einer Oeffnung versehene, matt geschliffene Glasplatte ersetzen, überall für luftdichten Verschluss sorgen und durch den Kork der Glocke $G$ ein Gaszuleitungsund ein Gasableitungsrohr schieben. Mit Hülfe eines Aspirators saugen wir Luft durch den Apparat, die z. B. bei Versuchen über den Einfluss der Temperatur auf die Transpiration vor ihrem Eintritt in die Glocke, 
nm sie völlig zu trocknen, Gefässe passirt hat, welche concentrirte Schwefelsäure und Chlorcalcium enthalten. Erwärmung der Luft erzielt man leicht dadurch, dass man das Gaszuleitungsrohr in der Nähe der Glocke $G$ mittelst einer Spiritusflamme auf höhere 'Temperatur bringt.

Lehrreich ist es, die Thatsache festzustellen, dass das Licht die Transpirationsgrösse erhöht. Ich benutzte bei meinen Versuchen den in Fig. 79 abgebildeten Apparat und experimentirte zumal mit Cucurbita. Man stellt die Beobachtungen in einem Zimmer an, das zur Zeit der Versuche nur diffuses Licht empfängt und ohne Müle schnell verdunkelt werden kann, wobei übrigens gar nicht auf absoluten Lichtausschluss zu sehen ist. Der Apparat steht am besten vor dem Fenster auf einer Waage. Man beleuchtet eine oder zwei Stunden lang, verdunkelt dann z. B. dureh Schliessen eines Fensterladens und belenchtet wieder nach Verlauf von 1 oder 2 Stunden etc. Während der einzelnen Versuchsperioden muss die Boden- und Lufttemperatur dieselbe bleiben; ebenso darf die Luftfeuchtigkeit nicht schwanken. Als Psyehrometer verwendet man bequem ein einfaches Stativ mit zwei Thermometern, von denen das eine trocken gehalten wird, während die Kugel des anderen mit nasser Leinwand umwickelt ist. Genaueres über meine Versuchsresultate ist in meiner Abhandlung: Beiträge zur Theorie des Wurzeldrucks, Jena, 1877, S. 77 , nachzusehen. Die Ursache der Transpirationssteigung durch Beleuchtung ist einerseits in der Wärmewirkung der in die Ptlanze eindringenden Liehtstrahlen zu suchen, andererseits wird jene Steigerung in manchen Fällen noeh wesentlich dadureh erhöht werden können, dass Lichtzutritt eine Erweiterung der Spalten der Spaltöffnungsapparate herbeiführt.

Dieses letztere Moment ist auch in erster Linie zu beachten, wenn es sich darum handelt, die Resultate der folgenden einfachen Versuche $\mathrm{zu}$ verstehen. Wir stellen zwei mit Wasser angefüllte enghalsige Glasflaschen auf. Die eine Flasche dient zur Aufnahme eines grösseren Zweiges von Tilia grandifolia, die andere zur Aufnahme eines Sprosses ron Salix fragilis. Auf das Wasser beider Gläser sehichten wir noch Olivenöl und wägen die Apparate. Beide werden alsdann diffusem Tageslicht ausgesetzt und nach einiger Zeit durch Wägung der Transpirationsverlust der Untersuchungsobjecte ermittelt. Ich fand, dass

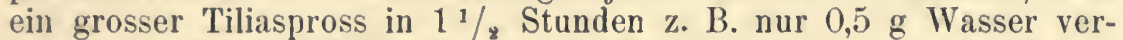
dunstete, wïhrend Weidenzweige unter den bezeichneten Umständen recht lebhaft transpirirten. Dem directen Sonnenlicht ausgesetzt, gab der Tiliazweig in $1 \frac{1}{2}$ Stunden $45 \mathrm{~g}$ Wasser ab. Bei Tilia sind die Spaltöffnungen nur in directem Sonnenlicht weit geöffnet, sie schliessen sich schon in diffusem Licht. Bei Salix bleiben die Stomata auch in diffusem Licht offen, daher transpiriren die Sprosse auch unter diesen Umständen recht stark.

Dass die Spaltöffnungsapparate der Linde in der That sehr lebhaft auf Beleuchtungswechsel reagiren, lässt sich leicht mit Hülfe der Kobaltprobe constatiren. Abgeschnittene Zweige von Tilia grandifolia werden mit der Basis in Wasser gestellt und theils dem directen Sonnenlicht, theils schwachem diffusem Tageslicht ausgesetzt. Nach Verlauf von 2 Stunden ergiebt die Kobaltprobe (vgl. S. 181), dass die Blätter der ersteren Zweige das mit ihrer Unterseite in Berührung gebrachte Kobaltpapier sehr stark röthen, wälırend die Blätter der Zweige, welche im diffusen Licht verweilt haben, dies nur in geringem Grade vermögen. Mit Hülfe der Kobaltprobe fand ich anch, dass Blätter 
von Tiliazweigen, die dem directen Sonnenlicht, ohne sich mit Wasser in Berülıung zu befinden, ausgesetzt werden, ihre Stomata schnell sehliessen.

Ungemein energisch reagiren auch die Spaltöffuungsapparate von Aspidistra elatior und Ficus elastica nach STAnL's Beobachtungen auf den Wechsel der Beleuchtungsverhältnisse. Im directen Sonnenlicht öffnen diese Pflanzen ihre Stomata weit, während dieselben im nicht zu hellen diffusen Tageslicht selbst bei holıer 'Temperatur $\left(30^{\circ} \mathrm{C}\right.$.) geschlossen bleiben. Aspidistra und Ficus verdunsten daher im diffusen Licht selır selıwach, in directen Sonnenlicht stark. Wird ein in einem Blumentopf wurzelndes Exemplar von Ficus elastica, welches etwa eine Stunde lang besonnt gewesen war, gewogen, und das Gewicht der Pflanze nach 2-4 Stunden abermals ermittelt, so ergiebt sich ein beträchtlicher Transpirationsverlust, wenn das Untersuchungsobject direetes Sonnenlicht empfing. Stellt man die Pflanze nunmehr an die Hinterwand eines nach Norden gelegenen Zimmers und beginnt einen neuen Transpirationsversuch, nachdem das Beobachtungsobject sich nach Verlauf etwa einer Stunde den veränderten Bedingungen angepasst hat, dann ergeben die Wägungen sehr geringe Wasserverluste. Bei diesen Experimenten kann die Wasserabgabe seitens des Topfes und des Bodens dureh Bedecken mit Stanniol und Umwickeln des Topfes mit einem weissen Tuch ausgeschlossen werden, oder man verfährt, um dies noch sicherer zu erreichen, in der auf S. 182 angegebenen Weise.

Wir schneiden Zweige von Salix fragilis und Tilia grandifolia ab. Die Zweige, welche nahezu das nämliche Gewicht haben müssen, bringen wir in einem nach Norden gelegenen Zimmer auf einen Tisch. Wasser wird ihnen nicht dargeboten. Wiederholte im Laufe von 1-2 Tagen vorgenommene Wägungen ergeben, dass der WeidenZweig viel stärker transpirirt als der Lindenzweig. Die Blätter des ersteren sind daher auch schon trocken, wenn die Lindenblätter noch relativ viel Wasser enthalten. Untersucht man welkende Lindenund Weidenblätter (den letzteren ganz ähnlich verhalten sich z. B. auch die Blätter vòn Cyperus alternifolius) mit Hüilfe der Kobaltprobe, so findet man die Stomata der Linde geschlossen, diejenigen der Weide aber offen. Die Linde und viele andere Pflanzen sind im Stande, ihre Transpirationsgrösse selbst zu reguliren. Sie schliessen, wenn die Gefahr des Welkens droht, ihre Stomata. Die Weide rermag dies nicht; ihre Blätter vertroeknen daher sehr schnell, wenn Wasserzufuhr ausgeschlossen ist.

Will man im Winter Versuche anstellen, die lehren, dass welkende Blätter ihre Stomata schliessen, so verwendet man Tradeseantien des Gewächshauses als Untersuchungsobjecte. Frisch abgeschnittene Blätter rötlıen das mit ihrer Unterseite in Berührung gebrachte Kobaltpapier. Wenig angewelkte Tradescantiablätter vermögen dies nicht mehr. Werden dic auch im Winter stets zur Verfügung stehenden Sprosse von Cyperus alternifolius und Blätter von Aspidistra abgeschnitten und sich bei diffusem Licht selbst überlassen, ohne dass man ihnen Wasser zuführt, so welken erstere schnell, weil ihre Spaltöffinungen sich nicht schliessen können, die letzteren bleiben aber, da ilıre Stomata geschlossen sind, lange frisch. Die Kiobaltprobe kann auch hier bequem Aufschluss ïber den Zustand der Spaltöftinungsapparate geben. 
Wenn man Cucurbitaexemplare oder andere PHanzen mit Hülfe der in Fig. 79 oder 82 dargestellten Apparate auf ihre Transpirationsgrösse untersucht und zunächst eine halbe Stunde lang, ruhig auf einer Waage stehen lässt, dann den Transpirationsverlust ermittelt, um die Pflanzentheile nun einige Secunden heftig zu schütteln, so ergiebt sich sofort, dass in dieser letzten Zeit eine unverhältnissmåssig bedeutende Wassergasmenge aus den Untersuchungsobjecten entwichen ist. Plötzliche Erschütterungen erhöhen die Transpirationsgrösse der Gewächse erheblich. Ich habe mich hiervon mehrfach iiberzengt ${ }^{1}$ ).

\section{S4. Jas IIolz als wasserleitendes Gewebe und der Einfluss der Transpiration anf die Wasserbewegung in der Pflanze.}

Wir bringen an der Basis eines reich beblätterten Zweiges eines Baumes oder Stranches (ich experimentirte mit Pavia rubra), ohne denselben von seiner Mutterpflanze zu trennen, einen Ringelschnitt an, indem wir einen etwa $5 \mathrm{~cm}$ breiten Rindenring rings im Umfange des Zweiges bis auf das Holz entfernen.

Das Untersuchungsobject bleibt lange Zeit frisch, trotzlem die Blätter lebhaft transpiriren, denn die Wasserzufuhr ist nicht in Folge der Ringelung aufgehoben. Somit kann die Rinde nicht als dasjenige Gewebe betrachtet werden, dem irgend welche besondere Bedeutung bei der Wasserleitung im Stamm zukommt; vielmehr ist es der Holzkörper der Fibrovasalstränge, in welchem sich das Wasser bewegt. Das trockene oder gar bereits theilweise zerstörte Mark in ler Mitte der holzigen Stammgebilde spielt natürlich keine Rolle bei der Wasserbewegung in der Pflanze.

Uebrigens ist es sicher, dass nicht der gesammte Holzkörper das Wasser leitet, sondern nur das Splintholz, während das Kernholz leitungsunfähig geworlen ist. Natürlich eignen sich zu bezüglicben Experimenten nur solche Pflanzen gut, bei denen ein ausgeprigiter Gegensatz zwischen Keln- und Splintholz besteht. Wenn man z. B. den etwa 12-16i cm Durchmesser besitzenden Stamm einer Robinia im Sommer bis auf das Kernholz kreisförmig einsägt, so welkt die Pflanze oft noch am Versuchstage. Wenn man krätigen Zweigen von Rhus typhina einen Rindenring voll wenigen Centimetern Breite entnimmt, so welkt dieser Zweig schnell. Bei Rhus typhina ist der Splint so diün, dass er bereits in Folge der Rindenringelung leidet, und somit die Wasserleitung unterbrochen werien muss ${ }^{2}$ ). Bei meinen Versuchen war der über der Ringelungsstelle gelegene Theil des Zweiges von Rhus typhina bereits nach wenigen Stunden welk. Rhus glabra verhält sich nicht in der nämlichen Weise.

Wir schneiden cinen Spross von Impatiens noli tangere oder I. parviflora ab und stellen ihn mit seiner Schnittläche in wässerige

1) Literatur: Uxger, Anatouie u. Physiologie d. Pflanzen, 1855; SACHs, Haudbuch der Experimentalphysiologic d. Pflanzen, 1865; BA ANEт\%к, Botan. Zeitung, 1S72; Wiksxer, Sitzungsber. d. Akaden. d. Wiss. in Wien, 1876, Octoloerheft; Dermir, Beiträge zur Theoric d. Wurzeldrucks, Jena 1877, S. 47 ; Kol1, Transpiration d. Pflanzen, 13raunschweig 1886; EBERDT, Transpiration d. Pflanzen, IIarburg 1859 .

2) Ygl. Dutrocher, Mémoires pour servil à l'histoire anatomique et physiologique de végétaux, 1837, p. 193. 
Lösung von Methylgrün. Die Stengel unserer Untersuchungsobjecte sind in hohem Grade durchscheinend, so dass man die Erscheinungen, um die es sich hier für uns handelt, bei ihrer Benutzung besonders schön beobachten kann. Bei einem mit Impatiens parviflora angestellten Versuch ergab sich, dass die Farbstofflösung in dem Stengel eines ziemlich stark transpirirenden Sprosses nach Verlauf von 1/4 Stunde bereits einige Centimeter hoch hinaufgestiegen war, und bei mikroskopischer Untersuchung von Stengelquerschnitten erschien nur der Holztheil der im Kreise angeordneten Gefässbündel tingirt.

Die Resultate dieses und ähnlicher Versuche haben neuerdings durch die Arbeiten Wifler's ') und Strasburger's ${ }^{2}$ ) wieder eine grössere Bedeutung gewonnen. Sie können in der That zur Begründung des Satzes verwerthet werden, dass die Bewegung des Wassers in der Pflanze im Holz erfolgt. Bei der Beurtheilung der Resultate dieser Versuche mit Farbstofflösungen ist aber immer, zumal wenn es sich um Detailfragen handelt, viel Kritik und Vorsicht erforderlich.

Wir stellen einen ungefähr $20 \mathrm{~mm}$ im Durchschnitt besitzenden beblätterten Zweig von Robinia, der zunächst in Wasser gestanden hat, ohne seine Schnittfläche mit der Luft in Berührung zu bringen, in wässerige Eosinlösung, die so verdünnt gewählt wird, dass sie in $10 \mathrm{~cm}$ dicker Schicht noch durchscheinend ist. Die nach Verlanf einiger Stunden vorzunehmende Prüfung lehrt, dass nur die äusseren Holztheile, nicht die centraler gelegenen gefärbt sind. Die letzteren leiten das Wasser nicht mehr. Wenn man das Experiment nicht allzulange auslehnt, ist auch leicht unter Berücksichtigung der Vertheilung des Eosins zu constatiren, dass nur die trachealen Bahnen, nicht aber die Holzfasern bei der Wasserbewegung betheiligt sind. Die letzteren bleiben ungefärbt.

Wenn man Tiliazweige in der angegebenen Weise behandelt, so lässt sich das Eosin nach Verlauf einiger Stunden nur in den Gefässen und Tracheiden nachweisen. Holzfasern und Bast bleiben ungefärbt. Bei Versuchen mit Aristolochia färbt sich das Holz; der Ring von Sklerenchymfasern bleibt ungefärbt.

Haben wir durch die angeführten Versuche die Bewegung des Wassers in den tracliealen Bahnen des Holzes festgestellt, so wollen wir nurmehr zeigen, dass die Wasserleitung nicht, wie man früher annahm, in den verholzten Membranen der Elemente des Xylems, sondern im Lumen derselben erfolgt ${ }^{3}$ ).

Ich fülı te bezügliche Versuche z. B. in folgender Weise aus. Zwei Zweige ven Salix fragilis $(a$ und $b$ ) wurden abgeschnitten und mit der Basis in Wasser enthaltende Gläschen gestellt. Das Wasser für $a$ wurde noch mit einer Sehicht Olivenöl bedeckt. $a$ und $b$ gelangten nun in den in Fig. 84 abgebildeten Apparat, naclidem die Porzellanschale sowie die Krystallisirschale mit Chlorcalcium beschickt und rlie Luft im Zinkeylinder auf $32{ }^{\circ} \mathrm{C}$. erwärmt worden war. Nach Verlauf einer Stunde wurde $b$ herausgenommen, der Weidlenzweig in ein

1) Vgl. Wielser, Jahrbüeher f. wissenschl. Butanik, Bd. 19. und 569

2) Strasiburger, Bau und Verrichtung der Leitungsbahnen, Jena 1891, S. 549

3) Vgl. Elfyisf, Botan. Zeitung, 1SS2, S. 714; Vrsque, Ann. d. sc. nat. Bot. VI. Sér., T. XIX, p. 188; Schifit, Botan. Zeitung 1884, S. 201; Errera, Compt. rend. de la société roy. de bot. de Belgique, T. XXV, II. Th., p. 2S; Strasburger, Bau und Verrichtung der Leitungsbahnen, Jena 1891, ડ. 541. 
Gläschen gestellt, das :3-proc. Gelatinelösung enthielt, und die Ober-

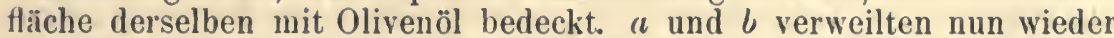
eine Stunde lang im Apparat. Die Untersuchungsobjecte transpirirten und $b$ nahm labei die Gelatinelösung auf. Nach Verlauf der angegebenen Zeit wurden $\iota$ und $b$ aus dem Apparat herausgenommen. $b$ wurde, nachdem durch Entfernen eines einige cm langen stïckes an ler Basis des 'Zweiges eine neue Schnittfläche hergestellt worden war, in Wasser getaucht, um die Untersuchungsobjecte nunmehr bei $20^{\circ} \mathrm{C}$. sich selbst zu ïberlassen. Die Gelatine erstarrte in den Gefässen von $b$, was die Wasserbewegung in denselben störte. Nach Verlauf von 20 Stunden waren die Blätter von $b$ deni auch welk, während diejenigen des Controlzweiges $a$ noch frisch erschienen.

Das nämliche Resultat liefert auch der folgende Versuch $\left.{ }^{1}\right)$. Am Mittag oder am Nachmittag eines sonnigen Sommertages werden Zweige von Vitis unter einer Gelatinelösung (auf 100 Thl. Wasser 20 Thl. Gelatine), die man mit chinesischer Tusche gefärbt hat, abgeschnitten. Die Flüssigkeit ist auf $33^{\circ} \mathrm{C}$. erwärmt, bei welcher Temperatur sie sich völlig flüssig zeigt. Stellt man die Zweige nun schnell mit der Basis in kaltes Wasser und erneuert die Schnittfläche, so welken die Untersuchungsobjecte alsbald, weil sie in Folge Verstopfung der Lumina ihrer Holzelemente durch die erstarrte Gelatine kein Wasser leiten können. Zweige von Vitis, die man unter Wasser abschneidet und in dieser Flïssigkeit stehen lässt, bleiben lange frisch. (Vgl. auch STrasburger's citirte Schrift, S. 697.)

Was die Kräfte anbetrifft, durch welche die Wasserhebung in der Pflanze vermittelt wird, so sind diese noch nicht sicher ermittelt. Es existirt leider noch keine allseitig befriedigende Theorie der Wasserbewegung in den Gewächsen ${ }^{2}$ ). Vielleicht kommen die von WESTERMEYER und GODLEwSKI über die Ursachen der Wasserströmung geäusserten Ansichten der Wahrheit am nächsten; vielleicht ist aber auch STRASBURGER's Ansicht die richtige ${ }^{3}$ ); indessen die Zukunft kann erst tiefere Einsicht bringen, und es ist hier nicht der Ort, den Gegenstand näher zu verfolgen. Wir gehen daher lieber dazu über, verschiedene Erscheinungen $\mathrm{zu}$ constatiren (unter 85 auch die Leichtbeweglichkeit des Wassers im Holz), welche auf alle Fälle von grosser Wichtigkeit für das Verständniss der Frage nach den Ursachen der Wasserströmung in den Pflanzen sind.

Wir schneiden zwei möglichst gleichartig entwickelte Sprosse von Impatiens ab und stellen sie beide mit ihrem unteren Ende in Wasser. Beide Sprosse verweilen zunäclıst einige Stunden lang unter einer grossen Glasglocke, deren Wand im Innern mit Wasser benetzt worden ist. Dann bringen wir ihre Schnittfläche mit Auflösungen von Methylgrïn oder Eosin in Berïhrung. Der eine Spross wird Bedingungen ausgesetzt, unter denen er lebhaft transpiriren kann. Den anderen schüitzen wir möglichst vor Wasserverlust, indem wir ihn unter der Glas-

1) Vgl. Errerra, Berichte d. Deutschen botan. Gesellschaft, 13d. 4, S. 16.

2) Literatur ïber Wasserlewegung: SACHs, Vorlesungen über Pflanzenphysiologie, 1887; Hartig, Gasdrucktheorie, 1883; Westerneyer, Berichte d. Deutschen botan. Gescllschaft, 1883; GoDLEwskI, Jahrbücher f. wissenschl. Botanik, Bd. 15; ScIEIT, Jenaische Zeitschrift für Naturwissenschaft, N. F. Bd. 12; STRASBURGER, Bau und Verrichtung der Leitungsbahnen in den Pflanzen, Jena 1891; ScrwfxDENER, Sitzungsber. d. Akadem. d. Wiss. zu Berlin, 1892. Vergl. auch die letzten Aninerkungen.

3) STRAsBurger's merkwürdige Experimente mit getödteten Pflanzen konnte ich bis jetzt noch nicht wiederholen. 
glocke belassen. In diesem letzteren Spross steigt die Farbstofflösung nur wenig empor, während sie sich in den Gefässbündeln des transpirirenden Pflanzentlıeiles in kurzer Zeit bis zu beträchtlicher Höhe erhebt.

Die Wirkung des Transpirationsprocesses kann auch noch durch anderweitige Experimente leicht festgestellt werden. Wir verwenden dazu den in Fig. 86 abgebildeten Apparat. Wir befestigen einen beblätterten Spross mit Hülfe eines Kautschukschlauches luftdicht an oberen Eudle einer geraden Glasröhre, füllen dieselbe mit Wasser an und tauchen ihr unteres Ende in Quecksilber ein. In dem Maasse, in welchem das Wasser in Folge der Transpiration verbraucht wird, tritt in das Glasrolı Quecksilber ein und ich fand, dass sich das Quecksilber bei ziemlich lebhafter Wasserverdunstung des Untersuchungsobjectes (ich benutzte z. B. Sprosse von Lonicera tatarica) in wenigen Stunden einige Centimeter hoch erheben kann.

Wenn man den Stamm einer Birke nicht weit entfernt vom Erdboden im zeitigen Frühjahr (Ende März, Anfang April) anbohrt und den einen Schenkel eines im rechten Winkel gebogenen Glasrohres mit Hülfe eines Kautschukschlauches oder mit Hülfe von Siegellack luftdicht in der Boh-

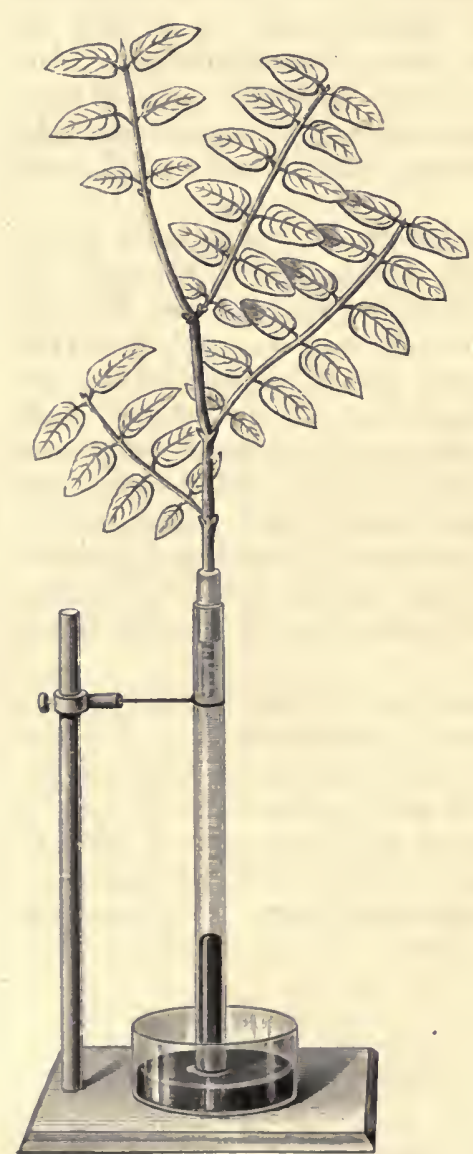

Fig. S6. Apparat zum Nachweis der saugenden Wirkung der Transpiration. rung befestigt, so zeigt sich, dass, zumal zur Zeit der Nacht eine erhebliche Flüssigkeitsmenge in Folge der Thätigkeit des Wurzeldruckes aus dem Baume ausgepresst wird. Wiederholt man den nämlichen Versuch im Sommer, z. B. im Juni, so fliesst kein Tropfen Saft aus der Birke aus, sondern es kann sogar Wasser von dem Stamme eingesogen werden, wie sich leicht feststellen lässt, wenn man das offene Ende des rechtwinkelig gebogenen Glasrohres in Wasser eintaucht. Diese Erscheinung wird durch die Wirkung der Transpiration hervorgerufen.

Wenn einer transpirirenden Pflanze, deren Holzelemente zunächst reichliche Wassermengen enthalten, keine sehr grossen Flüssigkeitsmengen zur Verfügung stehen - und es wird dies zumal im Sommer der Fall sein - dann verschwindet das Wasser mehr und mehr aus dem Lumen der Holzgefässe und Tracheiden. Aus dem intercellularen Luftsystem der Pflanzen geht die Luft, wie früher gezeigt wurde, nur schwierig in das cellulare System über, und ebenso sind die Luftmengen, welche das in den Gewächsen vorhandene Wasser aufgelöst enthält und unter bestimmten Bedingungen an seine Umgebung abzugeben vermag, keine erheblichen. Bei starker Transpiration der Pflanzen im Sommer bildet also nicht Wasser den alleinigen Inhalt der Holz- 
elemente, sondern ausser der Flüssigkeit ist viel wasserdampfreiche, verdünnte Luft vorhanden, eine Thatsache, auf die bereits S. 154 hingewiesen worden ist.

Wenn wir ein Stück Holz aus einem transpirirenden Baum herausschneiden und dasselbe in Wasser werfen, so schwimmt es auf demselben. Wären die Lumina der Holzelemente völlig mit Wasser angefüllt gewesen, so hätte das Holz untersinken müssen, denn das specifische Gewicht der Holzsubstanz an sich ist grösser als dasjenige des Wassers. Ein in Wasser geworfenes Stück frischen Holzes sinkt übrigens allmählich tiefer in die Flüssigkeit ein, indem es zugleich eine Gewichtszunahme erfährt, eine Erscheinung, die nur Folge von Wasseraufnahme sein kann.

Ebenso lehrt der folgende Versuch, dass, während das Lumen der Holzelemente der Pflanzen unter Umständen völlig mit Wasser angefüllt ist, dies keineswegs immer der Fall sein kann ${ }^{1}$ ). Zwei kräftige Exemplare von Cucurbita oder einer Begoniaspecies werden in der unter 75 angegebenen Weise decapitirt und mit Steigröhren versehen, nachdem die eine Pflanze vorher einen Tag lang stark transpirirt hatte, während die andere durch Ueberdecken mit einer Glasglocke vor bedeutenderem Wasserverlust geschützt worden war. Diese letztere Pflanze liefert sofort Saft, der sich unter dem Einfluss des Wurzeldrucks in dem aufgesetzten Steigrohre erhebt. Das erstere Untersuchungsobject liefert zunäehst noch keinen Saft; es saugt sogar Wasser, welches man in das Steigrohr hineinbringt, ziemlich begierig ein. Erst allmählich kommt ein Saftausfluss zu Stande.

\section{S5. Die Beweglichkeit des Wassers im Holz.}

Wir verschaffen uns ein $15-30 \mathrm{~cm}$ langes und $2-4 \mathrm{~cm}$ Durchmesser besitzen les Stamm- oder Aststiick von Abies pectinata. Das Untersuchungsobject muss recht wasserreich sein, weshalb man es am zweckmässigsten im Winter einer lebensfrischen Pflanze entnimmt und eventuell vor dem Versuch noch längere Zeit in Wasser legt. Die sorgfältig geglätteten Schnittfächen des Tannenholzes erscheinen trocken. Bringen wir aber auf die obere Schnittfläche des Untersuchungsobjectes, indem wir dasselbe in verticaler Stellung halten, mit Hülfe eines Pinsels eine dünne Wasserschicht, so beobachten wir, dass dieses Wasser schnell in das Holz einsinkt, während die Schnittfläche am unteren Ende feucht wird. Ein schnelles Undrehen des Holzstückes lässt eine Wiederholung des Vorganges beobachten. Es genügt also ein minimaler Druck, $1 \mathrm{~m}$ die im Holz vorhandenen Wasserfäden in Bewegung zu setzen. Zu gleichem Schluss füliren die Resultate der folgenden Experimente. Befestigt man in den kürzeren Schenkel eines U-förmigen Glasrohres ein Stück frischen 'Tannenholzes und füllt das Rohr mit Wasser an, so quillt so lange Fliissigkeit aus dem oberen Holzquerschnitt hervor, bis der Druck völlig ausgeglichen ist. Ein gerades, $2-4 \mathrm{~cm}$ weites Glasrohr $G$ (vgl. Fig. 87 ) wird an seinen einen Ende mit einem durchbohrten Kautsclukkork verschlossen, dessen Bohrung zur Aufnahme des dünnen Glasrohres $R$ bestimnt ist. In das andere Ende des weiteren Glasrohres wird ein Stück frischen Tannenholzes (ich benutzte ein solches ron $15 \mathrm{~cm}$ Länge und $2 \mathrm{~cm}$

1) Vgl. Detmfr, Beiträge zur Theoric d. Wurzeldrucks, in Prlyen's physiologischen Abhandlungen, 1877, Bd. 1, Heft S, S. 37. 
Durchmesser) $T$ luftdicht eingekittet. Das zweimal im rechten Winkel gebogene Glasrohr $R$ steht mit dem Kolben $K$ und dieser mittelst iles Glasrohres $R^{\prime}$ mit einer Luftpumpe in Verbindung. Taucht man die freie Schnittfläche des Holzes in Wasser ein und evacuirt, so filtrirt sofort Wasser durch das $\mathrm{Holz}$ in das weite Glasrohr hinein. Wir stellen uns nun den in Fig. $88 \mathrm{ab}$ gebildeten Apparat zusammen.

In einem eisernen Ring eines auf einen hohen Schrank gestellten schweren Stativs hängt ein recht grosser Trichter T. Das Trichterrohr ist mit Hülfe eines Kautschukschlauches mit der etwa $150 \mathrm{~cm}$ langen Glasröhre $G$ in Verbindung gesetzt, deren unteres Ende in das weite Glasrohr $G^{\prime}$ einmündet. Der untere Theil dieses letzteren wird durch das ca. $6 \mathrm{~cm}$ lange und $2 \mathrm{~cm}$ im Durchmesser besitzende Aststïck von Abies pectinata oder Taxus baccata $A$ luftdicht abgeschlossen. Der ganze Apparat wird nun mit staubfreiem destillirtem Wasser angefüllt. Der Wasserdruck presst das Wasser durch die Aststücke, die man im berindeten oder entrindeten Zustande zur Anwendung bringen kann, hindurch, so dass in kurzer Zeit bedeutende Flüssigkeitsmengen abfiltriren. Die Quantität des ablaufenden Wassers wird mit der Zeit geringer, wie man leicht ermitteln kann. Es tritt dies auch dann ein, wenn man dafür Sorge trägt, dass das Wasserniveau im Trichter stets auf gleicher Höhe erhalten bleibt, und die Ursache der erwähnten Erscheinung ist in einer nach und nach zu

Stande kommenden Veränderung (Verunreinigung) der Schnittfläche des Holzes, durch welche das Wasser eintritt, zu suchen.

Wir stellen einen weiteren Versuch mit unserem Apparat an, füllen denselben aber jetzt nicht mit reinem
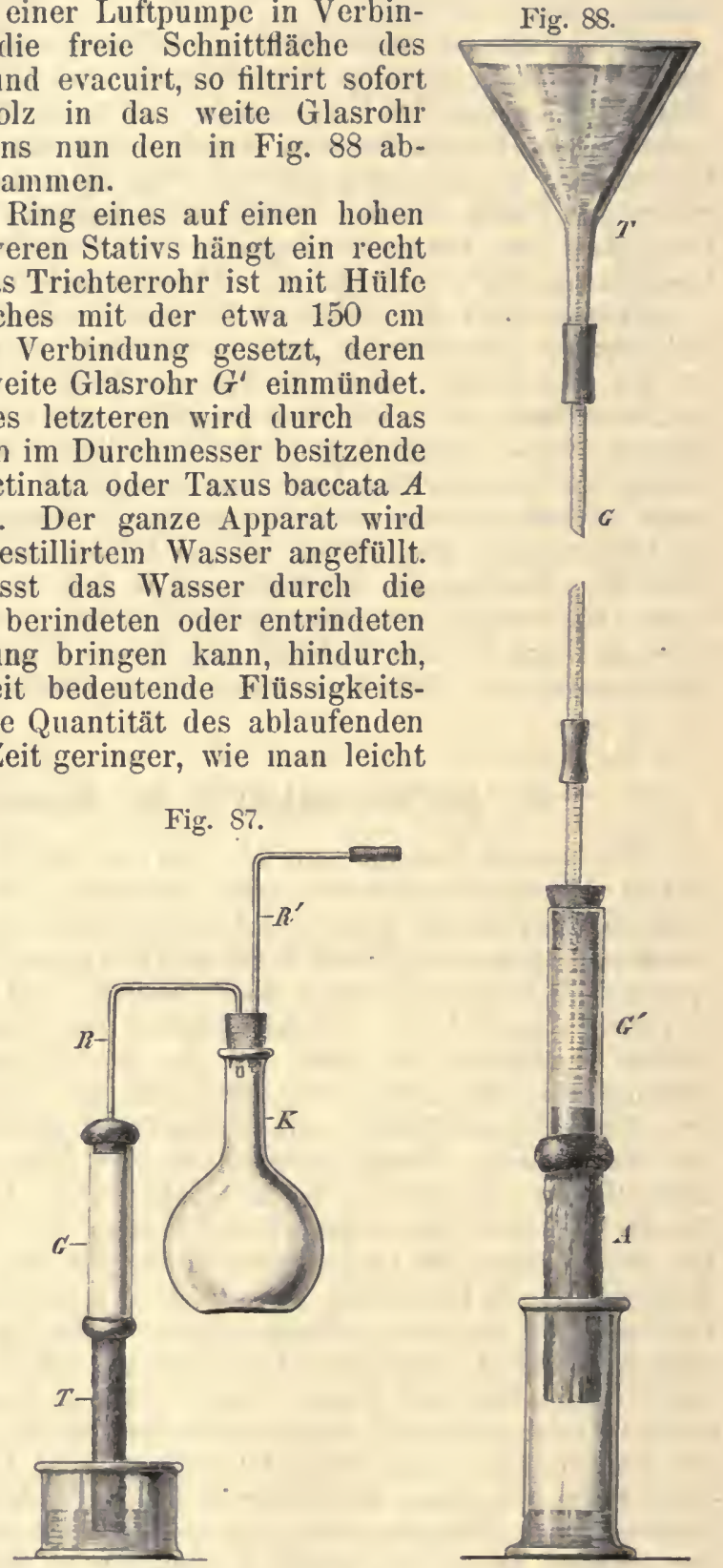

Fig. 8i. Apparat zur Constatirung der leiehten Beweglichkeit des Wassers in Holz.

Fig. SS. Apparat zur Constatirung der leichten Beweglichkeit des Wassers im Holz und der Thatsaehe, dass die Schliessmembranen der gehöften Tüpfel der Tracheiden gesehlossen sind. 
Wasser, sondern mit Wasser, in welchem wir Zinnober ganz fein vertheilt haben. Eine grössere Menge destillirten Wassers wird mit bestem Zinnober versetzt, die Flüssigkeit mehrfach filtrirt, so dass nur äusserst kleine Zinnoberköruchen in ihr suspendirt bleiben, die sich selbst im Laufe mehrerer Tage nicht zu Borlen setzen. Das im Laufe von 1-2 Tagen durch den Holzcylinder am unteren Ende unseres Apparates abfiltrirte Wasser ist vollkommen klar. Die Untersuchung des Holzstücks selbst ergiebt, dass nur die obere Schnittfläche desselben bis zu einer Tiefe von einigen Millimetern nit Zinnober imprägnirt ist. Die mikroskopische Beobachtung zarter Holzschnitte lässt uns die Gegenwart des Zinnobers in den Tracheiden erkennen, und wir gelangen schliesslich zu der folgenden Beurtheilung der Resultate unseres Experimentes.

Es ist natürlich, dass die Tracheiden des Tannenholzes, welche an die Schnittfläche der zum Versuch benutzten Holzcylinder grenzen, bei der Herstellung derselben geöffnet worden sind. Bei der Filtration dringen Wasser und Zinnober in die Tracheiden ein. Es unterliegt nun gar keinem Zweifel, dass das Wasser selbst bei minimalem Druck durch die Schliessmembranen der behöften Tüpfel der Tracheiden filtrirt; alle unsere Experimente lassen diese Thatsache klar hervoltreten. Die Zinnobertheilchen sind aber nicht im Stande, aus einer in eine andere Tracheide überzugehen, weil sie die Schliessmembranen der Tüpfel nicht passiren können. Zugleich ist hiermit der experimentelle Beweis von dem Vorhandensein der Schliessmembranen zwischen den Elementen des Coniferenholzes beigebracht ").

Die Leichtigkeit, nit der das Wasser durch Holz filtrirt, ist für die Wasserbewegung im Holzkörper der Pflanzen von grosser Beleutung.

\section{Die Gesehwindigkeit der Wasserbewegung in der Pllanze.}

Man hat oft versucht, sich eine Vorstellung von der Geschwindigkeit, mit der sich das Wasser in den Pflanzen bewegt, dadurch zu bilden, dass man die Untersuchungsobjecte mit ihrer Basis in Farbstofflösungen brachte und die Höhe feststellte, in der sich der Farbstoff nach bestimmter Zeit in den Pflanzentheilen nachweisen liess. Diese Methode kann aber nicht zu genauen Werthen führen. In der Pflanze erfolgt nämlich eine Zerlegung der aufgenommenen Farbstofflösung. Der Farbstoff wird von bestimmten Elementen des Gewebes (zumal (den verholzten) zurückgehalten, während das Wasser sich weiter bewegt. Man kann sich leicht von der Zerlegbarkeit der Farbstofflösungen ïberzeugen, wenn man in einen hohen Glascylinder etwas wässerige Metlıylgrün- oder Eosinlösung (letztere so concentrirt, dass sie in 10 cll dicker Schicht noch durchscheinend ist) bringt, den $\mathrm{Cy}$ linder mit einer Glasplatte bedeckt und an dieser einen schmalen Fliesspapierstreifen so befestigt, dass sein unteres Ende eben in die Farbstofflösung eintaucht. Nach Verlauf kurzer Zeit hat sich der Farbstoff bis zu bestimmter Höhe im Papier erhoben; oberhalb der Grenze, bis zu der er vorgedrungen ist, erscheint das Papier aber

1) Vgl. Th. Hartig, Botan. Zeitung, 1863, und zumal Sacus, Arbeiten d. botan. Instituts in Würzburg, B. 2, S. 296. 
nicht trocken, sondern feucht. Das Wasser ist also weiter emporgestiegen als der Farbstoff.

Wenn man einen Streifen Fliesspapier mit seinem unteren Ende in eine etwa 2-procentige Lösung von Lithiumsalpeter eintauchen lässt, so ist hingegen leicht nachzuweisen, dass das Lithiumsalz bis zur nåmlichen Höhe wie das Wasser emporsteigt. Schneidet man nämlich den obersten, noch durchfeuchteten Querstreifen des Papieres ab und hält ilın in die Flamme eines Bunsex'schen Gasbrenners, dann lässt sich die Gegenwart von Lithium auf spectroskopischem Wege (Auftreten der bekannten rothen Lithiumlinie im Spectrum) leicht constatiren. Die Lösung des salpetersauren Lithiums ist nun vielfach von SACHS ${ }^{1}$ ) zur Ermittelung der Geschwindigkeit der Wasserbewegung in der Pflanze benutzt worden, und anch wir wollen unsere Untersuchungen in derselben Weise wie SAcHs ausführen.

Es ist aus naheliegenden Gründen zunächst am besten, die Experimente nicht mit abgeschnittenen Pflanzentheilen, sondern mit röllig intacten, bewurzelten Pflanzen anzustellen. Wir können z. B. mit Weiden experimentiren. Es werden vorjährige Zweige im Früljalır abgeschnitten, mit der Basis in Nährstofflösungen gestellt und erst nach Verlauf einiger Monate zum Versuch benutzt, wenn die Zweige ein reiches Wurzelsystem sowie viele Blätter entwickelt haben. Auch Maispflanzen, die man mit Hülfe der Methode der Wassercultur zur Entwickelung gebracht hat, können zweckmässig verwendet werden: ebenso in Blumentöpfen in guter Gartenerde erzogene Exemplare von Nicotiana, Cucurbita, Helianthus etc. Die Pflanzen müssen kräftig ausgebildet und reich beblättert sein. Man stellt sie 1 oder 2 Tage vor Beginn des eigentlichen Versuchs vor einem Südfenster auf, so dass sie dem Sonnenschein und hoher Temperatur ausgesetzt sind. Die Erde in den Töpfen wird in dieser Zeit nicht begossen. Unmittelbar vor Anfang der Experimente über die Aufnahme der Lithiumlösung seitens der Pflanzen werden diese letzteren, wenn sie sich seither mit einer Nährstofflösung in Berührung befunden hattên, aus dieser herausgenommen, um sie in eine 2-procentige Lithiumsalpeterlösung zu stellen. Arbeitet man dagegen mit in Erde eingewurzelten Pflanzen, so durchtränkt man den Boden in den Töpfen sehr stark mit 2-procentiger Lithiumlösung. Die Untersuchungsobjecte bleiben aucl jetzt sehr günstigen Transpirationsbedingungen exponirt. Nach Verlauf einer Stunde schneidet man den Stanm der Pflanzen über der Erde ab, zerlegt ihn von oben nach unten in kleine Stücke und schneidet die Blätter ab. Bei diesen Operationen ist grosse Sauberkeit nöthig, um das eventuell in einem Theil der Pflanze vorhandene Lithiumsalz mit dem Messer nicht auf andere Theile zu übertragen. Zur Prïfung auf Lithium werden dünne Stengelstiicke der zerschnittenen Untersuchuingsobjecte oder kleine Blattstückchen mit der Pincette gefasst und in die Gasflamme gehalten, auf die man das Spectroskop gerichtet hat. Grössere Lithiummengen sind sofort $\mathrm{zu}$ erkennen; kleinere erst dann, wenn die Asche glïht. Um auf jeden Fall zu keinem zu hohen Werth für die Steighöhe des Lithiumsalzes (und also auch des Wassers) zu gelangen, wird stets nur die Entfernung des am höchsten gelegenen Stamm- oder Blattstückes, in welchem Lithiumsalz nachzuweisen ist, vom Wurzelhals in Beritck-

1) SACHS, Arbeiten des botan. Instituts in Würzburg, B. 2, S. 148. 
sichtigung gezogen. Häufig kann es auch zweckmässig sein, den Pflanzen nach Verlauf einer bestimmten Versuchszeit, ohne sie zu decapitiren, einfach Blattstïckehen zu entnelımen, um dieselben auf Lithiumgehalt zu prüfen. Beachtenswerth ist die Thatsache, von deren Richtigkeit ich mich bei der Prüfung der Methode von SACHS zur Bestimmung der Wasserleitungsgesclıwindigkeit in Pflanzen überzeugte, dass man zuweilen erhebliche Mengen des aufgenommenen Lithiums ill den Blättern der Untersuchungsobjecte nachweisen kann, während ein solcher Nachweis in tiefer liegenden Stammstückchen nicht gelingt. Offenbar häuft sich das Lithiumsalz in den Blattgeweben oft in grösseren Mengen als in den Stammtheilen an. SAcHs macht folgende Angaben über die Steighöhe des Wassers, resp. des Lithiumsalzes in einigen Pflanzen.

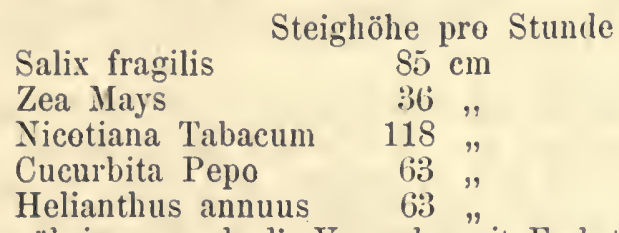

Neuerdings haben übrigens auch die Versuche mit Farbstofflösungen zur Ermittelung der Geschwindigkeit der Wasserleitung an Bedeutung gewonnen, indem Strasburger ${ }^{1}$ ) nachwies, dass sich namentlich Eosinlösungen von der schon angegebenen Concentration recht gut zu den Experimenten selbst unter Benutzung abgeschnittener Pflanzentheile eignen. Die bei Anwendung des genannten Farbstoffes gewonnenen Resultate sind freilich nicht absolut genau; indessen sie verdienen dennoch $\mathrm{Be}$ achtung. Wir durchschneiden einen Spross einer Humulus- oder Bryoniapflanze, die im Freien wächst, an einem heissen Sommertage an der Basis unter Wasser. Die Schnittfäche bleibt nun $1 / 8-1$ Stunde mit dem Wasser in Berührung und gelangt dann erst in die Eosinlösung. Diese Vorsicht ist erforderlich, damit die Farbstofflösung nicht durch den Luftdruck in das Untersuchungsobject hineingepresst werde. Das Eosin steigt sehr schnell in den transpirirenden Sprossen empor. Es kann z. B. nach Verlauf einer halben Stunde bereits $2-3 \mathrm{~m}$ weit vorgedrungen sein, wie die Untersuchung von Querschnitten lehrt, die man den Pflanzen an den betreffenden Stellen entnimmt.

\section{S\%. Die Erseheinung des Welkens der Pflanzen.}

Wenn die Transpirationsverluste einer Pflanze dauernd grösser sind, als die Wasseraufnahme, so geht dieselbe allmählich in den welken Zustand über. Ihre Blätter hängen. schlaff herab, und bei ausbleibender erneuter Wasserzufuhr vertrocknet sie schliesslich. Wird dagegen der Boden, in welchem in Blumentöpfen cultivirte, eben angewelkte Gewächse (z. B. Bolınen- oder Kürbispflanzen) wurzeln, begossen, dann turgesciren die Zellen der Blätter aufs Neue, und die Untersuchungsobjecte nehmen wieder schnell ein frisches Ausselien an. Dieselbe Erscheinung tritt hervor, wenn wir den angewelkten Pflanzen kein Wasser zuführen, dafür aber ihre Transpirationsgrösse herabsetzen, indem wir sie z. B. unter eine Glasglocke stellen.

1) Vergl. Strasıurger, Histologische Beiträge, Heft III, S. 550 und 590. 
Werden reich beblätterte Zweige von Bäumen oder Sträuchern ab)geschnitten und mit dem unteren Ende ihres verholzten Stammtheiles in Wasser gestellt, so bleiben die Untersuchungsobjecte gewöhnlich tagelang frisch. Um so überraschender ist es, dass die Zweige einiger Gewächse, wenn sie in der angegebenen Weise behandelt werden, trotzdem ihr Stammtheil stark verholzt ist, recht schnell welken. In der Weise verhalten sich z. B. nach meinen Beobachtungen oft die Zweige von Salix fragilis. Im Allgemeinen bleiben aber doch abgeschnittene und in Wasser gestellte Sprosse um so länger frisch, je weiter die Entwickelung des Holzes in ihrem Stammtheil fortgeschritten ist. Wenn man z. B. etwa $1 \mathrm{~m}$ lange Sprosse von Helianthus tuberosus abschneidet und in Wasser stellt, so bleiben sie mehrere Tage hindurch frisch; 20-30 cm lange Sprosse derselben Pflanze welken dagegen, in Wasser gestellt, sehr schnell, indem zuerst die jüngeren der entfalteten Blätter, später auch die älteren schlaff werden.

Wir stellen nun den folgenden sehr lehrreichen Versucl mit Helianthus tuberosus an. Wir biegen lange Sprosse von Helianthus, ohne sie von der Pflanze zu trennen und ohne sie zu knicken, so lierab, dass eine $20 \mathrm{~cm}$ vom Gipfel entfernte Stelle in das Wasser eines untergestellten Gefässes taucht, der Gipfel sowie die Blätter selbst aber nicht benetzt werden. Jetzt trennen wir das $20 \mathrm{~cm}$ lange Sprossende durch einen mit Hülfe eines scharfen Messers gefülırten Schnitt von der Pflanze und sorgen vor allem dafür, dass die Schnittfläche gar nicht mit der Luft in Berührung kommt, sondern stets unter Wasser bleibt. Unser Spross bleibt tagelang frisch, während $20 \mathrm{~cm}$ lange Helianthussprosse, die man in der Luft abgeschnitten und dann alsbald (z. B. nach 1-2 Minuten) in Wasser gestellt hat, schnell welk werden. Die welken Helianthussprosse kann man aber auf verschiedene Weise wieder turgescent machen. Entfernt man einige der angewelkten Blätter, so nehmen die noch vorhandenen Blätter bald ein frisches Aussehen an, weil die Transpirationsverluste des Pflanzentheils jetzt durch die Wasseraufnahme gedeckt werden können. Ein welker Heliantluusspross wird mit Hülfe eines Kautschukschlauches oder Kautschuckkorkes auf dem kürzeren Schenkel eines Wasser enthaltenden U-förnig gebogenen Glasrohres luftdicht befestigt, so dass die Schnittfläche in das Wasser eintaucht. Jetzt wird Quecksilber in den längeren Schenkel der Glasröhre gegossen. Ein Quecksilberdruck von wenigen Centimeterı genügt freilich nicht, um den welken Spross frisch zu machen; pressen wir das Wasser aber mit einem Quecksilberdruck von $30-50 \mathrm{~cm}$ in den welken Helianthusspross ein, so wird dieser wieder turgescent. Von einem mit seinem unteren Ende in Wasser stehenden angewelkten Helianthusspross von $20 \mathrm{~cm}$ Länge schneiden wir mit Hülfe eines scharfen Messers ein 5 cin langes Stengelstïck unter Wasser ab und sorgen dafür, dass die neu hergestellte Schnittfläche nicht mit der Luft in Berührung kommt. Der Spross wird alsbald ein frisches, turgescirendes Aussehen annehmen.

Unsere Untersuchungen an Helianthussprossen, die man auch an anderweitigen Objecten wiederholen kann, lehren vor allem, dass die Sprosse welken, wenn sie in Luft abgeschnitten und dann in Wasser gestellt werden, während sie, unter Wasser abgeschnitten, frisch bleiben. Diesen merkwürdigen Phänomenen liegen verschiedene Ursachen zu Grunde. Beim Abschneiden von Pflanzentheilen in Luft werden schleimige oder klebrige Stoffe, die an der Wundfläche hervortreten, nicht entferut, sondern sie 
bleiben an der Schnittfläche haften und vermindern so die Fähigkeit des Gewebes, Wasser aufzunehmen. Beim Abschneiden in Luft wird auch der negative Druck, der in den Holzelementen unversehrter transpirirender Pflanzen herrscht (vgl. Seite 154), mehr oder minder ausgeglichen, und dadurch die Wasserleitung in den Stengeltheilen wesentlich beeinträchtigt. Diese verschiedenen nachtheiligen Folgen treten beim Durchschneiden der Sprosse unter Wasser, wie leicht einzusehen ist, nicht hervor ${ }^{1}$ ).

\section{Die Mineralstoffaufnahme seitens der Pflanzen.}

\section{Die Wurzeln der Pllanzen als Organe der Mlineralstoff- aufnahme.}

Den Pflanzenwurzeln kommt die Aufgabe zu, die Gewächse im Boden zu befestigen; andererseits fungiren sie aber aucl als Organe der Wasser- und Mineralstoffaufnalıme. Wenn wir Pflanzen mit Hülfe der Methode der Wassercultur in wässeriger Nährstoftlösung cultiviren, so treten diese beiden letzteren Functionen der Wurzeln in klarster Weise hervor. Aber auch im Boden, der den Gewächsen zum Standort dient, finden sich häufig Nährstofflösungen vor, denn die von den Bodenelementen festgehaltenen und $z$ wischen denselben circulirenden Flüssigkeitsmengen repräsentiren kein reines Wasser, sondern verdünnte Nährstoftlösungen. Das Wasser ist im Stande, lösend und zersetzend auf die Bodenelemente einzuwirken. Diese geben in absorbirter Form oder in noch fester gebundener Form vorhandene Mineralstoffe an das Wasser ab, und die lösende Kraft des letzteren wird häufig noch durch die Gegenwart grösserer Kohlensäuremengen, die im Boden durch Verwesungsprocesse entstehen, wesentlich erhöht.

Auf die Mineralstoffaufnahme der Wurzeln aus Nährstofflösungen will ich hier nicht specieller eingehen, da wir die bezüglichen Verlältnisse unter 89 besprechen werden; hingegen wollen wir an dieser Stelle auf einige Beobachtungen hinweisen, die mit Rücksicht auf das Verhalten der Wurzeln im Boden Interesse beanspruchen.

Wir bringen einige Weizenkörner in guter Gartenerde, mit welcher ein Blumentopf angefüllt ist, zur Keimung, um die jungen Pflänzchen, wenn sie 4 oder 5 Wurzeln gebildet haben, vorsichtig aus dem Boden zu entfernen. Schüttelt man die Keimpflanzen kräftig, so fällt ein beträchtlicher Theil der an den Wurzeln haftenden Erde ab, ein anderer Theil löst sich aber nicht von denselben los. Die Gesammtoberfiäclee der Wurzeln wird von einer Erdschicht eingehüllt; nur an den Wurzelspitzen liaften keine Bodentheilchen. Die genauere mikroskopische Untersuchung der Wurzeln lehrt uns, dass die Wurzelspitzen frei von Wurzelhaaren sind, während die ganze ïbrige Oberfläche der Wurzeln mit selir zahlreichen Wurzelhaaren bedeckt erscheint. An diesen lang-

1) Vgl. H. NE VRIEs in Arbeiten d. botan. Instituts in Würzburg, Bd. 1, S. 287, und F. V. HöHxes in HabenuavnT's wissensch.-praktischen Forschungen auf d. Gebiete d. Pflanzenbaues, Bd. 2, S. 120. 
gestreckten, einzelligen Organen haften die feineren Bodenelemente sehr fest; die Haare verwachsen förmlich mit den Erdtheilchen, und bei starker Vergrösserung ist dies leicht festzustellen. Dic Wurzelhaare sind die Organe der Wurzeln, durch welche dic Wasser- und Mineralstoffaufnahme in erster Linie vermittelt wird. Sic entziehen dem Boden die vorhandenen verdünnten Nährstofflösungen, aber indem die Wurzelhaare in der unter 91 angegebenen Weise auf die ihnen dicht angeschmiegten Bodenelemente einwirken, bereiten sie auch selbst Nährstofflösungen für die Pflanzen, welche sofort in den Organismus übertreten.

Wenn man Pflanzen von Triticum vulgare etwa 5 Wochen lang in guter Gartenerde cultivirt und die Untersuchungsobjecte nun vorsichtig aus dem Boden hebt, so ergiebt sich nach kräftigem Schütteln, dass an den Wurzelspitzen sowie an den gesammten älteren Theilen der Wurzeln keine Erde haften bleibt, wohl aber an den jüngeren Regionen der Organe oberhalb ihrer Spitzen. Diese jüngeren Regionen elscheinen mit zahlreichen Wurzelhaaren bedeckt, während die Haare der älteren Wurzeltheile bereits abgestorben sind ${ }^{1}$ ).

Verschiedene Beobachter haben festgestellt, dass das Auftreten von Wurzelhaaren an den Wurzeln der Gewächse von einer Reihe äusserer Factoren abhängig ist, von denen die Feuchtigkeitsverhältnisse als die wichtigsten angesehen werden müssen ${ }^{2}$ ). Wir cultiviren Keimlinge von Zea, Avena, Triticum, Pisum, Phaseolus in mässig feuchter Gartenerde und werden durch mikioskopische Untersuchungen zarter Längs- oder Querschnitte der einigermaassen entwickelten Wurzeln feststellen können, dass dieselben unter den bezeichneten Verhältnissen viele Haare producirt haben. IVir bringen ferner einige Individuen der genannten Pflanzen bei Ausschluss des Bodens zur Entwickelung, indem wir die Samen nach dem Anquellen oder Ankeimèn auf Tüll legen, der über ein mit Wasser angefülltes Becherglas gespannt ist. Dies Glas stellen wir in eine etwas Wasser enthaltende Krystallisirschale und bedecken mit einer Glasglocke, so dass deren unterer Rand in das Wasser der Schale eintaucht. Während der Keimung der Samen sorge man durch häufigeres Entfernen der Glasglocke dafür, dass die Untersuchungsobjecte keinen Sauerstoffmangel leiden. Die in dem Wasser des Becherglases zur Ausbildung gelaugenden Wurzeln mancher Pflanzen (Avena, Triticum) besitzen ebenso wie die in Contact mit mässig feuchtem Boden entwickelten Wurzeln Wurzelhaare, wovon ich mich bei Versuchen mit Triticum vulgare überzeugte. Nach Fr. Schwarz erzeugen die Wurzeln von Zea, Pisum und Phaseolus dagegen in Contact mit Wasser keine Haare. Ich muss aber bemerken, dass ich wenigstens an den sich im Wasser ausbildenden, durchaus normal ausschenden und geradegestreckten Hauptwurzeln von Zea Mays zahlreiche. Wurzelhaare auftreten sah. Vielleicht verhalten sich die Wurzeln verschiedener Maisvarietäten in der hier in Rede stehenden Hinsicht nicht gleichartig. Vielleicht ist es auch nicht gleichgültig, ob sich die Wurzeln in Brunnenwasser oder destillirtem Wasser entwickeln, ob sie im Finstern oder bei Lichtzutritt zur Entwickelung gelangen. In destillirtem Wasser bei Lichtabschluss erwachsene Erbsen-

1) Vgl. SAcris, Handbuch der Experimentalphysiologie der Pflanzen, 1865, S. 185.

2) Vgl. Fr. Scrwarz in Untersuehungen aus d. botan. Institut zu Tübingen, Bd. 1, H. 2 . 
hauptwurzeln fand ich frei von Wurzelhaaren, während in Gartenerde zur Entwickelung gelangte Erbsenwurzeln sehr haarreich sind.

\section{Die Jineralstoffuufuahme der Wurzeln aus Nährstofflösungen.}

In meinem Lehrbuche der Pflanzenphysiologie (S. 136) habe ich schon darauf hingewiesen, dass die Verhältnisse, welche sich auf die Mineralstoffaufnahme der Wurzeln aus Nährstofflösungen bezichen, sehr complicirter Natur und noch keineswegs in wünschenswerther Weise aufgeklärt sind. Das Resultat, welches schliesslich erzielt wird, ist nicht allein abhängig von dem Concentrationszustande der Lösung, der Natur der vorhandenen Nährstoffe, ihrem Verbrauch im Organismus der Pflanze etc., sondern ebenso von der Natur der Pflanze, den äusseren Bedingungen, unter denen sie sich entwickelt, und manchen anderen Umständen. Weitere Forschungen müssen hier unter sorgfältiger Zergliederung des Gesammtphänomens näheren Aufschluss geben. An dieser Stelle legen wir uns die Frage vor, in welcher Weise sich dic Mineralstoffaufnahme der Wurzeln gestaltet, wenn denselben die wässerige Lösung eines einzigen Salzes zur Verfügung steht, eine Frage, die sicher mit Rücksicht auf die Mineralstoffaufnalıme seitens der Wurzeln aus completen Nährstofflösungen Interesse beansprucht.

Wir quellen eine Anzahl wohl ausgebildeter Samen von Phaseolus multiflorus oder Zea in Wasser ein, keimen sie in feuchten Sägespänen an, bestimmen das Lebendgewicht jeder Keimpflanze und befestigen sie einzeln mit Hülfe von Watte in den Bohrungen passender Korke, welche kleine Glasgefässe von etwas über $100 \mathrm{ccm}$ Inlialt verschliessen. Einige Gefässe sind vorher mit $100 \mathrm{ccm} 0,250$-proc., andere mit $100 \mathrm{ccm}$ 0,050 - oder 0,025 -proc. Kalisalpeterlösung beschickt worden. Wir stellen das Gewicht der Apparate fest und lassen sie nun so lange an einem wohlbeleuchteten Orte stehen, bis sic etwa $50 \mathrm{~g}$ an Gewicht verloren haben, also etwa die Hälfte der ur'sprünglichen Flüssigkeitsmenge durch die Wurzeln der Bohnenpflanzen aufgesogen worden ist. Die Versuchspflanzen werden aus den Lösungen entfernt, mit destillirtem Wasser abgespült (dies Wasser fügt man dann den Rückständen in den Gläsern hinzu), mit Fliesspapier abgetrocknet und gewogen. Man hat also einerseits die unter Vermittelung der Pflanzen verdunstete, andererseits die in das Lebendgewicht der Pflanzen übergegangene Wassermenge ermittelt. Eine Fehlerquelle unseres Versuchsverfahrens liegt darin, dass durch die Watte kein luftdichter Verschluss unserer Apparate hergestellt wird, und somit eine kleine Wasserquantität auch ohne Beihülfe der Pflanzen in die Luft übergehen kann. Die Grösse dieser Fehlerquelle ist aber leicht zu constatiren, und der Versuchsfehler auch auszuschliessen, wenn man einige Gläser mit $100 \mathrm{ccm}$ der Salzlösungen anfüllt, nicht mit Pflanzen beschickt, sondern nur mit einem Kork sowie Watte verschliesst und ihren Gewichtsverlust wälirend der Versuchszeit ermittelt. Ebenso hat es ja gar keine Schwierigkeit, die Zunahme an Trockensubstanz, welche die Untersuchungsobjecte während ihrer Vegetationszeit erfahren, mit in Berïcksichtigung zu ziehen. Wird schliesslich noch der Salzgehalt der Flüssigkeitsrïickstände in den Gläsern durch Verdunsten des Wassers der Lösung und Wägung des Rïckstandes festgestellt, so liegen alle Daten zur 
Berechnung vor. Diese ergiebt, dass Bohnenpflanzen aus 0,250-proc. Kalisalpeterlösungen relativ viel Wasser und wenig Salz aufnehmen; es bleibt also ein Flüssigkeitsrückstand in den Gläsern zurüick, der concentrirter ist als die ursprünglich den Versuchspflanzen dargebotene Lösung. (DE Saussure'sches Gesetz ${ }^{1}$ ). In Contact mit 0,050- oder 0,025 -proc. Kalisalpeterlösungen nehmen die Bohnenpflanzen aber eine relativ concentrirte Lösung auf; der Flüssigkeitsrückstand ist verdïnnter als die ursprünglich dargebotene Lösung ${ }^{2}$ ). Auf jeden Fall beansprucht die Thatsache also Interesse, dass die Pflanzenwurzeln die ihnen zur Disposition stehenden Nährstofflösungen nicht als solche aufsaugen, sondern je nach Umständen mit einer bestimmmten Wasserquantität bald kleinere, bald grössere Salzmengen aufnehmen. Zu einem nahezu richtigen Resultat gelangt man übrigens auch schon, wenn man Bolınenkeimlinge in angegebener Weise in Glasgefässen, die $100 \mathrm{ccm}$ der Lösungen des Kalisalpeters von versehiedenen Concentrationen enthalten, cultivirt und ohne weitere Wägungen einfach den Salpetergehalt der Flüssigkeitsrückstände bestimmt, nachdem die Hälfte der ursprünglichen Flüssigkeitsquantitäten aufgesogen worden ist.

\section{Die Corrosionserscheinungen.}

Die Wurzeln sind nicht allein im Stande, die Gewächse mit Nährstoffen zu versorgen, indem sie fertige Nährstofflösungen aufnehmen, sondern sie vermögen auch den compacten Bodenelementen absorbirte oder gar noch fester gebundene Substanzen zu entziehen. Die auf-

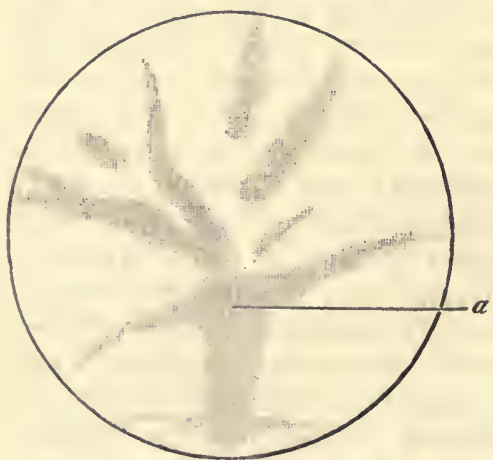

Fig. S9. Marmorplatte, deren Oberfläche durch die Wurzeln eines Phaseolusexemplares corrodirt worden ist. periment an. Ein kleiner Blumentopf wird etwa bis zur Hälfte mit feuchtem Sand angefüllt. Wir legen nun eine auf der Oberfläche sorgfältig polirte Marmorplatte auf den Sand. (Die Marmorplatte, mit welcher ich experimentirte und welche bei Abschluss des Versuchs die in Fig. 89 dargestellten Corrosionen erfahren hatte, besass $45 \mathrm{~mm}$ Durchinesser und $7 \mathrm{~mm}$ Dicke.) Der Blumentopf wird jetzt völlig mit

1) Vgl. JE Saussure, Recherches sur la végétation, 1804, S. 247.

2) Vgl. W. Wouf, Versuchsstationen, B. 6 1. 7. 
feuchtem Sand angefüllt und ein gepuollener Same von Phaseolus in denselben gelegt. Die Keimung beginnt alsbald. Die Wurzeln der Pflanzen dringen nacl unten in den Sand vor, aber treffen nacl einiger Zeit auf die Marmorplatte. Auf dieser wachsen sie in horizontaler Richtung hin, um, wenn sie den Rand der Platte erreicht haben, wieder mehr oder minder vertical im Sande weiter $\mathrm{zu}$ wachsen. Unterbricht man den Versuch, nimmt die Marmorplatte aus dem Bodenmaterial heraus, spült sie mit Wasser ab und trocknet sie mit einem weichen Tuche ab, so erblickt man an ihrer Oberfläche ein getreues Abbild derjenigen Wurzeltheile, die ih" angeschmiegt waren. Die Politur ist an den Contactstellen $\mathrm{z}$ wischen Marmor und Wurzeln entfernt. Ich erhielt, wic Fig. 89 zeigt, ziemlich breite Corrosionslinien, eine Erscheinung, die offenbar auf die corrodirende Thätigkeit der seitlich von den Wurzeln ausgehenden Wurzelhaare zurïckzuführen ist. Die abwärts wachsende Hauptwurzel traf bei $a$ auf die Marmorplatte; sie schlug dann die durch den breiten Streifen in der Abbildung angedeutete Richtung ein, wälırend die übrigen Corrosionslinien den Seitenwurzeln ihre Entstehung verdanken. $\mathrm{Zu}$ bemerken ist noch, dass es sich empfiehlt, die Bohnenpflanze, deren Wurzeln die Corrosionen bedingen, nicht zu lange Zeit (etwa nur 10-14 Tage) vegetiren zu lassen, da bei längerer Versuchsdauer sehr zahlreiche Wurzeln mit der Marmorplatte in Contact gerathen und die Corrosionslinien der einzelnen Wurzeln nicht mehr deutlich hervortreten ${ }^{3}$ ).

\section{Die Ursachen der Corrosionserseheinungen.}

Die Corrosionserscheinungen können offenbar nur dadureh zu Stande kommen, dass die den Gesteinmassen oder den Bodentheilehen dicht anliegenden Wurzeln bestimmte Stoffe ausscheiden, die befähigt sind, zersetzend auf jene einzuwirken. Es ist hier natürlich vor allem an die Kiohlensäure zu denken, welche in Folge des Athmungsprocesses in den Wurzelzellen entsteht, aber auch organische Säuren, ja selbst Salzsïure, kommen als weitere Substanzen, die mit Rücksicht auf die Entstelıung der Corrosionen Berücksichtigung verdienen, in Betracht. Wenn die Zellhäute der Wurzelzellen mit verdünnten Lösungen der elwähnten Körper imbibirt sind, so ist damit sofort die Möglichkeit einer Einwirkung der Wurzeln auf die Gestein- und Bodenelemente gegeben, ein Verhältniss, das unter Beachtung der Resultate des folgenden Experimentes sofort klar lervortritt ${ }^{*}$ ).

Wir stellen den in Fig. 90 abgebildeten Apparat zusammen. Das Glas $G$ enthält verdünnte Salzsäure. Durch die Bohrung des dlies Glas verschliessenden Korkes gelit das ziemlich weite Glasrohr $R$, welches an seinem unteren Ende mittelst eines Stückes Schweinsblase verschlossen ist. In unserem Apparat vertritt die Flïssigkeit den Zellinhalt, die Schweinsblase aber die Membran der Wurzelzellen. Legen wir ein Stïckelıen Marmor auf die mit verdünnter Salzsäure imbibirte Scliweinsblase, so wird dlasselbe alsbald theilweise in Lösung übergehen, und die gebildete Lösung von Chlorcalcium geht auf dem Wege

1) Die Corrosionserscheinungen sind zuerst von SAcus, vgl. dessen Handbuch der Experimentalphysiologie der Pflanzen, 1865, S. 185, eingeliender studirt worden.

2) Dies Experiment ist zuerst von ZöLLAR auf Anregung LiEBIG's ausgefïhrt morden. 
der Diffusion in die Salzsäure über. Wir können die Gegenwart von Calcium leicht mit Hülfe von oxalsaurem Ammoniak in der Flüssigkeit, die in Apparat vorhanden ist, feststellen. Ebenso üben die in den Membranen der Wurzelzellen in imbibirtem Zustande vorhandenen Lösungen einen zersetzenden Einfluss auf Gesteine sowie Bodenelemente aus; es entstehen die Corrosionserscheinungen, und die gelösten Stoffe werden seitens der Pflanze aufgesogen.

Aus den folgenden Experimenten, welche

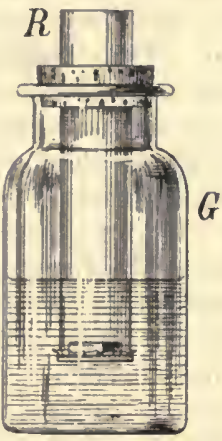

Fig. 90. Apparat zur Veranschaulichung einiger Vorgänge, die sich bei dem Zustandekommen der Corrosionserseheinungen geltend machen. Maispflanzen wurden nun aus der erwähnten Nährstofflösung heraúsgenommen und in zwei Gefässe versetzt, von denen das eine Wasser $(a)$, das zweite 0,1-proc. Chlorammoniumlösung enthielt (b). Ferner wurde ein drittes Gefäss (c) nur mit Chlorammoniumlösung ohne Pflanze beschickt. Eine Pflanze blieb in der stickstofffreien Nährstofflösung $(d)$, eine fernere Pflanze verblieb ebenfalls in der ursprünglichen Nährstofflösung, nachdem derselben Chlorammonium (auf $100 \mathrm{ccm}$ Wasser $0,1 \mathrm{~g}$ ) hinzugefügt worden war (e). Nach etwa 8 Tagen wurden Lakmuspapierstreifen 30 Secunden lang mit den Flüssigkeiten von $b$ und $e$, andere 15 Secunden lang mit den Flüssigkeiten von $a$, sowie $d$, und darauf 15 Secunden lang mit der Flüssigkeit von $c$ in Berührung gebracht. Jene Streifen des blauen Lakmuspapiers färbten sich erheblich intensiver roth als diese, eine Thatsache, die nicht anders als durch die Annahme erklärt werden kann, dass das Chlorammonium unter Bildung freier Salzsäure durch Vermittelung der Pflanzen zersetzt worden ist. Das in das Gewebe der Pflanzen eingedrungene Chlorammonium kommt in den Zellen mit organischen Säuren in Contact. Diese wirken zersetzend auf die Chlorverbindung ein, und da die entstehende Salzsäure keine Verarbeitung in den Gewächsen findet, so wird sie in die Nährstofflösung ausgeschieden und erhöht den sauren Charakter derselben.

Will man sich davon überzeugen, dass organische Säuren im Stande sind, Chloride auch ausserhalb der Pflanze unter Salzsäurebildung zu zersetzen, so sind die folgenden Experimente auszuführen.

Wir stellen zwei Bechergläser auf, die $500 \mathrm{ccm}$ destillirtes Wasser enthalten. $a$ erhält einen Zusatz von $3 \mathrm{~g}$ Oxalsäure, $b$ einen solchen ron $3 \mathrm{~g}$ Oxalsäure und $0,4 \mathrm{~g} \mathrm{NaCl}$. In beide Gefässe hängen wir nun in der 
Weise, wie es unter $2 \overline{5}$ angegeben worden ist, Marmorplatten hinein. Die Flüssigkeit in $a$ bleibt klar, weil sich die Marmorplatte schnell mit einer Kruste von oxalsaurem Kalk umgiebt, die der weiteren Einwirkung der Oxalsäure ein Hinderniss entgegenstellt. Die Flüssigkeit in $b$ trübt sich dagegen schnell bedeutend, eine Thatsache, deren Ursache nur in folgender Reaction liegen kann. Die Oxalsäure zersetzt das Chlornatrium. Die freigemachte Salzsäure wirkt anf den Marmor ein. Es entsteht Chlorcalcium, und auf dieses wirkt nun die Oxalsäure ein. Der gebildete oxalsaure Kalk, welcher sich alsbald in grosser Menge zu Boden setzt, ruft die Trübung der Flüssigkeit hervor.

Auch auf andere Weise kann man sich nach meinen Erfahrungeu davon überzeugen, dass organische Säuren im Stande sind, zersetzend auf Chloride einzawirken ${ }^{2}$ ). Es werden sechs Versuchsflüssigkeiten hergestellt: a) $15 \mathrm{ccm}$ destillirtes Wasser; b) $15 \mathrm{ccm}$ Wasser mit $0,020 \mathrm{~g} \mathrm{Ci}$ tronensäure; c) $15 \mathrm{ccn}$ Wasser mit $0,7 \mathrm{~g}$ Chlorkalium; d) $15 \mathrm{ccm}$ Wasser mit $0,7 \mathrm{~g}$ Chlornatrium; e) $15 \mathrm{ccm}$ Wasser mit $0,020 \mathrm{~g}$ Citronensăure und 0,7 Chlorkalium; f) $15 \mathrm{ccm}$ Wasser mit $0,020 \mathrm{~g}$ Citronensäure und $0,7 \mathrm{~g}$ Chlornatrium. Die Flüssigkeiten bleiben nun etwa 24 Stunden lang ruhig stehen und erhalten dann einen Zusatz von einigen Tropfen wässeriger, sehr verdünnter Methylanilinviolettlösung. Die Flüssigkeiten $a, b, c$ und d zeigen nahezu den nämlichen violetten Farbenton; die Flüssigkeiten e und $f$ sind dagegen deutlich blau gefärbt. Diese Reaction zeigt die Gegenwart freier Salzsäure an, denn während sehr verdünnte Citronensäurelösungen die Farbe des Methylanilinvioletts kaum verändern, nimmt der Farbstoff in Contact mit sehr verdünnter Salzsäurelösung einen blauen Farbenton an ${ }^{2}$ ).

\subsection{Das Absorptionsrermögen des Borlens.}

Es ist eine sehr wichtige Thatsache, dass der Boden im Stande ist, eine Reihe von Körpern, mit denen er in Berülırung kommt, sehr energisch festzuhalten (zu absorbiren). Kali, Ammoniak und Phosphorsäure werden vom Boden am lebhaftesten absorbirt und dadurch vor dem Versinken in die Tiefe geschützt, eine Thatsache, die offenbar von hoher Bedeutung für das Pflanzenleben ist. Wenn in Wasser lösliche Salze, mögen dieselben im Boden selbst entstanclen oder dem Boden direct von aussen zugeführt worden sein, die Kali, Ammoniak oder Phosphorsäure enthalten, mit den Feinerdepartikeln in Berïhrung gerathen, so erfolgt je nach der Natur des Bodens eine mehr oder minder lebhafte Absorption der genannten Stoffe. Sie werden chemisch gebunden, und wir wollen uns im Folgenden von der Thatsächlichkeit der Absorption eines Kïrpers, nämlich des Ammoniaks, durch geeignete Experimente ïberzeugen ${ }^{3}$ ). (Methode nach Kixop.)

1) Vergl. Dismur, Botan. Zeitung, 1884, No. 50.

2) Auch die GüxsıUra'sche Reaction auf Salzsäure bei gleichzeitiger Gegenwart von Chloriden dürfte hier sehr gute Dienste leisten. Man mischt mit $30 \mathrm{~g}$ Alkohol $1 \mathrm{~g}$ Vanillin und $2 \mathrm{~g}$ Phloroglucin. Einige Tropfen dieser Mischung sowie eimige Tropfen der Versuchsflüssigkeit werden in eine weisse Porzellanschale gebracht. Tritt beim Erhitzen Rothfärbung ein, so ist die Gegenwart freier Salzsäure nachgewiesen.

3) Ausführliches über das Absorptionsvermögen des Bodens und dessen Ursachen vgl. bei DeTMEr, Lehrbueh d. Bodenkunde, Leipzig 1876. 
$100 \mathrm{~g}$ lufttrockener Feinerde eines Bodens werden mit $10 \mathrm{~g}$ Kreidepulver innig gemischt und in einer Flasche mit $200 \mathrm{ccm}$ einer Salmiaklösung übergossen, die in $208 \mathrm{ccm}$ genau $1 \mathrm{~g}$ Salmiak enthält. Man lässt die Erde mit der Flüssigkeit 48 Stunden lang unter häufigem Umschütteln in Berührung, filtrirt $40 \mathrm{ccm}$ Flüssigkeit ab und dampft unter Zusatz eines 'Tropfens reiner Salzsäure bis auf etwa $10 \mathrm{ccm}$ ein. In diesen $10 \mathrm{ccm}$ Flüssigkeit bestimint man den Stickstoff; ebenso in $40 \mathrm{ccm}$ der ursprünglichen Salmiaklösung, die man auch durch Eindunsten auf $10 \mathrm{ccm}$ concentrirt hat; $40 \mathrm{ccm}$ der Chlorammoniumlösung müssen, wenn dieselbe richtig bereitet worden ist, genau $40 \mathrm{ccm}$ Stickstoff (bei $0^{\circ} \mathrm{C}$. und $760 \mathrm{~mm}$

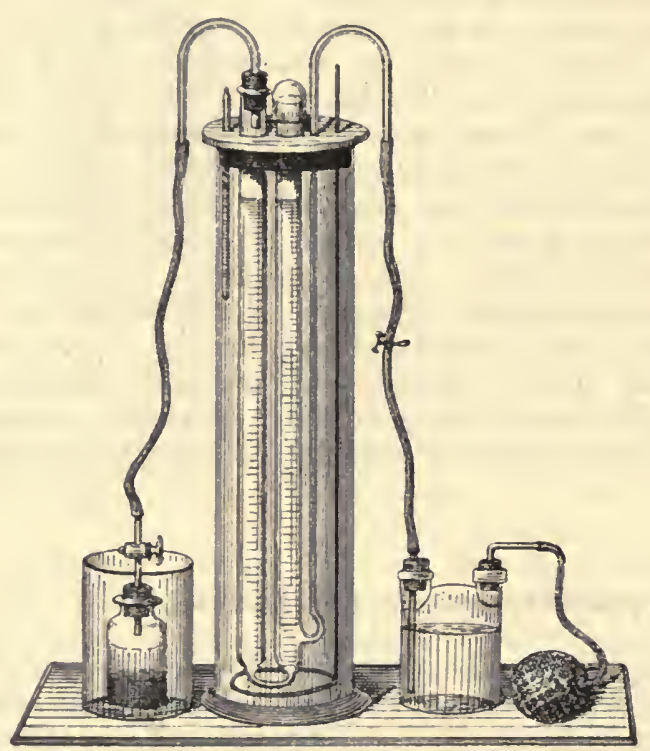

Fig. 91. Azotometer. Barometerstand) geben. Aus den Resultaten der Stickstoffbestimmungen, die man mit Hülfe eines Azotometers (vgl. über diesen Apparat Zeitschr. f. analytische Chemie, Bd. 9, S. 226, und ebendaselbst Bd. 13, S. 101 u. S. 383) und bromirter Natronlauge ausfülırt, lässt sich die rom Boden absorbirte Ammonialimenge leicht berechnell. Die bromirte Lauge (Auflösung von unterbromigsaurem Natron) stellt man durch Auflösen von 100 g Aetznatron in 1250 ccm Wasser und Zusatz von 25 ccm Brom zu der erkalteten Flüssigkeit her. Man wendle für jeden Versuch auf je 10 ccm durch Eindampfen concentrirter Salmiaklösung $50 \mathrm{ccm}$ Lauge an. Für Feststellung der Stickstoffabsorption durch $60 \mathrm{ccm}$ Entwickelungsflüssigkeit $(50 \mathrm{ccm}$ bromirte Lauge und $10 \mathrm{ccm}$ Wasser benutze man die von Dietrich (Zeitschrift f. analytische Chemie, Bd. 5) berechnete Tabelle. Das Azotometer ist für einen Preis von etwa $30 \mathrm{Mk}$. von EhrHard und MetzGer in Darmstadt zu beziehen.

Dieser Apparat, der in Fig. 91 dargestellt ist, besteht zunächst aus einem Entwickelungsgefäss, welches durch eine nicht bis oben hinaufreichende Glaswand - in der Figur nicht sichtbar - in zwei Theile getheilt wird. In die cine Abtheilung bringt man $50 \mathrm{ccm}$ der bromirten Lauge, in die andere $10 \mathrm{ccm}$ Untersuchungsflüssigkeit. Man verschliesst das Entwickelungsgefäss mit einem Kautschukkork, taucht es in ein Kühlgefäss ein, das ebenso, wie der lange Glascylinder, mit Wasser angefüllt worden ist. Durch den Kork des Entwickelungsgefässes geht ein mit Glashahn versehenes Glasrohr hindurch. Dasselbe steht mittelst eines Schlauches mit dem graduirten Glasrohr im Cylinder in Verbindung. Der Glashahn wird herausgezogen und die im Glascylinder eingeschlossenen 
communicirenden Röhren durch Zusammendrücken des mit einem Loch versehenen Kautschukballes unter gleichzeitigen Oeffnen des Quetschhahues mit Wasser angefüllt. Durch Ablassen des Wassers durch den Quetschhahn stellt man den unteren Meniscus des Wasserspiegels genau auf den Nullpunkt der graduirten Röhre ein. Nach Ablauf von 5 Minuten wird der Glashahn wieder eingesetzt, jedoch so gestellt, dass das Entwickelungsgefäss mit dem graduirten Rohr in Communication bleibt. Man controlirt nun nach einiger Zeit, ob der Wasserspiegel in dem letzteren keine Veränderungen erfährt. Sollte dies der Fall sein, so muss der Glashahn nochmals gelockert und die Einstellung des Wassermeniscus auf den Nullpunkt wiederholt werden.

Das Entwickelungsgefäss wird nun aus dem Kühlgefäss herausgenommen. Durch Neigen des Glases lässt man die bromirte Lauge langsam zur Untersuchungsflüssigkeit treten, nachdem man durch den Quetschhahn 20-30 ccm Wasser hat abfliessen lassen. Darauf schliesst man den Glashahn, schüttelt das Entwickelungsgefäss kräftig und öffnet den Hahn wieder, damit der Stickstoff in das graduirte Glasrohr übertreten kann. Diese Operationen werden mehrfach wiederholt. Darauf wird das Entwickelungsgefäss wieder in den Kühlcylinder zurückgestellt und durch den Glashahn mit der graduirten Röhre in Verbindung gebracht. Nach Verlauf von etwa 15 Minuten hat dasselbe die frühere Temperatur wieder angenommen, und man lässt nun durch den Quetschhahn so viel Wasser ab- bezw. zufliessen, dass das Niveau in den beiden communicirenden Röhren gleich hoch steht; endlich liest man noch die entwickelten Cubikcentimeter Stickstoff, die Temperatur des im Cylinder befindlichen Thermometers und den Barometerstand ab. Die Reductionen der Gasvolumina sind leicht unter Benutzung der dem Apparat beigegebenen Tabellen durchzuführen. 
Dritter Abschnitt.

\section{Die Stoffwechselprocesse im vegetabilischen Organismus.}

\section{Das Verhalten der stickstoffhaltigen Verbindungen.}

\section{Die Eiweissstoffe, welche man aus Pflanzentheilen abseheiden kann.}

Wir sehen hier gänzlich von den bereits unter 46 behandelten organisirten plasmatischen Gebilden der Pflanzenzellen ab, sondern wollen nur den Nachweis liefern, dass verschiedene Eiweisskörper im vegetabilischen Organismus angetroffen werden.

Wenn man Weizen- oder Gerstenfrüchte zermahlt und das Pulver (ca. $25 \mathrm{~g}$ ) mit Wasser einige Zeit in Berührung lässt, so kann man durch Filtration eine klare Flüssigkeit gewinnen, in der das Vorhandensein von Albumin nachzuweisen ist. Erhitzt man diese Flüssigkeit, so gerinnt das Eiweiss und scheidet sich als Coagulum ab. Wenn man den aus Früchten (z. B. Weinbeeren) ausgepressten und filtrirten Saft erwärmt, so erhält man ebenfalls ein Eiweisscoagulum.

$\mathrm{Zu}$ der zweiten grossen Gruppe der pflanzlichen Eiweissstoffe. den Pflanzencaseinen, rechnet man das Legumin der Bohnen, Erbsen etc., das Conglutin der Lupinen und das Glutencasein der Gräser. Wir untersuchen das Conglutin etwas genauer. Samen von Lupinus luteus werden auf einer kleinen Handmühle zermahlen, das Pulver (ca. 25 g) wird mit destillirtem Wasser übergossen, und dem Gemisch so viel Kalilauge hinzugefügt, dass die Flïssigkeit bleibend schwach alkalisch reagirt. Die Samenrückstände werden mit Hülfe eines Haarsicbes von der conglutinhaltigen Flüssigkeit getrennt, diese darauf filtrirt und ganz schwach mit Essigsäure angesäuert. Das ausgefällte Conglutin sammelt man auf einem Filter und wäscht den Eiweisskörper mit Wasser aus. Das Conglutin ist unlöslich in Wasser. Suspendirt man aber etwas Conglutin in Wasser und fügt Phosphorsäure, Essigsäure, Citronensäure oder eine Auflösung von phosphorsaurem Natron $\left(\mathrm{Na}_{2} \mathrm{HPO}_{4}\right)$ hinzu, so wird der Eiweissstoff aufgelöst $\left.{ }^{1}\right)$.

1) Genaueres vgl. bei I)ETMER in Wolisy's Forschungen auf dem Gebiete der Agriculturphysik, Bd. 2, Heft 4. Auf WEYL's Untersuchungen über die Pflanzencaseine (vgl. Derser, Lehrbuch der Pflanzenplyysiologie, 1883, S. 157) gehe ich hier nicht näher ein. 
Repräsentanten der dritten Gruppe der pflanzlichen Eiweissstoffe sind zumal in grosser Menge im Weizenmehl vorhanden. Dasselbe wird mit Wasser angerührt und der Teig zwischen den Händen unter einem continuirlichen, dünnen Wasserstrahl ausgeknetet. Es bleibt eine zähe, elastische Masse, der Kleber, zurück, welcher nur noch kleine Mengen Stärke beigemischt sind. Der Kleber, der in kalihaltigem Wasser löslich ist, besteht aus einer Reihe von Eiweissstoffen (Kleberproteinstoffen), namentlich aus Glutenfibrin, Gliadin und Mucedin, welche ihm zum Theil durch Alkohol entzogen werden können ${ }^{1}$ ).

\section{Die makro- und mikrochemisehen Eiweissreactionen.}

Handelt es sich darum, eine der wichtigeren mikrochemischen Eiweissreactionen (die Biuretreaction) kennen zu lernen, so wird eine wässerige Albuminlösung oder Wasser, in welchem etwas Conglutin aus Lupinensamen suspendirt ist, zum Sieden erhitzt, wenig Natronlauge hinzugesetzt und in die heisse Flüssigkeit ein Tropfen FenLINGscher Lösung mit Hülfe eines Glasstabes gebracht. Die Gegenwart von Eiweissstoffen giebt sich durch Violettfärbung der Versuchsflüssigkeit zu erkennen. Zur Darstellung der FEHLING'schen Lösung werden $34,65 \mathrm{~g}$ durch Umkrystallisiren gereinigten Kupfervitriols in $200 \mathrm{ccn}$ Wasser aufgelöst. Diese Lösung vermischt man mit einer Auflösung ron $173 \mathrm{~g}$ weinsauren Natron-Kalis in $480 \mathrm{ccm}$ Natronlauge von 1,14 spec. Gewicht (ca. 10-proc. Natronlauge) und verdünnt die Flüssigkeit bei $15^{\circ} \mathrm{C}$. auf $1000 \mathrm{ccm}$.

In den Zellen des Parenchyms der Cotyledonen von Phaseolus siul bekanntlich neben den Stärkekölnern reichliche Eiweissmengen vorhanden. Schnitte aus den Bohnencotyledonen, welche aber mindestens zwei Zellschichten dick sein müssen, kann man daher bequem benutzen, um die mikrochemischen Eiweissreactionen kennen zu lernen. Einige ccm concentrirter Kupfervitriollösung ${ }^{2}$ ) oder einer Lösung von weinsaurem Kupferoxyd ${ }^{3}$ ) werden in ein Schälchen gebracht. Das weinsaure Kupferoxyd bereitet man, indem man eine Lösung von 5 Thl. Kiupfervitriol mit einer Lösung von 9 Thl. einfach weinsaurem Kali mischt und von dem entstehenden, relativ schwer löslichen schwefelsauren Kali abfiltrirt. Die Schnitte gelangen in eine der Kupfersalzlösungen, werden nach einigen Minuten mit einer Pincette gefasst, durch Eintauchen in reines Wasser oberflächlich abgespült und sofort in Kalilauge gelegt, die zum Sieden erhitzt ist. Der Inhalt der Zellen färbt sich in Folge seines Eiweissgehaltes violett 4 .

Wird ein Schnitt aus den Cotyledonen einer trockenen Erbse auf dem Objecttråger in ein aus 1 Thl. Wasser und 2 Thl. Glycerin bestehendes Gemisch gelegt, mit Deckglas bedeckt, und ein Tropfen Jorllösung an den Deckglasrand gebracht, so färben sich die Stärkekörner alsbald blau, die Aleuronkörner und die Grundmasse, in der letztere eingebettet sind, aber in Folge ihres Eiweissreichthums gęlb.

1) Genaueres rgl. bei Rrtwhadsex, Die Eiweissstoffe der Getreidearten, 1872, S. 28.

2) Vgl. Sachs, Prixgshen's Jahrbücher, Bd. 3, S. 187.

3) Vgl. Pfeffer, Prixgsinem's Jahrbücher, Bd. 8, S. 538.

4) Diese Eiweissreaction ist übrigens, cbenso wic andere, nicht durchaus cindeutig. Bei der Ausführung der Reaction kann man dic Schnitte übrigens auch auf dem Objectträger in cinen Tropfen FEHLIxG'scher Lösung legen, mit Deckglas bedecken und erhitzen, bis sich kleine Blasen bilden. 
In Contact mit Zucker und Schwefelsäure färben sich die Proteillstoffe rotll, und um diese Reaction kemmen. zu lernen, bringen wir $\mathrm{z}$. B. Sclınitte aus den Cotyledonen eines trockenen Bolınensamens auf den Objectträger in einen Tropfen concentrirter Rohrzuckerlösung und lassen vom Deckglasrande aus concentrirte Schwefelsäure auf das Object cinwirken.

Werden Schuitte aus eiweissreichen Pflanzentheilen auf dem Objectträger einige Minuten lang in einen Tropfen kalter rauchender Salpetersäure gelegt und dann mit Ammoniak behandelt, so nehmen sie eine intensir gelbe Farbe an (Xanthoproteinsäurereaction).

Das Millow'sche Reagens, welches man bereitet, indem man Quecksilber in der Kälte mit dem gleichen Gewichtstheil concentrirter rauchender Salpetersäure behandelt und die Flüssigkeit nach erfolgter Auflösung des Metalls mit ihrem gleichen Volumen Wasser verdünnt, färbt die Eiweissstoffe ziegelroth. Es ist zu empfehlen, das Reagens nur im frisch bereiteten Zustande zu benutzen. Wenn man Schnitte aus den Cotyledonen von Pisum in einen Tropfen des eventuell etwas erwärmten Mrllow'schen Reagens einlegt, so wird der Inhalt der Zellen desorganisirt; er färbt sich aber in Folge der Anwesenheit der Eiweissstoffe nach einiger Zeit ziegelroth.

In neuerer Zeit hat man zahlreiche Reagentien (zumal Lösungsmittel) auf die protoplasmatischen Gebilde der Zellen einwirken lassen und auf Grund der erzielten Ergebnisse die Ansicht zu begründen versucht, nach welcher eine ganze Reihe verschiedener eiweissartiger Stoffe im Protoplasma, Zellkern etc. vorhanden sind. In der That ist sicher, dass z. B. das Nuclein, wie wir unter 97 sehen werden, wesentlich andere Eigenschaften als das gewöhnliche Eiweiss besitzt; indessen, abgesehen von diesem und einigen wenigen anderen Resultaten, hat der bezeichnete Weg, obgleich principiell nichts gegen denselben einzuwenden ist, bis jetzt $\mathrm{zu}$ keinen wesentlichen Ergebnissen geführt. So z. B. kann man den meisten diesbezüglichen Angaben von Frank Schwarz (vgl. Cohx's Beiträge zur Biologie d. Pflanzen, Bd. 5, H. 1) von einem streng chemischen Standpunkte aus keinen Werth beimessen.

\section{9.). Allgemeines iiber das Verhalten der Eiweisstoffe in der Pflanze.}

An anderer Stelle sind schon die Aleuronkörner der Samen besprochen worden. Dieselben sind reich an Reserveproteinstoffen, und ebenso wie die Stärkeliörner bei der Keimung der Samen bedeutsame Veränderungen erfahren, unterliegen auch die Aleuronkörner solchen Veränderungen, wenn der Keimungsprocess beginnt. Die Proteinkörner werden nämlich aufgelöst, ihre Substanz wird zur Bildung lebensthätiger, protoplasmatischer Gebilde verbrauclit. Wir haben nur nöthig, um uns von diesem Auflösungsprocess zu überzeugen, Samen von Ricinus communis anzukeimen und dann möglichst zarte Schnitte aus dem Endosperm zu untersuchen. Die Proteinkörner erscheinen nicht mehr als glänzende Gebilde, wie im ruhenden Samen, sondern ihre Hüllmasse ist aufgelöst und mit der Grundmasse zu einer trüben Emulsion vermischt. 
Wenn man Lupinensamen auf einer Handmühle zermahlt und das Pulver mit Wasser behandelt, so kann man sich leicht davon überzeugen, dass in der Lösung reichliche Eiweissmengen vorhanden sind. Man braucht zu der zum Sieden erhitzten Flüssigkeit nur etwas Kali und einen Tropfen Fenlixg'seher Lösung hinzuzufügen. Auf jeden Fall geht bei der Behandlung des Lupinensamenpulvers mit Wasser und ebenso bei der Quellung der unversehrten Samen vor allem Conglutin in Lösung. Dieser Eiweissstoff ist aber unlöslich in reinem Wasser, daher müssen Substanzen zugegen sein, welche die Auflösung des Proteinkörpers vermitteln. Untersucht man die Reaction der Lupinenpulverextracte mit Hülfe von Lackmuspapier, so ergiebt sich, dass dieselbe eine ziemlich intensiv saure ist. Diese saure Reaction wird unter Umständen durch die in manchen Lupinensorten vorhandene Citronensäure bedingt (und die Citronensäure ist ja ein Lösungsmittel für Conglutin); sie kann aber auch auf andere Weise zu Stande kommen. Vertheilt man etwas Conglutin in Wasser, so nimmt die Flüssigkeit höchstens eine ganz schwach saure Reaction an. Fügt man eine Lösung von phosphorsaurem Kali $\mathrm{K}_{2} \mathrm{H} \mathrm{PO}_{4}$, die als solche schwach alkalisch reagirt, hinzu, so löst sich das Conglutin auf, und die Flüssigkeit reagirt viel stärker sauer als zuvor. Der Eiweissstoff entzieht dem $\mathrm{K}_{2} \mathrm{H} \mathrm{PO}_{4}$ Kali, wodurch seine Auflösung zu Stande kommt, während sich andererseits saures phosphorsaures $\mathrm{Kali} \mathrm{K} \mathrm{H}_{2} \mathrm{PO}_{4}$ bildet. Die Samen enthalten nun bekanntlich relativ reichliche $\mathrm{Kali}$ - und Phosphorsäuremengen, und wenn sie mit Wasser in Berührung gelangen, so kann sich nach dem Gesagten offenbar leicht eine Lösung bilden, die stark sauer reagirt und doch erhebliche Quantitäten von Eiweissstoffen aus der Gruppe der Pflanzencaseine enthält ${ }^{1}$ ).

Auf Experimente, welche lehren, dass in Folge des Stoffwechsels bei der Keimung der Samen weder Ammoniak noch freier Stickstoff abgeschieden werden, ist schon an anderer Stelle (vgl. unter 19) hingewiesen worden.

\section{Das Pepsin und die Peptone.}

Die Eiweissstoffe als solche sind nicht im Stande, die Zellhaut oder Membrallen von ähnlicher Beschaffenheit auf osmotischem Wege zu passiren. Es besitzt daher die Thatsache ein physiologisehes Interesse, dass manche Pflanzen Fermente produciren, welché die Eiweisskörper in Peptone, Substanzen, die wenigstens eine geringe Diffusionsfähigkeit besitzen, umzuwandeln vermögen.

Peptonisirend wirkende Fermente (Pepsin) werden von den Drüsenköpfchen der Droseraarten secernirt und sind im Nepenthessecret sowie in manchen Milchsäften (z. B. demjenigen von Carica Papaya) vorhanden ${ }^{2}$ ). Wem kein Papayotin, das übrigens käuflich ist, oder kein pepsinhaltiger Milchsaft zur Verfügung steht, der kann den folgenden lehrreichen Versuch anstellen, um wenigstens den Process der Peptonisirung überhaupt kennen $\mathrm{zu}$ lernen. Eine Pepsiulösung ist nämlich leicht zu erhalten, wemn man frische Stücke der Schleimhaut

1) Vgl. Detarer in Wolisy's Forschungen auf dem Gebiete der Agriculturphysik, Bd. 2, Heft 4.

2) Vgl. zumal Haxseas, Arbeiten des botan. Instituts in Wïrzburg, Bd. 3, H. 2. Ferner vgl. über Pepsingehalt der Keimpflanzen Neumeistra, Zeitsehr. f. Biologie, Bd. 30 . 
des Schweinemagens mit Glycerin extrahirt und filtrirt. Werden nun etwa $500 \mathrm{ccm}$ Wasser, das 0,2 Proc. Salzsäure enthält, in einer Polzellanschale auf dem Wasserbade auf $40^{\circ} \mathrm{C}$. erwärmt, $40 \mathrm{~g}$ Fibrin einige Zeit mit der warmen Flüssigkeit digerirt, bis der Eiweissstoff möglichst aufgequollen ist, so bewirkt Zusatz einiger Tropfen des fermenthaltigen Glycerins in einigen Minuten eine fast vollständige Peptonisirung und Verflüssigung des Fibrins. Das erforderliche Fibrin (aus Ochsenblut) ist vom Fleischer $\mathrm{zu}$ beziehen und kann in Glycerin aufbewahrt werden. Will man den Eiweissstoff zu einem Verdauungsversuch benutzen, so wäscht man ihn sorgfältig mit Wasser aus und bringt ihn dann in die verdünnte, warme Salzsäure. Benutzt man Nepenthessecret oder Milchsäfte als pepsinhaltige Flüssigkeiten, so ist wenigstens in manchen Fällen dafür Sorge zul tragen, dass die verdïnnte Salzsäure, in der man das Fibrin aufgequollen hat, längere Zeit auf einer Temperatur von $40^{\circ} \mathrm{C}$. erhalten bleibt, denin die Peptonisirung geht in diesen Fällen oft nicht so schnell vor sich. Uebrigens ist in manchen Fällen der Pepsingehalt von Milchsäften sehr schmell zu constatiren, und ich beobachtete dies z. B. bei Ausführung des folgenden Experiments, das leicht wiederholt werden kann. In ein Probirglas wurden einige $\mathrm{ccm}$ sehr verdünnter Salzsäure gebracht, wenige Stückchen Fibrin hinzugefügt und das Probirglas nun in Wasser eingetaucht, das auf $40^{\circ} \mathrm{C}$. erwärmt war. Nach erfolgtem Aufquellen des Fibrins wurden der Flüssigkeit einige Tropfen Milchsaft hinzugesetzt, der aus den Stielen im unreifen Zustande abgeschnittener Feigenfrüchte ausgeflossen war. Die Peptonisirung und Verflüssigung des Fibrins trat in wenigen Augenblicken ein.

Wenn Pepsin auf Eiweissstoffe einwirkt, so machen sich complicirte chemische Processe geltend. Als Endproducte sind verschiedene Peptone anzusehen, die aber durch die Biuretreaction leicht als solche erkannt werden können. Wenn man eine kleine Quantität einer peptonhaltigen Flüssigkeit erwårmt, mit Kalilauge neutralisirt und nun Fenlixg'sche Lösung hinzufügt, so nimmt die Mischung keine violette Färbung, wie bei Gegenwart von Eiweissstoffen, sondern eine purpurrothe Färbung an.

\section{9\%. Das Nuclein.}

Während das Protoplasma besonders reich an Eiweissstoffen ist, muss das Nuclein als ein charakteristischer Bestandtheil des Zellkerns angesehen werden. Von den Proteinstoffen unterscheidet sich das stickstoffhaltige Nuclein durch seinen Phosphorgehalt sowie sein eigenthümliches Verhalten zu Reagentien. In letzterer Beziehung ist namentlich wichtig, dass das Nuclein nicht von pepsinhaltigen Flüssigkeiten angegriffen wird. Um dies zu beobachten, bringt man ein Stückchen der Epidermis von der Blattunterseite einer Tradescantie (ich benutzte mit vorzüglichem Erfolg Tradescantia virginica) auf den Objectträger und fügt eine pepsinhaltige Flüssigkeit (Mischung von 1 Volumentheil Glycerinextract aus Schweinemagen mit 3 Volumentheilen 0,2-proc. Salzsäure) hinzu. Die Untersuchung lehrt, dass das Protoplasma sich contrahirt liat, während die Kerne in den Zellen bald völlig homogen werden. Die Kerne nehmen dann an Volumen zu und stellen endlich gelbliche, stark lichtbrechende Gebilde dar, 
die keine weitere Veränderung erfahren. Wenn die homogen gewordenen Kerne beginmen, sich zu vergrössern, wird das contrahirte Protoplasma an einer oder an mehreren Stellen blasig aufgetrieben. Schliesslich platzt die Blase, und es bleiben nur unbedeutende Protoplasmareste übrig, die den Kern umgeben. Verdünnte Salzsäure verändert die mit der künstlichen Verdauungsflüssigkeit behandelten Kerne nicht, während sie sich in verdïnnter Sodalösung sofort auflösen ${ }^{1}$ ).

\section{Der mikrochemische Nachweis des Asparagins.}

Ich habe mit Nachdruck die Ansicht zur Geltung zu bringen gesucht ${ }^{2}$ ), dass die lebendigen Eiweissmolekïle des Protoplasmas, die physiologischen Elemente, wie ich dieselben nenne, unter allen Umständen und in jeder in Lebensthätigkeit begriffenen Zelle durch Dissociationsprocesse in stickstoffhaltige und stickstofffreie Verbindungen zerfallen (Dissociationshypothese). Diese letzteren werden verathmet und liefern das für den Wachsthumsprocess der Zellen erforderliche Material etc., während die ersteren sich bald in melır oder minder grossen Quantitäten in den Zellen anhäufen oder unter Beihülfe von stickstofffreien Körpern zu Proteinstoffen regenerirt werden. Zudem besitzen die stickstoffhaltigen Dissociationsproducte der physio-

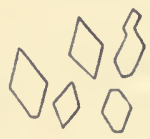

Fix. 92. Isparaginkrystalle. (Nach ZincmerMANN.) logischen Elemente des Protoplasmas (Asparagin, Glutamin, Leucin, Tyrosin, Allantoin) insofern grosse Bedeutung, als sie bei der Stoffwanderung im vegetabilischen Organismus eine wichtige Rolle spielen.

Unter allen stickstoffhaltigen Zersetzungsproducten der Eiweissstoffe scheint das Asparagin (Amidobernsteinsäureamid) die hervorragendste Bedeutung $\mathrm{zu}$ beanspruchen. Wir widmen demselben aus diesem Grunde unsere specielle Aufmerksamkeit und wollen zunächst sehen, in welcher Weise es gelingt, seine Gegenwart auf mikrochemischem Wege in den Pflanzenzellen zu constatiren.

Versetzen wir eine concentrirte wässerige Asparaginlösung mit absolutem Alkolhol, so scheidet sich das Asparagin ab, da es fast unlöslich in Alkohol ist. Ebenso kann man das Asparagin, welches im Zellsaft gelöst ist, durch Alkohol niederschlagen, und da die sich bildenden, dem rhombischen System angehörenden Krystalle, zumal diejenigen, welche in Form rhombischer Tafeln mit einem stumpfen Winkel von $129^{\circ} 18^{\prime}$ auftreten, eine beträclitliche Grösse sowie charakteristische Form besitzen, so ist es in der angedeuteten Weise möglich, die Gegenwart des Säureamids in den Zellen auf mikrochemischem Wege festzustellen ${ }^{3}$ ). (Vgl. Fig. 92.)

Die Schnitte, welche dicker sein nuïssen als eine Zellenschicht, damit nicht alle Zellen geöffnet sind, legt man in ein Uhrgläschen,

1) Vgl. Zacharias, Botan. Zeitung, 1881, S. 169.

2) Vgl. Detmer, Vergleichende Physiologie d. Keimungsprocesses der Samen, 1850, PrLvgsielu's Jahrbuicher, Bd. 12, Woldexy's Forschungen auf d. Gebiete d. Agrieulturphysik, Bd. 5, und Lchrbuch d. Pflanzenphysiologic, 1883.

3) Vgl. Pferfer, Prixgsheln's Jahrbücher, Bd. 8, S. 533, und Borodix, Botan. Zcitung, 1878, S. 804. 
in dem sich absoluter Alkohol befindet, schwenkt sie schnell in der Flüssigkeit hin und her und untersucht sie. Ist nur sehr wenig Asparagin in den Zellen vorhanden, so thut man am besten, die Schnitte auf dem Objectträger mit absolutem Alkohol zu betupfen, das Deckglas aufzulegen, um das Präparat nach dem Trocknen der mikroskopischen Beobachtung zu unterziehen.

Um jede Verwechselung der ausgeschiedenen Asparaginkrystalle unit anderen Körpern, z. B. Salpeterkrystallen, zu vermeiden, behandelt man die Sclmitte nachträglich mit einer völlig gesättigten Asparaginlösung. Bestehen die durch Alkohol erzeugten Krystalle wirklich aus Asparagin, so lösen sie sich nun nicht auf. Andere Krystalle werden aber von der Asparaginlösung aufgenommen.

\section{Die quantitative Bestimmung des Gesammtstickstoffs und des Stickstoffs der Proteinstoffe und der Såureamide in Keimpflanzen.}

Aus einem grossen Vorrath der Samen von Lupinus luteus werden etwa :300 Stück, die sehr normal und gleichmässig ausgebildet sind, ausgesucht. Man stellt das mittlere Gewicht eines Samenindividuums fest und ermittelt den Trockensubstanzgehalt der Untersuchungsobjecte (vgl. unter 1). Die Samen gelangen nun zum Quellen 24 Stunden lang mit Wasser in Berührung. Jetzt durehfeuchtet man Sägespäne völlig mit Wasser und füllt grosse Blumentöpfe oder Zinkblechkästen mit denselben an, indem man die Späne zwischen den Händen zerreibt und in die Töpfe oder Kästen einfallen lässt, so dass ein ganz lockeres Keimbett entstelit. Die Samen werden in dasselbe eingelegt, mit feuchten Sägespänen bedeckt und bei etwa $20^{\circ} \mathrm{C}$. bei Lichtabschluss sich selbst überlassen. Man hat nur für Ersatz des verdunstenden Wassers Sorge zu tragen.

Nach 3,5 oder 7 Tagen wählt man diejenigen Keimlinge aus, welche sich sehr gleichförmig entwickelt liaben. Sie werden gesäubert, in einer Reibschale zerquetscht, zunächst unter häufigerem Umrülıren des Breies auf dem Wasserbade, dann in Trockensehrank bei 50 bis $60^{\circ} \mathrm{C}$. getrocknet. Das Untersuchungsmaterial bleibt alsdann, lose bedeckt, 24 Stunden lang an der Luft stehen; es wird gewogen, um darauf sogleich Proben zu Trockensubstanzbestimmungen zu entnehmen. Man kennt nun das Trockengewicht der geernteten Anzahl der Keimlinge. Das Trockengewicht der entsprechenden Anzahl von Samen ist ebenfalls bekannt, und somit ist man im Stande, die Resultate der folgenden Untersuchungen auf siclı entsprechende Mengen von Samenund Keimpflanzentrockensubstanz zu beziehen.

Zur Bestimmung des Gesammtstickstoffs werden 1-2 g Trockensubstanz der Samen und Keimlinge in gut gepulvertem Zustande nach KJeldahl untersucht. (Vergl. Methode in Köxig's Untersuchung landwirthschl. wichtiger Stoffe, 1891, S. 150.)

Den Stickstoff der Eiweissstoffe bestimmt man nach StuTzER's Methode. (Vergl. Kösig, S. 212.)

Subtrahirt man die Menge des Stickstoffs der Eiweisskörper von der Quantität des Gesammtstickstoffs, so erhält man einen Werth, durch den die Menge des Stickstoffs der nicht eiweissartigen Verbindungen zum Ausdruck gelangt. Die Samen enthalten nur sehr kleine Quantitäten 
solcher Stoffe, währond die Keimpflanzen, zumal weiter entwickelte, reich an Amidosäuren und Säureamiden etc. sind.

Will man speciell den Gehalt der Untersuchungsobjecte an Säureamiden (in den Lupinenkeimlingen ist fast nur von solchen Körperr Asparagin vorhanden) feststellen, so werden etwa $8 \mathrm{~g}$ Trockensubstanz zweimal mit $40 \mathrm{ccm}$ kaltem Wasser je 1 Stundo lang extrahirt. Nach dem Filtrirel unter Benutzung einer Saugpumpe wird der Rückstand einmal mit $50 \mathrm{ccm}$ Wasser ausgekocht, um alle Filtrate, sowie die zum Auswaschen des Rückstandes benutzte Flüssigkeit zu vereinigen ${ }^{1}$ ). Man kocht die Flüssigkeit nun zur Ausfällung gelöster Eiweissstoffe schnell auf, filtrirt und bringt das Filtrat auf $200 \mathrm{ccm}$.

$100 \mathrm{ccm}$ werden nach Zusatz von $10 \mathrm{ccm}$ Salzsäure $1-1 / 2$ Stunde lang unter Ersatz des verdunsteten Wassers gekocht, wodurch das Asparagin sich in Asparaginsïure und Ammoniak spaltet. Den Stickstoff des Ammoniaks bestimmt man mit Hülfe bromirter Lauge (bereitet durch Auflösen von $100 \mathrm{~g}$ Aetznatron in $1250 \mathrm{ccm}$ Wasser und Eintragen von $25 \mathrm{ccm}$ Brom in die völlig erkaltete Lösung) im Azotometer (vgl. unter 92). Es kommen dabei je $10 \mathrm{ccm}$ Untersuchungsflüssigkeit zur Verwendung. Das gefundene Stickstoffvolumen wird auf $0^{\circ} \mathrm{C}$. und $760 \mathrm{~mm}$ Barometerstand reducirt, und es ist dann leicht, die Gewichtsmenge des Stickstoffs und daraus die Quantität des vorhandenen wasserfreien Asparagins $\left(\mathrm{C}_{4} \mathrm{H}_{8} \mathrm{O}_{3} \mathrm{~N}_{2}\right)$ zu berechnen. Manchmal enthalten Keimpflanzenextracte kleine Mengen eines Körpers, der schon ohne vorheriges Kochen mit Salzsäure Stickstoff bei der Behandlung mit bromirter Lauge ausgiebt. Es ist daher erforderlich, $10 \mathrm{ccm}$ des Reimpflanzenauszugs direct im Azotometer mit der Lauge zu schütteln und die eventuell gefundene Stickstoffquantität von derjenigen abzuziehen, die man nach dem Kochen des Extractes mit $\mathrm{HCl}$ findet ${ }^{2}$ ). Den Stickstoff der Säureamide kann man auf die angegebene Weise recht genau in seiner Menge feststellen. Eine Berechnung dieser Stickstoffquantitäten auf Asparagin ist nur dann einigermaassen zulässig, wenn die Untersuchungsobjecte, wie es allerdings bei den Lupinen der Fall ist, neben dem Asparagin nur noch geringe Mengen anderer Aride enthalten.

\section{Das Verhalten des Asparagins in den Pflanzen.}

Handelt es sich darum, Aufklärung über die physiologische Function des Asparagins zu gewinnen, so bieten sich uns in erster Linie die Keimpflanzen von Lupinus luteus als ausgezeiclnete Untersuchungsobjecte lar. Bei der Keimung der Lupine streckt sich das hypocotyle Glied sehr bedeutend, die Cotyledonen werden über die Erde gehoben, streifen die Samenschale alsbald ab und fungiren als Assimilationsorgane. Alsbald streckt sich dann auch das epicotyle Stengelglied, und die ersten Laubblïtter entfalten sich. Das hypocotyle Glied hat ein mächtiges Rindenparenchym entwickelt, welches den Gefässbiundelkreis sowie das Mark umschliesst. In den Stielen der Cotyledonen sind die Gefässbündel halbmondförmig angeordnet. Das Grundgewebe der Cotyledonen ist nur in der peripherischen Region

1) Sollte das Filtriren der gekochten Flüssigkeit Schwierigkeiten machen, so leitet man in dieselbe etwa $1 / 2$ Stunde lang cinen kräftigen Strom gewaschener Kohlensäure ein. Das Filtriren geht dann sehr sehnell vor sich.

2) Vgl. SAcirsse, Die Chemie und Physiologie d. Farbstoffe ctc., 1877, S. 257, und Detmer, Plyysiol.-ehemische Untersuchungen über die Keimung etc., 1875, S. 74. 
lerselben reich an Chlorophyllkörnern. Die Vertheilung des Asparagins in der sich unter normalen Verhältnissen, also bei Yichtzutritt, entwickelnden Keimpflanze von Lupinus gestaltet sich nun nach den mikrochemischen Untersuchungen PFEFFER's, von denen ich eine ganze Reihe wiederholt habe, wie folgt: Die Samen sind asparaginfrei. Hat die Wurzel 12 und das hypocotyle Glied $2-4 \mathrm{~mm}$ Länge erreicht, so ist in diesen Organen sowie im unteren Theile der Samenlappenstiele wenig Asparagin vorhanden. Keimpflanzen von $30-40 \mathrm{~mm}$ Wurzellänge, deren Cotyledonen noch nicht wesentlich über die Erde hervorgehoben worden sind, führen in der Wurzel Asparagin; dasselbe fehlt aber der Wurzelspitze. In den Rindenzellen des hypocotylen Gliedes sowie im unteren Theile der Stiele der Cotyledonen ist Asparagin vorhanden. Der Lamina der Cotyledonen fehlt aber das Asparagin noch. Ist die Keimung so weit fortgeschritten, dass sich die Cotyledonen ausbreiten, dann ist in diesen Asparagin vorhanden. In den Samenlappenstielen, zumal aber im hypocotylen Glied finden sich jetzt sehr reichliche Asparaginmengen. Das Säureamid kommt aber nur in den Zellen des Parenchyms dieser Organe vor; den Elementen der Gefässbündel fehlt dasselbe, wie immer, vollkommen. Wenn sich das epicotyle Stengelglied streckt, so ist auch in diesem Asparagin nachzuweisen, während die übrigen Organe der Keimpflanze, zumal das hypocotyle Glied, allmählich asparaginärmer werden. Bei weiter fortschreitender Entwickelung der Pflanzen unter normalen Vegetationsbedingungen verschwindet das Asparagin gänzlich aus allen Organen, weil jetzt in Folge lebhafter Assimilation so erhebliche Mengen stickstofffreier organischer Körper erzeugt werden, dass die durch Dissociation gebildeten sickstoffreichen Zersetzungsproducte der physiologischen 'Elemente sofort ihrer Gesammtmasse nach zu Eiweisstoffen regenerirt werden können. Beachtung verdient auch noch die Thatsache, dass in dem Maasse, wie die Asparaginbildung bei der Keimung Fortschritte macht, die Menge der Reserveproteinstoffe in den Reservestoffbehältern abnimmt. Untersucht man z. B. die Cotyledonen von Lupinus, wenn die Streckung des epicotylen Gliedes beginnt, so erscheint der Zellinhalt bereits sehr aufgeklärt, und die Behandlung der Schnitte mit Jod lehrt, dass der Eiweissgehalt der Zellen kein übermässig grosser mehr sein kann ${ }^{1}$ ).

Um den bestimmten Nachweis dafür zu liefern, dass die Rückbildung von Eiweissstoffen aus Asparagin nur unter Vermittelung von stickstofffreien Körpern erfolgen kann, füllen wir zwei Blumentöpfe mit Sand an, den wir mit Nährstofflösung getränkt haben, und legen einige Samen von Lupinus luteus in den Boden. Die Pflanzen des einen Topfes entwickeln sich unter ganz gewöhnlichen Bedingungen vor einem Fenster. Der andere Topf wird in dem unter 16 beschriebenen Apparat ebenfalls dem Licht ausgesetzt, aber die Untersuchungsobjecte bilden sich in kohlensäurefreier Luft aus. Sie können somit nicht assimiliren, und daher hört ihr Wachsthum, wenn sich das zweite Laubblatt entfaltet hat, auf. Jetzt und auch noch später bis zu ihrem schliesslich erfolgenden Absterben sind reichliche Asparaginmengen in den Organen der Keimlinge, zumal im hypocotylen Gliede, nachzuweisen, weil keine Kohlehydrate gebildet werden, welche die Eiweissregeneration vermitteln könnten. Die sich unter normalen Verhältnissen ausbildenden Lupinen-

1) Vgl. Pfeffer, Prixgsuein's Jahrbücher f. wissenschaftl. Botanik, Bd. \&. 
pflanzen, welche fort and fort kräftig weiter wachsen, enthalten hingegen zu derselben Zeit, während welcher die bei Kohlensäureausschluss entwickelten Untersuchungsobjecte sehr asparaginreich sind, kein Asparagin mehr oder höchstens kleine Quantitäten desselben ${ }^{1}$ ).

Werden Keimlinge von Lupinus bei Lichtabschluss zur Entwickelung gebracht, so sind auch noch die nach Verlauf längerer Zeit absterbenden Untersuchungsobjecte asparaginreich, weil es unter den bezeichneten Umständen an stickstofffreiem Material, das für die Eiweissregeneration verwendet werden könnte, fehlt. Alles dies ist durch mikrochemische Untersuchung (vergl. unter 98) oder durch Analyse (vergl. unter 99) festzustellen.

\section{Der Athmungsprocess der Pflanzen.}

\section{Experimente zur allgemeinen Orientirung iiber die Pflanzenathmung.}

Die bei genauen quantitativen Untersuchungen über den Athmungsprocess der Pflanzen in Anwendung zu bringenden Methoden sollen erst in den folgenden Abschnitten Erwähnung finden; hier handelt es sich zunächst nur um Demonstrationsversuche, welche uns namentlich über die verschiedenen Formen der Pflanzenathmung orientiren werden.

Wir stellen zwei weithalsige Glaseylinder auf. In den einen $\mathrm{Cy}$ linder bringen wir grössere Mengen von Blüthen oder Keimptlanzen (Weizen, Erbsen, Bohnen) und verschliessen beide Gefässe mit Glasstöpseln oder Korken. In jeden Cylinder führen wir nach Verlauf einiger Stunden ein an einem Draht befestigtes brennendes Licht ein. Dasselbe wird in dem mit Pflanzen beschickten Cylinder erlöschen; in dem anderen brennt es ruhig weiter. Die athmenden Pflanzen haben den Sauerstoff der Luft im Apparat verbraucht und dafür Kohlensäure erzeugt, welche den Verbrennungsprocess nicht zu unterhalten im Stande ist.

Diesen einfaclien Vorlesungsversuch verbinden wir mit einem ferneren, der die Kohlensäureproduction in Folge der normalen Athmung direet nachweist. Wir stellen den in Fig. 93 abgebildeten Apparat zusammen. Die mit Wasser angefülte Flasehe von etwa 101 Inhalt dient als Aspirator. Der Kork, welcher die Mündung der Flasche verschliesst, ist doppelt durchlocht. In der einen Bohrung steekt das Rohr $G$, welches mit dem mit einem Glashahn versehenen Glasrohr $R$ in Verbindung steht. Vor Beginn des Versuchs werden die Röhren $G$ und $R$ mit Wasser angefüllt. Das Rohr $G^{\prime}$ ist mit den Apparaten $a, b, c$ und $d$ in Verbindung gesetzt. Die Cylinder $a$ und $c$ enthalten klares Barytwasser. Man übergiesst Barythydrat in einer grösseren Flasche mit destillirtem Wasser, schüttelt wiederholt tüchtig um, lässt absetzen und bringt eine hinreichende Menge der Flüssigkeit mit Hülfe einer gut ausgetrockneten Pipette in die völlig trockenen Cylinder $a$ und $c$. In dem U-förmigen Rohr $b$ befinden

1) Vgl. Pfefrer, Botan. Zeitung, 1874, S. 249. 


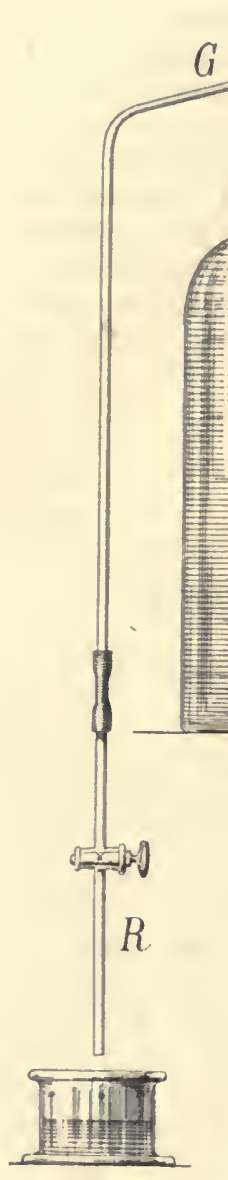

sich die athmenden Pflanzentheile (Blüthen oder Keimlinge). Der untere Theil des Gefässes $d$ entlä̈lt Kálilauge, der obere Aetzkalistücke. Oeffnen wir sogleich nach Zusammenstellung des Apparates den Glashahn der Röhre $R$ wenig, so fliesst Wasser aus dem Rohr $R$ ab und den ganzen Apparat

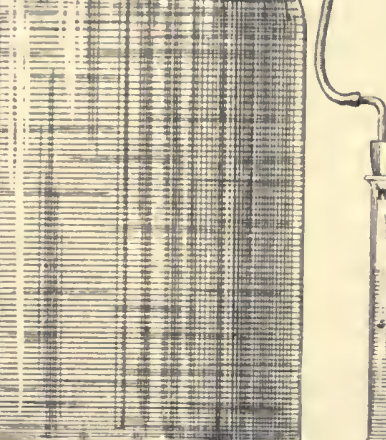

.

Fig. 93. Apparat zur Demonstration der Kohlensäureproduction bei der Athmung der Pflanzen.

passirt ein Luftstrom. Die Luft wird in $d$ von Kohlensäure befreit. Das Barytwasser in $c$ bleibt daher auch klar. In $a$ entsteht dagegen sehr schnell eine Trübung des Barytwassers resp. ein Niederschlag von kohlensaurem Baryt, wodurch eben die Kohlensäureproduction der Untersuchungsobjecte nachgewiesen wird.

Zur Demonstration des Sauerstoffverbrauchs bei normaler Athmung dient der folgende Apparat (vgl. Fig. 94). In einem Holzgestell $H$ hängen zwei röhrenartige Gefässe, die am unteren Ende in Wasser eintauchen, das sich in den Gläsern $G$ und $G^{\prime}$ befindet. Der dünnere, etwa $45 \mathrm{~cm}$ lange und $15 \mathrm{~mm}$ weite Theil dieser Gefässe $A$ und $B$ ist bis auf $0,2 \mathrm{ccm}$ genau calibrirt, er erweitert sich oben in den $30 \mathrm{~cm}$ langen und $40 \mathrm{~mm}$ weiten Theil $W$ und $W$ der Apparate. In den sorgfältig ausg̀ewählten, sehr gut schliessenden durchbohrten Kautschukkörken stecken die mit Glashähnen versehenen Glasröhren $h$ und $h^{1}$ ). Das kleine recht weite Gläschen des einen Apparates hängt an einem Draht und enthält völlig klare concentrirte Kalilauge. Nun werden z. B. in jeden Apparat 25 Erbsenkeinlinge, die 3 Tage alt sind und sich bei $15^{\circ} \mathrm{C}$. entwickelten gebracht. Sie finden auf feuchter Glaswolle ihren Platz im oberen, erweiterten Theil der Vorrichtungen. Die Apparate stellt man in einem Raume von recht constanter Temperatur auf, saugt etwas Wasser in den Röhren $A$ und $B$ empor, schliesst die wohl eingefetteten Hähne und wartet etwa

1) An Stelle der Kautschukkörke können auch eingeschliffene Glasstopfen Verwendung finden. 
eine halbe Stunde lang, bevor man den Stand des Wassers in den Rölıren $A$ und $B$ abliest. Man notire ferner die an Thermometer $T$ abgelesene Temperatur. Bei einem von mir mit 25 Erbsenkeimlingen bei $15^{\circ} \mathrm{C}$. angestellten Experiment stieg das Wasser im mit Kalilauge beschickten Apparat in Laufe von 21 Stunden von 22,2 bis 60,4 ccm. Im Apparat ohne Kalilauge verändert sich der Wasserstand bei nahezu constant bleibender Temperatur dagegen nur wenig, weil die in Athmungsprocess erzeugte Kohlensäure der Hauptmasse nach an Stelle des verbrauchten Sauerstoffs tritt. Bei Kaligegenwart muss aber las Wasser emporsteigen, denn die von den Pflanzen producirte Kohlensäure wird schnell absorbirt und ersetzt den consumirten Sauerstoff nicht.

Auch für den folgenden Demonstrationsversuch genügt es, Wasser und nicht Quecksilber als Sperrflüssigkeit $\mathrm{zu}$ verwenden. Beide Apparate werden olne Benutzung von Kalilauge mit Pflanzenmaterial beschickt. Als solehes finden $5 \mathrm{~g}$ Erbsensamen oder $5 \mathrm{~g}$ Weizenkörner und $5 \mathrm{~g}$ Hanfkörner Verwendung. Je 5 g des Beobachtungsmaterials werden abgewogen, und nach dem Anquellen führt man in einen unserer Apparate die stärkereichen, in den anderen die fettreichen Untersuchungsobjecte ein. Beobachtet man den Wasserstand in den Röhren $A$ und $B$, während die Apparate in einem Raum stelien, in welchem bedeutendere Temperaturschwankungen nicht stattfinden, so findet man im Laufe von $1-2$ Tagen, dass derselbe in Apparat, der mit stärkereichen Samen beschickt worden ist, keine erhebliche Veränderung erführt. Im anderen Apparat erhebt sich die Fliissigkeit aber beträchtlich. Die fettreichen Körner unterhalten freilich, ebenso wie die stärkereichen, normale Athmung; zugleich bringen die ersteren bei der Kieimung aber noch jene Athmungsform zur Geltung, welche ich als Vinculationsathmung bezeichnet habe. Das Wesen derselben besteht in einer Sauerstoffabsorption ohne entsprechende Kohlensäurebildung, und der gebundene Sauerstoff findet zur Ueberführung des Fettes in sauerstoffreichere Körper

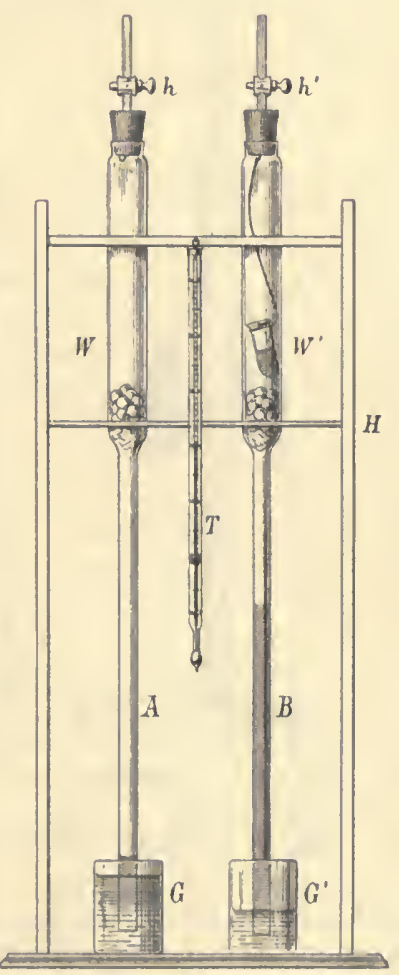

Fig. 94. Apparat für Experimente über Pflanzenathunung. (Kohlehydrate) Verwendung.

Endlich füllen wir noch den oberen Theil eines unserer Apparate völlig mit Blüthen (Rosa oder Dahlia etc.) oder mit Keimlingen von Vicia Faba an. Wir saugen das Wasser bis zu bedeutender Höhe empor, schliessen den Glashahn und lassen die Vorrichtung ruhig stehen. Die Untersuchungsobjecte unterhalten zunächst nolmale Athmung. Bald aber ist der Sauerstoff der Luft im Apparat verbraucht, und nun macht sich selbst bei etwas sinkender Temperatur 
ein Fallen der Wassersäule geltend. Die Pflanzentheile produciren in Folge intramolekularer oder innerer Athmung im sauerstofffreien Raum Kohlensäure. Dadureh wird das Gasvolumen im Apparat vergrössert und das Wasser im Rohr hinabgedrückt.

Um die Production von Kohlensäure (Athmung) bei der Gährung zu constatiren, stellen wir den in Fig. 95 abgebildeten Apparat zusammen. Wir bringen in den Kolben $A 200 \mathrm{ccm}$ Pasteur'sche Nährlösung (vgl. unter 18) und fügen zu derselben etwa 5 g Presshefe. Alsbald beginnt die Gährung. Die entweichende Kohlensäure kann durch das in dem Gefässe $B$ vorhandene klare Kalk- oder Barytwasser als solche nachgewiesen werden. Gährung und reichliche

Fig. 95.

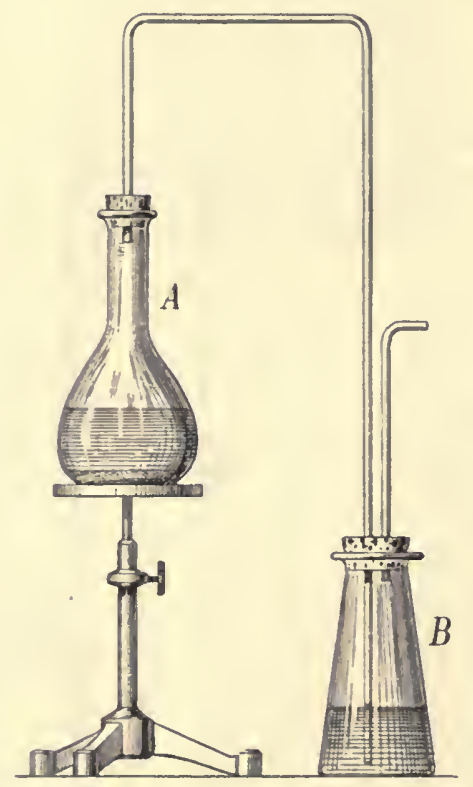

Fig. 96.

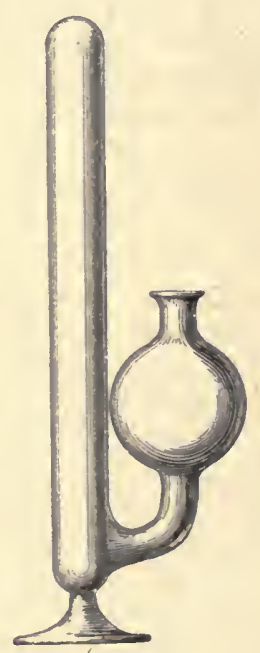
Gährung.

Fig. 95. Apparat zur Demonstration der Kohlensäureproduction bei der

Fig. 96. Kuihne'sches Guilırungsgefiiss.

Kohlensäureentwickelung findet nicht statt, wenn man die Hefe im Kolben $A$ mit einer Flüssigkeit in Berührung bringt, welche ebenso wie die PASTEUR'sche Nährlösung zusammengesetzt ist, der aber der Zucker fehlt und die an Stelle des weinsauren, salpetersaures Ammoniak enthält.

Auch unter Benutzung der KÜHNE'scheı Gährungsgefässe ') (Fig. 96) kann man sich leicht von der Kohlensäurebildung bei der Gährung überzeugen. Das Rohr des Apparates wird völlig mit PASTEUR'seher Nährlösung angefüllt, während die Kugel frei davon bleibt. Wir bringen nun ein Hefekügelehen in die Flüssigkeit. In Folge der alsbald beginnenden Kohlensäureentwickelung wird die Nährlösung

1) Diese Apparate stellt jeder Glasbläser her. 
aus dem Rohr in die Kugel des Apparates gedrängt. Wenn man dann ein Stückchen Aetzkali in denselben einführt, so steigt die Flüssigkeit, da eine Absorption der Kohlensäure erfolgt, wieder in das Rohr zurück.

Wird ein langer Glascylinder bis zur Hälfte mit PASTEuR'scher Nährlösung beschickt, derselben Presshefe zugesetzt, und das Gefäss nun nicht völlig luftdicht verschlossen, so kann man die alsbald gebildete Kohlensäure einfach nachweisen, indem unan in den geöffneten Cylinder ein brennendes Licht einführt. Die Flamme wird erlöschen ${ }^{1}$ ).

\section{Methode zur Bestimmung der bei intramolekularer und normaler Athmung der Pflanzen producirten Kohlensïure.}

In Fig. 97 ist ein Apparat abgebildet, der bequem bei Untersuchungen iiber Kohlensäureproduction in Folge intramolekularer Athmung der Pflanzen Verwendung finden kann. Wir wollen hier zunäclist diesen Apparat näher kennen lernen. Dic bei Experimenten iiber normale Athmung zu benutzende Vorrichtung ist eine weit einfachere ${ }^{2}$ ).

Bei der Ausführung der Untersuchungen handelt es sich darum, ïber das Beobachtungsmaterial einen kohlensäurefreien Wasserstoffstrom hinzuleiten und die von den Pflanzen bei Sauerstoffausschluss producirte Kohlensäure ihrer Quantität nach festzustellen. Dic Geschwindigkeit des Wasserstoffstromes kam leicht mit Hülfe des Aspirators $A$ regulirt werden. Man kann ja dic in den Cylinder $M a b$ fliessende Wassermenge z. B. von $10 \mathrm{zu} 10$ Minuten messen und den Glashahn $H^{\mathrm{r}}$ so reguliren; dass z. B. pro Stunde $3 \mathrm{l}$ Wasser abHiessen. Behufs genauer Einstellung ist der Glashahn $H^{\prime \prime r}$ mit einer lang ausgezogenen Spitze versehen, die vor dem Gradbogen $G b$ spielt. Wenn das Wasserniveau im mindestens $15-201$ Wasser fassenden Aspirator $A$ erheblich sinkt und dadurch eine Verminderung der Stromgeschwindigkeit z.u Stande kommt, so muss der Hahn Ḧ liäufiger verstellt werden. Es ist daher vortheilhaft, den Aspirator stets möglichst mit Wasser angefüllt zu benutzen, zumal die Füllung durch Verbindung des Abflussrohres (an der Stelle i) mit der Wasserleitung mittelst eines Gummischlauches sehr bequem und schmell vor jerlem Versuch bewirkt werden kann. Auch die Benutzung recht grosser Aspiratorgefässe, z. B. grosser Säureballons, ist sehr empfehlenswerth.

Das Wasserstoffgas wird im grossen Krpp'schen Apparat $W$ aus cliemisch reinem, arsenfreiem Zink und arsenfreier Salzsäure (1 Thl.Wasser und 1 Thl. Säure) entwickelt. Um sicher jede Spur für die Pflanzen schäd-

1) Meine Ansichten über das Wesen der normalen und intramolekularen Athnunng sowie der Gährung labe ich in meinem Iehrbuch der Pflanzenphysiologie, Breslau 18S3, ausgesprochen. Vergl. ferner Detmer, Prux(ishlin's Jahrbücher f. wissenschl Botanik, Bd. 12, und Berichte d. Deutschen botan. Gesellschaft, Bd. 10, S. 433 .

2) Ich bespreche hier die Methorlen, welche von mir und menen Schülern mit bestem Erfolg benutzt wurden. Vgl. Detmer, Physiolog. Untersuclunngen ïber die Keimung, Jena 1875, und Sitzungsber. d. Jenaisehen Gesellschaft f. Medicin u. Naturwiss., 1881; Cr.AUsex, Landwirthschl. .Jahrb., 1890, Bd, 19; A Mm, PrixgsHEIM's Jahrb. f. wiss. Botanik, 13d. 25; DetsMer, Botan. Zeitung, 1888, und Berichte der Deutschen botan. Gesellschaft, Bd. 8, 10 und 11; Znegris bets, Privgshein's Jahrb., Bd. 25; AEREBos, Woldxy's Forschungen auf den Gebiet der Agriculturphysik, Bd. 16. 
licher Beimengungen zu beseitigen, passirt das Gas die Waschflasehe Ue, welehe eine Lösung von Kaliumpermanganat enthält, und das mit Bimsteinstückchen, die mit einer Lösung von salpetersaurem Silberoxyd getränkt sind, angefüllte U-Rohr $S$. Der Inlalt beider Vorlagen

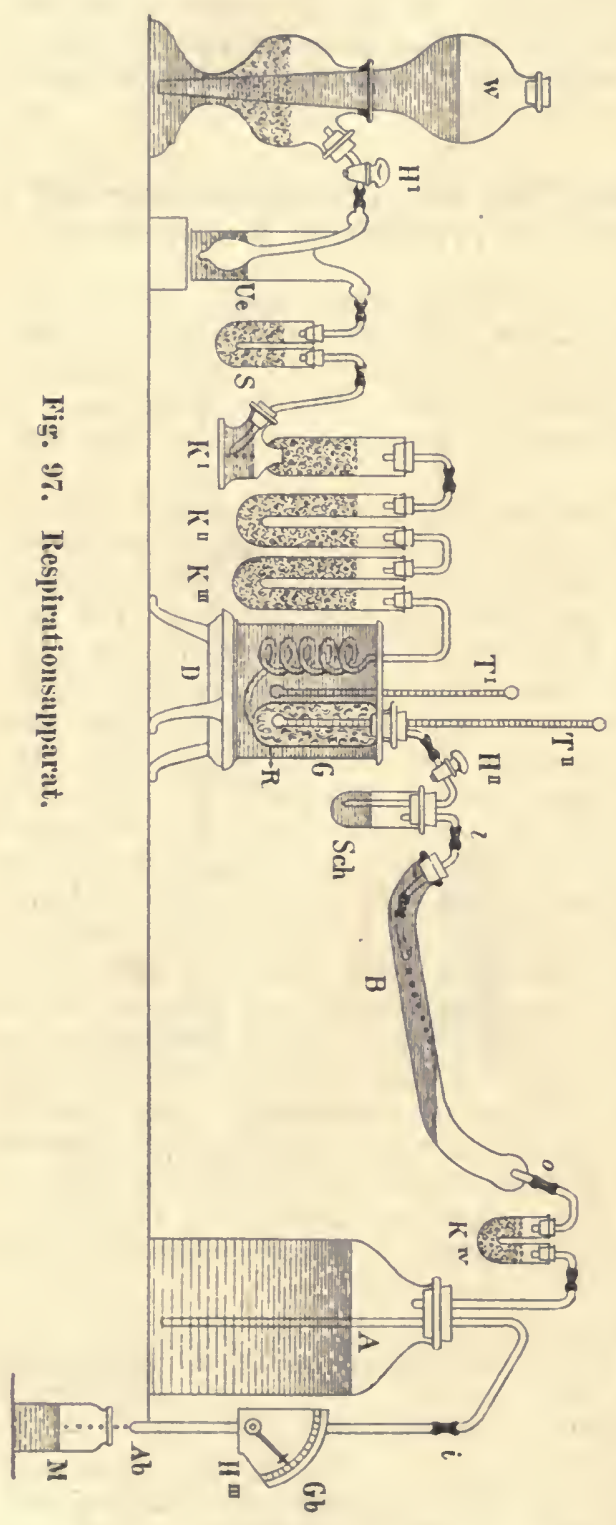
ist häufiger zu erneuern. Indem das Wasserstoffgas das unten mit concentrirter Kalilauge, oben mit Aetzkalistücken angefüllte Absorptionsgefäss $K^{\mathrm{I}}$ sowie die mit Kalilauge getrïnkten Bimsteinstückchen in den U-Röhren $K^{\prime \prime}$ und $K^{\prime \prime \prime}$ durchströmt, wird es jeder Spur von Kohlensäure beraubt. Zwischen $K^{\text {III }}$ und dem Schlangenrohr des die Pflanzen enthaltenden Respirationsgefässes $R$ wird zweckmässig noch eine kleine als Sperrventil dienende und wenig concentrirte Schwefelsäure enthaltende Flasche eingeschaltet. Dies Ventil, ebenso beschaffen wie das Ventil Sch und in ter Abbildung nicht dargestellt, macht einen, übrigens ohnedies kaum stattfindenden, Rücktritt von Kohlensäure aus dem Schlangenrohr in $K^{\text {'r }}$ absolut unmöglich.

Das zur Aufnahme der Untersuchungsobjecte bestiminte Gefäss besitzt je nach Bedürfniss einen Inhalt ron $200-400 \mathrm{ccm}$ und läuft unten in ein Schlangenrohr aus, welches neben dem eigentlichen Respirationsraum $R$ in die Höhe steigt. Dieser letztere ist oben durch einen doppelt durchbohrten Kautschukkork verschlossen. In der einen Bohrung steckt das Thermometer $T \amalg$, in der anderen ein im stumpfen Winkel gebogenes Glasrohr. Das

Thermometer, in ZehntelGrade getheilt, besitzt zweckmässig einen langen, cylindrischen Quecksilberbehälter, der sich inmitten der Versuchspflanzen befindet. Der Nullpunkt der Thermometerscala muss über dem Kautschukkork liegen, damit sichere Ablesungen möglich sind, wenn man bei niederer Temperatur arbeitet. Auf den Grund des Respirationsgefässes bringt man etwas angefeuchtete Glaswolle und auf diese das Pflanzenmaterial, eventuell im benetz.ten Zustande. 
Das Respirationsgefïss findet in einem mit Wasser angefüllten, mit Holzdeckel versehenen und auf einem Dreifuss $D$ stehenden thönernen Umhüllungsgefäss $G$ Platz. Durch Zugiessen von warmem oder kaltem Wasser, oder durch Erwärmen des Wassers mittelst einer Gasflamme kann die Temperatur der F'lïssigkeit, welehe das Thermometer 'T' anzeigt, und somit auch diejenige der Untersuchungsobjecte in $R$ regulirt werden.

Der gereinigte und kohlensäurefreie Wasserstoff wird in dem Sehlangenrohr auf die Temperatur des Wassers gebracht, durchstreicht den Pflanzenbehälter dann von unten nach oben, tritt in das mit wenig concentrirter Schwefelsäure beschickte Sperrventil Sch ein und giebt die von den Untersuchungsobjecten producirte Kohlensäure in dem mit $75 \mathrm{cem}$ Barytwasser gefüllten PETTENKofen'sehen Barytrohr $B$ ab. Das Sperrventil hat den Zweek, den Uebertritt von Luft in den Respirationsraum unmöglich zu machen; dieser letztere kann übrigens noch durch den Hahn $H^{\Perp}$ gegen das Ventil hin völlig abgesperrt werden. Die Röhre $K^{1 v}$, welche Aetzkalistückehen enthült, hat den Zweck, den Uebertritt von kohlensäurehaltiger Luft aus dem Aspirator in die Barytröhre auszuschliessen.

Soll ein Experiment über intramolekulare Athmung angestellt werden, so leitet man zunächst eine Stunde lang einen kräftigen Wasserstoffstrom durch den vor der Hand bei $l$ geöffneten Apparat. Dann wird die Verbindung zwischen $l$ und $o$ mittelst eines Glasrohres hergestellt und unter Benutzung des Aspirators weiter $1 / 2-1$ Stunde lang Wasserstoffgas durchgeleitet. Die Temperaturverhältnisse in $R$ und die Stromgeschwindigkeit (3 l pro Stunde) sind dabei sorgsam zu reguliren. Erst jetzt, nachdem, wie die eingehende Prüfung der Untersuchungsmethode gelehrt hat, der Sauerstoff verdrängt ist, schaltet man zwischen $l$ und $o$ die Barytröhre ein; nach Verlauf je einer Stunde werden neue Röhren vorgelegt ' $)$.

Absolut luftdichter Sehluss aller Theile des Apparates ist natürlich Hauptbedingung für das gute Gelingen der Experimente. Man benutze nur sorgsam ausgewählte Kautschukkörke und Schläuche (letztere gut eingefettet), wohl eingeschliffene Glashähne und achte darauf, dass die Glasröhren an den Verbindungsstellen mit ihren Enden zusammenstossen. Von dem guten Sehluss des funetionirenden Apparates kann man sieh dann leicht durch Zudrehen der Hähne $I^{\mathrm{t}}$ oder $H^{\prime \prime \prime}$ überzeugen. Im ersteren Falle muss alsbald der Wasserabfluss bei $A b$, im letzteren die Wasserstoffentwickelung aufhören.

Zur Herstellung des Barytwassers übergiesst man Barythydrat und Chlorbarium mit destillirtem Wasser (auf je 11 Wasser $21 \mathrm{~g} \mathrm{Ba-}$ rythydrat und $3 \mathrm{~g}$ Chlorbarium). Man lässt die Mischung längere Zeit unter häufigem Umschïtteln stehen und giesst in die hochgestellte Flasche (Fig. 98) ab. Diese Flasche fasst etwa 10 l Flüssigkeit. Das mit Kalistüekchen angefüllte Rohr $k^{\prime \prime}$ dient dazu, das klare Barytwasser vor Kohlensäureaufnahme zu schützen. Das Barytwasser kann in die Bürette $b$, welche am oberen Ende das Kalirohr $k^{\prime}$ trägt, ab-

1) Will man constatiren, ob aller Sauerstoff durch den Wasserstoff aus dem Apparat verdrängt ist, so braucht man das Sperrventil Sch nur mit einem Gläschen in Verbindung zu setzen, welches etwas P'hosphor enthält. Von der völligen $\mathbf{A b}$ sorption der producirten $\mathrm{CO}_{2}$ durch $75 \mathrm{ccm}$ Barytwasser überzeugt man sich, inden man an die Barytröhre noch ein weiteres Barytwasser enthailtendes Gefässs anschliesst. Dies Barytwasser bleibt klar. 
gelassen werden, und von der Bürette aus erfolgt endlich das Füllen der gut gereinigten und vollkommen trockenen PETTENKofER'schen Barytröhren. Den Inhalt dieser Röhren bringt man bei Abschluss jedes Versuches schnell in lange, wohl verschliessbare Cylindergläser, und nach dem Absetzen des Niederschlages werden von der darüberstehenden wasserklaren Flüssigkeit mit Hülfe einer Pipette zweimal $25 \mathrm{ccm}$ zum Titriren abgehoben. Hierbei (ebenso natürlich auch beim Titriren des ursprünglichen Barytwassers) kommt eine Oxalsäurelösung in Anwendung, die im Liter 2,8636 g krystallisirte Säure enthält und von der $1 \mathrm{ccm}$ $1 \mathrm{mg} \mathrm{CO}$ entspricht. Die Oxalsäurelösung wird aus einer mit Schwimmer versehenen Bürette zu dem Barytwasser gelassen. Als Indicator dienen stets einige Tropfen einer Phenolphtaleinlösung (100 cem Alkohol und 0,5 g Phenolphtalein). Die Methode gestattet es, die Kohlensäure bis auf $1 / 10 \mathrm{mg}$ genau zu bestimmen. Ueberhaupt ist die Untersuchungsmethode von mir und meinen Schülern mehrfach nach verschiedenen Richtungen hin auf ihre Brauchbarkeit geprïft worden und es haben sich dabei sehr befriedigende Resultate ergeben ${ }^{1}$ ). $\mathrm{Zu}$ beachten bleibt aber, dass die Resultate der Beobachtungen, wenn man dieselben in angegebener Weise anstellt, stets etwas zu hoch ausfallen. Experimentirt man nämlich mit dem Apparat ohne Pflanzenmaterial, so findet man dennoch, dass der Titer des Barytwassers sich geändert hat. Diese Aen-

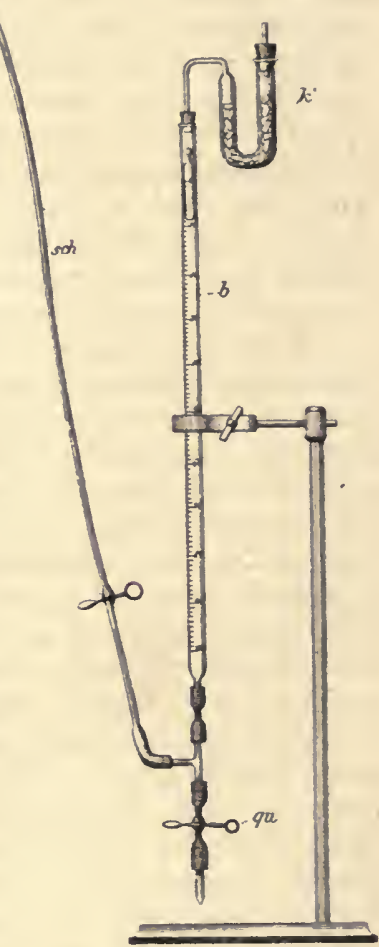

Fig. 9S. Titrirapparat. derung, auf eine Stunde und $75 \mathrm{ccm}$ Barytwasser bezogen, entspricht einer Kohlensäuremenge von $0,5-1 \mathrm{mg}$. Der Versuchsfehler, dessen Höhe bei den Respirationsversuchen häufiger in angegebener Weise festzustellen ist, kann in manchen Fällen völlig vernachlässigt werden, da thatsächlich sehr oft die aus der Individualität der untersuchten Pflanzen entspringenden Differenzen in der Kohlensäureproduction sogar noch grösser ausfallen.

Handelt es sich bei Respirationsversuchen darum, nicht die Kohlensäureproduction bei intramolekularer, sondern bei normaler Athmung festzustellen, so arbeitet man ebenfalls mit unserem Apparat.

1) Vergl. auch SACHSSE, Ueber einige chemische Vorgänge bei der Keimung von Pisum sativum, Leipzig 1875, PfefFer, Unters. a. d. botan. Institut zu Tübingen, Bd. 1, S. 636, u. MöLLER, Ber. d. Deutschen botan. Gesellsehaft, Bd. 2. 
Es werden nur der KrIPP'sche Apparat, die Waschflache mit Kaliumpermanganat und das U-Rohr mit Höllensteinlösung ausgeschaltet. Experimentirt man mit leicht welkenden Pflanzentheilen (z. B. Kronenblättern oder zarten Blüthen), dann empfiehlt es sich, die Luft, bevor sie in das Schlangenrohr eintritt, ein Gefäss passiren zu lassen, welches feuchte Glaswolle enthält. Man leitet bei Ausführung der Versuche zunächst $1 \frac{1}{2}-2$. Stunden Luft mit Hülfe des Aspirators durch den Apparat (3 1 p. Std.). Dann hat die Luft im Respirationsraum bezüglich ihres Kohlensäuregehaltes sicher einen stationären Zustand angenommen. Jetzt schaltet man die erste Barytröhre ein, nach einer Stunde die zweite und so fort. Um sicher zu sein, dass beim Vorlegen der Barytrölıren keine Kohlensäure aus dem Respirationsraum entweicht, thut man gut, den Glashahn $H^{\prime \prime}$ (das Sperrventil Sch kann fehlen) und einen zweiten, am oberen Ende des Schlangenrolıres anzubringenden Glashahn (oder Quetschhahn) zu schliessen, wenn eine neue Röhre eingeschaltet werden soll. Ueber die Vorsichtsmaassregeln, welche bei tagelang und ununterbrochen fortzufülirenden Respirationsversuchen zu beachten sind, vergl. die citirten Abliandlungen von SACHSSE (1872) und von mir (1875).

Mit Bezug auf Untersuchungen, die den Zweck haben, das Verlältniss der Kohlensäureproduction bei innerer und normaler Athmung $\left(\frac{\mathrm{J}}{\mathrm{N}}\right)$ für ein gegebenes Pflanzenmaterial unter übrigens gleichen Bedingungen festzustellen, ist Folgendes zu bemerken. Wir stellen den gesammten Apparat zusammen; nur der KrPP'sche Apparat bleibt fort. Haben wir $1 \frac{1}{2}$ Stunde unter Benutzung des Aspirators Luft durchgeleitet, so beginnt die Feststellung der bei normaler Athmung producirten Kohlensäure. Nach 1 oder 2 Stunden schalten wir dann den KIPP'schen Apparat ein, leiten 1 Stunde lang einen starken Wasserstoffstrom, dann 1 Stunde lang mit Benutzung des Aspirators $3 \mathrm{l} \mathrm{H}$ über die Pflanzen und legen zur Ermittelung der bei intramolekularer Athmung producirten Kohlensäure eine Barytröhre vor. Schliesslich wird der Wasserstoff durch Luft verdrängt, um abermals die Höhe der normalen Athmung zu constatiren.

Bei vergleichenden Untersuchungen über die Athmung der Pflanzen in reinem Sauerstoff und in Luft, leitet man an Stelle des Wasserstoffs, dessen man bei der Prüfung intramolekularer Athmung bedarf, reinen Sauerstoff aus einem grossen Gasometer über die Untersuchungsobjecte hin. Der 0 passirt zur Reinigung eine Waschflasche, welche Kalilauge enthält. Den $O$ gewinnt man in bekannter Weise durch Erhitzen einer Mischung von chlorsaurem Kali und Braunstein in einer Retorte. Sehr bequem ist es auch, den Gasometer unter Benutzung einer Sauerstoffbombe, die comprimirten Sauerstoff enthält (zu beziehen aus der chemischen Fabrik von Dr. Elrkax in Berlin), zu füllen. Es empfiehlt sich, das Wasser, welches zur Verdrängung des $\mathrm{O}$ aus dem Gasometer dient, vorher mit $\mathrm{O}$ zu sättigen. Keimpflanzen von Pisum sativum athmen wenigstens zunächst ebenso lebhaft in reinem $O$ wie in atmosphärischer Luft, andere Keimpflanzen verhalten sich nicht genau in derselben Weise ${ }^{1}$ ) Bd. 1.

1) Vgl. Jorrassex, Untersuchungen aus dem botan. Institut zu Tübingen, 


\section{Die Ḱohlensäureproduction bei normaler Athmung der Pflanzen.}

Nach den im vorigen Abschnitt gegebenen Darstellungen wird es nicht gar zu śchwierig sein, bei Untersuchungen über die normale Athmung der Pflanzen zu richtigen Resultaten zu gelangen. Zur Uebung in der Benutzung der Methode bringe man z. B. $25 \mathrm{~g}$ frischer Blumenblätter von Rosa oder einer anderen Pflanze in das Respirationsgefäss und ermittele, wie viel Kohlensäure dieselben pro Stunde bei einer Temperatur von $20^{\circ} \mathrm{C}$. produciren. Die Resultate der einzelnen Experimente werden bei sorgsamer Arbeit nur ganz kleine Differenzen (etwa $1 \mathrm{mg}$ ) zeigen. Man kann sich auch leicht davon überzeugen, dass die Blüthentheile der Pflanzen im Allgemeinen unter übrigens gleichen Umständen lebhafter athmen als die Vegetationsorgane, z. B. die Laubblätter.

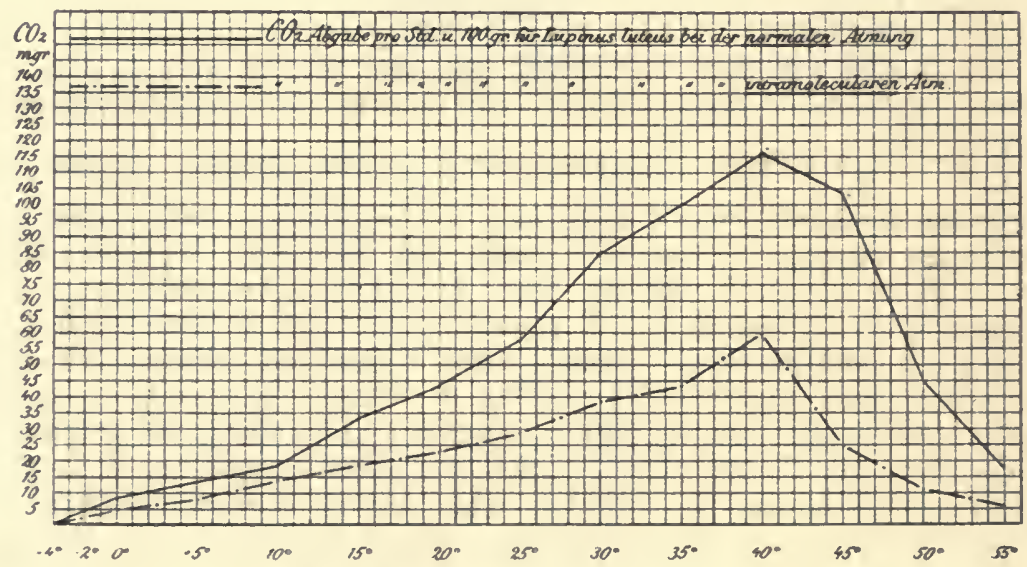

Fig. 99. Ithmungseurren. (Nach AMм.)

Studien über die Abhängigkeit der Pflanzenathmung von den Temperaturverhältnissen stellt man in der Weise an, dass man die Kohlensäureproduction der Untersuchungsobjecte wiederholt bei 0,5 , $10^{\circ} \mathrm{C}$. etc. ermittelt. In den Versuchen bei $0^{\circ} \mathrm{C}$. steht das Respirationsgefäss sammt Schlangenrohr in einem mit Eisstückchen angefüllten Umhüllungsgefäss von erheblicher Grösse. Die Temperaturverhältnisse müssen stets während des Durchleitens der Luft vor Einschaltung der Barytröhre regulirt werden, um zu genauen Resultaten zu gelangen. Recht bequem ist es, mit Keimpflanzen, z. B. mit denjenigen von Lupinus luteus, zu experimentiren. Eine grössere Menge der Samen wird 24 Stunden lang eingequollen und dann in Sägespänen, mit denen geeignete Zinkkästen angefüllt sind, bei $20^{\circ} \mathrm{C}$. (eventuell in einem Wärmeschrank) zur Keimung gebracht. Die 4 bis 5 Tage alten Keimlinge mit Hypocotylen von ca. 2 und Wurzeln von ca. $3 \mathrm{~cm}$ Länge dienen nach Säuberung von den Sägespänen in Mengen von je $50 \mathrm{~g} \mathrm{zu}$ den Experimenten. Es ist sorgfältig darauf zu achten, dass stets ein genügender Vorrath sehr gleichförmig aus- 
gebildeter Keimlinge zur Disposition steht. Die Resultate der Beobachtungen sind in der Art, wie es die obere Kurve in Fig. 99 zeigt, graphisch darzustellen. Bei $0^{\circ} \mathrm{C}$. athmen die Lupinenkeimlinge bereits deutlich nachweisbar. Bei $40^{\circ} \mathrm{C}$. liegt das Temperaturoptimum und bei $45^{\circ} \mathrm{C}$. das Temperaturmaximum für die normale Athmung der Lupinenkeimlinge. Bei noch höherer Temperatur treten bereits Absterbevorgänge in den Zellen ein, und die Kohlensäureproduction sinkt daher rapide.

Prüft man $50 \mathrm{~g}$ Lupinenkeimlinge zunächst bei $20^{\circ} \mathrm{C}$. auf ihre Athmungsgrösse und setzt die Untersuchungsobjecte dann im Respirationsgefäss längere Zeit einer Temperatur von etwa $100^{\circ} \mathrm{C}$. aus, um sie dann abermals auf Kohlensäureproduction zu prüfen, so findet man, dass die Kohlensäureproduction jetzt völlig erloschen ist. Getödtete Pflanzen athmen nicht. Die Athmung ist eine Function des lebensthätigen Protoplasmas. Die Pflanzen sind natürlich beim Erhitzen vor erheblichem Wasserverlust zu schützen. Empfehlenswertli ist es auch, um jede nachträgliche Bacterienentwickelung auszuschliessen, dem Untersuchungsmaterial, nachdem dasselbe im normalen Zustande auf seine Athmungsgrösse geprüft worden ist, etwas Salicylsäure beizumischen.

Bei Experimenten über den directen Einfluss des Lichtes anf die Pflanzenathmung benutzt man als Respirationsraum das in Fig. 100 dargestellte Gefäss. Dasselbe wird von TitTel \& Co. in Geiers. thal bei Wallendorf (Thüringen) gefertigt und stellt eine GlasHlasche unit parallelen Wänden dar. Der Durchmesser der kreisförmigen Wände beträgt $13 \mathrm{~cm}$, der Abstand der Wände von einander ea. $20 \mathrm{~mm}$. In den Hals am unteren Ende des Respirationsgefässes wird das Schlangenrohr luftdicht eingeführt; die obere, weitere Oeffnung dient zur Aufnahme des Thermometers und des Gasableitungsrohres. Das Gefäss liängt in Wasser hinein, mit welchem der $30 \mathrm{~cm}$ hohe und $10 \mathrm{~cm}$ weite Zinkblechkasten, dessen Vorder- und Rückwand

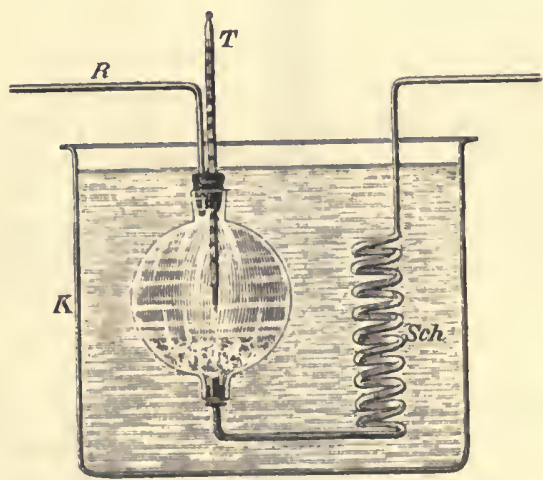

Fig. 100. Apparat zur Prïfung des Lichteinflusses auf die Athmung der Pflanzen. durch Glasplatten gebildet werden, angefüllt ist. Diesen Kasten stellt man an einem nach Süden gelegenen Fenster etwas nach rückwärts geneigt auf, so dass die aus Glas hergestellte Vorder- und Rückwand schräg gerichtet sind. Vor dem Kasten, also nach dem Fenster zu, findet noch ein zweiter, grösserer, ebenfalls etwas nach rückwärts geneigter Glaskasten Platz, der concentrite, filtrirte Alaunlösung enthält. Als Untersuchungsobiecte benutzt man völlig chlorophyllfreie Blüthentheile, Wurzeln oder Pilze (etwa je 25-40 g Sb). Bei den Experimenten selbst sind die schon früher angegebenen Vorsichtsmaassregeln zu beachten. Näheres ist auch noch in der citirten Arbeit von AEREBOE nachzulesen. Die grösste Aufmerksamkeit hat man darauf zu richten, dass die in den verschiedenen Versuchsperioden abwechselnd dem Licht und der Dunkel- 
heit (Verdunkelung kaun leicht dadurch erzielt werden, dass man den Wasserkasten mit einem geeigneten, unten offenen Pappkasten bedeckt) ausgesetzten Untersuchungsobjecte stets der $n$ ä m li chen Temperatur exponirt bleiben. Dies ist, wie ich aus Erfalırung weiss, bei Be-

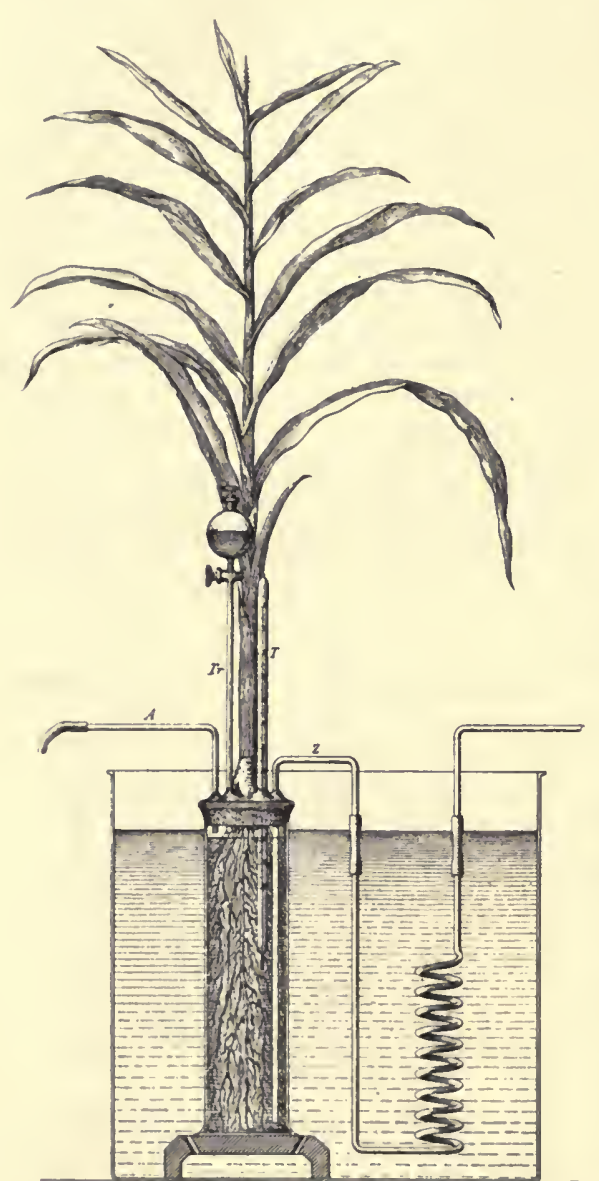

Fig. 101. Apparat für Experimente über die Athmung der Wurzeln. nutzung der Alaunlösung in den Lichtversuchen selbst dann möglich, wenn man mit directem Sonnenlicht arbeitet. Die Experimente lehren, dass die Lichtstrahlen vielleicht nur in ganz wenigen Fällen eine photochemische Wirkung auf die Pflanzenathmung geltend machen; selır gewöhnlich athmen die chlorophyllfreien Pflanzen im Licht die gleiche Kollensäuremenge wie im Dunkeln aus.

Indirect übt das Licht natürlich einen bedeutsamen Einfluss auf die Pflanzenathmung aus, indem ja unter Vermittelung desselben in Folge der Assimilation diejenigen Stoffe erzeugt werden, welche beider Athmung eine Oxydation erfahren. Um diese Thatsache festzustellen, cultiviren wir Keimlinge von Lupinus bei Lichtzutritt in Blumentöpfen. Sind die Pflanzen einige Wochen alt, so schneiden wir von 25 recht gleichförmig entwickelten Pflanzen die Stengel dicht über dem Boden ab und stellen die Kohlensäure fest, welche sie bei $20^{\circ} \mathrm{C}$. in 2 Stunden produciren. Die Töpfe gelangen jetzt ins Dunkle. Nach $2-3$ Tagen prüfen wir abermals 25 Pflanzen auf ihre Athmungsgrösse. Nun werden die

Pflanzen in den Culturgefässen wieder normal beleuchtet, um 25 Exemplare nach 4 Tagen wieder auf ihre Kohlensäureproduction zu untersuchen. Eine von AEREBOE unter meiner Leitung ausgefülirte Versuchsreihe lieferte folgende Resultate: Je 25 PHanzen producirten in 2 Stunden bei $20^{\circ} \mathrm{C}$. $\mathrm{CO}_{2}$

6. August, Abends 18,35 mg (beleuchtet gewesen),

$9 . \quad ", \quad 7,95, "(2 \% / 2$ Tage verdunkelt),

13. " " " $" 18,72 "$ (vom 9. bis 13. Aug. beleuchtet).

Untersuchungen" über die "normale Athmung der Wurzeln stellt man zweckmässig mit dem in Fig. 101 abgebildeten Apparat an, wenn es sich darum handelt, die Kohlensäureproduction der normal vege- 
tirenden und mit den oberirdischen Theilen der Pflanze in Zusammenhang stehenden Organe zu bestimmen. Ein grösserer Glascylinder, der in einem Wasserkasten Platz gefunden hat, dient als Culturgefäss. Der Cylinder enthält eine Nährstofflösung. Der zum Verschluss der Oeffnung des Cylinders dienende halbirte Kork kann so weit eingeschoben werden, dass von seiner Oberfläche bis zum Rande des Culturgefässes noch ein Raum von ca. $3 \mathrm{~cm}$ Höhe bleibt. Der Kork hat fünf Bohrungen, eine für die Pflanze (z. B. Mais), eine für das Thermometer $T$, eine für das mit Glashahn versehene Trichterrohr $T r$, durch welches der Nährlösung nach Bedürfniss ausgekochtes destillirtes Wasser zugeführt werden kann, eine für das mit Schlangenrohr versehene Gaszuleitungsrohr $Z$ und eine für das Gasableitungsrohr $A$. Zur Herstellung eines völlig luftdichten Verschlusses füllt man den Raum über dem Kork mit einer bei relativ niederer Temperatur (ca. $40^{\circ}$ C.) schmelzenden Mischung, aus Wachs, Olivenöl und Hammeltalg bestehend, aus. Die Regulirung der Temperaturverhältnisse der Nährlösung, in welche die Pflanzenwurzeln eintauchen, macht keine besonderen Schwierigkeiten, da das Culturgefäss ja in dem grossen Wasserkasten steht. Für Verdunkelung der Wurzeln ist zu sorgen; die oberirdischen Theile des Untersuchungsobjectes können dem Licht ausgesetzt bleiben. Vor Beginn eines jeden Versuchs leitet man, ohne zunächst die Kohlensäureproduction der Wurzeln zu bestimmen, längere Zeit (etwa 4 Stunden lang) Luft durch die Nährlösung. Da der Widerstand dieser letzteren recht erheblich ist, inuss der Luftstrom stets ziemlich kräftig sein (ca. 8-10 l pro Stunde). Als Aspirator verwendet man eine sehr grosse Flasche. Das Wurzelsystem der in der Fig. 101 abgebildeten grossen, normal vegetirenden Maispflanze producirte in je 2 Stunden bei $20^{\circ} \mathrm{C}$. $80 \mathrm{mg} \mathrm{CO}$. Wenn das Untersuchungsobject nur ab und an zur Bestimmung der Kohlensäureproduction benutzt wird, so muss in der Zwischenzeit stets Luft durch die Nährlösung geleitet werden, damit die Wurzeln keinen Sauerstoffinangel leiden.

\section{Die Kohlensäureproduction bei intramolekularer Athmung der Pflanzen.}

Die Kohlensäureproduction bei intramolekularer Athmung der Gewächse stellt man nach der unten angegebenen Methode fest. Gewöhnlich ist die von den Pflanzen intramolekular producirte Kohlensäuremenge unter übrigens gleichen Umständen weit kleiner als die bei normaler Atlımung gebildete. In einigen Fällen (z. B. Keimlinge von Vicia Faba) ist das Verhältniss $\frac{\mathrm{J}}{\mathrm{N}}$ aber doch gleich 1. Natürlich sind bei vergleichenden Experimenten über normale und intramolekulare Athmung Untersuchungsobjecte von gleichem Entwickelungsstadium zu benutzen, wenn es sich z. B. darum handelt, den Einfluss der Temperatur auf die Athmung festzustellen. Am allerbesten ist es, mit ein und demselben Material mehrere vergleichende Experimente hinter einander durchzuführen. Bei niederen Temperaturen ertragen die Pflanzen ein längeres (vielstündiges) Verweilen in Wasserstoff ohne Schädigung; sie produciren dann nachträglich bei wiederkehrender normaler Athmung ebenso viel $\mathrm{CO}_{2}$, wie vor Beginn der intramolekularen Athmung (vgl. die Versuche von Am in dessen citirter Ab- 
lıandlung). Bei höherer Temperatur (von 30 oder $35^{\circ} \mathrm{C}$. an) leiden die Pflanzen leicht, wenn sie zu lange in Wasserstoff verweilen; die Experimente dürfen daher nur über wenige Stunden ausgedehnt werden. Die Resultate der Versuche kann man graphisch darstellen. Fig. 99 zeigt, dass Keimlinge (4-5 Tage alte) von Lupinus bei intramolekularer Athmung stets weit weniger $\mathrm{CO}_{2}$ produciren als bei normaler. Das Temperaturoptimum liegt für beide Athmungsformen bei $40^{\circ} \mathrm{C}^{1}{ }^{1}$ ).

Die Erscheinung der intramolekularen Athmung tritt auch ein, wenn Pflanzen in das Vacuum gebracht werden.

Experimente im Vacuum, die ich z. B. mit Pisumkeimpflanzen nach Wortmans's ${ }^{2}$ ) Methode ausführte, stellt man in folgender Weise an. Ein starkwandiges Glasrohr von etwa $100 \mathrm{~cm}$ Länge und $1,5 \mathrm{~cm}$. Weite, das an einem Ende zugeschmolzen ist, wird mit gereinigtem, völlig trockenem Quecksilber gefüllt. Ueber Reinigung des Quecksilbers vergl. unter 13. Das Adhäriren von Luftblasen an den Wänden des erwähnten Rohres beim Füllen desselben vermeidet man dadurch am besten, dass man das Quecksilber mittelst eines mit ziemlich feiner Spitze endigenden Trichters durch ein dünnes Glasrohr, welches bis auf den Boden des zu füllenden Rohres reicht, laufen lässt. Nach dem Füllen des Rohres wird die Mündung desselben verschlossen und der Apparat umgekehrt in ein flaches, theilweise mit Quecksilber angefülltes Glasgefäss gestellt. Man hat jetzt also ein Barometer mit ziemlich grosser TonRICELLI'scher Leere vor sich. In dem Quecksilber der Barometerröhre lässt man jetzt einige von den Samenschalen befreite, mit Fliesspapier abgetrocknete Keimpflanzen, die sich in Contact mit feuchten Sägespänen entwickelt haben, und ebenso, um das Untersuchungsmaterial während der Versuchsdauer feucht zu erhalten, ein mit ausgekochtem Wasser durchtränktes Fliesspapierkügelchen aufsteigen. Bei Experimenten mit Pisum sativum oder Vicia Faba verwendet man 6-10 Keimpflanzen; experimentirt man mit Keimpflanzen von geringem Gewicht, so ist eine entsprechend grössere Zabl derselben zu benutzen. Wenn das Quecksilber in der Barometerröhre nach Einbringung der Untersuchungsobjecte zur Ruhe gekommen ist, so schreitet man dazu, die Zeit, die Temperatur, den Baroneterstand, sowie den Stand der Quecksilbersäule (den oberen Stand und den unteren Stand, also die Stelle, an welcher das Barometerrohr das Quecksilber in dem flachen Glasgefäss berührt) zu bestimmen. Arbeitet man mit nicht calibrirten Barometerröhren, so fixirt man den oberen sowie unteren Stand der Quecksilbersäule durch aufgeklebte Papiermarken, wiederholt dies bei jeder vorkommenden Ablesung, misst die fixirten Quecksilberhöhen und ermittelt später die ihnen entsprechenden Volumina, indem man aus einer Burette Quecksilher bis zu den die Volumina anzeigenden Marken fliessen lässt. Alle Volumina werden auf $0^{\circ} \mathrm{C}$. und $1000 \mathrm{~mm} \mathrm{Hg}$ reducirt.

1) Dies letztere, zuerst von AMm festgestellte Resultat bestätigte auch CHUDLAkow (Landwirthschl. Jahrbücher, Bd. 23). Dagegen bestreitet er die Richtigkeit einiger Schlussfolgerungen von AмM und mir. Wir hatten gefunden, dass der Werth $\frac{J}{N}$ nicht bei allen Temperaturen der nämliche sci, eine Angabe, deren Richtigkeit CrIUDIakow auf Grund der Ergebnisse sciner Versuche in Abrede stellt. Die Ausführungen des genannten Beobachters sind aber nicht zwingend für mich, und daher haben weitere Untersuchungen Klarheit zu gewähren.

2) Vgl. Wortmaxx, Arbeiten d. botan. Instituts in Würzburg, Bd. 2. 
War bei Anfang des Versuchs:

$V o$ das Volumen,

$h$ die Höhe des $\mathrm{Hg}$ in der Barometerröhre,

$t$ die Temperatur und

$b$ der Barometerstand,

bezeichnet ferner

ts die der Temperatur entsprechende Tension des Wasserdampfes auf das Quecksilber der Röhre und

$a$ den Ausdehnungscoefficienten der Luft,

so war das reducirte Volumen:

$$
V=\frac{b-(h+t s)}{1000} \cdot \frac{V_{0}}{(1+a \cdot t)}
$$

War $V$ das Volumen bei Beginn des Versuches, $V$, das etwa nach 6 Stunden berechnete Volumen, so war mithin $V_{1}-V$ das in dieser Zeit ausgeschiedene Kohlensäurequantum. Da beim Vacuum das Anfangsvolumen gleich Null war, so bezeichnet $V_{1}$ direct die ausgeschiedene Kohlensäuremenge.

Es ist vielfach erwünscht, die Grösse der intramolekularen Athmung mit der Grösse der normalen Athmung vergleichen zu können, und wenn dies geschehen soll, so wird neben dem Barometerrohr ein zweites Glasrohr von derselben Grösse wie jenes aufgestellt, nachdem man obenfalls Keimpflanzen in dasselbe eingeführt hat, die möglichst genau das gleiche Gewicht und den nämlichen Entwickelungsgrad wie diejenigen im Vacuum haben müssen. Um das Herabfallen der Untersuchungsobjecte zu verhindern, wird ihnen ein kleiner Kork nachgeschoben. Das Glasrohr taucht mit seinem unteren, offenen Ende in Quecksilber ein, und es werden etwa $20 \mathrm{ccm}$ der in dem Rohre vorhandenen atmosphärischen Luft durch Heraussaugen entfernt, wodurch natürlich das Quecksilber emporsteigt (vgl. Fig. 102). Um einen Theil der Luft aus dem Rohr zu entfernen, wird ein Glaskolben, welcher durch einen Kautschukkork verschlossen ist, in dessen Bohrung ein gebogenes, einen Kautschukschlauch tragendes Glasrohr steckt, erwärmt, der Schlauch mit einer

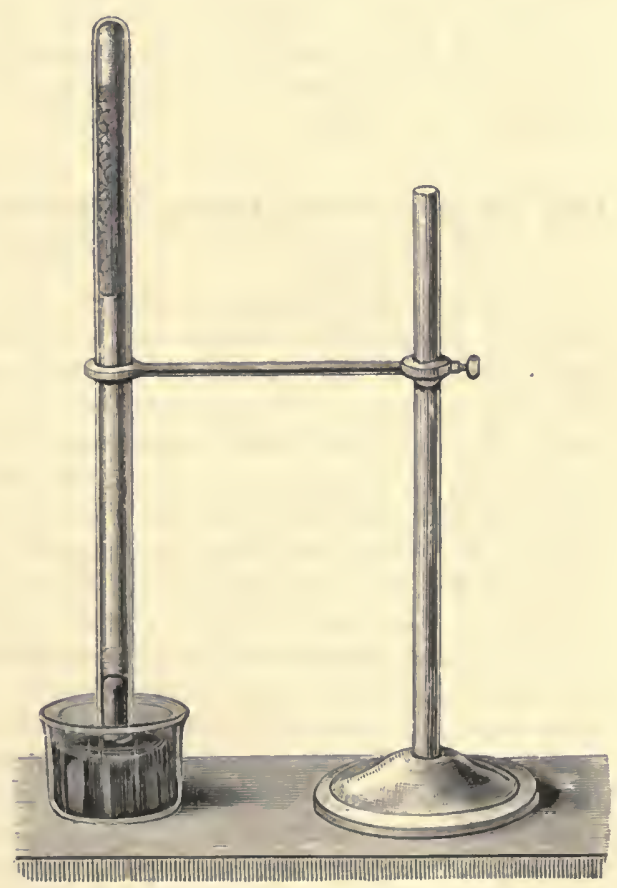

Fig. 102. Apparat zur Bestimmung der Sauerstoffmenge, welche Pflanzentheile bei der Athmung aufzunehmen verinögen. Klemme verschlossen und sein Ende in das die Keimpllanzen enthaltende Glasrohr eingeführt. Der erkaltende Glaskolben dient also, wenn die Klemme geöffnet wird, als Saugapparat; es ist mit Hülfe desselben leicht, das Quecksilber in 
dem Glasrohr zum Steigen zu bringen. Man bedeckt nun endlich noch das Quecksilber im Glasrohr mit einer etwa $3 \mathrm{~mm}$ hohen Wasserschicht, macht die zur Bestimmung des Luftvolumens im Apparat erforderlichen Ablesungen und führt ein Stückchen Kalihydrat in das Glasrohr ein. Das Aetzkali wird von dem Wasser über dem Quecksilber schnell aufgelöst, und da die gebildete Kalilauge die bei der normalen Athmung der Keimpflanzen entstehende Kohlensäure absorbirt, so kann man jeder Zeit neue Ablesungen zur Feststellung der producirten Kohlensäurequantität vornehmen. Diese Methode liefert freilich durchaus nicht so genaue Resultate wie die unter 102 angegebene.

Wenn man die Untersuchungen über die intramolekulare Athmung längere Zeit, z. B. einige Tage lang, fortsetzt, so wird man finden, dass eine gegebene Menge Keimpflanzen in der Zeiteinheit und unter sich gleich bleibenden äusseren Umständen fortschreitend weniger Kohlensäure producirt. Die Untersuchungsobjecte gerathen allmählich in einen pathologischen Zustand, und es ist wichtig, dies $\mathrm{zu}$ wissen, weil sich daraus ergiebt, dass man bei vergleichenden Untersuchungen über intramoleknlare und normale Athmung keine zu lange Versuchsdauer (etwa nur 6-8 Stunden) innehalten darf. Derartige vergleichende Experimente lehren wieder, dass nur wenige Pflanzen, z. B. Keimpflanzen von Vicia Faba, bei intramolekularer Athmung ebenso viel $\mathrm{CO}_{2}$ wie bei normaler Athmung produciren. Die meisten Untersuchungsobjecte liefern in Contact mit Sauerstoff erheblich grössere Kohlensäurequantitäten als bei Ausschluss desselben.

\section{Elementaranalytische Untersuehungen über den Athmungs- process.}

Für die Behandlung mancher sich auf den Athmungsprocess der Pflanzen beziehenden Fragen ist es erforderlich, den Gehalt der Untersuchungsobjecte an Kohlenstoff, Wasserstoff und Sauerstoff vor Beginn der Experimente und nach Abschluss derselben festzustellen. Ermittelt man z. B. den absoluten Gehalt von $100 \mathrm{~g}$ Samen, sowie den absoluten Gehalt der aus $100 \mathrm{~g}$ Samen nach bestimmter Zeit hervorgegangenen Keimpflanzen an den genannten Elementen, so gewinnt man vergleichbare Zahlen, die sofort erkennen lassen, wie gross die Menge des verathmeten Kohlenstoffs, Wasserstoffs etc. ist. Besondere Bedeutung besitzen elementaranalytische Untersuchungen, wenn es sich z. B. um die Frage handelt, ob die Gesammtmasse des Kohlenstoffs, den keimende Samen verlieren, in Form von Kohlensäure abgeschieden wird, oder ob bei der Keimung auch noch andere kohlenstoffhaltige Gase (Kohlenoxyd, Kohlenwasserstoffe) entstehen. Bei solchen Untersuchungen vergleicht man die Resultate directer Kohlensäurebestimmungen, die nach der unter 102 angegebenen $\mathrm{Me}-$ thode anzustellen sind, mit den Ergebnissen der elementaranalytischen Untersuchungen. Ergiebt sich eine gute Uebereinstimmung zwischen denjenigen Zahlen, welche durch die Respirationsversuche über den Kohlenstoffverlust bei der Keimung ermittelt werden können, und jeuen, welche die elementaranalytischen Untersuchungen bezüglich des Kohlenstoffverlustes feststellen lassen, so ist der Schluss berechtigt, dass sämmtlicher Kohlenstoff die keimenden Samen in Verbindung mit Sauerstoff als Kohlensäure verlässt. Bezüglich mancher Details der Untersuchungsmethode sind die in der Anmerkung citirten Abhandlungen nachzusehen. Ich bemerke nur noch bezüglich der Elementaranalysen, deren Ausführung übrigens grosse Uebung 
voraussetzt, dass die Samen- und Keimpflanzensubstanz mit Rücksicht auf ihren Chlor- und Schwefelgehalt mit chromsaurem Bleioxyd gemischt verbrannt werden muss, und dass mit Rücksicht auf den Stickstoffgehalt der Untersuchungsobjecte metallisches Kupfer (Kupferdrehspäne) vorzulegen ist. Die Verbrennung selbst geschieht am besten im Sauerstoffstrom ${ }^{1}$ ).

\section{Sanerstoffaufnahme bei der Athmung und Ermittelung des Respirationsquotienten $\frac{\mathrm{CO}_{2}}{\mathrm{O}}{ }^{2}$ ).}

Bei Untersuchungen, welche den Zweck haben, die Grösse der Sauerstoffaufnahme und zugleich die Grösse der Kohlensäureproduction bei normaler Athmung festzustellen, benutzt man zweckmässig den in Fig. 103 dargestellten Apparat.

Die Glasglocke $a$ von ca. $800 \mathrm{ccm}$ Inhalt ruht mit ihrem sorgfältig abgeschliffenen breiten und eingefetteten Rande auf einer geschliffenen Glasplatte. Als Kittmaterial benutzt man eine durch Zusammenschmelzen von 1 Thl. Wachs und 3 Thl. Schmalz hergestellte Mischung. Oben wird die Glocke mittelst eines Kautschukkorkes luftdicht verschlossen, in welchem die Röhren $r_{1}$ und $r$ stecken. $r_{1}$ ist mit Glashahn versehen und gestattet es, die Verbindung des Innenraumes mit der Atmosphäre herzustellen. Das Glasrohr $r$ taucht mit scinem längeren Schenkel, der einen lichten Durchmesser von $7 \mathrm{~mm}$ besitzt und bis auf Zehntelcubikcentimeter calibrirt ist, in ein Quecksilbergefäss ein. $b$ ist ein mit durchlöchertem Boden versehenes und auf einem Glasdreifuss ruhendes Porzellangefäss, in welches man die Untersuchungsobjecte bringt. Sie liegen hier auf feuchtem Filtrirpapier oder auf feuchter Glaswolle, $g$ stellt ein flaches Schälchen dar,

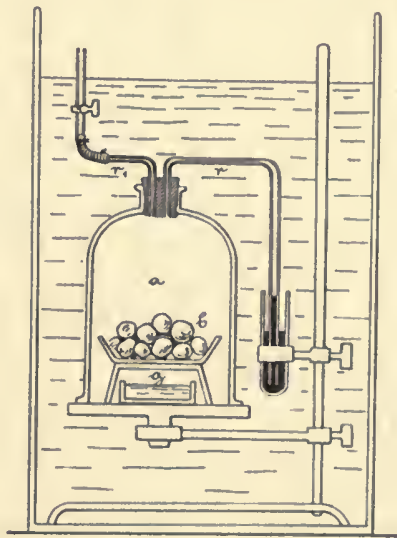

Fig. 103. Apparat nach STICH zur Bestimmung der Sauerstoffaufnahme und Kohlensäureproduction bei der Athmung der Pflanzen.

in welchem sich die zur Absorption der Kohlensäure dienende Kalilauge befindet. Die ganze Vorrichtung, auf einem vernickelten Stativ ruhend, wird beim Gebrauch in Wasser versenkt, mit welchem ein Glaskasten mit paralleler Vorder- und Rückwand angefüllt ist. Man ist auf solche Weise im Stande, die Temperaturverhältnisse im Apparat bequem zu reguliren und constant zu erhalten.

Bei Beginn eines Experimentes hebt man das Quecksilber in $r$ durch Saugen an $r_{1}$ etwas empor, schliesst den gut eingefetteten Glas-

1) Vgl. Sacusse, Ueber einige chemische Vorgänge bei der Keimung von Pisum sativum, Leipzig 1872; DETMER, Physiologisehe Untersuchungen über die Keimung ölhaltiger Sainen ete., Jena 1875.

2) Literatur: Detsmer, Physiol.-chem. Unters. über Keimung, 1875; GoDLewski, Prixgsheim's Jahrb., Bd. 13; Moeller, Berieht d. Deutschen botan. Gesellschaft, Bd. 2; STICI, Flora, 1891; Bonvier und Margis, Annal. d. sc. nat, Sér. 6, T. 17 u. 18, geben hier eine z. B. auch von STICII benutzte Methode der Gasanalyse an, die in manchen Füllen sehr gute Dienste leistet. Ferner vergl. Boxvier und MANGIx in Annal. d. se. nat.ję Sér. 6, T. 19; Sér. 7, T. 2. 
hahn und wartet etwa eine halbe Stunde, bis man zur Ablesung des Quecksilberstandes in $r$ schreitet. Die Ablesungen werden stets unter Benutzung eines Fernrohres ausgeführt. Man ermittclt natürlich auch die Länge der Quecksilbersäule, bestimmt ebenfalls die Temperatur sowie den Barometerstand. Für die Berechnungen ist es erforderlich, den Volumeninhalt der Glasglocke, des Rohres $r$ und des Rohres $r_{1}$ bis zum Glashahn zu kennen. Von diesem Volumen ist aber dasjenige sämmtlicher Gegenstände im Apparat (Schälchen mit Kalilauge, Glasdreifuss, Porzellanschale, feuchtes Fliesspapier, Untersuchungsobjecte) zu subtrahiren. Das Volumen dieser Objecte ermittelt man zum Theil durch Eintauchen in Wasser, das sich in einem calibrirten Gefass befindet. Grosses Gewicht ist auf genaue Ablesung der Temperatur sowie des Barometerstandes zu legen. Die Reduction der Gasvolumina kann leicht unter Benutzung der auf S. 231 angegebenen Formel geschehen.

Die wesentlichste Fehlerquelle der Methode liegt darin, dass man die Ablesungen bei Beginn der Versuche nicht sofort, sondern erst nach etwa einer halben Stunde, wenn die Temperaturverhältnisse sich ausgeglichen haben, vornehmen kann. Während dieser halben Stunde nehmen die Pflanzen aber schon Sauerstoff auf, und um die Quantität desselben annähernd $\mathrm{zu}$ bestimmen, corrigirt man das thatsächlich gefundene Volum von den Pflanzen absorbirten Sauerstoffs, indem man demselben eine Quantität hinzuaddirt, die sich durch Rechnung für die Zeit einer lalben Stunde ergiebt. Diese Correctur ist natürlich nur dann nahezu zutreffend, wenn die Untersuchungsobjecte während der Beobachtungszeit keine wesentliche Aenderung ihrer Athmungsenergie erfahren.

Die zur Absorption der Kohlensäure dienende Kalilauge wird genau gewogen. Sie muss nahezu concentrirt und völlig klar sein. Bei Abschluss eines jeden Experinentes bringt man die Lauge in ein Kölbchen, verdünnt mit Wasser und füllt die Kohlensäure mit $\mathrm{B} \mathrm{Cl}_{2}$ aus. Zum Auswaschen des Niederschlages auf dem Filter benutzt man zunächst mit $\mathrm{Ba} \mathrm{CO}_{3}$ gesättigtes, dann reines Wasser. Das Quantum des gefüllten kohlensauren Baryts bestimmt man nach dem Trocknen und schwachem Glühen durch Wägung und rechnet die Kohlensäure auf das Volumen bei $0^{\circ} \mathrm{C}$. und $1000 \mathrm{~mm}$ Barometerstand um. Da die benutzte Kalilauge stets schon von vornherein mehr oder minder reich an kohlensaurem Kali ist, so muss durch besondere Versuche der Kohlensäuregehalt der Lauge festgestellt und mit in Rechnung gestellt werden ${ }^{1}$ ).

Unter Benutzung unseres Apparates kann man zahlreiche physiologische Fragen behandeln. Vor allem ist es lehrreich, die Athmung keimender Samen näher zu verfolgen, und die bezüglichen Experimente führt man aus, indem man z. B. $2 \mathrm{~g}$ Weizenkörner, $4 \mathrm{~g}$ Erbsen oder $1 \mathrm{~g}$ Samen von Raphanus sativus nach dem Anquellen auf das feuchte Fliesspapier legt. Nach je 24 Stunden, wird der Apparat geöffnet, die Kalilauge durch neue ersetzt und die Beobachtung fortgeführt. Die Temperatur ist stets recht constant, z. B. auf 15 oder $20^{\circ} \mathrm{C}$. zu halten.

Bei den Experimenten mit Weizen findet man z. B., dass $2-2,5 \mathrm{~g}$ Körner mit fortschreitender Keimung auch wachsende Mengen $\mathrm{O}$ aufnehmen und $\mathrm{CO}_{2}$ produciren. Vom 5. Tage an werden in je 24 Stunden bei $20^{\circ} \mathrm{C}$. etwa $20 \mathrm{ccm} \mathrm{CO}_{2}$ producirt und $20 \mathrm{ccm} \mathrm{O}$ absorbirt. Der

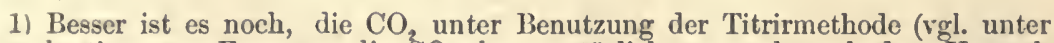
102) zu bestimmen. Es muss die $\mathrm{CO}_{2}$ dann natürlich vor und nach dem Versuch aus der Kalilauge mit $\mathrm{Ba} \mathrm{Cl}_{2}$ ausgefällt werden, um erst die restirende Flüssigkeit $\mathrm{zu}$ titriren. 
Respirationsquotient ist hier (und überhaupt bei stärkereichen Pflanzentheilen) nahezu $=1$. Bei der Keimung fettreicher Samen (z. B. Raphanus) findet man einen Quotienten von $0,6-0,8$. Es wird voll ilınen relativ viel $\mathrm{O}$ aufgenommen, da das Fett bei der Keimung eine Oxydation erleidet und Kohlehydrate aus demselben entstehen.

\section{0\%. Das Verhalten der Pflanzen in Contact mit Stickstoff- oxydulgas.}

Es ist mehrfach die Behauptung' aufgestellt worden, dass die Pflanzenzellen im Stande seien, den Sauerstoff des Stickstoffoxydulgases für die Zwecke der normalen Athmung zu verwerthen. Ich habe die bezïglichen Fragen einer speciellen Untersuchung unterzogen ${ }^{1}$ ), und zwar sind meine Experimente in folgender Weise angestellt worden. Ein retortenartiges Gefäss (vgl. Fig. 11) von ca. $90 \mathrm{ccm}$ Capacität wurde mit ausgekochtem und dann wieder in einem verschlossenen Gefäss völlig abgekühltem, destillirtem Wasser angefüllt, und das Wasser (larauf durch Stickstoffoxydulgas verdrängt $(n)$. Eine Retorte $(b)$ wurde mit ausgekochtem Wasser angefüllt und $\mathrm{N}_{2} \mathrm{O}$ eingeleitet, nachdem zuvor 20 Stück 7 Tage alte, im Dunkeln erwachsene Erbsenkeimlinge eingeführt worden waren. Eine dritte Retorte (c) wurde ebenso mit Wasser sowie Erbsenkeimlingen beschickt, dann aber atmosphärische Luft eingelassen. Das Stickstoffoxydulgas stellt man dar, indem man käufliches salpetersaures Ammonium in einer Retorte erhitzt und das entweichende Stickstoffoxydulgas vor dem Auffangen zur Befreiung von etwa vorhandenen kleinen Mengen von Stickstoffoxyd und salpetriger Säure durch eine Auflösung von schwefelsaurem Eisenoxydul sowie durch Kalilauge leitet. Beim Einleiten der Gase ist darauf zu achten, lass eine ganz kleine Wassermenge in der Retortenröhre zurückbleibt. Die Apparate blieben bei meinen Versuchen, nachdem sie in der angegebenen Weise beschickt worden waren, 20 Stunden lang bei etwa $20^{\circ} \mathrm{C}$. ruhig stehen. Ihre Röhrenmündungen tauchten in Quecksilber ein, und die erwähnten geringen Wasserquantitäten hatten eben den Zweck, die Keimpflanzen vor den schädlichen Quecksilberdämpfen $z u$ schützen. Nach Verlauf von 20 Stunden wurden sämmtliche Apparate, ohne dass aber Luft in dieselben eintrat, unter Wasser gebracht, welches man zweckmässig durch Eisstücke auf niederer Temperatur erhält. Es erfolgte nun allmählich eine fast völlige Absorption der in den Retorten $a$ und $b$ vorlandenen Gasmengen, während in der Retorte $c$ ein grosses Gasvolumen zurückblieb. Das Stickstoffoxydul konnte demnach nicht von den Keimpflanzen zersetzt worden sein. Die geringen Gasmengen, welche nach der Absorption des $\mathrm{N}_{2} \mathrm{O}$ in der Retorte $a$ (bei Abwesenheit von Kieimpflanzen), sowie in (ler Retorte $b$ (bei Gegenwart von Keimpflanzen) zurückblieben, stammten offenbar aus dem als Absorptionsflüssigkeit dienenden Wasser ${ }^{2}$ ).

1) Vgl. Detmer, Landwirthschaftl. Jahrbücher, Bd. 11, S. 213. Vgl. auch Mölluer, Ber. d. Deutschen botan. Gesellsch., Bd. '2.

2) Mit dem Finleiten des Stickstoffoxyduls in die retortenartigen Gefässe beginnt man natürlich erst nach längerer Entwickelungsdauer des Gases, wenn dasselbe luftfrei ist. Bei Abschluss der Experimente bringt man die Apparate zweckmässig nicht in kaltes Wasser, sondern in kalten Alkohol, der das Stickstoffoxydulgas stärker absorbirt. 
Wir stellen ferner den folgenden Versuch an, um uns noch specieller davon zu überzeugen, dass Samen nicht im Stickstoffoxydulgas zu keimen vermögen. Zwei letortenartige Gefässe ( $a$ und $b$ ) werden mit ausgekochtem und in verschlossenen Gefässen völlig abgekühltem, destillirtem Wasser angefüllt. In jedes Gefäss bringen wir noch einige angequollene Weizenkörner, tauclien die Mündung der Apparate unter Quecksilber und verdrängen das Wasser in a dureh Stickstoffoxydulgas, das Wasser in $b$ aber dureh atmosphärische Luft. Im Laufe von einigen Tagen keimen die Körner in $b$; diejenigen in $a$ keimen nicht. Werden sie abel an die Luft gebracht und normalen Keimungsbedingungen ausgesetzt, so entwickeln sich ihre Keimtheile nachträglich, im Falle die Untersuchungsobjecte nicht zu lange Zeit, z. B. nur 2 Tage, im Stickstoffoxydulgas verweilt haben.

\section{Die Alkoholbildung in Pflanzen und das Verhalten anaërober Organismen.}

Wir verschaffen uns aus einer Brauerei Bierwürze, füllen etwa $200 \mathrm{ecm}$ derselben in einen Kolben und fügen ihr eine kleine Menge recht reiner Hefe hinzu, die mit etwas Wasser zu einem Brei angerührt worden ist. Den Trockensubstanzgehalt der Hefemenge haben wir durch einen Controlversuch erinittelt. Nach Verlauf längerer Zeit, wenn die Gährung, die alsbald lebhaft wird, sehwächer geworden ist, sammeln wir die Hefe des Kolbens auf einem gewogenen Filter und finden bei der Trockensubstanzbestimmung, dass unter dén bezeichneten Umständen eine bedeutende Hefeproduction stattgefunden hat.

Saccharomyces cerevisiae wächst lebhaft bei reichlichem Saucrstoffzutritt. Unter diesen Umständen vermag der Pilz aber auch in gewissen Nährlösungen ebenso wie bei beschränktem Luftzutritt oder völligem Sauerstoffmangel recht lebhafte alkoholische Gährung zu erregen, eine Thatsache, die man leicht constatiren kann, wenn man durch Bierwürze, die einen reichlicheren Hefezusatz empfangen hat, Luft mit Hülfe eines Aspirators hindurchsaugt oder gar Sauerstoff aus einem Gasometer in dieselbe einleitet.

Hierbei und in vielen anderen Fällen kommt es darauf an, ein Maass für den Verlauf der Gährung zu gewinnen. Dies Maass gewinnt man durch Ermittelung der bei der Gährung zersetzten Zuckermenge oder der producirten Alkoholquantität.

Bei den Zuckerbestimmungen werden 10 ccm der PASTEuR'schen Lösung, mit der man z. B. experimentirte, derartig verdünnt, dass sie nur noch $1 / 4-1 / 2 \%$ Zucker enthalten, und, wenn Rohrzucker zur Herstellung der PASTEUR'schen Lösung benutzt worden war, mit Schwefelsäure längere Zeit erhitzt. (Vgl. unter Zuckerbestimmung.) Die Zuckerbestimmungen sind dann mit Hülfe der FeHLrvg'schen Lösung leicht auszuführen. Die gegohrene Flüssigkeit ist in jedem Fall vor Ausführung der Zuckerbestimmungen im verdïnnten Zustande längere Zeit zu erhitzen, urn den Alkohol zu verjagen.

Quantitative Alkoholbestimmungen sind in folgender Weise auszuführen. 200 cem der vergohrenen Flüssigkeit werden, ohne sie $\mathrm{zu}$ filtriren, in einem $400 \mathrm{ccm}$ fassenden Kolben der Destillation unterworfen. Zur Vermeidung des Ueberschäumens der Flüssigkeit bringt man ein Stückchen Paraffin in dieselbe. Der Kolben, in welchem man 
das Destillat auffängt, ist, un Alkoholverlusten volzubeugen, fast luftdicht zu verschliessen. Den Kühler muss während der Destillation kaltes Wasser durchströmen. Hat man etwa $100 \mathrm{ccm}$ Destillat gewonnen, so bestimmt man das specifische Gewicht desselben mittelst der Westrual'schen Waage. Aus dem gewonnenen Resultat lässt sich dann direct unter Benutzung geeigneter Tabellen (vergl. KösIG, Untersuchung landwirthschaftlich und gewerblich wichtiger Stoffe, Tabelle 15) der Alkoholgehalt von $100 \mathrm{ccm}$ Destillat in Gewichtsoder Volumenprocenten ableiten. Die gefundene Zahl ist endlich noch bei Anwendung von $200 \mathrm{ccm}$ vergohrener Flüssigkeit und $100 \mathrm{ccm}$ Destillat durch $2 \mathrm{zu}$ dividiren, da das Destillat die Gesammtalkoholmenge der ursprünglichen Flüssigkeit enthält.

Kommt es darauf an, Gährungsversuche unter Durchleiten von Gasen (Luft, Wasserstoff) durch die Nährlösungen auszuführ'en, so benutzt man den in Fig. 104 dargestellten Apparat. Der trichterförmige Theil $A$ des die Nährlösung aufnehmenden Gährgefässes geht in das mit einer Kugel versehene Glasrohr $B$ über. In dem Kautschulikork $K$ steckt das Thermometer $T$ und das Gasableitungsrohr $G$. Durch $B$ wird der Flüssigkeit $G$ as zugeführt, welches sie von unten her durchströnt. Der Theil $A$ des Apparates hat einen Gehalt von ca. $250 \mathrm{ccm}$. Um den Alkohol nicht zul verlieren, den das Gas mit fortreisst, wird $G$ mit einem Condensationsapparat in Verbindung gesetzt. Dieser besteht aus einem Glaskölbchen, das mittelst eines doppelt durchbohrten Korkes verschlossen werden kann. In der einen Bohrung steckt ein Gasableitungsrohr, in der anderen das Gaszuleitungsrohr, dessen in dem Kölbchen befindlicher Theil ein Schlangenrohr darstellt. Das untere Ende dieses Schlangenrolires taucht in Wasser ein, das den Boden des Kölbchens bedeckt. Die Condensationsvorrichtung findet in einem grossen Glase Platz, welches Wasser und Eisstückchen enthält. Soll ein Versuch, bei dem die Gährung noch nicht vollendet ist, unterbrochen werden, um z. B. nach bestimmter

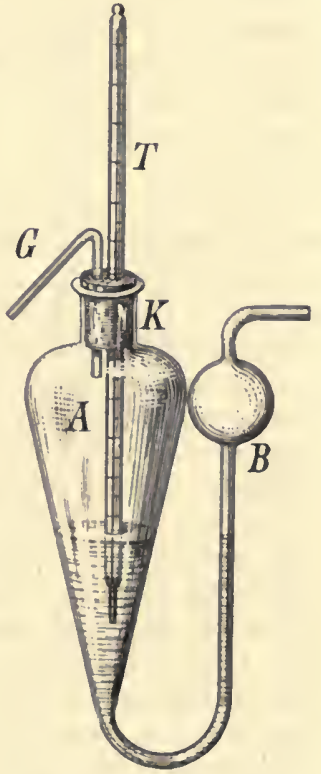

Fig. 104. Apparat zu Gährungsversuchen. Zeit die producirte Alkololmenge zu ermitteln, so öffnet man das Gährgefäss und fügt der Nährlösung, um momentanen Stillstand der Gährung zu erzielen, 20 ccm 5-proc. Sublimatlösung hinzu.

Der hier beschriebene Apparat leistet z. B. gute Dienste, wenn es darauf ankommt, den Nachweis zu liefern, dass Hefe in Bierwürze sowohl bei Sauerstoffabwesenheit als auch bei Luftzutritt starke Gährung hervorbringt, während die Gährung unter Benutzung PASTEUR'scher Nährlösung bei Luftzutritt nur schwach, bei Sauerstoffabwesenheit aber lebhaft ist. Ueber die $\mathrm{zu}$ verwendende Hefe vgl. unter „Bezugsquellen“. Der Nährlösung in $A$ sind einige cem Hefeflüssigkeit zuzusetzen ${ }^{1}$ ).

1) Näheres über Gährungsversuche siche bei Cirudrakow in Landwirthsehl. Jahrbücher, Bd. 23. Vergl. Anmerkung 1 auf S. 240. 
Handelt es sich nur darum, qualitativ die Alkoholbildung in Folge der Gährung festzustellen, so verfährt man genau in derselben Weise. Das gewonnene Destillat wird aber nochmals der Destillation unterzogen. Die nun resultirende Flüssigkeit riecht stark nach Alkohol; sie ist brennbar. Löst man doppeltchromsaures Kali in wenig Wasser auf, setzt etwas concentrirte Schwefelsäure hinzu und bringt einige Tropfen dieser Mischung in das letzte Destillat, so färbt sich dasselbe grün, weil die Chromsäure, indem der vorhandene Alkohol oxydirt wird, eine Reduction erleidet.

Um die selır wichtige Thatsache zu constatiren, dass höhere Pflanzen bei Abwesenheit des freien Sauerstoffs, indem sie intramolekulare Athmung unterhalten und schliesslich allmählich absterben, Alkohol produciren, experimentiren wir mit Weinbeeren, Kirschen oder Erbsen. Die Untersuchungsobjecte werden 1 Minute lang zur Tödtung ihnen etwa äusserlich anhaftender Hefezellen in Sublimatlösung $(1: 1000)$ gelegt und gut mit Wasser abgespült. Die Früchte benutzt man dann sofort zum Versuch. während die Erbsensamell durch Uebergiessen mit Wasser angequollen und auf feuchtem Fliesspapier $1-2$ Tage lang angekeimt werden ${ }^{1}$ ). Nun füllt man einen Literkolben mit den Früchten oder Keimpflanzen gänzlich an und verschliesst mit einem durchbolirten Kautschukkork, in dessen Bohrung der kürzere Schenkel eines zweimal im rechten Winkel gebogenen Glasrohres steckt, während der längere Schenkel in Quecksilber eintaucht. Der Sauerstoff im Apparat ist bald verbraucht. Es kommt schnell intramolekulare Athmung zu Stande, und diese hat eine oft wochenlange Gasentwickelung zur Folge, die schliesslich langsam wird, um endlich völlig aufzuhören, wenn die Untersuchungsobjecte abgestorben sind. In diesem Zustande gehen sie, an die Luft gebracht, schnell in Zersetzung über. Haben die Früchte oder Keimlinge 3-4 Wochen lang im Apparat verweilt, so öffnet man denselben, zerquetscht das Pflanzenmaterial und unterwirft es (die Keimpflanzen nach Zusatz von Wasser) der Destillation. Die Früchte liefern etwa $1 \% \%$ Alkohol (auf das Gewicht des frischen Materials bezogen), die Erbsenkeimlinge $5 \%$ Alkohol vom Gewicht der Trockensubstanz. Der Alkohol ist in oben angegebener Weise leicht als solcher nachzuweisen. Dem gebildeten Alkohol sind stets aromatische Verbindungen und Fuselöl in mehr oder minder grosser Menge beigemischt 2 ).

Die Hefe vermag, wie zumal PAsteun's werthvolle Untersuchungen ergeben haben, nicht nur bei Zutritt der Luft, sondern auch, freilich langsamer, bei völligem Sauerstoffmangel zu wachsen. Dagegen gehört der Butter'säureorganismus (Clostridium butyricum, ein Spaltpilz) zu den obligaten Anaërobien. Der Spaltpilz tritt in Form kurzer und längerer Stäbchen auf. Wir bereiten 5-proc. Rohrzuckerlösung, der wir etwas Fleiscliextract, so dass die Flüssigkeit gelblich erscheint, hinzusetzen. Ausserdem fügen wir zu der Lösung etwas kohlensaures

1) Wasser und Fliesspapier sind vorher zu sterilisiren.

2) Die Alkoholproduction seheint wirklich, so weit wir heute orientirt sind, eine Function des lebensthätigen Protoplasmas zu sein. Der ganze Gegenstand bedarf aber einer ferneren, sehr eingehenden experimentellen Behandlung. Es sind dabei zumal auch die Schädigungen ins Auge zu fassen, welche Pflanzenzellen thatsächlich erfahren, wenn sie längere Zeit in sauerstofffreiem Raun verweilen. 
Kali, so dass sie $\mathrm{schwach}$ alkalisch reagirt. Noch geeigneter ist folgende Nährlösung. Auf 11 Wasser $50 \mathrm{~g}$ Kartoffelstärke, 0,5 g Chlorammonium, 0,2 g schwefelsaure Magnesia, $1 \mathrm{~g}$ saures phosphorsaures Kali und $25 \mathrm{~g}$ Kreide. Werden die Lösungen sich in nicht gar $z u$ fest verkorkten, dickwandigen Gefässen in Thermostaten bei $35^{\circ} \mathrm{C}$. selbst überlassen, so macht sich schon an 2. oder 3. Tage lebhafte Gährung geltend. Die Gasentwickelung $\left(\mathrm{CO}_{2}\right.$ und $\left.\mathrm{H}\right)$ ist in Folge des spontanen Auftretens des Buttersäureorganismus, wie ich es auch beobachtete, eine so energische, dass die Korke mit Gewalt fortgeschleudert werden, und die Flüssigkeiten nehmen alsbald den charakteristischen Geruch nach Buttersäure an. Wir wollen nun den Nachweis von der anaëroben Natur des Clostridium butyricum führen. Dazu stellen wir den in Fig. 105 abgebildeten Apparat zusammen.

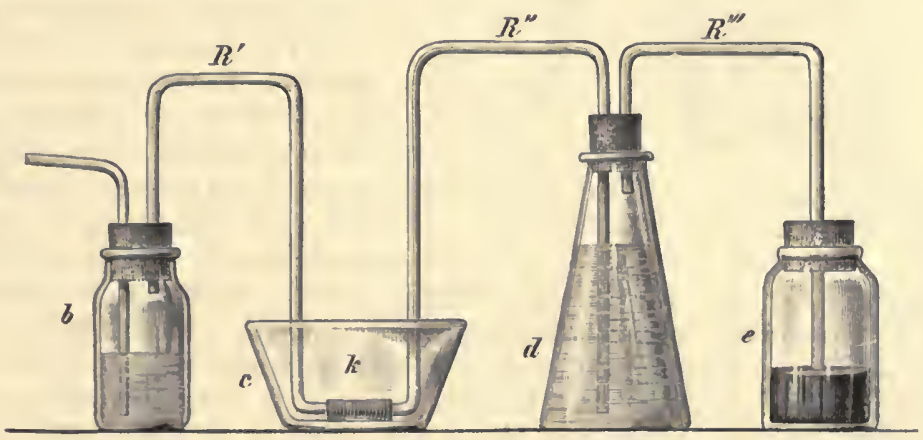

Fig. 105. Apparat zur Constatirung der Thatsache, dass es Organismen giebt, die bei völligen Sauerstoffausschluss $\mathrm{zu}$ wachsen vermögen.

Der Kolben $d$ von ca. 500 ccm Capacität wird zu $2 / 3$ mit Nährlösung von der angegebenen Zusainmensetzung angefüllt. Man versieht die Mündung des Kolbens mit einem Wattepfropf und kocht die Lösung etwa $1 / 2$ Stunde lang zur Sterilisirung. Nach dem Erkalten entfernt man die Watte, inficirt den Kolbeninhalt schnell mit einigen Tropfen einer Flüssigkeit, in der bereits Butter'säuregährung eingetreten ist, und verschliesst die Mündung des Gefässes sofort mit einem doppelt durchbohrten, sehr gut passenden Kautschukkork. Die Glasröhren $R^{\prime}, R^{\prime \prime}$ und $R^{\prime \prime \prime}$, welche in der aus der in Fig. 105 ersichtlichen Art gebogen sind, hat man vor Zusammenstellung des Apparates sterilisirt. Das Rohr $R^{\prime \prime}$ mündet mit seinem längeren Schenkel in das Quecksilber des Gefüsses $e . \quad R^{\prime}$ und $\mathrm{R}^{\prime \prime}$ sind in dem Gefässe $c$ mittelst des kurzen Kautschukschlauches $k$ mit einander verbunden. Das Gefäss $b$ enthält eine Lösung von übermangansaurem Kiali.' Nun entwickelt man aus arsenfreiem Zink und Salzsäure (dlas zur Verdünnung derselben dienende Wasser ist vorher, um es möglichst von Luft zu befreien, ausgekocht worden) Wasserstoffgas, welches, bevor es in $b$ eintritt, noch eine mit Kalilauge beschickte Waschflasche passirt hat. Diese Waschflasche sowie der KIPP'sche Apparat sind in unserer Figur nicht dargestellt (vgl. aber Fig. 97). Man leitet etwa 2 Stunden lang Wasserstoff durch den zusammengestellten Apparat, um allen Sauerstoff $\mathrm{zu}$ verdrängen, giesst dann Quecksilber in die Schale $c$ und 
entfernt den Schlauch $k$, so dass die Mündung des Glasrohres $R^{\prime \prime}$ nun unter Quecksilber geöffnet ist. Der Apparat wird bei $35^{\circ} \mathrm{C}$. im

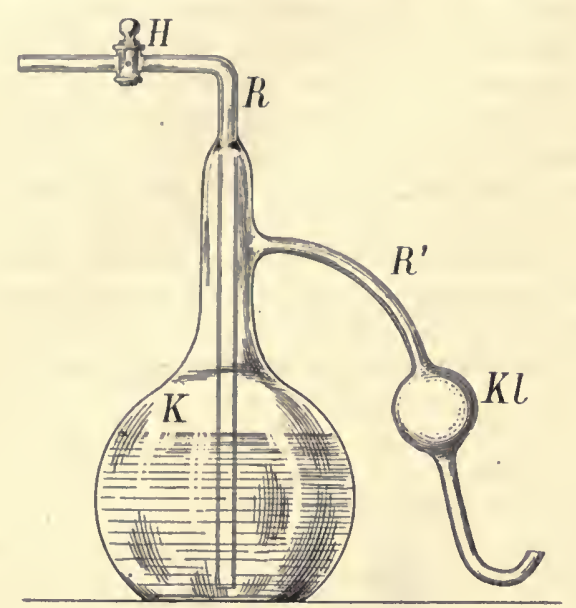

Fig. 106. Apparat zu Gährungsversuchen bei Ausschluss des freien Sauerstoffs. Thermostaten aufgestellt. Im Laufe einiger Tage beginnt die Gährung. Die Flüssigkeit in $d$ trübt sich mehr und mehr, und man sieht also, dass der

Buttersäureorganismus im Stande ist, sich bei völligem Ausschluss des freien atmosphärischen Sauerstoffs zu entwickeln ${ }^{1}$ ). Will man den Versuch mit Hefe ausführen, so verwendet man Bierwürze als Nährlösung, die man mit wenig möglichst reiner Hefe inficirt.

Sehr bequem ist es auch, bei den Experimenten den in Fig. 106 abgebildeten Apparat zu verwenden. Der Kolben $K$ fasst ea. $250 \mathrm{ccm}$. Man füllt ihn mit Nährlösung an und kocht diese zur Sterilisirung.

Nach dem Erkalten der Lösung führt man durch das mit dem Glashahn $H$ versehene Gaszuleitungsrohr $R$ mittelst einer dünnen Glasröhre cine kleine Flüssigkeitsmenge in den Apparat ein, die Clostridium oder Hefezellen enthält, leitet 2 Stunden lang Wasserstoff durch die Lösung im Kolben, führt das Ende des Rohres $R^{\prime}$ unter Quecksilber und schliesst den Hahn $H$ sofort. Die Kugel $K l$ am Rohr $R^{\prime}$ hat nur den Zweck, den Uebertritt von Quecksilber in den Kolben bei erheblicherer Temperaturabnahme im Laboratorium unmöglich zu machen.

\section{Die Wärmeentwickelung und die Phosphorescenz der Pflanzen.}

Mit dem Athmungsprocesse der Pflanzen ist nothwendig eine Freiwerdung von Wärme verbunden. Die Eigenwärme der Gewächse kann unter Umständen eine bedeutende Höhe erreichen, und man hat z. B. gefunden, dass lebhaft athmende Gewebemassen zuweilen um mehrere Grade wärmer als ihre Umgebung sind. Insbesondere ist die Selbsterwärmung des Kolbens der Aroideenblüthenstände eine beträchtliche ${ }^{2}$ ),

1) Literatur zu diesem Abschnitt: A. MAYER, Lehrbuch d. Gährungschemie, 1874, Nachtrag 1876; PAsteur, Compt. rend., 1861, T. 52; ebenso in den Jahrgängen 1863, 1872 u. 1875, ferner in Etude s. l. bière, 1876; BREFELD. Landwirthschaftl. Jahrbücher, 1874, 1875 u. 1876. Ueber Alkoholbildung in Zellen höherer Pflanzen vergl. BREFELD, Landwirthschaftl. Jahrbücher, 1876, S. 324, und LECHARTIER et BELLAMY, Compt. rend., T. 69,75 und 79 . Ueber anaërobe Organismen vergl. PASTEur's citirte Schriften und Prazmowskr, Unters. über einige Bacterienarten, Leipzig 1880; DETMER, Lehrbuch der Pflanzenphysiologie, 1883, S. 173.

2) Vgl. G. Kraus, Abhandlungen d. naturforsch. Gesellschaft zu Halle, Bd. 16. In dieser Schrift ist auch die Literatur zusammengestellt. 
aber da dieses Untersuchungsobject nicht immer zur Verfügung steht, so wollen wir zur Constatirung der Thatsache, dass Pflanzen Wärme produciren, zunächst keimende Samen verwenden, mit denen die Experimente zu jeder Zeit bequem ausgeführt werden können. Wir benutzen Ien in Fig. 107 abgebildeten Apparat. Unter einer Glasglocke steht ein Gefäss $G$, welches starke Kalilauge enthält. Auf den Trichter $T$ gelangt zunächst ein kleines durchstochenes Filter, und ferner werden die Keimpflanzen, welche man bezüglich ihrer Selbsterwärmung untersuchen will, ill den Trichter gebracht. Der Tubulus der Glasglocke ist mittelst eines Korkes versehlossen, durch dessen Bohrung ein Thermometer $T m$ in den Apparat eingeführt wird, so dass die keimenden Samen den Quecksilberbehälter des Thermometers vollkommen umgeben. Das Keimpflanzenmaterial gewinit man leieht, indem man die Samen (Pisum, Triticum) nach dem Anquellen in Glasschalen auf feucht gehaltenes Fliesspapier legt, auf welchem die Keimung alsbald beginnt. Neben den mit Keimpflanzen beschickten Apparat stellt man noch einen zweiten, genan ebenso eingerichteten auf. Der Trichter wird aber nicht mit in Entwickclung begriffenen Pflanzen, sondern mit Papierkügelchen, die mit Wasser durchtränkt worden sind, angefüllt. Ich experimentirte z. B. mit 4 Tage alten Weizenkeimlingen, die auf einem Trichter von etwa $200 \mathrm{ccm}$ Capacität zusammengehäuft waren. Das Thermometer zeigte nach Verlauf einiger Zeit $19^{\circ} \mathrm{C}$., während das Thermometer des mit feuchten Papierkügelchen beschickten Apparates nur $17^{\circ} \mathrm{C}$. angab. Temperaturüberschuss ler Keimpflanzen also $=2{ }^{\circ} \mathrm{C}$. Bei der Benutzung des beschriebenen Apparats braucht man nicht $\% u$ befürchten, dass dic Untersuchungsobjecte Sauerstoffmangel leiden, denn es ist ja kein luftdichter Verschluss hergestellt, und die producirte Kohlensäure wird

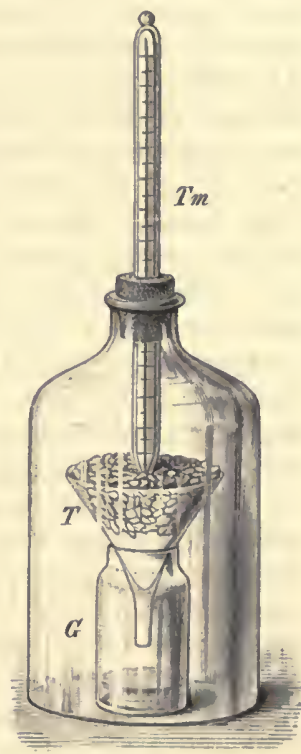

Fig. 107. Apparat zum Nachweis der Eigenwärme der Pflanzen.

von der Kalilauge absorbirt. Dagegen ist es wichtig, die Apparate einige Stunden, bevor die Temperaturablesungen (z. B. in einer Vorlesung) gemacht werden sollen, zusammenzustellen und mit Keimpflanzen, resp. Papierkügelchen zu beschicken. Ebenso ist es nothwendig, die beiden Thermometer, welche man benutzt, vor Anstellung der Experimente sorgfältig mit einander zu vergleichen. Lehrreich ist es auch, an Stelle der Keimpflanzen Blüthen, z. B.' von Anthemis oder Bellis, als Untersuchungsobjecte zu verwenden. Die Wärmeproduction dieser Pflanzentheile ist eine ziemlich ausgiebige.

Zur Constatirung ler Thatsache, dass bei der durch Hefezellen erregten allkoholischen Gährung Wärme frei wird, verfährt man cinfach in folgender Weise. Man stellt zwei Cylinder $(A$ und $B$ ) auf. In $A$ bringt man $300 \mathrm{ccm}$ PAsteur'scher Nährlösung (vgl. über Bereitung derselben unter 18), in $B 300 \mathrm{ccm}$ Wasser. Beide Flüssigkeiten erhalten einen erheblichen Hefezusatz und werden sich dann bei etwa $24^{\circ} \mathrm{C}$. selbst überlassen. Wenn in Cylinder $A$ lebhafte 
Gährung eingetreten ist, bestinmt man den Temperaturzustand der Flüssigkeiten. Es ergiebt sich, dass die Flüssigkeit im Cylinder $A$ um $1-2^{\circ} \mathrm{C}$. wärmer ist als das Wasser im Cylinder $B$.

Bei eingehenderen und genaueren Untersuchungen über die Eigenwärme der Pflanzen können wir bequem das in Fig. 97 abgebildete, mit Schlangenrohr versehene Respirationsgefäss von ca. $200 \mathrm{ccm} \mathrm{In-}$ halt verwenden. Wir bedürfen zweier solcher Apparate. Den einen füllen wir mit 4 oder 5 Tage alten Weizen- oder Gerstenkeimlingen an, die in Sägespänen erwachsen sind, den anderen mit Keimlingen, die wir in kochendem Wasser, welchem etwas Salicylsäure zugesetzt war, getödtet haben. Beide Apparate werden mit einander mittelst eines Kautschukschlauches verbunden, mit den sorgfältig verglichenen Thermometern versehen und, völlig in Watte verpackt, in einen Holzkasten gestellt. Dieser findet in einem nach Norden gelegenen Raum, in welchem die Temperatur wenig schwankt, seinen Platz. Den Apparat mit den lebenden Pflanzen verbinden wir mit einem Aspirator und leiten einen langsamen dampfgesättigten Luftstrom über die Untersuchungsobjecte hin. Die Luft tritt in das Schlangenrolır des mit dem getödteten Material angefüllten Gefässes ein. Die von Zeit zu Zeit (etwa jede halbe Stunde) anzustellenden Temperaturbeobachtungen ergeben, dass die frischen Untersuchungsobjecte alsbald eine um $2-3^{\circ} \mathrm{C}$. höhere Temperatur gewinnen als die getödteten. Diese letzteren entwickeln keine Eigenwärme, während die lebendigen Keimlinge eine erhebliche Temperatursteigerung erfahren.

Wir wollen nun noch durch unsere Apparate etwa 1 Stunde lang einen kräftigen Wasserstoffstrom (das Gas wird gereinigt, indem man es Waschflaschen passiren lässt, die übermangansaures Kali und Kalilauge enthalten) leiten. Ist dies geschehen, so schliessen wir den Hahn $H^{\prime \prime}$ (Fig. 97) und ebenso einen Hahn, welcher sich an dem Schlangenrohr des mit den getödteten Pflanzen angefüllten Apparates befindet. Die Gefässe, immer in Watte eingepackt, bleiben sich nur einige Stunden lang selbst überlassen. Der Temperaturüberschuss der lebendigen Keimlinge ist jetzt, da dieselben intramolekulare Athmung unterhalten, ein nur sehr geringfügiger, etwa $0,2-0,3^{\circ} \mathrm{C}$; er steigt aber schnell wieder auf $2-3^{\circ} \mathrm{C}$, wenn man abermals Luft durch die Apparate leitet.

Beobachtungen über Wärmeentwickelung von Keimlingen bei normaler Athmung zeigten mir auch, dass dieselbe um so bedeutender ausfällt, je mehr sich die Temperatur, bei der man experimentirt, dem Temperaturoptimum $\left(40^{\circ}\right.$ C.) nähert. Dies ist ganz natürlich, denn mit steigender Temperatur machen sich Stoffwechsel sowie Athmung in den Pflanzenzellen (also auch Wärmeentwickelung) lebhafter geltend als beï niederer Temperatur.

Wenn man unsere Apparate statt mit Keimlingen mit hinreichenden Mengen der Keulen der Blüthenstände von Arum maculatum beschickt, deren Spatha sich eben geöffnet hat (den einen Apparat mit getödteten, den anderen mit lebendigen Keulen), so findet man den Temperaturüberschuss des normalen Untersuchungsmaterials bei intramolekularer Athmung etwa $=0,2^{\circ} \mathrm{C}$, bei normaler Athmung aber $=10-15^{\circ} \mathrm{C}$.

Eingehende Untersuchungen über die Eigenwärme der Blüthen sind von Dutrochet, Hoppe, G. KraUs und vielen Anderen durchgeführt worden. Man benutzt zu denselben zweckmässig in Töpfen cultivirte Exem- 
plare von Colocasia cordifolium oder von Arum maculatum, die man längere Zeit vor der Blüthe im Frühjahr mit dem Erdballen in Töpfe eingesetzt hat. Die Pflanzen werden in einem nach Norden gelegenen Zimmer, in welchem möglichst geringe Temperaturschwankungen herrschen, diffusem Licht ausgesetzt. Die Eigenwärme der Blüthen lässt sich erst dann leicht constatiren, wenn die Geschlechtsorgane des Blüthenstandes zur Reifo gelangt sind und die Scheiden sich öffnen. Diese Eigenwärme. kann man schon durch einfaches Anlegen empfindlicher Thermometer z. B. an die Blüthenkeule nachweisen.

Besser experimentirt man in folgender Weise. Die Keule eines blühenden Arumexemplares wird etwas aus der Scheide hervorgezogen und dem cylindrischen Quecksilberbehälter eines empfindlichen Thermometers, das an einem geeigneten Stativ befestigt ist, angelegt. Mittelst eines dünnen Kautschukringes erfolgt die Befestigung des Pflanzentheiles am Thermometer. Man kann auch zweckmässig Thermometer mit dem oberen Keulenende in Berührung bringen, deren Quecksilberbehälter man die Form einer doppeltwandigen Glocke gegeben hat. In jedem Falle ist natürlich auch die Lufttemperatur im Versuchsraum genau zu ermitteln. Es ergiebt sich, dass die untersuchten Pflanzentheile um einige Grad C. wärmer als die umgebende Luft sind. Bei längere Zeit (mehrere Tage) fortgeführten Beobachtungen findet man die Differenz zwischen der Temperatur der Luft und der Theile des Blüthenstandes nicht zu jeder Tageszeit genau gleich. Vielmehr ist diese Differenz gewöhnlich zu einer bestimmten Zeit des Nachmittags am grössten. Es besteht also, was sehr merkwürdig ist, eine tägliche Periodicität der Blüthenwärme ${ }^{1}$ ).

Kommt es darauf an, überhaupt nur den Nachweis zu führen, dass in den Keulen der Aroideenblüthenstände eine selır erhebliche Wärmeproduction erfolgt, so werden z. B. blühende Pflanzen von Arum maculatum abgeschnitten, mit der Stengelbasis in Wasser gestellt und einige Keulen nach Entfernung der Blüthenstandsscheiden mittelst dünner Kautschukringe an dem cylindrischen Quecksilberbehälter eines empfindlichen Thermometers befestigt.

Wir stellen zwei Kolben von ca. $500 \mathrm{ccm}$ Inlialt ( $a$ und $b$ ) auf.

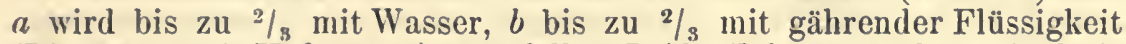
(Bierwürze mit Hefezusatz) angefüllt. Beide Kolben werden mit dreifach durchbohrten Kautsclıkkörken verschlossen. Die Bohrungen eines jeden Korkes dienen zur Aufnahme eines Thermometers, eines bis auf den Boden reichenden Gaszuleitungs- und eines Gasableitungsrohres. Das Ableitungsrohr des Kolbens $b$ wird, nachdem man die Kolben in Watte eingepackt hat, mit einem Aspirator in Verbindung gesetzt. Ein langsamer Luftstrom passirt dann zunächst den Kolben $a$ und dann den Kolben $b$, der mit ersterem durch einen Gummischlauch verbunden ist. Nach Verlauf einiger Zeit findet man, dass die gährende Flüssigkeit ca. $2^{\circ} \mathrm{C}$. wärmer als das Wasser ist, und diese Temperaturdifferenz bleibt auch bestehen, wenn man Wasserstoff durch die Flüssigkeiten leitet. Die Hefe erzeugt also, im Gegensatz zu anderen Pflanzen, bei normaler sowie intramolekularer Athmung etwa die gleichen Wärmemengen ${ }^{2}$ ).

1) In manchen Fällen empfiehlt es sich auch, die Pflanzen bei den Untersuchungen, um deren Transpiration recht zu beschränken, unter grossen, nicht völlig luftdicht schliessenden, aus Zink und Glastafeln construirten Käfigen zu halten.

2) Vgl. Erikssox, Unters. a. d. bot. Inst. zu Tübingen, Bd. 1. 
In manchen Fällen ist es zweckınässig, die. Eigenwärıne der Pflanzen unter Anwendung thermoelektrischer Apparate nachzuweisen. Diese Methode kann unter anderem bei der Untersuchung von Sprossen benutzt werden, deren Erwärmung im Allgemeinen eine nur geringfügige ist. Ich hatte Gelegenheit, bei derartigen Versuchen $\mathrm{zu}$ erfahren, dass z. B. lebendige Helianthussprosse von ea. $15 \mathrm{~cm}$ Länge •im dampfgesättigten Raum einen Temperaturüberschuss von ca. $0,3^{\circ} \mathrm{C}$. gegenüber len getödteten Vergleichsobjecten zeigten. Wir experimentiren mit dem in Fig. 108 dargestellten Apparat nach DuTrocheT's Vorgange ${ }^{1}$ ).

Die durch Zusammenlöthen der Enden des Eisenbügels $e$ mit den Kupferdrähten $o$ und $h$ gewonnenen und sorgfältig mit Firniss

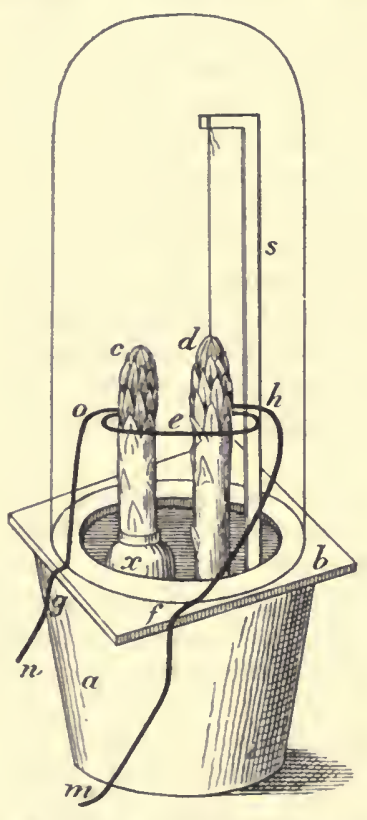

Fig. 105. Dutrochet's Apparat zu thermoelektrischen Untersuchungen an Pflanzen. überzogenen Spitzen sind in den lebenden Spross $c$ und in den durch Eintauchen in heisses Wasser getödteten Spross $d$ eingeführt, deren 'Temperaturdifferenz durch den Ausschlag des zwischen den Drähten $n$ und $m$ eingeschalteten Galvanometers ermittelt werden soll. Durch besondere Vorversuche ist natürlich festzustellen, wie gross der Ausschlag am Galvanometer ist, der $z$. B. $0,1^{\circ}$ C. Temperaturdifferenz entspricht.

In unserel Figur ist der getödtete Spross $d$ mittelst eines am Träger $s$ befestigten Fadens aufgehängt, während der lebende Spross in das Wassergefäss $x$ eingestellt ist. Zur Erzielung dampfgesättigter Luft sind die Versuchspflanzen in den Blumentopf $a$ gebracht, dessen Rand mit einer Gypsplatte $b$ bedeckt ist, auf welcher eine am unteren Rande mit feuchtem Sand umgebene Glasglocke ruht.

Bei der Handhabung der hier erwähıten Methode ist mehr, als dies seither geschehen, auf die Möglichkeit zu achten, dass schon allein in Folge der Berührung der thermoelektrischen Nadeln init den feuchten Pflanzentheilen elektrische Ströme entsteheı.

Dass einige Pflanzen in Folge ilıres Lebensprocesses Licht entwickeln, ist eine erwiesene Thatsache. So existiren z. B. eine Reihe phosphorescirender Bacterienarten, und ich hatte selbst einmal Gelegenheit, das durch Spaltpilze verursachte Leuchten faulender Fische zu beobachten.

Ebenso ist die Pliosphorescenz von Agaricus olearius, Agaricus melleus und Xylaria hypoxylon bekannt. Die bezüglichen Erscheinungen sind besonders voll FABRE und LUDwIG in Greiz studirt worden. Agaricus melleus wächst zumal an Nadelhölzern, und wenn man im Herbst Wurzeln der befallenen Bäume ausgräbt oder Theile der Holzstöcke sammelt, welche sein Mycelium enthalten, so kann man das

1) Vgl. Dutrochet, Annal. d. sc. nat., 1840, Sér. II, T. 13, p. 5. Vgl. auch Pfeffer, Handbuch, Bd. 2. 
Leuchten des Holzes im Dunkelı leicht beobachten, besonders wenn dasselbe vorher einen Tag lang in feuchten Keller verweilt hat. Merkt man sich die von der genannten Agaricusart befallenen Bäume oder Stöcke, dann hat man Gelegenheit, zu jeder Jahreszeit „Leuchtlıolz: zu beschaffen.

Die erwälınte Xylariaspecies ist während des ganzen Jalıres an Buchenstöcken zu finden. Das inficirte Holz leuchtet mit grünlichgelbem Licht. 'Das Licht, welches vom Mycel des Agaricus melleus durchsetztes "Leuchtholz" aussendet, erscheint dagegen weisslich mit einem Stich ins Grünliche.

Wird Leuchtholz kurze Zeit lang in Wasser von 80 oder $100^{\circ} \mathrm{C}$. eingetaucht, so leuchtet es nachträglich im Dunkeln nicht mehr, da der Pilz durch den Einfluss der hohen Temperatur getödtet worden ist. Ebenso hört das Leuchten des Holzes bei Sauerstoffentziehung, Z. B. in einem Wasserstoffstrom auf, stellt sich aber bei Luftzutritt wieder ein. Das Leuchten ist Folge eines Oxydationsprocesses, dev durch das lebensthätige Protoplasma in noch nicht näher bekannter Weise vermittelt wird.

\section{Das Verhalten der stickstofffreien plastischen Stoffe der Pflanzen.}

\section{Das Amylum als Reservestoff.}

In sehr zahlreichen Reservestoffbehältern sind die stickstofffreieu Substanzen in Form von Amylum abgelagert. Man kann sich von dieser Thatsache überzeugen, wenn man zarte Sclınitte aus den Cotyledonen der Erbse oder Bohne, aus dem Endosperm eines Weizenkornes, aus einer Kartoffelknolle oder dem Rhizom von Canna indica in einen Wassertropfen auf den Objectträger bringt und dic Schnitte miliroskopisch untersucht. Die Stärkekörner in den Zellen sind leicht als solche zu erkennen, und zum Ueberfluss kann man sie noch durch Jodzusatz blau färben. Auch in den Markstrahlen sowie im Holzkörper der Bäume und Sträucher wird die Stärke sehr allgemein während des Winters als Reservestoff aufgespeichert ${ }^{1}$ ). Ich erhielt besonders günstige Resultate, als ich Zweige von Berberis vulgaris, Fraxinus excelsior und Fagus silvatica im Januar und Februar mit Bezug auf das in Rede stehende Verhältniss untersuchte. Man stellt Quer- und Längsschnitte durch das $\mathrm{Holz}$ von Berberis vulgaris her, legt dieselben in einen auf dem Objectträger befindlichen Tropfen von Jorlglycerin (darlurch bereitet, dass man Joll längere Zeit mit Glycerin in Berührung gelassen hat), bedeckt mit einem Deckglas und erwärmt den Objectträger über einer Spiritustlamme. Nach dem Erkalten zeigt sich bei mikroskopischer Untersuchung, dass zumal die Markstrahlen, aber auch Elemente des Holzes blau gefärbte,

1) Vgl. Saxio, Untersuchungen über die in Winter Stärke führenden Zellen des Holzes, Halle 1858. 
verkleisterte Stärkemassen enthalten. Das Holz von Fraxinus besteht aus weiten und engen Gefässen, spärlichem Holzparenchym, das sich zumal in der Umgebung der Gefässe vorfindet, und Holzfasern. Querschnitte durch das Eschenholz, die man in der angegebenen Weise mit Jodglyeerin behandelt, lehren, dass namentlich die Markstrahlzellen reich an Amylum sind. Bei Fagus ist im Holz ausser den Gefässen und Holzfasern ziemlich viel Holzparenchym, das in tangentialen Binden auftritt, vorhanden. Dieses letztere, sowie die Zellen der breiten Markstralılen, ist sehr amylumreich. Im Frühjahr verschwindet die Stärke aus den Markstrahlen und dem Holztheil der Gefässbündel. Offenbar wandert das Amylum jetzt aus den erwähnten Geweben, in denen es als Reservestoff aufgespeichert war, aus, um den wachsenden Theilen der Pflanzen zuzuströmen.

Wollen wir uns genauer über den Stärkegehalt oines Rhizoms orientiren, so wählen wir den horizontal im Boden kriechenden Wurzelstock von Pteris aquilina zur Untersuchung. Wir können Alkoholmaterial benutzen, wählen aber nicht zu dicke Rhizomstücke aus. Das Grundgewebe besteht der Hauptsache nach aus Parenchym, dessen Zellen sehr reichliche Amylummengen führen, und wird von sehr mächtig entwickelten Sklerenchymplatten durchsetzt, die schon bei makroskopischer Betrachtung eines Rhizomquerschnittes als breite, schwarze Linien hervortreten. Zwischen diesen Sklerenchymplatten sind die bicollateralen Gefässbündel leicht zu erkennen. Jedes Gefässbündel wird von einer einfachen Schicht stärkereicher Zellen (Vorscheide) und der eigentlichen, aber stärkefreien Endodermis umgeben.

Auf die Bedeutung der in Reservestoffbehältern aufgespeicherten Stärke kommen wir noch oft zurück. Es sei hier nur erwähnt, dass die Stärke das wichtigste stickstofffreie Reservematerial der Pflanzen darstellt und dass sie, wenn sie für die Entwickelung bestimmter Organe der Gewächse verwerthet werden soll, zunächst in lösliche Verbindungen übergefübrt wird, welche die Reservestoffbehälter verlassen können. Unter Vermittelung diastatischer Fermente wird nämlich die Substanz der Stärke, wie wir unter 112 sehen werden, in Glycose umgewandelt, welche die Wanderung der Amylumsubstanz ermöglicht.

\section{Die quantitative Amylumbestimmang.}

Es sind bereits an anderer Stelle zalllreiche Angaben über die Eigenschaften sowie das Verhalten der Stärkesubstanz gemacht worden. Hier handelt es sich zumal darum, auf die Methode hinzuweisen, welche bei quantitativen Amylumbestimmungen in Anwendung zu bringen ist. Das Amylum als solches ist bekanntlich nicht im Stande, reducirend auf FEHLING'sche Lösung einzuwirken; dagegen kann die Stärke durch Einwirkung von Säuren in Traubenzucker übergeführt werden, und die Menge desselben lässt sich leicht mit Hülfe der FEHLivg'schen Flüssigkeit feststellen. 2-3 g reiner Kartoffelstärke, die bei $100-110^{\circ} \mathrm{C}$. vom Wasser befreit worden sind, werden in einem Kolben mit $200 \mathrm{ccm}$ Wasser erhitzt. Die Flüssigkeit erhält dann noch einen Zusatz von $20 \mathrm{ccm}$ 25-proc. Salzsäure und wird unter Ersatz des verdunstenden Wassers 3 Stunden lang in lebhaft kochenden 
Wasserbade erhitzt ${ }^{1}$ ). Die erkaltete Flüssigkeit wird mit Kali neutralisirt und auf 500 cem gebracht ${ }^{2}$ ). Man erhitzt jetzt verdünnte FenLING'sche Lösung in einer Porzellanschale auf dem Wasserbade. fügt $20 \mathrm{cem}$ der zuckerhaltigen Lösung hinzu und erhitzt noch weitere $10-15$ Minuten $^{3}$ ). Das gebildete Kupferoxydul wird möglichst schnell auf einem Filter gesammelt, mit heissem Wasser ausgewaschen und getrocknet. Jetzt verbrennt man das Filter, glüht das Kupferoxydul im Platintigel unter Zusatz von etwas Salpetersäure und bestimmt schliesslich das Gewicht des erhaltenen Kupferoxyds. 220,5 Theile desselben entsprechen 100 Theilen Traubenzucker oder 90 Theilen Stärke. Die erforderliche FenLrNG'sehe Flüssigkeit wird in folgender Weise dargestellt. Man löst 34,65 g reinen schwefelsauren Kupferoxyds in $200 \mathrm{ccm}$ Wasser auf, vermischt mit einer Auflösung von $173 \mathrm{~g}$ weinsaurem Natron-Kali in $480 \mathrm{ccm}$ Aetznatronlauge voll 1,14 spec. Gew. (ca. 10-proc. Natronlauge) und verdünnt die Flüssigkeit bei $15^{\circ} \mathrm{C}$. auf $1000 \mathrm{ccm}$.

Es ist noch zu bemerken, dass die Stärke sehr kleine Mineralstoffmengen enthält. Dieselben sind zu bestimmen und in Abzug zu bringen.

\section{Das Vorkommen der Diastase in den Pflanzen und die Wirkungsweise des Fermentes.}

Die Diastase ist freilich sehr verbreitet im Pflanzenreich, aber die in verschiedenen Pflanzenarten vorhandenen Diastasequantitäten sind keineswegs die nämlichen. Sehr diastasereich ist die gekeimte Gerste. Wird das aus einer Brauerei bezogene Malz auf einer kleinen Handmühle zermahlen, so gewinnt man ein Pulver, das sich in hohem Grade zur Darstellung einer diastasehaltigen Lösung eignet. $25 \mathrm{~g} \mathrm{Malz-}$ pulver übergiesst man mit $100 \mathrm{ccm}$ Wasser, lässt die Flüssigkeit einige Zeit (z. B. 1-2 Stll.) unter häufigem Umrühren mit dem Pulver in Berührung und filtrirt die Lösung endlich ab. Versetzt man $25 \mathrm{ccm}$ 1-proc. Stärkekleister (hergestellt durch Vermischen von $100 \mathrm{ccm}$ destillirten Wassers mit $1 \mathrm{~g}$ Kartoffelstärke 'und Erhitzen bis zum Sieden) mit $5 \mathrm{cem}$ der klaren Diastaselösung, so macht sich die Amylumumbildung alsbald bemerklich. Sogleich nach Herstellung des aus Kleister und Malzextract bestehenden Gemisches nimmt eine Probe desselben auf Zusatz einer Spur alkoholischer Jodlösung eine blaue Farbe an. Nach wenigen Minuten ist die Stärke und Diastase enthaltende Flüssigkeit klar geworden, aber eine Probe derselben färbt sich auf Jodzusatz noch blau. Wartet man einige Zeit, so nimmt eine Probe der Versuchsflüssigkeit auf Jodzusatz eine violette Färbung an. Noch später färbt sich eine Probe der Versuchsflüssigkeit auf Jodzusatz braun, und schliesslich (etwa nach $2-3$ Stunden) bringt Jod keine erhebliche Färbung einer Probe der Versuchsflüssigkeit

1) Früher benutzte man Schwefelsäure zur Ueberführung des Amylums in Traubenzucker. Der Gebrauch der Salzsäure ist aber vorzuziehen. Vgl. R. SACHSSE, Phytochemische Untersuchungen, 1850, S. 47.

2) Ueber anderweitige, zum Theil noch genauere Methoden der Stärkebestimmung vergl. Kösıg, Anleitung zur Untersuchung landwirthschaftl. wichtiger Stoffe, 1891, S. 231.

3) Zu bemerken ist noch, dass die zuckerhaltigen Flüssigkeiten, welche der heissen FEHLING'schen Lösung zugesetzt werden, nicht mehr als etwa 1/4-1/2 \% Zucker enthalten dürfen. 
ınehr hervor. Unter dem Einflusse der Diastase wird die Anylumsubstanz bekanntlich in eine Reihe nach einander entstehender Dextrinarten sowie Zucker (Maltose) umgewandelt. Diese Dextrine färben sich auf Jodzusatz nicht sämmtlich in der nämlichen Weise, und daher gewährt die Jodreaction ein sehr bequemes Mittel, um den Fortgang des Processes der Stärkeumbildung durch Diastase genauer zu verfolgen. Aus Gründen, die Wortmanx in seiner unten citirten Arbeit näher darlegt, ist es zur ganz sicheren Constatirung der diastatischen Wirkung eines Pflanzenauszuges geboten, zumal bei Gegenwart geringer Fermentquantitäten, das Jod erst nach Aufkochen und völliger Viederabkïlllung der aus dem Pflanzenextract und Kleister bestehenden Flüssigkeit zuzusetzen. Tritt dann keine Bläuung ein, so ist sicher keine Stärke mehr vorhanden. Die Zuckerbildung lässt sich ebenfalls leicht constatiren. Man bestimmt mit Hülfe der FEHLING'schen Lôsung den Zuckergehalt von $5 \mathrm{ccm}$ Malzextract (vergl. unter 115), versetzt $25 \mathrm{ccm}$ Kleister mit $5 \mathrm{ccm}$ Malzextract und ermittelt nach einigen Stunden den Zuckergehalt der Versuchsflüssigkeit. Es ergiebt sich, dass dieselbe weit zuckerreicher ist als 5 cem Malzextract.

Wird eine nicht zu kleine Menge möglichst concentrirten Malzextractes mit einem grossen Ueberschuss von absolutem Alkohol versetzt, so entsteht ein voluminöser Niederschlag. Man sammelt denselben auf einem Filter, wäscht mit Alkokol aus und trocknet den Rückstand an der Luft. Derselbe besteht aus einer Reihe verschiedener Stoffe, enthält aber auch die durch den Alkohol gefällte Diastase. Löst man eine kleine Menge der trockenen Masse in Wasser auf, so erhält man eine sehr energisch stärkeumbildend wirkende Flüssigkeit.

Von Interesse ist es, noch einige Versuche anzustellen, welche beweisen, dass nicht nur Gerstekeimpflanzen, sondern ebenso andere Keimpflanzen, Blätter und Stengel verschiedener Gewächse Diastase enthalten. Ich habe einige Tage alte Weizenkeimlinge sowie 10 Tage alte Erbsenkeimpflanzen (die Untersuchungsobjecte hatten sich im Finstern entwickelt), ferner Laubblätter von Sedum maximum und Stengel von Impatiens Balsamina im Mörser zerquetscht, mit wenig Wasser übergossen und die Flüssigkeiten nach einiger Zeit abfiltrirt. Die gewonnenen Lösungen wirkten in Berührung mit Kleister, wie sich mit Hülfe der Jodreaction feststellen liess, stärkeumbildend. Da die Untersuchungsobjecte aber bei weitem nicht so viel Diastase wie die Gerstenkeimlinge enthalten, so ist es zweckmässig, sehr verdünnten Kleister $z u$ benutzen und nur eine kleine Menge desselben (vielleicht $2 \mathrm{ccm}$ ) mit grösseren Quantitäten der Pflanzenauszüge (etwa $20 \mathrm{ccm}$ ) in Berührung zu bringen ') ${ }^{2}$ ).

Zur Herstellung der diastasehaltigen Auszüge werden die Pflanzentheile zerschnitten, mit etwas Wasser im Mörser zerquetscht und dann 2-6 Stunden lang mit ihrem doppelten bis vierfachen Volumen Wasser in Berülırung gelassen. Endlich erfolgt Filtration. Wenn man in dieser Art operirt, so kann man das Ferment freilich in Pflanzentheilen entdecken, die reich daran sind. Bei Gegenwart kleiner Diastasequantitäten reicht die Methode aber nicht aus, und Wortmans kommt daher auch zu dem Schluss, dass z. B. viele

1) Vgl. Detmer, Landwirthschaftl. Jahrbücher, Bd. 10.

2) Näheres vergl. bei Wortmaxx, Botan. Zeitung, 1890. 
Laubblätter, in denen er unter Benutzung des angegebenen Verfahrens keine Diastase auffinden konnte, kein isolirbares Ferment führen. Die Stärkeauflösung soll dann durch das Protoplasma direct vermittelt werden. Dies mag seine Richtigkeit für manche Fälle haben; indessen Brown und MorRIs wiesen neuerdings mit Nachdruck darauf hin, dass es in vielen Fällen überhaupt nicht zu enıpfehlen sei, die frischen Pflanzentheile zur Extraction der Diastase mit IIasser zu behandeln. Die Zellen dieser frischen Pflanzentheile sind nicht leicht sämmtlich zu zerquetschen, so dass die Bereitung der Auszïge unvollkommen gelingt, und ein negatives Resultat bei der Prüfung auf Diastase erhalten werden kann, wälırend das Ferment thatsächlich doch in den Pflanzentheilen vorhanden ist. Man gelangt zu viel sichereren Ergebnissen, wenı man die Untersuchungsobjecte zunächst bei etwa $40^{\circ} \mathrm{C}$. trocknet, dann feinstens zerreibt und nun dies Pulver oder Extracte desselben in Stärkekleister einträgt. So findet man, dass auch viele Laubblätter recht diastasereich sind, wovon ich mich unter Benutzung der Laubblätter von Pisum sativum überzeugte ').

Es ist mit Rücksicht auf die Wirksankeit der Diastase in ler PHlanze von Wichtigkeit, sich davon zu überzeugen, dass das Ferment nicht nur Stärkekleister, sondern auch unversehrte Stärkekörner verändern und auflösen kann. 3 cg lufttrockencr Weizenstärke werden in einem Uhrschälchen mit $3 \mathrm{ccm}$ concentrirten Malzextracts oder mit 3 ccm einer wåsserigen Lösung des durch Alkohol gefällten Ferments übergossen. Wendet man diese letztere Flüssigkeit an, so fügt man ihr eine selır kleine Citronensäuremenge hinzu, da, wie unter 113 angegeben ist, Säuregegenwart die Wirksamkeit der Diastase wesentlich begünstigt. Das Uhrglas wird gut zugedeckt, und inan beobachtet im Laufe von $24-28$

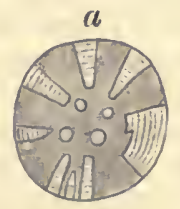

C

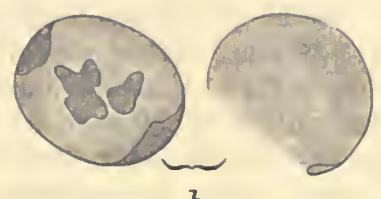

$b$
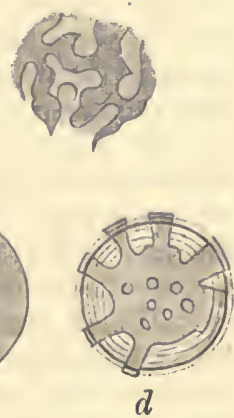

Fig. 109. Stïrkekörner aus dem Endosperm des Weizenkornes in verschiedenen Stadien der Corrosion. $a$ schwach, $b$ stärker, $c$ noch stärker, $d$ am stärksten corrodirt. (Nach BARANETZKY.)

Stunden wiederholt die Veränderungen, welche relativ grosse Stärkekörner erfahren, indem man Tropfen der Flüssigkeit auf den Objectträger bringt und mikroskopisch untersucht. Ich ïberzeugte mich davon, dass sich die einzelnen Körner individuell sehr verschiedenartig unter dem Einfluss der fermenthaltigen Lösung verhalten; im Allgemeinen machen sich die zu Stande kommenden Corrosionen an den Amylumkörnern in der Weise geltend, wie dies in Fig. $109 a, b$, $c$, /l dargestellt ist. Die Auflösung der Stärkesubstanz schreitet von aussen nach innen fort; es entstehen helle, radial gerichtete Streifen, diese werden mit zunehmender Corrosion der Körner breiter, und allmählich schreitet die Veränderung der Körner immer mehr in das

1) Sehr eingehend ist die Literatur über das diastatische Ferment von Schleictiert behandelt worden. Vgl. Nova Acta d. Leop.-Carol. Academ., Bd. 62. 
Innere derselben vor, wobei sich die unter dem Einflusse des Fermentes gebildeten Corrosionscanäle auch vielfach verzweigen, so dass schliesslich das Stärkekorn zerfällt ${ }^{1}$ ).

\section{Der Einfluss versehiedener Substanzen sowie der Tempe- raturverhialtnisse auf den Verlauf des Processes der Stairke- umbildung dureh Diastase.}

In eine Anzahl kleiner Gläser bringt man je $25 \mathrm{ccm}$ 1-proc. Stärkekleisters. Das Gefäss $a$ erhält zunächst keinen weiteren Zusatz. $b$ erhält einen Zusatz von einigen Tropfen Salzsäure, $c$ einen Zusatz von einigen Tropfen einer concentrirten Citronensäurelösung, $d$ einen Zusatz von einigen Tropfen Kalilauge, $\boldsymbol{e}$ einen Zusatz von einigen Tropfen Alkohol, $f$ einen Zusatz von einigen Tropfen Chloroform. In jedes Glas bringt man jetzt noch $5 \mathrm{ccm}$ Malzextract, um den Flüssigkeiten nach Verlauf vou 24 Stunden eine kleine Menge alkoholischer Jodlösung mit Hülfe eines Glasstabes hinzuzufügen. Die Flüssigkeiten $a, e$ und $f$ färben sich nicht blau; alle übrigen nehmen auf Jodzusatz eine blaue Farbe an. Alkohol sowie Chloroform haben die Wirksamkeit der Diastase nicht aufgehoben; die Säuren und das Kali haben das Ferment dagegen unwirksam gemacht.

Mit Bezug auf den Einfluss, welchen Säuren dem diastatischen Fermente gegenüber geltend machen, ist übrigens $\mathrm{zu}$ betonen, dass nur grössere Säuremengen die Wirksamkeit der Diastase vernichten. Versetzt man einerseits $25 \mathrm{ccm}$ Kleister mit $5 \mathrm{ccm}$ Malzextract, andererseits aber $25 \mathrm{ccm}$ Kleister mit $5 \mathrm{ccm}$ Malzextract und $2-3 \mathrm{mg}$ Citronensäure, so erfolgt die Amylumumbildung in der letzteren Flüssigkeit schneller als in der ersteren. Kleine Citronensäuremengen (ähnlich verhalten sich kleine Mengen anderer Säuren) heben die Wirksamkeit der Diastase also nicht auf, sondern begünstigen dieselbe im Gegentheil.

Wenn man einerseits $25 \mathrm{ccm}$ Stärkekleister von 15 oder $20^{\circ} \mathrm{C}$. mit $5 \mathrm{ccm}$ Malzextract von 15 oder $20^{\circ} \mathrm{C}$. versetzt und das Gemisch bei 15 oder $20^{\circ}$ C. stehen lässt, andererseits aber $25 \mathrm{ccm}$ Kleister sowie $5 \mathrm{ccm}$ Malzextract nach erfolgter Abkühlung auf $4^{\circ} \mathrm{C}$. mit einander vermischt, so kann man sich mit Hülfe der Jodreaction leicht davon überzeugen, dass der Process der Stärkeumbildung durch Diastase bei höherer Temperatur weit schneller als bei niederer verläuft. Das Temperaturoptimum für die Diastasewirkung liegt bei $63^{\circ} \mathrm{C}$. (KJELdahL).

Erhitzt man Malzextract zum Sieden und vermischt die wieder erkaltete Flüssigkeit mit Kleister, so ergiebt sich, dass keine Stärkeumbildung erfolgt. Das Ferment ist durch den Einfluss der hohen Temperatur zerstört worden ${ }^{2}$ ).

\section{Die Entstehung der Diastase in den Zellen höherer Pflanzen.}

In zwei retortenartige Gefässe von etwa $90 \mathrm{ccm}$ Capacität bringt man je 20 lufttrockene Weizenkörner, füllt die Gefässe mit ausge-

1) Vgl. Baranetzky, Die stärkeumbildenden Fermente in den Pflanzen, 1878, S. 48. Vgl. auch KrABBE, Jahrbücher f. wissenschl. Botanik, Bd. 21.

2) Vgl. DetMer, Pflanzenphysiologische Untersuchungen über Fermentbildung und fermentative Processe, Jena 1s84, ferner Landwirthschaftl. Jahrbücher, Bd. 10. 
kochtem und wieder abgekühltem Wasser an, verschliesst die Mündungen der Gefässe mit den Finger und stellt jedes derselben in der Art, wie es Fig. 11 zeigt, in einem mit Quecksilber und Wasser gefüllten Glase auf. Nach Verlauf von 24 Stunden wird das Wasser des einen retortenartigen Gefässes durch atmosphärische Luft, dasjenige des anderen durch Wasserstoffgas verdrängt. Den Wasserstoff stellt man durch Uebergiessen von arsenfreiem Zink mit verdünnter Salzsäure in einem geeigneten Apparate dar und leitet das Gas zunächst durch eine Lösung von Aetzkali, dann durch eine solche von iibermangansaurem Kali, um eventuell vorhandene Spuren von Schwefelwasserstoff sowie Kohlenwasserstoffen $\mathrm{zu}$ beseitigen. In den Röhren der retortenartigen Gefässe muss übrigens eine kleine Wassermenge ïber dem Quecksilber zurückbleiben, damit die Untersuchungsobjecte nicht mit Quecksilberdämpfen in Berülırung kommen. Die Weizenhörner, welche sich mit atmosphärischer Luft in Contact befinden, keimen alsbald; im Wasserstoffgas erfolgt keine Keimung. Controlversuche lehren aber, dass die Körner im Wasserstoffgas keineswegs schnell zu Grunde gehen, sondern ihre Keimfähigkeit ziemlich lange (mindestens mehrere Tage) bewahren und ihren Embryo daher zur Entwickelung bringen, wenn sie nachträglich günstigen Keimungsbedingungen bei Luftzutritt ausgesetzt werden. Haben die Untersuchungsobjecte sich 2-3 Tage lang mit atmosphärischer Luft, resp. Wasserstoffgas in Berührung befunden, so werden sie aus den retortenartigen Gefässen herausgenommen, im Mörser zerquetscht und der Brei mit $20 \mathrm{cem}$ Wasser übergossen. Nach einiger Zeit filtrirt man durch vorher nicht angefeuchtete Filter. Versetzt man nun $10 \mathrm{ccm}$ der Filtrate mit $20 \mathrm{ccm}$ verdünnten Stärkekleisters, so ergiebt die Jodreaction, dass der Extract aus den in dem retortenartigen Gefäss bei Luftzutritt zur Entwickelung gelangten Weizenkeimptlanzen ziemlich energisch stärkeumbildend wirkt, während der Auszug aus den Untersuchungsobjecten, die sich in Contact mit Wasserstoff befunden hatten, eine sehr schwache stärkeumbildende Kraft geltend macht. Diese letztere ist nicht grösser wie diejenige eines Extractes, den man durch Behandlung von 20 zerquetschten ruhenden Weizenkörnern mit 20 cem Wasser hergestellt hat. Der angestellte Versuch lehrt also, dass sich in den Zellen höherer Pflanzen nur bei Zutritt des freien atmosphärischen Sauerstoff's Diastase bilden kann').

\section{Dic Bestimmung und der mikrochemische Nachweis der Glyeose.}

Dextrose, Maltose etc. besitzen die Fähigkeit, unmittelbar reducirend auf FEHLING'sehe Flüssigkeit einzuwirken. Diejenigen Zuckerarten, welche sich in dieser Weise verhalten, werden unter der gemeinschaftlichen Bezeichnung "Glycose“ zusammengefasst. Handelt es sich z. B. darum, den Gehalt des Malzes an Glycose zu bestimmen, so wird zunächst in eiwer kleinen Quantität des auf einer Handmühle zermahlenen Untersuchungsmaterials der Trockensubstanzgehalt festgestellt. Ferner werden etwa $\mathbf{3} \mathrm{g}$ des Malzpulvers wielerholt mit

1) Vgl. Drsmer, Botan. Zeitung, 1883, No. 37, und Pflanzenphysiologische Untersuchungen über Fermentbildung und fermentative Processe, Jena 1884. 
kaltem Wasser behandelt und die entstandene Lösung filtrirt. Extracte aus Samen oder Keimpflanzen, mit denen wir es hier ja auch zu thun haben, lassen sich häufig nicht ohne weiteres klar filtriren. Dies gelingt aber leicht, wenı inan längere Zeit gewaschene Kohlensäure in die Flüssigkeit einleitet. Die vereinigten Filtrate fällt man mit Bleiessig, filtrirt und bringt sie auf ein bestimmtes Volumen, z. B. $200 \mathrm{ccm}$. In der erhaltenen Flüssigkeit bestimmt man den Zucker mit FEHLING'scher Lösung (vgl. unter 111).

Nicht zu vergessen ist übrigens bei der Berechnung der Versuchsergebnisse, dass 100 Theile Maltose, die in erster Linie als Zucker in Malzausziigen auftritt, erst so viel Kupferoxyd wie 61 Theile Dextrose reduciren (BROwN und HERON).

Handelt es sich darum, die Gegenwart der Glycose in Geweben auf mikrochemischem Wege zu ermitteln, so stellt man zunächst Schnitte aus den Untersuchungsobjecten, z. B. aus Birnen oder Aepfeln her, die aber nicht zu dünn sein dürfen, damit nicht alle Zellen geöffnet sind. Am besten ist es, wenn die Schnitte 3 Lagen unversehrter Zellen enthalten. Die Schnitte werden in eine concentrirte Kupfersulfatlösung von gewöhnlicher Temperatur gelegt, nach kurzer Zeit mit der Pincette erfasst und oberflächlich abgespült, indem man sie in reines Wasser eintaucht. Jetzt bringt man die Schnitte sofort in siedende Kalilauge ${ }^{1}$ ) oder besser ${ }^{2}$ ) in eine siedende Lösung von $10 \mathrm{~g}$ weinsaurem Natronkali und $10 \mathrm{~g}$ Aetzkali in $10 \mathrm{~g}$ Wasser. Ist Glycose vorhanden, so ist nach wenigen Secunden in denjenigen Zellen, welche dieselbe enthalten, ein schön roth gefärbter Niederschlag von Kupferoxydul entstanden. Die mikroskopische Untersuchung der Schnitte gewährt Aufschluss über die Vertheilung des Zuckers in Gewebe.

Sehr bequem ist auch die folgende Methode des Glycosenachweises. Die Schnitte werden nach dem Umschwenken in Wasser auf dem Objectträger unter Deckglas in einen Tropfen FEHLING'scher Lösung (vgl. unter 111) gelegt. Man erhitzt nun, bis kleine Blasen entstehen, aber nicht länger. Kupferoxydul hat sich dann bei Zuckergegenwart in den Zellen abgeschieden.

\section{Das Dextrin.}

$100 \mathrm{ccm}$ Wasser werden mit $1 \mathrm{~g}$ Kartoffelstärke vermischt und zum Sieden erhitzt. Der erkaltete Kleister empfängt einen Zusatz von einigen Tropfen Schwefel- oder Salzsäure und wird dann wieder erwärmt. Die Flüssigkeit klärt sich schnell, und eine kleine Probe derselben nimmt nach dem Erkalten auf Jodzusatz noch eine blaue Farbe an. Kocht man die saure Lösung weiter, um derselben von Zeit zu Zeit (etwa alle 5 Minuten) kleine Proben zu entnehmen, die man nach dem Erkalten mit Jodlösung versetzt, so zeigt sich, dass die ersten Proben auf Jodzusatz einen violetten, weitere einen rothbraunen und noch weitere einen gelblichen Farbenton annehmen. Diese Farbenreactionen lehren, dass sich unter dem Einflusse der Säure

1) Vgl. Sacis, Prixgsheim's Jahrbücher f. wissenschaftl. Botanik, Bd. 3, S. 187.

Vgl. Artifur Meyer, Berichte d. Deutschen botan. Gesellschaft, Bd. 3, 
aus dem Amylum successive verschiedene Dextrinarten bilden. Zunächst zerfällt die Amylumsubstanz in das sich auf Jodzusatz violett färbende Amylodextrin I und Zucker. Das erstere spaltet sich dann durch die Säurewirkung in Zucker und Amylodextrin II, das sich durch Jod rothbraun färbt. Ferner bilden sich aus dem Amylodextrin II neben Zucker neue Dextrinarten, die sich auf Jodzusatz gelblich färben, und schliesslich verschwindeu die Dextrine völlig; weil sie ihrer Gesammtmasse nach in Zucker übergeführt worden $\operatorname{sind}^{1}$ ). Nach neueren Untersuchungen ist der Vorgang vielleicht ein anderer.

- Dass in den Zellen der Pflanzen Dextrinarten (und zwar auch solche, die sich auf Jodzusatz bräunlich färben) vorkommen, kann man auf folgende Weise feststellen. Erbsensamen werden auf einer Handmühle zu Pulver zermablen. Das Pulver übergiesst man mit nicht zu viel Wasser und leitet nach Verlauf einer Stunde reine Kohlensäure in die trübe Flüssigkeit ein. Dann filtrirt man, und zwar wird diese Operation durch die Gegenwart der Kohlensäure in hohem Grade erleichtert. Eine kleine Menge des klaren Filtrates bringt man mit einem Jodkrystall in Berührung, und man wird finden, dass sich die Flüssigkeit nach und nach bräunlich färbt; sie verhält sich ebenso wie die wässerige Lösung des käuflichen Dextrins, wenn diese mit Jod in Contact gelangt. Reines Wasser nimmt in Berührung mit festem Jod nur einen gelblichen Farbenton an ${ }^{2}$ ). Wird das Verhalten des wässerigen Erbsensamenextractes zu Fu1L1xg'scher Lösung untersucht, so zeigt sich, dass keine Reduction erfolgt. Kocht man dagegen den wässerigen Extract nach Zusatz einiger Tropfen Schwefelsäure längere Zeit, so ist die Flüssigkeit nunmehr im Stande, energisch reducirend auf FeHLING'sche Lösung einzuwirken, weil das Dextrin unter dem Einfluss der Säure in Glycose übergeführt wurde.

\section{1\%. Die Bestimmung und der mikrochemisehe Nachweis des Rohrzuckers.}

Der Rohrzuclier ist ein Bestandtheil vieler Pflanzensäfte, und besonders reich an Rohrzucker ist der Saft der Zuckerrübe. Handelt es sich darum, die Menge des in den Wurzeln vorhandenen Zuckers festzustellen, so verfälırt man nach E. v. WoLFF ${ }^{3}$ ), wie folgt. Die sorgfältig gereinigten Rüben werden in Scheiben zerschnitten. $500-1000 \mathrm{~g}$ dieser Scheiben hängt man an Fäden im Trockenschrank bei $60-70^{\circ} \mathrm{C}$. auf. Die trockene Masse wird zu einem nicht zu feinen Pulver zerstossen, und nach der Gewichtsbestimmung des Pulvers in einer kleinen Quantität desselben $(5-6 \mathrm{~g})$ der Trockensubstanzgehalt festgestellt. 2 -3 g des Rübenpulvers kocht man wiederholt mit 80-85-proc. Weingeist aus, filtrirt die Lösung nach jeder Auskochung ab und wäscht den Rückstand auf dem Filter schliesslich mit heissem Alkohol aus. Die gesammte Lösung velsetzt man nummehr mit viel Wasser und erwärmt so lange auf dem Wasserbade, bis der Alkohol völlig verdampft ist. Jetzt wird die Flüssigkeit auf $300 \mathrm{ccm}$ aufgefüllt. $100 \mathrm{ccm}$ untersucht man sofort mit FEHLING'seher Lösung auf einen Gehalt

1) Vgl. W. NäGEL, Beiträge zur näheren Kenntniss der Stärkegruppe, 1879, und Detien, Landwirthschaftl. Jahrbücher, Bd. 10, S. 752.

2) Vgl. Detwer, Journal f. Landwirthschaft, 27. Jahrgang, S. 379.

3) Vgl. E. v. WolfF, Anleitung zur chem. Unters. landwirthschl. wichtiger Stoffe, $187 \overline{5}$, S. 184 . 
an Traubenzucker; es muss aber bemerkt werden, dass die Menge dessclben, wenn er überhaupt nicht völlig fehlt, selır gering ist. $200 \mathrm{ccm}$ Flüssigkeit erwärınt man nach Zusatz von 4 Tropfen Schwefelsäure 3 Stunden lang unter Ersatz des verdunstenden Wassers auf dem Wasserbade, füllt auf $400 \mathrm{ccm}$ auf und bestimmt in $100 \mathrm{ccm}$ nach erfolgter Neutralisation mit kohlensaurem Natron mit Hülfe der FenLING'schen Lösung die vorhandene Traubenzuckermenge. Schliesslich ist es leicht, aus den gefundenen Werthen den Rohrzuckergehalt der frischen Rüben oder der Rübentrockensubstanz zu berechnen. Ueber Darstellung und Anwendung der FEHLING'schen Lösung ist schon früher (vgl. unter 111) das Erforderliche mitgetheilt worden.

Nach dem Gesagten ist es ohne weiteres klar, in welcher Weise man zu verfahren hat, wenn es sich nur darum handelt, qualitativ die Gegenwart des Rohrzuckers in Rüben nachzuweisen.

Kommt es darauf an, das Vorhandensein des Rohrzuckers in den Rüben auf mikrochemischem Wege nachzuweisen, so werden Schnitte, die nicht $\mathrm{zu}$ dünn ausfallen dürfen, damit nicht sämmtliche Zellen geöffnet sind, in derselben Weise, wie es unter 115 angegeben ist, mit Kupfer- und Kalilösung behandelt. Bei mikroskopischer Betrachtung der Schnitte zeigt sich, dass der Inhalt ihrer Zellen eine schön blaue Färbung angenommen hat, was die Gegenwart von Rohrzucker anzeigt ${ }^{1}$ ). Dieselbe Reaction tritt ein, wenn man die Schnitte auf dem Objectträger unter dem Deckglas in einem Tropfen FEHLiNGscher Lösung erwärmt. (Vergl. unter 115.)

\section{Die Reservecellulose und das Amyloid.}

Es giebt manche Samen, in denen die Cellulose als stickstofffreier Reservestoff auftritt. Ein Dattelkern wird quer durchschnitten, um nun mit Hülfe eines sehr scharfen Rasirmessers einen zarten Querschnitt aus dem Endosperm herzustellen. Die Wände der gestreckten Zellen sind ausserordentlich stark verdickt, aber es sind viele einfache Tüpfel vorhanden. Wir imprägniren einen Schnitt aus dem Endosperm des Dattelkerns mit Jodjodkaliumlösung und lassen darauf vom Deckglasrande aus verdünnte Schwefelsäure, die durch Vermischen von 2 Volumthl. Schwefelsäure mit 1 Volumthl. Wasser hergestellt worden ist, zutreten. Die Verdickungsschichten der Zellwände färben sich schön blau. Werden Schnitte aus dem Endosperm in der früher (unter 42) angegebenen Weise mit Phloroglucinlösung und dann mit Salzsäure behandelt, so tritt keine Rothfärbung der Objecte ein. Die Verdickungsschichten der Endospermzellen sind also nicht verholzt; sie bestehen aus Cellulose. Bei der Keimung des Dattelsamens wird dicse Cellulose verbraucht.

Dieselbe ist aber nicht durchaus identisch mit der gewöhnlichen Cellulose, wie neuere Untersuchungen, z. B. diejenigen von Reiss, (Landwirthschaftliche Jahrbücher, 1889) gezeigt haben, und sie wird daher als Reservecellulose unterschieden.

In den Zellen der Cotyledonen ruhender Samen von Tropaeolum majus sind die Parenchymelemente, wie leicht bei der Untersuchung von Querschnitten zu sehen ist, nit stark verdickten, getüpfelten Membranen

1) Vgl. Sachs, Prixgisielu's Jahrbücher, Bd. 3, S. 183. 
ausgestattet. Zwischen den Zellen beobachtet man dreiseitige Intercellularen. Die Verdickungsschichten färben sich bei Behandlung mit verdünnter Jodjodkaliumlösung direct blau; sie bestehen nicht aus Reservecellulose, sondern aus Amyloidsubstanz. Dieses Amyloid wird bei der Keimung der Tropaeolumsamen verbraucht. Es wird unter Bildung von Corrosiorskanälen aufgelöst, und schliesslich bleibt nur noch die Mittellamelle zwischen den benachbarten Elementen des Parenchyms der Cotyle- 、 donen erhalten.

\section{Das Inulin.}

Das Inulin ist besonders reichlich in den unterirdischen Organen vieler Compositen vorhanden. Es tritt als gelöster Körper im Zellsaft auf und hat die Functionen eines stickstofffreien Reservestoffes. Wird etwas Inulin mit kaltem Wasser übergossen, so zeigt sich, dass sich die Substanz ziemlich schwer in demselben auflöst. Erwärmt man, so löst sich das Inulin dagegen völlig auf. Das Inulin ist nicht im Stande, reducirend auf FEHLING'sche Lösung einzuwirken. Versetzt man aber heisse FEHLING'sche Flüssigkeit mit einer bei höhcrer Temperatur bereiteten Inulinlösung, so tritt die Abscheidung kleiner Mengen Kupferoxyduls ein, weil schon heisses Wasser im Stande ist, geringe Quantitäten des Inulins in Glycose umzuwandeln. Wird wässerige Inulinlösung nach Zusatz einiger Tropfen Schwefelsäure gekoclit, so bildet sich vicl Glycose, und die Flüssigkeit wirkt nunmehr sehr energisch reducirend auf FEHLING'sche Lösung ein. Eine heisse Inulinlösung zeigt beim Erkalten die merkwürdige Erscheinung, dass sich das Inulin nicht sofort, sondern erst nach Verlauf längerer Zeit wieder abscheidet. Fügt man aber zu einer eben erkalteten Inulinlösung einen Ucberschuss von Alkohol linzu, so erfolgt die Abscheidung des Inulins schnell. Die Unlös-

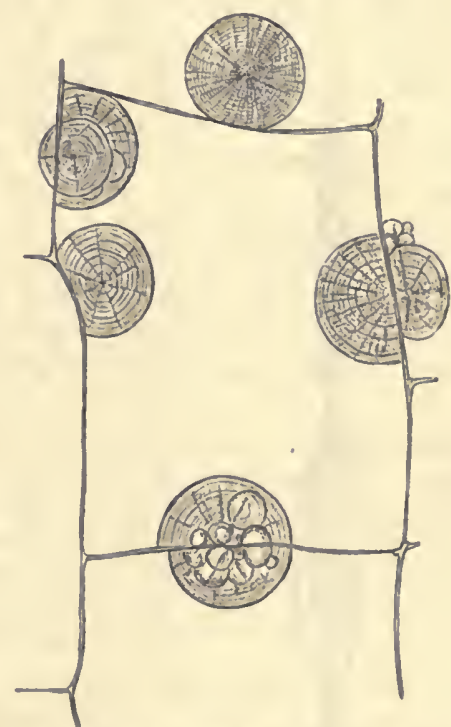

Fig. 110. Zelle aus einem Stück einer Knolle von Dahlia variabilis welches mehrere Monate lang in Alkohol gelegen hatte. Sphärokrystalle an den Wänden. Vergr. 240. (Nach STRASBURGer.) lichkeit des Inulins in Alkohol wird nun bei der mikrochemischen Nachweisung desselben in Pflanzentheilen verwertlıet. Nicht zu dünne Schnitte aus dem Mark der Georginenknolle (Dahlia variabilis) werlen auf dem Objectträger mit Alkohol bedeckt und nach einiger Zeit in Wasser eingetaucht. Bei mikroskopischer Untersuchung der in Wasser liegenden Schnitte zeigt sich, dass sich das Inulin abgeschieden hat. Unter Unständon scheidet sich das Inulin in Form schöner Sphärokrystalle in den Zellen ab. Sehr deutlich treten dieselben hervor, wenn man grössere Stücke der Georginenknollen mindestens 8-14 Tage lang in Spiritus liegen lässt, aus dem 
Alkoholmaterial die Schnitte herstellt und dieselben in Wasser untersucht. Die Sphärokrystalle sitzen den Zellwänden an; sie stellen kugelige Gebilde von charakteristischem Aussehen dar ${ }^{1}$ ) (vgl. Fig. 110).

\section{Die Pflanzenfette und die quantitative Bestimmung derselben.}

Wenn man getrocknete und zerkleinerte Pflanzenmassen mit Aether extrahirt, so erhält man eine Lösung, die beim Eindunsten einen wesentlich aus Fett bestehenden Rückstand liefert. Gewöhnlich ist die Menge der dem Fett beigemengten anderweitigen Stoffe so gering, dass man bei der quantitativen Bestimmung des Fettgehaltes von Pflanzentheilen meist keine Rücksicht auf diese Verunreinigungen zu nehmen braucht. Bei Fettbestimmungen benutzt man zweckmässig den in Fig. 111 dargestellten Apparat.

Der Apparat, nach Soxhlet's Angaben zusammengestellt, ist im Preis von ca. 10 M. von Muencke in Berlin zu beziehen. Er besteht aus dem Kolben $K$, dem eigentlichen Extractionsraum $E$ und

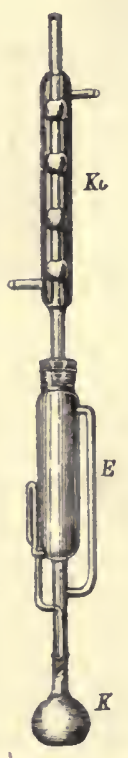
der Kühlvorrichtung $K v$, die mit der Wasserleitung in Verbindung gesetzt wird. Als Extractionsflüssigkeit benutzt man wasserfreien Aether.

Bei der Ausführung der Untersuchungen bringt man $3-5 \mathrm{~g}$ der sehr fein gepulverten und bei Anwendung sehr fettreicher Körper am besten mit reinem Quarzsand zerriebenen Substanz in eine aus Fliesspapier gefertigte Patrone. Diese stellt man her, indem man um einen Holzcylinder, dessen Durchmesser $4 \mathrm{~mm}$ geringer ist als derjenige des Extractionscylinders $E$, ein Stück Fliesspapier zweimal herumrollt, über die Basis des Holzcylinders ein dem Durchmesser desselben entsprechendes Stück der gebildeten Rolle hervorstehen lässt, dieses ähnlich, wie man ein Packet schliesst, umbiegt und den gebildeten Boden der Rolle durch kräftiges Aufdrücken ebnet. Hat man die Substanz eingefüllt, so schliesst man die obere Oeffnung der Patrone ebenfalls durch Umbiegen.

Die gefüllte Hülse wird nun 2-3 Stunden lang im Trockenschrank einer Temperatur von $45^{\circ}$ C. ausgesetzt. Dann erfolgt in bekannter Weise die Extraction mit Aether. Schliesslich wird der Aether der

Fig. 111. Fettextractionsapparat.

Fettlösung im Kolben $K$ abdestillirt und der Rückstand (Rohfett) $1-2$ Stunden lang bei $95^{\circ}$ C. getrocknet, um endlich sein Gewicht festzustellen.

Die Fette bestehen aus Gemischen von freien Fettsäuren und Glyceriden. Um das Glycerin in diesen letzteren überhaupt nachzuweisen, verfuhr ich in folgender Weise. Etwa $75 \mathrm{ccm}$ Olivenöl wurden längere Zeit in einer Porzellanschale auf dem Wasserbade mit verdünnter Kalilauge digerirt. Nach dem Erkalten wurde der Flüssigkeit viel schwefelsaures Natron hinzugefügt, die abgeschiedene Seife abfiltrirt, und das

1) Vgl. Sachs, Botanisehe \%eitung, 1864, S. 25, und Praxtr, Das Inulin, München, 1870 . 
Filtrat mit Schwefelsäure neutralisirt. Ḋann wurde die Flüssigkeit eingedunstet, der Rückstand mit Alkohol behandelt, dio Lösung von den schwefelsauren Salzen abfiltrirt, eingedunstet und der Rückstand zur Reinigung abermals mit Alkohol behandelt, um die Lösung nach erfolgter Filtration wieder einzudunsten. Es bleibt eine syrupartige Flüssigkeit von süsslichem Geschmack, eben das Glycerin, zurück. Wird dieser Rückstand in Wasser aufgelöst und ein Theil der Flüssigkeit mit einer verdünnten Lösung von schwefelsaurem Kupferoxyd vermischt, in der man durch Zusatz von Kalilauge eine Abscheidung von Kupferoxydhydrat hervorgebracht hat, so wird dieser letztere Körper aufgelöst. (Glycerinreaction.)

\section{Die Reactionen der fetten 0ele.}

Wir bringen eine kleine Menge irgend eines fetten Oeles mit Hülfe eines Glasstabes auf den Objectträger, fügen eine Mischung von Alkohol und Aether hinzu, damit sich das Fett auflöse, bedecken mit dem Deckglase und beobachten unter dem Mikroskop. Wenn der Alkoliol und der Aether verdunstet sind, so sehen wir grosse sowie kleine Tropfen in unscrem Präparat, die Fettmassen darstellen. Sie erscheinen, auf den optischen Durchschnitt eingestellt, hellgrau und sind von einem schmalen, schwarzen Ring umgrenzt. Wird der Tubus gesenkt, 'so erscheint jeder Oeltropfen nicht mehr von einem schwarzen, sondern von einem hellen Ringe umsäumt. Die Oeltropfen können nicht wohl mit Luftblasen verwechselt werden, denn hat man diese letzteren im Mikroskop eingestellt und senkt den Tubus, so wird ihre Randpartie nicht hell, sondern der schon bestehende dunkle Rand nimmt im Gegentheil noch an Breite zu.

In den Zellen des Endosperms von Ricinus oder in denjenigen der Cotyledonen von Brassica sind neben den Eiweissstoffen reichliche Fettmengen vorhanden, und um diese nachzuweisen, brauchen wir nur dünne Schnitte aus den erwälnnten Samen auf dem Objectträger mit einer Mischung von Alkohol und Aether zu behandeln. Die sich alsbald abscheidenden Fettropfen sind leicht als solche zu erkennen.

Auch die Alkannatinctur (ein tief gefärbter Auszug aus der Alkannawurzel, der durch Bchandlung derselben mit 70-80-proc. Alkohol hergestellt worden ist) kann zum Nachweis der Fette dienen. Untersucht man z. B. Schnitte aus dem Endosperm von Ricinus, dessen Zellen ein Fett enthalten, das im Gegensatz $\mathrm{zu}$ anderen Fetten löslich in Alkohol ist, so versetzt man die Alkannatinctur mit dem gleichen Volumen Glycerin, schwenkt dic Schnitte in der Mischung einige Male hin und her, spült sie oberflächlich mit Alkohol ab und legt sie in Glycerin. Die Aleuronkörner erscheinen gar nicht oder schwach gefärbt, während die Grundmasse in Folge ihres Fettgehaltes tief roth tingirt ist.

Ein weiteres Reagens auf fette Oele ist die Ueberosmiumsäure in wässeriger 1-proc. Lösung. Legt man Schnitte aus dem Endosperın von Ricinus in diese Lösung, so nehmen dieselben nach einiger Zeit eine dunkle Farbe an, weil die Ueberosmiumsäure das vorhandene Fett schwärzt. $\mathrm{Zu}$ beachten ist übrigens, dass durch die Alkannatinctur sowie die Ueberosmiumsäure nicht nur Fett gefärbt wird. 


\section{Das Verhalten des Fettes bei der Keimung der Samen.}

Sehr zahlreiche Samen (Ricinus, Helianthus, Cucurbita, Brassica etc.) enthalten Fett als stickstofffreien Reservestoff. Dieses Fett ist dem Amylum stärkereicher Samen physiologisch gleichwerthig. Es liefert das Athmungsmaterial und ebenso das Material zur Bildung der Zellhäute. Das Fett geht aber, bevor es an die Verbrauchsorte gelangt, in vielen Fällen (z. B. Ricinus, Cucurbita) zunächst in Stärke und Zucker über. In anderen Fällen, z. B. bei Linum, ist dies fast gar nicht zu beobachten, und dann müssen auch die Fette der Hauptsache nach als solche in den Keimpflanzen wandern, um die Translocation des stickstofffreien plastischen Materials zu ermöglichen. In der That ist von H. SснміDт eine solche Wanderung der Fette von Zelle zu Zelle beobachtet worden. Wir wollen hier den Stoffwechsel bei der Keimung eines fettreichen Samens näher verfolgen, welcher mit der Bildung reichlicher Quantitäten von Kohlehydraten verbunden ist.

Wir wählen als Untersuchungsobject die Samen von Ricinus communis. In einer centralen Höhlung des mächtig ausgebildeten Endosperms liegt der Embryo, der aus den beiden dünnen Cotyledonen und der Keimachse besteht. Die grossen Zellen des Endosperms enthalten, wie wir schon bei anderer Gelegenheit feststellten, eine fettund eiweissreiche Grundmàsse, in der die Aleuronkörner liegen. Stärke ist in den Endospermzellen und ebenso in denjenigen des Embryo, wie man mit Hülfe von Jodreagentien leicht feststellen kann, nicht vorhanden.

Einige Samen von Ricinus werden in Gartenerde, die sich in einem Blumentopfe befindet, bei Lichtabschluss und bei nicht $\mathrm{zu}$ niederer Temperatur (etwa $20^{\circ}$ C.) zur Keimung gebracht. Wenn sich die Hauptwurzel und ebenso das hypocotyle Glied beträchtlich gestreckt haben, der obere Theil des letzteren Organs aber noch gekrümmt erscheint, weil die Cotyledonen noch im Endosperm stecken, so enthalten die Zellen dieses Gewebes, ebenso wie vor der Keimung, keine Stärke, sondern nur Eiweiss und Fett. Die Cotyledonen haben die Aufgabe, die Reservestoffe des Endosperms aufzusaugen, damit diese von der jungen Keimpflanze verwerthet werden können. In den Zellen des Parenclıyms der Cotyledonen ist viel Fett vorhanden; Amylun, das dem Keimblattgewebe vor Beginn der Kcimung, wie erwähnt, völlig fehIte, findet sich in denjenigen Parenchymzellen reichlich, welche den Mittelnerven nach aussen umgeben. Die Cambiumzellen des hypocotylen Gliedes enthalten nur Eiweissstoffe. Das Parenchym der Rinde und des Markes des oberen, noch nicht völlig gestreckten Theiles des hypocotylen Gliedes ist, wie sich in bekannter Weise leicht feststellen lässt, sehr stärke- sowic zuckerreich, während die Menge dieser Körper im unteren gestreckten Theile des hypocotylen Gliedes mehr und mehr abnimmt. In dem fertig gestellten Theile des hypocotylen Gliedes fehlen. Zucker und Stärke im Parenchym; nur in den Zellen der den Gefässbündelring umgebenden Stärkescheide sind Amylumkörner nachzuweisen. Im Gewebe der Hauptwurzel ist jetzt weder Stärke noch Fett zu finden, dagegen führt das Parenchym der sich lebhaft streckenden Nebenwurzeln viel Zucker.

Schreitet die Keimung weiter fort, so verschwindet das Fett immer 
mehr und mehr aus dem Endosperm des Ricinussamens, weil es für die Zwecke des Wachsthums der Keimpflanze Verwendung findet. Das hypocotyle Glied streckt sich gerade, und die Holz- sowie Basttheile der Gefässbündel desselben erfahren eine weitere Ausbildung. In dem Maasse, in welchem diese Streckung des oberen Theiles des hypocotylen Gliedes zu Stande kommt, versehwinden auch die aus dem Fett entstandenen Stärke- und Zuckermengen aus den Zellen des Parenchyms; nur in den Zellen der die Fibrovasalstränge umgebenden Stärkescheide sind noch Amylumkörner nachzuweisen.

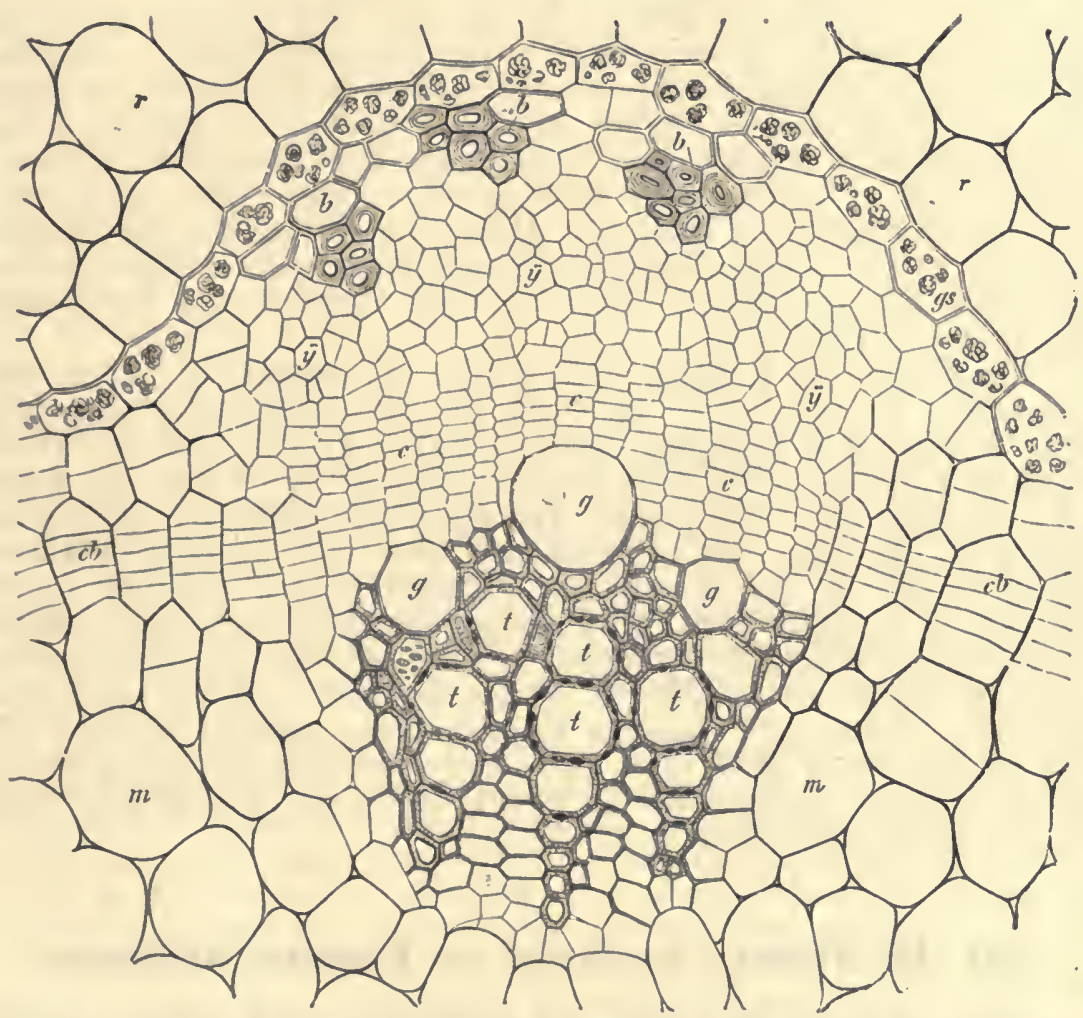

Fig. 112. Theil eines Quersehnittes aus dem fertig gestreekten hypoeotylen Glied vou Ricluns communis. Der Längsschnitt ist in Fig. 33 dargestellt. $r$ Parenchym der primären Rinde, $m$ des Markes. Zwischen $r$ und $b$ die einfache Gefässbündelscheide mit Stärkekörnern (Stärkescheide). Der Fibrovasalstrang besteht aus dem Phloëm $b, y$, dem Xylem $t$, $g$ und den Cambium $c$ c. Das Cambium des Stranges $c \quad c$ setzt sich auch in das zwischen den benachbarten Strängen liegende Grundgewebe fort, als Interfascicularcambium $c b$. Im Phloëm sind $b b$ Bastfasern, y $y$ der Weichbast, z. Th. Parenchym, z. Th. Siebröhren; im Xylem sind $t$ t enge getïpfelte, $g g$ weite getüpfelte Gefä̀sse, dazwischen Holzfasern. (Nach SACHs.)

Die Function der Stärkescheide wird weiter unten genauer behandelt werden; hier genügt es, auf ihre Existenz hinzuweisen. Sie tritt als geschlossene Scheide auf, welche den Gefässbündelkreis umgiebt, und ist, wie Fig. 112 zeigt, im Hypocotyl von Ricinus schön entwickelt. Im Uebrigen vergleiche man die Figurenerklärung. 
Im Allgemeinen lässt sich sagen, dass die Ausbildung der Organe des Ricinusembryo von der Wurzel durch das hypocotyle Glied za den Cotyledonen allmählich aufwärts steigt. Bei beginnender Streckung und innerer Entwickelung der Organe tritt reichliche Stärke in den Zellen des Parenchyms auf. Wenn die Streckung schnell fortschreitet, so ist im Parenchym auch viel Zucker vorhanden. Aber die erwähnten Kohlehydrate verschwinden wieder mit vollendeter Streckung und Ausbildung der Organe aus dem Parenchym; sie sind eben zur Bildung von Zellstoff verbraucht worden ${ }^{\mathbf{1}}$ ).

Es ist angeführt worden, dass im Rinden- und Markgewebe des oberen Theiles des hypocotylen Gliedes von Ricinus, wenn dasselbe noch gekrümmt ist und die Cotyledonen noch im Endosperm stecken, reichliche Stärkemengen vorhanden sind. Diese Amylummenge ist, wie ich feststellte, eine so grosse, dass es möglich ist, ihre Gegenwart in einer Vorlesung makroskopisch zu demonstriren. Schnitte aus dem oberen Theil des hypocotylen Gliedes werden dazu auf dem Objectträger mit Chloralhydrat und Jodjodkaliumlösung behandelt. Halten die Zubörer das mit Deckglas bedeckte Präparat gegen das Licht, so können sie sich in Folge der eingetretenen Blaufärbung des Objects von dem Vorbandensein bedeutender Stärkemengen überzeugen.

Auch bei der Keimung der Samen von Raphanus sativus tritt ziemlich viel Stärke auf. Ich fand im sich streckenden Hypocotyl etwa 4 Tage alter Keimlinge der genannten Art, die sich bei $20^{\circ} \mathrm{C}$. entwickelt hatten, reichlichere Amylummengen. Die Wurzel der Keimpflanzen war recht stärkearm. Im Hypocotyl fand sich die Stärke zumal in der Nähe der Gefässbündel, aber auch in übrigen Parenchym. Wenn in den Keimtheilen ölreicher Samen reichlich Stärke auftritt, so enthalten meist auch die im ruhenden Samen amylumfreien Cotyledonen bei Beginn der Keimung mehr oder minder grosse Stärkemengen und die stickstofffreien Körper wandern in Form von Kohlehydraten. Wenn sich dagegen Fettwanderung geltend macht (z. B. bei Linum), dann sind die Cotyledonen stets stärkefrei, und Kohlehydrate treten auch in den übrigen Organen der Keimpflanze meist nur in geringerer Quantität auf.

\section{Die Keimung der Samen ron Phaseolus multiflorns.}

Ein sehr günstiges Object für das Studium einer Reihe von Stoffwechselprocessen sowie mancher Erscheinungen der Stoffwanderung in der Pflanze bietet der keimende Same der Scliminkbohne (Phaseolus multiflorus) dar ${ }^{2}$ ). Die Samenschale der Bohne besteht, woron man sich bei dem Studium von Querschnitten überzeugen kann, aus vier Schichten. Die innerste Schicht besteht aus zusammengedrückten Zellen. Es folgt dann eine aus mehreren Zelllagen zusammengesetzte Schicht, und zwar führen die Zellen, wenn man es mit bunten Samen zu thun hat, einen rothen Farbstoff. An diese Schicht schliesst sich

1) Vgl. SAcHs, Botanische Zeitung, 1859, S. 177, rgl. ferner DetMer, Vergleichende Physiologie des Keimungsprocesses der Samen, 1880, S. 316, und H. SchMidt, Flora, 1891, S. 320,342 und 314.

2) Vgl. SACHS, Sitzungsberichte der Akadem. d. Wiss. zu Wien, 1859, Bd. 37, S. 57, und Detmer, Vergleichende Physiologie des Keimungsprocesses der Samen, 1880 , S. 308 . 
eine dritte an, die aus recht kleinen Zellen besteht, und endlich folgt die Palissadenschicht, deren Elemente radial zur Samenoberfläche gestreckt und stark verdickt sind. Gruppen von Palissadenzellen führen einen schwarzen Farbstoff, wodurch die Samen ihr geflecktes Aussehen erlangen. Um recht günstige Präparate aus der Samenschale zu gewinnen, ist es nach meinen Erfahrungen zweckmässig, die Bohnen zunächst 24 Stunden lang einzuquellen und dann 12 Stunden lang austrocknen zu lassen. Das auf diese Weise vorbereitete Material lässt sich gut zur Herstellung dünner Querschnitte der Samenschale verwenden. Die Samenschale umschliesst den Embryo, welcher aus den beiden grossen Cotyledonen und der Keimaxe (Wurzel, hypocotyles Glied, erstes Stengelglied, Terminalknospe) mit den beiden Primordialblättern zusammengesetzt ist. Man überzeugt sich leicht davon, dass die Cotyledonen, da ihre nach innen gerichteten Flächen concav sind, einen Hohlraum zwischen sich lassen, und dass die Axe des Embryo knieförmig gebogen ist. Die Cotyledonen bestehen aus der Epidermis, dem mächtig entwickelten Parenchym und den dieses durchziehenden Gefässbündeln. Die Epidermiszellen führen keine Stärke, dagegen sind die Elemente des Parencliyms sehr stärkereich. Ueberdies führen sie Eiweissstoffe, wovon man sich bei der Behandlung von Sehnitten aus den Cotyledonen mit Jod und FEHLING'seher Lösung überzeugen kann. Die Zellen der Gefässbünclel sind amylumfrei; sie führen aber Eiweissstoffe. Feine Querschnitte durch die Keimaxe lehren, dass diese aus der Epidermis, dem Rinden- sowie Markparenchym und der dazwischen liegenden Gefässbïndelregion zusammengesetzt ist. Die Primordialblätter besitzen einen Stiel sowie eine Lamina. Wird ein Blatt auf dem Objectträger im Wassertropfen ausgebreitet, mit Deckglas bedeckt und mikroskopischer Betrachtung unterzogen, so kann man sich von dem Vorhandensein der Nerven in der Lamina überzeugen. Alle Zellen des Parenchyms dieser letzteren sind stärkefrei, füliren aber Eiweissstoffe.

Werden Bolnnensamen in feuchte Erde eingelegt, so beginnt die Keimung alsbald. Die junge Pflanze wächst auf Kosten der in den Cotyledonen vorhandenen Reservestoffe. Man achte besonders' bei der Betrachtung der sich entwickelnden Keimpflanzen auf das zuerst erfolgende Hervorbrechen der Wurzel aus der Samenschale, auf das Hervortreten des an seiner Spitze gekrümmten Stengels, auf die Entsteliung der Nebenwurzeln, die Bildung der Wurzelhaare sowie der Haare ain Stengel, welche am ruhenden Keim noch fehlen, auf das Wachsthum der Primordialblätter und die Differenzen, welche sich bei der Keimung in Dunkeln einer- und bei Lichtzutritt andererseits herausstellen ete.

Mit Bezug auf das Verhalten des plastischen Materials bei der Keimung ist namentlich das Folgende zu bemerken. Hat die Wurzel eine Långe von $2-3 \mathrm{~cm}$ erreicht, so finden sich in der Rinde und dem Mark der Wurzel sowie des hypocotylen Gliedes viele kleine Stärkekörner, während die Zellen der Axe des Embryo vor Beginn der Keimung gewöhnlich nur wenig Amylum führtel. Glycose ist, wie man bei Behandlung von Schnitten mit Kupferlösung und Kali constatiren kanı, in den Rinden- und Markzellen der Axe vorhanden, während sich Eiweissstoffe zumal in der Gefässbuindelregion vorfinden. Indem sich bei dem Fortgang der Keimung die Wurzel verlängert und das erste Stengelglied bedeutend streckt, verschwindet das Amylum 
aus den fertig gestreckten Zellen der Rinde sowie des Markes. So z. B. sind die Zellen der Rinde und des Markes an der Basis des Stengels alsbald amylumfrei, während Rinde und Mark der höheren Theile des Stengels noch Stärke führen. Endlich verschwindet diese aber auch. Ebenso verschwindet das Amylum in dem Maasse aus den Primordialblättern, in welchem sich diese ausbilden. Ist die Streckung des ersten Stengelgliedes vollendet, so sind Rinde und Mark desselben völlig stärkefrei. Nur die bei der Bohne selır schön entwickelte Stärkescheide, welche aus einer Zellenlage besteht und den Gefässbündelkreis umgiebt, führt noch reichlich Amylumkörner. Die Mark- und Rindenzellen, welche ihre Stärke verloren haben, führen jetzt Zucker, der aber auch mehr und mehr versehwindet, wenn die Keimung ihrem Ende naht. Eiweissstoffe sind besonders reichlich, wie sich mit Hülfe von Kupferlösung und Kali feststellen lässt, im Siebtheil der Gefässbündel vorhanden. Wenn sich die Primordialblätter völlig entwickelt haben, so kann das Keimungsstadium der Bohnenpflanze als abgeschlossen betrachtet werden. Die Cotyledonen sind fast völlig frei von Reservestoffen. Schnitte, die man mit Kupferlösung und Kali behandelt, färben sich nicht mehr violett, da kein Eiweiss vorhanden ist, sondern hellblau. Der Amylumgehalt der Cotyledonen ist nur noch ein geringer.

Die Auflösung der Stärkekörner in den Keimblättern beginnt sofort, wenn das Leben im Keim angeregt wird, und zwar sind es die der Axe zunächst liegenden Zellen der Cotyledonen, in denen die Stärkekörner zuerst angegriffen werden. Wenn das erste Stengelglied der Bohnenkeimpflanzen in lebhafter Streckung begriffen ist, so sind bereits reichliche Mengen corrodirter Amylumkörner, freilich neben noch unverschrten, in den Zellen der Cotyledonen vorhanden, und fernerhin greift der Process der Amylumauflösung immer weiter um sich.

\section{Die Keimung ron Triticum vulgare.}

Handelt es sich darum, die Natur der ruhenden Weizenfrucht genauer kennen zu lernen, so ist nicht das trockene Korn, sondern es sind bis zu einem gewissen Grade in Wasser aufgeweichte Körner zur Herstellung der erforderlichen Schnitte zu benutzen. Die Frucht besteht aus der Frucht- und Samensehale, die wir bereits an anderer Stelle besprachen, dem Endosperm und dem Embryo. Wir stellen zunächst Querschnitte dureh ein Korn her und constatiren, dass die äusserste Schicht des Endosperms eine einfache Lage auf dem Querschnitt fast quadratisch erscheinender Zellen darstellt, deren Membranen stark verdickt sind, und die körnige Masse als Inhaltsstoffe führen. Stärkekörner sind in diesen Zellen nicht vorhanclen; sie führen aber, wie sich leicht mit Hülfe von Jod oder schwefelsaurem Kupferoxyd und Kali ermitteln lässt, reichliche Eiweissmengen. Die Hauptmasse des Endosperms zeigt sich aus Zellen von rundlichem Querschnitt zusammengesetzt, die Stärkekörner von verschiedener Grösse sowie Eiweissstoffe enthalten. Letzteres ist bei Behandlung von Schnitten mit schwefelsaurem Kupferoxyd und Kali festzustellen. Der Embryo liegt dem Endosperm seitlich an. Für das Studium des Keims sind mediane Längsschnitte durch das Weizenkorn anzufertigen, und die Betrachtung derselben zunächst bei schwacher, dann bei stärkerer 
Vergrösserung, führt uns ein complicirtes Bild vor das Auge. (Vergl. Fig. 71). Zunächst ist auf denjenigen Theil des Embryos hinzuweisen, der direct an das Endosperm angrenzt. Es ist das Schildchen (Scutellum), welches unsere besondere Aufmerksamkeit erfordert. Dasselbe besteht seiner Hauptmasse nach aus kleinen, abgerundeten Zellen; nur die an das Endosperm anschliessende Zellschicht des Schildehens ist, wie man namentlich bei Behandlung der Schnitte mit Kalilauge deutlich sieht, von anderer Beschaffenheit. Dic Zellen dieses Epithels des Scutellums sind nämlich von gestreckter, eylindrischer Form. An oberen Theil des Keims erkennen wir weiter das geschlossene Scheidenblatt, die jungen Laubblattanlagen und den Vegetationskegel. Dic Wurzel des Weizenembryos ist von einer Wurzelscheide (Coleorhiza) umschlossen, und zwar ist die Grenze zwischen jener und dieser scharf durch eine helle Linie markirt. Amylum oder Glycose sind weder in den Zellen des Schildchens noch in denjenigen der übrigen Theile des lieims vorhanden. Dagegen führen die sämmtlichen Zellen des Embryos reichliche Eiweissquantitäten. $\mathrm{Zu}$ beinerken ist noch, dass auch das Endosperm des ruhenden Weizenkornes keinen Zucker enthält.

Werden angequollene Weizenkörner auf in Wasser liegende Bimsteinplatten gebracht, so beginnt die Keimung alsbald, indem die Organe des Embryos auf Kosten der ihnen aus dem Endosperm zukommenden plastischen Stoffe wachsen. Die Wurzel tritt hervor, und die ersten Seitenwurzeln, welche sich fortan lebhafter als jene entwickeln, kommen zum Vorschein. Ebenso erfahren die Blattanlagen schnell eine bedeutende Streckung, sie bleiben aber noch zunächst von dem lebhaft wachsenden ersten scheidenförmigen Blatt umschlossen. (Vgl. Fig. 113.) Der Stengel entwickelt sich erst später. Das Keimpflanzenmaterial muss nun von Zeit zu Zeit untersucht werden, wenn es sich darum handelt, Aufschluss über die Stoffwechselprocesse bei der Keimung zu erlangen. Bald nach Beginn der Keimung treten im Endosperm bedeutende Glycosemengen auf, wie mit Hülfe von

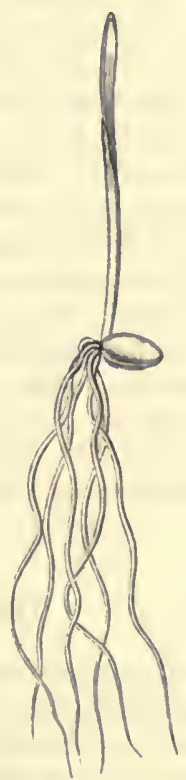

Hig. 113. Keimpflanze von Triticum vulgare. schwefelsaurem Kupferoxyd und Kali leicht festzustellen ist. Das Schildchen, welches bei der Keimung im Weizenkorn stecken bleibt, vermittelt den Uebertritt des gesammten plastischen Materials aus dem Endosperm in den Keim, aber es ist wichtig, dass die Zellen des Seutellums niemals Zucker führen.

Das Cylinderepithel dient dem Schildchen als Saugorgan, und wenngleich in den Epithelzellen niemals dic Gegenwart von Amylum oder Glycose nachzuweisen ist, so enthalten die übrigen Zellen des Schildchens doch alsbald nach Beginn der Keimung transitorische Stärke. Die Gegenwart dieses Körpers ist namentlich bei Behandlung von Schnitten mit Kali, Essigsäure und verdünnter Jodlösung in den Zellen des Seutellums leicht festzustellen. Uebrigens ist hier $\mathrm{zu}$ bemerken, dass die gekeimten Weizenkörner, um für die Untersuchung 
brauchbare Schnitte herzustellen, etwas ausgetrocknet werden müssen. Eiweissstoffe werden der sich entwickelnden Kieimpflanze ebenso wie stickstofffreie Körper unter Vermittelung des Schildchens aus dem Endosperm zugeführt. Haben sich die Weizenkeimlinge z. B. 5 Tage lang bei gewöhnlicher Zimmertemperatur entwickelt, so ist es namentlich leicht, die Gegenwart grösserer Eiweissmengen mit Hülfe von schwefelsaurem Kupferoxyd und Kali in den jüngeren. Theilen der Wurzeln sowie in den einander diametral gegenüberstehenden Gefässbündeln des Scheidenblattes nachzuweisen. Dieses letztere wächst jetzt. noch sehr lebhaft und ist dem entsprechend auch reich an plastischem, aus dem Endosperm stammendem Material. Im Parenchym des Scheidenblattes sind zahlreiche Stärkekörner leicht zu erkennen, deren Menge sich in dem Maasse vermindert, in welchem das Wachsthum der Scheide mit fortschreitender Keimung allmählich erlischt. Auch die Zellen der übrigen wachsenden Blätter führen Amylumkörner. Das Vorhandensein von Glycose habe ich zu keiner Zeit in irgend einem Theil des Weizenembryos nachweisen können (die von mir untersuchten Keimpflanzen entwickelten sich in Dunkeln); es ist nur in Endosperm des keimenden Weizens Glycose zugegen. Uebrigens ist es gar nicht ausgeschlossen, dass unter bestimmten Umständen Glycose auch im Embryo der Weizenkeimpflanze auftritt. Die Zellen des Endosperms werden natürlich mit fortschreitender Entwickelung der Keimpflanze immer ärmer an Reservestoffen (Eiweissstoffen sowie Amylum), und wenn man kleine Mengen des ziemlich erschöpften Endospermgewebes im Wassertropfen auf dem Objectträger vertheilt, so lassen sich bei möglichst starker Vergrösserung neben noch unversehrten Amylumkörnern andere erkennen, die in Folge der Einwirkung des bei der Keimung des Weizens entstehenden diastatischen Fermentes corrodirt und gleichsam zerfressen erscheinen ${ }^{1}$ ).

\section{Die Keimung der Kartoffelknollen.}

Das Gewebe der Kartoffelknollen besteht fast ausschliesslich aus dünnwandigem, stärkeführendem Parenchym. Es ist nämlich nicht allein das Mark- sowie das Rindengewebe der Hauptsache nach von solcher Beschaffenheit, sondern ebenso fast das gesammte Gewebe der im Kreise angeordneten Gefässbündel besitzt parenchymatische Natur und führt Stärkekörner von verschiedener Grösse. Im Holztheil der Gefässbündel sind nur einzelne Gruppen verholzter Elemente (Gefässe und Holzfasern) vorhanden, während im Basttheil einzelne Stränge vorkommen, deren Zellen kein Amylum, wohl aber Eiweissstoffe enthalten. Das Rindenparenchym der Kartoffelknolle wird von innen nach der Schale zu kleinzelliger und stärkeärmer. Dagegen führen die Rindenzellen dicht unter der Schale häufig in Zellsaft gelöste Farbstoffe etc. Die Schale der Knollen besteht aus Korkgewebe, dessen Zellen tafelförmige Beschaffenheit besitzen.

Ich habe mich oft davon überzeugt, dass die Keimung solcher Kartoffeln, die man im Herbst in einen mit einem nicht luftdicht schliessenden Deckel versehenen Kasten legt, lange auf sich warten lässt. Die Knollen machen unter gewöhnlichen Umständen eine Ruhe-

1) Vgl. SACHs, Botan. Zeitung, 1862. 
periode vor der Keimung durch. Diese letztere beginnt erst etwa zu Neujahr, indem einzelne Knospen gewisser Augen (zumal solcher, welche in der Nähe des dem Nabelende entgegengesetzten Theiles der Knollen stehen) sich langsam durch Wachsthum vergrössern. Wir lassen die Knollen nun ruhig bei Lichtabschluss und ohne ihnen Wasser zuzufülıren liegen. Anfang März sind bereits manche Triebe der Knollen einige Centimeter lang geworden und es sind schuppenartige Blättchen an denselben sichtbar. Auf Querschnitten durch den Stengeltheil der Triebe ist es leicht, die Epidermis, das Parenchym der Rinde sowie des Markes, und den Gefässbündelkreis zu erkennen. Sucht man die Stoffvertheilung in den Trieben von verschiedenen Entwickelungszuständen mit Hülfe der bekannten mikrochemischen Methoden festzustellen, so ergiebt sich zumal das Folgende. Das Parenchym sehr junger Triebe enthält viel Stärke. Wenn die Zellen des Parenchyms sich mit zunehmendem Alter leblaft strecken, so sind sie zumal glyeosereich. Eiweissstoffe sind in Weichbast der Gefässbündel auf der Wanderung begriffen. Das Cambium, die Stengelvegetationspunkte und die in den Internodien entstehenden Anlagen der Nebenwurzeln, welche, wie ich oft constatirte, bei solchen Trieben, die sich in Contact mit trockener Luft entwickeln, die Epidermis nicht durchbrechen, enthalten nur Eiweissstoffe, wie es denn überhaupt eine allgemeine Erfahrung ist, dass in denjenigen Geweben, z. B. dem Cambium, deren Zellen sich in sehr lebhafter Theilung befinden, Kohlehydrate in Folge des ausserordentlich schnellen Verbrauchs derselben nicht nachgewiesen werden können. Auf Details gehe ich hier nicht näher ein; sie sind übrigens leicht festzustellen ${ }^{1}$ ). Vergl. auch unter 126.

\section{Der Einfluss der Temperaturverhältnisse auf den Zuekergehalt der Kartoffelknollen.}

Die Untersuchung der Kartoffelknollen auf ihren Zuckergehalt bietet hohes Interesse dar, da derartige Prüfungen Resultate liefern, die für die Beurtheilung einer ganzen Reihe physiologischer Fragen von Interesse sind. Die Untersuchung selbst fülnt man in der Weise aus, dass man die Knollen (etwa 4 Stück) auf dem Reibeisen oder mittelst einer breiten Feile (Raspel) zu einem feinen Brei zerreibt, denselben auf ausgekochte Leinwand, die in einer grossen Porzellanschale liegt, bringt und mit der Hand auspresst. Man spült das Reibeisen oder die Feile, sowie die Hände mit Wasser ab, mischt das Spülwasser mit dem Pressrückstand, presst abermals aus und wiederholt diese Operationen noch zwei Mal. Die gewonnenen Flüssigkeitsmengen werden in einen Kolben von $1 / 2$ Liter Capacität gebraclit. Man füllt bis zur Marke auf, versetzt eine gewisse Flüssigkeitsmenge zur Fällung ron Eiweiss etc. mit etwas Bleiessig, filtrirt und ermittelt im Filtrat mit Hülfe der FEHLING'sehen Lösung den Zuckergehalt. Eben gereifte Kartoffeln enthalten Zucker. Werden ungekeimte Knollen untersucht, die längere Zeit (einige Wochen) im warmen Zimmer bei $15-20^{\circ} \mathrm{C}$. verweilt haben, so zeigt sich, dass diese Knollen zuckerfrei sind. Werden derartige zuckerfreie Kartoffeln etwa 14 Tage lang in einem

1) Vgl. H. DE Vries, Landwirthsch. Jahrbücher, Bd. 7, S. 217. 
Raum (z. B. in einem Keller) aufbewahrt, in welchem die Temperatur nicht unter $0^{0}$ sinkt, aber auch nicht über $2-3^{\circ} \mathrm{C}$. steigt, so sind sie süss geworden und enthalten viel Zucker. Besonders zweckmässig ist es, die Knollen bei Abkühlungsversuchen in einen in einem Keller aufgestellten Thermostaten zu bringen, der aus einem doppeltwandigen Zinkbleclgefäss hergestellt ist. Der Zwischenraum zwischen den Wänden wird mit Eis angefüllt, und zum Verschliessen des Apparates benutzt man keinen gewöhnlichen Deckel, sondern ein mit Eis angefülltes Blechgefäss. Die Knollen sind also im Thermostaten einer constanten Temperatur von $0^{\circ}$ C. ausgesetzt. Näheres über einen solchen Thermostaten vergl. unter 49. Werden Kartoffeln, die keinen oder nur wenig Zucker enthalten, in ein Glasgefäss gebracht, dieses in eine Kältemischung (Schnee oder Eis und Kochsalz) gestellt und auf diese Weise bewirkt, dass die Knollen schnell gefrieren und klingend hart werden, so ergiebt die Untersuchung der in gefrorenem Zustande zerriebenen und mit Wasser extrahirten Knollen keine Veränderung in ihrem Zuckergehalte. Die hier erwähnten Thatsachen sind zuerst von MÜLLER-Thurgau constatirt worden ${ }^{1}$ ). Einige bezügliche Angaben finden sich auch in einer von mir publicirten Abhandlung ${ }^{2}$ ). MÜLLERThurgau hat nachgewiesen, dass das Verhältniss zwischen den Processen der Zuckerbildung und der Athmung in den Kartoffelknollen bei verschiedenen Wärmegraden ein sehr verschiedenes ist, und dass es bei der Erklärung der festgestellten Erscheinungen, wenn auch nicht ausschliesslich, so doch in erster Linie darauf ankommt, diesen Gesichtspunkt nicht aus dem Auge zu verlieren. Bei höherer Temperatur (etwa $15-20^{\circ} \mathrm{C}$.) verläuft die Athmung relativ energisch, so dass der Zucker in dem Maasse, wie er sich bildet, verbraucht wird und sich nicht in den Knollen anhäufen kann. Bei niederer Temperatur (z. B. $0-3^{\circ}$ C.) wird mehr Zucker aus der vorhandenen Stärke gebildet, als die unter, diesen Umständen schwache Athmung zu verbrauchen im Stande ist. Daher tritt bei niederen Wärmegraden Zuckeransammlung in den Knollen ein. Das Gefrieren der Kartoffelknollen selbst ist ohne Einfluss auf den Zuckergehalt derselben. Ueber Ausführung von Beobachtungen über Athmung vergl. unter 102.

\section{2\%. Das Reifen der Friichte und Samen.}

Wird ein dünner Querschnitt aus dem reifen Samen von Brassica Napus untersucht, so zeigt sich, dass die Samenschale aus einer Reihe verschiedener Schichten besteht. Von aussen nach innen folgt zunächst auf eine aus zusammengedrückten Zellen bestehende, farblose Schicht eine andere, die aus braun gefärbten Zellen, deren Lumina ziemlich deutlich sind, zusammengesetzt ist. Daran schliesst sich eine aus zusammengedrückten, braunen Zellen bestehende Schicht. Es folgt eine vierte Schicht, deren Zellen stark verdickt sind und deutliche Lumina erkennen lassen, während die fünfte Schicht ebenso wie die erste keine zellige Structur mehr zeigt. Die zweite und dritte Schicht der Samenschale bedingen die braune Färbung des Samens. In den

1) Vgl. MǗLLER-Thurgau, Landwirthschl. Jahrbücher, Bd. 11, S. 751.

2) Vgl. Detmer, Pflanzenphysiologische Untersuchungen über Fermentbildung und fermentative Processe, 1S81, S. 41. 
Zellen der gefalteten Cotyledonen sind reichliche Eiweiss- und Fettmengen vorhanden. Stärke fehlt dem reifen Samen vollkommen. Die sich entwickelnden noch unreifen Samen enthalten aber viel Amylum. Dasselbe strömt ihnen aus den Assimilationsorganen der Rapspflanze zu und wird schliesslich vollkommen zur Fettbildung im Samen verbraucht. Wir stellen Querschnitte aus einer grünen Schote von Brassica Napus (ich untersuchte z. B. an 20. Mai $6-8 \mathrm{~cm}$ lange Schoten) her. Zwischen den beiden Fruchtblättern sieht man bei der Untersuchung die falsche Scheidewand. Das Fruchtgewebe selbst besteht aus einer stark cuticularisirten Epidermis, grünem und farblosem Grundgewebe, sowie einer Anzahl Gefässbündel. Die jungen Samen sitzen an den verwachsenen Rändern der Fruchtblätter. Behandelt man Querschnitte init Chloralhydrat und Jodjodkaliumlösung. so zeigt sich, dass Frucht- und Samengewebe viel Stärke enthalten.

Das Hypanthium der reifen Birnen ist bekanntlich sehr zuckerreich. Da nun die Frucht selbst nur wenig Chlorophyll enthält, so muss ihr auf jeden Fall das meiste Material, dessen sie zu ihrer Ausbildung und zur Erzeugung des in dem Hypanthiumgewebe abgelagerten Zuckers bedarf, zugeführt werden. Der Fruchstiel vermittelt die Zuleitung des plastischen Materials. Stellt man Querschnitte aus dem Fruchtstiel der Birne her (ich untersuchte dieselben z. B. an 8. Juni), so lässt sich der Gefässbündelkreis zwischen der Rinde und dem Mark sofort selbst bei schwacher Vergrösserung erkennen. Der Bastheil der Gefässbündel besitzt nach aussen zu einen starken Beleg von Bastfasern. An diese letzteren grenzt unmittelbar eine Zellenschicht (die Stärkescheide), in deren Elementen man reichliche Amylummengen beobachtet. Im Parenchym des Hypanthiums der Birnen fand ich am 8. Juni wenig Stärke, nur einzelne Zellen enthielten dieselbe, offenbar ein Beweis dafür, dass das Amylum selır schnell verbraucht wird. In einem noch früheren Entwickelungsstadium der Birne (am 2. Mai) konnte ich selbst durch Behandlung dünner Sclınitte des Hypanthiums mit Chloralhydrat und Jodjodkaliumlösung keine Stärke in den Zellen nachweisen.

Wenn man von einer Pliaseolusblüthe die Blumen- sowie Kelchblåtter entfernt und den noch übrigen Theil der Blüthe zur Herstellung von Querschnitten benutzt, so erblickt man bei der Untersuchung den monomeren Fruchtknoten, umgeben von der geschlitzten Staubfadenröhre. Bei Phaseolus und vielen anderen Papilionaceen sind ja von den 10 Staubgefässen nur 9 mit einander verwachsen; ein Staubgefäss ist frei. Der Fruchtknoten trägt die Ovula an seiner Bauchnalit. Nach SACHS ${ }^{1}$ ) ist bei dem Reifen der Früclite und Samen von Phaseolus (Ph. vulgaris) namentlich das Folgende zu constatiren.

Sogleich nach dem Abblühen findet sich sowohl in den Zellen der äusseren grünen als auch in denjenigen der inneren farblosen Schicht des Fruchtknotens keine Stärke. Nur in unmittelbarer Nähe der Gefässbündel an der Bauch- und Rückennaht ist wenig Amylum vorhanden. Der Embryosack enthält keine Stärke (wohl in Folge starken Verbrauchs derselben). Amylum ist aber in der Umgebung des Embryosackes und im Parenchym des Funiculus vorhanden. Hat die Frucht eine Länge von $3 \mathrm{~cm}$ erreicht, so enthält die äussere grüne

1) Vgl. Sachis, Prixgsheim's Jahrbücher f. wissensehl. Botanik, Bd. 3, S. 231. 
Schicht des Fruchtknotens Stärke, die innere farblose aber keine, dagegen viel Zucker. In Funiculus und in nächster Umgebung des Embryosackes ist Stärke vorhanden. Der noch sehr kleine Embryo ist stärkefrei. Schreitet die Frucht- und Samenentwickelung weiter fort, so ist immer noch viel Stärke (aber kein Zucker) in dem Parenchym des als Zuleitungsorgan dienenden Funiculus zu finden, und auch in den Cotyledonen des sich ausbildenden Embryos häuft sich allmählich viel Anylum an.

Es sind mir Falle vorgekommen, in denen weder im Embryosack noch im Gewebe des Kinospenkernes und Funiculus (wohl in Folge sehr lebhaften Waclısthums der Zellen) Stärke oder Zucker nachzuweisen waren. Ich untersuchte am 4. Mai Blüthen von Tulipa sylvestris und fand in den Zellen der anatropen Samenknospen, die der dreifächerige Fruchtknoten in grosser Zahl beherbergt, nur reichliche Eiweissmengen, aber weder Stärke noch Glycose.

\section{Die Gewinnung des fiir quantitative ehemische Unter- suchungen iiber Stoffiweehselprocesse erforderlichen Materials.}

Eine der wichtigsten, aber zugleich auch schwierigsten und mühevollsten Aufgaben bei quantitativ-chemischen Untersuchungen über Stoffwechselprocesse im Organismus der Pflanzen besteht in der Gewinnung des geeigneten Materials. Am zweckmässigsten ist es, Keimpflanzen bei derartigen Beobachtungen, z. B. bei dem Studium über das Verhalten der Stärke oder der Fette, zu benutzen. Zunächst sucht man sich Samenmaterial von gleichförmiger Ausbildung der einzelnen Individuen sowie hoher Keimfähigkeit $\mathrm{zu}$ verschaffen, bestimınt den Trockensubstanzgehalt desselben, indem man zur Erlangung eines Mittelwerthes mehrere Proben des durch Zermahlen der Samen auf einer Handmühle hergestellten Samenpulvers bei $102^{\circ} \mathrm{C}$. trocknet, und berechnet alle Ergebnisse der Samenuntersuchung auf Samentrockensubstanz.

Die zur Gewinnung der Keimpflanzen zu benutzenden Samen müssen genau gewogen werden; ihr Trockensubstanzgewicht lässt sich somit leicht berechnen. Das Einquellen der Samen, die Cultur der Keimpflanzen und die Ermittelung des Trockensubstanzgewichts dieser letzteren werden in derselben Weise ausgeführt, wie dies bei der experimentellen Behandlung der Frage naclı der Verwerthbarkeit des freien atmosphärischen Stickstoffs für die Pflanzen geschehen ist (vgl. unter 19). Die Keimpflanzen müssen sich aber natürlich bei völligem Lichtabschluss, z. B. in einem Schrank, entwickeln und brauchen nicht unter Glasglocken zur Ausbildung zu gelangen.

Die hauptsächlichste Schwierigkeit bei den Untersuchungen besteht darin, gleichförmig ausgebildetes Keimpflanzenmaterial zu gewinnen. Legt man eine Anzall Samen zum Keimen aus, so kommt es sehr oft vor, dass manche Keimpflanzen sich kräftig, andere schwächlich entwickeln, oder dass einige Samen gar nicht keimen und faulen. Beim Experimentiren mit manchen Samen (z. B. Weizen oder Erbsen) erhält man übrigens bei einer Anzahl von Culturen solche, die durchaus befriedigend ausfallen, bei denen also alle benutzten Samen nahezu gleichförmig ausgebildete Keimpflanzen geliefert haben, und das ist ja der denkbar günstigste Fall. Experimentirt man mit kleinen 
Samen (Raps, Mohn), die man am besten nach dem Anquellen auf im Wasser liegenden Bimssteinplatten, auf feuchtem Filtrirpapier oder feuchter Glaswolle zur Keimung bringt, so ist es zweckmässig, die Samen zu zählen, das mittlere Gewicht eines Samens zu berechnen, die nicht gekeimten Samen zu zählen und ihr ursprüngliches Gewicht von dem anfänglichen Gewicht der benutzten Samenquantität in $\mathrm{Ab}$ zug zu bringen. Wenn nicht zu viele Samen schlecht oder gar nicht keimen, so bringt dieses Verfahren keine allzu grossen Fehler mit sich. Bei Versuchen mit grossen Samen (Bohnenarten) ist es zweckmässig, jedes einzelne Untersuchungsobject individuell $\mathrm{zu}$ behandeln. Jeder einzelne Same wird für sich gewogen, nach dem Quellen auf feuchter Glaswolle angekeimt und dann jede einzelne Keimpflanze in einem besonderen Glase, welches destillirtes Wasser enthält, zur weiteren Entwickelung gebracht, in älnnlicher Weise, wie dies bei der Handhabung der Methode der Wassercultur geschicht (vgl. unter 1). Auf mancherlei kleine Vorsichtsmaassregeln, die aber dennoch von Wichtigkeit sind, um brauchbares Keimpflanzenmaterial zu gewinnen, wird man bei der Ausführung der Arbeiten leicht selbst aufmerksam werden.

Handelt es sich um ein vergleichendes Studium der Abhängigkeit der Stoffwechselprocesse von den Temperaturverhältnissen, so müssen die Samen natürlich in Thermostaten (vgl. unter 77) bei verschiedenen Wärmegraden zur Keimung gebracht werden.

\section{Quantitativ-chemische Untersuchungen iiber das Verhalten der Fette und Kohlehydrate bein pflanzlichen Stoff'wechsel ').}

Das Studium derjenigen Vorgïnge, die sich bei der Keimung der Samen geltend machen, ist sehr geeignet, uns Aufschluss über das Verhalten der Fette und Kohlehydrate beim Stoffwechsel zu geben. Wir suchen zunächst die procentische Zusammensetzung der Samen und diejenige der Keimungsproducte, welche in der unter 128 angegebenen Weise gewonnen worden sind, zu ermitteln und rechnen dann, um vergleichbare Zahlen zu gewinnen, die Ergebnisse dieser Untersuchungen auf $100 \mathrm{~g}$ Samentrockensubstanz und auf die aus $100 \mathrm{~g}$ Samentrockensubstanz hervorgegangene Menge Keimpflanzentrockensubstanz um. Hatten $100 \mathrm{~g}$ Samensubstanz z. B. $90 \mathrm{~g}$ Keimpflanzensubstanz ergeben, so müssen die für die procentische Zusammensetzung der Keimpflanzen gefundenen Werthe auf $90 \mathrm{~g}$ umgerechnet werden. Die Analyse der Samen sowie Keimpflanzen wird in folgender Weise ausgeführt.

Etwa 3 g Samen-oder Keimpflanzentrockensubstanz werlen in sehr fein zerriebenem Zustande in der unter 120 angegebenen Weise mit Aether zur Fettbestimmung extrahirt. Den Rüickstand von der Fettbestimmung digerirt man wiederholt einige Zeit mit Wasser von gewöhnlicher Zimmertemperatur, filtrirt und füllt das Filtrat auf 200 ccm auf. Je 50 ccm dienen zur Zuckerbestimmung (vgl. unter

1) Neuerdings sind viele werthvolle Methoden aufgefunden worden, um die Menge der einzelnen in den Samen und Keimpflanzen vorhandenen Körper genau festzustellen. Hier ist nicht der Ort, auf solche Details einzugehen. Man vergleiche daher die neuere agriculturchemisehe Literatur und KöNIG's mehrfach citirtes Buch. 
115), je $50 \mathrm{ccm}$, nachdem man die Flüssigkeit mit etwas Schwefelsäure gekocht hat, zur Dextrinbestimmung (vgl. unter 116).

Den mit Wasser erschöpften Rückstand oder besser etwa $3 \mathrm{~g}$ neuer Samen- resp. Keimpflanzensubstanz (nur bei sehr fettreichen Samen oder Keimpflanzen muss das Fett zunächst entfernt werden) übergiesst man in einem $500 \mathrm{ccm}$ fassenden Kolben mit $200 \mathrm{ccm}$ Wasser, kocht längere Zeit bis zur völligen Verkleisterung der Stärke und digerirt die Flüssigkeit noch etwa 2 Stunden lang bei $70^{\circ} \mathrm{C}$., nachdem man ihr einige Tropfen Salzsäure zugefügt hat. Man füllt nach dem Erkalten bis auf $500 \mathrm{ccm}$ auf, lässt ruhig stehen und filtrirt $200 \mathrm{ccm}$ durch ein nicht befeuchtetes Filter klar ab. Das Filtrat vermischt man mit $15 \mathrm{ccm} 25$-proc. Salzsäure, kocht 3 Stunden lang unter Ersatz des verdunstenden Wassers und füllt nach dem Erkalten wieder bis auf $200 \mathrm{ccm}$ auf. In je $50 \mathrm{ccm}$ Flüssigkeit ermittelt man mit Hülfe der FeHLiNG'schen Lösung den Zucker, dessen Menge dann auf Stärke umgerechnet wird (vgl. unter 111) ${ }^{1}$ ).

Den Rückstand von der Behandlung mit Salzsäure kocht man eine halbe Stunde lang mit $200 \mathrm{ccm}$ 1-proc. Kalilauge aus, filtrirt und kocht die auf dem Filter gesammelte Masse eine halbe Stunde lang mit $200 \mathrm{ccm}$ Wasser. Der nun noch bleibende Rückstand wird auf einem gewogenen Filter gesammelt, mit Alkohol und Aether ausgewaschen, getrocknet und gewogen. Von der Menge der erhaltenen Rohfaser ist die in ihr vorhandene und zu bestimmende Quantität Asche sowie die Menge an Eiweissstoffen in Abzug zu bringen.

Besondere Proben der Samen- und Keimpflanzensubstanz dienen zur Ermittelung des Aschengehaltes derselben. Ebenso ist die Quantität der in den Samen sowie den Keimpflanzen vorhandenen Eiweissstoffe, eventuell auch die Menge des vorhandenen Asparagins etc. festzustellen (vgl. unter 99).

Bei der Berechnung der procentischen Zusammensetzung der Samen und Keimpflanzen auf Grund der Resultate der angeführten Untersuchungen bleibt stets ein nicht unerheblicher Rest. Die Menge der ,unbestimmten Stoffe" muss aber mit aufgeführt werden.

Ueber die Bedeutung quantitativ-chemischer Untersuchungen beim Studium des Stoffwechsels habe ich mich an anderer Stelle eingehend ausgesprochen ${ }^{2}$ ). Hier sei nur erwähnt, dass man sich mit Hülfe der quantitativ-chemischen Methode z. B. darüber Klarheit verschaffen kann, in welchem Verhältniss die beim Stoffwechsel verschwindende Stärkemenge zu der Menge der verschwindenden Trockensubstanz steht, wie viel Zucker unter bestimmten Umständen entsteht, wie gross die Menge des Amylumquantums ist, das bei der Keimung fettreicher Samen gebildet wird, wenn eine gewisse Fettmenge verschwunden ist, etc. etc. Alle diese Fragen haben ein hohes wissenschaftliches Interesse ${ }^{3}$ ).

1) Vgl. auch Köxıg, Untersuchung land wirthschl. wichtiger Stoffe, 1891, S. 231.

2) Vergl. DetMer, Vergl. Physiologie d. Keimungsprocesses der Samen, 1890.

3) Vgl. am soeben angegebenen Orte auch die Literatur. Ferner rgl. DETMER, Physiol. Untersuchungen über die Keimung ölhaltiger Samen und die Vegetation von Zea Mays, 1875; DETMER in WoLlsY's Forschungen auf dem Gebiete der Agriculturphysik, Bd. 2, und SACrsse, Ueber einige chem. Vorgänge bei der Keimung ron Pisum sativum, 1872. 


\section{Die Nebenproducte des pflanzlichen Stoffwechsels.}

\section{Die organisehen Säuren der Pflanzen.}

Die organischen Säuren in den Pflanzen sind nicht als Assimilationsproducte anzusehen, sondern sie entstehen, wie unter 131 noch specieller gezeigt werden soll, meistens durch Oxydationsprocesse aus Kohlehydraten. Entweder sind die in den Pflanzen vorkommenden organischen Säuren (Oxal-, Citronen-, Apfelsäure etc.) in freier Form in den Zellsäften vorhanden, oder sie treten, wie wohl meistens, in Verbindung mit Basen in sauren resp. neutralen, leicht löslichen oder sehr schwer löslichen Salzen in den Zellen auf. Die Säfte des Parencliyms enthalten ganz allgemein melır oder minder bedeutende Quantităten freier organischer Säuren oder saurer Salze derselben, und man kann sich sehr leicht von dieser Thatsache überzeugen, wenn man die frische Schnittfläche irgend eines beliebigen Pflanzentheiles mit blauem Lackmuspapier in Contact bringt. Die eintretende Röthung des Papiers zeigt die Gegenwart der Säure an: In zahlreichen Fällen lässt sich der saure Charakter der Pflanzensäfte schon durch den Geschmackssinn wahrnehmen.

Den freien Säuren sowie ihren sauren Salzen kommen mannigfaltige Functionen in den Zellen zu, die wir zum Theil schon erwähnten. Die Säuren erhöhen die Turgorkraft des Zellinhaltes ganz wesentlich, sie beschleunigen den Verlauf des Processes der Stärkeumbildung durch Diastase, sie dienen manchen Pflanzen als Schutzmittel gegen den Angriff schädlicher Thiere, sie zersetzen die aus dem Boden mit Hülfe der Wurzeln aufgenommenen Nitrate, ein Vorgang, der für die Eiweissbildung von grosser Wichtigkeit ist, sie binden den seitens der Pflanzen im Uebermaass aufgenommenen Kalk und sie zersetzen die Chloride im vegetabischen Organismus unter Freimachung von Salzsäure.

Eine sehr grosse Verbreitung besitzt die Oxalsäure im Pflanzenreich. Sie kommt im freien Zustande und in sauren Salzen, die im Zellsaft löslich sind, zudem aber ungemein häufig in Verbindung mit Kalk vor. Die Krystalle des oxalsauren Kalkes trifft man in besonderen Zellen an, und wir haben schon einmal auf ihr Vorkommen hingewiesen (vgl. unter 24). Hier mögen fernere Beispiele Erwähnung finden.

Wir stellen einen Längsschnitt rechtwinklig zur Blattfläche aus dem Blatt von Aloë arborescens her. Die Epidermis, das grüne Parenchym und das chlorophyllfreie Wassergewebe sind bei mikroskopischer Untersuchung leicht zu erkennen. In dem grünen Gewebe sehen wir überdies parallel zur Längsaxe des Blattes gestreckte, schlauchförmige Zellen, die mit grossen Mengen nadelförmiger Krystalle von oxalsaurem Kalk dicht angefüllt sind. Diese Rhaphidenbündel ruhen in einem schleimigen Inhalt der Zellen, und bei der Herstellung der Schnitte treten häufig, wenn ein Rhaphidenschlauch zufällig geöffnet wird, diese Schleimmassen mit den Rhaphiden aus den Zellen hervor, so dass man sie ausserhalb des Untersuchungsobjectes in der dasselbe umgebenden Flüssigkeit beobachtet. Behandelt man die Schnitte mit 
Kalilauge oder Essigsäure, so lösen sich die Rhaphiden nicht auf. Wir stellen ferner Quersehnitte aus dem Blatt von Beta vulgaris her. Bei mikroskopischer Untersuchung sieht man die Epidermis der Blattober- und -unterseite, das wenig ausgeprägte Palissadenparenchym und das an Intercellularen reiche Schwammparenchym deutlich. In dem letzteren liegen die sog. Körnchenschläuche, Zellen, welche mit kleinen Krystallen von Kalkoxalat dicht angefüllt sind. Wir stellen auch noch einen Querschnitt aus einem etwa $5 \mathrm{~mm}$ dicken Zweige von Tilia parvifolia her. Das Quersehnittsbild ist bereits unter 42 beschrieben worden; hier verdient nur die Thatsache Beachtung, dass im äusseren Theil der Markstrahlen sowie im Gewebe der primären Rinde viele Zellen vorhanden sind, die Krystalldrusen von Kalkoxalat enthalten.

Einige Pflanzen, zumal die Crassulaceen (z. B. Sempervivum, Echeveria, Bryophyllum), sind dadureh ausgezeichnet, dass ihre Säfte sehr bedeutende Mengen Aepfelsäure enthalten, die, wie KRaUs ${ }^{1}$ ) specieller nachwies, zum grössten Theil an Kalk gebunden ist. Das im Zellsaft lösliche Malat macht zuweilen 50 Proe. der Trockensubstanz des Saftes der Blätter der genannten Pflanzen aus. Wir zerreiben einige Bryophyllumblätter im Mörser, bringen den Brei auf ein trockenes Filter und bestimmen in einem kleinen Theil des gewonnenen Saftes den Trockensubstanzgehalt desselben, während die grössere Saftmenge mit der 4-5-fachen Menge 96-proe. Alkohols vermischt wird. Es seheidet sich das Malat in Form eines weissen, pulverigen Niederschlages ab, den man abfiltriren, auswaschen, trocknen und wägen kann.

Es kommt heute in der Pflanzenphysiologie sehr oft darauf an, die Acidität von Pflanzensäften, d. h. den Gehalt derselben an titrirbarer Säure, festzustellen, Je nach Umständen werden verschiedene Methoden zur Anwendung kommen müssen, und wir wollen hier auf dieselben eingehen. In erster Linie ist es wiehtig, die Säfte oder Extrakte aus den Pflanzen zu gewinnen, in denen die Säuremenge bestimmt werden soll. Handelt es sich bei vergleichenden Untersuchungen nur um die Ermittelung relativer Werthe für die Acidität, so werden die Untersuchungsobjecte, wenn sie, wie z. B. Rheumblattstiele, sehr wasserreich sind, auf dem Reibeisen zerrieben, oder man zerquetseht die in Stücke zerschnittenen wasserärmeren Pflanzentheile möglichst vollständig in einem Porzellanmörser. Die breiigen Massen presst man im Colirtuch unter Anwendung möglichst gleichartigen Druckes mit den Händen oder unter Zuhülfenahme einer Presse aus, un den erhaltenen Saft schliesslich durch Filtration zu klären. Unter Umständen ist es auch zweckmässig, die zerquetsehten Pflanzenmassen mit wenig Wasser auszulaugen und die erhaltenen Flüssigkeiten zu filtriren. Handelt es sich darum, absolute Werthe für die Acidität der Pflanzentheile zu gewinnen, so werden dieselben, nachdem sie gewogen worden sind, zerquetseht, der Brei mit etwas Wasser in diekwandigen Gläsern 1 Stunde lang bei 80 bis höchstens $90^{\circ} \mathrm{C}$. im Wasserbade erwärmt, um Kohlensïure auszutreiben, dann auf ein Filter gebracht und mit mögliehst wenig heissem Wasser ausgewasehen (vgl. unter 60). Bei Untersuchungen über das Verhalten der freien

Bd. 16 .

1) Vgl. G. Krats, Abhandlungen der Naturforschenden Gesellschaft zu Halle, 
organischen Säuren im Organismus der Crassulaceen (vgl. unter 131) verfährt man an besten derartig, dass man die als Untersuchungsobjecte dienenden Blätter nach dem Wägen im Mörser zerquetscht, den Brei mit der erforderlichen, aber möglichst geringen Spülwassermenge in dickwandigen Gläsern 1 Stunde lang bei 80 bis lı̈̈chstens $90^{\circ} \mathrm{C}$. im Wasserbade erhitzt, um ihn dann wieder mit etwas Spülwasser in den Mörser zurüiclzubringen und nach dem Abkühlen direct zu titriren.

Zum Titriren der Säfte, Extracte oder der breiartigen Massen verwendet man verdünnte Kali-oder Natronlauge. Man löst in $1000 \mathrm{ccm}$ Wasser 1 g Aetzkali oder Aetznatron auf, fügt Barytwasser in geringem Ueberschuss hinzu und dann Natriumsulfat, um den Barytüberschuss wieder zu beseitigen. Die klare und nun kohlensäurefreie Lauge darf mit Schwefelsäure keinen Niederschlag geben. Zum Einfüllen der Lauge in die Bürette wird eine ähnliche Vorrichtung verwandt, wie eine solche in Fig. 98 dargestellt ist. Die Kali- oder Natronlauge lässt man beim Titriren aus der Bürette zu den säurchaltigen Säften, Extracten oder zu dem Brei fliessen und benutzt, wenn man es mit sehr klaren Säften $\mathrm{zu}$ thun hat, 3-5 Tropfen einer verdünnten, alkoliolischen Lösung ron Phenolphtalein als Indicator. In anderen Fällen, zumal beim Titriren von breiartigen Massen, muss man Curcumapapier verwenden. Bei vergleichenden Untersuchungen ist es gar nicht erforderlich, den Titer der Natron- oder Kalilauge festzustellen. Soll dies übrigens geschehen, so stellt man sich eine Normallösung einer Saure lier, d. h. eine Lösung, die in $1000 \mathrm{ccm} 1$ Aequiv. einer einbasischen Säure in g ausgedrückt, enthält. Bei Benutzung von Oxalsäure $\left(\mathrm{C}_{2} \mathrm{H}_{2} \mathrm{O}_{4}+\mathrm{H}_{2} \mathrm{O}=126\right)$ müssen 63 g reiner Säure in $1000 \mathrm{ccm}$ Wasser aufgelöst werden. Mit dieser Lösung ist der Titer der Kali- oder Natronlauge leicht zu ermitteln ${ }^{1}$ ).

\section{Das Verhalten der freien organischen Säuren im Organismus der Crassulaceen und einiger anderer Pflanzen.}

Zahlreiche Crassulaceen und andere Pflanzen, zumal succulente Gewächse, zeigen bezüglich des Gehalts ihrer Säfte an organischen Säuren (wir haben es in diesen Fällen namentlich mit Aepfelsäure zu thun) die höchst merkwïrdige Erscheinung, dass derselbe am Tage viel geringer als in der Nacht ist. Die bezüglichen, äusserst verwickelten Verlıälnisse sind noch keineswegs nach allen Richtungen hin gründlich untersucht worden. Aber einige Thatsachen stehen doch fest, und diese sollen weiter unten experimentell constatirt werden, nachdem ich zunächst in aller Kürze die Anschauungen mittheilen will, welche ich inir auf Grund der vorliegenden Untersuclıungen über das Verhalten der organischen Säuren in den Crassulaceen gebildet habe ${ }^{2}$ ). In Gewebe (zumal dem Blattgewebe) der Crassulaceen sowie

1) Ueber Titrirmethoden vergl. MoHR, Lehrbuch d. analytiseh-chem. Tritrirmethode.

2) Literatur: A. MAYER, Landwirthschaftliche Versuchsstationen, Bd. 18 und Bd. 21; Detuer, Prisgsheim's Jahrbücher, Bd. 12, und Lehrbuch der Pflanzenphrsiologie, 1883; H. DE Vrmes, Verslagen en Mededeclingen der Koninkl. Akaden. vai Wetenschappen, 1884; G. KraUS, Abhandlungeu der Naturforschenden Gesellschaft zu Halle, Bd. 16; WARBura, Untersuchungen aus dem botan. Institut zu 
einiger anderer Pflanzen laufen continuirlich und unter allen Umständen zwei Processe neben einander her, die für die Aciditatsverhältnisse ihrer Säfte von hervorragender Bedeutung erscheinen. Einerseits erfolgt stets Säureproduction, andererseits wird immer Säure zersetzt. Der momentane Säuregehalt ist also die Resultirende aus diesen beiden Processen ${ }^{1}$ ).

Es ist von grosser Wichtigkeit, dass sich in den Zellen der Crassulaceen unter bestimmten Umständen sehr schnell erhebliche Mengen freier Säure anhäufen können, eine Thatsache, die ohne Zweifel biologische Bedeutung für diese Organismen besitzt. Dieselben wachsen nämlich der Regel nach an trockenen und oft sehr kalkreichen Standorten; sie bedürfen daher bestimmter Mittel, durch welche die osmotische Leistungsfähigkeit ihres Zellinhaltes für den Zweck reichlicher Wasseransammlung in ihrem Gewebe erhöht und zugleich eine Bindung des ihren Zellen im Uebermaass aus dem Boden zugeführten Kalkes ermöglicht wird. Die organischen Säuren leisten beides.

Die Säuren bilden sich aus Kohlehydraten unter dem Einfluss des Sauerstoffes. Sie entstehen durch Oxydation der Assimilationsproducte. Dass sich gerade im Gewebe succulenter Pflanzen so erhebliche Säureinengen ansammeln, hängt mit der Organisation dieser Gewächse zusammen. Die Succulenten können nämlich in Folge des Besitzes einer dicken Cuticula, relativ weniger Spaltöffnungen und fleischiger Gewebe einen nur recht beschränkten Gaswechsel mit der Aussenwelt unterhalten. Sauerstoff steht ihren Zellen nicht in überreicher Menge zur Disposition, und die Verbrennung der Kohlehydrate ist daher nur eine unvollständige. Sie geht wenigstens unter bestimmten Umständen nicht bis zur Erzeugung von Kohlensäure und Wasser, sondern es werden erhebliche Quantitäten organischer Säuren als unvollständige Verbrennungsproducte angehäuft.

Der Process der Säurezersetzung, welcher continuirlich neben dem Vorgange der Säurebildung im Gewebe der Crassulaceen verläuft, ist bezüglich der Energie, mit der er erfolgt, in hohem Grade abhängig von den Temperatur-, sowie den Beleuchtungsverhältnissen. Höhere Temperatur und Lichtzutritt beschleunigen die Säurezersetzung sehr erheblich. Danach muss eine Abnahme der Acidität des Crassulaceengewebes erfolgen, wenn die Pflanzen im Dunkeln hoher Temperatur ausgesetzt, oder wenn sie dem Lichteinfluss exponirt werden. Im Dunkeln — zumal bei niederer Temperatur - steigt die Acidität des Crassulaceensaftes hingegen. Und in der That wissen wir, dass die Acidität des Crassulaceensaftes einem täglichen periodischen Wechsel unterworfen ist; am Tage reagirt der Saft schwach, in der Nacht stark sauer.

Das Wesen der Säurezersetzung ist auf jeden Fall in einem mit Kohlensäureproduction verbundenen Oxydationsprocesse zu suchen. Die durch Oxydation gebildete Säure wird vollkommen verbrannt, und es handelt sich hier namentlich noch um die Frage, wie es kommt, dass.

Tübingen, Bd. 2. Die Ansichten, welche ich in meinen citirten Schriften über unseren Gegenstand ausgesprochen habe, sind wesentlich verschieden ron den hier von mir vertretenen.

1) Abgesehen von der Zersetzung freier organischer Säuren im Gewebe der Crassulaceen findet in demselben noeh continuirlich eine Bindung der Säure durch Basen statt (Kracs). Dadurch häufen sich allmählich grosse Mengen gewisser Salze in den Zellen an, und die Entstehung dieser Verbindungen, die wir hier indessen nicht weiter berücksichtigen, ist natürlich ebenfalls nicht ohne Bedeutung für die Aciditätsverhältnisse des Crassulaceensaftes. 
die Lichtstrahlen beschleunigend auf diesen Vorgang einwirken. Es wurde schon erwähnt, dass die Crassulaceen aus verschiedenen Gründen einen nur beschränkten Gaswechsel unterhalten können. Dieser Umstand ist für das Zustandekommen einer beträchtlichen Säureansammlung von maassgebender Bedeutung. Im Dunkeln herrscht offenbar Sauerstoffmangel im Crassulaceengewebe; Lichtzutritt steigert dagegen die Sauerstoffquantität im Gewebe wesentlich, denn bei dem Processe der Assimilation wird Sauerstoff frei. Die assimilirenden Chlorophyllkörper sind nicht direct an dem Säurezersetzungsprocesse betheiligt, wohl aher indirect, indem sie zur Entstehung reichlicherer Sauerstoffmengen im Gewebe der Crassulaceen Veranlassung geben, die nun ihrerseits eine vollständige Verbrennung der Säure bewirken. Die dabei entstehende Kohlensäure kann in den Chlorophyllkörpern wieder verarbeitet werden, und der in Freiheit gesetzte Sauerstoff ist aufs Noue im Stande, die Säurezersetzung zu beschleunigen.

Die angeführten Verhältnisse sind in allererster Linie für die gesteigerte Säurezersetzung von Bedeutung; durch sie allein kann die Beschleunigung der Säurezersetzung unter dem Einflusse des Lichtes zur Geltung kommen. Aber es ist mir wahrscheinlich, dass die Lichtstrahlen hierbei auch noch in directer Weise betheiligt sind. Wir werden unten Experimente kennen lernen, deren Resultate zeigen, dass Lichtzutritt die Oxydation organischer Säuren ausserhalb des Organismus begïnstigt. Eine directe Beeinflussung des Säurezersetzungsprocesses in den Zellen der Pflanzen durch Lichtstrahlen erscheint daher sehr wohl möglich.

Man weiss, dass Theile succulenter Pflanzen, die einige Zeit (z. B. eine Nacht lang) in einer beschränkten Luftmenge verweilen, das Volumen derselben vermindern. Es wird eben Sauerstoff bei der Bildung organischer Säuren gebunden. Dieselben Pflanzentheile vergrössern dagegen das sie umgebende Luftvolumen am Tage, indem sie Sauerstoff expiriren. Dieser Sauerstoff wird aber nicht direct aus den Molekülen der sich zersetzenden orgauischen Säuren abgespalten, sondern er ist ein Product wirklicher assimilatorischer Thätigkeit der Chlorophyllkörper. Die erforderliche Kohlensäure liefern freilich in der oben erörterten Weise die sich zersetzenden organischen Säuren.

Wir kommen nunmehr dazu, Anleitung zu Experimenten zu geben, deren Resultate uns über das Verhalten organischer Säuren im Organismus der Crassulaceen orientiren können.

Als Beobachtungsobjecte verwendet man in Töpfen gezogene, unter günstigen äusseren Verhältnissen kräftig entwickelte Exemplare von Bryophyllum calycinum, Echeveria metallica oder Rochea falcata (die letztere Pflanze ist besonders geeignet). Bei vergleichenden Untersuchungen iuber die Säureansaminlung, resp. Säureabnahme im Gewebe der Bliitter benutzt man entweder die beiden opponirten Glieder eines Blattpaares (z. B. Rochea), oder man experimentirt nur mit einem Blatt (z. B. Echeveria metallica) und theilt dasselbe der Länge nach in zwei möglichst gleiche Theile. Die von der Pflanze abgetrennten Untersuchungsobjecte werden sofort gewogen. Wenn es sich darum handelt, ihren Gelialt an freier Säure nicht sofort, sondern erst nach Verlauf einiger Zeit zu bestimmen, so gelangen die Blätter z. B. auf durchfeuchtetes Fliesspapier unter Glasglocken. Den Säuregehalt der Blätter ermittelt man durch Titriren. Die beim Titriren verbrauchte Menge an Kalilauge giebt ein unmittelbares Maass für die Acidität des Zellsaftes der Untersuchungsobjecte (vgl. die Methode unter 130). 
Wir führen zunächst die folgenden Versuche aus. Gegen Abend, etwa um 5 oder 6 Uhr, wird ein Blattpaar von Rochea abgeschnitten, nachdem die Pflanze den Tag über dem directen Sonnenlicht ausgesetzt gewesen war. Experimentirt man mit Bryophyllum, so entnimunt man der Pflanze einige Blattpaare, und bei Versuchen mit Echeveria verwendet man nur eins der grossen Blätter. Die Hälfte der Untersuchungsobjecte wird sofort acidimetrisch geprüft; der andere Theil am nächsten Morgen, nachdem die Blätter bis dahin bei völligem Lichtabschluss in feuchter Luft unter einer Glasglocke verweilt haben. Ich fand z. B., dass die beiden Blätter eines Blattpaares von Rochea falcata 12,6 (a) und 13,6 g (b) wogen. $a$ wurde nach dem Abschneiden sogleich an Abend untersucht, $b$ erst am nächsten Morgen. Der Brei von $a$ bedurfte 2,6 , derjenige von $b 12,5 \mathrm{ccm}$ verdünnter Kalilauge zur Neutralisation. Auf je $10 \mathrm{~g}$ Blattsubstanz bezogen, erhalten wir für $a$ 2,1, für b 9,2 ccm Kalilauge, Differenz $7,1 \mathrm{ccm}$. Man kann auch derartig verfahren, dass man nur ein Blatt der Pflanze am Abend abschneidet, um dasselbe sogleich auf seinen Säuregehalt zu prüfen, wälırend man das zweite erst am nächsten Morgen von der Pflanze entfernt, nachdem dieselbe bis dahin bei völligem Lichtabschluss verweilt hat. Die Experimente ergeben stets eine erheblich höhere Acidität für den Saft derjenigen Blätter, die einige Zeit in Dunkeln verweilt liaben.

Will man sich noch sicherer davon überzeugen, dass die Acidität des Saftes der Crassulaceen durch Lichtzutritt vermindert, im Dunkeln aber erhöht wird, so ist es erforderlich, das folgende Experiment auszuführen. Es werden zwei opponirte Blätter eines Exemplars von Rochea früh am Morgen abgeschnitten. Das eine Blatt wird der Länge nach halbirt, $1 \mathrm{~m}$ in der einen Blatthälfte, nachdem man dieselbe gewogen hat, sofort die Acidität des Zellsaftes durch Titriren festzustellen. Die zweite Blatthälfte hängt man in dampfgesättigten Raum unter einer Glasglocke auf und verdunkelt durch Ueberdecken mit einem Pappcylinder. Das zweite Blatt wird im dampfgesättigten Raum unter einer Glasglocke bei Zutritt recht hellen, diffusen Tageslichtes aufgehängt und dafür Sorge getragen, dass auch die Rückseite des Blattes durch einen in geeigneter Weise aufgestellten Spiegel reflectirtes Licht empfängt. Bei dieser Versuchsanordnung sind die Untersuchungsobjecte nahezu den gleichen Temperaturverhältnissen ausgesetzt, und es ist daher eine Wärmeentsäuerung möglichst ausgeschlossen. Prüft man Abends die Acidität der Blatthälfte sowie des Blattes, so findet man jene (natürlich bezogen auf gleiche Gewichtsmengen frischer Blattsubstanz) säurereicher als dieses. Von dem bedeutsamen Eintiusse der Temperaturverhältnisse auf den Process der Säurezersetzung in den Crassulaceenblättern kann man sich leicht überzeugen, wenn man Exemplaren von Bryophyllum, Rochea oder Echeveria, die seither normalen Lebensbedingungen ausgesetzt waren, am frühen Morgen einige säurereiche Blätter entnimmt, um in einem Theil derselben sofort die Acidität des Saftes festzustellen, während die übrigen erst auf ihren Gehalt an freier Säure untersucht werden, nachdem sie bei völligem Lichtabschluss etwa 12 Stunden lang theils bei niederer Temperatur (z. B. $12-16^{\circ} \mathrm{C}$.), theils in einem Thermostaten bei $30^{\circ} \mathrm{C}$. verweilt haben. Es wird sich ergeben, dass der Einfluss der hohen Temperatur trotz des Lichtausschlusses eine starke Entsäuerung herbeigefiihrt hat. 
Wir entnehmen einem Exemplar von Rochea (man kann auch mit Echeveria oder Bryophyllum experimentiren) gegen Abend ein Blattpaar. Das eine Blatt wird sogleich auf seinen Gehalt an freier Säure untersucht, das andere Blatt halbirt man der Länge nach. Jedes der Blattstücke wird nach dem Wägen in kleine Stücke von etwa $1 \mathrm{~cm}$ Länge zerschnitten, um diese Stücke in retortenartige Gefässe zu bringen, die mit ausgekochtem und wieder völlig abgekühltem, destillirtem Wasser angefüllt sind. Das Wasser der einen Retorte wird durch Luft, dasjenige der anderen durclı reinen Wasserstoff verdrängt (Methode vergl. unter 10). Am nächsten Morgen bestimmt man den Säuregehalt der Untersuchungsobjecte, und es wird sich zeigen, dass die Blattstücke in der Luft viel freie Säure entwickelt haben, während im Wasserstoffgas höchstens geringe Quantitäten freier Säure gebildet worden sind. Es ist demnach freier Sauerstoff für die ausgiebige Säureproduction erforderlich.

Es ist schon erwähnt worden, dass Lichtzutritt die Zersetzung organischer Säuren ausserhalb des Organismus zu beschleunigen vermag, eine Thatsache, welche, wie ich bereits bemerkte, wohl sicher mit Rücksicht auf die uns hier beschäftigenden Fragen Interesse beansprucht. Den Einfluss des Lichtes auf die Säurezersetzung kann man leicht (auch in der Vorlesung) demonstriren, wenn man zu einer Lösung von 0,2 Aequiv. Oxalsäure, mit der ein Reagensglas völlig angefüllt ist, etwas frisch bereitetes Eisenoxydhydrat (hergestellt durch Vermischen einer Eisenchloridlösung mit Ammoniak und sorgfältiges Auswaschen des Niederschlages) bringt und die nach einiger Zeit intensiv gelb gefärbte Flüssigkeit in dem Probirrohr nunmehr über Quecksilber dem directen Sonnenlicht aussetzt. Es beginnt sogleich Gasentwickelung. Das Gas (Kohlensäure) sammelt sich im oberen Theile des Apparates an, während sich die Flüssigkeit unter Abscheidung eines Niederschlages von oxalsaurem Eisenoxydul entfärbt. Es ist nicht unmöglich, dass der Oxydationsprocess organischer Säuren in der Pflanze ebenfalls durch den directen Einfluss der Lichtstrahlen wesentlich gefördert wird.

Endlich wollen wir noch Experimente anstellen, welche lehren, dass succulente Pflanzentheile, wie schon erwähnt wurde, in der That relativ viel Sauerstoff aufnehmen, wenn in ihren Zellen Säureanhäufung erfolgt. Für Demonstrationszwecke in Vorlesungen genügt es vollkommen, wenn man das Experiment in folgender Weise ausführt. Wir entnehmen einem Exemplar von Rochea falcata am Abend eines heissen Sommertages ein Blatt (bei meinen Versuchen besass dasselbe ein Gewicht von $24 \mathrm{~g}$ ), zerschneiden dasselbe in Stücke und bringen diese in den oberen, bauchig erweiterten Theil des unter 10 in Fig. 11 abgebildeten Eudiometers. Wir tauchen den unteren Theil des Steigrohres in Wasser, verschliessen den Apparat und stellen ihn iu Dunkeln auf. Nach Verlauf längerer Zeit (z. B. 12 Stunden) stellen wir fest, dass das Wasser sich beträchtlich im Steigrohr erhoben hat, während dies nicht bei Parallelversuchen der Fall ist, in denen wir in ein zweites Eudiometer junge Stengeltheile nicht succulenter Pflanzen (z. B. Helianthus) eingeführt haben. Die Rocheablattstücke unterhalten eben nicht nur normale Athmung, sondern zugleich Vinculationsathmung. Es wird Sanerstoff ohne entsprechende Kohlensäureproduction zur Ueberführung von Kohlehydraten in organische Säuren von ihnen absorbirt. 
Bei genauen quantitativen Untersuchungen über die Sauerstoffinspiration der Succulenten muss man natürlich Quecksilber als Sperrflüssigkeit des Eudiometers benutzen und die Versuche überhąupt in einer Weise ausführen, die sich nach demjenigen, was unter 13 angeführt worden ist, von selbst ergiebt.

\section{Die Gummiarten und die Pflanzensehleime.}

Das arabische Gummi (Stammpflanzen: verschiedene Acaciaarten) besteht der Hauptsache nach aus Arabinsäure. Wenn man etwas arabisches Gummi in einem Uhrschälchen mit Jodjodkaliumlösung behandelt und dann Schwefelsäure hinzufügt, so nimmt die Masse nur eine braune Färbung an. Alle echten Gummiarten verhalten sich so, während sich die Pflanzenschleime bei der Behandlung mit Jod und Schwefelsäure violett oder blau färben. Das Traganthgummi entsteht nach den Untersuchungen von Монг durch Desorganisation der Mark- und Markstrahlzellen verschiedener Astragalusarten. Das Traganthgummi stellt keine homogene Masse dar, wovon man sich leicht überzeugen kann, wenn man das käufliche und gepulverte Material mit viel Wasser behandelt. Es entsteht eine Lösung, die beim Eindampfen eine farblose, glasartige Masse, das eigentliche Traganthgummi, zurücklässt, und es bildet sich ein Bodensatz, der, wie die mikroskopische Untersuchung lehrt, aus Amylumkörnern sowie Zellhautfragmenten besteht. Der Gehalt der einzelnen Traganthsorten an Zellmembranen, die nicht völlig in Gummi umgewandelt sind, ist ein verschiedener.

Gummibehälter der Pflanzen lassen sich leicht nachweisen, wenn man Schnitte aus etwa $5 \mathrm{~mm}$ dicken Zweigen von Tilia parvifolia untersucht. Die luftführenden Markzellen sind gross; sie sind rosettenförmig um einzelne kleinere Zellen gruppirt, welche Gerbstoff, Stärke oder Krystalldrusen enthalten. Die Gummibehälter, als Höhlungen auftretend, liegen in den äusseren Theilen des Markes. Die Peripherie des Markes, in welche die primären Holztheile hineinragen, wird von einem kleinzelligen Parenchym gebildet, dessen Elemente Gerbstoff oder Stärke führen.

Untersucht man einen Querschnitt aus einer Knolle von Orchis mascula oder 0. Morio mikroskopisch, so zeigt sich, dass das Parenchym, in welchem die Gefässbündel zerstreut liegen, aus kleinen, stärkeführenden Zellen und grossen Zellen besteht, die sehr schleimreich sind. Zieht man pulverisirte Orchideenknollen mit kaltem Wasser aus oder behandelt man den käuflichen Salep mit kaltem Wasser, so erhält man nach dem Filtriren eine klare Flüssigkeit, in der sich auf Alkoholzusatz weisse, flockige Massen des in Weingeist unlöslichen Orchideenschleims abscheiden. Dampft man die auf die angegebene Weise gewonnene Schleimlösung ein und behandelt den Rückstand mit Jodjodkalium und Schwefelsäure, so färbt er sich violett bis blau. Die schleimigen Massen in Oruhideenknollen repräsentiren also kein Gummi, sondern echten Pflanzenschleim ').

\section{Die Gerbsäuren.}

Die Gerbsäuren scheinen zumal als Schutzmittel der Pflanzen gegen den Angriff von Thieren und als antiseptisch wirkende Sub-

1) Die Literatur über Gummiarten und Pflanzenschleime findet man zusammengestellt bei SACHSSE, Die Chemie und Physiologie der Farbstoffe, Kohlehydrate etc., Leipzig 1877, S. 161 . 
stanzen zu dienen. Damit hängt es auch wohl zusammen, dass in sehr vielen Fällen gerade die peripherisch gelegenen Pflanzengewebe besonders gerbsäurereich sind. Das beste Reagens auf Gerbsäuren ist das zweifach-chromsaure liali ${ }^{1}$ ), und wir wollen mit Hülfe desselben z. B. untersuchen, welche Gewebe der Zweige von Corylus Avellana Gerbsäure enthalten. Zur Orientirung stellen wir uns zunächst einen Querschnitt aus einem etwa $4 \mathrm{~mm}$ dicken Zweige her. Auf das Periderm folgt Collenchym, dann Rindenparenchym, ferner ein Ring, der aus stark verdickten Sklerenchymzellen besteht, ferner der Bast mit eingestreuten Bastfasern und endlich das Holz. Lassen wir der Länge nach halbirte Zweigstücke von Corylus (ich untersuchte $4 \mathrm{~mm}$ dicke Zweige im November) einige Tage in einer 10 -proc. Lösung von zweifach-chromsaurem Kali liegen und untersuchen dann feine Querschnitte mikroskopisch, so ist das Vorhandensein von Gerbsäure in gewissen Geweben (namentlich in der Rinde, dem Bastparenchym und den meist einchichtigen Holzmarkstrahlen) leicht zu constatiren, denn der Inhalt der gerbsäureführenden Zellen hat sich rothbraun gefärbt.

Bei der Untersuchung des Längsschnittes aus dem Mark eines diesjährigen Rosenzweiges sehen wir, dass dasselbe einerseits aus grossen Zellen besteht, sowie ferner aus der Länge nach verlaufenden und unter einander verbundenen Zellenzügen, die das grosszellige Gewebe durchsetzen. Untersuchen wir Schnitte aus dem Rosenmark, welche auf dem Objectträger in einen Tropfen einer 10-proc. wässerigen Lösung von zweifach-chromsaurem Kali gebracht worden sind, so zeigt sich, dass der Inhalt der meisten schmalen Zellen rothbraun gefärbt erscheint. Die Gegenwart von Gerbsäure in den schmalen Zellen kann man ebenso feststellen, wenn man Schnitte des Rosenmarkes in einen Tropfen wässeriger Eisenchloridlösung oder in einen Tropfen der Lösung des schwefelsauren Eiserroxyds legt. Der Inhalt der gerbsäureführenden Zellen färbt sich dann dunkelblau. Auch die Blätter der Rosen sind sehr gerbsäurereich, und um diese Thatsache z. B. in der Vorlesung zu demonstriren, presst man ein auf Fliesspapier liegendes, zusammengefaltetes Blatt stark mit den Fingern aus, so dass der aus den Zellen austretende Saft von dem Papier festgehalten werden kann. Auf Betupfen der feuchten Papierstellen mit Eisenchloridlösung tritt die Gerbsäurereaction sofort hervor.

Neuerdings hat man sich mehrfach bemüht, quantitativ chemische Untersuchungen über das Auftreten des Gerbstoffs in den Pflanzen anzastellen, um zu einem näheren Verständniss derjenigen Processe zu gelangen, welche die Entstehung der Gerbstoffe im Organismus vermitteln. Bei diesen Untersuchungen und ebenso bei den mit Hülfe mikrochemischer Methoden durchgeführten Studien über die genetischen Beziehungen der Gerbstoffe darf freilich nicht vergessen werden, dass diejenigen Körper, welche man als "Gerbstoff ${ }^{\mu}$ bezeichnet, recht verschiedener chemischer Natur sein können, und daher sämmtliche Arbeiten nach der bezeichneten Richtung hin noch immer einen provisorischen Charakter tragen müssen. Die erwähnten Untersuchungen verdienen aber dennoch, wie cin näheres Studium derselben lehrt, hohe Beachtung, und wir dürfen sie hier nicht ausser Acht lassen.

Bei quantitativen Gerbstoffbestimmungen verwendet man bei $100^{\circ} \mathrm{C}$.

1) Vgl. Saxio, Botan. Zeitung, 1863, S. 17. 
getrocknetes Untersuchungsmaterial, wenn man es mit Rinden, Hölzern oder massigen Rhizomen zu thun hat. Die Substanz wird auf geeigneten Mühlen ${ }^{1}$ ) feinstens zermahlen. Ebenso benutzt man Trockensubstanz bei der Untersuchung, wenn man mit weichen Rhizomen oder Wurzeln, mit Blättern, Samen oder Keimlingen experimentiren will. Die Substanz wird in diesen Fällen in Wasser aufgeweicht, um sie alsdann in der Reibschale feinstens $\mathrm{zu}$ zerkleinern ${ }^{\mathbf{2}}$ ).

Zur Extraction des Gerbstoffs verwendet man sehr zweckmässig den in Fig. 114 dargestellten Extractionsapparat, welcher vom Zinngiesser C. Focke in.Dresden (Grosse Kirchgasse 3) in vorzüglicher Ausführung geliefert wird. Der aus Zinn gefertigte Apparat besteht aus einem mit Ausguss verseheven Kochcylinder von $12,5 \mathrm{~cm}$ Höhe und $7 \mathrm{~cm}$ Durchmesser im Lichten, mit einer am Stempel befindlichen Siebplatte zum Abpressen. Beim Gebrauch wird eine dünne Gaze über die Siebplatte gebunden, was mit besonderer Sorgfalt geschehen muss. $2-5 \mathrm{~g}$ des bei $100^{\circ} \mathrm{C}$. getrockneten Untersuchungsmaterials werden mit $200 \mathrm{ccm}$ Wasser übergossen, um die Fliissigkeit nach 12 Stunden

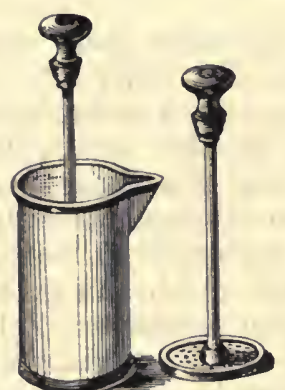

Fig. 114. Extractionsapparat für Gerbstoffbestimmungen. in einen Literkolben zu giessen. Der Rückstand gelangt jetzt in den Extractionsapparat und wird in demselben $4 \mathrm{mal}$ je eine halbe Stunde béi Kochhitze, indem man den Kochcylinder in ein Wasserbad setzt, mit $200 \mathrm{ccm}$ Wasser digerirt. Der Extract wird schliesslich filtrirt. Den Gerbstoffgehalt der Auszüge bestirmt man genau nach der LöwenthaL - v. Schröder'schen Methode, wie sie in dem in der letzten Anmerkung citirten Commissionsbericht dargelegt ist, durch Titriren mit Chamäleonlösung und indigschwefelsaurem Natron (Carminum coerul. apt. von GEHE \& Co. in Dresden).' Die einzelne Dosis von der Gerbstofflösung ist derartig zu wählen, dass der Chamäleonverbrauch für sie nicht viel hinter dem für die Indigodosis $(10 \mathrm{ccm})$ zurückbleibt. Die gefundenen Cubikcentimeter verbrauchter Chamäleonlösung werden auf sog. Gerbstoffprocente berechnet, unter der Annahme, dass $1 \mathrm{ccm}$ der Lösung $2 \mathrm{mg}$ Tannin entsprechen.

$\mathrm{Zu}$ den wichtigsten Thatsachen, die Kraus in seiner citirten Schrift feststellte, gehören diese, dass die Gerbstoffe in grünen Blättern bei Lichtzatritt und bei Gegenwart von Kohlensäure, nicht aber im Dunkeln oder bei Kohlensäureabwesenheit entstehen. Trotzdem sind die Gerbstoffe nicht als Assimilationsproducte anzusehen; sie entstehen vielmehr vermuthlich in Folge von Stoffwechselprocessen als Nebenproducte bei der Synthese der Eiweissstoffe. Manche Pflanzen bilden zudem überhaupt keine Gerbstoffe, und oft werden sie auch in normalerweise gerbstoffführenden Organen, trotzdem sich Kohlehydrate durch Assimilation bilden,

1) Hat man es nicht unit gar zu harten Pflanzentheilen zu thun, so empfiehlt es sich, eine sogen. Excelsiormühle zn benutzen, die im Preise von $30 \cdots 40$ M. von Grusos in Magdeburg-Buckau zu beziehen ist. "Zum Zermahlen von Holz etc. sind Mühlen von G. Wexderotu in Cassel zu beziehen.

2) Näheres vgl. bei KraUs, Grundlinien zu einer Physiologie des Gerbstoffs, Leipzig 1889, und Berichte über die Verhandlungen der Commission zur Feststellung einer einheitlichen Methode der Gerbstoffsbestimmung, geführt am 10. Nov. 1883 zu Berlin, Verlag von Fischer in Cassel, 1Ss5. 
nicht erzeugt. Dies letztere ist z. B. bei relativ schwacher Lichtintensität der Fall.

Wir schneiden im Sommer bei warmer Witterung 6 ausgewachsene Blätter von Saxifraga crassifolia ab, trennen von jedem Blatt der Mittelrippe entlang (ohne diese aber $\mathrm{zu}$ verletzen) die eine Blatthälfte ab und isoliren aus diesen Hälften Stücke von je etwa $50 \mathrm{qcm}$ Fläche unter Benutzung von Matrizen, die aus Millimeterpapier bestehen. Die Blattstücke werden getrocknet und sofort auf Gerbstoffgehalt untersucht. Die mit der Blattrippe noch versehenen Blatthälften stellt man mit ihrem Stiel in Brunneuwasser, mit dem kleine Gläser angefüllt sind. Diese gelangen in einen Glaskasten, der nach Bedürfniss oben mit einer Glasplatte geschlossen werden kann. So vorbereitet, exponirt man die Untersuchungsobjecte im leichten Schatten, wio ihn z. B. Birken geben, dem Einfluss des Lichtes. Nach Verlauf einiger Tage entnimmt man den Blatthälften ebenso wie den früher abgeschnittenen und zwar an genau entsprechenden Stellen mit Hülfe des Millimeterpapiers für die Trockensubstanz- und Gerbstoffbestimmung geeignete Stücke. Zu ähnlichen Versuchen eignen sich auch die Blätter von Quercus und Viburnum. Man wird finden, dass die Blätter in Folge des Verweilens am Licht an Trockensubstanz- und an Gerbstoffgehalt zunehmen; dies ist nicht der Fall, wenn die Blätter einige Tage im Finstern gehalten werden. Stellt man Experimente in der soeben angegebenen Weise mit Blättern von Saxifraga, aber mit der Modification an, dass die Untersuchungsobjecte dem Licht unter einer grossen Glasglocke in kohlensäurefreier Atmosphäre ausgesetzt werden, so ergiebt sich, dass keine Gerbstoffvermehrung erfolgt. Wir haben demnach bewiesen, dass Gerbstoff in grünen Blättern nur unter dem Einfluss des Lichtes und bei Kohlensäuregegenwart entstehen kann (indirecter Einfluss der Assimilation) ${ }^{1}$ ).

Von 10 Blättern der Alnus glutinosa, die man aber nicht von der Pflanze abtrennt, werden Blatthälften am Abend eines warmen Sommertages abgeschnitten, um $150 \mathrm{qcm}$ Blattfläche auf Gerbstoff zu untersuchen. Am nächsten Morgen kommen die übrigen Blatthälften zur Prüfung. Es hat ein Gerbstoffverlust stattgefunden. Die eingehenden Versuche von Kraus (S. 9 seiner Arbeit) lehren, dass der Gerbstoff keine Zersetzung in den Blättern erfährt. sondern aus denselben auswandert. Er bewegt sich durch die Blattnerven in die Stengel oder Zweige, wandert in der Rinde weiter und wird endlich je nach der Pflanzenart in Rhizomen, dem Holz oder an anderen Orten abgelagert. Dieser in den Blättern gebildete primäre Gerbstoff tritt nicht wieder in den Stoffivechsel ein. Er dient namentlich dazu, die Organe, in denen er abgelagert worden ist, gegen Thierfrass und Fäulniss zu schützen.

Abgesehen von den primären, giebt es nun aber noch sog. secundäro Gerbstoffe, d. h. solche, die sich im Dunkeln in Folge von Stoffwechselprocessen in manchen Pflanzen bilden. Prüft man Samen von Vicia Faba, so findet man diese gerbstofffrei. Wenn man dagegen die im Dunkeln erwachsenen Keimlinge von Vicia untersucht, so erweisen sie sich recht gerbstoffreich.

1) Dies Resultat ist für die benutzten Untersuchungsobjecte und unter den in unseren Expcrimenten eingehaltenen Bedingungen sicher richtig. Unter modificirten Umständen gestaltet sich das Ergebniss der Versuche aber etwas anders. Vergl. darüber BÜsGFx, Beobachtungen über das Verhalten des Gerbstoffes in den Pflanzen, Jenạ 1889, S. 28. 
Handelt es sich darum, die Entstehung und das weitere Verhalten der Gerbstoffe mit Hülfe mikrochemischer Methoden näher zu studiren, so geht man am besten, wie folgt, vor. Man injicirt die Untersuchungsobjecte unter der Luftpumpe mit einer 10-proc. Lösung von Kaliumbichromat, lässt sie darin absterben und untersucht sie dann nach sorgsamem Auswaschen sofort oder nach Aufbewahrung in Alkohol. Mit Hülfe dieser Methode kann man z. B. leicht feststellen '), dass secundärer Gerbstoff in Keimlingen von Vicia Faba, die sich im Dunkeln entwickelt haben, in besonders grosser Menge auftritt, in der Epidermis sowie dem subepidermalen Gewebe und in dem die Gefässbündel umgebenden Parenchym. Die Hauptwurzel der Viciakeimlinge führt in der Rinde viel Gerbstoff, ihr Centralcylinder ist fast gerbstofffrei.

Secundären Gerbstoff führen auch die Stengel im Dunkeln .erwachsener Keimlinge von Phaseolus multiflorus. Der Gerbstoff kommt in besonderen Schläuchen des Siebtheils der Gefässbündel vor. Die Keimwurzel von Phaseolus ist gerbstofffrei; ebenso enthält der Embryo ruhender Phaseolussamen gar keinen Gerbstoff. Zum Nachweis des Gerbstoffs in den Phaseoluskeimlingen benutzt man ebenfalls eine Lösung von doppeltchromsaurem Kali oder von Eisenchlorid.

Wir schneiden im Frühjahr Zweige von Lonicera tatarica ab, die wir mit ihrer Basis in Wasser stellen. Das Austreiben der Knospen dieser Zweige erfolgt theils im Dunkeln, theils bei Lichtzutritt. Nur in dem Axentheil der jungen Triebe, die sich im Licht entwickelt haben, ist auf mikrochemischem Wege (z. B. in Epidermis und Rindenparenchym) primärer Gerbstoff nachzuweisen. Die im Dunkeln entstandenen Triebe sind gerbstofffrei. Weiteres vergleiche in BüsGEN's Abhandlung.

\section{Die ätherischen 0ele und Harze.}

Die ätherischen Oele dürfen in vielen Fällen sicher nicht als Excrete angesehen werden, sondern man muss sie als Secrete, d. h. als Absonderungen, denen physiologische Functionen zukommen (Anlockung für die Uebertragung des Pollens nothwendiger Thiere, Fernhaltung schädlicher Thiere etc.) betrachten. Ebenso sind viele Harze gewiss als Secrete aufzufassen ${ }^{2}$ ).

Aetherische Oele sind häufig in Intercellularräumen vorhanden. Untersuchen wir z. B. nicht gar zu dünne Querschnitte aus dem Stengel von Ruta graveolens, so sehen wir, dass auf die Epidermis ein hypodermales Gewebe und unter diesem grünes Parenchym folgt. In dem letzteren sind hier und dort mit einer gelblichen, stark lichtbrechenden Flüssigkeit (eben dem ätherischen Oele) angefüllte Lücken vorhanden. Ebenso sind die intercellularen, mit ätherischem Oel angefüllten Secretbehälter leicht zu sehen, wenn man Blattquerschnitte von Citrus untersucht. Alkohol löst die ätherischen Oele auf.

Aber nicht nur in Intercellularräumen, sondern auch in Zellen eingeschlossen kommen ätherische Oele in den Pflanzen vor. Derartige

1) Vgl. BüsGEx, Beobachtungen über das Verhalten des Gerbstoffes in den Pflanzen, Jena 1859.

2) Vgl. H. DE VRIEs, Landwirthschaftl. Jahrbïcher, Bd. 10. 
Secretbehälter, und zwar speciell solche, die nach DE BARY zu der Kategorie der "kurzen Schläuche" gehören, weil die betreffenden Zellen nahezu isodiametrisch sind, finden wir z. B. bei Aristolochia Siplı. Bei der Untersuchung des Querschnittes aus einem etwa $4 \mathrm{~mm}$ dicken Stengel dieser Pflanze erkennen wir leicht das Mark sowie die Gefässbündel mit ihrem entwickelten $\mathrm{Holz}$ - und Basttheil. Jedes Gefässbündel ist nach aussen umrahmt vom parenchymatischen Rindengewebe, und an dieses schliesst sich ein geschlossener Ring von Sklerenchymfasern an, der zwischen den Gefässbündeln etwas nach innen vorspringt. Ausserhalb des erwähnten Ringes folgt grünes Parenchym, dann Collenchym und die Epidermis. In dem Rindenparenchym, welches ausserhalb und innerhalb des Sklerenchymfaserringes liegt, beobachtet man nun bei der Untersuchung von Quer- und auch von Längsschnitten des Aristolochiastengels das Vorhandensein zerstreut liegender Zellen, die einen gelblichen, stark lichtbrechenden Inhalt führen. Es sind dies eben die Secretbehälter, um deren Nachweis es uns zu thun war. Gegen Alkannatinctur und Osmiumsäure verhalten sich die ätherischen Oele ebenso wie die Fette. Erhitzt man die Schnitte aber auf dem Objectträger ohne Deckglas 10 Minuten lang in Wärmeschrank bei $130^{\circ} \mathrm{C}$., so verschwinden die ätherischen Oele, weil sie flüchtig sind.

Lehrreich ist es auch, die Thatsache festzustellen, dass die Früchte vieler Umbelliferen reich an ätherischem Oel sind, das hier in Intercellularräumen angetroffen wird und offenbar als Schutzmittel gegen schädliche Thiere fungirt. Wir stellen z. B. Querschnitte durch die von der Seite zusammengedrückte Frucht von Carum Carvi her. Jede der beiden Theilfrüchte ist mit Endospermmassen ausgefüllt, in deren Mitte der Embryo ruht. Ferner sieht man die fünf Hauptrippen jeder Theilfrucht. Im Gewebe der Fruchtwand erblickt man die Oelstriemen, welche die mit ätherischem Oel erfüllten Intercellularräume darstellen.

Handelt es sich darum, Harzgänge kennen zu lernen, so untersucht man zweckmässig sehr zarte Querschnitte der Nadeln von Pinus sylrestris. Auf die Epidermis, deren Zellen sehr stark verdickt sind, folgt hypodermales Gewebe. An den beiden Kanten des Blattes ist diese Schicht stärker entwickelt. Die Harzgänge (es ist stets eine ganze Anzahl derselben vorhanden) liegen im grünen Gewebe des Untersuchungsobjectes. Jeder Harzgang ist von einer Schicht dünnwandiger Zellen, dem Epithel, umkleidet, die ohne Zweifel das Material liefern, aus welchem sich das Secret bildet, und ferner wird jeder Harzgang von einer Schicht stark verdickter Sklerenchymfasern umsäumt. Weiter erblickt man das grüne Blattgewebe und das fast chlorophyllfreie Gewebe in der Mitte des Blattes, welches von dem grünen Gewebe durch eine Endodermis abgegrenzt ist. Das fast farblose Grundgewebe der Blattmitte zeigt sich aus dickwandigen und dïnnwandigen Elementen zusammengesetzt und schliesst zwei Gefässbündel ein. Achnlich wio das Blatt von Pinus sylvestris ist dasjenige von Pinus Pinaster gebaut. Die Nadeln der letzteren Pflanze lassen sich besser als diejenigen der ersteren Pflanze schneiden, und man hat ihnen daher, wenn sie zur Disposition stehen, bei der Untersuchung den Vorzug zu geben.

Ferner ist es sehr leicht, das Vorhandensein von Harzgängen im Stengelgewebe vieler Umbelliferen festzustellen. Wir untersuchen z. B. Querschnitte des Blüthenschaftes von Foeniculum officinale bei schwacher Vergrösserung. Die Epidermis, das Rindengewebe, der Bast- sowie Holztheil der Gefässbündel und das Mark treten deutlich hervor. Die Harz- 
gänge sind den Gefässbündeln vorgelagert. Sie liegen in der Rinde, zwischen den Fibrovasalsträngen und einem Gewebe, das wir sofort als Collenchym erkennen.

\section{Die Farbstoffe.}

Zahlreiche Pflanzentheile führen Farbstoffe von sehr verschiedenartiger Natur. Es ist hier zunächst zu betonen, dass diese Farbstoffe schon deshalb ein nicht geringes physiologisches Interesse beanspruchen, weil manche derselben uns unmittelbar Aufschluss über die Reaction derjenigen Zellen gewähren, in denen sie angetroffen werden. Im Zellsaft der Haare von den Blattstielen mancher Begoniaspecies sind rothe Farbstoffe gelöst, was auf saure Reaction des Zellsaftes schliessen lässt. Wird ein Haar auf dem Objectträger mit sehr verdünnter Kalilauge behandelt, so geht in der That dis rothe Farbe des vorhandenen Pigmentes in eine blaue über; auf Säurezusatz tritt die rothe Farbe aber wieder hervor. Im Zellsaft der Myosotisblumenblattzellen ist blauer

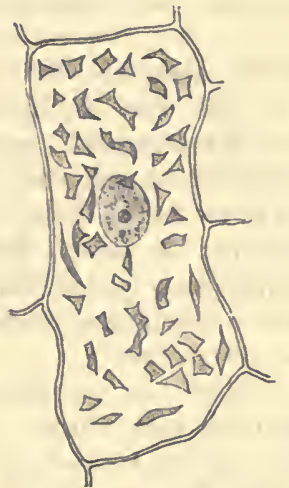

Fig. 115. Von der Oberseite des Kelches von Tropaeolum majus. Untere Wandung einer Epidermiszelle mit den ihr anliegenden Farbkörpern. Vergr. 540. (Nach STRASBURGER.) Farbstoff gelöst. Die Reaction des Zellsaftes ist hier cine schwach alkalische, denn Säurezusatz färbt das Pigment roth.

Wenn wir Staubfädenhaare einer Tradescantia mikroskopisch untersuchen, so können wir leicht feststellen, dass in dem Zellsafte ihrer Zellen ein violetter Farbstoff aufgelöst ist. Wir ziehen mit einer Pincette ein Stückchen Epidermis von dem Blumenblatte einer Vincaart und einer rothen Rose ab. Bei mikroskopischer Prüfung finden wir, dass beide Präparate im Zellsaft aufgelöste Pigmente enthalten. In einem Falle ist der Farbstoff aber blau, im anderen rosa. Die blauen, violetten oder rothen, im Zellsaft gelösten Farbstoffe werden als Anthocyan bezeichnet.

Manche Pigmente kommen nicht im gelösten Zustande in den Zellen vor, sondern sie werden, an eine Grundmasse gebunden, in denselben angetroffen. Die mit dem Pigment imprägnirten Farbkörperchen (Chromatophoren) besitzen meistens charakteristische Formen, und wir wählen zunächst nicht gar zu reife, aber doch bereits schön geröthete Hagebutten als Untersuchungsmaterial. Wir stellen Schnitte aus dem Hypanthiumfleisch her. Die Zellen desselben enthalten neben Protoplasma und Kern zugespitzte, orangefarbene Spindeln oder in derselben Weise tingirte dreieckige Gebilde, eben die Farbkörperchen. Die orangerothe Farbe der Wurzeln der Mohrrübe (Daucus carota) wird durch Farbliörper hervorgerufen, die man leicht in Form rechteckiger Tafeln oder gestreckter Prismen bei mikroskopischer Untersuchung in den Zellen auffinden kann. Weiter stellen wir Flächenschnitte von der Oberseite der Kelchblätter eben geöffneter Blüthen von Tropaeolum majus her. In den Zellen, zumal in den Epidermiszellen, sind zahlreiche eckige, gelb gefärbte Farbkörper bei mikroskopischer Untersuchung leicht zu entdecken (vergl. Fig. 115.) Die brauuen Streifen an der Oberseite der Tropaeolumkelchblätter rühren, 
wovon man sich beim Studium geeigneter Schnitte überzeugen wird, daher, dass die betreffenden Epidermiszellen carminrothen Zellsaft enthalten. Die gelben Pigmente der Pflanzen sind fast ausnahmslos an eine protoplasmatische Grundmasse gebunden. Nur selten treffen wir sie im Zellsaft gelöst an. Dies letztere ist z. B. der Fall in den Epidermiszellen der Blumenblätter von Verbascum nigrum ').

Der in den meisten gelben Blüthen enthaltene Farbstoff ist nicht ohne weiteres im Wasser löslich, wohl aber in Alkohol." Er kann mit Hülfe dieses Lösungsmittels z. B. den Kronenblättern einer gelb blühenden Ranunculusspecies leicht entzogen werden. Die meisten rothen Blüthenfarbstoff $\theta$ sind hingegen in Wasser löslich, und wenn man z. B. Blumenblätter einer rothen Rose oder von Paeonia in einem Mörser mit Wasser zerquetsclıt, un die erhaltene Lösung abzufiltriren, so erhält man ein roth gefärbtes Filtrat, das nach meinen Beobachtungen (ich experimentirte mit Paeonia) auf Ammoniakzusatz eine blaue Farbe annimmt. Zusatz von Salzsäure stellt die rothe Farbe der Flüssigkeit wieder her. Es kann auch Interesse besitzen, die Extracte aus gelben oder rothen Blüthen spectroskopisch zu untersuchen ${ }^{2}$ ). Dabei sind die unter 7 angegebenen Methoden in Auwendung zu bringen.

Lehrreich ist es auch, sich mit den Farbstcffen, welche das Kernholz mancher Bäume enthält, bekannt zu machen. Wir untersuchen z. B. einen Querschnitt des rothen Sandelholzes (Stammpflanze: Pterocarpus santalinus). Die weiten Grefässe lehnen sich an die den Jahresringen parallel laufenden Binden des Holzparenchyms an. Ferner sehen wir die zahlreichen Markstrahlen, deren Zellen eine harzige, tief schwarzrothe Masse enthalten, und die Holzfasern mit stark verdickten Wänden. Alle Elemente des Sandelholzes führen in ihren Membranen Farbstoff, und zwar ist es besonders die rothe Santalsäure, welche in den Membranen vorkommt. Destillirtes Wasser extrahirt aus dem Sandelholz nur Spuren von Farbstoff; mit ammoniakalischem Wasser erhält man aber leicht einen carminrothen Auszug.

Die Elemente des Fernambukholzes (Stammpflanze: Caesalpinia echinata) führen in ihren Membranen einen gelblichen Farbstoff, das Brasilin. Behandelt man Fernambukholz mit heissem Wasser, so geht eine zieniliche Quantität dieses Körpers in Lösung, und die Flüssigkeit nimmt auf Ammoniak- oder Kalizusatz eine blutrothe Farbe an ${ }^{3}$ ).

\section{Der mikrochemisehe Nachweis ron Alkaloiden und einiger anderer Stoffe in den Pflauzen.}

Es ist eine bekannte Thatsache, dass in den Geweben der verschiedensten Pflanzen Alkaloide, Glycoside oder andere Stoffe vorkommen, über deren physiologische Bedeutung bis jetzt wenig bekannt ist. Manche dieser Körper dienen den Gewächsen ohne Zweifel als Schutzmittel gegen schädliche Thiere, andere (z. B. Glycoside) liefern wohl auch unter bestimmten Umständen in Folge von Zersetzungen, denen sie unterliegen,

1) Bezüglich verschiedener hier erwïhnter Verhältnisse vgl. Strasburglı, Das botanische Praktikum, 1884, S. 59.

2) Vgl. HAssex, Verhandlungen der Physikalisch-medicinischen Gesellschaft zu Würzburg, Neue Folge Bd. 18, No. 7.

3) Ueber den anatomischen Bau des Férnambukholzes vgl. Wresswr, Rohstoffe des Pflanzenreiches, 1873 , S. 555. 
plastisches Material (Zucker), aber alle diese Verhältnisse sind noch wenig studirt. Ebenso sind die mikrochemischen Reactionen, deren man sich bedient hat, um die Gegenwart wenigstens einiger Alkaloide sowie Glycoside im pflanzlichen Gewebe zu constatiren, zum Theil noch ziemlich unsichere, wovon ich häufiger Gelegenheit hatte mich zu überzeugen. Einige Reactionen mögen hier dennoch Erwähnung finden, und bei der Ausführung derselben wird man finden; dass die fraglichen Körper wenigstens häufiger zumal in den peripherisch gelagerten Geweben der Organe oder in der Umgebung der Gefässbündel angehäuft sind, Beobachtungen, die schon von vornherein auf die Function der betreffenden Substanzen als chemisch wirkende Schutzmittel der Pflanzen gegen Thierfrass hindeuten ${ }^{1}$ ).

Untersuchen wir einen dünnen Schnitt aus dem hornigen Endosperm des Samens von Strychnos nux vomica, so lässt sich leicht feststellen, dass die Zellen ziemlich dickwandig sind. Ihr Inhalt besteht aus Eiweissstoffen, Zucker und fettem Oel. Werden dünne Schnitte aus dem trockenen Samen auf dem Objectträger in einen Tropfen concentrirter Schwefelsäure gebracht, so färbt sich der Zellinhalt in einigen Minuten röthlich. Wir fügen dem in Schwefelsäure liegenden Object nun ein Splitterchen chromsauren Kalis zu, bedecken mit dem Deckglas und beobachten. Der Zellinhalt, zumal derjenige der subtestalen Endospermzellen, färbt sich bald schön violett, während die Membranen ungefärbt bleiben (Strychninreaction) ${ }^{2}$ ).

Bei der Untersuchung von Querschnitten aus dem Stamm oder den Zweigen von Berberis vulgaris (man benutze z. B. etwa $6 \mathrm{~mm}$ dicke Zweigstücke) unterscheidet man das Rindengewebe ${ }^{3}$ ) und die Gefässbündel leicht. In der Rinde, dem Weichbast sowie den Phloëmstrahlen fallen viele Zellen mit gelbem Inhalt auf, und zwar rührt diese Farbe von der Gegenwart des Berberins her. Auch im peripherischen Theil des Holzkörpers ist Berberin (nämlich als Einlagerung in die Membranen) vorhanden. Bei Behandlung der Schnitte mit Alkohol und sehr verdünnter Salpetersäure (1 Thl. Salpetersäure auf $50 \mathrm{Thl}$. Wasser) verschwindet die gelbe Farbe der berberinführenden Elemente. Die Anwesenheit grösserer Berberinmengen bedingt nun aber die Abscheidung gelber Krystalle von salpetersaurem Berberin.

Wir stellen feine Quer- oder Längsschnitte aus einer Knolle von Colchicum autumnale her. In unmittelbarer Nähe der Gefässbündel gewahrt man Zellen, die eine stark lichtbrechende, gelbliche Flüssigkeit führen, während die Hauptmasse des Parenchyms sehr stärkereich ist. Jene gelblich erscheinenden Zellen führen das Colchicin. Bei Behandlung der Schnitte mit Ammoniak nimmt ihr Inhalt eine intensiv gelbe Farbe an. Die Wurzeln von Colchicum enthalten Colchicin in der Epidermis und der Schutzscheide.

Im Stengel von Aconitum Napellus findet sich Aconitin in der Gefässbündelscheide und in dem dieser benachbarten Parenchym. Das Aconitin giebt mit Jodjodkalium einen braunrothen Niederschlag und mit Schwefelsäure, die mit $1 / 2-1 / 3$ ihres Volumens Wassers verdünnt ist, zumal

1) Vgl. Errera, Botan. Centralblatt, Bd. 32, S. 71.

2) Rosolu, Sitzungsber. d. Akadem. d. Wiss. zu Wien, Abthl. I, Bd. 89.

3) Genaue Angaben über den Baul der Berberisstammtheile, zumal auch ihrer Rinde, findet man in einer von BöxixG abgefassten Königsberger Dissertation rom Jahre 1885 über die Anatomie des Stammes der Berberitze. 
nach vorheriger Behandlung der Präparate mit Rohrzuckerlösung, eine carminrothe Färbung (ERRERA).

Werden Querschnitte von etwa $3 \mathrm{~mm}$ dicken Zweigstücken der Syringa vulgaris auf dem Objectträger in verdünnte Schwefelsäure (1 Volumthl. concentrirte Schwefelsäure und 2 Volumthl. Wasser) gelegt, so färben sich dio Membranen der Holzelemente, der Holzmarkstrahlen sowie der Bastfasern gelbgrün und später blaugrün. Alle übrigen Zellen bleiben ungefärbt. Die erwähnte Reaction wird durch das Vorhandensein les Syringins bedingt. Dieser Körper ist in den Membranen abgelagert. Zuweilen nimmt auch der Inhalt der Zellen des Rindenparenchyms bei Behandlung der Syringaschnitte mit Schwefelsäure eine bläuliche Farbe an. Diese Erscheinung rührt aber nur daher, dass etwas Syringin bei Ausführung der Reaction durch Diffusion in diese Zellen übergetreten ist.

Wir stellen Querschnitte aus etwa $3 \mathrm{~mm}$ Durchmesser besitzenden Zweigstücken von Rhamnus Frangula her und behandeln dieselben auf dem Objectträger mit weingeistiger Kalihydratlösung. Verschiedene Elemente der Schnitte, zumal die dünnwandigen Elemente des Bastes, färben sich intensiv roth, eine Fürbung, die aber wenig beständig ist (Frangulinreaction).

Beim Studium der Querschnitte aus der Wurzel von Rumex crispus werden wir das Korkgewebe, die Rinde, den Bast- sowie den Holztheil der Gefässbündel leicht unterscheiden. Das Holz bildet in den etwas älteren Wurzeltheilen einen geschlossenen Cylinder, der von Markstrahlen durchsetzt wird. Werden die Schnitte mit verdünnter Kalilauge behandelt, so färbt sich namentlich der Inhalt der dickwandigen Rinden- und Phloëmelemente intensiv roth, und zwar ist diese Färbung eine sehr beständige (Chrysophansäurereaction) ${ }^{1}$ ).

\section{3\%. Die Nebenproducte des pflanzliehen Stoffweehsels als Schutzmittel der Pflanzen.}

Zahlreiche Thiere, zumal Säugethiere, Insekten und Schnecken würden das Leben der Pflanzen im höchsten Grade gefährden, wenn dieselben nicht melır oder minder gegen Thierfrass geschützt wären. Diese Schutzmittel der Pflanzen sind theils mechanische, theils chemische, und man findet oft, freilich nicht immer, dass Pflanzen, die mechanisch geschützt sind, keine sog. chemischen Schutzmittel produciren und umgekehrt.

Viele Nebenproducte des pflanzlichen Stoffwechsels habel nun, wie schon mehrfach angedeutet wurde, unter anderem in erster Linie die Aufgabe, den Pflanzen einen chenischen Schutz gegen Thiere zu gewähren, und wir wollen hier unter Zugrundelegung der Untersuchungen von Sтанц ${ }^{2}$ ) Versuche angeben, durch welche diese Thatsache leicht festgestellt werden kann. Es wird sich für uns namentlich darum handeln, zu zeigen, dass Gerbstoffe, Pflanzensäuren, ätherische Oele etc. als Schutzmittel der Pflanzen gegen Schneckenfrass dienen.

1) Vgl. Borskow, Botan. Zeitung, 1874, und O. Herracasw, Leipziger Dissertation, 1876 .

2) Vgl. Stahu, Pflanzen und Schnecken, Jena 1888. 
Man sammelt eine Anzahl Sehnecken, z. B. Helix pomatia und H. hortensis. Den Thieren wird 2-3 Tage lang kein Futter verabreicht, damit sie, wenn die eigentlichen Versuche beginnen sollen, reeht hungerig sind. Je 2 oder 3 Exemplare von Helix pomatia oder eine grössere Zahl von Individuen der kleineren Schnecken gelangen nun in geräumige Krrystallisirschalen, die man mit Glasplatten bedeckt. Diese Platten beschwert man, um das Auskriechen der Thiere zu verhindern. Den Sehnecken in den Krystallisirschalen wird verschiedenartige Nahrung dargeboten. Wir wollen mit folgenden Blättern experimentiren: Trifolium pratense (gerbstoffhaltig), Rumex, Oxalis (säurereich), Ruta graveolens (reich an ätherischem Oel), Ranunculus acris und Tropaeolum majus. In die Krystallisirschalen zu den Sclinecken gelangen je ein oder einige frische Blätter dieser Pflanzen; zugleich aber bieten wir den Thieren noch Blätter dar, die zur Extraction der chemischen Schutzmittel zunäehst durch Erwärmen mit Alkohol ausgezogen, dann an der Sonne oder im-Trockenschrank ausgetrocknet und endlich mit destillirtem Wasser ausgewaschen worden sind. Da die Schnecken besonders Abends und Nachts fressen, so empfiehlt es sich, die Krystallisirschalen mit den Thieren und Blättern stets längere Zeit stehen zu lassen. Die frischen Blätter werden gar nicht oder nur wenig von den Schneeken berührt; die extrahirten vertilgen sie schnell. Auch die folgenden Versuche lehren bestimmt, dass z. B. Gerbstoffe und Pflanzensäuren den Pflanzen einen ausgezeichneten Schutz gegen Schneckenfrass gewähren müssen. Man bietet den in Krystallisirschalen verweilenden Schnecken einmal dünne Scheiben der Mölhre (Daucus carota) dar, daneben aber auch solche Möhrenscheiben, die in siedendem Wasser getödtet, in Ofen getrocknet und endlich in einer 1-proc. Gerbstofflösung oder 1-proc. Lösung von saurem oxalsaurem Kali aufgeweicht worden sind. Die frischen Möhrenstücke werden von den Schnecken sehr gern gefressen; die gerbstoff- und säurehaltigen Scheiben verschmähen sie durchaus.

Wir wollen nicht versäumen, um auch die Wirkung mechanischer Schutzmittel kennen zu lernen, die folgenden Versuche anzustellen, Wịr legen einigen Schnecken, die sich in Krystallisirschalen befinden, unversehrte Blätter von Symphytum officinale oder Boraya officinalis vor. Zugleich erhalten die Thiere Blätter dieser Pflanzen, die mittelst eines scharfen Messers von den die Oberfläche der Organe bedeckenden spitzen, rauhen Borsten befreit worden sind. Diese letzteren Blätter werden gern von den Versuchsthieren gefressen; sie rühren die unversehrten Blätter dagegen kaum an.

Blätter von Arum maculatum werden selbst von sehr hungerigen Selnnecken nicht gefressen. Diese Blätter sind dureh Rhaphiden mechanisch geschïtzt, die sich, wenn die Pflanzentheile benagt werden, sofort in. die Mundwerkzeuge der.Thiere einbohren und dadureh eine höchst unangenehme Enpfindung hervorrufen. Wenn man kleine Stüeke der Arumblätter zerkaut, so nimmt man einen intensiy brennenden Geschmack wahr, der ebenfalls durch die Rhaphiden verursacht wird. Der ausgepresste, unfiltrirte Arumsaft ruft, auf die Zunge gebracht, die nämliche Empfindung hervor, wälıend der durch Filtriren von den Rhaphiden befreite Saft nur süsslich schmeckt. 


\section{Die Translocation plastischer Stoffe in den Pflanzen.}

\section{Experimente mit keimenden Pollenkörnern.}

Die Beobachtungen und Experimente, welche wir über das Verhalten oler stickstofflaltigen und sticktofffreien Körper in den Pflanzen austellten, haben uns bereits mit einer grossen Reihe verschiedener sich auf die Stoffwanderung im vegetabilischen Organismus beziehender Thatsachen bekannt gemacht. Hier und im Folgenden sollen einige Verhältnisse der Stofftranslocation specieller behandelt werden. Als erstes Untersuchungsobject wählen wir Pollenkörner.

Wir stellen uns zuerst eine kleine feuchte Kammer her, indem wir aus nicht $\mathrm{zu}$ dicker Pappe einen Rahmen schneiden, dessen inneres Lumen etwas kleiner als das zu benutzende Deckglas sein muss. Dieser Papprahmen wird, nachdem er vollständig mit Wasser durchtränkt worden ist, auf einen Objectträger gelegt. Wir bringen nun einen Tropfen derjenigen Flüssigkeit, in welcher die Pollenkörner keimen sollen, auf ein Deckglas, fügen das Pollenmaterial, welches wir reifen Antheren entnommen haben, hinzu und drehen das Deckglas jetzt mit rascher Wendung um. Es wird mit nach unten gekehrtem Tropfen auf den Papprahmen gelegt, und die Keimung der Pollenkörner kann nun in dem hängenden Tropfen vor sich gehen. Wir haben nur dafür zu sorgen, dass in der feuchten Kammer kein Wassermangel eintritt. Es empfiehlt sich daher, die Objectträger, welche die feuchte Kammer tragen, auf feuchtes, in einer Krystallisirschale befindliches Fliesspapier zu legen und das Gefäss mit einer Glasplatte zu bedecken. Die Pollenkörner von Alliumarten, von Tulipa Gesneriana und von Narcissus poëticus keimen nach Strasizurger besonders leicht, wenn man sie in eine etwa 3-proc. Auflösung von Rohrzucker in Brunnenwasser legt, und ich habe z. B. sehr schöne Resultate erzielt, als ich mit dem Pollen von Allium Victoriale experimentirte. Ich übertrug die Pollenkörner einmal in einen hängenden Tropfen Brunnenwassers, ferner andere Körner in einen Tropfen 3-proc. Zuckerlösung. Bei $18-19^{\circ} \mathrm{C}$. liatten sich nach Verlauf von 2 Stunden bei Lichtabschluss schon Pollenschläuche entwickelt, und nach ferneren 2 Stunden waren dieselben beträchtlich gewachsen. In der Zuckerlösung keimte eine grössere Anzahl der Pollenkörner, und es wurden in derselben Zeit längere Pollenschläuche als im Brunnenwasser gebildet. Dass die Keimung der Pollenkörner mit einer Stoffwanderung verbunden sein muss, liegt auf der Hand, denn bei der Entwickelung der Pollenschläuche geht ja das Protoplasma und gehen Reservestoffe aus den Pollenkörnern in die Schläuche über. Wenn die Pollenschlauchbildung besser in ler Zuckerlösung als im Wasser stattfindet, so macht diese Thatsache es wahrscheinlich, dass der von aussen aufgenommene Zucker von den keimenden Pollenkörnern als Nahrungsmittel verwerthet werden kann.

\section{Experimente mit Blättern.}

Die in den Blättern durch Assimilation gebildete Stärke wird nur zum kleinsten Theil für die Ausbildung des Blattes selbst verbraucht. 
Die Hauptmasse des Amylums verlässt das Blatt; sie wandert aus demselben in andere Organe der Pflanze, um deren Entwickelung zu ermöglichen. Das Lösungsproduct der Stärke ist in vielen Fällen ohne allen 'Zweifel Glycose, und diese entsteht, indem die in den Blättern vorhandenen diastatischen Fermente (vgl. unter 112) auf die Amylumkörner einwirken. Es werden Blätter von Tropaeolum, Solanum oder Cucurbita am Abend eines warmen Sommertages abgesclinitten. Man kocht sie mit Wasser aus, behandelt sie zur Entfernung des Chlorophyllfarbstoffes mit Alkohol und legt einige, um sich von der Anwesenlieit reichlicher Stärkemengen in ihren Zellen zu überzeugen, in Jodlösung (vgl. unter 14). Die übrigen Blätter werden nach der Behandlung mit Alkohol mit Wasser ausgewaschen und in einem frisch bereiteten Malzextracte einige Stunden lang einer Temperatur von $45^{\circ} \mathrm{C}$. ausgesetzt. Legt man die Blätter nun in Jodlösung, so geben sie keine oder höchstens noch eine schwache Stärkereaction, woraus hervorgeht, dass die Diastase im Stande ist, die durch Assimilation in den Blattzellen erzeugte Stärke aufzulösen. Dieser Auflösungsprocess geht häufig mit ganz merkwürdiger Geschwindigkeit vor sich.

Wir schneiden am Abend eines recht warmen Sommertages des Juni oder Juli einige Blätter von sehr kräftig im Freien wachsenden Solanum-, Nicotiana-, Atropa-, Cucurbita- oder Phaseoluspflanzen ab und untersuchen dieselben sofort nach der unter 14 angegebenen Methode makroskopisch auf Stärke. Die Blätter erweisen sich als sehr stärkereich. Wenn wir den genannten Pflanzen am nächsten Morgen bei Sonnenaufgang abermals einige Blätter entnehmen, um ihren Stärkegehalt makroskopisch zu prüfen, so finden wir, falls die Nacht warm war, kein Amylum in den Zellen; dasselbe ist während der Nacht aufgelöst worden und aus den Blättern in andere Organe gewandert.

Sehr lehrreich ist der folgende Versuch, den ich mit in Töpfen cultivirten Exemplaren von Tropaeolum majus anstellte. Man überzeugt sich zunächst auf makroskopischem Wege, dass die Blätter der kräftig entwickelten Untersuchungsobjecte reichliche Stärkemengen enthalten. Sie werden jetzt ins Dunkle gestellt, nachdem man noch einige Blätter von ihnen abgeschnitten hat, die man unter einer Glasglocke auf eine feuchte Unterlage bringt und ebenfalls verdunkelt. Nach einiger Zeit (bei meinen Versuchen, die bei einer Temperatur von nur $12-15^{\circ} \mathrm{C}$. angestellt wurden, erst nach 5 Tagen) untersucht man die abgeschnittenen Blätter und ferner solche, : welche nicht abgetrennt worden waren, makroskopisch auf Amylum.

Die nicht abgetrennt gewesenen Blätter enthalten nur in den Nerven Stärke, während die abgeschnittenen noch mehr oder minder stärkereich sind. Diese letzteren konnten sich während des Verweilens im Finstern ihrer Kohlehydrate nicht entledigen, weil sie nicht mehr, wie die an der Pflanze belassenen Blätter, mit anderen Organen im Zusammenhang standen.

Wenn man Blätter von Impatiens parviflora (diese Pflanze wächst oft bei uns wild oder kann leicht im Garten an einem etwas 'schattigen Orte aus Samen gezogen werden) makroskopisch auf Stärke prüft, so findet man dieselbe in reichlicher Menge in den normalen Vegetationsverhältnissen ausgesetzt gewesenen Untersuchungsobjecten. Es fällt aber auf, wovon ich mich überzeugte, dass die Nerven im Vergleich 
zum Mesophyll stärkearm sind; sie nehmen daher in Contact mit Jodlösung eine gelbe oder nur schwach bläuliche Farbe an. Werden in Töpfen cultivirte Impatiensexemplare und einige von diesen abgeschnittene Blätter ins Dunkle gebracht, so findet man die an der Pflanze belassenen und ebenso die abgetrennten Blätter nach 48 oder 72 Stunden stärkefrei. Abgeschnittene Impatiensblätter verhalten sich also in der hier in Rede stehenden Hinsicht im Finstern anders wie abgeschnittene Tropaeolumblätter. Diese vermögen die als Lösungsproduct des Amylums entstehende Glycose, welche die noch an der Pflanze befindlichen Blätter verlässt, wieder in Stärke umzuwandeln; die Impatiensblätter sind dazu höchstens in geringem Grade im Stande.

Wir stellen nun einen Querschnitt durch das Blatt von Impatiens parviflora her und erkennen leicht, dass das Mesophyll in Palissadenund Schwammparenchym gegliedert ist. Der Hauptnerv besteht, wie gewöhnlich bei den Blättern, aus einer peripherischen Lage langgestreckter chlorophyllarmer Zellen und aus mehreren Gefässbündeln, deren Bastseite von einer Stärkeschicht überzogen ist. Jene Schicht langgestreckter Zellen, welche die Gefässbündel der dickeren und ebenso diejenigen der dünneren Nerven umgiebt, bezeichnet man zweckmässig als Leitscheide.

Es ist schon erwähnt worden, dass die Nerven, zumal die dickeren Nerven, der unter normalen Verhältnissen zur Entwickelung gelangten Impatiensblätter auf jeden Fall stärkearm sind. Werden in Töpfen cultivirte Impatiensexemplare 24 Stunden lang verdunkelt, um einige dann abgeschnittene Blätter makroskopisch auf Stärke zu prüfen, so tritt die Stärkearmuth der Nerven noch klarer hervor. Dieselben heben sich als gelbes Netz vom blau tingirten, noch ziemlich amylumreichen Mesophyll ab. Wir belassen ferner in Töpfen cultivirte Impatienspflanzen und ebenso abgeschnittene Blätter derselben, die wir unter eine Glasglocke in einen wassergasreichen Raum bringen, 48 Stunden lang im Finstern. Sämmtliche Blätter sind fast oder völlig stärkefrei geworden. Die mikrochemische Prüfung auf Glycose (vergl. die Methode unter 115) ergiebt, wovon ich mich überzeugte, dass in den Zellen der Leitscheide der abgeschnitten gewesenen Blätter viel Zucker vorhanden ist, während die entsprechenden Zellen der nicht abgeschnittenen Blätter zuckerarm erscheinen.

Wir gelangen zu dem Schluss, dass die Leitscheide der Nerven als dasjenige Gewebe der Blätter anzusehen ist, welches die Auswanderung der Assimilationsproducte aus delı Blättern in andere Organe vermittelt. Bei vielen Pflanzen, z. B. Tropacolum, kann das aus der Stärke gebildete Lösungsproduct, zumal in den Zellen der Leitscheide, mit Leichtigkeit wieder transitorisch in Stärke übergeführt werden. Bei anderen Pflanzen, z. B. Impatiens, ist dies nicht oder nur in beschränktem Maasse möglich ${ }^{1}$ ).

\section{Experimente mit Zweigen.}

Wenn man im Herbst gleich nach eingetretenem Laubfall die mehrjährigen Zweige oder Stämme unserer Bäume mit Hülfe der unter

1) Literatur: SACHS, Arbeiten des botanischen Instituts in Würzburg, Bd. 3. Heft 1 (sehr wichtige Arbeit). Scmmper, Botanische Zeitung, 1885, No. 47-49. 
110 angegebenen Methode auf Stärke untersucht, so findet man reichliche Mengen derselben in den Geweben, zumal in den Markstrahlen sowie dem Holz- und Rindenparenchym. Bei Quercus und Betula etc. enthält auclı das Mark viel Stärke; in anderen Fällen (z. B. bei Corylus) ist das Mark stärkefrei ${ }^{1}$ ). Den Zustand, in welchem sich die Bäume oder Sträucher nach dem Laubabfall befinden, könneı wir als denjenigen des herbstlichen Stärkemaximums bezeichnen. Die Gewebe ihrer Stammgebilde sind dann mit sehr reichlichen Reservestoffmengen angefüllt, welche die Blätter producirt hatten. Neben der Stärke führen aber auch bei vielen Bäumen gewisse Elemente des Holzes und der Rinde, was besonders wichtig ist, im Herbst (und auch im Sommer) Glycose. Zum Nachweis der Glycose benutzen wir die von A. Fischer angegebene Methode. Aststücke werden median gespalten, 5 Minuten lang in eine concentrirte Lösung von Kupfervitriol gelegt, mit Wasser abgespült und dann 2-3 Minuten lang in einer siedenden Lösung von weinsaurem NatronKali in Natronlauge belassen. Die erforderlichen Schnitte sind jetzt leicht herzustellen. In den glycosehaltigen Elementen hat sich ein Niederschlag von Kupferoxydul gebildet. Authellung der Schnitte ist meist nicht erforderlich; sie kann übrigens nöthigenfalls durch Glycerin herbeigeführt werden.

Untersucht man die mehrjährigen Zweige von Alnus, Betula, Acer, Syringa etc. im Sommer in angegebener Weise, so findet man reichliche Zuckermengen in den Gefässen. Die Holzfasern sowie die lebendigen Holzelemente (Markstrahl- und Holzparenchymzellen) sind meist glycosefrei. In den Gefässen der dickeren Blattnerven ist ebenfalls keine Glycose vorhanden, wohl aber in dem die Nerven umgebenden und als Leitscheide dienenden Parenchym. Zur Zeit des herbstlichen Stärkemaximums ist die Vertheilung der Glycose ungefähr noch dieselbe, wie im Sommer.

Wenn der Laubfall eingetreten und das herbstliche Stärkemaximum erreicht ist, so beginnt alsbald eine Auflösung der Stärke in den Stämmen und Aesten unserer Bäume und Sträucher. Es führt dieser Vorgang zur Entstehung des winterlichen Stä rkeminimu ms, das z. B. schon im December völlig eingetreten sein kann und bis etwa Anfang März dauert. In zahlreichen Fällen (Salix, Quercus, Corylus, Syringa) enthält das Holz zur Zeit des winterlichen Stärkeminimums noch viel Stärke, während das Amylum aus dem Rindengewebe verschwunden und wahrscheinlich der Hauptsache nach in Form von Glycose, die übrigens im Winter, ebenso wie im Sommer, in der Rinde nicht fehlt, in die tiefer liegenden Baumtheile ausgewandert ist (Stärkebäume). Untersuchen wir dagegen Aeste von Tilia oder Betula im Januar, so finden wir weder im $\mathrm{Holz}$ noch in der Rinde Stärke (Fettbäume). Dieselbe lat sich in Fett umgewandelt, und dieser Körper ist bei Behandlung der Schnitte mit Alkannatinctur leicht in den Geweben nachzuweisen (vergl. unter 121).

Bei Tilia z. B. sind zumal die Markstrahlen und inneren Rindengewebe im Winter fettreich, während dieselben im Herbst viel Stärke führen. Im Mark von Tilia ist im Winter neben Fett reichlich Glycose vorhanden, während namentlich der peripherische Theil des Markes im Herbst viel Stärke beherbergt.

1) Vgl. über das Gesagte und Folgende A. Fiscuer, Jahrbücher f. wissenschl. Botanik, Bd. 22. 
Wir setzen unsere Untersuchungen nun derartig fort, dass wir Aeste von Corylus und Tilia im April auf Stärke prïfen. In der That finden wir jetzt wieder sowohl im Holz als auch in der Rinde Amylum. Dasselbe ist offenbar aus Fett und Glycose regenerirt worden. Dieser Process beginnt Anfang März (bei Fettbäumen zuerst in der Rinde); er (lauert bis gegen Ende April. Um diese Zeit ist das Frühlings - S tärkemaximum erreicht.

Bei beginnender Laubentfaltung wird die Stärke wieder aufgelöst, und auf solche Weise kommt das Stärkeminimum des späteren Früljahres zu Stande. Die Auflösung beginnt in den jungen Aesten, so dass diese schnell (etwa im Laufe von 14 Tagen) in der Rinde sowie im Holz entstärkt erscheinen; sie macht sich später auch in den älteren Aesten geltend. Ein gutes Untersuchungsobject ist Betula.

Wenn die Blätter sich nun endlich völlig entfaltet haben, so dass reichliche Mengen von Kohlehydraten entstelien, dann wandern dieselben nach und nach in fortschreitend grösseren Mengen in die Stammgebilde ein, ein Process, der natürlich in seinem Verlauf ganz wesentlich durch die herrschenden Witterungsverhältnisse beeinflusst werden muss. Schliesslich kommt auf solche Weise das herbstliche Stärkemaximum zu Stande, von welchem oben die Rede war.

Wir stellen auch noch das folgende interessante Experiment an, um zu zeigen, dass der Process der Rückbildung von Stärke aus Fett oder Glycose in den Aesten unserer Bäume ganz wesentlich abhängig ist von den herrschenden Temperaturverhältnissen. Zur Zeit des Stärkeminimums in Winter, also z. B. im December oder Januar, wird ein Lindenast abgeschnitten, ins warme Zimmer gebracht und sich hier, mit der Basis in Wasser stehend, selbst überlassen. Die Stärkeregeneration beginnt bereits nach einigen Tagen und macht fernerhin weitere Fortschritte.

\section{Die Ringelungsversuche.}

Zu Ringelungsversuchen eignen sich vor allem Weidenzweige. Am zweckınässigsten ist es, die Beobachtungen im Frühjahre anzustellen, und ich erhielt besonders gute Resultate bei Versuchen mit Salix fragilis. Die etwa $200 \mathrm{~mm}$ langen und $12 \mathrm{~mm}$ dicken Weidenzweige werden an ihrer morphologischen Basis geringelt, indem man z. B. $40 \mathrm{~mm}$ von ihrem unteren Ende entfernt einen ca. $20 \mathrm{~mm}$ breiten Rindenring fortnimmt, wodurch also der Holzkörper an dieser Stelle frei gelegt wird. Nun wird der Zweig in einem genügend hohen Glascylinder aufgehängt, indem man einen Bindfaden um das obere Zweigende schlingt und den Faden mit Hülfe von Siegellack an einer die Oeffnung des Glascylinders verschliessenden Glasplatte befestigt. Der Boden des Cylinders ist einige $\mathrm{mm}$ hoch mit Wasser bedeckt, in das das untere Zweigende aber nicht eintauchen darf. Feuchte Fliesspapierstreifen, welche die Innenfläche des Cylinders bedecken, tragen nicht unwesentlich zu einer möglichst gleichmässigen Feuchtigkeitsvertheilung im Apparat bei. Bei einem von mir angestellten Versuch verweilte ein Weidenzweig vom 19. März bis zum 21. April bei Lichtabschluss in einem Glascylinder. Das Resultat des 
Ringelungsversuchs ist aus untenstehender Abbildung zu ersehen. Das kurze, $45 \mathrm{~mm}$ lange Zweigstück unterhalb der Ringelungsstelle hat kleine Wurzeln erzeugt; aus dem Zweigstück oberhalb der Ringelungsstelle sind lange Wurzeln und am oberen Ende auch Triebe hervorgegangen. Die Ursache, weshalb an dem kurzen Zweigstück unter der Ringelungsstelle nur kurze Wurzeln producirt werden, ist darin zu

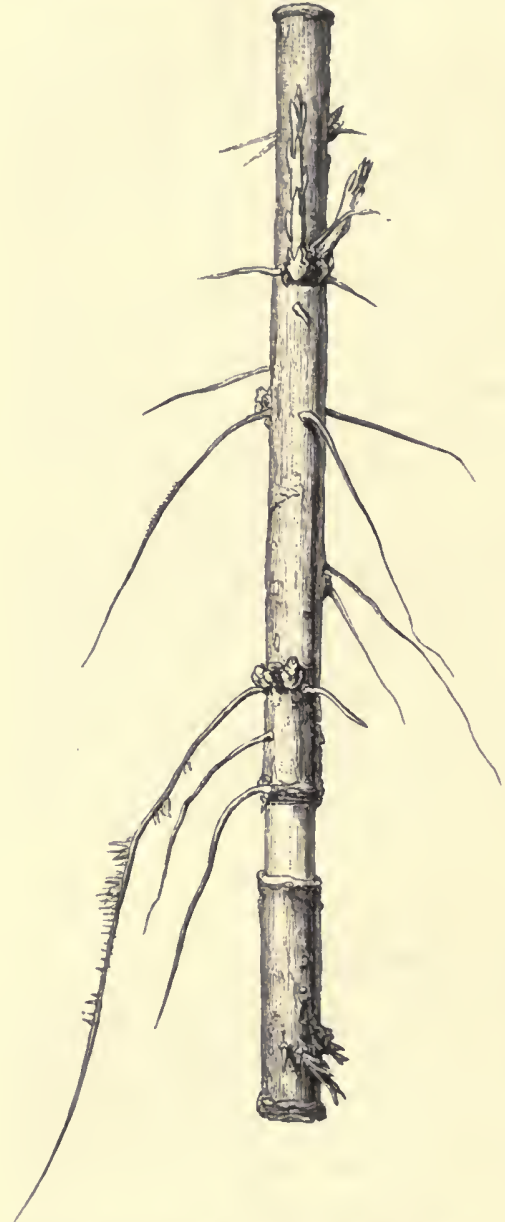

Fix. 116. Geringelter Zweig von Salix fragiiis, an dessen oberem Theil kräftige Wurzeln und Triebe zur Entwickelung gekommen sind. suchen, dass in diesem Theil des Untersuchungsobjects nicht genügende Mengen plastischen Materials zur Verfügung stehen. Die kleine Quantität stickstoffhaltiger und stickstofffreier Baustoffe im Zweigstück unter der Ringelungsstelle ist bald verbraucht. Dann können demselben freilich eventuell noch stickstofffreie Substanzen zuströmen, denn es lässt sich, wovon ich mich z. B. im Februar unter Benutzung eines Zweiges von Salix fragilis von $6 \mathrm{~mm}$ Durchmesser überzeugte, leicht feststellen (vergl. Methode unter 110), dass zumal die peripherische Holzregion der Weidenzweige viel Stärke enthält. Aber die Eiweisszuleitung, die, wie gerade die Ringelungsversuche sowie anderweitige Beobachtungen (vgl. unter 143) lehren, zumal durch Elemente des Weichbastes vermittelt wird, ist in Folge der Ringelung unterbrochen. Natürlich wird die Wurzelbildung unterhalb der Ringelungsstelle um so ausgiebiger, je höher die Stelle am Zweige liegt, von der man den Rindenring entfernt. Andererseits sah ich gar keine Wurzelbildung unterhalb der Ringelungsstelle mehr eintreten, wenn das kurze Stück am unteren Zweigende nur $20 \mathrm{~mm}$ Länge besass. Wenn man keine vollständige Ringelung vornimmt, sondern zwischen dem langen oberen und dem kurzen unteren Zweigstücke einen senkrechten Rindenstreifen als Brücke bestehen lässt, so erfolgt eine relativ ausgiebige

Wurzelbildung am unteren Zweigstücke, da nicht unerhebliche Eiweissmengen die erwähnte Brücke passiren können.

Untersucht man Querschnitte aus Weidenzweigen mikroskopisch, so überzeugt man sich leicht, dass der Holzkörper der Fibrovasalstränge auf seiner Innenseite direct an das Mark grenzt. Es ist nur zwischen der eigentlichen Rinde sowie der Aussenseite des Holzes Bastgewebe vorhanden, und somit muss durch eine bis aufs Holz gehende Ringelung die Eiweissleitung unterbrochen werden. 
Ganz andere Resultate wie an geringelten Weidenzweigen oder überhaupt an solchen Zweigen, welche den für die Stammgebilde dicotyler Gewächse typischen Bau besitzen, treten bei Ringelungsversuchen hervor, wenn man z. B. mit Mirabilis Jalappa oder Nerium Oleander experimentirt. Und in der That ist der anatomische Bau der Stammgebilde dieser Pflanzen ein sehr eigenthümlicher.

Stellt man Querschnitte aus etwa $4 \mathrm{~mm}$ dicken Stengeln von Mirabilis her, so erblickt man bei mikroskopischer Untersuchung die Epidermis', die primäre :Rinde mit ihrem äusseren Collenchymring, ferner besonders einen aus stark verholzten Zellen (Sklerenchymfasern) und eingeschalteten Gefässbündeln bestehenden Ring und den centralen Stengeltheil. Dieser besteht aus Markgewebe, dessen Zellen ich noch Ende October, nachdem Blätter der Pflanze bereits idurch einen Nachtfrost getödtet waren, reichlich mit Stärke angefüllt fand, und in dem Grundgewebe vertheilten Gefässbündeln mit deutlichem Bast- und Holztheil. Von einer Ringelung werden diese centralen Gefässbündel gar nicht berührt, so dass also durch die Fortnahme eines Rindenringes in diesem Fall weder die Leitungsbalınen für| die stickstofffreien noch diejenigen für die stickstoffhaltigen plastischen Stoffe eine wesentliche Unterbrechung erleiden.

Wir wählen einen kräftigen, reich beblätterten Spross von Nerium Oleander aus, entfernen in einer Höhe von etwa $20 \mathrm{~mm}$ über der Sprossbasis einen Rindenring und befestigen das Untersuchungsobject derartig unter Beihülfe von Watte in der Bohrung eines Korkes, der ein mit Wasser angefülltes Gefäss verschliesst, dass der Spross mit seinem unteren Ende etwa $80 \mathrm{~mm}$ weit in das Wasser eintaucht.

Bei hinreichend hoher Temperatur und nicht $\mathrm{zu}$ grosser Trockenheit der Luft (es ist zweckmässig, die Neriumsprosse im Warmhause zu halten) brechen nach einiger Zeit zahlreiche Wurzeln aus dem oberhalb der Ringelungsstelle befindlichen, noch vom Wasser benetzten Stammtheile hervor. Weiterhin entwickeln sich ebenfalls ziemlich viele Wurzeln an der Basis des Sprosses, also unterhalb der Ringelungszone. Die Neriumsprosse verhalten sich also wesentlich anders wie die Weidensprosse, und die Ursache dieser Erscheinung ist im anatomischen Bau der Untersuchungsobjecte zu suchen. Bei Salix sind nur an der Peripherie der Gefässbündel Weichbastelemente vorhanden. Nerium besitzt nicht nur auf der Aussen-, sondern ebenso auf der Innenseite der Gefässbündel Weichbast, wovon man sich durch mikroskopische Untersuchung zarter Querschnitte leicht überzeugen kann. Bei Nerium wird also die Bahn für die Eiweissleitung durch die Ringelung keineswegs völlig unterbrochen, während dies bei Salix der Fall ist. Bei Nerium können dem unterhalb der Ringelungsstelle liegenden Stengeltheile erhebliche Mengen stickstofffreier und auch stickstoffhaltiger plastischer Stoffe zuströmen, und aus diesem Grunde ist eine ziemlich ausgiebige Wurzelbildung an demselben möglich $\left.{ }^{1}\right)^{2}$ ).

Was die Wanderung der stickstofffreien Körper in den sich nnter normalen Vegetationsverhältnissen befindenden Bäumen und Sträuchern anbetrifft, so ist auf Grund der Untersuchnngen von Th. Hartig, Sachs

1) Literatur: Hanstein in Privgshems's Jahrbüchern f. wissenschl. Botanik, Bd. 2, und SACHS, Flora, 1863,.S. 33.

2) Uebrigens können Eiweissstoffe auch in manchen Fällen im Holz translocirt werden. Vgl. Stasburger, Bau und Verrichtung der Leitungsbahnen, 1891, S. 900 und 911. Die Translocation von Amiden etc. findet im Parenchym statt. 
und A. Fischer ') nicht daran \%u zweifeln, dass die in den Blättern gebildeten Kohlehydrate fast nur im Parenchym der Rinde translocirt werden, während die Aufwärtsbewegung der Kohlehydrate im Frübjahr beim Austreiben der Knospen in den glycosereichen Gefässen des Holzes stattfindet.

Ein mehrjähriger Ast von Betula, dessen basaler Theil zweig- und blattlos sein muss, wird, ohne von der Pflanze getrennt zu werden, Anfang Juni etwa $10 \mathrm{~cm}$ über seiner Ansatzstelle geringelt. Das frei ge. legte Holz überzieht man mit Baumwachs. Anfang August schneidet man den Ast ab und prüft entsprechende Querschnitte auf Stärke. Es genügt oft schon eine makroskopische Untersuchung, indem man die Querscheiben mit Jodlösung betupft. Oberhalb der Ringelungsstelle erweisen sich Holz und Rinde als überaus stärkereich. Das Holz der Ringelungsstelle ist sehr stärkearm; ebenso das Holz sowie die Rinde unterhalb der Ringelungsstelle. Die Kohlehydrate konnten in unserem Ast die Ringelungsstelle, weil hier die Rinde fehlte, offenbar nicht passiren. Im unversehrten Ast bewegen sie sich dagegen im Rindenparenchym nach abwärts, um sich von hier aus über das Holz, die Markstrahlen und das Mark zu verbreiten, woselbst sie in Form von Stärke zur Ablagerung gelangen.

Die Thatsache der Aufwärtsbewegung der Kohlehydrate im Holz zur Zeit des Austreibens der Knospen wird durch folgendes Experiment festgestellt. Man schneidet Ende Januar einen Syringazweig, der zwei einjährige Gabeläste trägt, ab, stellt ihn mit der Basis in Wasser und bringt dicht unter der Gabelung einen Ringelschnitt an. Im warmen Zimmer entfalten sich die Knospen im Laufe von 14 Tagen bis 3 Wochen. Das durch die Ringelung freigelegte $\mathrm{Holz}$ ist mit Baumwachs $\mathrm{zu}$ bedecken. Bei Beginn des Versuchs enthält der Holzkörper des Zweiges viel Stärke. Haben die Knospen sich entfaltet, so ist die Stärke njcht nur aus den Gabelästen, sondern auch aus dem Holz der Ringelungsstelle und aus demjenigen $\mathrm{Holz}$ fast völlig verschwunden, welches dem zweijährigen Zweigtheil unterhalb der Ringelungsstelle angehört. Die Substanz der Stärke ist in Form von Glycose in den Gefässen des Xylems nach aufwärts befördert worden.

\section{Die Stärke- und Znekerseheide und ihre Funetionen bei der Stoffwanderung.}

Zahlreiche Pflanzen sind durch den Besitz einer entwickelten Stärkescheide ausgezeichnet, und wir können dieselbe z. B. bequem beobachten, wenn wir Querschnitte durch den Stengel von Bohnenpflanzen ausführen, die sich im Dunkeln so weit ausgebildet haben, dass das erste Stengelglied erheblich gestreckt ist. Epidermis, Rinde, Mark sowie Gefässbündelkreis sind leicht zu unterscheiden. Der letztere wird an seiner Peripherie, also auf seiner Bastseite, rings von einer Zellenschicht umgeben, deren Elemente kleiner sind als diejenigen des Rindengewebes, und dies ist eben die Stärliescheide. Wir finden reichliche Mengen von Stärke in den Zellen der erwähnten Gefässbündelscheide, eine Thatsache, die zu der Vermuthung geführt hat, dass die Translocation der Kohlehydrate in allererster Linie in der Stärkescheide stattfinden möchte. Indessen-verschiedene Verhältnisse

1) Vgl. A. Fischer, Jahrbücher f. wissenschl. Botanik, Bd. 22, S. 137 u. 142. 
sind nicht mit einer derartigen Anschauung in Einklang zu bringen. Man stelle im Juli Querschnitte aus dem unteren Stengeltheile kräftiger und im Freien zur Entwickelung gelangter Phaseolusexemplare her. Jedes Gefässbündel ist an seiner Aussenseite mit einem mächtigen Bastfaserbeleg versehen, und bei mikroskopiseher Untersuchung kanı man sich leicht davon überzeugen, dass in dem Rinden- sowie Markparenchym reichliche Amylummengen vorhanden sind. Die Zellen der Stärkescheide sind dagegen, wovon ich mich überzeugte, sehr stärkearm oder sie enthalten gar keine Stärkekörner. Danach findet die Translocation der Kohlehydrate sicher hauptsächlich. in der Rinde sowie im Mark statt. Die Stärkescheide enthält nur dann viel Amylum, wenn die Elemente des Bastfaserbeleges der Fibrovasalstränge noch nicht völlig ausgebildet sind. Mit fortschreitender Entwickelung derselben verschwindet aber die Stärke mehr und mehr aus den Zellen der Stärkeseheide, weil sie beim Aufbau der dickwandigen Bastelemente verbraucht wird ').

Es ist eine schon von uns erwähnte Thatsache, dass viele Pflanzen die Fähigkeit besitzen, die aus dem Mesophyll der Blätter auswandernden Kohlehydrate transitorisch in den Ableitungsbahnen (den Blattncrven) in Stärke umzuwandeln. Andere Gewächse vermögen dies nur in geringem Grade, weshalb wir ihre Blattnerven nicht mit Stärke, sondern z. B. mit Glycose erfüllt finden. Wir stellen Querschnitte aus dem unteren Theil der Lamina und dem oberen Theil des Blattstieles eines ausgewachsenen Rübenblattes her. Die in der Spreite durch Assimilation gebildete Stärke wandert unter normalen Verhältnissen durch die Nerven und den Blattstiel in die Rübenwurzel, die Entwickelung der letzteren bedingend. Aber wir finden mit Hülfe mikrochemischer Methoden in dem Parenchym, das die Gefässbündel der Nerven sowie des Blattstieles umgiebt, nur sehr kleine Stärkemengen, hingegen sehr grosse Glycosequantitäten, und man kann das die Kohlehydrate leitende Gewebe daher als Leitscheide, speciell als Zuckerscheide, bezeichnen ${ }^{2}$ ).

\section{Die Siebröhren und ihre Function bei der Stoffwanderung.}

Wenn wir den Stengel eines Exemplars von Cucurbita durchschneiden, so quillt eine bedeutende Mengc einer schleimigen Flüssigkeit aus dem Querschnitt hervor. Unter Berücksichtigung der Quantität des ausfliessenden Saftes wird es uns sofort klar, dass derselbe unter Mitwirkung von Druckkräften aus der verletzten Pflanze ausgepresst werden muss, und in der That sind, wie wir weiter unten sehen werden, die Bedingungen für das Zustandekommen solcher Druckwirkungen im Organismus gegeben. Zunächst wollen wir uns ïber dic Natur des ausgepressten Saftes unterrichten.

Wir durchschneiden den Stengel eines Exemplars von Cucurbita, z. B. C. Pepo (ich experimentirte mit C. minensis). Jetzt bringen wir ein Stückchen rothen Lackmuspapiers mit dem Stengelquerschnitt in Berührung und werden zu unserer Ueberraschung wahruehmen, lass sich dasselbe blau färbt. Auf jeden Fall besitzt demnach ein grosser

1) Vgl. H. Heine, Berichte der Deutschen botan. Gesellschaft, Bd. 3, Heft 5.

2) Vgl. H. DE VRIEs, Landwirth. Jahrbūcher, Bd. 8, S. 445. 
Theil des aus dem Cucurbitastengel ausfliessenden Saftes eine relativ stark alkalische Reaction, während die meisten Pflanzen, wenn sic verwundet worden sind, einen Saft von überwiegend saurer Reaction liefern, der also blaues Lackmuspapier roth färbt. Wenn wir unseren Stengelquerschnitt von ${ }^{\circ}$ Cucurbita wiederholt mit rothem Lackmuspapier abtupfen, so finden wir bald nicht mehr die Gesammtfläche des den Querschnitt berührenden Papiers gebläut, sondern nur einzelne Stellen desselben zeigen diese Farbe, diejenigen nämlich, welche mit den Gefässbündeln in Berührung gekommen sind. Bringen wir den Stengelquerschnitt nun mit blauem Lackmuspapier in Contact, so färbt sich derselbe mit Ausnahme einzelner Stellen roth. Unmittelbar nach dem Durchschneiden eines Cucurbitastengels fliesst aus dem Querschnitt ein Saftgemisch von überwiegend alkalischer Reaction aus. Auf die angegebene Weise kann man sich aber leicht davon überzeugen, dass der Saft des Parenchyms bei Cucurbita, wie bei anderen Pflanzen, sauer reagirt, während die Säfte gewisser Gewebe der Fibrovasalstränge, nämlich diejenigen des Weichbastes, eine alkalische Reaction besitzen. Bei anderen Pflanzen liegen die Verhältnisse ähnlich; sie sind aber nicht so leicht sicher festzustellen ').

Wir stellen nun einen Querschnitt aus dem hypocotylen Gliede von Cucurbita Pepo her, und zwar benutzen wir Alkoholmaterial. Bei den meisten Gewächsen ist nur auf der Aussenseite der Gefässbündel Weichbast vorhanden; unser Untersuchungsobject lässt aber auf der Aussensowie Innenseite des Holztheiles der Fibrovasalstränge das Vorhandensein von Weichbast erkennen. Stellen wir nach der unter 94 angegebenen Methode Prüfungen über den Eiweissgehalt der Gewebe an, so ergiebt sich, dass die Weichbastelemente sehr reich an Proteïnstoffen sind. Der alkalisch reagirende, eiweissreiche Schleim, welcher beim Durchschneiden von Cucurbitastengeln hervorquillt, ist in besonders grosser Menge in den Siebröhren des Weichbastes vorhanden, eigenthümlichen, lang gestreckten Elementen, die durch mit vielen Poren versehene Querwände (Siebplatten) gegliedert sind. In den Siebröhren ist wandständiges Protoplasma vorhanden, und sie sind mit einem eiweissreichen, alkalisch reagirenden Schleim erfüllt, der unter Vermittelung der Siebporen aus einem Siebröhrengliede in ein anderes übergehen kann. Und in der That muss eine solche Bewegung des. Schleimes in der unversehrten Pflanze durch dieselben Ursachen erfolgen, welche es bedingen, dass aus verletzten Pflanzen der Schleim hervorquillt. Die Siebröhren stehen nämlich unter dem Druck des in der Nähe vorhandenen, turgescirenden Parenchyms. Somit kann ihr Inbalt nach den Orten geringeren Druckes, zumal nach den noch sehr jugendlichen Theilen des Pflanzenkörpers hin, befördert werden, und man sieht also, was mit den Ergebnissen der Ringelungsversuche in völligem Einklange steht, dass die Siebröhren als Translocationsorgane für Eiweissstoffe im Organismus functioniren. Das Circulationseiweiss des Schleimes der Sicbröhren unterliegt einer Massenbewegung in denselben und kann von einem Orte in der Pflanze zu anderen, oft weit entfernten transportirt werden. Wir müssen uns aber noch etwas genauer mit dem Bau der Siebröhren, zumal mit demjenigen der Siebplatten, vertraut machen.

Wir stellen Querschnitte aus einem $10 \mathrm{~mm}$ dicken Stengel von Cucurbita Pepo her (Alkoholmaterial). Bei schwacher Vergrösserung

1) Vyl. SAcris, Botan. Zeitung, 1862. 
erkennt man die Epidermis, das unterbrochene Collenchym, das Rindengewebe, den Sklerenchymring und die in doppeltem Kreise gruppirten Gefässbündel leicht. Diese besitzen einen Holztheil mit sehr weiten Gefässen und einen inneren sowie äusseren Basttheil. Der innere Bast-

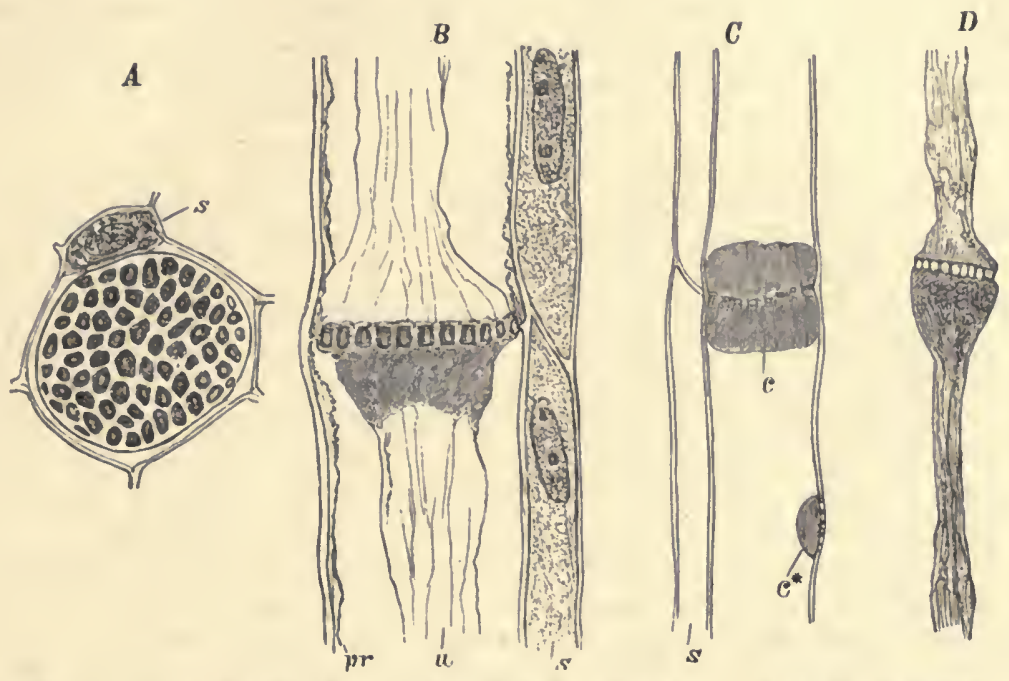

Fig. 117. Cueurbita Pepo. Theile von Siebrölren nach Ilkoholmaterial. $A$ im Querschnitt, $B-D$ im Längsschnitt. $A$ eine Siebplatte von oben, $B$ und $C$ die zwei anstossenden Siebröhrenglieder von der Seite, $D$ die verbundenen Inhaltsmassen zweier Siebröhrenglieder nach Schwefelsäurebehandlung. $s$ Geleitzellen, $u$ Schleimstrang, $p r$ Protoplasmaschlauch, $c$ Callusplatte, $c^{*}$ kleine, einseitige Callusplatte eines seitenständigen Siebfeldes. Vergr. 540. (Nach STrasburGER.)

oder Siebtheil umfasst die Innenseite des Holz- oder Gefässtheils mondsichelförmig. Zur genaueren Untersuchung bei stärkerer Vergrösserung thut man nach Strasburger gut, die Schnitte !kurze Zeit lang in Anilinblau zu legen, um sie dann in einem Tropfen Glycerin auf den Objectträger zu bringen. Das Gewebe des inneren und äusseren Bastes besteht aus weitlumigen Siebröhren, deren Geleitzellen mit ihrem dunkelblau tingirten Inhalt (vgl. Fig. 117) und aus C'ambiformzellen. Die porösen Siebplatten sind, wo der Schnitt solche getroffen hat, leicht kenntlich ${ }^{1}$ ).

\section{Der Milchsaft.}

Zahlreiche Pflanzen enthalten bekanntlich Milchsaft. Schneidet man z. B. eine Euphorbia an, so quillt der weiss gefärbte Milchsaft oft (zumal wenn man mit cactusartigen Euphorbien experimentirt) in grosser Menge aus der Wunde hervor. Offenbar steht der Inhalt der Milchsaftbehälter unter einem nicht unerheblichen Druck, der von den turgescirenden Zellen des benachbarten Parenchyms geltend gemacht

1) Vgl. WILHELM, Beiträge zur Kenntniss des Siebröhrenapparates dicotyler Pflanzen, Leipzig 1880, und Fisc1ikr, Untersuehungen über das Siebröhrensystem der Cucurbitaceen, Berlin 1884. 
wird, denn sonst könnten beim Anschneiden Milchsaft enthaltender Pflanzen nicht so grosse Flüssigkeitsquantitäten aus der Wunde herausfliessen, wie es thatsächlich der Fall ist.

Die Frage nach der physiologischen Function der Milchsäfte ist noch ungelöst. Ich kann mich dem Eindruck nicht entziehen, dass die Milchsäfte unter anderem eine ernährungsphysiologische Bedeutung besitzen; auch die Experimente FaIvres sprechen dafür. Besondere Wichtigkeit dürfte der Milchsaft aber als Schutzmittel der Pflanzen haben.

In der wässerigen Flüssigkeit der Milchsäfte sind, ebenso wie im Serum der thierischen Milch, zahlreiche kleine, feste Körpertheilchen suspendirt, wodurch die Milchsäfte meist von weisser Farbe erscheinen. Die Menge dieser festen Partikelchen ist aber je nach der Herkunft sowie dem momentanen Zustande des Milchsaftes eine sehr verschiedene. Wenn man einen Tropfen Milchsaft aus den Stengeln oder den Blättern der Feige ohne Wasserzusatz auf den Objectträger bringt, so kann man sich durch Beobachtung bei starker Vergrösserung leicht davon überzeugen, dass der Gehalt dieses Milchsaftes an suspendirten Theilen ein relativ geringer ist. Der Milchsaft der Euphorbien und derjenige von Ficus elastica erscheint gewöhnlich viel reicher an festen Bestandtheilen.

In der wässerigen Flüssigkeit der Milchsäfte sind Mineralstoffe, Zucker, Eiweissstoffe, zuweilen auch Pepsin (vergl. untel 96) etc. im aufgelösten Zustande vorhanden. Die suspendirten Körpertheilchen werden sehr oft der Hauptsache nach von Kautschuk gebildet. Manche Milchsäfte enthalten aber auch Fett oder Amylumkörner.

Wird etwas Milchsaft einer Euphorbie mit wenig Wasser oder Alkohol auf dem Objectträger vermischt, so tritt Gerinnung des Milchsaftes ein. Bei mikroskopischer Untersuchung ergiebt sich, dass sich die ursprünglich gleichmässig im Milchsaft suspendirten Bestandtheile desselben zu grösseren Massen zusammengeballt haben.

Die Milchsaftbehälter der Pflanzen sind von sehr verschiedenartiger Natur. Ein sehr günstiges Object für das Studium von Milchsaftbehältern giebt die Wurzel von Scorzonera hispanica (Schwarzwurzel) ab. Wir verwenden Alkoholmaterial und stellen nach Entfernung der oberflächlichen Rindenschichten tangentiale Längsschnitte her. Die leicht an ihrem Inhalt kenntlichen Milchsaftbehälter stellen in unserem Falle vielfach unter einander anastomisirende, lang gestreckte Gefässe dar, welche das kleinzellige Parenchym durchziehen.

Wir nehmen ferner Stengeltheile ron Chelidonium majus in Untersuchung, und zwar benutzen wir Alkoholmaterial. Bei Beobachtung von Querschnitten sehen wir die Epidermis, Collenchym und grünes Rindenparenchym. An dieses schliesst sich nach innen ein geschlossener Ring mechanischen Gewebes, dessen Elemente stark verdickt sind. Die Gefässbündel besitzen einen entwickelten Bast- und Holztheil. Im ersteren, aber auch im Grundgewebe, welches die Fibrovasalstränge umgiebt, erblicken wir Elemente; die einen braunen Inhalt führen. Es sind das die Milchsaftgefässe. Der Milchsaft von Chelidonium besitzt bekanntlich im frischen Zustande eine orangerothe Farbe. In Folge der Behandlung des Untersuchungsmaterials mit Alkohol ist er in seinen Behältern in einen geronnenen Zustand übergegangen. 


\section{Dic Stoffaceumulation.}

Es ist offenbar eine merkwürdige Thatsache, dass bestimmte Gewebecomplexe des Pflanzenkörpers als Leitungsbalmen, andere als Ablagerungsorte für bestimmte Stoffe dienen. Wir sind leute nicht im Stande, uns im Detail Rechenschaft über die Ursachen dieser Phänomene zu geben; es ist dies nur im Allgemeinen möglich, und ich habe die bezüglichen Verhältnisse auch schon in meinem Lehrbuche der Pflanzenphysiologie besprochen.

Wenn z. B. eine Accumulation von Stärke in den Geweben der Reservestoffbehälter stattfinden soll, so müssen in den Zellen dieser letzteren Ursachen thätig sein, welche es bedingen, dass das zugeführte stickstofffreie Material in Form von Amylumkörnern niedergeschlagen wird. Aehnliche Ursachen müssen ferner auch bei der transitorischen Stärkebildung in den Zellen der Leitungsbahnen der Kohlehydrate zur Geltung kommen. Die Stärkeaccumulation kann nur in Zellen erfolgen, in denen Stärkebildner ihre Thätigkeit entfalten, und indem dies geschieht, wird die Bedingung erfüllt, welche gegeben sein muss, wenn ein erneuter Zustrom gelöster Kollehydrate nicht ausbleiben soll. Die Resultate der folgenden Experimente sind geeignet, uns eine Vorstellung von dem Wesen der Stoffaccumulation zu gewähren.

Wir füllen ein Becherglas mit verdünuter Kupfervitriollösung an und hängen in die Flüssigkeit ein an seinen beiden Enden mit Pergamentpapier verschlossenes, etwa $6 \mathrm{~cm}$ langes und weites Glasrohr hinein, das vorher mit Wasser angefüllt worden ist und in das man auch eine Zinkspirale gebracht hat. Die Lösung des schwefelsauren Kupferoxyds dringt in das Glasrohr ein, sie verbreitet sich in dem Wasser, wird aber, wenn sie mit dem Zink in Berührung gelangt, zersetzt. Es entsteht lösliches schwefelsaures Zinkoxyd, während sich das Zink mit einer allmählich an Dicke zunehmenden Kruste von metallischem Kupfer und Kupferoxyd bedeckt. Die Accumulation von Kupfer in dem Glasrohr ist also leicht zu constatiren.

Dass gelöste Stoffe ihren Lösungsmitteln durch imbibitionsfähige Körper entzogen und aufgespeichert werden können, lässt sich in folgender Weise demonstriren.

Wir versetzen Wasser mit einigen Tropfen alkoholischer Jodlösung, so dass die Flüssigkeit eine gelbliche Farbe annimmt, und fügen Weizenstärke hinzu. Diese letztere speichert das Jod auf; sie färbt sich in Folge dessen blau, während die Flüssigkeit alsbald entfärbt ist. Wir versehen ferner einen Glastrichter mit 6 oder 8 in einander gesteckten Fliesspapierfiltern und giessen eine verdünnte, wässerige Methylanilinviolettlösung auf das Filter. Das Papier hält den Farbstoff vollkommen zurück. Es läuft eine wasserklare Flüssigkeit vom Filter $a b$. 
Zweiter Theil.

\title{
Physiologie des Wachsthums und der Reizbewegungen.
}

\author{
Vierter Abschnitt. \\ Die Zuwachsbewegungen der Pflanzen.
}

I. Die Eigenschaften wachsender Pflanzentheile und die auf inneren Ursachen beruhenden Wachsthumsbewegungen.

\section{Die Dehnbarkeit und Elastieität wachsender Pflanzentheile.}

Für die Theorie des Wachsthums ist es von grosser Bedeutung, dass die wachsenden Pflanzentheile in einem hohen Grade dehnbar und elastisch sind. Auf Details kommen wir weiter unten zurück; hier handelt es sich zunächst nur darum, diese Thatsache ganz im Allgemeinen $\mathrm{zu}$ constatiren ${ }^{1}$ ).

Als Untersuchungsobjecte wählen wir ganz frische, abgeschnittene Stengelstücke von Aristolochia Sipho oder Sambucus nigra. Wir bringen an oberen, sowie an unteren Ende eines jüngeren und des folgenden älteren Internodiums mit chinesischer Tusche feine Striche als Marken an, fassen den Pflanzentheil mit den beiden Händen und dehnen ihn, während er auf einer Millimetertheilung liegt, so stark wie möglich, aber ohne dass die Gefahr des Zerreissens eintritt. Es ist nun leicht $\mathrm{zu}$ constatiren, dass die jüngeren Internodien viel dehnbarer als die älteren sind, und ich fand z. B., dass die Delinbarkeit eines jungen, $50 \mathrm{~mm}$ langen Internodiums von Aristolochia Sipho $9 \%$ betrug. Ueberlässt man die Sprosse nach der Dehnung sich selbst, so ziehen sie sich wieder mehr oder minder zusammen; ihr Gewebe ist also elastisch, aber da sie ihre ursprüngliche Länge nicht wieder völlig annehmen, sondern nach erfolgter stärkerer Dehnung dauernd länger bleiben, so ergiebt sich, dass sie als unvollkommen elastisch bezeichnet werden müssen.

1) Vgl. SACHS, Lehrbuch d. Botanik, 4. Aufl., S. 753. 
Völlig frische, gerade gewachsene, etwa $6 \mathrm{~mm}$ dicke Internodien von Vitis oder Aristolochia werden auf einem Carton, auf dem concentrische Kreise aufgezeichnet worden sind, mittelst der beiden Hände derartig gebogen, dass die Axe des Untersuchungsobjectes mit einem der Kreise zusammenfällt. Den bekannten Radius dieses Kreises notirt man als Krümmungsradius des gebogenen Internodiums. Ueberlässt man den Pflanzentheil sich selbst, so streckt er sich nicht wieder gerade, sondern bleibt ziemlich stark gekrümmt, und man kann seinen Krümmungsradius auch jetzt leicht feststellen. Wachsende Pflanzentheile sind demnach biegsam. Sie besitzen freilich Biegungselasticität; dieselbe ist aber eine unvollkommene.

Wenn man geraden, in lebhaftem Längenwachsthum begriffenen Sprossen an ihrem unteren Theil, dessen Längenwachsthum bereits vollendet ist, mit Hülfe eines Stockes einen Schlag oder einige Schläge beigebracht hat, so schreitet die der gestossenen Region ertheilte Krümmung in Form einer Welle bis in den frei schwebenden Gipfel fort. Dieser erscheint in Folge dessen gekrümmt und zwar liegt die Concavität der Krümmung stets auf derjenigen Seite, von welcher der Schlag unten eintraf. Das Auftreten dieser Stoss- oder Erschütterungskrümmungen, welches ich besonders schön bei Experimenten mit Vitissprossen und Sprossen von Lonicera tatarica beobachtete, verdankt, wie in meinem Lehrbuch der Pflanzenphysiologie näher nachzusehen ist, der Biegsamkeit und unvollkommenen Elasticität der Pflanzentheile seine Entstehung.

\section{4\%. Relatlonen zwisehen der Grösse der Turgorausdelınung, dem Wachsthum und der Dehnbarkeit der Pflanzentheile.}

Für unseren Zweck ist es zunächst unerlässlich, die relative Wachsthumsgeschwindigkeit der auf einander folgenden Partialzonen eines Pflanzentheiles festzustellen. Wir experimentiren mit abgeschnittenen jungen Blüthenscliäften von Butomus umbellatus, Plantagio media und Papaver oder mit nicht abgeschnittenen epicotylen Gliedern von Phaseolus multiflorus, welche sich bis zur Länge von einigen Centimetern im Dunkeln entwickelt haben. Auf den Untersuchungsobjecten bringen wir mit Hülfe von chinesischer Tusche in Entfernungen von je 10 oder $20 \mathrm{~mm}$ feine Striche als Marken an und theilen sie dadurch der Länge nach in Partialzonen ab. Das Auftragen der Marken erfordert einige Sorgfalt und ist in der unter 59 und 148 angegebenen Weise auszuführen ${ }^{1}$ ). Die abgeschnittenen Blüthenschäfte werden nun senkrecht in einem mit Brunnellwasser angefüllten Cylinder aufgestellt, so dass sie völlig von der Flüssigkeit bedeckt sind, während man die Bohnellstengel auch jetzt noch nicht abschneidet. Nach 12 oder 24 Stunden bestimmt man die Entfernungen der Marken und wird finden, dass dieselben nicht mehr 10 oder $20 \mathrm{~mm}$ betragen, sondern grösser geworden sind. Diese Erscheinung ist die Folge eingetretenen Wachsthums. Es lässt sich nun aber leicht constatiren, was besonderes Interesse beansprucht, dass der Zuwaclis der einzelnen Partialzonen keineswegs derselbe ist. Das stärkste Wachsthum lıat entweder in der jüngsten

1) Handelt es sich darum, gekrümmte Pflanzentheile, z. B. die Epicotyle von Phaseolus, mit Tuschemarken zu versehen, so kann dies unter Zuhülfenahme eines mit einer Millimetertheilung versehenen Papierstreifens geschehen. 
Zone stattgefunden (so fand ich es in Uebereinstimmung mit H.DE VrIEs, als ich einen jungen Blüthenschaft von Plantago, der in Partialzonen von $20 \mathrm{~mm}$ Länge eingetheilt worden war, zum Versuch benutzte), oder das Wachsthumsmaximum liegt nicht in der allerjüngsten, wohl aber in einer der jüngsten (z. B. in der dritten) Zonen. So fand ich es bei Experimenten mit dem epicotylen Glied von Phaseoluskeimlingen, die sich im Finstern, in Sägemehl wurzelnd, entwickelten. Das Epicotyl besass eine Länge von $70 \mathrm{~mm}$, und es wurden in Entfernungen von nur je $5 \mathrm{~mm}$ Tuschestriche aufgetragen. Im Laufe von 48 Stunden und bei $15^{\circ} \mathrm{C}$. wuchs die jüngste Partialzone um 1, die zweite um 3 , die dritte um 8 , die vierte um 6 , die fünfte um 5 , die sechste um 3 und die siebente um $1 \mathrm{~mm}$. Es ergiebt sich überhaupt immer, dass die Wachsthumsgeschwindigkeit der Zellen mit fortschreitendem Alter mehr und mehr abnimmt, bis ihr Wachsthum schliesslich völlig erlischt.

Haben wir die Vertheilung der Wachsthumsgeschwindigkeit an unseren Untersuchungsobjecten constatirt, so versetzen wir sie in den plasmolytischen Zustand (vgl. unter 59) indem wir sie in eine 10-proc. Kochsalz- oder Salpeterlösung legen. $2-3 \mathrm{~mm}$ dicke Stengeltheile können ohne weiteres in die Salzlösung gebracht werden; dickere muss man vorher halbiren. Nach kürzerer oder längerer Zeit (3 bis 12 Stunden) ist vollkommene Plasmolyse eingetreten. Die Partialzonen haben sich in Folge der Aufhebung des Turgors verkürzt, und wenn man die Verkürzung auf die Anfangslänge der Zonen (also 5, 10 oder $20 \mathrm{~mm}$ ) berechnet, so ergiebt sich, dass sie in denjenigen Regionen der Stengeltheile im Allgemeinen oder genau am bedeutendsten ausgefallen ist, in welchen das ausgiebigste Wachsthum stattfand. Es ist eine deutliche Relation zwischen der Grösse der Turgorausdehnung der Zellen der einzelnen Partialzonen und ihrer Wachsthumsgesch windigkeit vorhanden, ein Ergebniss, welches zu der Anschauung führt, dass die Geschwindigkeit des Flächen wachsthums der Zellen von der Grösse ihrer Turgorausdehnung abhängt. Diese letztere wird nun aber bestimmt durch die Grösse der Turgorkraft und durch die Grösse des Widerstandes der gespannten Zellschicliten (Protoplasma und Zellhaut). Dieser Widerstand hängt unter anderem von der Dehnbarkeit der gespannten Zellschichten ab, so dass es ein besonderes Interesse gewährt, die Grösse dieser Dehnbarkeit genauer zu ermitteln.

Wir benutzen z. B. ein $30 \mathrm{~mm}$ langes Epicotyl von Phaseolus zum Versuch, das wir in Partialzonen von je $5 \mathrm{~mm}$ Länge eingetheilt haben, dessen Wachsthumsgeschwindigkeit wir ermittelten und das wir dann in den plasmolytischen Zustand versetzt haben. Der schlaffe Stengel wird vorsichtig auf eine Korkplatte gelegt, sein oberes Ende mit einer kleinen Korkplatte bedeckt, und diese letztere mittelst einer Ḱlemmschraube gegen die erstere Platte angedrückt. An dem älteren Ende des Stengels befestigt inan einen Faden mit einer Schlinge. Dieser wird angezogen, und, sobald die gewünschte Dehnung des Untersuchungsobjectes erzielt ist, mit Hülfe einer Nadel auf der Korkplatte festgesteckt. Die Dehnung wird nur so weit geführt, bis dem Stengel jene Länge künstlich aufgenöthigt worden ist, die er vor der Plasmolyse besass. Wir stellen mit Hülfe eines Millimetermaassstabes die Dehnungsgrösse der einzelnen Partialzonen fest und berechnen dieselbe auf gleiche Anfangslänge der Zonen $(5 \mathrm{~mm})$. Es ergiebt sich, dass die Dehnbarkeit des Gewebes in den jüngeren Regionen des Pflanzentheiles erheblich viel grösser ist, als in den 
älteren. Es lässt sich also eine Beziehung zwischen der Wachsthumsgeschwindigkeit, der Grösse der Turgorauslehnung der Zellen und der Dehnbarkeit des Gewebes in den einzelnen Partialzonen constatiren $\left.{ }^{1}\right)$. Wortuans hat z. B. bei Experimenten mit einem jungen Bohnenepicotyl, das er durch Tuschestriche in 6 Zonen von je $5 \mathrm{~mm}$ Anfangslänge getheilt hatte, die folgenden Werthe für den Zuwachs der Partialzonen in 24 Stunden, für die Verkürzung in der Salzlösung und für die Längenzunahme bei der Dehnung erhalten.

\begin{tabular}{|c|c|c|c|c|c|c|}
\hline Zone & 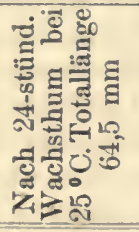 & 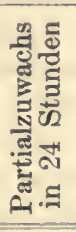 & 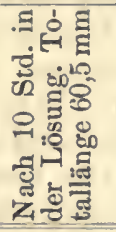 & 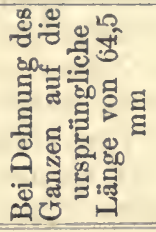 & 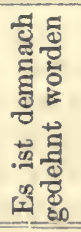 & 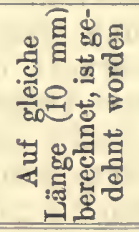 \\
\hline I & 8,5 & 3,5 & 7,5 & 8,5 & 1,0 & 1,33 \\
\hline II & 17,5 & 12,5 & 16,0 & 18,0 & 2,0 & 1,25 \\
\hline III & 17,5 & 12,5 & 16,5 & 17,5 & 1,0 & 0,60 \\
\hline IV & 9,0 & 4,0 & 8,5 & 8,5 & 0,0 & 0,00 \\
\hline$V$ & 6,0 & 1,0 & 6,0 & 6,0 & 0,0 & 0,00 \\
\hline VI & 6,0 & 1,0 & 6,0 & 6,0 & 0,0 & 0,00 \\
\hline
\end{tabular}

Diese und andere Beobachtungen ergaben stets, was nicht völlig mit den von H. DE VRIES gewonnenen Resultaten übereinstimmt, dass die Zone grösster Dehnbarkeit in der jüngsten Region der Untersuchungsobjecte liegt und nicht mit der Zone ausgiebigsten Wachsthums zusammenfällt. In den jüngsten Zonen ist die Turgorkraft der Zellen, wie Wortmans (Botan. Zeitung, 1889, S. 250) constatirte, aber relativ gering, daher wachsen sie trotz hoher Dehnbarkeit ihrer Membranen noch nicht so sehr energisch. Das Maximum des Wachsthums fällt in eine Zone, deren Zellen noch recht dehnbar sind und gesteigerte Turgorkraft entwickeln (daher auch hier die Turgorausdehnung der Zellen am grössten ist), während in den älteren Zonen das Wachsthum wieler langsamer wird, trotzdem die Turgorkraft der Zellen eine bedeutende Grösse behält, weil die Dehnbarkeit der Membranen sehr erheblich abnimmt.

\section{Die Contraction der Wurzeln.}

Bei aufmerksamer Beobachtung zahlreicher Pflanzen fällt es auf, dass, während dic Keimlinge ihre Cotyledonen über der Erde ausbreiten und die Plumula mehr oder weniger aus der Erde hervorragt, die Ansatzstellen der Cotylen und der aus der Knospe hervorgetretenen Blätter später im Boden versteckt sind. Dies nachträgliche Hineinschieben der Ansatzstellen der Blattgebilde in den Boden kann nur

1) Die Grundgedanken unserer heutigen Wachsthumstheorie sind von SACHS entwickelt worden. Vergl. darüber mein Lehrbuch d. Pflanzenphysiologie, S. 213. Bezüglich der angeführten Experimente ist auf die Arbeit von H. DE VRIES, Ueber mechanische Ursachen der Zellstreckung, Halle 1877, hinzuweisen. Ferner vergl. WortMans, Botan. Zeitung, 1889.

I) etmer, Pflanzenphysiolngisches Praktikum, 2. Auf, 
durch eine Contraction der Wurzeln verursacht werden, und in der That ist das Vorhandensein einer solchen von H. DE VRIES ${ }^{1}$ ) sicher festgestellt worden. Die Contraction, deren biologische Bedeutung darin $\mathrm{zu}$ suchen ist, dass durch sie den Knospen im Boden Schutz gewährt wird, kommt durch sehr eigenthümliche Wachstlumsverhältnisse der Wurzeln zu Stande. In den Zellen der parenchymatischen Gewebe der Wurzeln herrscht ein starker Turgor. Dieser ist die Vorbedingung für das Zustandekommen des Wachsthums. Aber da nun in den schon etwas älteren Wurzeln die Dehnbarkeit der Membranen der Zellen in der queren Richtung bedeutender ist als in der Richtung parallel zur Längsaxe der Wurzeln, so findet thatsächlich eine stärkere Dehnung der Zellen in jener als in dieser Richtung durch den Turgor statt, und es muss in Folge dessen eine Contraction der Organe eintreten. Die Verkürzung wird dann allmählich durch Wachsthum fixirt. Für uns ist es nun von besonderem Interesse, die durch den Turgor hervorgerufene Wurzelcontraction genauer kennen zu lernen, denn sie ist ja die unerlässliche Vorbedingung für die nachträglich durch das Wachsthum bedingte bleibende und nicht wieder rückgängig zu machende Verkürzung.

Wir säen Samen von Carum carvi im Sommer in gute Gartenerde im Freien aus und lassen die Pflanzen heranwachsen, bis sie 2-3 Monate alt geworden sind. Ich säete Ende Juli und benutate das Untersuchungsmaterial Ende October. Man zieht die Pflanzen, wenn die Experimente über die Wurzelcontraction angestellt werden sollen, aus dem Boden heraus, schneidet das Kraut sofort ab, um vor einem erheblichen Wasserverlust der Wurzeln durch Transpiration der Blätter gesichert zu sein, bringt die Wurzeln ins Laboratorium und befreit sie nach dem Abwaschen und Abtrocknen von den Nebenwurzeln sowie ihrem dünnen unteren Ende. Es kommt jetzt darauf an, die Wurzeln mit Tuschemarken zu versehen, und um dies auszuführen, legt man die zu untersuchende Wurzel auf eine Korkplatte, auf deren einer Längshälfte eine zweite Korkplatte befestigt ist, welche ungefähr die Höhe der zu verwendenden Wurzel besitzt. Die Wurzel wird nun gegen den Rand der oberen Korkplatte angelegt, mit Nadeln, welche dicht neben der Wurzel in die untere Platte.gesteckt werden, befestigt, um endlich unter Benutzung eines Millimetermaassstabes und eines Pinsels Tuschestriche als Marken in bestimmten Entfernungen aufzutragen. Bei meinen Versuchen mit Carumwurzeln, die am oberen Ende, d. h. an ihrer morphologischen Basis, eine Dicke von 6-9 $\mathrm{mm}$ besassen, betrug die Entfernung der beiden Marken $70-100 \mathrm{~mm}$. Die Wurzeln gelangen jetzt in flache, mit Wasser angefüllte Glasschalen ${ }^{2}$ ). Misst man die Entfernung der Marken von einander nun nach bestimmter Zeit zu wiederholten Malen, z. B. nach $2,4,24,2 \times 24,4 \times 24$ Stunden, so findet man, dass sie sich näher und näher rücken, bis endlich keine weitere Wurzelcontraction mehr eintritt. Die Grösse der Contraction ist erheblich; sie betrug in verschiedenen von mir beobachteten Fällen nach 24 Stunden 2,5-4 Proc.

Trocknet man die contrahirten Wurzeln ab, und legt man sie

1) Vgl. H. ve VRIEs, Landwirthschaftl. Jahrbücher, Bd. 9, S. 37.

2) Es ist zu empfehlen, die mit Marken versehenen Wurzeln vor dem Einbringen in das Wasser wenige Minuten in feuchter Luft liegen zu lassen, um das Adhăriren der Tusche zu sichern. 
dann, um sie in den plasmolytischen Zustand zu versetzen, in Kochsalz- oder Kalisalpeterlösung, so ergiebt sich, dass sich die Untersuchungsobjecte unter Erschlaffung schon nach einigen Stunden erheblich verlängert haben, eine eigenthümliche Erscheinung, die aber mit der Contraction der Wurzeln bei Erhöhung des Turgors ihrer Zellen durch Wasseraufnahme im genauesten Zusammenhange steht.

Wenn Wurzeln in Wasser liegen, so wächst natürlich, trotzdem sie sich verkürzen, ihr Gesammtvolumen und ebenso das Volumen ihrer einzelnen Zellen. Es erfolgt Ausdehnung der Zellen in der zur Längsaxe der Wurzel rechtwinkeligen Richtung; die Wurzel wird dicker, und wir stellen die folgenden Beobachtungen an, um diese Ausdehnung festzustellen.

Man stellt $1 / 2 \mathrm{~mm}$ dicke Querschnitte aus den Carumwurzeln her, isolirt durch zwei parallele Schnitte einen mittleren Theil und zeichnet die Länge desselben bei sclıwacher Vergrösserung (etwa 10 maliger) mit Huilfe des Zeichenprismas auf Papier auf. Die Schnitte gelangen nun sofort in Wasser. Zeichnet man ihre Länge nach etwa einer Stunde wieder auf, so ergiebt ein Vergleich der neuen mit den früheren Zeichnungen, dass die Wurzelstreifen an Länge zugenommen haben. Misst man die Länge der gezeiclıneten Linien und dividirt die gefundenen Zahlen durch 10 (bei benutzter 10 maliger Vergrösserung), so erhält man absolute Werthe für die Länge der Wurzelstreifen vor und nach der Wasseraufnahme.

\section{Die Längsspannung.}

Handelt es sich darum, die Thatsaclie festzustellen, dass in vielen Pflanzentheilen Längsspannungen vorhanden sind, so werden ganze, gerade gewachsene Internodien oder Stücke derselben auf dicken Carton, auf dem feine Linien gezogen worden sind, gelegt, und die Länge der Pflanzentheile durch zwei Punkte mittelst eines schr spitzen Bleistiftes fixirt. Hierauf zieht man mit Hülfe eines scharfen Rasirmessers Streifen der einzelnen Gewebe der Internodien (Epidermis [gewöhnlich mit dem Collenchym verbunden], Rinde, Holz, Mark, das man durch Längsschnitte voin Holze befreit) vollständig und olne Continuitätstrennung ab, legt die isolirten Streifen, ohne sie zu zerren, auf den Carton und fixirt ihre Länge durch Punkte. Man kann nun mit Hülfe eines Millimetermaassstabes die fixirte Länge der unversehrten Internodien sowie ihrer isolirten Gewebe feststellen. Die Beobachtungen, von denen hier die Rede ist, werden zweckmässig unter Benutzung lebhaft wachsender, etwa $50 \mathrm{~mm}$ langer Internodien von Sambucus nigra, Nicotiana Tabacum, Vitis vinifera, Helianthus tuberosus angestellt. Es ergiebt sich stets, dass die Länge der isolirten Gewebestreifen von aussen nach innen zunimmt, und zwar ist das isolirte Mark lebhaft wachsender Internodien gewöhnlich weit länger, die isolirte Epidermis aber kürzer als das unversehrte Internodium, während ein isolirter Gewebestreifen, der sich ursprünglich zwischen Epidermis und Mark befand, genau oder nahezu die Länge des unversehrten Pflanzentheiles aufweist. Das Mark ist also stark positiv oder activ, die Epidermis negativ oder passiv gespannt.

Wird die Länge des unversehrten Internodiums $=100$ gesetzt, und die Differenz zwischen der Länge der isolirten Epidermis sowie 
des isolirten Markes in Procenten ausgedrückt, so erhält man Werthe (freilich nicht solche von absoluter Genauigkeit), durch welche die Spannungsintensität in den unverletzten Pflanzentheilen zum Ausdruck gelangt. Beträgt z. B. die Gesammtlänge eines zum Versuch benutzten Internodiums $50 \mathrm{~mm}$, die Länge der isolirten Epidermis 49, diejenige des isolirten Markes $54 \mathrm{~mm}$, so wäre die Spannungsintensität im unversehrten Pflanzentheil (auf $100 \mathrm{~mm}$ Länge desselben bezogen) durch die Zahl 10 ausgedrückt. In der That erhält man derartige Werthe häufig, wenn man z. B. Internodien von Sambucus nigra untersucht.

Es ist lehrreich, die Spannungsintensität in den einzelnen auf einander folgenden Internodien eines Sprosses nach der angegebenen Methode zu ermitteln. Wenn man die Längendifferenz der isolirten Epidermis sowie Markstreifen stets auf 100 berechnet, so erhält man vergleichbare Werthe, und es ergieht sich dann, dass die Spannungsintensität in den jüngsten Internodien gering ist, während sie in den schon etwas älteren zu bedeutender Höhe ansteigt, um in den noch älteren wieder viel geringer zu werden. Sprosse von Sambucus nigra sind hier besonders gute Untersuchungsobjecte.

Mit Bezug auf die Ursachen der Längsspannung in den Internodien ist zu bemerken, dass die Entstehung derselben in erster Linie auf die

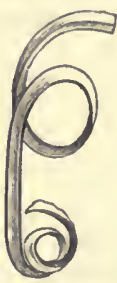

Fig. 118. Der Lainge nach halbirter Bluithelsehaft voll Talaxacum officinale, welcher, in Wasser gelegt, in Folge von Wasseraufnahme spiralige Einrollungen erfahren hat. starke Turgescenz der Zellen des Markes zurückgeführt werden muss. Die Markzellen vermögen sehr grosse Wassermengen aufzunehmen. Das Mark sucht sich in Folge dessen möglichst zu strecken und ist bestrebt, die dehnbaren peripherischen Gewebe zu zerren. Diese sind aber nicht allein dehnbar, sondern zugleich elastisch und suchen ihrerseits das Mark zu comprimiren. Die bedeutende Turgescenz der Markzellen führt ferner ein besonders energisches Wachsthum derselben herbei, ein Umstand, der die Spannungsgrösse in den Internodien noch mehr steigern muss. Wenn das Mark mit fortschreitendem Alter der Stengel sein Wasser verliert und nicht mehr wächst, so erlischt nun auch die Längsspannung. Dafür kommt aber in Verbindung mit dem jetzt eintretenden ausgiebigeren Dickenwachsthum der Pflanzentheile die Querspannung zur Geltung, auf die wir unter 150 näher einzugehen haben.

Dass das Mark in der That das Vermögen besitzt, ohne Schwierigkeit beträchtliche Wassermengen aufzunehmen, lässt sich leicht in der Vorlesung über Pflanzenphysiologie unter Zuhülfenahme der Blüthenschäfte von Taraxacum officinale demonstriren. Die mikroskopische Untersuchung eines Querschnittes lehrt, dass von aussen nach innen Epidermis, Collenchym, grünes Gewebe und Markparenchym folgen; im Grundgewebe liegen die Fibrovasalstränge. Spaltet man einen jungen Blüthenschaft der Länge nach und legt die erhaltenen Stücke in Wasser, so rollen sie sich unter den Augen des Beobachters rasch schneckenförmig ein, und zwar wird die Markseite convex (vgl. Fig. 118). Das Markgewebe nimmt schnell reichliche Wassermengen auf, seine Zellen strecken sich in Folge dessen, und dadurch kommt die spiralige Einrollung des Untersuchungsobjectes zu Stande. Wird ein Internodium einer Pflanze unmittelbar nach dem Abschneidon auf seine Spannungsgrösse in der früher angegebenen Weise 
geprüft, ein zweites, das dem ersteren möglichst ähnlich sein muss, aber erst analysirt; nachdem dasselbe durch Liegen an der Luft etwas welk geworden ist, so findet man die Differenz zwischen der isolirten Epidermis und dem isolirten Mark für das erstere grösser als für das letztere, was wieder beweist, dass der Wassergehalt der Gewebe von hoher Bedeutung für die in den Pflanzentheilen herrschenden Spannungsgrössen ist ${ }^{1}$ ).

\section{Die Querspannung.}

Handelt es sich darum, das Vorhandensein der Querspannung an irgend einer Stelle eines Stengels oder Stammes zu constatiren, so schneidet man an dieser Stelle eine Quersclieibe heraus, misst den Umfang derselben mit Hülfe eines Papierstreifens, trennt durch einen senkrechten radialen Schnitt die Continuität der peripherischen Gewebe und schält dann die ganze Rinde von dem Untersuchungsobject ab. Der isolirte Rindenring wird nun wieder, ohne ilın zu delınen, in seine natürliche Lage zurückgebracht. Es zeigt sich aber, dass seine Schnittflächen nicht mehr zusammenschliessen, woraus sich ergiebt, dass die Rinde im unversehrten Stengel oder Stamm passiv oder negativ gespannt gewesen sein musste (vgl. Fig. 119). Bestimmt man die Weite des Abstandes der Schnittflächen des nach dem Isoliren wieder in seine natürliche Lage zurückgebrachten Rindenringes durch Messung und subtrahirt den erhaltenen Werth von dem für den Umfang der unversehrten Querscheibe gefundenen, so erhält ınan eine Zahl, durch welche die Grösse des nach dem Isoliren verkürzten Rindenringes zum Ausdruck gelangt. Die Spannungsintensität kann schliesslich leicht in Procenten des ursprünglichen Umfanges des Untersuchungsobjectes angegeben werden. Geeignete Untersuchungsobjecte zur Constatirung des Vorhandenseins der Querspannung sind Helianthusstengel sowie $\overline{5}-10$-jährige Stamm-

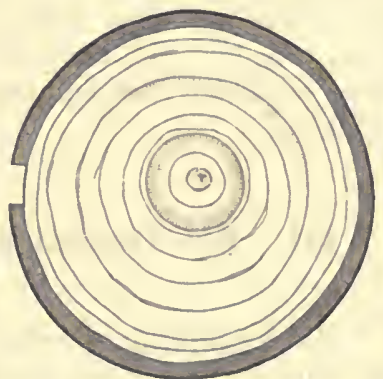

Fig. 119. Querscheibe aus eiuem Ast von Prunus. Die Rinde ist zunäehst abgelöst und dann wieder um den Holzkörper gelegt worden. oder Aststïcke von Prunus-, Pyrus- oder Salixarten. Ich habe z. B. $5 \mathrm{~mm}$ hohe Querscheiben aus Aesten von Prunus insititia und einer Salixart auf ihre Spannungsintensität geprüft. Umfang der Querscheiben 106 (Prunus), resp. 132 (Salix) mm. Abstände der Schnittflächen 4,5, resp. $6 \mathrm{~mm}$. Spannungsintensitäten 4,2, resp. 4,5 Proc. Ermittelt man die Spannungsintensität in der angegebenen Weise gleichzeitig an verschiedenen Stellen eines Stammgebildes, indem man z. B. aus einem Stengel von Helianthus annuus an der Basis, in der Mitte sowie am oberen Ende Querscheiben herausschneidet, um von diesen Rindenringe zu isoliren, so ergiebt sich im Allgemeinen, dass die Intensität der Querspannung in den jüngeren Regionen des Untersuchungsobjectes relativ gering ist, in den älteren aber erheblich zunimmt.

1) Vgi. Kraus, Botan. Zeitung, 1867. Mancherlei Angaben, die für die Beurtheilung der sich auf die Gewebesp:tnnung beziehenden Verhültnisse von Wichtigkeit sind, finden sich in meinem Lehrbuch der Pflanzenphysiologie, 1883, S. 229. 
Das Auftreten beträchtlicherer Querspannung in den Stengeln und Stämmen ist an das Stattfinden ausgiebigeren Dickenwachsthums derselben gebunden. Der Umfang der centralen Gewebe (zumal des Holzes) nimmt in Folge des Dickenwachsthums bedeutender $\mathrm{zu}$ als derjenige der peripherischen. Diese werden daher gedehnt und verkürzen sich boim Isoliren. Die producirte Holzmasse besitzt nun aber keineswegs stets den gleichen Umfang; vielmehr kann die Grösse desselben beträchtliche Schwankungen erfahren, eine Thatsache, die sich leicht erklärt, wenn man bedenkt, dass der jeweilige Gehalt des Holzes an Imbibitionswasser von bedeutsamem Einfluss auf dessen Volumenverhältnisse ist. Erhöhung des Wassergehaltes des Holzes muss danach eine Steigerung der Spannungsintensität im Stamme zur Folge haben. Wenn man z. B. Querscheiben aus einem Ast von Prunus insititia herstellt, die Spannungsintensität einiger Querscheiben sofort ermittelt, diejenige anderer aber erst feststellt, nachdem die Untersuchungsobjecte 24 Stunden lang in Wasser gelegen haben, so findet man die Spannung in den letzteren grösser als in den ersteren. Bei Versuchen, die ich mit etwa $15 \mathrm{~mm}$ hohen und ca. $100 \mathrm{~mm}$ Umfang besitzenden Prunusquerscheiben ausführte, stieg die Intensität der Querspannung durch 24-stündiges Verweilen derselben in Wasser von 4,5 auf 5,5 Proc. Mit Bezug auf die Abhängigkeit der Spannungsverhältnisse von anderen äusseren Factoren (Temperatur, Licht) verweise ich auf die Abhandlung, von G. Kraus in der Botanischen Zeitung sowie auf mein Lehrbuch der Pflanzenphysiologie. Ebenso sind an diesen Stellen die merkwürdigen, freilich noch lange nicht eingehend genug studirten Erscheinungen der Periodicität der Gewebespannung besprochen.

\section{Die Vegetationspunkte und das Längenwachsthum der Pflanzen.}

Die Vegetationspunkte der Pflanzenorgane sind je nach Umständen von sehr verschiedenartiger Beschaffenheit. Für unsere Zwecke genügt

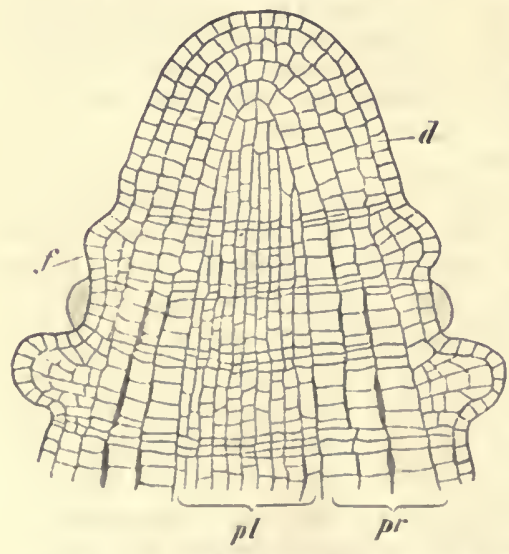

Fig. 120. Laingsschnitt durch den Vegetationskegel von Hippuris vulgaris. $d$ Dermatogen, $p r$ Periblem, $p l$ Plerom, $f$ Blattanlage. Vergr. 240. (Nach Strasburger.) es, den Vegetationspunkt von Hippuris vulgaris genauer ins Auge zu fassen; ähnlich wie bei dieser Pflanze ist er auch in anderen Fällen gebaut. Wir schneiden von recht kräftig entwickelten Sprossen die Endknospe in einer Länge von etwa $1 \mathrm{~cm}$ ab, entfernen die vorhandenen Blätter so viel wie möglich und stellen zarte Längsschnitte aus der Knospe her. In Fig. 120 erblicken wir das Bild eines wohl gelungenen medianen Längsschnittes. Es ist erforderlich, die Schnitte, um die Anordnung der Zellen des Vegetationskegels klar und deutlich erkennen zu können, aufzuhellen, was z. B. dadurch erreicht wird, dass wir die Präparate mit concentrirter Kalilauge behandeln, dann mit 
Wasser auswaschen und in concentrirte Essigsäure legen. Die Scheidewände der mantelförmig über einander gelagerten Zellschichten bilden eine Schaar confocaler Parabeln. Die äusserste Zellschicht, aus der die Epidermis hervorgeht, bezeichnet man als Dermatogen $(d)$. Es folgt dann das die Stengelrinde erzeugende, mehrschichtige Periblem $(p r)$. Endlich folgt das Plerom $(p l)$, aus welchem, wie tiefer am Schnitt constatirt werden kann, der axile Gefässbündelcylinder des Stengels hervorgeht. Bei Hippuris, keineswegs aber bei allen höheren Pflanzen, ist also eine scharfe Trennung des Dermatogens, Periblems und Pleroms am Vegetationskegel vorhanden.

Die Anordnung der Zellen in den Vegetationspunkten entspricht nach SAcris ${ }^{1}$ ) dem von diesem Forscher aufgestellten Princip der rechtwinkeligen Schneidung. Die Antiklinen, d. h. die senkrecht die Oberfläche des Vegetationspunktes treffenden Zellwände, und die Periklinen, d. h. die mit der Oberfläche gleichsinnig gekrümmten Wände, schneiden sich in rechten Winkeln. Die antiklinen Wände stellen also eine Schaar orthogonaler Trajectorien für die Periklinen dar. Die Erscheinung, dass die Zellwände in einem rechten Winkel auf einander treffen, ist übrigens sehr allgemein im Pflanzenreich $\mathrm{zu}$ beobachten. In einfachster Form können wir die rechtwinkelige Schneidung bei der Untersuchung von Algenfäden (z. B. Spirogyra) feststellen.

Errera ${ }^{2}$ ) und Berthold ${ }^{3}$ ) haben nun neuerdings betont, dass es ein noch allgemeineres Princip als dasjenige der rechtwinkeligen Schneidung für die Anordnung der Membranen giebt. Es ist dies das Princip der kleinsten Oberflächen. Viele Erscheinungen, z. B. diese, dass die Zellwände oft nicht in einem rechten, sondern im spitzen Winkel auf einander treffen (vergl. BERTHoLd, S. 231 und 253), sind nur unter Berücksichtigung des zuletzt erwähnten Princips verständlich, wie die genannten Autoren auch näher ausführen. Dieselben kommen zu dem Resultat, dass die Gruppirung der Membranen von den nämlichen Gesetzen beherrscht wird, welche ebenfalls für die Ausbildung von Flüssigkeitslamellen maassgebend sind. Für diese ist das Princip der kleinsten Oberflächen, wie zumal Puateau nachwies, entscheidend, und es gewährt daher Interesse, einige Experimente anzustellen, welche dies darzuthun im Stande sind.

Wir lösen $3,75 \mathrm{~g}$ gepulverte medicinische Seife (aus der Apotheke zu beziehen) in einem Gemisch von $187,5 \mathrm{~g}$ destillirtem Wasser und $75 \mathrm{~g}$ concentrirtem Glycerin auf. Die Lösung kocht man einmal auf und kann sie dann lange aufbewabren. Nun verfertigt man sich Modelle verschicdener Körper (Würfel, Tetraëder, Cylinder) ans Draht. Der Draht wird derartig zusammengebogen, dass er die Kanten der erwähnten Körperformen bildet. Beim Cylinder wird die obere Kreisfläche mit der unteren durch drei Drähte verbunden. Modelle von etwa $50 \mathrm{~mm}$ Höhe genügen vollkommen. Die Seifenlösung wird in ein Becherglas gebracht, und nun taucht man die Modelle an einem an geeigneter Stelle befestigten Draht in dieselbe ein. Hebt man dic Modelle aus der Lösung heraus, so sieht man zwischen deu Drahtkanten Seifenlamellen ausgespannt. Dieselben sind nun eben," wie die specielle Prüfung und mathematische Rechnnng ergiebt, nach dem Princip der kleinsten Oberflächen angeordnet. Zerstört man eine der ausgespannten Lamellen durch vorsichtiges Berühren mit

1) Vgl. SACHS, Arbeiten des botan. Instituts in Würzburg, Bd. 2.

2) Vgl. Errera, Ber. d. Deutschen botan. Gesellsch., 1886, S. 441.

3) BERthold, Studien über Protoplasmamechanik, 1S86, S. 219. 
einem Glasstab, dann wird in dem Lamellensystem ein neuer Gleichgewichtszustand angestrebt und durch Bildung oft sehr merkwürdiger Lamellenformen erzielt, die aber immer dem erwähnten Princip Genüge leisten.

Sehr lehrreich ist das folgende Experiment. Ein auf 4 Drahtstiften von ca. $1 \mathrm{~cm}$ Höhe ruhendes Drahtquadrat von ca. $60 \mathrm{~mm}$ Seitenlänge wird mittelst eines an geeigneter Stelle befestigten Drabtes in dio Seifenlösung eingetaucht. Das aus der Lösung herausgenommene Drahtmodell wird in horizontale Lage gebracht und auf die ausgespannte Lamelle ein Faden in beliebiger Weise aufgelegt, dessen Enden man mit einander ver-

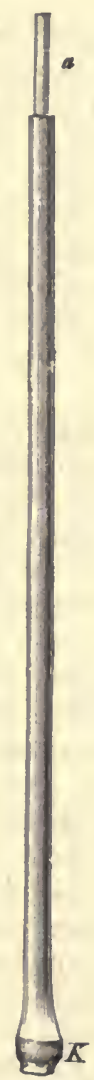

Fig. 121. Unterer Theil eines Internodiums aus dem Halme ron Secale. Das Stück $a$ ist durch intercalares Wachsthum hervorgeschoben worden. knüpft hat. Durchsticht man die Seifenlamelle nun mit Hülfe eines Glasstabes an einer Stelle, die innerhalb der von dem Faden umgrenzten Zone liegt, so bildet die Lamelle sofort eine Minimalfäche, und der Faden ordnet sich daher in Kreisform an.

Wollen wir Wurzelvegetationspunkte untersuchen, so stellen wir mediane Längsschnitte aus den Wurzeln von Zea Mays oder Hordeum her. Es ist hier auch ein Dermatogen, Periblem und Plerom vorhanden; besonders auffallen wird uns die Wurzelhaube, welche den Scheitel der Wurzeln bedeckt.

Die Zellen der Vegetationspunkte der Stengel und Wurzeln sind in lebhafter Theilung begriffen. Ein ausgiebiges Flächenwachsthum, das zur Streckung der Organe führt, erfahren die Zellen erst, wenn sie etwas älter geworden $\operatorname{sind}^{1}$ ).

Bezüglich der weiteren Ausbildung der in den Vegetationspunkten erzeugten Elemente ist namentlich zu betonen, dass dieselbe entweder an der Spitze oder der Basis der neu entstehenden Organe stattfinden kann. Halten wir uns hier an diejenigen Verhältnisse, welche beim Wachsthum der Sprossaxen höherer Pflanzen beobachtet werden können.

Bei den Gräsern - aber auch bei manchen anderen Gewächsen - bewahrt das an der Basis der einzelnen Internodien von der Blattscheide umschlossene Gewebe der Axe längere Zeit einen jugendlichen Charakter, während die höher liegenden Theile der Internodien schon in Dauergewebe übergegangen sind. Diese merkwürdige Thatsache des Vor. handenseins einer basalen, intercalaren Vege-

1) Auf Grund der Ergebnisse der neueren Untersuchungen von Zimmermavs, Corress, Zaciarias, Klebs u. A. darf man wohl behaupten, dass das Flächenwachsthum der Zellhäute unter normalen Umständen durch Apposition und Intussusception vermittelt wird. Jene führt zur Anlagerung neuer Zellstoffschichten, diese zur Einlagerung neuer Cellulosemoleküle. Das Wachsthum turgorloser Zellen (vergl. KLEBS, Untersuchungen aus dem botan. Institut zu Tübingen, Bd. 2, S. 561) wird allein durch Apposition vermittelt; ebenso erfolgt das normale Dickenwachsthum der Zellhänte (und auch das Wachsthum der Stärkekörner) durch Apposition. 
tationszone lässt sich sehr leicht durch das folgende Experiment demonstriren. Wir schneiden aus einem Halm von Secale ein Internodium heraus. Dasselbe wird in eine oberc und eine untere Hälfte zerlegt. Wir stellen nun die beiden Stücke des Internodiums, die mit ihrer Basis in Wasser eintauchen, unter cine Glasglocke und finden nach Verlauf von 24 Stunden, dass sich an der oberen Hälfte des Internodiums keine Wachsthumsvorgänge geltend gemacht haben, wohl aber an der unteren. In Fig. 121 ist die untere Hälfte cines Internodiums von Secale, nachdem dieselbe 24 Stunden in feuchter Luft verweilt hatte, dargestellt. $K$ ist das Knotengelenk. Der Theil $a$ ist durch Wachsthumsprocesse aus den äusseren Theilen hervorgeschoben worden.

Bei (ler Bohne (Phaseolus) und bei vielen anderen Pflanzen befindet sich die in Streckung begriffene Region der Internodien an der Spitze derselben. Wenn man z. B. an oberen Ende des zweiten Internodiums einer Bohne, d. h. desjenigen Stengelgliedes, welches auf das Epicotyl folgt, zwei Tuschestricle als Marken in einiger Entfernung von cinander anbringt, während das dritte Internodium schon lebhafte Streckung zeigt, so ergiebt sich nach 24 Stunden, dass die Entfernung der Marken erheblich grösser geworden ist. Die Bohneninternodien wachsen noch an ihrer Spitze, nachdem ihre basalen Theile bereits aufgelört haben zu wachsen; sic verhalten sich also ganz anders wie die Internodien der Gräser.

\section{Das Dicken wachsthum.}

Das Dickenwachsthum verschiedener Pflanzen und Organe geht durchaus nicht in ein und derselben Weise vor sich. Wir wollen uns hier darauf beschränken, das Dickenwachsthum der Stammgebilde und Wurzeln einiger dicotyler Gewächse ins Auge zu fassen.

Fig. 122. Querselınitt durch einen $5 \mathrm{~mm}$ dicken Zweig von Aristolochia Sipho. $m$ Mark, $f v$ Gefässbündel, und zwar $v l$ Gefässtheil, $c b$ Siebtheil, $f c$ Fascicularcambium, ifc Interfascicularcambium, $p$ Cribralparenchym an der Aussenseite des Siebtheiles, das den Uebergang zum Grundgewebe vermit-. telt, $p c$ Pericykel, sk Sklerenchymring, $e$ Stärkescheide, $c$ "grüne Rinde, $c l$ Collenchym. Vergr. 9. (Nach StrasBURGER.)

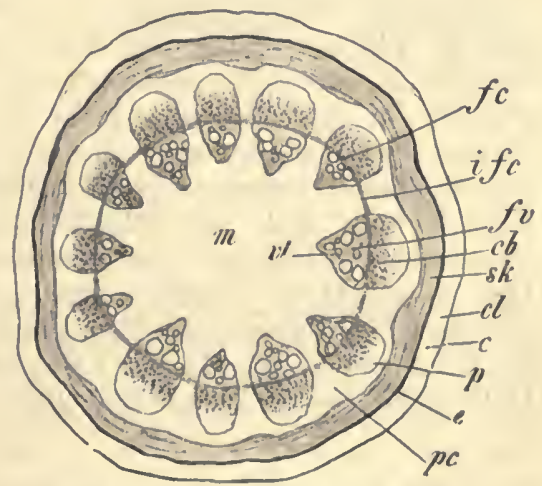

Wir nehmen zunächst eine $3-4 \mathrm{~mm}$ dicke Sprossaxe von Aristolochia Sipho in Untersuchung und können frisches Material oder Alkoholmaterial verwenden. In Fig. 122 ist das Bild eines zarten Querschnittes bei schwacher Vergrösserung dargestellt. Man orientirt sich leicht, und es sei hier besonders darauf aufmerksam gemacht, dass die in einem Kreise angeordneten Gefässbündel noch ziemlich weit von einander getrennt 
sind. Das aus schmalen, radial angeordneten Zellen bestehende Fascicularcambiun $(f c)$ der einzelnen Stränge setzt sich zwischen diesen in das aus dem Parenchym des Grundgewebes hervorgegangene Interfascicularcambium (ifc) fort, und dadurch entsteht ein geschlossener Cambiumring.

Bei weiterer Entwickelung der Sprossaxen von Aristolochia erzeugt nun das Cambium (hier nur das Fascicularcambium) nach innen fortdanernd Holz-, nach aussen Bastgewebe. Das auf diese Weise zu Stande kommende Dickenwachsthum der Stammtheile führt zumal zu einer sehr bedeutenden Massenzunahme des Holzkörpers der Fibrovasalstränge, wie man sofort erkennt, wenn man z. B. Querschnitte aus $10 \mathrm{~mm}$ dicken Aristolochiastengeln untersucht. Wir erblicken dabei auch etwa 10 primäre Markstrahlen, die den Holzkörper seiner gesammten Dicke nach durchsetzen, also vom Cambium bis zum Mark reichen. Secundäre Markstrahlen sind in beträchtlicher Anzahl vorhanden. Zu achten ist noch darauf, dass in der Peripherie der älter gewordenen Sprossaxen Peridermbildung eingetreten, und dass der in den jüngeren Pflanzentheilen geschlossene Sklerenchymring (vgl. Fig. $122 \mathrm{sk}$ ) in einzelne Stücke zerlegt ist.

Ein günstiges Object zur Orientirung über diejenigen Veränderungen, welche in Stammtheilen in Folge des Dickenwachsthums derselben eintreten, stellt auch das hypocotyle Glied von Ricinus communis dar. In Fig. 112 ist das Bild des Querschnittes eines Gefässbündels aus dem völlig gestreckten Hypocotyl von Ricinus dargestellt. Wir untersuchen Alkoholmaterial und stellen ohne Mühe das Vorhandensein des Interfascicularcambiums und des Fascicularcambiums fest. In Folge des Dickenwachsthums des Ricinusstengels wird nach innen secundäres Holz, nach aussen secundäres Bastgewebe erzeugt.

Wir stellen uns Schnitte aus dem oberen Theil der Wurzel einer Keimpflanze von Phaseolus multiflorus her, die eben beginnt, die ersten Nebenwurzeln zu bilden. Wir erblicken die Epidermis, das Rindengewebe und den die Gefässbündel einschliessenden Centralcylinder. Dieser wird in seinem ganzen Umfange von einem eigenthümlichen Gewebe umgeben, welches man als Endodermis bezeichnet. Besonders charakteristisch ist für die Wurzeln, dass der Holz- und Basttheil ihrer Gefässbündel eine wesentlich andere Anordnung wie in den Sprossen besitzen. Es sind nämlich in den Wurzeln mehrere Xylembündel vorhanden, mit denen ebenso viele, mehr nach der Peripherie des Centralcylinders gerückte Phloëmbündel alterniren. Der Querschnitt der Bohnenwurzel zeigt uns vier Xylem- und vier Phloëmbündel; wir bezeichnen sie daher als tetraarch. Wenn mit fortschreitender Entwickelung der Wurzeln das Dickenwachsthum derselben sich geltend macht, so verwandelt sich das zwischen den Xylem- und Phloëmbündeln vorhandene Gewebe in Cambium. Es entsteht ein geschlossener Cambiumring, der nun nach innen secundäres Holz, nach aussen secundären Bast erzeugt.

\section{Apparate zur Messung der Zuwachsbewegungen.}

Zur Demonstration der Zuwachsbewegungen eignet sich besonders ein Apparat, der von SACHS zuerst benutzt wurde und als ,Zeiger am Bogen" bekannt ist. Dieser Apparat, in Fig. 123 in der Form, wie er von PFEFFER construirt worden ist, dargestellt, kann in sehr guter Ausführung im Preise von $60 \mathrm{Mk}$. vom Universitätsmechaniker Albrecht in Tübingen bezogen werden. 
Der an die Pflanze angekuppelte Faden $f$ ist über die auf den Mittelpunkt des Quadranten $q$ centrirte Rolle $r$ geführt. Als Untersuchungsobjecte benutzte ich zumal junge Keimpflanzen von Phaseolus, die sich in Gartenerde, mit welcher Blumentöpfe angefüllt waren, so weit entwickelt hatten, dass das Epicotyl etwa $2 \mathrm{~cm}$ aus dem Boden hervorragte. Der Faden kann leicht mit einer Schlinge an der Pflanze befestigt werden. Die Rolle trägt einerseits den Zeiger $z$, andererseits den Arm $a$, welcher den Faden $f$ durch eine Durchbrechung zu führen gestattet und ferner die zum Aequilibriren des Zeigergewichtes, respect. zur Herstellung

Fig. 123.

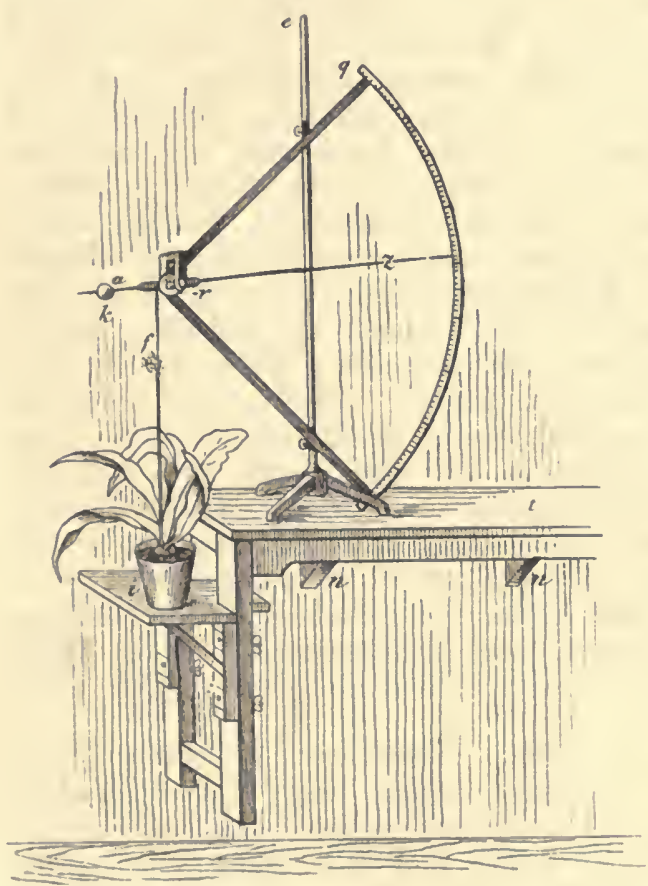

Fig. 124

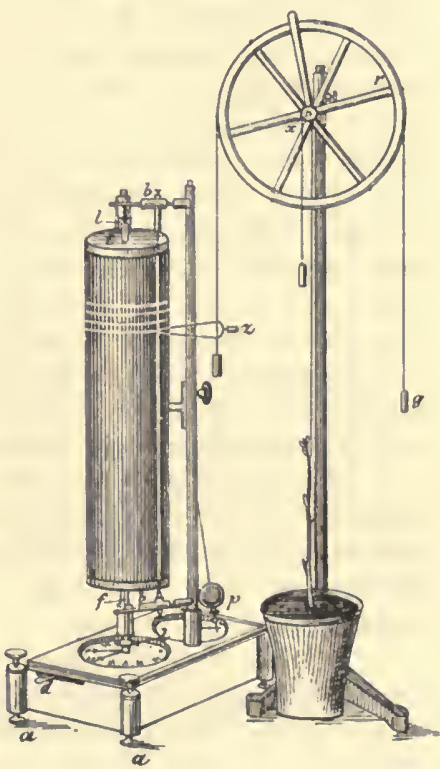

Fig. 2123. Zeiger am Bogen. (Nach PfEFFer.)

Fig. 124. Auxunometer. (Nach PFeffer.)

eines gewissen einseitigen Uebergewichtes dienende verstellbare Kugel $k$ trägt. Am besten ist es, den Zeiger vollkommen zu äquilibriren und das einseitig gewünschte Uebergewicht durch einen entsprechend über die Rolle geführten, durch ein Gewicht gespannten Faden herzustellen. Der Quadrant hat $70 \mathrm{~cm}$ Radius; die Rolle $r$ ist klein, so dass eine etwa 43-fache Vergrösserung des Zuwachses von dem aus einem sich verjüngenden Messingrohr gebildeten Zeiger $z$ angezeigt wird. Der Quadrant ist an dem schweren Eisenstativ $e$ verschiebbar; er muss zitterfrei aufgestellt werden, z. B. auf einem Consoltisch, der an einer massiven Wand angeschlagen ist.

Für viele Zwecke ist es bei genaueren Untersuchungen über Wachsthumsvorgänge sehr wünschenswerth, ja oft nothwendig, einen Apparat 
zu haben, der die Zuwachsgrösse selbstthätig registrirt. SACHs ${ }^{1}$ ) hat einen solchen Apparat, das selbstregistrirende Auxanometer, zuerst construirt. Nach ihm gaben Wiesner, Baranetzky, Pfeffel ${ }^{2}$ ) und Andere der Vorrichtang veränderte Form, und am aller lcistungsfähigsten dürfte wohl der Apparat von Pfrefrer sein, der im Preis von 320 Mk. vom Universitätsmechaniker Albrecir in Tübingen bezogen werden kann. Aufstellung der Vorrichtung (Fig. 124) auf einem zitterfreien Tisch ist natürlich Hauptbedingung für das Gelingen, der Experimente ${ }^{3}$ ). ${ }_{n}$ Der an die Pflanze gekuppelte Faden wird über das kleine $\operatorname{Rad} x$ geführt, das mit dem grossen Rad $r$ verkettet und mit diesem auf dem gleichen Mittelpunkt genau centrirt ist. Ein an dem grösseren Rad befestigter und um dieses geschlungener Faden trägt den in unserer Aufstellung mit dem Zuwachs sich senkenden Zeiger $z$, der durch ein an einem entgegengesetzt geschlungenen Faden befestigtes Gewicht $g$ äquilibrirt wird. Die berusste Trommel $t$ wird durch ein in einem schweren Eisenkasten $L$ befindliches Federuhrwerk getrieben, dessen Regulation ein conisches Pendel $p$ besorgt. Die $70 \mathrm{~cm}$ hohe Trommel erlaubt durch Umsetzung der Führungsachse $f$ eine centrale und eine excentrische Stellung, kann ausserdem mitsammt der Achse aus den Lagern (bei $L$ ) entfernt werden. Die Spitze des horizontalen, aus Messing gefertigten und nicht zu leichten Zeigers hat, wie die Figur zeigt, auf der Trommel zu schleifen, die in einer Stunde eine Umdrehung macht. Die Anpressung gegen die Trommel wird durch eine dem Faden gegebene Torsion erreicht, und wenn die excentrisch gestellte Trommel nur zeitweise gestreift werden soll, gleitet der Zeiger inzwischen auf der zwischen den verstellbaren Backen $b$ ausgespannten Darmsaite. In der hier abgebildeten Zusammenstellung liefert das Auxanometer eine 15-fache Vergrösserung des Wachsens."

Die Befestigung des Fadens (Seidenzwirn) an der Pflanze kann leicht dadurch erreicht werden, dass man an dem einen Fadenende eine Schlinge anbringt, das andere Fadenende durch diese hindurchsteckt, um den Faden endlich um das obere Ende eines Internodiums unmittelbar unter die Basis eines Blattes zu legen.

Um die Fehlerquellen des Apparates, soweit sie ihren Grund in den hygroskopischen Eigenschaften der Fäden haben, möglichst einzuengen, empfiehlt es sich, nur für die über die Rollen laufenden und zur Ankuppelung an die Pflanze dienenden Theile der Fäden Seidenzwirn, sonst aber dünnen Silber- oder Platindraht, der an beiden Enden scharf umgebogen ist, so dass leicht kleine Fadenschlingen befestigt werden können, $\mathrm{zu}$ verwenden.

Stellt man die Beobachtungen bei Lichtzutritt an, so muss man senkrecht und parallel zu dem Fenster einen Spiegel hinter die Pflanze stellen, um die störenden heliotropischen Krümmungen auszuschliessen. Die Experimente sind ferner in einem Raume, der möglichst geringe Temperaturschwankungen erfährt, auszuführen. Temperaturbestimmungen sind natürlich stets vorzunehmen (Näheres vergleiche unter 77). Der Boden, in welchem die Pflanzen bereits geraume Zeit gewurzelt haben, muss

1) Vgl. SAcHS, Arbeiten d. botan. Instituts in Würzburg, Bd. 1, S. 113.

2) PFfFFer, Handbuch d. Pflanzenphysiologie, Bd. 1, S. 86.

3) Der hier abgebildete und zu beschreibende Apparat ist derselbe, den auch Preffer in seinem Handbuche erwähnt. Neuerdings ist das Auxanometer noch in einiger Hinsicht ron PFEFfer verbessert worden und in dieser Form zu dem erwähnten Preise aus Tübingen zu beziehen. 
längere Zeit vor dem Versuch begossen worden sein und darf während der Beobachtungen nicht austrocknen.

Der rotirende Cylinder des Auxanometers muss noch vor dem Gebranch des Apparates mit Papier überklebt werden. Man legt dazu ein hinreichend grosses Stück auf einer Seite geglätteten Glacépapiors auf den Tisch, überstreicht die raube Seite des Papiers gleichmässig mit einem mässig feuchten Schwamm, überzieht die beiden langen Ränder mit Gummilösung und rollt den Cylinder über das Papier hin. Wenn das Papier angetrocknet ist, führt man den Cylinder so über einer grossen, breiten Terpentinflamme hin und her, dass das Papier gleichmässig mit Russ bedeckt wird. Beim Gebrauch des Auxanometers kommt der in Folge des Wachsthums in Bewegung versetzte Zeiger $z$ bei excentrischer Trommelstellung stündlich einige Zeit lang mit dem rotirenden Cylinder in $\mathrm{Be}$ rührung und entfernt den Russ an den Berührungsstellen von der $\mathrm{Cy}$ linderoberfäche. Bestimmt man die Entfernung der entstehenden Linien von einander, nachdem man das berusste Papier von der Trommel abgenommen, zur Fixirung der Linien durch eine alkoholische Colophoniumlösung gezogen nnd getrocknet hat, so gewinnt man unmittelbar einen Maassstab zur Feststellung der Grösse der Zuwachsbewegung des Untersuchungsobjectes. SAcHs hat sich über Art der Messuug sowie überhaupt über die ganze Methode der Untersuchung und deren Fehlerquellen so eingehend geäussert, dass wir noch besonders auf seine citirte Arbeit, zumal S. 116, 118 und 119, hinweisen.

Das selbstregistrirende Auxanometer kann bei zahlreichen Untersuchungen über das Wachsthum Verwendung finden. Ganz insbesondere ist es unentbehrlich, wenn es sich darum handelt, näheren Aufschluss über den Verlauf der täglichen Periode des Wachsthums von Internodien zu gewinnen (vgl. weiter unten).

Unentbehrlich für genaue Messungen sehr kleiner Zuwachsbewegungen vertical wachsender Pflanzentheile ist ein horizontal gestelltes Mikroskop (oder Fernrohr). Sehr empfehlenswerth ist der in der Fig. 125 abgebildete Quixcke-Pfeffer'sche Apparat, der im Preise von $110 \mathrm{Mk}$. vom Universitätsmechaniker Albrecht in Tübingen bezogen werden kann. "Der Tubus des Mikroskops wird durch den Trieb $t$ auf das zu beobachtende Object eingestellt. Zur groben Verschiebung in verticaler Richtung dient die in der Hülse $h$ bewegliche Säule $s$, während mit der Mikrometerschraube $\boldsymbol{m}$ die feine Einstellung erzielt und das Object von neuem eingestellt wird, wenn es die Scala des Ocularmikrometers durchlaufen hat. Mit Hülfe dieser genau gleichförmig geschnittenen Schraube kann man zugleich, analog wie mit einem Kathetometer, grössere, das Gesichtsfeld

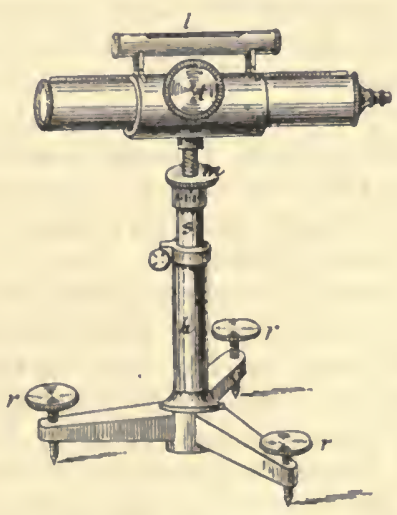

Fig. 125. ILrizontales Messmikroskop. (Nach PFeffFr.)

überschreitende Distanzmarken messen. Bei dem Instrument entspricht z. B. eine Umdrehung $0,792 \mathrm{~mm}$, und auf der in 100 Theilen getheilten Trommel können $1 / 2$-Theilstriche exact abgolesen werden. Die Horizontalstellung des Tubus wird durch die Stellschrauben $r$ erreicht und durch die Libelle $L$ controlirt." 
Bemerkt sei noch, dass der Focalabstand des Mikroskops bei 20-facher Vergrösserung $80 \mathrm{~mm}$ beträgt. Das Ocularmikrometer ist in 120 Theile getheilt. Jeder Theilstrich hat bei 20 -facher Vergrösserung den Werth . von $0,07 \mathrm{~mm}$; der Werth einer Schraubenumdrehung beträgt, wie gesagt, $0,792 \mathrm{~mm}$. Die Schraube gestattet, Strecken bis zu $3 \mathrm{~cm}$, das Mikrometer Strecken bis zu $8 \mathrm{~mm}$ zu messen. Beide Messungsweisen können Verwendung finden.

Bei der Benutzung des beschriebenen Mikroskops ist dasselbe vor allem zitterfrei aufzustellen, z. B. auf einem geeigneten Consoltisch oder auf einer festen Tischplatte, die von einem starken hölzernen Dreifuss getragen wird und vertical verschiebbar ist. Auf den risch steht ferner ein Klinostat (vgl. im fünfteu Abschnitt), dessen Axe vertical gerichtet ist, so dass sich die mit derselben verbundene Scheibe langsam in horizontaler Ebene bewegt (Umdrehungszeit etwa eine Stunde). Als Untersuchungsobjecte können wir zunächst Fruchtträger von Phycomyces oder Mucor benutzen.

Ein Stück Brot wird zur Sterilisirung nach dem nicht zu starken Durchfeuchten mit $1 / 10^{-p r o c . ~ T r a u b e n z u c k e r l o ̈ s u n g ~ i n ~ e i n e r ~ m i t ~ G l a s p l a t t e ~}$ bedeckten Glasschale längere Zeit lang im Trockenschrank bei $100^{\circ} \mathrm{C}$. belassen und nach dem Abkühlen mittelst einer sterilisirten Nadel mit wenigen Phycomycessporen oder Mucorsporen besäet ${ }^{1}$ ). Mucorsporen kann man leicht nach dem unter 36 angegebenen Verfahren gewinnen. Das Brot bleibt unter einer Glasglocke im Dunkeln so lange sich selbst überlassen, bis die Fruchtträger genügende Grösse erlangt haben; es wird dann in einer Glasschale auf die Scheibe des Klinostaten gestellt und abermals mit einer Glasglocke, die zur Aufnahme eines Thermometers tubulirt sein muss, bedeckt. Die Fruchtträger wachsen jetzt, wenn der Klinostat in Bewegung gesetzt wird, auch bei Lichtzutritt gerade in die Höhe. Heliotropische Krümmungen können unter den bezeichneten Umständen nicht zur Geltung kommen. Bevor das Uhrwerk des Klinostaten in Gang gebracht worden ist, haben wir unser Mikroskop derartig auf einen Fruchtträger eingestellt, dass der Scheitel des Sporangiums einen Theilstrich des Ocularmikrometers scheinbar berührt. Beginnt jetzt der Versuch, so gelangt das Sporangium bei einstündiger Rotationsdauer der Scheibe des Klinostaten erst nach einer Stunde wieder deutlich ins Gesichtsfeld. Die Zuwachsgrösse kann durch Drehung der Schraube $m$ (Fig. 125) leicht bestimmt werden. Unsere Fruchtträger erfahren in einer Stunde nicht selten einen Zuwachs von $1-2 \mathrm{~mm}$, und sie gestatten es auch, die Untersuchungen längere Zeit fortzusetzen (weitere Experimente nach dieser Methode vgl. weiter unten).

Kommt es darauf an, die in kurzen Zeiträumen stattfindende $\mathrm{Zu}$ wachsbewegung an Keimstengeln (z. B. am Hypocotyl von Lepidium) zu constatiren, so sind auf den Untersuchungsobjecten feine Striche mit chinesischer Tusche anzubringen. Die Keimlinge werden alsbald, nachdem ihre Entwickelung begonnen hat, mit Hülfe von Watte so in kleine Gläschen eingesetzt, dass ihre Wurzeln in Wasser eintauchen, oder man cultivirt die Untersuchungsobjecte in kleinen Thoncylindern in Sägespänen. Ihr weiteres Wachsthum erfolgt bei langsamer Drehung des Klinostaten unter einer Glasglocke, und bei den mikroskopischen Messungen dienen scharfe Ecken oder Kanten der aufgetragenen Tuschestriche als Distanzmarken.

1) Besser ist es noch, einige Sporangien in sterilisirtes Wasser zu bringen, in welchem sie alsbald platzen und ihre Sporen entlassen, um dann das Brot mit einigen Tropfen der sporenhaltigen Flüssigkeit zu inficiren. 


\section{Die grosse Wachsthumsperiode.}

Es ist eine Thatsache von fundamentaler physiologischer Bedeutung, dass alle wachsenden Pflanzentheile (Wurzeln, Stengel, Blätter etc.) selbst bei constant bleibenden äusseren Bedingungen in auf einander folgenden gleichen Zeitabschnitten nicht die nämlichen Zuwachse erfahren. Jeder Pflanzentheil wächst im Beginn seiner Entwickelung langsam; allmählich wird das Wachsthum lebhafter, erreicht ein Maximum der Geschwindigkeit, un dann wieder langsamer zu werden und schliesslich völlig zu erlöschen. Will man sich zunächst ganz im Allgemeinen über diese Thatsache unterrichten, so genügt es, einige Erbsensamen nach den Anquellen in eine Krystallisirschale zu legen, welche nur so viel Wasser enthält, dass die Samen halb von demselben bedeckt sind. Oder man befestigt den eben angekeimten Samen einer Erbse oder Bohne mit Hülfe von Watte in der Bohrung eines Korkes, der ein mit Wasser angefülltes Glasgefäss̀ verschliesst, so dass die Wurzel in die Flüssigkeit hineinwächst. Die Keimung der Samen erfolgt im Dunkeln bei möglichst constanter Temperatur (etwa $20^{\circ} \mathrm{C}$.), und man stellt täglich $\mathrm{zu}$ bestimmter Stunde die Länge der Keimwurzeln fest. Es ergiebt sich, dass die Zuwachsgrösse jeder Wurzel zunächst relativ gering ist, allmählich beträchtlicher wird, früher oder später (bei meinen Versuchen, die bei $16^{\circ} \mathrm{C}$. ausgeführt wurden, am 9. Tage) ein Maximum erreicht, um dann wieder geringfügiger $\mathrm{zu}$ werden.

Wir quellen schön ausgebildete Samen von Pisum, Phaseolus oder Vicia Faba 24 Stunden lang in Wasser ein. Die Samen werden dann in feuchte Sägespäne eingelegt, die vorher jedesmal zwischen den flachen Händen gerieben und $\mathrm{zu}$ einem möglichst lockeren Keimbett in grossen Holzkästen oder Blumentöpfen angehäuft waren. Es ist hierbei darauf zu achten, dass die austretenden Wurzeln keine Krümmungen zu machen brauchen, um senkrecht nach abwärts wachsen zu können. Die Viciasamen legen wir derartig in die Sägespäne, dass ihre Mikropyle nach abwärts gerichtet ist. Den Phaseolussamen ertheilen wir eine horizontale Lage, so dass die austretende Hauptwurzel eimen rechten Winkel mit der Längsachse des Samens bildet. Haben die Wurzeln eine Länge von $1,5-2 \mathrm{~cm}$ erreicht, so werden die Keimlinge aus dem Keimbett herausgenommen, sorgfältig abgewaschen, mit einem Stück weicher Leinwand abgetrocknet und mit Marken verschen. Man benutzt beste schwarze chinesische Tusche, die man mit etwas Wasser auf einer Porzellanplatte angerieben hat und mit Hülfe eines Marderpinsels in Form feiner Striche auf die Untersuchungsobjecte aufträgt. Die Entfernung der einzelnen Marken von einander kann je nach Unständen 1, 1,5 oder 2 mm betragen. Der erste Strich wird also 1, 1,5 oder $2 \mathrm{~mm}$ entfernt vom Vegetationspunkt der Wurzel aufgetragen ${ }^{1}$ ), der $\mathrm{z}$ weite 1, 1,5 oder $2 \mathrm{~mm}$ entfernt vom ersten etc. Am besten ist es, $1 \mathrm{~mm}$ Entfernung $\mathrm{zu}$ wällen. Um das Auftragen bequem und mit Ruhe vornehmen zu können, benutzt man eine etwa 2 cin dicke Korkplatte, an deren linkem Rande mittelst einer runden Feile verschiedene grosse Kerben eingefeilt worden sind; von jeder

1) Den Vegetationspunkt sieht man freilich nur undeutlich durchschimmern er liegt ca. 0,2-0,5 mm entfernt ron der Wurzclspitze. 
derselben gehen auf der Oberfläche des Korkes einige mit dünner runder Feile gemachte Rinnen nach verschiedenen Richtungen aus. Man probirt nun, in welche Kerbe sich der Same mit einiger Reibung so einschieben lässt, dass er festhält und seine Wurzel zugleich in eine der Rinnen zu liegen kommt. Neben diese legt man eine Millimetertheilung derartig hin, dass man die mit

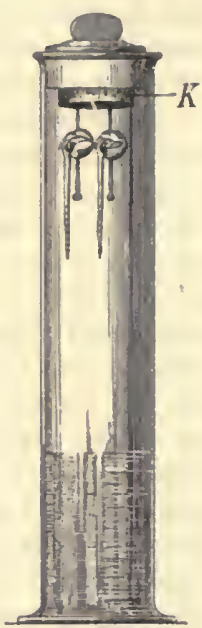

Fig. 126. Glaseylinder zur Cultur von Keimpflanzen. dem Pinsel aufzutragenden Striche als Verlängerungen der Theilstriche des Maassstabes ziehen kann. Die Keimpflanzen, deren Wurzeln markirt worden sind, werden nun in der Weise, wie es Fig. 126 zeigt, mit Hülfe von langen Stecknadeln in Glascylindern befestigt. Ich benutzte Cylinder von etwa $30 \mathrm{~cm}$ Höhe und $7-8 \mathrm{~cm}$ Durchmesser oder auch, was vorzuziehen ist, weit grössere Gefässe. Die mit Hülfe von Siegellack an die untere Fläche des Glasstöpsels festgekittete Korkplatte $K$, welche man mit Wasser durchtränkt hat, dient zur Aufnahme der Nadelspitzen. Der Boden jedes Cylinders wird mit einer Wasserschicht bedeckt. so dass die Wurzeln von feuchter Luft umgeben sind. Wenn es erforderlich scheint, kann man die Wurzeln auch noch ab und an mit etwas Wasser bespritzen oder die Wände im Innern des Cylinders mit feuchtem Fliesspapier belegen. Man stellt die Cylinder ins Dunkle und setzt die Keimpflanzen möglichst constanten Temperaturverhältnissen (z. B. $20^{\circ}$ C.) aus. In den Cylindern kann man die Wurzeln auch in Wasser wachsen lassen. Man befestigt die Keimlinge an recht langen Nadeln und lässt die Wurzeln, aber nicht die Reservestoffbehälter, in die Flüssigkeit eintauchen, mit der die ca. 3 Liter fassenden Gefässe bis zur Hälfte angefüllt sind.

Nach Verlauf von 12 oder 24 Stunden wird man leicht durch Messung feststellen können, dass das Wachsthum in der jüngsten, dem Vegetationspunkte der Wurzeln nächsten Partialzone kein übermässig ausgiebiges gewesen ist. In der nächsten Zone hat sich schon ein energischeres Wachsthum geltend gemacht. Eine der folgenden Zonen ist diejenige, in welcher das Wachsthum am lebhaftesten vor sich gegangen ist. Es folgen dann Zonen, in denen wieder langsameres Wachsthum constatirt werden kann, und die ältesten Theile der Wurzeln haben gar keinen Zuwachs mehr

Fig. 127. Links Erbsenkeimling, auf dessen Wurzel Tuschemarken aufgetragen worden sind. Rechts derselbe Keimling, nachdem die Wurzel einige Zeit gerrachsen ist. erfahren. Vergl. Fig. 127. Die älteren Partialzonen der Wurzeln haben das Stadium stärksten Wachsthums schon hinter sich; die jüngsten sind noch nicht in dieses Stadium eingetreten. Jede Querzone eines Pflanzentheils wächst aber, ebenso wie jedes Organ in seiner Gesammtheit, zuerst langsam, dann schneller, erreicht ein Maximum der Wachsthumsgeschwindigkeit, um schliesslich wieder langsamer zu wachsen. Daher findet man auch, 
dass die jüngsten Querzonen einer Wurzel, welche z. B. im Verlaufe von 12 Stunden nicht sehr stark gewachsen sind, in den folgenden 12 Stunden schon lebhafter wachsen. $\mathrm{Zu}$ einer bestimmten Zeit liegt natürlich in diesen Zonen das Maximum des Wachsthums, aber später nimmt die Wachsthumsgeschwindigkeit dann wieder ab. Es ist überhaupt lehrreich, das Wachsthum der Partialzonen einer Wurzel während längerer Zeit zu beobachten und $a b$ und an (aber in relativ kurzen Zwischenräumen von 6-10 Stunden) die Zuwachse festzustellen. Eine Sehwierigkeit, die aber nicht unüberwindlieh ist, liegt hierbei in dem Umstande, dass die auf die Wurzeln aufgetragenen Tuschestriche in Folge des Wachsthums auseinandergezogen werden ${ }^{1}$ ).

Bei den Untersuchungen über das Wurzelwachsthum wird dem Beobachter die beachtenswerthe Thatsache nicht entgehen, dass die Länge der wachsenden Wurzelstrecke, d. h. die Länge der ursprünglich markirten Strecke, in der nach Verlauf einiger Zeit (z. B. 20 Stunden) iberhaupt Wachsthum stattgefunden hat, stets recht gering ist. Je nach der Samenart und der Individualität der Untersuchungsobjecte ist die wachsende Wurzelregion (z. B. bei Pisum, Phaseolus etc.) nämlich nur etwa $4-8 \mathrm{~mm}$ lang. Die wachsende Region der Stengel ist im Gegensatz hierzu, wie wir sehen werden, weit länger ${ }^{2}$ ).

Wir gehen nunmehr dazu über, die grosse Wachsthumsperiode der Stengeltheile näher zu verfolgen, und es hat keine besonderen Schwierigkeiten, den allgemeinen Verlauf des Wachsthums dieser Organe festzustellen. Wir cultiviren Keimlinge von Phaseolus oder Pisum, die in lockerer Gartenerde wurzeln, bei Aussehluss des Liehts und möglichst constanten Temperaturverhältnissen. Durch einfache, von Tag zu Tag wiederholte Messungen kann man constatiren, dass die Internodien (die epicotylen oder die folgenden) zunächst langsam, dann schneller wachsen, zu einer bestimmten Zeit das Maximum der Streckungsgeschwindigkeit erkennen lassen, um dann wieder langsamer zu wachsen. Im Dunkeln wachsende Keimlinge (ich experimentirte z. B. mit Pisumptlanzen, die aus grossen Samen hervorgegangen waren) könuen unter Umständen sehr lange, aus einer ganzen Anzahl von Internorlien bestehende Stengel erzeugen. Ein Exemplar meiner Untersuchungsobjecte hatte einen Stengel von über $500 \mathrm{~mm}$ Länge gebildet, und dieser bestand aus 7 Internodien. Misst man die Länge der ausgewachsenen Internodien, so findet man, dass die ältesten relativ kur' sind; es folgen längere (bei meinen Pflanzen war das fünfte das längste), und die jüngsten Internodien sind dann wieder kürzer. Es ist eine sehr allgemein zu beobachtende Erscheinung, dass die auf einander folgenden, fertig gestreckten Internodien eines Stengels nicht die nänliche Länge besitzen, eine Thatsache, die einen einfachen Ausdruck dadurch finllet, dass wir sagen, die Wachsthumsenergie der einzelnen Stengelglieder ist aus inneren Wachsthumsursachen eine versehiedene.

Wir cultiviren lieimlinge von Phaseolus multiflorus bei Lichtabschluss in Bhmmentöpfen. Wenn die epicotylen Glieder eine Länge

1) Vgl. SAchs, Arbeiten (l. botan. Instituts in Würzburg, Bd. 1, S. 421. Zur Vermeidung von Fehlern thut man gut, jedesmal einen feinen Tuschestrich in die Mitte der Marke eimzutragen, um diesen Strich zum Ausgangspunkt für die weiteren Messungen zu nehmen. Vergleiche auch bei SAcrrs weiteres über die hier angegebenen Methoden.

2) Vgl. SAcrs, Arbeiten des botan. Instituts in Würzburg, Bd. 1, S. 413. 
von etwa $50 \mathrm{~mm}$ erreicht haben, so bringen wir auf den am kräftigsten entwickelten Stengeln eine Anzahl von Tuschestrichen als Marken in Entfernungen von 3 oder $5 \mathrm{~mm}$ an (Methode vgl. unter 147 u. 148). Die Untersuchungsobjecte bleiben im Dunkeln möglichst constanten Temperaturverhältnissen ausgesetzt. Alle 24 Stunden bestimmen wir die Grösse der Zuwachsbewegung in den einzelnen Partialzonen durch Messung. Die wachsende Region des Stengels ist im Gegensatz zu derjenigen rler Wurzeln eine sehr ausgedelinte. Ich fand $z$. B. dass eine Strecke von $35 \mathrm{~mm}$ des Phaseolusepicotyls im Wachsthum begriffen war. In der jüngsten (obersten) Partialzone ist das Wachsthum bei Beginn des Versuchs nicht sehr ausgiebig. In der folgenden schon lebhafter. In der dritten oder vierten liegt das Wachsthumsmaximum, in den folgenden nimmt die Wachsthumsgeschwindigkeit wieder ab. Setzt man die Beobachtungen längere Zeit hindurch fort, so erlischt das Wachsthum alsbald in den älteren Partialzonen, während das Wachsthumsmaximum nicht mehr in der dritten oder vierten Zone, sondern in einer jüngeren liegt. Später nimmt auch in diesen letzteren Partialzonen die Wachsthumsgeschwindigkeit $\mathrm{ab}^{1}$ ).

Will man das Vorhandensein der grossen Periode bei dem Wachsthum der Blätter constatiren, so cultivirt man Kürbis- oder Tabakpflanzen in grossen Blumentöpfen und stellt dieselben, wenn sich einige Blätter entfaltet haben, unter grosse Glasglocken in einen Raum von möglichst constanter Temperatur, z. B. in ein nach Norden gelegenes Zimmer. Die Untersuchungsobjecte bleiben dem Licht ausgesetzt. Nahe der Basis der iSpreite einiger junger Blätter hat man mit Hülfe von 'Tusche Punkte als Marken aufgetragen. Man misst täglich mit Hülfe eines Millimetermaass'stabes die Entfernung zwischen dem Punkte an der Basis eines Blattes und der Blattspitze. Die Temperaturverhältnisse sind natürlich stets genau zu notiren. Als ich im Mai und Juni das Längeuwachsthum im Freien wachsender Blätter von Aristolochia Sipho verfolgte, trat zunächst bei ziemlich constant bleibender Temperatur das Phänomen der grossen Wachsthumsperiode deutlich hervor. Der Zuwachs betrug in je 24 Stunden zunächst nur 5, dann 7, fernerhin $10 \mathrm{~mm}$. Später machten sich in Folge bedeutender Temperaturschwankungen grosse Unregelmässigkeiten im Blattwachsthum geltend, aber es ist dennoch lehrreich, derartige Beobachtungen zu wiederholen, weil sie uns zeigen, wie wichtig es bei dem Studium der grossen Wachsthumsperiode der Pflanzentheile erscheint, die äusseren das Wachsthum beeinflussenden Momente keinen Augenblick unberücksichtigt zu lassen ${ }^{2}$ ).

Handelt es sich darum, die Ursachen der grossen Wachsthumsperiode ganzer Organe festzustellen, so hat man, wie ich in meinem Lehrbuch der Pflanzenphysiologie S. 249 hervorhob, namentlich die Frage nach den Ursachen der im Laufe der Entwickelung sich verändernden Wachsthumsgeschwindigkeit einzelner Partialzonen der Pflanzentheile zu beantworten. Dies ist, soweit es heute möglich erscheint, unter 147 geschehen, so dass wir hier auf die bezïglichen Angaben verweisen muissen. Bei Beginn des Wachsthums eines ganzen Organs summiren sich anfangs nur wenige und geringe Partialzuwachse, später mehr und grössere, bis endlich die Partialzuwachse wieder unbedeutender werden.

1) Vgl. SAchis, Arbeiten des botanischen Institnts in Würzburg, Bd. 1, S. 99, und WonTMAXx, Botan. Zeitung, 1882.

2) Tgl. Praxts, Arbeiten d. botan. Instituts in Würzburg, Bd. 1, S. 371. 


\section{Die Wachsthumsgesehwindigkeit und Wachsthumsenergie.}

Die tägliche Erfahrung lehrt, dass die Wachsthumsgeschwindigkeit der Pflanzen eine ibberaus verschiedenartige ist. Selbst die einzelnen Individuen einer und derselben Pflanzenspecies lassen unter gleichen äusseren Verhältnissen eine verschiedene Wachsthumsgeschwindigkeit erkennen. Der experimentirende Pflanzenphysiolog hat bei seinen Untersuchungen stets Rücksicht auf das individuell differente Verhalten seiner Untersuchungsobjecte zu nelımen, das oft den Fortgang der Beobachtungen in sehr unliebsamer Weise beeinflusst, und deshalb ist es lehrreich, einmal den folgenden Versuch anzustellen. Möglichst normal und gleichartig ausgebildete Erbsen, Bohnen oder Samen an-

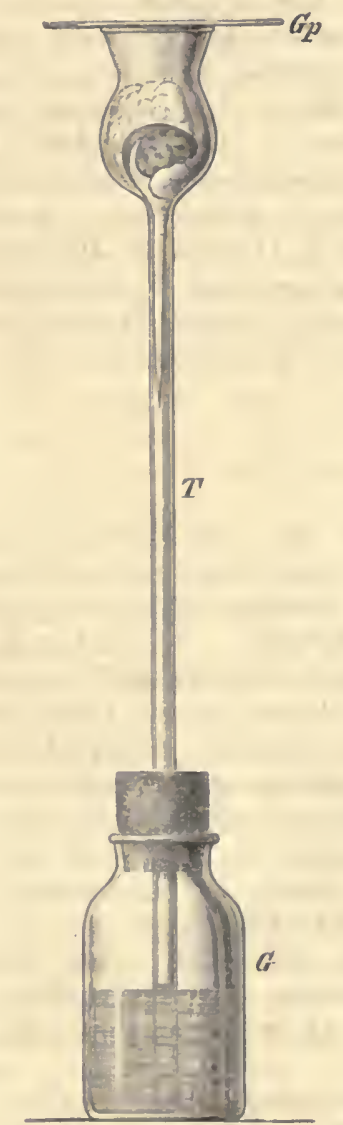

Fig. 128. Apparat \%ur Untersuchung des Wurzelwachsthums. derer Pflanzen werden in grösserer Anzahl in feuchten Sägespänen zum Keimen gebracht. Genaue Messungen der Wurzeln, Stengeltheile sowie Blätter, die man nach Verlauf einiger Zeit vornimmt, lehren, dass die Wachsthumsgeschwindigkeit der einzelnen Organe bei verschiedenen Individuen derselben Species, trotzdem sämmtliche sich unter dem Einfluss genau der, nämlichen äusseren Bedingungen entwickelten, keineswegs die gleiche gewesen ist. Das individuell oft sehr verschiedene Verhalten der einzelnen Untersuchungsobjecte tritt bei derartigen Beobachtungen deutlich hervor.

Unter gleichen äusseren Umständen besitzen aber auch die gleichnamigen Organe verschiedener Pflanzenspecies eine specifisch verschiedene Wachsthumsgeschwindigkeit. Die Stengel und Blätter von Aristolochia Sipho und Humulus lupulus wachsen z. B. relativ schnell; die entsprechenden Organe anderer Pflanzen sehr langsaln. Sehr schnell wachsen ferner z. B. die Stengel von Polygonum Sieboldi, und ich fand \%. B., dass ein Trieb dieser Pflanze, der am 3. Mai $60 \mathrm{~cm}$ Höhe besass, nach 24 Stunden bei warmer, feuchter Witterung ('Temperatur Abends um 11 Uhr noch $15^{\circ}$ C.) eine Höhe von $71 \mathrm{~cm}$ erreicht hatto.

Die Wachsthumsenergie ist eine Function der Wachsthumsdauer und Wachsthumsgesclıwindigkeit. Es ist selbst die Wachsthumsenergie, also der schliesslich erlangte Zuwachs, der einzelnen Internodien eines Stengels nicht die gleiche. Entwickelu sich Erbsenkeimpflanzen z. B. einige Wochen im Dunkeln, und bestimmt man die Länge der einzclnen Internodien, wenn das Stengelwachsthum völlig erloschen ist, so ergiebt sich, dass die unteren Internodien kurz, die mittleren lang, die oberen wieder kürzer sind "). 
Von Interesse ist es ferner, sich davon zu überzeugen, dass es möglich ist, den Zuwachs, welchen Pflanzentheile in kurzer Zeit (z. B. 20 Minuten) erfahren, festzustellen. Auf die bei genauen Beohachtungen in Anwendung zu bringende Methode ist schon unter 153 aufmerksam gemacht worden. Hier folgt ein Demonstrationsversuch. Ein Trichterrohr (Fig. $128 \mathrm{~T}$ ) wird mit seinem unteren Ende durch die Bohrung eines Kautschukkorkes geschoben, welcher ein kleines, etwas Wasser enthaltendes Glas $G$ verschliesst. In den oberen, erweiterten Theil des Trichterrohres bringt man einen in feuchten' Sägespänen angekeimten Samen von Pisum oder Phaseolus und breitet etwas nasse Watte über demselben aus. Die obere Oeffnung des Trichterrohres wird durch die kleine Glasplatte $G p$ verschlossen. Die Keimwurzel wächst in der feuchten Luft, welche sie umgiebt, ganz gut; sie verlängert sich beträchtlich. Wir stellen unseren Apparat nun auf einen Klinostaten (der Apparat ist weiter unten beschrieben und abgebildet), dessen Axe senkrecht gerichtet ist, und versetzen die Keimpflanze, um jede heliotropische Krümmung der Wurzel auszuschliessen, in langsame Rotation. Bevor der Klinostat in Gang gebracht wird, haben wir die Wurzelspitze in das Gesichtsfeld eines mit Hülfe eines geeigneten Stativs horizontal gerichteten Mikroskops eingestellt. Wir benutzen natürlich nur schwache Vergrösserung. Jetzt wird der Klinostat in Rotation versetzt, und wenn z. B. nach 20 Minuten die Wurzel wieder im Gesichtsfeld des Mikroskops erscheint, so lässt sich constatiren, zumal dann, wenn der Versuch bei relativ hoher Temperatur $\left(20-25^{\circ}\right.$ C.) angestellt wird, dass der Pflanzentheil gewachsen ist.

\section{Die Torsionen.}

Torsionen sind häufig an Internodien und auch an Blättern zu beobachten. Schöne Torsionen lassen zumal ältere Internodien windender Stengel, worauf an anderer Stelle zurückgekommen werden soll, sowie im Dunkeln erwachsene Ptlanzen erkennen. So sind \%. B. lie bei Lichtabschluss zur Ausbildung gelangten Blïthenschäfte von Hyacinthus orientalis häufig stark tordirt und ebenso die im Dunkelı erwachsenen hypocotylen Glieder von Helianthus annuıs, während die entsprechenden Organe der unter normalen Verhältnissen 'erwachsenen Keimlinge dieser Pflanzenspecies keine Torsionen zeigen. Werden Samen von Helianthus annuus in feuchten Sägespänen ausgelegt, und die Untersuchungsobjecte theils in Finstern, theils bei Lichtzutritt cultivirt, so kann man sich leicht von der Thatsächlichkeit der erwähnten Verhältnisse überzeugen. Es ergiebt sich auch, dass die 'Torsionen an den etiolirten hypocotylen Gliedern der Helianthuskeimpflanzen erst gegen Ende des Längenwachsthums derselben zum Vorschein kommen.

Viele Torsionen sind Folge innerer Wachsthumsursachen. Andere, von denen hier gleich die Rede sein mag, entstehen auf ganz anderem Wege. Der Stengel einer kräftigen, in einem Blumentopf erwachsenc.. Kürbispflanze wird derartig an einen Stab angebunden, dass or keine Krümmungen ausführen kann. Auf die Oberseite einiger Blattstiele und die Mittelrippen ihrer Spreiten werden mit Tusche eine Anzahl Punkte, die in einer Linie liegen, aufgetragen, um das vorbereitete Untersuchungsobject jetzt, nachdem der Erdballen in Topfe durch Sperrhölzchen befestigt worden ist, in umgekehrter Lage im Finstern aufzustellen. Aus 
verschiedenen Ursachen (Geotropismus, photoepinastische Nachwirkungen) tritt im Laufe einiger Stunden eine nach aufwärts gerichtete Krümmung der Blattstiele ein, aber da die Last der von den Stielen getragenen Spreiten fast niemals gleichnässig zu beiden Seiten der Krümmungsebene vertheilt ist, so kommen Torsionen zu Stande, deren Ausdehnung leicht beurtheilt werden kann, wenn man die nun nicht mehr in gerader Linie stelenden Tuschemarken ins Auge fasst. Diese Torsionen können durch Wachsthumsvorgänge zu bleibenden werden ${ }^{1}$ ).

\section{5\%. Elnige spontane Nutationserscheinungen.}

Wir legen einige angequollene Samen von Vicia Faba mit nach abwärts gewandter Mikropyle in lockere, feuchte Sägespäne. Untersuchen wir unsere Keimpflanzen genauer, wenn der Keimstengel soeben beginnt, zwischen den Cotyledonen herauszutreten, so finden wir, dass sie gerade, senkrecht nach abwärts gerichtete Wurzeln besitzen. Wir befestigen nun einige Viciakeimlinge mit Hülfe von Nadeln in einem Recipienten und sorgen für Lichtabschluss. Nach Verlauf von 24 Stunden constatiren wir, dass die Wurzeln ihre ursprïngliche senkrechte Richtung verlassen haben. Die Wurzeln sind in der Weise gekrïmmt, wie es Fig. 129 darstellt, eine Erscheinung, die wesentlich durch eine im lyppocotylen Gliede und oberen Wurzeltheile stattindende Krïmmung hervorgerufen wird. Das fortwaclisende Wurzelende kommt natïrlich in Folge der eingetretenen Nutation schief gegen die Verticale zu liegen und sucht sich daher vermöge seiner geotropischen Reizbarkeit in einem Bogen nach abwärts zu wenden. Aehnlich wie die Keimpflanzen von Vicia verhalten sich in der in Rede stehenden Hinsicht diejenigen verschiedener anderer Papilionaceen,

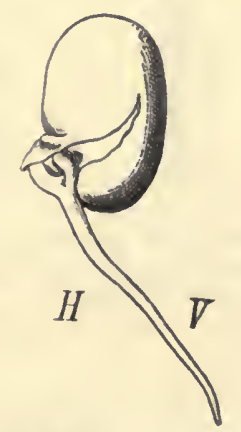

Fig. 129. Keinpflanze von Vicia Faba. und es ist noch zu bemerken, lass die Wurzeln die erwähnte Nutation nicht nur in feuchter Luft, sondern auch, obgleich in schwächerem Grade, ausführen, wenn sie sich in lockerer Erde oder Sägespänen entwickeln. Bezeichnet man bei den Keimpflanzen der Papilionaceen diejenige Seite als hintere (vergl. Fig. $129 H$ ), auf welcher die Convexität des Keimstengels liegt, die entgegengesetzte, nach welcher sich unsere Wurzeln stets hinwenden, als vordere $(V)$, so fällt die Medianebene der Keimpflanzen genau mit derjenigen Ebene zusammen, in der sich die beiden Cotyledonen beriihren. Die Thatsache, dass die aus der Nutation des Hypocotyls und der Wurzelbasis resultirenden W'urzelkrümmungen stets in den Medianebenen der Keimlinge erfolgen, ist bei Untersuchungen über das Verlalten der Wurzeln in horizontaler Iage aus leicht verständlichen Gründen wohl zu beachten. Man muss den Viciakeimlingen 7. B. auf einer horizontalen Unterlage eine solche Stellung geben, dass sie dieser Unterlage mit ihrer rechten

1) Vgl. H. DE VRIEs, Arbeiten d. botan. Instituts in Würzburg, Bd. 1, S. 268, und SAcus, Lehrbuch i. Botanik, 1874, S. 833. 
oder linken Flanke, also mit der Aussenfläche einer ihrer Cotyledonen, aufliegen ").

Interessante Nutationserscheinungen sind ferner an den ersten Stengelgliedern vieler Dicotyledonen $\mathrm{zu}$ beobachten, und wir wollen uns etwas genauer mit denselben bekannt machen, indem wir Phaseolus multiflorus als Untersuchungsobject wählen. Wenn wir einen im Wasser zur Quellung gebrachten Samen durchschneiden, so beobachten wir an der Spitze des zwischen den Cotyledonen liegenden Stengeltheiles des Embryo eine ziemlich starke Krümmung. Bei der Keimung der Samen wird diese Krümmung noch erheblicher, so dass die Endknospe in völlig nickendem Zustande aus dem Boden hervortritt. Die

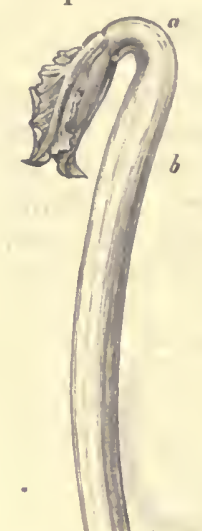

Fig. 130. Keimpflanze von Phaseolus multiflorus, oberer Theil derselben. Convexität der Krümmung liegt auf der von den Cotyledonen abgewandten, also hinteren Seite des Epicotyls, und die Nutationserscheinung kommt durch ein beschleunigtes Wachsthum eben dieser hinteren Seite zu Stande. (Vergl. Fig. 130. Bei a liegt die Convexität der Krümmung). Entwickeln sich unsere Phaseoluspflanzen dauernd im Finstern, so bleibt die Nutation am oberen Ende des Keimstengels lange bestehen; nur in den letzten Keimungsstadien richtet sich die Endknospe senkrecht empor. Dies geschieht dagegen sehr schnell, wenn man junge Keimlinge, deren Endknospe z. B. eben den Boden durchbrochen hat, dem Einfluss hellen diffusen Tageslichts aussetzt. Die Krümmung des Epicotyls gleicht sich dlann alsbald völlig aus.

Wenn man an derjenigen Stelle eines nutirenden Epicotyls von Phaseolns, welche die stärkste Krïmmung zeigt (Fig. 130 bei $a$ ), einen Tuschestrich als Marke anbringt, so findet man diese Marke nach -24 oder 48 Stunden, während welcher Zeit das Untersuchungsobject natürlich im Dunkeln verweilen muss, bei $b$ wieder. Daraus erhellt, dass die ursprünglich nutirenden Theile des Epicotyls sich in Folge ihres Wachsthums alluählich gerade strecken. Die Nutation geht aber anf die neu entstandenen Stengeltheile ïber. Es zeigt sich aher bei genauerer Betrachtung der Marken auch oft, dass die Ebene, in 'ler die Nutation erfolgt, nicht immer die nämliche ist. Uebrigens muss die Nutation als eine durchaus spontane angesehen werden. Sie tritt auch ein, wenn die Keimlinge im Dunkeln langsam um eine horizontale Achse rotiren. Näheres vergl. im Abschnitt ïber Experimente mit dem Klinostaten.

Der Winkel, welcher von dem nutirenden Theile des Phaseolusepicotyls gebildet wird, beträgt gewöhnlich $1,80^{\circ}$, d. h. also die Endknospe des aufwärts wachsenden Stengels ist senkrecht abwärts gerichtet. Bei genauerer Beobachtung zumal recht lebhaft wachsender Phaseoluskeimlinge findet man aber, lass jener Winkel nicht immer derselbe bleibt. Ist er an einem Tage $=180^{\circ}$, so kann er am folgenden z. B. $=90^{\circ}$, am dritten $=145^{\circ}$ sein $^{*}$ ).

Spontane Nutationen zeigen die meisten Pflanzentheile, wie es scheint, sehr allgemein. Hierher gehören auch die Circumnutationen

1) Vyl. Sacus, Arbeiten d. botan, Instituts in Würzburg, 13d. 1, S. 402.

2) Vgl. Wortuaxx, Botan. \%citung, 1S82, No. 52. 
vieler Keimlinge '), und wenn man z. B. Haferkeimlinge im Dunkeln cultivirt, so kann man durch oft (z. B. jede Viertelstunde) wiederholte Beobachtungen feststellen, dass die Spitze der ca. $1-2 \mathrm{~cm}$ langen Plumula der Untersuchungsobjecte in einer mehr oder minder kreisförmigen Bahn in Raum herumgeführt wird. Uebrigens gehe ich nicht näher auf die Circumnutation ein, da der ganze Gegenstand einer eingehenden kritischen weiteren Untersuchung bedarf. Zumal ist bei den Arbeiten der Einfluss äusserer Verhältnisse auf die Bewegung der Organe mehr als seither zu beachten.

\section{Die nothwendigen Wachsthumsbedingungen und die Beeinflussung der Zuwachsbewegung durch äussere Verhältnisse.}

\section{Das Stoffbediirfniss wachsender Pflanzentheile.}

Das Wachsthum eines Pflanzentheils kann nur dann in normaler Weise erfolgen, wenn die erforderlichen Stoffe und Kräfte für las Wachsthum del einzelnen Zellen disponibel sind. Entwickeln sich \%. B. Keimlinge bei völligem Lichtabschluss, so hört das Wachsthum der Keimtheile auf, wenn ler Reservestoffvorrath der Samen erschöpft ist. Es ist lehrreich, sich etwas specieller über die Beziehungen zwischen der Energie, mit der das Wachsthum erfolgt, und dem Vorrath an Reservestoffen zu unterrichten. Zu dem Zweck pflanzen wir Samen von Phaseolus multiflorus in Gartenerde ein, die sich in Blumentöpfen befindet. Ein Topf wird mit möglichst grossen Samen beschickt; ein zweiter mit ebensolchen, von denen wir aber, wenn die Keimung eben begonnen liat und die Hauptwurzel aus der Samenschale hervorgebrochen ist, je einen der beiden Cotyledonen entfernen. In einen dritten Topf säen wir kleine Phaseolussamen ein. Die Keimung erfolgt in Dunkeln oder bei Lichtzutritt. Wir finden, dass sich die aus grossen Samen erwachsenden Pflanzen kräfticrer entwickeln als diejenigen, welche aus den kleinen oder jenen hervorgehen, von welchen wir einen der Cotyledonen abgeschnitten haben. Bei meinen Versuchen, die bei Lichtzutritt ausgeführt wurden, zeigten sich zunächst keine sehr auffallenden Differenzen im Aussehen der Untersuchungsobjecte. Dies trat erst ein, als sich das erste gedreite Blatt entfaltet hatte, und das dritte Internodium in lebhafter Streckung begriffen war. Dic aus grossen Samen hervorgegangenen Pflanzen besassen erheblich grössere Blätter und längere Internodien als jene, welche sich aus kleinen oder eines ihrer Cotyledonen beraubten Samen entwickelten. Messungen zur Bestimmung der Dimensionsverhältnisse der einzelnen Theile der Versuchspflanzen sind leicht vorzunehmen. Der Reservestoffyorrath der Bohnensamen ist cin sehr grosser, so dass die ersten Stadien der Keimung bei meinen Experimenten in allen Fällen norınal durchlaufen werden konnten. Später machte sich dann, trotzdem die

1) Vgl. Darwix; Bewegungsvermögen d. Pflanzen, 1881. 
assimilatorische Thätigkeit der Untersuchungsobjecte nicht ausgeschlossen war, ein wesentlicher Unterschied im Wachsthum der Pflanzen geltend, und derselbe liess sich der Hauptsache nach nur auf den mehr oder minder bedeutenden Vorrath an Reservestoffen in den Cotyledonen der Samen zurückführen.

\section{Der Wassergehalt der Pflanzen und das Wachsthım.}

Normales Wachsthum der Pflanzenzellen ist nur dann möglich, wenn dieselben hinreichende Wassermengen enthalten. Diese Thatsache ist unter Berücksichtigung verschiedener Verhältnisse leicht verständlich. Hier sei nur darauf hingewiesen, dass ein ausgiebiges Wachsthım eine energische Turgorausdehnung der Zellen zur Voraussetzung hat, welche ihrerseits nur bei reichlichem Wassergehalt der Gewebe möglich ist. Sinkt die Turgorausdehnung der Zellen, indem sie Wasser verlieren, so vermindert sich zugleich auch ihre Wachsthumsgeschwindigkeit. Wir bringen Mais-, Erbsen- oder Bohnensamen in Sägespänen zur Keimung. Haben die Wurzeln einige cm Länge erreicht. so bringen wir auf ihnen $2 \mathrm{~cm}$ entfernt von ihrer Spitze feine Tuschestriche als Marken an und befestigen die Keimpflanzen in der Weise, wie es unter 154 angegeben ist, mit Nadeln in geeigneten Glascylindern. Diese letzteren füllen wir mit verschiedenen Flüssigkeiten an; einen mit Brunnenwasser, einen zweiten mit einer 0,5-, einen dritten mit einer 1,0-, einen vierten mit einer 2,0-proc. Kalisalpeterlösung. Die Wurzeln müssen senkrecht in die Flüssigkeiten hineinragen. Nach Verlauf von 24 oder 48 Stunden stellen wir die Zuwachse, welche die Wurzeln erfahren haben, fest. Jeder einzelne Versuch wird, um \%u Mittelwerthen zu gelangen, mit 3 oder 4 Keimpflanzen durchgeführt. Es ergiebt sich, dass die Wurzeln in Contact mit Brunnenwasser am lebhaftesten wachsen. Mit zunehmender Concentration der Salpeterlösung wird ihr Wachsthum aber geringer, weil dic Salzlösungen den Zellen Wasser zu entziehen vermögen und dadurch deren Turgorausdehnung herabsetzen. In Berührung mit ziemlich concentrirten Salpeterlösungen (z. B. mit 10-proc.) wachsen die Wurzeln gar nicht. Sie verkürzen sich vielmehr, indem sie in den plasmolytischen Zustand übergehen ${ }^{1}$ ).

Merkwürdig ist. dass Pilze auch noch in Contact mit Flüssigkeiten wachsen, deren Concentration für das Wachsthum der Zellen höherer Gewächse viel zu bedeutend ist. Wir stellen eine Lösung her, die in 100 Thl. Wasser 0,4 Thl. Ammoniumnitrat, 0,2 Thl. saures phosphorsaures Kali, 0,02 Thl. schwefels. Magnesia und $0,01 \mathrm{Thl}$. Chlorcalcium enthält. Je $50 \mathrm{ccm}$ dieser Lösung gelangen in Glaskölbchen und werden mit $5 \mathrm{~g}$ (10 Proc.), $10 \mathrm{~g}$ (20 Proc.), $25 \mathrm{~g}$ (50 Proc.) Traubenzucker versetzt. Die mit Watteverschluss versehenen Kölbchen werden im Dampfapparat sterilisirt. Als Beobachtungsobject wählen wir Penicillium glaucum. Die Flüssigkeiten werden mit den Sporen dieses Pilzes inficirt und dann sämmtlich den nämlichen äusseren Bedingungen ausgesetzt. Es ergiebt sich, dass die Entwickelung des Pilzes selbst noch in der 50-proc. Zuckerlösung erfolgt; freilich wächst er in der betreffenden

1) Vgl. H. DE VRIEs, Untersuchungen ïber die mechanischen Ursachen der Zellstreckung, Halle 1877, S. 56. 
Flüssigkeit erheblich langsamer als in den übrigen. Die Ursache des Wachsthums von Zellen bei hoher Fliissigkeitsconcentration ist wohl darin zu suchen, dass diese letztere selbst als Reiz auf die Zellen einwirkt und den Stoffwechsel derselben derartig beeinflusst, dass eine hinreichende Steigerung der osmotischen Leistungsfähigkeit des Zellinhaltes erzielt wird ${ }^{1}$ ).

\section{Die Athmung und das Wachsthum.}

Es giebt, wie hereits unter 108 hervorgehoben worden ist, einige Pflanzen, die auch bei völligem Ausschluss des freien Sauerstoffes zu wachsen vermögen. Die meisten Pflanzen sind aber nur zum Wachsthum befähigt, wenn ihnen freier Sauerstoff zur Disposition steht. Diese Thatsache lässt sich leicht in folgender Weise constatiren ${ }^{2}$ ). Zwei 'retortenartige Gefässe von ca. $90 \mathrm{ccm}$ Capacität (vgl. Fig. 11) werden mit ausgekochtem und bei Luftabsćhluss wieder völlig abgekühltem, destillirtem Wasser angefüllt. In jedes Gefäss bringt man einige lufttrockene Weizenkörner oder Erbsensamen und taucht die Mündungen der Gefässe unter Quecksilber. Nach 24 Stunden, wenn die Samen gequollen sind, verdrängt man das Wasser des einen Gefässes bis auf einen 'ganz kleinen Rest durch atmosphärische Iuft, dasjenige des anderen durch reines Wasserstoffgas. Dieses entwickelt man aus arsenfreiem Zink durch Uebergiessen desselben mit verdiunnter Salzsäure und leitet es zur Befreiung von schädlichen Stoffen durch wässerige Lösungen von Kalihydrat und übermangansaurem Kali. In Contact mit rler I uft keimen die Samen alsbald; in Wasserstoff tritt keine Keimung ein. Haben die Samen keine allzu lange Zeit (etwa nur 2-3 Tage) im Wasserstoff verweilt, so keimen sie aber, wenn man sie nachtrïglich normalen Keimungsbedingungen aussetzt. Fs ist ferner lehrreich. Keimlinge (z. B. solche von Pisum), die bereits Wurzeln ron einigen cm Iẫnge besitzen, in mit luftfreiem Wasser angefüllte und durch Quecksilber abgesperrte Gefässe zu bringen, un rlas Wasser in den einen Apparat durch Luft, im anderen dlagegen durch Wasserstoff zu verdrängen. Die Wrurzeln der Keimlinge wachsen in der Luft weiter, im Wasserstoff aber gar nicht, wovon man sich leicht durch Messungen ïberzeugen kann.

Mit Huilfe der angegebenen Methode ist auch der Nachweis zu führen, dass die Keimung der Samen noch in einem recht sauerstoffarmen Gasgemisch (welches z. B. aus atmosphärischer Luft und mehr oder mincler grossen Wasserstoffquantitäten besteht) möglich ist.

Um in sehr exacter Weise den Nachweis zu führen, dass ohne Sanerstoffgegenwart höhere Pflanzen nicht wachsen, verfährt man, wie folgt. In ein Reagensglas $R$ (Fig. 131) von etwa $15 \mathrm{~mm}$ Durchmesser und ca. $60 \mathrm{ccm}$ Capacität bringt man einen in Sägespänen zur Entwickelung gekommenen Erbsenkeimling, auf dessen Wurzel je zwei Tuschestriche als Marken aufgetragen sind. Die Innenwand des Glases wird mit einigen Tropfen ausgekochten Wassers angefeuchtet. Das Glas wird mit einem vollkommen passenden, mit zwei Bohrungen versehenen Kautschukpfropfen verschlossen. Die eine Bohrung dient zur Aufnahme des Glasrohres $g$, die andere zur Aufnahme des Rohres $g^{\prime}$, dessen einer Schenkel in das Quecksilber des Gefässes $G f$

1) Vgl. Eschentragen, Finfluss von Lösungen anf das Wachsthum von Schimmelpilzen, Stolp 1888.

2) Vgl. DetMrer, Landwirthschaftl. Jahrbücher, Bd. 11, S. 225. 
eingetancht worden kann. Nun leitet man, um die Luft völlig aus dem Apparat zu verdrängen, 1-2 Stunden Wasserstoff durch den Apparat und schmilat das Rohr $g$ bei $s$ ab. Den Wasserstoff entwickelt man z. B. im Krpp'schen Apparat (vergl. unter 102) aus arsenfreiem Zink und

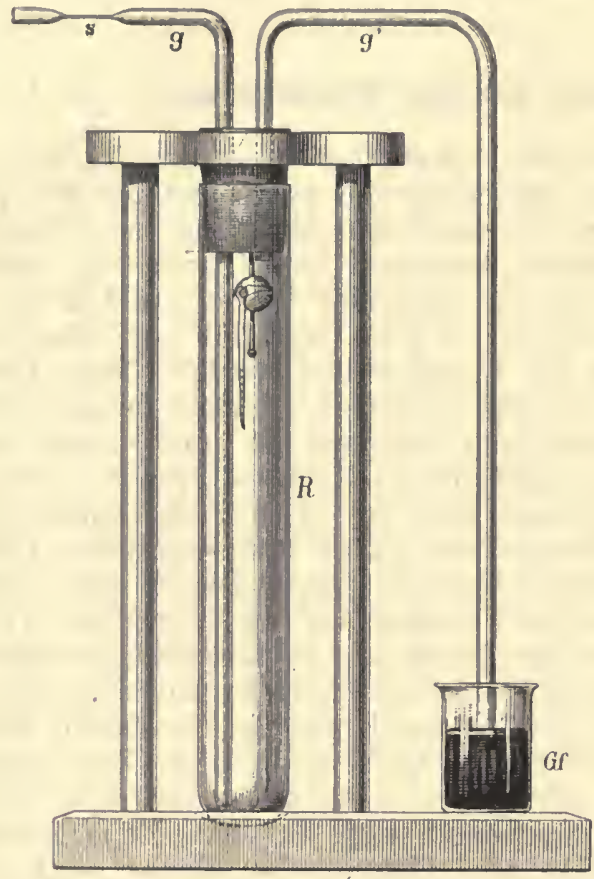

Fig. 131. Apparat zur Constatirung der Thatsache, dass Wurzelin bei Ausschluss des freien Sanerstoffs nicht zu wachsen vermögen. verdünnter Salzsäure. Zur Reinigung durchstreicht das Gas Gefässe, welche Lösungen von Kali und übermangansaurem Kali enthalten. Das Wasser, welches zur Herstellung der verdünnten Salzsäure, sowie dieser Lờsungen dient, wird zweckmässig vor dem Gebrauch ausgekocht und in verschlossenen Flaschen abgekühlt. Dass unsere Untersuchungsobjecte in der Atmosphäre des reinen Wasserstoffs nicht wachsen, lässt sich leicht constatiren, indem man die Entfernung der aufgetragenen Marken mit Hülfe des horizontalen Mikroskops (vergl. unter 153) in Intervallen von einigen Stunden misst. Oeffnet man den Apparat, so beginnt das Wachsthum der Pflanzen sogleich wieder.

Dem reinen Sauerstoff gegenüber scheinen sich die Samen verschiedener Pflanzenspecies bei der Keimung nicht gleichartig zu verhalten ${ }^{1}$ ). Ich fand, dass

Weizenkörner im reinen Sauerstoff ebenso schnell wie in atmosphärischer Luft keimen. Den erforderlichen Sanerstoff entwickelt man in einer Retorte aus einem Gemisch von chlorsaurem Kali und Braunstein, leitet ihn zur Reinigung durch Kalilauge und fängt ihn in den Gefässen, welche in der angegebenen Weise mit luftfreiem Wasser und den Samen beschickt worden sind, auf ${ }^{2}$ ).

\section{Die Beeinflussung des Wachsthums durch Druck und Dehnung.}

Aus der Theorie des Wachsthumsprocesses ergiebt sich ohne Weiteres, dass Druckkräfte, deren Wirkung auf die turgescirenden Zellen in einer Compression der gespannten Zellentheile (Hyaloplasma

1) Die ältere Literatur ist in meiner vergleichenden Physiologie d. Keimungsprocesses der Samen, 1859, S. 272, zusammengestellt.

2) Specielleres vgl. bei WIELER und JFNTYs in Untersuchungen aus dem botan. Institut zu Tüibingen, Bd. 1, S. 216 und Bd. 2. 
und Zellmembran) besteht, eine Verlangsamung des Wachsthums herbeiführen müssen. Umgekehrt wird eine Dehmung der nämlichen Zellentheile Wachsthumsbeschleunigung zur Folge haben. Ebenso sind Druckkräfte und dehnende Kräfte nicht olne Einfluss auf die Richtung des ausgiebigsten Wachsthums.

Nach den Untersuchungen von Scholtz ${ }^{1}$ ) und Hegler ${ }^{\text {*) }}$, auf die wir hier aber nicht näher eingehen, wirkt übrigens Dehnung keineswegs stets entsprechend ihrem mechanischen Aequivalent fördernd auf das Wachsthum ein, denn wenn z. B. Stengel durch eine Zugkraft beeinflusst werden, so verlangsamt sich ihr Wachsthum zunächst, um erst späterhin eine dem mechanischen Acquivalent des Zuges entsprechende Beschleunigung zu erfahren. Der Zug wirkt bei Beginn als Reizursache auf das Protoplasma ein. Man kann sich denken, dass die Zellhăute durch das gereizte Plasma Qualitätsänderungen erfahren, die ihr verlangsamtes Wachsthum zur Folge haben.

Wenn man die Gestalt der Epidermiszellen der langen Blätter vieler monocotyler Pflanzen ins Auge fasst, so findet man, dass diese Zellen sehr langgestreckt sind. Diese Erscheinung hat ihren Grund wohl wesentlich darin, dass die Epidermiszellen der erwähnten Organe durch die Gewebespannung hauptsächlich in longitudinaler Richtung gezerrt werden. Wenn wir ein kleines Epidermisstückchen des Blattes von Syringa oder anderer Dicotyledonen untersuchen, so ergiebt sich, dass die Epidermiszellen die Gestalt polygonaler Tafeln besitzen, eine Erscheinung, die sicher mit der nach zwei Richtungen hin in nahezu derselben Weise erfolgenden Flächenentwickelung der Blätter im Zusammenliang steht.

Wir stellen Querschnitte durch einen etwa $5 \mathrm{~mm}$ dicken Zwoig von Tilia parvifolia her. Das Bild, welches sich uns bei mikroskopischer Untersuchung darstellt, ist schon unter 42 beschrieben worden. An dieser Stelle hat wesentlich nur der Holzkörper der Gefässbündel für uns Interesse. Wir sehen, dass mehrere Jahresringe vorhanden sind. Das Frühlingsholz geht ganz allmählich in das Herbstholz des nämlichen Jahresringes über, während das Frïhlingshol\% des nächsten Jahresringes ganz scharf gegen das Herbstholz des vorjährigen ahgesetzt ist. Für das Frühlingsholz ist namentlich das Vorhandensein woiter Gefässe charakteristisch. Weiterhin verschwinden diese mehr und mehr. Das Herbstholz besteht nur aus englumigen Elementen.

SACHS hat schon vor längerer Zeit auf einen Zusammenhang zwischen dem verschiedenartigen Bau des Frühlings- sowie Herbstholzes einerseits und den im Laufe einer Vegetationsperiode zur Geltung kommenden Schwankungen der Intensität der Querspannung andererseits hingewiesen. Im Frühling wird die Rinde offenbar weniger gespanut als später, wenn die Holzentwickelung weitere Fortschritte gemacht hat. Im Frïhling ist daher der Druck, welchen das Holz erleidet, geringer als später, und in diesen Umständen ist vor allem die Ursache der Erscheinung zu suchen, dass die aus den Cambiumzellen bei Beginn der Vegetationsperiode entstehenden Holzelemente weitlumig sind, während ferner, zumal gegen den Herbst hin, nur englumige Elemente entstehen.

Wir wollen sehen, in welcher Weise Drucksteigerung und Druckverminderung, denen wir in die Dicke wachsende Pflanzentheile künstlich

1) Vgl. Schоцтz, Cohn's Beiträge zur Biologie der Pflanzen, Bd. 4.

2) Vgl. Hegler, ebendaselbst, Bd. 6. 
aussetzen, auf dieselben einwirken. Als Untersuchungsobjecte dienen 2-3-jährige Aeste verschiedener Sträucher oder Bäume. Druckerhölıung erzielt man, indem man Anfang April um eine einige cm lange Strecke der Aeste einen nicht zu dicken Bindfaden in einer Schraubenlinie windet. Die einzelnen Umgänge der Schraube müssen einander möglichst eng berühren, und die Ligatur wird fest angezogen. Drucksverminderung bewirkt man, indem man auf einer etwa $3 \mathrm{~cm}$ langen Strecke das Rindenund Bastgewebe 3-jähriger Aeste durch 6 radiale Einschnitte, die in gleichen Entfernungen von einander angebracht werden, spaltet. Prüft man die Untersuchungsobjecte im August, so ergiebt sich, dass der Durchmesser der Aeste unter den Ligaturen von Bindfaden ein erheblich geringerer ist, als oberhalb und unterhalb der Ligaturen, während die Druckverminderung andererseits eine nicht unwesentliche Steigerung des Dickenwachsthums an den betreffenden Versuchsstellen der Aeste hervorgerufen hat. Zu Experimenten über den Einfluss gesteigerten Druckes auf das Dickenwachsthum von Zweigen verwandte ich mit sehr gutem Erfolg Salix cinerea als Versuchspflanze. Die Ligatur wurde Anfang April angelegt und Anfang August entfernt. Die Versuchsstelle unter der Ligatur war bei Abschluss des Versuches viel dünner als die Asttheile ober- und unterhalb derselben ${ }^{1}$ ).

\section{Die Beeinflussung des Waehsthums durch dle Temperaturverhältnisse.}

Es ist eine bekannte Thatsache, dass dlas Wachsthum aller Pflanzentheile bei verschiedenen Temperaturen durchaus nicht mit rler nämlichen Geschwindigkeit verläuft. Wachsthumsvorgänge machen sich nur innerhalh bestimmter Temperaturgrenzen geltend: bei gewissen niederen und höheren Temperaturen erlischt das Wachsthum aber vollkommen, und Wärmegrade festzustellen, führen wir das folgende Experiment aus. Fin wohl entwickelter Erbsenkeimling, den wir so lange in lockeren, feuchten Sägespänen cultivirt haben, bis seine Hauptwurzel eine Länge von 3-4 cm erreicht hat, wird mit etwas fenchter Watte in den in Fig. 126 abgehildeten Apparat gebracht. Ich fand z. B.; dass die Wurzel in $\&$ Stunden bei $20^{\circ} \mathrm{C}$. einen Zuwachs von $5 \mathrm{~mm}$ erfuhr. Als ich die Vorrichtung nun 22 Stunden lang in einem ungeheizten Zimmer bei $1-2^{\circ} \mathrm{C}$. stehen liess, konnte nach Verlauf dieser Zeit kein merklicher Zuwachs festgestellt werden. Ein solcher $(10 \mathrm{~mm})$ war aber zu constatiren, naclidem der Apparat fernere 18 Stunden lang in einem Raume, in welchem eine Temperatur von $15^{\circ} \mathrm{C}$. herrschte, verweilt hatte.

Genaute Untersuchungen über den Einfluss verschiedener Wärmegrade auf rie Wachsthumsgeschwindigkeit der Pflanzen sind mit vieler Mïhe verbunden, aber trotzdem mïssen wir versuchen, uns mit den wichtigen bezüglichen Verhältnissen bekannt zu machen. Als Untersuchungsmaterial benutzen wir Keimpflanzen. Die Samen, aus denen dieselben erzogen werden sollen, müssen sorgfältig ausgewählt werden.

1) Fingehende Untersuchungen iüber jden anatomischen Bau drs Holzes das hei künstlicher Erhöhung orler Verminderung des Druckes entsteht, sind von H. I'E VRIEs ausgeführt worden. Vgl. Flora, 1872, No. 16, und 1875, No. 7. 
Wir verwenden nur gleichförmig und wohl entwickelte, völlig ausgereifte Individuen. Man wird finden, dass dieselben bei günstigen Temperaturverhältnissen (etwa $20-25^{\circ} \mathrm{C}$.) gut keimen; dagegen bemerkt man auch bald, dass die Keimfähigkeit derselben Samen bei relativ hohen oder relativ niedrigen Wärmegraden keine so vollkommene mehr ist. Die Samen (wir experimentiren mit Pisum, Phaseolus, Zea, Cucurbita etc.) werden zunächst 24 Stunden lang in Wasser gelegt, um sie in einen völlig gequollenen Zustand zu versetzen. Dann bringen wir sie in einer derartigen Lage in feuchte Sägespäne oder Gartenerde, dass die hervorbrechenden Hauptwurzeln, olne erhebliche Krümmungen ausfülıren zu müssen, gerade nach abwärts wachsen können. Die Erde ist die humusreiche Gartenerde, wie sie bei der Cultur von Gewächshausptlanzen Verwendung findet. Sie wird vor dem Gebrauch so weit angefeuchtet, dass sie sich eben noch zwischen den Händen zu einer feinkrümeligen Masse zerreiben lässt, dann durch ein Sieb mit Oeffnungen von $1,5 \mathrm{~mm}$ geworfen und in Blumentöpfe locker eingefüllt. Die in angemessener Entfernung von einander in das Keimbett eingelegten gequollenen Samen bedeckt man schliesslich mit Erde und sorgt besonders dafür, dass sämmtliche Untersuchungsobjecte möglichst genau die nämliche Tieflage erhalten. Jeder Blumentopf wird mit einem Thermometer versehen, welches die Temperatur derjenigen Bodenschicht anzeigt, in der die keimenden Samen ruhen. Auch auf Ersatz des verdunsteten Wassers ist zu achten. Die Gefässe, in denen die Samen zum Quellen gebracht werden, müssen von Anfang an ebenso wie auch die mit den gequollenen Samen beschickten Blumentöpfe denjenigen Temperaturverhältnissen exponirt werden, deren Einwirkung auf das Wachsthum wir zu constatiren wïnschen. Wollen wir bei 'Temperaturen von 25, 30, 35, 40 ader' $45^{\circ} \mathrm{C}$. experimentiren, so sind wir gezwungen, die Culturgefïsse in Thermostaten $\%$ stellen, in denen die gewünschte 'Temperatur constant erhalten werden kann. Wir benutzen z. B. den in Fig. 76 abgebildeten Apparat. Beobachtungen bei $5,10,15,20^{\circ} \mathrm{C}$. wird man oft an zweckmässigsten ohne Thermostaten in geeigneten, ungeheizten oder durch gute Reguliröfen erwärmten Localitäten (im Sommer \%. B. in nach Norden gelegenen Zimmern oder in Kellerı) ausführen. Es dürfen aber im Lanfe von 24 Stunden lieine irgendwie erheblichen Temperaturschwankungen vorkommen; darauf ist besonders zu achten, und es muss der 'Temperaturzustand des Mediums, in welehem die keimenden Samen-liegen, daher täiglich mehrfach controlirt werden.

Dasselbe muss natürlich auch bei Benutzung von Thermostaten geschehen. Die Resultate aller 'Temperaturablesungen sind zu notiren, um das Temperaturmittel berechnen zu kïnnen.

.. Jeder Versuch wird iiber $49-7 \%$ Stmuden oder über eine noch längere Zeit ausgelehnt. Fr beginnt mit dem Momente des Einquellens der Samen. Nach Verlauf der angegebenen Zeit nimmt man die Keimpflanzen aus dem Boden heraus, bestimmt durch Messung die Länge ihrer Wurzeln und gewinnt auf diesem Wege Zahlen, aus denen sich leicht ein Mittelwerth für die Länge, welche eine Wurzel in Laufe bestimmter Zeit bei bestinmtel 'I'emperatur erreicht hat, ableiten lässt. Bei $25^{\circ} \mathrm{C}$. kann z. B. die Haujtwurzel von Zea Mays in 48 Stunden eine Länge voll $30 \mathrm{~mm}$ erreichen. Bei $: 34^{\circ} \mathrm{C}$. kann in 48 Stunden eine Wurzellänge von über 50 mu erzielt werden, während eine 'Temperatur von $42^{\circ} \mathrm{C}$. das Wachsthum der Wurzel von Zea be- 
deutend beeinträchtigt. Auch bei einer Temperatur von $15^{\circ} \mathrm{C}$. wächst die Wurzel nur langsam und erreicht daher selbst in 96 Stunden noch keine erhebliche Länge.

Das Wachsthum der Pflanzenzellen beginnt bei einer gewissen niedrigen Temperatur (dem Temperaturminimum), es nimmt bis zu einem bestimmten Temperaturgrade (dem 'Temperaturoptimum) an Geschwindigkeit $\mathrm{zu}$, um mit noch mehr steigender Temperatur wieder langsamer zu werden. Den höchsten Temperaturgrad, bei dem überhaupt noch Wachsthum stattfindet, bezeichnet man als Temperaturmaximum. Die Lage der Temperaturminima, -Optima und -Maxima ist für das Wachsthum verschiedener Pflanzentheile übrigens nicht die gleiche, eine Thatsache, die sich z. B. mit Bezug auf das Temperaturminimum auch darin ausprägt, wie unschwer festzustellen ist, dass manche Samen bei Temperaturen noch gar nicht keimen, durch welche die Evolution der Keimtheile anderer Samen bereits ermöglicht wird. Die Samen von Cucurbita keimen selbst im Verlauf langer Zeit bei $10^{\circ} \mathrm{C}$. nicht, während die Weizenkörner sowie die Samen von Phaseolus multiflorus bei dieser Temperatur keimen können ${ }^{1}$ ).

In der folgenden Tabelle ist die Lage der Cardinalpunkte für die Keimungstemperatur einiger Samen angegeben:

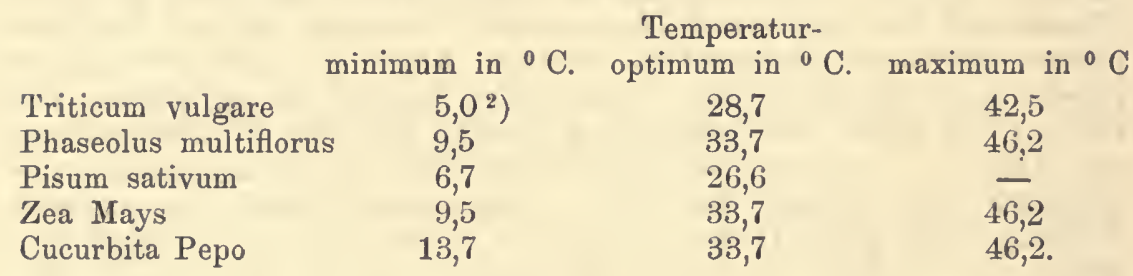

\section{Die Jahresperiode der Pflanzen.}

Bei zahlreichen Gewächsen wird der allgemeine Gang ilırer Entwickelung durch Ruheperioden unterbrochen, denen ihre Organe zu bestimmten Zeiten unterliegen. Die meisten bei uns einheimischen Bäume und Sträucher werfen ja in Herbst ihre Blätter ab, und die vorgebildeten Knospen überdauern den Winter in einem Ruhezustande, un sich erst im nä̈chsten Frühjahre zu entfalten. Ohne Zweifel haben wir es hier mit einem ursprünglich durch den Wechsel der Jahreszeiten inducirten Phänomen zu thun, das aber in derjenigen Form, in welcher es uns heute entgegentritt, keineswegs mehr eine unmittelbare Abhängigkeit von äusseren Factoren erkennen lässt. Wenn nämlich auf ein Pflanzenindividuum oder auf Generationen von Individuen stets dieselben äusseren Umstände in einem bestimmten Wechsel einwirken, so erlangen die Pflanzen dadurch in Folge von Nachwirkungen specifische Eigenschaften, die sogar erblich werden können, und diese Eigenschaften erscheinen dann oft in einem so hohen Grade fixirt,

1) Literatur: SACIIS, in Prixgshims's Jahrbüchern f. wissensehaftl. Botanik, Bd. 2 ; FR. HABERI ANIT in wissensehaftl.-praktischen Untersuehungen auf dem Gebiete des Pflanzenbaues, und Dermer, Vergleichende Physiologie des lieimungsprocesses der Samen, 1880. tiefer.

2) Die Temperaturminima liegen im Allgemeinen nach neneren Untersuchungen 
dass sie es in erster Linie sind, welche das gesammte Verhalten der Gewächse bestimmen. Dieser Umstand muss namentlich Berücksichtigung finden, wenn es sich um Beantwortung der\$Frage handelt, weshalb die Winterknospen unserer Bäume und Sträucher nicht stets alsbald austreiben, wenn man sie unter geeigneten Umständen im Winter höherer Temperatur aussetzt. Die Ruheperiode der Knospen ist freilich anfänglich durch den Wechsel der Jalıreszeiten inducirt, aber sie ist schliesslich in angegebener Weise zu einer specifischen Eigenthümlichkeit der Pflanzen geworden, die sich er'st im Laufe langer Zeit wieder beseitigen lässt.

Werden nicht zu kleine Zweige von Prunus avium Ende October nit der Basis in Wasser gestellt und ins Warmhaus gebracht, so treiben ihre Knospen trotz ler dargebotenen günstigen Vegetationsbedingungen nicht aus, sie gehen vielmehr allmällich zu Grunde. Prunuszweige, die man Mitte December ins Warmlıaus bringt, blühen dagegen nach etwa 4 Wochen. Wenn man die Zweige erst Mitte Januar zum Versuch abschneidet, so entfalten sich die Blüthen noch schneller. Aehnliche Resultate erhält man bei Versuchen mit den Zweigen anderer Bäume, z. B. Tilia. Sehr schnell treiben auch Forsythiazweige. Als ich solche Anfang December in Wasser stellte, entfalteten sich ihre Blätter und Blüthen in drei Wochen.

Uebrigens ist die Energie, mit ler die Winterknospen verschiedener Pflanzenarten austreiben, wenn man abgeschnittene Zweige derselben in Wasser stellt und in einen warmen Raum bringt, graduell sehr verschieden. Die Knospen von Weidenzweigen entwickeln sich z. B. recht schnell, ebenso diejenigen von Syringa (ich fand, dass gegen Ende Februar abgeschnittene Zweige in Warmhaus nach kaum 14 Tagen ihre Blätter völlig entfaltet hatten), während die Kunospen des Goldregens schon nicht ganz so leicht zur Entfaltung gelangen. Experimente, die man mit versehiedenen Ptlanzen $\mathrm{zu}$ versehiedenen Zeiten des Winters anstellt, liefern hier in mancher Hinsicht interessante Resultate. Man braucht die möglichst gross gewählten Aeste oder Zweige dabei nur mit ilırem unteren Ende in Wasser zu stellen und hat ferner daranf zu achten, dass die Luft, welche die Ptlanzen umgiebt, nicht \%u trocken ist, weshalb die Versuche in Warmhause gewöhnlich besser als im Zimmer gelingen.

Wenn man im Herbst Kartofielknollen ins warme Zimmer bringt und dieselben in einem Kasten ruhig liegen lässt, so findet man, dass sie erst un Neujahr zu keimen beginnen. Den Knollen ist also ebenso wie den Ḱnospen eine Ruheperiode eigenthümlich. MüLLERThurgau ${ }^{1}$ ) hat sich benı̈ht, die Ursachen dieser Ruheperiode festzustellen, und ich habe mich nach ihm mit derselben Frage beschäftigt ${ }^{2}$ ). Untersucht man die schon einige Zeit im Zimmer liegenden Kartoffelknollen auf '/ucker, indem nan einige Knollen auf einem Reibeisen zerreibt, dem Brei etwas Wasser hinzufïgt, um die vorhandene Flüssigkeit nach Verlauf einiger Zeit abzufiltriren und mittelst FEHLING'scher Lösung zu prüfen, so findet man keine Glycose oder nur

1) Vgl. MüLLLR-Thurgau, Laıdwirthsehaftl. Jahrbĩcher, Bd. 11, S. 813.

2) Vgl. Detmer, Pflanzenphysiologische Untersuchungen über Fermentbildung ete., Jena 1884, S. 41. 
Spuren derselben. Bei Beginn der Keimung der Knollen im Januar ist ihr Zuckergelialt ebenfalls noch sehr gering; er wächst aber allmählich beträchtlich. Wenn man im December eine klcine Menge (20 ccm) der in angegebener Weise aus Kartoffelknollen gewonnenen Flüssigleit mit wenig verdünntem Stärkekleister versetzt, so ist das Vorhandensein von Diastase nicht sicher zu constatiren (vgl. Methode unter 112). Im Keimen erheblich fortgeschrittene Kartoffelknollen enthalten aber, wovon ich mich überzeugte, sicher Diastase.

Danach darf man annehmen, dass die Kartoffelknollen im Herbst deshalb nicht sofort keimen, weil sie nicht im Stande sind, Diastasemengen zu bilden, die für eine ergiebige Zuckerproduction hinreichen. Die Zuckermengen, die im Herbst in den Knollen entstehen, reichen freilich hin, die Athmung der Knollen zu unterhalten, aber sie häufen sich nicht merklich im Gewebe an und genügen nicht für das $\mathrm{Zu}$ standekommen eines energischen Wachsthums der Knospentheile. Allmählich bildet sich mehr und mehr Diastase in den Knollen; es entstehen grössere Zuckerquantitäten, und die Keimung kann beginnen. Es ist sehr wahrscheinlich, dass die Resultate, zu denen man bei dem Studium der Ruheperiode der Kartoffelknollen gelangt ist, von Bedeutung für die Beurtheilung der Frage nach der Ruheperiode der Winterknospen unserer Bäume und Sträucher sind, und es dürfte laher von um so grösserem Interesse sein, noch das folgende von MüLLER-Thurgau ausgeführte Experiment zu erwähnen.

Wir bringen einige Kartoffelknollen in August unmittelbar nach dem Ausgraben in einen Thermostaten, in welchem eine Temperatur von $0^{\circ} \mathrm{C}$. herrscht (vgl. unter 49). Nach etwa 4 Wochen werden die Knollen in lockerer, feucht gehaltener Gartenerde, die sich in Blumentöpfen befindet, bei Lichtabschluss günstigen Keimungsbedingungen ausgesetzt. Die Entwickelung der Knospen beginnt alsbald, während Parallelversuche lehren, dass nicht vorher abgekühlte Ḱnollen keineswegs im Herbst, sondern erst viel später keimen. Man hat die Ruheperiode der Knollen also durch die Abkühlung beseitigt. Unter 126 ist gezeigt worden, dass die Knollen in ihren Geweben bei niederer T'emperatur erhebliche Zuckermengen anhäufen, weil bei diesen geringen Wärmegraden die Athmung der Zellen sehr schwach ist. Nach der Abkühlung steht den Knospen also eine ziemlich reichliche Menge plastischen Materials zur Verfügung, und sie können sich daher schnell entwickeln. Im Zusammenhang mit dem Angeführten besitzen nun auch die Resultate einiger Beobachtungen, die ich an Paviazweigen machte, Interesse. Paviazweige, die Mitte Januar abgeschnitten, mit ihrer Basis in Wasser gestellt und ins Warmhaus gebracht worden waren, entfalteten ihre Knospen Mitte März. Als iclı Paviazweige Ende October abschnitt und ins Warmhaus brachte, trat die Evolution der Knospen erst nach Mitte März ein. Die relativ schnelle Entfaltung der Kinospen solcher Zweige, die erst in Januar ins Warmhaus gelangten, hat vielleicht darin ihren Grund, dass sich in ihren Geweben wälırend ilıres Verweilens in Freien in Folge der herrschenden niederen T'emperatur Zucker anhäufen konnte. Die sehon in October ins Warmhaus gestellten Zweige haben hier auch woll Zucker gebildet, derselbe wurde aber, solange die Glycoseerzeugung nicht sehr ausgiebig war, für die Zwecke der Athmung verbraucht, so dass sich die Knospen erst im März entfalten komnten. 
Zu dieser Zeit tritt gewiss eine besonders energische Production diastatischer Fermente in den. Zweigen ein; es wird eine Zuckermenge gebildet, die sowohl für die Unterhaltung der Athmung als auch für den Beginn des Wachstlıums der Knospentheile genügt ${ }^{1}$ ).

Interesse beansprucht noch folgende Beobachtung. Die auf S. 7 erwälhnte Weide (Salix fragilis), welche in Wassercultur gezogen wurde und den ganzen Winter über im warmen Zimmer stand, ist völlig gesund, hat aber erst heute, am 26. März 1895̆, Triebe zur Entfaltung gebracht. Auch von dieser Weide abgeschnittene und in Wasser gestellte Zweige bildeten erst in den letzten Tagen neue Triebe. Als ich dagegen Mitte December im Freien stchenden Exemplaren von Salix fragilis Zweige entnahm und dieselben im warmen Zimmer in Wasser stellte, bildeten die Untersuchungsobjecte im Laufe von 4 Wochen Wurzeln und neue Triebe.

\section{Das Wachsthum der Pflanzentheile in constanter Finsterniss.}

Ein ausgiebiges Wachsthum in constanter Finsterniss können natürlich nur Pflanzentheile erfahren, denen unter diesen Umständen hinreichende Mengen plastischer Stoffe zur Verfügung stehen. Aus diesem Grunde eignen sich zu den nachfolgenden Experimenten vor allem Keimpflanzen, denn in den Rescrvestoffbchältern der Samen sind ja mehr oder mindèr grosse Mengen plastischer Stoffe vorhanden. Handelt es sich zunächst ganz im Allgemeinen darum, die Erscheinungen zu constatiren, welche Pflanzen bei ihrem Wachsthum in constanter Finsterniss im Vergleich $\mathrm{zu}$ ihrem Wachsthum unter normalen Beleuchtungsverhältnissen erkennen lassen, so legen wir einige angequollene Samen von Pisum, Phascolus und Cucurbita in mit durchfeuchteter Gartenerde angefüllten grossen Blumentöpfen aus. Einige Töpfe werden am Fenster dem Wechsel von Tag und Nacht ausgesetzt, andere stehen unmittclbar daneben unter cinem grossen, mit schwarzem Papier überzogenen Pappkasten. Man stellt die Experimente zweckmäsig in einem Raume an, in welchem die Pflanzen nur von diffusem Licht getroffen werden, denn unter dem Einfluss des directen Sonnenlichtes würde die Luft unter dem Pappkasten leicht eine sehr hohe Temperatur annehmen. Es ergiebt sich bald, dass die Untersuchungsobjecte, die sich im Finstern einer- und unter normalen Beleuchtungsverhältnissen andererseits entwickeln, ein sehr verschiedenartiges Aussehen besitzen. Sehen wir hier von der nicht grünen Farbe der im Dunkeln cultivirten etiolirten Pflanzen völlig ab, so finden wir z. B. bei Cucurbita, dass das hypocotyle Glied im Dunkeln eine sehr bedeutende Länge erreicht, während es bei den Lichtpflanzen relativ kurz bleibt. Die Cotyledonen der Dunkelpflanzen sind hingegen weder so breit noch so lang wie diejenigen der bei Lichtzutritt cultivirten Untersuchungsobjecte. Durch genauere Messungen (es sind dabei stets mehrere Pflanzen zu berücksichtigen, um brauchbare Mittelwerthe $z u$ erhalten) kann man sich von dieser Thatsache noch

1) Für die geltend gemachten Anschauungen sprechen auch die Resultate der Untersuchungen A. Fisciren's, vgl. Jahrb. f. wissenschl. Botanik, Bd. 22, S. 127 und 154. Etwas anders fasst MÜLLER-Thurgau neuerdings das Zustandekommen der Ruheperiode bei den Pflanzen auf, vgl. Landwirthschaftl. Jahrbücher, Bd. 14, S. 878. Man vgl. auch noch AskexASY, Botan. Zeitung, 1877. 
specieller überzeugen. In Fig. 132 ist der oberirdische Theil einer etiolirten, in Fig. 133 derjenige einer normalen Cucurbitakeimpflanze dargestellt. Bei der Cultur von Phaseoluskeimlingen im Licht und im Dunkeln (vergl. Fig. 134 und Fig. 135) überzeugt inan sich leicht

Fig. 132.

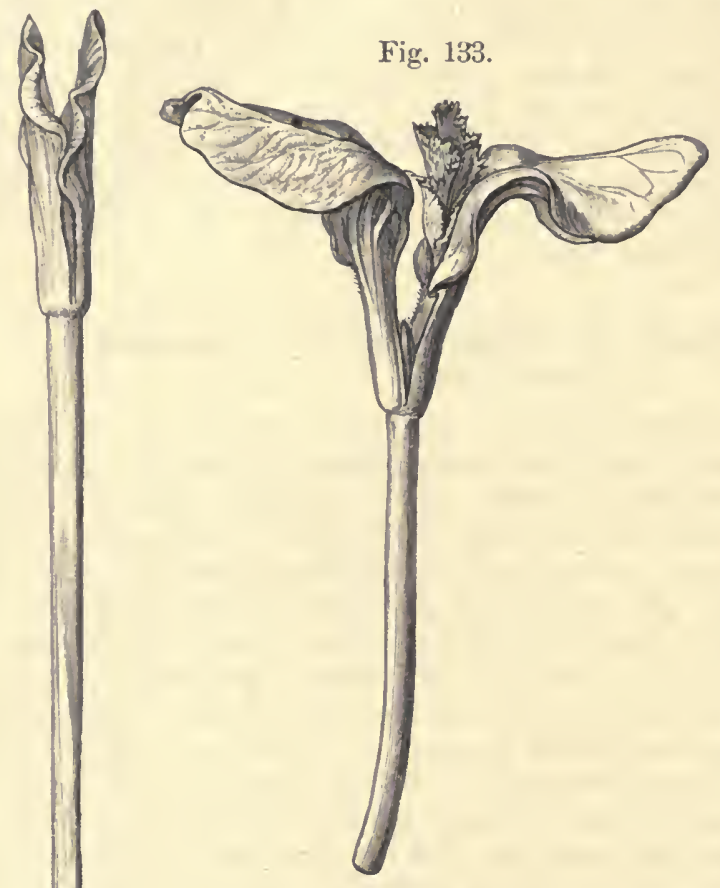

Fig. 132. Oberirdischer Theil eincr im Dunkein erwachsenen Keimpflanze von Cucurbita.

Fig. 133. Oberirdischer Theil einer unter normalen Verhältnissen erwachsenen Keimpflanze von Cucurbita. davon, dass das hypocotyle Glied der Untersuchungsobjecte auch in Finstern sehr kurz bleibt, während namentlich das Epicotyl $\mathrm{zu}$ viel bedeutenderer Länge als bei Lichtzutritt heranwächst.

Die Blattstiele der Primordialblätter werden im Finstern länger als unter normalen Verhältnissen; die Spreiten der Blätter erreichen dagegen nur bei Lichtzutritt ihre normale Form und Grösse. Aehnlich wie die Phaseoluskeimlinge verhalten sich auch Pisum- und Viciakeimpflanzen. Ausgezeichnete Untersuchungsobjecte sind ferner Keimpflanzen von Tropaeolum majus. Bei Versuchen mit manchen monocotylen Gewächsen (Zea, Triticunı) stellt man fest, dass die in constanter Finsterniss erwachsenen Blätter der Keimpflanzen im Vergleich zu gleichalterigen Blättern, die bei Lichtzutritt zur Entwickelung gelangt sind, eine bedeutende Länge, aber geringe Breite erreichen ${ }^{1}$ ).

Es ist von Interesse, dass nicht allein Pflanzen, welche einerseits bei gewöhnlicher Beleuchtung, andererseits in tiefer Finsterniss cultivirt werden, bedeutende Unterschiede mit Bezug auf ihre gesammte Entwickelung erkennen lassen, sondern dass derartige Differenzen anch schon bei der Cultur von Pflanzen in einem mehr oder weniger intensiven Licht klar hervortreten ${ }^{2}$ ). Ich habe zur Feststellung der bezüglichen Thatsache Holzkästen von $55 \mathrm{~cm}$ Höhe und etwa $680 \mathrm{qcm}$ Grundfläche benutzt, in welchen die Culturgefässe mit den Pflanzen standen. Die Kästen waren im Innern geschwärzt. An Stelle ihrer vorderen Wand konnten

1) Vgl. SACHS, Botan. Zeitung, 1863, Beilage.

2) Vgl. Detmer, Versuchsstationen, Bd. 16. 


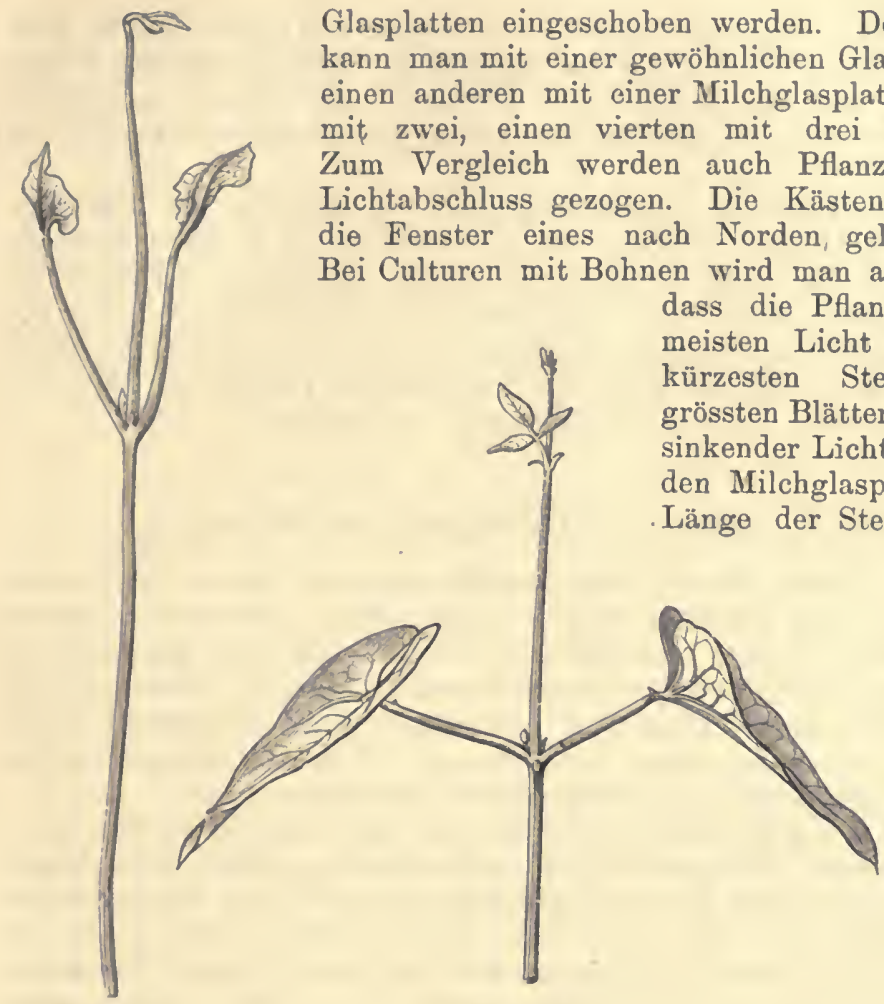

Fig. 134.
Fig. 135 .

Fig. 134. Oberirdischer Theil einer im Dunkeln erwachsenen Keimpflanze von Phaseolus.

Fig. 135. Oberirdischer Theil einer unter normalen Verhältnissen erwachsenen Keimpflanze von Phaseolus.

Den einen Kasten asplatte versehen, einen anderen mit einer Milchglasplatte, einen dritten
mit zwei, einen vierten mit drei Milchglasplatten. Zum Vergleich werden auch Pflanzen bei völligem die Fenster eines nach Norden, gelegenen Raumes. alsbald bemerken grössten Blätter produciren. Mit inkender Lichtintensität hinter den Milchglasplatten steigt dio eltheile, während die Grösse der Blätter abnimmt.

Es giebt verschiedene

Pflanzen, die in Stande sind, nicht allein zahlreiche

Blätter und lange Stengel, sondern auch Blüthen in constanterFinsterniss zur Ausbildung zu bringen. Werden Hyacinthenzwiebeln in sogen. Hyacinthengläsern bei dauerndem und völligem Lichtausschluss zum Austreiben gebracht, so kommen die Untersuchungsobjecte in der That zur Blüthe. Ich überzeugte mich davon, dass die Blüthen, was die Form und Farbe derselben anbelangt, in völliger Dunkelheit eine durchaus normale Entwickelung erfahren, sich also abweichend von den meisten Stengeln und Laubblättern verhalten ${ }^{1}$ ).

Von Interesse ist es weiter, das folgende Experiment anzustellen. Man cultivirt Pflanzen von Phaseolus multiflorus in Blumentöpfen. Wenn sich die Primordialblätter unter gewöhnlichen Verhältnissen normal entwickelt haben und die auf das Epicotyl folgenden Internodien in lebhafter Streckung begriffen sind, so führt man den Gipfel einer Pflanze in einen dunkeln Raum ein, während der übrige Theil des Untersuchungsobjectes dem hellen Tageslicht ansgesetzt bleibt. Ein Stativ trägt einen grossen Metallring, auf dem in horizontaler Lage eine in der Mitte mit einem Loch versehene dicke Pappscheibe ruht. Der Gipfel der Bohnenpflanze wird durch dies Loch geführt und in demselben mit Watte wohl befestigt. Man

1) Vgl. auch SAcHs, Arbeiten d. botan. Instituts in Würzburg, Bd. 3, S. 372. 
deckt endlich einen möglichst hohen, mit schwarzem Papier überklebten Pappcylinder, dessen Ränder auf der Pappscheibe ruhen, über den Gipfel der Pflanze und wird im Laufe von 2-3 Tagen wahrnehmen, dass die im Finstern neu entstehenden Internodien abnorm lang werden, während die Blätter klein bleiben ${ }^{1}$ ).

Soll das Experiment schön gelingen, so müssen die Pflanzen z. B. an einem Fenster 'stehen, wo sie wenigstens längere Zeit am Tage directes Sonnenlicht empfangen. Einer zu starken Erwärmung des Pflanzentheiles unter der Papphülle ist durch Verwendung geeignet aufgestellter Schirme vorzubeugen. Bei meinen Versuchen fand ich auch, dass die im Dunkeln wachsenden Theile der Bohnenstengel sich um eine Stütze zu schlingen vermochten.

\subsection{Die Ursachen der Etiolirungserscheinungen.}

Es ist Thatsache, dass zahlreiche Pflanzenarten, wenn sie in völliger Finsterniss zur Entwickelung gelangen, überverlängerte Stengeltheile und kleine Blätter erzeugen. Es fragt sich zunächst, ob die eigenthümliche Formbildung etiolirter Gewächse nicht vielleicht Folge der im Dunkeln ausgeschlossenen assimilatorischen Thätigkeit ihrer Blätter ist. Zur Beantwortung dieser Frage führen wir die folgenden Versuche mit Keimpflanzen von Raphanus sativus aus ${ }^{2}$ ).

Wir quellen Raphanussamen in Wasser an, legen dieselben dann auf mit verdünnter Nährstofflösung begossenen grobkörnigen Sand, mit welchem $\mathrm{zwei}$ kleine Blumentöpfe angefüllt sind, und bringen diese letzteren in Apparate, wie sie unter 16 beschrieben und in Fig. 18 abgebildet wurden. Der eine Apparat wird hellem, diffusem Tageslicht ausgesetzt, der andere wird in unmittelbarer Nähe des ersteren unter einen mit schwarzem Papier überzogenen Pappkasten gestellt. Die Samen keimen bald, und während die sich im Dunkeln entwickelnden Pflänzchen lange hypocotyle Glieder und Cotyledonen von geringer Breite sowie Länge besitzen, zeigen die bei Lichtzutritt erwachsenen und ergrünten Keimlinge ein ganz normales Aussehen. Diese letzteren konnten aber trotz ihres Chlorophyllgelıalts nicht assimiliren, da sie von kohlensäurefreier Luft umgeben waren, und somit muss geschlossen werden, dass das Fehlen assimilatorischer Thätigkeit nicht als Ursache der eigenthümlichen Formbildung etiolirter Pflanzen angesehen werden kann ${ }^{3}$ ).

Für denjenigen, der sich specieller mit den Ursachen der Etiolirungserscheinungen bekannt machen will, ist es von Wichtigkeit, die folgenden Experimente anzustellen. Es werden einige Raphanussamen

1) Dies Resultat meiner Versuche stimmt mit gewissen Angaben von SACHS, Vorlesungen über Pflanzenphysiologie, 1857, S. 538, nicht völlig überein. Bei den Experimenten von SACHS waren aber auch die Bedingungen andere, als bei den meinigen, denn seine Untersuchungsobjecte besassen zahlreiche, am Licht befindliche und stark assimilirende Blätter. Die im Dunkeln befindlichen Blätter erreichten dabei eine bedeutende Grösse, und Aehnliches mag auch bei Phaseolus unter gleichen Umständen geschehen. Uebrigens bedarf die ganze Frage einer weiteren experimentellen Prüfung. Vgl. noch Fraxk, Lehrbuch der Botanik, Bd. 1, und Asreidusg, Flora, 1894.

2) Vgl. Godlewski, Botan. Zeitung, 1879.

3) Wohl aber kann das Licht von Wichtigkeit für die Bildung specifischer Stoffe sein, die für eine normale Ausbildung der Blätter erforderlich sind. Diese Körper können vorlāufig als blattbildende Stoffe bezeichnet werden. 
von möglichst gleicher Grösse ausgewählt. Wir bestimmen das Gewicht jedes einzelnen Samens und benutzen nur solche Samen zum Versuch, die nahezu das nämliche Gewicht besitzen. Nach dem An(quellen legen wir die Samen auf mit Nährstofflösung durchfeuchteten Sand, der sich in kleinen Blumentöpfen befindet. Jeder Topf wird mit 4 oder 6 Samen beschickt. Die eine Cultur wird in angegebener Weise in kohlensäurefreier Luft bei Lichtzutritt, die andere im Finstern vorgenommen. Wenn die Pflanzen nach Verlauf einiger Tage ziemlich weit in der Keimung vorgeschritten sind, heben wir sie sorgfältig aus dem Sande heraus und zerlegen sie in ihre einzelnen Organe. Nicht durchaus normal entwickelte PHänzchen lassen wir bei Seite. Es genügt für uns, nur das hypocotyle Glied und die Cotyledonen weiter zu berücksichtigen. Wir stellen das Lebendgewicht dieser Organe fest, trocknen sie in kleinen Gläschen bei $100^{\circ} \mathrm{C}$. und wägen wieder. Wir gelangen bei sorgfältiger Arbeit zu folgenden Resultaten. Die hypocotylen Glieder der bei Lichtzutritt erwachsenen Pflanzen sind absolut ärmer an Trockensubstanz als diejenigen der im Dunkeln zur Entwickelung gelangten Untersuchungsobjecte. Jene enthalten procentisch weniger Wasser als diese. Die im Licht erwachsenen Cotyledonen sind absolut reicher an Trockensubstanz als die im Dunkeln ausgebildeten. Diese letzteren sind procentisch wasserärmer als jene ersteren ${ }^{1}$ ).

Es handelt sich nun um die speciellere Beantwortung der Frage, weshalb etiolirte Internodien gewöhnlich beträchtlich länger als normale sind, und weshalb die Blätter bei Lichtmangel meistens bedeutend im Wachsthum zurüickbleiben. Mit Bezug auf die Ueberverlängerung etiolirter Internodien ist zunächst darauf hinzuweisen, dass die Membranen der Eleniente ihrer Gewebe (Epidermis, Collenchym, Bast, Holz) auf einer frühen Stufe der Entwickelung verharren und nicht ihre normale Dicke erreichen. Diese Thatsache lässt sich z. B. constatiren, wenn man, wie ich es gethan habe, die Ausbildung der Membranen der Holzelemente bei Lichtzutritt erwachsener und etiolirter epicotyler Glieder von Phaseolus mit einander vergleicht. Das Gewebe etiolirter Interıodien muss demnach dehnbarer als dasjenige normaler sein, und jede einzelne Zelle etiolirter Stengeltheile wird auch, weil ihre Membranen der Turgorkraft einen relativ nur geringen Widerstand entgegensetzen, lebhafter wachsen können, als die entsprechenden Zellen unter den Einfluss des Wechsels von Tag und Nacht ausgebildeter Internodien. Es sei hier auch darauf hingewiesen, was mit dem Gesagten in unmittelbarem Zusammenhang steht, (lass, wie KRAus zuerst nachgewiesen hat, die Intensität der Gewebespannung (Längsspannung) in etiolirten Internodien erheblich geringer als in normalen ist. Man kann sich von dieser Thatsache überzeugen, wenn man nach der unter 149 angegebenen Methode vergleichende Untersuchungen über die Gewebespannung normal ausgebildeter und etiolirter epicotyler Glieder von Phaseolus anstellt. Man prüfe gleichalterige, in lebhaftem Wachsthum befindliche Objecte.

Ein weiterer Grund für das lebhafte Wachsthum etiolirter Internodien scheint in gewissen Fällen darin zu liegen, dass in ilıren Zellen eine grössere Turgorkraft entwickelt wird als in denjenigen der normalen Organe. Einige Beobachtungen von WIESNER und H. DE VRIEs ${ }^{2}$ )

1) Ich habe schon früher (Versuchsstationen, Bd. 16, S. 212) gezeigt, dass etiolirte Pflanzen wasserreicher als bei Lichtzutritt erwachsene sind.

2) Vgl. H. DE VRIEs, Botan. Zeitung, 1879, S. 852. 
deuten auf einen relativ hohen Gehalt etiolirter Pflanzentheile an organischen Säuren hin, und da diese Körper eine grosse Bedeutung für das Zustandekommen des Turgors besitzen, so würde es Interesse beanspruchen, den Gegenstand näher zu verfolgen. Geeignete Untersuchungsobjecte würden sich z. B. in den epicotylen Gliedern von Vicia sativa oder Phaseolus darbieten. Es wäre nur erforderlich, den Säuregehalt der bei Lichtabschluss, sowie der bei Lichtzutritt erwachsenen Organe mit einander zu vergleichen (Methode siehe S. 273).

Freilich sprechen andere Beobachtungen (vgl. Pfeffer, Handbuch, Bd. 2, S. 145, DE V'RIES, Jahrb. f. wissensch. Botanik, Bd. 14, S. 561, und Wortmans, Botan. Zeitung, 1889, S. 296) dafür, dass die Turgorkraft der Zellen etiolirter Stengeltheile nicht grösser als diejenige normaler ist. Die ganze Frage bedarf einer eingehenden Untersuchung.

Das lebhafte Wachsthum etiolirter Stengeltheile beruht also auf einer bedeutenden Turgorausdehnung ihrer Zellen. Diese ist ihrer. seits Folge einer gesteigerten Turgorkraft des Zellinhalts (?) und zugleich einer relativ geringen Widerstandsfähigkeit der Zellmembranen. Es kann nach dem Gesagten von vornherein angenommen werden, dass die Zellen etiolirter Stengel eine bedeutendere Länge besitzen, als die entsprechenden Zellen normaler Internodien. In der That ist dies der Fall. Ich habe z. B. die Länge der Markzellen aus dem mittleren Theil normaler und etiolirter epicotyler Glieder von Phaseolus init Hülfe eines Objectivmikrometers bestimmt. Jene waren etwa $0,2 \mathrm{~mm}$ lang (es ist stets erforderlich, eine ganze Anzahl von Zellen zu messen, um zu brauchbaren Mittelwerthen zu gelangen), diese 2-3mal länger ${ }^{1}$ ).

Bezüglich der Ursachen, welche es bedingen, dass die Blätter der meisten dicotylen Pflanzen im Dunkeln so sehr klein bleiben, sei nur das Folgende bemerkt. Im Dunkeln können in den Blattzellen diejenigen Processe, welche cin ausgiebiges Flächenwachsthum der Zellhäute vermitteln, nicht zur Geltung kommen. Um welche Vorgänge es sich hier handelt, ist nicht genauer bekannt (vgl. übrigens Anmerkung 3 auf S. 340). Sicher ist nur, dass diese Processe - und somit auch das Flächenwachsthum der Blattzellen — stattfinden können, wenn die Pflanzen von den Lichtstrahlen, sei es auch nur vorübergehend, getroffen werden. Ein Experiment Batalis's das leicht zu wiederholen ist, zeigt dies deutlich. Wir cultiviren Keimpflanzen von Phaseolus in Blumentöpfen bei Lichtausschluss. Wenn sich die Primordialblätter bis $\mathrm{zu}$ einem gewissen Grade entwickelt haben, suchen wir zwei Pflanzen ( $a$ und $b$ ) mit Blättern von möglichst glcicher Länge aus und messen die Länge sowie Breite der Blätter. $a$ bleibt auch ferner im Finstern. " w wird im Laufe von 8 Tagen jeden Tag etwa 2 Stunden lang schwachem, diffusem Licht ausgesetzt, verweilt sonst aber auch im Finstern. Die Blätter von $b$ dürfen nicht ergrünen, daher beleucliten wir sie jeden Tag nur so kurze Zeit lang. Die Blätter von $a$ bleiben klein, während hingegen diejenigen von $b$ beträchtlich wachsen ${ }^{2}$ ).

1) Vgl. G. Kraus in Prixgsueim's Jahrbüchern f. wissenschl. Botanik, Bd. 8. Neben der Zellüberverlängerung spielt auch noch die Zellübervermehrung eine Rolle bei dem Zustandekommen des Etiolements.

2) Vgl. Literaturzusammenstellung über das Etiolement bei DFTMER, Vergleichende Physiologic des Keimungsprocesses d. Samen, 1 SSO. 


\section{Der Einfluss des Lichts anf das Wachsthum.}

Es ist eine bekannte Thatsache, dass das Licht einen retardirenden Einfluss auf das Wachsthum der verschiedensten Pflanzentheile geltend macht. Zur Feststellung dieser Thatsache führen wir die folgenden Beobachtungen aus. Eine grössere Anzahl wohl ausgebildeter Erbsensamen wird nach dem Anquellen in einem mit feuchten Sägespänen angefüllten Kasten zur Keimung gebracht. Haben die Hauptwurzeln der Keinlinge eine Länge von $2 \mathrm{~cm}$ erreicht, so nehmen wir die Untersuchungsobjecte aus dem Kieimbett heraus und bringen $10 \mathrm{~mm}$ entfernt von der Wurzelspitze in bekannter Weise feine Tuschestriche als Marken an. Es ist mit besonderer Sorgfalt darauf zu achten, dass nur sehr gleichartig und völlig normal entwickelte Keimlinge zur ferneren Untersuchung Verwendung finden. Die weitere Cultur der Pflanzen erfolgt unter Zuhïlfenahme von etwa $25 \mathrm{~cm}$ hohen und 10 cm weiten Glascylindern, die mittelst eines passenden, mit einer Anzahl von Löchern versehenen Holzdeckels verschlossen werden können und mit Brunnenwasser gefüllt sind. Wir stellen zwei solche Cylinder auf. Jeder wird mit einer nicht zu kleinen Anzahl der Keimlinge (etwa 10-15) beschickt, die man mit Hülfe von etwas Watte in den Löchern der Holzdeckel befestigt, so dass die Wurzeln in das Wasser eintauchen. Die Wurzeln in dem einen Culturgefäss bleiben dem Licht ausgesetzt; es ist zweckmässig, dicht hinter dem Cylinder und parallel mit dem Fenster einen Spiegel aufzustellen oder den Cylinder auf einem Kilinostaten langsam rotiren $\mathrm{zu}$ lassen, um jede heliotropische Kírümung der Wurzeln auszuschliessen. Der andere Cylinder ist mit schwarzem Papier beklebt, so dass das Licht keinen Zutritt zu den Wurzeln findet. Man stellt die Beobachtungen im Sommer in einem nach Norden gelegenen Zimmer bei möglichst hoher Temperatur an. Von Zeit zu Zeit, z. B. alle 24 Stunden, ermittelt man den Gesammtzuwachs, den sämmtliche Wurzeln in beiden Cylindern erfahren haben, - und man wird zu dem Ergebniss gelangen, dass dieser Zuwachs bei Lichtzutritt geringer als bei Lichtabschluss ausfällt.

Werden Pflanzen bei möglichst constanten Temperatur - und Feuchtigkeitsverhältnissen dem Wechsel von Tag und Nacht ausgesetzt, so lässt sich bei Untersuchungen ïber die Grösse der Zuwachsbewegung ihrer Organe feststellen, dass dieselbe im Allgemeinen vom Abend bis zum Morgen eine Steigerung, vom Morgen bis zum Abend aber eine Verminderung erfährt. Diese tägliche Periode des Wachsthums ist Folge der im Laufe von '24 Stunden wechselnden Beleuchtungsverhältnisse. Am Tage wirkt das Licht retardirend auf das Wachsthum ein; die Dunkelheit der Nacht beschleunigt den Verlauf der Zuwachsbewegung. SACHS ${ }^{1}$ ) hat die Thatsache der täglichen Periode des Wachsthums für die Internodien verschiedener Pflanzen unter Benutzung des Auxanometers festgestellt, und Prantu ${ }^{2}$ ) hat ebenfalls für Blätter das Vorlıandensein einer täglichen Periode des Wachsthums constatirt. Die erforderlichen Untersuchungen sind mit sehr vieler Mühe verbunden. Am einfachsten ist es noch, die Thatsache der täglichen Wachsthumsperiode an Blättern zu constatiren. Man hält dabei die unter 154, Seite 322 angegebene Methode ein. Die Untersuchungs-

1) Vgl. SAcrs, Arbciten d. botan. Instituts in Würzburg, Bd. 1, S. 99.

2) Vgl. Praxt, ebendaselbst, S. 371. 
objecte (Cucurbita- oder Nicotiana-Exemplare) werden unter Glasglocken in einem nach Norden gelegenen Zimmer dem Wechsel von Tag und Nacht bei möglichst constanter, aber recht hoher Temperatur ausgesetzt. Von Zeit zu Zeit (z. B. alle 3 oder 4 Stunden) misst man die Entfernung zwischen der Marke an der Basis der Blattspreite und der Blattspitze unter Benutzung eines Millimetermaassstabes, unter sorgfältiger Vermeidung irgendwie erheblicher Zerrungen beim Flachlegen der Blätter. Es ergiebt sich namentlich, dass die Zuwachsbewegung in der Nacht grösser als am Tage ausfällt. Wenn am Abend die Dunkelheit eintritt, so wird das Wachsthum der Blätter nicht sofort bedeutend beschleunigt, sondern ganz allmählich, so dass das Maximum des täglichen Zuwachses auf die Morgenstunden fällt. Ebenso drückt der Zutritt des Lichts die Wachsthumsgeschwindigkeit der Blätter nicht sofort auf das Minimum herab; dieses fällt vielmehr erst auf die Stunden des Abends.

Aehnliche Resultate erhält man auch, wenn man neben dem Längenzuwachs der Blätter zugleich deren Breitenzuwachs bestimmt. Die erforderlichen Marken werden an den beiden Längsrändern in der Nähe des grössten Breitendurchmessers der Blätter aufgetragen, um ihre Entfernungen in 3- oder 4-stündigen Zeitabschnitten festzustellen.

Bei Untersuchungen über die tägliche Wachsthumsperiode von Internodien verwendet man sehr zweckmässig bei Lichtzutritt zur Entwickelung gelangte Triebe von Dahlia variabilis. Die Knollen werden lange vor Beginn der Versuche in Erde, die sich in recht grossen Blumentöpfen befindet, eingesetzt, damit sich die Pflanzen schön bewurzeln. Mehrere Tage vor Beginn der Experimente wird die Erde in den Töpfen gründlich durchfeuchtet, und man stellt dieselben dann am besten, um ein Austrocknen der Erde, die sehr störend auf den Gang der Beobachtungen einwirkt, in einen Zinkblechrecipienten mit halbirtem Deckel. Die Versuche fïhrt man unter Benutzung des Auxanometers (vgl. unter 153 aus). Der Faden kann z. B-unter den Blättern des 3., 4. oder 5. Internodiums befestigt werden. Diese Blätter und auch die tiefer stehenden schneidet man alsdann zweckmässig dicht an ihrer Basis ab und bestimmt immer die Gesammtgrösse des Zuwachses der unter der Ankuppelungsstelle liegenden Stengeltheile, also z. B. des 2. und 3. oder 4. und 5. Internodiums. Die Pflanzen sind vor directem Sonnenlicht zu schützen; sie müssen also z. B. in einem nach Süden gelegenen Raum in genügender Entfernung vom Fenster aufgestellt werden. Zur Verhütung des Zustandekommens heliotropischer Krümmungen dienen Spiegel (vgl. unter 153). Die Temperatur- sowie Feuchtigkeitsverhältnisse der Luft sind durch trocken und feucht gehaltene Thermometer, welche in unmittelbarer Nähe der Beobachtungsobjecte frei aufgehängt sein müssen, zu ermitteln ( $\nabla$ gl. nnter 76). Um die Luft im Arbeitsraum annähernd gleichmässig feucht zu erhalten, sind die Dielen desselben mehrfach am Tage mit Wasser zu besprengen. Auch auf die Bewölkungsverhältnisse ist $\mathrm{zu}$ achten.

Die Deutung des Zahlenmaterials, welches die Temperaturbestimmungen und die Ermittelungen über die stündlichen Zuwachse ergeben, ist nicht ganz leicht. Ziemlich deutlich tritt die eigenartige Abhängigkeit der Zuwachsgrösse von den Beleuchtungsverhältnissen schon hervor, wenn man aus den stündlichen Werthen die dreistündigen Zuwachse und Mitteltemperaturen berechnet. Am allerdeutlichsten tritt das Abhängigkeitsverhältniss des Wachsthums von den Belenchtungsumständen hervor, wenn man die Resultate der Beobachtungen graphisch darstellt. Die Con- 
struction der Curven geschieht in bekannter Weise. Ueber einige beachtenswerthe Momente, auf die hier, um Raum zu sparen, nicht näher eingegangen worden soll, hat SAchs (Arbeiten d. botan. Instituts in Würzburg Bd. 1, S. 126, 185 u. 192) aufmerksam gemacht. Die Curven lehren, dass vom Morgen bis zum Abend Verminderung, vom Abend bis zum Morgen Steigerung des Wachsthums herrscht. Dies tritt selbst dann hervor, wenn die Temperatur in der Nacht etwas niedriger als am 'Tage ist.

Sehr lehrreich ist es endlich, das Wachsthum der Sporangienträger von Mucor bei Lichtzutritt und im Dunkeln zu beobachten. Wir verfahren genau so, wio es unter 153 auf S. 318 angegeben worden ist. Die Glasglocke, unter der sich die Mucorpflanzen entwickeln, wird abwechselnd mit einem Papprecipionten überdeckt oder unbedeckt gelassen. Während der Dunkelperioden des Versuches ist das Wachsthum der Sporangienträger lebhafter als bei Lichtzutritt (vgl. die folgende Tabelle und die correspondirende graphische Darstellung). Es ergiebt sich, dass Lichtzutritt das Wachsthum in dem vorliegenden Falle sofort retardirend beeinflusst, während Dunkelheit dasselbe sogleich beschleunigt ${ }^{1}$ ).

\begin{tabular}{|c|c|c|}
\hline $\mathrm{T}$ agesstunde & $\begin{array}{l}\text { Wachs- } \\
\text { thun } \\
\text { p. Stunde }\end{array}$ & $\begin{array}{l}\text { Tem- } \\
\text { peratur } \\
\text { in }{ }^{\circ} \mathrm{C} \text {. }\end{array}$ \\
\hline 8-9 Vorm. & 2,70 & 22,9 \\
\hline 10 & 2,70 & 24,3 \\
\hline $11 "$ & 2,30 & 26,0 \\
\hline 12 & 2,90 & 25,0 \\
\hline 1 Nachm. & 2,70 & 25,8 \\
\hline 2 & 3,20 & 25,8 \\
\hline 3 & 3,50 & 25,2 \\
\hline 4 & 2,90 & 25,0 \\
\hline 5 & $3,20^{\circ}$ & 25,1 \\
\hline 6 & 2,80 & 25,3 \\
\hline
\end{tabular}

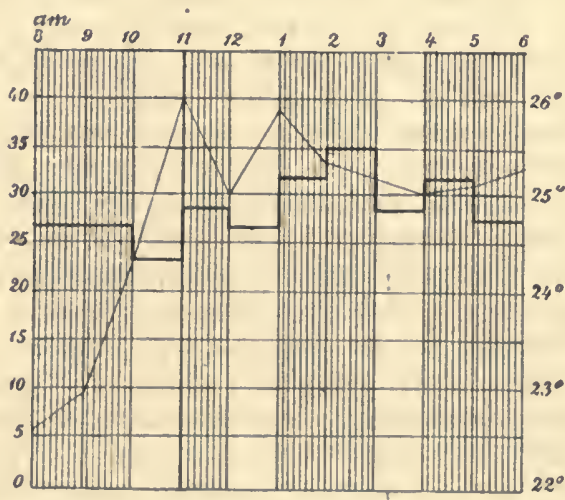

Fig. 136. Die dicke gebrochene Linie giebt die wechselnde Wachsthumsgeschwindigkeit eines Mucorschlauches bei wechselnder Beleuchtung und Verdunkelung.an. Die dünne Linie ist die Temperatureurve." (Nach Vines.)

\section{6\%. Der Einfluss der Beleuchtungsverhältnisse anf die Keimung der Kartoffelknollen.}

Wir legen einige Kartoffelknollen im Herbst oder im Laufe des Winters in einen Kasten, den wir mit einer Pappscheibe zudecken, um das Untersuchungsmaterial vor dem Lichtzutritt zu schützen. Andere Knollen bringen wir in einen mit einer Glasplatte bedeckten Kasten. Die Kästen stehen vor dem Fenster eines nach Norden gelegenen geheizten Zimmers. Wasser wird den Knollen gar nicht zugefübrt. Im Laufe des Winters keimen die Kartoffeln, aber während die Dunkelknollen ziemlich lange Triebe entwickeln, bleiben diejenigen der Lichtknollen kurz und von gedrungenem Aussehen. Wir können den Versuch bis in den Sommer hinein fortsetzen und constatiren stets, dass die Ausbildung der ersten

1) Vgl. Vixes, Arbeiten des botan. Instituts in Würzburg, Bd. 2, S. 133. 
Internodien der aus den Knollen hervorgehenden Kartoffeltriebe nur im Dunkeln (unter gewöhnlichen Verhältnissen im Boden) in normaler Weise vor sich gehen kann. Zerreiben wir ab und an eine Knolle der Lichtund Dunkelreihe auf einem Reibeisen, um den erhaltenen Brei mit etwas Wasser zu behandeln, und um die abfiltrirte Lösung mit Hülfe FFHLiva'scher Flüssigkeit auf Zucker zu prüfen, so finden wir in den Dunkelknollen viel Zucker, in den Lichtknollen aber gar keinen oder nur Spuren. Mit diesem Mangel an geeignetem, plastischem Material in den Lichtknollen laangt offenbar das schwächliche Wachsthum ihrer Triebe zusammen. Ich habe die Thatsache, dass bei Lichtzutritt keimende Kartoffelknollen keinen Zucker enthalten, zuerst constatirt ${ }^{1}$ ); Ziegexbein (Pringsh. Jahrb., Bd. 25) verfolgte den Gegenstand weiter.

Beachtenswerth ist noch, dass die dem Einfluss des Lichts ausgesetzten Kartoffelknollen allmählich ergrünen. Untersucht man zarte Querschnitte aus einer ergrünten Knolle mikroskopisch, so findet man dicht unter der Schale Zellen, die Chlorophyllkörper mit Stärkeeinschlüssen enthalten. Diese Chlorophyllkörper gehen unter dem Einfluss des Lichts aus farblosen Stärkebildnorn, welche die Kartoffelknollen enthalten, hervor.

Wesentlich anders gestaltet sich das Aussehen der Triebe keimender Kartoffelknollen, wenn ilır Wachsthum nicht bei Mangel von Wasserzufuhr erfolgt. Wir füllen einige Teller mit feuchtem Sand an und halten den Sand auch fernerhin stets feucht. Einige Knollen werden durch Eindrücken mit ihrer morphologischen Basis in den Sand senkrecht aufgestellt. Die Teller gelangen zum Theil unter eine grosse Glasglocke, zum Theil unter einen grossen Zinkblechrecipienten. Die Triebe der Lichtknollen, zumal die ersten Internodien, entwickeln sich als kurze, dicke, mit vielen Schuppenblättern besetzte Gebilde, aber es entstehen auch Wurzeln, die in den Sand eindringen. Die Triebe der Dunkelknollen erreichen auch hier bei geringem Durchmesser erhebliche Länge, und ihre Wurzelanlagen treiben aus. In feuchter Luft kommen also an den Kartoffeltrieben stets viele Wurzeln zur Entwickelung, was in trockener Luft nicht oder nur in sehr beschränktem Maasse der Fall ist. Auch die Ausbildung der Stolonen gestaltet sich in feuchter Luft meist günstiger als in trockener.

Wir legen Kartoffelknollen in mässig feuchte Erde ein, so dass sie völlig von derselben bedeckt sind. Die Erde befindet sich in grossen Blumentöpfen, und diese stellen wir im warmen Zimmer unter einen grossen Zinkblechrecipienten. Bei der Keimung der Knollen bilden sich sehr lange Triebe mit kleinen Blättern. Ferner entstehen viele oberirdische Wurzeln und alsbald als Achselsprosse auch Stolonen, die in die feuchte Luft hineinragen und an ihren Enden häufig zu kleinen Knollen anschwellen. Oft sind die Knollen aber auch ungestielt und sitzen direct in den Blattachseln. Ueberhaupt ist die Entwickelung der Pflanzen unter den bezeichneten Umständen nicht immer genau die nämliche; schon die Knollenvarietät ist in dieser Hinsicht von Bedeutung ${ }^{2}$ ). Winterknospen von Fagus sollen nach neueren Untersuchungen nur im Licht austreiben. Meine bezüglichen Experimente sind noch nicht abgeschlossen.

1) Vgl. Detmer, Pflanzenphysiologisehe Untersuchungen über Fermentbildung und fermentative Processe, Jena 1881, S. 34. Bei meinen Versuchen wurde den Kartoffelknollen gar kein Wasser dargeboten. Das für das Wachsthum der Triebe erforderliche Wasser strörnte den Zellen derselben aus den Knollengewebe zu.

2) Zahlreiche Detailangaben vgl. bei Vöcrtisg, Bibliotheea botanica, Cassel 1SS7, Heft 4. 
Fünfter Abschnilt.

\section{Die Reizbewegungen der Pflanzen.}

\section{Die Reizbewegungen protoplasmatischer Gebilde.}

\section{Die Bewegungserseheinungen des Protoplasmas.}

Als erstes Untersuchungsobject wählen wir Nitella, Algen, dic in stehenden, kalkarmen Gewässern ziemlich häufig vorkommen, und zwar benutzen wir zweckmässig jüngere Internodien zur mikroskopischen Beobachtung. Ohne hier näher auf die bekannten Eigenthümlichkeiten der langgestreckten Nitellazellen einzugehen, sei nur bemerkt, dass die Hautschicht oder das Hyaloplasma in denselben besonders mächtig entwickelt ist. Diese Hautschicht und ebenso die derselben anliegenden Chlorophyllkörper sind bewegungslos; dagegen ist in der Körnerschicht des Protoplasmas sehr lebhafte Bewegung wahrzunelımen. Wir haben es hier mit typischer Rotation zu thun, indem ein in sich zurücklaufender Strom vorhanden ist. Durch den Indifferenzstreifen wird der aufsteigende von dem absteigenden Theile des Stromes getrennt.

Wenn wir Blätter aus der Knosje von Elodea canadensis in einen Wassertropfen auf den Objectträger bringen und mikroskopisch untersuchen, so erkennen wir ohne jede Mülie in den Zellen den wandständigen Theil des Protoplasmas, die durch den Zellsaft ausgespannten Protoplasmabänder, den Zellkern sowie die Chlorophyllkörper. Alsbald sieht man auch Bewegungserscheinungen im Protoplasma zu Stande kommen, die leicht an der Ortsveränderung kenntlich sind, welche die Chlorophyllkörper erfahren. Die Protoplasmabewegung in den Blattzellen von Elodea trägt bald mehr den Charakter der Rotation, bald melsr denjenigen der Cireulation.

Bei dieser letzteren besitzen die Strömungen, welche sowohl in dem wandständigen Plasma als auch in den Protoplasmasträngen verlaufen können, die mannigfaclısten Richtungen: oft sind die Strömungen in einem Bande sogar verschieden gerichtet. Dabei machen sich Massenverschiebungen im Protoplasmakörper geltend; einige Stränge werden dünner, andere verschwinden völlig, oder es entstehen auch neue Stränge etc. etc. Gute Objecte für das Studium der Circulation des Protoplasmas sind z. B. die Staubfadenhaare von Tradescantia (z. B. T. virginica), die man im Oeffnen begriffenen Blüthen 
entnimmit, um sie unter Deckglas im Wassertropfen zu untersuchen, und die Haare der jungen Sprosse von Cucurbita Pepo.

In den Haaren von Tradescantia, Cucurbita etc. ist primäre Plasmabewegung gegeben, d. h. die Circulation macht sich schon in den völlig intacten Zellen geltend und kann daher sofort nach Herstellung der Präparate beobachtet werden. In den Blattzellen von Elodea (wir wählen solche aus, in denen wir die Plasmastränge gut sehen und an deren Vorderwänden nicht gar zu viele Chlorophyllkörner liegen) ist sofort nach dem Abschneiden der Blätter die Plasmabewegung nur schwach und oft nur schwierig zu erkennen. Allmählich, z. B. im Verlaufe von $1 / 2$ bis 1 Stunde, wird sie energischer und reisst dann auch viele Chlorophyllkörper mit fort.

Sehr allgemein erscheint das Plasma in den völlig intacten Pflanzenzellen in Ruhe; die Bewegung tritt erst in Folge der als Reiz wirkenden Verletzungen ein, welche bei der Herstellung der Präparate unvermeidlich sind. Wenn man von $6 \mathrm{~cm}$ hohen Maispflanzen Epidermisstreifen abzieht und am besten (um den nachtheiligen Einfluss des Wassers zu vermeiden) in 4-proc. Rohrzuckerlösung untersucht, so sieht man keine Protoplasmabewegung. Dieselbe tritt erst nach etwa $1 / 4-1 / 2$ Stunde deutlich hervor. Hier fehlt also, wie in sehr zahlreichen anderen Fällen, die primäre Protoplasmabewegung völlig. Die secundär auftretende ist Folge der Verletzung ${ }^{1}$ ).

Ueber die Ursachen, welche das Zustandekommen der Protoplasmabewegungen bedingen, ist noch wenig bekannt. Auf jeden Fall aber greifen eine ganze Reihe verschiedener Processe und wohl in verschiedenen Fällen nicht immer die nämlichen physikalischen sowie chemischen Vorgänge zusammen, wenn sich Protoplasmabewegungen geltend machen. BERTHOLD ${ }^{2}$ ) hat versucht, die verschiedenen Formen der Bewegung plasmatischer Massen unter Heranziehung derjenigen Bewegungserscheinungen begreiflich zu machen, welche todte Körpertheilchen unter bestimmten Umständen zeigen.

Es ist lehrreich, sich von der Thatsache zu überzeugen, welche, abgesehen von vielen anderen Momenten, ohne Zweifel bei Begründung einer zukünftigen Theorie der Protoplasmabewegungen Berücksichtigung finden muss, dass todte Substanzen oft zu Bewegungen befähigt sind, die mit Protoplasmabewegungen eine gewisse Aehnlichkeit haben.

Auf eine trockene Glasplatte, die auf einem Bogen weissen Papiers ruht, bringen wir mit Hülfe eines Glasstabes einige Tropfen nicht $\mathrm{zu}$ concentrirter alkoholischer Fuchsin- oder Methylanilinviolett-Lösung. Die Tropfen breiten sich an ihrem Umfange nicht gleichmässig auf der Glasplatte aus, sonrlern es bilden sich bald hier, bald dort, Flüssigkeitsausstülpungen, und man wird unwillkürlich an amöboide Protoplasmabewegungen erinnert. Wir bringen destillirtes Wasser in eine sorgsam gereinigte Krystallisirschale und werfen kleine Kampferstückchen in die Flüssigkeit. Die Kampferstückchen gerathen 11un, indem sie sich ganz allmählich in dem Wasser auflösen, in sehr leb-

1) Vgl. Hauptfleisch in Pringsheim's Jahrbüchem f. wissenschl. Botanik, Bd. 24, S. 173. KiENITZ-GerloFF, Botan. Zeitung, 1893, ist der Ansicht, dass in jeder lebensthätigen Zclle normalerweise Plasmabewegung bestehe. Er kommt zum Theil auf Grund allgemeiner Erwägungen zu diesem Resultat, welche Beachtung verdienen. Wenn Zellen, die aus ihrem normalen Verbande losgelöst sind, zunächst keine Bewegung zeigen, so ist das nach KuExrTz Folge des mechanisehen Eingriftes. Der Gegenstand bedarf weiterer Prüfung.

2) Vgl. Bertiold, Studien über Protoplasmamechanik, Leipzig 1856. 
hafte Bewegung, und ich sah diese letztere oft stundenlang fortdauern.

Wenn wir auf das Wasser, auf welchem sich der Kampfer bewegt, mit Hülfe eines Glasstabes eine Spur Olivenöl bringen, so hört die Bewegung schnell auf. Das sich ausbreitende Oel erhöht nämlich die Oberflächenspannung an der Wasseroberfläche sehr bedeutend, und dadurch kommt die zuletzt erwähnte Erscheinung zu Stande. Wird ein Tropfen Leberthran auf 0,25-proc. Sodalösung gesetzt, so treten sehr interessante Ausbreitungserscheinungen am Tropfen hervor. Es sind Veränderungen der Oberflächenspannungsverlältnisse, die für das Zustandekommen der hier in Rede stehenden Bewegungen vielfach maassgebend erseheinen, und Spannungsänderungen spielen auch bei dem Auftreten der Plasmabewegungen sicher eine grosse Rolle. Es wird aber noch sehr eingehender Studien bedürfen, um die complicirten Phänomene, wie sie sich in der lebendigen Zelle geltend machen, im Detail zu begreifen ${ }^{1}$ ).

Von sehr wesentlichem Einfluss auf die Geschwindigkeit der Protoplasmabewegung sind die Temperaturverhältnisse. Bei niederer Temperatur bewegt sich das Protoplasma langsam. Mit steigender Temperatur nimmt die Geschwindigkeit der Bewegung zu, um nach Ueberschreitung des Temperaturoptimums, welches z. B. nach $\nabla_{\text {eltren }}{ }^{2}$ ) für die Protoplasmabewegung in den Blattzellen von Elodea bei $36^{\circ} \mathrm{C}$. liegt, wieder langsamer zu werden. Lehrreich ist es, sich durch Beobachtung davon zu überzeugen, dass das Plasma bei einer bestimmten Temperatur, die nicht weit von derjenigen entfernt ist, durch welche die Zellen getödtet werden, den Zustand der vorübergehenden Wärmestarre annimmt.

Wir erwärmen Wasser in einer Porzellanschale auf dem Wasserbade. In das Wasser taucht ein Thermometer ein. Wir ziehen nun einen Epidermisstreifen von den jüngeren Theilen, z. B. einem jungen Blattstiel, eines Exemplars von Cucurbita Pepo ab, constatiren das Vorhandensein der Circulation des Plasmas in den Zellen der Haare, merken uns einige der beobachteten Haare genau und tauchen den Epidermisstreifen, den wir mittelst einer Pincette festhalten, in unmittelbarer Nähe der Thermometerkugel in das erwärmte Wasser ein. Verweilt das Untersuchungsobject zwei Minuten lang in Wasser von $46^{\circ} \mathrm{C}$., so ist, wie die mikroskopische Untersuchung ergiebt, jede Bewegung des Protoplasmas in den Haarzellen sistirt. Das Protoplasma ist in den Zustand der vorübergehenden Wärmestarre übergegangen. Nach Verlauf von 1 bis 2 Stunden macht sich die Protoplasmabewegung bei niederer Temperatur aber wieder geltend ${ }^{3}$ ).

Ebenso wie bei zu hoher Temperatur erlischt die Protoplasmabewegung bei niederen Wärmegraden. In manchen Fällen ist die Temperatur, bei der das Protoplasma freilich noch nicht abstirbt, wohl aber vorübergehend kältestarr wird, bei 2 oder $4^{\circ} \mathrm{C}$. zu suchen. Werden aber Cucurbitasprosse einige Zeit bei einer Temperatur von $10^{\circ} \mathrm{C}$. gehalten, so dass sie sich auf diesen Wärmegrad abkühlen, dann ist das Protoplasma in den

1) Ein näheres Eingehen auf diese Dinge ist hier nicht am Platze. Vergl. übrigens BÜTSCILI, Untersuchungen über mikroskopische Schäume; VERWORN, Bewegungen der lebenden Substanz, 1892. DETMER, Berichte der Deutschen botan. Gesellschaft, Bd. 10, S. 436; ENGELMANN, Ursprung der Mluskelkraft, 1893.

2) Vgl. Veltex, Flora, 1876.

3) Vgl. Saciss, Flora, 1864, S. 67. 
Haaren bereits kältestarr. Temperaturerhöhung ruft die Circulation des Plasmas wieder hervor.

Will man feststellen, dass mit steigender Temperatur vom Temperaturminimum aus die Protoplasmabewegung lebhafter wird, bei einer bestimmten Temperatur (z. B. etwa $35^{\circ}$ C. in den Haaren von Cucurbita) am lebhaftesten vor sich geht, um bei noch höherer Temperatur wieder an Geschwindigkeit abzunehmen, so bedarf man eines besonderen Apparates zur Temperaturregulirung.

Ein sehr leistungsfähiger Apparat dieser Art ist von Prefrer construirt worden ${ }^{1}$ ), aber auch der in Fig. 137 abgebildete Apparat von

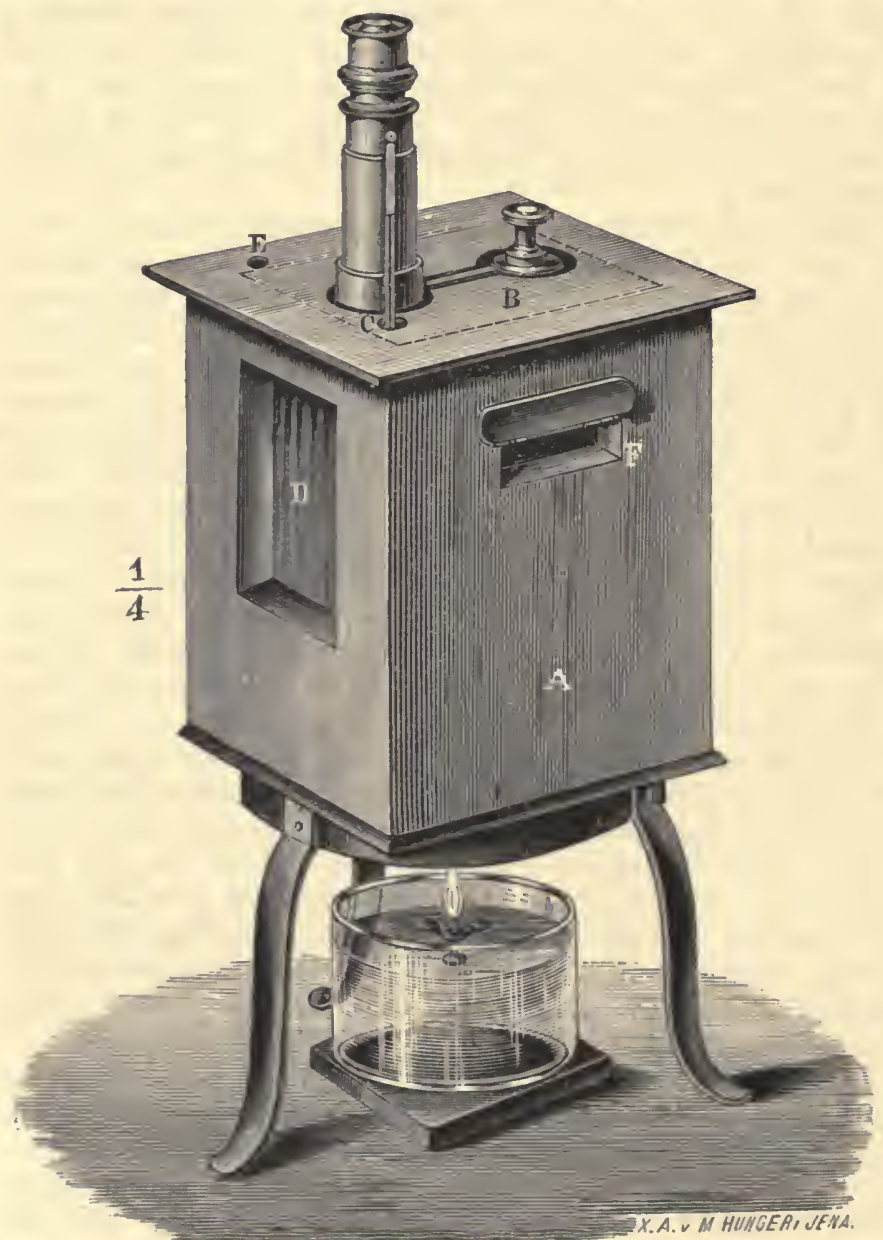

Fig. 137. Wïmekasten nach Sachs. SACHS kann Verwendung finden. Die Grösse des Wärmekastens muss derjenigen des Mikroskops entsprechen. Der nahezu würfelförmige Kasten hat unten und an den Seiten doppelte

Wände von Zinkblech, die einen Zwischenraum von $25 \mathrm{~mm}$ Dicke umschliessen, der mit Wasser gefüllt wird. Oben ist der Kasten ganz offen, an der vorderen Seitenwand aber eine Oeffnung angebracht, die mit einer gut passenden, aber nicht weiter befestigten Glasplatte verschlossen wird. Dies Fenster $D$ ist so gross und derartig angebracht, dass es hinreichend Licht auf den Spiegel des im Kasten stehenden Mikroskops gelangen lässt. Die Höhe

1) Vgl. Prefrfer, Zeitschrift f. wissenschl. Mikroskopie, Bd. 7.

2) Vgl. SACHS, Lehrbuch d. Botanik, 4. Aufl., S. 746. 
des Kastens ist so abgemessen, dass der obere Rand des Doppelkastens mit der Brücke des Mikroskops in gleicher Höhe liegt. Die Oeffnung des Kastens wird mit einem dicken Pappdeckel verschlosseu, in dem man eine Oeffnung so angebracht hat, dass sie die Brücke genau umschliesst. Noben dem Tubus ist in dem Deckel ein rundes Loch vorhanden, durch welches man mit starker Reibung ein kleines Thermometer einschiebt, so dass dessen Kugel neben dem Objectiv hängt. Der Kasten ist inwendig mit schwarzem Lack angestrichen, und ein mit Wasser durchtränktes Pappstück liegt unter dem Fuss des Mikroskops, welches dadurch fester steht. Auch hat der feuchte Pappdeckel den Zweck, die Luft in der Umgebung des Objects feucht zu erhalten. Dureh die über den Deckel hervorragende Stellschraube kann die Einstellung anf das Object bequem geregelt werden; zwei seitliche Oeffnungen, von denen die Figur eine zeigt, dienen dazu, den Objectträger, wenn nöthig, mit einer Pincette zu verschieben. Noch bequemer ist es, die Objectträger an einem Draht zu befestigen, der durch einen in dio Oeffnung $F$ passenden Kork geht. Der Wärmekasten ist von LEiтz in Wetzlar zu beziehen. Will man bei höherer Temperatur beobachten (über $50^{\circ} \mathrm{C}$. darf man nicht gehen, da die Objective sonst leiden), so erwärmt man das Wasser im Kasten durch eine untergestellte Spirituslampe; hat die Temperatur ungefähr die gewünschte Höhe erreicht, so setzt man statt jener eine Oellampe mit Schwimmer unter und wartet, bis die Temperatur constant bleibt. Um höhere oder niedere Temperaturen zu bekommen, genügt es, 1, 2 oder 3 Schwimmer mit Nachtlichtern in die Lampe zu setzen. Um bei niederen Temperaturen zu beobachten, genügt es, dem Wasser im Kasten ab und an Eisstückchen zuzusetzen. Sehr empfehlenswerth ist es, den aus dem Wärmekasten herausragenden Theil des Mikroskops mit Watte zu umwickeln, um auf der Hand liegende Fehlerquellen der Methode möglichst auszuschliessen.

Bei genauen Untersuchungen über den Einfluss der Temperatur auf Protoplasmabewegung ist es erforderlich, die Zeit festzustellen, welche ein Inhaltsbestandtheil einer Zelle, z. B. ein Chlorophyllkorn, bei bestimmter Temperatur bedarf, nm von dem einen Rande des Gesichtsfeldes, die Mitte desselben passirend, zum anderen $\mathrm{zu}$

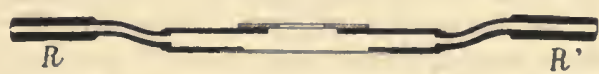

Fig. 13S. Gaskammer zum Gebrauch bei mikroskopischen Untersuchungen, im Durchschnitt dargestellt. gelangen. Auch kann man

die Zeit constatiren, welche ein Chlorophyllkorn braucht, um sich an der nicht das ganze Gesichtsfeld einnehmenden Längswand einer Zelle fortzubewegen. $\mathrm{Zu}$ beachten ist, dass man nur solche Chlorophyllkörper bei der Beurtheilung der Geschwindigkeit der Plasmabewegung ins Auge fasst, die sich frei und ungestört durch andere Chlorophyllkörper bewegen.

Handelt es sich um die Constatirung der wichtigen Thatsache, dass Mangel freien Sauerstoffs die Protoplasmabewegung aufhebt, so experimentirt man sehr bequem unter Benutzung einer vom Mechaniker AlBrecht in Tübingen im Preise von 15 Mk. gelieferten Gaskammer. Vergl. Fig. 138. Dieselbe hat etwa $7 \mathrm{~cm}$ Länge, $4,5 \mathrm{~cm}$ Breite und $5 \mathrm{~mm}$ Höhe. Sie ist aus Metall gearbeitet. In den unteren Boden ist eine ziemlich grosse Glasplatte luftdicht eingekittet; der obere Boden besitzt ein kreisrundes Loch. Hier wird das Deckglas aufgelegt, so dass sich das Untersuchungsobject im hängenden Tropfen im Innern der Gaskammer befindet. Der Boden derselben wird mit einer dünnen Schicht ausgekochten Wassers 
benetzt, um das Object vor Austrocknung zu schützen. Das Deckglas kann leicht mit Hülfe von Fett luftdicht aufgelegt werden. Die Röhren $R$ und $R$ dienen zum $\mathrm{Zu}$ - und Ableiten der Gase. Das zu verwendende Wasserstoffgas wird mit Berücksichtigung der unter 160 angegebenen Vorsichtsmaassregeln entwickelt und gereinigt. Dio Gaskammer findet ihren Platz auf dem Tisch des Mikroskops. Als Untersuchungsobjecte wählen wir z. B. Staubfadenhaare von Tradescantia oder Haare des jungen Blattstieles von Cucurbita Pepo. Bequem ist es auch mit Infusorien zu experimentiren. Wir erhalten dieselben leicht, wenn wir Heu mit Wasser übergiessen und etwa 8 Tage lang ruhig stehen lassen. In der Flüssigkeit sind dann meist viele Paramecien, deren gestreckter Körper mit Cilien besetzt ist, vorhanden. Auch Vorticellen findet man. Sind die Untersuchungsobjecte (Haare oder Infusorien) in den hängenden Tropfen gebracht, und hat man das Torhandensein von Bewegungserscheinungen constatirt, so beginnt man sogleich mit dem Durchleiten des Wasserstoffs. Mir ist aufgefallen, dass man oft lange Zeit (zuweilen mehrere Stunden lang) Gas durch den Apparat leiten muss, bevor die Bewegungen aufhören. Die Strömungen des Plasmas und ebenso die freien Ortsbewegungen der Organismen finden eben noch bei Gegenwart minimaler Sauerstoffmengen statt. Ist das Plasma endlich bewegungslos geworden, so kann der erzielte Zustand der Asphyxie durch Luftzutritt wieder aufgehoben werden ${ }^{1}$ ).

\section{Die freien Ortsbewegungen niederer Organismen (Schwärmerbewegungen etc.).}

Es giebt zahlreiche niedere Pflanzen, welche ebenso wie die typischen animalischen Wesen zu freien Ortsbewegungen befahigt sind. Die Mechanik dieser Bewegungen ist noch unklar, weshalb wir auf dieselbe nicht näher eingehen. Dagegen handelt es sich hier um Constatirung der Bewegungserscheinungen selbst und um Feststellung des Einflusses, den äussere Verhältnisse auf dieselben ausüben.

Wir wollen zunächst Euglena viridis in Untersuchung nehmen, einen Organismus, der freilich in morphologischer Hinsicht nicht mit typischen Algen, sondern mit den Infusorien zusammenhängt, aber sich in mehr als einer physiologischen Beziehung den Algen anschliesst. Das Untersuchungsmaterial ist leicht $\mathrm{zu}$ erlangen; es findet sich in stehenden Gewässern, Strassenrinnen und Dorflachen. Ich habe das Euglenamaterial, um recht lebenskräftige Individuen zur Untersuchung zu gewinnen, zunächst einige Tage auf Torfstücken cultirirt, die in einer Schale lagen, in welcher sich Nährstofflösung, wie man sie zu Wasserculturversuchen benutzt, befand. Die Torfstücke tauchten etwa bis $\mathrm{zu}$ halber Höhe in die Lösung ein, und das grüne Euglenamaterial wurde einfach auf ihre feuchte Oberfläche gebracht. Haben die Culturgefässe einige Tage vor einem nach Süden gelegenen Fenster gestanden, so werden die Torfstücke in eine Porzellanschale gelegt, mit Brunnenwasser übergossen und einige Stunden unter Wasser belassen. In dieser Zeit sammeln sich zahlreiche Euglenaschwärmer in dem Wasser an. Die mikroskopische Untersuchung ergiebt, dass der Körper der Euglena viridis von spindelförmiger Gestalt ist. Kern und Chlorophyll-

1) Vgl. auch Clakk, Berichte der Deutschen botan. Gesellschaft, Bd. 6, S. 273. 
liörper sind vorhanden. Am vorderen Körperende, das eine lange Cilie trägt, sind Vacuolen und ein rother Augenfleck zu sehen. Nach KLEBS ist der Euglenaorganismus zeitlebens von einer Membran umgeben, und unter ungünstigen äusseren Bedingungen gehen die Euglenen in einen Dauerzustand über, in welchem sie bewegungslos werden. Die freien Vorwärtsbewegungen der Euglenaschwärmer werden durch die Cilie vermittelt und sind stets mit Rotation des ganzen Körpers verbunden. Um diese Vorwärtsbewegungen genau verfolgen zu können, bringen wir Schwärmer mit Hülfe einer Glasröhre, die wir in das Euglenaindividuen enthaltende Wasser, in welchem unsere Torfstücke gelegen haben, eintauchen, in den hängenden Wassertropfen einer kleinen feuchten Kammer und beobachten mit. Hülfe des Mikroskops. (Ueber die Herstellung derselben vergl. unter 138.) Die Schwärmer vermögen sich bei völligem Lichtabschluss zu bewegen, ebenso wie bei Lichtzutritt; indessen ist das Licht von einem richtenden Einfluss auf die Bewegung der Euglena; diese gehört also zu den phototaktischen Organismen. Bei Beginn unseres Experiments sind die Schwärmer ziemlich gleichmässig in dem hängenden Tropfen der feuchten Kammer vertheilt. Es lässt sich aber leicht unter dem Mikroskop feststellen, dass sich fast alle Schwärmer, zumal wenn wir das vom Spiegel reflectirte Licht abblenden, sehr schnell an dem nach dem Fenster, also der Lichtquelle, zugewandten Tropfenrande ansammeln. Drehen wir den Objectträger mit der feuchten Kammer 1 m $180^{\circ}$, so gerathen die Schwämer wieder in lebhafte Bewegung und suchen anfs Neue den der Lichtquelle zugekehrten Tropfenrand zu erreichen. Diese Erscheinungen beobachtet inan aber nur dann, wenı das Licht, welches auf die Schwärmer einwirkt, kein $\mathrm{zu}$ intensives ist. Bei hoher Lichtintensität nämlich sammeln sich die meisten Schwärmer nicht am Lichtrande des Tropfens, sondern am gegenüberliegenden Rande desselben an. Sie fliehen also unter diesen Umständen das Licht.

Wird ein flacher Teller mit Wasser gefüllt, in welchem viele Euglenen vorhanden sind, und in die Nähe des Fensters gebracht, so sammeln sich die Schwärmer bei nicht $\mathrm{zu}$ intensivem Licht am Fensterrande des Tellers an. Dreht man den Teller um $180^{\circ}$, dann sind alsbald wieder die meisten Schwärmer am Fensterrande gruppirt. Ich habe mehrfach bei derartigen Experimenten mit Euglena eine so lebhafte Bewegung der Schwärmer zur Lichtquelle beobachtet, dass der richtende Einfluss der Lichtstrahlen auf die Organismen im Laufe einer Stunde mehrfach an demselben Material festgestellt werden konnte.

Unter gewissen Umständen, zumal damn, wenn die freie Vorwärtsbewegung der Schwärmer gehindert ist (z. B. in unserer feuchten Kanmer bei Ansammlung der Schwärmer am Lichtrande des Tropfens), veråndert sich die Körpergestalt der Schwärmer von Euglena in auffallender Weise (Metabolie). Euglena viridis schwillt mit Vorliebe in der Mitte an und zieht sich an den Enden dünn aus; die Schwärmer anderer Euglenaspecies krümmen sich halbmondförmig.

.... Geeignetes Untersuchungsmaterial bei Beobachtungen über Schwårmerbewegungen bietet auch Haematococcus lacustris dar, eine Alge, die z. B. bei Jena in der Leutra vorkommt und die Steine, auf denen sie sitzt, schön roth färbt. Wir bringen einige mit Haematococcus besetzte Steine in eine grosse flache Schale, deren Boden nur eben 
mit Wasser bedeckt ist, legen eine Glasplatte auf dic Schale und lassen dic Gefässe mehrere Tage ruhig stehen. Nach Verlauf dieser Zeit werden einige Steine in einem anderen Gefäss mit Wasser übergossen. Wir lassen sie bis zum nächsten Tage im Wasser liegen und finden gewöhnlich, dass dieses nun viele rothe Haematococcusschwärmer enthält. Die Schwärmer sind, ebenso wie diejenigen von Euglena, phototaktisch. Sie bewegen sich bei nicht $\mathrm{zu}$ intensivem Licht und günstigen Temperaturverhältnissen (etwa $20^{\circ} \mathrm{C}$.) dem Licht entgegen. Ich habe mich davon überzeugt, dass es wichtig ist, um recht viele Haematococcusschwärmer zu erhalten, die Steine, bevor man sie mit Wasser völlig übergiesst, einige Tage lang in angegebener Weise im dampfgesåttigten Raume aufzubewahren ${ }^{1}$ ).

Aehnliche Experimente, wie solche im Vorstehenden erwähnt worden sind, lassen sich auch mit den kleinen grünen Schwärmern von Clamydomonas ausführen, die sich z. B. zuweilen in nicht benutzten Brunnentrögen in grosser Menge entwickeln. Es ist noch zu beachten, was zumal bei Versuchen mit Haematococcus nicht selten sehr deutlich hervortritt, dass die Schwärmer in verschiedenen Entwickelungsstadien auf Licht von ganz verschiedener Intensität gestimmt sein können. Nicht immer z. B. suchen die Schwärmer, wenn man ihr Verhalten im hängenden Tropfen studirt, im diftusen Licht den Lichtrand des Tropfens auf. Oft sammeln sie sich vielmehr, wenn das Mikroskop dicht am Fenster aufgestellt ist, an dem dem Zimmer zugewandten Tropfenrande an. Die Schwärmer sind dann auf Licht geringer Intensität gestimmt, und um sie an den Lichtrand des Tropfens zu bringen, muss das Mikroskop inehr oder minder weit vom Fenster entfernt werden.

In einem Dunkelzimmer bringen wir im Fensterladen eine $\overline{5}-7 \mathrm{~cm}$ weite, kreisrunde Oeffnung an. Vor dieser Oeffnung können Glasflaschen mit parallelen Wänden Platz finden, die entweder eine Lösung von doppeltchromsaurem Kali oder eine solche von Kupferoxydammoniak enthalten. Die erstere Flïssigkeit ist derartig hergestellt, dass sie nur die minder brechbaren Strahlen (Roth, Orange, Gelb und etwas Grün) durchlässt; die zweite Lösung absorbirt diese Strahlen und lässt allein die stärker brechbaren Strahlen passiren. Steht kein Dunkelzimmer zur Disposition, so lässt sich der Versuch auch unter Benutzung eines grossen Kastens, der im Innern mit mattschwarzem Papier überklebt ist, durchführen. Wir setzen nun Schwärmer in hängenden Tropfen dem Licht von verschiedener Wellenlänge aus. Unter dem Einfluss der weniger brechbaren Strahlen verhalten sich die Organismen wie im Dunkeln; die Strahlen dagegen, welche die Kupferoxydammoniaklösung passirt haben, sind, ebenso wie gemischtes weisses Licht, von wesentlichem Eintluss auf die Bewegungsrichtung der Schwärmer.

Ueber die Methode, welche bei Untersuchung des Verhaltens der Schwärmer in den einzelnen Strahlengruppen des objectiven Spectrums anzuwenden ist (vgl. Strasburger's citirte Arbeit; Methodisches auch bei Pfeffer, Botan. Zeitung. 1872, Nr. 23). Hier und in manchen anderen Fällen dürfte es sich für pflanzenphysiologische Versuche sehr

1) VgL. StrasbdrakR, Wirkung der Wärme und des Lichts auf Schwärmsporen, Jena 1878, und KLEBs, Untersuchungen aus dem botan. Institut zu Tübingen, Bd. 1, H. 2. 
empfehlen, das Spectrum mittelst des RaulaND'schen Gitters herzustellen.

Auch unter dem Einfluss von Gaslicht lassen die Schwärmer ihre phototaktischen Eigenschaften erkennen. Wenn man zwischen das Gaslicht und das Mikroskop eine concentrirte Alaunlösung in geeigneter Weise einschaltet, so reagiren die Organismen in gewöhnlicher Weise auf den Lichtreiz. Diese Reaction hört aber bei Ein: schaltung einer Lösung von Jod in Schwefelkohlenstoff auf. Da die Alaunlösung sehr atherman, die zweite Flüssigkeit in hohem Grade diatherman ist, so darf man unter Beachtung der Resultate der letzten Experimente schliessen, dass dunkle Wärmestrahlen ohne Einfluss auf die Richtung der Schwärmerbewegung sind.

Ebenso kommen den Algenschwärmern, wie man leicht unter Benutzung von Papierstreifen nach der unter 171 angegebenen Methode constatiren kann, keine rheotropischen Eigenschaften zu. Dagegen sind die Algenschwärmer geotropisch reizbar, wie das folgende Experiment wohl sicher beweist ${ }^{1}$ ). Wir saugen etwas Wasser, das Euglenen enthält, in einer unten und oben offenen Capillare von 0,5 mm Durchmesser empor. Stellen wir die Capillare im Dunkeln senkrecht auf, so sammeln sich die Schwärmer im oberen Theil der Capillare an.

Von Interesse ist es, dass die Schwärmer mancher Algen in ausgeprägter Weise aerotropisch sind. Diese Erscheinung ist für die Schwärmer von Euglena specieller von ADERHOLD constatirt worden, und wir stellen das folgende Experiment an, um dieselbe kennen zu lernen. Eine kleine Schale wird mit Wasser angefüllt, das sehr zahlreiche Euglenaschwärmer enthält. Ebenso füllen wir ein Probirglas mit diesem Wasser bis zum Rande an, verschliessen die Mündung mit dem Daumen und stellen das Probirglas nunmehr derartig auf, dass sein offenes Ende in das Wasser eintaucht, welches sich in der Schale befindet. Bei Lichtabschluss haben nach Verlauf längerer Zeit fast sämmtliche Schwärmer das Wasser im Probirglase verlassen und sich in dem Wasser der Schale angesammelt. Diese Erscheinung ist keineswegs Folge von positivem Geotropismus der Schwärmer oder anderer Ursachen, sondern sie beruht auf dem Aerotropismus der Schwärmer; dieselben suchen an solche Orte zu gelangen, an welchen ihnen reichlichere Sauerstoffmengen zur Verfügung stehen. Dies geht mit aller Deutlichkeit aus den folgenden Beobachtungen hervor. Wenn die Schwärmer das Probirglas verlassen haben, so verdrängen wir etwas Wasser aus demselben durch Luft, breiten auf der Obertäche der an Schwärmern reichen Flüssigkeit in der Schale eine Oelschicht aus und überlassen den Apparat im Dunkeln sich selbst. Die Schwärmer treten nunmehr in erheblicher Menge aus dem Wasser der Schale in dasjenige des Probirglases über, weil sich ihnen hier reichlichere Sauerstoffmengen darbieten.

Eine weitere Verbreitung besitzen in stehenden Gewåssern und auf schlammigem Boden meistens blaugrün gefürbte Organismen, die in Form von Fäden auftreten und als Oscillarien bekannt sind. Diese Organismen zeigen verschiedene Bewegungserscheinungen, welche man unter dem Mikroskop näher verfolgen kann. Besonders auffallend sind

1) Vergl. Aderhoud, Jenaische Zeitschrift f. Naturwissenschaft, Bd. 22, und Jexsex, Archiv f. d. ges. Physiologie, Bd. 53. 
die unregelmässigen Krnümmungen, welche die sich nach vorn oder rückwärts bewegenden Oscillarienfädlen ausführen.

Bei dem Zustandekommen der bisher erwähnten Bewegungsphänomene verhalten sich die niederen Organismen activ. Es müssen hier aber ferner noch einige merkwürdige Erseheinungen Erwähnung finden, die ihre Ursache in rein passiven Bewegungen, denen Schwärmsporen unterliegen, haben.

Wird grün gefärbtes Wasser, welches viele Clamydomonas- oder Euglenuschwärmer enthält, in einen Teller gegossen und dieser nach $\mathrm{Be}$ deckung mit einer Glasplatte in die Mitte eines grossen Zimmers unter einen Papprecipienten gestellt, so findet man nach Verlauf einiger Zeit, dass sich die Algen in Form concentrisch angeordneter Wolken oder in Form anderweitiger regelmässiger Figuren in dem Wasser gruppirt haben. Entfernt man die Glasplatte von dem Teller, dann lösen sich die Figuren schnell auf. Wird ein Teller, in dem man algenhaltiges Wasser gegossen hat, derartig (z. B. vor einem Fenster) aufgestellt, dass der eine Tellerrand eine etwas höhere Temperatur als der andere annimmt, dann sammeln sich die Schwärmer (auch bei Lichtabschluss) je nach Umständen an diesem oder jenem Tellerrande an. Nach den Untersuchungen von SACHS ${ }^{1}$ ) kommen alle diese Phänomene durch Wasserströmungen zu Stande, welche die Schwärmer in bestimmter Weise gruppiren und ihrerseits ihren Grund in. Temperaturverhältnissen haben. Diesen Nachweis führte SACHS unter Berücksichtigung derjenigen Ergebnisse, zu denen er bei dem Studium von Emulsionsfiguren gelangte. Die Flüssigkeit, welche dazu dienen soll, uns diese Figuren zur Ansehauung zu bringen, bereiten wir in folgender Weise. Es wird grob zerkleinerte Alkannawurzel mit reinem Baumöl übergossen und das nach Verlauf von 24 Stunden intensiv roth gefärbte Oel abfiltrirt. Es wird weiter in einem Glascylinder eine Mischung von Wasser und Alkohol hergestellt, deren specifisehes Gewicht, wie die Prüfung mit dem Aräometer ergiebt, genau 0,920 beträgt. Diese Flüssigkeit hat fast genau das specifische Gewicht des Baumöls. Wenn man eine kleine Menge der Mischung des Wassers und Alkohols in ein Becherglas giesst und etwas gefärbtes Baumöl hinzufügt, so müssen grössere Oeltropfen sehr langsam in der Flüssigkeit emporsteigen; sie ist also von etwas höheremi specifischen Gewicht als das Oel.

Sind diese Controlversuche angestellt, so bringt man zu je $500 \mathrm{cem}$ des Gemisches von Alkohol und Wasser je $5 \mathrm{ccm}$ des rothen Oeles, schüttelt, worauf hesonderes Gewicht zu legen ist, sehr kräftig, wobei die grösseren Oeltropfen in Tausende feinster Tröpfchen zertrümmert werden, und. hat auf diese Weise die erforderliche Emulsionsflüssigkeit bereitet.

Zum Gebrauch wird sie in flache Porzellanteller gegossen, so dass sie in denselben eine Sehicht von etwa $10-15 \mathrm{~mm}$ Höhe bildet. Man bedeckt den Teller mit einer Glasplatte oder lässt ihn unbedeckt stehen und beobachtet, wie die sich bewegenden Oeltropfen zunächst Tupfen und Netze bilden und sich im Laufe einiger Zeit $(1 / 4-1 / 2$ Stunde) zu regelmässigen Figuren gruppiren. Hatte man den Teller nach dem Eingiessen der Emulsionsflüssigkeit mit einer Glasplatte bedeckt, und liebt man diese nach der Bildung der Emulsionsfiguren-ab, so lösen sich diese letzteren schnell unter den Augen des-Beobachters auf.

Die Gestalt der Emulsionsfiguren ist eine sehr mannigfaltige. In Fig. $139 B$ ist eine häufig auftretende Form dargestel]t. Solele concen-

1) Vgl. Sachs, Flora, 1876. 
trische Figuren-bilden sich aber nur, wenn die Teller, in welche man die Emulsion hineingiesst, in der Mitte des Zimmers stehen. Polarisirte Figuren, wie eine solche in Fig, $139 A$ abgebildet ist, entstehen dagegen, wenn man die Teller in del Nähe eines Fensters oder eines geheizten Ofens aufstellt und der eine Tellerrand also wärmes als der andere ist. Experimentirt man z. B. mit der erwähnten Emulsion, deren gefärbtes Oel ganz wenig specifisch leichter als das Gemisch von Alkohol und Wasser ist, so sind die Spitze und die Randlinien der polarisirten Figur stets nach dem kälteren Tellerrande hingewandt. Die Entstehung der Emulsionsfiguren ist auf Flüssigkeitsströmungen, die ihrerseits ihren Grund in Temperaturverhältnissen haben, zurückzuführen. Die Emulsionsfiguren selbst haben die grösste Aehnlichkeit mit denjenigen Figuren, welche die Zoosporen unter den schon oben bezeichneten Umständen bilden, und allen diesen Erscheinungen liegen auch die nämlichen ursächlichen Momente zu Grunde.

Von erheblichem Interesse ist es auch, die Beeinflussung der Bewegung von Bacterienschwärmern durch verschiedene Substanzen zu studiren. Auf das aerotaktische Verhalten dieser Schwärmer wurde bereits unter 11 hingewiesen; hier handelt es sich um die
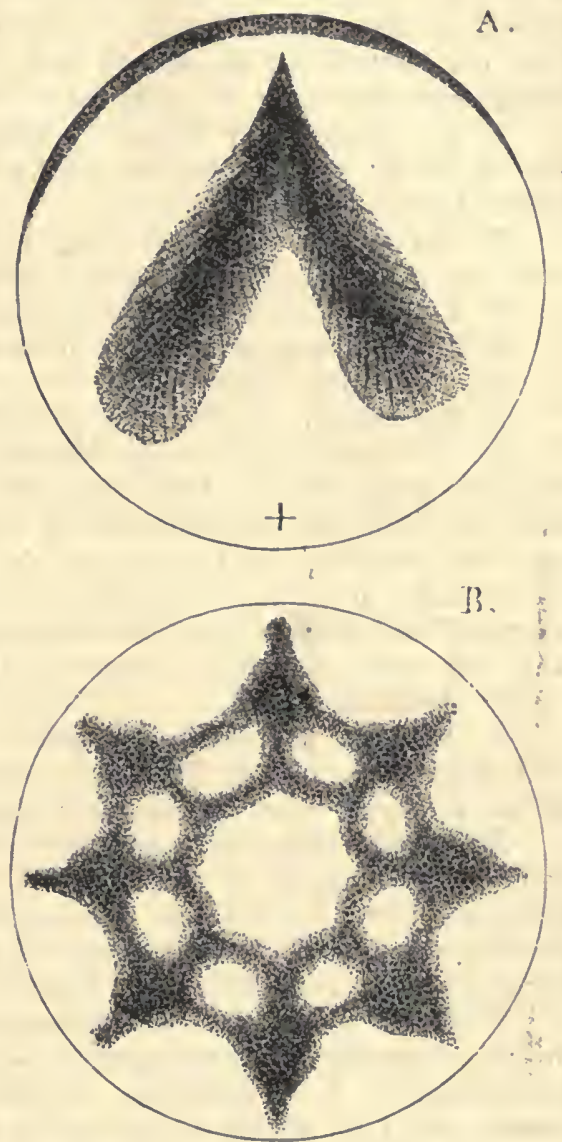

Fig. 189. Emulsionsfigureu. (Nach SAcus.) sog. chemotactischen Bewegungen derselben ${ }^{1}$ ) ${ }^{2}$ ).

Wir tödten einen Erbsensamen durch Eintauchen in kochendes Wasser; iibergiessen ihn mit $100 \mathrm{ccm}$ Wasser und lassen ein oder zwei Tage lang stehen, bis sich in der Flüssigkeit reichlichere Mengen von Bacterium termo entwickelt haben. Die Fliissigkeit wird zur Beseitigung grösserer Zusammenballungen von Spaltpilzen durch grobes Papier filtrirt und direct zu den Beobachtungen verwandt.

Bei stärkerer Vergrösserung sieht man, dass die Schwärmer von Bacterium termo langsamere oder schnelle, bald nach vorwärts, bald nach rückwärts gerichtete Bewegungen ausführen. Wir schieben nun dem auf

1) Freilich ist die Bewegung der Organismen nach Orten relativ grossen Sauerstoffreichthums auch nur eine Form des ehemotaktischen Verhaltens.

2) Tgl. Ausführliches bei PFFFFER, Untersuchungen aus dem botan. Institut zu Tübingen, Bd. I, S. 450, und Bd. 2, S. 584. 
offenem Objectträger befindlichen bacterienhaltigen Tropfen eine Capillare $\mathrm{zu}$, welche diejenigen Lösungen enthält, deren Wirkung auf den Spaltpilz geprüft werden soll. Die Capillare, etwa $6 \mathrm{~mm}$ lang und von $0,06 \mathrm{~mm}$ Weite, wird nach Einlegen in die Versuchsflüssigkeit durch partielles Evacuiren unter der Luftpumpe so weit gefüllt, dass am zngeschmolzenen Ende ein lufterfüllter Raum von etwa $3 \mathrm{~mm}$ Länge bleibt. Als Versuchsfüssigkeiten benutzen wir folgende:

1) In angegebener Weise bereiteten Erbsenaufguss, in dem durch Kochen die Bacterien getödtet worden sind und den man durch Schütteln wieder mit Luft gesättigt hat;

2) 1-proc. Fleischextractlösung, bereitet durch Auflösen von 0,5 g Extract von gewöhnlicher Consistenz in $50 \mathrm{~g}$ Wasser;

3) 2-proc. Lösung von Chlorkalium;

4) 2-proc. Lösung von Chlorkalium mit Zusatz von 5-proc. Citronensäure.

Resultate der Versuche:

1) Es dringen nur einzelne Spaltpilze in die Capillare ein.

2) In kurzer Zeit (einige Minuten) sind sehr viele Bacterien in die Capillare eingetreten. Auch sammeln sich zahlreiche Schwärmer in der Nähe der Oeffnung der Capillare an. Allmählich vertheilen sich mit Fortgang der Diffusion der Lösung aus der Capillare diese letzteren Bacterien wieder mehr und die in dem Glasrohr vorhandenen rücken in Folge ihres Sauerstoffbedürfnisses zum Theil bis zur Luftblase empor, hier eine zweite, nach und nach sehr dicht werdende Ansanmlung bildend.

3) Aehnlich wie 2.

4) Einzelne Individuen dringen in die Capillare ein und gehen hier zu Grunde. Die meisten Bacterien prallen, da die Citronensäure abstossend auf sie einwirkt, vom Capillarmund zurück.

Bei Ausführung der Experimente ist das Mikroskop zitterfrei aufzustellen. Strömungen im Bacterientropfen sind nach Möglichkeit auszuschliessen, und die mit den Versuchsflüssigkeiten beschickten Capillaren müssen, bevor sie dem Schwärmer führenden Tropfen zugeschoben werden, durch schnelles Schwenken in Wasser äusserlich abgespült sein.

Wollen wir uns von der Thatsache des galvanotropischen Verhaltens niederer Organismen überzeugen, so experimentiren wir sehr bequem mit Paramecien, z. B. Paramecium aurelia ${ }^{1}$ ). Dies Infusor von gestreckter Gestalt führt in seinem Innern einen Kern sowie zwei abwechselnd pulsirende Vacuolen und ist an seiner Oberfläche mit vielen Cilien besetzt. Wird eine Hand voll Heu in einem grösseren Glasgefäss mit Teichwasser übergossen, dann entwickeln sich im Laufe von 8-14 Tagen neben Bacterien so zahlreiche Paramecien in der Flüssigkeit, dass dieselbe milchig getrübt erscheint.

Wir stellen nun folgenden Apparat zusammen. Die Drähte, welche von einer aus mehreren Elementen bestehenden galvanischen Batterie kommen ${ }^{2}$ ), sind mit einem Stromwender (PoHL'schen Wippe) verbunden. Von der Wippe gehen noch zwei fernere Drähte ab, deren Enden an unpolarisirbaren Elektroden (vgl. unter 63) befestigt sind. In die eine dieser letzteren Drahtleitungen ist ein elektrischer Schlüssel eingeschaltet.

Nun stellt man ein Mikroskop auf. Auf dem Tisch desselben findet ein Uhrglas Platz, welches Paramecien haltige Flüssigkeit enthält. Man Bd. 46.

1) Vgl. Verwors, Pflüger's Arch. f. d. gesammte Physiologie, Bd. 45 und

2) Der Strom, mit dem man arbeitet, darf weder zu schwaeh noch zu stark sein. Starke Ströme vernichten die Lebensthätigkeil der Infusorien. 
sieht die Infusorion schon bei schwacher Vergrösserung in lebhaftor Bewogung die Flüssigkeit nach allen Richtungen hin durchkreuzen. 'Taucht man die Pinsel der unpolarisirbaren Elektroden in dieselbe ein und schliesst den Strom, so drehen sich sämmtliche Paramecien wie auf Commando mit dem vorderen Körperpol nach der negativen Elektrode und alle schwimmen schnell auf dieselbe zu. In kurzer Zeit ist die Anodenseite der Flüssigkeit frei von Paramecien; alle haben sich an der Kathode versammelt. Oeffnet man den Strom, dann wenden sich die Infusorien mit ihrem vorderen Körperpol der Anode zu; sie schwimmen derselben entgegen, samineln sich an, aber die Ansammlung wird keine so vollständige wie nach der Schliessung des Stromes an der Kathode, denn die Paramecien vertheilen sich alsbald wieder gleichmässig in der Flüssigkeit.

Haben sich in Folge der Stromschliessung die Paramecien an der Kathode angehäuft, und wird die Pons'sche Wippe jetzt umgelegt, so führen die Paramecien sofort Axeneinstellungen und Bewegungen aus, die don uunmehr gegebenen Verhältnissen ontsprechen, und die Infusorien könneıl durch abwechselndes Umlegen der Wippe jeden Augenblick zur Umkehr gezwuugen werden. Bei Euglena viridis sind bis jetzt noch koine galvanotropischen Eigenschaften mit Sicherheit constatirt worden.

\section{Dic Bewegungen der Chlorophyllkörper.}

Die Bewegungen der Chlorophyllkörper in den Pflanzenzellen besitzen eine grosse biologische Bedeutung. Wir haben es hier, wie es scheint, nicht mit Figenbewegungen der Chlorophyllkörper zu thun, sonder'n die Stellungsïnderung, welche dieselben erleiden, wird durch Bewegungen des Protoplasmas vermittelt. Will man sich über die Bewegungen der Chlorophyllkörper genauer orientiren, so ist es besonders zweckmässig, Moosblätter oder Farnprothallien als Untersuchungsobjecte zu wählen, denn im Palissadenparenchym der gewöhnlichen Laubblätter erfahren die Chlorophyllkörper im Allgemeinen nur unbedeutende Aenderungen ihrer Lage, und in Schwammparenchym, in dessen Zellen freilich erhebliche Stellungsänderungen der Chlorophyllkörper eintreten können, sind die beziiglichen Verhältnisse aus mehrfachen Grïnden oft nicht leicht $z u$ verfolgen.

Werden die Pflanzen von Funaria hygrometrica oder Farnprothallien, die man in Gewächshäusern, in denen Farne cultivirt werden, ziemlich leicht findet, unter sonst normalen Verhältnissen einige Zeit im Dunkeln gehalten, so gehen die Chlorophyllkörper in die Dunkelstellung iiber, d. h. sie wandern in unserem Falle auf die zur Fläche unserer Objecte senkrechten Zellwandungen. In den Zellen anderer Objecte verhalten sich die Chlorophyllkörper übrigens nicht genau in derselben Weise. Die Chlorophyllkörper sind nun, wenn die 'Verdunkelung nicht zu lange (nur mehrere Stunden) gedauert liat, der Inhalt der Zellen also nicht in den Zustand der Dunkelstarre übergegangen ist, sondern sich noch im Phototonus befindet, in eigenthümlicher Weise für Lichtreiz empfindlich. Wir setzen Rasen von Funaria oder. Farnprothallien, die im Dunkeln verweilt haben, dem diffusen Licht aus, so dass die Pflanzen von oben her von den Lichtstrahlen getroffen werden. Nach einigen Stunden bringen wir einige Funariablätter oder einige Prothallien in den Wassertropfen auf den Objectträger, legen ein Deckglas auf und untersuchen. Die Chlorophyllkörper 
sind nicht mehr wie in der Dunkelstellung den Seitenwandungen der Zellen angelagert, sondern sie haben sich auf die Vorder-und Hinterwände derselben begeben, und \%war kehren sie dem Beobachter ihre breitere Fläche (Flächenstellung) zu. Nun set»en wir unsere Untersuchungsobjecte auf dem Objectträger unmittelbar dem directen Sonnenlicht aus und sorgen, um eine zu starke Frwärmung der Pflanzentheile zu verhüten, dafür, dlass das Deckglas auf seiner Aussenseite stets reichlich mit Wasser benetzt ist. Untersuchen wir nach Verlauf einiger Minuten, so gewahren wir die Chlorophyllkörper noch an dem nämlichen Platze wie bisher, aber ihre Form hat sich geändert. Die vorher polygonal erscheinenden Körner haben ihre Ecken eingezogen; sie sind rundlich geworden, und es tritt das Bestreben der Chlorophyllkörper deutlich hervor, dem $\mathrm{zu}$ intensiven Licht eine möglichst geringe Oberfläche darzubieten. Diese Abrundung der grünen Inhaltsbestandtheile der Zellen ist Folge einer Eigenbewegung derselben, dagegen wird ausser dieser durch recht intensives Licht auch eine Lageänderung der Chlorophyllkörper hervorgerufen, die das Protoplasma vermittelt. Wenn wir nämlich unsere Untersuchungsobjecte längere Zeit (bei meinen Versuchen mit Funariablättern $3 / 4$ Stunden) dem directen Sonnenlicht exponiren, so haben sich die Chlorophyllkörner von der Vorder- und Hinterwand der Zellen nach den Seitenwandungen derselben begeben, und sie sind hier in Profilstellung angeordnet. Die Gruppirung der Chlorophyllkörper in der Flächenstellung an der Vorder- und Hinterwand der Zellen kehrt übrigens zurück, wenn die Präparate einige Zeit diffusem Tageslicht ausgesetzt werden. Es unterliegt keinem Zweifel, dass die hier erwähnten Stellungsänderungen der Chlorophyllkörper von biologischer Bedeutung für die Pflanzen sind. Im diffusen Licht nehmen die grünen Inhaltsbestandtheile der Zellen eine Lage ein, durch welche sie in den Stand gesetzt werden, die Lichtstrahlen für den Zweck der Assimilation in sehr vollkommener Weise auszunutzen, während sie vor dem zerstörenden Einfluss zu intensiven Lichtes und zu starker Wärme durch Umlagerung auf die Seitenwandungen der Zellen geschützt werlen ${ }^{\mathbf{1}}$ ).

Die bezeichneten, durch Lichtreiz verursachten Bewegungen der Chlorophyllkörper machen sich nur geltend, wenn die Zellen normalen Lebensbedingungen ausgesetzt sinl. Bei zu niederer Temperatur, Feuchtigkeits- und Sauerstoffmangel treten sie dagegen nicht hervor, wie man durcl "entsprechend angeordncte Experimente leicht constatiren kanu.

\section{Die Bewegung der Plasmodien ron Aethalium septicum.}

Die Plasmodien der Myxomyceten sind $\mathrm{zu}$ eigenthümlichen Bewegungen befähigt; sic können von einem $\mathrm{zu}$ einem anderen Orte kriechen und verändern dabei fortwälırend ihre Umrisse. Aeussere Umstände beeinflussen diese Bewegungen in hohen Grade, ein Verhältniss, welches fül die Plasmodien hervorragende biologische Bedeıtung besitzt. Das Aethalium septicum kommt zumal in der Gerberlolie vor. Die gelben Plasmodien sind im Frïhjahr (z. B. im Mai, zu welcher

1) Vgl. Staht, Botan. \%eitung, 18so, S. 3:21. 
Zeit ich zahlreiche Experimente mit denselben anstellte) in den älteren Lohemassen aufzufinden. Ausserrlem trifft man aber auch zu dieser Zeit und ebenso im Winter Aethaliumsclerotien in Form kleiner, etwa $2 \mathrm{~mm}$ langer, knotenförmiger, gelber Massen in rler I,ohe an, aus denen man leicht Plasmodien gewinnen kann. Es muss hier ausdrücklich bemerkt werden, dass the Plasmorlien selı zarte, leicht absterbende und gegen Berührung mit der Hand empfindliche Gebilde sind. Daher müssen die Lohemassen mit den dieselben durchziehenden Plasmodien vorsichtig behandelt werden, und man thut am besten, die plasmodienlaltige Lohe, ohne sie viel zu berühren, in einem Kasten aus der Gerberei ins Laboratorium zu bringen. Wir stellen nun die folgenden Experimente an.

Ein schmaler, befeuchteter Streifen schwedischen Filtrirpapieres wird mit seinem einen Ende in ein zur Hälfte mit Wasser angefülltes Becherglas. eingetaucht. Das andere Ende des Streifens hängt frei nach unten herab und wird bei der Ausfuihrung der Versuche auf der die Plasmodien enthaltenden Lohe ausgebreitet. Verdunkelt man nun die ganze Vorrichtung, und hat man sie in einem Raum aufgestellt, in dem cine Temperatur von $25-30^{\circ} \mathrm{C}$. herrscht, so treten alsbald Plasmodienmassen aus der Lohe hervor und kriechen mehr und mehr an dem Papierstreifen empor. Diese Wanderung der Plasmodien anf einem völlig mit Wasser durchtränkten Substrat ist keine hydrotropische Frscheinung, sondern sie wirl durch Wasserströmung bedingt. Die Plasmodien sind also rheotropisch, und zwar wandern sie stets dem Wasserstrom entgegen.

Die Plasmodien reagiren aber auch auf eine verschiedene Feuchtigkeitsvertheilung im Substrat; sie sind nicht nur rheo-, sondern ebenso lyydrotropisch. Um diese Thatsache festzustellen, bringt man Plasmodien, die sich unter dem Einflusse eines Wasserstromes auf Fliess: papier angesammelt haben, in die Mitte einer mit mehrfacher Lage durchfeuchteten Filtrirpapiers berleckten Glasplatte. Die Plasmodien breiten sich in einem Dunkelkasten, in welchem die Iuft mit Wasserdampf gesättigt ist, gleichmässig auf dem horizontalen und durchfeuchteten Substrat aus. Gelangen die Untersuchungsobjecte nuninehr in einen trockenen, aber verdunkelten Raum, und bringt man in geringer Entfernung über den Plasmodien einen mit verdünnter Gelatinegallerte bestrichenen Objectträger all, so ist alsbald (oft nach wenigen Stunden) eine interessante Erscheinung zu beobachten. Das Fliesspapier trocknet allmählich aus, und die Plasmodien ziehen sich von den austrocknenden Stellen des Substrats zurück, sammeln sich aber unter dem Feuchtigkeit spendenden Objectträger an. Die Plasmodien verhalten sich also positiv hydrotropisch. Es muss bemerkt werden, dass unsere Untersuchungsobjecte wälırend der grössten Zeit ihres Entwickelungsganges in der Weise, wie es hier angegeben worden ist, auf verschiedene Feuchtigkeitsvertheilung reagiren, Dic der Fructification nahen Plasmodien sind dagegen negativ hydrotropisch.

Geotropisch sind die Myxomycetenplasmodien gar nicht, denn wenn man Fliesspapierstreifen mit Plasmodien auf eine vertical stehende feuchte Unterlage (z. B. auf mit Wasser durchtränktes Papier, das einer Glasplatte anliegt) bringt, so breiten sie sich bei Lichtabschluss und im dampfgesïttigten Raume nach allen Richtungen hin gleichmässig auf dem Substrat aus. 
Iicht von irgendwie grösserer Intensität, z. B. schon diffuses Tageslicht, flichen die Plasmodien wie es scheint stets. Setzt man von Plasmodien durchzogene Lohestücke in dampfgesättigten Raum dem Licht aus, so zieht sich das Plasmodium in die Lohe zurück. Fbenso suchen auf Glasplatten ausgebreitete Plasmodien bei Lichtzutritt dic Orte geringster Lichtintensität, z. B. beschattete Stellen, auf. Auf die Glasplatten, \%. B. auch Objectträger, sind die Plasmodien leicht in folgender Weise $\mathrm{zu}$ bringen. Wir stellen ein mit Wasser angefülltes Trinkglas auf, bringen in das Wasser das eine Ende eines Fliesspapierstreifens, dessen Breite etwas geringer als diejenige unserer Objectträger ist, legen das andere Ende des Streifens auf die eine Fläche eines neben dem Glase vertical aufgestellten Objectträgers und stellen den ganzen Apparat auf einer Sandschicht auf, die das vom Objectträger abfliessende $W$ asser aufnimint. An der Basis des Objectträgers findet nun ein Stiick Lolıe mit aufsitzendem Plasmodium Platz, und zwar wird die Lohe derjenigen Glasfläche angelehnt, an der das Wasser herabrinnt. Die ganze Vorrichtung stellt man im Dunkeln unter einer Glasglocke auf. Die Plasmodien kriechen nun in Folge ihres rheotropischen Verhaltens auf den Objectträger und breiten sich auf demselben aus. Will man für den Zweck näherer Untersuchung Plasmodien auf dem Objectträger unter Deckglas haben, so thut man gut, diese letzteren auf dem Objectträger auf der Seite, auf der der Wasserstrom herabfliesst, dadurch aufzukitten, dass man unter ihre vier Ecken kleine Wachsfüsschen bringt. Es ist dann die Möglichkeit gegeben, dass Plasmodienzweige unter die Deckgläser kriechen und sich hier, zarte Fäden bildend, ausbreiten. Die Ansammlung der Plasmodien auf den Objectträgern geht nicht immer mit gleicher Schnelligkeit vor sich; meist erfolgt sie im Ianfe eines halben Tages sicher.

Von ganz besonderem Interesse ist es, die anziehenden sowie $a b$ stossenden Wirkungen, welche verschiedene Substanzen auf die Bewegungsrichtung der Plasmodien ausiiben, genauer kennen zu lernen. Man verwendet bei bezüglichen Experimenten Plasmodien, die durch einen Wasserstrom auf Fliesspapier gelangt sind, oder das Untersuchungsmaterial wird aus Aethaliumsclerotien gewonnen, die man auf eine feuchte Unterlage (mehrere Bogen mit Wasser durchtränkten Fliesspapiers) gebracht hat. Ich erhielt auf diesem letzteren Wege schöne Plasmodien, und als dieselben durch längeres Verweilen unter einer Glasglocke ziemlich ausgehungert waren, was für den folgenden Versuch gïnstig ist, wurden kleine mit Loheaufguss durchtränkte Fliesspapierkïgelchen auf die ausgebreiteten Schleimpilzmassen gelegt. Die Substanzen des Loheextracts wirken anziehend auf die Plasmodien ein. und daher erscheinen die Papierkügelchen bereits nach Verlauf einiger Stunden naclı allen Richtungen hin von Plasmodiensträngen durchsetzt. Der Trophotropismus der Schleimpilze ist hiermit constatirt.

Auf irgend eine Stelle in der Mitte eines auf horizontaler feuchter Unterlage ausgebreiteten Plasmodiums bringe man einen kleinen Kochsalzkrystall. Die direct berührten Schleimpilztheile bräunen sich und sterben $a b$, während sich die nicht getödteten Theile des Untersuchungsobjects von dem Kochsalz zurückziehen, so dass Lücken im Plasmodium entstehen, die sich übrigens wieder schliessen können, wenn eine hinreichend gleichmässige Vertheilung des sich allmählich auflösenden Kochsalzes im feuchten Substrat erfolgt ist. Chlornatrium 
wirkt also nicht anziehend, sonderu abstossend auf die Plasmodien ein ${ }^{1}$ ).

Dass die ausserordentlich feine Reactionsfähigkeit der Plasmodien auf die erwähnten sowie auf einige andere äussere Einflüsse von biologischer Bedeutung für ihren zarten Organismus ist, wird von vornherein klar sein, und wir brauchen hier darauf nicht näher einzugehen.

\section{Die geotropischen, heliotropischen und hydro tropischen Nutationen und einige andere Reizerscheinungen.}

\section{Das geotropische Verhalten der Wurzeln.}

Die Wurzeln, zumal die Hauptwurzeln der Gewächse, haben das Bestreben, senkrecht nach ahwärts zul wachsen, eine Erscheinung, die durch das positiv geotropische Verhalten der Organe bedingt ist. Um das positiv geotropische Verhalten der Wurzeln zu constatiren, stellen wir den folgenden Velsuch an. Samen von Pisum, Vicia Faba oder Phaseolus werden nach 24-stündigem Anquellen in Brunnenwasser in feuchte Sägespäne gelegt, mit denen grosse Blumentöpfe oder Holzkästen angefüllt worden sind. Das Keimbett muss sehr locker und gleichmässig durchfeuchtet sein, wenn die Entwickelung der Keimlinge normal erfolgen soll. Die Samen von Vicia Faba werden so mit der Mikropyle nach abwärts in die Sägespäne gelegt, dass die austretende Hauptwurzel keine Krün-

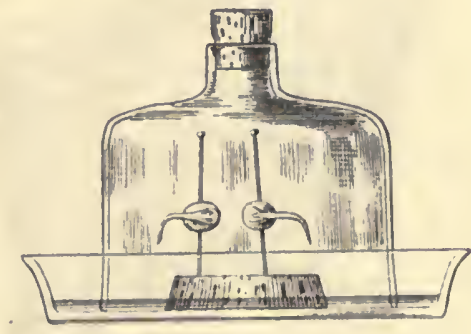

Fig. 110. Apparat zur Constatirung geotropischer Wurzelkrümmungen.

\section{mungen zu machen braucht. Die}

Samen von Phaseolus legt man horizontal in das Keimbett; die Hauptwurzel bildet dann nach ihrem Austritt einen rechten Winkel mit der Längsaxe des Samens. Wir stellen die Blumentöpfe odler Holzkästen unter grosse Pappkästen oder in einen Schrank und nehmen einige Keimlinge mit recht gerade gewachsenen Wurzeln aus den Sägespänen heraus, wenn die Wurzeln eine Länge von etwa $3 \mathrm{~cm}$ erlangt haben. Wir spiessen einige der Untersuchungsobjecte nach sorgfältigem Abwaschen auf langen Stecknadeln auf und befestigen jeden Keimling in der Weise, wie es Fig. 140 zeigt, unter einer genügend grossen Glasglocke so, dass die Wurzel horizontal gerichtet ist. Beim Aufspiessen ist das auf S. 325 Gesagte zu berïcksichtigen. Der untere Rand der Glasglocke taucht in Wasser, mit welchem eine Krystalli-

1) Vgl. StAнL, Botanische Zeitung, 1884, Nr. 10. Daselbst finden sich auch Angaben für weitere Experimente sowie Literaturzusammenstellungen. 
sirschale angefüllt ist, wälrend die Innenwand der Glasglocke mit feuchtem Fliesspapier ausgekleidet wird. Wir stellen unseren Apparat ins Dunkle. - Wir können das Experiment auch einfach in der Weise ausführen, dass wir einige unserer Keimlinge aus den Sägespänen herausnehmen und mit horizontal gerichteten Wurzeln wieder. in dieselben hineinlegen. Wir können nun bei genügend hoher Temperatur $\left(20-25^{\circ} \mathrm{C}\right.$.) sehon nach einigen Stunden (bei niederer Temperatur erst später) eine je nach Umständen mehr oder minder scharfe, nach abwärts gerichtete Krümmung der Wurzelspitze wahrnehmen.. Die Wurzel führt eine positiv geotropische Krümmung aus und wächst nicht horizontal, sondern nach abwärts weiter. Wenn wir Keimlinge von Phaseolus etc. derartig in Sägespäne legen, dass ihre Wurzeln senkrecht nach aufwärts, ihre Spitzen also nach oben gerichtèt sind, so -krịmmt sich die Spitze alsbald nach abwầrts ünd wächst dann -in dieser Richtung weiter. Bei meinerr Versuchen mit Phaseolus $\left(22^{\circ}\right.$ C. $)$ hatte sich die -Wurselspitze bereits nach Verlauf von 4 Stunden erheblich gekrümmt. Werden Keimpflanzen in der Weise in -Sägespäne gelegt, dass ihre Wurzeln schief nach aufoder abwärts gerichtet sind, dann treten natïrlich auch geotropische Krïmmungen ein, welehe bestrebt sind,- das Wurzelende senkrecht nach abwärts zu führen.

Für die weiteren, speeieller auf die geotropische Abwärtskrümmung der Wurzeln eingehenden Untersuehungen bedürfen wir zu-

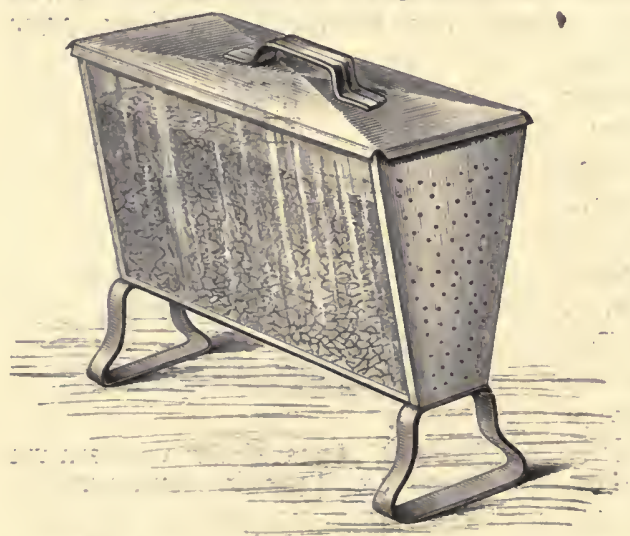

Fig. 141. Zinkkusten mit Glaswänden zu Beobachtungèn iiber Wurzelentwickelung. nächst eines besonderen Kastens, wie ein - solcher von SACHS zuerst construirt wurde und in Fig. 141 abgebildet ist. Ein solcher Kasten ist der Hauptsache nach aus starkem Zinkblech gefertigt. Die Vorder- und Hinterwand werden aber von ca. $20 \mathrm{~cm}$ hohen und ca. $30 \mathrm{~cm}$ breiten Glas: platten gebildet, und zwar dürfen diese Wände nieht senkrecht - stehen, sondern sie müssen einen Neigungswinkel von etwa $10^{\circ}$ besitzen. Der Boden des Kastens und seine metallenen Seiten: wände sind mit vielen kleinen Löchern versehen, um den Luftweehsel in der einzufüllenden Erde zu begünstigen. Wir verwenden leichte, sehr humusreiche Erde, wie sie für Gewächshauspflanzen benutzt wird, befeuchten dieselbe mit so viel Wasser, dass sie sich eben noch zwischer der Hand zu einer krümeligen Masse zerreiben lïsst, und werfen sie dann durch ein Sieb mit $1, \overline{5} \mathrm{~mm}$ weiten Oeffnungen. Das Bodenmaterial darf beim nun erfolgenden Einfüllen in den Kasten nicht zusammengepresst werden; es muss eine lockere Beschaffenheit haben, wenn sich die Wurzeln der Untersuchungsobjecte ungestört entwickeln sollen. Die erforderlichen Keimpflanzen haben wir in angegebener Weise in feuchten Sägespänen cultivirt. Wir verwenden sie, wenn ihre Wurzeln einige cm lang "geworden sind. Zunächst lịandelt es 
sich darum, feine 'l'uschestriche auf den Wurzeln, die als Marken dienen sollen, anzubringen. Wir trocknen die Wurzeln vorsichtig mit etwas Leinwand $a b$ und bringen dann mit Hülfe eines Pinsels in Entfernungen von je $2 \mathrm{~mm}$ die Tuschestriche auf ihnen an (vergl. unter 154). Diese sehr sorgfältig auszuführende Operation gelingt am besten, wenn man eine grosse, glatte, etwa $2 \mathrm{~cm}$ dicke Korkplatte zu Hülfe nimmt, an deren linkem Rande mittelst einer grossen Feile verschiedene grosse Kerben angebracht sind, von denen auf der Obertläche der Korkplatte mit dïnner, runder Feile hergestellte Rinnen ausgehen. In die Kerben werden die Samen eingeschoben; die Rinnen nehmen die Wurzeln auf, und neben ihnen liegt eine Millimetertheilung. Die vorbereiteten Keimlinge werden mit horizontal gerichteter Wurzel in die Erde unseres Kastens gelegt, so zwar, dass die Wurzel der einen Glasplatte dicht angeschmiegt ist, mit Erde locker bedeckt und beobachtet. Man klebt der Aussentläche der Glasplatte ein kleines, dreieckiges Papierstückchen auf, dessen eine Spitze genau auf die erste, gleich hinter ler Wurzelspitze angebrachte Marke hinweist. Bei Phaseolus fand ich, wie es SAcHs auch für Vicia angiebt, dass die Wurzel etwa eine Stunde lang horizontal weiter wuchs; die erste Marke entfernt sich dabei etwas von der Papierspitze. Dann aber machte sich alsbald eine geotropische Krümmung an den Wurzeln bemerklich, und von Zeit zu Zeit wiederholte Beobachtungen lehrten, dass zuerst eine Krümmung in der zwischen der ersten und zweiten Marke liegenden Zone deutlich $\mathrm{zu}$ constatiren ist; später dann auch in den übrigen Zonen. Man stellt fest, dass alle im Längenwachsthum begriffenen Zonen der Wurzel sich an dem Zustandekommen der geotropischen Abwärtskrümmung betheiligen; aber- um dies wichtige Resultat ganz sicher zu constatiren, füliren wir das folgende Experiment aus. Wir benutzen z. B. Keimlinge von, Vícia Faba mit $2 \mathrm{~cm}$ langen Wurzeln. Diese werden in angegebener-Weise in den Culturkasten gelegt, nachdem der-wachsende 11 urzeltheil durch aufgetragene Tuschestriche in Zonen von je $2 \mathrm{~mm}$ Länge getheilt worder ist. Nach etwa 8 Stunden hat die horizontal gelegte Wurzel bei $20^{\circ} \mathrm{C}$. hereits eine ansehnliche Krümmung vollzogen, und wir können zur Messung des erzielten Zuwachses schreiten. Wir benutzen đazu. ein diünnes Glimmerplättchen, auf dem mit der Zirkelspitze eine-Anzahl concentrischer Kreise von bekanntem Radius ${ }^{1}$ ) eingeritzt sind. Die Viertelkreise theilt man nun zweckmässig nicht in 90 'Theile, sondern durch leicht und genau ausfïhrbare fortgesetzte Halbirung in $8,16, ; 2$ Theile. Man berechnet für jeden Radius die. Länge eines solchen Bogenstückes. Die in einer Tabelle zusammengestellten Werthe dienen zur Feststellung der Bogenlängen der gekrümmten Wurzeln. Die Kreistheilung wird an der Glasplatte, hinter der sich die Wurzel befindet, angelegt. Man probirt, welcher Kreis mit der Krïmmung oder einem Theil derselben der convexen Seite der Wurzel zusammenfällt. Man befestigt die Glimmerplatte durch gummirte Papierstreifen an der Glaswand und stellt die weiteren Beobachtungen an. In unserem Falle beträgt der Gesamintzuwachs auf der convexen. Wurzelseite etwa $4 \mathrm{~mm}$. Die gesammte wachsende Region der Wurzel hat sich an dem Zustandekommen der geotropischen Abwärtskrümmung betheiligt. Das schnellste Wachsthum hat etwà in der dritten Zone stattgefunden.

1) Der grösste Kreis-möge einen Tiadius von-20.1nm haben. 
Wir suchen ferner je zwei seh r gleichartig ausgebildete Keimlinge von Vicia Faba aus, die sich in Sägespänen entwickelten und Wurzeln voll $1,5-2 \mathrm{~cm}$ Länge haben. Vom Vegetationspunkt aus tragen wir in Entfernungen von $2 \mathrm{~mm}$ feine Tuschestriche als Marken auf (die erste Marke liegt an Vegetationspunkt selbst) und legen je einen Keimling derartig in die Erde unseres Vegetationskastens, dass die Wurzel an der Glaswand völlig horizontal gerichtet ist, während der zweite Keimling mit genan vertikal gerichteter Wurzel in die Erde gelangt. Nach $12-16$ Stunden $\left(20^{\circ} \mathrm{C}\right.$.) messen wir den Zuwachs an der geraden und an der geotropisch gekrïmmten Wurzel. Diese letztere Messung wird in erwähnter Weise unter Benutzung des Glimmerplättchens ausgefïhrt. Wir bestimmen nicht nur den Zuwachs der convexen, sondern auch denjenigen der concaven (unteren) Wurzelseite. Ist z. B. der Zuwachs auf der convexen Wurzelseite $=10 \mathrm{~mm}$, derjenige auf der concaven $6 \mathrm{~mm}$, so beträgt der Zuwachs in der Mittellinie (Axe der Wurzel) $8 \mathrm{~mm}$. Dic gerade Vergleichswurzel mag sich um $9,5 \mathrm{~mm}$ verlängert haben. Daraus ergiebt sich, wie SACHS zuerst klarstellte, dass die convexe Seite sich krümmender Wurzeln etwas schneller wächst als eine gerade Wurzel unter gleichen Umständen. Die concave Seite der gekrümmten Wurzel wächst erheblich langsamer als die gerade, und der Gesammtzuwachs der ersteren ist merklich geringer als derjenige der letzteren.

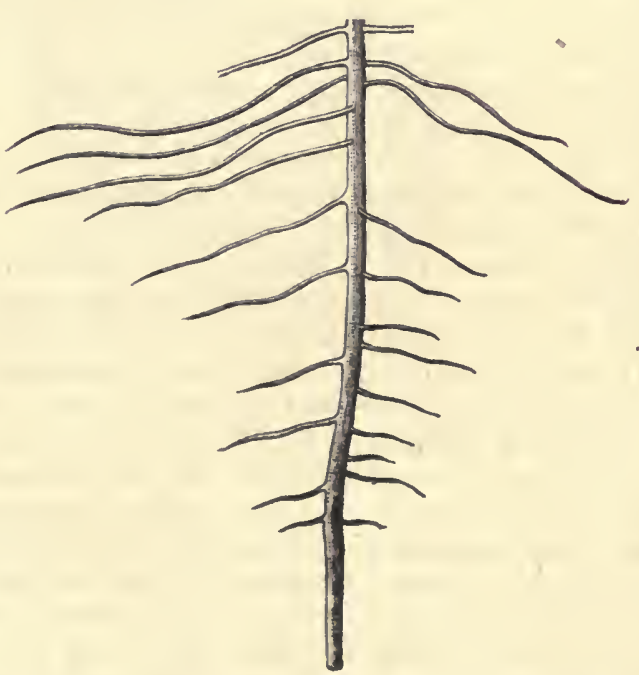

Fig. 14:. Theil einer hInter einer Glaswand erwachsenen Wurzel ron Phaseolus multiflorus.
Bei Gelegenheit der Untersuchungen über das Wachsthum der Hauptwurzeln von Phaseolus oder Vicia Faba hinter einer Glaswand wollen wir nicht versäumen, uns im Allgemeinen über die Form der geotropischen Krümmung, welche unsere Untersuchungsobjecte erfahren haben, zu unterrichten. Wir bedienen uns dabei der dünnen Glimmer-

platte, auf der ein System concentrischer Kreise mit der Zirkelspitze eingeritzt ist. Durch Anlegen der Glimmerplatte an die Glaswand, hinter welcher die Wurzel

wächst, können wir leicht erfahren, welche Form die Wurzelkrümmung besitzt. Sie gleicht bei beginnender geotropischer Nutation einem Kreisbogen von bedeutendem Radius. Die Wurzelkrümmung erscheint später weniger flach als im ersten Stadium der Beobachtung. Fernerhin gleicht die Krümmung aber keinem Kreisbogen mehr, sondern sie wird parabolisch. Die Zone des lebhaftesten Wachsthums der 
Wurzel ist stark gekrümmt; vor und hiıter dieser Region ist die Krümmung viel flacher.

Wir wollen nunmehr dazu übergehen, das geotropische Verhalten der Nebenwurzeln zu betrachten, und beschränken uns darauf, die aus den Hauptwurzeln von Phaseolus, Pisum, Vicia, Zea hervorgehenden Nebenwurzeln erster und zweiter Ordnung ins Auge zu fassen. Es werden Keimpflanzen in unserem Erdkasten hinter einer Glaswand cultivirt. Die Hauptwurzel wächst gerade nach abwärts. Die in acropetaler Reihenfolge sich an der Hauptwurzel bildenden Nebenwurzeln erster Ordnung schlagen diese Richtung aber nicht ein, sondern sie wachsen, wie es Fig. 142 zeigt, in mehr oder minder schiefer Richtung nach abwärts. Man kann sich leicht davon überzeugen, dass den Nebenwurzeln erster Ordnung in der 'That ein geotropisches Verhalten zukommt; denn wenn man den Erdkasten umkehrt, so dass die Spitze der Hauptwurzel nach oben gerichtet ist, dann findet man nach einiger Zeit, dass die Enden der fortwachsenden Nebenwurzeln sich in einem Bogen nach abwärts gewendet haben. Die Nebenwurzeln erster Ordnung wachsen also im Gegensatz zu den Hauptwurzeln nicht senkrecht nach abwärts, sondern ihre geotropische Abwärtskrümmung hört auf, wenn sie mit der Verticalen einen bestimmten Winkel, den ge otropis chen Grenzwinkel, bilden. Die aus den Nebenwurzeln erster Ordnung hervorgehenden Nebenwurzeln zweiter Ordnung sind, wie noch bemerkt werden mag, gar nicht geotropisch; sie wachsen ihrer Anlage gemäss weiter und reagiren nicht auf den Einfluss der Schwerkraft ${ }^{1}$ ).

\section{Das geotropisehe Verhalten der Sprosse.}

Zahlreiche Stengel besitzen ein ausgeprägt negativ geotropisches Verhalten und wir wollen dieselben daher benutzen, um uns weitere Aufklärung über die Einwirkung der Schwerkraft auf die Pflanzen zu verschaffen. Werden negativ geotropische Pflanzentheile in eine horizontale Lage gebracht, so krümmen sie sich aufwärts, eine Erscheinung, die unter Benutzung der verschiedensten Untersuchungsobjecte leicht constatirt werden kann. Wir bedecken den Boden eines grossen Zinkkastens mit feuchtem Sand, häufen den Sand an den Wänden derartig zusammen, dass er hier ziemlich hoch liegt, stecken in die auf diese Weise gebildeten Sandwälle das untere Ende der auf ihren Geotropismus zu prüfenden Stengelstücke hinein, so dass sie im Uebrigen frei hervorragen, ohne den Sand zu berühren, und verschliessen den Kasten mit einem Deckel. Als ich z. B. Blüthenknospen tragende Sprosse von Chrysanthemum Leucanthemum in den feuchten, dunkeln Raum des Zinkkastens in horizontale Lage brachte, hatten sich dieselben bei $24^{\circ} \mathrm{C}$. schon nach wenigen Stunden stark nach aufwärts gekrümmt. Die geotropische Wachsthumsbewegung hört schliesslich auf, wenn der obere Stengeltheil mit dem unteren einen rechten Winkel bildet. Das Auftreten geotropischer Kr rümmungen ist ebenso an abgeschnittenen epicotylen Gliedern der im Dunkeln erwachsenen

1) Die Literatur über den Geotropisıuus der Wurzelı habe ich in meinem Lehrbuch der Pflanzenphysiologie zusammengestellt. In Bezug auf die Untersuchungsmethode verdient in erster Linie eine Arbeit von SACHS in den Arbeiten d. botan. Instituts in Würzburg, Bd. 1, Beachtung. 
Bohnenkeimlinge in der angegebenen Weise leicht festzustellen (vgl. Fig. 143). Bei Experimenten mit Aristolochia Sipho, benutzte ich nicht ganze Sprosse, sondern aus leblaft wachsenden Internodien herausgesehnittene Stücke. Sie zeigten ein stark negativ geotropisches Verhalten, und diese Thatsache, die auch an Stengelstücken anderer Pflanzen (z. B. Stüeken aus dem Epicotyl im Dunkeln erwachsener Plaseoluskeimlinge) olne jede Schwierigkeit festgestellt werden kann, ist mit Rücksicht auf das unter 175 Angeführte, wo von der Bedeutung der Wurzelspitze für das Zustandekommen geotropischer Wurzelkrümmungen die Relle sein wird, von Interesse, denn sie lehrt mit aller Bestimmtheit, dass die Spitze des Phaseolusstengels für das geotropisehe Verhalten desselben nicht durchaus maassgebend erseheint. Das epicotyle Glied von Phaseolus eignet sich für Versuche über den Geotropismus besonders, weil Bohnenkeimlinge zu jeder Jahreszeit ohne Mühe cultivirt werden können. Die Reactionsfahigkeit verschiedener Pflanzentheile auf die Wirkung der Schwerkraft ist übrigens keineswegs in quantitativer Beziehung die gleiche. Während die erwähnten Objecte

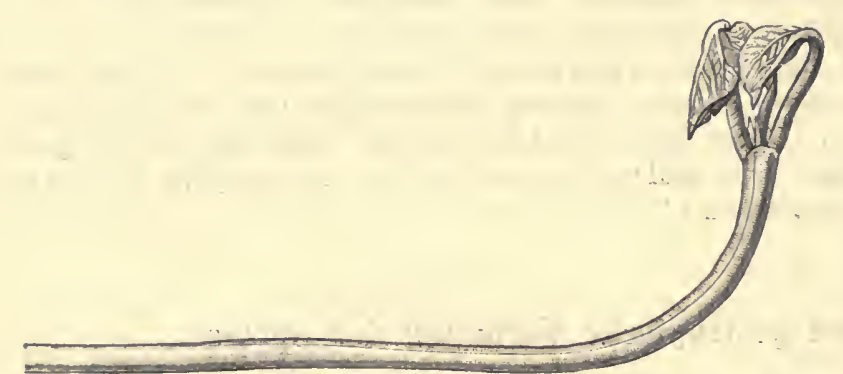

Fig. 143. Negatir geotropisch gekriimmtes . Epicotyl ron Pliaseolus multiflorus. sich sehr schnell und stark krümmen, wenn sie in einem feuchten Raum in horizontale Stellung gebracht worden sind, führen z. B. junge entblätterte Sprosse von Sambucus nigra unter gleichen Umständen nur langsam geotro-

pische Krümmungen aus. Hohe geotropische |Reizbarkeit besitzt die Plumula von Triticum vulgare. Legt man kleine Töpfe, in denen sich Weizenkeimlinge mit ea. $2 \mathrm{~cm}$ langer Plumula entwickelt haben, horizontal, so krümmt sich die Plumula derselben schnell aufwärts.

Lehrreich ist der folgende Versuch, den ich wiederholt ausführte. Wir stecken das untere Ende eines beblätterten Sprosses von Hippuris vulgaris in den feuchten Sand unseres Zinkkastens. Hat der.Spross bei höherer Temperatur $1-1 \frac{1}{2}$ Stunden in horizontaler Lage- verweilt, so ist schon eine deutliche, freilich. noch nicht sehr starke Krümmung wahrnehmbar. Jetzt bringen wir den Spross in senkrechter Stellung unter eine Glasglocke. Sein unteres Ende steckt in feuchtem Sand und das Licht wird vom Untersuchungsobjecte abgehalten. Wir gewahren nun nach einiger Zeit zu unserer Ueberraschung, dass die bei horizontaler Lage des Hippurisstengels aufgetretene Krümmung jetzt, wo derselbe in senkrechter Lage verweilt, erheblich stärker wird. Damit haben wir eine Erscheinung constatirt, die auf geotropischer Nachwirkung beruht, und welche - daher auch bald einer anderen Platz macht. Die bei verticaler Stellung -des Untersuchungsobjectes zunächst stärker gewordene Krümmung verschwindet nämlich allmählich vollständig; der Spross richtet sich gerade auf, weil die. Schwerkraft nach dem Erlösehen der geotropischèn Nachwirkung in gewöhnlicher Weise auf sein gekrümmtes Ende ein- 
wirkt. Das Phänomen der geotropischen Nachwirkung lässt sich übrigens auch unter Benutzung anderer Sprosse feststellen.

Bei den meisten Pflanzen beschränkt sich das Vermögen, Krümmungen unter dem Einflusse der Gravitation ausführen zu können, auf die Internodien des Gipfels. Die ausgewachsenen, tiefer liegenden Sprosstheile reagiren nicht mehr auf die Wirkung der Schwerkraft. Um so merkwürdiger ist daher das geotropische Verhalten der Halme der Gräser. Zwischen den einzelnen, scharf von einander abgesetzten Internodien dieser Pflanzen liegen bekanntlich die durch ihre Färbung und angeschwollene Form leicht kenntlichen Knotengelenke, welche nichts anderes als die basalen Theile der Blattscheiden repräsentiren. Während die zwischen ihnen liegenden Halmtheile schon ausgewachsen steif und hart geworden sein können, bewahren diese Knotengelenke ilıren jugendlichen Charakter relativ lange und sie vermögen daher auch das Zustandekommen geotropischer Wachsthumskrümmungen leicht zu vermitteln. Freilich erlischt schliesslich ebenfalls in den Zellen der Knotengelenke dies Wachsthumsvermögen. Die jüngeren Knotengelenke der Grashalme sind, weil ihr Parenchym noch sehr energisch turgescirt und weil die Zellen desselben noch die Fähigkeit zu sehr ausgiebigem Wachsthum besitzen, zu stärkeren geotropischen Krümmungen als die älteren Knotengelenke befühigt. Wenn man z. B. aus

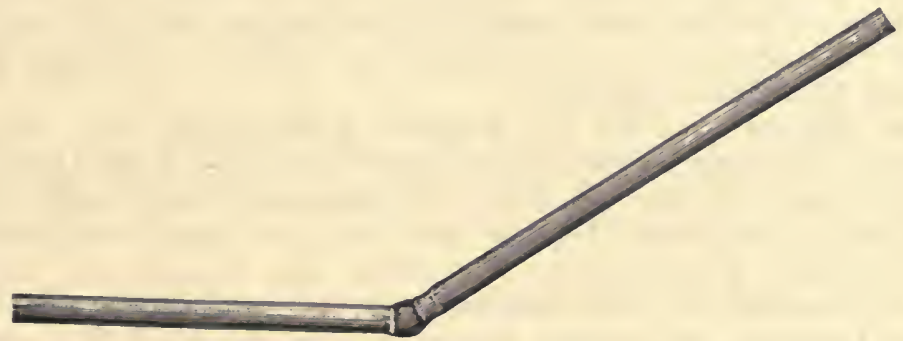

Fig. 144. Halmstiick eines Grases, geotropisch gekrümmt.

dem Halm einer blühenden Roggen- oder Gerstenpflanze einzelne, etwa $10 \mathrm{~cm}$ lange Stücke herausschneidet, von denen jedes einzelne in seiner Mitte einen Knoten trägt, um dem Untersuchungsmaterial nun sofort in unserem Zinkkasten eine horizontale Lage zu ertheilen, so findet man, dass sich die jüngeren Halmstücke z. B. nach Verlauf von 24 Stunden viel stärker geotropisch gekrümmt thaben als die älteren. Durch Winkelmessung lässt sich der Krümmungsgrad noch genauer angeben. Die ältesten Halmstücke krümmen sich gar nicht mehr. Die Form, welche geotropisch sich aufrichtende Grashalmstücke annehmen, ist in Fig. 144 zur Anschauung gebracht. Dureh einen Versuch kann man sich leicht davon überzeugen, dass nicht allein unversehrte, sondern auch der Länge nach gespaltene Grashalmstücke $\mathrm{zu}$ geotropischen Krümmungen befähigt sind.

Werden einige Grashalmstïcke, die in ihrer Mitte einen Knoten tragen (ich experimentirte mit Halmstücken von Hordeum), horizontal, andere, mit jenen gleichalterige, aber schief nach aufwärts gerichtet in feuchten Sand gesteckt, so findet man nach 1-2 Tagen, dass die ersteren sich stärker als dic letzteren gekrümmt haben, wie Winkelmessungen sofort ergeben. Nach dem Resultat dieses Experiments, 
das auch mit beliebigen anderen Stengeltheilen, die energisch auf den Reiz der Schwerkraft reagiren, wiederholt werden kann, ist die Einwirkung der Gravitation auf die Pflanzen eine um so kräftigere, je mehr sich der Winkel, in welchem sie ihren Einfluss auf dieselben greltend macht, einem Rechten nähert.

Schliesslich wollen wir noch einige Versuche über das Wachsthum sich geotropisch krümmender Grasknotengelenke und anderer Pflanzentheile anstellen. Es ist bekannt, dass die Knotengelenke, naclidem sie eine gewisse Entwickelung erfahren laben, ihr Wachsthum unter normalen Verhältnissen einstellen. Merkwürdigerweise beginnt aber das Wachsthum in den Zellen der Knotengelenke wieder, wenn dem Grashalmstücke eine horizontale Lage ertheilt wird. Wir schneiden aus Roggen- oder Gerstenhalmen Stücke heraus, die in ihrer Mitte ınit einem Knoten versehen sind, nıarkiren die Länge der Ḱnotengelenke auf zwei Seiten durch feine Tuschestriche und bringen die Untersuchungsobjecte in unseren Zinkkasten. Nach 2 oder 3 Tagen inessen wir die Entfernung der Tuschestriche wieder an den geotropisch gekrümmten Halmstücken, indem wir uns dabei einer auf einem Papierstreifen aufgetragenen Millimetertheilung bedienen. Es ergiebt sich, dass die convexe Unterseite des Knotengelenkes beträchtlich an Länge zugenommen hat, während die concave Oberseite sich in Folge eingetretener Compression ihres Gewebes verkürzt hat. Bei dem Zustandekommen negativ geotropischer Kirümmungen wird also auf jeden Fall die Wachsthumsenergie der Zellen der convex werdenden Unterseite ganz bedeutend gefördert.

Sehr lehrreich ist es, die folgende Beobachtung, die ich unter Benutzung stark geotropisch gekrümmter Halmstücke des Hafers mit besonders gutem Erfolg anstellte, vorzunelimen. Man stellt radiale Längsschnitte aus einem Knoten her und unterzielıt dieselben der mikroskopischen Betrachtung. Die Zellen des Parenchyms von der Unterseite erscheinen, wie sich sofort ergiebt, beträchtlich in Richtung der Längsaxe des Organs gestreckt, während die Zellen von der Oberseite eine tafelförmige Gestalt besitzen. Ihr Längsdurchmesser ist kürzer als ihr radialer Durchmesser. Die Erscheinung, dass die Unterseite der sich geotropisch krümmenden Grasknoten convex wird, beruht also auf einem sehr stark geförderten Wachsthum der Zellen dieser Seite.

$\mathrm{Zu}$ weiteren Beobachtungen über das Wachsthum sich geotropisch krümmender Pflanzentheile eignen sich besonders Stengelstücke von Sida Napaea oder Inula Helenium, und zwar benutzen wir 200-300 mm lange, ihrer Blätter sowie ihrer Endknospe beraubter, aus einigen Internodien bestehende Sprosse, die völlig gerade gewachsen sein müssen, und die wir sorgsam ausgewählt haben. Wir schneiden 9 solcher Stengelstücke $\mathrm{ab}$, machen sie sämmtlich gleich lang und bringen sie in Gruppen von je 3 Stück. Die 3 Stengelstücke der ersten Gruppe analysiren wir sofort, indem wir mit einem scharfen Rasirmesser zwei Rindenstreifen von denselben abziehen und ihre Länge durch Messung feststellen. 3 Stengelstücke bringen wir in unserem mit feuchtem Sand beschickten Zinkkasten in horizontale Lage, die 3 letzten Stücke führen wir in wenig geneigter Stellung in einen grossen Glascylinder ein, dessen Boden mit feuchtem Sand bedeckt ist und dessen Mündung mit Hülfe eines Korkes verschlossen werden kann. Nach 24 Stunden werden die Stengelstücke der zweiten und dritten Gruppe analysirt. Wir ziehen von ihrer concaven und convexen Seite Rindenstreifen $a b$ und messen deren Länge. Vergleichen wir 
die Mittelwerthe, welche sich bei unseren Untersuchungen mit Rücksicht auf die Zuwachsbewegung der horizontal gelegten, daher stark geotropisch gekrümmten Sidasprosse ergeben, so stellt sich heraus, dass das Wachsthum der convex gewordenen Seite derselben grösser, das Wachsthum der concav gewordenen Seite aber geringer gewesen sein muss als dasjenige der gleichnamigen Seiten der im Glascylinder aufgestellten und daher gar nicht oder nur schwach gekrümmten Vergleichsobjecte ${ }^{1}$ ).

Wenn man nach der S. 322 angegebenen Methode auf Sprossen mit Gipfelwachsthum (z. B. Epicotyl von Phaseolus) Tuschestriche als Marken zur Bestimmung der Zuwachse in den einzelnen Stengelzonen anbringt and den Spross in dem Zinkkasten horizontal legt, so findet man zu bestimmter Zeit (nach ca. 12 Stunden) die stärkste Krümmung in der am lebhaftesten wachsenden Stengelregion, später aber, wenn die geotropische Aufrichtung zum Abschluss gekommen ist, an der Basis der wachsenden Region des Sprosses, weil auf diese die Gravitation so lange Zeit als Reiz einwirken kann. Experimentirt man mit sehr schnell wachsenden, dünnen Sprossen (z. B. Agrostemma), dann ergiebt sich, dass der Sprossgipfel zu bestimmter Zeit, wenn die geotropische Nutation des ganzen Sprosses aber noch keineswegs ihren Abschluss gefunden hat, nicht senkrecht aufgerichtet, sondern in Folge geotropischer Nachwirkung (vgl. S. 368) weit über die Verticale hinausgeführt ist. Später richtet sich der Gipfel dann unter dem Einfluss der Gravitation senkrecht empor. Vgl. SAcus, Flora, 1873. Bei den Beobachtungen ist erforderlich, die jeweilige Krümmungsform der Sprosse aufzuzeichnen.

Dabei zeigt sich auch, dass die Krümmung bei Abschluss der geotropischen Nutation eine sehr scharfe ist. In früheren Stadien der Nutation sieht man zumal deutlich, dass die Krümmung keinem Kreisbogen entspricht, dass vielmehr an einer Stelle eine stärkste Krümmung (mit kleinstem Radius) gegeben ist, von wo aus sie nach hinten und vorn abuimmt.

\section{Die Ursachen der geotropisehen Krümmungen.}

Als Quelle derjenigen Kraft, welche die innere und äussere Arbeit bei dem Zustandekommen geotropischer Krümmungen leistet, ist natürlich nicht dic Erdanziehung anzusehen. Jene Kraft wird vielmehr von der Pflanze selbst geliefert, und die Schwerkraft, welche als Reizursache wirkt, löst sie nur unter bestimmten Umständen aus.

Dass bei dem Zustandekommen negativ geotropischer Krüinmungen eine erhebliche iussere Arbeit geleistet wird, ist ohne weiteres klar, wenn man sich an die durch die Krümmung lierbeigefülırte Hebung der oft ein nicht unbedeutendes Gewicht besitzenden Sprossenden erinnert. Aber auch bei dem Hervortreten positiv geotropischer Nutationen werden die Pflan. zentheile nicht einfach passiv durch die Schwere nach abwärts gezogen, sondern sie betheiligen sich in activer

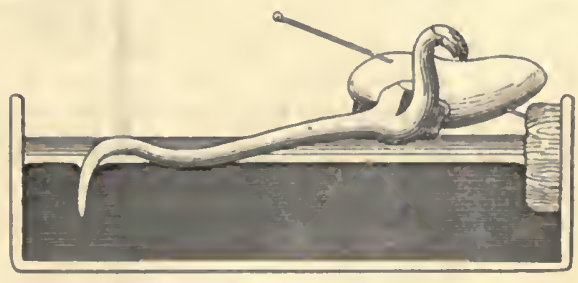

Fig. 145. Keimpflanze ron Vleia Faba, deren Wurzelspitze in Quecksilber eindringt. (Nach SAcHs.)

1) Vgl. zumal SAcis in Arbeiten des botanischen Instituts in Würzburg, Bd. 1, und H. DE VRIES in Landwirthschl. Jahrbüchern, Bd. 9. 
Weise an der stattfindenden Bewegung. Das Eindringen sich positiv geotropisch krümmender Wurzeln in Queeksilber zeigt dies deutlich. Vergl. Fig. 145. In ein Gefäss von etwa $10 \mathrm{~cm}$ Durchmesser wird bis zu einer Höhe von $3 \mathrm{~cm}$ reines Quecksilber gegossen. Wir befestigen nun an einer Stelle der Seitenwand ein Stück Kork mittest Siegellack oder in anderer Weise. Mit Hülfe einer langen Nadel wird dann eine Keimpflanze von Vicia Faba oder Phaseolus mit einer einige $\mathrm{cm}$ langen Wurzel derartig angespiesst, dass der vordere Theil ihrer Wurzel horizontal auf dem Quecksilber ruht. Nachdem wir noch etwas Wasser auf das Quecksilber gegossen haben und der Apparat unter eine Glasglocke gestellt worden ist, überlassen wir ihn sich selbst. Abgesehen von Nebenerscheinungen, lässt sich nach Verlauf längerer Zeit (etwa 24 Stunden) namentlich das Eindringen des Wurzelendes in das Quecksilber constatiren. Die geotropisch gekrümmte Wurzel überwindet den Widerstand, welchen das Metall ihr darbietet, und wächst senkrecht in dasselbe hinein. (Vergl. Fig. 145.)

Auch mit Hülfe des in Fig. 146 abgebildeten Apparates lässt sich die Thatsache demonstriren, dass Wurzeln sich mit erheblichem Kraftaufwand geotropisch nach abwärts krümmen. Auf dem Brett $B$ steht die Metallsäule $S$. Der Metallstab $S t$ kann an der Säule $S$ verschoben werden; ebenso ist er in horizontaler Richtung von rechts nach links beweglich. Zur Fixirung von St dienen Schrauben. An seinem Ende trägt $S t$ den von oben nach unten verschiebbaren Metallstab St . Dieser trägt die leicht bewegliche Rolle $R$. Ueber die Rolle läuft ein Faden. An dem einen Ende desselben hängt das kleine Gläschen Sch. Das andere Ende des Fadens ist. an einem Haken befestigt. Der leicht bewegliche Zeiger $Z$, der vor dem Gradbogen $G$ spielt, ist an seiner Basis etwas verbreitert. Hier wird der erwähnte Haken befestigt und ebenso ein zweiter, an den man ein kleines Gewicht hängt, um das Gläschen Sch, wenn es in Wasser eintaucht, das sich in einem untergestellten geeigneten Gefässe befindet, zu äquilibriren. Wir hängen nun an den Haken noch ein weiteres Gewicht,

z. B. etwa $1 \mathrm{~g}$, wenn wir mit Keimlingen

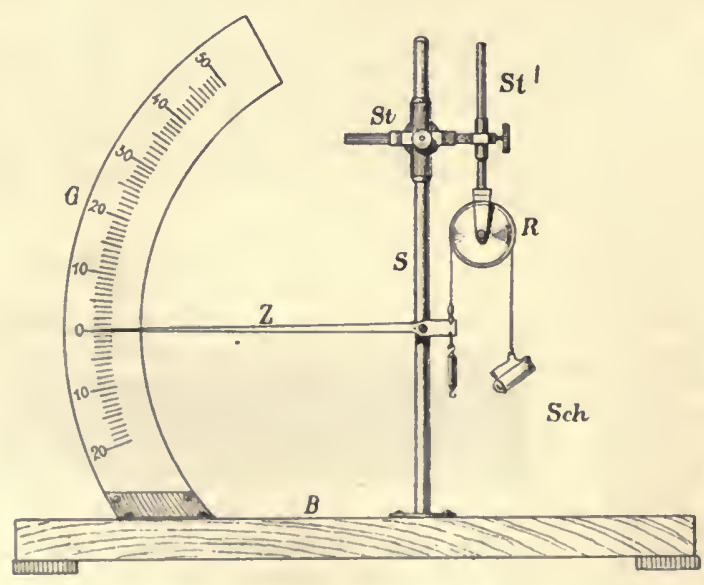

Fig. 146. Apparat zur Demonstration der Arbeitsleistung sich geotropisch krümmender Wurzeln. von Vicia Faba experimentiren. Die Keimlinge sind in geeigneter Weise mit Nadeln auf einem Korkstück befestigt, das in dem Wassergefäss fixirt ist. Die nach abwärts waclisende Hauptwurzel, deren Spitze in das Gläschen Sch eingeführt ist, übt auf dieses einen Druck aus. Der Druck, den die wachsende Wurzel geltend macht, 
drïckt das Gläschen trotz der Gegenwirkung von ca. $1 \mathrm{~g}$ herab und der Zeiger $Z$ verändert in Folge dessen seine Lage ${ }^{1}$ ).

Wir wissen - und wir kommen darauf noch specieller zurück dass die geotropischen Krüınmungen (abgesehen von den geotropischen Variationsbewegungen) durch Wachsthumsvorgänge zu Stande kommen. Die meisten Pflanzen wachsen nicht, wenn ihnen kein freier Sauerstoff zur Disposition steht, und somit werden auch die geotropischen Nutationen in einem sauerstofffreien Medium unterbleiben. Mit Hülfe des in Fig. 147 abgebildeten Apparates lässt sich diese Thatsache leicht feststellen. In einen Glascylinder bringen wir ein durch Auskochen in Wasser mit diesem getränktes dünnes Brettchen $(B)$, auf welchem wir mit Hülfe von Nadeln Keimlinge von Pisum oder Phaseolus oder abgeschnittene epicotyle Glieder dieser letzteren Pflanze oder z. B. mit Blüthenknospen versehene Schäfte von Taraxacum (St) befestigt haben. Die wachsthumsfähigen Regionen der Wurzeln resp. Stengel müsssen frei und horizontal schweben. Der Cylinder wird mit einem doppelt durchbohrten Kork verschlossen. Die Bohrungen dienen zur Aufnahme im rechten Winkel gebogener Glasröhren, und während die eine $(a)$ mit einem Wasserstoffentwickelungsapparat in Verbindung steht, dient die andere (b) zur Ableitung des den Cylinder verlassenden Gases. Wir leiten stundenlang

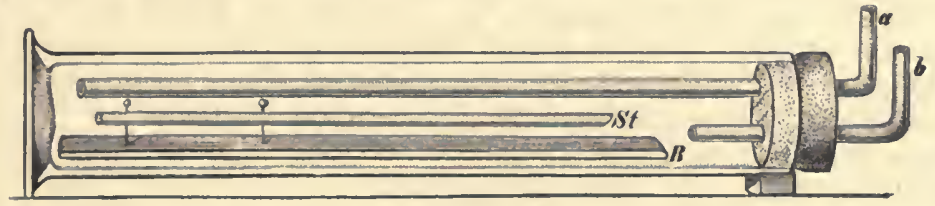

Fig. 147. Apparat zur Constatirung der Thatsache, dass Pflanzentheile bei Sauerstoffausschluss keine geotropischen Krümmungen erfahren.

einen Strom feuchten Wasserstoffs durch den Apparat, aber eine geotropische Krümmung lässt sich an den Untersuchungsobjecten nicht wahrnehmen, wenn der Cylinder horizontal gelegt wird, nachdem er zuvor (bis etwa eine halbe Stunde nach Beginn des Durchleitens von Wasserstoffgas) vertical gestanden hatte. In einem ähnlichen Cylinder führen Keimlinge oder Sprosse, welche in demselben in Contact mit atmosphärischer Luft verharren, zumal bei höherer Temperatur, schnell energische geotropische Nutationen aus ${ }^{2}$ ).

Experimentiren wir mit Keimlingen (z. B. von Pisum), so können wir auch sehr bequem den in Fig. 131 dargestellten Apparat benutzen. Das Gasableitungsrohr mündet aber nicht unter Quecksilber, sondern trägt einen kurzen, dickwandigen Kautschukschlauch und wird, nachdem man 1-2 Stunden lang Wasserstoffgas durchgeleitet hat, mittelst eines eingeführten Glasstabes luftdicht abgeschlossen. Legt man den Apparat nun horizontal, so tritt dennoch keine geotropische Krümmung der Wurzeln ein.

Die Untersuchungen über das Zustandekommen der geotropischen Krümmungen haben zu dem Resultat geführt, dass die Gravitation,

1) Sehr schöne und eingehende Untersuchungen über Druck und Arbeitsleistung durch wachsende Pflanzen stellte neuerdings PFEFFER an. Vergl. Abhandlungen der Königl. sächs. Gesellschaft d. IViss., 1893, Bd. 20. Leider konnte ich diese Arbeit nicht mehr berücksichtigen.

2) Vgl. G. KraUs, Abhandlungen der Naturforsehenden Gesellschaft zu Halle, Bd. 16, und Correxs, Flora, 1892. 
welche als Reizursache wirkt, nicht direct das Wachsthum der krüınmungsfähigen Organe, sondern zunächst die Turgorverhältnisse ihrer Zellen beeinflusst. Wir experimentiren mit dem epicotylen Stengclglied von Phaseolus, mit $20 \mathrm{~cm}$ langen, jungen Sprossenden von Aristolochia, Taraxacum, Plantago, Papaver etc. Die Untersuchungsobjecte werden in den feuchten, dunkeln Raum eines Zinkkastens (vgl. unter 173) in lorizontale Lage gebracht. Wenn nach Verlauf einiger Zeit (2-4 Stunden) eine deutliche geotropische Aufwärtskrümmung an ihnen zu sehen ist, so legen wir sie auf einen Carton, auf dem concentrische Kreise aufgetragen sind. Wir suchen denjenigen Kreis auf, dessen Krümmung mit derjenigen des Pflanzentheils möglichst genau zusammenfällt, und ermitteln den Radius des Kreises. Nun legen wir unser Untersuchungsobject in eine 20-proc. Kochsalzlösung enthaltende Krystallisirschale. Nach einigen Stunden stellen wir die Schale auf den Carton und suchen wieder, indem wir den plasmolytisch gemachten schlaffen Stengeltheil mit der Pincette verschieben, den seiner Krümmung entsprechenden Kreis auf. Der Radius dieses Kreises ist grösser als derjenige jenes Kreises, den wir vor der Plasmolyse auffanden. Man sieht, dass der in den plasmolytischen Zustand versetzte geotropisch gekrümmte Pflanzentheil eine bleibende Krümmung behält, eine Erscheinung, die eben Folge des durch die Schwerkraftwirkung erzielten Wachsthumsvorganges ist. Derjenige Theil der ursprünglichen Krünmung, welcher durch Plasmolyse beseitigt werden kann, ist dagegen auf Rechnung der Turgorverhältnisse zu setzen. Wenn die erwähnten Untersuchungsobjecte etwa 24 Stunden im Zinkkasten in horizontaler Lage verweilt haben, so wird ihre Krümmung durch Plasmolyse nicht zum Theil aufgehoben; sie bleibt in ihrem ganzen Umfang in der Salzlösung bestehen, weil sie durch Wachsthumsvorgänge in den Zellen fixirt worden und deshalb nicht mehr rückgängig $\mathrm{zu}$ machen ist.

Wenn man Halmstücke von Gräsern (ich experimentirte z. B. mit Secale), die $10 \mathrm{~cm}$ lang und in ihrer Mitte mit einem Knoten versehen sind, in horizontaler Lage in unserem Zinkkasten befestigt, indem man ihr unteres Ende in den an einem der Kastenwände zusammengehäuften Sandwall steckt, so tritt alsbald eine beträchtliche Krümmung im Knotengelenk ein. Diese betrug z. B. in einem Falle, den ich beobachtete, $45^{\circ}$. Als ich das Halmstück in den völlig plasmolytischen Zustand versetzt hatte, war die Krümmung nur noch $=25^{\circ}$. Die Betheiligung von Turgor- und zugleich von Wachsthumsverhältnissen an der geotropischen Aufwärtsbewegung ist also auch hier unzweifelhaft festgestellt ${ }^{1}$ ).

Nach demjenigen, was ich in meinem Lehrbuche der Pflanzenphysiologie über die Grundursachen der geotropischen Nutationen gesagt habe, darf wohl daran festgehalten werden, dass die Schwerkraft die Turgorkraft der Zellen auf der convex und concav werdenden Seite der sich krümmenden Pflanzentheile nicht, wohl aber die Widerstandsfähigkeit der unter dem Einfluss des Turgors gedehnten Zellschichten (Protoplasma sowio Zellhaut) modificirt. Bei negativ geotropischen Organen wird die Widerstandsfähigkeit dieser Schichten in den Zellen der convex werdenden Unterseite vermindert, diejenige der Zellen der concav werdenden Oberscite aber erhöht. Somit kann die Turgorausdehnung der Zellen der Unterseite bei gleich bleibender Turgorkraft derselben gesteigert, jene

1) Vgl. H. DE VRIEs, Landwirthschaftl. Jahrbücher, Bd. 9, S. 500. 
der Zellen der Oberseite herabgesetzt werden, und damit ist sofort dio Bedingung für ein verschiedenartiges Wachsthum der antagonistischen Seiten des Pflanzentheiles gegeben. Voraussichtlich wird auch der Wassergehalt der unteren Hälfte negativ geotropisch gekrümmter Pflanzentheile grösser als derjenige der oberen Hälfte sein, und in der 'That will KraUs ${ }^{1}$ ) derartige Differenzen im Wassergehalt constatirt haben. Es sind aber über die Wasservertheilung in geotropisch gekrümmten Pflanzentheilen erneute Untersichungen anzustellen, da wenigstens die Angaben von Kraus bezüglich der Wasservertheilung in beliotropischen Stengeln durch Thate's ${ }^{2}$ ) Beobachtungen keine Bestätigung gefunden haben.

Dass in der That die Turgorkraft der Zellen der antagonistischen Seiten geotropisch gekrïmmter Organe die nämliche ist, wie bereits angedeutet wurde, lässt sich auch experimentell mit Hülfe der plasmolytischen Methode nachweisen ${ }^{3}$ ). Werden im Dunkeln erwachsene Bohnenepicotyle horizontal gelegt, um den Untersuchungsobjecten nach erfolgter Aufwärtskrümmung an der convexen sowie concaven Seite der Krümmung zarte Rindenschnitte zu entnehmen, so zeigt die mikroshopische Prüfung derselben Folgendes. Legt man die Schnitte in 2-proc. Salpeterlösung, so macht sich noch keine Plasmolyse geltend. Dieselbe tritt erst ein, wenn man mit etwa 2,5-proc. Salpeterlösungen arbeitet, und zwar wirkt die Lösung von bestimmter Concentration in gleicher Weise auf die Rindenzellen von der convexen Unter-, sowie der concaven Oberseite des gekrümmten Epicotyls ein.

Wenn nicht Differenzen der Turgorkraft auf den antagonistischen Seiten gekrümmter Pflanzentheile als Ursachen der Nutationen zu betrachten sind, so sind diese Ursachen vermuthlich in einem besonderen Verhalten der Membranen zu suchen. WorTMaNN ${ }^{4}$ ) ist bestrebt, diese Ansicht durch folgende lehrreiche Experimente zu begründen. Eine in einem Blumentopf cultivirte Phaseolusptlanze mit lebhaft wachsendem Epicotyl wird horizontal gelegt, um die Stengelspitze ein Seidenfaden geschlungen, dieser über eine leicht bewegliche Rolle geführt und an seinem freien Ende mittelst eines Gewichtes so stark gespannt, dass das Epicotyl keine geotropische Krümmung ausführen kann. Nach 30-48 Stunden entnehmen wir der wachsenden Region des Epicotyls feine Querschnitte und constatiren das Folgende. Die Rindenzellen der Oberseite sind sehr plasmareich, englumig und haben sehr stark collenchymatisch verdickte Membranen. Die Rindenzellen der Unterseite erscheinen dagegen plasmaarm, weitlumig und dünnwandig.

Bei den Experimenten mit dem Bohnenepicotyl, deren geotropische Krümmung man in angegebener Weise verhindert, lässt man den Plasmakörper der Zellen natürlich Zeit, seine in Folge der Schwerkraftwirkung zu Stande kommende Reizbewegungen voll und ganz auszuführen. Diese Reizbewegungen bestehen aber in einer Wanderung des Plasmas von der Stengelunterseite zur Oberseite. Als Bahnen dienen dabei offenbar die Plasmaverbindungen zwischen den Zellen. Die bedeutende Plasmaansammlung in den Zellen der Oberseite der Stengel hat hier ein starkes Dickenwachsthum der Membranen und daher ein schwaches Flächenwachstlium derselben zur Folge. Auf Bd. 15 .

1) Vgl. G. Kraus, Abhandilungen der Naturforschenden Gesellsehaft zu Halle,

2) Vgl. Thate in Prixgsilem's Jahrbüchern f. wissensch. Botanik, Bd. 13.

2) Vgl. Wortmaxx, Berichte der Deutsehen botan. Gesellsehaft, Bd. 5, S. 461.

4) Vgl. Wortraxx, Botan. Zeitung, 1S87, S. 819, und 1888, S. 488. 
der Stengelunterseite macht sich geringfügiges Dickenwachsthum, aber cnergisches Flächenwachsthum der Zellhäute geltend. Die Turgorausdehnung der Zellen kann hier daher auch leicht eine grosse werden. Nach Wortmans kommen sämmtliche Reizbewegungen wachsender Organe in der Weise zu Stande, dass die Reizursachen zunächst Wanderungen des Plasmas zur Folge haben, welche dann ihrerseits las Wachsthum der Zellhäute beeinflussen. Die von dem genannten Forscher constatirten Thatsachen sind auch unzweifelhaft richtig, indessen bezüglich der Deutung derselben ist, worauf hier aber nicht nälıer eingegangen werden kann, noch keine Einigung erzielt ${ }^{1}$ ).

\section{Die Funetion der Wurzelspitze bei dem Zustandekommen geotropiseher Krïmmungen.}

DARWIN ${ }^{2}$ ) hat bekanntlich in neuerer Zeit mit grosser Bestimntheit die Behauptung aufgestellt, dass das Vorhandensein der Wurzelspitze von wesentlicher Bedeutung für das Zustandekommen geotropischer Krümmungen der Wurzeln sei. Er redet aus diesen und anderen Gründen von einer ,Gehirnfunction“ der Wurzelspitze, freilich ein unglücklich gewählter Ausdruck, der sehr leicht zu Missverständnissen führen kann. Die von DARwis angeregte Frage, welche übrigens schon früher von CiEsielski und SACHS behandelt worden war, hat Veranlassung zur Ausführung zahlreicher Untersuchungen gegeben, deren Resultate theils für, theils gegen die Ansicht des brittischen Naturforschers sprechen ${ }^{3}$ ). Man führt die Experimente am zweckmässigsten mit Keimpflanzen von Pisum, Zea, Vicia Faba oder Phaseolus aus. Nach dem Anquellen werden die Samen in feuchten Sägespänen zur Keimung gebracht, bis ihre senkrecht nach abwärts gewachsenen Wurzeln eine Länge von $2-3 \mathrm{~cm}$ erreicht haben. Jetzt bringt man auf einer Reihe von Wurzeln (es ist am besten, zahlreiche, z. B. 20 Untersuchungsobjecte zu verwenden) in einer Entfernung von 15-20 mm von der Spitze Tuschestriche als Marken an und legt die Hälfte der Keimlinge derartig in feuchte Sägespäne, dass ilıre Wurzeln horizontal gerichtet sind. Von den übrigen Wurzeln entfernt man ein 1,5-2 mm langes Stück der Spitze, indem man die Wurzeln an ein Korkscheibchen anlegt und mit Hülfe eines scharfen Rasirmessers in möglichst horizontaler Richtung Querscheibchen abträgt, bis der gewünschte Erfolg erzielt ist. Auch die Keimlinge mit den decapitirten Wurzeln werden nun horizontal in Sägespäne gelegt. Nach 24-48 Stunden stellt man die Grösse der Zuwachsbewegung an sïmmtlichen Untersuchungsobjecten fest und beobachtet, ob sie geotropische Krümmungen ausgeführt haben. Ich fand bei Versuchen mit Phaseolus multiflorus, dass die normalen Wurzeln im Laufe von 48 Stunden sämmtlich einen beträchtlich grösseren Zuwachs erfuhren als die decapitirten. Es war die Wurzelspitze in einer Länge von $2 \mathrm{~mm}$ abgetragen worden. Dies Resultat stelit aber nicht mit den

1) Vgl. zumal PfefFer, Abhandlungen der Königl. sächs. Gesell. d. Wissensch., Bd. 18 , S. 240.

2) Darwix, Das Bewegungsvermögen der Pflanzen, 1881.

3) Vgl. Wiesser, Bewegungsvermögen der Pflanzen, 1881; Derrlefsex, Arbeiten d. botan. Instituts in Würzburg, Bd. 2; KIrciner, Programm zur 64. Jahresfeier der Akademie Hohenheim, 1882; vergl. ferner die Angaben von KraBBE, Moliscir, Wmesver, Bruschorst im ersten und zweiten Jahrgang der Berichte der Deutschen botan. Gesellschaft. 
Angaben sämmtlicher, wohl aber mit denjenigen einiger Beobachter, die den nämlichen Gegenstand untersuchten, in Einklang. Meine Versuche mit Phaseolus lehrten ferner, dass die Wurzeln der intacten Pflanzen normale geotropische Krümmungen ausführten, während die decapitirten Wurzeln sich freilich ebenfalls krummten, aber in verschiedener Richtung, nämlich nach oben, seitlich oder auch nach unten.

Ich bin weit entfernt davon, aus meinen Beobachtungen Schlüsse über die Function der Wurzelspitze bei dem Zustandekommen der geotropischen Krümmungen ziehen zu wollen, denn dazu ist die Anzahl meiner Versuche mit Phaseolus und ebenso mit Viciakeimlingen zu gering gewesen. Bei Experimenten mit Vicia Faba fand ich übrigens, dass die decapitirten Wurzeln in den ersten 24 Stunden ebenso lebhaft wuchsen wie die intacten. Die verschiedenen Fragen, um welche es sich hier handelt, sind nach meinen eigenen Erfahrungen noch nicht als erledigt zu betrachten. Die neuesten Arbeiten PfEFfer's konnte ich nicht mehr berücksichtigen.

Wenn man die Literatur über die Function der Wurzelspitze durchgeht, so wundert man sich über die zahlreichen Widersprüche in den Angaben bezüglich der Bedeutung der Spitze für Längenwachsthum und geotropische Krümmungen. Mir scheint, dass viele der Experimentatoren eine Reihe von Gesichtspunkten bei ihren Untersuchungen nicht genügend gewürdigt haben. 1) Es ist möglich, dass die Wurzelspitze für Wachsthum und Geotropismus der Wurzeln verschiedener Pflanzenspecies nicht dieselbe Bedeutung besitzt. 2) Man hat, um zu einem sicheren Resultate zu gelangen, stets mit zahlreichen Untersuchungsobjecten zu operiren. 3) Es ist für den Erfolg der Versuche nicht gleichgültig, ob man die Wurzelspitze in einer Länge von 1, 1,5 oder $2 \mathrm{~mm}$ abträgt, denn häufig wird bei zu unbedeutender Decapitation noch ein Theil der den Reiz nach Darwix übermittelnden Wurzelspitze nicht entfernt sein. 4) Bei längerer Versuchsdauer ist auf die an den decapitirten Wurzeln erfolgenden Regenerationsvorgänge zu achten ${ }^{1}$ ). 5. Man hat mit Rücksicht auf die Nutationen der Wurzeln (vergl. unter 157) darauf Gewicht zu legen, welche Lage man den decapitirten und intact gelassenen Wurzeln ertheilt.

\section{Experimente mit dem Klinostaten.}

Der Klinostat, ein von SACHS ${ }^{2}$ ) eingeführter Apparat, gehört zu den wichtigsten Instrumenten bei zahlreichen pflanzenphysiologischen Untersuchungen. Er dient zur Ausschliessung heliotropiseher sowie geotropischer Krümmungen an Pflanzentheilen ${ }^{3}$ ). Eine vorzügliche Form hat PFEFFer dem Klinostaten gegeben, und ist der PFEFFER'sche Apparat im Preise von $320 \mathrm{Mk}$. voin Universitätsmechaniker AlBRECHT in Tübingen zu bezielen. Der hohe Preis des Apparates ${ }^{4}$ ) veranlasste Wortmaxx, den Klinostaten in erheblich billigerer Form (200 Mk.) von der technischen Anstalt der Gebrüder UNGERER in Strassburg herstellen zu lassen ${ }^{3}$ ). Diesen Wortмass'schen Apparat benutzte ich vielfach und kann ihn zur Anschaffung empfellen. Er wird freilich

1) In dieser Hinsicht vergl. Praxtu, Arbeiten d. bot. Instit. in Würzburg, Bd. 1.

2) Vgl. SACHS, Arbeiten des botan. Instituts in Würzburg, Bd. I, S. 597, und Bd. II, S. 215 .

3) Ueber das besondere Verhalten dorsiventraler Organe am Klinostaten sprachen sich zumal SAcirs und Noll (Flora, 1893) aus.

4) Uebrigens liefert jetzt auch ALBRECHT einen Klinostaten für 220 M.

5) Vgl. Wortmans, Berichte der Deutschen botan. Gesellschaft, Bd. 4 . 
an Leistungsfähigkeit von dem grossen PFEFfen'schen Apparat übertroffen, ist aber doch in den meisten Fällen gut zu verwenden.

Ueber Construction und Gebrauch des Apparates ist das Folgende zu sagen:

„Der ganze Klinostat, wie ihn Fig. 148 darstellt, besteht aus zwei Theilen, dem Triebwerk und den Nebenapparaten, welch letztere wesentlich die von Preffer gegebeno Cnnstruction besitzen. Das Triebwerk $A$ auf einem festen Fuss $B$ anfgeschraubt, besteht aus einem Uhrwerk, dessen Gang, um vollkommen ruhige Rotation zu erzielen, nicht durch einen Anker, sondern durch Windflügel regulirt wird, und drei senkrecht über einander liegenden Rotationsaxen, $a, b, c$, welche, für sich frei beweglich, durch einen Schieber $d$ auf gleich zu beschreibende Weise mit einem Rade des Uhrwerks in Verbindung gebracht und dadurch in Rotation gesetzt werden können. Die Axe $e$ dient zum Ansetzen des Uhrschliissels.

Die Nebenapparate bestehen zunächst aus einer soliden Axe $f$, welche durch ein Knotengelenk $g$ an einer der Rotationsaxen $a, b, c$, angeschraubt werden kann. Durch dieses Knotengelenk wird es ermöglicht, dass die Axe $f$ sowohl in horizontaler als auch in verticaler Richtung verschoben werden kann. Dadurch lassen sich, ohne den ganzen Apparat zu verstellen, Rotationen der Beobachtungsobjecte von horizontaler Lage der Drehungsaxe bis zu einer Neigung derselben um $45^{\circ}$ gegen die Horizontale einerseits, sowie verschiedene Stellungen zu einfallenden Lichtstrahlen erzielen. Auf der Axe $f$ ist ein verschiebbarer Ring aufgeschraubt, welcher an einem Stifte $h$ ein auf diesem verschiebbares Gewicht $i$ trägt. Stift und Gewicht dienen als Centrirungsvorrichtung, um ein eventuelles Uebergewicht des in Rotation zu setzenden Gegenstandes zu eliminiren, ohne dessen Vermeidung die Regelmässigkeit der Axenumdrehungen sehr gestört werden kann. Die Axe $f$ ruht bei $\alpha$ auf zwei Frictionsrollen, welche an der Axe 7 eines festen Stativs in verticaler Richtung - aufund abwärts - sowohl als auch um die Axe $\beta$ in horizontaler Richtung (letzteres bei Neigung der Drehungsaxe zur Horizontalen) verschiebbar resp. drehbar sind.

Auf das Ende der Axe $f$ wird der Topfhalter $l$ aufgeschraubt. Dieser besteht aus einem dreiarmigen Messingfuss, in dessen Arme drei eiserne Stäbe senkrecht eingenietet sind. An jedem dieser Stäbe ist ein verschiebbares Messingdreieck angebracht, welches, wie aus der Zeichnung ersichtlich ist, auf den Rand des Blumentopfes fest aufgesetzt werden kann und letzteren dadurch unverrückbar macht.

Soll nun ein Gegenstand, etwa eine im Topf gezogene Pflanze in Rotation versetzt werden, so verfährt man folgendermaassen: Der Topf wird zunächst in den Topfhalter $l$ eingesetzt und vermittelst der Messingdreiecke befestigt, welche Manipulation in weniger als ciner Minute vollzogen ist. Nach Anschrauben des Topfhalters an die Axe $f$ wird dieselbe durch einen entsprechenden Stoss mit der Hand, den man gegen den Stift $h$ führen kann (von welchem das Gewicht $i$ zuvor abgenommen ist), in Rotation versetzt. War nun der Topf so auf den Topfhalter aufgesetzt, dass ein Uebergewicht vorhanden ist, so wird durch Verrücken des Schwerpunktes unter die Horizontale immer eine bestimmte Seite des Topfes bei der eintretenden Ruhelage nach unten sehen. Durch entgegengesetzte Stellung der Centrirungsvorrichtung und geeignetes Verschieben des Gewichtes $i$ wird nun das Uebergewicht eliminirt, so dass nach mehreren, durch geringen Stoss hervorgerufene Rotationen der Topf in heliebiger Lage zur Ruhe kommt. Ist die Centrirung genau erreicht, so wird die 
Rotationsaxe mit dem Uhrwerk in Verbindung gesetzt. Das wird durch einfaches Verschieben eines Stiftes auf folgende Weise ermöglicht.

Jede der drei Rotationsaxen $a, b, c$ trägt, wie Fig. 149, einen Längsschnitt durch das Uhrwerk darstellend, andoutet, ein Zahnrad. Die Zahnräder der Axen $b$ und $c$ greifen dauernd in einander, dasjenige der Axe $a$ steht nicht in unmittelbarer Verbindung mit diesen. Durch Einschiebung eines in der Zeichnung schattirten Rades $q$, dessen Zähne in die der beiden obersten Axenräder und zugleich in die eines Rades vom Uhrwerk eingreifen, werden nun alle drei Rotationsaxen zugleich in Bewegung gesetzt. Wie diese Einschiebung geschieht, ist aus Fig. 150, welche einen anderen, zu Fig. 149 senkrechten Längsschnitt durch das Uhrwerk darstellt, ersichtlich.

Die Figur ist so gezeichnet, dass keine Communication zwischen Uhrwerk und den Rotationsaxen stattfindet, das Uebertragungsrad $q$ also zunächst nicht eingreift. Der Stift $p$, auf dem dasselbe befestigt ist, ruht in einer Führung, welche durch einen kleinen Knopf $p^{\prime}$ verschiebbar ist.

Durch einen Druck auf den Knopf des Stiftes $p$ wird nun das Uebertragungsrad $q$ eingeschoben; ein zweiter Druck auf den Knopf $p^{\prime}$ senkrecht abwärts macht den Stift (und dadurch auch das Uebertragungsrad) unverschiebbar, indem ein bei $x$ angedeuteterkleiner Gang des Stiftes in die Führung eingreift.

Muss an dem Beobachtungsobject während der Rotationszeitirgend etwas geändert werden, soll z. B. das Begiessen des Topfes u. dergl. vorgenommen werden, so ist jedesmal zuvor durch Ausziehen des Stiftes $p$ die Communication der Rotationsaxe mit dem Uhrwerk zu unterbrechen.

Fig. 148.

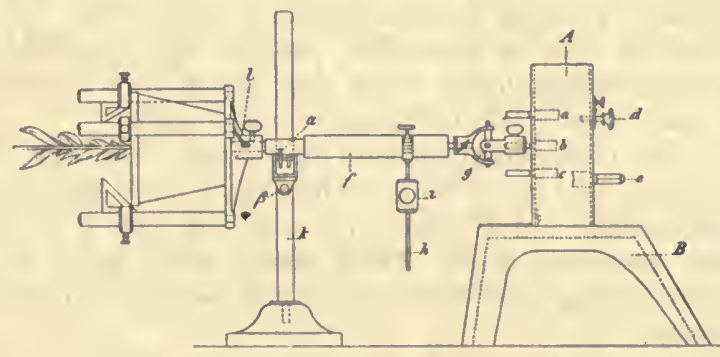

Fig. 149.

Fig. 150.

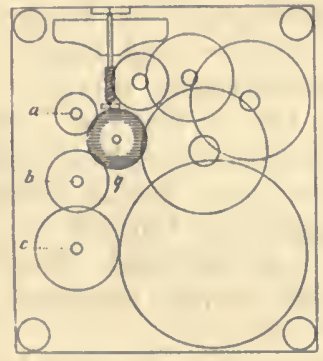

Fig. 151.

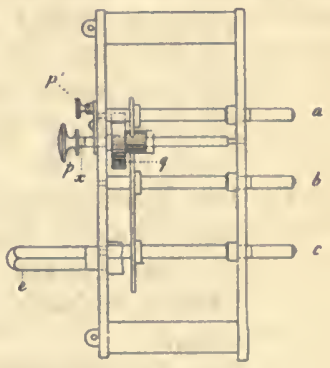

Fig. 152.

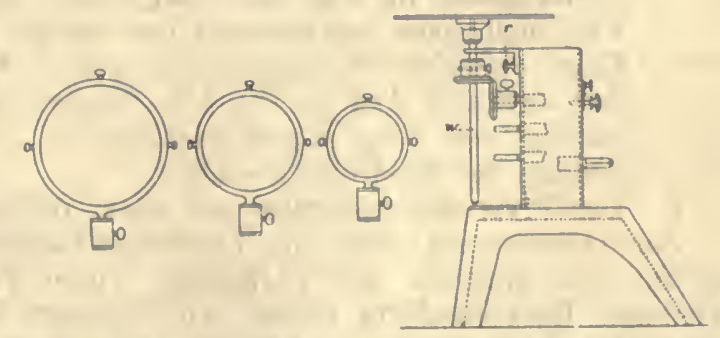

Fig. 148-152. Wortmann's Klinostat mit Yebenapparaten. 
Um eine Rotation um horizontale oder geneigte Axe, aber in einer, zu der in Fig. 148 angedeuteten, senkrechten Richtung zu ermöglichen, befestigt man mittelst Draht den Topf in einem der drei in Fig. 151 gezeichneten Ringe. Bei geneigter Umdrehungsaxe werden die Frictionsrollen an einem zweiten sehr starken Stative befestigt.

Handelt es sich um Beobachtungen von Gegenständen, welche im feuchten Raume verweilen müssen, wie etwa Pilze (Fruchtträger von Phycomyces), Wurzeln, abgeschnittene Pflanzentheile etc., so kann man dieselben an einer (durch keine Zeichnung wiedergegebenen) $80 \mathrm{~cm}$ langen Messingaxe befestigen, welche durch einen feuchte Luft enthaltenden Glaskäfig geführt wird und deren äusserstes Ende dann ausserhalb des Glaskäfigs durch das Stativ mit den Frictionsrollen gestützt wird.

Sollen die Beobachtungsobjecte um verticale Axe rotiren, so muss der Klinostat, da das Triebwerk nicht verstellbar ist, anders hergerichtet werden.

Fig. 152 zeigt denselben mit verticaler Drehungsaxe. Auf eine der Rotationsaxen $a, b, c$ wird ein konisches Rad gesetzt, dessen Zähne in die eines zweiten konischen Rades eingreifen. Dieses letztere ist an einer verticalen Axe $w$ beweglich, welche auf einem Stahllager ruht, oben eine flache Messingscheibe trägt und durch eine Schraube $r$ in kürzester Zeit an dem Triebwerk befestigt werden kann.

Die Umdrehungsgeschwindigkeiten der drei Rotationsaxen sind verschieden, und zwar so gewählt, dass ohne Belastung und bei horizontaler Drehungsaxe ein Umlauf von $a$ in 10 , von $b$ in 15 und von $c$ in 20 Minuten vollendet wird. Doch lassen sich, wenn es darauf ankommt, durch Verkleinerung der Windflügel auch grössere Umdrehungsgeschwindigkeiten erzielen.

Das Aufziehen des Uhrwerkes hat alle 20-21 Stunden zu geschehen.

Die Vorzüge des Klinostaten sind nun folgende:

1) Bei der Rotation ist jeder Stoss ausgeschlossen, so dass eine vollkommen ruhige Bewegung der Objecte ermöglicht wird.

2) Ist derselbe sehr bequem und leicht transportirbar und kann daher auf jedem Arbeitstische aufgestellt werden.

3) Da der Gang des Uhrwerkes fast geräuschlos ist, so ist der Apparat auch für Vorlesungsdemonstrationen geeignet.

4) Die Handhabung ist eine höchst einfache. Die zu beobachtenden Gegenstände können im Verlauf von 1-2 Minuten befestigt, an den Apparat gebracht und dieser in Gang gesetzt werden. Ebenso einfach und schnell geschieht das Abnehmen der Gegenstände.

5) Die Tragfähigkeit ist für gewöhnliche Versuche vollständig ausreichend. Bei der angestellten Prüfung fand bei horizontaler Drehungsaxe (in Fig. 148 dargestellt) bei einer Belastung von $2 \mathrm{~kg}$ noch ganz regelmässige und ruhige Bewegung statt. Allerdings bei einer Verlangsamung von 1 Minute pro Umdrehung. Bei verticaler Axe (in Fig. 152 dargestellt) aber konnte eine Belastung von $5 \mathrm{~kg}$ angewendet werden, ohne dass eine Verlangsamung der Umdrehung eintrat.

6) Der Preis des Apparates mit allem Zubehör ist 200 Mk."

Zur Orientirung über die Leistungsfähigkeit unseres Apparates und für das Studium des Verhaltens vieler Pflanzenorgane bei verschiedener Rotationsform führen wir folgende Experimente aus. Wir stellen den Klinostaten am Fenster auf und bringen auf die in horizontaler Ebene um verticale Axe rotirende Scheibe (vgl. Fig. 152) 
einen Blumentopf, in welchem wenige heliotropisch sehr empfindliche Keimlinge (Sinapis, Lepidium), die bis dahin im Dunkeln verweilten, eben die Erde durchbrochen haben. Bei fortdauernder Rotation erleiden diese Keimlinge trotz der einseitigen Beleuchtung doch keine heliotropischen Nutationen, während nicht gedrelıte Vergleichsobjecte sich sämmtlich nach dem Fenster hinkrümmen.

Handelt es sich darum, bei Experimenten mit Keimlingen etc. die einscitige Schwerkraftwirkung zu eliminiren, so muss die Rotationsaxe des Apparates genau horizontal gestellt werden (vergl. Fig. 148).

Die Rotation der Untersuchungsobjecte in verticaler Ebene erfolgt in 10-20 Minuten langsam genug, um jede Wirkung der Centrifugalkraft auszuschliessen. Vor allen Dingen ist aber äusserst wichtig, um eine gleichmässige Drehung der Axe zu erı̈öglichen, dass die Belastung derselben eine allseitig gleiche sei. Dies kann durch Verwendung des Stiftes $h$ und des Gewichtes $i$ (vergl. Fig. 148) erzielt werden. Die Keimlinge selbst, z. B. Mais-, Erbsen-, Bohnenkeimlinge, in Sägespänen cultivirt, gelangen in eine aus dünnem Zinkblech gefertigte Trommel. Diese wird an Stelle eines Blumentopfes dem Topfhalter aufgesetzt und auf irgend eine Art befestigt. Den Boden der Trommel bildet eine aus weichem Holz gefertigte Platte, so dass die langen Stecknadeln, welche die Keimlinge tragen, sich ohne Mühe befestigen lassen. Die Innenwände der Trommel werden mit mehreren Lagen angefeuchteten Fliesspapiers bedeckt, ebenso die nicht wachsenden Theile der Keimlinge. Auf dem Holzboden der Trommel breitet man feuchte Watte aus, die mit kleinen Stiften befestigt wird. Recht bequem ist es auch, in folgender Weise $\mathrm{zu}$ experimentiren. Man verbindet das eine Ende einer ca. $80 \mathrm{~cm}$ langen Axe mit dem Uhrwerk des Klinostaten; das andere Ende ruht aber auf den Frictionsrollen. Man schiebt nun cinen Kork mit starker Reibung über die Axe, so dass dieser wie ein Rad in verticaler Ebene gedreht werden kann. Am Umfang des Korkes werden nun mit je zwei Nadeln die Keimpflanzen derartig befestigt, dass die Last möglichst gleichmässig vertheilt ist. Unter dem rotirenden Kork. steht ein Wasser entlialtendes Bassin so, dass die Pflanzen bei jeder Umdrchung von 20 Minuten z. B. einen Theil ihres Weges (1-2 Minuten lang) in Wasser eintauchen. Durch Ueberdecken eines mit entsprechendem Schlitze für die Axe versehenen Glaskäfigs wird die Luft in der Umgebung der Keimlinge feucht erhalten. Der ganze Apparat ist in einem Dunkelzimmer aufgestellt.

Die Untersuchungsobjecte (z. B. 4 Keimlinge von Phaseolus Pisum oder Vicia Faba) werden auf dem Kork befestigt, wenn die Hauptwurzel eben hervorgetreten ist. Man befestigt die Keimlinge derartig, dass die Hauptwurzeln eine verschiedene Richtung zu der Axe einnchmen, und findet im Laufe einiger Tage (am besten ist es, bei relativ hoher Temperatur, etwa $20^{\circ} \mathrm{C}$. zu experimentiren), dass sämmtliche Wurzeln sich in der ursprünglichen Wachsthumsrichtung verlängert haben, einen gleichmässigen Gang des Apparates vorausgesetzt. Es treten wohl gelegentlich Krümmungen an den Wurzeln auf; dieselben sind aber keine in gleichem Sinne gerichtete, geotropische Nutationen, sondern spontane Nutationen.

Was nun das Verhalten der Nebenwurzeln anbelangt, so wachsen diese im Laufe einiger Tage aus den Hauptwurzeln der seit beginnender Keimung rotirenden Untersuchungsobjecte hervor. Der Winkel, den sie mit der Hauptwurzel bilden, der sog. Eigenwinkel der Neben- 
wurzeln erster Ordnung, wird in unserem Experiment allein durch innere Wachsthumsursachen bestimmt. Dieser Eigenwinkel ist bei verscliedenen Untersuchungsobjecten und bei den einzelnen Nebenwurzeln einer Hauptwurzel keineswegs immer derselbe. Im Allgemeinen ergiebt sich, wie leicht durch Winkelmessungen festzustellen ist, dass die Nebenwurzeln an der Wurzelbasis fast oder völlig rechtwinkelig zur Hauptwurzel gerichtet sind, während die weiterhin auftretenden Nebenwurzeln einen spitzen Eigenwinkel haben; ihre Spitze ist dem Scheitel der Hauptwurzel zugewandt. Häufig treten auch bogenförmige Krümmungen an den Nebenwurzeln hervor. Ganz besonders eignen sich Phaseoluskeimlinge zu den hier erwähnten Versuchen. Bei dieser Pflanze entspringen auch gewöhnlich Nebenwurzeln aus dem kurzen Hypocotyl, die, wie besonders zu erwähnen ist, einen stumpfen Eigenwinkel erkennen lassen.

Sollen Pflanzen einseitig beleuchtet, der einseitigen Wirkung der Schwerkraft aber entzogen werden, so richtet man die Axe des Klinostaten parallel $\mathrm{zu}$ den einfallenden Lichtstrahlen. Die Rotationsebene der Untersuchungsobjecte muss mit den Lichtstrahlen einen rechten Winkel bilden. Die Töpfe, in welchen die Pflanzen wachsen, werden in der bereits auf S. 380 angegebenen Weise in einem der in Fig. 151 abgebildeten Ringe befestigt. Näheres vergl. unter 178 .

Ein Brodwürfel von $4-5 \mathrm{~cm}$ Kantenlänge wird mässig (ja nicht zu stark) mit Wasser durchfeuchtet. Man thut am besten, den Würfel zur Sterilisirung im feuchten Zustande in einer mit Glasplatte bedeckten Krystallisirschale in einem Trockenschranke einige Stunden lang einer Temperatur von etwas über $100^{\circ} \mathrm{C}$. auszusetzen. Nun wird der Brodwürfel über die ca. $80 \mathrm{~cm}$ lange Messingaxe des Klinostaten geschoben, deren eines Ende mit dem Uhrwerk in Verbindung steht, während das andere Ende auf den Frictionsrollen ruht. Der Brodwïrfel befindet sich in der Mitte der völlig horizontal und parallel zu den Fensterscheiben gerichteten Axe. Ebenfalls über diese mit grosser Reibung geschobene, durchbohrte Korkstücke zur rechten und linken Seite des Würfels können zur sicheren Befestigung dieses letzteren dienen. Unter der Axe des Klinostaten steht eine etwas Wasser enthaltende Zinkschale von $50 \mathrm{~cm}$ Seitenlänge. Ein Glaskäfig, durch den die Rotationsaxe quer hindurchgeht und der in das Wasser der Zinkschale eintaucht, dient dazu, die Luft in der Umgebung des Brodwürfels feucht zu erhalten. Der Käfig besteht aus einem Zinkgestell, welches an den zwei Seiten, wo die Axe hindurchgeht, Schlitze besitzt, die nach völliger Zusammenstellung des Apparates genügend verschlossen werden können. Vorder-und Rückwand des Käfigs sowie das Dach desselben werden von Glasplatten gebildet.

Will man nun einen Versuch anstellen, so werden einige Sporangien von Mucor oder Phycomyces nitens in sterilisirtem Wasser vertheilt. Mit Hülfe einer ausgeglühten flachen Nadel besäet man darauf alle sechs Flächen des Brodwürfels mit Sporen und setzt den Klinostaten sofort nach Ueberdecken des Glaskäfigs in Gang. Nach Verlauf weniger Tage treten die Sporangienträger aus dem Substrat hervor und haben schnell eine erhebliche Längo erreicht. Die Sporangienträger auf den Flanken des Würfels, die wir nicht weiter berücksichtigen wollen, sind freilich etwas gekrümmt, weil sie zeitweilig bei jeder Umdrehung in den Schatten der Axe kamen und dadurch zu heliotropischen Krümmungen Veranlassung gegeben war. Auf den übrigen Flächen des Brodwürfels sind die Fruchtträger aber gerade aufgerichtet; sie stehen hier senkrecht zum 
Substrat ${ }^{1}$ ). Diese Substratrichtung der Organe, die sicher nicht, wie von einigen Physiologen vermuthet wurde, durch die Masse des Brodes bedingt ist, kommt in ziemlich complicirter Weise zu Stando ${ }^{2}$ ).

Der Geotropismus kann die erwähnte Substratrichtung des Mucor nicht bedingen, denn die einseitige Wirkung der Gravitation ist ja bei Bewegung der Untersuchungsobjecte am Klinostaten ausgeschlossen ${ }^{\mathbf{3}}$ ). Wohl aber ist der weiter unten noch näher zu besprechendo negative Hydrotropismus von Bedeutung für das Zustandekommen der Substratrichtung des Mucor, und ebenso verdient in dieser Hinsicht die Fähigkeit der Fruchtträger Beachtung, auf Berührung ${ }^{4}$ ) und auf einseitige Beleuchtung mit Reizkrümmungen zu reagiren.

Von der heliotropischen Reizbarkeit der Fruchtträger kann man sich leicht überzeugen, indem man die auf Brodwürfeln im Dunkeln zur Entwickelung gelangten gerade gestreckten Organe in einer heliotropischen Kammer (vergl. unter 178) einseitig beleuchtet. Und wenn nun bei Klinostatenversnchen bei Lichtzutritt die Fruchtträger schief zur Fläche des Substrates aus diesem hervorwachsen, so ist ihre dem Brodwürfel zugewandte Seite stets, mag die betreffende. Würfelfläche dem Fenster zugekehrt oder von demselben abgewandt sein, schwächer als die opponirte beleuchtet. Es müssen somit heliotropische Wirkungen eintreten, die den Sporangiumträger ebenso wie die freilich in erster Linie thätigen hydrotropischen Vorgänge in eine zum Substrat senkrechte Stellung bringen.

Wir bringen nun auf durchfeuchtete Torfwürfel von etwa $5 \mathrm{~cm}$ Kantenlänge, die wir auf der parallel zu den Fensterscheiben gerichteten Axe des Klinostaten befestigt haben, einige Samen von Lepidium sativum oder Sinapis nigra. Die beiden Flanken des Würfels wollen wir unbesäet lassen. Die Samen haften ohne weiteres am feuchten Torf. Unser Apparat, mit Glaskäfig bedeckt, ist hellem, diffusem Tageslicht ausgesetzt. Im Laufe mehrerer Tage beobachten wir an den rotirenden Untersuchungsobjecten, dass die entstehenden Wurzeln sich in Folge ihres positiven Hydrotropismus dem feuchten Substrat fest anschmiegen, zum Theil sogar in dasselbe eindringend. Die Hypocotyle nutiren zunächst stark; bald erlangen sie aber eine senkrechte Stellung zu den Flächen des Torfwürfels. Bei dem Zustandekommen dieser Substratrichtung spielen, wie DiETz nachwies, Hydrotropismus und Contactreiz keine oder nur eine ganz untergeordnete Rolle. Wesentlich kommen hier vielmehr beliotropische Wirkungen in Betracht, und zwar in dem nämlichen Sinne, wie dies für die Fruchtträger von Mucor angegeben worden ist. Lässt man nämlich Torfwürfel, die mit Lepidium oder Sinapis besäet sind, im Dunkeln um horizontale Axe langsam rotireu, dann stellen sich

1) Dic Fruchtträger auf den Kanten des Würfels haben eine solche Lage, dass ihre Richtung den Winkel der Kanten halbirt.

2) Vgl. SACHS, Arbeiten d. botan. Instituts in Würzburg, Bd. 2, S. 217, und Dutz, Unters. a. d. botan. Institut zu Tübingen, Bd. 2, S. 478.

3) Damit soll natürlich nicht gesagt werden, dass llucor nicht geotropisch reizbar sei. Dies ist vielmehr in hohem Grade der Fall. Wird z. B. cin mit Mucorsporen besäeter Brodwürfel, den man auf eine lange Nadel aufgespiesst hat, in einem grossen Glascylinder, dessen Boden mit Wasser bedeckt ist, schwebend befestigt, so treten nach einigen Tagen bei Lichtabschluss gerade gestreckte Sporangienträger aus der oberen Würfelfläche hervor. Die Sporangienträger, die an den Flanken des Würfels zur Entwickelung gelangen, sind im Bogen negativ geotropisch nach aufrärts gekrünmt, und aus der Unterfläche des Würfels wachsen positiv geotropiseh reagirende verzweigte Mycelfäden hervor.

4) Vgl. Wortmans, Botan. Zeitung. 1887, No. 49. 
die Hyposotyle nicht senkrecht zum Substrat, sondern sie nehmen die verschiedensten Richtungen an.

Sehr geeignet $\mathrm{zu}$ Versuchen am Klinostaten sind auch sicher Keimlinge von Phleum pratense, die sich allerdings nicht so schnell, wie z. B. diejenigen von Lepidium entwiekeln. Wenn man Torfwürfel, die in etwas Wasser enthaltenden Krystallisirschalen ruhen, mit Phleum besäet und unter einen Pappkasten stellt, so wächst die Plumula der Keimlinge an der horizontalen Oberfläche des Würfels senkrecht nach aufwärts. Die Plumula der Keimlinge, welche an den verticalen Seiten des Würfels liegen, erscheint bogenförmig nach aufwärts gekrümmt, eine Folge ihrer starken geotropischen Reizbarkeit.

\section{7\%. Experimente mit dem Centrifugalapparat.}

Zunächst will ich hier einen von mir construirten und in Fig. 153 abgebildeten Centrifugalapparat beschreiben, der selir leicht und billig hergestellt werden kann und für Demonstrationsversuche recht geeignet erscheint. Den wichtigsten Theil des Apparates bildet die ca. $50 \mathrm{~cm}$ lange Messingaxe $A$, welche die $40 \mathrm{~mm}$ Durchmesser besitzende Zinkscheibe $Z$ trägt, an der sechs $3 \mathrm{~cm}$ breite und $7,5 \mathrm{~cm}$ lange Metallflügel angelöthet sind. Der Axe ist ferner am entgegengesetzten Ende eine Holzscheibe von $140 \mathrm{~mm}$ Durchmesser $H$ aufgeschroben,

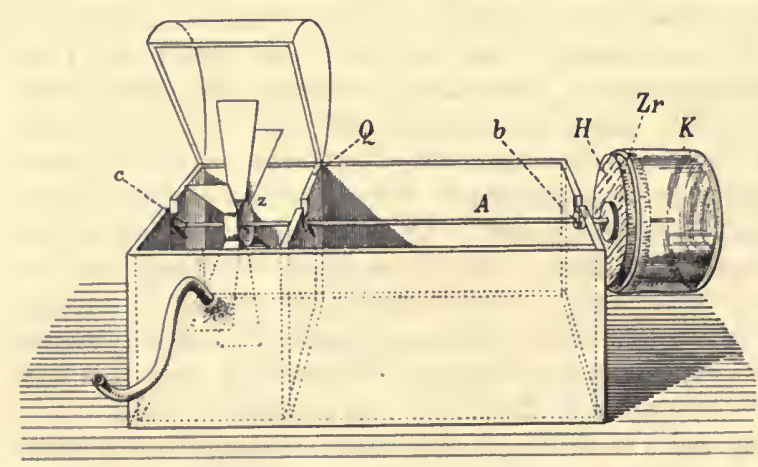

Fig. 153. Centrifugalapparat. auf der noch eine Korkplatte ruht. Der Zinkring $Z r$ ist an dem Rande der Holzscheibe befestigt, ragt aber über diesen hervor und kann benutzt werden, um einem an einem Ende verschlossenen, als Deckel dienenden Zinkcylinder von ca. 11 cm Länge Halt zu gewähren, so dass sich z. B. Keimlinge, die man mit Nadeln auf der Korkplatte befestigt, in einem verdunkelten Raum befinden, wenn der Zinkdeckel aufgesetzt ist. In der Abbildung trägt die Holzscheibe $H$ eine Glasglocke $R$. Die Axe $A$ ruht bei $b$ in einem Lager. Bei $c$ liegt ein zweiter Unterstützungspunkt für die Axe, deren Ende hier eine Spitze bildet. Wie unsere Abbildung zeigt, dient zur Aufnalime der beschriebenen Vorrichtung ein Kasten. Derselbe ist ca. $15 \mathrm{~cm}$ hocl, $27 \mathrm{~cm}$ breit und $41 \mathrm{~cm}$ lang. Die Wände der kleineren Abtheilung, in welcher sich die Flügel bewegen sollen, sind mit Zinkplatten ausgekleidet. In der Vorderwand befindet sich eine Oeffnung, welche mittelst eines durchbolirten Korkes verschlossen wird. In der Bohrung steckt ein Glasrohr. dessen den Flügeln zugekehrtes Ende etwas 
ausgezogen ist, während ïber das andere Ende ein mit der Wasserleitung in Verbindung stehender Schlauch gezogen werden kann. Es ist nun bei einigermaassen starkem Druck des Wassers in der Leitung, indem man einen Wasserstrahl auf die Flügel einwirken lässt, eine 200-300malige Rotation der Vorrichtung in der Minute zu erzielen. Zur Verlüutung des Umherspritzens des Wassers wirl die kleinere Abtheilung des Kiastens mittelst eines gewölbten Holzdeckels verschlossen. Das von den Metallflügeln abtropfende Wasser fliesst durch ein Loch im Boden des Kastens direct in den Ausguss der Wasserleitung, auf welchem der Apparat Platz gefunden hat.

Geeignete Untersuchungsobjecte sind z. B. Keimlinge der Erbse, die, in feuchten Sägespänen zur Entwickelung gelangen, Wurzeln von ca. $2 \mathrm{~cm}$ Länge besitzen. Man legt auf den mit Wasser durchtränkten Kork, ler auf der Holzscheibe $H$ rulit, nasse Watte. Diese wird mit Stecknadeln befestigt. Ebenso befestigt man die Keimlinge z. B. derartig init Nadeln nalie dem Unfange der Korkplatte, dass ihre Hauptwurzeln parallel zur Rotationsaxe gerichtet sind. Der Zinkdeckel wird innen mit feuchtem Fliesspapier ausgelileidet und aufgesetzt. Bei uneinen Versuchen bei ca $20^{\circ} \mathrm{C}$. war - ler Erfolg schon nach etwa 3-stündiger Rotation sehr deutlich. Die wachsenden Wurzelspitzen der an der Scheibe des Apparates in verschiedener Weise befestigten Keimlinge liatten sich sämmtlich nach aussen gekrümmt, so dass sie nunmelır einen rechten Winkel mit der Rotationsaxe bildeten (vgl. Fig. 154). Bei längere Zeit dauernden Rotationsversuchen, die z. B. den Zweek haben, das Verhalten der Nebenwurzeln von Keimphlanzen der Centrifugalkraft gegenüber zu studiren, ist es erforderlich, die Ex-

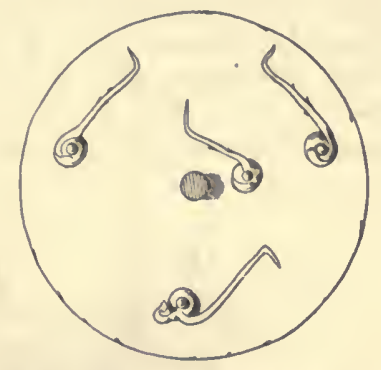

Fig. 15t. Keimlinge ron l'isum, deren Wurzelspitzen sich in Folge schneller Rotation der Scheibe eines Centrifugalapparates um eine horizontale Axc gekrüınınt haben. perimente etwa alle $3-4$ Stunden zu unterbrechen, um die Watte auf dem Kork sowie die Keimlinge aufs Neue durch Benetzen mit Wasser himreichend feucht $\%$ u erhalten.

Der erwälnnte Apparat ist zu sclıwach gebaut, um Blumentöpfe, die mit Erde und Keimlingen etc. beschickt sind, tragen zu können. Un aber doch den Eintluss der Centrifugalkraft auf wachsende Stengel zu demonstriren, verfahre ich in folgender Weise.

Zwei kurze Probirgläser von ca. $55 \mathrm{~mm}$ Länge und $25 \mathrm{~mm}$ Weite werden mit feuchten Sägespänen angefüllt. In diese legt man einige Samen von Lepiclium sativum ein. In Dunkeln beginnt die Keimung derselben schnell, und wenn die Hypocotyle mit nickendem Ende über die Sägespäne hervorgetreten sind, kann der Rotationsversuch beginnen. Zur Befestigung der Culturcylinder an einander diametral entgegengesetzten Punkten der Peripherie der Korkplatte schiebt man dieselben durch in der Mitte mit einer Bohrung von entsprechender Weite versehene liorkstücke hindurch und befestigt diese init Hülfe melirerer Nadeln auf der grossen Korkplatte des Apparates. Nach Verlauf einiger Stunden ist das Resultat des Rotationsversuches bereits leutlich zu constatiren. Die Hypocotyle, bei Beginn des Versuchs parallel zu der horizontalen Rotationsaxe gerichtet, haben etwas unterhalb derjenigen Stelle, an der sie in Folge ihres spontanen Nutations- 
vermögens gekrümmt erscheinen, eine neue Krümmung erfahren. Die oberhalb der zuletzt erwälnnten Krümmungszone gelegenen Theile des Hypocotyls haben sich dem Centrum der Scheibe, nicht wie die wachsenden Wurzelspitzen der Peripherie derselben, zugekehrt. Geeignete Untersuchungsobjecte sind auch Triticumkeimlinge.

Ich habe nun ferner noch einen grossen Centrifugalapparat construirt (zu beziehen für $70 \mathrm{M}$. von G. TeGTMEIER, Mechaniker am physikalischen Institut zu Jena), mit Hülfe dessen man z. B. auch grössere Blumentöpfe, in denen in Erde Pflanzen cultivirt worden sind, einer sclinellen Rotation (z. B. einer 300maligen in der Minute) aussetzen kann, und der sich für eingehende Studien über den Einfluss der Centrifugalkraft auf Pflanzen selır gut eignet. Ich führte auch selbst schon manche Experimente mit diesem Apparat aus.

In Fig. 155 ist der Apparat in der Weise, wie er sich uns bei vertical gerichteter Rotationsaxe darstellt, abgebildet.

Auf dem schweren Brett $B$ ist die Metallsäule $M$ befestigt. Neben dieser befindet sich der Axenhalter $A h$. Derselbe kann mittelst der Schraube $S c h$ und des Stiftes $S t$ unverrückbar an $M$ befestigt werden, wenn die Rotationsaxe vertical stehen soll. Diese Axe hat eine Länge von $20 \mathrm{~cm}$. Bei $a$ ruht sie auf einer in der Abbildung nicht sichtbaren Spitze; bei $l$ befindet sich ein Lager für die Axe. Ueber die

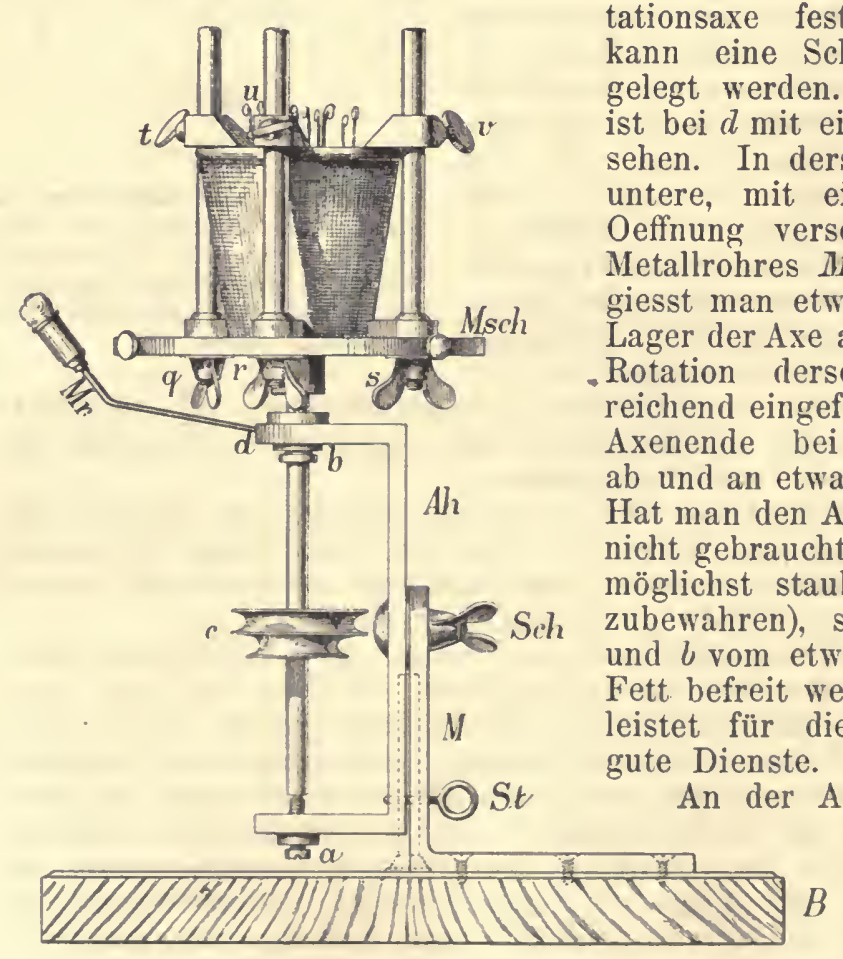

Fig. 155. Centrifugalapparat. Scheibe $c$, welche mit der Rotationsaxe fest verbunden ist, kann eine Schnur ohne Ende gelegt werden. Der Axenhalter ist bei $d$ mit einer Bohrung versehen. In derselben steckt das untere, mit einer sehr feinen Oeffnung versehene Ende des Metallrohres Mr. In dies Rohr giesst man etwas Oel, damit das Lager der Axe auch bei schneller - Rotation derselben stets hinreichend eingefettet bleibt. Den Axenende bei $a$ ist ebenfalls $a b$ und an etwas Oel zuzuführen. Hat man den Apparat lange Zeit nicht gebraucht (er ist an einem möglichst staubfreien Orte aufzubewahren), so muss er bei a und $\zeta$ vom etwa eingetrockneten Fett befreit werden. Petroleum leistet für diesen Zweck sehr An der Axe ist nun die ca. $17 \mathrm{~cm}$ Durchmesser besitzende Metallscheibe Msch befestigt. Diese Scheibe, in Fig. 156 von oben gesehen abgebildet, ist in der Nähe ihrer Peripherie mit drei Ausschnitten versehen, in denen die drei Topfhalter verschiebbar sind. 
Jeder dieser Topfhalter besteht aus einem verticalen Metallstab, der an der Basis, wie es in Fig. 156 bei $z$ zu sehen ist, eine Metallplatte trägt, einer unter der Rotationsscheibe vorhandenen Schraube (die 3 Schrauben der Halter sind mit $q, r$ und $s$ bezcichnet) zum Festklemmen der Halter und aus einem Schieber (die Schieber sind mit $t, u, v$ bezeichnet) zum Festhalten der Blumentöpfe, die man auf den Apparat gestellt hat. Soll die Rotation der Pflanzen nicht in horizontaler, sondern in verticaler Ebene erfolgen, um jede Scliwerkraftwirkung auszuschliessen, so muss die Rotationsaxe horizontal gelegt werden. Dies erreicht man, indem man die Schraube Sch lockert, den Stift $S t$ entfernt, den Axenhalter um $90^{\circ}$ dreht, so dass sein Ende auf dem in Fig. 155 durch punktirte Linien angedeuteten, senkrecht auf dem Brett $B$ stehenden Metallstab ruht, und die Schraube Sch wieder fest anzieht. Sollen die Pflanzen im Blumentopf bei der Rotation dem Lichteinfluss entzogen werden, dann bedient man sich eines hinreichend hohen Zinkblechrecipienten, dessen Mantel nahe am offenen Ende mit drei Löchern versehen ist, durch welche die in Fig. 156 durch $h, i, k$ bezeichneten Schrauben der Rotationsscheibe zur Befestigung des Cylinder's gefülırt werden können.

Beim Gebrauch wird der Centrifugalapparat auf eine Tischplatte gestellt, die am besten auf in der Wand befestigten eisernen Trägern unverrückbar ruht, und auf der Tischplatte mittelst Schrauben befestigt. Diese letzteren sowic auch alle übrigen Schrauben am Apparat sind sehr fest anzuziehen, damit sie sich bei schneller Rotation desselben nicht lockern. Der Centrifugalapparat wird mit Hülfe eines Wassermotors von HERBERTz in Köln in Bewegung gesetzt, dem man mittelst eines an den Ausflusshaln der Wasserleitung angeschraubten Hanfschlauches das erforderliche Wasserquantum zuführt. Der Motor steht

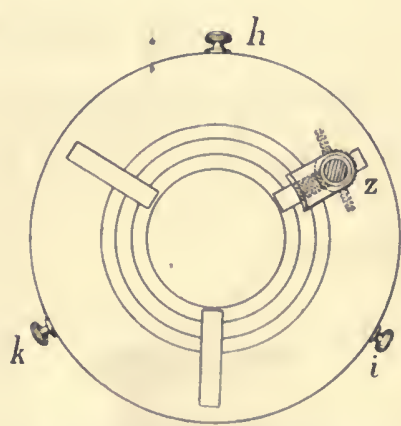

Fig. 156. Rotationsscheibe des in Fig. 155 dargestellten Centrifugalapparates. Die Scheibe von oben gesehen. mit dem Centrifugalapparat mittelst einer Schnur ohne Ende in Verbindung, und es kann leicht eine bedeutende Rotationsgeschwindigkeit des letzteren (4-5 Umdrehungen in der Secunde) erzielt werden.

Als Untersuchungsobjecte benutzen wir zunächst Kressekeimlinge, die in gut durchfeuchteter Gartenerde zur Entwickelung gelangt sind. Auf die Scheibe Msch legt man feuchtes Fliesspapier, stellt einen Blumentopf genau mitten auf die Scheibe, befestigt ihn sorgsam mit Hülfe der Topfhalter und beginnt den Versuch sofort, der alsbald las schon oben gekennzeichnete Resultat ergiebt.

Ich experimentirte z. B. auch mit jungen, in Töpfen cultivirten Weizenkeimlingen. Die Plumula derselben war bei hoher Sommertemperatur schon nach 2-3-stündiger Rotation dem Centrum der Scheibe zugekrümmt.

Bei Experimenten über den Einfluss der Centrifugalkraft auf das Wurzelwachsthum verfährt man am besten, wie folgt. Die Topfhalter werden von der Scheibe entfernt. Man setzt einen Zinkcylinder 
von ca. 15 cm Länge auf die Scheibe, dessen Mantel nahe seinem unteren Ende mit drei Löchern versehen ist, um ihn mittelst der Schrauben $h, i, k \mathrm{zu}$ befestigen. Dicht über diesen Löchern hat der Cylinder seinen Boden, der also direct auf der Scheibe Msch ruht. Das obere offene Ende des Cylinders kann mittelst eines Deckels verschlossen werden. Die Innenwand des Cylinders wird mit feuchtem Fliesspapier ausgekleidet. Auf dem Cylinderboden befestigt man eine mit Wasser durchtränkte Korkscheibe, die noch mit feuchter Watte bedeckt wird. Die Keimlinge spiesst man auf Nadeln auf und bringt sie in möglichster Entfernung vom Centrum auf der Korkscheibe an. Es ist dafür zu sorgen, dass die Untersuchungsobjecte stets feucht genug erhalten bleiben. Sehr geeignete Untersuchungsobjecte sind Keimlinge von Pisum mit ca. $2 \mathrm{~cm}$ langen Wurzeln. Will man das Verhalten der Nebenwurzeln studiren, so benutzt man Keimpflanzen von Vicia Faba. Die Rotationsversuche werden bei horizontaler Lage der Achse des Apparates längere Zeit fortgeführt, und man findet, dass sich die entstehenden Nebenwurzeln unter dem Einfluss der Centrifugalkraft sämmtlich nach aussen krümmen ${ }^{1}$ ).

\section{Die heliotropischen Nutationen.}

Zahlreiche Pflanzentheile, insbesondere jugendliche Stengel, wenden sich, wenn sie einseitigem Lichteinfluss ausgesetzt werden, den Lichtstrahlen $\mathrm{zu}$; sie sind positiv heliotropisch. Einige Pflanzentheile,

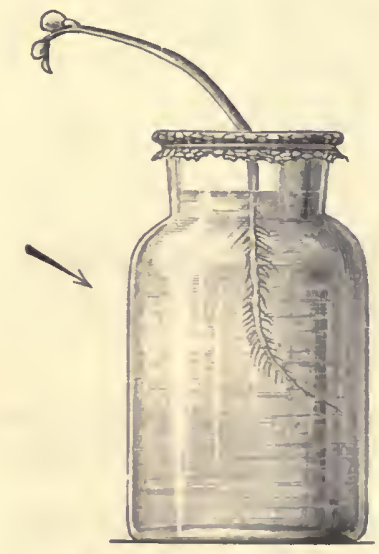

Fig. 157. Keimpflanze von Sinapis alba. Das Hrpocotyl ist positiv, die Wurzel negativ heliotropisch gekrümmt. z. B. die Wurzeln mancher Cruciferen, sind negativ heliotropisch; sie krümmen sich bei einseitiger Beleuchtung vom Lichte weg. Wir füllen ein kleines Glas, über dessen Mündung ein Stück engmaschigen Tülls festgebunden ist, völlig mit Brunnenwasser an, befestigen einige in Sägespänen angekeimte Pflänzchen von Sinapis alba mit Watte in den Maschen des Tülls und stellen das Gefäss einen Tag lang unter eine Glasglocke, über welche wir noch einen Papprecipienten decken. Bei der im Dunkeln erfolgenden Keimung wachsen die Wurzeln in das Wasser hinein; das hypocotyle Glied wächst aber senkrecht aufwärts. Um unsere Untersuchungsobjecte nun einseitigem Lichteinfluss auszusetzen, stellen wir das Gefïss mit den Keimpflanzen unter ein, bis auf einen schmalen Spalt mit mattschwarzem Papier beklebtes Becherglas oder unter cinen mit einem Spalt versehenen, im Innern mit mattschwarzem Papier überzogenen Pappkasten. Nach Verlauf einiger Stunden ist schon deutlich zu sehen, dass die hypocotylen Glieder der Keimlinge sich den durch den Spalt unserer Vorrichtung eindringenden Lichtstrahlen zu-

1) Vgl. Kxignt, Philosophical Transac., 1S06, T. I, p. 99, und SACHS, Arbeiten d. bot. Instituts in Würzburg, Bd. 1, S. 607 . 
gewendet haben, während sich die Wurzeln im Gegentheil vom Licht wegkrümmen. In Fig. 157 ist eine Keimptlanze dargestellt, deren Hypocotyl eine positiv heliotropische, deren Wurzel aber eine negativ heliotropische Nutation erfahren hat.

Es existiren nur verhältnissmässig wenige Pflanzentheile, die negativ heliotropisch sind. Dem positiven Heliotropismus kommt dagegen eine sehr allgemeine Verbreitung zu. Günstige Untersuchungsobjecte sind zumal im Dunkeln erwachsene Keimlinge von Phaseolus multiflorus, Vicia sativa, Lepidium sativum. Wir cultiviren die Pflanzell in mit lockerer Gartenerde angefüllten Blumentöpfen und setzen sie, wenn das Epicotyl resp. das Hypocotyl der Keimlinge in lebhaftem Wachsthum begriffen ist, in angegebener Weise einseitigem Lichteinfluss aus. Die heliotropischen Nutationen machen sich alsbald geltend; sie gehen oft so weit, dass die Enden der Stengeltheile parallel zu den Strahlen des einfallenden Lichtes gerichtet werden. Uebrigens ist die heliotropische Empfindlichlieit verschiedener Pflanzentheile keineswegs die gleiche. Sehr empfindlich sind z. B. die epicotylen Glieder von Vicia sativa und die ca. 2 cm lange Plumula von Triticum vulgare, während die Epicotyle von Phaseolus multiflorus schon nicht so energisch auf den Lichtreiz reagiren. Schneidet man junge Sprosse von Sambueus nigra ab, um sie nach dem Entblättern mit ihrer Basis in Wasser zu stellen und einseitig zu beleuchten, dann findet man, dass sie sich nur langsan dem Lichte zuwenden. Ihre heliotropische Reizbarkeit scheint auf jeden Fall geringfügig zu sein, obgleich Genaueres über dies Verhältniss erst durch eingehendere Untersuchungen unter Benutzung des Klinostaten und bei Ausschluss geotropischer Nutationen ermittelt werden kann. (Vergl. weiter unten.)

Sehr bequem ist es auch, zumal bei Demonstrationen, das $\mathrm{Zu}$ standekommen heliotropisclier Nutationen unter Benutzung einer sog. heliotropischen Kam-

mer nachzuweisen.

Dieselbe besteht aus einem aus starker Pappe gefertigten Kasten von etwa $16 \mathrm{~cm}$ Hölie, $20 \mathrm{~cm}$ Tiefe und $12 \mathrm{~cm}$ Breite. Vgl. Fig. 158. Deckel und Rückwand des im Innern mit mattschwarzem Papier

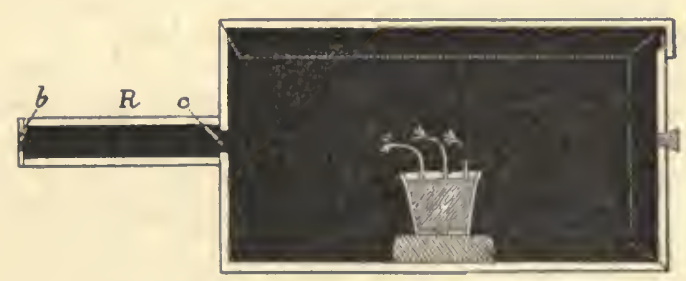

Fig. 15S. Heliotropische Kimmer. überklebten Kastens

können zurückgeschlagen werden. Die Vorderwand des Kastens ist mit einer $1 \frac{1}{2} \mathrm{~cm}$ weiten Oeffnung versehen und trägt das Ansatzrohr $R$. Das Rohr trägt am vorderen Ende eine mit Spalt versehene Verschlussplatte. Dieser Spalt $b$ liegt in gerader Liuie mit dem Spalt $c$ des Kastens. Man cultivirt Keimlinge von Sinapis oder Lepidium in kleinen Blumentöpfen. Wenn die Pflänzchen eben iiber die Erde gekommen sind, stellt man ein Culturgefïss in die heliotropische Kammer, richtet den Spalt $b$ zum Fenster hinaus nach weissen Wolken oder gegen eine von der Sonne beschienene weisse Wand und findet die Pflanzen bereits nach wenigen Stunden heliotropisch gekrümmt. (Vergl. SaCHs, Vorlesungen.) 
Wenn in Töpfen cultivirte Keimlinge von Lepidium sativum oder andere Untersuchungsobjecte von sèr Ischwachem Licht getroffen werden, so krümmen sie sich nur langsam dem Licht entgegen. Unmittelbar vor einem nach Süden gelegenen Fenster crfolgte bei meinen Versuchen die heliotropische Nutation der Stengel von bis dahin im Dunkeln cultivirten Lepidiumkeimlingen bei diffusem Licht schneller als dann, wenn die Pflanzen mehrere Meter entfernt vom Fenster einscitig beleuchtet wurden. Es scheint aber, dass hohe Lichtintensität das Zustandekommen heliotropischer Nutationen wieder verlangsamt. (Vergl. weiter unten.)

Werden in Töpfen cultivirte Keimlinge (ich experimentirte mit Lepidium) nach der unter 8 angegebenen Methode in einen Kasten gebracht, in welchem sie dem durch eine Lösung von doppelt-chromsaurem Kali hindurchgegangenen gemischten gelben Licht ausgesetzt sind, so krümmen sie sich den einfallenden Lichtstrahlen gar nicht oder nur sehr langsam entgegen.

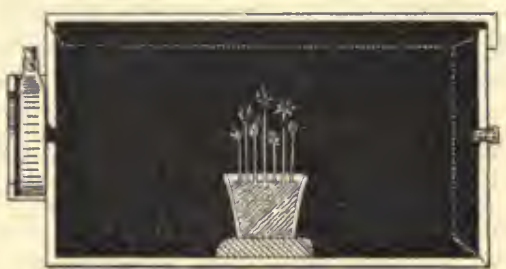

Fig. 159. Heliotropisehe Kammer. Bei dem Versuch, dessen Resultat durch Fig. 159 veranschaulicht wird, war gar keine heliotropische Krümmung der Keimlinge erfolgt. WresNER beobachtete dagegen auch im gemischten gelben Licht langsam zu Stande kommende heliotropische Nutationen, eine Angabe, die für die Bedingungen, unter denen er experimentirte, wohl richtig sein wird. Unter dem Einfluss des gemischten blauen Lichtes, das eine Lösung von Kupferoxydammoniak passirt hat, tritt aber eine energische heliotropische $\mathrm{Nu}$ tation auf.

Bei eingehenden Studien über den Einfluss des Lichtes von verschiedener Brechbarkeit auf das Zustandekommen der heliotropischen Nutationen ist es sehr zu empfehlen, unter Benutzung des objectiven Spectrums zu arbeiten. Ein vor dem Fenster zitterfrei aufgestellter Heliostat wirft ein Bündel paralleler Sonnenstrahlen durch einen schmalen Spalt in ein Dunkelzimmer. Der Spalt wird durcl die Gravesand'schen Schneiden gebildet. Nachdem das Licht eine Biconvexlinse passirt hat, die in nicht ganz der doppelten Brennweite vom Spalt aufgestellt ist, trifft es auf das Flintglasprisma, das einen brechenden Winkel von $60^{\circ}$ besitzt. Da Glas die stark brechbaren Strahlen energisch absorbirt, ist es sehr zweckmässig, den Heliostaten mit einem Silberspiegel zu versehen und mit einer Quarzlinse sowie Quarzprisma zu experimentiren.

Als Untersuchungsobjecte benutzt man z. B. in sehr kleinen Thongefässen im Finstern cultivirte Wickenkeimlinge. Sie werden derartig innerhalb des Spectrums aufgestellt, dass die Flanken der Stengel den einfallenden Strahlen zugewandt sind. Auch Sinapis- und Triticumkeimlinge eignen sich gut zu den Versuchen. Im Verlauf einiger Stunden tritt das Resultat der Versuche klar hervor. Sehen wir von dem Zustandekommen der sog. lateralen Flexion ab, so zeigt sich zumal, dass die Strahlen an der Grenze zwischen Violett und Ultraviolett die grösste heliotropische Kraft entfalten. Recht empfindlichen Objecten gegenüber nimıt die heliotropische Kraft der Strahlen von 
Violett bis Grün $a b$; Gelb ist unwirksam: im Ultraroth liegt ein zweites kleineres Maximum.

Wenn man nach der unter 181 angegebenen Methode Mucor Mucedo im Dunkeln auf Brot cultivirt und die heranwachsenden Pflänzchen dann einseitig beleuchtet, so krümmen sie sich dem Licht entgegen. Die einzelligen Mucorfruchtträger sind demnach positiv heliotropisch, eine Thatsache, die, wie ich S. 308 meines Lehrbuches der Pflanzenphysiologie specieller auseinandergesetzt habe, von Bedeutung für die Theorie des Heliotropismus erscheint.

Wenn sich heliotropische Nutationen geltend machen, so wächst stets in Folge des Lichtreizes die convex werdende Seite der Pflanzentheile stärker als die concav werdende. $\mathrm{Zu}$ heliotropischen Nutationen sind auch nur wachsende Pflanzentheile befähigt, wie ein sehr einfaches Experiment ergiebt. Wir cultiviren Bohnenkeimlinge im Dunkeln. Hat das Epicotyl eine Länge von einigen $\mathrm{cm}$ erreicht, so bringen wir mit Hülfe eines Pinsels feine Tuschestriche in Entfernungen von je $5 \mathrm{~mm}$ auf den Stengeln an und beleuchten unsere Untersuchungsobjecte dann einseitig. Eine heliotropische Krümmung tritt nur in der oberen, noch im Wachsthum begriffenen Region der epicotylen Glieder ein.

Wenn man etiolirte Wickenkeimlinge etwa 12 Stunden lang einseitig beleuchtet und die abgeschnittenen epicotylen Glieder dann in 15-proc. Kochsalzlösung bringt, so wird die heliotropische Nutation durch die Plasmolyse nicht wieder rückgängig gemacht, weil sie durch Wachsthumsvorgänge bereits völlig fixirt worden ist. Beleuchtet man aber Wickenkeimlinge nur so lange einseitig, bis das Epicotyl schwach gekrümmt erscheint, dann vermindert sich die Krüımung dureh Plasmolyse etwas, weil wenigstens derjenige Theil der ersteren, welcher auf einer Differenz der Turgorausdehnung der Zellen auf der convexen sowie concaven Seite der Pflanzentheile beruht und nicht bereits durch Wachsthumsprocesse fixirt worden ist, noch aufgehoben werden kann ${ }^{1}$ ).

\section{Weitere Orientirung ïber den Heliotropismus.}

Zur genaueren Constatirung mancher sich bei dem Zustandekommen der heliotropischen Nutationen geltend machenden Erscheinungen stellen wir noch folgende Versuche an. In einem Dunkelzimmer stellen wir unseren Klinostaten derartig auf, dass die Axe desselben parallel zu den durch die Oeffnung im Fensterladen einfallenden Lichtstrahlen gerichtet ist. Ein Blumentopf, in welchem sich eine Phaseoluspflanze bei Lichtabschluss entwickelt hat, wird nun derartig, wie es S. 380 angegeben ist, auf dem Klinostaten befestigt. Die Lichtstrahlen müssen senkrecht auf der Nutationsebene des Epicotyls stehen, und dies letztere muss sich noch in lebhaftem Wachsthum befinden und wird durch Tuschemarken, die man auf seiner dem Licht zugekehrten und auf der vom Licht abgewandten Flanke in Entfernungen von $5 \mathrm{zu} 5 \mathrm{~mm}$ anbringt, in einzelne Zonen eingetheilt.

1) Zahlreiche Literaturangaben über den Heliotropismus findet man S. 303 und 304 meines Lehrbuches der Pflanzenphysiologie, Breslau 1883. Zahlreiche werthvolle Details findet man zumal bei SACrs und Wilsser (Denksehr. d. Akad: d. Wiss. zu Wien, Bd. 39 und 43). 
Setzt man den Klinostaten in Bewegung, so können die heliotropischen Bewegungen in reiner Form beobachtet werden. Geotropische $\mathrm{Nu}$ tationen sind ausgeschlossen, und ebenso stört die spontane Nutation des Epicotyls nicht. Die heliotropische Nutation macht sich nun freilich nicht sofort, aber nach Verlauf einiger Zeit geltend. Ist sie recht ausgiebig geworden, so unterbrechen wir den Versuch und bestimmen mit dem Cyclometer (Carton mit concentrischen Kreisen, deren Radien 1, 1,5, 2 etc. cm betragen) den Radius der erzielten Krümmung sowie die Zuwachse unseres Untersuchungsobjectes. Wir finden, dass auf der convex gewordenen Seite des Epicotyls ein viel grösserer Zuwachs erfolgt ist als auf der concav gewordenen. Nur die noch nicht ausgewachsenen Theile des Epicotyls sind heliotropisch krümmungsfähig. Bei hinreichender Dauer des Versuchs haben sich auch nach einander sämmtliche Zonen des Epicotyls an der Nutation betheiligt, die noch im Stadium der Streckung begriffen waren ${ }^{1}$ ).

Unter 169 ist betont. worden, dass Algenschwärmer sich bei intensivem Licht von diesem abwenden, während sie schwächeres Licht aufsuchen. Daher darf man von vornherein vermuthen, dass auch die Organe höherer Pflanzen auf ein Licht ganz bestimmter Intensität gestimmt sind. Freilich bedarf es noch sehr eingehender Studien zur sicheren Begründung dieser Vermuthung; indessen die Resultate gewisser Experimente OLtmanss' ${ }^{2}$ ) sprechen sicher für die Richtigkeit derselben. Werden junge Lepidiumkeimlinge, die in einem Blumentopf zur Entwickelung gelangten, in einem innen geschwärzten Kasten mit etwa $3 \mathrm{~cm}$ breitem Spalt dicht vor diesem aufgestellt und directem Sonnenlicht ausgesetzt (durch Drehen des Kastens sorgt man dafür, dass er ungefähr immer die nämliche Stellung zur Sonne behält), dann bleiben die Hypocotyle gerade, während sie sich im minder intensiven Licht stark positiv heliotropisch verhalten. Ferner kann man derartig experimentiren, dass man die mittelst eines Heliostaten in ein Dunkelzimmer gelenkten Sonnenstrablen eine dicke Schicht concentrirter Alaunlösung und dann eine grosse biconvexe Linse passiren lässt. Hinter dieser wird ein Topf mit Lepidiumkeimlingen aufgestellt. Die Keimlinge sind in einer Reihe gepflanzt, und diese wird zu den vom Brennpunkt der Linse divergirenden Strahlen unter einen Winkel von etwa $45^{\circ}$ gestellt. Eine Keimpflanze steht somit nahe am Breunpunkt der Linse; die übrigen in wachsender Entfernung, ohne sich gegenseitig $\mathrm{zu}$ beschatten. Bei genügend starker Beleuchtung findet man, dass die Stengel derjenigen Lepidinmkeimlinge, welche dem Brennpunkt der Linse am nächsten sind, eine negativ heliotropische Krümmung ausführen. Keimling 3 oder 4 der Reihe bleibt völlig gerade, 5, 6, 7 führen positiv heliotropische Nutationen aus.

Wenn man über die Mitte eines Algenschwärmer enthaltenden Gefässes ein schmales Brettchen derartig legt, dass dasselbe senkrecht zum Fenster, also nahezu parallel zu den einfallenden Lichtstrahlen gerichtet ist, dann sammeln sich die Schwärmer nicht am Vorderrande der Schale, sondern zu beiden Seiten des Brettchens in dessen Halbschatten an. Famintzix und zumal Oltmaxis (Flora 1892, S. 203) schliessen daraus, dass nicht die Richtung der Lichtstrahlen, sondern die Lichtintensität oder der Lichtabfall maassgebend für die phototactische Bewegang der Schwärmer sei. Aehnliches nimmt Olmmaxss auch für die heliotropischen Nutationen an, und einige Versuche, die ich anstellte, sprechen vielleicht.

1) Vgl. MÜlLfF-Thurgau, Flora, 1876.

2) Vgl. Oltmaxxs, Flora, 1892, S. 223. 
auch zu Gunsten dieser Anschauung. Die wichtige hier berührte Frage bedarf aber sehr eingehender weiterer Prüfung, und bei den folgenden Versuchen scheint mir, ebenso wie bei den erwähnten, die Frage nach der Mitwirkung reflectirten Lichtes einer besonders genauen Berïcksichtigung zu verdienen, um Fehler in den Schlussfolgerungen auszuschliessen. $\mathrm{Zu}$ meinen Experimenten diente ein innen geschwärzter Kasten, dessen eine Wand mit einem Spalt von geringer Breite, aber erheblicher Länge versehen war. Hinter diesem Spalt fand im Innern des Kastens eine keilförmige, mit Wasser, in welchem chinesische Tusche vertheilt war, angefüllte Glasflasche Platz. Die Weite des mit der Flüssigkeit angefüllten, ca. $18 \mathrm{~cm}$ langen keilförnigen Raumes der Flasche betrug an dem einen Ende desselben nur etwa $3 \mathrm{~mm}$, am anderen aber über $25 \mathrm{~mm}$. Wurden Töpfe mit Lepidiumkeimlingen in den Kasten gebracht, und dieser im Freien derartig aufgestellt, dass der Glaskeil horizontal lag und die Lichtstrahlen von oben her in den Apparat eintraten, dann krümmten sich alle Keimlinge nach dem Orte stärkster Lichtintensität im Kasten, also rechtwinklig zu den einfallenden Strahlen nach demjenigen Kastenende hin, an welchem sich das Keilende von geringster Weite befand. Wurde der Kasten im Zimmer so aufgestellt, dass der Glaskeil parallel zur Fensterscheibe, also nahezu senkrecht zu den einfallenden Lichtstrahlen lag, und stand der mit Lepidiumkeimlingen beschickte Topf etwa in der Mitte hinter dem Glaskeil, dann krümmten sich die Hypocotyle freilich nicht genau rechtwinkelig zu den einfallenden Lichtstrahlen, sie wandten sich denselben aber auch nicht gerade entgegen, sondern krümmten sich schief dem Orte stärkster Lichtintensität im Kasten zu.

Auch die folgenden Experimente über heliotropische Nutationen beanspruchen grosses Interesse ${ }^{1}$ ).

Wir legen Körner von Avena sativa in Schalen, die wenig Wasser enthalten. Wenn die Keimung eben begonnen hat, suchen wir recht gleichmässig entwickelte Keimlinge aus, um sie in gute Gartenerde, mit der zahlreiche kleine Blumentöpfe angefüllt sind, einzusetzen. Wir benutzen zu den eigentlichen Experimenten nur solche Töpfe, in denen nach einiger Zeit 5-10 Haferkeimlinge mit ca. $2 \mathrm{~cm}$ langer Plumula bei Lichtabschluss zu sehr gleichförmiger Entwickelung gelangt sind. Die Töpfe stellen wir in geeignete heliotropische Kammern, deren vordere Wand mit einem einige $\mathrm{cm}$ breiten, horizontalen Spalt versehen ist. In Folge ihrer starken Circumnutation sind die im Dunkeln erwachsenen Pfänzchen oft nicht völlig gerade gerichtet. Man stellt die Töpfe in der heliotropischen Kammer daher derartig auf, dass keiner der Keimlinge dem Licht, welches vom Fenster her auf sie einwirkt, zugeneigt ist. Es lässt sich constatiren, dass die heliotropische Nutation an der äussersten Spitze des scheidenförmigen Blattes der Plumula beginnt und allmählich weiter nach unten fortschreitet, während der vorgeneigte Obertheil sich in immer längerer Ausdehnung gerade streckt. Zuletzt finden wir nur noch an der Basis des Scheidenblattes eine meist sehr scharfe Krümmung, und der Obertheil bildet mit der Basis des Blattes einen Winkel von $\left.60-90^{0}{ }^{2}\right)^{3}$ ). Dieser

1) Vgl. Rothert, Ber. d. Deutsehen botan. Gesellsch., Bd. 10, und CoHv's Beiträge zur Biologie d. Pflanzen, B. 7. Diese letztere Arbeit habe ieh leider nicht mehr eingehend berücksichtigen können.

2) Die Grösse der erfolgten Krümmung kann dureh Messung festgestellt werden. Die Messungen, bei denen man die Neigung des gekrümmten Theiles der Pflanzen zur Verticalen ermittelt, führt man mit Cartonquadranten aus, auf denen von $5 \mathrm{zu} 5^{\circ}$ Radien aufgetragen sind. Es ist stets das Mittel aus mehreren Messungen zun nehmen.

3) Dass bei dem Abschluss heliotropiseher Nutationen in den meisten Fällen 
Frfolg wird nach Verlauf von etwa 5 oder 8 Stunden erzielt. Wenn wir nun gleichzeitig mit den erwäbnten Objecten Avenakeimlinge dem Licht exponiren, nachdem wir eine etwa $3 \mathrm{~mm}$ lange Zone der Spitze ihrer Plumula durch Aufsetzen kleiner Stanniolkappen (hergestellt durch Umwickeln eines Drahtes von entsprechender Dicke mit Stanniolstreifen und sorgfältiges Zukneifen des einen Endes des entstandenen Röhrchens) verdunkelt haben, dann beginnt die Nutation an der Spitze des nicht verdunkelten Theiles des Scheidenblattes, sie schreitet langsamer als bei voller Belenchtung der Keimlinge nach unten fort und bleibt auch verhältnissmässig flach $10-40^{\circ}$. Die tiefer liegenden Theile des Scheidenblattes sind freilich, wie die Versuche lehren, an und für sich heliotropisch empfindlich, aber ihre Empfindlichkeit ist im Vergleich zu derjenigen der Spitze gering. Wenn die Spitze vom Licht getroffen wird und energisch heliotropisch reagirt, so pflanzt sich der Reiz auf den Untertheil des Scheidenblattes fort und löst eine weit stärkere Nutation aus, als sie in Folge seiner eigenen Empfindlichkeit zu Stande kommen könnte. Auch DARwis (vergl. Bewegungsvermögen der Pflanzen), hat schon auf diese interessanten Verhältnisse hingewiesen.

Die Thatsache der Reizfortpflanzung von der Spitze zur Basis der Scheidenblätter kann ferner in folgender Weise dargethan werden. Man cultivirt Haferkeimlinge in nicht völlig mit Erde angefüllten Töpfen. Hat die Plumula eine Länge von etwa $1,5 \mathrm{~cm}$ erreicht, so bedeckt man die Keimlinge soweit mit feingesiebter, trockener Erde, dass sie nur noch mit ihrer $3 \mathrm{~mm}$ langen Spitze aus derselben hervorragen. Die Erde ist schon in 2-3 $\mathrm{mm}$ dicker Schicht völlig undurchlässig für Licht, trotzdem krümmt sich der basale Theil der Plumula in Folge des ihm von der Spitze zugeführten heliotropischen Reizes, wenn die Keimlinge einseitig beleuchtet werden. Im zuletzt angeführten Experiment ist die heliotropische Krümmung des verdunkelten Theiles der Untersuchungsobjecte allein durch den zugeleiteten Reiz verursacht; unter normalen Umständen kommt die $\mathrm{Nu}$ tation der basalen Blattscheidentheile zu Stande, indem sich diese Reizfortpflanzung und die directe heliotropische Perceptionsfähigkeit des Organs summiren. Diese Resultate des Versuchs sind gewiss für die Beurtheilung der heliotropischen Phänomene überhaupt von grosser Wichtigkeit. Nicht minder verdienen die Ergebnisse der folgenden Experimente Beachtung.

Dic Plumula der Keimlinge von Avena von etwa 1,5 cm Länge wird durch Tuschemarken in Zonen von $2 \mathrm{~mm}$ Länge eingetheilt. Die in bekannter Weise angestellten Messungen über das erfolgende Wachsthum ergeben dann, dass die Spitze der Plumula nur sehr langsam wächst; nach unten zu steigt die Wachsthumsgeschwindigkeit, erreicht etwa in der 4. oder 5. Zone ihr Maximum, um dann wieder abzunehmen. Daraus erhellt, was gewiss interessant ist, dass die Zone stärkster heliotropischer Perceptionsfähigkeit (die Spitze) keineswegs zugleich auch diejenige ist, welche am lebhaftesten wächst.

Wenn man völlig gerade, im Dunkeln zur Ausbildung gelangte Keim-

gerade an der Basıs der wachsthumsfähigen Region, also keineswegs in der Zone des jeweiligen stärksten Wachsthums der Organe, die stärkste Krümmung bestehen bleibt, stimmt ganz mit den Angaben von SACHS (Flora, 1873, und Vorlesungen, S. 724) über geotropische Nutationen won Sprossen überein. Vgl. auch MÜLLERThurgau, Flora, 1876,, S. 90. 
linge von Avena köpft, indem man eine 3 oder $4 \mathrm{~mm}$ lange Zone ihrer Spitze durch einen scharfen Querschnitt abtrennt und die decapitirten Untersuchungsobjecte nun einseitig beleuchtet, so ist ihr Wachsthum ein nur langsames, und heliotropische Nutationen werden gar nicht ausgeführt. Nach Verlauf einiger Stunden wird die Wachsthumsgeschwindigkeit des Scheidenblattes aber wieder lebhafter, und die heliotropische Empfindlichkeit kehrt auch zurück ${ }^{1}$ ). Viele der hier erwähnten Versuche sind auch deshalb von grosser Bedeutung, weil sie lehren, dass die Reactionsfähigkeit und Perceptionsfähigkeit der Organe (Reizbarkeit und Empfindlichkeit derselben) als zwei verschiedene Dinge betrachtet werden müssen.

\section{Der Hydrotropismus der Wurzeln.}

Wenn die Feuchtigkeitsverhältnisse in denjenigen Medien, in welchen sich Wurzeln entwickeln, nicht gleichmässig vertheilt sind, so führen diese Pflanzentheile hydrotropische Krümmungen aus, und zwar lässt sich nach dem Vorgange von SACHS ${ }^{2}$ ) leicht feststellen, dass die Wurzeln positiv hydrotropisch sind. Der zur Demonstration der hier in Betracht kommenden Erscheinungen erforderliche Apparat ist in Fig. $160 \mathrm{im}$

Durchschnitt dargestellt. Ein Reifen von starkem Zinkblech $(a \quad a)$ von etwa $5 \mathrm{~cm}$ Höhe und $20 \mathrm{~cm}$ Durchmesser wird mit weitmaschigem Tüll derartig überspannt, dass man ein Sieb erhält, dessen poröser Boden von dem Tüll gebildet wird. Man füllt das Sieb mit feuchten Sägespänen an und legt in diese angequollene Samen aus. Ich experimentirte mit den Samen von Phaseolus; man kann aber auch ebenso gut andere Samen (Pisum, Zea etc.) be-

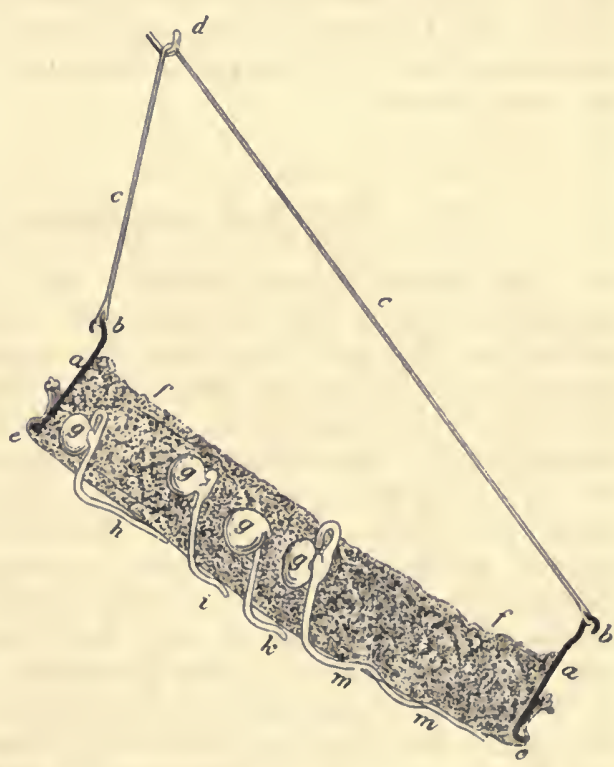

Fig. 160. Apparat für Beobachtungen über hydrotropische Wurzelkrümmungen. (Nach SACIrS.)

nutzen. Der Apparat wird an drei Bindfäden $(c, c, d)$ in einem Schranke oder unter einem grossen Pappkasten schief aufgehängt, so dass der Siebboden etwa unter $45^{\circ}$ gegen den Horizont geneigt ist. Die Hauptwurzeln der sich bei völligem Abschluss des Lichtes entwickelnden

1) Die Decapitirung vernichtet das heliotropische Perceptionsvermögen der Keimlinge zunächst völlig; dieselben krümmen sich daher nicht, trotzdem sie ein freilich langsames Wachsthum unterhalten. Später wird gewissermaassen eine "physiologische Spitze" an den Keimlingen regenerirt. Dieselben sind dann fast so reizbar wie völlig unversehrt gebliebene.

2) Vgl. SACHs, Arbeiten d. botan. Instituts in Würzburg, Bd. 1, S. 209. 
Keimpflanzen treten alsbald aus den Tüllmaschen hervor; sie wachsen aber nicht gerade nach abwärts, sondern ihre Spitze legt sich sofort schief an die Untertläche des Tülls an und wächst nun an dieser dicht angeschmiegt abwärts fort. Die Wurzeln wenden sich, wie es. auch unsere Abbildung zeigt, bei ihrem Austritt aus dem Siebboden nach derjenigen Seite hin, wo das Kieimbett mit der Verticalen den kleinsten, spitzen Winkel bildet. Die eintretende Krümmung ist Folge. einer verschiedenen Feuchtigkeitsvertheilung auf der dem Keimbett zu- und abgekehrten Seite der Wurzeln, indessen erscheint es besonders merkwürdig, dass gerade diejenige Seite der Wurzeln convex wird, also am energischsten wächst, welche denı feuchten Siebboden nicht zugewandt ist. Die erwähnten Krümmungen der Wurzeln unterbleiben vollkommen, wenn man den beschriebenen Apparat horizontal oder auch schief in einer völlig mit Wasserdampf gesättigten Atmosphäre, z. B. unter einer grossen Glasglocke, deren Wände mit Wasser benetzt sind, aufhängt. In diesem Falle wachsen die Hauptwurzeln der Keimpflanzen gerade nach abwärts. Wachsthumskrümmungen in Folge ungleichmässiger Feuchtigkeitsvertheilung können nicht eintreten; die Wurzeln folgen, wenn sie sich im dampfgesättigten Raum bei Ausschluss des Lichtes entwickeln, allein dem richtenden Einfluss der Schwerkraft.

\section{Der Hydrotropismus von Mucor Mucedo.}

Den Mucor Mucedo lernten wir bereits unter 36 kennen. Die Sporangienträger der Mucorarten zeichnen sich, wie WORTMANN ${ }^{1}$ ). feststellte, dadurch aus, dass sie negativ hydrotropisch sind. Entwickeln sie sich in der Nähe eines feuchten Körpers, so wenden sie sich daher von diesem ab. Ich habe mich davon überzeugt, dass es leicht gelingt, diese Thatsache in folgender Weise festzustellen.

Etwas Kuh- oder Pferdemist bleibt unter einer Glasglocke einige Tage sich selbst überlassen. Es entwickelt sich eine üppige Vegetation yon Mucor Mucedo, eben derjenige Pilz, den wir für unser Experiment brauchen. Wir legen einen kleinen, mit Wasser durchfeuchteten Brotwürfel in eine flache Glasschale und bedecken diese mit einer Glasplatte, welche dem Rande der Schale dicht aufliegt und in der Mitte mit einem Loch von einigen Millimetern Durchmesser versehen ist. Vor dem Bedecken der Schale mit der Glasplatte bringen wir mit Hülfe einer ausgeglühten Nadel einige reife Sporangien der Mucorvegetation des Mistes auf das Brot und vertheilen die Sporen auf diesem. Die Sporen keimen alsbald; nach 1 oder 2 Tagen wachsen schon einige Sporangienträger durch das Loch der Glasplatte hervor, und es handelt sich nun darum, das negativ hydrotropische Verhalten dieser Organe zu constatiren. Zu dem Zweck wird an einem Kork ein Streifen dicker Pappe mit Siegellack befestigt. Dann durchtränkt man den Pappstreifen mit Wasser und stellt ihn in unmittelbarster Nähe der aus dem Loche der Glasplatte hervorwachsenden Sporangienträger auf. Die ganze Vorrichtung wird jetzt, wie auch schon früher nach der Aussaat der Mucorsporen, mit einem Papprecipienten bedeckt, um das Licht auszuschliessen. Nach Verlauf von etwa 24 Stunden

.1) Vgl. Wortmaxy, Botanische Zeitung, 1881. 
hat die Länge der Sporangienträger erheblich zugenommen, und es ist leicht wahrzunehmen, dass sie nicht senkrecht emporgewachsen sind. Sie erscheinen vielmehr gekrümmt; ihre convexe Seite ist dem feuchten Pappstreifen zugewandt.

Wenn man keinen durchfeuchteten, sondern einen trockenen Pappstreifen in der Nähe der Sporangienträger aufstellt, so krümmen sich dieselben nicht. Die Nutation ist also nicht, wie vas 'Tieghem ${ }^{1}$ ) meinte, als eine somatotropische, d. h. als eine dureh die Masse der Pappe bedingte, sondern wirklich als eine hydrotropische anzusehen.

\section{Der Thermotropismus der Pflanzen.}

Es gewährt Interesse, sich davon zu ïberzeugen, dass wachsende Pflanzentheile Reizbewegungen ausführen, wenn ihre antagonistischen Seiten verschiedener Temperaturwirkung ausgesetzt sind ${ }^{*}$ ). Wir führen unsere Experimente in einem grossen, womöglich nach Norden gelegenen Zimmer aus, in welchem möglichst unbedeutende Temperaturschwankungen herrschen. Am einen Ende eines langen Arbeitstisches stellen wir eine vorn berusste, $60-70 \mathrm{~cm}$ hohe und breite Eisenblechplatte unter Benutzung eines starken Gestelles derartig auf, dass die Fläche der Platte senkrecht zu den Fensterscheiben gerichtet ist. Die hintere Fläche der Platte kann durch vier derselben genäherte und je nach Bedürfniss verschiebbare Gasflammen erwärmt werden. Die Untersuchungsobjecte (in Töpfen in Sägemehl cultivirte Keimlinge von Lepidium und Zea) können nun in versehiedenen Entfernungen von der Platte aufgestellt werden. Zur Ausschliessung heliotropischer Nutationen stellt man hinter die ursprünglich völlig geraden Keimlinge einen grossen Planspiegel parallel zum Fenster, durch welches durch Vorhänge gedämpftes licht einfällt. Vor Aufstellung der Töpfe erwärmt man die Platte und hängt in verschiedenen Entfernungen von derselben Thermometer auf. Zeigen diese bestimmte Temperaturen an, bei denen man experimentiren will, so werden die Keimlinge in ihre unmittelbare Nähe gebracht, und der Versuch beginnt. Versuch mit Lepidium. 10 Keimlinge. $3-4 \mathrm{~cm}$ hoch. Zimmertemperatur $12^{\circ} \mathrm{C}$. Temperatur über der Mitte des Topfes $30-35^{\circ} \mathrm{C}$. Nach einigen Stunden starke negativ thermotropische Nutation. Versuch mit Zea. 2 Keimlinge $2-3 \mathrm{~cm}$ hoch. Zimmertemperatur $12^{\circ} \mathrm{C}$. Temperatur über der Mitte des Topfes $30^{\circ} \mathrm{C}$. Nach einigen Stunden positiv thermotropische Nutation (Wortans).

Das Temperaturoptimum für das Wachsthum von Lepidium liegt etwa bei $28^{\circ} \mathrm{C}$., für Zea aber bei $33^{\circ} \mathrm{C}$. Das Zustandekommen der Krümmungen kann also nicht aufgefasst werden als Folge einer Wachsthumsdifferenz auf den antagonistischen Seiten der Keimlinge, die ihrerseits direct durch die auf diesen versehiedenen Seiten herrschenden Temperaturen bedingt ist. Läge die Sache so, dann lätten sich die Lepidiumkeimlinge unter den bezeichneten Bedingungen $\mathrm{z}$. B. gerade der Wärmequelle zukrümmen müssen, denn die von der Platte abgewandte Seite der Untersuchungsobjecte war einer für das Wachstlıum

1) Vgl. vax Treghem, Extrait du Bulletin de la Société botanique de France, T. XXIII.

2) Vgl. Wortmans, Botan. Zeitung, 1883 und 1885. 
an sich günstigeren Temperatur als die der Platte zugewandte Seite ausgesetzt. Die beobachteten Krümmungen sind vielmehr als Reizwirkungen aufzufassen, welche die Wärmestrahlen ausgelöst haben. Es bedarf übrigens noch sehr eingehender Studien zur näheren Erforschung des Thermotropismus der Pflanzen ${ }^{1}$ ).

\section{Aërotropismus und Chemotropismus der Pollen- und Pilz- schläuche.}

Die Keimung der Pollenkörner, von der im Folgenden oft die Rede sein wird, erfolgt am besten in Zuckerlösungen (Rohrzucker) von bestimmter Concentration. Diese Concentrationen sind zunächst für einige Pollensorten in nachstehender Uebersicht angegeben:

$\begin{array}{lrc}\text { Allium Victoriale } & 3 & \text { Proc. } \\ \text { Anthyllis vulneraria } & 15 & , \\ \text { Berberis vulgaris } & 20 & , \\ \text { Colchicum autumnale } & 40 & \\ \text { Digitalis ambigua } & 10 & \text { " } \\ \text { Fritillaria imperialis } & 10 & " \\ \text { Narcissus poeticus } & 10 & , \\ \text { Vincetoxicum officinale } & 15\end{array}$

Wir stellen nun Zuckerlösungen unter Zusatz von $1-2$ Proc. Gelatine her. Diese Lösung erstarrt bei $18^{\circ} \mathrm{C}$. zu einer zitternden Gallerte. Ein Tropfen der Lösung gelangt auf einen Objectträger und wird mit Pollenkörnern versetzt, die man schnell mittelst einer Nadel recht gleichmässig in Tropfen vertheilt. Nun legt man ein Deckglas auf, wobei darauf zu achten ist, dass keine Flüssigkeit über den Rand des Deckglases heraustritt. Auch die Bildung von Luftblasen ist thunlichst zu vermeiden. Die Objectträgerculturen gelangen bei $18^{\circ}$ C. unter eine durch Wasser abgesperrte Glasglocke. Experimentiren wir z. B. mit den Pollenkörnern von Narcissus Tazetta (7-proc. Rohrzuckerlösung), so sehen wir schon nach 6 Stunden viele Körner gekeimt. Aber nur die Pollenkörner in der Nähe des Deckglasrandes haben Schläuche entwickelt; die übrigen sind in Folge von Sauerstoffmangel überhaupt nicht gekeimt. Die Schläuche wachsen fast sämmtlich der Mitte des Tropfens zu; sie lassen ein ausgeprägt negativ aërotropisches Verhalten erkennen. Uebrigens ist zu bemerken, dass es manche Pollenarten giebt, deren Schläuche in keiner Weise aërotropisch reizbar sind (Orobus vernus etc.)

Ein vorzügliches Object zur Feststellung des negativ aërotropen Verhaltens wachsender Pollenschläuche sind nach meinen Erfahrungen diejenigen von Lathyrusarten. Die Körner werden in Zuckergelatine, die 15 Proc. Rohrzucker enthält, ausgesäet.

Viele Pollenschläuche (Narcissus Tazetta, N. poeticus, Fritillaria imperialis, Vincetoxicum officinale etc.) sind auch recht energisch chemotropisch reizbar.

1) Die Wurzeln sollen nach Jöxssox, Berichte der Deutschen botan. Gesellschaft, Bd. 1, S.512, auch rheotropische Eigenschaften besitzen. Meine bezüglichen Untersuchungen sind noch nicht abgeschlossen. Ueber den Aërotropismus der Wurzeln (vgl. Morisch, Berichte d. Deutschen botan. Gesellschaft, Bd. 2, S. 160) und den Galvanotropismus derselben (vgl. Elfvisa, Botan. Zeitung, 1882) stellte ich bis jetzt keine Experimente an. 
Wir vertheilen die Pollenkörner im Zuckergelatinetropfen und legen in die Mitte desselben ein Stückchen frisch abgeschnittenen Narben- oder Griffelgewebes oder Samenknospen der betreffenden Pflanzen. Im feuchten Rqum keimen die Körner, und die in der Nähe der Narbenstüeke etc. zur Entwickelung kommenden Schläuche wenden sich, da sie ein positiv chemotropisches Verhalten zeigen, diesen Stücken zu. Tödtet man die Narbenstücke durch Eintauchen in heisses Wasser, bevor man sie auf den Zuckergelatinetropfen legt, so verhalten sich die Pollenschläuche ebenso, wie es bereits angegeben wurde. Hierdurch ist festgestellt, dass die bezeichnete Wachsthumsrichtung der Sehläuche im vorliegenden Falle nicht Folge ihrer aërotropischen Reizbarkeit sein kann, denn die todten Gewebemassen produciren, was die lebendigen ja thun, keine Kohlensäure, die von Einfluss auf die Vertheilung der Sauerstoffspannung im Präparat sein könnte.

In vielen Fällen ist es bei Untersuchung des Chemotropismus der Pollenschläuche zweckmässig, dieselben in einem Gelatinetropfen zu vertheilen, dem nur wenig Zucker (z. B. 0,2-0,4 Proc.) beigemengt wurde, die Narbenstücke ete. auf die Gelatine zu legen und das Präparat in einen feuchten Raum zu bringen.

Als Reizmittel für die Schläuche wirkt in erster Linie Rohrzucker, der in dem Gewebe des Gynaeceums vorhanden ist und von den Zellen desselben ausgesehieden wird.

Wir injiciren Blätter einer Tradescantia (z. B. T. discolor) unter der Luftpumpe'mit Rohrzuckerlösung von bestimmter Concentration. Die durchscheinend gewordenen Blätter spült man mit Wasser raseh $\mathrm{ab}$ und trocknet sie äusserlich mit Fliesspapier. Nun vertheilt man Pollen auf der spaltöffnungsreichen Unterseite der Blätter und bringt sie in einen wassergasreichen Raum. Nach kürzerer oder längerer Zeit stellen wir fest, dass die Pollensehläuche bei ihrem Wachsthun die Neigung zeigen, sich den Spaltöffnungen zuzuwenden, um in diese einzudringen. Hat man das Blatt nur mit Wasser injicirt, so wachsen die Sehläuche indifferent über die Fläche dahin. Der Rohrzucker ist also ein Körper, der die Pollensehläuche zu chenıtropischen Bewegungen veranlasst.

Auch die Keimschläuche der Pilze sind chemotropisch reizbar. Werden Tradescantiablätter mit 2-proc. Rohrzucker- oder Fleischextractlösung injicirt, uın auf die Unterseite der Blätter dann Mucorsporen im dampfgesättigten Raum zur Keimung zu bringen, so findet man, dass die Sehläuche sich auch hier wieder den Spaltöffnungen zuwenden und in dieselben eindringen. Hat die Rohrzuckerlösung nur 0,1 Proc. Concentration, so reagiren die Schläuche nur noch sehr schwach positiv chemotropisch; dasselbe ist bei hohen Concentrationsgraden der Zuckerlösung (z. B. bei 20 Proc.) der Fall ').

\section{Die durch den Weehsel der Beleuchtungsverhältuisse und durch Temperaturschwankungen inducirten Bewegungen der Laub- blätter und Bliithentheile. (Nyetitropische Bewegungen.)}

Es existiren zahlreiche Laub- und Blumenblätter, welche, wie die experimentellen Untersuchungen mehrerer Physiologen ergeben haben,

1) Vgl. Mourscr, Sitzungsber. d. Akadem. d. Wiss. zu Wien, Bd. 102, Abthl. 1. Juli 1893; Mryoshr, Botan. Zeitung, 1895, und Flora, 1894. 
nur in geringem Grade durch Wachsthumsbewegungen auf Temperaturschwankungen, dagegen in ausgezeichneter Weise auf den Wechsel der Beleuchtungsverhältnisse reagiren. Wir wollen uns zunächst bemühen, einige Erscheinungen, um die es sich hier handelt, genauer festzustellen.

Wir beobachten im Freien wachsende Exemplare von Impatiens parvitlora, Chenopodium bonus Henricus und Mirabilis jalapa. Die für uns Interesse besitzenden Bewegungserscheinungen treten an den jüngeren, noch nicht ausgewachsenen Laubblättern deutlich hervor. Am Tage sind diese Blätter mehr oder minder horizontal gestellt; nachts nehmen sie dagegen eine andere Lage ein. Bei Chenopodium und zumal bei Mirabilis heben sich die Blätter am Abend, während sie sich bei Impatiens zu dieser Zeit senken und daher mit Eintritt der Dunkelleit aus einer horizontalen in eine verticale Lage übergehen. Am folgenden Tage kehren die Blätter wieder in ihre Lichtstellung zurück.

Beobachtet man in Blumentöpfen cultivirte Keimlinge von Raphanus sativus, so zeigt sich, dass die Cotyledonen derselben am Tage ausgebreitet, nachts aber mehr oder minder zusammengeschlossen erscheinen. Junge Blätter von Tropaeolum majus, welche man von oben beleuchtet, nehmen am Tage eine solche Stellung ein, dass sie rechtwinkelig von den einfallenden Lichtstrahlen getroffen werden. Nachts stellen sie sich vertical. Dies tritt nach den Resultaten meiner Versuche mit Topfpflanzen aber nur bei relativ hoher Temperatur in vollem Maasse ein.

Ueber die durch Beleuchtungswechsel inducirten Wachsthumsbewegungen der Blüthen stellte ich, meistens unter Benutzung im Freien wachsender Pflanzen, folgende Beobachtungen an, welche man wiederholen möge.

Ich constatirte, dass sich die Blüthenköpfe der meisten Exemplare von Taraxacum officinale an sonnigen Tagen zu Anfang Mai zwischen 7-8 Uhr morgens öffnen, um sich nachmittags zwischen 4 -5 Uhr wieder zu schliessen. Die Blüthen von Tradescantia bleiben tagsüber geöffnet, wenn der Himmel bedeckt ist; bei wolkenlosem Himmel schliessen sie sich aber morgens um 10 Uhr. Die Blïthenköpfe von Tragopogon pratensis sind morgens offen. Im Juni schliessen sie sich aber bei Sonnenschein um 9 Ulir, bei bedecktem Himmel etwa um 11 Uhr. Abends schliessen sich die Blüthen von Adonis vernalis sowie die Blüthenköpfe von Bellis perennis und Leontodon hastilis (vgl. Fig. 161 und 162, in denen Blüthenschäfte von Leontodon mit einem geschlossenen und einem offenen Blüthenkopfe dargestellt sind), um sich am nächsten Morgen wieder zu öffnen. Ich fand, dass sich die Blüthen von Adonis Ende April um 3 Uhr nachmittags schliessen, während das Schliessen der Blütlıenköjfe von Bellisexemplaren, die dicht daneben standen, erst $1 \frac{1}{2}$ Stunden später erfolgte. Die Blüthen von Oenothera biennis blühen abends auf und morgens schliessen sie sich. Ich braclite abgeschnittene und in Wasser gestellte Blüthenschäfte von Leontodon hastilis am Tage ins Dunkle. Die Blüthenköpfe schlossen sich abends, öffneten sich aber wieder am folgenden Tage, trotzdem die Untersuchungsobjecte constant verdunkelt blieben, und zeigten am Abend abermals, freilich keine sehr ausgiebigen, Schliessungsbewegungen. Am nächsten Tage wurden die Blüthenschäfte aufs Neue dem Tageslicht ausgesetzt. Am Abend dieses Tages 
schlossen sich die Blüthenköpfe in durchaus normaler Weise. Die Resultate dieser Experimente lehren, dass die Einzelblüthen der Blüthenköpfe von Leontodon hastilis - und ihnen analog werden sich anch manche andere Blüthen verhalten - wenn sie constanter Dunkelheit ausgesetzt werden, Nach wirkungsbewegungen zeigen, welche ein Oeffnen der Köpfe zur Tageszeit und ein Schliessen derselben zur Nachtzeit herbeiführen. Freilich dauern diese Nachwirkungsbewegungen nicht lange fort. Die Blüthen werden nach einiger Zeit bewegungslos (dunkelstarr), können aber wieler durch erneute Beleuchtung in den phototonischen Zustand zurück versetzt werden.

Nach dem Gesagten ist nun klar, dass die unter normalen Verhältnissen, d. h. bei Wechsel von Tag und Nacht, stattfindenden periodischen Bewegungen der Laubblätter und Blüthen nicht allein unmittelbare Folge des Beleuchtungswechsels sind. Vielmehr combiniren sich die durch diesen letzteren erzielten paratonisehen Wirkungen bei dein $\mathrm{Zu}$ standekommen der Tagesperiode mit Nachwirkungsbewegungen, die freilich ihren letzten

Fig. 161.

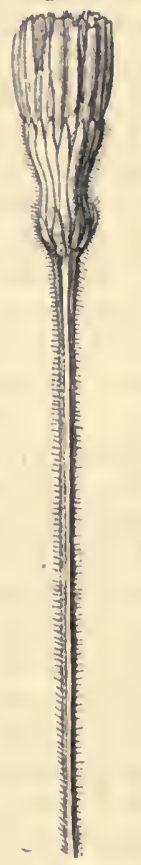

Fig. 162

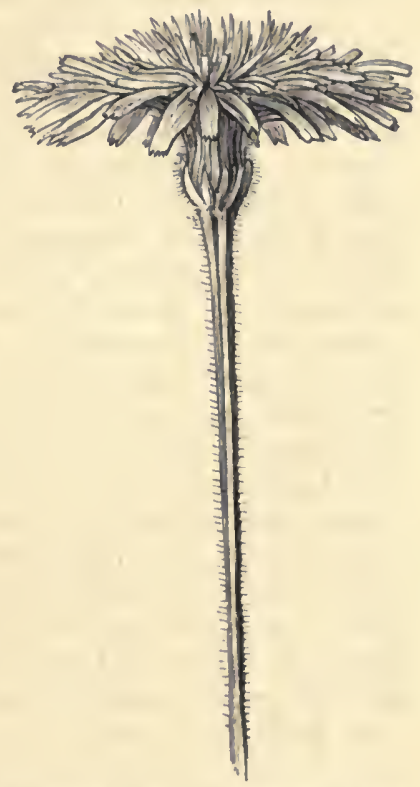

Fig. 161. Bliithenschaft ron Leontodon hastilis mit geschlossenem Blüthenstand.

Fig. 162. Bliithensehaft ron Leontodon hastilis mit geöffnetem Blüthenstand. Grund auch nur in dem Wechsel der Beleuchtungsverhältnisse haben. Dieser Umstand macht die Thatsache auch verständlich, von deren Richtigkeit ich mich überzeugte, dass sich z. B. Blüthenköpfe von Leontodon hastilis, die am Vormittag ins Dunkle gestellt werden, abends nur einige Zeit früher als solche schliessen, die am Tage beleuchtet gewesen sind. Die paratonische Wirkung der Verdunkelung ist im Resultat des Experiinentes freilich zu erkennen, aber die Blüthenköpfe schliessen sich in Folge des Vorhandenseins der Nachwirkungen erst dann, wenn die Verfinsterung längere Zeit gedauert hat. In anderen Fällen können übrigens die paratonischen Wirkungen viel ansehnlicher werden.

Die durch den Wechsel der Beleuchtungsverhältnisse inducirten Bewegungen der Laub- sowie Blumenblätter werden, wie PFEFFER ${ }^{1}$ ) mit aller Sicherheit nachwies, durch Wachsthumsprocesse herbei-

1) Vgl. Pfeffer, Pflanzenphysiologische Untersuchungen, 1873. 
geführt. Der Beleuchtungswechsel wirkt gleichsinnig auf das Wachsthum der die Bewegungen vermittelnden basalen Partien der Blattgebilde ein, aber die antagonistischen Gewebecomplexe der Organe werden ungleich schnell afficirt, und dadurch kommen die hier behandelten nyctitropischen Bewegungen zu Stande. Die biologische Bedeutung der nächtlichen Verticalstellung vieler Laubblätter ist offenbar darin zu suchen, dass durch dieselbe einer zu starken Wärmeausstrahlung, die leicht von nachtheiligen Folgen für die Pflanzen sein könnte, vorgebeugt wird, während das Oeffnen und Schliessen der Blüthen $\mathrm{zu}$ den Bestäubungsverhältnissen in Beziehung steht.

In ähnlicher Weise wie durch den Wechsel der Beleuchtungsverhältnisse werden an verschiedenen Pflanzentheilen lebhafte Bewegungen durch Temperaturschwankungen hervorgerufen. Wir haben es hier zumal mit Blüthen $\mathrm{zu}$ thun, und als ausgezeichnete Untersuchungsobjecte sind blühende Exemplare von Tulipa gesneriana, vor allem aber solche von Crocus vernus (weiss blühende Varietät) zu nennen. Ich brachte in Blumentöpfen cultivirte Exemplare dieser letzteren Pflanze aus einem Zimmer, in welchem eine Temperatur von $19^{\circ} \mathrm{C}$. herrschte, in ein solches von $5^{\circ} \mathrm{C}$. Die zunächst geöffneten Blüthen schlossen sich alsbald. Wurden Crocuspflanzen mit geschlossenen Blüthen aus einem Zimmer, in welchem eine Temperatur von $5^{\circ} \mathrm{C}$. herrschte, in ein solches von $19^{\circ} \mathrm{C}$. gebracht, so öffneten sich die Blüthen schnell. Die Schliessungsbewegungen der Blumenblätter bei der Abkühlung einer- und die Oeffnungsbewegungen bei der Erwärmung andererseits gingen in meinen Versuchen so lebhaft vor sich, dass der Beginn derselben, wenn der Temperaturwechsel erfolgt war, bereits nach Verlauf einiger Minuten mit dem unbewaffneten Auge constatirt werden konnte. Crocusblüthen reagiren übrigens auch schon auf sehr geringe Temperaturschwankungen. Die durch Temperaturschwankungen inducirten Bewegungen machen sich sowohl bei Zutritt des Lichtes als auch in constanter Finsterniss geltend.

Handelt es sich darum, festzustellen, dass die hier besprochenen, durch den Wechsel der Beleuchtungs- und Temperaturverhältnisse inducirten Bewegungen Folge von Wachsthumsvorgängen sind, so kann dies nur durch die Ausführung feinerer Messungen geschehen. Wir wählen Crocus als Untersuchungsobject. Hier liegt die Zone, in welcher in erster Linie die Bewegung der Perigonblätter erfolgt, dicht über der Perigonröhre im unteren Fünftel der Perigonzipfel. Wir schneiden die inneren 3 Perigonzipfel fort und bringen auf Aussen- sowie Innenseite der äusseren Zipfel in der Mitte der Zone stärksten Bewegungsvermögens in Entfernungen von etwa $3 \mathrm{~mm}$ feine Tuschepunkte an. Leicht kenntliche Spitzen oder Ecken dieser Punkte dienen bei den Messungen mit Hülfe des unter 153 erwähnten horizontal gelegten Mikroskops als Marken. Wenn z. B. auf die Perigonzipfel der geschlossenen Blüthen Punkte aufgetragen. sind und wir bestimmen die Entfernung der Marken abermals, nachdem die Untersuchungsobjecte durch höhere Temperatur zu Oeffnungsbewegungen veranlasst wurden, dann finden wir diese Entfernung auf der Aussenseite der Zipfel fast unverändert, auf der Innenseite aber merklich gewachsen, vielleicht um 0,08 $\mathrm{mm}$ bei $3 \mathrm{~mm}$ anfänglicher Entfernung. Diese Verlängerung auf der convex gewordenen Seite der Perigonzipfel ist eine bleibende, also eine durch Wachsthumsvorgänge fixirte. Bei Schliessungsbewegungen der Blüthen verlängert sich die convex werdende Aussenseite der Zipfel viel ansehnlicher als die antagonistische Seite. 


\section{Die Darwin'sche Krïmmung ete.}

Wir bringen Samen von Vicia Faba in Sägespänen zur Keimung und lassen die Untersuchungsobjecte so lange in dem Keimbett liegen, bis dio Wurzeln die Länge von einigen $\mathrm{cm}$ erreicht haben. Es kommt nun darauf an, die Wurzelspitzen der Keimlinge einseitig zu verletzen, und dies geschieht nach meinen Erfahrungen in bequemster Weise dadurch, dass wir eine Seite der Wurzeln unter Benutzung kleiner Stückchen Höllensteins betupfen. Es ist darauf zu achten, dass nur eine kurze, etwa $1,5 \mathrm{~mm}$ lange Strecke der Wurzelspitze mit dem Höllenstein in Berührung gelangt. Nach demjenigen, was unter 157 gesagt worden ist, erscheint es nicht gleichgültig, welche Wurzelseite den Reiz empfängt, und es ist am meisten $\mathrm{zu}$ empfehlen, weder die vordere, noch die hintere Wurzelseite, sondern eine der Flanken der Wurzel zu reizen. Die Untersuchungsobjecte werden nun in der Weise, wie es unter 154 angegeben worden ist, in Glascylindern befestigt und sich im Dunkeln selbst überlassen. Nach 12-24 Stunden findet man, dass diejenige Wurzelflanke, welche mit Höllenstein betupft worden war, convex gekrümmt ist. Auf der gereizten Seite ist das Wachsthum in der wachsthumsfähigen Region der Wurzel beträchtlich lebhafter als auf der antagonistischen Seite, so dass oine einseitige Verletzung der Wurzelspitze eine eigenthümliche Nutationserscheinung zur Folge hat, die man als DARwis'sche Krümmung bezeichnet. Wird die Wurzelspitze nicht durch Höllenstein, sondern auf andere Weise verletzt, so treten ebenfalls Nutationen hervor; es ist aber von biologischer Bedeutung, dass sich die Wurzeln in Folge derselben stets von den als Reizursache wirkenden, die Verletzung bedingenden Körpern wegwenden ${ }^{1}$ ).

In einem Gegensatz hierzu stehen Nutationen der Wurzeln, die zu Stande kommen, wenn nicht die Wurzelspitze, sondern die in lebhaftem Wachsthum begriffene Wurzelregion gereizt wird. Die Wurzeln wenden sich dann, ähnlich wie die Ranken, den als Reizursache wirkenden Körpern zu. Einige Erbsenkeimlinge werden auf Nadeln aufgespiesst und unter einer Glasglocke, die durch Wasser abgesperrt ist, derartig aufgestellt, dass ihre etwa $2 \mathrm{~cm}$ langen Wurzeln horizontal gerichtet sind. Neben jeder Keimpflanze bringen wir noch eine dünne Nadel an, welche die Wurzel in ihrer am lebhaftesten wachsenden Region (also etwa $3 \mathrm{~mm}$ ontfernt von der Spitze) berührt. Der Contact wirkt, ebenso wie bei den Ranken, als Reiz, und indem die nicht berührte Wurzelseite in Folge lebhafteren Wachsthums convex wird, krümmt sich die Wurzel im Laufe einiger Zeit der Nadel zu.

Eigenthümliche Reizwirkungen an Pflanzentheilen ruft, wie hier kurz erwähnt werden mag, der Stich von Insekten hervor. Die zahllosen, so sehr verschiedenartigen Gallen, welchen man auf Blättern begegnet, entstehen z. B. auf diese Weise, und es ist daher nicht ohne physiologisches Interesse, eine Galle genauer zu untersuchen.

Auf den Blättern zahlreicher Weidenarten gewahrt man im Laufe des Sommers oft einer kleinen Bohne ähnlich sehende, fleischige, auf beiden Blattseiten vorragende Gallen, die durch den Stich von Blattwespen (Nematus Vallisnerii) entstehen. Die Wespen legen ihre Eier in das Gewebe der ganz jungen Blätter, und die aus dem Ei auskriechende

1) Vgl. Darwix, Das Bewregungsvermögen der Pflanzel1, 1881, S. 109, und WLEsNer, Bewegungsvermögen der Pflanzen, S. 139. 
Raupe entwickelt sich in der eine relativ beträchtliche Grösse erlangenden Galle. Der durch den Stich des Insekts gegebene Reiz ruft die Hypertrophie des Blattgewebes hervor, die sich uns in der Gallenbildung darstellt. Die mikroskopische Untersuchung zarter Querschnitte lehrt, dass

\begin{abstract}
die Nematusgalle der Hauptsache nach aus kleinzelligem Gewebe, dessen Elemente nahezu isodiametrisch sind, besteht. Diesem Gewebe sind aber an verschiedenen Stellen in radialer Richtung gestreckte Zellen eingelagert. Bemerkt sei noch, dass das Gewebe in der Mitte der Galle kleinzelliger als in den peripherischen Theilen derselben ist.
\end{abstract}

\section{Das Winden der Ranken und Schling pflanzen.}

\section{Allgemeines iiber das Winden der Sehling- pflanzen.}

Wenn man einen $1 \mathrm{~m}$ eine Stütze gewundenen Hopfenstengel betrachtet, so findet man, dass die Windungen desselben stets von rechts unten nach links oben verlaufen. Der Hopfen ist eine typisch rechts windende Pflanze ${ }^{\prime}$ ). Es sei an dieser Stelle auch bemerkt, dass die Stengel sowie Blattstiele des Hopfens mit eigenthümlich gestalteten Anhangsgebilden versehen sind, denen die Function von Haft- oder Klammerorganen zukommt, indem sie zur weiteren Befestigung der Pflanzen dienen. Zieht man z. B. vom Blattstiel von Humulus Epidermisstückchen ab und untersucht sie mikroskopisch, so zeigt sich, dass auf der Oberhaut warzenförmige Emergenzen sitzen. Jede derselben trägt an ihrem Ende ein ankerartig gestaltetes Haar, das ein vorzügliches Haftorgan darstellt.

Einige nicht $\mathrm{zu}$ kleine Blumentöpfe werden mit gut durchfeuchteter Gartenerde angefüllt, und in diese angequollene Samen von Phaseolus multiflorus ausgelegt. Es ist zweckmässig, jeden Blumentopf mit mehreren Samen zu beschicken, um später die schwächlicheren Pflanzen zu beseitigen, und nur ein kräftiges Exemplar in jedem Culturgefässe zu weiterer Entwickelung $\mathrm{zu}$ bringen. Die Pflanzen sind am besten an einem Ort zu cultiviren, wo sie nur kurze Zeit

Fig. 163. Windender Spross von Phaseolus multiflorus.

1) In der Botanik verbindet man herkömmlicher Weise mit den Ausdrücken ,rechts windend" und „links windend" die entgegengesetzten Vorstellungen wie in der Mechanik. 
am Tage vom directen Sonnenlicht, im Uebrigen von hellem diffusem Tageslicht getroffen werden. Wenn das dritte Internodium sich auszubilden beginnt, so stellt man lange Holzstäbe in unmittelbare Nähe der Pflanzen. Diese umwinden die Stäbe, aber die Bohne ist nicht wie der Hopfen eine rechts, sondern eine links windende Pflanze. Die Windungen verlaufen von links unten nach rechts oben. Unsere Fig. 163 zeigt dies deutlich; ferner lässt dieselbe erkennen, worauf wir aber erst unter 189 genauer eingehen, dass die älteren Windungen enger sind und steiler emporsteigen als die jüngeren. Diese Erscheinungen treten zumal deutlich hervor, wenn die Stützen, welche man benutzt, dünn sind, z. B. bei Experimenten mit Phaseolus eine Dicke von wenigen mm nicht überschreiten. Es ist überhaupt nicht uninteressant, Schlingpflanzen zu beobachten, die sich um Stützen von verschiedener Dicke gewunden haben. Ich liess z. B. Bohnenstengel um gespannte Bindfäden, Drähte von $1 \mathrm{~mm}$ Durchmesser sowie Holzstäbe von 4, 16 und selbst $30 \mathrm{~mm}$ Durchmesser winden.

\section{8\%. Die rotirende Nutation.}

Von grösster Wichtigkeit ist es, wenn man die Erscheinungen des Windens der Scllingpflanzen genauer verfolgen will, sich mit der rotirenden Nutation zum Schlingen befähigter Sprosse bekannt zu machen. Wir legen Samen von Phaseolus multiflorus in Gartenerde. mit der ziemlich grosse Blumentöpfe angefüllt sind, aus. Die ersten Internodien der jungen Pflanzen zeigen das Phänomen der rotirenden Nutation nicht oder nicht deutlich, wohl aber die folgenden. Die langen Sprossgipfel neigen seitwärts über, und wenn man sie genauel beobachtet, so ergiebt sich, dass sie sich nicht in Ruhe befinden, sondern ununterbrochen in Bewegung begriffen sind, wodurch der Gipfel in einem Kreise herumgeführt wird.

Um das merkwïrdige Phänomen der rotirenden Nutation näher zu studiren, können wir, abgesehen von Phaseolus, auch andere Untersuchungsobjecte, z. B. $30 \mathrm{~cm}$ lange Sprosse von Calystegia oder die Sprosse anderer Schlingpflanzen verwenden. Es kommt aber selı1 darauf an, dass sich die Beobachtungsobjecte im Zustande lebhaften Wachsthums befinden und dass sie recht günstigen Vegetationsbedingungen ausgesetzt werden. Der basale Theil der Sprosse ist vertical aufgerichtet, ler Sprossgipfel erscheint aber in einem weiten Bogen gekrümmt, so dass dic Spitze horizontal steht oder gar etwas nach abwärts schaut. Wir tragen nun auf der convexen Seite des Sprosses mit Tusche eine Längslinie auf, welche der Mittellinie desselben parallel läuft, und stellen den Spross dann derartig auf, dass seine convexe Seite uns zugekehrt ist. (Vergl. Wortmann, Botan. Zeitung, 1886.) Die Krümmungsebene steht dann senkrecht zu unserer Brust; die Spitze des Sprosses ist uns abgewendet und zeigt z. B. nach Osten. Betrachten wir den Spross jetzt wieder nach Verlauf einer halben Stunde oder nach $\%$ Stunden, so gewahren wir auffallende Veränderungen an demselben. Die horizontal schwebende Spitze zeigt nach Norden, die Krümmungsebene ist, wie vorher, senkrecht, aber jetzt parallel zu unserer Brust, und die Tuschelinie liegt nicht mehr auf der convexen Seite, sondern auf der linken Flanke des Sprosses. Somit ergiebt sich, dass die durch die convexe Seite 
des Sprosses angegebene Zone des stärksten Wachsthums des Sprosses bei unserem Versuch um $90^{\circ}$ nach rechts gerückt ist. Die Stengelspitze hat aber dadurch einen lorizontalen Kreisbogen von $90^{\circ}$ nach links beschrieben. Das weitere Verhalten des Untersuchungsobjectes ist leicht zu verfolgen. Nach abermals $1 / 2$ oder $3 / 4$ Stunden liegt der Tuschestrich auf der concaven Seite des Sprosses, und erst nach im Ganzen 2 oder 3) Stunden ist die ursprüngliche Stellung wieder hergestellt. Dann beginnt eine neue Kreisbewegung. Bemerkenswerth ist noch, dass die Zone stärksten Wachsthums fast stets auf der Oberseite der gekrüınmten Partie des Sprosses verläuft, was die immer senkrechte Lage dder Krümmungsebene zur Folge hat. Die kreisende Bewegung der Endknospe kommt nach allem, was wir gesehen haben, dadurch zu Stande, dass die Zone stärksten Wachsthums successive den Stengel umläuft.

Es ist hier nun nachdrücklich zu betonen, dass die Geschwindigkeit, mit der eine volle Kreisbewegung von der Sprossspitze vollzogen wird, wesentlich abhängig ist von äusseren Factoren, namentlich der Temperatur. Wenn die nutirenden Sprosse einseitiger Beleuchtung ausgesetzt sind, so wird die Bewegung zum Licht in Folge heliotropischer Vorgänge schneller durchgemacht als von der Lichtquelle hinweg. Phaseolus- und Calystegiasprosse zeigen recht lebhafte Bewegungen, andere Schlingpflanzen nur langsame, indessen auch bei ein und demselben Untersuchungsobject und bei nahezu constanten äusseren Bedingungen kann sich im Laufe längerer Zeit die Geschwindigkeit der Bewegung nicht unwesentlich ändern. Es kommen auch insofern Abweichungen yom normalen Verhalten der Sprosse vor, als die Krümmungsebene nicht immer senkrecht steht, d. h. die Zone stärksten Waclısthums liegt nicht stets auf der Oberseite der Krümmung, sondern sie wird verschoben. Verschiedene Partien des rotirenden Stengels, können auch in verschiedenen Ebenen gekrümmt erscheinen. Auf alle diese Dinge ist $\mathrm{zu}$ achten, und man thut gut, einige Objecte anhaltend $\mathrm{zu}$ beobachten und die Befunde genau zu notiren.

Um weitere Einsicht in den Verlauf der uns hier interessirenden höchst complicirten Erscheinungen zu gewinnen, ist es erforderlich, zunächst den folgenden Versuch auszuführen. Phaseoluspflanzen oder Calystegiasprosse, die so weit entwickelt sind, dass sie dicht vor dem Beginn der rotirenden Bewegung ihrer Gipfel stehen, werden zur Ausschliessung heliotropischer Nutationen mit Hülfe des Klinostaten in horizontaler Ebene langsam gedrebt. Man kann auch bereits in rotirender Bewegung befindliche Sprosse beobachten, muss dann nur die unteren Sprosstheile durch Anbinden an einen Stab fixiren, so dass das etwa 10 oder $15 \mathrm{~cm}$ lange Ende der Pflanzentheile völlig vertical und frei aufgerichtet bleibt. In jedem Falle wird man früher oder später wahrnehmen, wie das freie Sprossende in einer Länge von einigen $\mathrm{cm}$ eine meist sehr scharfe Krümmung auszuführen beginnt. Das Zustandekommen dieser sog. Vorkrümmung wird nicht einfach durch das Gewicht des Sprossgipfels bedingt, wie daraus hervorgeht, dass sie bestehen bleibt, mag man dem Spross auch irgend eine beliebige Lage ertheilen.

Ferner ist das Folgende wichtig. Sprosse, die rotirende Nutation ausführen können, sind ebenso wie andere Sprosse in ihrer wachsenden Region geotropisch reizbar. Wenn man z. B. Sprossenden von Schling. pflanzen in der Weise, wie es unter 173 angegeben ist, mit der Basis in feuchten Sand steckt, so tritt ihr negativ geotropisches Verhalten klar hervor. Die Zone stärkster Reizbarkeit liegt stets einige, z. B. $10 \mathrm{~cm}$ 
entfernt von der Sprossspitze, wovon man sich leicht unter Benutzung von Sprosstheilen, die verschiedene Länge haben, überzeugen kann.

Die hier constatirten Thatsachen sind zuerst besonders von BARANETzKI ${ }^{1}$ ) und Wortmax ${ }^{2}$ ) festgestellt worden. Beide zeigten auch, dass die rotirende Nutation selbst nicht, wie man früher meinte, eine rein spontane Nutationserscheinung sei, sondern durch das Zusammenwirken zweier Bewegungsformen der Sprosse zu Stande komme. Die Sprosse der Schlingpflanzen sind allerdings zu spontanen Bewegungen befähigt, und in Folge dessen führen sie sog. Flankenkrümmungen aus, denen auch die erwähnte Vorkrümmung ihre Entstehung verdankt. Diese als horizontale Componente der rotirenden Bewegung zu bezeichnende Flankenkrümmung ist dadurch ausgezeichnet, dass immer eine Flanke der Sprosse, also z. B. bei links windenden Gewächsen die rechte, stärker als alle übrigen wächst, und somit, wenn sie ausschliesslich wirksam wäre, eine spiralförmige Einrollung der Sprossenden zur Folge haben müsste. Zu der horizontalen Componente gesellt sich aber noch eine in verticaler Richtung thätige, nämlich der negative Geotropismus. Er wirkt nicht, was betont wurde und sehr wichtig ist, auf sämmtliche Zonen der Sprosse gleich energisch ein und führt ferner dahin, dass die Convexität der Krümmung rotirender Sprosse normalerweise stets auf ihrer Oberseite liegt. Damit wird eine Verlegung der Flanken und der Beginn der rotirenden Bewegung erzielt. (Vergl. Wormmans, Botan. Zeitung, 1886, S. 638-642.)

Auf Worturans's theoretische Ausführungen am angegebenen Ort und an anderen Stellen seiner Arbeit kann bier nicht weiter eingegangen werden. Im Wesentlichen halte ich dieselben für zutreffeud.

Von besonderer Wichtigkeit ist es nun, um zu der Ueberzeugung zu gelangen, dass die rotirende Nutation eine durch das Zusammenwirken zweier Factoren (spontane Nutation und negativer Geotropismus der Sprosse) zu Stande gebrachte Combinationsbewegung ist, Experimente unter Benutzung des Klinostaten auszuführen. Der Apparat wird auf einem zitterfreien Tisch aufgestellt, und wir arbeiten mit in Blumentöpfen cultivirten Phaseoluspflanzen oder ebenfalls aus Samen erwachsenen Exemplaren von Ipomoea chrysantha. Wir befestigen den unteren Theil der noch nicht um eine Stütze gewundenen Versuchspflanze an einem geeigneten, in der Erde des Culturgefässes steckenden Stab, so dass nur der Sprossgipfel in Länge von einigen Centimetern frei bleibt. Dieses Sprossende muss recht kräftig entwickelt sein und darf bei Horizontallegung der Pflanzen durch sein Gewicht keine wesentliche Lageänderung erfahren. Bei horizontaler Lage des Untersuchungsobjectes tritt nun sehr bald an dem ursprünglich gerade gestreckten Sprossende eine Flankenkrümmung (Vorkrümmung) ein. Wenn die Pflanze jetzt auf den Klinostaten gelangt und in verticaler Ebene langsam rotirt (es genügt, wenn der Klinostat derartig eingestellt wird, dass eine Axendrehung im Laufe von etwa 10 Minuten vollendet ist, vergl. unter 176), so verschwindet die Vorkrümmung alsbald wieder, indem sie durch Wachsthumsvorgänge ausgeglichen wird, und der Spross erscheint gerade gestreckt. Es treten aber alsbald neue Nutationen auf, die abermals ausgeglichen werden oder mehr oder weniger erhalten bleiben. Der Spross hat also eine innere

1) Baranetzki, Mémoires de l'académie impér. de St. Pétersbourg, Sér. VII, T. 31 , No. 8, 1883.

2) Wortmaxs, Botan. Zeitung, $18 \$ 6$. 
Disposition zu Nutationsbewegungen. Bei der Rotation am Klinostaten kann aber, da die Wirkung der Schwerkraft eliminirt ist, keine rotirende Nutation, sondern nur eine undulirende Nutation zu Stande kommen. Das Vermögen der Sprosse, spontane Nutationen auszuführen, ist eine Vorbedingung für das Auftreten der Flankenkrümmungen, die, wie wir sahen, als horizontale Componenten bei dem Stattfinden der rotirenden Nutation thätig sind. Diese letztere resultirt also aus zwei Factoren, dor spontanen Nutation der Sprosse und ihren negativ geotropischen Bcwegungen.

Die Experimente am Klinostaten sind womöglich längere Zeit fortzuführen, um sich durch genaue Beobachtung über das Verhalten der Pflanzen von dem Fehlen der rotirenden Nutation zu überzeugen. Dann ist es bequem, als Stütze eine etwa $1 \mathrm{~cm}$ Durchmesser besitzende Glasröhre zu verwenden, die mit ihrem einen Ende in der Erde des Culturgefässes steckt, und in die man eine Anzahl engerer Glasröhren hineingeschoben hat. Diese letzteren zieht man in dem Maasse, wie der Spross wächst, hervor, um denselben bei zunehmender Verlängerung stets bequem befestigen zu können, so dass immer nur sein lebhaft wachsendes Gipfelende frei schwebt.

\section{Die freien Windungen.}

Man schneide recht kräftige, $20-30 \mathrm{~cm}$ lange Sprossenden ron Ipomoea purpurea oder von Phaseolus, die im Freien erwachsen, dabei

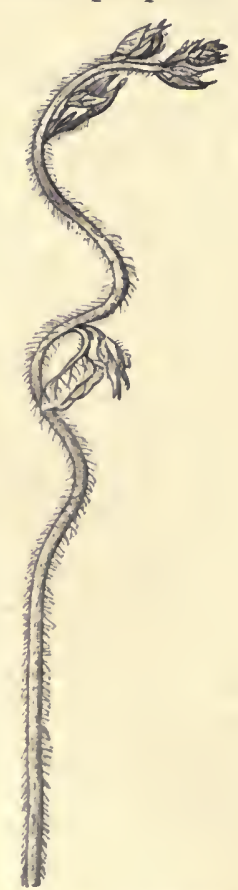

Fig. 164. Spross roll Iponoes purpurea mit freien Windungen. möglichst gerade sind und noch keine Stütze erfasst haben, ab. Die Untersuchungsobjecte werden nun mit ihrem unteren Ende in ein mit Wasser angefülltes kleines Glas gestellt und unter eine grosse Glasglocke oder in ein grosses Glasgefäss gebracht, dessen Oeffnung mit einer Pappscheibe bedeckt ist. Um die Luft, welche die Pflanzentheile umgiebt, recht feucht zu erhalten, benetzt man die Wandungen der Glasglocke oder des Glasgefässes mit Wasser. Unter den bezeichneten Umständen wachsen die Sprosse weiter, und nach 2-3 Tagen haben sich einige freie Windungen gebildet ${ }^{1}$ ). Ich habe dies Ergebniss bei Experimenten mit Sprossenden von Phaseolus und Ipomoea purpurea erhalten. Die letztere Pflanze eignet sich besonders gut zum Versuch und ich sah freie Windungen entstehen, wenn die Untersuchungsobjecte im Dunkeln verweilten oder dem diffusen Tageslicht ausgesetzt waren. Die nebenstehende Abbildung (Fig. 164) stellt einen Ipomoeaspross dar, der freie Windungen gebildet hatte. Man erkennt, was ich in anderen Fällen übrigens nocl deutlicher hervortreten sah, dass die weiter nach abwärts liegenden, also älteren Theile des gewundenen Stengels steiler als dessen

1) Vgl. SAcHs, Vorlesungen über Pflanzenphysiologie, 1852, S. 821. 
jüngere Theile gerichtet sind, eine Erscheinung, auf deren Ursache wir noch zurückkomınen.

\section{Die Mechanik des Windens der Schlingpflanzen.}

Wenn das Ende des Stengels einer Schlingpflanze durch die rotirende Nutation in Raum lierumgeführt wird, so kann dasselbe offenbar leicht mit einer geeigneten Stütze in Berührung gelangen.

Für das Verständniss der Phänomene, die beim Winden beobachtet werden können, ist es vor allem wichtig, die rotirende Nutation, bei deren Zustandekommen das fortdauernd negativ geotropische Verhalten der Stengel, wie wir unter 187 sahen, eine so wichtige Rolle spielt, und ferner den Widerstand der Stïtzen zu berücksichtigen. Diese beiden Momente bedingen es, dass windende Stengel um Stützen in einer Schraubenlinie herumlaufen, und sie reichen auch hin, um die Erscheinung $\mathrm{zu}$ erklären, die wir bei Windungen um Stützen beobachteten, dass die obersten Windungen flach und relativ weit, die unteren aber steiler sind. Es ist nämlich zu berücksichtigen, dass die Stengel der Schlingpflanzen, wenn Windungen an ihnen hervorgetreten sind, noch längere Zeit fortwachsen, und sie werden dabei in Folge der Wirkung der Schwerkraft geotropisch aufgerichtet. Ist eine Stütze vorhanden, so kann eine völlige Geradestreckung der älteren Stengeltheile nicht zu Stande kommen, denn die Stütze tritt ja hindernd in den Weg. Die windenden Stengel legen sich den Stützen nun in einer Schraubenlinie dicht an, und der Neigungswinkel der Sprossaxen wird sehliesslich ein um so geringerer sein, je dünner die Stütze ist. Beim Winden um dicke Stuitzen erfolgt das Anlegen der älteren Stengeltheile an dieselben hingegen früher; die Aufrichtung der Internodien ist alsbald gehindert, und die fertigen Windungen erscheinen daher relativ flach.

Auffallend ist vielleicht auf den ersten Blick die Thatsache, dass freie Windungen an überhängenden Sprossenden der Schlingpfianzen, die sich unter durchaus normalen Verhältnissen im Freien entwickeln, nur selten in typiseher Form hervortreten, während sie an abgeschnittenen Stengelstücken, wie wir gesehen haben, leicht entstehen. Indessen bei genauerer Ueberlegung wird die Sache alsbald klar. Die Wachsthumsfähigkeit abgeschnittener Sprosse ist auf jeden Fall eine erheblich geschwächte. Freie Windungen können freilich durch die mit dem Waclisthum verbundene rotirende Nutation zu Stande kommen, aber die geotropisehe Aufrichtung der Internodien macht sich nur in unvollkommenem Maasse geltend. Die in der Natur kräftig wachsenden und über die Stützen hinausragenden Sprossenden der Schlingptlanzen reagiren meistens so lebhaft auf die Einwirkung der Gravitation, dass dadurch gewöhnlich eine fast völlige Geradestreckung ihrer Internodien herbeigeführt wird und somit keine bleibenden freien Windungen entstehen können.

Wir stellen nun noch verschiedene Experimente an, deren Resultate dazu geeignet sind, uns weitere Einsicht in die Mechanik des Windens der Schlingpflanzen zu gewähren.

Neben eine in einem Blumentopf oder in freien Boden zur Entwickelung gelangte junge, recht kräftige Pflanze von Phaseolus multiflorus wird eine Stütze von $30 \mathrm{~mm}$ Durchmesser gestellt. Nachdem die Stütze einige Male vom Stengel umwunden ist, wird sie entfernt 
und schnell durch eine dünne von nur wenigen Millimetern Durchmesser ersetzt. Die Windungen liegen dieser dünnen Stütze natürlich zunächst nicht an. Man beobachtet jetzt, dass das obere fortwachsende Ende des Bohnenstengels neue Windungen bildet, aber für uns ist von besonderer Wichtigkeit, dass die jüngeren derjenigen Windungen, welche schon um die dicke Stütze gebildet worden waren, im Laufe von 1-2 Tagen steiler werden und sich der dünnen Stütze dicht anschmiegen. Diese Erscheinung ist Folge des in den betreffenden Stengeltheilen noch fortdauernden Wachsthums und der damit zu Stande kommenden geotropischen Aufrichtung derselben. Die älteren, schon um die dicke Stütze gebildeten Windungen bleiben hingegen relativ flach; sie erfahren keine Veränderungen mehr, weil das Wachsthum der älteren Internodien bereits erloschen ist.

Ein kräftiges, in einem Blumentopf erwachsenes Exemplar von Phaseolus, das einige Windungen um eine Stütze gebildet hat, wird in umgekehrter Lage, d. h. mit der Spitze nach abwärts, aufgestellt, nachdem man auf die Erde im Topfe, um das Herausfallen des Erdballens zu verhindern, einige Sperrhölzer gelegt hat. Es erfolgt alsbald ein Abwickeln der jüngeren, noch lebhaft wachsenden Theile des Stengels der Bohnenpflanze von der Stütze, und das Stengelende richtet sich empor. Dies Resultat des Experiments wird nur verständlich, wenn man bedenkt, dass in jeder noch wachsenden Querzone eines Bohnenstengels durch den Einfluss der rotirenden Nutation stets die Tendenz vorhanden ist, in Richtung einer links aufsteigenden Schraubenwindung weiter $\mathrm{zu}$ wachsen. Nach dem Umkehren einer Bohnenpflanze muss daher die der Stütze zugewandte concave Seite des Stengels convex werden, und dies hat ein Abwickeln der noch wachsenden Partien der Internodien zur Folge.

Dass wirklich die Schwerkraftwirkung für das Zustandekommen der rotirenden Nutation und des Windens von Bedeutung ist, wurde bereits unter 187 näher dargelegt. Auch der folgende Versuch lehrt das Nämliche. Der Blumentopf, in welchem sich eine kräftige Bohne entwickelt hat, die bereits mehrere Windungen um eine Stütze ausführte, wird auf dem Klinostaten befestigt und der langsamen Rotation in verticaler Ebene ausgesetzt. Die Rotation erfolgt in einer dem Verlauf der normalen Windungen entgegengesetzten Richtung. Wir sehen nun, dass die noch wachsthumsfähigen Theile des Bohnenstengels sich von der Stütze loslösen. Die jüngsten Windungen wickeln sich $a b$, und der Spross streckt sich mehr oder minder gerade. Dieses Resultat kommt zu Stande, indem sich der gewundene, noch wachsende Theil des Sprosses bei Aufhebung der Schwerkraftwirkung am Klinostaten genau so verhält, wie z. B. ein einfach geotropisch gekrümmter. Dieser letztere streckt sich, wenn er noch wachsthumsfähig ist, unter den bezeichneten Umständen gerade; ebenso sin gewundener Spross, der ja ebenfalls sein Windevermögen der Mitwirkung des Geotropismus verdankt. Die Geradestreckung überhaupt ist Folge innerer Wachsthumsursachen, welche sehr allgemein thätig sind, wenn Pflanzentheile, die Nutationen zeigen, unter Bedingungen gelangen, wo die krümmende Ursache nicht wirksam ist. Dies Vermögen der Pflanzentheile, Krümmungen auszugleichen, bezeichnet Vöchtrsa (Bewegungen der Blüthen und Früchte, S. 31), ohne damit übrigens das Wesen der Sache erklären zu wollen, als $R$ ectipetalität.

Als eine Folge der Mitwirkung des Geotropismus beim Winden der Schlingpflanzen muss es auch angesehen werden, dass horizontale Stützen 
nicht unwunden werden können, wovon man sich leicht durch den Versuch überzeugen kann. Bohnenpflanzen unwinden auch solche Stützen nicht, die über $40^{\circ}$ geneigt sind.

Sehr lehrreich ist ferner das folgende Experiment, welches auch unter anderem zeigt, dass die Entstehung der Windungen bei Schlingpflanzen ganz sicher nicht Folge eines Contactrcizes ist. An der Endknospe einer jungen Bohnenpflanze, die in einem Blumentopfe cultivirt wird und bereits einige um eine Stiitze gewundene Internodien gebildet hat, wird ein feiner Faden befestigt, der über eine senkrecht ïber der Pflanze angebrachte, leicht bewegliche Rolle läuft. An das noch freie Fadenende hängt man ein kleines Gewicht (bei meinen Versuchen benutzte ich $1 \mathrm{~g})$, das eben hinreicht, um das Umsinken des Bolınenstengels zu verhüten. Nach Verlauf von 1-6 Tagen hat der Gipfel der Pflanze einige freie Windungen gebildet (vgl. Fig. 165), die aber, während der Stengel an seiner Spitze fortwächst, allmählich wieder verschwinden, da der Geotropismus, wie auch unter anderen Umständen, schliesslich eine Geradestreckung der Internodien herbeiführt. Hat man vor Beginn des Experiments auf einer Längsseite des Stengels mit Tusche feine Punkte in geringer Entfernung von einander aufgetragen, so ergiebt sich, dass diese Punkte nach erfolgter Geradestreckung der zuerst gebildeten freien Windungen nicht mehr in einer geraden Linie liegen, sondern in Richtung einer links aufsteigenden Schraubenlinie angcordnet sind. Es ist also an unserem Untersuchungsobject eine homodrome Torsion hervorgetreten, eine Erscheinung, dic man sehr oft an schlingenden Stengeln beobachten kann. Dic Entstehung dieser

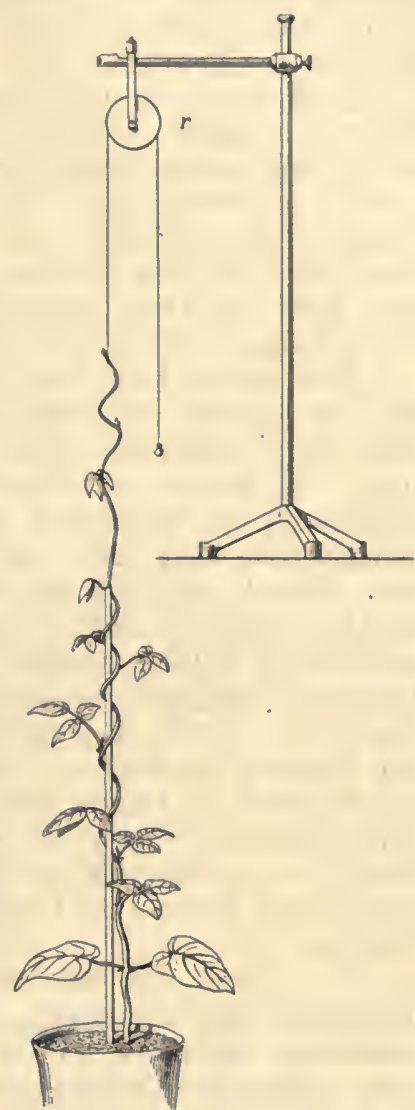

Fig. 165. Phaseoluspflanze, deren Stengel oberhalb der Stütze freie Windungen gebildet hat. Torsionen hängt auf das Innigste mit der Bildung der freien Windungen an unserem Untersuchungsobjecte zusammen. Wenn die Windungen durch Geradestreckung des Stengels verschwinden, so verwandeln sie sich eben in eine homorlrome Torsion, d. h. in eine Torsion, die mit der Richtung, in welcher die Pflanze windet, gleichläuft ${ }^{1}$ ).

1) Die neweren Untersuchungen über Schlingpflanzen finden sich namentlich in den folgenden Abhandlungen nierlergelegt: H. DE VRIES, Arbeiten d. botan. Instituts in Würzburg, Bd. 1; ScHwexnex ER, Monatsberichte d. Berliner Akademie, 1881, December; AMBnosN, Berichte d. sächsischen Gesellschaft d. Wissenschaften ; Wortmans, Botan. Zeitung, 1886. Die Erfahrungen, welehe ich bei dem Studium der Erseheinungen des Windens der Schlingpflanzen sammelte, stimmen in allen wesentlichen Punkten mit denjenigen von SACHs und WORTMAxx überein. 


\section{Experimente iiber das Ranken der Cucurbitaceen.}

Es giebt viele Gewächse, die sehr verschiedenen Familien angehören, welche mit Ranken ausgerüstet sind. Diese fadenförmigen Organe dienen den Pflanzen zum Klettern. Sie vermögen sich an Stützen zu befestigen und verhüten dadurch das Umsinken der Gewächse.

Will man sich mit den merkwürdigen Eigenschaften der Ranken vertraut machen, so ist es sehr bequem, eine Reihe von Cucurbitaceen, zumal Cyclanthera explodens und Sicyos angulatus als Untersuchungsobjecte zu verwenden. Die erstere Pflanze cultivire man in nicht $\mathrm{zu}$ kleinen Blumentöpfen, die letztere im freien Lande. Die beiden genannten Gewächse werden aus Samen erzogen $\left.{ }^{1}\right)$. Haben die Pflanzen eine gewisse Grösse erreicht, so ist es nothwendig, ihnen Stützen zur Befestigung der Ranken darzubieten.

Beobachtet man ein kräftig entwickeltes Individuum von Cyclanthera explodens, so zeigt sich zunächst, dass die nicht an Stützen befestigten, geradegestreckten Ranken fortwährend in Bewegung begriffen sind. Sie werden im Raume in einen Kreise herumgeführt, eine Erscheinung, die wesentlich durch die Nutation der die Ranken tragen. den Sprosse zu Stande kommt. Ich sah, dass eine Ranke von Cyclanthera einen vollen Kreis bei hoher Sommertemperatur (über $20^{\circ} \mathrm{C}$.) im Laufe èiner Stunde beschrieb. Aber nicht allein diejenigen Sprosse, welche die Ranken tragen, auch die Ranken selbst sind bei manchen Pflanzen befähigt, rotirende Nutationen zu vollführen $\left.{ }^{*}\right)$. Diese Bewegungen treten in reiner Form hervor, wenn man die Nutationen der Sprosse ausschliesst, indem man dieselben an der Insertionsstelle der Ranken an einem Stab befestigt. Die biologische Bedeutung der Nutationen ist eine recht erhebliche. Die wachsenden Ranken werden durch sie im Raume herumgeführt, und sie werden dabei leicht mit geeigneten Stützen in Contact gerathen, an denen sie sich befestigen können.

Will man die Reizbarkeit der Ranken genauer studiren, so empfiehlt es sich besonders, die Ranken von Sicyos angulatus als Untersuchungsobjecte zu wählen, und ich habe mit denselben denn auch sehr zahlreiche Experimente angestellt. Im jugendlichen Zustande sind die einzelnen Zweige dieser Ranken spiralig eingerollt. Haben sie sich aber ausgestreckt, so kommt ihnen, wälırend sie noch lebhaft wachsen, ein sehr hoher Grad von Empfindlichkeit zu. Bei niederer Temperatur ist die Reizbarkeit natürlich eine geringere als bei recht warmem Wetter. Zieht man an einem warmen Tage einen gerade gestreckten Rankenzweig vorsichtig $\mathrm{zwischen}$ den Fingern hindurch, so krümmt sich derselbe alsbald bedeutend, und die zur Geltung kommende Bewegung ist eine so lebhafte, dass man sie mit dem Ange direct verfolgen kann. Fig. 166 stellt einen Spross mit Ranke von Sicyos angulatus dar. Der Rankenzweig $a$ ist nicht gereizt, daher noch gerade gestreckt. Der Zweig $b$ hat in Folge schwacher Reizung mittelst eines Holzstäbchens eine unbedeutende Krümmung erfahren, während der

1) Die Sicyospflanzen bringt man zunächst in Blumentöpfen zur Entwickelung, um sie später ins freie Land zu versetzen, wenn sie genügende Grösse crlangt haben.

2) Vgl. Wortmaxi, Botan. Zeitung, 1887, No. 7. 
Rankentheil $c$ stärker gereizt worden ist, daher auch starke Krüınmungen erfahren hat. Auf den Rankenzweig $d$ kommen wir weiter unten zurück. Hat man eine Ranke von Sicyos durch vorübergehende Berührung mit einem festen Körper veranlasst, sich zu krümmen, und übcrlässt inan die Ranke nunmelır sich selbst, so streekt sic sich wieder vollkommen gerade und ist abermals für Berührung empfindlich. Bei hoher Sommertemperatur geht die Geradestreckung der Sicyosranken relativ schnell vor sich, und auch bei Experimenten mit Cyclantheraranken fand ich, dass sich eine in Folge eines Reizes stark gekrümmte Ranke bei etwa $22^{\circ} \mathrm{C}$. schon nach Verlauf von einer Stunde wieder ausgestreckt latte und abermals reizempfindlich war.

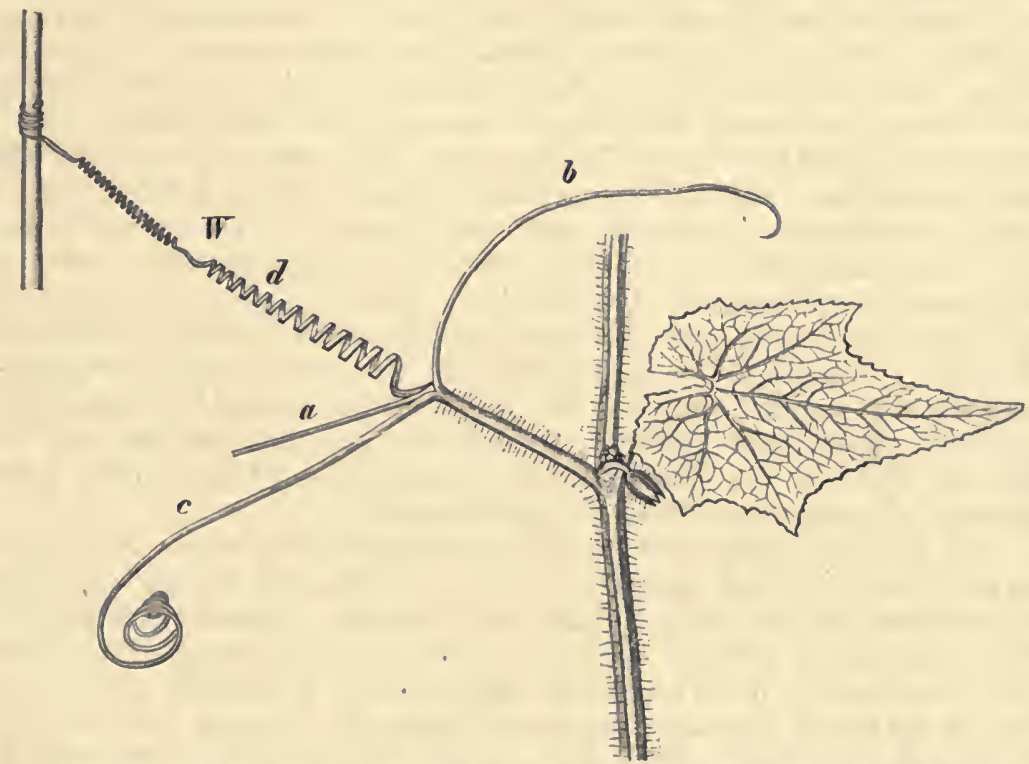

Fig. 166. Theil eines Sprosses ron Sicyos anguiatus mit einer Ranke.

Wird ein Zweig einer Sicyosranke an verschiedenen Punkten mit einem dünnen Holzstäbchen berührt, so findet man leicht, dass die Reizbarkeit des Organs besonders gross im vorderen Drittel ist, von hier aus nach der Basis zu aber erheblich abnimmt. Ferner kann man feststellen, dass in der sensiblen Zone nur eine Flanke der Rankenzweige auf den Contactreiz reagirt, und zwar ist allein diejenige Seite der Sicyosranken für Berührung empfindlich, welche, wenn die Rankenzweige noch sehr jung und daher noch spiralig eingerollt sind, die Convexität bildet. Es sei hier übrigens bemerkt, dass es auch Pflanzen giebt,I deren Ranken nicht nur auf einer, sondern auf allen Seiten reizbar sind. Will man sich von dem hohen Grade der Empfindlichkeit der Sicyos- oder Cyclantheraranken specieller überzeugen, so ist es zu empfehlen, Stückchen baumwollenen Garnes oder kleine Papierreiter von wenigen Milligramm Gewicht sanft auf die Rankenspitzen $\mathrm{zu}$ bringen. Es treten sehr schnell deutliche Krümmungen hervor. Andere Ranken, z. B. diejenigen von Vitis, welche wir weiter unten genauer untersuchen wollen, sind weit weniger empfindlich als die 
hier erwälnten; Belastungen mit Körpern von wenigen Milligramm Gewicht bringen sie überhaupt noch gar nicht zur Einkrümmung.

Von principieller Wichtigkeit ist die durch geeignete Experimente leicht festzustellende Thatsache, dass die Ranken nicht schlechthin für Druck, Stoss oder Berührung empfindlich sind, sondern dass nur eine bestimmte Form der Berührung als Reiz wirkt '). Werden rankentragende Sicyossprosse kräftig, aber unter sorgfältiger Vermeidung jeder Berührung der Ranken mit einem festen Körper geschüttelt, so treten an den Ranken wohl Erschütterungskrümmungen auf, aber jene auffallende Reizwirkung, welche durch Contact mit einem festen Körper zur Geltung kommt, unterbleibt. Das Ergebniss unseres Experimentes lehrt auch, dass Luftreibung nicht als Reiz auf die Ranken einwirkt. Auch durch einen Wasserstrahl, den man z. B. aus einer Spritzflasche gegen die reizbare Seite der Ranken von Sicyos richtet, werden dieselben nicht gereizt. Wesentlich anders wie die Ranken verhalten sich, wovon ich mich überzeugte, die empfindlichen Blätter von Mimosa pudica sowohl einem Wasserstrahl als auch einfacher Erschütterung gegenüber. Diese Blätter werden durch jede beliebige mechanische Erschütterung gereizt, und wenn man z. B. einen Wasserstrahl gegen ein ausgebreitetes Blatt richtet, so erfolgen die bekannten Schliessungsbewegungen sehr schnell. Die Ranken sind nicht durch jede beliebige mechanische Erschütterung reizbar, sondern sie reagiren nur dann, wenn in ihrer sensiblen Zone discrete Punkte beschränkter Ausdehnung gleichzeitig oder in genügend schneller Aufeinanderfolge von Stoss oder Zug betroffen werden. Wir haben also zwischen Stossreiz, auf den z. B. die Mimosablätter reagiren, und Contactreiz, der die Rankenbewegungen auslöst, $\mathrm{zu}$ unterscheiden.

Wird in der Nähe der Ranken von Cucurbita, Sicyos oder Cyclanthera eine Stütze, z. B. ein Draht oder ein dünner Holzstab, aufgestellt, so gelangen die reizbaren Organe in Folge der schon erwähnten Nutationsbewegungen alsbald mit der Stütze in Berührung. Der Contact löst eine Reizwirkung aus, und die Ranken krümmen sich. Durch diese Krümmung kommen weitere Punkte der Ranken mit der Stütze in Contact, neue Reizwirkungen machen sich geltend, und so kommt schneller oder langsamer ein Umwinden der Stütze zu Stande (vergl. Fig. 166, Rankenzweig d). Hat eine Ranke eine Stütze ergriffen, so treten an demjenigen Rankentheile, der zwischen der Stütze und der Pflanze ausgespannt ist, sehr schnell merkwürdige Veränderungen ein. Dieser Rankentheil bildet nämlich, wie es in Fig. 166 dlargestellt ist, korkzieherförmige Einrollungen, und aus freilich rein meclianischen Gründen entstehen $\mathrm{zwischen}$ entgegengesetzt verlaufenden Windungen sog. Wendepunkte (vergl. Fig. 166 bei $W$ ). Ich sah z. B., dass eine Sicyosranke, die am 1. Juli nachmittags um $4 \mathrm{Uhr}$ eine Stütze ergriffen hatte, schon am Murgen des nächsten Tages in ihrem zwischen der Stütze und der Pflanze ausgespannten Theile korkzieherförmig gewunden war; Wendepunkte waren auch bereits vorhanden. Ich sah ferner, dass eine Cyclantheraranke, die eine Stütze ergriffen hatte, bei hoher Sommertemperatur schon nach 8 Stunden die ersten korkzieherförmigen Windungen an dem zwischen Stütze und Pflanze ausgespannten Theile hervortreten liess. Diese ersten Windungen bildeten

1) Vgl. Pfeffer, Untersuchungen aus dem botan. Institut zu Tübingen, Bd. 1, S. 483. 
sich in unmittelbarer Nähe des Befestigungspunktes der Ranke an der Stütze. Die Entstehung der korkzieherförmigen Windungen schreitet im frei ausgespannten Rankentheil von der Spitze nach der Basis fort. Ranken unserer Cucurbitaceen, welche keine Stütze ergriffen haben, zeigen ebenso wie die befestigten Organe Einrollungserscheinungen, aber man kann sich leicht davon überzeugen, lass dieselben, während sie an befestigten Ranken schnell entstehen, an solchen Ranken, die keine Stïtze ergriffen haben, nur sehr langsam zur Ausbildung kommen. Diese Thatsachen lassen keinen Zweifel darüber bestehen, dass das beschleunigte Auftreten der Einrollungen befestigter Ranken Folge des Contactreizes ist, dem dieselben ausgesetzt gewesen sind, und zudem leuchtet ein, dass hierbei auch eine Reizfortpflanzung eine wichtige Rolle spielen muss, denn die korkzieherförmigen Windungen bilden sich ja am frei ausgespannten, nicht am direct berührten Rankentlieile.

Mit Bezug auf die Mechanik der Rankenbewegungen ist so viel mit Sicherheit bekannt, dass, wenn eine Ranke durch Berührung gereizt. worden ist und Krümmungen eingetreten sind, die Turgorausdehnung der Zellen auf der concaven Seite geringer ist als diejenige der Zellen der convexen Seite. Diese zunächst zur Geltung kommende und durclı den Contactreiz hervorgerufene Differenz der Turgorausdehnung ist. dann ferner die Ursache eines verschiedenartigen Wachsthums der Zellen der concav sowie convex gewordenen Rankenseite. Die Zellen der letzteren wachsen lebhafter als diejenigen der ersteren, und dadurch werden die durch den Contactreiz hervorgerufenen Krümmungen fixirt. Mit Hülfe der plasmolytischen Methode (vgl. unter 59) ist man im Stande, den Antheil festzustellen, den die Turgorausdehnung der Zellen einer- und das Wachsthum derselben andererseits an dem Zustandekommen der Rankenkrümmungen nehmen, und es ist lehrreich, derartige Experimente auszuführen. Man verfährt dabei derartig, dass man die Ranken schwächer oder stärker reizt und dann, wenn mehr oder minder erhebliche Krümmungen eingetreten sind, abschneidet, um sie sofort in 20-proc. Kochsalzlösung $\mathrm{zu}$ legen. Strecken sich die gekrümmten Ranken bei der Plasmolyse wieder völlig gerade, so war die in Folge des Contactreizes erzeugte Krümmung nur durch Verschiedenartigkeit der Turgorausdehnung der Zellen auf der concaven und convexen Rankenseite hervorgerufen. Wenn dagegen durch Plasmolyse keine völlige Geradestreckung crzielt wird, so ist damit die Betheiligung des Wachsthums an der Ausbildung der Windungen erwiesen. Ich habe Sicyosranken gereizt und, nachdem sie $1 / 4, y / 4$ oder $1 \frac{1}{4}$ Windungen gebildet liatten, der Plasmolyse unterzogen. Die beiden ersten Ranken streckten sich alsbald völlig gerade; an der letzten blieb in der Salzlösung $1 / 4$ Windung erhalten ${ }^{1}$ ).

Die Ranken der Cucurbitaceen sind, worauf für Sicyosranken bereits hingewiesen wurde, nur an ihrer Spitze sehr reizbar; nach ihrer Basis zu nimmt die Reizbarkeit allmählich ab. Hiermit im Zusammenhang steht olıne allen Zweifel die Thatsache, von deren Richtigkeit ich mich nach den Angaben von O. MÜLLER ${ }^{2}$ ) überzeugte, dass die Basis der Cucurbitaceenranken radiär gebaut ist, während der dorsi-

1) Vgl. H. DF VRIEs, Arbeiten des botanischen Instituts in Würzburg, Bd. 1, S. 302, und Landwirthschaftliche Jahrbücher, Bd. 9, S. 511.

2) Vgl. O. Müller in CoHx's Beiträgen zur Biologie der Pflanzen, Bd. 4, S. 120. 
ventrale Bau der Ranken um so mehr hervortritt, je mehr wir uns der sehr empfindlichen Rankenspitze nähern. Wir stellen z. B. eine ganze Anzall von Schnitten aus einer Ranke von Bryonia dioica her. An der Basis ist die Ranke völlig oder nahezu radiär gebaut. Wir erblicken die regelmässig im Mark vertheilten Gefässbündel, einen geschlossenen Sklerenchymring, dessen Elemente aber noch nicht verholzt zu sein brauchen, dann grünes Gewebe, das aber nur an einigen Stellen bis zur Epidermis reicht, da reichliches Collenchym vorhanden ist.

Wenn wir Schnitte aus der Mitte oder dem oberen Theile der Bryoniaranken untersuchen, so tritt der dorsiventrale Bau des reizbaren Organes inmer klarer hervor. Die Gefässbündel sind im Grundgewebe auf der Rankenunterseite zusammengedrängt, das Sklerenchym bildet keinen Ring mehr, sondern einen Bogen auf der Rankenunterseite. Ebenso ist das Collenchym hier besonders reichlich entwickelt, während das grüne Parenchym vor allem als Hauptgewebe der Rankenoberseite auftritt.

\section{Experimente mit Ampelideenranken.}

Die verzweigten Ranken von Vitis vinifera sind bei weitem nicht so reizempfindlich, wie die unter 190 besprochenen Ranken von Sicyos und Cyclanthera. Diese letzteren reagiren unter günstigen Umständen ja fast momentan sehr energisch auf Berührung. Die Vitisranken krümmen sich selbst nach starker Reizung nur langsam. Ich fand einmal, dass ein Zweig einer Vitisranke, der mehrfach zwischen den Fingern hindurchgezogen worden war, bei hoher Sommertemperatur nach 20 Minuten deutlich gekrümmt erschien. In allen anderen Fällen, zumal bei nicht so hoher Temperatur, wurde die Reizwirkung erst nach Verlauf von einer oder einigen Stunden deutlich sichtbar. Ist eine Ranke von Vitis vorübergehend gereizt worden, und hat sie sich in Folge dessen gekrümmt, so streckt sie sich langsam wieder gerade und ist dann abermals reizbar. Stellt man in die Nähe einer Vitisranke einen dünnen Holzstab als Stütze auf, so kann dieser leicht umwunden werden. Der zwischen der Stütze und der Pflanze ausgespannte Rankentheil zieht sich korkzieherartig zusammen, aber dies erfolgt langsam, oft erst im Laufe einiger Tage.

Sehr eigenthümlich verhalten sich die Ranken von Ampelopsis quinquefolia (wilder Wein). In Fig. 167 ist eine solche Ranke abgebildet, welche noch gar keine Befestigung erfahren hat. Die Rankenzweige sind nur bei einzelnen Individuen zum Winden befähigt; meist vermögen sie es nicht, sich in typischer Weise wie viele Cucurbitaceenranken oder Vitisranken zu befestigen. Dagegen sind die Enden der Rankenzweige im Stande, Haftballen zu erzeugen. Wenn nämlich diese Enden mit dem Mauer- oder Holzwerk, an dem die Pflanze wächst, in Berührung gerathen, so schwellen sie in Folge des Contactreizes alsbald $\mathrm{zu}$ den Haftballen an. Die Zellen dieser letzteren scheiden klebrige Secrete ab, vermittelst welcher eine Befestigung der Rankenenden herbeigeführt wird. In Fig. 168 ist eine Ampelopsisranke abgebildet, die von einer Holzwand abgelöst worden war, nachdem die Enden ihrer Zweige eben begonnen liatten, Haftballen zu erzeugen. Hat sich eine Ampelopsisranke in der angegebenen Weise 
befestigt, so treten in den zwischen den Befestigungspunkten und der Pflanze ausgespannten Rankentheilen korkzieherförmige Windungen auf. Die Entstehung dieser letzteren ist, wie bei den Ranken von Sicyos, Vitis etc., Folge einer Reizfortpflanzung und hängt mit dem Contactreiz, der zur Haftballenbildung führte, innig zusammen. Wenn die Ampelopsisranken sich nämlich nicht befestigen, so unterbleibt das Auftreten der korkzieherförmigen Windungen. Die nicht befestigten Ranken unserer Pflanze werden sogar im Laufe einer oder zweier

Fig. 167.

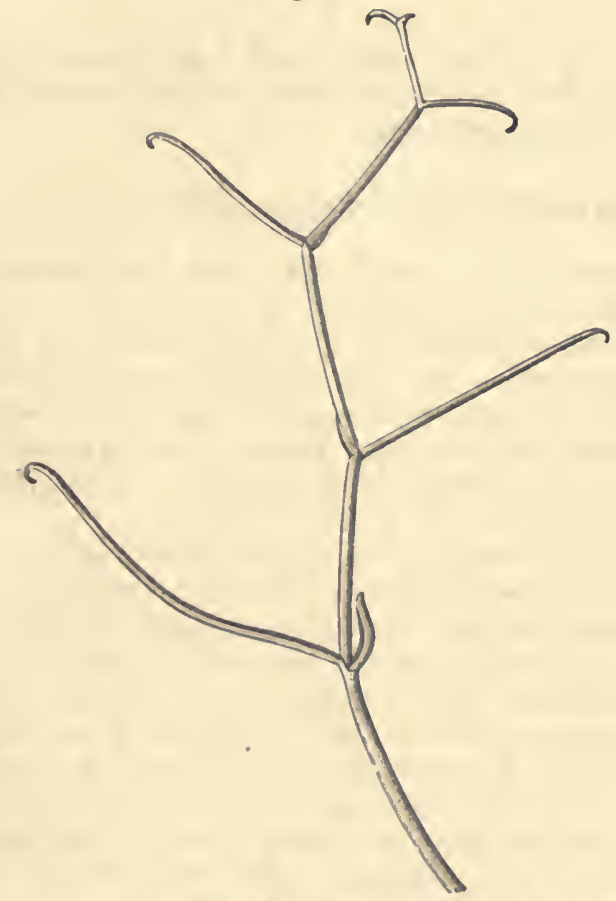

Fig. 168.

Fig. 167. Ranke ron Ampelopsis quinquefolia, nicht befestigt.

Fig. 168. Ranke von Ampelopsis quinquefolla mit Haftballenbildung.

Wochen welk und fallen ab. Der zur Haftballenbildung führende Contactreiz an den Enden der Rankenzweige ruft aber nicht nur die Bildung der erwähnten korkzieherförmigen Windungen hervor, sondern es machen sich in Folge von Reizfortpflanzung noch weitere Veränderungen im frei ausgespannten Rankentheile geltend.

Untersucht man einen zarten Querschnitt eines noch nicht befestigten Rankenzweiges von Ampelopsis, so gewahrt man ein grosszelliges Mark, das von einem Gefässbündelkreis umgeben wird. Die Verbindung $\mathrm{z}$ wischen dem Mark und der grünen Rinde stellen grosse Markverbindungen her, und in der Peripherie der Rinde, dicht unter der Epidermis, ist Collenchym vorhanden. Wenn die Ampelopsisranken sich befestigt haben, so erführt ihr Bau zugleich mit der Bildung der korkzicherförmigen Windungen wesentliche Veränderungen. In den Markverbindungen tritt Zwischencambium auf; der Holzkörper 
der Gefässbündel vergrössert sich in bedeutendem Maasse, bis endlich ein geschlossener Holzring entstanden ist, wodurch die Ranken sehr bedeutend an Festigkeit und Widerstandsfähigkeit gewinnen und der Pflanze erst von rechtem Nutzen werden ${ }^{1}$ ).

\section{Die Dorsiventralität, Polarität und Anisotropie der Pflanzenorgane und die Correlationserscheinungen im Pflanzenreich.}

\section{Die Dorsiventralität der Pflanzentheile.}

Viele Pflanzentheile, zumal plagiotrope (z. B. viele Laubblätter), sind in ausgeprägter Weise dorsiventral gebaut. Es giebt aber auch Stengeltheile, denen in morphologischer resp. physiologischer Beziehung Dorsiventralität eigenthümlich ist, und für gewisse derselben ist sogar die Ursache der Dorsiventralität bekannt; sie kann daher in bestimmter Weise hervorgerufen werden. Einige Beobachtungen sollen uns näheren Aufschluss über diese interessanten Verhältnisse. gewähren.

Wir legen im Sommer einige Samen von Tropaeolum majus in gute Gartenerde aus, die sich in Blumentöpfen befindet. Die Culturgefässe stellen wir vor ein Fenster, welches recht helles Licht empfängt. Die epicotylen Glieder der sich entwickelnden jungen Keimlinge (wir dürfen stets nur wenige in einem Blumentopf cultiviren, damit sie sich nicht gegenseitig beschatten) wenden sich zunächst dem Licht entgegen; sie verhalten sich positiv heliotropisch. Bleiben die Pflanzen unverrückt im hellen Licht vor dem Fenster stehen, so geht der positive Heliotropismus der epicotylen Glieder der Keimlinge in einen negativen Heliotropismus über. Sie wenden sich, ebenso wie die weiteren neu. entstehenden Stengeltheile, von der Lichtquelle ab. Ihre Lichtseite (Oberseite) wird daher convex. Der Einfluss intensiven. Lichts ruft also einen Plagiotropismus der Tropaeolumstengeltheile hervor; derselbe ist aber kein tief eingreifender, denn die Axenglieder unserer Pflanzen bewahren stets, sowohl mit Rücksicht auf ihren anatomischen Bau als auch in Bezug auf die Stellung der an ihnen entstehenden Blätter einen multilateralen oder radiären Charakter. Es. ist wichtig, dass die Licht- oder Oberseite des epicotylen Stengelgliedes von Tropaeolum nicht allmählich convex wird, wenn die Beobachtungsobjecte schwachem Licht ausgesetzt sind; das negativ heliotropische Verhalten der Pflanzentheile kommt dann nicht zur Geltung; sie krümmen sich dann nur positiv heliotropisch dem Licht entgegen. Uebrigens kann jede beliebige Flanke der Tropaeolumstengel (eben die am stärksten beleuchtete) zur Oberseite derselben werden ${ }^{2}$ ).

1) Vgl. Darwin, Die Bewegungen und Lebensweise der kletternden Pflanzen, 1876 , S. 105, und v. LeNGERkEN, Botan. Zeitung, 1885, No. 22-26.

2) Vgl. SACHS, Arbeiten des botan. Instituts in Würzburg, Bd. 2, S. 271. 
Ein ausgezeichneter Fall localer Induction von Dorsiventralität lässt sich bei Experimenten mit den horizontal wachsenden Sprossen von Thuja occidentalis constatiren ${ }^{1}$ ). An diesen Sprossen sind vier Blattzeilen vorhanden: je eine Blattzeile auf der Ober- und Unterseite (Facialblätter); je eine an den beiden Flanken (Marginalblätter). Die unter gewöhnlichen Verhältnissen erwachsenen Thujasprosse sind nun deutlich dorsiventral gebaut, wovon man sich leicht bei mikroskopischer Untersuchung zarter Querschnitte überzeugen kann. Ihr Mesophyll z. B. ist auf der Oberseite palissadenartig entwickelt, auf der Unterseite besteht es aus nahezu isodiametrischen Zellen (vergl. Frank, Pringsheim's Jahrbücher, Bd. 9, Tafel 16, Fig. 4). Wenn man nun im zeitigen Frühjahr vor dem Erwachen der Vegetation (die von mir ausgeführten Versuche begannen Anfang März) horizontale Thujasprosse umkehrt und in dieser Lage fixirt, ohne sie von der Mutterpflanze abzutrennen, so dass ihre morphologische Unterseite nach oben gewandt ist, dann entwickeln sich die Sprossenden im Laufe des Frühlings ganz normal und erlangen auch wie gewöhnlich dorsiventralen Bau. Diejenige Seite der Thujasprosse aber, welche ohne Umkehrung zur morphologischen Unterseite geworden wäre, wird jetzt zur Oberseite, wie z. B. das Vorhandensein von Palissadenparenchym deutlich zeigt, während die erdwärts gewandte Seite der umgekehrten Sprosse den normalen Charakter der Unterseite annimmt. Die Dorsiventralität der Thujasprosse ist also Folge localer Induction. Sie wird durch Lichtwirkung hervorgebracht, nicht, wie FRANK noch specieller nachzuweisen sucht, durch Schwerkraftwirkung.

Werden die mehr oder minder zweizeilig beblätterten Sprosse von Taxus baccata zur Zeit des Austreibens der Knospen, also im Mai, um $180^{\circ}$ gedreht und in dieser Lage, ohne sie von der Mutterpflanze abzutrennen, durch Festbinden fixirt, so beobachtet man, dass die jungen Triebe (natürlich nicht die älteren, schon ausgewachsenen) nach Verlauf einiger Tage durch Drehung wicder in diejenige Lage zurückgekehrt sind, welche sie vor Beginn dos Experiments besassen. Wenn man die Taxussprosse vor dem beginnenden Austreiben der Knospen (meine Versuche begannen Mitte März) um $180^{\circ}$ dreht und in dieser Lage fixirt, dann wird, wohl namentlich unter dem Einfluss der Schwerkraft, alsbald eine Dorsiventralität in den sich entwickelnden Sprossen inducirt, die der neuen Lage entspricht, so dass dic Jahrestriebe nunmehr nach einer Umkehrung in die beim Austreiben angenommene Orientirung zurückstreben. Der Unterschied zwischen solchen Taxussprossen, die sich in gewöhnlicher Weise entwickelt haben, und solchen, welche aus Knospen hervorgegangen sind, die an zeitig im Frühjahr um $180^{\circ}$ gedrehten älteren Spross sassen, prägt sich aber wesentlich darin aus, dass bei jenen die Länge der Nadeln von der Unter- zur Oberseite der Zweige abnimmt, während bei diesen die längsten Nadeln der Oberseite angehören (Anisophyllie) ${ }^{2}$ ).

\section{Die Polaritat der Pflanzentheile.}

Zahlreiche Pflanzentheile, zumal viele Sprosse, lassen die Erscheinung einer ausgeprägten Polarität deutlich erkennen. Die

1) Vgl. Frank in PrLvasheiv's Jahrbüchern, Bd. 9, S. 147. S. 24 .

2) Vgl. FraNk, Die natürliche wagerechte Richtung von Pflanzentheilen, 1870, 
Organisationsverhältnisse oder auch das physiologische Verhalten solcher Pflanzentheile weisen direct auf einen Unterschied von Basis und Spitze hin, und wir wollen zunächst einige Experimente anstellen, um zu einem genaueren Verständniss der hier berührten merkwürdigen Thatsachen zu gelangen (VöchtiNG).

In einen Glascylinder wird etwas Wasser gebracht, so dass dieses den Boden des Cylinders etwa $1 \mathrm{~cm}$ hoch bedeckt. Die Innenwand unseres Apparats belegen wir ihrer ganzen Ausdehnung nach mit durchfeuchteten Fliesspapierstreifen; dieselben müssen mit ihrem unteren Ende in das Wasser eintauchen. Die Oeffnung am oberen Ende des Cylinders wird durch Bedecken mit einer Glasplatte verschlossen. Wir können unseren Versuch zu sehr verschiedener Jahreszeit anstellen und wollen zunächst sehen, welchen Erfolg wir bei Experimenten mit Weidenzweigen im Februar oder März erzielen. Wenn

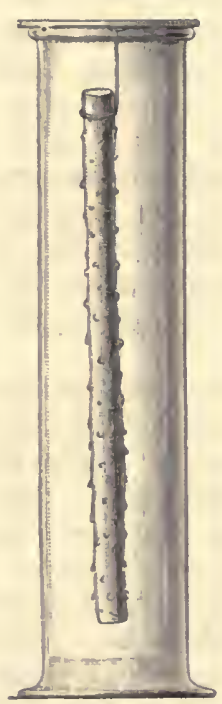

Fig. 169. Glaseylinder, in welchem ein austreibendes Weidenzweigstück hängt. minder deutlich, dass die Wurzeln nach der morphologischen Basis der Zweigstücke hin an Zahl und Länge zunehmen. (Vergl. auch Fig. 116.) Wenn wir im Juli aus dem mittleren Theile eines kräftigen diesjährigen Weidenzweiges, dessen Blätter wir entfernt haben, Stücke von etwa $200 \mathrm{~mm}$ Länge herausschneiden und dieselben in angegebener Weise in einem Glascylinder in feuchter Luft aufhängen, so entwickeln sich am oberen Ende unseres Untersuchungsobjectes Triebe. Was die Wurzelbildung anbelangt, so ist dieselbe bei den jungen Zweigstücken im Gegensatz zu älteren, auf deren morphologische

1) Betont muss werden, dass die Wurzelanlagen unter der Rinde gleichmässig über den ganzen Weidenz weig vertheilt sind.

2) Vgl. Vöchtisk, Ueber Organbildung im Pflanzenreich, 1878. Vergl. ferner Vöchring, Ueber Transplantationen am Pflanzenkörper, Tübingen 1892. 
Basis beschränkt. Wir hängen auch noch ältere oder jüngere Weidenzweigstüeke im März oder Juli derartig in Glascylindern auf, dass ihre morphologische Spitze nach abwärts, ihre morphologische Basis aber nach oben gekehrt ist. Es ergiebt sich wieder, dass an der Spitze Triebe, an der morphologischen Basis aber besonders zahlreiche und kräftige Wurzeln zur Ausbildung gelangen. Die Experimente mit umgekehrt aufgehängten Zweigstücken lehren also, dass die Wirkung der Schwerkraft nicht die un mittel bare Ursache der von uns bezüglich der Entwickelung von Trieben und Wurzeln constatirten Erscheinungen sein kann.

Es ist sicher, dass die Polarität von Pflanzentheilen, d. h. der Gegensatz von Basis und Spitze an denselben, nicht Folge geheimnissvoller vitaler Kräfte ist, sondern dass dieselbe äusseren Kräften ihre Entstehung verdankt. Wir haben allen Grund zu der Annahme, nach welcher in erster Linie die Schwerkraft jene Polarität ursprünglich bedingte, und wir können uns mit Rüeksicht auf die hier in Betracht kommenden Fragen etwa die folgende Vorstellung bilden. Wenn die Gravitation stets in der nämlichen Richtung und durch zahllose Generationen hindurch auf die Gewächse einwirkt, so kann durch Summirung der Wirkungen schliessliel eine erbliche Eigenschaft der Pflanzentheile resultiren, die wir cben als Polarität bezeichnen. Diese letztere wäre danach als eine durch die Schwerkraft herbeigeführte, über das Leben des Individuums hinausgreifende Nachwirkungserscheinung, als ein Phänomen inhärenter oder stabiler Induction, oder, wie man gewöhnlich zu sagen pflegt, als eine erbliche Disposition aufzufassen. Von diesem Gesichtspunkte aus würde auch die Thatsache begreitlich sein, dass die Schwerkraft keinen wesentlichen directen Eintluss auf das Auswachsen der Knospen und Wurzeln an Pflanzentheilen mit ausgeprägter Polarität geltend zu machen im Stande ist "). Uebrigens übt die Gravitation auf diese letzteren dennoch unter bestimmten Bedingungen eine in die Augen fallende Wirkung aus, wovon man sich leicht durch ein Experiment, das ich in folgender Form anstellte, überzeugen kann. Ein ziemlich grosser Zinkkasten wurde bis zur Hälfte mit Wasser angefüllt. Ueber die Wasserfläche wurde dann eine Reihe von Weidenzweigstïcken von $200 \mathrm{~mm}$ Länge und $12 \mathrm{~mm}$ Durchmesser in eine horizontale Lage gebracht, was leicht geschehen kann, indem man sie an ihren Enden auf geeignete, aus dem Wasser hervorragende Unterlagen auflegt. Das Zinkblechgefäss schloss ich nicht vöflig luftdicht mit einem Deckel ; die Untersuchungsobjecte befanden sich aber im Dunkeln. Die Experimente, welche im Mårz und April angestellt wurden, ergaben, dass die Knospen sich vorwiegend an der morphologischen Spitze der Weidenzweigstïcke entwickelten, während zumal die Basis derselben Wurzeln bildete. Es ist aber hier für uns besonders die speciellere räumliche Orientirung der Triebe und Wurzeln von Bedeutung. Jene bildeten sich nämlich insbesondere an der Ober-, diese an der Unterseite der horizontal gelegten Weidenzweigstücke aus, ein Erfolg, der ohne Zweifel auf Schwerkraftwirkung beruht. Uebrigens sind bei derartigen Versuchen mit Rücksicht auf das individuell recht verschiedenartige Ver-

1) Nicht alle Sprosse besitzen eine derartig ausgeprägte Polarität wie die Weidenzweige, und solche sind dann auch localer Induction zugänglich. Vergl. SACHS, Vorlesungen über Pflanzenphysiologie. 
lıalten der Zweigstücke stets eine Anzahl Objecte neben einander zu verwenden.

Beiläıfig sei noch bemerkt, dass, wie Vöchting specieller nachgewiesen hat, das Licht einen bedeutsamen Einfluss auf die Ausbildung von Wurzeln an Weidenzweigen geltend macht. Wenn man Weidenzweigstücke in angegebener Weise in Glascylindern aufhängt, einen Glascylinder unter einen schwarzen Recipienten stellt, den anderen aber diffusem Tageslicht aussetzt, so findet man, dass bei Lichtzutritt nicht so viele Wurzeln wie im Dunkeln aus der Rinde der Zweigstücke hervorbrechen, und dass sich die Wurzelentwickelung bei Lichtzutritt auch langsamer als im Finstern vollzieht.

1. 我 An vielen Pflanzentheilen ist eine ebenso ausgeprägte Polarität wie an den Weidenzweigen zu constatiren. Ich habe z. B. Kartoffel-

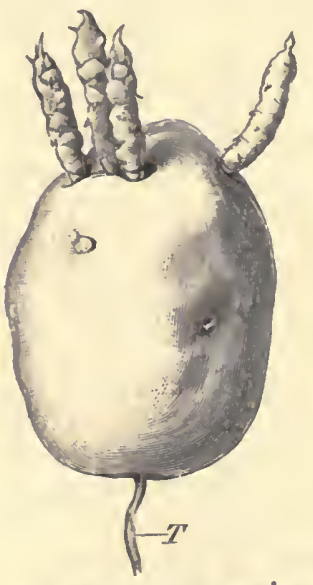

Fig. 170. Keimende Kartoffelkmolle. $T$ Tragfaden. knollen im Winter in einem Kasten aufgestellt, so dass sie vor dem Licht geschützt waren ${ }^{1}$ ). Die Spitze mehrerer Knollen war nach aufwärts, diejenige anderer nach abwärts gerichtet, aber stets entwickelten sich vorwiegend nur an der morphologischen Spitze, d. h. an demjenigen Knollenende, das dem Nabelende entgegengesetzt ist, kräftige Triebe. Das für ihre Ausbildung erforderliche Wasser sowie die Nährstoffe entnehmen die Triebe unter den bezeichneten Umständen allein der Knolle (vergl. Fig. 170).

Werden $100-150 \mathrm{~mm}$ lange und $10 \mathrm{~mm}$ dicke Wurzelstücke, z. B. solche von Ulmus campestris, bei Lichtabschluss in Glascylindern, die etwas Wasser enthalten, derartig aufgehängt, dass ihre morphologische Spitze nach'abwärts oder aufwärts gerichtet ist, so produciren sie stets nur an ihrer morphologischen Basis Adventivsprosse. Neue Wurzeln werden an der morphologischen Spitze der Untersuchungsobjecte seltener erzeugt; sie entstehen hier überhaupt nicht leicht. Die Sprosse bilden, wie wir gesehen haben, an ihrer morphologischen Spitze neue Triebe, die Wurzeln erzeugen hingegen Triebe an ihrer morphologischen Basis.

\section{Die Anisotropie der Pflanzenorgane.}

Die Richtung, welche die Pflanzentheile bei ihrem Wachsthum einschlagen und schliesslich beibehalten, ist keineswegs abhängig von zufälligen Umständen, sondern sie steht in bestimmter Weise in einer causalen Beziehung $\mathrm{zu}$ einer Reihe innerer sowie äusserer Wachsthumsmomente. Aus diesem Grunde ist es auch in manchen Fällen möglich, die Ursaclien wenigstens bis zu einem gewissen Grade darzulegen, weshalb ein Pflanzentheil unter gegebenen Umständen diese und keine andere Wachsthumsrichtung einschlägt, und es mögen hier einige dieser Fälle speciellere Erörterung finden.

1) Vgl. Detmer, Sitzungsberichte der Jenaischen Gesellschaft f. Naturwissenschaft und Medicin, 1884, S. 5. 
Cultivirt man Phaseoluskeimlinge in der Weise, wie es unter 172 angegeben worden ist, in einem Zinkkasten hinter Glaswand, so ist leicht zu constatiren, dass die Nebenwurzeln erster Ordnung mit der Hauptwurzel einen bestimmten Winkel, den man als geotropischen Grenzwinkel bezeichnet, bilden. Wir haben unsere Cultur im Dunkeln angestcllt, und wenn eine Anzahl von Nebenwurzeln zur Ausbildung gelangt ist, bezeichnen wir die Richtung ihrer Spitzen durch auf die Aussentläche der Glasscheibe angebrachte Tuschestriche. Jetzt setzen wir unseren Apparat bei constant bleibender Temperatur dem Einfluss des diffusen Tageslichtes aus. Die Spitzen der Nebenwurzeln verändern, wie schon nach 24 Stunden unzweifelhaft hervortritt, ihre Wachsthumsrichtung erheblich. Freilich wachsen die Wurzeln auch bei Lichtzutritt nicht senkrecht nach abwärts, aber der geotropische Grenzwinkel der ncu gebildeten Wurzeltheile ist doch ein erheblich geringerer als derjenige der im Finstern entstandenen. Das Licht ist also im Stande, das geotropische Verhalten der Wurzeln in bestimmter Weise zu beeinflussen.

Untersuchen wir im Frülijahr den Boden in der Nähe blühender Exemplare von Adoxa Moschatellina, so findet man, dass zahlreiche elfenbcinweisse Rhizome dieser Pflanze das Erdreich durchzichen. Sie wachsen horizontal im Boden fort, und es fragt sich, welche Umstände den Plagiotropismus der in Rede stehenden Organe bedingen. Wir schneiden die Enden einiger Rhizomzweige in einer Länge von mehreren Centimetern ab, stecken sie mit ihrer Basis in feuchte Erde, die sich in eincm Blumentopfe befindet, so dass ihre Spitzen gerade nach aufwärts gewandt sind, und stellen unsere Vorrichtung unter einer Glasglocke in einen dunkeln Raum. Nach Verlauf von einigen Tagen (bei meinen Versuchen nach 2-3 Tagen) ist der fortwachsende Theil der Rhizomspitzen horizontal gerichtet, und zwar ist dic cingetretene Wachsthumskrümmung, wie aus unserem Experiment sowie anderweitigen Versuchen hervorgeht, ausscllliesslich Folge einer Schwerkraftwirkung. Der Geotropismus der Rhizome von Adoxa bringt dieselben aber nicht in eine verticale, sondern, worauf das Hauptgewicht zu legen ist, in eine horizontale Stellung ${ }^{1}$ ).

Wenn wir die mit ihrer Basis in Erde gesteckten Adoxarhizome in verticaler oder besser in horizontaler Stellung einseitig beleuchten, so krümmen. sich ihre wachsenden Spitzen im Laufe einiger Tage vertical abwärts. Die Abwärtskrümmung erfolgt bald nach dieser, bald nach jener Seite hin; sie zeigt keine bestimmten Beziehungen zu dem Lichteinfall. Das Licht beeinflusst auch hier wieder das geotropische Verhalten der Organe in eigenthümlicher Art (heterogene Induction nach NoLL).

Lehrreich ist es ferner, das folgende Experiment, welches ich mit entblätterten Sprossen von Sida Napaea ausführte, anzustellen, da dasselbe lehrt, dass vorübergehend auch geotropische Nachwirkungen von Bedeutung für die Wachsthumsrichtung von Pflanzentheilen sein können (vergl. übrigens unter 173). Wir stecken das untere Ende eines Sidasprosses in den an einer Wand cines Zinkkastens zusammengehäuften feuchten Sand und überlassen das Untersuchungsobject bei etwa $20^{\circ} \mathrm{C}$. $11 / 2$ Stunden lang sich selbst in horizontaler Lage, bis eine geotropische Aufwärtskrümmung eben begonnen hat. Jetzt drehen wir den Spross um $90^{\circ}$ nach rechts oder links. Nacli ferneren $2-3$ Stunden

1) Vgl. Starl, Berichte der Deutschen botanischen Gesellschaft, Bd. 2, H. 8. 
finden wir, dass die Krümmung des Sprosses in Folge einer geotropischen Nachwirkung in horizontaler Richtung eine sehr energische geworden ist. Mit dieser Krümmung hat sich aber eine andere, nach aufwärts gerichtete, die ihr Zustandekommen einer directen Schwerkraftwirkung verdankt, combinirt, so dass der Spross schief aufwärts gewandt erscheint.

Von erheblichem Interesse ist es, die Thatsache festzustellen, dass es Pflanzentheile giebt, deren Richtung sich in Folge ihrer heliotropischen Eigenschaften von dem Stande der Sonne abhängig erweist. Wenn man im Freien wachsende Exemplare von Tragopogon orientalis zur Blüthezeit betrachtet, so findet man, dass die Blüthenstände nur am Morgen geöffnet sind. Sie schliessen sich im Laufe des Vormittags. In den Morgenstunden sind nun die Blüthenköpfchen nach Osten gewandt; sie folgen am Tage dem Laufe der Sonne über Süden nach Westen, ein Phänomen, das ich oft beobachtete, und richten sich in der Nacht gerade empor. Die Bewegung der Blïthenstände von Tragopogon wird durch den sie tragenden Stengeltheil vermittelt. Dieser ist zur Blüthezeit der Pflanze stark heliotropisch reizbar und wächst auf seiner jeweiligen Schattenseite immer stärker als auf seiner der Sonne direct zugekehrten Seite, so dass die angeführten Bewegungserscheinungen resultiren müssen ${ }^{1}$ ).

Dic radiär gebauten Pflanzentheile sind sehr allgemein orthotrop; sie wachsen gerade nach abwärts oder aufwärts. Plagiotrope Organe sind dagegen gewöhnlich dorsiventral.

Wir bedecken den Boden eines grossen Zinkkastens mit feuchtem Sand, häufen einen Theil desselben an einer der Wände des Kastens. $\mathrm{zu}$ einem Wall zusammen, in welchen wir das untere Ende der Untersuchungsobjecte hineinstecken, so dass dieselben im übrigen den Sand nicht berühren und horizontal gerichtet sind. Wir experimentiren mit Pflanzentheilen, die unter normalen Verhältnissen deutlichen Plagiotropismus erkennen lassen, denn es handelt sich gerade für uns. darum, die Ursachen desselben festzustellen, und wählen zunächst junge Stengeltheile von Pyrus Malus, Ausläufer von Potentilla reptans. oder solche von Ajuga reptans zur Beobachtung. Es müssen stets. mehrere möglichst gleichartig entwickelte Untersuchungsobjecte von $15-20 \mathrm{~cm}$ Länge sorgfältig ausgewählt werden; wir entblättern sie und bringen einige derartig in unseren Kasten, dass ihre Oberseite nach oben, andere so, dass ihre Unterseite nach oben gewandt ist. Nun bedecken wir den Kasten mit einem Deckel. Die Stengeltheile bleiben längere Zeit (z. B. 24 Stunden lang) in dem feuchten, dunkeln Raume sich selbst überlassen. Nach dieser Zeit finden wir alle Objecte aufwärts gekrümmt, diejenigen, welche mit der Unterseite nach oben horizontal gelegt worden sind, aber stärker als die übrigen, wie man noch genauer durch Feststellung der Krümmungsradien ermitteln. kann. Diese Aufwärtskrümmung ist in jedem Falle Folge des negativen Geotropismus der Stengeltheile, aber bei normaler Lage wirkt demselben die Epinastie entgegen, während das Zustandekommen einer stärkeren Wachsthumskrümmung bei verkehrter Lage der Sprosse als Folge des gleichsinnigen Zusammenwirkens von Geotropismus und Epinastie angesehen werden muss. Die Epinastie, d. h. das stärkere Wachsthum der Oberseite von Pflanzentheilen, ist nach H. DE VRIES

1) Vgl. Wiesser, Denkschrift. d. Akademie d. Wiss. in Wien, Bd. 43. 
auf innere Wachsthumsursachen zurïckzuführen, eine Anschauung, auf die wir noch zurückkommen.

Ausserordentlich stark epinastisch sind auf jeden Fall die Blüthen tragenden, unter normalen Verhältnissen horizontal gerichteten Sprosse von Atropa Belladonna. Schneidet man solche Sprosse ab und stellt sie mit ihrer Basis in Wasser, so findet man, dass die bei Beginn des Versuches vertical gerichteten Sprossenden nach Verlauf von etwa 12 Stunden, während welcher Zeit die Untersuchungsobjecte im Dunkeln verweilt haben, horizontal gerichtet sind (vgl. Fig. 171).

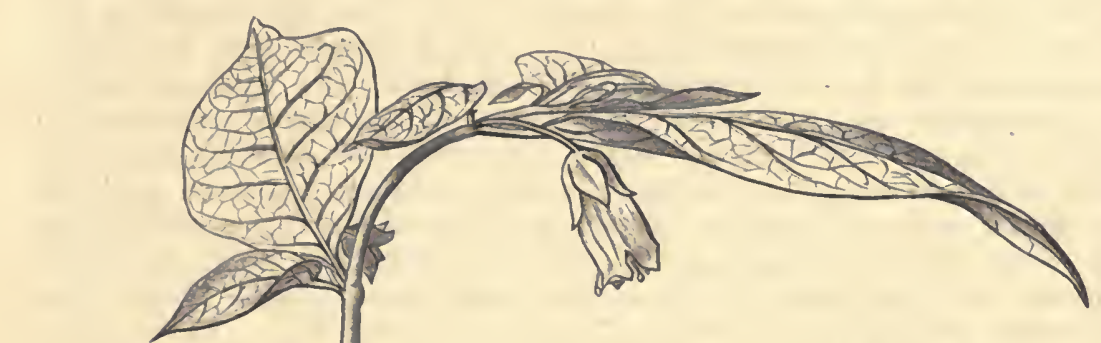

Ich habe auch jugendliche Enden plagiotropischer Sprosse von Corylus Avellana in der schon angegebenen Weise unter Benutzung des feuchten Sand enthaltenden Zinkkastens untersucht. Bei diesen häufig im Laufe des Sommers wiederholten Experimenten fand ich stets, was mit den Angaben von H. DE VRIEs nicht übereinstimmt, dass sich die entblätterten, mit der Oberseite nach oben gewandten Sprosse im Zinkkasten nach abwärts, die nit der Unterseite nach oben gewandten Sprosse aber stark nach auf-

Fig. 171. Spross ron Atropa Belladouna, dessen Gipfel sich epinastisch gekrümmt hat. wärts krümmten. Es wirken hier also starke Epinastic und schwächerer Geotropismus zusammen.

Sprosse von Corylus humilis krümmen sich bei normaler Lage nach meinen Experimenten im Zinkkasten aufwärts, bei verkehrter Lage indessen gar nicht. Aehnlich verhalten sich nach H. DE VRIEs Sprosse von Prunus avium. In diesen Fällen ist die Wachsthumsrichtung der Pflanzentheile die Resultirende aus dem Zusammenwirken von Geotropismus und Hyponastie, d. h. dem lehhafteren, auf inneren Ursachen beruhenden Wachsthum der Sprossunterseite.

Wir wollen nun ähnliche Experimente, wie wir solche mit Sprossen ausgeführt haben, auch mit Blattstielen und Blattmittelrippen anstellen. Wenn man z. B. mit wachsenden Blattstielen von Calla palustris und Petasites, mit den allgemeinen Blattstielen der gefiederten Blätter vom Sambucus nigra oder Juglans regia (stets olıne Spreiten), mit der Blattmittelrippe von Sambucus experimentirt und die Untersuchungsobjecte in normaler oder verkehrter Lage mit der Basis in den Sandwall des Zinkkastens steckt, so findet man stets, dass sie negativ geotropisch, sowie mehr oder minder stark epinastisch sind. 
Ich prüfte zumal das Verhalten von Calla und dasjenige der Blattmittelrippe von Sambucus. In normaler Lage krümmten sie sich abwärts, in verkehrter stärker aufwärts. Werden Blattstiele oder Rippen im Zinkkasten horizontal auf die Seite gelegt, so dass also ihre Medianebene horizontal liegt, dann muss der negative Geotropismus eine Aufwärtskrümmung in verticaler Ebene anstreben, die Epinastie aber eine Krümmung in horizontaler Ebene. Die thatsächlich erfolgende, resultirende Krümmung muss also in schiefer Ebene stattfinden.

Werden wachsende Blattstiele, und zwar theils nach Entfernung, theils ohne Beseitigung der Spreite, in dem Zinkkasten in horizontale Lage gebracht, wobei darauf zu achten ist, dass die Oberseite der Organe stets nach oben gewandt ist, dann krümmen sich die Stiele, denen man die Spreite belassen hat, im Falle ihre Epinastie keine $\mathrm{zu}$ bedeutende ist, gar nicht oder doch viel schwächer aufwärts als jene, welche von der Spreite befreit wurden. Die Belastungsverhältnisse sind hier also von Einfluss auf den Erfolg des Versuchs gewesen. Zahlreiche weitere Angaben über die besprochenen Erscheinungen und auch über Bestiminung der Zuwachsgrösse bei dem Zustandekommen der erwähnten Krümmungen von Spross- sowie Blatttheilen findet man in einer werthvollen Abhandlung von H. DE VRIES über unseren Gegenstand ${ }^{1}$ ).

Es ist bereits erwähnt worden, dass die Blattspreiten, Blattstiele und viele Sprosse das Vermögen besitzen, auf ihrer morphologischen Oberseite energischer als auf ihrer Unterseite zu wachsen. Dies epinastische Verhalten der erwähnten Organe besitzt grosse Bedeutung für das Zustandekommen ihrer normalen plagiotropen Orientirung, und H. DE VRIES vertritt die Ansicht, nach welcher die Epinastie Folge innerer Wachsthumsursachen sein soll. Ich bin bei Untersuchungen über die Ursachen der Epinastie der Blätter von Phaseolus multiflorus und Cucurbita $\mathrm{zu}$ anderen Resultaten gelangt ${ }^{2}$ ). Man cultivire Keimlinge von Phaseolus und Cucurbita bei völligem Lichtabschluss in Blumentöpfen. Bei etwa $20^{\circ} \mathrm{C}$. hat sich das hypocotyle Glied von Cucurbita in etwa 10 Tagen bis $\mathrm{zu}$ beträchtlicher Länge entwickelt; die Cotyledonen sind gerade aufgerichtet, sie schliessen mit ihrer Oberseite dicht zusammen. In etwa 14 Tagen ist das Epicotyl von Phaseolus bis zu bedeutender Länge herangewachsen, und die langgestielten Primordialblätter zeigen in Folge hyponastischen Wachsthums, d. h. stärkeren Wachsthums ihrer Unter- als ihrer Oberseite, ein muscheliges Aussehen. Werden die Keimpflanzen nunmehr hellem, diffusem Tageslicht ausgesetzt, so verlieren die Primordialblätter der Bohne in Folge epinastischen Wachsthums ihre muschelige Gestalt; ebenso wächst jetzt die Oberseite der Cucurbitacotyledonen lebhaft, so dass diese Organe aus ihrer ursprünglich orthotropen in eine plagiotrope Stellung übergehen. Das Licht ruft aber erst das energischere Wachstlum der Blattoberseite hervor; im Finstern kommt dasselbe nicht zu Stande. Die Epinastie ist keine spontane, sondern eine paratonische Nutationserscheinung, und wir reden fernerhin nicht mehr kurzweg von Epinastie, sondern von Photoepinastie der Blätter. Bringen wir unsere Phaseolus- oder Cucurbitakeimlinge, nachdem sie im Finstern das bezeichnete Entwickelungsstadium erreicht haben,

1) Vgl. H. DE Vries, Arbeiten d. botan. Instituts in Würzburg, Bd. 1, S. 223.

2) Vgl. Detaer, Botan. Zeitung, 1882, No. 46. 
3-5 Stunden lang in diffuses Licht, so ist noch keine photoepinastische Bewegung eingetreten. Stellen wir die Untersuchungsobjecte nun aber ins Dunkle zurück, dann breiten sich die Blätter im Laufe von 6-12 Stunden aus. Es kommt hier also eine photoepinastische Nachwirkungserscheinung zur Geltung.

Die photoepinastischen Nutationen treten stets ein, wenn die im Dunkeln erwachsenen und noch nicht zu alten Keimpflanzen beleuchtet werden, mag das Licht die Untersuchungsobjecte von oben oder in einer anderen Richtung treffen. Die Blätter suchen sich nahezu rechtwinkelig $\mathrm{zu}$ der Richtung der einfallenden Lichtstrahlen $\mathrm{zu}$ stellen, und bei den Experimenten mit Cucurbita wird man auch leicht die Thatsache constatiren, dass hier - und Aehnliches gilt ebenso für andere Fälle - ein Organ (nämlich das hypocotyle Glied) einen wesentlichen Einfluss auf die schliessliche Orientirung anderer Organe (der Cotyledonen) zum Licht geltend macht. Das stark positiv heliotropische Verhalten des hypocotylen Gliedes spielt bei dem Zustandekommen der Lichtlage der Blätter, wenn die Keimpflanzen nur von einer Seite aus beleuchtet werden, eine wesentliche Rolle.

Werden wachsende Blätter aus ihrer normalen Lage in abnorme Stellung zum Licht gebracht, so haben sie das Bestreben, wieder in jene erstere zurückzukehren. Ich habe zur Feststellung dieser Thatsache eine Reihe von Experimenten angestellt, und es ist lehrreich, dieselben zu wiederholen. Man cultivirt einige Exemplare von Cucurbita in Blumentöpfen. Haben die Pflanzen mehrere Blätter gebildet, so beginnen die Versuche. Einige Blätter werden derartig aufgerichtet, dass ihr Blattstiel vertical gestellt ist und die Spitze der Spreiten nach oben weist. Die Blätter werden an kleinen Stäben durch Anbinden befestigt, und zwar bringt man die Fäden dicht unter den Spreiten am Ende der Stiele an. Stellt man die Pflanzen bei einseitiger Beleuchtung derartig auf, dass die Unterseiten der befestigten Blätter dem Licht zugewandt sind, so werden die Spreiten in Folge photoepinastischer Bewegungen alsbald wieder eine normale Stellung zum Licht erreicht haben. Ertheilt man einem Blumentopf, in welchem sich Cucurbitapflanzen entwickeln, bei einseitiger Beleuchtung eine derartige Lage, dass die nicht festgebundenen Blattstiele ebenso wie die mit ihrer Unterseite dem Licht zugekehrten Blattspreiten eine verticale Stellung einnehmen, dann führen die Organe heliotropische und photoepinastische Bewegungen aus, um wieder in die normale Lichtlage zurückzukehren. Bringen wir Cucurbitapflanzen, die sich unter normalen Verlıältnissen entwickelt haben, ins Dunkle und sorgen wir dafür, dass einige ihrer Blätter (Stiel und Spreite derselben) vertical gerichtet sind, so führen die Spreiten photoepinastische Nachwirkungsbewegungen aus, bis sie eine horizontale Stellung erreicht haben.

Von besonderem Interesse mit Rücksicht auf die Fragen, welche sich auf die natürliche Richtung der Pflanzentheile und deren Anisotropie beziehen, ist es, einige Beobachtungen und Experimente über das Wachsthum der Sprosse von Hedera Helix anzustellen. Die Epheusprosse sind, abgesehen von dem erst in einem höheren Alter der Pflanzen zur Entwickelung kommenden und orthotropen Fruchtsprosse, ausgeprägt dorsiventral und plagiotrop. Werden frei schwebende Epheusprosse von etwa $30 \mathrm{~cm}$ Länge abgeschnitten, in Töpfe eingepflanzt und nach Verlauf von $6-8$ Wochen, wenn sie kräftig angewurzelt sind, an einem verticalen Stabe festgebunden, so kann 
man an dem über das Stabende hervorragenden Gipfel der Sprosse unter geeigneten Umständen interessante Erscheinungen wahrnchmen.

Als ich die Epheupflanzen, die in der soeben angegebenen Weise vorbereitet waren, im August vor das Fenster eines nach Norden gelegenen Zimmers stellte, zeigte sich, dass die Sprossenden sich als-

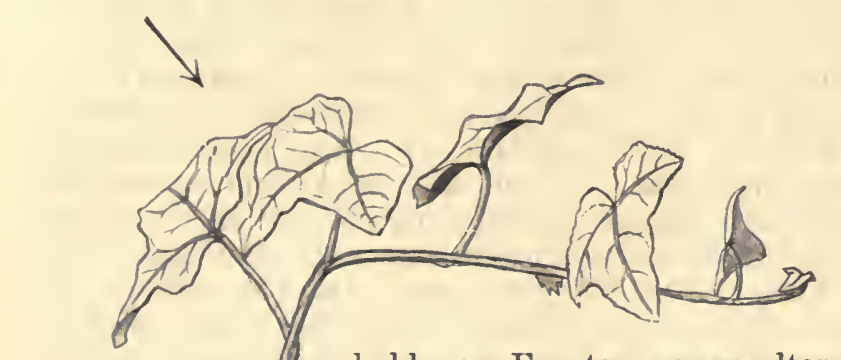

Fig. 172. Spross ron Hedera Helix, dessen Gipfel sich bei einseitiger $\mathrm{Be}$ leuchtung von den einfallenden Lichtstrahlen weggekrümmt hat.

bald vom Fenster wegwandten. Die Gipfelenden wuchsen in horizontaler Richtung in das Zimmer hinein und besassen nach Verlauf von 4 Wochen das in Fig. 172 dargestellte Aussehen. Die Sprosse führten negativ heliotropische und photoepinastische Krümınungen aus (über den Modus der Lichteinwirkung sind übrigens noch weitere Untersuchungen anzustellen). Die Lichtseite der Sprosse musste in Folge dessen convex werden und eine Horizontalstellung der Sprossenden herbeiführen. War diese erreicht, so krümmten sich die Sprossenden nicht noch weiter nach abwärts, weil jetzt der negative Geotropismus (die geotropischen Eigenschaften der Epheusprosse sind von Sachs speciell constatirt) sein Recht energisch geltend machen konnte. Es ergiebt sich, dass die Horizontalstellung der Epheusprosse also eine Resultirende aus der richtenden Wirkung des Lichtes einerund der Schwerkraft andererseits ist (?). Dieselben Momente sind auch maassgebend für die Richtung, welche die Sprosse der in der freien Natur wachsenden Epheupflanzen einschlagen.

Im Vorstehenden sind zunächst nur gewisse Eigenschaften der Blattheile und mancher Sprosse festgestellt worden. Man hat nun versucht, die normale Stellung der Blätter und Sprosse unter Berücksichtigung dieser Eigenschaften zu erklären. Man fasste die normale Stellung der Organe vielfach als eine aus dem Zusammenwirken verschiedener Kräfte hervorgehende auf. Die so häufig rechtwinkelige Stellung der Blattspreiten soll danach z. B. wesentlich durch das Zusammenwirken der Photoepinastie einer- und des negativ geotropischen Verhaltens der Organe andererseits zu Stande kommen.

In der That ist sicher, dass die normale Stellung von Blattstielen und auch gewiss vieler Sprosse in der angedeuteten Weise erklärt werden kann. Aber gerade mit Bezug auf die Blattspreiten lässt uns der bezeichnete IVeg im Stich. Vöchting, Schwendener und 
Andere wiesen nach, dass weder geotropische Bewegungen der Spreiten, noch Belastungsverhältuisse bei dem Zustandekommen ihrer fixen Lichtlage direct und nothwendig betheiligt sein müssen. Vielmehr ist das Licht selbst hier als maassgebender Factor $\mathrm{zu}$ betrachten, wie auch ich jetzt annehme ${ }^{1}$ ). Die Bewegungen, welche von den Spreiten zur Erreichung der günstigsten Lichtlage ausgefülırt werden (dieselbe ist meist eine solche, dass sich die Spreiten senkrecht zu den einfallenden Lichtstralılen stellen), vollziehen sich auf dem kürzesten Wege mit Ueberwindung der geringsten Schwierigkeiten. Diese durch das Licht ausgelösten Bewegungen sind aber von sehr verschiedener Natur (photoepinastische Nutationen, Torsionen) und bedingt durch die ursprüngliche Stellung der Blätter selbst. Bei .dem Zustandekommen der Orientirungsbewegungen der Blattspreiten braucht der Geotropismus, wie gezeigt werden soll, keine Rolle zu spielen. Ihre geotropische Reizbarkeit, die nach den bereits angeführten Experimenten aber doch unter bestimmten Umständen (im Dunkeln) vorhanden ist, kann sogar wahrscheinlich durch Lichtwirkung aufgehoben werden.

Dass die Photoepinastie bei dem Zustandekommen der normalen Lichtlage der Blattspreiten betheiligt ist, ist schon nach den oben angeführten Experimenten mit Phaseolus- und Cucurbitaptlanzen klar, denn dieselbe bringt ja z. B. das Ausbreiten der bei vielen Pflanzen im Dunkeln muschelig eingerollten Blätter bei Lichtzutritt hervor.

Kieimlinge von Cucurbita, die sich so lange im Dunkeln entwickelt haben, bis ihr Hypocotyl ziemlich gestreckt ist und die Cotyledonen aufgerichtet sind, werden in einen mit mattschwarzem Papier ausgeklebten Kasten gestellt, dessen Rückwand ziemlich hoch, dessen vordere Wand aber niedrig ist, so dass der Deckel des Kastens durch eine in einem Winkel von etwa $45^{\circ}$ geneigte Glasplatte gebildet werden kann. Das Hypocotyl der Keimlinge wird, um das Auftreten heliotropischer Nutationen an demselben $\mathrm{zu}$ verhindern, durch Festbinden an einem Stab fixirt, welcher in der Erde des Culturgefässes steckt. Man stellt die Pflanzen nun derartig im Kasten auf, dass die breiten Flächen der Cotyledonen dem Fenster, vor welchem der Apparat Platz fand, zugewandt sind. Beide Cotyledonen haben sich nach Verlauf einiger Zeit senkrecht zu den einfallenden Lichtstrahlen gestellt. Das vordere Keimblatt muss dazu einen Kreisbogen von $135^{\circ}$ nach abwärts beschreiben, das hintere aber nur einen solchen von $45^{\circ}$ nach rückwärts. Wollte man die Entstehung der Orientirungsbewegungen der Cotyledonen unter Zuhülfenahme der Schwerkraftwirkung (und anderer Kräfte) erklären, so müsste man die doch gewiss nicht zutreffende Annalime machen, dass die geotropische Reizbarkeit der beiden Keimblätter einer Pflanze eine verschiedene sei. Besonders eignen sich aber die folgenden Experimente dazu, den Nachweis zu führen, dass die Lichtstellung der Blattspreiten lediglich durch die Lichtwirkung erzielt werden kann.

1) Literatur: Frank, Die natürliche wagerechte Stellung der Pflanzentheile, Leipzig 1870 ; C. Darwix, The Potrer of Movement in Plants, London 1880; F. Darwix, Extr. f. the Linnean Society's Journal, Botany, Vol. 18 (Dec. 1880); Schmmo, Dissertation, Berlin 1S83; NolL, Arbeiten des botan. Instituts in Würzburg, Bd. 3; KrabBe, Pringsmeny's Jahrbücher, Bd. 20; Vöchting, Botanische Zeitung, 18s8; NoLs, Ueber heterogene Induction, Leipzig 1892; ScHWENDENER und KRaBbE, Abhandl. d. Königl. preuss. Akad. d. Wiss., Berlin 1892; Noll, Die Orientirungsbewegungen dorsiventraler Organe, München 1892. 
Wir cultiviren Keimpflanzen von Phaseolus in Blumentöpfen. Die Objecte sind zur Untersuchung geeignet, wenn die Primordialblätter sich entfaltet haben, sich aber noch in sehr lebhaftem Wachsthum befinden. Beleuchten wir die Pflanzen von oben, dann zeigen die Blätter die in Fig. 173 dargestellte Stellung. Lässt man nun das Licht nicht senkrecht von oben, sondern horizontal und zwar annähernd senkrecht zur Insertionsebene der Blätter einfallen, so tritt im Polster der Blattstiele sowie der Spreiten eine Torsion von nahezu $90^{\circ}$ ein. Die Spreiten stehen dann abermals rechtwinkelig zu den einfallenden Lichtstrahlen (vergl. Fig. 175). Jetzt werden Pflanzen mit der Blattstellung von Fig. 173 langsam gedreht, so dass ihre Sprossaxen eine senkrecht stehende Kreisfläche beschreiben, während das Licht ziemlich senkrecht zur Insertionsebene der Blätter einfällt. Die Schwerkraftwirkung ist aufgehoben, und die sich nunmehr

Fig. 173.

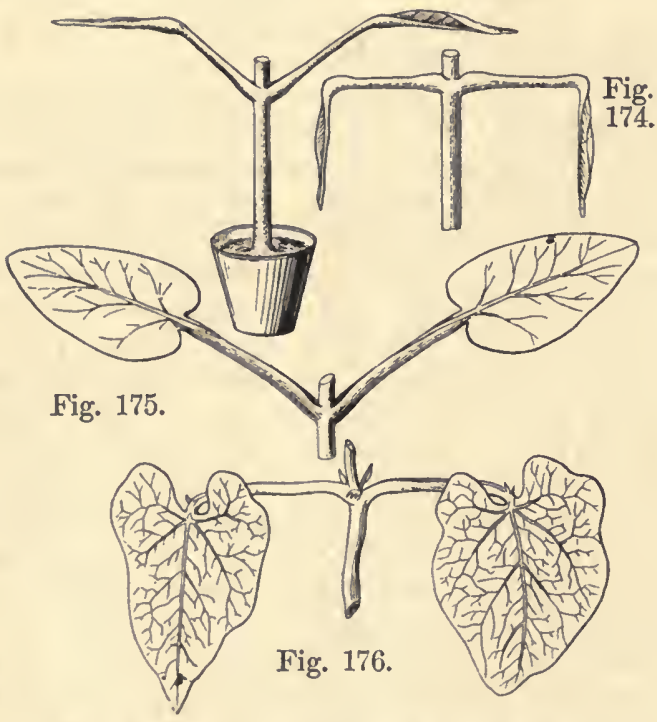

Fig. 173-176. Junge Phaseoluspflanzen. (Nach SCHWENDENER.) ungehindert geltend machende Epinastie der Polster der Blattstiele sowie Spreiten führt zunächst. dahin, dass die Blätter die in Fig. 174 wiedergegebene Stellung annehmen. Dann aber macht sich nach kurzer Zeit im Spreitenpolster und auch eventuell im Blattstiel eine Krümmung (keine Torsion) geltend, wodurch die Lamina schräg nach vorn dem Licht zugewandt wird (vergl. Fig. 176). Wir sehen also, dass die Blätter auch bei völligem Ausschluss der Schwerkraftwirkung eine fixe Lichtlage gewinnen können. Bei dem Zustandekommen derselben sind, was besonders $\mathrm{zu}$ betonen ist,

Torsionen ausgeschlossen.

Diese letzteren spielen aber, wie wir gesehen haben, unter anderen Umständen bei den Orientirungsbewegungen der Blätter zu den einfallenden Lichtstrahlen eine wichtige Rolle.

\section{Allgemeines über die Festigung der Pflanzenorgane.}

Die Pflanzen bedürfen ebenso wie die Thiere bestimmter Einrichtungen, um gewissen äusseren Einwirkungen gegenüber widerstehen und ihre Gestaltungen bewahren zu können. In manchen Fällen spielen Turgor- und Gewebespannung eine wichtige Rolle als Mittel zur Festigung des Organismus, aber durch die Untersuchungen ScHweNDENER's ${ }^{1}$ ) wurde ferner noch der Nachweis geliefert, dass den

1) Vgl. Schwendener, Das mechanische Princip im anatomischen Bau der Monocotylen, Leipzig 1874. 
Pflanzen ein mehr oder minder zusammenhängendes mechanisches System (Stereom) eigenthümlich ist, dem in vieler Hinsicht ganz ähnliche Functionen wie dem Knochengerüst der höheren Thiere zukommt.

Als Elementarorgane (Stereiden) des mechanischen Systems kommen vor allem die Sklerenchymfasern im Grundgewebe, die echten Bastfasern, die Collenehymfasern und die Libriformfasern in Betracht. Die Sklerenchymzellen und die echten Bastfasern sind lang gestreckte Elemente, deren oft verholzte Membranen stark verdickt erscheinen (vgl. Fig. 177). Ilınen in vieler Hinsicht ähnlich sind die Libriformfasern des Holzes, deren stark verdickte Wandung häufig mit spaltenförmigen Tüpfeln versehen ist. Sehr reich an Libriformfasern ist" $z$. B. das secundäre Holz von Tilia. Als mechanisches Gewebe vieler jugendlicher, noch im Wachsthum begriffener Pflanzentheile ist endlich das Collenchym anzusehen. Die Elemente desselben sind leicht an der charakteristischen Form ihrer Wandverdickung kenntlich, denn diese letztere ist der Hauptsache nach nur auf die Kanten der Zellen beschränkt (vgl. Fig. 178).

Fig. 178 .
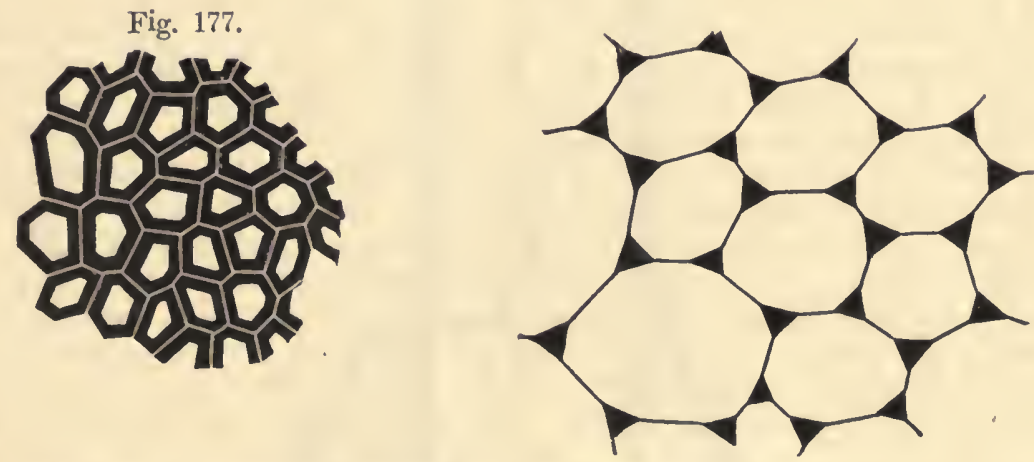

Fig. 177. Sklerenchymgewebe im Querselmitt.

Fig. 178. Collenchymgewebe im Quersehnitt.

Zur Erzielung von Biegungs-, Zug - und Druckfestigkeit der Pflanzenorgane genügt nun aber keineswegs das Vorhandensein von Stereiden überhaupt, sondern dieselben müssen zugleich eine ganz bestimmte Anordnung im übrigen Gewebe besitzen.

Bei Herstellung allseitig biegungsfester Constructionen (zumal der Stengel) genügt es, wenn die mechanischen Elemente rings im Umkreis des Querschnittes, also peripherisch, angeordnet sind. Die Füllung zwischen den Gurtungen wird von Parenchym und anderem Gewebe gebildet. Bei vielen Organen, zumal den Blättern, die keiner allseitigen Biegungsfestigkeit bedürfen, ist das mechanische Gewebe nur auf der Ober- und Unterseite vertheilt. Zugfeste Constructionen werden im Pflanzenreiche dadurch erzielt, dass die mechanischen Elemente in den betreffenden Organen nicht peripherisch, sondern im Gegentheil central und zu einer einzigen compacten Masse verbunden angeordnet sind (Wurzeln, Rhizome). Bei Herstellung druckfester Constructionen ist es nicht gleichgültig, ob dieselben auf einen longi- 
tudinalen Druck oder auf einen radialen Druck in Anspruch genommen werden. Einem radialen Druck sind ausser einem erheblichen Zuge namentlich die sich im Boden entwickelnden Wurzeln und Rhizome

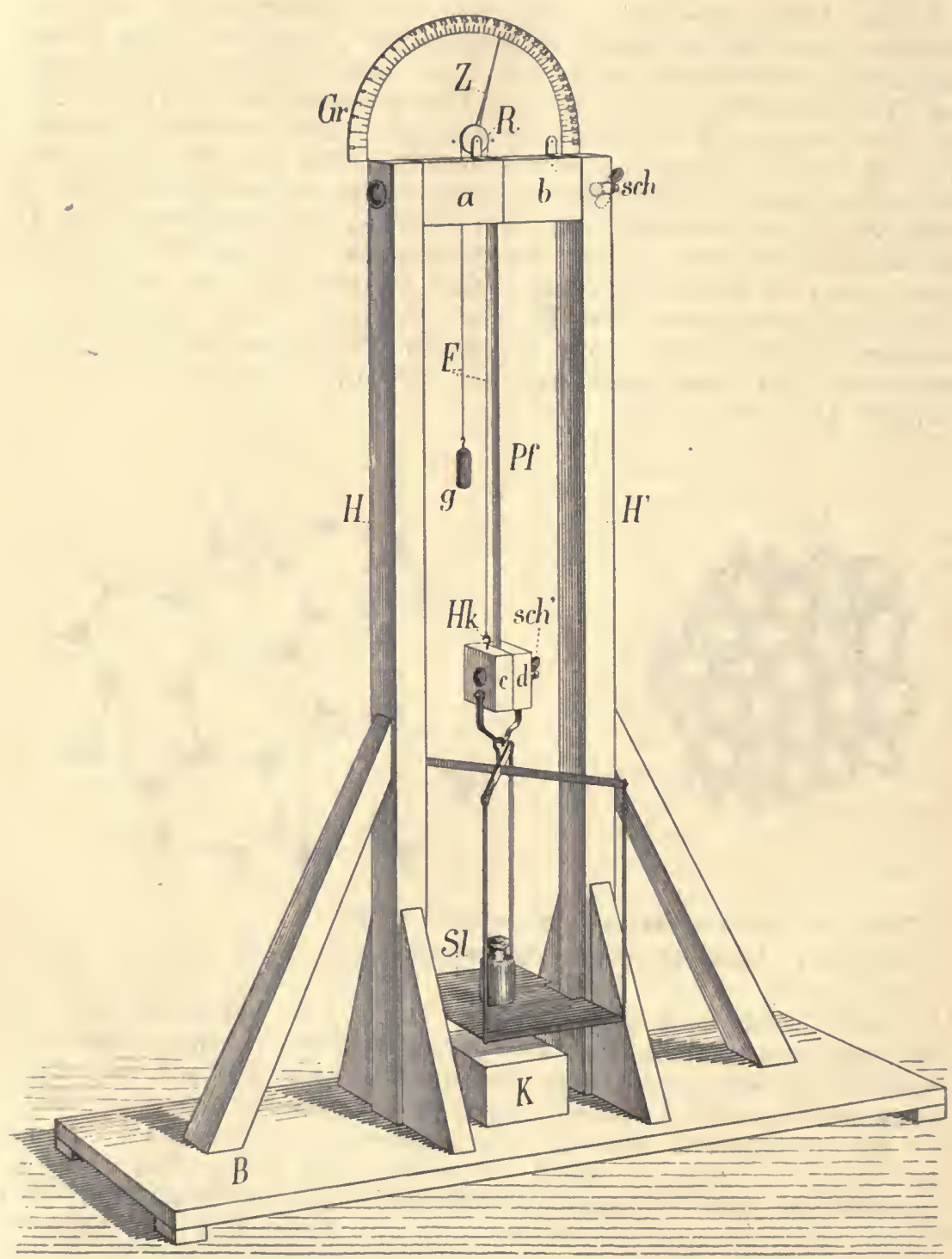

Fig. 179. Apparat zur Bestimmung der Dehnbarkeit, Elasticität und Festigkeit ron Pflanzengeweben.

ausgesetzt; sie sind daher häufig, abgesehen von anderweitigem Stereom, mit einem peripherisch gelegenen Mantel mechanischen Gewebes ausgestattet. 
Für die richtige Beurtheilung der Leistungsfähigkeit der mechanischen Gewebe im pflanzlichen Organismus ist es von Wichtigkeit, sich genauer ïber die Festigkeit, das Tragvermögen ${ }^{1}$ ) und die Elasticitåtsverhältnisse des Stereoms zu unterrichten; es kann dies mittelst des in Fig. 179 abgebildeten Apparates geschehen, den ich kürzlich construiren liess. Derselbe ist in allen seinen Theilen sehr solide construirt. Er besteht aus einem Brett $B$, auf dem die beiden Holzsäulen $H$ und $H^{\prime}$ von ca. $86 \mathrm{~cm}$ Höhe befestigt sind. Der Zwischenraum zwischen den Säulen beträgt $14 \mathrm{~cm}$. Der zu untersuchende Pflanzentheil von ca. $300-400 \mathrm{~mm}$ Länge wird mit seinem oberen Ende zwischen die Holzklötze $a$ und $b$, mit seinem unteren Ende aber zwischen die Holzklötze $c$ und d durch Anziehen der Schrauben sch und sch eingeklemmt. Die Schale SI, welche an $c$ und $d$ hängt, dient zur Aufnahme von Gewichten, um das Untersuchungsobject $\mathrm{zu}$ dehnen resp. zu zerreissen. An dem Häkchen $H k$ des Holzklotzes $c$ ist ein Seidenfaden $F$ befestigt, der durch eine Bohrung, welche die Berührungsflächen der Klötze $a$ und $b$ in sich aufnimmt und durch diese halbirt wird, über die leicht bewegliche Rolle $R$ und durch eine Bohrung in $a$ geführt ist. An seinem Ende trägt der Faden $F$ das spannende Gewicht $g$. Die Rolle $R$ trägt den Zeiger $Z$, der die 10-fache Länge des Radius der Rolle besitzt. $Z$ spielt vor dem in Millimeter eingetheilten Gradbogen $G r$. Die in Folge der Belastung eingetretene Ausdehnung des zu untersuchenden Pflanzentheils kann also verzehnfacht am Gradbogen abgelesen werden. Beim Gebrauch des Apparates sind dicht unter die Schale $S l$ Holzklötze $K$ zu stellen, damit die Fallhöhe der belasteten Schale beim Zerreissen des Pflanzentheils eine nur geringe ist.

Zur Beobachtung verwendet man zunächst $\mathrm{zweckmässig,} \mathrm{wie} \mathrm{ich}$ es auch gethan habe, einen etwa $400 \mathrm{~mm}$ langen und $2 \mathrm{~mm}$ breiten Riemen aus dem mittleren Theile des Blattes von Phormium tenax. Auch lange Internodien aus Roggenhalmen sind geeignete Untersuchungsobjecte. Man spannt aber nicht die ganzen Internodien in den Apparat ein, sondern Riemen, die man durch Zerspalten des Materials in vier Theile erhalten hat.

Ist ein solcher Riemen in den beschriebenen Apparat eingespannt worden, so dehnt man ihn durch $1 \mathrm{~kg}$ Belastung, ermittelt die Grösse der eingetretenen Dehnung und entfernt das Gewicht wieder. Nimmt der Pflanzentheil jetzt seine ursprüngliche Länge aufs Neue an, so war durch die Dehnung seine Elasticitätsgrenze noch nicht überschritten. Man wiederholt den Versuch nun mit 2,3--10 kg Belastung, bis der Riemen endlich bei einer gewissen Belastung zerreisst. Experimentirt man mit Gewebestreifen, die, wie diejenigen aus dem Phormiumblatt, Bastfasern oder Sklerenchymfasern als mechanisches Gewebe enthalten, so wird man finden, dass sie selbst bei hoher Belastung noch fast vollkommen elastisch bleiben, während collenchymreiche Pflanzentheile, obgleich sie auch eine bedeutende Festigkeit besitzen, nur sehr unvollkommen elastisch sind, sich also in Folge einer Dehnung bleibend verlängern. Zur genaueren Bestimmung der Festigkeit eines Gewebestreifens muss man dieselbe auf 1 qmm Stereom-

1) Die auf die Flächeneinheit des Querschnittes bezogene maximale Belastung, bei welcher die Elasticitätsgrenze noch nicht überschritten ist, repräsentirt das Tragmodul. Das Festigkeitsmodul stellt dann jene Belastung für die Flächeneinheit dar, bei welcher das Zerreissen erfolgt.

Detmer, Pflanzenphysiologisches Praktikum, 2. Auf. 
fläche berechnen. Wenn z. B. bei 30-facher Vergrösserung ${ }^{1}$ ) das mechanische Gewebe eines Phormiumblattquerschnittes einen Flächenraum von 900 qum einnimmt, so ist die thatsächliche Querschnittfläche des Stereoms $=1 \mathrm{qmm}$. Reisst der Phormiumriemen bei $15 \mathrm{~kg} \mathrm{Be-}$ lastung durch, dann wäre das Festigkeitsmodul von 1 qmm Phormiumstereom $=15 \mathrm{zu}$ setzen. Es hat übrigens häufig ganz bedeutende Schwierigkeiten, die wirkliche Querschnittfläche des Stereoms auch nur einigermaassen genau zu ermitteln. In vielen Fällen ist man hier auf ungefähre Schätzungen angewiesen ${ }^{2}$ ).

Am besten gelangt man noch zum Ziel, wenn man zarte Schnitte aus dem Untersuchungsobject, die der schwächsten Stelle desselben zu entnehmen sind, also z. B. derjenigen, an welcher das Zerreissen durch die Belastung erfolgte, bei schwacher (etwa 30-facher) Vergrösserung mit Hülfe des Zeichenapparates skizzirt, um sodann die Querschnittfläche der mechanischen Elemente mittelst des Polarplanimeters (zu beziehen nebst Gebrauchsanweisung von J. KERN in Aarau, Schweiz, für $45 \mathrm{Mk}$.) oder mittelst Millimeterpapier (durchscheinendes Pause-Skizzirpapier ist zu beziehen von Schleicher und Schüll in Düren, Rheinpreussen; Preis von 25 Bogen $12 \mathrm{Mk}$.) auf der Skizze zu messen. Wenn erforderlich, ist das Verhältniss des Lumens zur Wanddicke zu berücksichtigen. Feste Xylemstränge werden bei der Messung mit in Rechnung gestellt.

In vielen Fällen, namentlich bei Prüfung der Festigkeitsverhältnisse des Collenchyms, empfiehlt es sich, folgendes Verfahren zur Bestimmung der Querschnittfläche des mechanischen Gewebes einzuhalten. Man zeichnet bei stärkerer Vergrösserung das getreue Bild einer grösseren Anzahl Collenchymzellen auf gutes Schreibpapier, von dem man annehmen kann, dass es an allen Stellen nahezu die nämliche Dicke besitzt. Man bestimmt nun das Gewicht des Papierstückes, welches von der Zeichnung bedeckt wird, entfernt die Zelllumina mittelst eines Messers und wiegt das übrig bleibende Netz wieder. Das Verhältniss der beiden Gewichte ergiebt dann das Verhältniss des Gesammtquerschnittes zu demjenigen der Zellwandung. Skizzirt man nun bei schwacher Vergrösserung den Gesammtumriss der Collenchymstränge eines Querschnittes des Untersuchungsobjectes und bestimmt die Querschnittfäche desselben, so kann man den Gesammtquerschnitt der Wandsubstanz des mechanischen Gewebes leicht ermitteln. Gute Untersuchungsobjecte bei Versuchen über die Festigkeitsverhältnisse des Collenchyms sind z. B. Streifen aus den Stengeln von Levisticum officinale und Foeniculum officinale.

\section{Die Anordnung des mechanischen Gewebes in biegungs-, zug- und druckfesten Pflanzentheilen.}

Es soll hier eine Reihe von Objecten, die ich der Mehrzahl nach selbst untersuchte, aufgeführt werden, welche sich für das Studium

1) Um die Vergrōsserung, mit der man arbcitet, genau zu bestimmen, zeichnet man die Striche eines in $0,01 \mathrm{~mm}$ getheilten Objectivmikrometers unter Benutzung der Camera lucida auf das Papier des Zeichenpultes auf. Wir messen nun die Entfernung der gezeichneten Striche mittelst eines Millimetermaassstabes und gelangen so zu einem Werth, aus dem sich dic Stärke der Vergrösserung direct ableiten lässt.

2) Weitere Literatur: AMbrowx in Pringsheim's Jahrbūchern, Bd. 12; HaberLavdt, Physiol. Pflanzenanatomie, Leipzig 1884, S. 96; Tschirch in Pringsheim's Jahrbüchern, Bd. 16; LUkAs, Sitzungsberichte d. Akad. d. Wiss. zu Wien, Bd. 85; SonvtaG, Landwirthschl. Jahrbücher, Bd. 21. 
der Anordnung des Stereoms gut eignen. Mall braucht dazu nur Querschnitte der Pflanzentheile mikroskopischer Beobachtung zu unterziehen, und wir beginnen mit biegungsfest gebauten Organen.

In Blattstiel von Begonia wird das mechanische Gewebe von einem direct unter der Epidermis gelegenen mächtigen Collenchymring gebildet. Derselbe umgiebt Parenchymgewebe, in welchem die Gefässbündel vertheilt sind. Im Stengel von Lamium album verlaufen in den vier Kianten Collenchymgurtungen, die zwei kreuzweise combinirte Träger bilden. Der Querschnitt des Stengels von Falcaria rivini lässt ein grosses Mark, den Gefässbündelkreis und unter der Epilermis Collenchymstränge als mechanisches Gewebe erkennen, welches mit Assimilationsparenchym wechselt.

In den Blüthenschäften von Papaver, Armeria maritima, Lychnis viscosa und Anthericum ramosum ist das mechanische Gewebe in Form eines geschlossenen Sklerenchymrings vorhanden. Zwischen diesem und der Epidermis befindet sich grünes Gewebe, wälırend im Innern die Gefässbündel ihren Platz haben. Bei mikroskopischer Untersuchung eines Querschnitts aus dem Halm von Juncus glaucus erblickt man unter der Epidermis grünes Gewebe und Sklerenchymbündel, welche mit jenem abwechseln. Ferner sicht man weite Luftkanäle und zahlreiche Grefässbündel mit einigen ziemlich weiten Gefässen, die auf ihrer Innen- sowic Aussenseite mit einem Bastfaserbeleg versehen sind, in Grundgewebe vertheilt. Das Bild, das man bei dem Studium eines Querschnittes aus dem Halm von Sesleria coerulea erblickt, ist leicht zu deuten, und vor allem interessiren uns hier die Bastbelege der Gefässbündel, weil sie als mechanisches Gewebe dienen. Im $\mathrm{Halm}$ von Molinia coerulea ist ein geschlossener Ring mechanischen Gewebes vorhanden, der noch durch subepidermale Rippen, die an ihn anschliessen, verstärkt wird. Die Gefässbündel sind jenem Ringe theils eingebettet, theils werden sie von demselben umgeben. Aehnlich ist auch der Halm des Roggens gebaut.

Von Interesse ist es auch, das mechanische Gewebe der Blattscheiden der Gräser kennen zu lernen. Diese röhrenförmigen Scheiden umfassen die Stengeltheile des Halmes, und es kommt ihnen zumal die Aufgabe zu, die zarten, wachsenden Stengelregionen, welche bekanntlich bei den Gräsern an der Basis der Internodien liegen, zu schützen. Wir stellen z. B. feine Querschnitte aus dem dicht über einem jungen Knoten liegenden Theile eines Roggenhalmes her. Unter der Epidermis der Innenseite der Blattscheide erblicken wir chlorophyllfreies, unter der Epidermis der Aussenseite aber chlorophyllhaltiges Gewebe. Die Gefässbündel sind leicht $\mathrm{zu}$ erkennen; sie sind auf ihrer Aussen- sowie Innenseite mit mächtig entwickelten Bastfaserbelegen versehen.

Wollen wir die Anordnung des mechanischen Gewebes in nicht allseitig biegungsfest gebauten Organen kennen lernen, so stellen wir z. B. Querschnitte durch das Blatt von Phormium tenax und durch die Mittelrippe völlig ausgewachsener Blätter von Zea Mays her. Das Phormiumblatt ist in seinem oberen und unteren Theile nicht völlig gleichartig gebaut, aber auf jeden Fall werden die die Gefässbündel bedeckenden Stereombündel an der Blattober- und Blattunterseite uns sofort in dic Augen fallen. Bei Zea sind an der Blattoberseite subepidermale Sklerenclymmassen vorhanden; das mechanische Ge- 
webe der Blattunterseite steht in genauer Beziehung zur Gruppirung der grösseren Gefässbündel.

Zug- sowie druckfest sind, wie früher schon bemerkt, zumal Rhizome und Wurzeln gebaut. Wir stellen einen Querschnitt durch das Rhizon von Carex glauca her. Der freilich nicht sehr mächtig entwickelte peripherische Sklerenchymring gewährt Schutz gegen radialen Druck. Der central gelegene, aus dickwandigen Elementen bestehende Hohlcylinder, in welchen die meisten Gefässbündel eingestreut sind (einige Gefässbündel liegen auch ausserhalb dieses Cylinders), dient zur Herstellung der Zugfestigkeit des Organs. Einer ganz ähnlichen Anordnung der mechanischen Gewebe begegnet man bei der Untersuchung des Querschnitts aus den Nebenwurzeln erster Ordnung von Zea Mays. Der peripherische Sklerenchymring ist hier nur viel mächtiger als im Carexrlizom entwickelt ${ }^{1}$ ).

Es sei noch beinerkt, dass sich in allen Fällen, welche ich untersuchte, die Sklerenchymfasern und Bastfasern des mechanischen Gewebes bei Behandlung der Schnitte mit Phloroglucin und Salzsäure (vgl. unter 42) roth färbten, also verholzt gewesen sein mussten.

\section{Die Correlationserscheinungen im Pflanzenreich.}

Das Wachsthum eines Pflanzentheils übt häufig einen bestimmten Einfluss auf dasjenige anderer Theile desselben Individuums aus. Man hat in neuerer'Zeit damit begonnen, den Thatsachen, welche sich auf Correlationen im Pflanzenreich beziehen, eine besondere Aufmerksamkeit zu widmen, und wir wollen uns hier mit einigen dieser Thatsachen bekannt machen.

Wenn man junge Fichten (Abies excelsa) ihres Gipfeltriebes beraubt, so ergiebt sich, dass sich im Laufe von 1-3 Jahren einer oder mehrere der horizontal abstehenden Seitensprosse des obersten Quirls erheben. Einer der Seitensprosse gewinnt gewöhnlich die Oberhand; er ersetzt dann den entfernten Gipfeltrieb vollständig. Dies zeigt sich nicht allein in seinem orthotropen Wuchs, sondern auch in der Form seiner Verzweigung. Ein horizontaler Seitenspross der Fichte verzweigt sich vorwiegend in horizontaler Richtung nach rechts und links, während ein normaler Gipfeltrieb oder ein diesen ersetzender aufgerichteter Seitenspross der Fichte vier- oder fünstrahlige Astquirle bildet. Die Versuche, welche ich anstellte, un die hier besprochene Correlationserscheinung kennen zu lernen, wurden mit im Walde wachsenden, etwa mannsholien Fichten ausgeführt ${ }^{2}$ ).

Wenn man Kartoffelknollen in einem dunkeln Raum derartig aufstellt, dass ihr Nabelende nach abwärts gewandt ist (die Knollen brauchen nicht in Erde gelegt zu werden, und man braucht ihnen auch kein Wasser zuzuführen), so findet man, dass nach kürzerer oder längerer Zeit fast nur solche Knospen austreiben, die nahe der morphologischen Spitze der Knollen stehen. Entfernt man nun aber bei einigen Untersuchungsobjecten die sich an ihrer Spitze entwickelnden Sprosse in dem Maasse, wie sie entstehen, so ergiebt sich, dass

\footnotetext{
2) Vgl. SAcus, Vorlesungen über Pflanzenphysiologie, 1882, S. 612.
} Werk.

1) Man vergl. auch die unter 195 citirten Schriften, zumal.Schwexdexer's 
diese Operation das Austreiben tiefer stehender Augen bedingt, deren Knospen nicht oder nur in unbedeutendem Grade zur Ausbildung gelangt wären, wenn man die Sprosse an der Spitze nicht abgebrochen hätte.

Eine weitere Correlationserscheinung kann man an Keimlingen von Phaseolus multiflorus leicht constatiren. Wenn man dieselben in lockerer Gartenerde cultivirt und das Epicotyl, nachlem es einige cm lang geworden ist, dicht über dem Borlen absclmeidet, so entwickeln sich statt des entfernten Stengeltheils die in den Achseln der Cotyledonen vorhandenen Knospen zu Sprossen, welche bald aus dem Boden hervortreten.

Es ist eine bekannte Thatsache, dass sich die Stiele der Blüthenknospen fast aller Arten der Gattung Papaver in einem gewissen Entwickelungsstadium nach abwärts krümmen, eine Erscheinung, die, soweit die Untersuchungen reichen, auf Correlation berulit. Die mit ihrem Stiel in organischer Verbindung befindliche Knospe übt auf denselben einen bestimmten Einfluss aus, welcher dahin führt, dass er sich stark krümmt und nach abwärts biegt. Der Beweis für das Gesagte liegt in dem Resultat des folgenden, zuerst von VöcHiring ${ }^{1}$ ) ausgeführten Experiments, das ich mit gutem Erfolg unter Benutzung einer im Freien wachsenden Mohnpflanze wiederholte. Man schneidet einige Knospen von ihren Stielen ab und überlässt die letzteren nun ohne weiteres sich selbst oder befestigt in anderen Fällen die Knospen mit Hülfe feiner Seidenfäden wieder an ilıren Stielen. Die Krümmung der Stiele verschwindet stets nach Verlauf einiger Zeit, und unser Versuch lehrt, dass ihr Vorhandensein keineswegs einfach Folge des Knospengewichts ist, sondern auf Correlation beruht.

In lohem Grade lehrreich ist es, mit Rücksicht auf den uns hier interessirenden Gegenstand die Eigenthüınlichkeiten und das Verhalten der Knospenschuppen verschiedener Ptlanzen genauer ins Auge zu fassen ${ }^{2}$ ). Bei Aesculus und Pavia sind die äusseren Schuppen der Winterknospen braun und häutig. Es folgen dann saftige, grüne, recht grosse Schuppen und endlich die Laubblätter. Die entwickelungsgeschichtliche Untersuchung lehrt schon, dass alle Knospenschuppen nichts anderes sind als auf geringen Stufen der Ausbildung zurückgebliebene Laubblätter, und $\mathrm{zu}$ dem nämlichen Resultat führt das folgende Experiment. Wenn man Aesculus- und Paviasprosse gleich nach dem Austreiben der Winterknospen, olne dic Zweige von der Mutterpflanze abzutrennen, entgipfelt und ihrer Blätter beraubt, so entwickeln sich die in den Blattachseln angelegten Knospen im Laufe des Sommers zu Laubtrieben, wälirend sie normalerweise zu Winterknospen würden. Das Merkwürdige der sich geltend machenden Correlationserscheinung besteht nun aber darin, dass die zur Ausbildung kommenden Triebe keine Knospenschuppen, sondern (so beobachtete ich es wenigstens bei meinen Experimenten) nur Zwischenformen zwischen Schuppen und Laubblättern sowie Laubblätter produciren. Die unteren Blätter der Sprosse haben kleine, aber schon gegliederte Spreiten, und diese letzteren sitzen einem grünen, schuppenartigen Blatttheile auf, während die höher stehenden Blätter die Gestalt normaler Laubblätter besitzen. Es besteht bei Aesculus und Pavia sowie auch

1) Vgl. Vöchtisg, Die Bewegungen der Blüthen und Früchte, Bonn 1882.

2) Vgl. GöBEL, Botanische Zeitung, 1850, S. 771 u. 807. 
bei anderen Gewäclısen demnach eine sehr ausgeprägte Correlation zwischen dem Vorhandensein resp. der Abwesenheit des Gipfels sowie der Blätter einerseits und der Form, in der die Entwickelung der Knospen vor sich geht, andererseits.

\section{Die Variationsbewegungen der Pflanzen.}

\section{Experimente mit Acacia lophanta.}

Variationsbewegungen, welche in den meisten Fällen unter Vermittelung von besonderen Gelenken zur Geltung kommen, sind manchen Pflanzentheilen eigenthümlich. Sie werden theils durch innere Ursachen, theils durch den Einfluss äusserer Verhältnisse (Beleuchtungswechsel, Erschütterungen) bedingt, aber alle diese Umstände rufen, was besonders wichtig ist und wie wir weiter unten sehen werden, nur Veränderungen der Turgorausdehnung in den Zellen derjenigen Gewebecomplexe hervor, von denen dic Bewegungen ausgehen. Eine ganze Reihe von Experimenten, zunächst solche mit Acacia lophanta, werden uns genauer mit den merkwürdigen Variationsbewegungen der Gewächse bekannt machen.

Die Blättchen des zusammengesetzten Blattes von Acacia lophanta, eine Pflanze, die man in Blumentöpfen aus Samen zur Entwickelung bringen kann, sind horizontal ausgebreitet, wenn die Pfianze hellem, diffusem Tageslicht ausgesetzt ist. Abends legen sich die Blätter nach oben zusammen, um sicl am folgenden Tage unter dem Einfluss des Lichtreizes wieder auszubreiten. Man kann die Blättchen aber auch am Tage zwingen, die Nachtstellung einzunehmen, wenn man die Untersuchungsobjecte in einen dunkeln Raum bringt. Nach Verlauf einer halben bis einer Stunde haben sich die Blättclien zusammengelegt, dagegen breiten sie sich wieder aus, wenn die Pflanzen aufs Neue diffusem Licht ausgesetzt werden. Die Bewegungen der Acaciablättchen sind Folge des Wechsels der Beleuchtungsverhältnisse, denn sie machen sich, wie leicht festzustellen ist, auch geltend, wenn die Temperaturverhältnisse wälırend der angeführten Beobachtungen constant bleiben.

Ich konnte feststellen, dass die Blättchen von Acacia loplıanta auch dann eine der Dunkelstellung gleiche Stellung annehmen, wenn die Pflanzen dem directen Sonnenlicht ausgesetzt werden. Eine Acacia mit ausgebreiteten Blättern wird unter einer Glasglocke ins directe Sonnenlicht gestellt. Die Blättchen haben sich alsbald zusammengelegt; sie breiten sich aber wieder horizontal aus, wenn man das Untersuchungsobject, ohne Entfernung der Glasglocke, hellem diffusem, Tageslicht exponirt.

Sehr interessant ist die Thatsache, dass Exemplare der Acacia lophanta, die normalen Beleuchtungsverlältnissen ausgesetzt waren und nun der Einwirkung des Lichtes völlig entzogen werden, indem man sie in einen völlig dunkeln Raum (z. B. einen Schrank) stellt, 
dennoch fortfalıren, die unter den normalen Verhältuissen in Folge des täglich wiederkelırenden Wechsels von Beleuchtung und Verdunkelung inducirten periodischen Bewegungen der Blätter auszuführen. Ein besonders lebenskräftiges, in einem kleinen Blumentopf wachsendes Exemplar von Acacia lophanta, welches ich in constanter Dunkelheit hielt, breitete 4 Tage lang seine Blättchen zur Tageszeit aus und legte dieselben zur Nachtzeit zusammen; freilich nahm die Amplitude der Bewegung allmählich ab, und nach 4 Tagen hörte die Nachwirkungsbewegung völlig auf; die Blättchen waren jetzt dunkelstarr geworden, und zwar zeigten die Blättchen der älteren Blätter nunmehr eine horizontale Stellung, während diejenigen der jüngeren Blätter mehr oder minder nach oben zusammengelegt erschienen. Als die Pflanze wieder normalen Beleuchtungsverhältnissen ausgesetzt wurde, kehrte der phototonische Zustand der Blättchen zurück, d. h. dieselben reagirten aufs Neue auf den Wechsel von Tag und Nacht. Will man die periodischen Nachwirkungsbewegungen, wie sie an den Blättchen solcher Acaciaexemplare auftreten, die zunächst normalen Lebensbedingungen ausgesetzt waren und dann in constante Finsterniss gelangt sind, genauer verfolgen, so verfälırt man dabei nach PFefFer's Vorgange in folgender Weise. Man verfertigt sich aus steifem Papier eine ganze Anzahl Dreiecke, die verschiedene, aber bekannte Winkelgrösse besitzen. Es genügt, wenn jedes folgende Dreieck von dem vorhergehenden um 10 Grad differirt. Diese Dreiecke werden zur Bestimmung der Neigung der Blättchen gegen einander zwischen dieselben gehalten, und indem man die Untersuchungen an einem bestimmten Blatte der im Dunkeln verweilenden Acaciapflanzen im Laufe eines Tages recht oft (z. B. alle zwei Stunden) wiederlıolt, gelangt inan zu genauer Kenntniss des Verlaufs der periodischen Nachwirkungsbewegungen ').

\section{Experimente mit Phaseolus multillorus.}

An den Blättern von Phaseolus sind ebenso wie an denjenigen von Acacia lophanta periodische Bewegungen zu beobachten, die in Folge des täglich wiederkehrenden Beleuchtungswechsels auftreten. Der Hauptblattstiel hebt sich abends und senkt sich morgens, während die drei Einzelblättchen (vgl. die nebenstehenden Abbildungen Fig. 180 u. 181) unter dem Einfluss des Lichtes eine nahezu horizontale Stellung annehmen ${ }^{\gamma}$ ), sich in Folge von Lichtmangel aber nach unten zusammenlegen. Genaueres ergeben Winkelmessungen. Die Blättchen von Phaseolus lassen auch periodische Nachwirkungsbewegungen erkennen, wenn die zunächst unter normalen Verhältnissen erwachsenen Pflanzen später constanter Dunkelheit ausgesetzt werden. $\mathrm{Zu}$ den bezüglichen Beobachtungen benutze man kräftige, in Blumentöpfen cultivirte Pflanzen. Bei Versuchen, die ich anstellte, gingen die periodischen Nachwirkungsbewegungen melirere Tage lang, freilich mit sich vermindernder Amplitude, fort. Schliesslich wurden die

1) Vgl. PFFFFer, Die periodischen Bewegungen der Blattorgane, Leipzig 1875.

2) Dies geschicht aber nur in hellem, diffusem Licht. In directem Sonnenlicht nehmen die Bohnenblättchen zumal mittags cine Stellung ein, die ihrer Nachtstellung in gewisser Bezichung ähnelt. 
Blätter dunkelstarr, in welchem Zustande sie horizontal ausgebreitet erschienen. Aufs Neue normalen Beleuchtungsverhältnissen ausgesetzt, kehrten die jüngeren Blätter alsbald wieder in den phototonischen Zustand zurück; die älteren reagirten offenbar weit weniger energisch auf den Lichtreiz.

Bei dem Zustandekommen der periodischen Bewegungen nicht völlig ausgewachsener Phaseolusblätter spielen freilich Wachsthumsvorgänge eine gewisse Rolle. Die Bewegungen ausgewachsener

Fig. 180 .

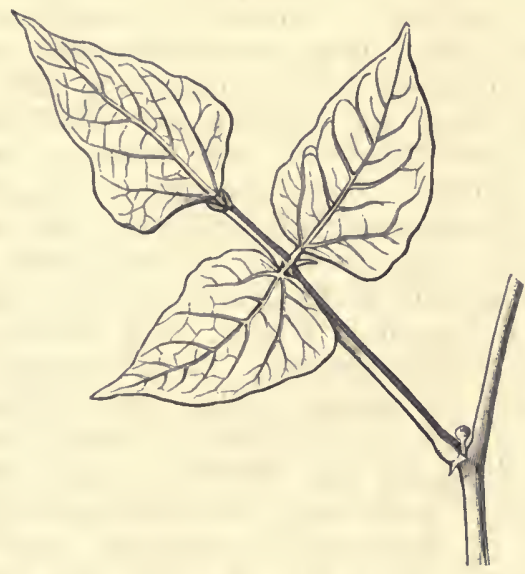

Fig. 181.

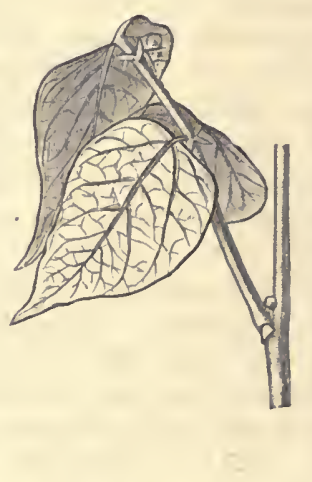

Fig. 180. Blatt ron Phaseolus multiflorus in Tagesstellung.

Fig. 181. Blatt von Phaseolus multiflorus in Nachtstellung.

Bohnenblätter werden aber, ebenso wie es bei vielen anderen Pflanzen (Mimosa, Oxalis etc.) der Fall ist, lediglich durch Veränderungen der Turgorausdehnung bedingt. Und zwar machen sich diese die Bewegungen vermittelnden Veränderungen in den Gelenken der Blätter (dem Gelenk des Hauptblattstieles sowie den Gelenken der drei Blättchen) geltend. Es ist lehrreich, den anatomischen Bau der Gelenke mit demjenigen des übrigen Gewebes der Blattstiele zu vergleichen. Untersucht man Querschnitte des grossen Gelenkes an der Basis des Hauptblattstieles von Phaseolus, so fällt namentlich auf, dass unter der mit Haaren besetzten Epidermis ein sehr mächtig entwickeltes Parenchym vorhanden ist, dessen Zellen auf der Gelenkober- und -unterseite nahezu die gleiche Beschaffenheit besitzen. Ziemlich in der Mitte des Querschnitts beobachtet man eine Anzahl von Gefässbündeln, welche das Mark umgeben. Bei mikroskopischer Untersuchung eines Querschnitts aus der Mitte des Hauptblattstieles der Bohne fällt sofort auf, dass das Rindengewebe, welches im Gelenk eine so bedeutende Ausbildung erfahren hat, hier nur relativ schwach entwickelt, übrigens als Collenchym (in den vorspringenden Kanten) und als gewöhnliches Rindenparenchym vorhanden ist. Die das Mark umgebenden Gefässbündel sind niclıt in der Mitte des Querschnitts zusammengedrängt, sondern liegen mehr peripherisch. Die Zellen des Gelenkrindenparenchyms verinitteln bei der Bohne und ebenso bei Acacia, Mimosa etc. die Variationsbewegungen der 
Blätter, und zwar werden dieselben, wie schon bemerlit, nicht durch Wachsthum, sondern allein durch Turgorverhältnisse hervorgerufen, wenn man es mit ausgewachsenen Organen zu thun hat, eine Thatsache, deren Richtigkeit sofort klar wird, wenn man bedenkt, dass die Gelenke die nach Vollendung ihres Wachsthums erlangte Grösse beibehalten, obgleich sie noch Monate lang Bewegungen der Blätter vermitteln.

Um festzustellen, dass sich bei dem Zustandekommen der Variationsbewegungen keine Wachsthumsvorgänge geltend machen, bringen wir nach der unter 153 angegebenen Methode Tuschepunkte als Marken auf einer Gelenkflanke all, um deren Entfernung wiederholt im Laufe mehrerer Tage mit dem horizontal gelegten Mikroskop zu messen. Es ist sehr darauf zu achten, dass das Gelenk bei jeder Messung stets die nämliche Stellung habe.

Die durch den Wechsel der Belenchtungsverhältnisse inducirten periodischen Variationsbewegungen kommen nun dadurch zu Stande, dass das Rindenparenchym der Gelenke auf zwei gegenüberliegenden Seiten in Folge von Turgorschwankungen verschiedene Verlängerungen erfährt. So z. B. tritt die abendliche Senkung der Einzelblättehen des Bohnenblatts ein, weil die Zellen des Parencliyms der Oberseite der Gelenke stärker turgesciren als diejenigen der antagonistischen Seite, und dadurch eine convexe Krümmung der Gelenkoberseite bewirkt wird.

Ein wichtiger hier in Betracht kommender Factor wird aber erst dureh folgenden Versuch klargestellt. Von einer in einem Blumentopf cultivirten Bohnenpflanze entfernt man gegen Abend init Hülfe eines sehr scharfen Messers die obere Gelenkhälfte am Endblatt eines der gedreiten Blätter. Tritt die Dunkelheit ein, so senken sich die Seitenblättchen wie gewöhnlich, das operirte Blatt hebt sich aber, und ich fand dasselbe z. B. bei einem im Juli angestellten Versuch (die Operation war um 5 Uhr abends vorgenommen und die Pflanze dann an einen schlecht beleuchteten Ort gestellt) un 11 Uhr nachts fast gerade aufgerichtet. An nächsten Morgen hatte sich das Endblatt in meinem Experiment wieder gesenkt. Daraus folgt, dass die abendliche Stellungsänderung solcher Blätter, die mit Variationsbewegung begabt sind, nicht dadurch zu Stande kommt, dass nur der Turgor der Zellen der einen der antagonistischen Gelenkhälften (in unserem Falle der oberen) durch Dunkelheit erhölıt wird. Vielmehr steigert Finsterniss den Turgor sämmtlicher Zellen des Parenclıymmantels im Gelenk, während Lichtzutritt ihn herabsetzt, aber diese Steigerung respect. Erniedrigung des Turgors geht in den antagonistischen Gelenkhälften nicht mit der gleichen Geschwindigkeit vor sich. In den Gelenken der Bohnenblättchen wächst der Turgor z. B. in den Zellen der oberen Hälfte derselben schneller als in denjenigen der unteren; daher wenden sich die Blättchen abwärts. Dass aber der 'Turgor zugleich in der unteren Gelenkhälfte zunimmt, lehrt das Resultat unseres Experiments; denn würde dies nicht geschehen sein, so hätte sich das operirte Blatt nicht am Abend erheben können.

Es mögen hier noch einige Versuche angefülırt werden, welche lehren, dass die Bewegungsgelenke der Bohnen - und ilinen ähnlich verhalten sich auch diejenigen anderer Pflanzen - geotropiseh empfindlich sind.

Wir eultiviren Bohnen in Blumentöpfen in lıellen, diffusem Licht. 
Wenn die Phaseoluspflanzen einige dreizählige Blätter entwickelt haben, legen wir, um das Herausfallen der Erde aus den Töpfen zu verhüten, Sperrhölzer auf den Boden, kehren die Pflanzen um und lassen sie in dieser Stellung bei Lichtzutritt (am besten im lichten Schatten eines Baumes) verharren. Vortheilhaft ist es, wenn sich die Bohnen überhaupt von Anfang an im Freien im lichten Baumschatten entwickelten. An den umgekehrten Pflanzen können wir, wenn die Temperatur hoch ist, schon nach Verlauf von 6-8 Stunden Beobachtungen anstellen. Wir hatten vor der Umkehrung die Winkel gemessen, welche die Stiele der Primordialblätter sowie der dreizähligen Blätter mit der Sprossaxe bildeten. Ebenso hatten wir die Winkel bestimmt, in denen sich die Spreiten der Primordialblätter und der dreizähligen Blätter zu den Blattstielen befanden. Wiederholen wir solche Bestimmungen, nachdem die Untersuchungsobjecte mehrere Stunden in umgekehrter Lage verweilten, so finden wir vor allen Dingen die Spreiten bedeutend gehoben, und eine langsamer nachfolgende Hebung macht sich ebenfalls in Folge der negativ geotropischen Reizbarkeit der Gelenke an den Blattstielen geltend ').

Bringt man die Pflanze jetzt in aufrechte Stellung zurück, so gewinnen die Blätter im Laufe eines Tages ihre normale Lage aufs Neue. Hat eine Bohnenpflanze mehrere Tage in umgekehrter Stellung verweilt, und wird sie dann aufgerichtet, so kehren die Blätter sehr langsam oder gar nicht wieder in die normale Lage zurück, weil die geotropische Kr rümmung der Blattgelenke jetzt durch Wachsthumsprocesse fixirt ist.

\section{Experimente mit dem Hebeldynamometer.}

Zur Gewinnung eines annähernden Maasses für die Kraft, welche bei Ausführung von Bewegungen in Gelenken entwickelt wird, kann das Hebeldynamometer dienen ${ }^{2}$ ).

An der Messingsäule $s$ (Fig. 182) ist die durch die Schraube ${ }^{\circ}$ feststellbare Hülse $e$ verschiebbar. An dieser befindet sich ausser einem Gradbogen ein auf einer Schneide ruhendes dreiarmiges Hebelwerk. Von den beiden in gerader Linie liegenden Hebelarmen $h$ und $h^{\prime}$ dient der längere als Index auf dem Gradbogen, der kürzere zum Auflegen der Untersuchungsobjecte, während der dritte Arm $p$ einen rechten Winkel mit den Armen $h$ und $h^{\prime}$ bildet. Wird er z. B. durch Druck auf den kürzeren Hebelarm aus dieser Lage gebracht, so wächst, wie beim Pendel, die Kraft, mit welcher er seiner Gleichgewichtslage zustrebt, mit dem Sinus des Ausbiegungswinkels. Durch Einschrauben verschieden langer und schwerer Stifte sowie durch Anbringen von Kugeln lässt sich natürlich die $\mathrm{zu}$ gleicher Ausbiegung nöthige Kraft modificiren, und so auch der an dem Gradbogen abzulesende Ausschlag reguliren, welchen die Auflegung eines Pflanzentheils auf den kurzen Hebelarm bewirkt. Das Hebeldynamometer ist vom Mechaniker ALBRECHT in Tübingen zu beziehen.

1) Weiteres bei Pfeffer, Periodische Bewegungen, 1875, und A. Fischer Botan. Zeitung, 1890. und 97 .

2) Vgl. PFeffer, Die periodischen Bewegungen der Blattorgane, 1875, S. 9 
Als Untersuchungsobject wählen wir ein kräftig ausgebildetes Exemplar von Phaseolus. Wir befestigen einen Draht längs der Mittelrippe auf der Oberseite eines Primordialblattes, so dass er einerseits bis an das Gelenk reicht, andererseits eine Strecke weit über die Blattspitze hinausragt. Der Draht muss so gewählt werden, dass er bei den in Betracht kommenden Kräften keine Biegung erfährt. Erfahrungsgemäss leistet bei Experimenten mit Bohnenblättern ein aus zwei feinen Eisendrähten zusammengewickelter Stift ron $60-80 \mathrm{~mm}$ Länge und etwa 0,2 g Gewicht gute Dienste. Die Befestigung des Drahtes erreicht man dureh Festbinden an mindestens drei Blattstellen, wobei jede Fadenschlinge Mittelrippe und Draht umfassen muss. Das über das Blatt hinausragende Drahtende wird dem kurzen Hebelarm des Dynamometer's aufgelegt und hier am besten mittelst Zwirn oder Draht befestigt.

Vor Ausführung der Experimente muss noch festgestellt werden, welches Verhältniss zwischen der am kurzen Hebelarm des Dynamometers wirkenden Kraft einerseits und der dieser entsprechenden Ausbiegung andererseits besteht. Bei nicht $\mathrm{zu}$ starker Ausbiegung lässt sich diese Relation recht genau feststellen, indem man an den kurzen Hebelarm eine Wagschale anhängt und diese mit Gewichten belastet. Die nämliche Ausbiegung kann natürlich, je nachdem der verticale Hebelarm $P$ melir oder weniger (z. B. durch Wachskügelchen oder auf andere Weise) belastet ist, einem verschiedenen auf $h$ ausgeübten Druck entsprechen. Ein Grad Ausbiegung wird z. B. je nach Umständen bedingt durch 0,1 oder auch $0,3 \mathrm{~g}$. Das Product, aus dem der abgelesenen Ausbiegung entsprechenden Gewichte und der Länge des auf dem Dynamometer aufliegenden Blatthebelarmes ergiebt das statische Moment, welches die Grösse des in einer Gelenkhälfte entwickelten Ueberdruckes anzeigt.

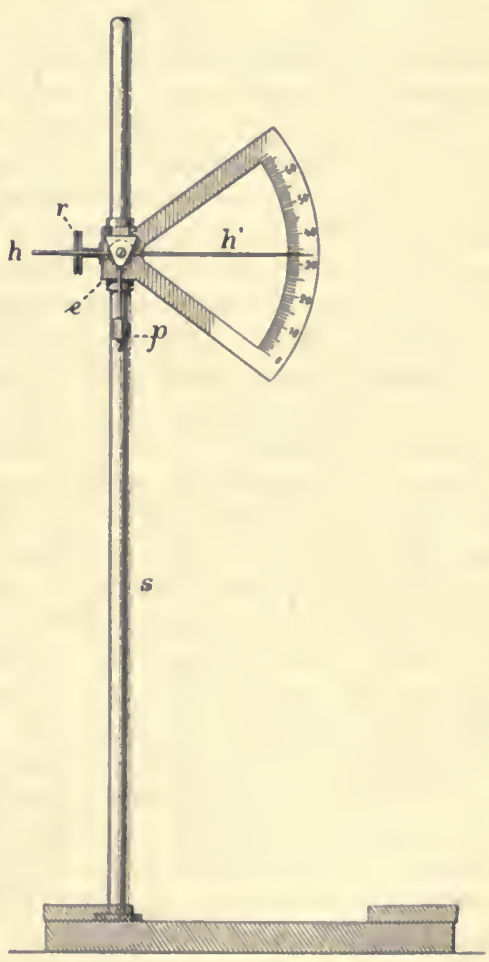

Fig. 182. Pfeffer's Dynamometer.

Bei den Experimenten mit den Bohnenblättern muss natürlich der Blattstiel bis zum Gelenk durchaus festgehalten werden. Ist der Apparat sorgfältig und zitterfrei aufgestellt, so rufen zumal die in Folge von Helligkeitssehwankungen eintretenden Aenderungen in der Expansionskraft der antagonistischen Gelenkhälften Stellungsänderungen der Hebelarme des Dynamometers hervor. Wenn man den Apparat z. B. nachmittags verdunkelt, so kann der Zeiger im Laufe einiger Stunden seine Stellung um $10^{\circ}$ verändern. Entspråche dabei $1^{0}$ einem auf den kurzen Hebelarm geltend gemachten Druck von $0,3 \mathrm{~g}$, und hätte der Blatthebelarm eine Länge von $70 \mathrm{~m}$, so würde 
sich für den Ausschlag von $10^{\circ}$ ein statisches Moment von $210 \mathrm{~g}$ berechnen.

Die Bohnenblätter führen auch autonome Bewegungen von mässiger Amplitude und einer Schiwingungsdauer von ca. 2 Stunden aus. Für diese liegt das mechanische Moment oft zwischen 10 und $25 \mathrm{~g}$. Je nachdem diese autonomen Bewegungen den paratonischen und täglichen periodischen Bewegungen gleichsinnig oder entgegengesetzt sind, wird das mechanische Moment dieser vergrössert oder verringert werden (Weiteres bei PFEFfer).

\section{Experimente mit Mimosa pudiea und anderen Pflanzen.}

Die Blätter von Mimosa pudica führen sowohl in Folge von Erschütterung oder Berührung als auch in Folge des Wechsels der Beleuchtungsverhältnisse Bewegungen aus, welche durch die Gelenke der primären sowie der secundären Blattstiele und der Einzelblättchen vermittelt werden. Bei der Cultur der Pflanzen, die man zweckInässig in Blumentöpfen vornimmt, ist darauf zu achten, dass die sich aus den Samen entwickelnden Pflanzen möglichst hoher Temperatur $\left(20-25^{\circ}\right.$ C.) ausgesetzt sind, und dass ihnen reichliche Wassermengen zur Disposition stehen.' Das letztere erreicht man bei Culturen, die in einem gewöhnlichen Zimmer vorgenommen werden, dadurch am besten, dass man über die Culturgefässe, bald nachdem die Pflanzen über die Erde hervorgekommen sind, grosse Glasglocken stülpt, natürlich ohne die Luftcirculation allzu sehr zu behindern. Die in grösserer Zahl in einem Blumentopf zur Ausbildung gekommenen Keimlinge verpflanzt man alsbald, so dass sie einzeln in Töpfen stehen, und cultivirt sie in möglichst warmer, feuchter Luft am Fenster weiter. Bei kräftigen Pflanzen ist der Hauptblattstiel am Tage inehr oder minder nach aufwärts gerichtet, die Blättchen sind ausgebreitet. Verdunkelt man eine Pflanze plötzlich am Tage, indem man über die Glasglocke, unter welcher sie sich befindet, einen Pappkasten deckt, so heben sich die Hauptblattstiele nicht unwesentlich, so dass der Winkel, den sie mit dem Stengel bilden, spitzer wird, und die Blättchen legen sich nach oben zusammen. Werden Mimosapflanzen unter Glasglocken an Tage unberührt dem Einflusse des Lichts überlassen, so zeigt sich, dass sich die Blättchen gegen Abend zusammenlegen, und dass die Hauptblattstiele sich mit eintretender Dunkelheit senken. Plötzliche Verdunkelung am Tage einerund die normale abendliche Verdunkelung andererseits wirken also gleichsinnig auf die Blättchen, ungleichartig aber auf die Hauptblattstiele der Mimosa pudica ein ${ }^{1}$ ).

Werden zunächst unter normalen Verhältnissen cultivirte Mimosapflanzen in hinreichend feuchter Atmosphäre constanter Finsterniss ausgesetzt, so machen sich, wie bei Acacia und Phaseolus, nach einiger Zeit Nachwirkungsbewegungen der Blätter geltend, d. h. die Blättchen sind zur Tageszeit ausgebreitet, zur Nachtzeit zusammengelegt. Allmählich hören diese Bewegungen auf, und es ist auch die Fähigkeit der Blätter verschwunden, auf Erschütterung oder Be-

1) Ueber die Ursachen dieser complicirten Erscheinungen vergl. PFEFFer, Die periodischen Bewegungen etc., 1875, S. 74. 
rührung zu reagiren. Bei der Beobachtung ins Dunkle gestellter Mimosapflanzen ist übrigens darauf zu achten, Tass die Blâtter verschiedenen Alters einer Pflanze sich nicht gleichartig verhalten. Wenn die täglichen periodischen Nachwirkungsbewegungen nicht mehr stattfinden, so erscheinen die dunkelstarren Blätter nicht in der normalen Nachtstellung, sondern im Gegentheil, der Hauptblattstiel dunkelstarrer Blätter hat eine nahezu horizontale Stellung, und die Blättchen sind ausgebreitet. Wird die Pflanze jetzt kurze Zeit beleuchtet und dann wieder ins Dunkle gebracht, so reagirt sie noch nicht auf den Beleuchtungswechsel und auf Erschütterungen oder Berührung; ilıre Blättchen schlagen sich nicht zusammen. Die Pflanze ist noch dunkelstarr. Der phototonische Zustand tritt erst nach länger dauernder Beleuchtung wieder ein, und zwar gewinnt die Mimose zunächst ihre Fähigkeit wieder, auf den Wechsel der Beleuchtungsverhältnisse zu reagiren; später kehrt auch der Zustand zurück, in welchem sie für Erschütterung oder Berührung empfindlich ist. Ich hielt eine Mimosa pudica (a) vom 16. bis 21. August $7 \frac{1}{2}$ Uhr abends bei etwa $20^{\circ}$ C. im Finstern. Am Abend des 21. August waren alle Blätter bis auf die beiden jüngsten völlig dunkelstarr. Die Pflanze $a$ wurde jetzt mit einer anderen (b), die normalen Beleuchtungsbedingungen ausgesetzt worden war, an ein Fenster gestellt. Am 22. August konnte das Licht von Sonnenaufgang bis um 10 Ulır auf beide Pflanzen einwirken; sie wurden dann beide ins Finstere gestellt, aber während die Blättchen von $b$ sich schlossen, blieben diejenigen von $a$ ausgebreitet. Die Blätter der Pflanze $n$ reagirten auch noch nicht auf Erschütterung oder Berührung; sie waren noch dunkelstarr. Nach der eine halbe Stunde lauernden Verdunkelung gelangten beide Pflanzen wieder ans Licht. Am Abend des 22. August legten sich einige Blättchen der Pflanze a zusammen, und am 23. August kehrte auch die Reizbarkeit für Berührung sowie eine recht energische Schliessungsbewegung der Blättchen ain Abend zurück. Uebrigens waren viele Blättchen der Pflanze $a$ während der letzten Tage des Versuchs gelb geworden und abgefallen.

Werden Exemplare von Trifolium pratense im Freien beobachtet oder werden Pflanzen ins Auge gefasst, die man in Töpfen aus Samen erzogen hat, so ergiebt sich, dass sich die Blättchen, während dieselben am Tage ausgebreitet sind, abends nach oben zusammenlegen. Die Blättchen von Oxalis Acetosella legen sich hingegen abends nach abwärts zusammen.

\section{Die durch Erschuitterung oder Beriihrung hervorgernfenen Variationsbewegungen von Limosa pudica.}

Die Mimosa pudica ist nur bei ziemlich hoher Temperatur und hinreichendem Feuchtigkeitsgehalt des Bodens sowie der umgebenden Luft in bedeutsamerer Weise reizbar. Werden aber unter solchen Umständen in Töpfen aus Samen erzogene Mimosaexemplare, ohne dass man die Pflanze selbst berührt, erschüttert, so macht sich eine auffallende Reizwirkung geltend. Dic Hauptblattstiele senken sich, die secundären Blattstiele nähern sich einander, und die Blättchen legen sich nach vorn und oben zusanmen (vergl. Fig. 183). Diese Bewegungen werden sämmtlich durch Gelenke vermittelt, welche an 
der Basis der Blattstiele sowie Einzelblättchen sitzen und einen ähnlichen Bau wic diejenigen der Phaseolusblätter besitzen. Man kann die Mimosa aber nicht nur durch Erschütterungen, sondern ebenso durch Berührungen zu Bewegungen veranlassen. Wird die Oberseite des grossen Gelenkes an der Basis des primären Blattstiels vorsichtig berührt, so erfolgt freilich keine Bewegung; dieselbe tritt aber sofort ein, wenn man die Unterseite in der nämlichen Weise reizt. Danach reagirt also nur die Gelenkunterseite auf Stossreiz, das Parenchym derselben verliert Wasser, welches wohl wesentlich in die zwischen den Zellen vorhandenen Intercellularen übertritt, es tritt eine Störung des hydrostatischen Gleichgewichtes im Gelenk ein, so dass nach HABERLANDT schliesslich auch die reizleitenden Elemente in der

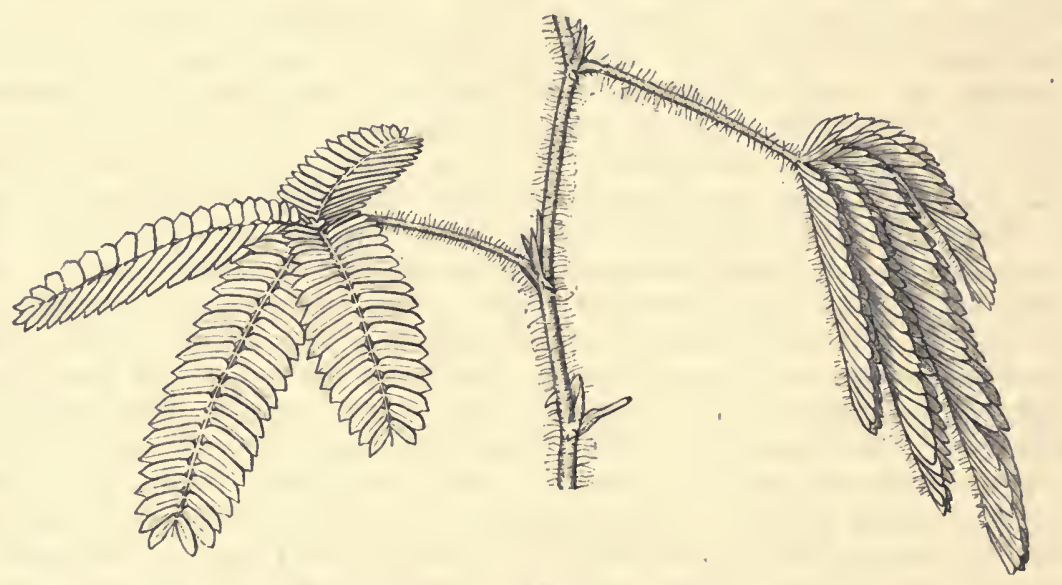

Fig. 183. Theil eines Sprosses von Mimosa pudiea. Das Blatt links ist im ungereizten Zustande, das Blatt rechts im gereizten Zustande dargestellt.

Gefässbündelregion Flüssigkeit austreten lassen. Indem sich die Gelenkunterseite in Folge des Wasserverlustes ihrer Zellen contrahirt, ferner aber auch das stark positiv gespannte Parenchym der Gelenkoberseite mitwirkt, kommt eine energische, nach abwärts gerichtete Bewegung des primären Blattstiels zu Stande. Den Wasserverlust des Gelenkes in Folge einer Reizung und die Existenz von Spannungsverhältnissen im Gelenk kann man in folgender Weise demonstriren.

Der primäre Blattstiel wird durch einen scharfen Schnitt vom Gelenk abgetrennt, und die Mimosa jetzt einige Zeit unter einer Glasglocke im dampfgesättigten Raum belassen. Wird das Gelenk, nachdem es sich einigermaassen erholt hat, gereizt, so senkt es sich, und es tritt Wasser aus der Schnittfläche hervor. In der unversehrten Pflanze wird das Wasser aus dem Gelenk zumal in den Stengel oder Blattstiel befördert. Schneidet man eins der grossen Gelenke, ohne dasselbe von seinem Blattstiel zu befreien, hart an der Sprossaxe weg, so krümmt es sich natürlich in Folge des Reizes in bekannter Weise. Trennt man nun durch zwei Längsschnitte das obere und untere Parenchym des Gelenkes vom Fibrovasalkörper ab, so krümmt sich jenes stark abwärts, dieses schwach aufwärts. Wird das so präparirte, sich noch mit dem Blattstiel im Zusanımenhang befindende Bewegungs- 
organ in Wasser gelegt, dann erfährt die Kriummung des oberen Parenchyms, insbesondere aber die nach aufwärts gerichtete Krümınung des unteren, indem die Zellen desselben wieder turgescent werden, eine wesentliche Steigerung. Die isolirten Parenchymlamellen übertreffen auch den Fibrovasalkörper des Gelenkes an Lünge, und alles beweist, dass in unverletzten Bewegungsorganen beträchtliche Spannungen zwischen dem axilen Strang einer- und dem Parenchym andererseits bestehen müssen.

Sehr lehrreich ist der folgende einfache Versuch. Man schneidet mit einer Scheere eines der kleinen Blättchen am Ende eines secundären Blattstieles recht reizbarer Mimosapflanzen vorsichtig, und ohne das Untersuchungsobject $\mathrm{zu}$ erschüttern, $\mathrm{ab}$, oder man reizt ein $\mathrm{Mi}$ mosablättehen, indem man die mit Hülfe einer Sammellinse in einen Brennpunkt vereinigten Sonnenstrahlen auf dasselbe fallen lässt. Es macht sich nun eine durch Wasserbewegung in der Pflanze bedingte Reizfortpflanzung geltend. Von der Spitze nach der Basis des secundären Blattstiels vorrïckend, bedingt die Reizfortpflanzung ein Zusammenlegen immer entfernter stehender Blattpaare, darauf legen sich auch,die Blättchen benachbarter secundärer Blattstiele (zunächst die unteren, weiterhin die höher stehenden) zusammen, ja es kann sogar eine Senkung des Hauptblattstiels und eine Uebertragung des Reizes auf ganz andere Blätter des Untersuchungsobjectes erfolgen. Hat die Fortleitung des Reizes aufgehört, und werden keine weiteren Bewegungen ausgelöst, so kehren die Blätter nach einigen Minuten wieder in ihre Ruhelage zurück ${ }^{1}$ ).

\section{Beobachtung weiterer dureh Ersehiitterung und Berihrung hervorgerufener Variationsbewegungen.}

Die Einzelblättchen von Oxalis Acetosella, einer Pflanze, die häufig in feuchten Wäldern angetroffen wird, sind mit Gelenken versehen und reagiren auf Berührung oder Erschütterung. Wird der Hauptblattstiel erschüttert, so ist die eintretende Reizbewegung der Blättchen (Senkung derselben) deutlich zu verfolgen, aber es müssen viele Stösse auf den gemeinschaftlichen Blattstiel ausgeübt werden, um die maximale Senkung der Blättchen hervorzurufen, während die volle Reizbewegung bei Mimosa pudica schon in Folge einer einzigen schwachen Erschïtterung eintritt.

Sehr reizbar sind, wovon ich mich mehrfach überzeugte, die Narbenlappen von Martynia (Gesneraceae). Wird die Innenseite der Narbenlappen berührt, so legen sich dieselben sofort zusammen. Ebenso reagiren die Narbenlappen von Mimulus (z. B. M. cardinalis) auf Berührung.

Die fünf Filamente der Cynareen sind mit ihrem unteren Ende an der Blumenkronenröhre befestigt. Die Antheren sind zu einer Röhre verklebt, durch welche der Griffel hindurchwächst. Zur Zeit der Pollenreife sind die Filamente reizbar, und während sie in un-

1) Vgl. Pfeffer, Physiologische Untersuchungen, 1873, und SAcus, Vorlesungen über Pflanzenphysiologie, 1882, S. 787. HA BERLANDT's Ausführungen (D2s reizleitende Gewebesystem der Sinnpflanze, Leipzig 1890) stimme ich nicht in jeder Hinsicht $\mathrm{zu}$. 
gereiztem Zustande convex nach aussen gebogen erscheinen, strecken sie sich in Folge eiller Erschütterung oder Berührung unter Verkürzung gerade. Gelenke fehlen den Filamenten; ihr gesammtes, das axile Gefässbündel umgebende Parenchym ist vielmehr reizbar und verliert, wenn eine Reizursache auf dasselbe einwirkt, in Folge von Wasserabgabe bedeutend an Expansionskraft, wodurch die Contraction hervorgerufen wird. Will man sich von der Reizbarkeit der Cynareenfilamente überzeugen, so verwendet man zweckmässig Blüthen von Centaurea jacea zu den bezüglichen Experimenten. Man isolirt einzelne Blüthen aus dem Blüthenlïpfehen, schneidet die Corolle, Filamente und den Griffel etwas über der Insertion der Staubgefässe quer durch und befestigt den befreiten Sexualapparat mit Hülfe einer Nadel auf einem Kork. Derselbe wird unter eine Glasglocke in wasserdampfreiche Luft gebracht. Haben sich die Präparate erholt, so sind sie reizempfänglich. Die freien Filamente bewegen sich in Folge von Berührungen und erlangen nach ausgefülırten Bewegungen ihre Reizbarkeit unter günstigen äusseren Verhältnissen in einigen Minuten wieder. Die Bewegung der freien Filamente kommt dadurch zu Stande, dass ihre berührte Seite unter Verkürzung stets zunächst coneav wird.

\section{Die spontamen Variationsbewegungen.}

Spontane Variationsbewegungen lassen sich an den mit Gelenken versehenen Blättern verschiedener Pflanzen (Mimosa, Oxalis, Trifolium) beobachten und kommen dadurch zu Stande, dass die Turgorausdehnung der Zellen der antagonistischen Gelenktlieile aus inneren Ursachen Schwankungen erfährt. Wir wählen, um uns über die spontanen Variationsbewegungen zu orientiren, Trifolium pratense als Untersuchungsobject und cultiviren die Pflanze aus Samen in einem Blumentopfe. Haben sich die Pflanzen schon ziemlich weit entwickelt, so ist es zweckmässig, die schwächlichen Individuen $\mathrm{zu}$ beseitigen und nur einige kräftige zur Beobachtung stehen zu lassen.

Es ist schon erwähnt worden, dass die Blätter von Trifolium recht energisch durch Bewegungen auf den Wechsel von Beleuchtungsverhältnissen reagiren. Um diese Bewegungen möglichst auszuschliessen.

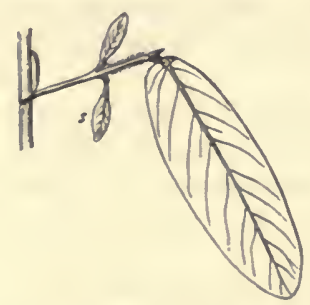

Fig. 184. Blatt von Desmodium gyrans, verkleinert. (Nach PFEFFER.) bringen wir den Blumentopf mit den Trifoliumexemplaren in einen dunkeln Schrank oder unter einen Pappkasten und lassen die Pflanzen auch am nächsten Tage, an welchem die eigentlichen Beobachtungen beginnen sollen, im Finstern stehen. Von Zeit zu Zeit, etwa alle halbe Stunde, bestimmen wir die Stellung gewisser Kleeblättchen, und zwar ist es am zweckmässigsten, die jeweilige Lage derselben durch Aufzeichnen zu fixiren. Zahlreiche Versuche, die ich bei einer Temperatur von etwa $18^{\circ} \mathrm{C}$. ausführte, ergaben mir, dass die Blättchen von Trifolium pratense im Finstern auf- und abgehende Bewegungen ausführen, deren Amplitude oft weniger, oft mehr als $90^{\circ}$ betrug. Zur Vollendung einer vollen Schwingung waren einige Stunden erforderlich.

Sehr ansehnliche autonome Variationsbewegungen führen die Seiten- 
blättchen vou Desmodium gyrans aus. Sie beschreiben elliptische Bahnen, deren lange Axe nahezu parallel dem Hauptblattstiel ist. Das Temperaturminimum für diese Bewegungen liegt bei etwa $22^{\circ} \mathrm{C}$. Einen Umlauf sall ich bei hoher Temperatur in wenigen Minuten vollendet. Die aufsteigende Bahn wird etwas langsamer als die absteigende durchlaufen (vgl. Fig. 184).

\section{Der Einfluss äusserer Verhältnisse auf einige Variations- bewegungen.}

Auf die Beeinflussung der Variationsbewegungen durch äussere Verhältnisse ist schon mehrfach hingewiesen worden. Hier mögen weitere Angaben folgen. Um den Einfluss von Aether- oder Chloroformdämpfen auf die Gelenke von Mimosa pudica festzustellen, verfährt man nach meiner Erfahrung am zweckmässigsten in der nachstehend angegebenen Weise. Ein abgeschnittenes Blatt, dessen Blättchen in Folge eines schwachen Reizes zum Zusammenlegen gebracht worden sind, wird mit seinem Stiel in ein kleines, Wasser enthaltendes Glas gestellt. Dieses Glas steht auf einem Teller, in den man Aether oder Chloroform gegossen hat. Nach Ueberdecken des Tellers mit einer Glasglocke wird das Untersuchungsobject dem directen Sonnenlicht ausgesetzt. Während der einige Minuten dauernden Narcose breiten sich die Blättchen vollkommen aus; sie reagiren jetzt aber nicht auf Berührung oder Erschütterung. Der reizbare Zustand kehrt indessen zurück, wenn man das Mimosablatt in eine äther- und chloroformfreie, aber wasserdampfreiche Atmosphäre bringt.

Sehr lehrreich ist der folgende Versuch. Die Unterseite des Gelenkes am Hauptblattstiel einer sich unter sehr günstigen Lebensbedingungen befindenden Mimose wird mit Hülfe eines kleinen Holzstäbchens wiederholt und in kurzen Intervallen gereizt. (Bei meinen Versuchen wurde die Reizung in Intervallen von je einer halben Minute 5 oder 6 Minuten lang fortgesetzt, und der Gelenkunterseite wurden stets nach einer halben Minute mehrere Stösse ertheilt.) Wird die Pflanze unter einer Glasglocke sich selbst überlassen, so erhebt sich der gesenkte Hauptblattstiel in einigen Minuten, aber trotzdem reagirt das Gelenk jetzt nicht auf Berührung. Das durch oft wiederholte Berührung für neuen Reiz unempfindlich gewordene Bewegungsorgan erlangt den reizbaren Zustand übrigens nach Verlauf kurzer Zeit wieder. Die Thatsache, dass die nach aufgehobener Narcose mit Aether oder Chloroform ausgebreiteten Mimosablättchen, und dass die nach Sistirung von Stössen emporgehobenen Hauptblattsticle von Mimosa nicht sofort, sondern erst nach einiger Zeit wieder reizbar sind, beansprucht besonderes Interesse. Sie lehrt nämlich, dass die Ursachen, welche die Rückkehr der Mimosablatttheile auf den reizempfänglichen Zustand einer- und andererseits die Reizbarkeit selbst bedingen, nicht durchaus die gleichen sein kömuen.

Wird die Erde, in welcher eine Mimose wurzelt, längere Zeit nicht begossen, das Untersuchungsobject sonst aber normalen Lebensbedingungen ausgesetzt, so nimmt in Folge des eintretenden Wassermangels die Reactionsfähigkeit der Blättchen für Erschütterung oder Berührung mehr und mehr ab. Bei einem von mir bei etwa $20^{\circ} \mathrm{C}$. angestellten Versuch trat nach 4 Tagen eine völlige Unempfindlichkeit der Mimosablättchen für Berührung ein. Die im Zustande der Trockenstarre verharrenden Blättchen sind ausgebreitet, erscheinen aber noch 
keineswegs immer welk und erlangen ihre Reizbarkeit wieder, wenn der Pflanze aufs Neue reichliche Wassermengen zugeführt werden. Wird eine Mimose einer Temperatur unter $15^{\circ} \mathrm{C}$. (z. B. $10^{\circ} \mathrm{C}$.) einige Stunden lang ausgesetzt, so geht die Pflanze in den Zustand der vorïbergehenden Kältestarre über. Die Empfindlichkeit für Berührung sowie für den Wechsel der Beleuchtungsverhältnisse verschwindet. Der normale, reactionsfähige Zustand kehrt aber zurück, wenn man das Untersuchungsobject wieder in einen Raum bringt, in welchem eine Temperatur über $15^{\circ} \mathrm{C}$. herrscht.

Handelt es sich darum, Mimosen in den Zustand der vorübergehenden Wärmestarre zu versetzen, so bringe man die Pflanzen in einen geeigneten Thermostaten, in welchem eine Temperatur von $40^{\circ} \mathrm{C}$. herrscht. Nach etwa einer Stunde (bei $45^{\circ} \mathrm{C}$. in viel kürzerer Zeit) ist der erwähnte Zustand des Untersuchungsobjectes eingetreten. Die Blättchen haben sich selbst bei Lichtzutritt nach aufwärts zusammengelegt. Günstige Temperaturverhältnisse rufen den normalen Zustand der Mimose in einigen Stunden zurück ${ }^{1}$ ).

\section{Nachtrag.}

Unter 84 ist das Problem der Wasserbewegung im Holzkörper der Pflanzen besprochen worden. Wir baben gesehen, dass sich das Wasser im Lumen der leitenden Holzelemente bewegt, und wenn wir hier nun noch etwas näher auf die Ursachen dieser Wasserbewegung eingehen, so geschiebt dies zumal deshalb, weil AsKENA8Y ${ }^{2}$ ) kürzlich eine kleine Abhandlung publicirte, deren Inbalt mir allerdings in Verbindung mit den wichtigen Arbeiten StrasberGrR's von hoher Bedentung zu sein scheint.

SACHs ${ }^{8}$ ) hat schon nachdrücklich betont, dass der Warzeldruck auf keinen Fall ausreicheu kann, um die Wasserverluste stark transpirirender Pflanzen zu decken. Freilich kann das Wasser in der intacten Pflanze unter dem Einfluss des Wurzeldrucks in grösserer Menge und auch bis zu bedeutenderer Höhe emporgehoben werden als in der decapitirten, denn auf die durch das Decapitireu hergestellte Scbnittfäche wirkt der Luftdruck ein, während derselbe die Wasserhebung in der unversehrten Pfanze nicht beeinflussen kann. Trotz alledem spielt der Wurzeldruck auch in der unverletzten Pfanze anf keinen Fall eine Rolle bei dem Vorgange der Wasserbewegung im Holzkörper stark transpirirender Gewåchse, und HaNsen 4 ) zeigte, dass sogar Pflanzen mit getödteten Wnrzeln, die also absolut keinen Wurzeldruck zur Geltung bringen können, noch lebhaft transpiriren. In Töpfen zur Entwickelang gelangte Nicotians. oder Helianthuspflanzen, die 6-10 grössere Blätter tragen, stellen wir nach dem Durchfeuchten des Bodens in den Töpfen in doppeltwandige Zinkblechbehälter, die auf Dreifüssen ruben. Der Zwischenraum zwiscben den Doppelwānden ist mit Wasser angefüllt. Wir führen Thermometer in den Boden der Töpfe ein, bedecken diese mit halbirten und in der Mitte mit einem Ausschnitt zur Aufnahme des Stammes des Untersuchungsobjectes versehenen Platten aus dicker Pappe und orhitzen das Wasser. Die Warzeln werden 1-2 Stunden lang einer Temperatur von $70^{\circ} \mathrm{C}$. ausgesetzt. sie sind dann, wie übrigens mikroskopische Untersuchung bestảigen kann, sicher getödtet. Nun wickeln wir die Töpfe sorgsam in Stanniol ein, bedecken auch die Bodenoberfiäche sowie den Stammtheil des Untersuchungsobjectes mit Stanniol und könuen durch wiederbolte Wagungen constatiren, dass die oberirdischen Theile der Pfianzen bei nicht zu niedriger Lufttenperatur ohne zu welken noch tagelang erhebliche Wassermengen durch Transpiration verlieren. Die getödteten Wurzeln müssen dabei Wasser aus dem Boden aufnehmen.

Capillarkräfte sind wohl von Bedoutung, um das Wasser in den trachealen Bahuen festzuhalten, dagegen spielen sie, wie Strasburger ${ }^{8}$ ) überzeugend nachwies, kaum eine Rolle bei der Hebung des Wassers selbst.

1) Vgl. besonders Cladde Branard, Leçons s. I. phénomènes d. 1. vie, 1878; SAchs, Flora, 1863, und Pfeffer, Physiol. Untersuchungen, 1873.

2) Vergl. Askenasy, Verhandlungen d. Naturhistorisch-med. Vereins zu Heidelberg, N. F. B. 5 .

3) Vergl. SACH8, Vorlesungen über Pflanzenphysiologie, 1887, S. 257.

4) Vergl. Haxsex, Arbeiten d. botan. Instituts in Würzburg, B. 3, S. 312.

is 5) Vergl. Strasborgra, Bru and Verrichtung der Leitungsbahnen in den Pfanzen, 1891, s. 808 . 
Den Luftdruck kð̋nen wir ebenfalls nicht herænziehen, wenn es sich um die Hebung des Wassers bis $2 u$ bedeutenden Höben (z. B. 200-300 Fuss) handelt, und so scheint man seine Zuflucht zu der Mitwirkung der lebensthätigen Zellen des Holzkörpers nehmen zu müssen.

Indessen ich möchte hier die besondere Aufmerksamkeit auf gewisse Versuche STRAsHURGRRs (I. c. S. 607) hinlenken, die ich freilich leider noch nicht selbst wiederholt habe, deren Resultate aber gewiss sehr beachtenswerth erscheinen.

Schlanke, in dichtem Bestande erwachsene Bäume von Acer platanoides, Fagus, Pinus Laricio (Schwarzkiefer) oder von Abies excelsa werden an ihrer Basis etwas schräg anter einem starken, nach der Schnittfläche zu gerichteten Wasserstrom abgesägt. Die Båume von ca. $20 \mathrm{~m}$ Höbe bleiben zunächst mit der Basis eine halbe Stunde im Wasser stehen; sie werden dann mittelst eines Flaschenzuges gehoben, um die Schnittiäche nach dem Glätten mit 5-10-proc. Kupfervitriollösung in Berübrang zu bringen.

Die Băume, mit denen Strasmurger experimentirte, nahmen unter günstigen Trans. pirationsbedingungen im Laufe mehrerer Wochen oder Monate reichliche Mengen der Kupferlösung auf. Dieselbe stieg, wie leicht nachzuweisen war, bis in die Kronen der Bäume empor, so dass die Blätter allmählich abstarben, und das Holz des Stammes sich völlig oder fast völlig mit Kupfersalz durchtrănkt zeigte. Osmotische Wirkangen lebens. thätiger Zellen des Holzkörpers können hier also die Wasserhebung nicht vermittelt baben, denn das Kupfersalz tödtet diese ja, indem es mit denselben in Berührung gelangt.

Unter Berücksichtigung dieser Experimente mit grossen Pfianzen gewinnen auch die Resultate solcher Versuche Interesse, die man mit kleinen Objecten anstellt, nachdem ein Theil der Leitungsbahn derselben getödtet worden ist. Wenn man den unteren Theil von Populus- oder Salixzweigen in einer Länge von ca. $20 \mathrm{~cm}$ durch $1 / 2-1-s t u ̈ n d i g e n$ Aufenthalt in siedendem Wasser tödtet, wăhrend der obere beblätterte Tbeil des Beobachtungsmaterials unversehrt bleibt, so saugt dasselbe, in Eosinlösung gestellt, noch reichliche Flüssigkeitsmengen im Laufe längerer Zeit auf. Ebenso erbebt sich 5-proc. Kupfervitriollösung in den Sprossen, die man direct nach dem Abschneiden mit ihrer Basis in die Flüssigkeit stellt, bls zu bedeutender Höbe in denselben, trotzdem das Kupfersalz die lebendigen Holzelemente tödtet.

Fïr das Verstăndniss der Wasserbewegung in der Pflanze ist es wichtig, daran zu orinnern, dass die Leitungsbahnen im Holzkörper sich in dem Maasse, in welchem sie ausgebildet werden, also schon vom Keimungsstadium der Pflanze an und auch weiter hin, mit Wasser füllen. Daher führen auch die peripherischen Regionen des Holakörpers in ihren trachealen Elementen selbst zu Zeiten starker Transpiration der Hauptsache nach nur Wasser und keine Luft, während allerdings die centraler gelegenen Holzelemente wasserleer sein können. Besonders geeignet sind zur Untersuchnng Radialschnitte ans Abietineenstămmen oder Aesten ${ }^{1}$ ) von 1-2 cm Länge und von solcher Dicke, dass mindestens eine Schicht der Tracheiden nicht angeschnitten ist. Die Untersuchung der Schnitte lebrt, dass im Allgemeinen der Wassergehalt der Elemente von aussen nach innen abnimmt ${ }^{3}$ ).

In den Leitungsbahnen wird das Wasser, wenn keine Transpiratiou stattfindet, durch die von der Wandsubstanz derselben ausgehende Adhäsion und durch die Cohäsion der Wassertheilchen, die, worauf AskrsasY mit Recht besonderes Gewicht legt, gewaltig gross ist, festgehalten, und ein Zerreissen der Wasserfäden findet nicht statt.

Wenn nun die Sonnenwärme die Transpiration hervorruft und die Blattzellen Wasser verlieren, so suchen sie den erlittenen Wasserverlust wieder zu ersetzen. Sie entnehmen den Leitungsbahnen der Gefüssbündel Flüssigkeit; sie üben auf das Wasser in den trachealen Babnen einen $\mathrm{Z} \mathbf{u g}$ ans, der sich in Folge der hohen Cohäsion der Wassertheilchen bis in die Wurzel fortsetzt und hier Veranlassung zu erneuter Wasseraufnahme giebt. Diese Ansichten Askenasy's über das Wesen der Wasserbewegung im Holz sind gewiss sehr beachtenswerth; das Hauptgewicht ist immer auf die durch die Physik festgestellte bedeutende Grōsse der Cohäsionskräfte zu legen, welche zwischen den Wassermolekülen besteht.

Die Theorie Askenasy's ist auch für den Fall aufrecht zu erhalten, wie in der Ab-t handlung des genannten Forschers näher dargelegt wird, dass die trachealen Bahnen nicht nur Wasser, sondern daneben nicht zu viel Luft von geringer Spannung führen. Dring aber viel Luft in die Leitungsbahnen ein, z. B. in Folge des Abschneidens von Pflanzentheilen in der Atmosphäre, dann ist eine schnelle Wasserströmung in den Untersuchungs objecten alsbald ausgeschlossen, und dieselben welken, wenngleich sie mit der Schnittfläche in Wasser eintauchen.

1) Vergl. Russow, Botan. Centralblatt, 1883, B. 13, S. 101, und Strasburger, Leitungsbahnen, S. 685.

2) Bezüglich der Untersuchung auf Luftgehalt sind die Angaben Strasnorgrn's, L.citungsbahnen, S. 682 , zu beachten. 


\section{Register.}

Absorption der Gase 135.

Absorptionsvermögen des Bodens 205.

Accumulation plastischer Stoffe 301.

Acidität von Pflanzensäften 272.

AërotropischesVerhalten der Algenschwärmer 355.

Aërotropismus der Pollen- und Pilzschläuche 398.

Aetherische Oele 282.

-, Reactionen ders. 283.

Aggregationen 88.

Aleuronkörner 101.

Alkaloide 285.

Alkannatinctur 257.

Alkoholbestimmung 236.

Alkoholbildung in Pflanzen 236.

Ammoniak als Pflanzennahrungsmittel 49, 61.

-, Nachweis dess. 57.

Amyloid 254.

Amylumherd 14.

Anaërobe Organismen 236 .

Anilin, schwefelsaures 92.

Anisotropie der Pflanzentheile 422.

Anthocyan 284.

Arbeitsleistung bei der Quellung 119 .

- bei geotropischen Nutationen 371.

Aschenanalyse 68.

Aschenbestandtheile der Pflanzen 65 .

Asparagin, Nachweis dess. 213.

-, quantitative Bestimmung dess. 214.

-, Verhalten dess. in der Pflanze 215.

Asphyxie des Protoplasmas 352.

Aspirator 221.

Assimilation, Abhängigkeit ders. von äusseren Verhältnissen 42.

Assimilationsenergie, specifische 40 .

Assimilationsorgan 8.

Assimilationsprocess 1.

Assimilationsproducte 39 .

Athmong, Beeinflussung ders. durch äussere Verhältnisse 226.

- der Pflanzen 217.

-, intramolekulare 220,221 .

-, normale 226 .
Atmosphärische Luft, Zusammensetzung ders. 33.

Austrocknen, Wirkung dess. auf die.Pflan. zen 112.

Auxanometer 315.

Azotometer 206.

Bacillus subtilis 83 .

Bacterien, Reinculturen ders. 82.

Bacterienmethode nach ENGELMANN 32.

Bacterium Radicicola 52.

- Termo 32, 82.

Bacteroiden 56.

Barytwasser 223.

Bastkörper, Bau dess. 93.

Bewegungen der Algenschwärmer, Beeinflussung ders. durch Temperaturverhältnisse, 356 .

- der Chlorophyllkörper 359.

- der Schwärmer 352.

- von Plasmodien 360.

- niederer Organismen 352.

Bewegungserscheinungen an Pflanzen, durch Wasseraufnahme bedingte 157 .

Biuretreaction 209.

Bleiessig 40.

Bodenanalyse, mechanische 65 .

Bodenbestandtheile 66 .

Brucin 58.

Buttersäuregährung 239.

Cacaowachs 47.

Calcium als Pflanzennährstoff 71.

Calciumoxalat 62.

Cambium 314.

Cellulosereactionen 90 .

Centrifugalapparate, Experimente mit denselben 384 .

Chemotaktische Bewegungen der Bacterien 357.

Chemotropismus der Pollen- und Pilzschläuche 398.

Chloralhydrat 8, 39.

Chloroform, Einwirkung dess. auf Pflanzen $116,449$. 
Chlorophyllfarbstoff 17.

- bei Fucus 16.

- bei Neottia 16.

-, Absorptionsspectrum dess. 18.

-, Entstehung dess. 26.

- Fluorescenz dess. 18

-, Zersetzung dess. 22.

Chlorophyllkörper 13.

Chlorzinkjod 90.

Chromsâureelement 114.

Chromsaures Kali 23.

Circumnutationen 326.

Collenchym 431.

Contactreiz 414.

Contraction der Wurzeln 305.

Correlationserscheinungen 436 .

Corrosionserscheinungen 202.

Corrosionen der Stärkekőrner durch Diastase 249.

Cuticula 90 .

Cyclometer 392.

Cytoplasma 97.

DARWIN'sche Krümmung 403.

Dehnbarkeit von Pflanzengeweben 432.

- wachsender Pflanzentheile 30\%, 304.

Dextrin 252.

Dialysator 123.

Dialyse der Gase 137.

Diaphanoskop 12.

Diastase, Entstehung ders. 250.

-, Vorkommen ders. 247.

-, Wirkungsweise ders. 247.

Dickenwachsthum 313.

Diffusion 120.

- der Gase 136.

Diphenylamin 58.

Dissociationshy pothese 213.

Dorsiventralität von Pflanzentheilen 418.

Druckflasche 127.

Dunkelstarre 440, 444.

Dunkelzimmer 21.

Durchleuchtung der Pflanzengewebe 11.

Dynamometer 442.

Eigenwinkel der Nebenwurzeln 381.

Eisbildung in gefrierenden Pflanzentheilen 105.

Eisen als Pflanzennährstoff 71 .

Eiweissbildung, Ort ders. 61.

Eiweissreactionen 209.

Eiweissstoffe der Pflanzen 208.

-, Entstehung ders. 49.

- Verhalten ders. 210.

Elasticität von Pflanzengeweben 432.

- wachsender Pflanzentheile 302.

Elektricität, Einwirkung ders. auf Pflanzen 113.

Elektrode, unpolarisirbare 133.

Elektromotorische Wirkungen an Pflanzen 132.

Elementaranalytische Untersuchungen $23^{2}$.

Emulsionsfiguren 357.

Endodermis 314.

Endosmose 120.
Eosinlősung 190.

Epinastie 426

Erfrieren der Pflanzen 103.

Erschütterungskrümmungen 303 .

Etiolement, Ursachen dess. 340.

Etiolinkőrner 18.

Etiolirte Pflanzen 338.

Eudiometer 35.

Farbstoffe 284 .

- in bunten Blättern 16.

FeHIING'sche Lösung 209.

Feinerde des Bodens 65 .

Festigung der Pflanzentheile 430.

Fett, Bestimmung dess. 256.

Fettbäume 292.

Fette Oele, Reactionen ders. 257.

Fette, Verhalten ders. bei der Keimung 258.

Filtriren, Erleichterung dess. 215.

Filtration von Gasen 148, 153.

Flankenkrümmung bei Schlingpflanzen 407.

Flechten 86.

Fleischverdauende Pflanzen $86^{\circ}$

Gallenbildungen 403

Galvanometer 132, 244.

Galvanotropismus niedererOrganismen 358.

Gartenerde als Culturmedium 26.

Gasabsorption 135.

Gasbewegung in der Pflanze 135.

Gasdruck in den Pflanzen, negativer 147.

-, positiver 147 .

Gaskammer 351.

Gaswechsel bei der Assimilation 35.

Gährung, alkoholische, 236.

Gefässe des Holzes, Länge ders. 150.

Gefrierkasten 107.

Geotropische Nutationen, Ursachen ders. 371.

Geotropisches Verhalten der Grasknoten 369.

- der Sprosse 367.

- der Wurzeln 363.

Gerbsäuren 278.

-, Nachweis ders. 279

Gérbstoff, quantitative Bestimmung dess. 279.

Gifte, Einwirkung ders. auf Pflanzen 115.

Glasglocken, doppelwandige 24.

Globoide 101.

Glycerin als Bestandtheil der Pflanzenfette 256 .

-, Nachweis dess. 256.

Glycose, 251.

- Nachweis ders. '252.

Glycoside 285.

Grenzwinkel, geotropischer 367 .

Gummiarten 278.

Iaemoskop '21.

Haftballen 416.

Harze 282.

Hefe, Ernährung ders. 81. 
Heliostat 21.

Heliotropische Kammer 389.

- Nntationen 388.

Heliotropismus und Lichtintensität 392.

Herbstliche $\mathrm{F}$ ärbung der Blätter 25.

Holz als wasserleitendes Gewebe 189.

- Verhalten dess. gegen Gase, die unter Druck stehen 149.

Holzkōrper, Bau dess. 93.

Holzreactionen 91 .

Humuskörper 76.

Hyaloplasma 99.

Hydrotropisehes Verhalten der Plasmodien 361.

Hydrotropismus der Wurzeln 395.

- von Mucor 396.

Hypochlorinreaction 23.

Imbibition 117.

Induction, heterogene 423.

Inductionsapparat 114.

Intercellularen 138.

Inulin 255.

Isotonische Coefficienten 127.

Jahresperiode der Pflanzen 334.

Jod, in Schwefelkohlenstoff gelöst 28.

Jodglycerin ' 245.

Jodjodkalium 38 .

Jodprobe 38.

Kammer, feuchte 289.

Kältemischung 103.

Kalium als Pflanzennährstoff 71 .

Keimung der Kartoffelknollen 264.

-, Beeinflussung ders. durch Beleuchtungsverhältnisse 345 .

- von Phaseolus 260.

- von Triticum 262.

Kittmaterial 32, 45, 51, 137, 141, 147, 177, 180.

Kieselskelett 70.

KIPp'scher Apparat 221.

Kleinste Oberflächen, Prineip ders. 311.

Klinostat, Experimente mit demselben 377. Kobaltprobe 181.

Kohlensäure, Bedeutung derselben für die Assimilation 44.

—, Darstellung derselben 30.

-, Nachweis derselben 33.

-, Zersetzung derselben bei der Assimilation 34,37 .

Kohlensäurebestimmungsapparat 68 .

Kohlensäureproduction bei d. Gährung 220.

- bei der Athmung 217.

- bei intramolekularer Athmung 229.

- bei normaler Athmung 226.

Korkgewebe 91.

Körnerschicht des Plasmas 99

Krystalloide 101.

Kupferoxydammoniak 23.

Kyanophyll 17.

Längenwachsthum der Pflanzen 310.

Längsspannung 307.

Laubblatt, Bau desselben 9.
Leitscheide 291.

Lenticellen 140.

Lichtstimmung der Algenschwärmer 353.

Lithium, Vorkommen dess. in der Pflanze 69.

Macerationsmethode 93 .

Magnesium als Pflanzennährstoff 71.

Maltose 252.

Marken, Auftragen ders. auf Pflanzentheile $126,306,319,365$.

Mechanische Eingriffe, Wirkung ders. auf die Pflanzen 111.

Mechanisches Gewebe, Anordnung dess. in den Pflanzen 434

Mechanisches System 431.

Membranen der Zellen 90.

Mesophyll 9.

Metabolie der Schwärmer 353.

Methylgrünessigsäure 100 .

Methylviolett 17.

Micellen 97.

Mikroskop, horizontales, zum Messen des Zuwachses 317.

Mikrospectralobjectiv 33.

Mikrospectroskop 19.

Milchsaft 212, 299.

Millimeterpapier 434.

MrLLON'sches Reagens 210.

Mineralstoffe, Formen, in denen sie in den Pflanzen vorkommen 74.

-, mikrochemischer Nachweis ders. 74 .

Mineralstoffaufnahme der Pflanzen 199.

Mineralstoffbedürfniss der Pilze 73.

- höherer Pflanzen 70.

Mycorhiza 77.

Nachwirkungsbewegungen 438，439， 444. - an Blüthen 401.

- geotropische 368 .

Nährstofflösung für Bacterien 82.

- für Hefe 49 .

- für höhere Pflanzen 2, 71.

- für Nitromonasculturen 58.

- für Penicillium 78.

- für Saccharomyees 73, 81.

- nach CoHN 82.

- nach PAsteur 81.

Natrium, Entbehrlichkeit dess. 70.

Nebenproducte als Schutzmittel 287.

- des Stoff wechsels 271

Nectarien 175.

Nervatur der Blätter 8 .

NESSLER'sches Reagens 57.

Niederschlagsmembran 124, 126.

Nitrate, Vorkommen ders. in den Pflanzen, 58 .

Nitratzersetzung in der Pflanze 63, 64.

Nitrification 59 .

Nitromonas 58.

Nuclein 212.

Nutation, rotirende 405 .

Nutationen, spontane 325 . von Wurzeln 403.

Nyctitropische Bewegungen 399.

-, Ursachen ders. 402. 
Oefen 170.

Organische Süuren, Verhalten ders. in den Crassulaceen 273.

-, Vorkommen in den Pflanzen 271.

Organische Substanz, Krzeugung ders. 1.

Orthotrope Organe 424.

Oxalsäurelősung 224.

Palissadenparenchyn der Blätter \%.

Papilionaceen als Stickstoffsammler 52.

PAsTEuR'sche Nährlősung 49.

Periderm 91.

Pepsin 211.

Peptone 211.

Pepton als Pflanzennahrungsmittel 50.

Pettenkofer'sche Röhre 224.

Perceptions- und Reactionsvermögen der Pflanzen 395.

Pflanzenschleime 278.

Phenolphtaleinlösung 224.

Phloroglucinlösung 91.

Phosphor als Pflanzennährstoff 71 .

Phosphorescenz der Pflanzen 245.

Photoepinastische Nutationen 427.

Phototaktische Schwărmer 3553 .

Phycocyan 17.

Phycoerythrin 17

Phycophacin 17.

Physiologische Elemente 213.

Pilze, parasitisch lebende 84 .

-, saprophytisch. lebende 80 .

Plagiotrope Organe 424.

Plasmolyse 126.

Polarisationsapparat 97.

Polaritat von Pflanzentheilen 419.

Polarplanimeter 434.

Pollenkörner, Keimung ders. 289.

Poroskop 151.

Prothallien der Farne 14.

Protoplasma 97.

-, diosmotische Eigenschaften ders., 122

Protoplasmabewegungen 347.

- , Beeinflussung ders. durch Temperaturverhăltnisse 349.

- , Ursachen ders. 348.

Protoplasmabewegung, A bhãngigkeit ders. ron Sauertoffgegen wart 351 .

Protoplasmaverbindungen 98.

Psychrometer 168.

Pyrenoid 14.

Ouecksilber, Reinigung dess. 36 .

Quellung von Pflanzentheilen 117.

- der Samen 161.

Quellungscapacităt 163.

Querspannung 309.

Ranken der Ampelideen 416.

- der Cucurbitaceen 412.

Rechtwinkelige Schneidung, Prineip d. 311.

Rectipetalitåt der Pflanzentheile 410.

Reifen der Früchte und Samen 266.

Reinculturen von Bacterien 82.

- von Pilzen 79.
Reizbewegungen 347.

Reizfortpflanzung bei heliotropischen $\mathrm{Nu}$ tationen 394.

- bei Mimosa 447.

Reservecellulose 254 .

Respirationsapparat 222 .

Respirationsquotient 233.

Rhaphidenbündel 62 .

Rheotropisches Verhalten der Plasmodien 361.

Ringelschnitt 189.

Ringelungsversuche 293.

Rohrzucker 253.

Sägespäne als Culturmedium 2.

Saftausfluss aus Bäumen $16 \%$.

Saftausscheidung aus Baumstämmen 175.

- an Pflanzen 173.

Sand als Culturmedium 53.

Salpetersäure als Pflanzennahrungsınitlel $49,60$.

- Nachweis ders. 57.

Salzsäurebildung in der Pflanze 204.

Samenschalen, Bau ders. 160.

Saprophyten 80.

Sauerstoff, Darstellung dess. 225.

Sauerstoffaufnahme bei der Athmung '233.

Sauerstoffbombe '225.

Sauerstoffproduction bei der Assimilation 29.

Sauerstofferbrauch bei der Athmung 218 .

SaussurE'sches Gesetz 202.

Schlämmcylinder 66.

Schnecken und Pflanzen 287.

Sehwammparenchym der Blïtter 9

Schwefel als Pflanzennährstoff 71 .

Scutellum der Gräser '263.

Siebröhren 297.

Silberlösung, alkalische 99.

Silicium, Entbehrlichkeit dess. 70.

Sklerenchym 431.

Somatotropische Nutation 397.

Spaltöffnungen 142 .

-, Einfluss von Inductionsströmen auf dies. 145.

-, Oeffnungs- u. Schliessungsbewegungen ders. 144.

- und Assimilation 47.

- und Transpiration 180.

Spectralapparate 18.

Spectrum, objectives 390 .

Stärke als Assimilationsproduct 39.

- in Reservestoffbehältern 245.

Stärkebäume 292.

Stärkebestimmung 246.

Stärkebildner 100 .

Stärkekörner 93.

-, Verhalten ders. in polarisirten Licht 97.

- Verhalten zum Jod 96.

Stärkenachweis, makroskopischer 38.

_, mikroskopischer 38 .

Stärkescheide 296.

Stereiden 431.

Stereom 431.

Sterilisiren 82. 
Stickstoff, freier, als Pflanzennährstoff |Wachsthum in constanter Finsterniss 337. 52.

Stickstoffbestimmung 50,214 .

Stickstoffoxydul, Wirkung dess. auf Pflanzen 235 .

Stickstoff versorgung niederer Organismen 49.

Stoff wanderung in Blättern '289.

- in Zweigen 291 .

Stoffwechsel der Pflanzen 208.

-, quantitativ-chemische Untersuchungen über dens. 269.

Stossreiz 414.

Substratrichtung 383.

Symbiose der Hydra mit Algen 14.

Temperatur, Wirkung der hohen auf die Pflanzen 108.

-, Wirkung der niederen auf die Pflanzen 103.

Temperaturzustand der Gewächse 130.

Thermoelektrischer Apparat 244.

Thermometer 169 .

Thermoregulatoren 170 .

Thermostaten 170 .

Thermotropismus 397.

Titrirapparat 224.

Titrirmethode $224,273$.

Torsionen 324 .

Tracheiden 195

Translocation plastischer Stoffe 289.

Transpiration, Beeinflussung ders. durch äussere Verhältnisse 181.

- und Organisation der Gewăchse 176.

- und Spaltöffnungen 180, 186.

Transpirationstersuche 178.

Trockensubstanzbestimmung 1.

Trophotropisches Verhalten der Plasmodien 362.

Turgor 125 .

Turgorausdehnung wachsender Pflanzentheile 303.

Turgorkraft 129.

Tüpfelbildungen 92 .

veberosmiumsâure 101, 257.

Variationsbewegungen 438.

-, Beeinflussung ders. durch äussere Verhältnisse 449.

-, durch Beleuchtungswechsel verursachte 438, 439, 444.

- , durch Erschütterungen verursachte $445,447$.

-, spontane 448.

-, Ursachen ders. 440.

Vegetationspunkte 310 .

Vegetationszonen, intercalare 31\%.

Vergrösserung, Bestimmung ders. 434.

Vorkrümmung bei Schlingpflanzen 407 .

Wachsthum, Beeinflussung dess. durch Druck und Dehnung 330.

-, durch Licht 343.

-, durch Temperaturverhältnisse 332.

- und Athmung 329.

- und Stoffbe lürnniss der Pflanzen 327.

- und Wassergehalt der Pflanzen 328.

Wachsthumsbedingungen 327.

Wachsthumsenergie 323 .

Wachsthumsgesch windigkeit 323 .

Wachsthumsperiode, grosse 319 .

- , tägliche 343 .

Wårmeen twickel ung bei der Imbibition 119.

- der Pflanzen 240.

Wärmekasten für mikroskopische $Z$ wecke 350.

Wårmeleitung im Holz 131.

Wărmestarre 450 .

Wasser, Beweglichkeit dess. im Holz 193. -, Gehalt desselben an Pflanzennăhrstoffen, 67.

Wasseraufnahme der Blätter 157.

- der Früchte 160.

- der Moose 164.

- der Samen 160.

- der Wurzeln 156.

Wasserbewegung, Geschwindigkeit ders. in der Pflanze 105.

- im Holz, Ursachen ders. 191, 450.

Wassercultur, Methode ders. 2.

Wassergewebe 178:

Wasserleitung im Stamm 189.

W asserstoff, Darstellung dess. 29.

Welken der Pflanzen 197.

WESTPHAL'sche Waage 237.

Winden der Ranken 41\%.

- der Schlingpflanzen 404.

- der Schlingpflanzen, Mechanik ders. 409.

Windungen, freie, der Schlingpflanzen 408.

Winterliche Färbung von Pflanzentheilen 25.

Wurzeldruck 166.

-, Einfluss äusserer Verhältnisse auf dens. 169.

-, Periodicitāt dess. 172.

-, Ursachen dess. 172.

Wurzelhaare 199.

Wurzelknöllichen der Papilionaceen 5̄5.

Wurzeln als Organe der Mineralstoffaufnahme 199.

Wurzelspitze, Function ders. bei geotropischen Nutationen 376.

Xanthophyll 17.

Zeiger am Bogen 314 .

Zelle, künstliche nach Traube 126.

Zellhaut, diosmotische Eigenschaften ders. 122.

Zellkern 100.

Zellsaft, Zusammensetzung dess. 127.

'Zucker als Assimilationsproduct 39.

Zuckerarten der Pflanzen '251.

Zuckerbildung in Kartoffelknollen 265.

Zuckerscheide 296. 


\section{Anzeigen. \\ Farbstoffe Reagentien}

\section{Mikroskopie und Bakteriologie}

gewissenhaft nach Angabe der Autoren.

Physiologisch-chem. Präparate Dr. G. Grübler, Leipzig, Bayrische Strasse,

Preislisten gratis und franko.

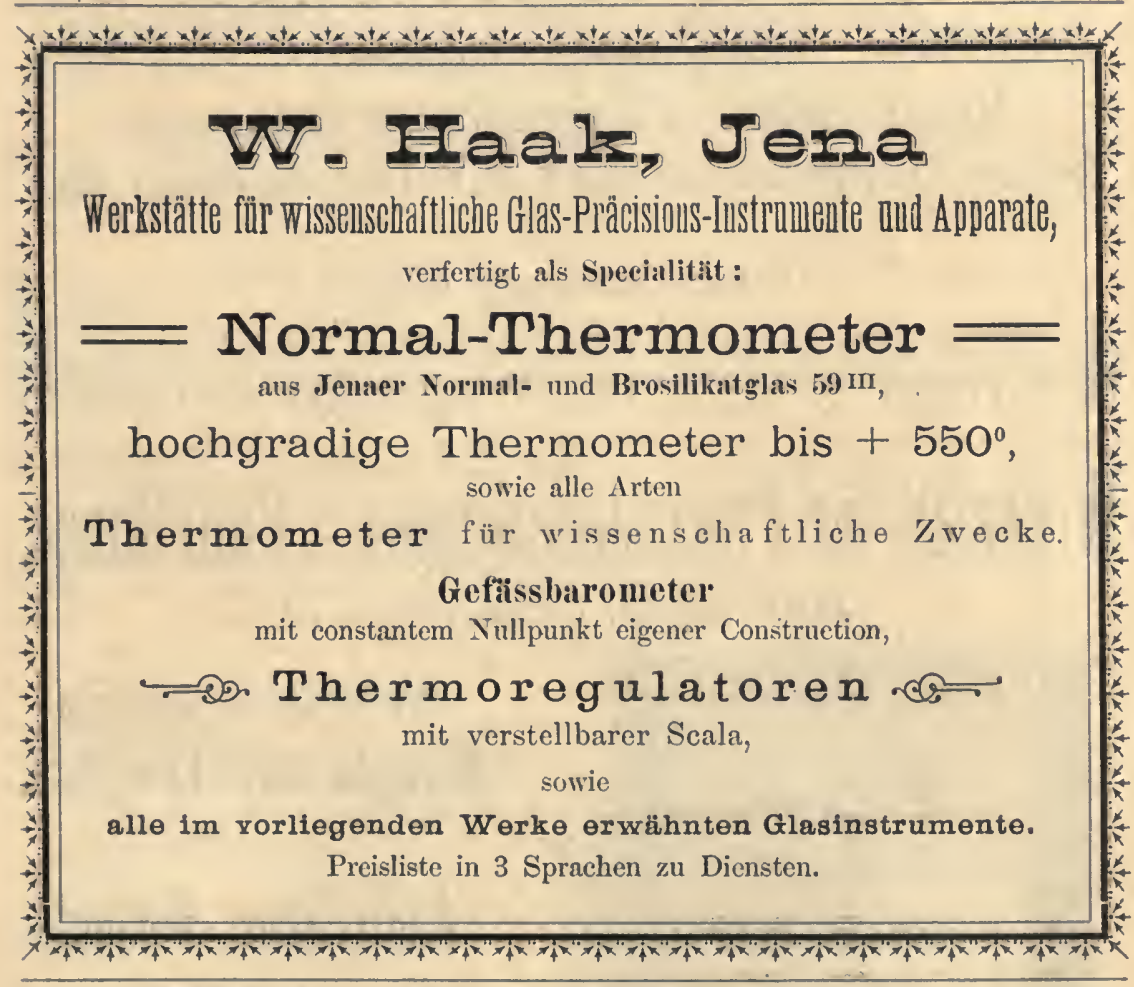

\section{NI. C. Heraeus, \\ Ianau}

empfiehlt alle Apparate ans Platin u. Feinsilber für Laboratoriumsarbeiten als:

Blech- und Draht in beliebigen Dimensionen,

Schalen, Tiegel, Spatel, Löffel, Filtrirconuse, Gewebe etc. etc. Apparate zar Electrolyse.

Alle Salze und Verbindungen des Platins und seiner Neben-Metalle. Illustrirte Preisliste. 


\section{Carl Zeiss,}

Optische Werkstätte, Jena. zoor

Mikroskope mit Zubehör;

Mikrophotographische Apparate;

Photographische 0bjective;

Mechanische undl optische Messapparate;

Neue Doppelfernxohre für Handgebrauch.

\section{Cataloge gratis und franco.}

Hamburg, Ottostrasse: 13.

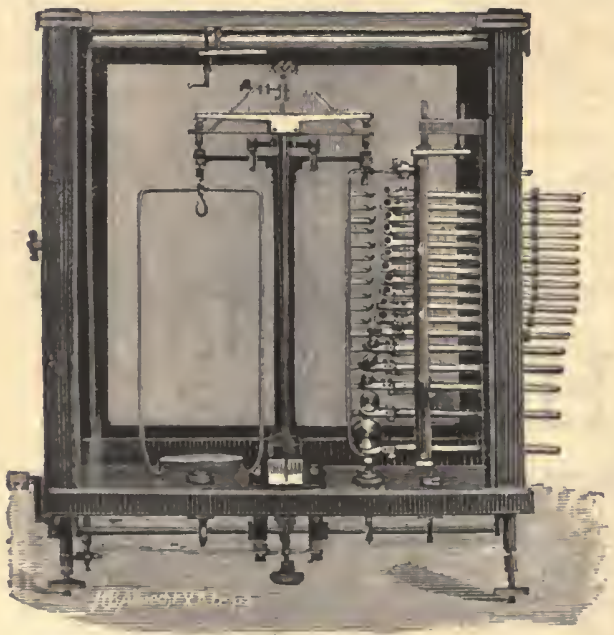

Physikalische and Analytische Waagen und Gewichte.

Nur Originalconstructionen.

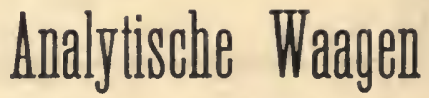

mit kilirzester Selwringungsdauer bei hoher constanter Empfindliehkeit.

\section{- Preislisten sowie Broschüren \\ über Constructionsmotixe kostenfrei.}

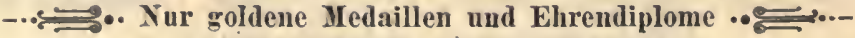
auf besehickten Ausstellungen.

Wien 1573. Hamburg 1S76. Briissel 1SSs. Hamburg 1S59. Chieago 1593. 


\section{Dr. Rob. Muencke}

Luisenstrasse $5^{8}$ BERLIN NW. Luisenstrasse 58

Fabrik und Lager chemischer Geräthschaften.

Vollständige Einrichtungen und Ergänzungen chemischer,

bacteriologischer Laboratorien etc.

Geaichte Normal-Instrumente. Benzinlampen- und Benzin-Verbrennungsöfen.

Hochgradige Quecksilberthermometer fiir Temperatnren bis $550^{\circ} \mathrm{C}$.

+ Illustrirte Cataloge gratis und franco. -

\section{Ephraim Greiner, Stïtzerbach (Thüringen)}

(Inhaber: Bieler, Greiner of Kïhn.)

Glas-Instrumenten-, Apparaten- und Hohlglas-Fabrik,

Praieisions-Glasschleiferei, Ietzerei, Tischlerei und Dreehslerei,

fabricirt und liefert ans Glas ron rorziiglich ehemisth-techniseher Besehaffenheit als Specialitïten fiir chemisehe Laboratorien ete.

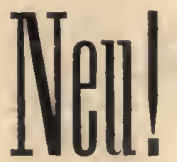
Geaichte chemische Messger:ithe nach den Vorschriften d. K. Normal-Aich.-Kommission.

Geaichte Thermo-Ariometer 1 . Mineralöle u. spee. Gewicht, mit Aichschein und Tabelle.

Glashithe mit elastischem Zug, das Herausfallen des Kükens verhindernd, I). R. G. M.

Normal. Alkoholometer, Aräometer, Milchprober, Saccharometer, Thermometer, sowie chemische Thermometer aus Jenaer Normalglas mit und ohne amtl. Prüfungsschcin

Wagen fir alle speeiellen Fliissigkeiten der Alkoholonetric, Aräometrie, Saccharometrie etc.

Biiretten, Crlinder, Mensuren, Mess- und Vollpipetten $u$. alle graduirten Geräthe. Apparate unil Instrumente jeder Art für Chemiker, Physiker, Aerzte, Pharmaceuten, Techniker, allerlei Fabrikgebrauch, zur technischen Gasanalyse, zur Maassanalyse, zur Prüfung und Untersuchung von Milch etc. - PatentKiihlapparate nach Dr. Ferd. Evers.

Thermometer fi $r$ all e $Z$ w e cke, Oneckilber-Barometer und Barometerrihren. Glasrïhren und -St ibe. In der Glashütte gefertigte Hohlglasartikel.

IIor'l- und Bein waren, Platin- md Porzellangerithe. Stative und Ausritistungsartikel. Aualysen-, Brief-, Hund-, Hydrostatisehe, Prảeisions- mud Taríwaagen, sowie fewichte, geaicht u. ungeaicht, hester Qualitit zu Fabrikpreisen.

Exacte Export nach allen Ländern. Mässige Ausführung. Besteller erhalten Kataloge gratis mul franeo. Preise.

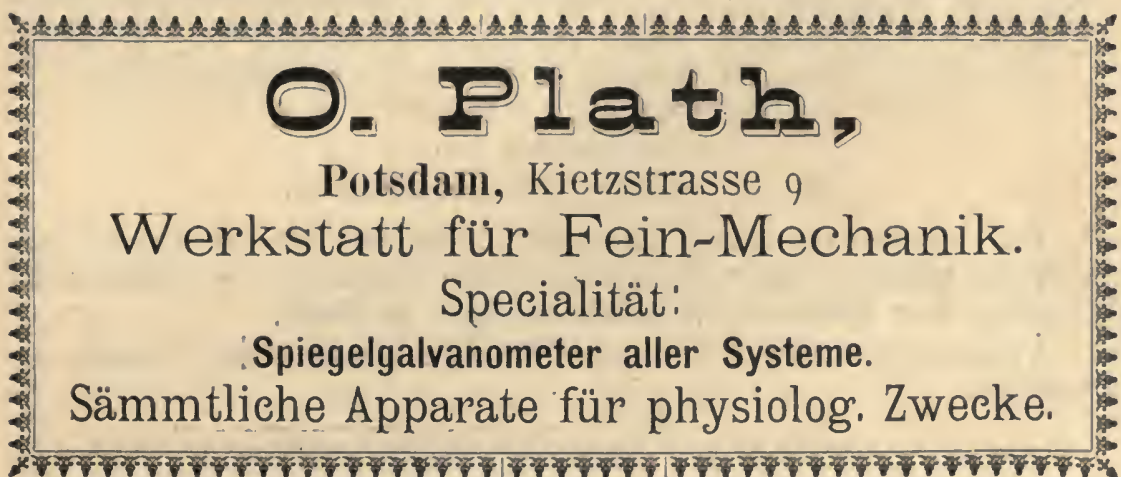




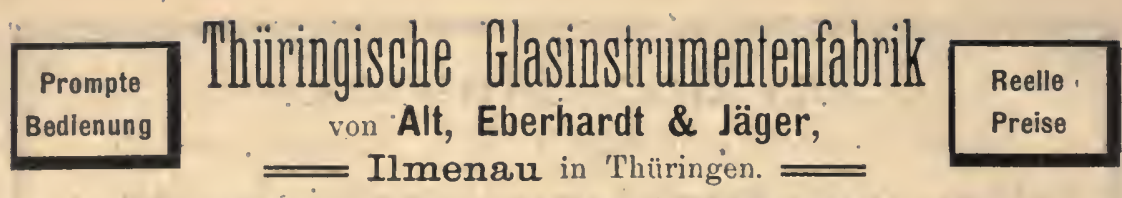

\section{Eigenes Hohlglashüttenwerk,}

Glasschleiferel, Lampenbläsereien,

Thermometer- und Holzwarenfabriken - Ieehanisehe Werkstatt,

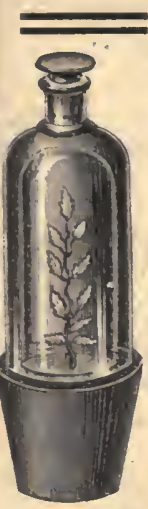

Schriftmalerei und Emaillieranstalt.

Specialität:

Grosse Glaskïrper (Glocken, Flaschen) bis 40 Liter Inhalt.

Ipparate fiir alle speeiellen Untersuchungen der Teehnik, Ar:iometer amtlich geprüft für Wissenschaft und Technik.

\section{Lager won Glassgetässen}

für naturwissenschaftliche Museen, Apotheken, Laboratorien.

Vollständige Einrichtungen von ehem. Laboratorien.

Naturwissenschaftliche Apparate und Utensilien.

Bakteriologische, gasanalytische. bodenkundliche, chemische, physikalische und mikroskopische Glasapparate.

- Intlich gepr. Therutometer aus Jenaer Normalglas, sowie

Kochflaschen u. Kochbecher aus Jenaer Gerätheglas u. Natron-Kali-Salz.

Chemische und Acratliche Thermoneter mit Prüfungsscheisen.

Sämmtliche Apparate werden auf das Exakteste nach neuesten wissensehaftl. Principien ausgeführt und vor dem Versand anf ihre Brauchbarkeit im eigenen Laboratorium gepriift.

Verlag ron Gustar Fischer in Jena.

Seit dem I. Januar I895 erscheint:

\section{Centralblatt}

\section{für Bakteriologie und Parasitenkunde.}

\section{Zweite Abteilung :}

Allgemeine, landwirtschaftlich-technologische Bakteriologie, Gärungsphysiologie und Pflanzenpathologie.

In Verbindung mit

Prof. Dr. Adametz in Krakau, Dr. W. M. Beyerinck in Delft, Prof. Dr. A. B. Frank in Berlin, Dr. . Freudenreich in Bern, Prof. Dr. Emil Chr. Hansen in Kopenhagen, Dr. Lindner in Berlin, Prof. Dr. Miiller-Thurgan in Wädensweil, Prof. Dr. Stutzer in Bonn, Privatdocent Dr. Welumer in Hannover, Dr. Weigmamn in Kiel,

Dr. Wilfarth in Bernburg und Dr. Winogradsky in St. Petersburg

herausgegeben von

Dr. O. Uhlworm in Cassel.

Die zweite Abteilung erseheint zunåchst alle 14 Tage. Der Jahrgang umfasst somIt 26 Nummern im Umfange von mindestens 2 Bogen; der Abonmementspreis beträgt 16 Mark. Diensten.

Probenummern stehen auf Wunsch gratis und franko zú 


